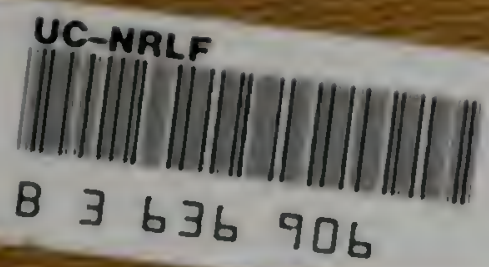




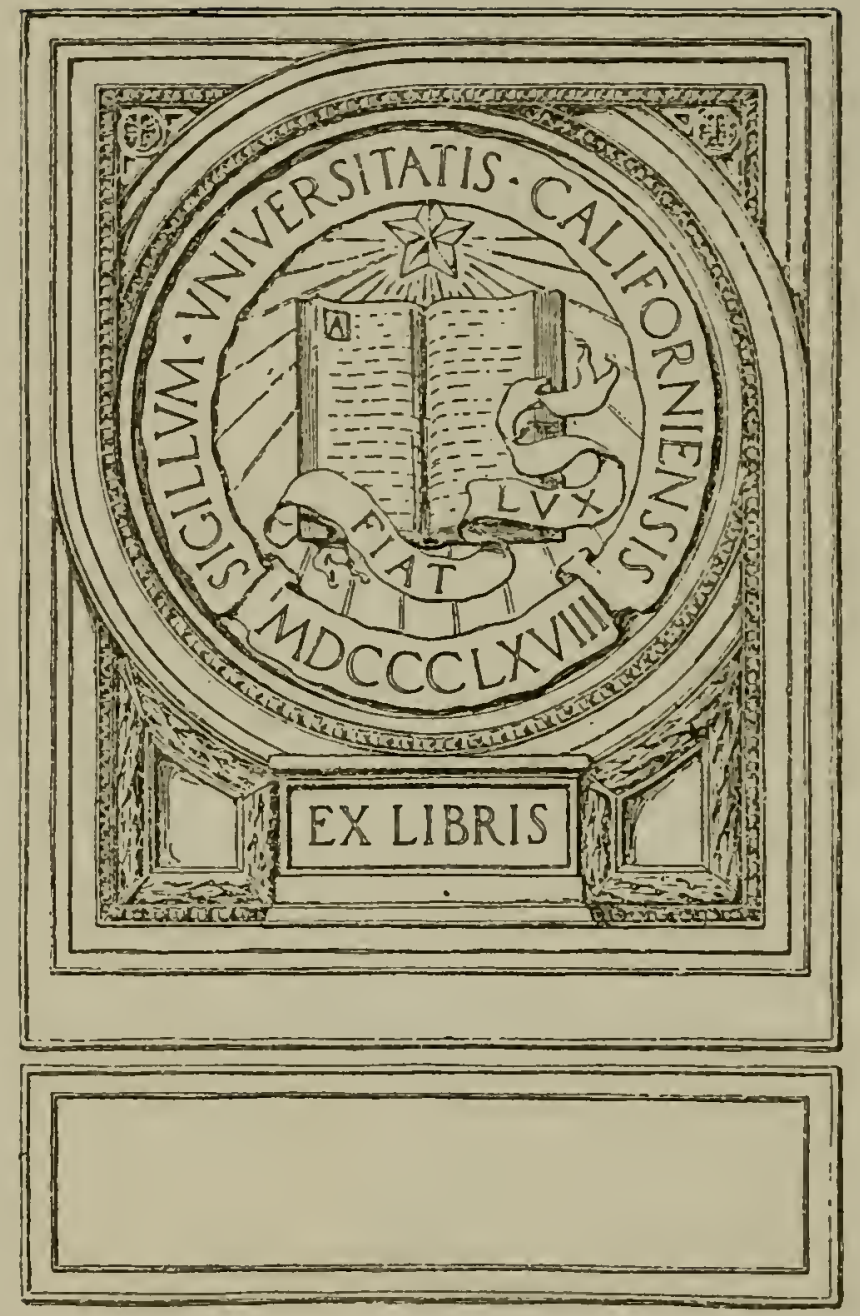





\section{AGRICULTURAL APPROPRIATION BILL, 1924}

\section{HEARING}

131:1\%OKY:

\section{SUBCOMMITTEE OF HOUSE COMMITTEE ON APPROPRIATIONS}

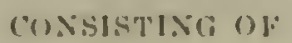

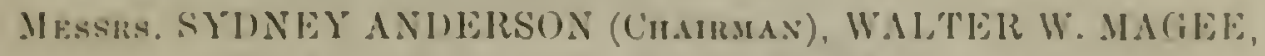
LIWARI) H. WASON, JAMISS P. BUCHANAN,

A.N GORI) LE LE:

IN CHAKGl: OF THE

AGRICULTURAL APPROPRIATION BILL FOR 1924

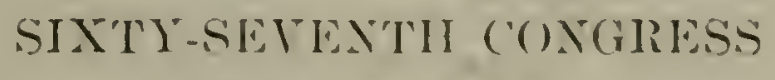

lOOTRH SISSIOX

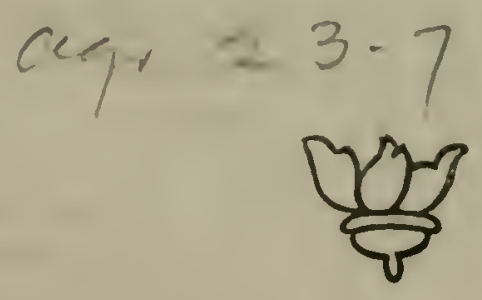

WASHINGeron

(inv 


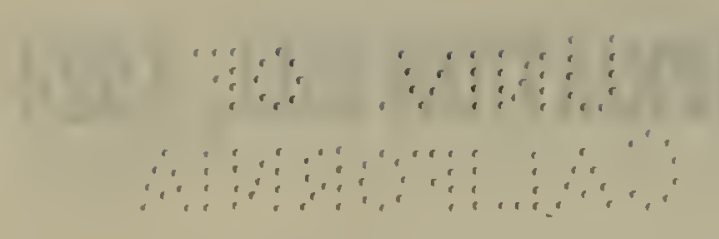

\section{COMMITTEE ON APPROPRIATIONS.}

\section{House of Represextatives.}

\section{SIXTY-SEVENTH CONGRESS, FOLITH SESSION゙.}

MARTIN B. MADDEN, Illinois, Chaimmn.

CIARLES R. DAVIS, Minnesota. DANIEL R. ANTHONY, JR. Kansas. WILLIAII S. VARE, Pennsylvania. JOSEPH G. CANNON, Illinois. C. BASCOM SLEMP, Virginia. SIDNEY ANDERSON, Minnesota. WILLIAII R. WOOD, Indiana. LOUIS C. CRAMTON, Michigan. PATRICK H. KELLEY, Michigan. EDWARD II. WASON, New IIampshire. WALTER W. MAGEE. New lork. (iEORGE HOLIEN TINKHAM, Massachnsetts. BURTON L. FREACI, Idaho. MILTON W. SIIREYE, I'ennsylvania. CIIARLIS F. OGDES, Kentucky. WILLIAM II. STAFFORD, Wisconsin. JAMES W. IIUSTED, New York.
EIIJAII C. HUTCHIN⿴囗十, New Jersey. hodERT E. EVANS, Nebraska. L. J. DICIINSON, Iowa. HENRT Z. OSIORNE. California. FRANK MURIIY, Ohio. JUSEPH W. BYISAS. Tennesser. TIOMAS UPTOY SISSON, Misissippi. JAMEN I'. BUCIIANAX, Texas. JAJES A. GALLIVA., Iassachusetts. JAMES F. IBIRES, Sauth Carolina. GORDON LIES, Georgia. HEN JOIINSON, Gentucky. CIARLES D. CAR'TEIR, Oklahomit. EDWARD T. T.IYLOR, Colorado. WILLIAM I. OLIVER, A Iabama. TIIOAAS W. IIAIRISOX, Virginia. ANTIONI J, (IRIFFIN, New York.

Marcellus C. Sireld, Clerk.

II 


\section{JAMES H. MacLAFFERTY}

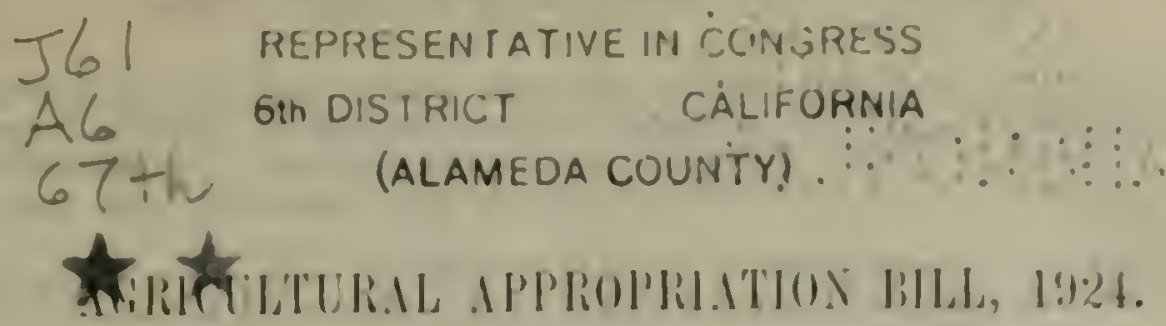

HEARINGS CONDUCTED BY THE SUBCOMMITTEE (MESSRS. SYD. NEY ANDERSON (CHAIRMAN), WALTER W. MAGEE, EDWARD H. WASON, JAMES P. BUCHANAN, AND GORDON LEE) OF THE COMMITTEE ON APPROPRIATIONS, HOUSE OF REPRESENTATIVES. IN CHARGE OF THE AGRICULTURAL DEPARTMENT APPROPRIATION BILL FOR THE FISCAL YEAR 1924, ON THE DAYS FOLLOWING, NAMELY:

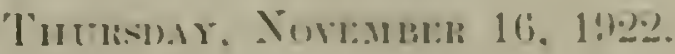

\section{STATEMENT OF MR. W. A. JUMP, BUDGET OFFICER AND ADMIN. ISTRATIVE ASSISTANT, DEPARTMENT OF AGRICULTURE.}

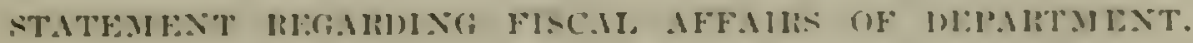

Mr. Axmmsox. We will take up the oflice of the secretary. on palge of the Book of Estimates, and Mr. Jump. who is the Bunget oflicer of the department. will make a preliminary statement in respect to the items in the bill.

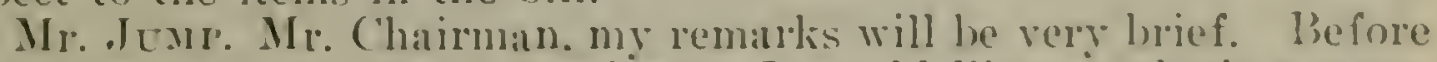
proceeding to the detailerl estimates I would like to submit a statement which the Secretary. knowing the interest of this committee in the manner in which the affairs of the Department of Acriculture are conducted generally. isked me to present to you this morning. This is an excerpt from the Secretary anmul report for the last fiscal vear. which was sent to the printer vesterday and which will be released. of course, in the usual manner when the regulal session of Congress convenes. 'The statement deals with the reserves which were set up from the appropriations for the fiscal pear 19.22 and indicates trpical instances of some of the economies which have been effected in the department. I shall be glad to read it, or I will present it for the record. whicherer rou prefer.

Mr. Brcmasax. It will he satisfinctory to me to balve it inserted.

Mr. Ixplsisox. Without ohjection. it will he inserted in the record.

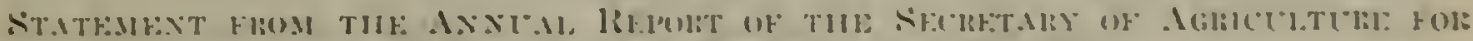

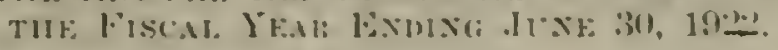

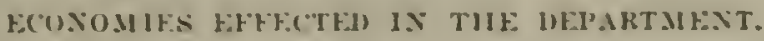

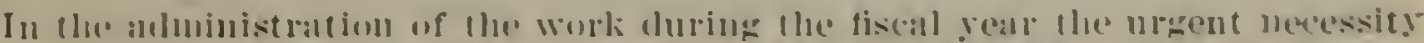

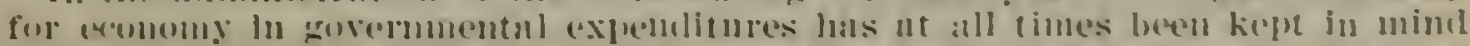

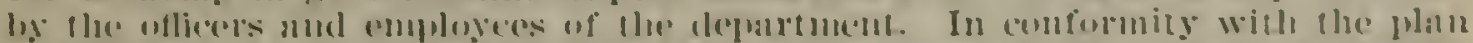

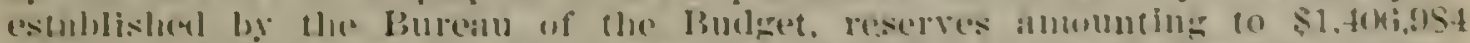

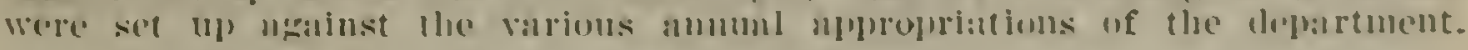




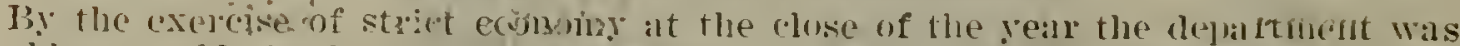

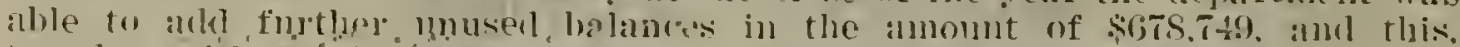

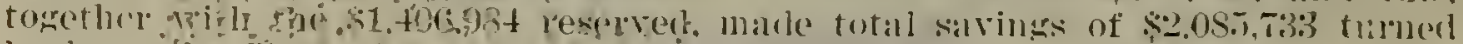

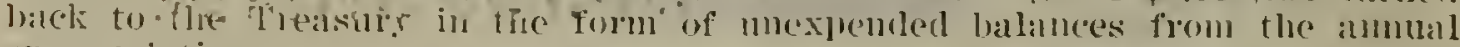

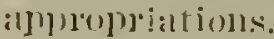

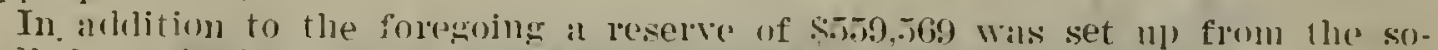

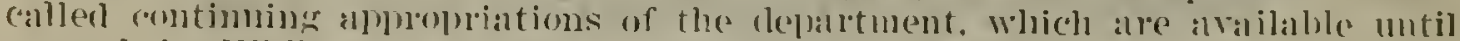

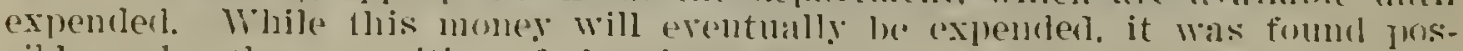

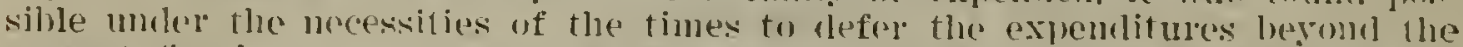
present fis.al year. and thus for llo mosent to silve the withllawal of the

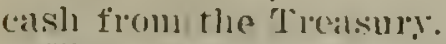

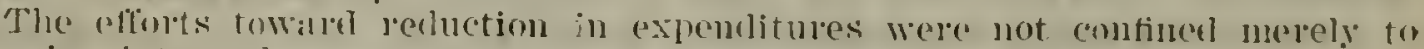

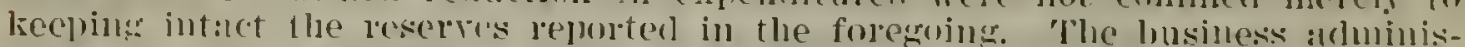

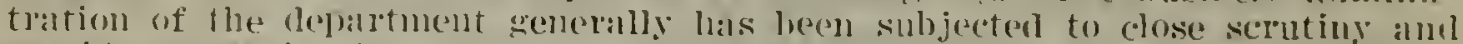

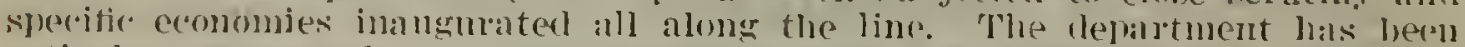
actively representod on the various coovlinating anencies crenterl ander the

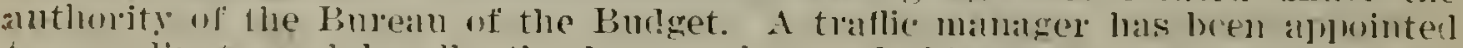
to courdinate and hamble the ladge volume of shipments and extensive jas-

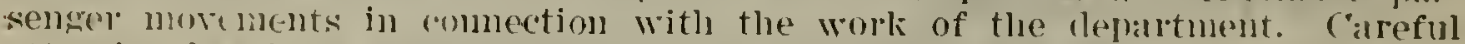

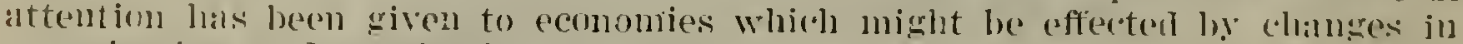

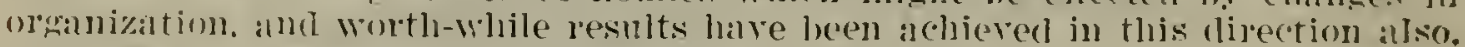
somo of whicll will he mentioned later.

I'articular attention lats bech given to the purchasing work of the department. Aftel a sulver of this work was malc by an expert detallei from the Purean of the Bublet, a dilectur of purcluses and sales was lesignaterl to courdinate the purchasing work and the disposition of surplus properts. Changes have been made in former procednre. The work has heen placed

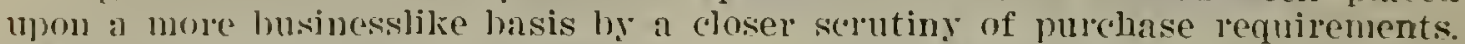
By remanization and extension of the powels of the department hoard of aw:ills competition lias been willened on supplies and equipment bonght. By. consultius with commodity experts in this and other departments prior to. muchasing the depalment has kept informed on market conditions in various lines and has been able to place orders more adrantageously. The purchase of certain commorlities has been centralized for Washington and neal'-by field stations, enabling the department to secule better prices by quantity oreler's.

Investigation is constantly being made into the availability of smplus property from other depaltments and its use wherever economical instead of the purbase of new equipment by the department. The stocks amd equipment of the entile d(p)artment itself have besn wome orer carefully. both in Waslington and in the field, and molel a system which has been established a lare amoment of surplus equipment for which the lololing loweaus liave no furtlel use is furnished to other bureaus. thus aroiding adritional pmichases. Serviceal)le motor trucks lave been secured at nominal costs flom sumplus stocks of other (lepartusejts to replace worn-out trucks in the centralizal trucking unit of the department, maling better lauling selvice avilialule to the bureaus at lowel cost. The revemues foum the sale of perisliallo proplucts fonm the field stations of the depatment mear Wasjingtom have becus mole

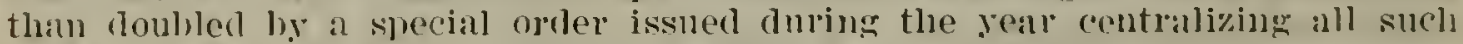
sales in the department's smplyly division.

'Jo smmmalize. here, as elsewhere in the sejpice, "Eennomy with efliciency" luas been the watchworl. The constant aim during the veal has bern to

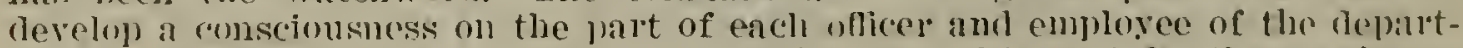
ment of the necessity amd personal responsibility on his part for thr maximum

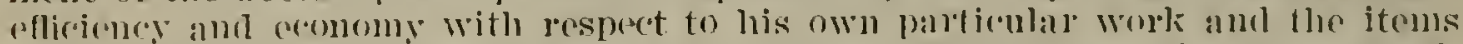
of expouliture with which le maly have to do. lyomomies and incoensid efli-

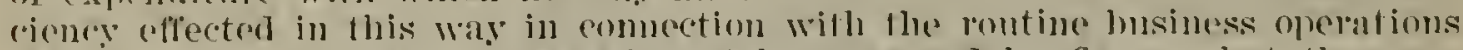

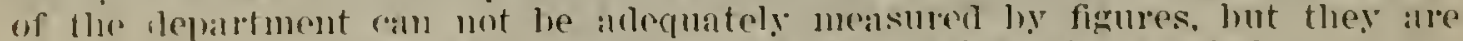

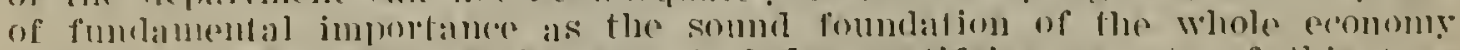

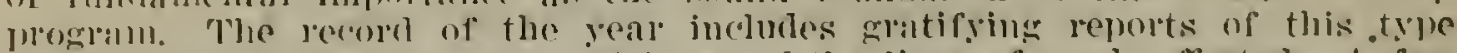

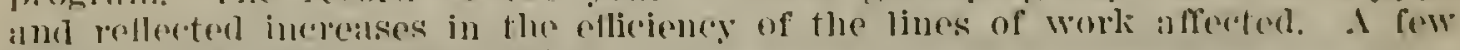
typicatl instancess alle inloresting.

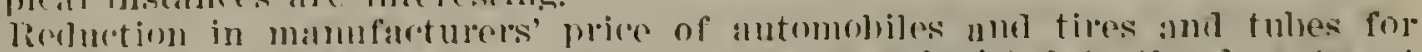

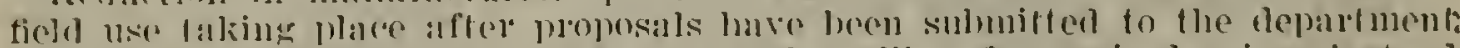

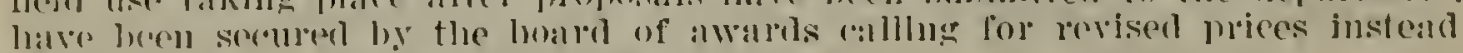
of accopting the hids as origrimally submitted.

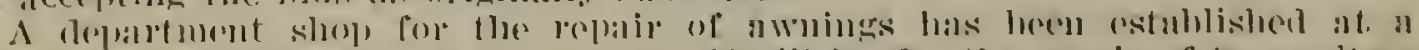

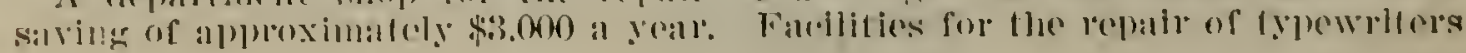


mInI I,

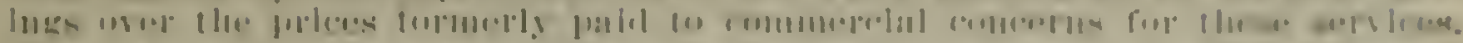

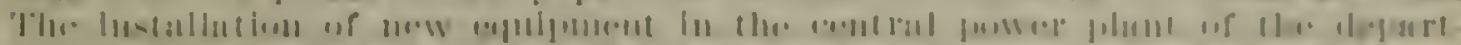

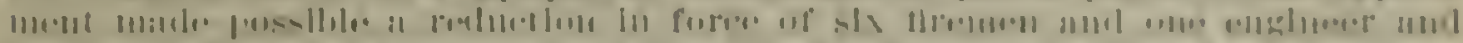

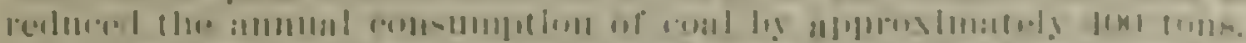

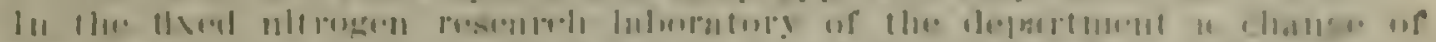

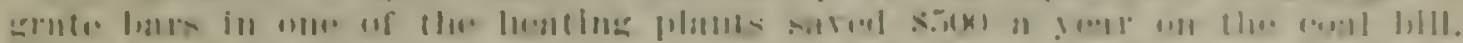

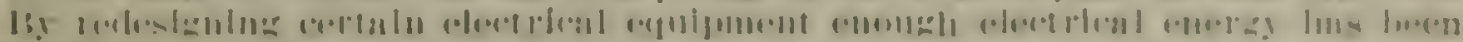

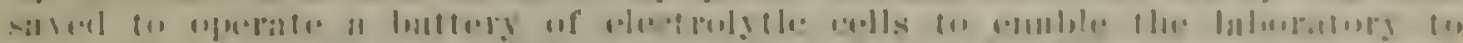

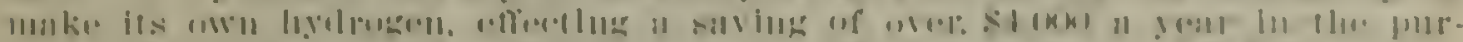

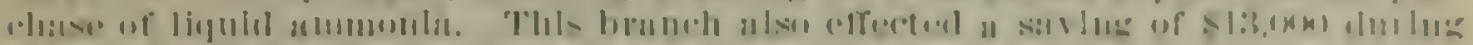

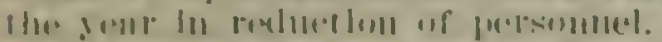

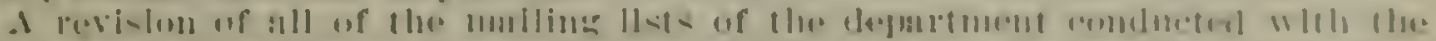

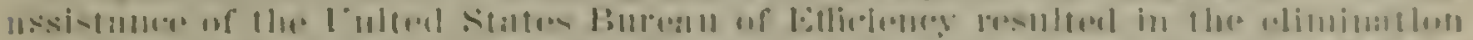

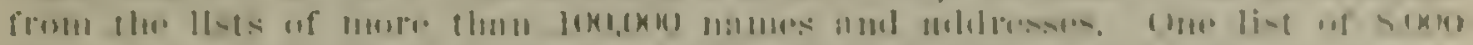

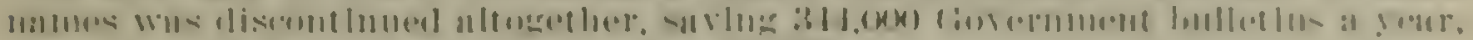
(1)

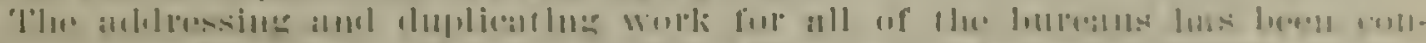

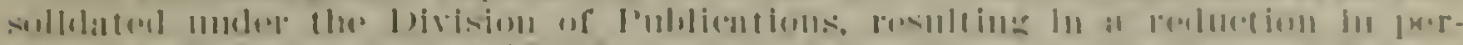
s(1)

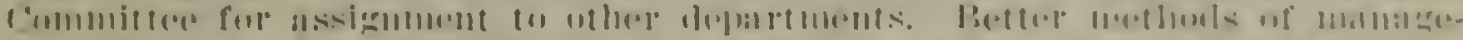

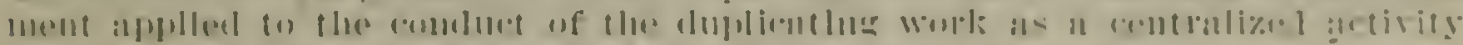

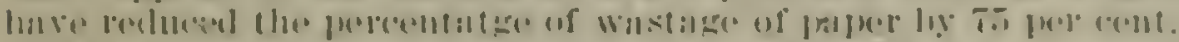

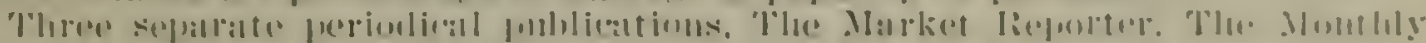

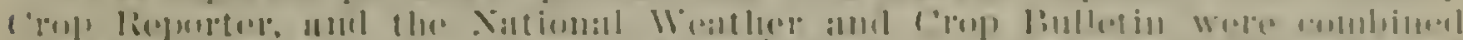

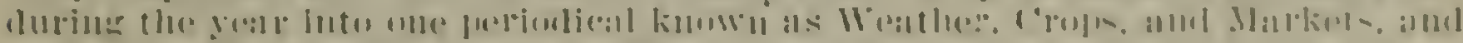

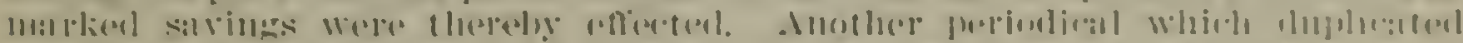

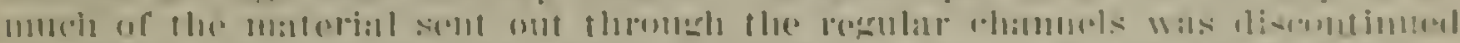

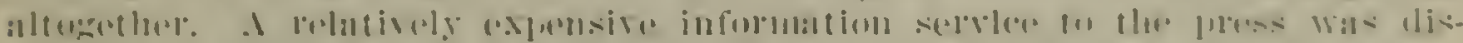

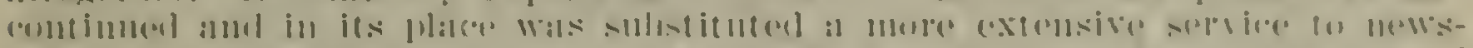

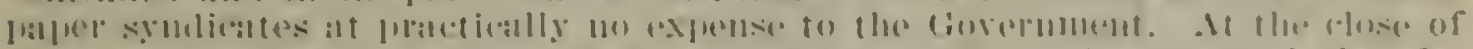

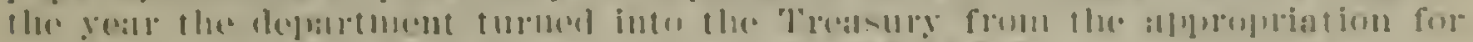

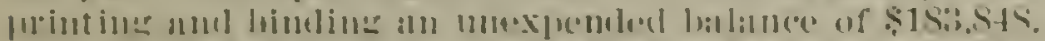

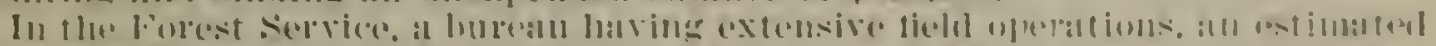

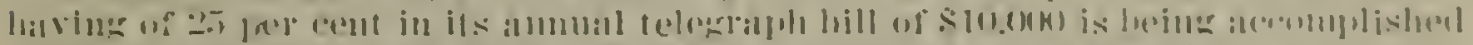

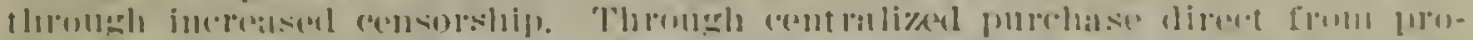

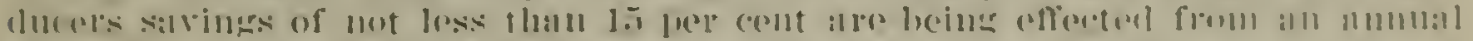

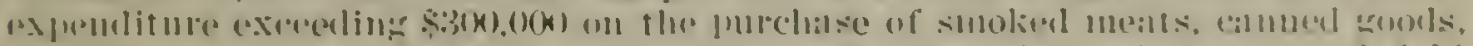

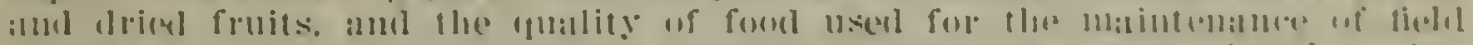

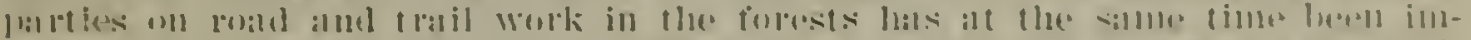

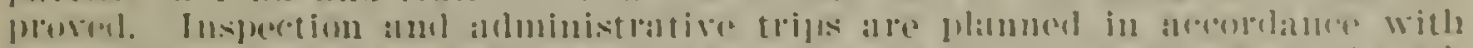

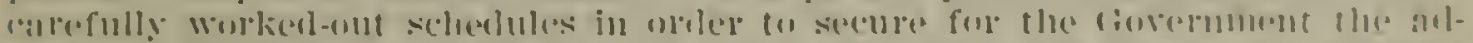

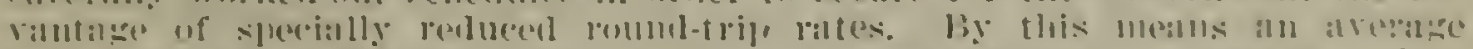

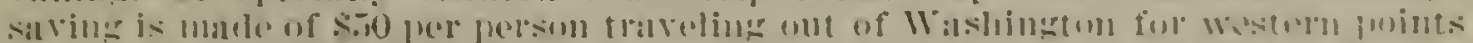

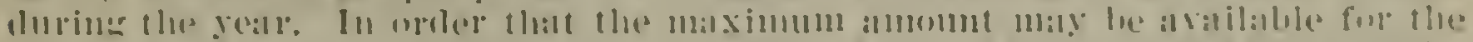

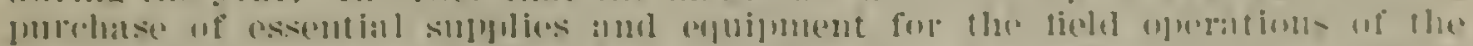

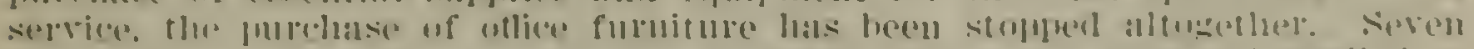

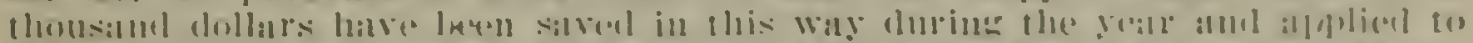

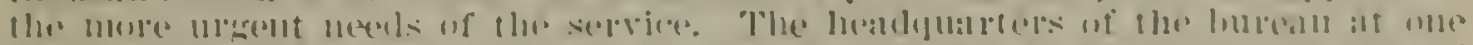

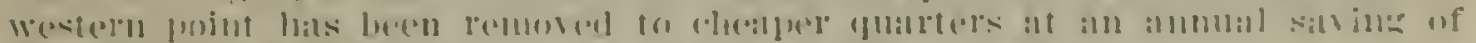
(1)1? (1)

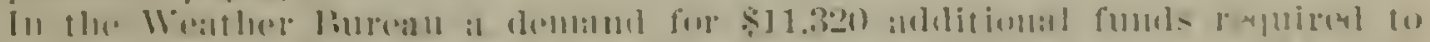

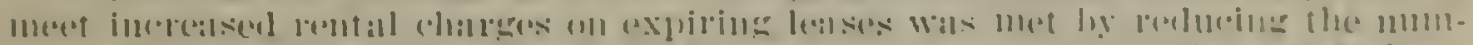

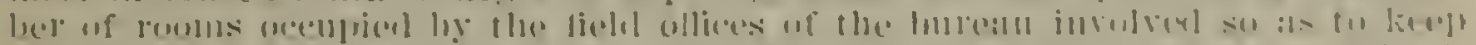

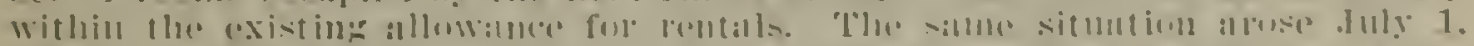

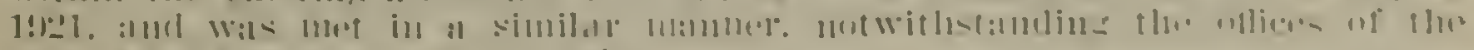

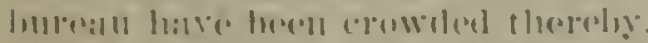

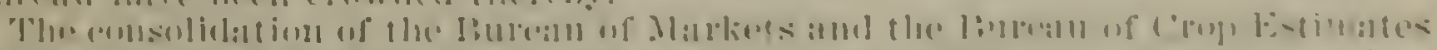

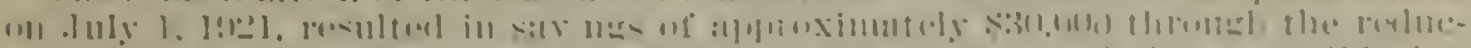

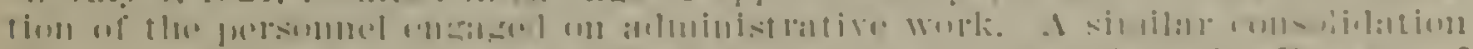

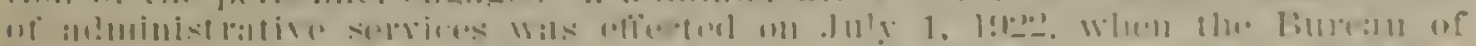

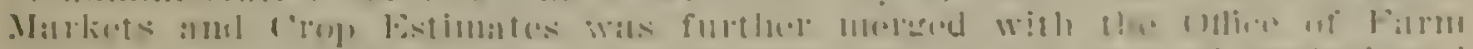

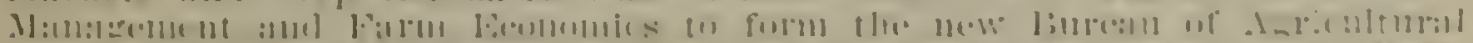

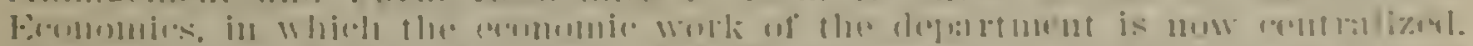

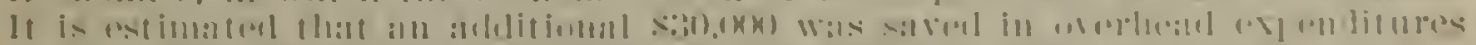

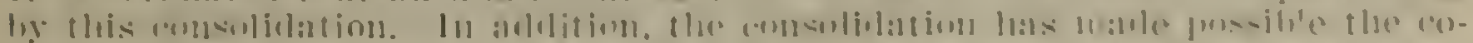

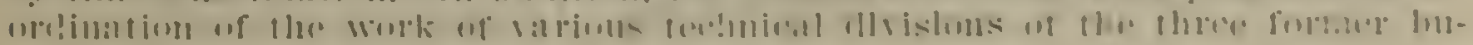


reaus, thereby eliminating duplication and overlapling throughout the economic units.

In the Insecticile and Fungiciele Board the field work las been redistricted. resulting in a saving of approximately $\$ 1,500$ a year without loss of efliciency.

In the States Relations service, by the consulidation of the two Waslington coftices engatged in directing the work of agricultural extension, salaries agrregating atpproximately $\$ 20,000$ have been sived, and as the result of centralizing ancl rearranging the clerical work in the administrative offices of the same burealu salaries of clerks to the amount of $\$ \$, 000$ hare been sived.

One liefl office of the Burean of Animal Industry was discontinued during the year and the work of that office consolidated with another, resulting in a saring of annoximately $\$ 4000$. Two divisions of the lurean in llashington were mer'serl, resulting in the saving of the salary of one chief of division and one clerk, amomting to $\$ 5,070$. By consolidating the work of an emploree on the Canalian borter with the tuties of another inspeetor, a saving of $\$ 1.510$ was effected, and the recall of one inspector from overseas has resulted in a further saving of \$3.300. In the meat-inspection service by realignment of the force the alctual expenditure during 1922 was reduced sereral thousand dollajs, notwithstancling the fact that nearly $1,000.000$ nore animals were slaughtered undel inslection during the year and almost $300,000,400$ more pomels of meat foor products were reinspected, thus avoiding the necessity for additimal al)propluations. In the work of supervising the preparation of biological proulucts a siving of approximately $\$ 4,000$ was accomplisher through reduced tratrel. During the reat there were prodnced 3.037.771 more doses of tuberculin thin in the tiscal yen 1921. and this wals accomplished at a saving of $\$ 20.58$.j ovel the anount expented during the previous yeals. The manufactme and distribution of blackleg toxin was also discontinued on July 1. Jesulting in al silving of $\$ 10,000$ per amnum.

In the office of exhibits the agrieultural displays have been prepared in surde

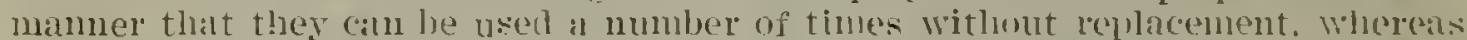
formerly the department exllibits flequently were suitalule for use unly durine one or two seisuns.

In the Bureau of Biolngical surey it was possible during the rear to use $\$ 20,000$ of the money sot asicle als al reserve to enable the flepartment in conper:ition with one of the Westerm sitates tu cope with a serious outheale of rabies almong corotes Whirh threatened to spreat into of her stork-producing states.

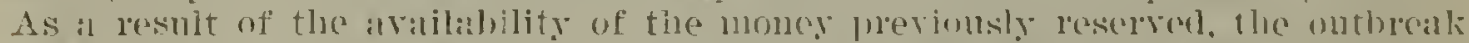
was bromglat undro conteol. "It" the reserve had not been avalable it would

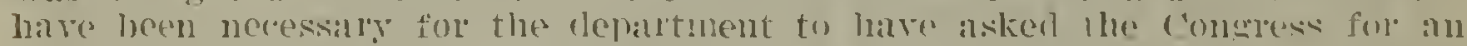
adflitional alpurepliation in comnertion! with this emergency.

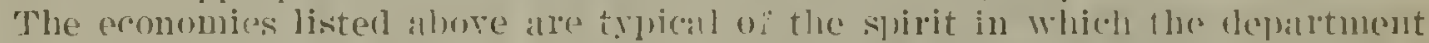
has enterest into the plan to condluct lhe business of the (iovernment on the most economical and efliciont hasis mussible.

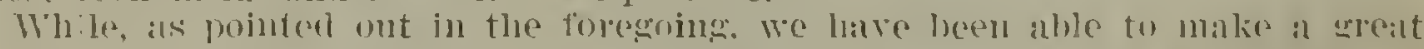

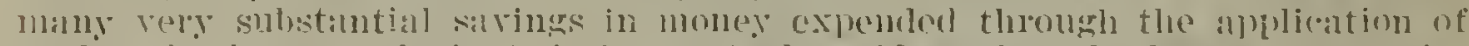

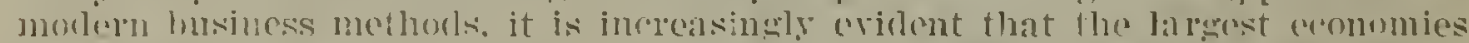

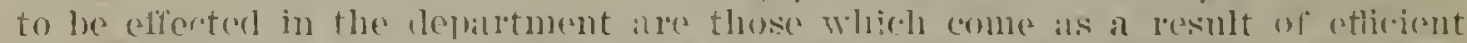

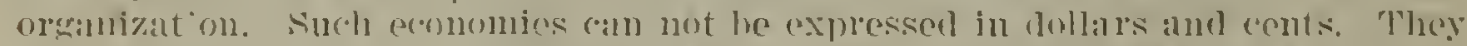

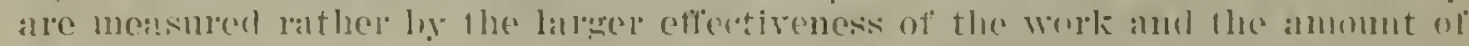

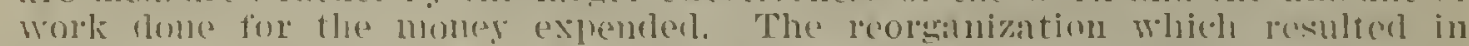

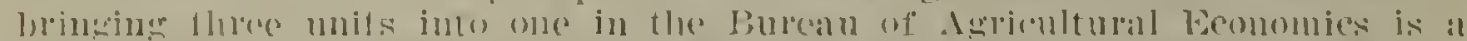

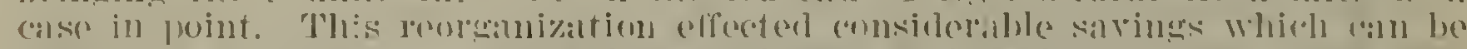

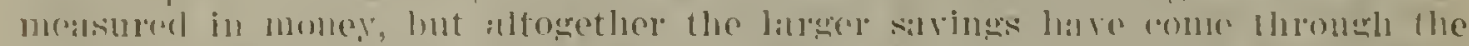

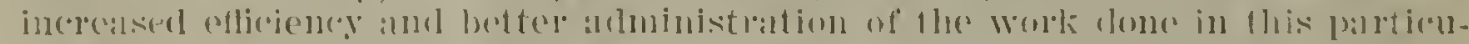

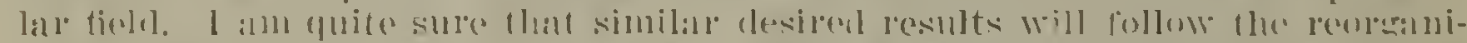

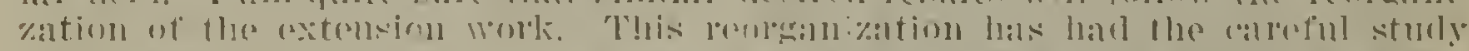

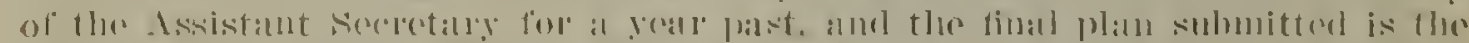

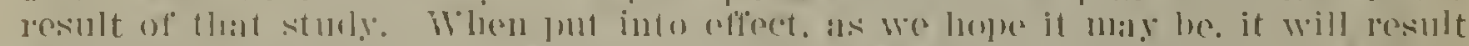

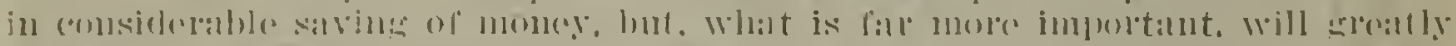

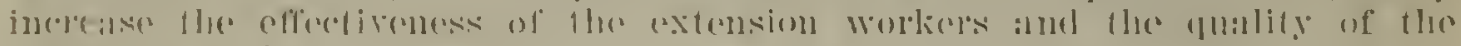
('Xtrilsiun work.

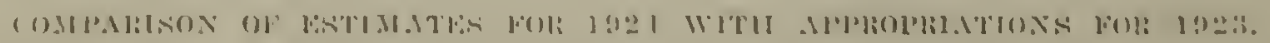

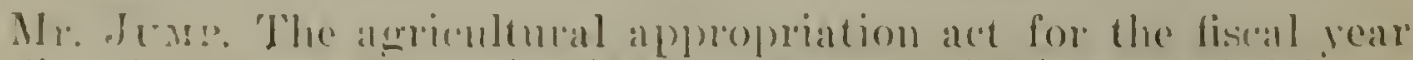

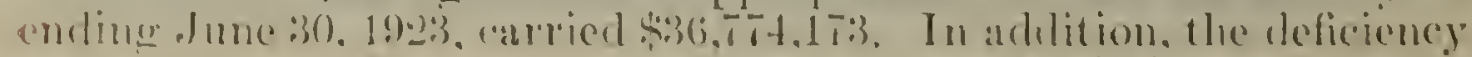

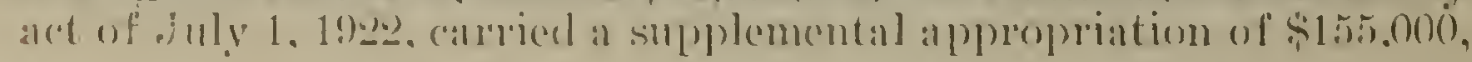




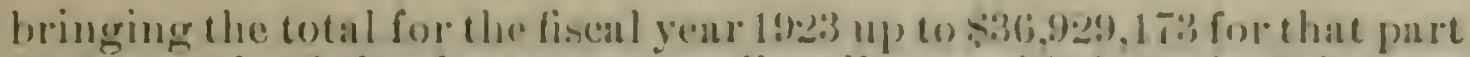
of the work of the department ordinnty provided for in this was. It the rerre outset I would like to invite the attention of the com-

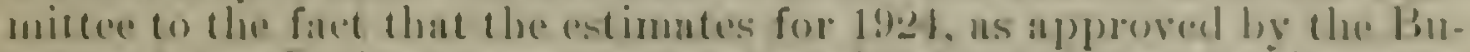

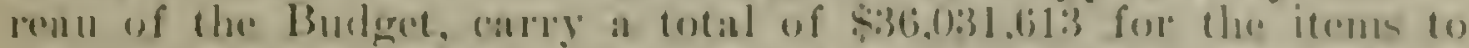
which the regulat agricoiltural act has previously beren andined.

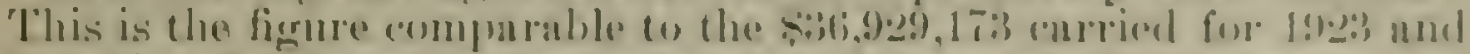
(1) which I refored n mement ago, mol therefore the estimates for the department proper contemplate a net reduction of 5499.5130 over the apporoprittons a vajlahle this year for the sane purpuses. There

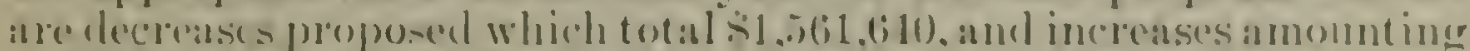

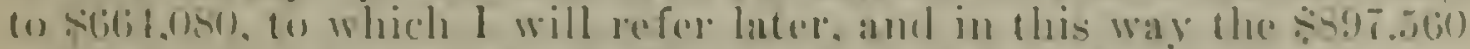

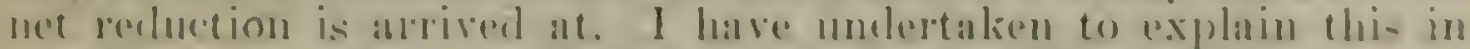
drat for the reason that in the rotimates for logl as submitted there

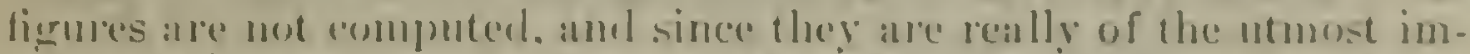
protance in any consideration of the apprepriations for the renglar work of the department. it exemened to me that the eommittee would

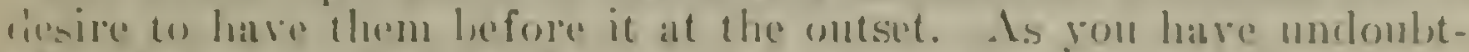
edly observed. the total fignre of the entimates is changed contirely

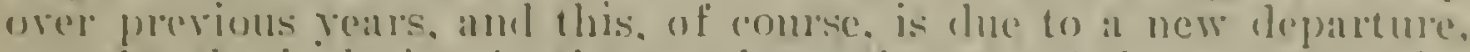
namele. the inclusion in the regrilat estimates of the recommemalat tions for the actual apprepriations. pursuatut to existing antherizat

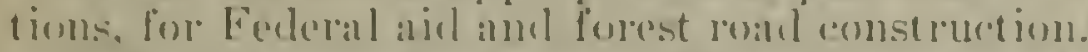

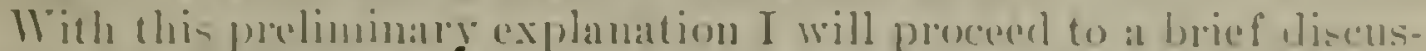
sion of thr Bulget as a whole, containing. as I have inclicatorl. not only

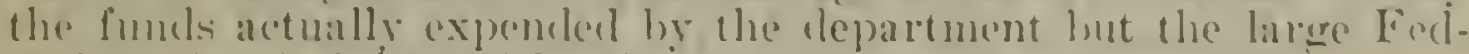

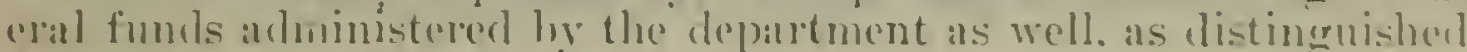
from those which it actually uses.

'The estimates as approved by the Burean of the Budero. contemplates, as the eommittee has seme the appurepriation of $\$-1.251 .61:$ : for all purposes. This is an apparent increase of \$18.8:9.9T orel

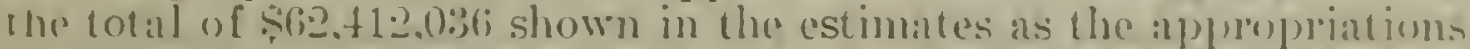
to dall for the same purposes during the fiscal youl 19:2:? But for

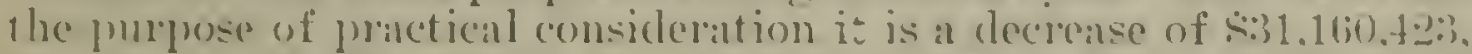
for the reasem that while the $5.50,000.000$ alpropriation antherized

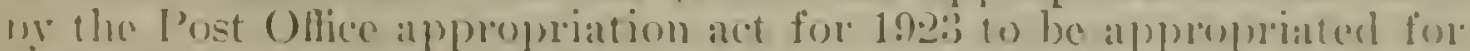
Firleral atil to the states in hiegway eonstruction during the liscal

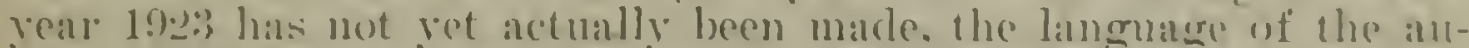
ihorization is sudi as to empower the Secretary of Aericulture to malie apportiomments amomer the states and to cinter into contractual obligitims on that hasis. It would seem. therefore. that the sint.-

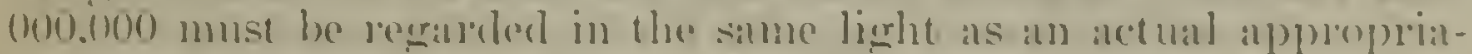

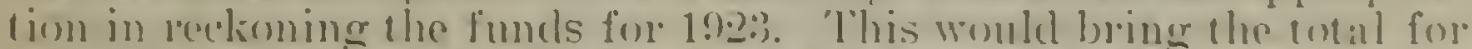
$102: 3$ up (1) \$110.412.(1):6, which compared with the total of the present entimales. I halle referped.

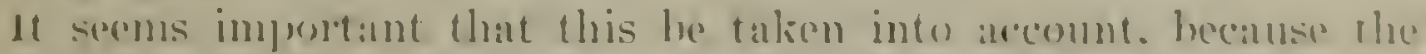
compilations which have been made of the actual appropriations for

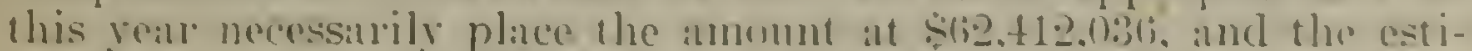

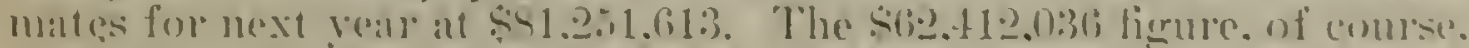

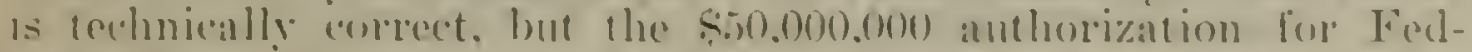
eral atil should be taken into ateonum with it, since. purstunt to the language of the anthorization. the apportionments have besn mate 
among the States for 1923 and contractual obligations lave been entered into. 'That is not true of 1924 and 192\%) but it is true of 1023.

Mr. Becrasax. Will it not be true in 1924? Till you not have some more to charge up to the $\$ \$ 1,000.000$ ?

Mr. J Irr. Yes; in 1924.

Mr. Bucrusis. Then ought not that also be taken into consideration?

Mr. Jurr. Not so far as the present escimates are concerned. for the reason that the $\$ 30.000,000$ included in the Budget represents the amount which will be required to be appropriated for cash withdrawals from the Treasury during the fiscal year 1924 , at the present rate of expenditures and without interference with the Federalaid program indicated by the authorizations.

Mr. Buchaxax. Then the economy comes from expending a less amount on the public roads?

Mr. Jurr. No. sir. The handling of the road appropriations is the factor which causes the material change in the total of the estimates over previous years, but I was not referring to it with the object of making the particular point of economy. I simply want to make clear that the estimates as submitted at this time do not actually contemplate the increase of some $\$ 18.000 .000$ which the totals apparently indicate, but, on the other hind. contemplate a decrease. The gist of the whole thing. with reference to the matter of a decrease, is that the items which in previons years malle up the regular Agricultural bill call for approximately $\$ 000.000$ less than the appropriations for this year for the same purposes.

\section{ITEMS INCLUDED IX ESTIMATES FOK 1924.}

Considering the Budget as a whole. the total of $\$ 81.251 .61: 3$ rexommended for 1924 is made up in the following manner:

First, as I have explained previously. the items comparahle to those formerly included in the regular Agricultural appropriation act carry a total of $\$ 36,031.613$. 'This is a net rentuction of $\$ \$ 97,560$ below the amount carried for similar purposes in the Agricultural act and related supplemental acts for the fiscal vear 1923.

Second, the group of appropriations to which we refer as "Permanent. indefinite, and special" funds carries a total of $\$ 1.2 .200 .000$ for 1924 , a reduction of $\$ 30,000$ orer the current rear.

Third, the committee. of conrse is entirely familiar with the provision contained in the Post Office appropriation act of 1923.3 , to which I have referred previonsly. and which anthorizes appropriations for

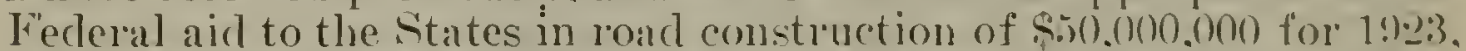
$\$ 65,000,000$ for 1224 , and $\$ 75.000,000$ for 122.5 . and $\$ 6.500 .000$ eatch for 1024 and 192:) for forest roads. The burean of the l3urlact has inclurled \$30,000.000 Federal aid and \$\$3,000,000 for forest roalds in the repartment hudget for 1924 . 'The remainder of the anthorizations for 192-t presumably will be recommented when the rate of cals withdrawals from the Treasury seems to require it. This, I helieve. is the point Mr. Buchanan hat in mind a moment ago.

Ir. A numerson. Autlorizations only? 


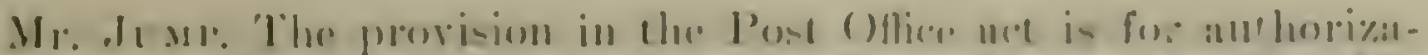

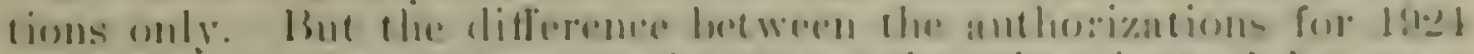

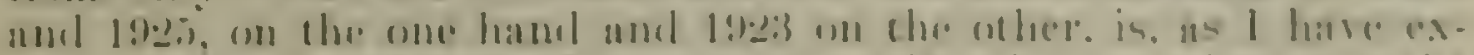

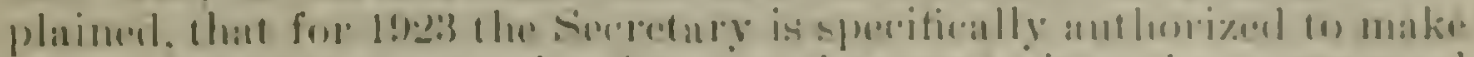

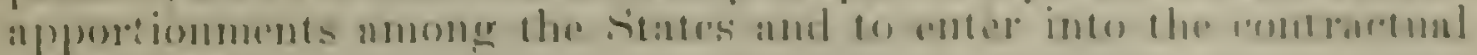
olligintions.

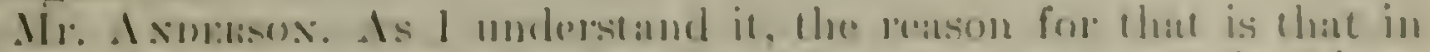

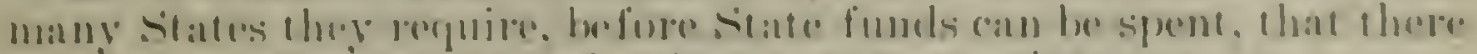

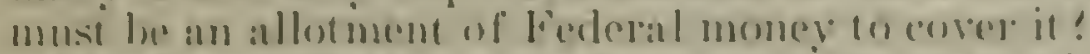

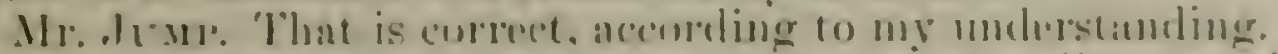

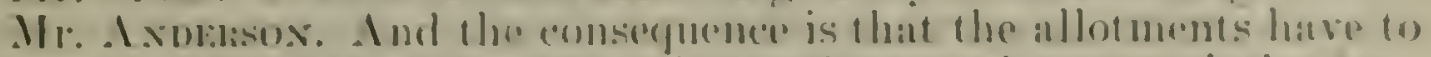

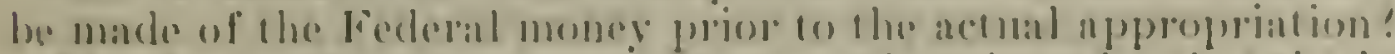

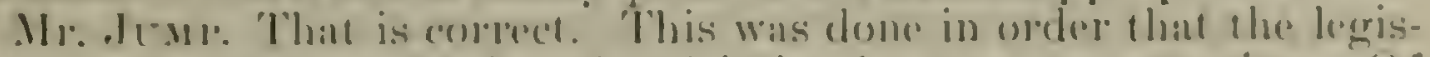

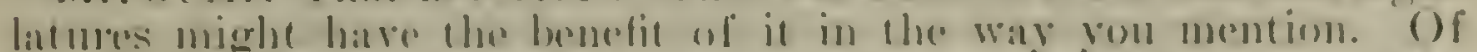
comse. I an only deal ling with this in the mest groneral way now: Mr. Melomald. the Chiof of the Burran of Publie Roads. will gen inte) this fully when he comes hefore the commitles. I merely want to erior an idea of the there anderal divisions into which the estimates inay be classified.

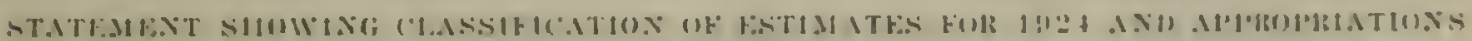
1018 $19: 2:$.

'Tu smmmarize the whole thing, we find that for practical considerattion the estimates now submitted, as compatred with the appropriations for the current liscal rear. are as follows:

(The table here submited by $\mathrm{Mr}_{\mathrm{r}}$. Jump is printed in full, as follows:)

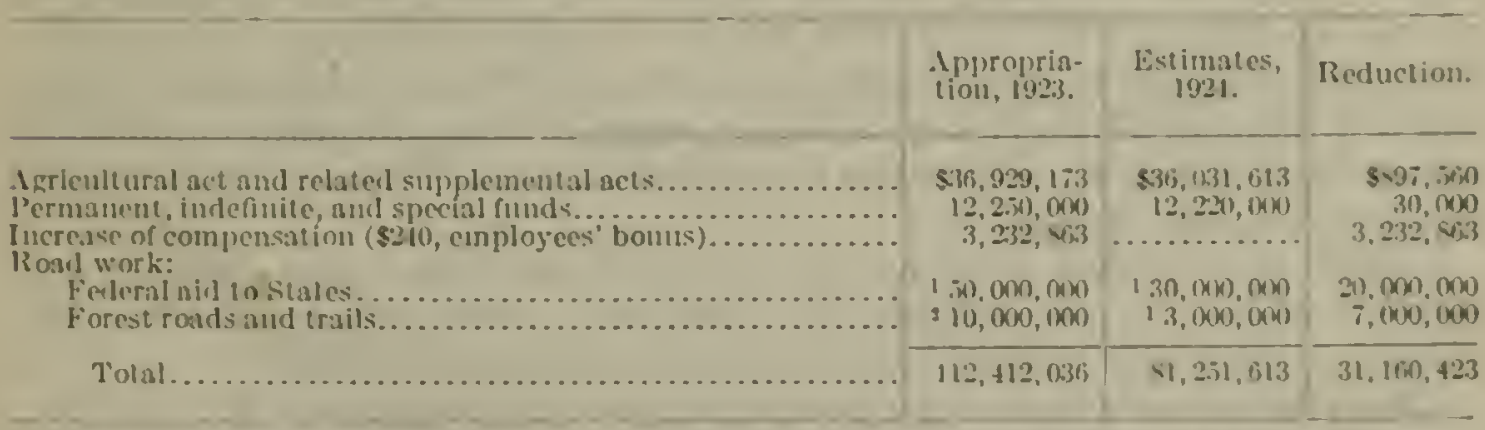

1 Tho post office appropriatlon act for 1923 nuthorizes ajpropriations for federal aid in road eonstruc

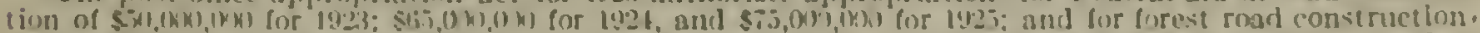

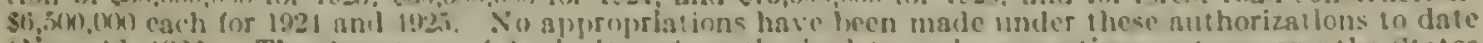

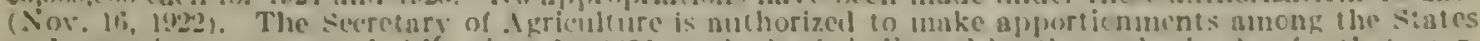

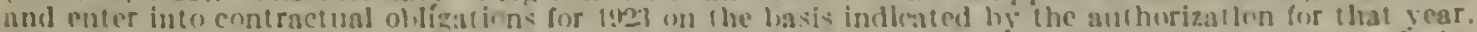

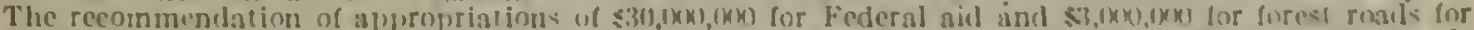

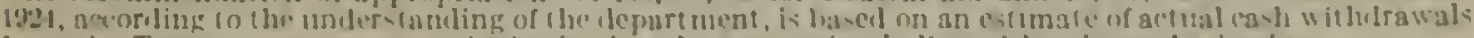

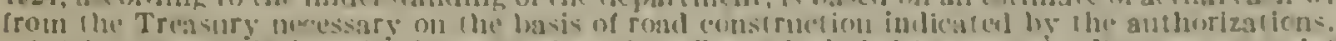

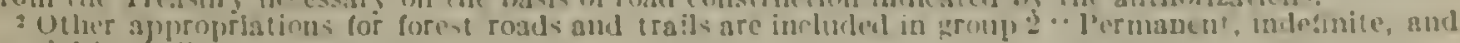
pecial furds.,"

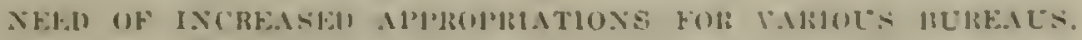

Mr. Jump. Now, if I may do so, I would like to return to a further brief discussion of that part of the estimates which deals with what may be termed the regrilar work of the department. Despite the net reduction of nearly sign)(0.000 which has been made in this portion of the astimates provision is made with the approvill of the Burean of the Budget for a limited number of items. most of them involving 
very modest amounts, but which the Secretary regards as of the utmost importance, because they deal with constructive research work, which the department-and I feel sure also the members of this committee-believe to be absolutely fundamental to the future prosperity. not only of the agricultural industry, but of the entire Nation. The work of scientific research, which has been so productive in the past, in dereloping improred practices and adding year after year to the economic wealth of the Nation is the basic work of the Department of Agriculture and the Secretary is very hopeful that the committee will give the most farorable consideration to the items in the estimates which provides small increases for certain lines of work under the heading. When it is taken into account that less than a fourth of the total appropriation for the regular work of the department is available for scientific research it is clear that this is the type of work which must receive increased support if the progress of the industry is to be assured.

The total amount of increases carried in the estimates is $\$ 664.080$. and as I have said before, these are offset, in the estimates as passed by the Bureau of the Budget. by reductions totaling $\$ 1,561.610$ below the 1923 appropriation.

In the Bureau of Animal Industry. for instance. we hare increases requested of $\$ 15.680$ for animal husbandry investigation and $\$ 15.000$ for the dairy experimental work at the Beltsville farm.

Under the Bureau of Plant Industry we have listed here 10 projects which the chief of the burean will take up in detail, totaling an increase of $\$ 96.100$. These particular increases have been selected with the utmost care from a long list of items which the department really regard as necessary, all of which we would feel warranted in taking up except for the present need for urgent economy in expenditure. These particular projects have been selected as the most urgent and we have kept them down to the verv lowest amounts consistent with effective work. This may be said with equal force of each one of the items in the estimates.

Under the Forest Service we have three items, an increase of $\$ 43.000$ which we are asking for absolutely necessary improvements on the forests and experimental work on forest products.

The Bureau of Chemistry items include an increase of $\$ 22.500$ for agricultural investigations along chemical lines: $\$ 20.000$ for sirup and sugrar work: and an increase of $\$ 35.000$ in connection with that important food and drugs act. The latter seems absolutely necessary in oreler to give the public and the better elemerits in the inclustries affected the protection contemplated by the act.

A small inerease of $\$ 5000$ is asked for the department library in orfler to purchase books, the lack of which ereatly hampers the

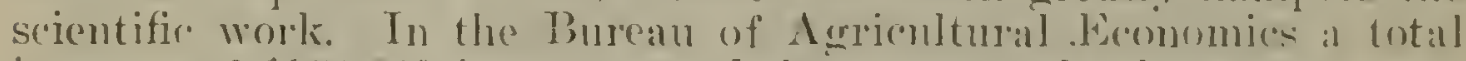
increase of $\$ 251.200$ is resommemied to cover only the most urent and important things which have heen selected hy the serentary as those which it serms to him shoulel reserive attention at this time in connertion with eronomic work. As you know. the seceretary has devoted a great rleal of personal attention to the aconomic work in the time he has been in the department. and the increases asked alongr this line seem vitally necessing at this time. 'The increases

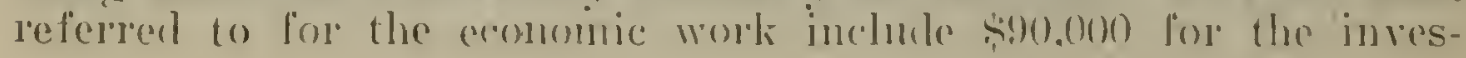


tigntions in the marketing mol distribution of farm proxlunts. s.2.

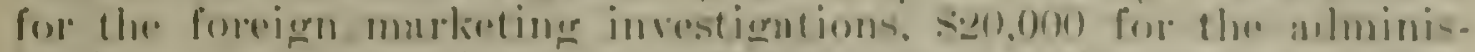

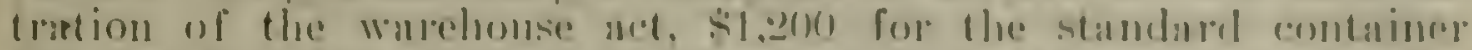

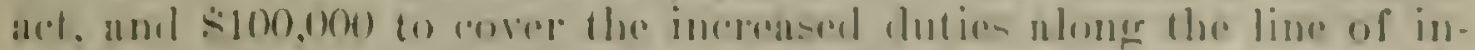

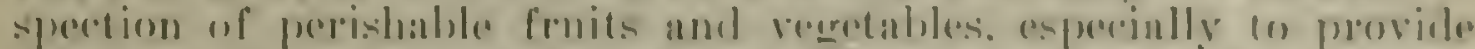

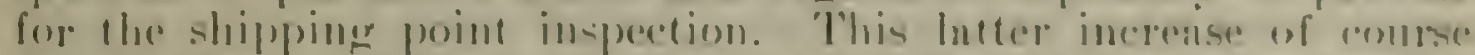

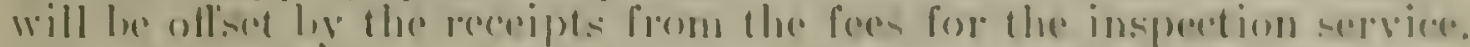

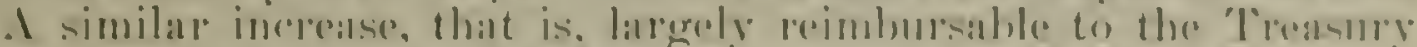

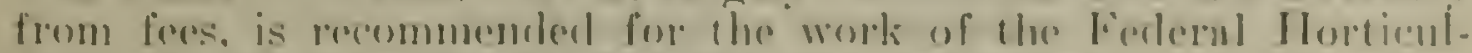

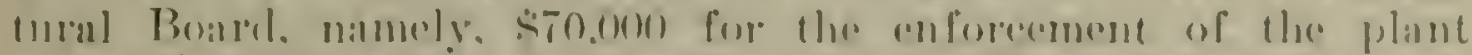

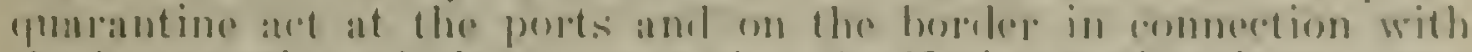
tho importation of plants. protecting low Notion against insoct prests

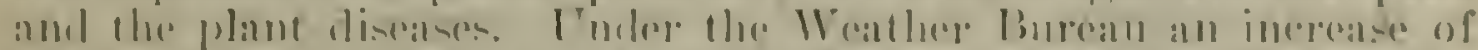

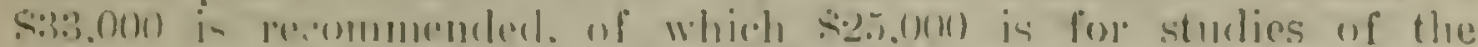
"1p

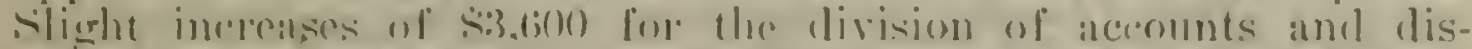

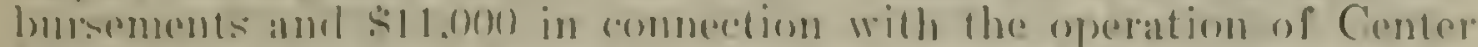

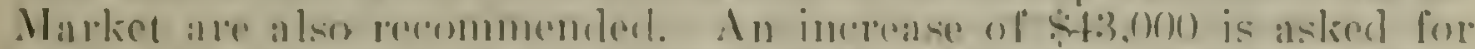
the important work of the Buresu of Entomologe in condurting its

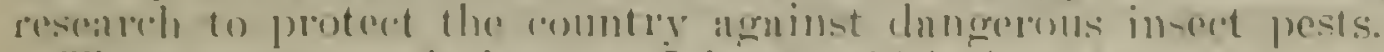

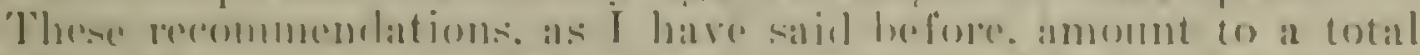

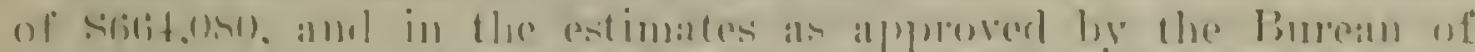

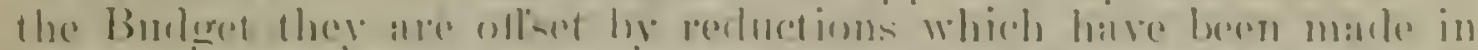

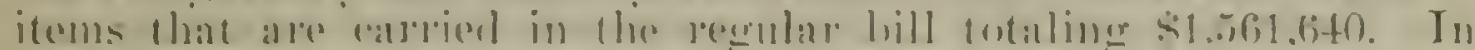

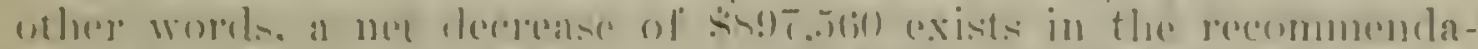

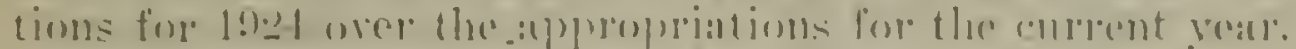

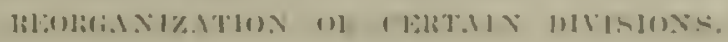

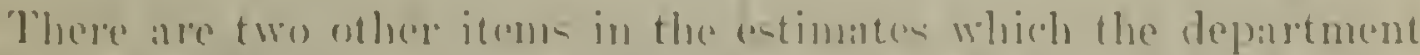

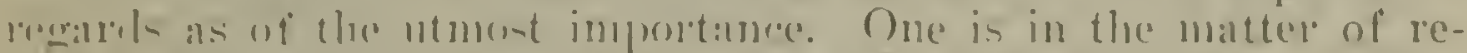

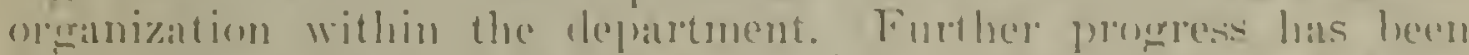

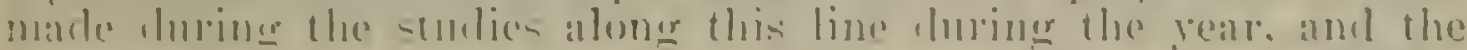

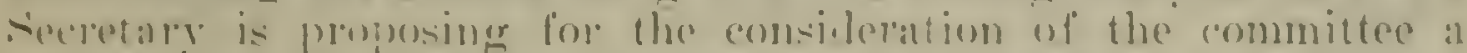

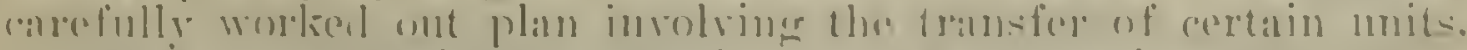

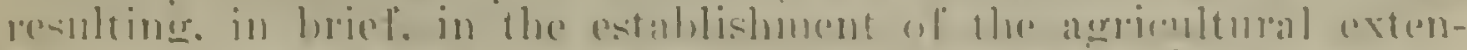

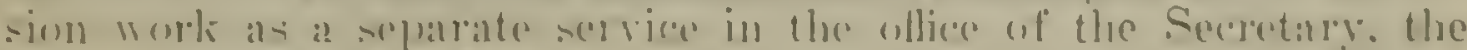
sepalation of the oflieres of experiment stations and the ofliere of

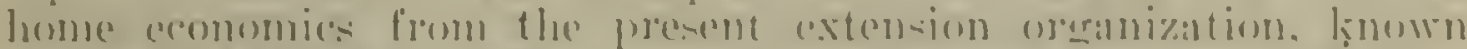

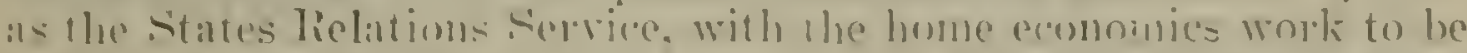

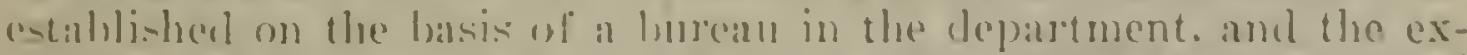
feriment station work to le a sepalrate ofliere moler the director of

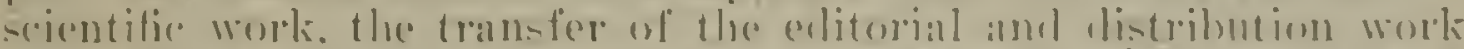
of the division of pmblinations into the oflice of the secretary and

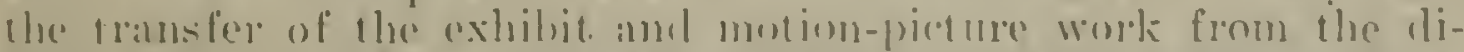

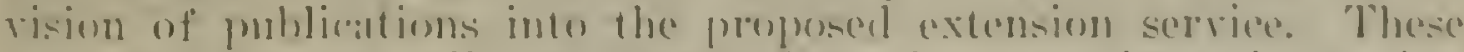
proposed rhanges will be presenter to the committee in a fow

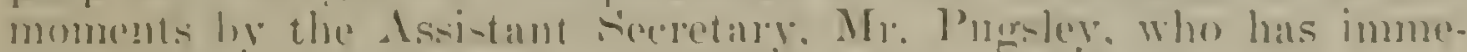

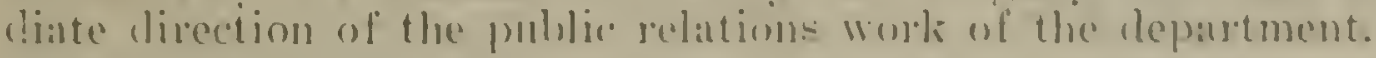

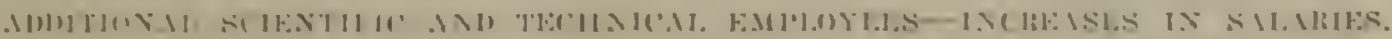

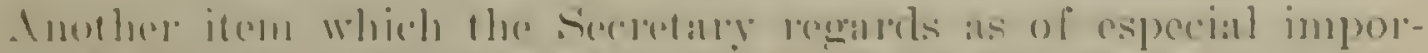

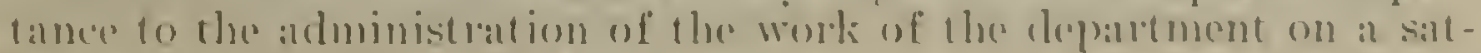

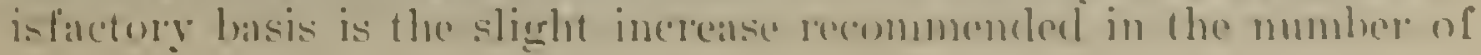


scientific and technical employees who can be emplored at the maximum salaries set for these grades. Doctor Ball. the director of scientific work. will give the committee the full details with regard to that item when it is reached.

I helieve the secretary has aheady assmed the charman of his willingness to come before the conmittee in connection with these items at any time you may desire. and of comrse he will be rery glad to do that if you wish it.

REDUCTIONS IN ST.ITUTORI ROLLS.

Before taking up the detailed estimate I wonld like to revert. for a moment, to the general subject of economy and at the same time clarify the situation with respect to the statutory rolls, as this is a point which will come up as we reach the rarious bureans in the estimates. The matter to which I refer deals with re.luctions in statutory places. During the consicleration of these estinates it hecame necessary at one stage to effect a considerable reduction in the total amount involved. The Secretary called npon the rarious branches of the department to make a sirvey and report to him the statutory positions which could be dropperl, amounting wherever possible to 3 per cent or more of the total of statutory saluries. these positions, most of them in the lowest grades. to be dropped at the close of the current fiscal year. The Secretary has had the feeling that these forces could be reduced somewhat without impailment to the service, and you will note that accordingry statutory reductions. amounting altogether to $\$ 157,620$ and involving 198 places, are proposed all the way through the bill. A great many of the positions to be dropped are vacant and as the rate of tmmover in these low irracles is extraordinarily high most of the places that are filled will become racant some time between now and ofnly 1, 1923. A sulnmary of this proposed reduction may be of interest to the connuittee, ancl if ron desire I will insert it in the record. (The statement referred to follows:)

Statutory positions recommended to be diropled in estimates of ammonniatims for Department of Alfriculture for fiscul yeur 1???.

\begin{tabular}{|c|c|c|}
\hline Name of burean. & $\begin{array}{l}\text { Number } \\
\text { of places. } \\
\text { droopers. }\end{array}$ & $\begin{array}{l}\text { Imomint } \\
\text { imsolverl. }\end{array}$ \\
\hline 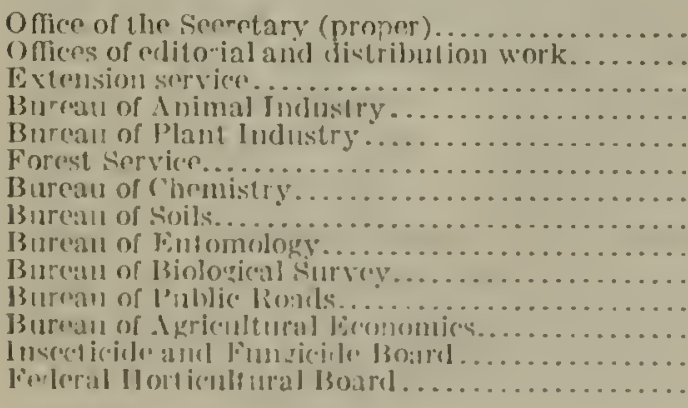 & 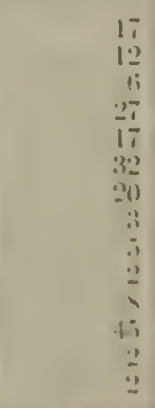 & 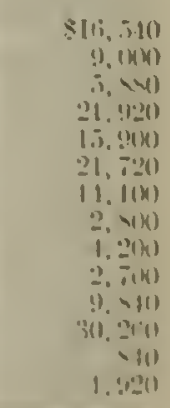 \\
\hline Total places iroppent..... & $1 ! 4$ & $1 ; i,(2,21)$ \\
\hline
\end{tabular}




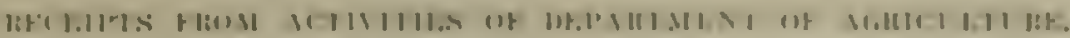

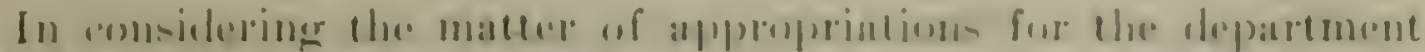

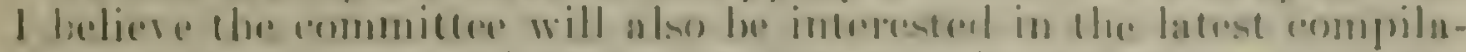

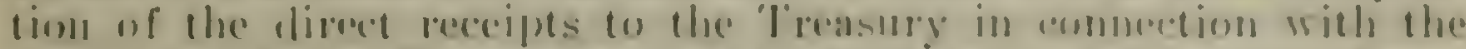

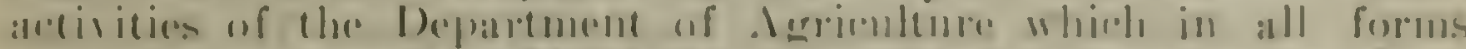

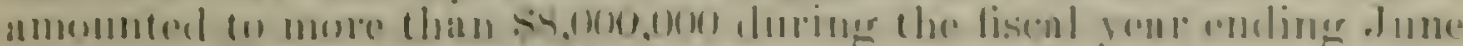

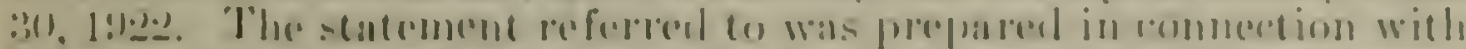

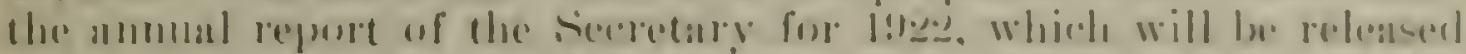

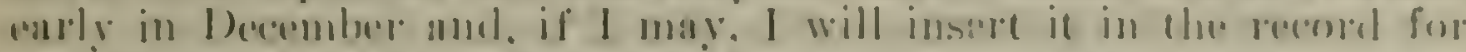
the information of the restumitler.

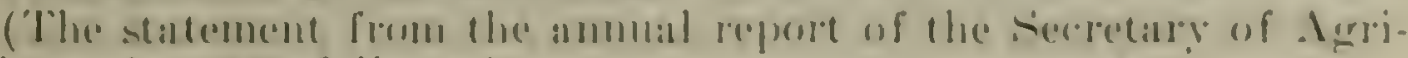

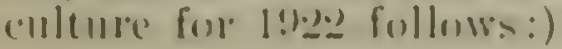

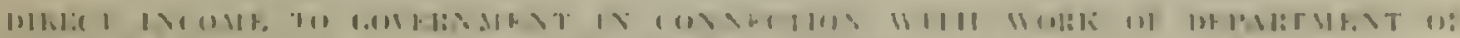

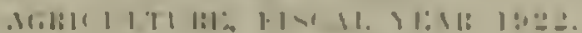

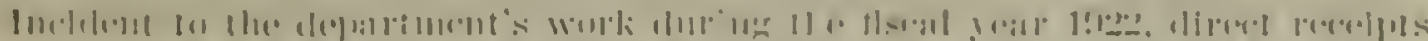

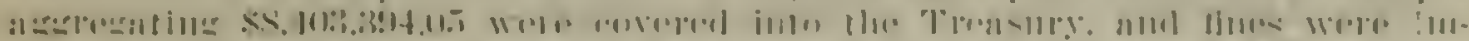
|

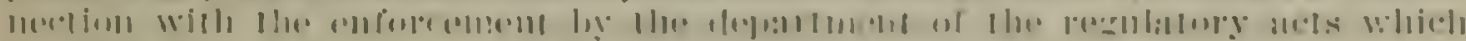

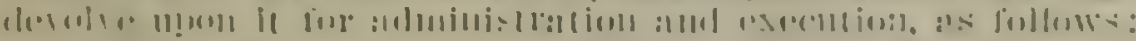

$\operatorname{lin}(1+i) 1 \div:$

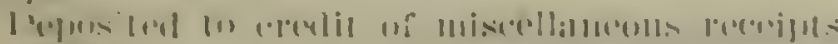

IIIIII-

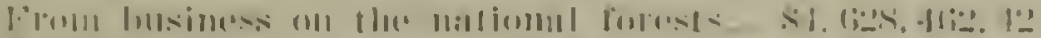

F"loll1

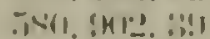

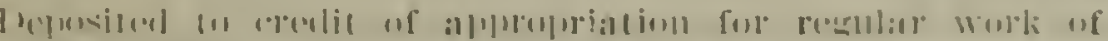

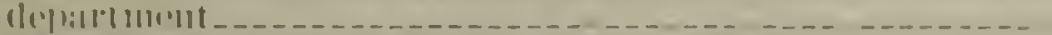

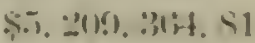

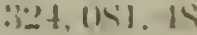

lapksilul ln iremlil

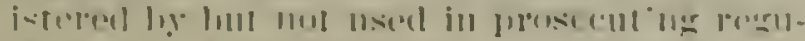

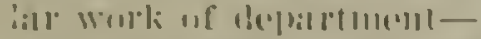

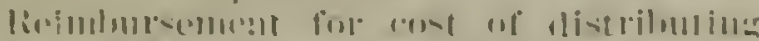
:

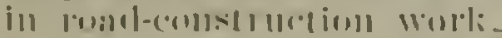

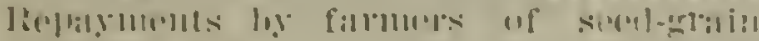
lo: $: 111$

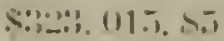

lifis. THב.: T

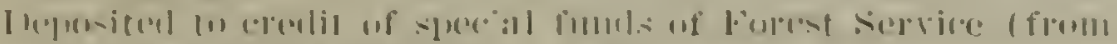

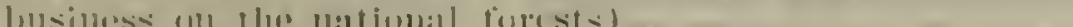

Tillal rupill: 1. ละ. 14ง. 1 t

S. $411 \%: 39.111$.

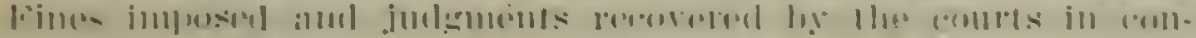

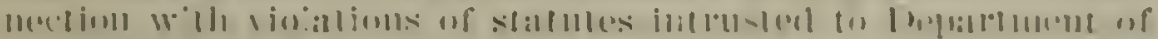

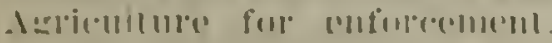

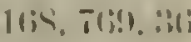

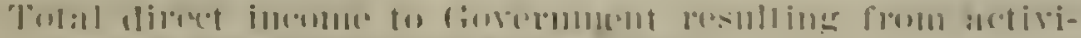

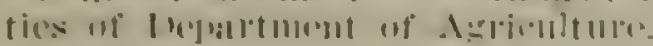

S. $.17 \div, 163 .+11$

OFFICL OF THE SECRETART.

STATEMENT OF MR. R. M. REESE. CHIEF CLERT DEPARTMENT OF AGRICULTURE.

S.M1..11:1t:-

Mr. likrse. I will hegin un the sixth line of the statutory roll. The italies indicate the propereel changres. We are recommemeling the fransfer of 14 places from the rolls of uther burenus of men permanenty needed in the secretary - hranch and which are carried on Imup rolls. with corresponding reduction an all the rolls allected. 
Mr. Anderson. Where do you get this traffic manager at $\$ 3,000$ ?

Mr. Reese. By direction of the IBurean of the Budget the Federal Traffic Board was created. with instructions to each of the departments to appoint a representative on that board. The secretary appointed the traffic man of the department as representative on the board. 'The business of the Federal 'Traffic Board dereloped so rapidly, and its results are so useful that the representative of the Department of Agriculture on the Board was clesignated traffic manager to deal with all the raried traflic problems of the department, to advise shipping clerks of the proper routings, proper classification of freight, the correct freight rates, and other traffic problems.

Mr. A nderson. Is there any a uthority of law for this place?

Mr. ReEse. I take it the anthority is the Secretary's general administrative authority under the act of March 1,1907 , to malie appointments on lump-fund appropriations. This would put it in the law.

Mr. Anderson. No; it would not. That is a transfer.

Mr. ReEse. It is a transfer from the lump-sum appropriation for the enforcement of the plant quarantine act.

Mr. Anderson. What is your next item?

ADAIXISTIATIVE ASSISTANT.

Mr. Reese. The next item is the transfer of one administrative assistant at $\$ 3,000$.

Mr. Axderson. Where do you get him from?

Mr. Reese. We take him from the Bureau of Entomology appropriation for preventing the spread of moths.

Mr. Anderson. What does he do?

Mr. Reese. This is Mr. E. H. Bradley.

Mr. Jump. Mr. Bradley handles special assignments mucler the Secretary's office. He assists in the preparation of the annual estimates, keeps track of legislation pertaining to the work of the department, compiles special statements, reports, etc. He has been employed in this capacity for some time.

Mr. Reese. The next change is the change in designation from executive clerks to executive assistants, the object being to make a uniform designation for a group of employers performing responsible work at varying salaries. There are three positions at $\$ 2.500$ calch. two transferred from farmers' cooperative demonstrations and the other meat inspection.

Mr. Anderson. Are these people employed in the secretary"s oflice now?

Mr. Resse. They are, and will be permanently employed to carry. on the work of that branch.

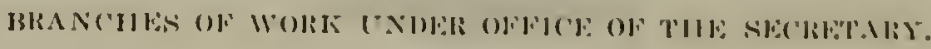

I should like to say, to prerent any misapplehension concerningr the phrase "the secretary"s oflice" that it is not limited to the immediate oflice of the Secretary of Agriculture. It means the Secretary"s branch, which includes at the present time the immediate oflice of the Secretary; the oflices of the Assistant Secretary, the directom ... 
seientific work, and the solicitor, an well as the ollices of the chief clerk, personuel, nnd inspertion. mechanical superintendent, etc. It is an administrative branch which. for brevity. we spenk of us the oflice of the secretury. but I would not like to create the impressien that that is the Sorcretary's immelinte oflice only. "These represent the ereneral administration and operation of the ilepurtment.

Mr. A xmosios. Is any part of it dependent upon dhange in the extension sorvice items?

Mr. Rrass:. No: only the direetore of the extension sprvice is set forth abore. Doetor Pugrsley will speak (o that. What I have denlt with, so far. are the men employed for the work of the sieceretarys branch.

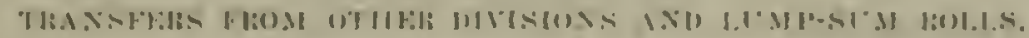

$(\stackrel{1}{*}$ P. 1.1.)

The next item is two exechtive assistants at \$2:20) transfered one

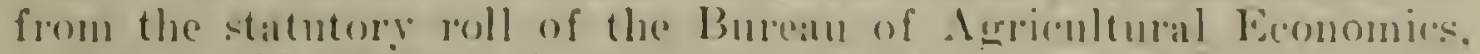

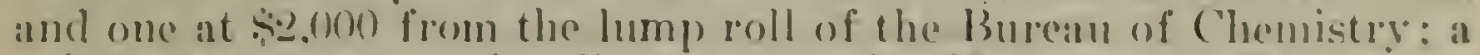

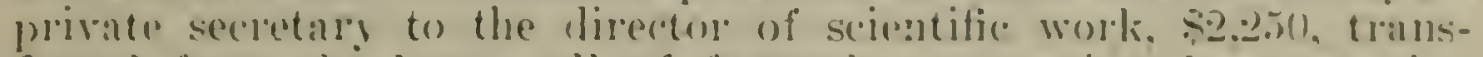
ferred from the hmp roll of farmer"s cosperative demonstration work.

There is a misprint in the thirteenth line down after " o at a. mach." That should follew is "one attorney. 4.000$)$. fone two at $\$ 0.500$.

Mr. Ixmbisox. You have heretofore explained the private secretary to the director of scientific work?

IIr. Rmsk. I referred to that. 'That is at transfer from the lump roll. There is no other change until vou get down to the thirteenth line-live law clerks, at \$2000 each.

Mr. Axmmon. I understand the remainder of that line goes ont? Mr. Rrask. les.

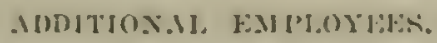

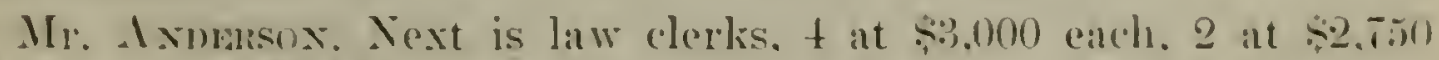
each. and 2 at 503,5$) 00$.

Mr. Bicnaxax. That will make two new places, one at $\$ 4.000$ and one at $\$ 3.500$ ?

Mr. Rarss. 'That is eorrect. sir.

Mr. Axmman. Are persons now employed at these salaries in the solicitor's office?

Mr. Rrisis. There is one at \$3.500.

Mr. Axnresus. But the other two places do not exist?

Mr. Reliss. The other two places do not exist. and we want to (reate them. In that connection it ought to be pointer out that we are rlopping out of the solicitor's oflice five at $\$ 2.000, \$ 10,000 \mathrm{in}$ all. So that this represents a reduction of $\$ 2.500$ in that stafl. The solicitor will, if desired. speak to his needs on that subject. They are, in brief, and we can not secure qualified lawers for the complicated work of the repartment at $\$ 2.000$.

Mr. Axmmox. 'There is no statutory anthority for the cmploy$1+1$ ment of these persons at these salaries, except the general anthority 
of the Secretary to employ persons to do the work of the Department of Agriculture.

Mr. Reese. That is true. That general authority is found. as to positions on lump-sum appropriations. in the act of March 4.1907, referred to above.

Mr. Buchasax. Let me ask you one question about these transfers. Are they all transferred to the Secretary's office at the same salary they are now receiving?

IIr. Ress. Tes, sir: all at the same salaries they are now receiring. There are no promotions.

Mr. Axmmison. The net result of this is that you drop five law clerks at $\$ 2,000 ?$,

Mr. Resse. Ies: and appoint one attorney at $\$ 4,000$ and one at $\$ 3.500$. making $\$ 7,500$.

Mr. Axpersox. Are any of these five places that you now have at $\$ 2.000$ filled?

Mr. Reese. Only one.

TRAXSFERS FROM OTHER DIYISION AND LLMP-SLAI ROLLS.

(See p. 13.)

The next change comes down at the fourth line at the bottom. transfer of one clerk, class 3 , at $\$ 1.600$, and one clerk, class 2.

Mr. Axnersox. Is that a transfer?

Mr. Rerse. Tes; these are all the same kind of transfers. from bureau lump-sum rolls, with rolls reduced accordingly.

The next item, as explained, is in the next to the last line. four clerks at $\$ 1.000$ reduced to three. We have changed the designation of one of those employees to skilled laborer. for the reason that he is a skilled laborer now carried in a clerks place by anthority of the Ciril Service Commission. It should be changed to agree with the actual facts.

In the next place, there are four at $\$ 900$. rechnced from six. One of those was changed for the same reason, a skilled laborer now carried in a clerk's place by authority of the Civil service: and the other is dropped, as set forth later in these notes.

One accountant and bookkeeper. \$2.000. is transferled from the Secretarys office to the Burean of Agricultural Economics: where he is now employed.

Page 3. one skillerl laborer, at $\$ 1.000$. is transferred from the Bureau of Animal Industry for the same reason. he is working for the Secretary's branch: six messengers or laborers, at \$600. reduced to four. One is a change in designation to a messenger boy. now occupying the place: the other is iropperl.

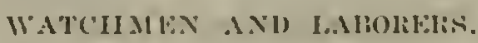

Fifty-two watchmen are reduced to 51 : one place is dropperl.

One skilled laborer at $\$ 1,200$ is transfered from the Burean of Soils, for the same reasons as the others.

Four skilled laborers increased to tive. That provides for transfer of the man I have referred to above, whose designation is changered from clerk to skilled laborer. 


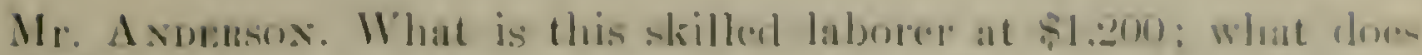
he do?

Mr. Tirist. The mun really has a clerical status: he is working for the Assistant Secretury.

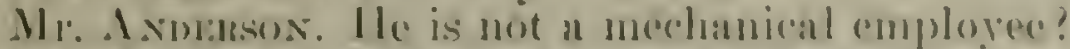

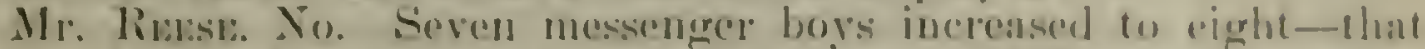
refers to the change just ahove, where one at sigon was dounered in

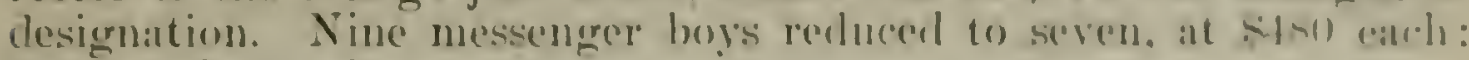
two are dropped.

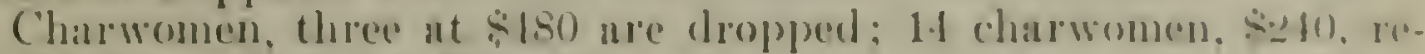
duced from 16-2 ine dropped.

P'ate 69 of these notes refers to the list of places clropped in the ollice of the secretury ungregnting $\$ 16,0.41)$.

Mr. Buchaxax. Speaking of this skilled laborer at $\$ 1.200)$, now doing elerieal work, is it practioal for the department to put a skilled lahorer moler a statutory roll doing clerical wenls!

Mr. Rives. I should modify that statement, perhaps. in this way He is not doing exclusively clerical work, but clerical work in addition to his other duties. He has a clerical status.

Mr. Bremaxis. Is he employed as a skilled laborer or under his status lor clerical work?

Mr. Risis. He is employed in both wayse if I can make myself clalls. He does some work as skilled laborer and incidentally cherical lahor. There is no impropriety from the civil servire in "irroing a clerk as a skilled laborer if the employee is willing.

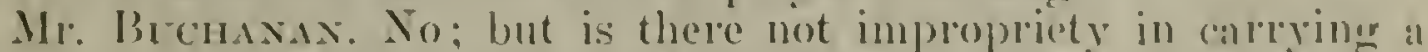
clerli on a statutory roll as skilled laborer?

Mr. Reser. No.

Mr. Bucusax. Then you could put all skilled laborer's at clerical work, as I mulerstand it.

Mr. Axmeksox. Not unless they had a civil-service status.

Mr. hass. Not unless they liad civil-service status. This man h:ls.

Mr. Buchaxas. And employed as such?

Mr. Ratri. Paltly as clerk and partly as skilled laborer. We could not use skilled laborer's as clerks unless they had clerical status. which he really has.

Mr. Brenuxix. (Of course, he has a higher status than skilled laborer?

Mr. Rass. There are quite a few skilled laborers at $\$ 1,200$ scattereel through this book.

Mr. Bucruxax. I just thought that muler the civil service rules and regulations that a man has to be one or the other" he can not be both.

Mr. Rersis. That is a natural and a proper question. The fact is that he was a skilled laborer and doing skilled labor work. He passed the derical examination, as his work dereloped. griving him il clericil stitus.

Mr. Bechaxax. But he was not employed or assigned to any duty after his examination: he just passed it and the department liept him on the rolls as skilled laborer and put him at cherical work?

Mr. Riswa. More or less clerical. Ile does not spend his whole time at clerical work; he does it incidentally. 
Mr. Magef. He is a skilled laborer with civil service status of clerk?

Mr. Rirse. les. There is nothing else on that statutory roll we care to speak about.

Mr. BCchisas. All of these people that have been transferred from other rolls to the Secretary's branch have been dropped on those other lolls!

Mr. Rrese. Tes. sir.

Mr. Brchaxax. And no additional employees are required in the department on bureau from which they have been dropped?

Mr. Rerse. No: they have been working right along for the Secretary's office. and the appropriations--

Mr. Bucrasax (interposing). I mean, in the estimates in force now there are no additional employees requested to take their places?

Mr. Reese. No.

\section{DECREASES IN STATUTORL ROLIS OF DEPARTAENT.}

Mr. Jumr. As a mattel of fact, Mr. Chairman, the department is recommending decreases in the statutory rolls in the net figure of approximately 200 places, amounting to $\$ 15 \%, 000$. During the consideration of the estimates it became necessary to effect a consiclerable reduction, and the Secretary required the bureaus to make a survey and indicate a list of statutory positions amounting as nearly as possible to 3 per cent of the personnel on the statutory roll, these positions, most of them in the lowest grades, to be dropped at the end of this fiscal year. The Secretary has had the feeling that these forces could be reduced somewhat, and as a result of that you note these statutory reductions all the way through the bill as the various units are reached, dropping positions from the routine grades on the statutory rolls.

\section{MECHANICAL SHOPS AND POWEK P'LANT.}

Mr. Anderson. The next item, page 5 , miscellaneous expenses.

Mr. Reese. Referring to page 4 just a moment, if you please: Salilries and compensation of necessary employees in the mechanical shops and power plants of the Departiment of Agriculture. It is recommended that that proviso be dropped as permanent legislation"that hereafter." That is the only change. "The amomnt is the same.

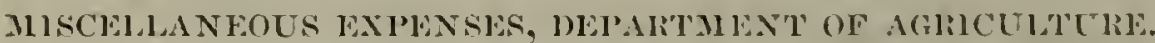

M1. Anmbinon. 'The next item, page to.

Mr. Rvast. Miseellaneons expenses. There are two things there. The italic lines indicate anthority for maintenance, alde. and operation for antomobile for oflicial wise of the seceretary of $\mathrm{A}$ gr ienlture. It was thought hetter to got that specific anthority in this plate.

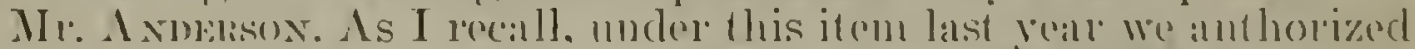

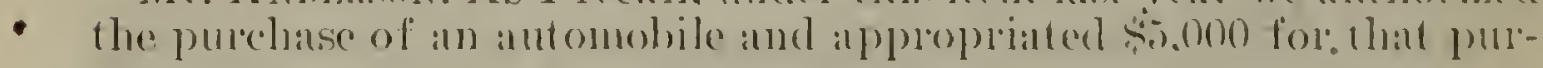
pose.

Mh. Risks. 'That was done.

Mr. A viblesen. You propese now to drop the item?

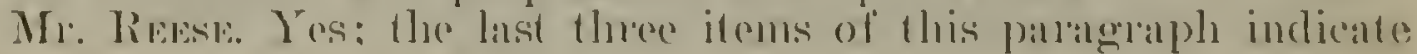
the diropping out of thit $\$ 5,000$. 


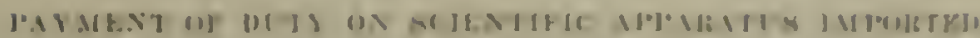

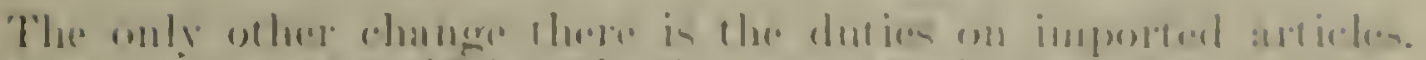

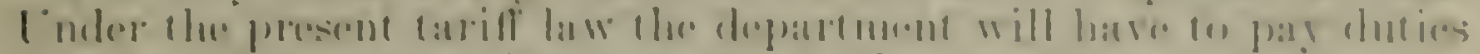

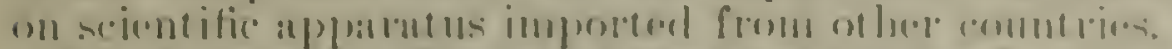

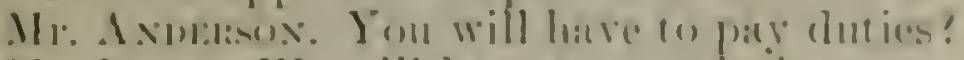

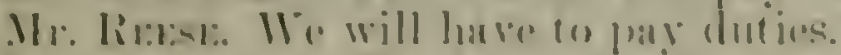

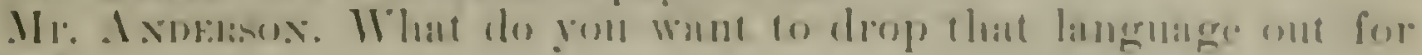
then!

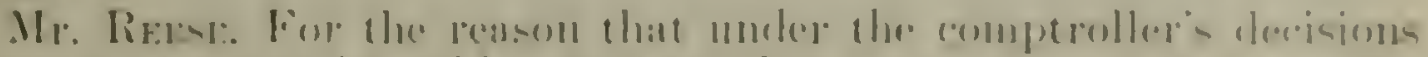
those huties maly be paid on of amy lump-sum sppropriation. The

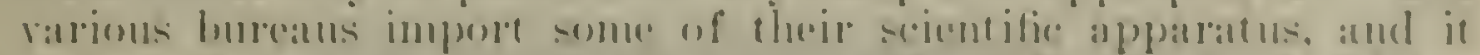

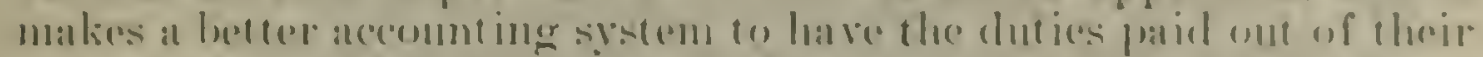
own appropriations rathe ihan lo have it (onte ont of miscellaneous (exp) 'וlsists.

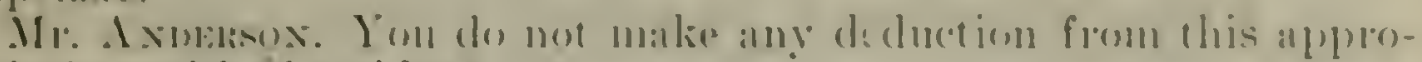
priation with that idea!

Ilr. Rrast. No: we do not.

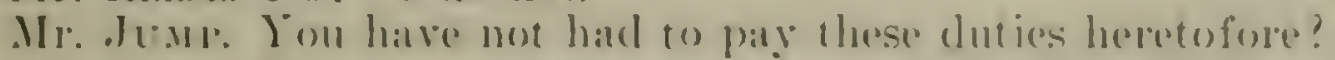

Mr. Rriss: No.

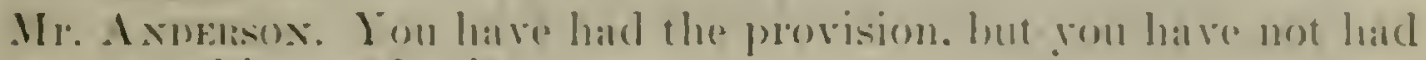
to pay anything moler it!

Mr. Risks. Fo. It is a matter of no trreat importance. The thenght we could drop this mut of here. but it could stily in.

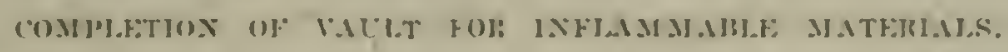

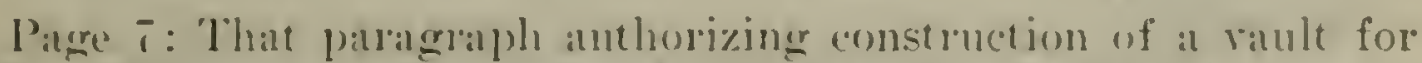
inflammable materials is dropped. The vamle is narly finished.

Mr. A smbsos. You think it will be finished before the and of this fiscall year?

Mr. Rass. It will be finished inside of a few weeks.

Mr. AxDrhisos. Where is thi- rault?

Mr. Rerse. It is constructed on a knoll just aloout sontle of the department shops.

Mr. Axmensos. How bier is it?

Mr. Rrise. It is about 301 by 2. feet.

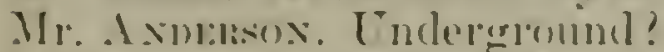

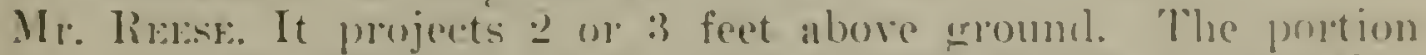

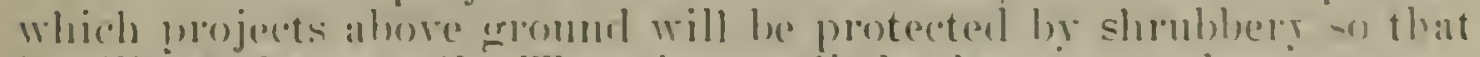
it will not slow at all. There is rery little aluove grouml.

M1. Axurasus. What disl the rallilt ("ost?

Mr. Rraral: sion.

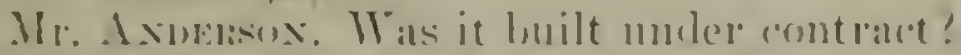

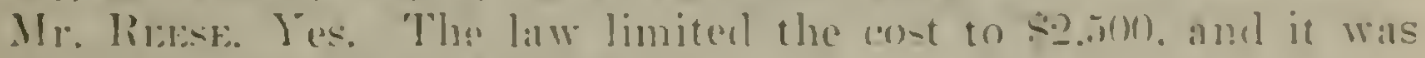
built under contratet for that figntre.

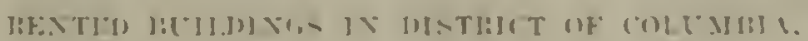

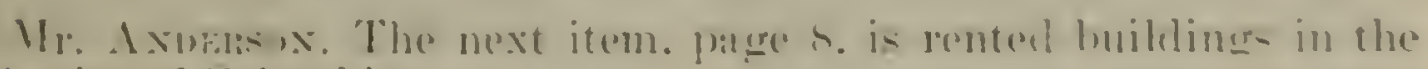
D)i-trict of (olumbi:t.

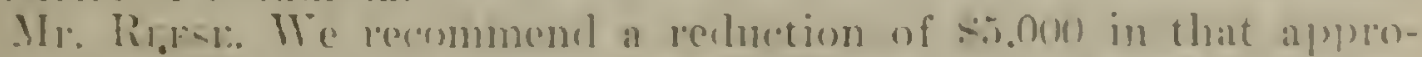

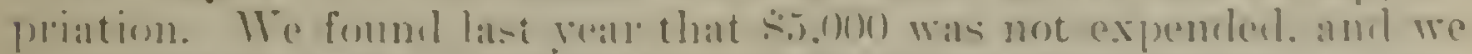

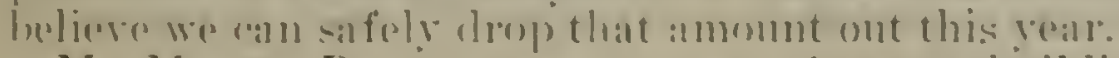

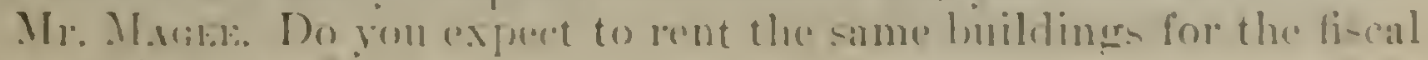
rear as list year! 
Mr. Rerse. Practically. On the 1st of July last year by direction of the Public Buildings Commission re gave up the building on F Street occupied by the office of foreign seed and plant introdnction. and mored them into quarters in the auditor"s building owned by the Government. It is quite possible that before the end of this fiscal year or cluring the next fiscal year some other shifts of that kind will be made. But we can not possibly tell in adrance what will happen along that line.

Mr. Ardersox. My recollection is that you were rather skeptical last year about being able to get along with the appropriation you had.

Mr. Bucmaxax. They have increased the estimate.

Mr. Reese. The appropriation last year was increaserl.

Mr. Becmaxax. Increased orer the estimate?

Mr. Rerse. Increased over the estimate. because demands for increased rents came after the estimates had left my hands.

Mr. Axperson. Did you make a new lease on that Forest Service Building?

Mr. Reese. Yes, sir.

Mr. Axpersor. What was that made at?

Mr. ReEse. $\$ 35.000$.

Mr. Axdersox. What were you paying previonsly?

Mr. Reese. $\$ 22,800$.

Mr. Axpersor. And this was included in your last year's appropriation-\$6.000 motion-picture laboratory. Has that lease been consummated?

Mr. Resse. The building is not ret finished: it is under construction now. We expect to have it finished in the comrse of the next month.

Mr. A xprasox. Have you made a lease on it?

Mr. Rerse. We have made a contract to lease it as soon as it is finished at $\$ 9,000$ a rear.

Mr. Axprersox. That is $\$ 3,000$ more than you figured last rear?

Mr. Resse. Tes. That is becanse of a change in the plan of the building, an increase in size, and the impossibility of getting builders to consider anything whatever. unless they get a reasonable return on the present high cost of building.

RENT OF BUILDXG JOL STATES WHLATIONS SERYICE.

Mr. Axblasox. Then you had $\$ 4,000$ rent of building for States Relations Service.

Mr. Resse. The lease on that large building at 220 Fourteenth Street expired the 30 th of last. June, and the owner declined to renew the lease unless he got a little more money. All these realestate men are putting up the plea that taxes have hearily increased. and they ale somewhat increased : and such of them as are carrying loans on their buildings say they have had to renew them at higher rates of interest than they had to pay when they male the original loan.

Mr. Axumisus. Ias this lease been made?

Mr. Rewse Yes, sir.

Mr. Axmbisox. At what rate?

Mr. Risks. At $\$ 24,000$. 


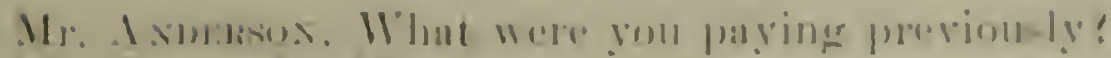

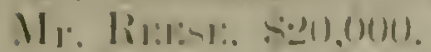

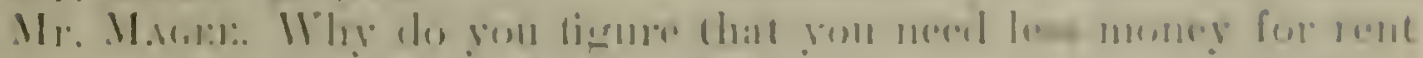

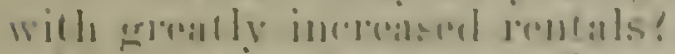

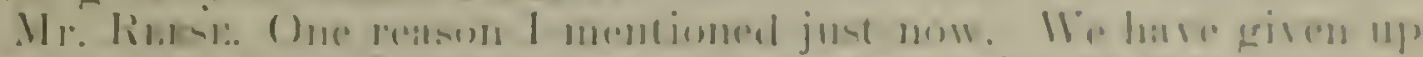

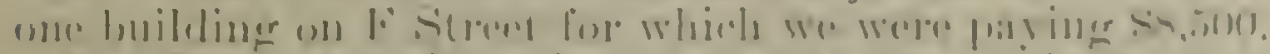

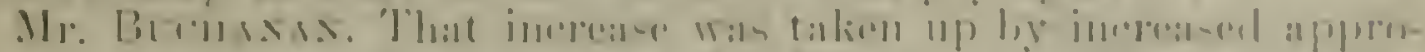

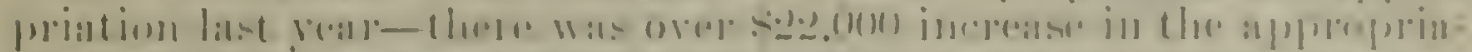

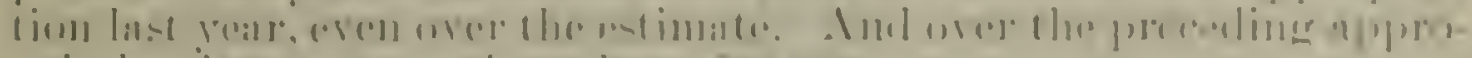

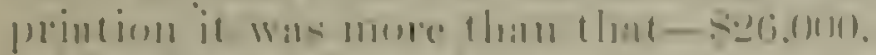

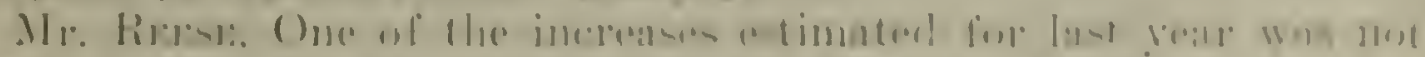

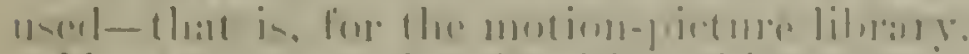

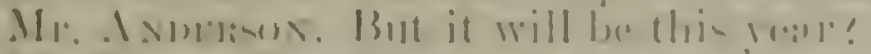

IIr. lia:-1. It will ln this your.

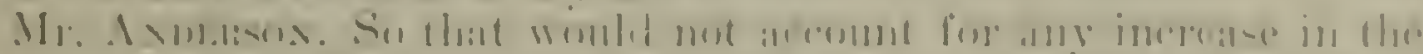

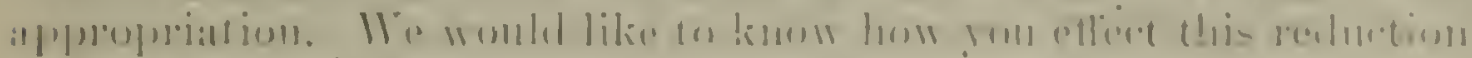

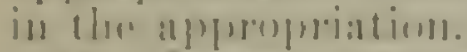

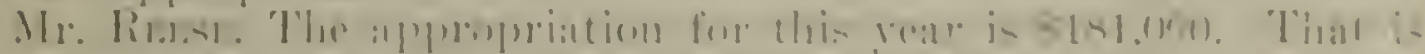

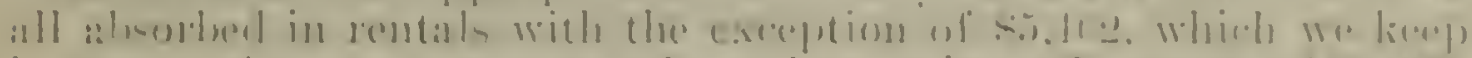

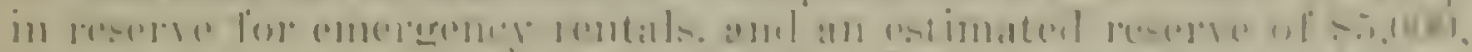

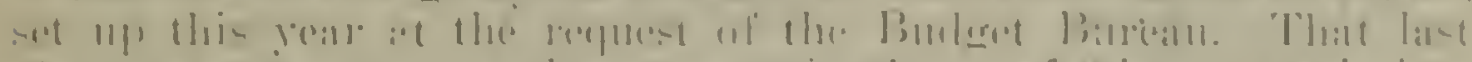

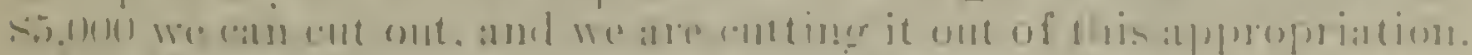

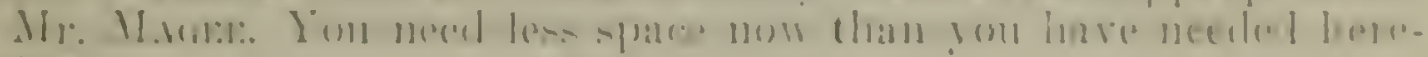
(1) forte!

Mr. Ri:l:ol: No.

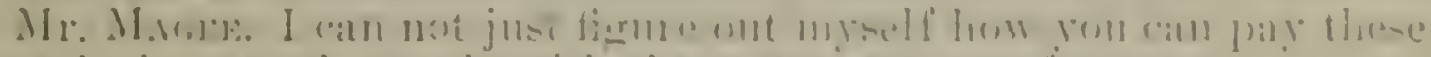

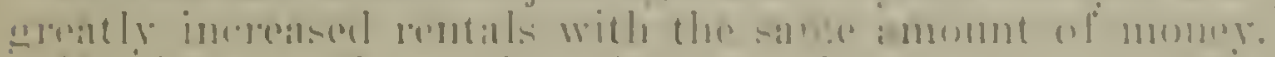

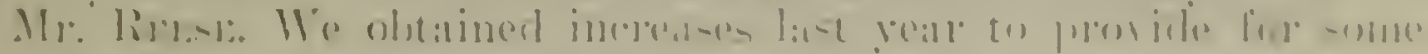
i) $\operatorname{th}(\mathrm{s}-1 \mathrm{c}$.

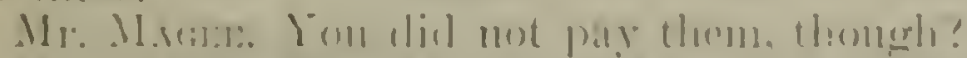

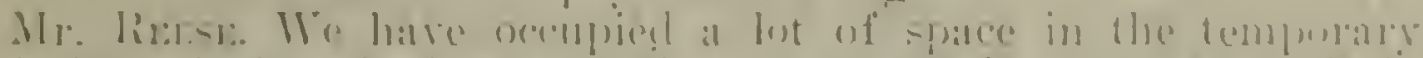

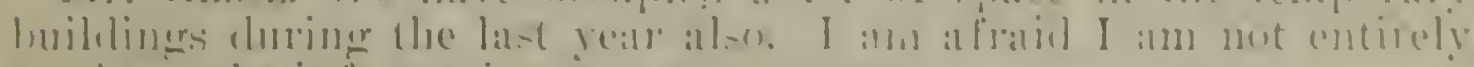
al wake (n) the information ion want to gert.

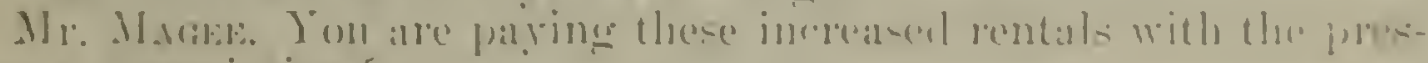
(mit ilpupurition!

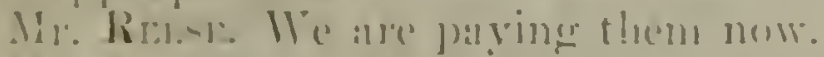

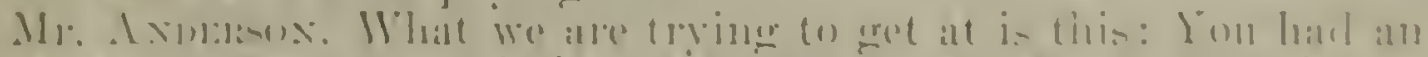

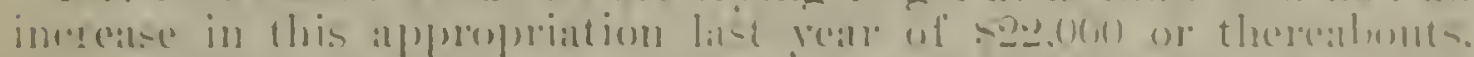

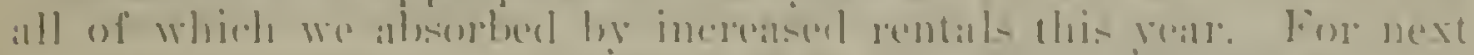

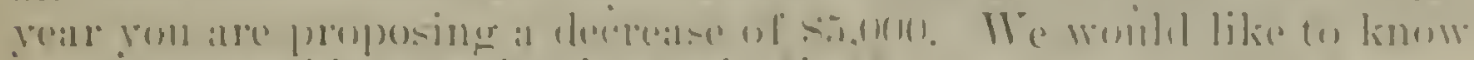
fiow von are able to malie thatt reshetion!

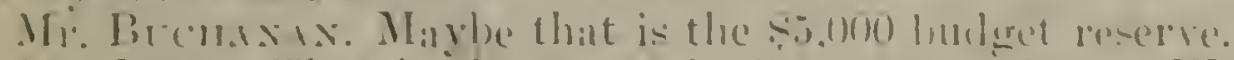

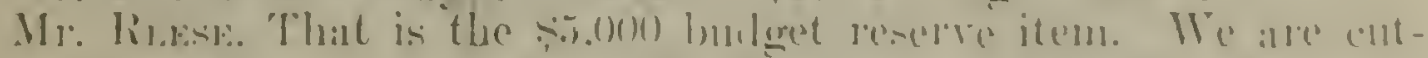
tiilır that cillt.

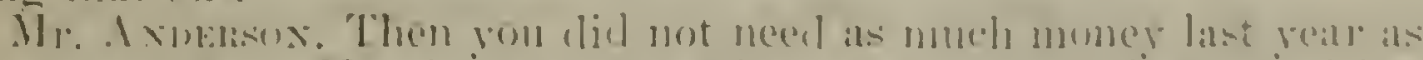

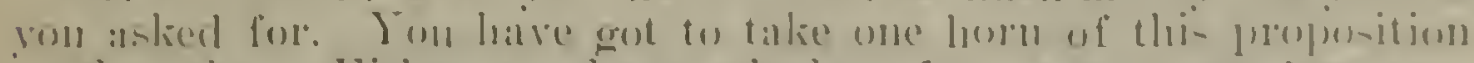

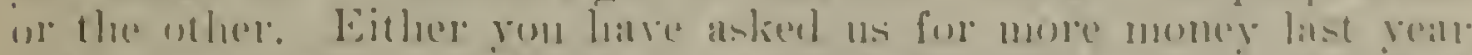

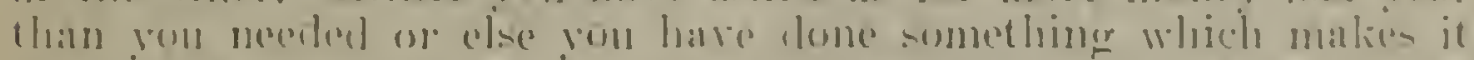

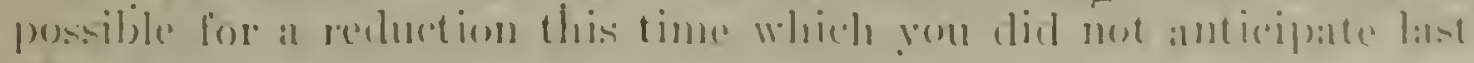
reill.

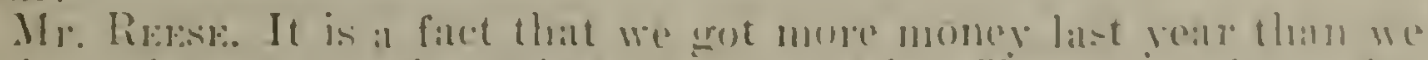

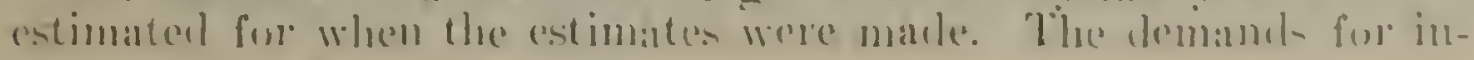


creased rentals came in after that time. They were allowed by the Senate and conference committees.

Mr. Mrafe. How long do rou make these leases for?

Mr. Rrass. The leases miler the lar run for the fiscal realr, but we secure in each case the option of renewal hy the department for a certain number of years beyond that - from 5 years up to 10 years. as the case may be.

Mr. MLare. What did you do in the case of the Forest Serrice?

Mr. Ruxs:. In the case of the Forest Service we secured the option of renewal for 10 years: in the case of the other building at 220 Fomrteenth Street. the same. option to renew for 10 years longrer.

Mr. Junr. Mr. Chairman. may we go back for a minute to the statement that we really asked for more money last year than we neederl? I think the real point is this: If it had not been for the fact that we were able to move offices ont of the Homer Building at Thirteenth and $F$ Streets. which is. of course, in a very expensire section, down to a Government-orned building at Fourteenth and $B$ Streets. we would have had to continne paying rent at the Homer. Building. and that would have eaten up this amount. and more.

Mr. Axdisox. What rere you paying there?

Mr. Reese. $\$ 8.500$.

Mr. Jump. That explains the whole thing. Tre were able to move. however. from the Homer Building into the auditor's building. so we do not hare to pay rent for those offices this rear. But we did not anticipate that at the time the estimates rere submitted last rear. If that had not been the case. it would not have been possible to make any reduction this year so far as re can see.

\section{PASSENGER-CARRYING VEIICLES.}

Mr. Rerse. Turn to page 322. This is an authorization, not an appropriation, for passenger-carrying vehicles. It is proposed to anthorize expenditures from the limp sums of the department for the purchase. maintenance. repar. and operation of motor-propelled and horse-dramn passenger-calrying rehicles necessary in the condect of the field work of the department outside of the District of Colmmbia. This provides for purchases not to exceed $\$ 32.000$. used only for official service outside of the District of Columbia. The proviso that the Secretary shall report to Congress showing the amomint expended is diropped.

Mr. A comsos. Why do you want to eut that out?

Mr. Ruscr. I guess Mr. Jump will have to answer that question.

Mr. Juar. When the estimates were compiled it was regatroded as permanent legislation. providing that the Secretary shall on the first day of each session malie a report to Congress. and the report will contimue to be made.

Mr. Axprsos. It was never considered so before. It has been carried as long as I "an remember. I do not know of alny reason why it should not be mate permanent law.

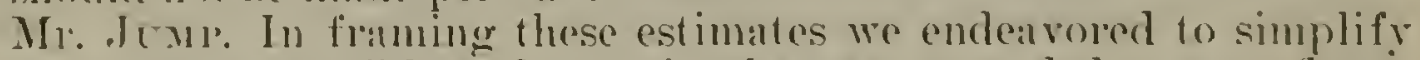
them ats far as possible and to omit what was regalded as superfluonis language, which aceonts for the dropping of this proviso. The department, however, will of course continue making reports. It 


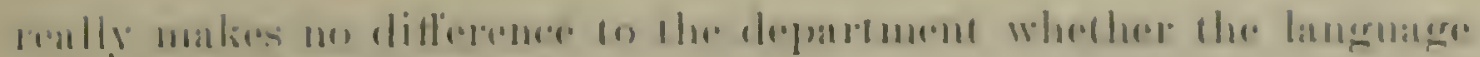

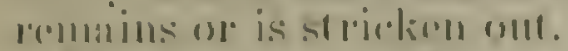

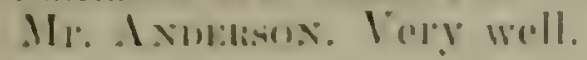

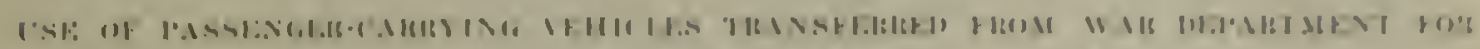

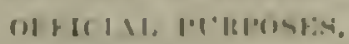

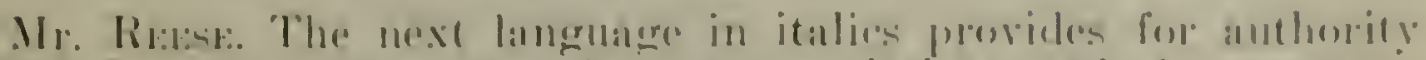

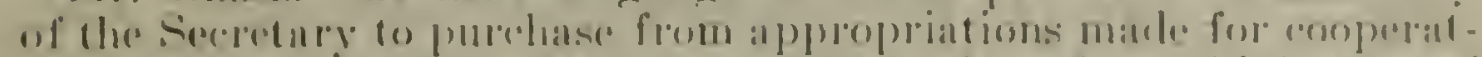

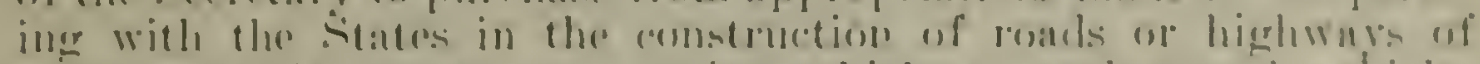

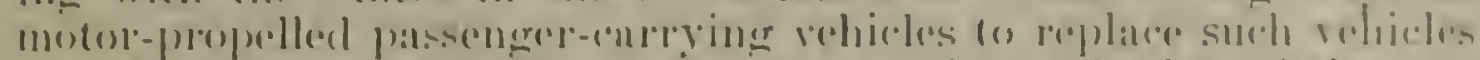

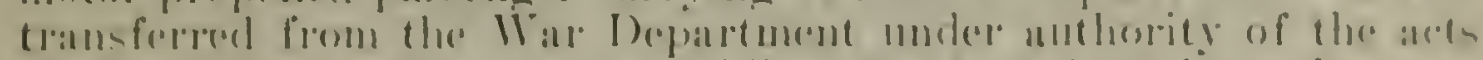

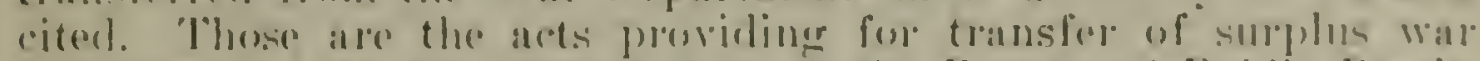

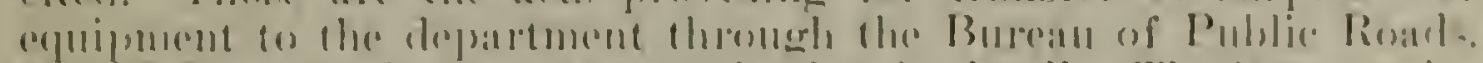

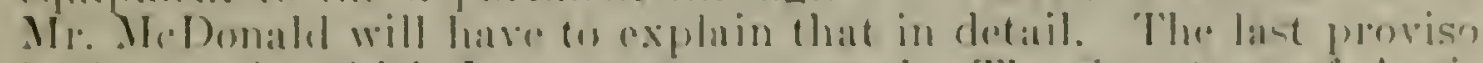

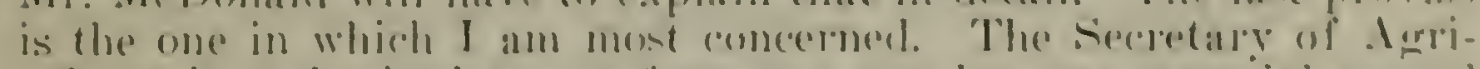

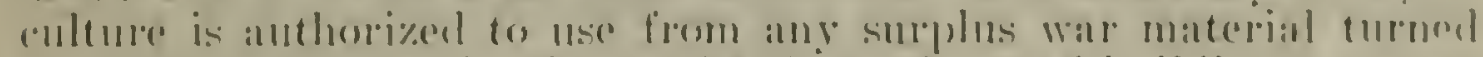

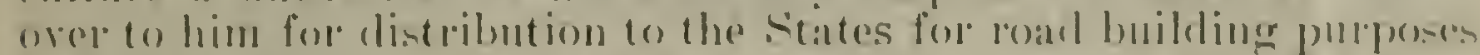

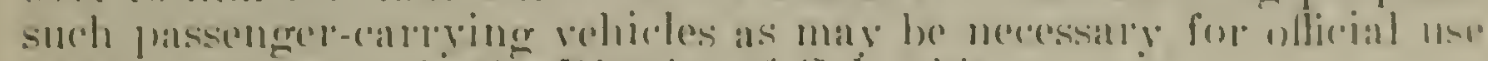

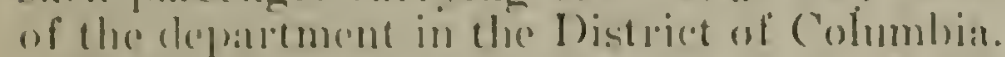

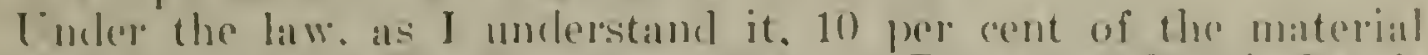

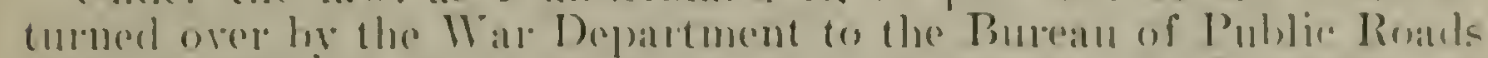

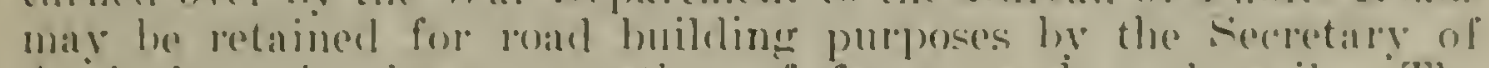
Aericulture in the comstruction of forest roads and trails. "Tho

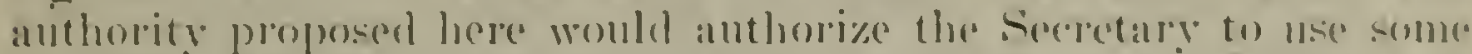

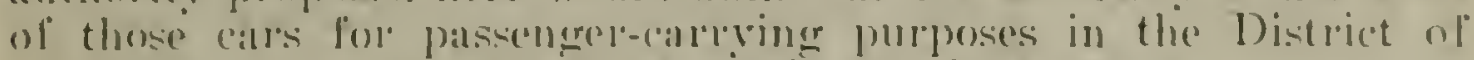
('olumbia for necossary othicial nse in the department.

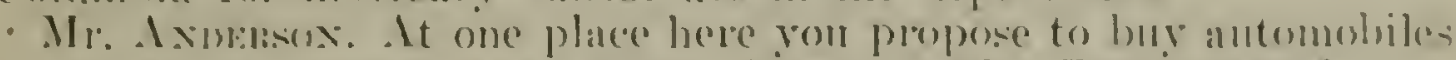

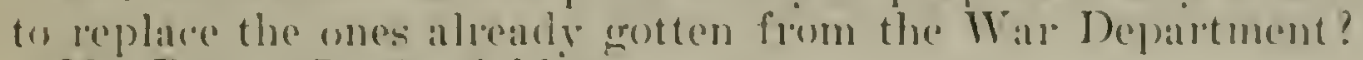

Mr: Rraslis. In the lield.

Mr. Iximensex. In the next phace pon propose to talie some of those antomolsiles and use thom in the District of (olmmbia. Where flo rou cret anvthing ont of that excopt a lot of languacre?

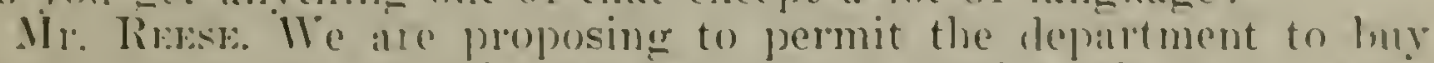
cars to replace those which are worn out in service. which havo husen trinslereel from the Tra Department.

Mr. Ixmisisos. I muderstand that. But if rou have erot to buy cars to replare those. Where ro vou make anything hy taking some of those to mse in the District of Columbia?

Mr. If work of the Burean of Public Roads. It has no relation whateve: to the second proviso.

Mr. Axufisox. I think it has.

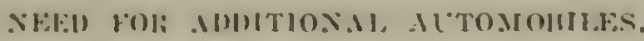

Mr. Jume. It was not so designerl, for this reason: "The serond proviso was prepatred at the secretary direction. Without recrat for the first one, contemplating that the few machines that are nocessary for use by the droaletment in Washington wombl not be exchangerl for new machines at all, hut would be olal machines talion from the surplus stocks of the War Department. Which are retained in the repartusent murler the plovision of the law eroverning the distribution of roinl materials to the states. The two things alr not 
related at all, although I can readily see that it might appear from the language that they are. That can be remedied. of course, by making the language more explicit.

Mr. Axprasos. The two items are not related, but it is all one proposition, because you either buy one place or another. I cin not see any use of putting in a lot of language and providling a lot of changes when you have got to buy machines anyway.

Mr. JxMr. I am not well enough informed personally as to all of the reasons which make the first proviso necessary. MIr. MacDonald will go into that in detail, howerer. When he comes before the committee. With respect to the second proviso, howerer. mder present conditions at the department, with the hureaus nceupreing some to buildings in widely scattered sections of the city. inil with the numerous ontlying experiment stations. all of them necessary for different pmposes. it is absolutely necessiry to hare mitahines for official use in order to transact lusiness ind to aceommorlate people who risit the department on foremment husiness of such nature that they should not have to spend all day romming around firom one part of the city to another to reach the places they want to find and which it is to the Govermment's interest thait they do find without undue ageraration. It is coublly clesirahle to provide the department some way of getting ont to the experinental fallons. For instance, two members of the Board of Estimates of the Inudget Burealu who went orer these estimattes clesired to malie an inspection of the Beltsrille experimental firm of the Bureatu of Animal Industry. The way we handled that was he calline on the IBurean of Public Roads for the use of one of their calls to take them ont there and bring them back.

From time to time during the rear we have listinguished ri-itors who come to this country, as well as onr own people who come from the varions States. and their status is such that it is desiralile to show them some of the work done at the ontlying experimental farms. Sometimes the department desires their judgment and adrice. In such rases we are obliged to go to the Bureatu of P'ublic Roals and ask them to sencl orer one of their car's.

NI. Ardmox. Where are you embarrassed by having to elo that?

Mr. J J IrP. Tre ale not embarrassed in malking the request on the burean, as it is a part of the department the same as any other branch. and under the direction of the secretary. but the burean natmrally is not expipped or organized especially to rendel that kind of service for the clepartment generally. It has work to do with its marhines, and I shonld say it embarrasses them by discommoding their work and clisrupting their armanements for use of their force otherwise when we must (all upon them (onstantly to detail madhines for general repartment purposes.

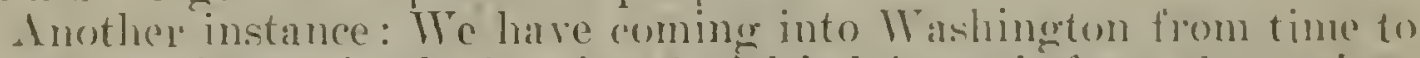
time the wimners in the boys and girls" alub work from the varions states. They were sent here by their states. a trip to Irishington being one of the rewards for their ontstanding atcherements alongr anricultural lines.

The ilepartment oflicers concermed take them to points of interest in the department, to the farms, ete.. and nther artivities or work of 


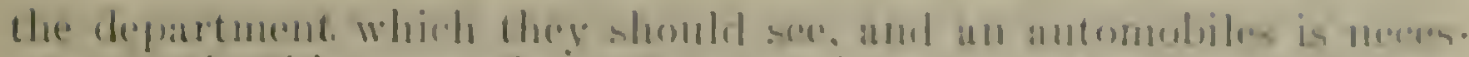
sary to to this properly und at a minimum espermliture of time.

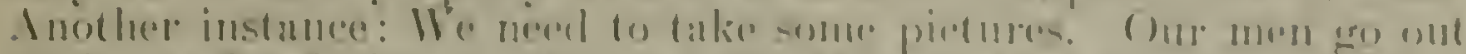

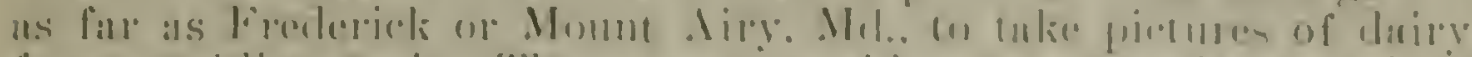

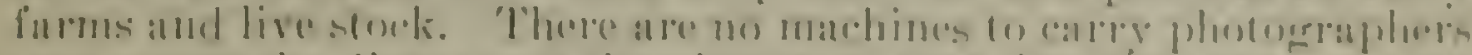

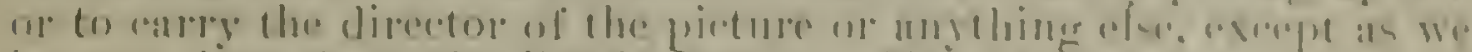

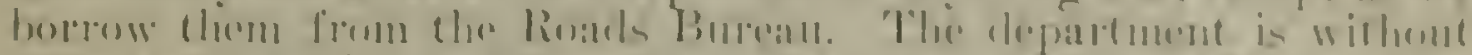

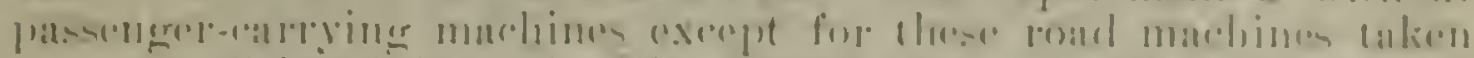

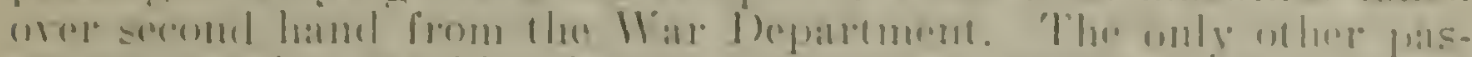

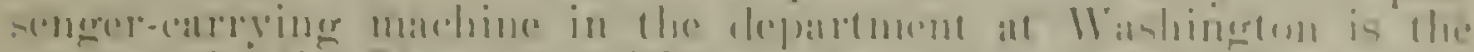

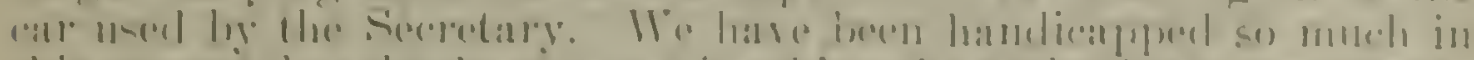

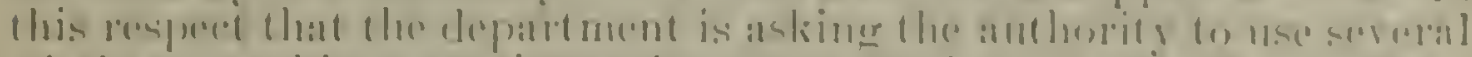

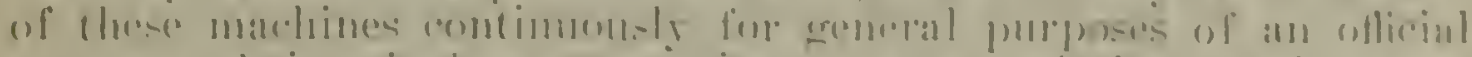

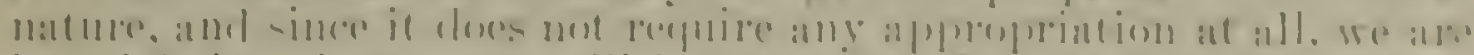

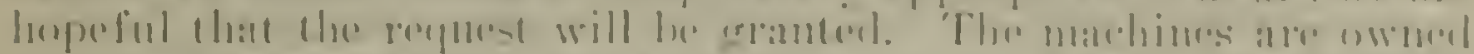

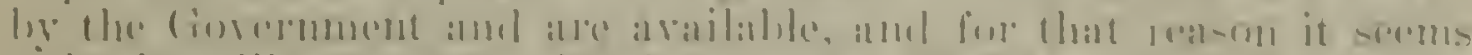

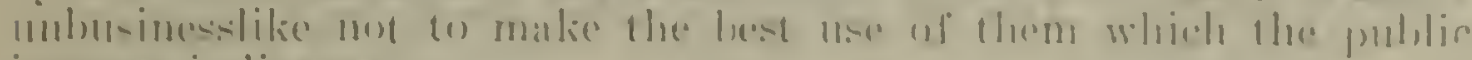
interest inllinales.

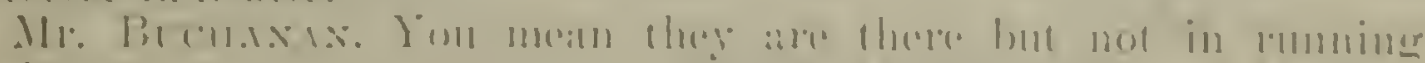
ardin!

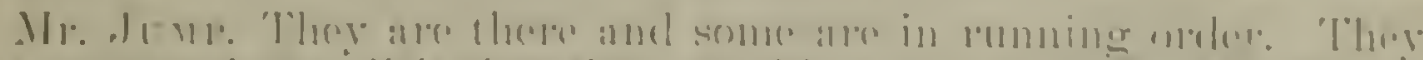

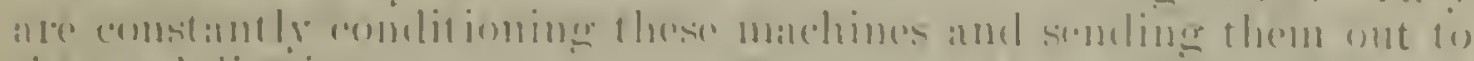
Herome rlistivis.

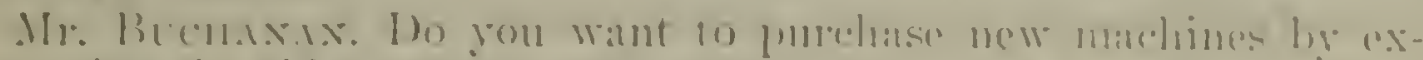
chamering l he olel omest

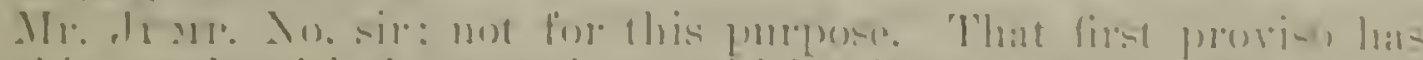

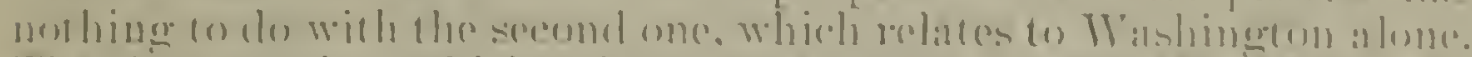

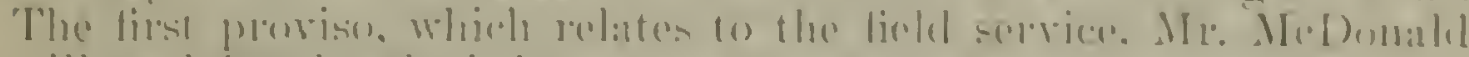
will (explain when lo is here.

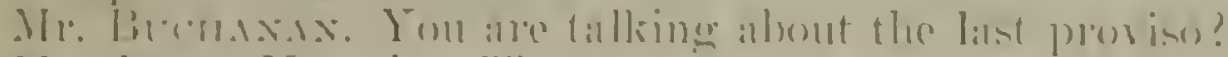

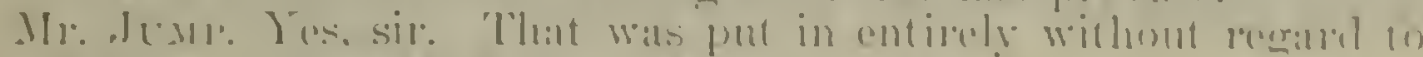

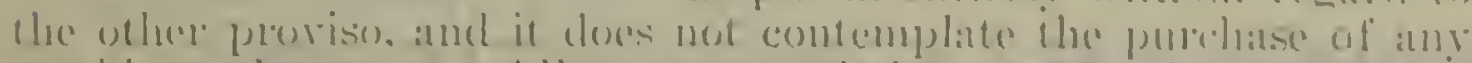

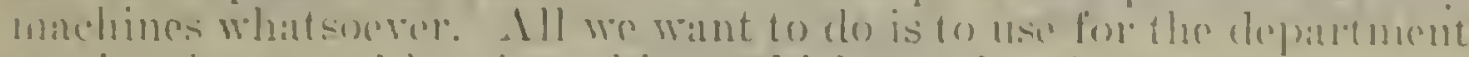

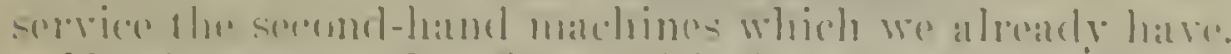

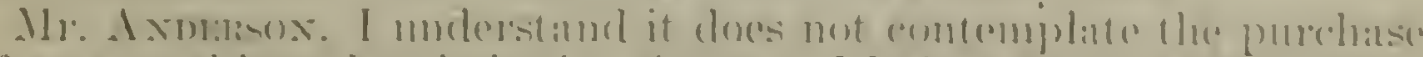
of any machines. but is it six of one and hall a dozen of the where.

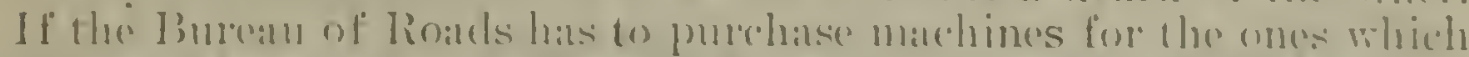

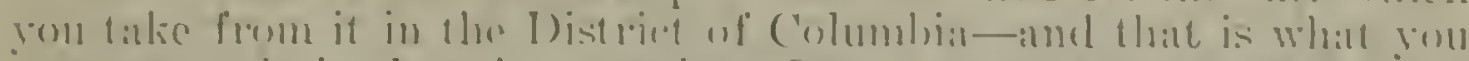

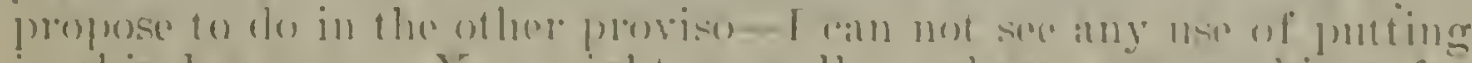

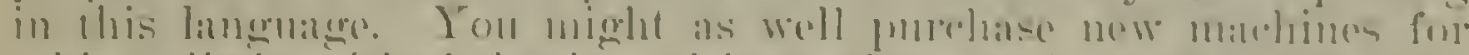

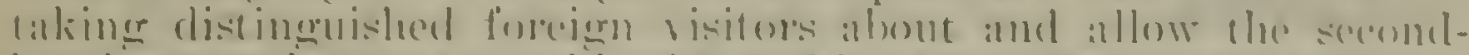

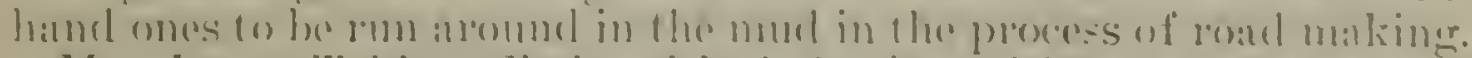

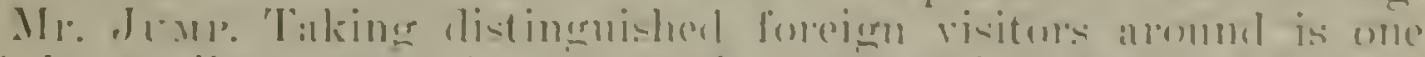

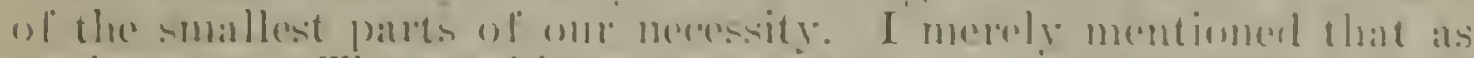

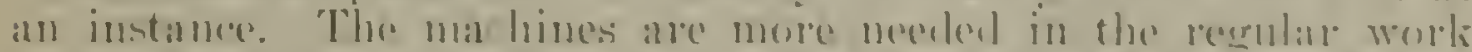
of the depastment-eretting the department people aroums withent

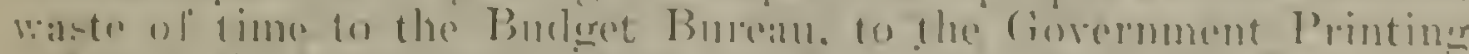

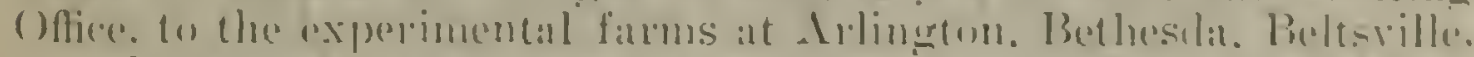

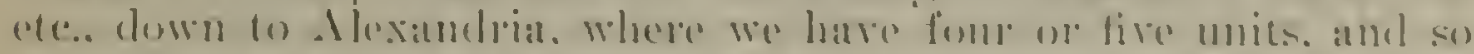

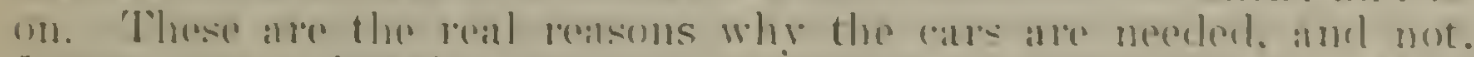
I maty say primarily for taking foreign visitors alromel: that is parely incidental. 
Mr. Buchaxax. The Secretary takes these machines which were turned over to him by the War Department for the purpose of distribution among the States in connection with road building. This proviso authorizes him to take some of those machines and use them here in the District of Columbia for Agricultural Department purposes. It seems to me like that prorision is in direct conflict with the statutory law and absolutely new legislation, is it not?

Mr. Irnip. It might he so construed. I3ut it is strictly in the public interest and required for the most efficient administration of the department. Some of these machines are in use in Washington already, hecause the Bureau of Roads has one of its hearlquarters here for one of its districts. The fact of the matter is that we are constantly having to borrow these machines temporarily for these purposes anyhow, and what we would like to do is to malie the use of them entirely regr:lar and under the central control of the departnent.

Mr. Brchaxax. You are asking for these machines withont number, without limitation of any character. Have you any idea how many you need?

Mr. Junip. Tre would sav, offhand. from three to six. and we conld make the limitation accordingly if the committee desires. Tre just want a small number. and what we propose to do is to put them in the central garage of the department. All our motor trucks. Which formerly were scattered about, are now pooled under the mechanical superintendent of the department. who comes directly under the Secretary's office, and that arrangement has effected a tremendous saving and put the trucking service on an efficient basis. It will not be our purpose to assign these cars anywere. They will be under the office of the Secretary and each request for transportation will be closely scrutinized by the man in charge before he attempts to take care of it.

\section{STATEMENT OF MR. C. W. PUGSLEY, ASSISTANT SECRETARY OF AGRICULTURE.}

\section{REORGANIZATION OF OFFICES TNDER OFFICE OF THE SLCLI:ALIT.}

Mr. Pugster. Mr. Chairman, I would like to read just one paragraph from the statement of the Secretary on the economies effected in the department during the past year, made a part of the record a moment ago:

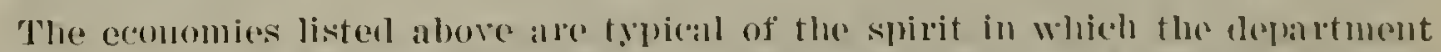

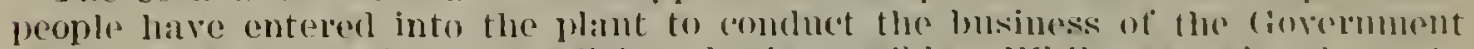

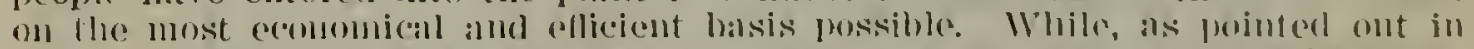

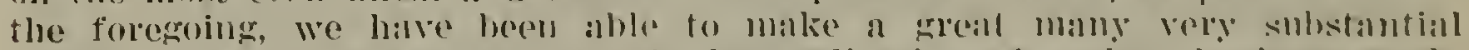

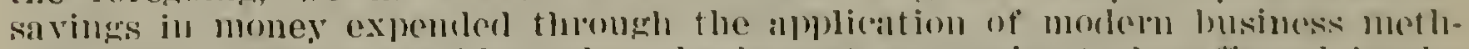

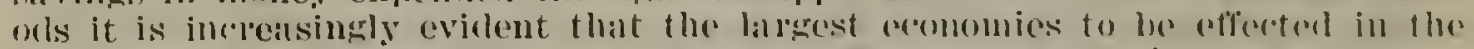

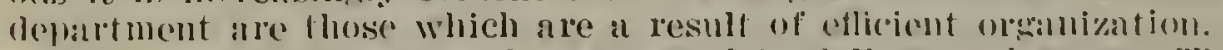

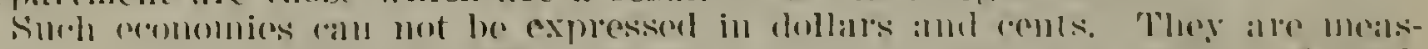

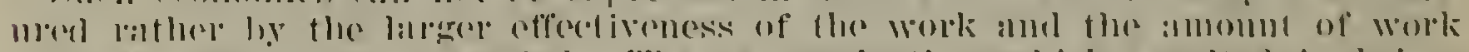

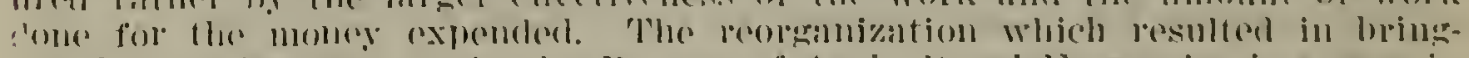

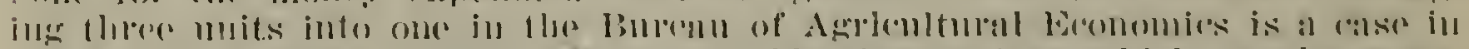

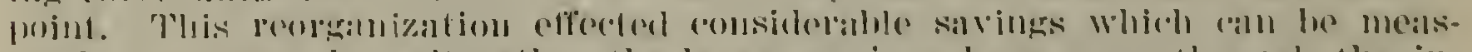

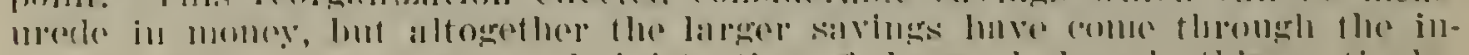

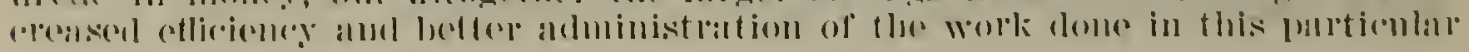




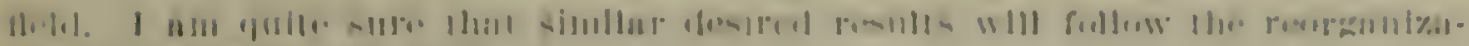
Hen of Har (x)

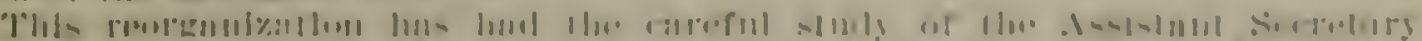

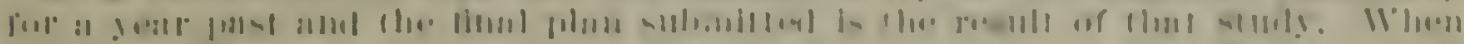

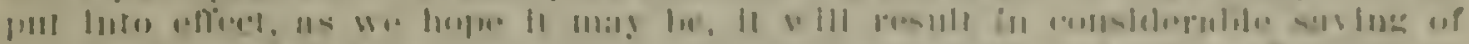

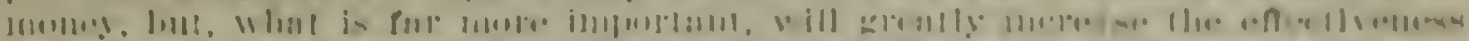

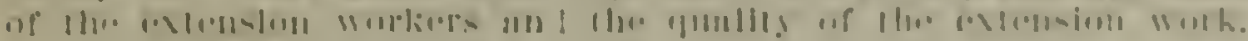

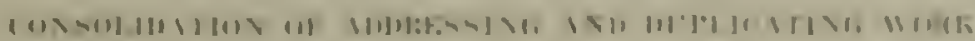

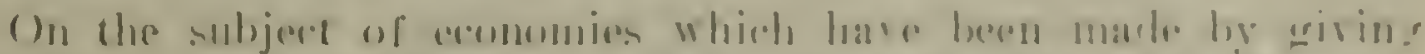

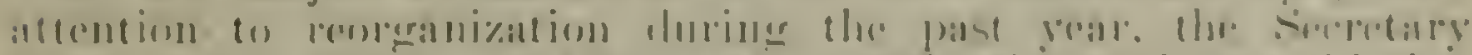
points ont in this repost that in the eombination and comsulielation

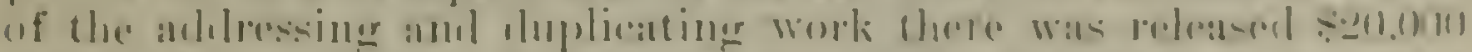

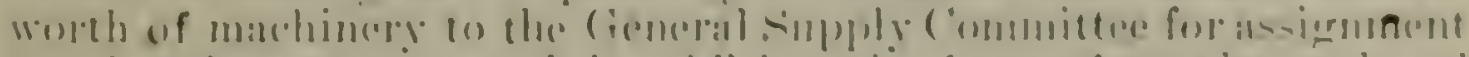

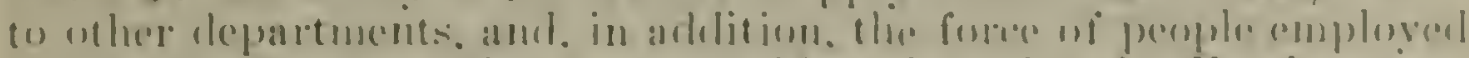
I11

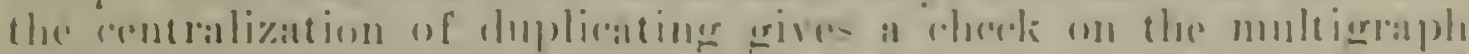

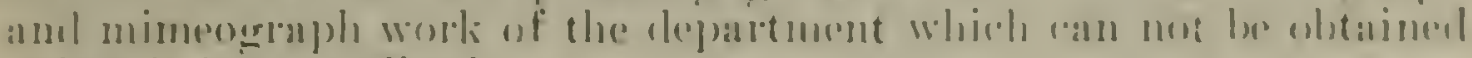
moless it is comtralimel.

(").ง

He also prints ont that in the consolinlation of the Burean of Markets. Burean of ("rop) Estimates. and the Office of Farm Management there was a salving of 500000 merely in the overlead in the operation of what were formerly three hureans.

li:Mlis.

By consolidating two extension oflices in the States Relation Servire into one ofliere for the purpose of anministering the Smith-I tever and othere (ooperative extension funds. there was al salving of alpproximately sovono in the overhead.

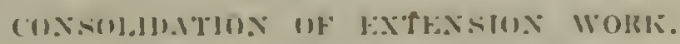

Is a matter of interest. I thonght you might like to be informed concerning the type of orranization that existed in the oflices of extension in the States Relation Service before the consoliclation was malle. This chart represents the organization of the office of extension work in the Sonth [inclieatine]. where lis States were arministered, and this [indiciting] the offier of extension work in the North and Test. Where the rest of the States of the Union were achinistered. Ion will note that there are quite a lare number of subdivisions in each one. Confusion was hrought about by that sort of an orianization. It was impossible to get a mited and eorrelated extension promran. Tunler the new plan there are lut two divisons. aside from the repieal division. with lut two heals. who act as rounsel with the rhief of the extension oflice. That is where we sared overheal and at the same time increased efliciency.

In addition. lon have a logreal type of alministration of the eooperatise extension work of the department. where it is consiglerest from the stanclpoint of the two prohlems of anduinstration. C'mler

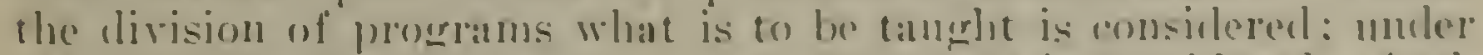
the division of methenls how it is to be tanght is considerest. Ambl. after all, those are the only two things that you have to deal with- 
the "what" and the "how." It is al solutely essential that we have a united extension program with the home and the rural rommunity ats the object of the agricultural sextension teaching. While the details of the work differs in the local communities. the Fedelal oflice must inject national and world aspects of the problem.

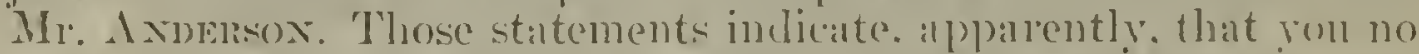
longer have the country divided up into districts, with district learlers: is that correct?

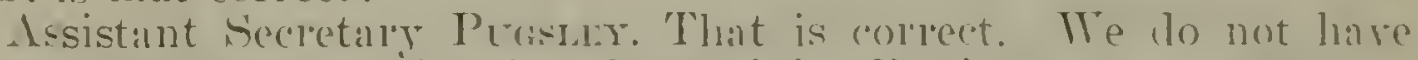
separate offices arlministering the work hy listriets.

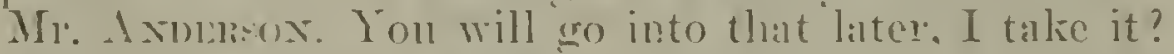

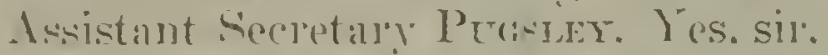

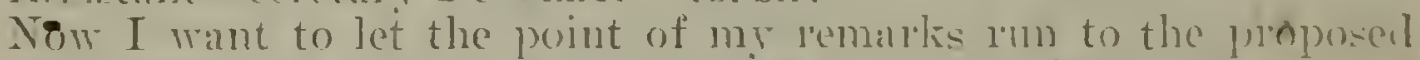
reorganization of the entire axtension work of the department. The Secretary asked me to malke a specrial sturly of the extemsion and pulslication activities of the department. and as a result of that -tudy this is what I foumd [presenting alart to the subeommittee]. Practically erery linrean in the elepintment is anthorized by the lanse of Congress to do resealdeh work, many of them to do resulatory work. and a considerable number of then to lo extension worts.

To cally out and cooldinate the researed work and the resulatory

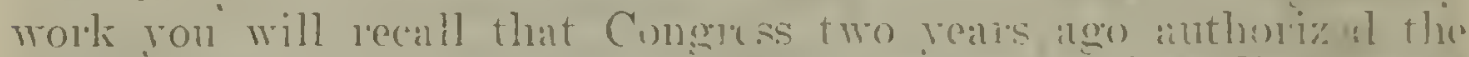
appointment of a director of scientific work and a director of regnlatory work. There ares howerere, three lines of work in the Department of A grienture. To my minel. all the work that is authorized in the department falls logically into one of three clateres: Research. regulatory. or extemsions : hint mp io the present time there has been no dijector of extension work, ontside of the sereretiliy

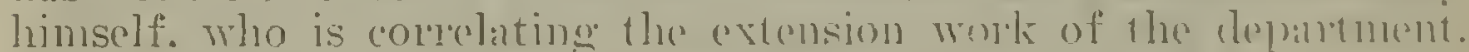

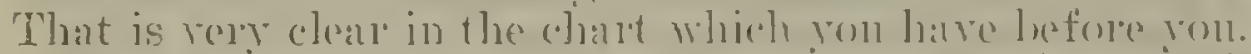

Tou will note that the states Relitions selvire has the oflice of cooperative extension work. In that oflice is lodgerd the achninistration of those funds which ane spent in the states for conperative

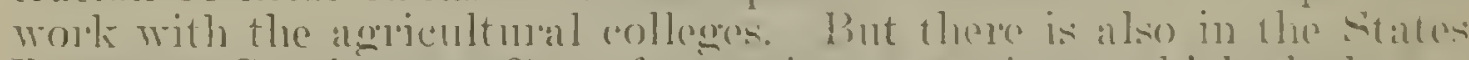
Relations Service an office of experiment stations. Which deals en-

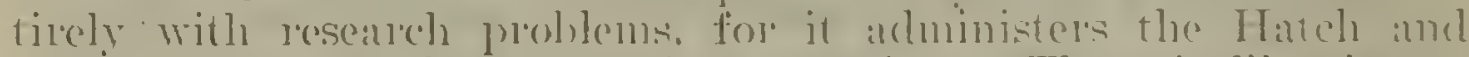
Adanis funds for State exporiment stations. There is likewiat an

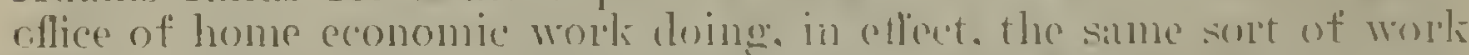
that a hurran does-resealleh work and extensiom work. So you

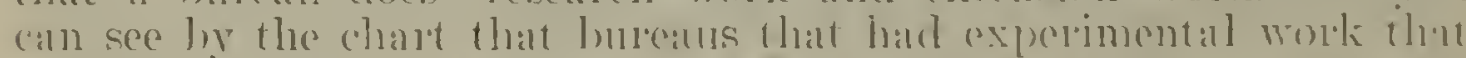
was done in cooperation with the states had lo 20 throngh an of -

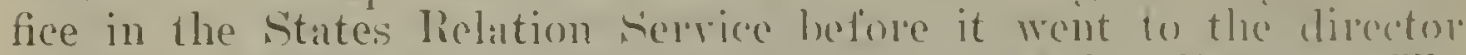

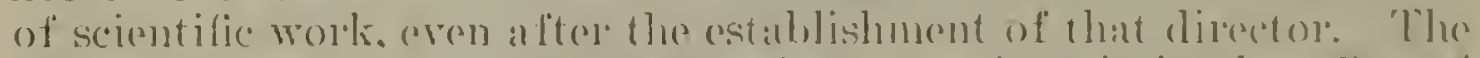
logieal plater for the oflier of exprepineme stations is in the olliere of the director of scientifie work.

In the Division of P'ublications we hare the eliting and printing of bulletins, the releake of prest matreial. and the duplicatinge and

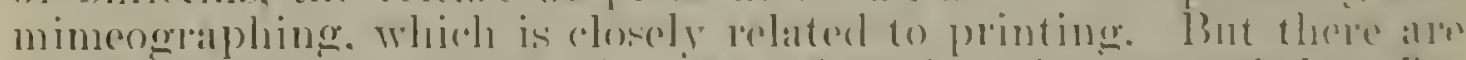

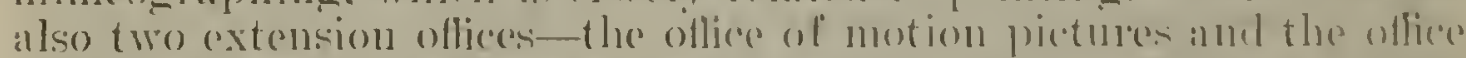
of exhibits-hoth oflices for ristlal extension work. Whon a hurean

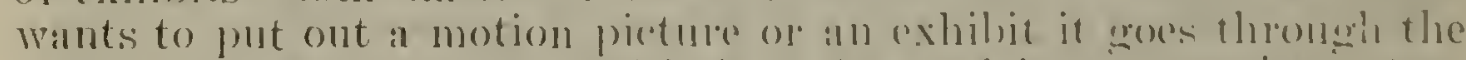

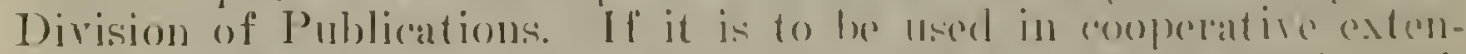

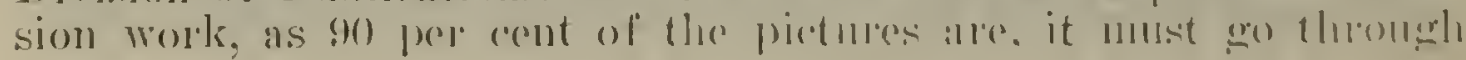




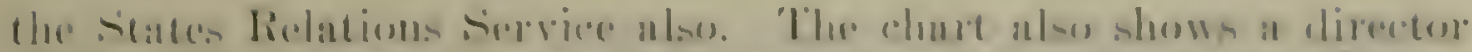

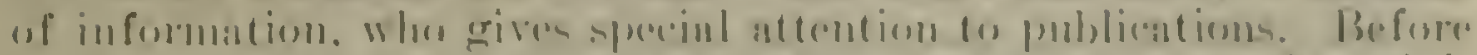

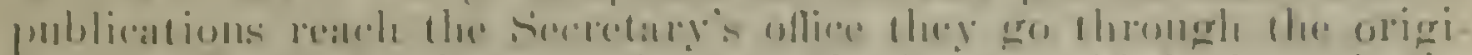

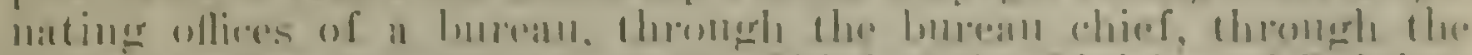

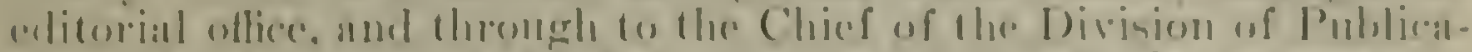

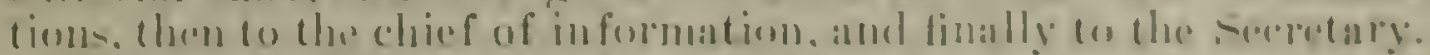

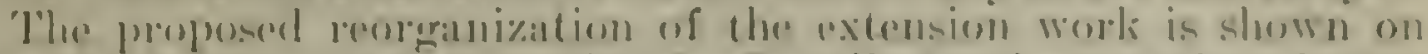

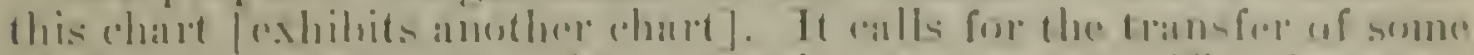

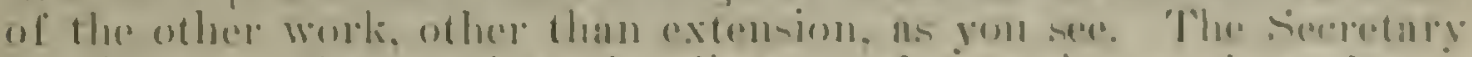

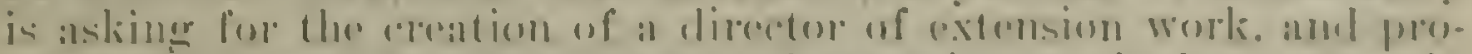

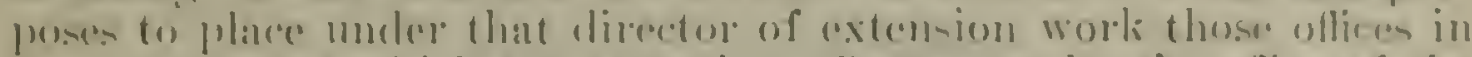

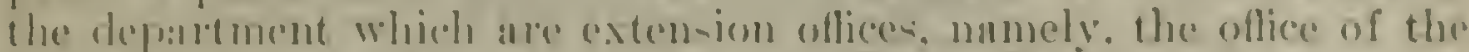

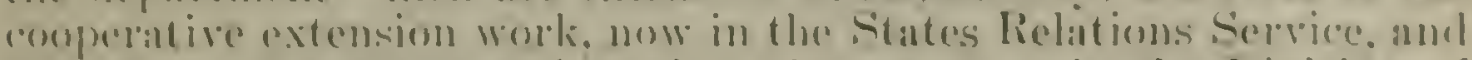

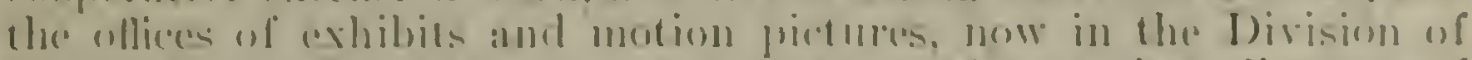

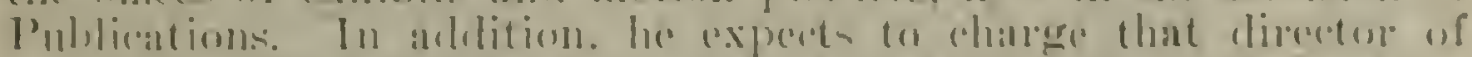

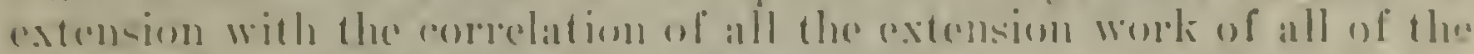

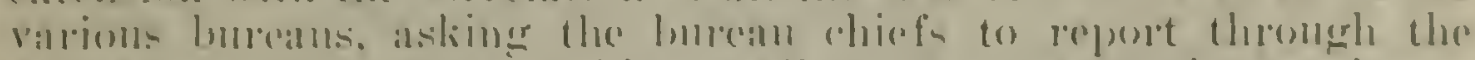
diresetor of the cextension to him on all matters of extension work.

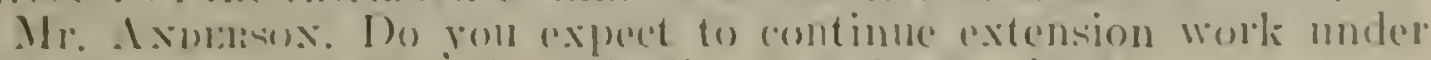
the bureall as well at under this direeter of extension?

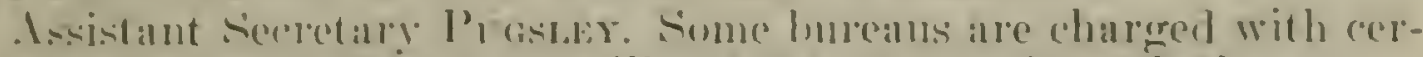
tain extension worki as you will note as you gu through the appropriations. In adilition, most extension work is of a more or less technical natme and must hare technicial direction. But those lines of extension work will chear thromerh the director of extension. so that they will be correlated. and so there will not he duplication in the bureans. At the present time there is nolooly ontside of the secretarys office who can do that sort of thing. In other words. these three extension ollices of the department ales in eflect. the arenues throngh which the extension work of the burean is cleared. We really hatre no thingrs to extend exrept those things which oriorinate in the scientilie hurealls of the department.

'The reoliganimation proposes to put minler the director of scientific work the Office of the Experimental Stations.

The puldieations of the department may appeare at first grance to be retension. They do fumish an arenue thromgh which the department can gret its information to the public. but publications ane of there different types. There are these publientions which are highly technical and which are published for the information of othere reseirch workers. The direetor of scientitic work and the research people of the department are therefore tremendously interested in that type of pullication. and in a sense that type of publication is nut entirely axtension.

Tikewise. there must he published a larere number of regulatory anmoncements. They do not nexel to gro to the public in ereneral: they only need to gro to the recrulatory oflices ont in the states. These ale not extension. in the erroneral sense of the worel. and they shomkl alear thromerl the office of the director of recrulatory work.

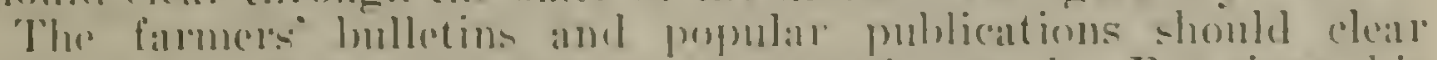
threnters the oflue of the dinector of extensom work. But since this editorial work afferets the there lines of work in the departmentscientific. extension, and recrulatery-it has serened best to plate the oflice of editerial work in the soretary's office. where we will have 
direct contact with it and where he will pass on all work finally. probably throngh the Assistant Secretary.

Mr. Axuersox. If appropriated for separately now, I do not see anything to prevent you putting it an where roil please.

Assistant Secretary Prosier. The alplopriation hill proviles that the appropriation for the work in question is a part of the work of some burean. We are asking that the wording of this year"s bill will make the appropriations run in the direction in whicli we think they ought to run for the most efficient organization of the department.

BUHEAU OF HOME H(O)NOMU'S.

The Secretary, I think, is tremendousiy interested in another change. The office of homo economirs. miler the States Relations Service. is to all intents amd pmrposes al subjert-1natter burean in the same sense of the other bureans in the depratment. He believes that the time has come when this office shonld be made a burean in fact; and it is his intention, if Congress approves of the proposal to make it a burean, to place it in charge of a woman of scientific training.

Mr. Magee. What do we know about all this theory and red tape!

Mr. Axpersox. He is telling you something aluont it.

Mr. Mages. He says be prits it up to us for determination. It. seens to me you have enongli horse sense to he alble to put before the conmittee the facts. and then we might be alble to reach soma reasonable conclusion.

Assistant Secretary Prowsy. That is what we are trying to do.

Mr. Magee. There is so much lone-drawn-out postulations and reed tape that sonetimes I think it is almost impossible for men in Congrees to do any business. as it takes about half of the forenoon to attend to one little job now.

Assistant Secretary Pugsiry. I fully srmpathize with you.

Mr. Buchasax. Wrhen was this clejartment reorqunized? Was it not organized a few yeal's ago?

Assistant Secretary Prosily. What department?

Mr. Beclidxax. All this publication department, hurean of distrilution or publication, whatever ron want to call it.

Assistant Secoetaly Prastery. The Division of Publications has. so far as I know, never been fixed in its organization ly the approrpriations which have heen made

Mr. Bucraxax (interposing). Was reroumized in the department

Assistant Secretary l'ugsily (contimuiner). In all ol its details The Division of Publications has been created hy the applopriations.

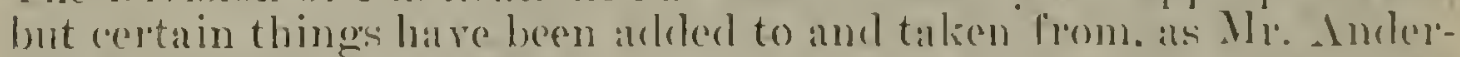

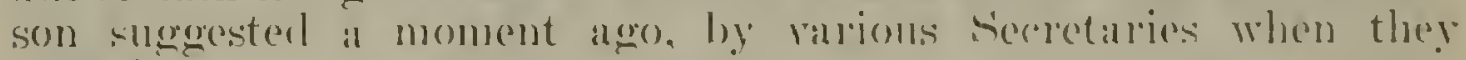
("ilme in.

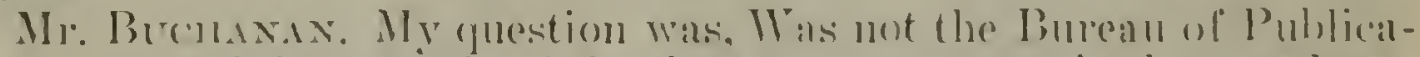

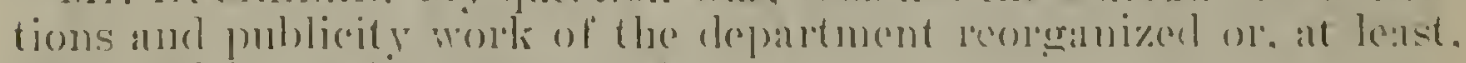

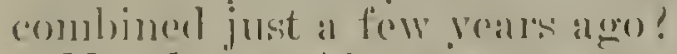

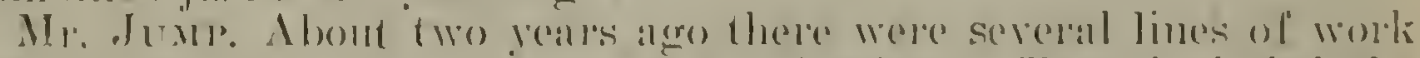
transferest inte the Division of Publieations. 'They induled the press service, motion picture, and exhihits work. 


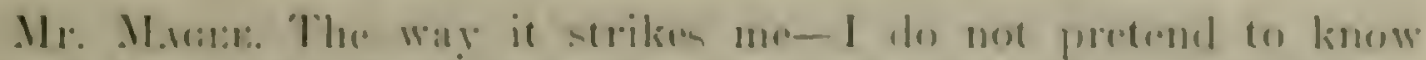

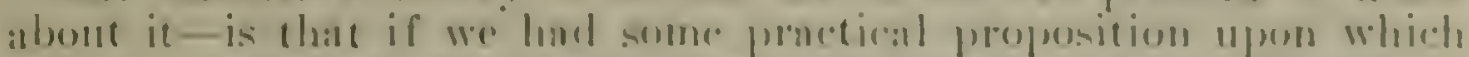

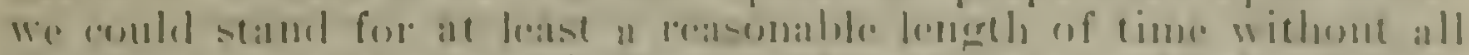

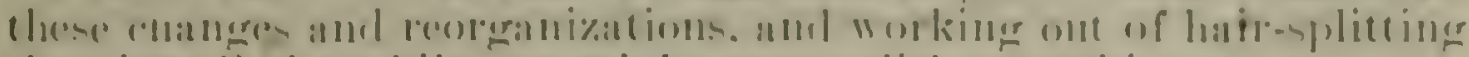
theories all the while, we might atreomplishs something.

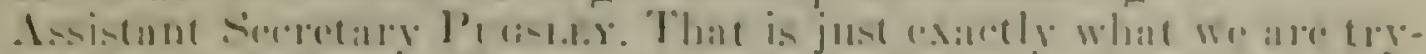

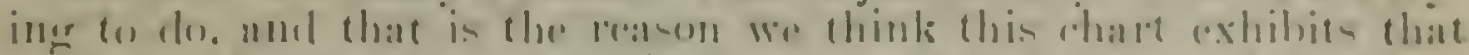
formlametal basis. I do not think youl have corel had presented to rou hefore-

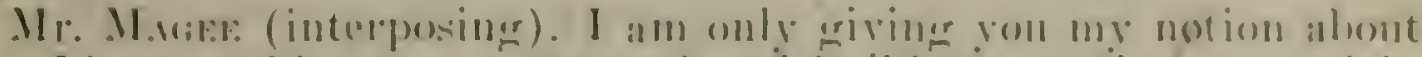

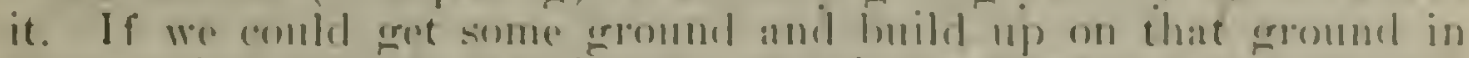

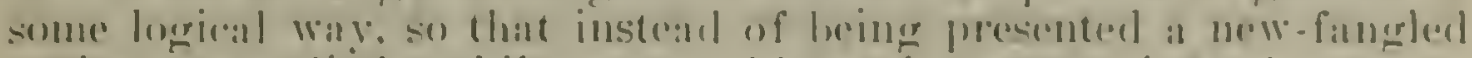
notion every little while. we romla rench some print where construretive moirli wias possilile.

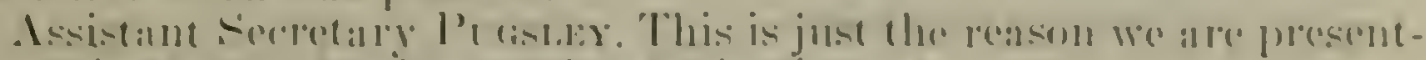
ing this plan of fumilamental oreranization.

Mr. Bromas. Will not this split up the pullicity work. or adrertising work, instand of comsoliclating it! Fon talio the exlitorial work and the publication work ont of this new organization you have grot.

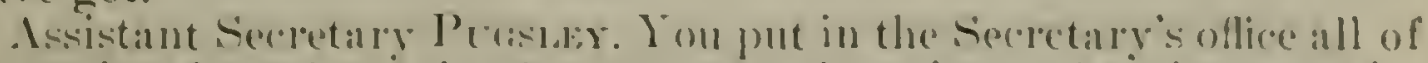
the printed work of the deparment. Where it cin he griven special supervision: rou put muler the director of extension all of those extension activities hy means of enoperatior extension agronts als well as hy (xhibits and hy motion piatures.

Mr. Axmersox. Is not this what you really do! You propose to brine the extension atetivities under the lirevor of extension work.

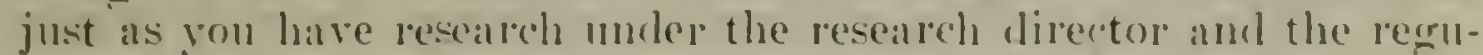
latory work under the elirector of regrulatory work?

Assistant seceretary Prosistir. Yes. sir.

Mr. Axmsisus. Then you propose to put this extension work, together with the activities allied with it. like puhlications. under the Lssistant secretary. or substantially so-I suppose that means under the Secretary-so as to gret a correlation there?

Assistant Fecotary P'tosidy. Yes, sir. But no work in the Division of Publications. except the editorial. printing. and distribution work, eroes into the secretary's oflice proper.

Mr. Asurisox. Is there anything olse there?

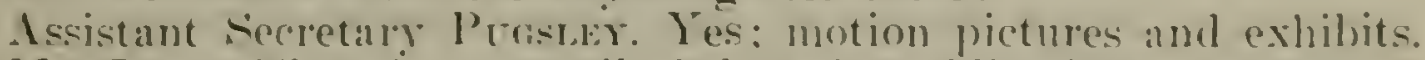

Mr. Tump. They do not really helong in publications now.

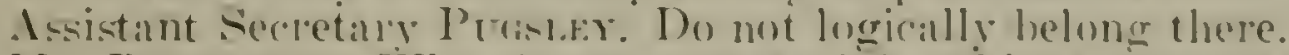

Mr. Bronaxis. Why do goum not do it? This is aldoninistrative business that it is propere for your to do. as I luok at it. We lid not oranize this thing the way you have it now by at of Congress.

Mr. Jusl. Ies: Mr. Brichanan. The wal the hill reals mow, the Division of Publications hats in it these two activitie:- - motion pietures and exhihits. which are not really publication work. Libuinistratively, the secretury (an rom theni any way he wants to. hut it

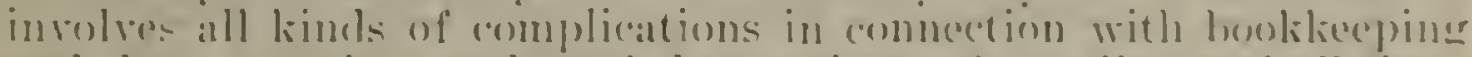
and the acoounting work and the purchase of supplies. and all that: se that what he would like to do is. als Mr. PMgrsley hals axplanerl.

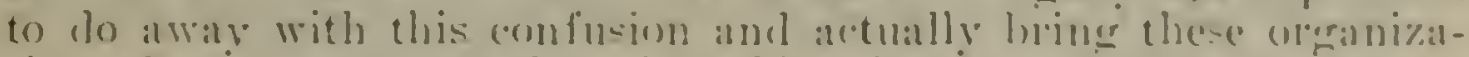
tions that ilo not now helone in publirations out of it. and to attach 
them to the unit to which they really do belong-leaving the Publication Division to handle purely the publication work.

Mr. Bucinasax. I thought we authorized the Secretary of Agriculture to carry on these activities generally by act of Congress, and that the manner in which he organizer them and carried them on is an administrative function, purely and simply.

Mr. Axmisox. Of course, that is true. Mr. Buchanan, but what they are trying to do here, as I understand it, is to gret these appropriations arranged in such a way as to facilitate the organization of the department. which the Secretary thinks is the most efficient.

Assistant Secretary Pegsify. Is it not true that if rou make an appropriation for motion pictures attached to the Division of Publication. that in effect places the motion-picture office in the Division of Publications?

Mr. Andensor. I think so.

Assistant Secretary Pegsulir. What we are asking is that that appropriation read to the extension service and that a director of extension be created, so that we will have those things all togrether. We are asking merely for the changes in the language of the hill which will make that possible. It does not cost any extra money. We believe it will save money.

Mr. Magee. Without submitting things to our approral which we do not know anything about-at least. I do not feel I do-why not make reasonable appropriations you need and let you run this business in your own way?

Assistant Secretary Pugster. Of comrse, we would be perfectly willing to do that.

Mr. Buchaxax. In this reorganization do you contemplate changes of men of different positions, and so on?

Assistant Secretary Pugsier. Just what do you mean by that?

Mr. Bucianas. Do you contemplate putting some new men in there who are not now in there?

Assistant Secretary Pugsicy. Yes, sir' we contemplate securing a director of extension work.

Mr. Buchasax. Is that the only new person you contemplate securing?

Assistant Secretary Pugsiry. On the extension end of the work. it is. The Secretary is also asking for an editor in chief, at at salary which will permit him to eret some person competent to clo a lot of things that ought to be done in connection with the department bulletins.

Mr. Bucmaxax. Are those two men the only two men ontside of the service you contemplate employing?

Assistant Secretary Persisy. Those are the only two new positions we are asking for.

Mr. Juslr. And the amount of money required for these two statutory positions, namely, the director of extension and the assistant in chare of the oflice of editorial work, is specifically offect by recluetions which are made in the relaterl appropriations, so that there is no total increase whaterer in appropriations eonnecterl with this proposed reoreanization.

M. Buchanax. You speak of "Pelated appropriations." Do pou mean appropriations under the dirision of publications? 


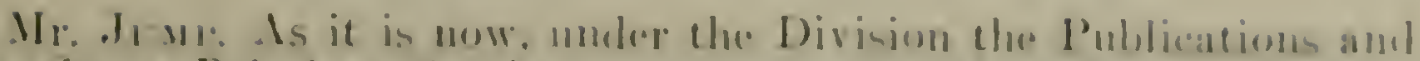
the States Relations sionorion.

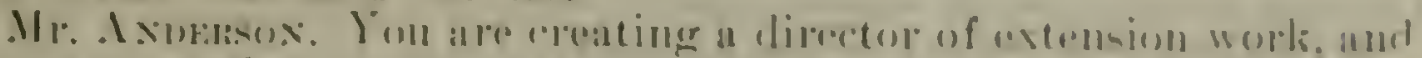
roul ane putting molere that director of extensions work the work

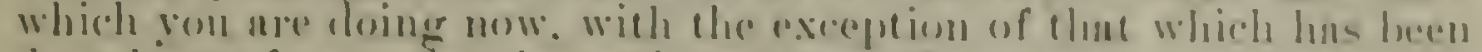
done heretofore medep the rarions bureans?

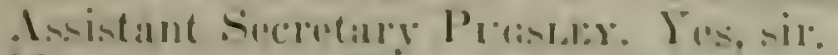

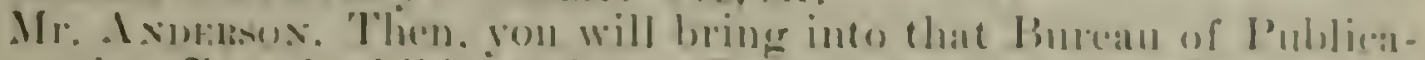
tions the oflice of exhibits and the office of motion piodules?

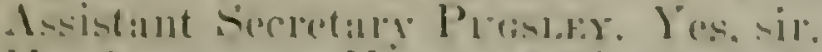

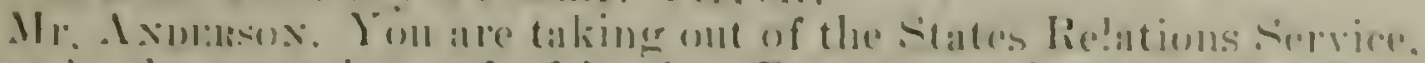
that is. the extension end of it. The offiee of experiment stations?

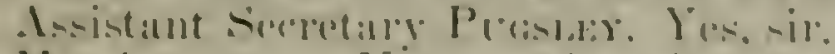

Mr. I xmbasos. Jou are changing the name of the oflice of publi. cations to the oflice of editorial and distribution work?

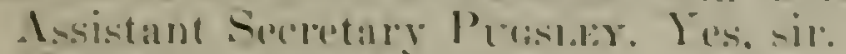

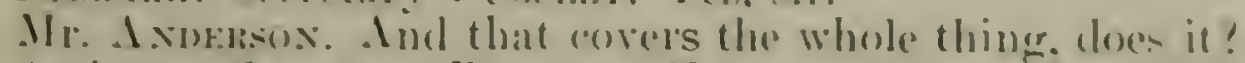

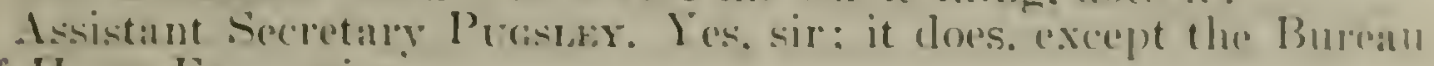
of Home Eeonomics.

Mr. Axmersos. And you take ont of the extension service the Burean of Home Eeconomines and make a separate burean of that.

Assistant Secretary Prosicky. Yox. sir: and when that is fone we lo away with the Division of Publications and the States Relaltiuns solvier. as sulh.

Ifr. A vinfison. All you do in this hill is to male such transfors of the appropriations as will accomplish these transfers of functions?

desistant secretary Proister. That is exactly it. No incereases in appropriations are asked and no new lines of work establisherl.

Mr. Bromsin. Jou have no increases in salaries? What are those? Just let the record show that.

Iscistant Fecretary Pursisy. If there are any increases those will be taken up under the itesn's as you come to them. There alre mo increases in salaries due to the reorganization. other than alrealy explainerl.

Mr. Buchaxax. Jou have the chief in charere. at 5.5000 ?

Aesistant secretary Proister. That is the editorial position I spoke of a moment aro. the man that the Secretary wants to talie charge of all the publications of the department.

Mr. Bucusxax. That is ome increase. is it not?

Assistant Secetary Proster. That is a new position by transfer from a lump fund of the extension service. which fund his been reduced accosdingrly.

Mr. Bromaxi.: Then there are positions at $\$ 3.000$, an increase of \$.000. is there not?

Assistant secretary Pugsider. No, sir.

Mr. Jrar. That is a position which is now carried as the (hief of Dirision of Publications. and if there is to be no more Division of Publicationsoly that exact name. the title of the position should be changed accordingly.

Assistant Secretary Prosis: There are only two new positions askerl for: One is for a man to take chare of this editorial work in $220: 2-2-2-3$ 
the Secretary's office and the other is the director of extension work. There is no increase in money asked for.

Mr. Buchavax. What is his salary?

Assistant Secretary Pucsler. $\$ 5,000$ for the director of extension. the same as the other directors-the director of scientific work and the director of regulatory rork.

Mr. Bucmaxax. That is, the other directors provided for last year by Congress come under that bill. allowing the Secretary to employ so many at not to exceed $\$ 5.500$ ?

Assistant Secretary Pegscey. No, sir. That was another matter and did not refer to directors, but to salary increases on lump funds.

Mr. Mages. So you wanted a lot of changes. and I think that the committee acquiesced in them. It seemed to me. then. as if we were getting down to some fundamental foundation on which we could build. Now, you come along again this year and you want to change all that.

Assistant Secretary Pugsuer. No, no: we want to change none of that at all. I think we are on the foundation with that. This is something which was not taken up then. and has not been taken up with you before.

Mr. Magee. You bave new ideas as to the director of regulatory work, a director of extension work, a director of scientific work. etc. Now, you will probably come along another year-you may not be here, and somebody else wants something different: and so we will keep on changing and shifting and transferring. It seems to me matters of appropriation ought to be simplified rather than being made more complex all the time, and that instead of having a volume representing agricultural appropriations of 300 or 400 pages, it could be greatly simplified and reduced in size.

Mr. Bucilarax. I have no objection to any system that will improve the service, and I am inclined to aid any system that will make that improvement. In this reorganization. do you contemplate the dismissal of any employees now in there or demotion of any employees now there?

GRADUAL ADOPTION OF PIAN OF REORGAXIZATION.

Mr. Jump. As I understand the details of this plan, Mr. Buchanan, they do not contemplate making any great eut. because we latre got to go step by step. But we are doing this, and I think this will appeal to the committee and to the Congress as an added reason for making this change. Here, moler the Secretarv's oftice, when we place these other units in operation we will have six or seven diflerent branches of the service. We propose to do something at the beginning of the fiscal year that has not been done enough in the Government service, and that is place the overhead, work for all these branches in one centralized accounting oflice under the immediate supervision of the Secretary. It will do the comting and purchasine and all that sort of thing for all these branches. In that consolidation of overhead, if past experience is to be our wnide, it seems quite likely that there will be some reduction in the force.

for instance, every time we have consolichated we have found. after we grot ruming, as we did in the andressing and duplicating that the $\hat{\Lambda}$ ssistant Secretary mentioned, and exomomic work, some employees conld be dispensed with; and undouldedly the Secretary 


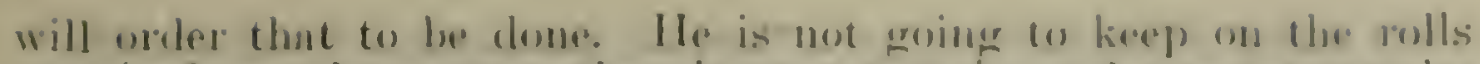

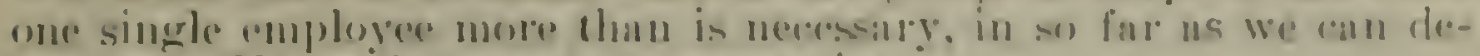
termine. He resilly expeces to anomize.

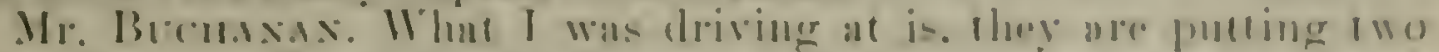

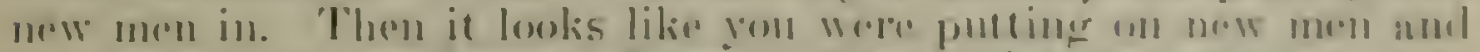

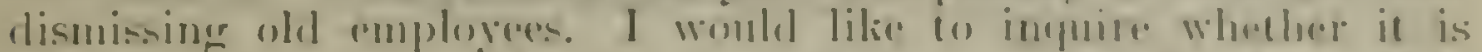

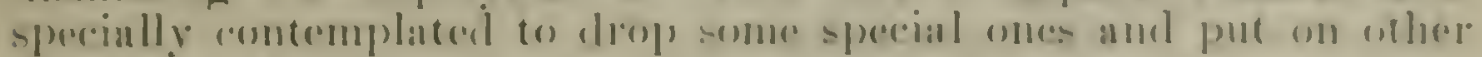
spercial inges?

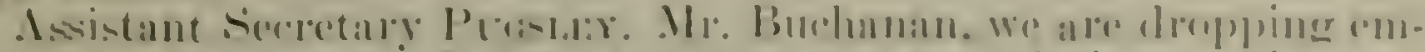

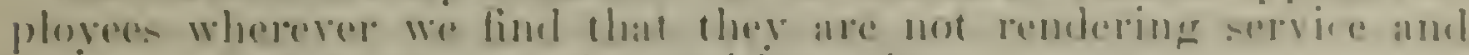
where wo find wo rant get nlonge withont them.

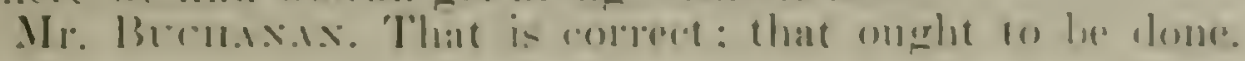

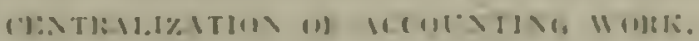

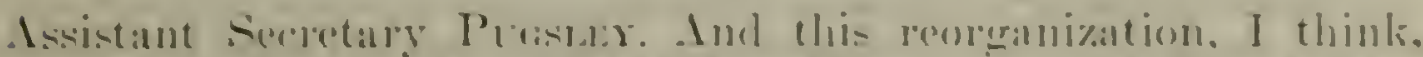

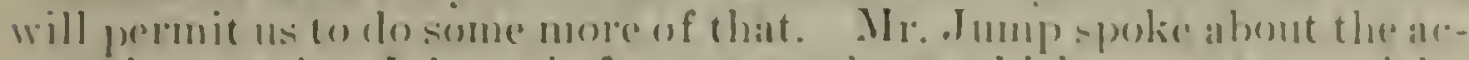

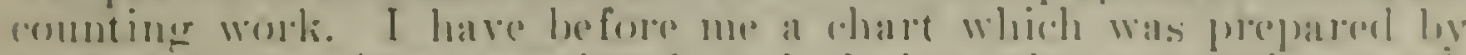
a special committee appointed to look into the accomnting work

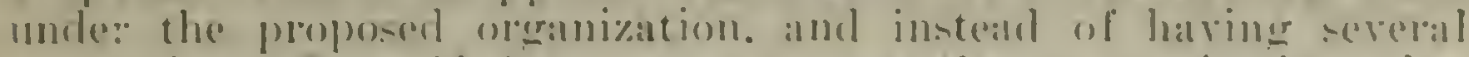
accounting oflices. if (ongress appores the rempranization plan which I have just sulmited. wo expeet to have one alcounting oflice

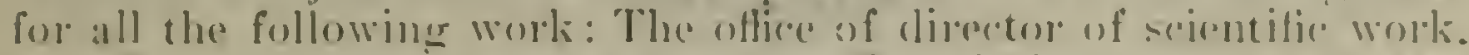

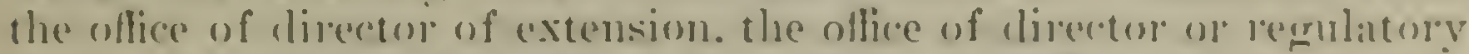
work-the orlitorial and alistribution wo:k-the olliere of the enlicitor: the oflice of the rhief clerk, the oftices of inspection, personnel. mechanical shopse and traffic manatger: all of which atre murler the secretary now. yol see. many of which have separate acounting oflices at the present time.

Mr. Bionuxas. The only reason I asked that puestion is that pesu remember when this item was up last rear l was told by four o five Members of Congress that the department contemplated dismissing a rertain man. and I asked the director a question-I do not remember his name now

Assistant Secretary Prosistix. And we told you we dicl not: and I (an say this. we do not have in mind a dismissal of any individual. What we do have in mind is letting eno such people as can be let gro hy the sarings that will be eflecterl hy any reorganization.

Mr. Bucruxas. That is entirely proper. The only reason I asked the question was calling to mind other Members of Congress coming to me about this man. I can not lieep those names in mind. I did not know him. I just wanted to inquire about that. Congress is not in session anil my other eolleagues are not here.

Assi-tant secretary Prgst.ry. Tou can assure any of them that we do not have in mind any individual to be drepped.

Mr. Bucraxax. No inan is more in favor of economizing and entting ont all the employees you can and at the same time maint nin the efficiency of the service than I am.

Mr. IInife. How does the number of employees compare with a year ago?

Assistant Secretary Prostar. That I can not answer. I know they have heen cut down in certain parts. and probalsly added to in others becallse of increased appropriations made last year. 
Mr. Junl. The had some new lines of work-the Center Market: the fixed-nitrogen research laboratory. transferred from the IVar Department: and the administration of the packers and stockrards and the grain futures acts.

Mr. Magee. Can rou grive us a statement on that?

Mr. Jrur. In retail?

Mr. Marres. In the agraregate.

Mr. Irarr. I can tell pon, offhand, there was a slight increase in the total of the department of several hundred employees during the last fiscal year, due principally. of conrse, to additional responsibilities placed upon the department. such as those I mentioned a moment ago.

Mr. Macier. You are talking about a decrease, and I was interested in knowing to what extent the force had been decreased.

Assistant Secretary Pugsuer. The statement of the Secretary relating to economies in the department. which was not read but which was made a part of the record. will corer a considerable part of that.

\section{OFFICES OF EDITORIAL AND DISTRIBUTION WORK. \\ STATEMENT OF MR. JOHN L. COBBS, CHIEF, DIVISION OF PUBLICATIONS.}

REASONS FOR CIIANGE OF TITIE.

Mr. Axpersos. Who is going to present this phase of the editorial and distribution work? First. Mr. Pugsley, if you will, I would like to ask one or two things about this reorganization before we start in on the details of the statutory roll. Among the other changes that prorides is a change in the name of the Division of Publications to offices of editorial and distribution work. Now. in the last appropriation bill a question arose as to whether a change in name of that sort was legishation. My recollection is that the Chair held that it was. If it was. this change can not be malc in the appropriation bill without lecislative anthority. In view of that fact. I would like to ask you what importance. in your mincl. attaches to this change of name?

Assistant Secretary Pugstay. The ehange in name from division to offices would be in accordance with the general plan that is now being considered within the department of nomenchature in connection with the names of the varions bureans and divisions and offices. It would more clearly represent in the minds of the people in the department the exact place that they would ocerupy in the general scheme of organization and would be rery helpful psychologically.

Mr. Anmerson. Are there any further questions?

Mr. Biphanas. I have none.

Mr. Axmensox. Are there any othep changes of names. exerpt in the case of the Burean of Eeonomies, involved in this reorganization?

Assistant Secretary Prosisy. That (hange was made last year.

Mr. Axbensos. Yes: hut I mean the Burean of IOne Economics.

Assistant Secretary l'u(sider. No: that is all. We merely ask the change of name from oflice to burealle.

Mr. A xublisox. Then you change the title of the extension serviee? 


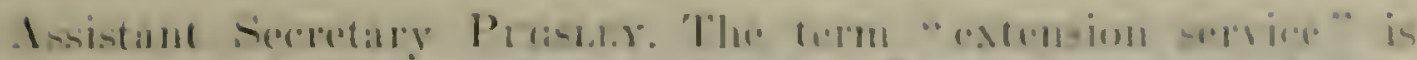

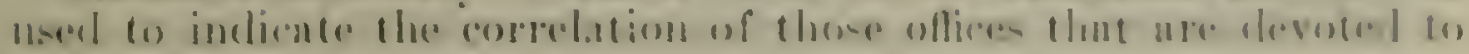
rxtollsion work.

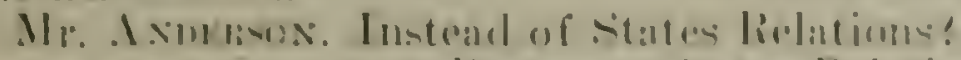

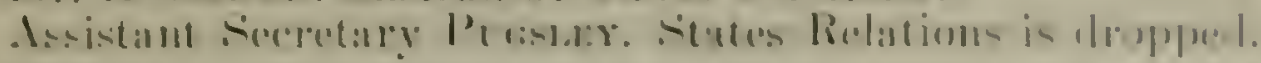

S11.11:1r:s.

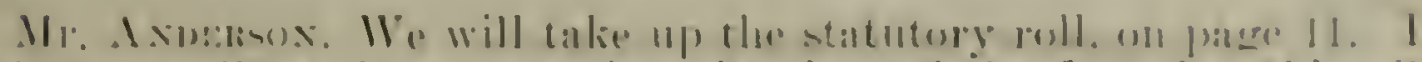
think we will perhalss sate time, in view of the ford that thin all

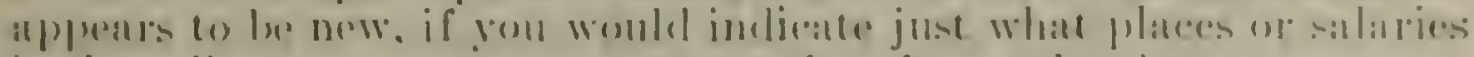

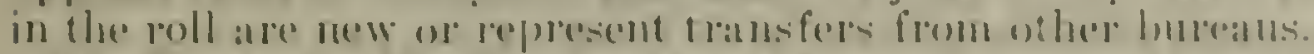

Mr. C'onss. As Mr. Pugrsley has tolel von, the present dirision is to be abolishoel and the work it now includes is to lo put partly into the new oftlee of extension and partly into the new oflies of editing and distributon. These places nese on the division roll which are assigned to the oflices of motion pietures and rexhitits have been manserred to the extension oflier roll. The roll as presented on bar 11 for the editorial and distribution work conseguently shows only these places actually acoupied by people in editoriai and distribution work, the press service. and the illustrat ions and chuplicat ion icroints.

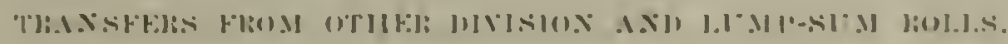

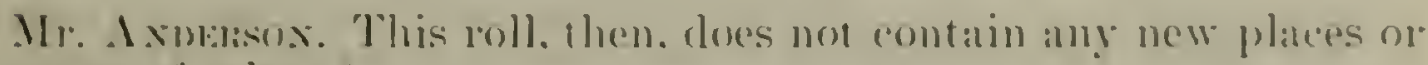
(hilnges of salury"

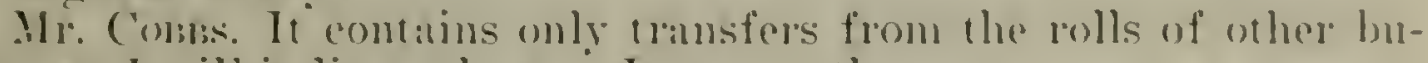
realls. I will indicate those as I come to them.

The first platee, page 11. assistant in chatrege of editorial oflice. at so.(n)(), is at transfer from a lomp-sum fund of the extension service. whinh his been errespondingly reduced. and is to provide for a person to take chatre of the offices of the editorial and clistribution

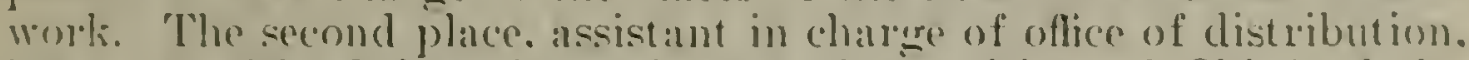
is a new title. loeing changed from the position of Cluief of the 1)ivision of Publications. The thirel platere editor. is a change of title form ahe enditor of the Disision of Publieations. That is the place at 50.0140 . The executive assistant is a new place in lien of the pesition now on the statutory roll in the Division of Publications. assistant in chanere of information. The next place assistant elitur.

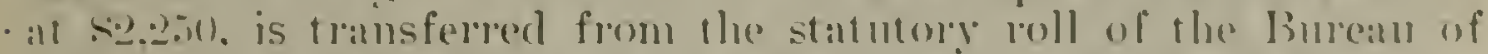
Animal Industry. with a change of "title from elitor" and ampiler.

Mr. Burmax. That is the ats-istant exlitor?

Mr. ('oms. Assistant editor': yes.

Mr. Bromax. That is the first one?

Mr. (coms. The first one. at s.2.2.n.

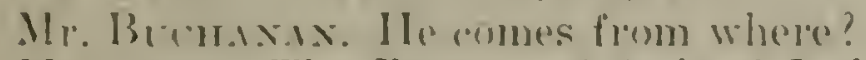

Mr. Combs. The Burean of Animal Industry. Xow, mulere as-istants in rhatre-

Mr. Bronks. they?

Ifr. Coms. They ane pusitions num an the etatutery roll af the

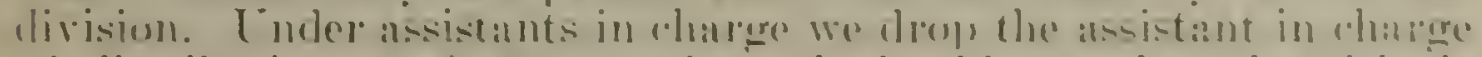

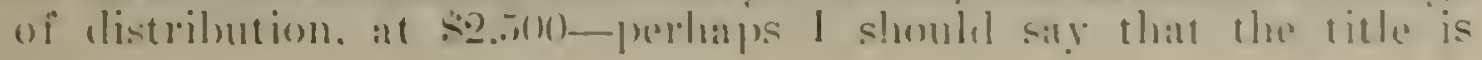


changed from assistant in charge of distribution to assistant. You will see below that we have two assistants at $\$ 2.500$. instearl of one. as we have at the present time.

Mr. B3comasis. Let me get that straight. Is this another new position at $\$ 2.500$ that you have just mentioned?

Mr. Conbs. No: just a change in title from assistant in charge of distribution. which is the present title. at $\$ 2.500$, to assistant, at $\$ 2.500$.

Mr. Brchasas. That is just one of them.

Mr. Conbs. And we have one already. which will make two for the next year. If I may ro back just a second. Tnder assistant editors, at $\$ 1.800$. we have at the present time two. one of whom is attached to the office of motion pictures. and that position is accordingly transferred to the extension office. learing one in the division.

The next change comes in draftsmen and photographers. at \$1.600. At the present time the division has three places. Two of these are employed in the motion-picture office. and have consequently heen transferred to the office of extension. Liliewise. there is at the present time clraftsman or photographer. at $\$ 1.500$. in the motion-picture office who has been also transferred. Other transfers inchucle an assistant photographer. at $\$ 960$. and a laboratory a dirl. at $\$ 900$.

In the clerks. we have now of class $t$ : two of them are assigned to the office of exhibits and have been transferred. Three clerks of class 2. assigned to the office of exhibits. and 1 of (']ass 2. assigned to the office of motion pictures have been transferred. redncing the number of positions of that class in the division to 10 . Two clertss of class $1 \mathrm{in}$ exhibits and 1 of the same gracle in motion pietures have been transferred to the office of extension. reducing onl total to 18 . One clerk at $\$ 1.100$ in the oflice of exhibits. and two clerks at $\$ 960$ in the oflice of motion pictures have heen transferrect. with change in title to laboratory aid.

The next change there occurs. I think. in the sstn mesemenger of lahorer arate, in which one position in the oflice of motion pietures is transferred to extension: in the sizo urade one is transferrect.

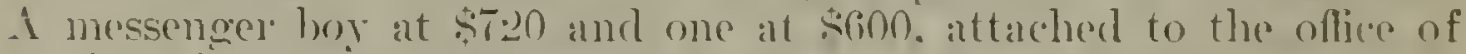
motion pictures, ane transfered to the statutoly roll of the extension office, and this roll has been reduced aceordingly.

The assistant in charge of motion pictures and the chice cincenallogralphes lat re heen transtereed to the statutory roll of the office of extension work: the assistant in charege of exhilhits and the assistant in exhilits, with saluries of $\$ .8 .000$ and $\$ 2.000$. respectively, have

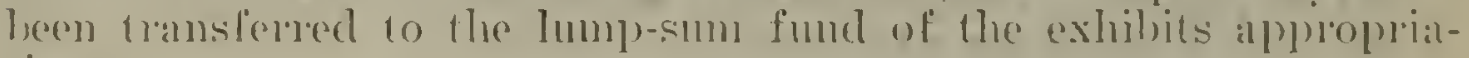
tions.

POSITIUNS H.IMIXITHO.

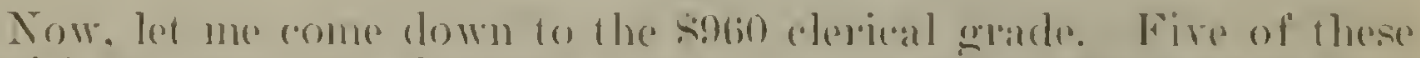
positions have beon dropped in aldition to those which have heon

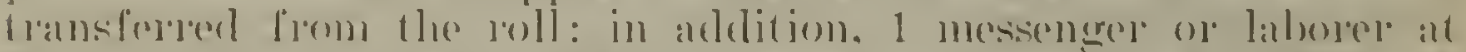

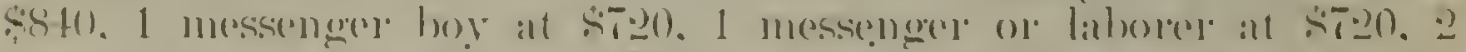

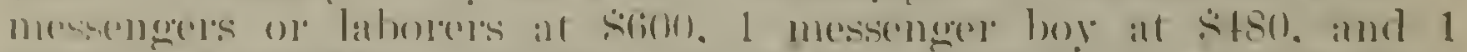

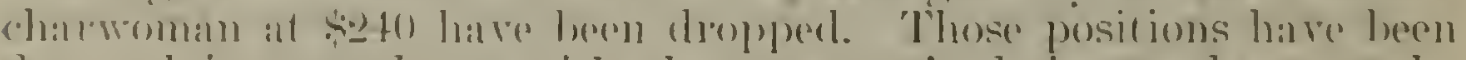

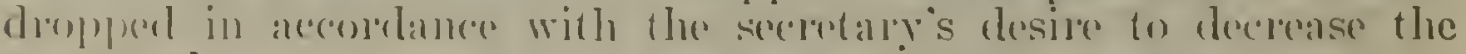
perisomnel. 
Mr. Bochaxis. Now, are those positions dropped out of this organization as it now exists, under the present uppopriation?

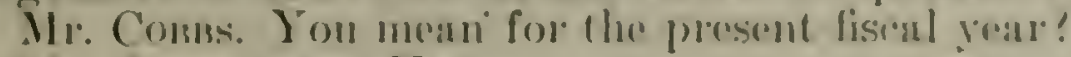

Mr. Bumaxas. Yis.

Mr. Comss. The totals in the estinnate for next year have heren decreatserd.

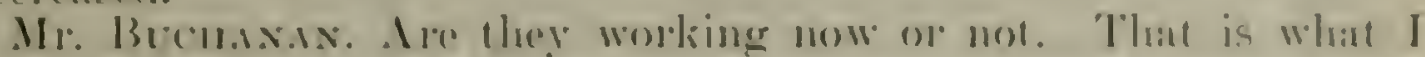
winl 10 linow.

Mr. ('oms. Part of those positions are filled ut the present time.

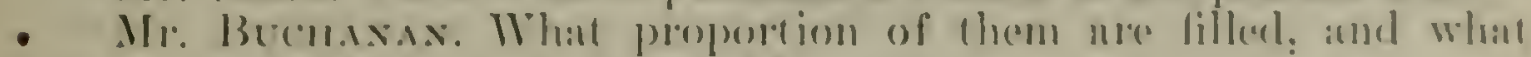
proportion of them nre droppred?

Mr. Comss. I ran tell rou which of those are filled: Messengere hoy

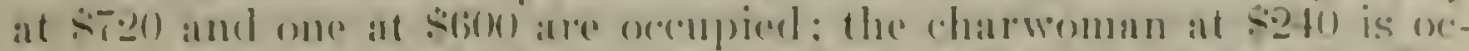

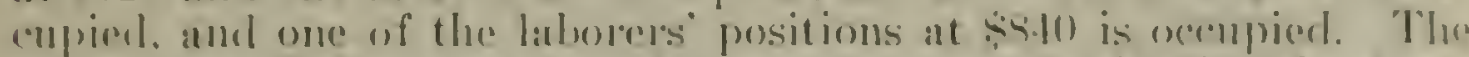

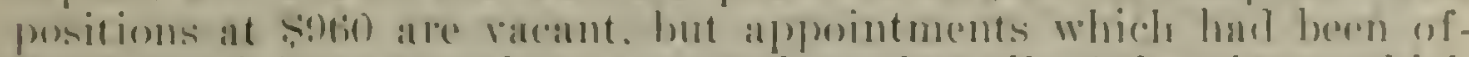
ford to eligribles have been accepterl. so that all of the places which

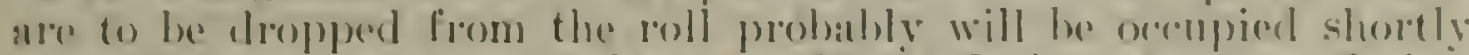

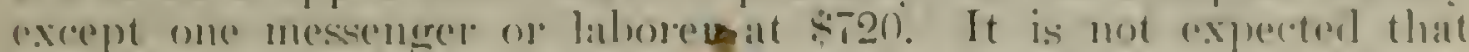
ally cherk will have to he dismissed on duly 1 as it is thought that the will be emongh clerical valdancies calused be resignation durind the remainder of the fiscal vear to malke mi the live position droppere. The charwoman. laborerse and mesengere boys will have to be dropped at that time, moless they an be transfored of their positions have heeneme valant otherwise.

Mr. Bermsx.s. Ifow many of them?

Mr. Corms. There are fire of those that have been dropped.

$\mathrm{Mr}_{1}$. Bromax. So that saving is already matle under the present hill and the present plan-fire positions at safon.

Mr. Comss. I wonlal like to make this statement there. We have

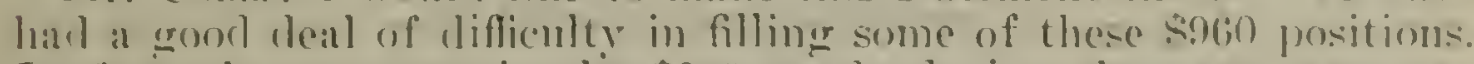

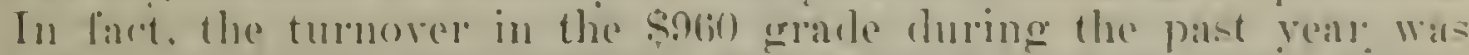
in exess of $t 0$ pere cent. and we have had a creat deal of diffioulty in eretting competent people for our work at that salary so that we have hatl at grool many vacancies thromghont the year which were in process of beingr tilleri. and two or three which we havent filled, becallese we folt veremlel gret alonge in a pinch withont them.

Mre. Berentax. If you harl wanted to hatre had some of these five positions lilled, your conld have had them fillenl?

Mr. (omss. Jes: we could eventmally have filled them.

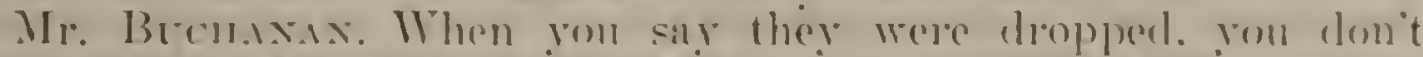
mean you dischalered anylurly: they jusi quit. Is that it?

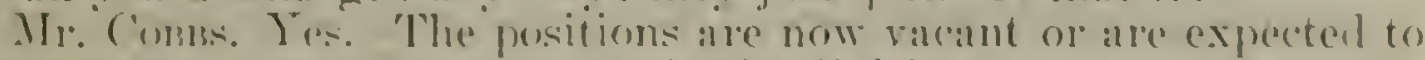
the rancint as al result of turnorer in the livision.

A-sistant Secretaly Prostsy. And. I think you might add. the

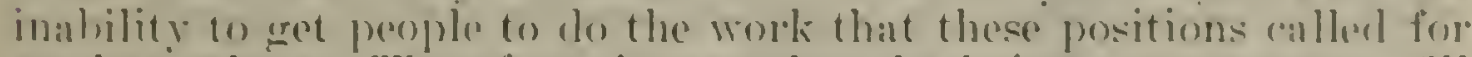
at that salary. "Therefore. it was thomerat better" not to try to fill the pesitions.

Mr. ('obss. It has taken during the past year any where from three to fire wereks to lill those positions satisfatorily. Wo have hat to do a tremendens amomnt of cormespondence with people all wer the colintry.

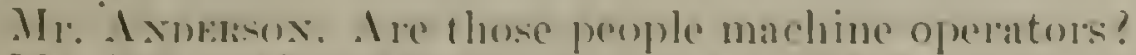

Mr. Coms. No. These alre clerical position- 1 am speakinger about. 
Mr. Axpruson. The net result of this business is that you transferred into this item $\$ \$ .930$, you dropped places amounting to $\$ 9.000$, and you transferred ont of it to other bureans $\$ 36.160$ ?

Mr. Coliss. Yes. sir.

Mr, Armensox. Is there anything further on this item?

MI. Conss. One machine operator's place at $\$ 1,200$ has been added by transfer from the Federal Horticultural Board. and one messenger boy's place at $\$ 480$ from lump fund, extension service. I think that is all, so far as I am concerned.

GENERAL EXIPXNES.

Mr. Axuensor. Then, we will take up the item on parge 1:3. "(reneral expenses."

Mr. Comis. General expenses. The languagre is changed from "Division of Publications" to "()flices of Editorial and Distribution Work," and the total-amount of $\$ 57.930$ has been decreased by $\$ 10.080$, which represents that part of the appropriation that we used to know as the extra labor find, which was due to the oflice of exhibits. This office has been transferred to the extension service and the exhibits appropriation for that service has been increased by that amount. That necessitated a change in the amount which is now available for extra labor and employment, \$11.380, to \$1.300.

Mr. Avipensox. Do you still require all of that language?

Mr. Cosns. That was changed last year. So far as I am concerned, I would like to let it stay just about as it is. You see. last year we combined all the varions small appropriations we had into this one large appropriation to give us greater leeway in handling it.

PRINTING AND BINDING.

Mr. Brchanax. If there are no questions on that item. we will take up the next item. That is all there is of that stuff. isn't it. except printing and binding?

Mr. Conss. Shall we talk abont that now?

Mr. Axmmson. Yes.

$\mathrm{Mr}$. Conss. The language in the bill has been entirely changed in order to bring it into conformity with instructions of the Bureau of the Budget in regard to combining all printing expenditures of the department in one appropriation. That is to say, whereas we formerly had a lump appropriation which was allotted to the bureans for printing and binding some of the bureans which had funds a vailable for the purpose also had what we know as " repay" worli done at the Printing Oflice. You are probalbly familiar with that. 'The effect of this wording is to bring into one fund all of the moners of the depaldenent which will be expended for printing. The anomnt

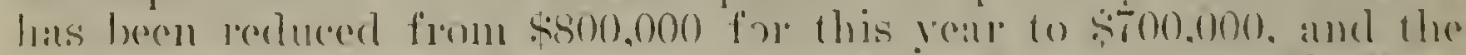

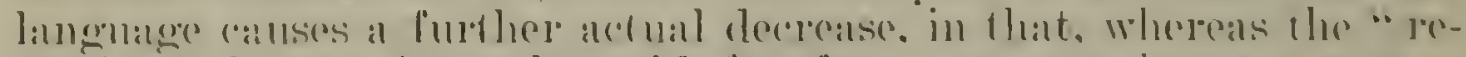
pay" work was formerly paid for from separate horeans approm-

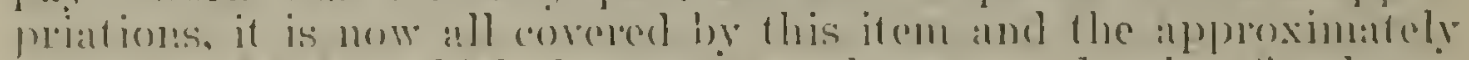

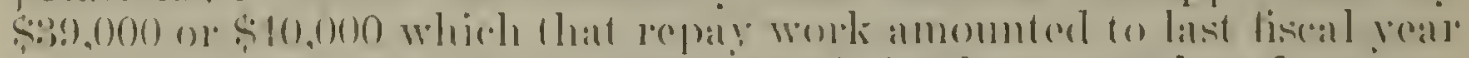

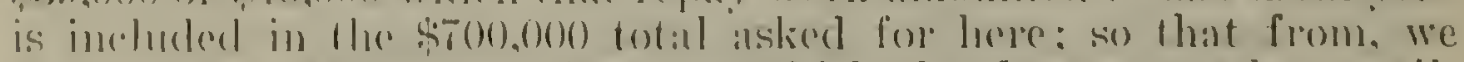

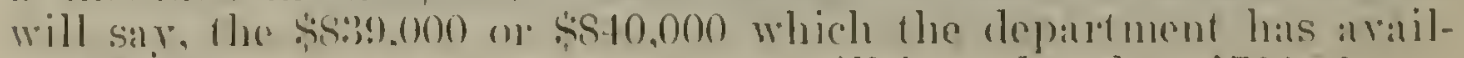

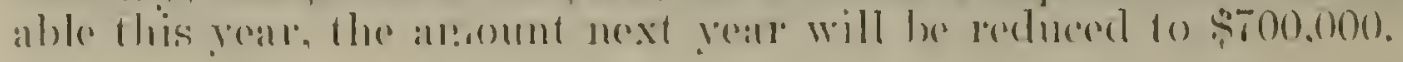


Mr. I xumasos. This practionlly does away, lhem, whth all the "repay " work in the hepartment?

Ifr. ('oms. Jis. I homk thut is the phun.

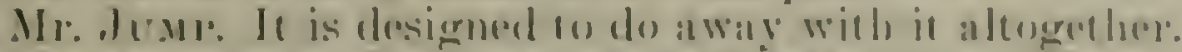

Mr. I. legrislative bill up) on that, my imderstanding was that when we hat this bill completed the repay work was 10 be dome at way with aldoErofher.

Mr. Just. I dont sie low any repay work can be done next peatr.

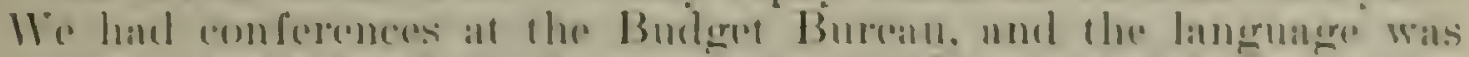

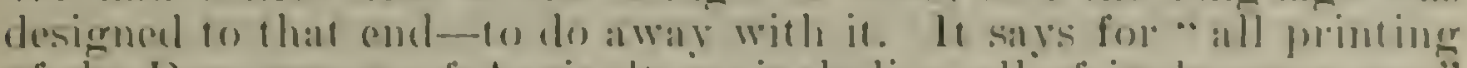
of the Department of Agriculture, inchuling all of its hureats, etce"

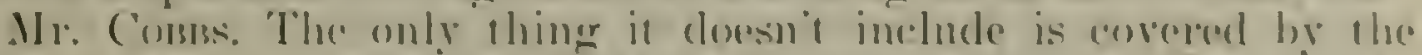

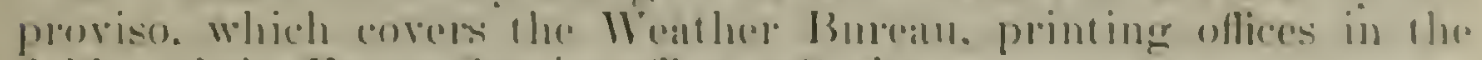

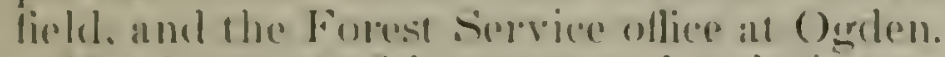

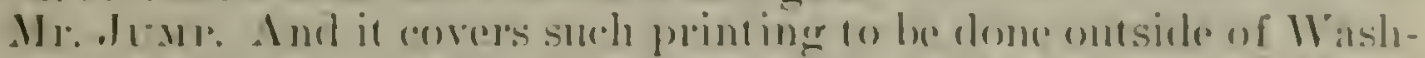

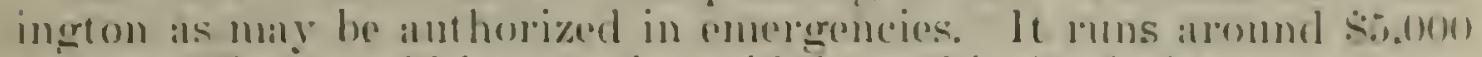
a veat. Thal would have whe patd form this fund also.

เหร)

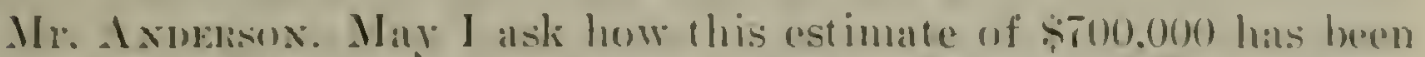
arrived at? Was it in (o)llaluerat ion with the Printing () flice of based rmtirely upon your own fignre!

Ir. Coms. il is bised. so fan as I know. upon ome own ligure. Ir. Itum] ("an tell you about thatt.

Mr. Il'me. 'i'he department's original recommendation was for the samb amommt as this yould, and this is one of the cuts which became necessary after the estimates were submitted to the Budget Bureatu. The Dejartment will merely accommodate itself to the eut and try (1) get along in the best manner possible with the reduced amomnt.

IIr. A splasson. Do you happen to know whether that cut was made by the budget oflicer's in accordance with estimates submitted by the (iovermment Irinting Ollice, or was it a purely arbitrary proposition.

Mr. I [ mur. I feed latther hesitant about saying as to that. I do not kmow that they consulted with the Goverminent Printing Oflice, but. in any event I would not say it was arbitrary hecanse that might cast i reflection on the Budgret Burean that is imwarinted and that 1 doni want to cast on them. My impression is that since couts hat (o) be made this was rearareded as a grond place to cut. In other words. a cut enold be made here, in all probability, with less ham to the work than in some of here places. It is one of the latre lump funds. ambl th" department's apparent turnlatek last rean. I think. was a considerable factor. The department turned bate a considerable

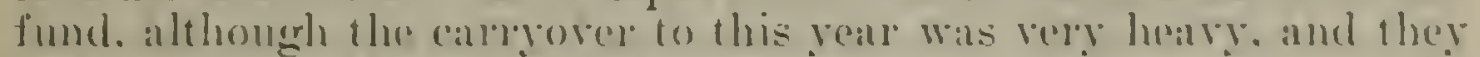
problably thonght the printing business onght to be restivetred. Of

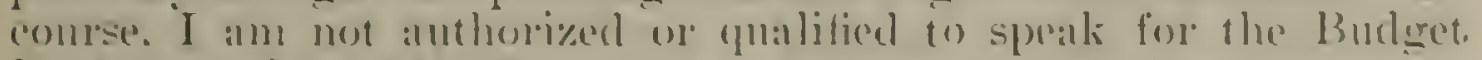
fimritll on thes mattirs.

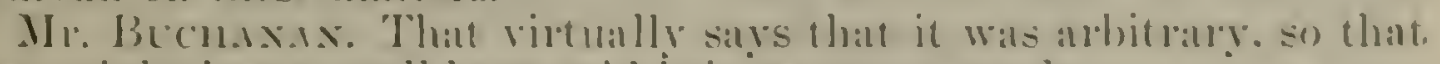
rou migrlit just as well hatre satil it in so many words.

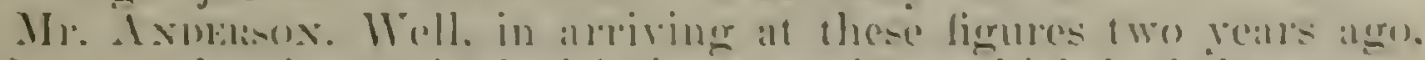
I happened to be on the leagishtive commitge which hat the alpho- 
priations for the Government Printing Office, and my recollection is that at that time we arrived at the conclusions we reached as a result of representations by the Government printer that the cost of paper, the greater efficieney of the offices, and the general reduction of expenditures accomplished there made it possible to do the same amount of work for less money, but, on the other hand, if this means there is going to be less printing done, that is different.

Assistant Secretary Pugsur. I think it means there will have to be less printing done than there would be with a larger appropriation, because it is impossible to do as much printing, even with the reduced costs, as it would be with the $\$ \$ 00,000$. On the other hand, we are constantly making combinations of periodicals and making improrements and changes in the work of the printing, and the Public Printer is doing the same thing, I think, so that the reduction in the amount of printing will be less, perhaps, than the reduction in the total.

Mr. Anderson. Well, my observation of investirational researeh work is that it is a whole lot easier to make an investiquation and get the facts together than it is to get them ont and get people to read them, and nothing is gained by a policy which involves spenting an enormous amount of money to get facts, by research work, and then cuts at the other end, so that what you do is embalmed in the brains or in the library of the Department of Anriculture. So, as far as I am concerned, I would hesitate a good deal before cutting this appropriation below the limit of the useful work that can be done through the distribution of the publications.

Mr. Conss. Mr. Anderson, suppose I give you just a few figures which will give you the actual status of the printing fund as to last year. We had a total of $\$ 850.000$. We returned to the 'Treasury unused, \$183,848.79. But we had a carry-over at the end of the year at the Government Printing Office of approximately $1+1.000$. 'That is to say, had we been able to get delivery of the work which was at the Printing Office we would have had an unuserl anount in our printing fund of approximately $\$ 42,000$.

Assistant Secretary Pugshrer. That is, there was work turned in, but because of the rush at the Printing Ollice it could not be delivered until after July 1. and that will have to come from this applorepriation. A good many manuscripts were submitted for printing against the deficiency appropriation. Mr. Marvin har a number of manuscripts he was very anxious to get ont.

Mr. Anmersox. The charge, then, I take it, is not marle by the Govermment Printing (Ofliee against the Department of Agriculture until the work is delivered?

Mr. Corss. 'The final chane is not made motil delivery.

Mr. Anmerisox. So that while you may have hat work in their oflice which would hate alosorbed that entire alperopriation this yeald.

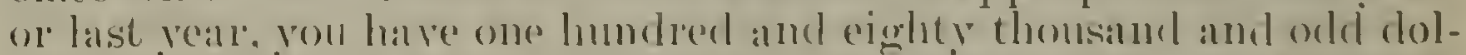
lats come batek into the Treasury heeanse the work was not delibered

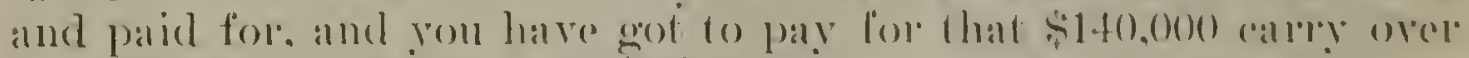
this yeall out of this appropriation!

Mi. Comss. 'That is the sitnal ion exaletly, and some of the bureans-

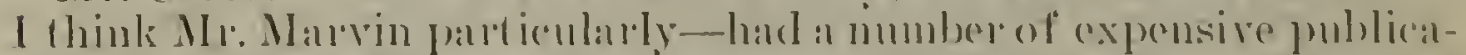
tions which were put in aldy last year and wheh were not delivered 


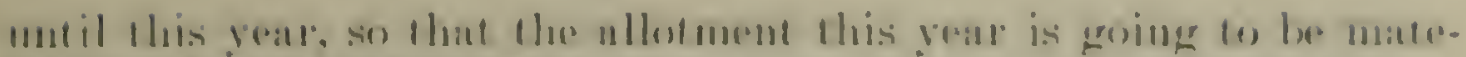

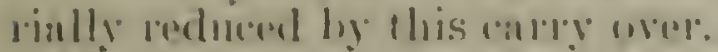

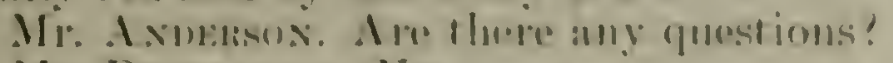

Mr. Brinasis. No.

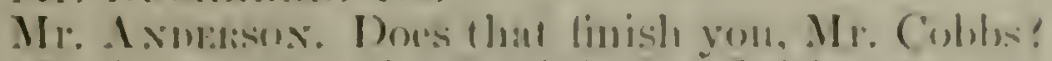

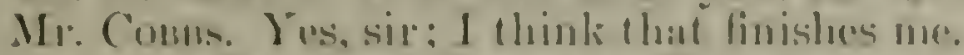

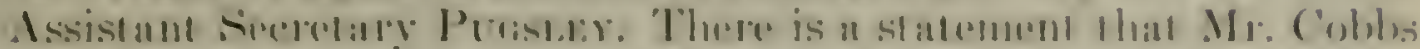

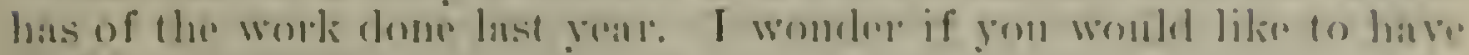
llant in the recort.

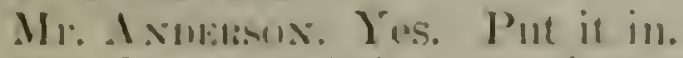

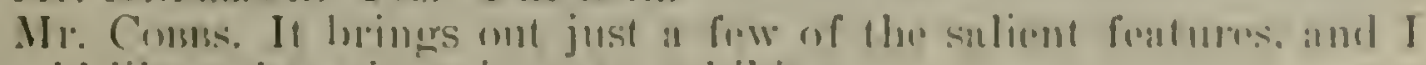
wonld like wo have it go in us an exhibit.

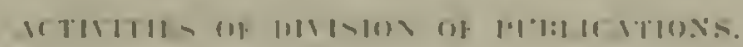

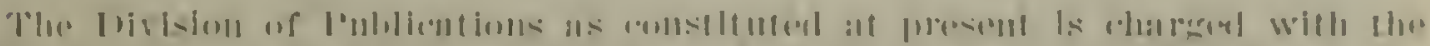

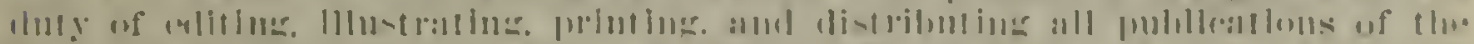

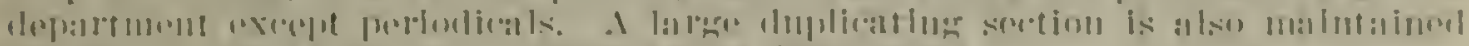

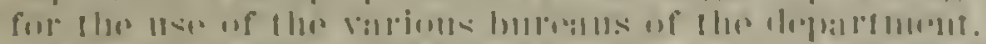

Ill fmblhatiuns, wh the

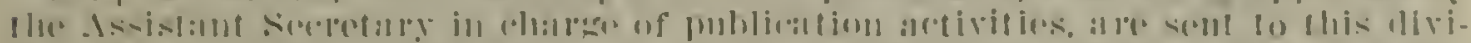

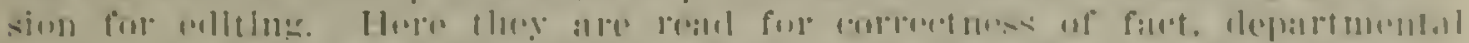

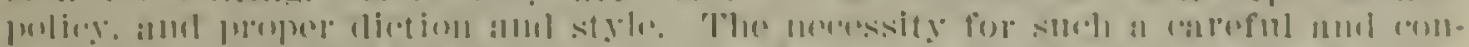

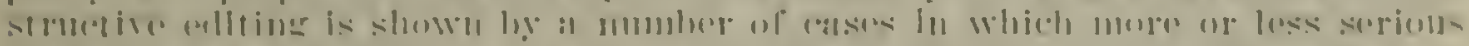

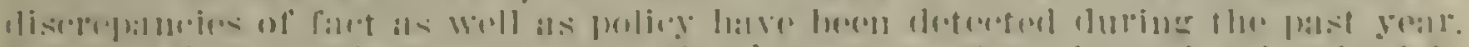

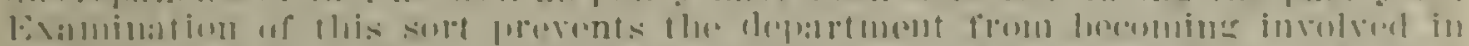
coml ros

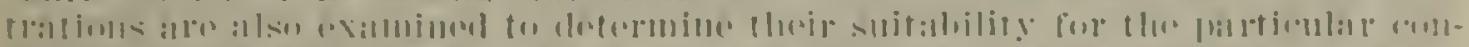

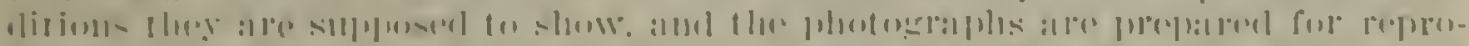

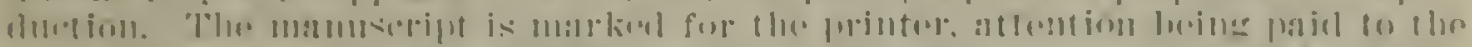

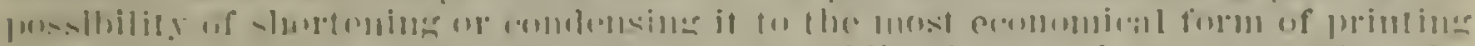

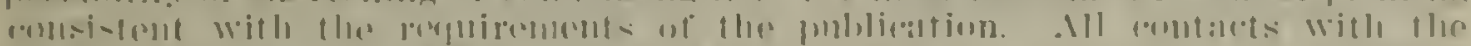

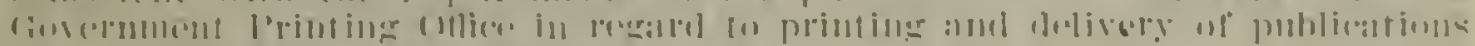

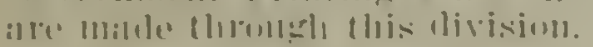

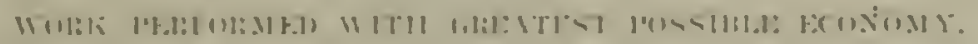

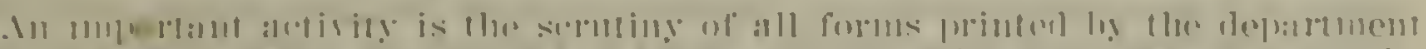

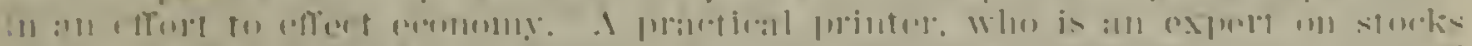

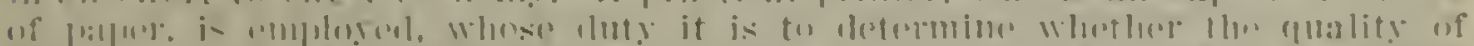
|

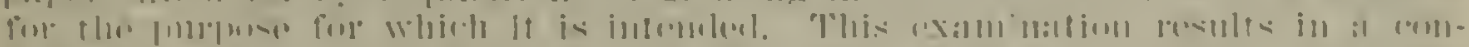

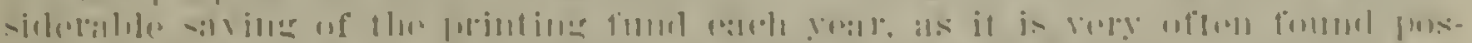

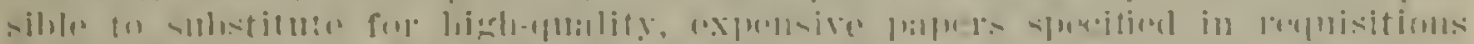

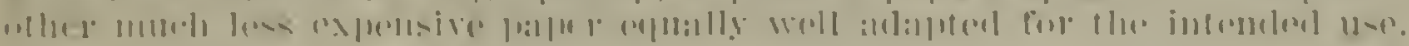

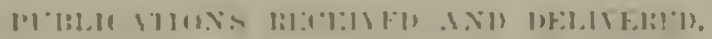

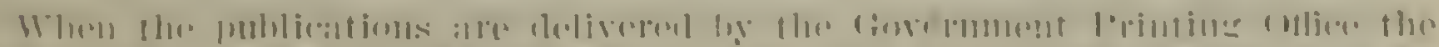

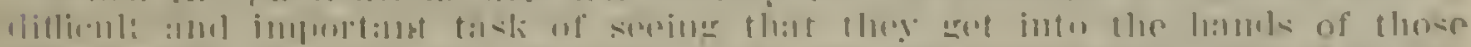
| listrilut

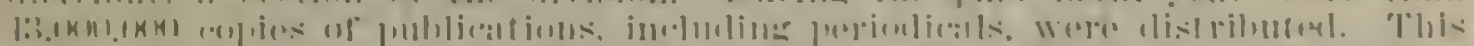

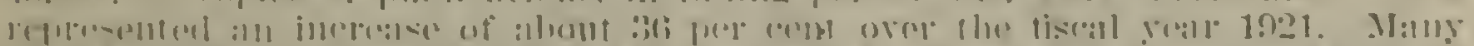

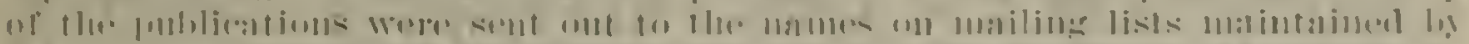

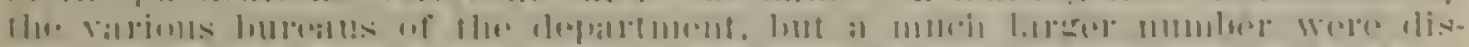

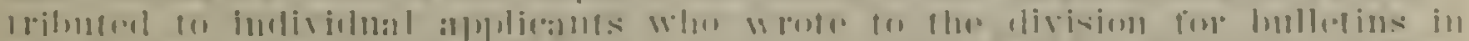

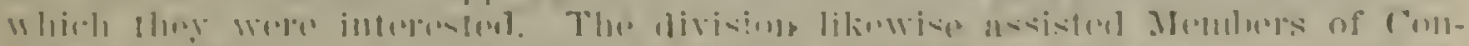

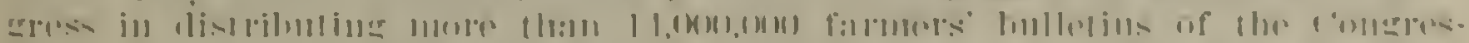

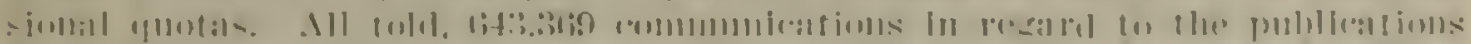

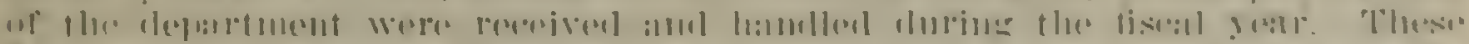

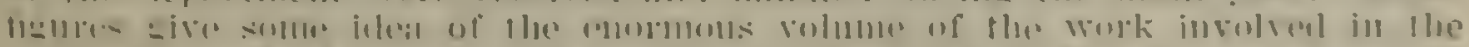

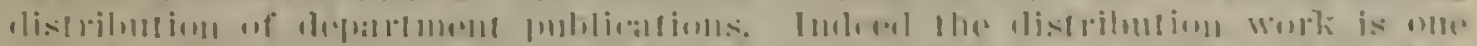

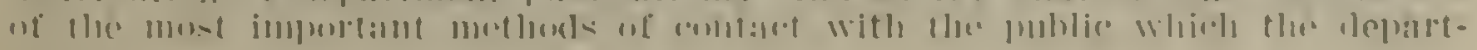
I11:11t li:ls. 
MAIING I.ISTS.

Gne important part of the distrilution work is the maintenames of the mati-

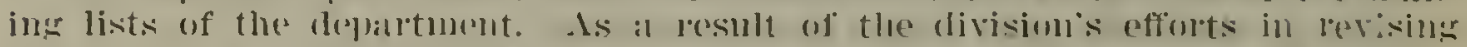

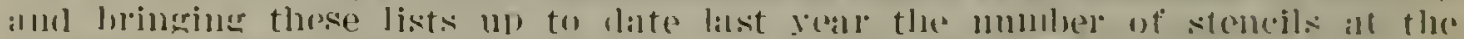

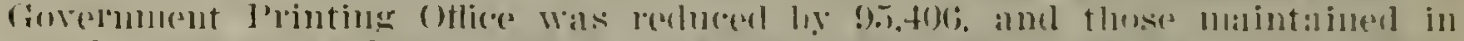

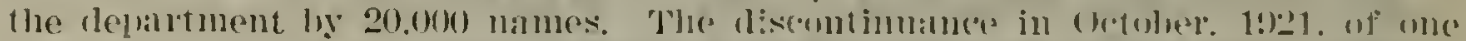

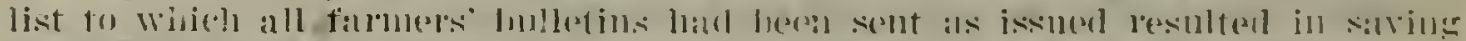

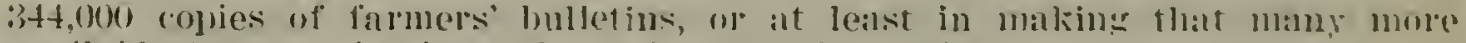

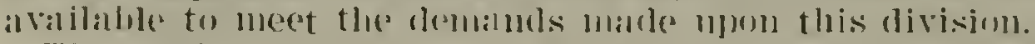

The section of illustrations, in alllition to purformine a consuleralule amount of photograthic field and laboratory work fol the villows hureatus of the department, prepares the illustritions fon department publications.

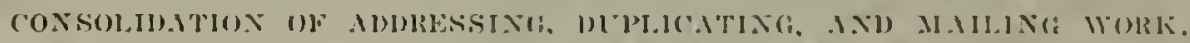

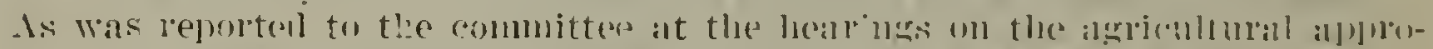

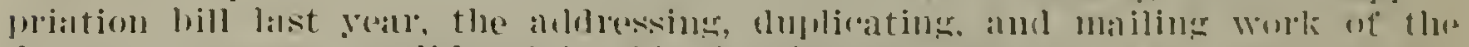

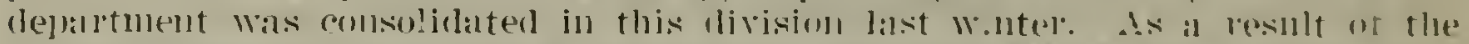

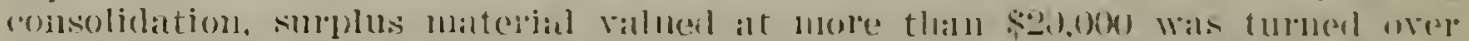

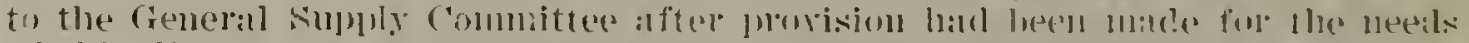

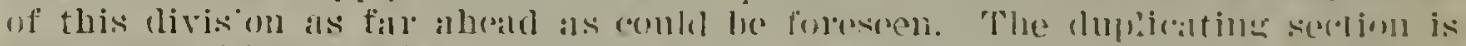

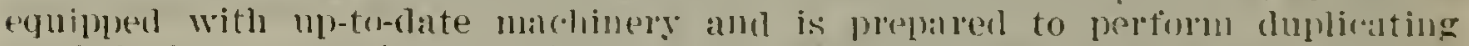

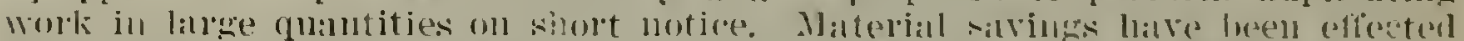

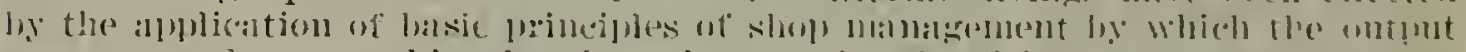

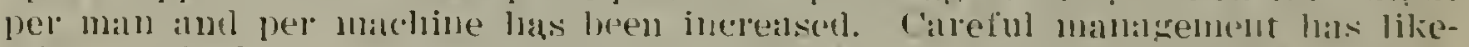

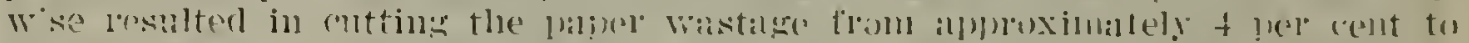
about 1 ger cent, while the quality of the work has been materially immored.

At the hegiming of the fiscall feall 19201 all the information and publicity activities of the depaltment. including exhilits and the press servire. Weres

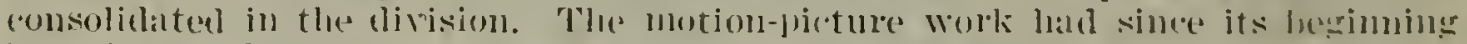

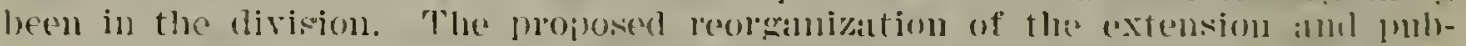

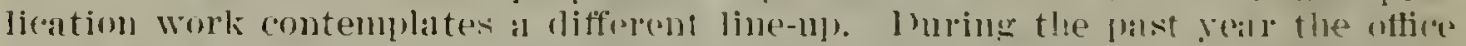

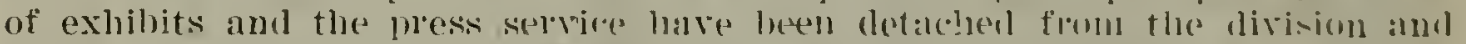

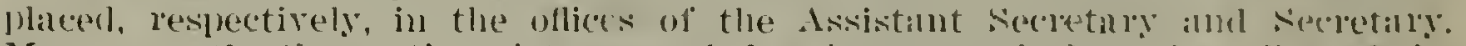

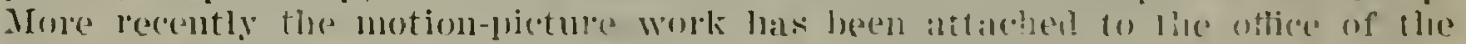

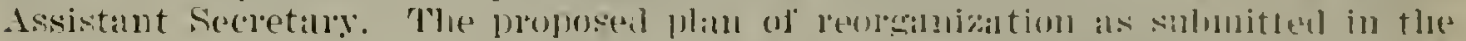

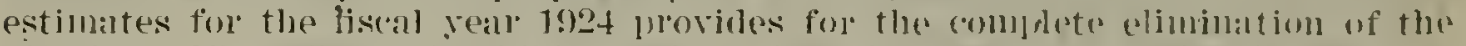
division. The oflices of exhibits and motion pietures alde inchuled in the furo-

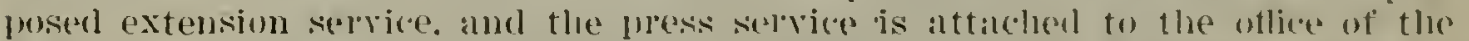
secretary. The other antivities mow andured hy the division are ro be placed in oflices of editorial ant distrilution work and attalehed to the otlier of the Sexcetary. The persommel formerly allotted to motion liketures and

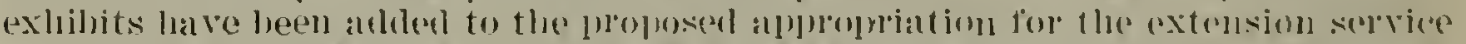

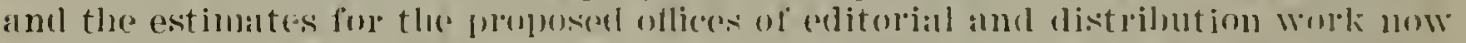

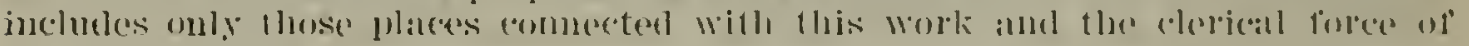
the press service.

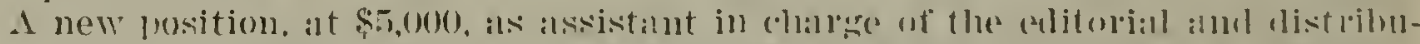

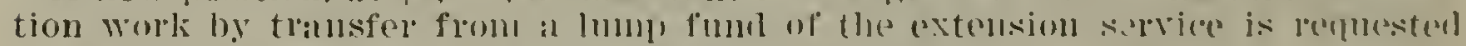

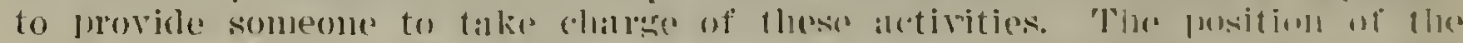

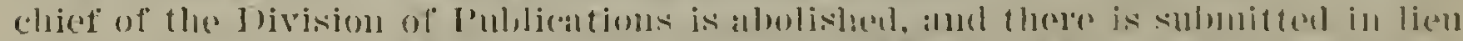

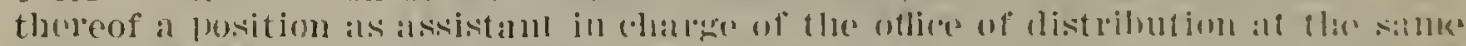

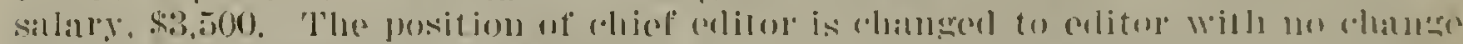

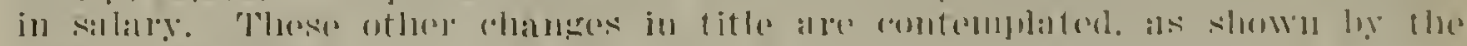
detaileml restimatres.

\section{(OFHIE OF EXPERIMENT NTATIONA.}

STATEMENT OF DR. E. W. ALLEN, CHIEF OFFICE OF EXPERIMENT STATIONS, AND DR. W. N. EVANS, CHIEF DIVISION OF INSULAR EXPERIMENT STATIONS, STATES RELATIONS SERVICE.

\section{I)"Mls.}

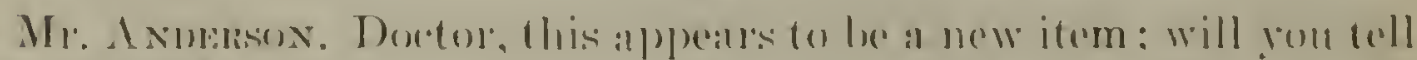
lls alsont it ?

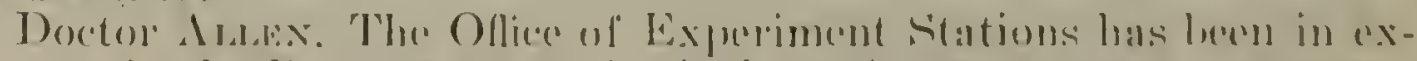

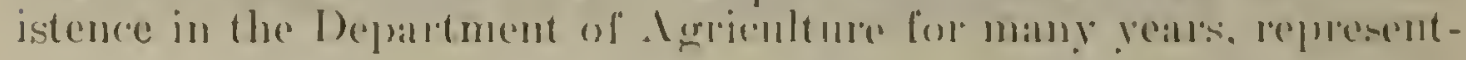




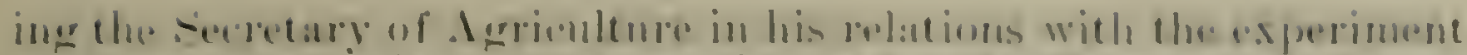

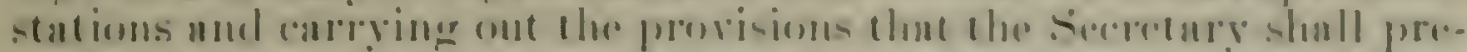
-cribe the form of the anmos fimmeial statement moler the Hatch

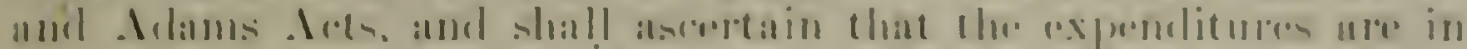

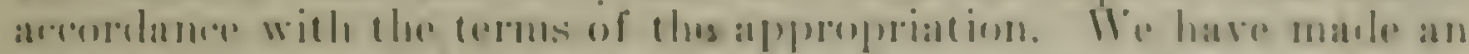

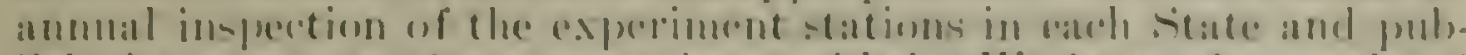

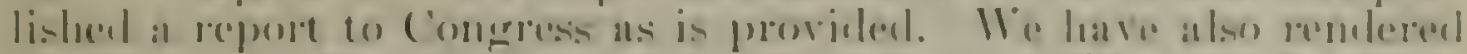
varions as astances to the experiment stations in the way of getting

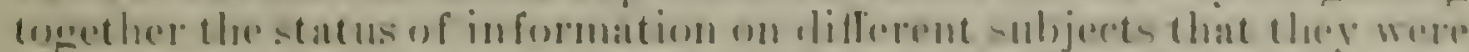

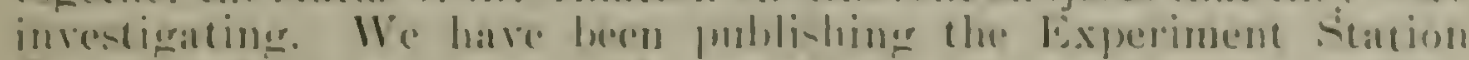

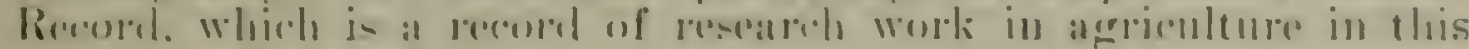

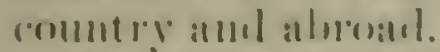

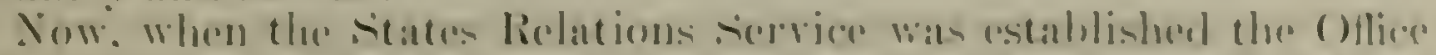

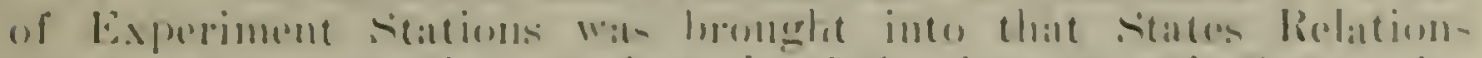

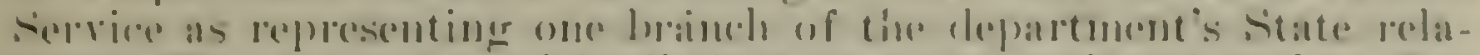

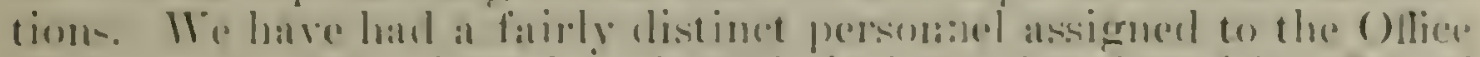

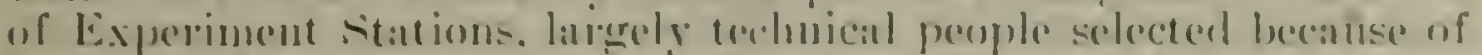

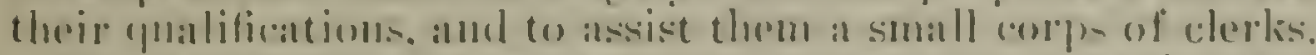

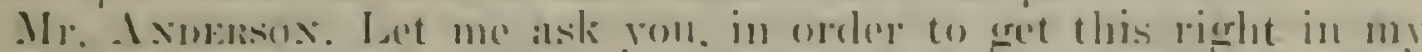
mincl. I molerstand that this is the merheal for the supervisory

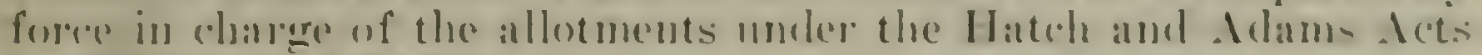

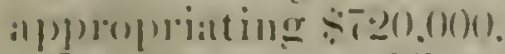

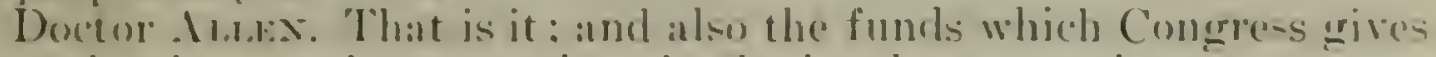
to maintan experiment stations in the insular posecssions.

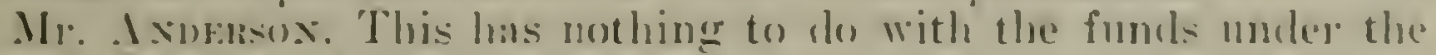
sinith-Iaver-110t

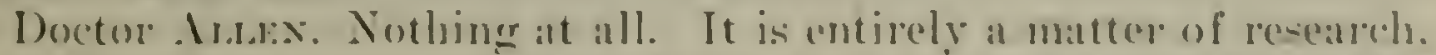
and therefore in the reorerangation it is proposed to assign this oflice to the director of scientific work.

S.IIAIRIES.

In the alppropriation asked for there are no increases and no decreases. There are transfers of three clerks, totiling $\$$ t. 400 . which decreates the lump-sum appropriation and increases the statutory roll by a corresponding amount. raising the statutory roll from 59.900 the current rear to 5.34 .300 for the coming rear.

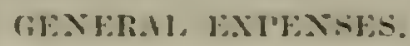

Mr. Axmersox. All right. Any questions on that! If not, we will take up the matter on page 19. General expenses. 'This is the Ilatch Act?

Doctor Drasis. 'This is the Hatch and Arlams Acte-the same for each state and Territory eatch year.

Mr. Axmonsox. "The ionditions unler which this is made in provided br the act itself?

Doctor Arex:s. Yes. In complying with the tems of the lat w w hat ve to-

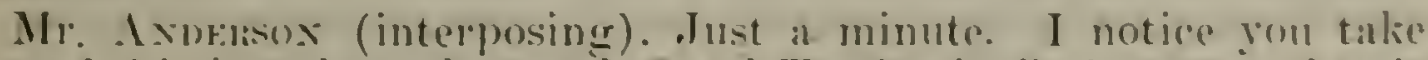
out of this item here the words "and Territories." I assume that is due to the sulseduent assigmment of the appropriation to the insular posessions-Cerritories and insular possessions? 
Doctor Allex. No. sir: when the Hatch Act was passed there were quite a number of Territories-Arizona and others. Those have all become States, so that this only provides for continental ['niter States.

Mr. Axpersox. So that that language is not applicable any more.

Doctor Alluex. It is superfluous.

Mr. Axpersox. And the same thing is true of the item on pare 20 ?

Doctor Aluex. Yes, sir; and that second limitation. providing that not more than $\$ 15.000$ should not be paid to each State and Territory, was deemed superfluous, because it is carriel in the dilams Act itself.

AGRICULTLLAL COLLFGF FATENSION WORK, ETC.

Mr. Axperson. The next item is the one on page 21.

Doctor Aldex. 'That provides for superrision by the Secretary of Agriculture of these funds under these two appropriations and the supervision also of the insular experiment stations.

Mr. Axderson. I see you have some languagre eliminaterl here. It apparently eliminates reference to the acts of May 8.1914. and the act approved .July 2. 1862.

Doctor Allex. That was the origrinal Morrill Act. This May 8. 1914, is the Smith-Lever Act: that has been taken out and prit under the extension office.

Mr. Axplasox. Oh. I see. This is all one proposition and talies out of the operation of this particular appropriation the arork under the Smith-Lever Act?

Dactor Allex. Yes. sir.

Mr. Axnersox. I see. Evidently you are not spending much money under this appropriation for supervision of that act.

AGRICULTURA, EXPEIMENT STATIONS OLTSIDE CONTINNTAL LNITED STATES.

The next item is on page 2:), $* * * *$ to establish agricultural stations in Alaska," ete. There you make a reduction of tit. (0)10. If my recollection is correct, last year there was a proposition which inrolved the construction of some buildings in Alaska. ('an you tell us what happened to that?

Doctor Alusx. Doctor Evans will explain that.

\section{AL.ASKA EXPLRIMENT STATION.}

Doctor Evaxs. The situation, Mr. Chairman, so far as the builuingrs in Alaska are concerned, is practically the same as it was. We did not get the appropriation we asked for 1223. The only building work that has been done was some repar work at the Fairbanks Station to render the old logr buildingr habitable and to replace the root cellar at the Fairbanks Station, and one at the Sitka Station. both of which had fallen in. and it had berome nevessilsy to replace them to take care of the root crops and other things that hat to be kept from freezing during the winter.

Mr. Axplessox. Tell, this item for Mlaska, then, doesn't rover any new construction for this year? 
Doctor lisass. No, sir. The appropriation reormmenderl for

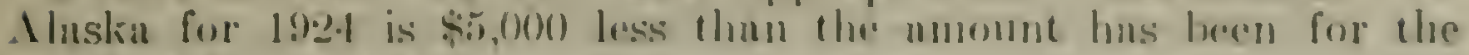
previons four yeats.

Mr. A xumasox. What was the iden of making 11.400 immeliately aritiluble!

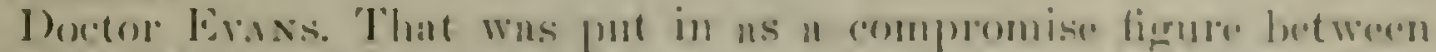

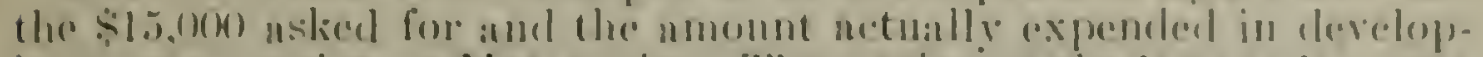

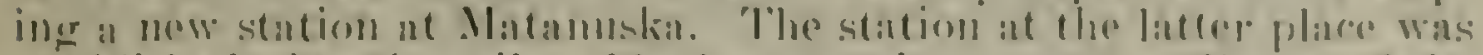

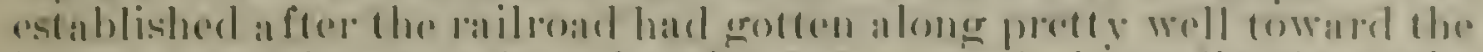

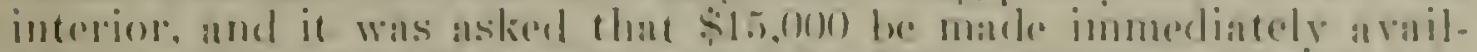

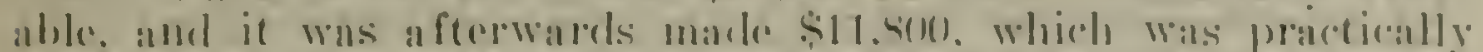
the amount spent at Matamestit during the first rear of eonstruetion and derelopment work. That item has been in the apperopriation hill

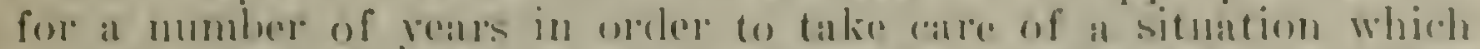
sometimes arises in Alaskat. Where the work would be rery materially

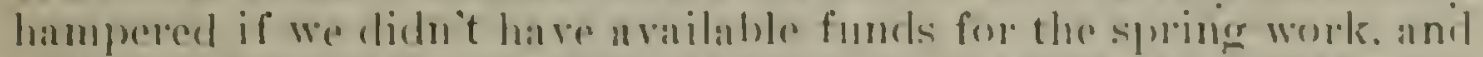

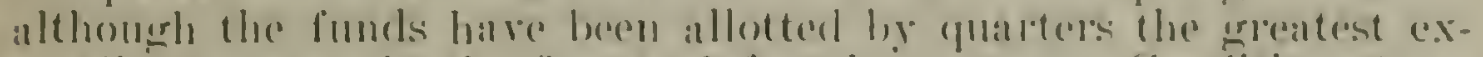

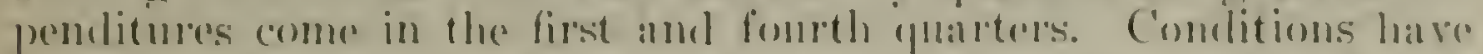
arisen in emerenencies where it has leen quite noressily (1) have it immorliately avalable. That matter has been taken oit this your, although it was requested it he kept in. 'This last year there has beren pratetically mone of the immediately a valable portion spent beranse it was a very late spring and the ficid work diol not herin ant il albont a month latere than nsuil.

Mr. Axmmasos. Yom weather hasn't changed up there any and since it hasut I 'ant see any reason for talking thes thing onte if it was a groot thing in the beginning.

Doctor Liss: Doctol Georesen has always mantained that was a good thing. so that the work would not be returded in the spming.

Mr. Burruxax. When does spring open up mp there?

Doctor Exaxs. It elepends on the part of Alaskat. Orelinarily in sonthern and sontheastern Maska abont the loth of May: in the interior about the 20th: but this year it was much later than usualalmost a month later than usual, and that was also true of a great deal of the northern part of the country. The spming was very late.

Mr. Iunr. I think I can clear up the reason why that was left ont. Whern we erot these astimates all tocerether we discovered that for the first time in many years we had a set of estimates that diul not require some money to be male immediately arailable. We thonght it would be a good thing. in the interest of simplicity. to let this Mlaskil provision stay out. The same argument for liaring it left in could be applied to any number of lines of work in the department-the erreater part of the work coming in the first and fourth quarters. 'That is true of a nmber of different projects.

As we understand it, this man will not have to we his money this reall. and we thonght if he conld start anew one year. he would always have presumably, in his fourth quarter money enough to do his work for that year, and we conld thus avoid chittering up the bookkeping with this thing of having money immediately aralable every year. The department wants to aroid that as far as possible. and we have understood that to be the policy of Congress.

Mr. Axnersox. I think it is very desirable. 
Mr. Jump. If a vital emergency should arise and the money would need to be expended to protect Gorernment property we would be anthorized to fleal with it as an emergency, and we wonld also have the benefit of the 10 per cent transfer provision.

ACCOMPL.ISHMKTS IX AI.AKA.

Mr. Buchavax. What are you doing in Maska: are ron getting any results from these experiment stations? I have heard various things about them.

Mr. Evaxs. The work at the Alaska stations divides itself $1 p$ into the work at different stations, where we have been carrying on inrestigations-at Sitka, which represents southeastern Alaska. horticultural work prevails; at Kodiak, where live-stock experiments are carried on: at Fairbanks. which is in the interior of Alaska. grain growing; at Rampart, on the Yukon.River, where we have found a place exceedingly well adapted to grain breeding investigrations: and at Matanuska, which represents the transition point between interior Alaska, with its intense winter cold, and the coast regrion where the temperatures are not so low and where the rainfall is much hearier and foggy weather prevails. At the interior stations I am very sorry to have to report to the committee this year that in spite of the fact that there was a larger acreage planted to wheat and other cereals than ever before. there will be but little grain. as a severe frost on the 27 th of August practically destroyed it all. 'The year before-that is, the summer of 1921 -there were $6,00(0)$ bushels of grain grown in the vicinity of Matamuska.

Mr. Bucmanax. What yield per acre?

Mr. Erans. Tarions langes are reported-in some places as high as 35 bushels per acre. depending upon the location, the soil. ete. The average ranged from 25 to 35 bushels per alce. But the 3..010 bushels of wheat grown near Fairbanks in 1921 was grown ly the farmers and not by the station. At the Matanuska station alont 1,000 bushels of wheat was grown in 1921. The latest adrice I had from those stations was that they thomght they wonld save enomorh for seed purposes this next rear, but that there would be very little for milling.

Mr. Bucmanas. Is that the first time rou noted frost in Aunnst?

Mr. Evaxs. That is the first time we have had anything like a meat failure of rops since we hearan work in the interior of Alaska in 1907 . There is an ordinary annual arerage of los days without frost. This year it was less than 100 .

Another thing that mate the thing worse was the late springe. which was followed by an musinally rany only, which kept the grain growing late into the seatson instead of letting it mature andry. as commonly.

The other work we are putting in at Matamuska and Fablunks is prospering very well. The development of om live-stock herds is making it very essential that we shall have more money for eonstruction of bivildinges and for clearing and fencing land for pasturare and grrowing forests. 
Mr. Inuacos. I suppose the work is groing on in these other stalions as Instal!

M1. Evass. They ure goinge alenge as ustal. In Hawaii the

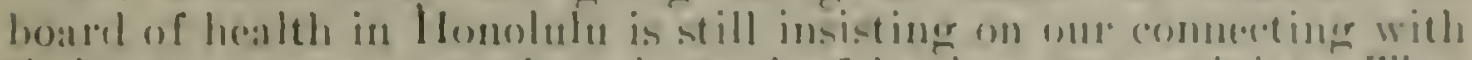
their sowerage system there instend of having open privies. Thas

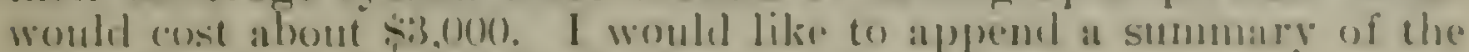
work for lhe past gear at all the insular stations.

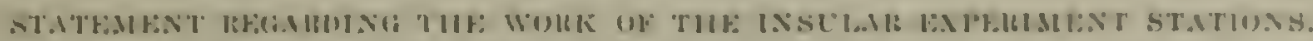

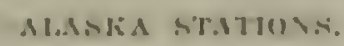

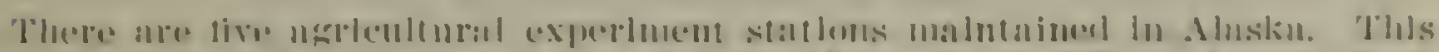

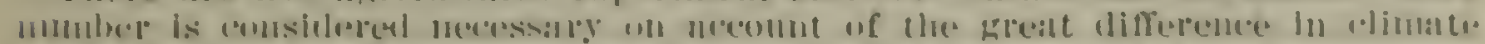

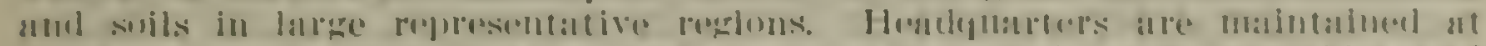

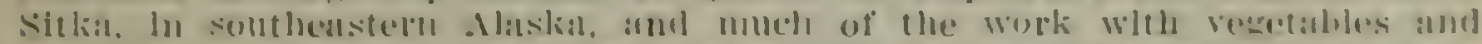

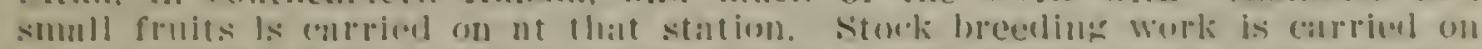

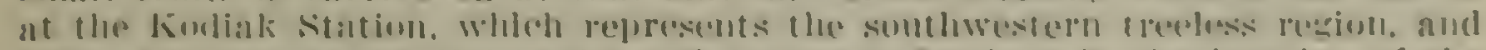

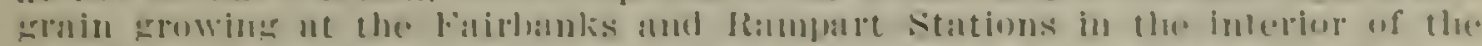

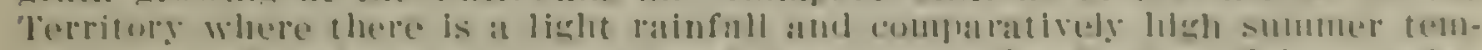

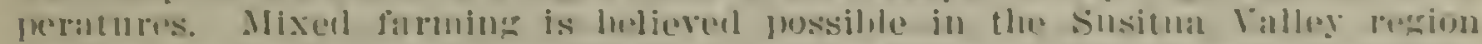

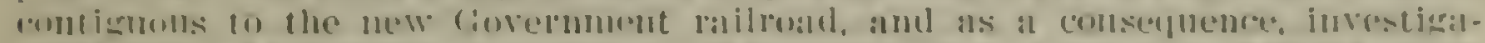

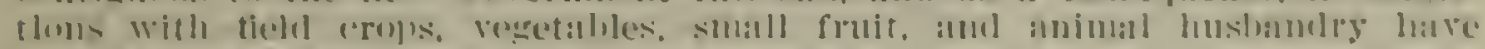
leren lewerm at the Maltanuskil sitation.

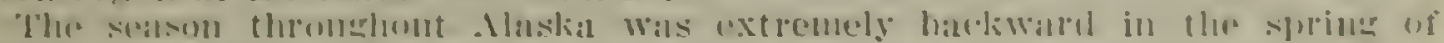

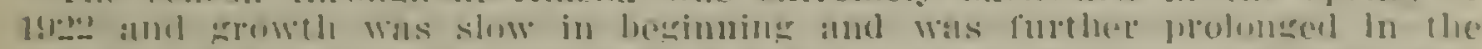

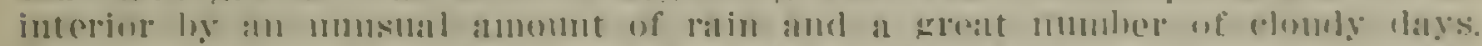

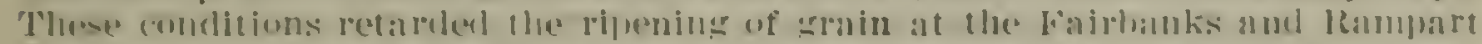

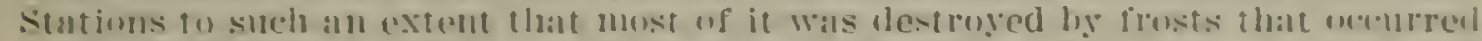

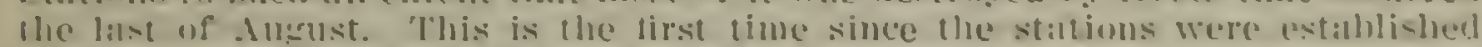
in limir that the majority of the varicties of cereals falled to mature. It the

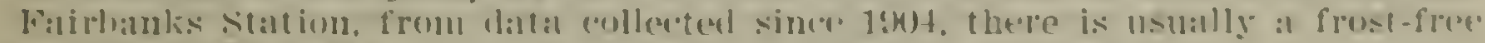
perionl uf 1 (1) dars.

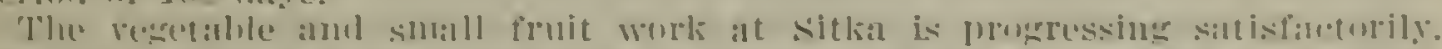

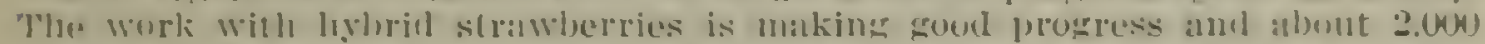

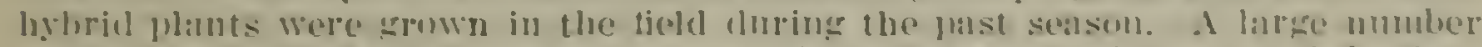

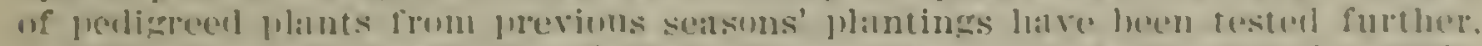

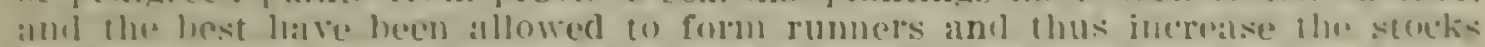
for (en)

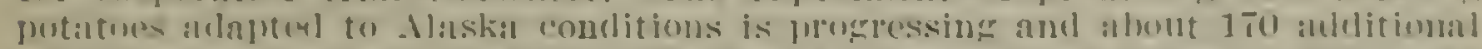

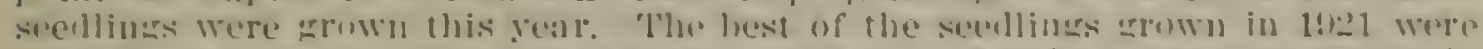

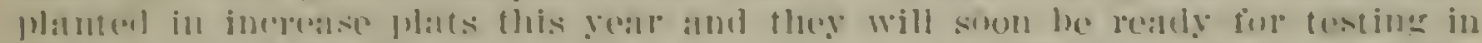

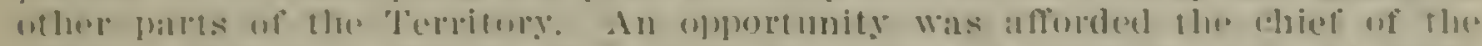

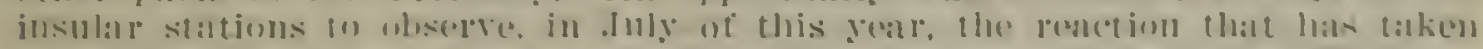

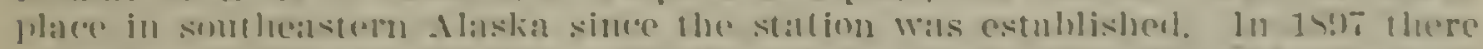

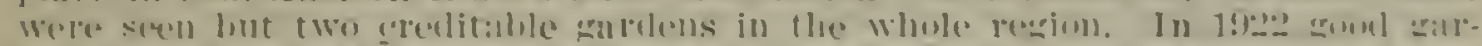

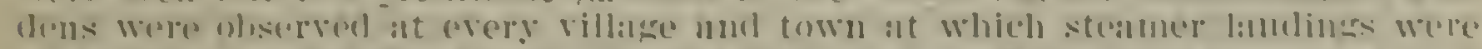

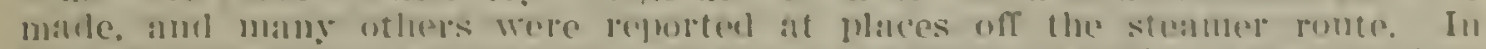

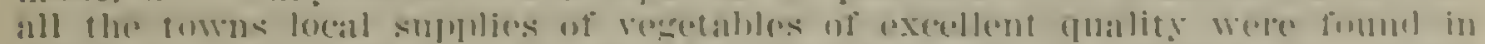

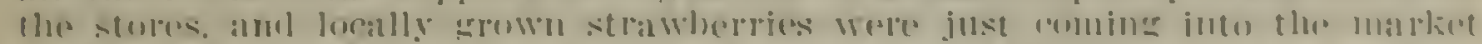

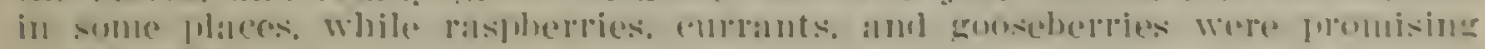
litr:er (rouls.

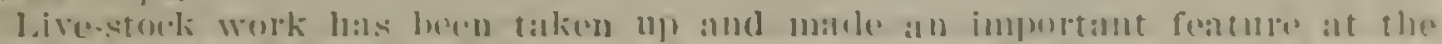

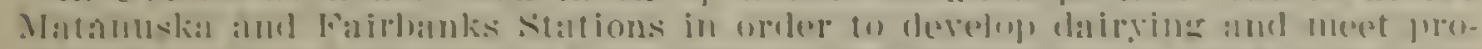

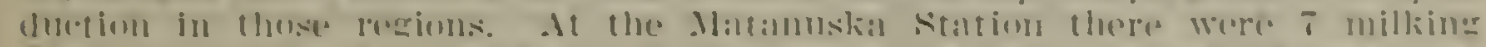

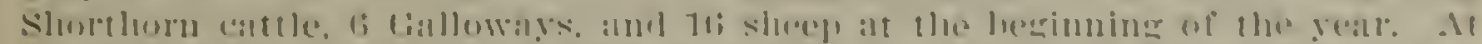

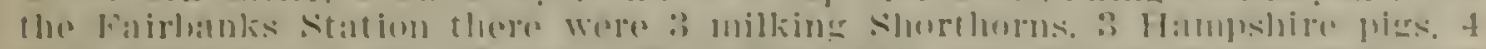

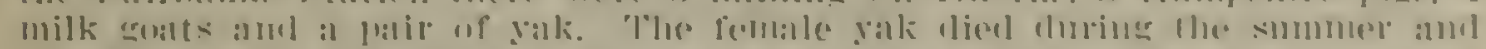

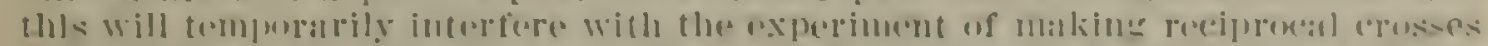

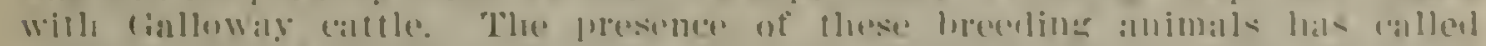

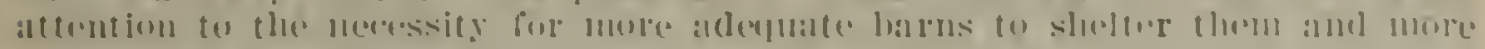
$20(1) \geq 3-2.1-4$ 
clared and fenced land for pastures and forage probuction. At nome of the stations is the area of cleared land moder fence andequate for the support of thr stock now on hand and to continue the (rop) work unlel the conditions pertaining in that country.

(he of the groat needs of Alaska is extension work in ingreulture. Mlost of the honesteaders were formerly miners, fishermen. or lumbermen, and when funds are aviliblue it is lesired to lave an agent who will visit the virious

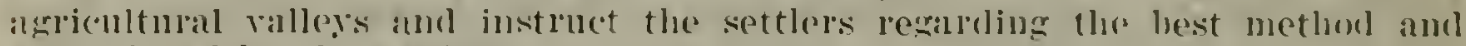
(cills fountl lig the stallions.

\section{HAWAII STATION.}

The Hawaii station reports progress in its cofforts to diversify the arricultures

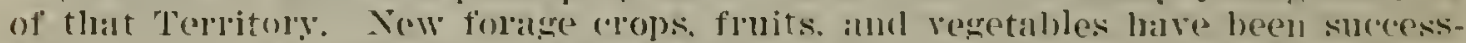

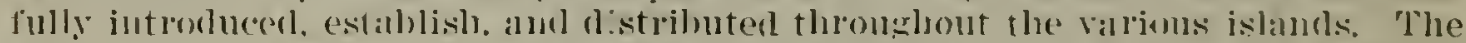

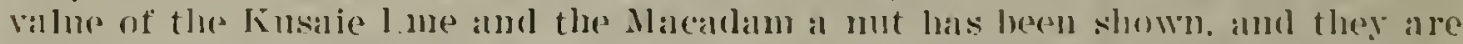
being widely planterl. 'The ralliety of tomato oreginated log the station continues to be resistant to the Mediterranean fruit fly, and large mumbers of plants have been distr buted for extensive trial. The demand for the stat ion's improred

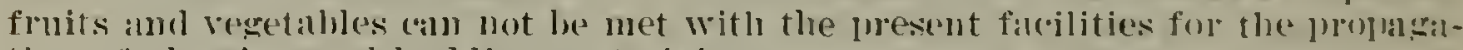
tion of planting and budding materials.

The selection made from Guam coln lous proved to be arbipted to roltivat on

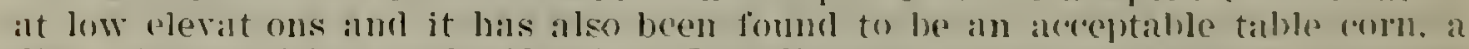
dist net acquisition in the Tropies. Breorling experiments witls swert gutatoses latre resulted in the develomment of new valiet es of wreat morit.

()wing to qualautine regulations only a few kinds of fouits eam be shipperl from Hawai and there are often supplies in excess of local romamls. The

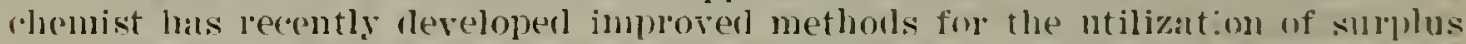
fruits and vegetalules by which much material that is now wasted an be used to a profit. There is sail to he a rather common lelief that locally glown vegetables are deficient in certain constituents. patricularly lacking lime aml iron. A proliminary test indicated there wis little hasis for this boliof. hut to letemine it more detinitely an experinent is in pogress in which regurblos from the same lots of seed have been grown in two places in Hawail. alt the Arlington Fam, near Washington, D. C., and at licllinglum Wash. 'Thr produrets will be subjected to andlysis to determine whether there is any real inferiority on the part of Hawaijan zrown regetables. If no inferiority is showl there should be enlarged demands fol ho(ally anown profluce. A special study is in progress of the salt content of irrigation watres amel the linits of tolemance by colos in an effort to extend the irrigation supplies now arabible. In some places slightly brackish waters are fomml that it is hoprol to use to it motit.

The agromomist in charge of the station has bern repeatedly alled upon for arlvice regarling the agricultural problems commected with lle Haw wibun Homes Commission, which is sepking to locate native Hawilians on falms on the iskind of Molokili.

'The station is conducting experiunents on the sloples of Halealialat on the

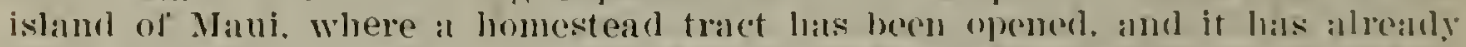

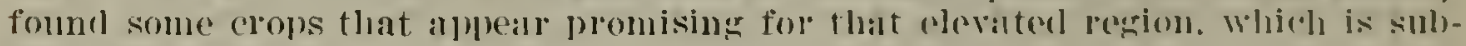
juet to high wincis.

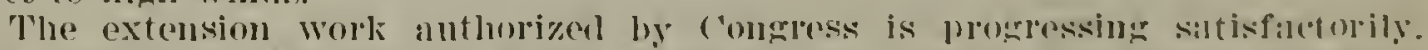

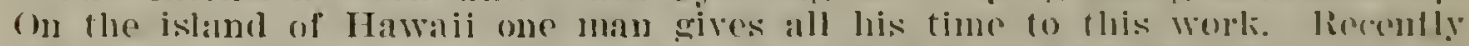

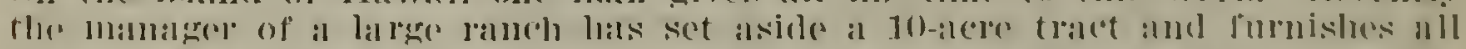

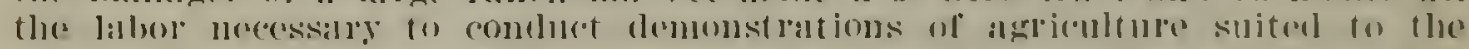

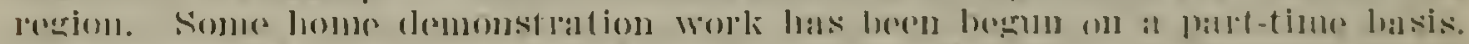

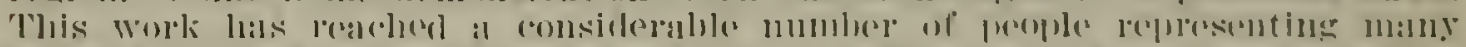

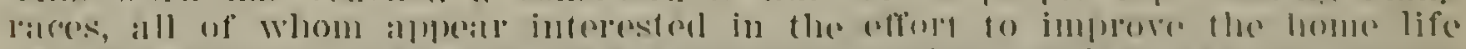

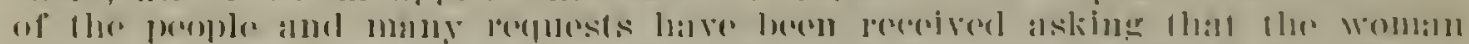

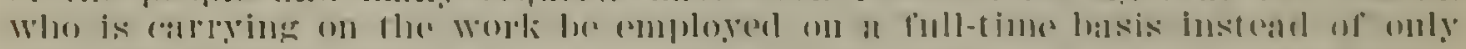
1

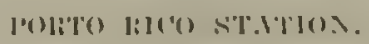

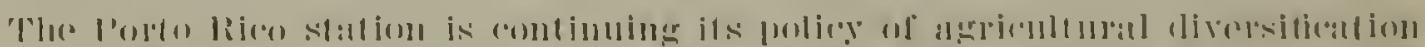

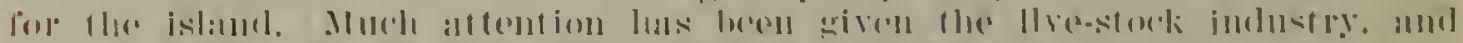

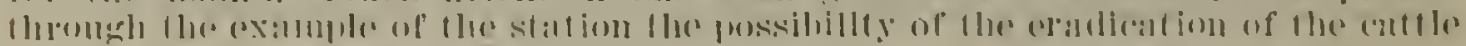

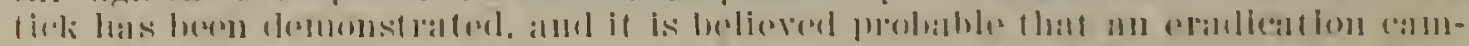

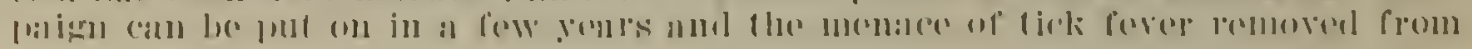




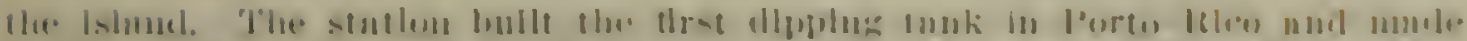

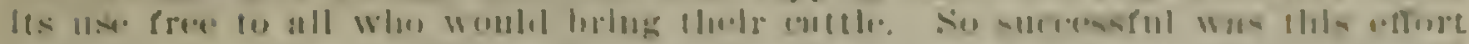

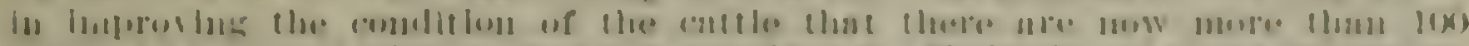

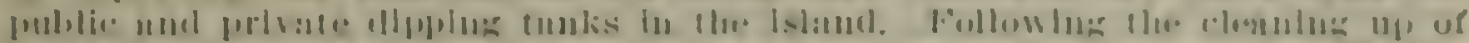

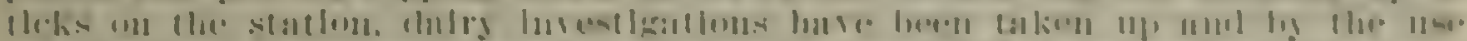

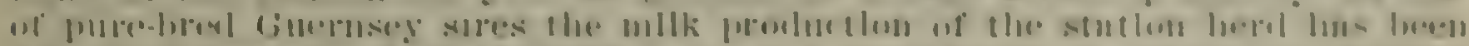

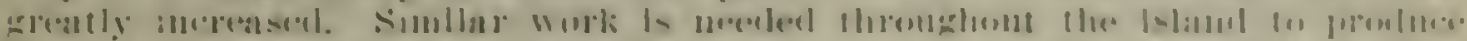

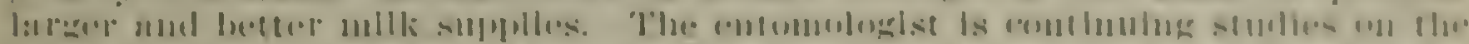

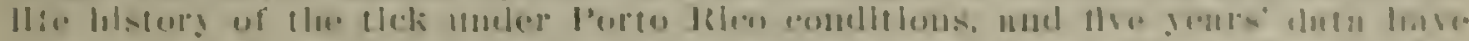

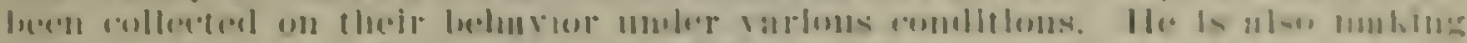

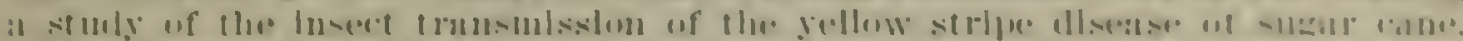

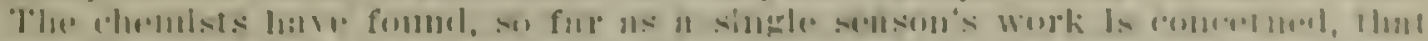

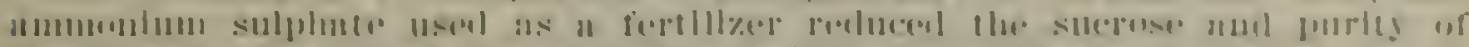

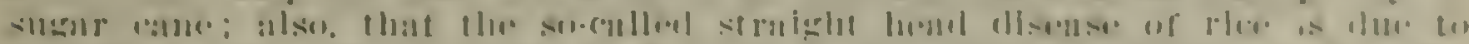

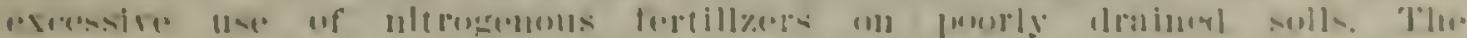

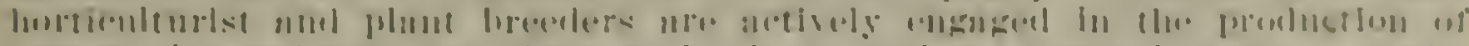
mow st:alas :

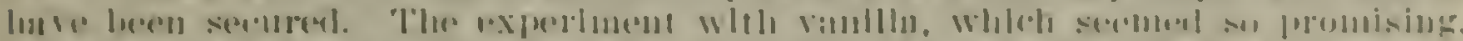

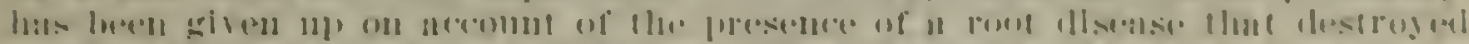

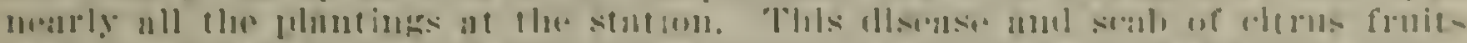

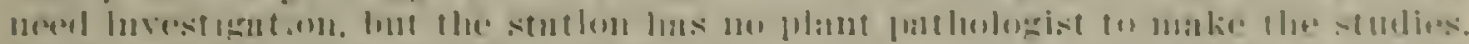

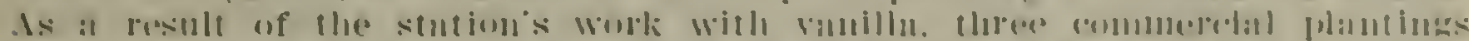

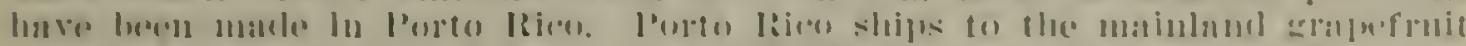

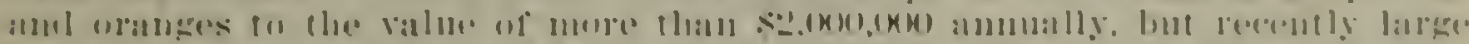

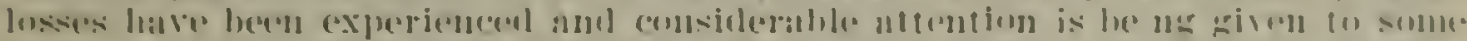

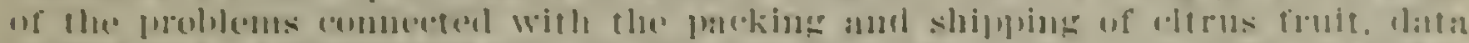

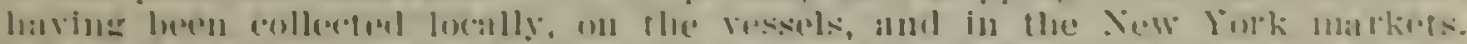

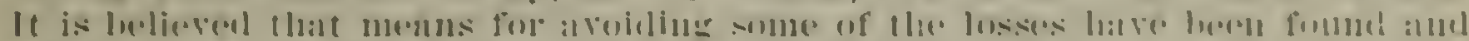

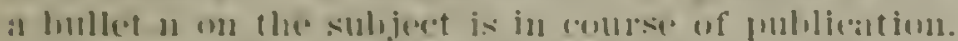

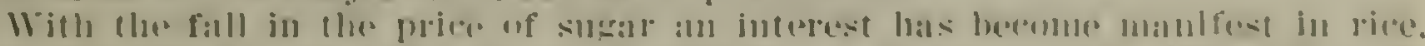

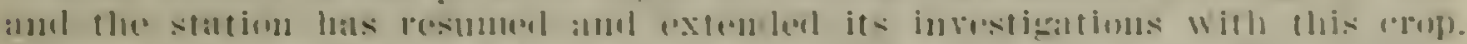

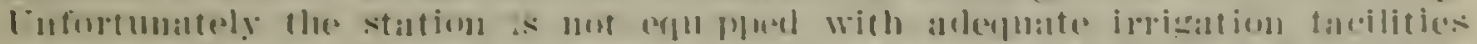

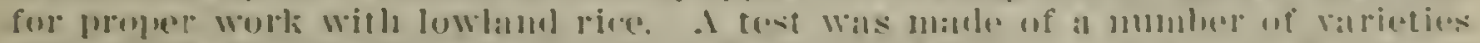

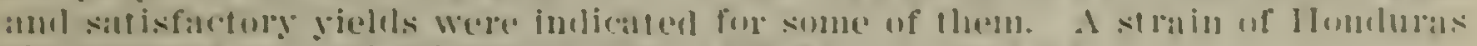

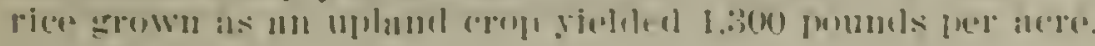

\section{(1. L.IL $\rightarrow$ T.ITIIS:}

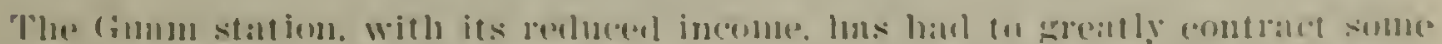

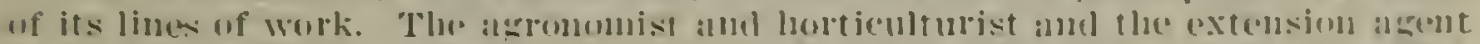

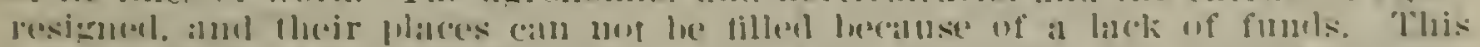

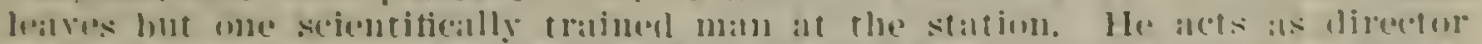

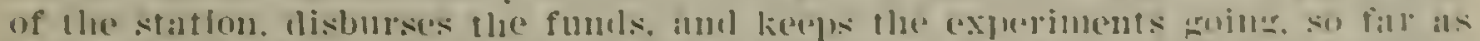

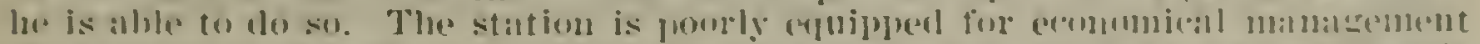

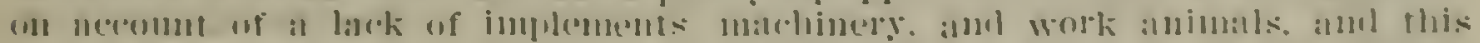

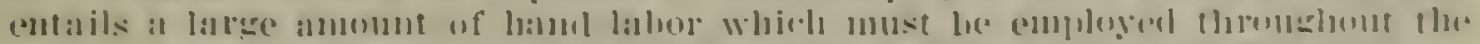

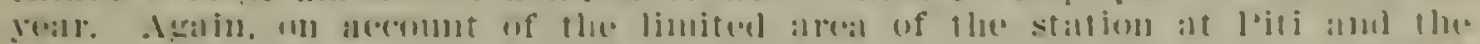

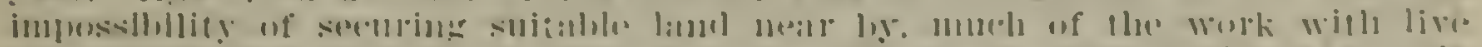

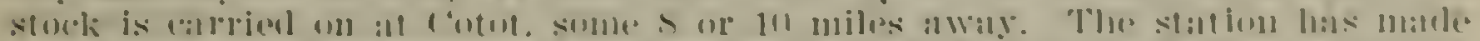

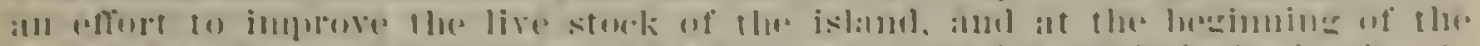

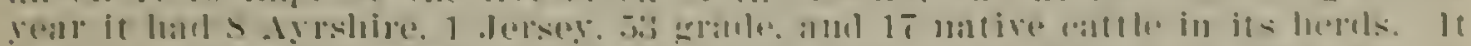

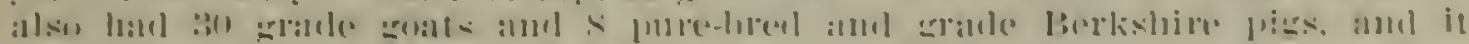

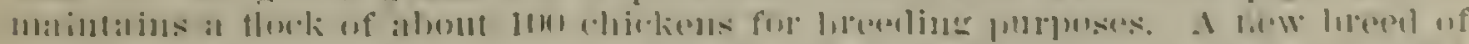

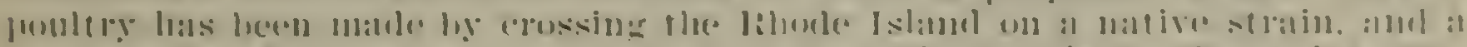

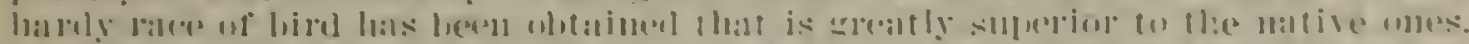

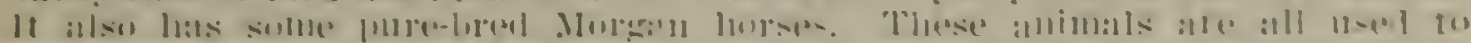

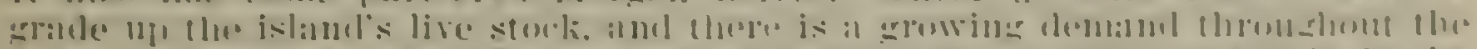

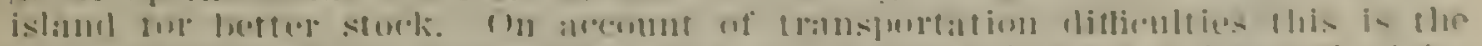

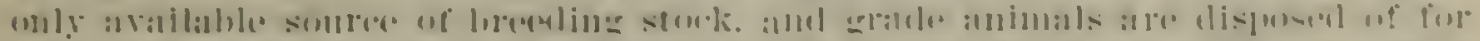

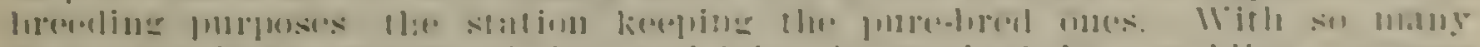

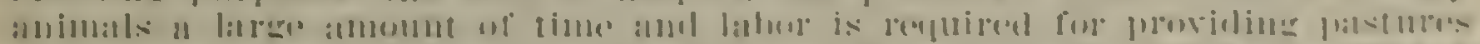

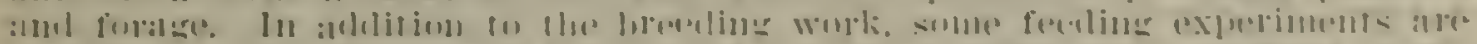

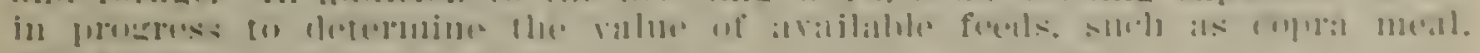
henנus. el1:

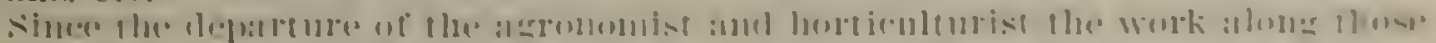

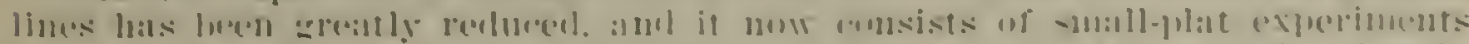

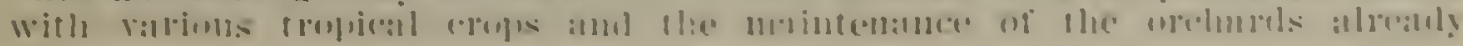


planted. No comprehensive experiments are possible without a trained agronomist and horticulturist.

The extension work, begun so anspliciously, has sufferen on account of the reduction in the appropriations. The work is mathtaned as well as possible, but the number's now in the boys and girls' club latre diminished greatly anol

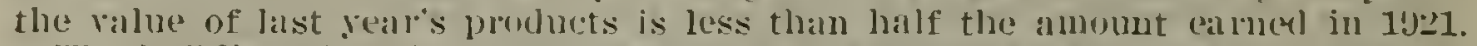

The building situation at the station is matisfactory and new huidings. as well as extensive rejuirs to the oli ones, are urently neemled. Builaings in the Trupics, unless of concrete. deteriurate very lapilly, and the agent in charge reports sereral humdreds of dollars of leparirs as urgent.

\section{VIHGIX ISLAXDS STATION.}

The Virgin Islands have just gone through a period of two sears of aleficient raintall. This has had a depressing effect on the atriculture of the islinds. and it has most seriously interferesl with the experinental work of the station. as there ale no facilities for irrigation, and only mealsel subplies fol the lost and other experinental work and for the live stock. The rainfall for 1020 was omly about 75 per cent of the normal, for 1921 alsout (i.i per cent, and for the

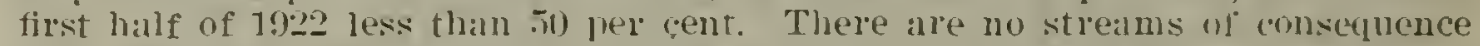

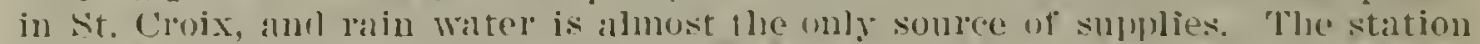

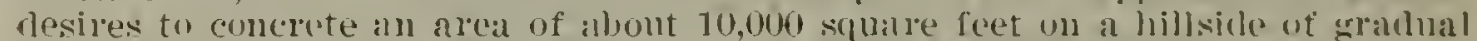
slope to serve as a catchment basin to aid in tilling a reserroir trom which an aderpute water suply could he obtained for experimental work and for tire protection. It is now ratching rain water from a combined area of ahout 3.(kx) sfluare feet. lut this is not suflicient in periods of lisht rainfall.

A chimge in the oflicer in dhallwe of the station was malle during the past rear and J. 1. Thompuson. formerly of the Guam Station, is now in charge. The

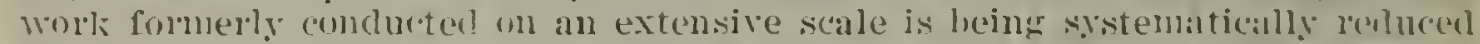

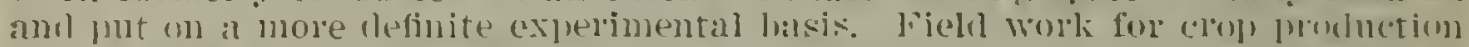

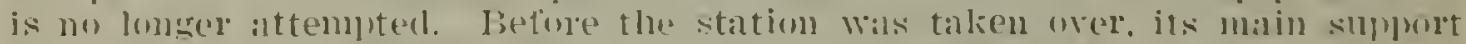

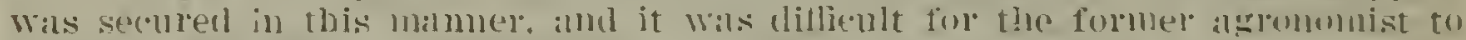
clianse his methods.

Crop) improvement is an jumortant part of the stations work. sumar cance

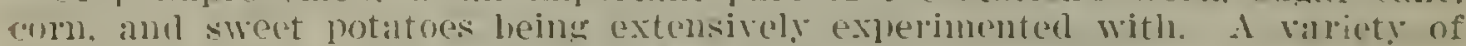

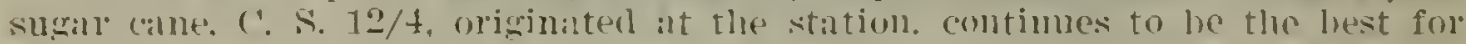

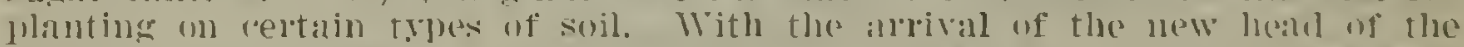

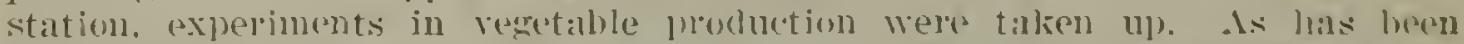
repeatedly pointed out. there is a starcity of fruits and vegretalus in the

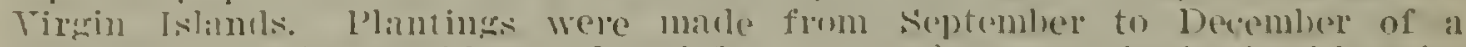

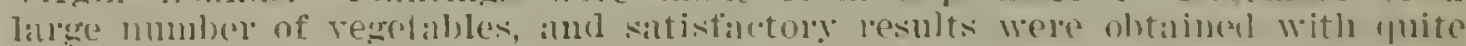

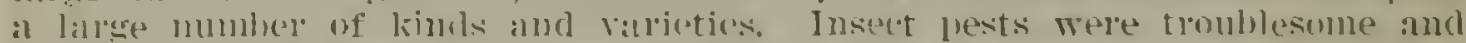

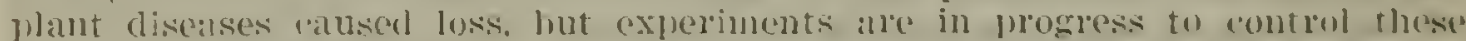

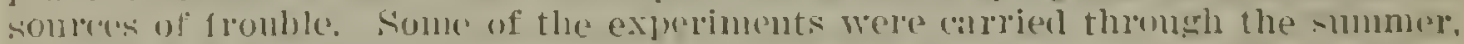

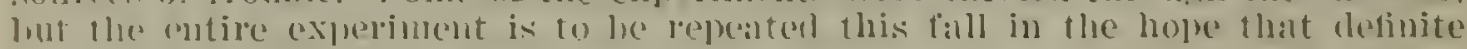

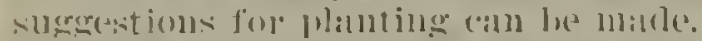

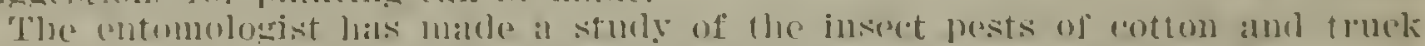

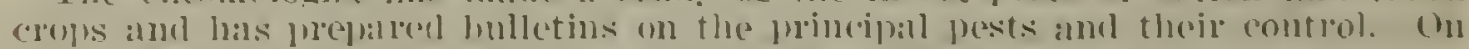

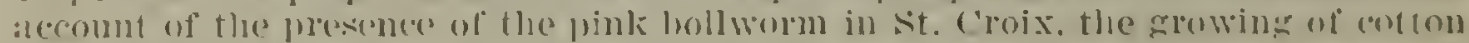

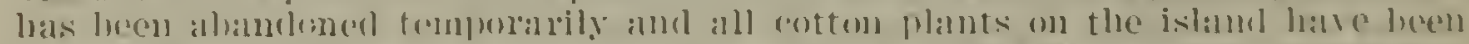

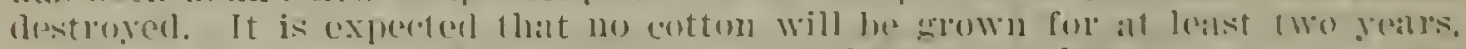

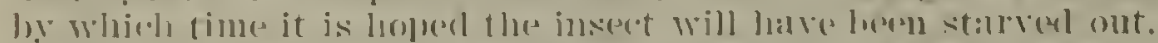

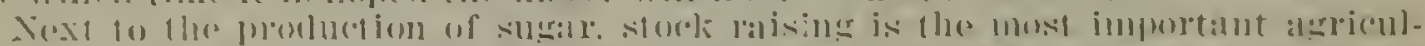

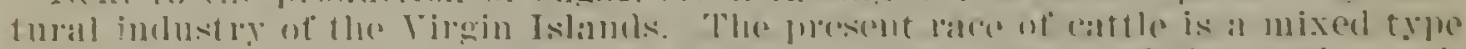

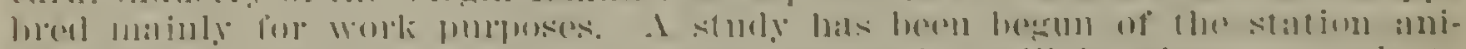

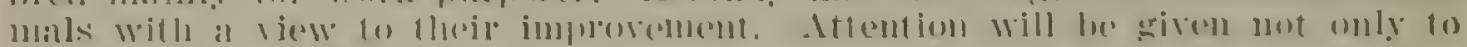

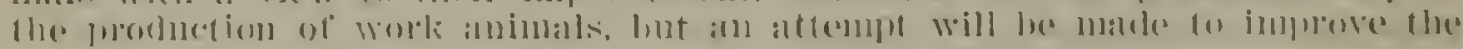

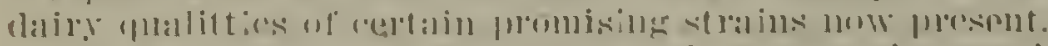

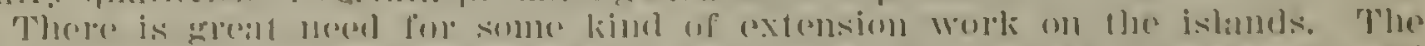

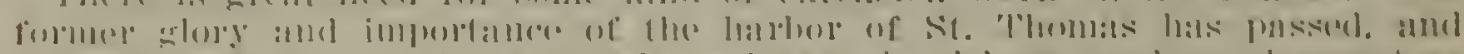

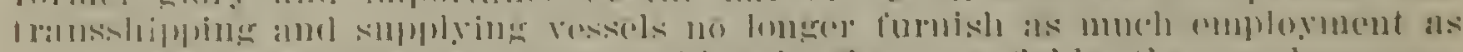

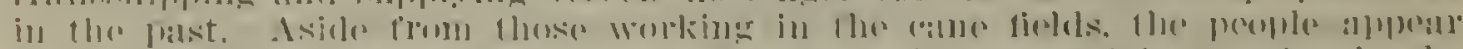

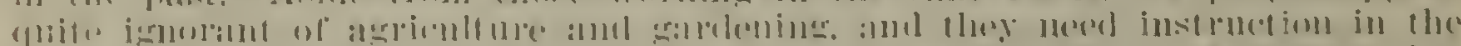

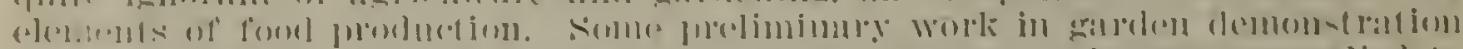

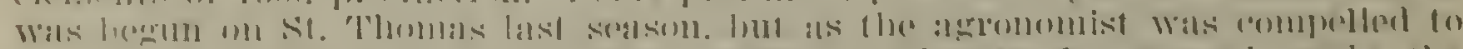

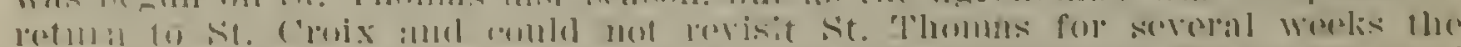

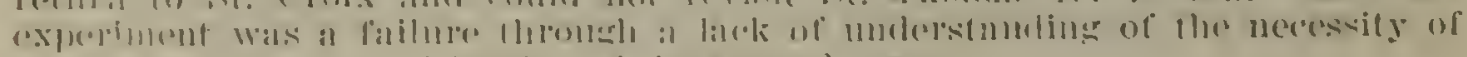

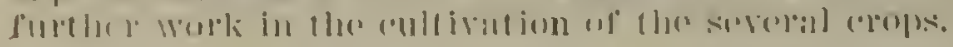




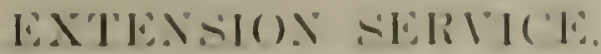

\section{STATEMENTS OF DR. A. C. TRUE, DIRECTOR STATES RELATIONS SERVICE, AND MR. D. M. GREENE, OFFICE OF EXHIBITS, DE. PARTMENT OF AGRICULTURE.}

\section{\$.11.11:11:-}

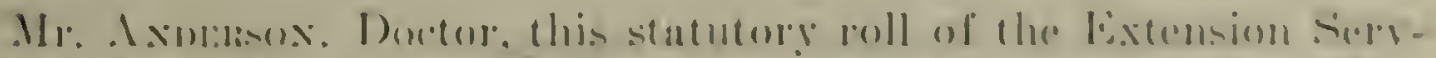

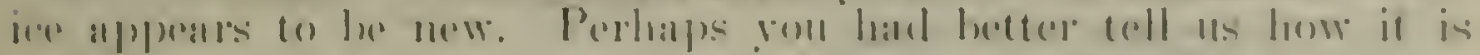
makle al).

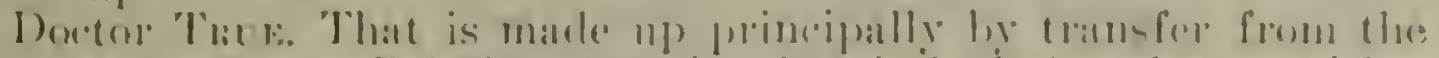

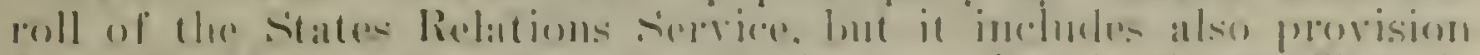
for some plares taken from the Division of Pullieations. "Jhat is

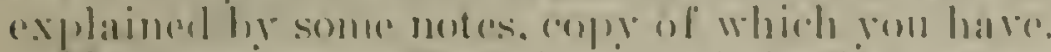

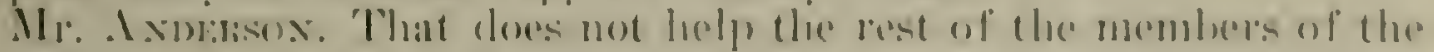
Honse. I think rom hath leeter grige us a general statement at least in the houring of how the list is mald mp)

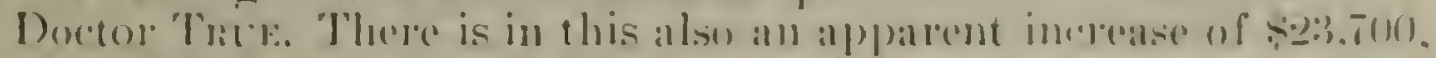

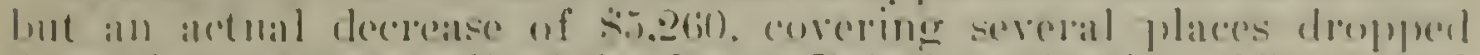
from the statutory roll of the statre Rolations service. 'These. as I

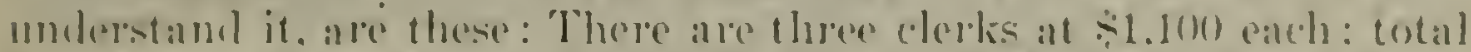

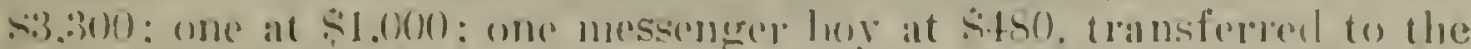

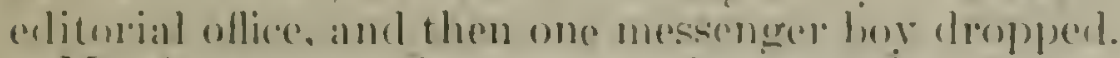

\r. Axurasox. Suppose you just put that statement in the record and we will let it wo at that.

Doctor 'Tret:. Woll, we ean do that.

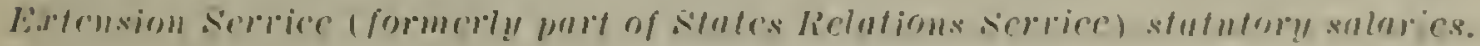

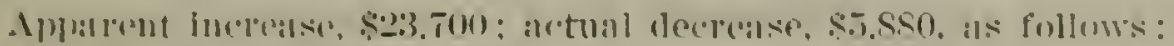

Plaldes dropped:

4 ilerlis at $\$ 1,100$ aich

('lerk

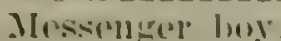

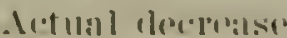

$\therefore, \operatorname{sSO}$

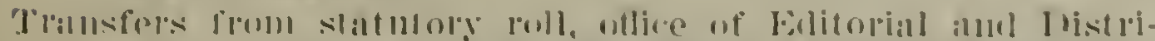

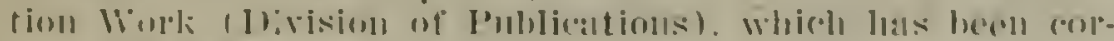
lespmolinsly renlureel :

Assistant in ehatrge of olliee of motion pictures, with

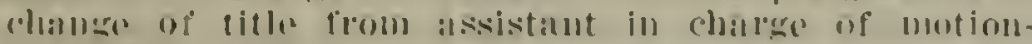
pinctilce activilies.

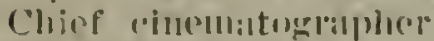

Issistalnt ellitol

2 rlorkis, clisss 4

is (dilks, rluss :-

3 clorks, clisss 1

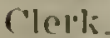

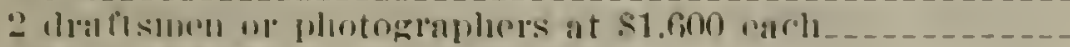

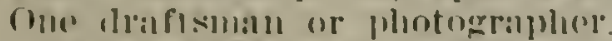

2 rlerks al stolo rach, with chatuge of title

I Alboratory a a is

Assistant photominglaer

8.3. 1000

2.801

$1, \sin 0$

3.

$+.200$

3. link

1,100

3. 2011

1.

1. 900

(n)

960

Missonger or laboler

$$
\text { Do. }
$$


Transfers from lump-funnl, Extension service (states Relations service), which have been colrespondingly reduced:

Executive clerk (from farmers cooperative demonstration work)

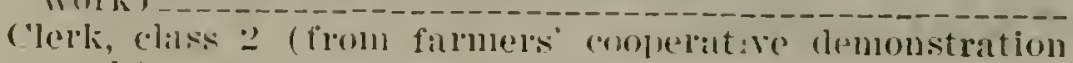
work)

$$
\begin{array}{r}
\$ 2,000 \\
-\quad 1,400 \\
\hline
\end{array} \frac{\$ 3.400}{34,560}
$$

Trinsfor to statutory roll. oflice of the Seretary. and the roll reduced accordingly:

Inirector". with ehanger of title

'Transfer to statutory roll. Oflice of Boliturial and Inistrilution Work: and the roll rednced accordincly: :

Mesichuger boy

$$
\$ 4.500
$$

Almilent increase $-\frac{4.980}{20.580}$

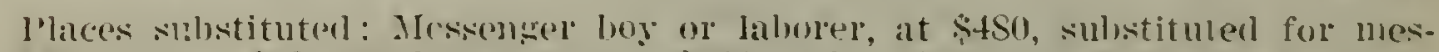

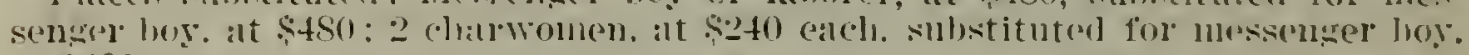
at $5+480$.

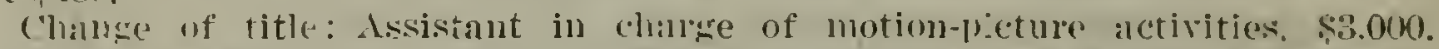

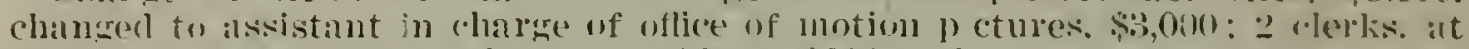

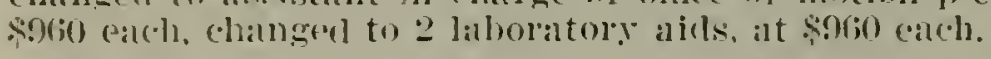

Mr. Brchasax. There is no increase of salaries. is there?

Doctor 'True. No increase of salaries.

Mr. Bromatis. No increase of personnel or salary?

Doctor' 'Trite. No. sir'.

Mr. Brcmavax. There has been quite a decrease in personnel that happened this year. Iou do not mean to say that decrease has been bronerht about by this arrangement, do you?

Assistant Secretary Prastry. Yes: by the consolidation of the offices of the Yorth and South.

Mr. Buchaxax. I mean to say under this new arrangement?

Assistant Secretury Pugsur. Yo; that has not been possible. hecause it has not gone into effect ret.

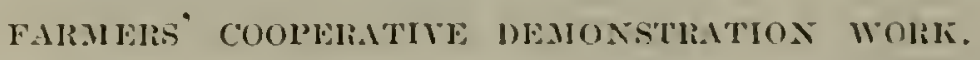

Mr. Axpersox. The next item is on pare 30. for farmers cooperative lemonstration work. which inclules special investimations of plans and methorls for more effective dissemination of the results of the work of the Department of Aericulture and the agrienltural experiment stations, etc. Fonr estimate is for $41.28+3.30$.

Doctor' 'Tates. Yes, sir. That is a decrease of this.tind in that item.

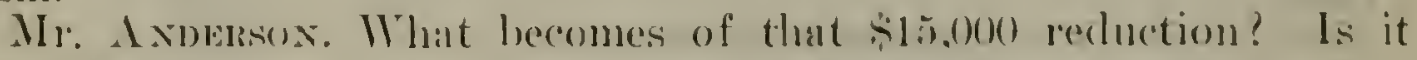
satred!

Mr. Jump. These are some of the transfers to the Sermetary"s roll albont which voul bave been told hy Mr. Reese. There were two of the detailed cleriss transferred from that roll. A reduetion of $\$ 50,(000$ is also marle in that roll in ordere to proviste for the new place of assistant in chatrene of the oflice of editorial and istribution work at

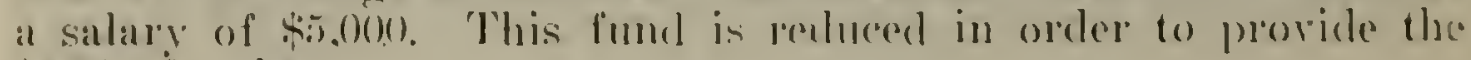
s.5, (1) 00 for that. 


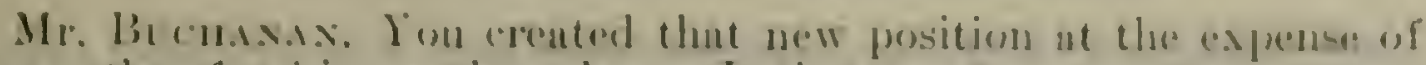
some other funcl in anothere place. Is that truse!

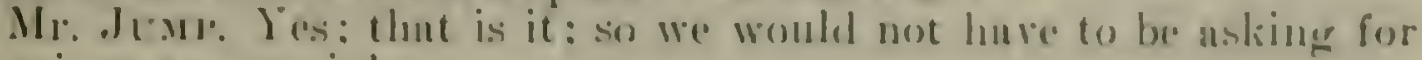
ally incrense outright.

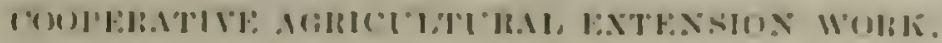

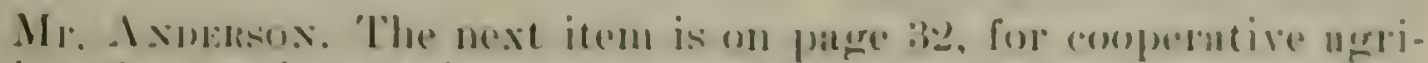
rultural extension work.

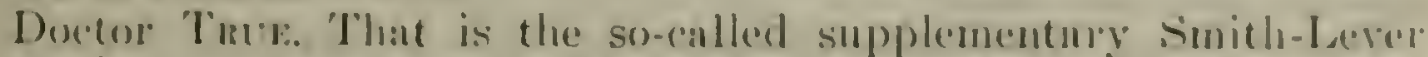

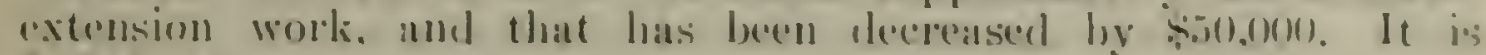

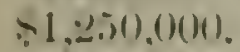

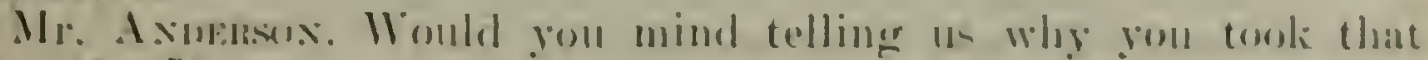
$\therefore(1) .(1)(0)$ off !

Doctor 'Tlare. It wats dome ly the Bulgeret Bureatu.

Mr. Ixmotisos. Is this money used for parment of eomnty agento suliniris:

Doctor Ture. lés, sir: almost entirely. Lou will notice a proviso in it that of the ahove appropriation iot more than s.300.000 shall he expended for porposes other than the salaries of combty atents.

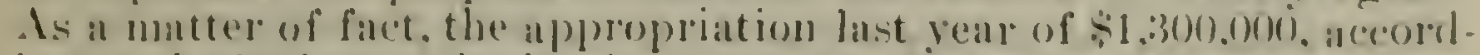
ind to the burgerets submitterl to us hy the states for the present liscal year. hass $\$ 1.168 .173$ allotted to county agrents.

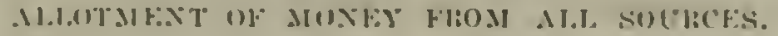

Mr. A volmons. Last year if I remember right, you furnished us with a statement showing the disposition of this fumd, the fomd alp propriated molere the preceding it em and the funds moler the smith-

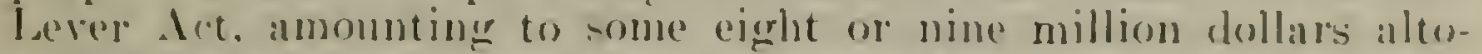
grether. as between county agents, home economies, specoilists, ete. Have rou such a statement for the next fiscal rear?

Doctor 'Tute. We would not have that for the next fiscal rear, but for the present fiscal year I have a statement here. which, however. rloe's not go so much into detail.

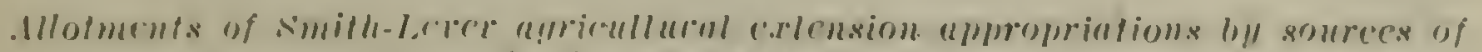
fouds and lines of $10 \mathrm{or})$.

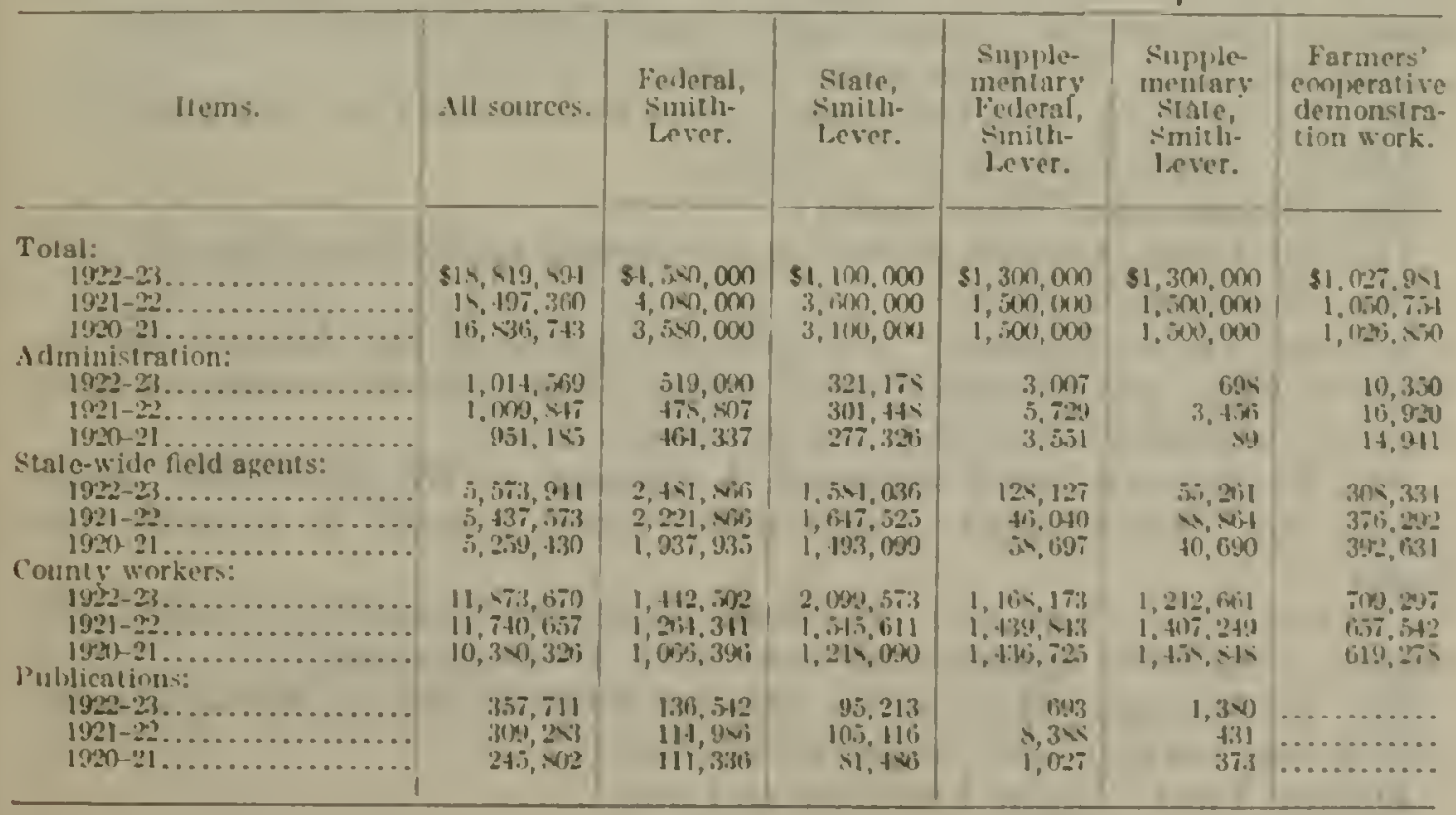


Mr. Axperson. I notice under one item here that you have statewide field agents for which you made an allotment of \$,5,573,944. What are these state-wide field agrents?

Doctor True. They are people who work a large share of the time in the counties but who have their headquarters either at the college or some point in the State.

Mr. Axdrison. Are they specialists, commodity experts. or organizers. or what are they?

Doctor Trus. Two kinds of agrents are included in this statement. (1) a considerable number representing different subject matters. such as dairying and food and nutrition, and (2) other's who go out to assist the comnty agents in the organization of the work, methods of instruction, etc.

Mr. Axidersox. Is part of the salary of these state-wide agents paid by the State as well as by the comnty?

Doctor 'True. The state-widle agrents are paid either by the collere or in part by the department out of the farmers cooperative demonstration appropriation.

Mr. Buchasax. The county is paying what part of the salary?

Doctor True. The county is paying no part of their salaries.

Mr. Buchaxax. Can you give me any idea of the division of the $\$ 11,873,670$ which goes to county workers, as between county agents. home demonstration agents, and other people?

Doctor 'True. Yes, sir'; for the county agricultural agents. \$S.97t.806; for the home-de. istration agents, s. 347.761 : and for boy's club leaders, some of whi.s are men and other women. \$.5.51.103.

NLMBER OF AGRICULTLRAL COUNTIES ANI) AGENTS.

Mr. Brchanas. How many comties have you county agents in now?

Doctor True. About 2,100 .

Mr. Bucruxax. How many anricultural counties are there in the country?

Doctor True. We count about 2,650 .

Mr. Buchasax. Two thousand six hundred and fifty agricultural comnties, and you have about 2,100 counties with extension agents.

Doctor Trice. We have about 2,100.

Mr. Bucrivix. Are there many that have more than one agent?

Doctor 'True. Only a few counties.

Mr. Buchasas. How many?

Doctor 'Trus. Do you mean by one agent agricultural agent?

Mr. Bucimanax. Ies.

Doctor 'Trux. Probably not more than 100 in the Inited States. Most of them are in some New England States or in connties where they have plenty of money for extension work.

Mr. Burmaxan. And they are, I suppose, in the diversified areas where you have a comnty agent that devotes himself to a particular ('Top?

Doctor Trus. Yes, sir. In New York, for exmple, in the Lake region they have agents who deal with fruit growing.

Mr. Bocmaxas. How many regular home economic workers have you doing work in the comnty as agrents?

Doctor Trus. Eight hundied and one. 


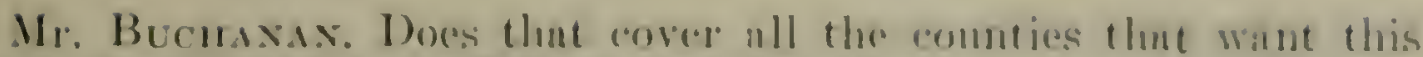
kind of work and ate willing to pay for it?

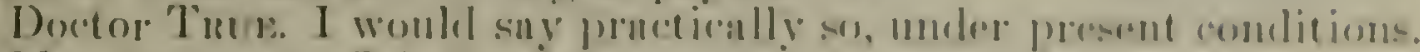

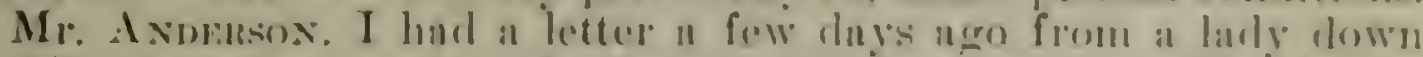

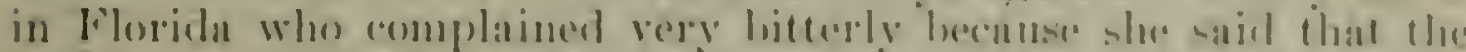

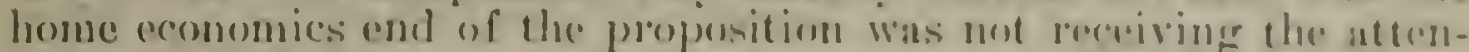

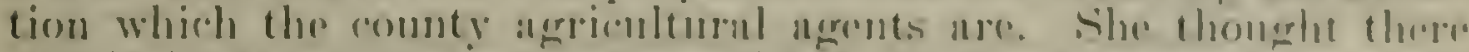

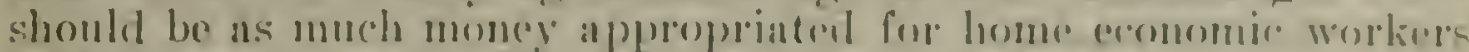

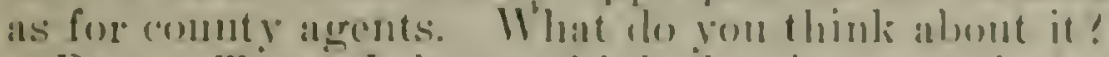

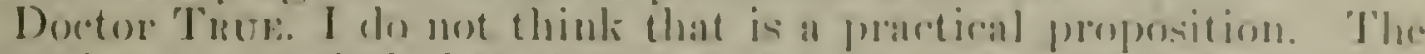

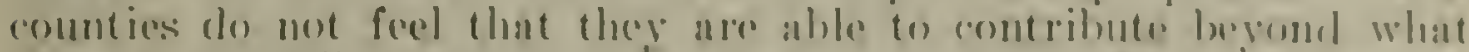
they are contributing now. There is a constant coffort oil the part of the colleges and ourselves to stimulate the woments work. ame

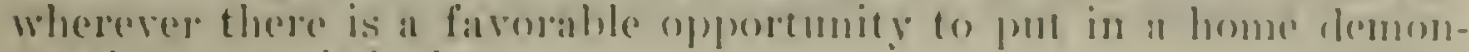
stration angent it is done.

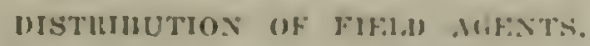

Mr. Axmasox. How many of the state-wille field ancents (e) 1 tribute directly to the home economir work?

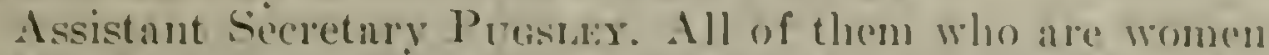

Mr. A xmalisox. 'That does not answer' the question.

Assistant secretary l'rostar. And mamy of the mon.

Mr. Ixmensox. "Thiat still toes not answer the guestion.

Assistant secretary l'owsur. We have not those fienres. We can insert that in the recorel.

Doctor 'True. There are about 12.5 women fiehl agents dealingr with food and diet, rothing homschold exuipment, etc.

Mr. Axpersos. Doctor 'True, will you put into the record or furnish me with a statement-I do not care which-that will show the distribution or classilication of the workers emploved under this as state-wirle field anents? I supposed these connty worliers included only county units.

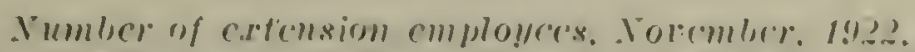

Connly-izent wink (111en) :

lifereturs and sialle leallers

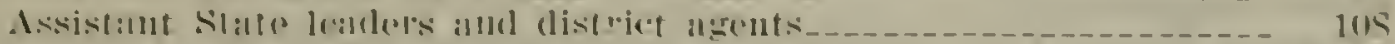

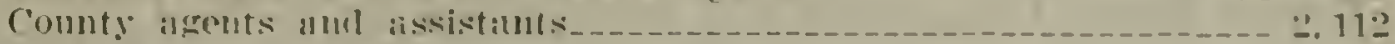

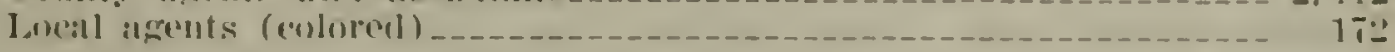

Tist:il

Home denonstration work (women) :

Sinte lonclers

Assistant slaste leadlers and distriet atgents-

Comuty ifrents and assistants

Jocial isgents (eolored)

City agents

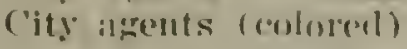

'rol:1]

lbogs and gills (all, work (men and women):

siato dridlers.

Assistant State leatlers.

connty linder's.

'Tot:1 
State-wicle subject-matter agents:

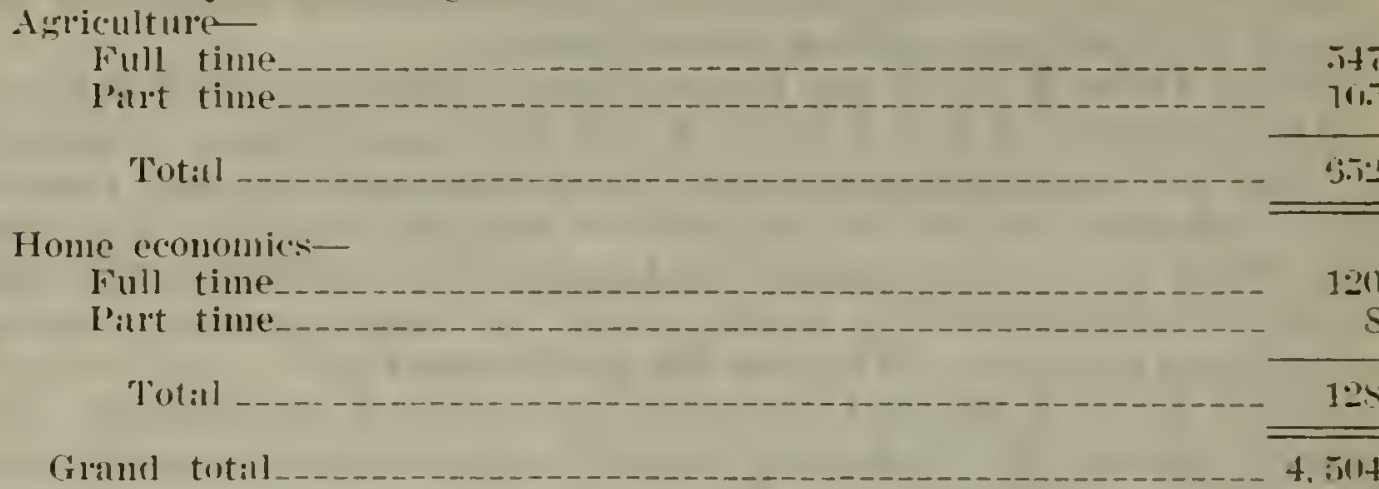

Doctor Tris. Couniy rorkers inclurle both men and women.

Mr. Axderson. They are divided into home and club and other workers?

Doctor True. Yes.

Mr. Axprasox. This statement for which $\$ 1,014.569$ is appropriated for administration shows what? 'That inchules. I talke it. only the Federal end of the administration of it?

Doctor Tuce. That is the State end. All those figrures rou have represent the moneys that are spent in the States. They do not inclucle the amounts spent in maintenance of our $T$ ashington office.

Mr. Axmersox. Of what does this arministration in the States consists?

Doctor Trus. That includes the expenditmes for what is known as the extension director's office. his own salary and that of his clerical assistants, accountants, people who are preparing charts and illustrative material, or who are engaged in handling the manuscript work. cte. Of course a great many publications are issued and it involves a larce amount of preparation clone by rontine workers gretting the manuscripts in shape and seeing them thromgh the press.

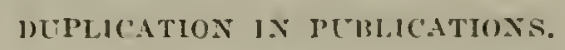

Mr. Arnersox. What is the distinction between the publications issued under this fund here and the ordinary, regular publications of the department?

Doctor 'Tres. The publiations issued muler the Smith-Lerer Act by the colleges are distinct from the department publications. There is a special provision for publications in the Lever Let up to an amount not to exceed five pere cent of the appropriation.

$\mathrm{Mr}_{\mathrm{r}}$. Axmensox. I molerstancl the financial distinction but what I want to know is the distinction in the character of the publications if there is any.

Doctor 'Taits. The States gret ont a latrer number of special subject matter pullications for use in extension work.

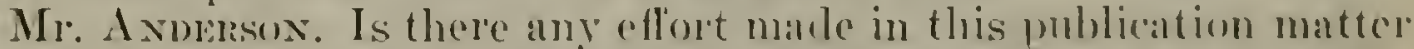
to aroid duplication of publications as between those issued by the State and these issued by the Federal (rovernment?

Doctor 'l'me. I do not think there is any duplication.

Mr. A xiblisux. I think there is guite a lot.

Doctor 'Turs. 'The department isclies only a fow publientions especially designed for use in extension work. 


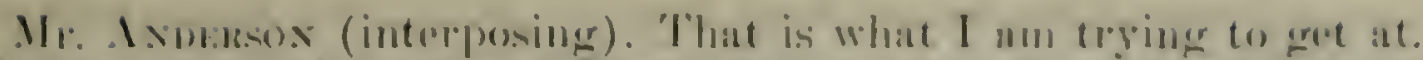

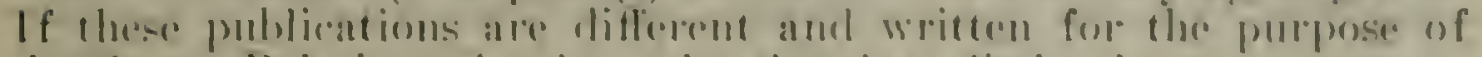
the states Relations serrice only. that is a listinction.

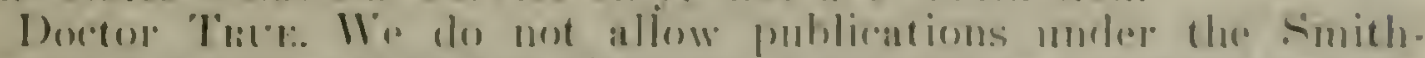

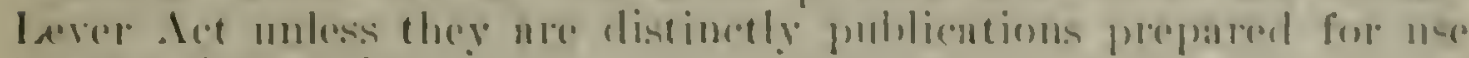
in externsion work.

Mr. Ixplatox. Itow nre they used in extension work?

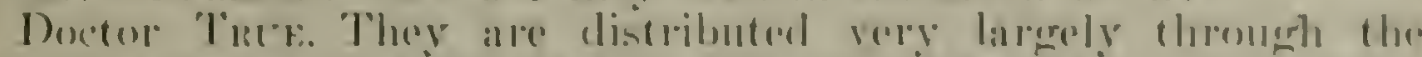

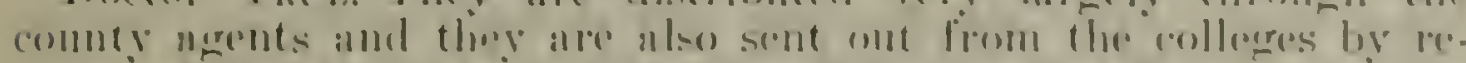
quest of the people in the state. and they are used in rennection with the externsion solonols, farmeres institutes. ote.

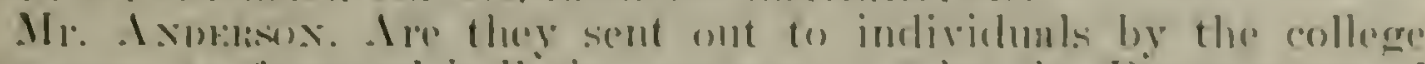
the same as farmers holletins are sent ont by the Depurtment of Aerriculture?

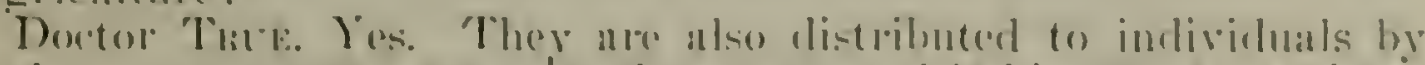

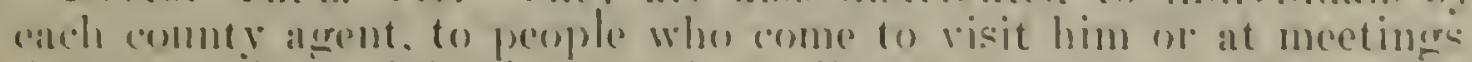
Anye extension publication that is applicalsle to any problem bronght

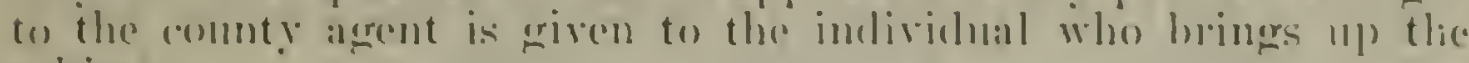
subject.

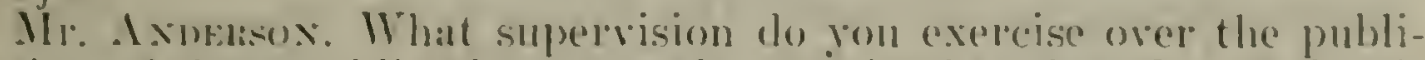
(ation of these publications te make certain that they do not duplieate the publieations which are alrearly issued or about to be issined by the Department of Aerriculture?

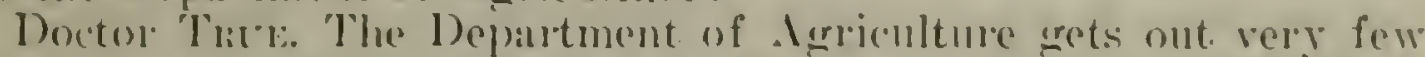
suljoct-matter publications expecially for extension work. Sinch publications as farmers bulletins are fol gremeral distribution. But the number of mew farmers bulletins issued each rear by the de-

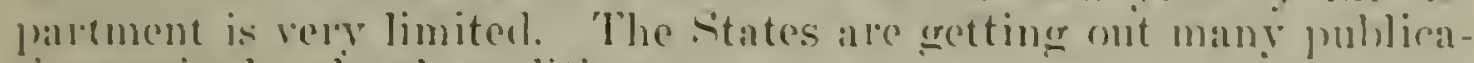
tions sulted to jocil conclitions.

Mr. Axblisox. They spend pretty nearly as much money ar you (w) They ought to get ont some farmers bulletins for that amount.

Doctor 'Trite. The extension publications they cret out are esperially intended for use in extension work.

Mr. Ixmansox. Perhaps 1 am dense. l,ut I would like to gret a distinetion hetween extension hulletins and fanmers" bulletins.

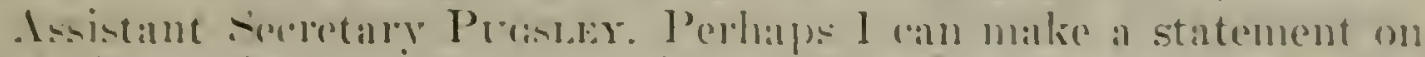
that. drawn from my own rexperence in the states ats well an in the dopartment. 'The publications of the state acricultural colleges. imelucline the extenton service and experimental service. are cleally State pribliantions written for the most part hy state people: corcring, if they are research bulletins. wolk that is done within the State by the state workers: covering. if they are extension hulletins. work which may be done there. and if not ilone there. they are publications rery raluable to the work that is done within the state. There have the local point of riew much more combinant than the

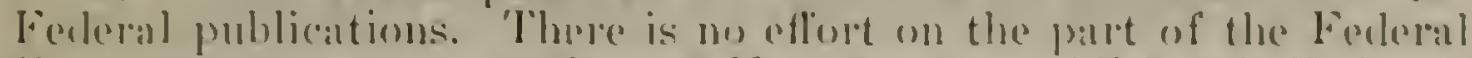
(iovermment to sily to a state. " Jou (an not publish al bulletin on spring wheat in Nebraska for the use of yom extension worker. he(anse the Ferleral Govermment at Washingrton has a bulletin on that

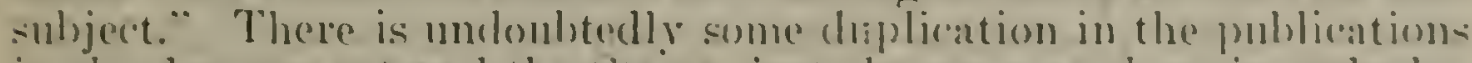
in the department and the states. just the same as there is moldouldeedly duplication in the experimental work. Lut most of the money which is put into the extension publeations in the state is state money rather than Ferleral money. There is shown in this state- 
ment not any of the State money that is put into the State publications other than Smith-Lever offset. The State spends much more for its publications than is shown on this list: many of the collegre publications are extension publications.

Tow, if you are directing your question to whether or not there is effort on the part of the I)epartment of Anriculture to aroid duplication of publications. the answer to that is that there is not an conscious effort at the present time. But I wonld like to and the thought that I think there is little serious inplication. and that it might be well to take the matter up with the state colleges to see if cluplication can be avoided.

Mr: Axomesos. Of course. I do not believe the Federal Government ought to undertake to censor the publications which may be issued by the State for the entuation of its own citizens. But I du think where Federal money is spent in publishing docmusuts for citizens of a State that it might le wise to see that that moner is spent in such a way that it does not duplicate expentitures alleamly being made for Federal purposes. I think that is as far as we (am gro. but it seems to me we can legritimately go that far.

Assistant Secretary Prgstar. "The way it worlis out is practicallyo like this: An extension dinector in at State finds a need for lulleting on a certain subject for use of county worker's. He scans not only the State bulletin list but the Forleral bulletin list avalable for that purpose: he may find the Fecleral bulletin on that sulject is not local enough and then he aslis for the publication of a luilletin to cover his territory. Or he may find that the supply of Federial bulletins is not sufficient to meet the need of his colinty workers and he publishes a bulletin witten by the workers of the sime State, in which they incorporate many of the things contaned in the Federal bulletins.

Mr. Axperson. There is no inerease in the total amomnt arailable for publication work under the Smith-I erer Aet for the next fiseal year, is there?

Doctor True. No, sir.

Mr. Axmenson. That act is entirely matured, is it not?

Doctor 'True. Yes, sir.

STATEMENTS OF MR. G. I. CHRISTIE, DIRECTOR OF EXTENSION, PURDUE UNIVERSITY, LA FAYETTE, IND.; MR. B. H. CROCHERON, DIRECTOR OF AGRICULTURAL EXTENSION, UNIVERSITY OF CALIFORNIA COLLEGE OF AGRICULTURE; MR. T. 0. WALTON, DIRECTOR OF EXTENSION SERVICE, STATE COLLEGE OF AGRICULTURE, TEXAS; AND MR. W. M. JARDINE, PRESIDENT KANSAS STATE AGRICULTURAL COLLEGE.

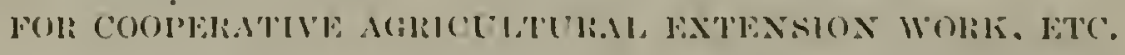

Mr. Anmmon. The committer will fetmm this morning to the

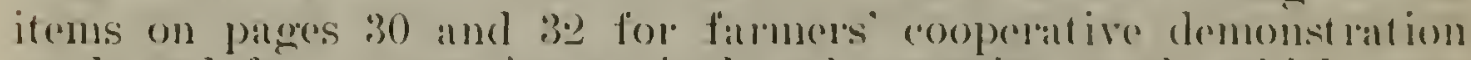
work and for cooperative agricultural extension worls, which were

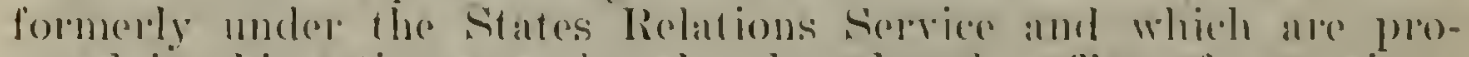
posed in this estimate to be placed moler the oflice of extensions. tro will heatr the replesentalives of the land-grant colleges this morning. 


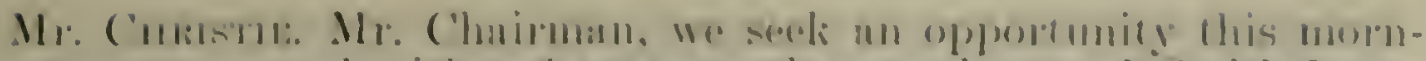

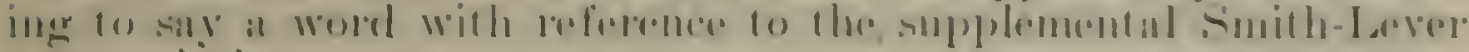

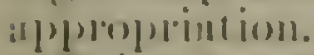

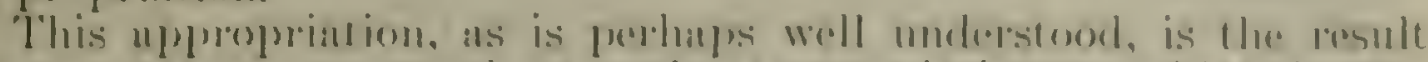

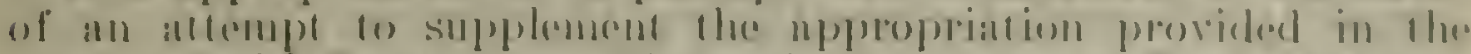

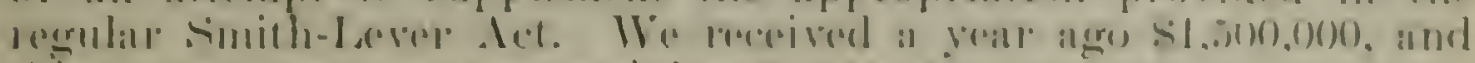
this (1)

Tre malerstand that the. Director of the Budget has recommonded

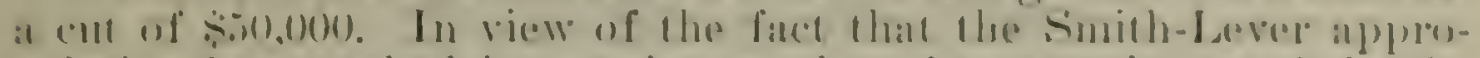

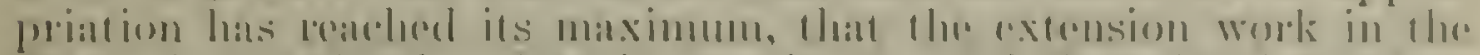

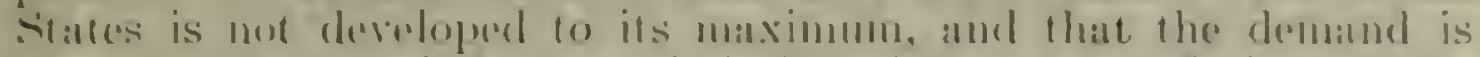

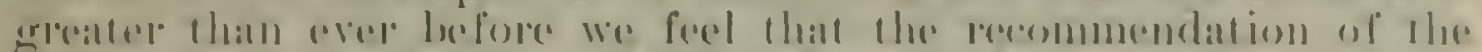

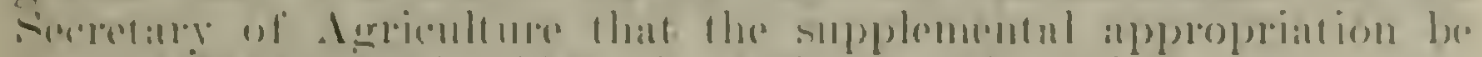

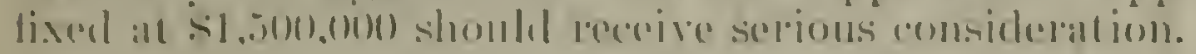

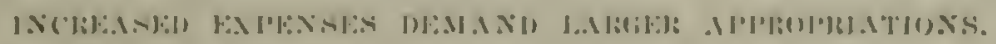

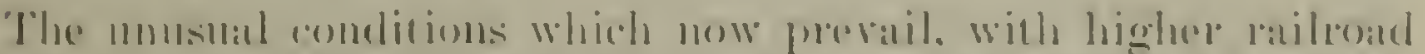

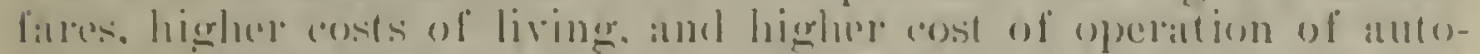
mobiles have cansed the ast of extension work to more than double

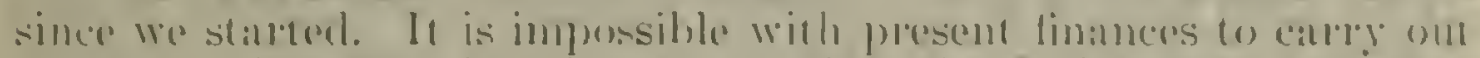
the plans that were in mind at the time the smith-Lever ded wats pits=arle

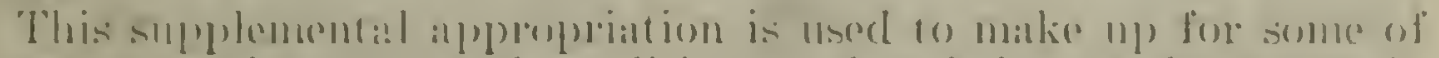

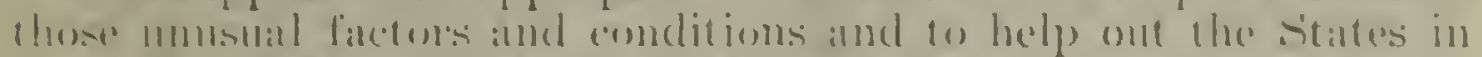

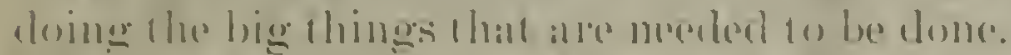

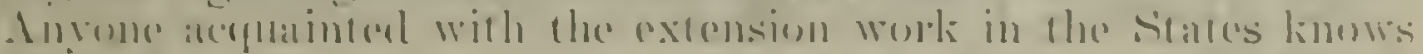

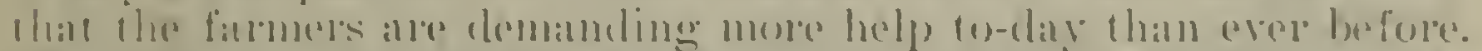

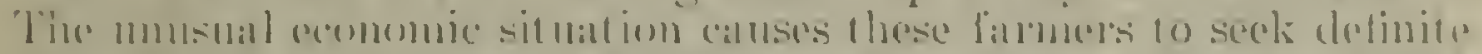

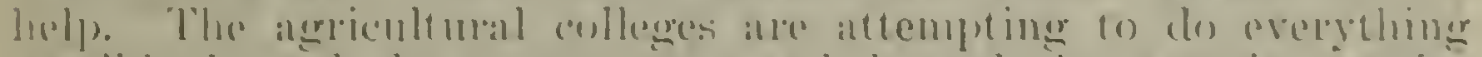

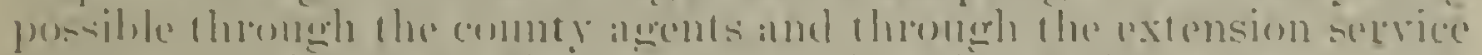

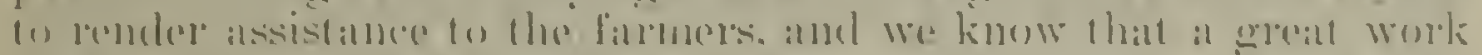
hal- leren alcenuplisherl.

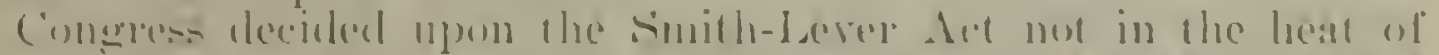

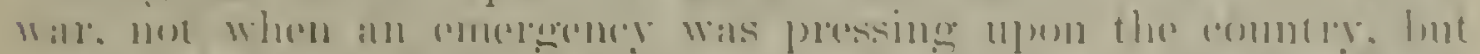

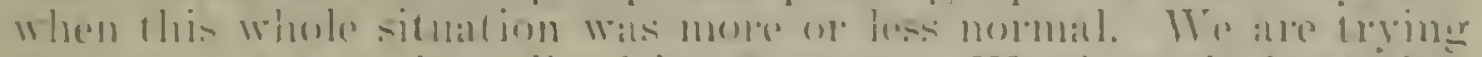

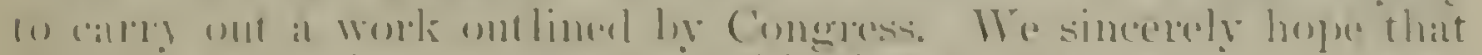

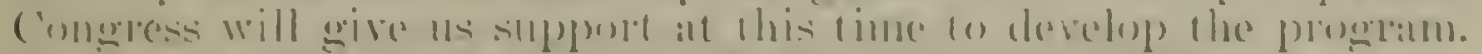

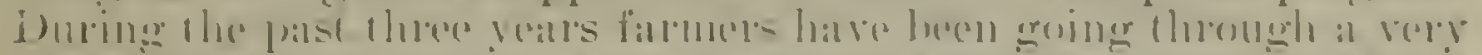

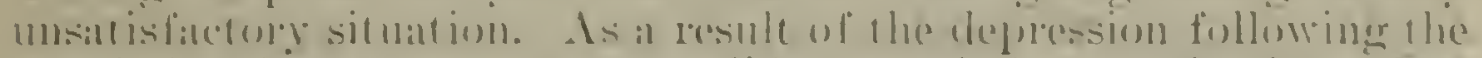

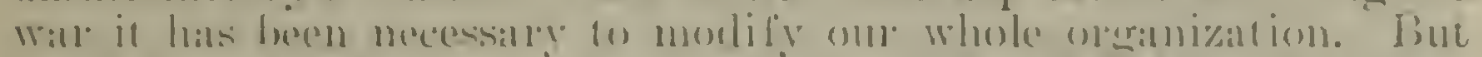
it is impessible 60 matmain an edmettional working fores if appropriat lathler tham less.

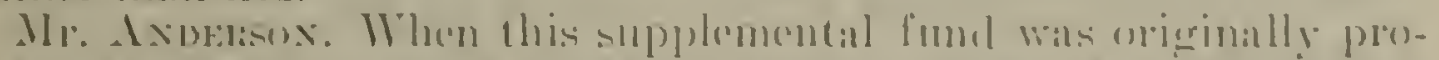

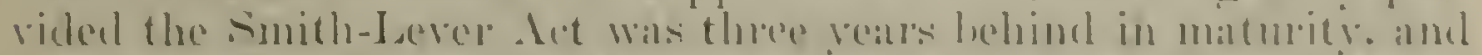
the ieleat at that time, as I reeall it, was io mature immesliately insteat of rear ly year. and the experetition of some members of the commitere was that as the sunth-Lever fumls matureel the supplemental

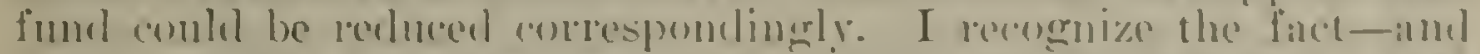
I suppose the other members of the commintee ilo, erenerally-that there have heen increases in eperating expenses. which probsaly. male the comre origrinally intemed impessible. Lint I lo not think 
it is quite aceurate to assume that at the time this supplemental fund was established anybody supposed that it was to be a permanent appropriation.

Mr. Chustue. I think you are right, Mr. C'hairman. IBut it was hoped-and it surely has been the hope of everyboty-that we would return to a more or less normal lasis. Infortmitely, we have not returned to that basis.

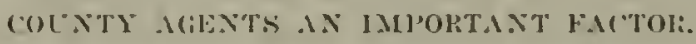

'Then, there is another factor. When the smith-Level' let was passed we had the county agent only. In addition has come the greatest demand for home demonstration work and bors" and grills" club work. It has been necessiary to adrance those interests amb develop that side of the work. Xaturally the cost has increased and has placed a burden on the institutions on that account. Talking these factor's all into consideration we caln not handle all the worli with only smith-Lever funds. While I understand that Congress hoped that the Smith-Lever fund would meet the needs of extention work. conditions have changed since the passige of that act. If we could go back to the previous situation. with railroal fares at 2 cents a mile, gasoline at 11 cents, with meals from 3.5 to ie) (ents. as they were when we hegan this work: if we (ould go back to a basis of a lower cost of printing and other reasonable expenses. then we conld do as much work with the smith-Lever fund as we ale doing with the Smith-Lever fund and the supplenental funcl.

Mr. Axperson. I to not fool myself with the itlea that that time is coming.

Mr. Curistre. That is the unfortunate rondition we are experiencing at this time. I do wish to impress this fatct. that the arricultur'al colleges. the United States I)epartment of A Secretary of Agriculture himself have all given this whole matter. very serious consideration. It is not a matter of supporting the lepartment in connection with the performance of this work. or of supporting the agricultural colleges, but it is a matter of trring (n) render service to the farmer's at this time-sorve which 1 think is greatly needed.

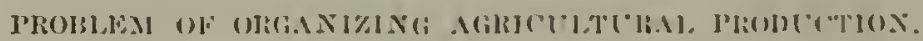

Mr. Axmbeson. I would like to ask you one question. if I and express myself so our minds will meet on it. 'To what extent is the extension servia giving its attention to the problem of oreanizinge acricultural production?

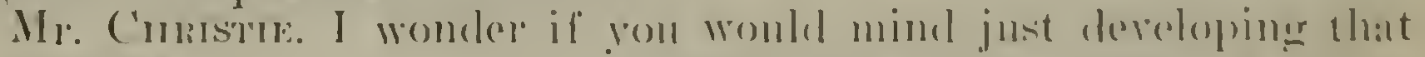
at monent.

Mr. Ixplasox. What I have in mind is this: I am protty thom-

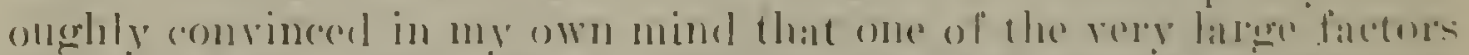

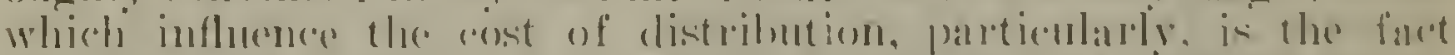

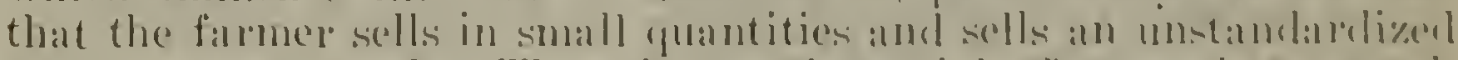

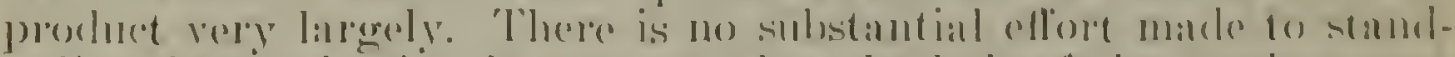

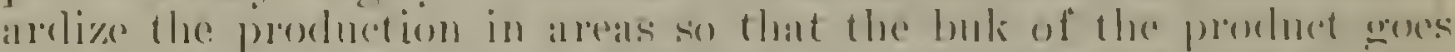
into primary or terminal mallets and thus milkes the cost of hatndling less. 


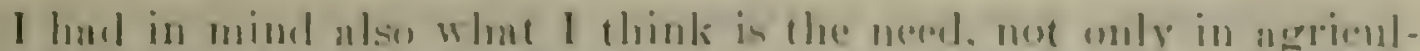

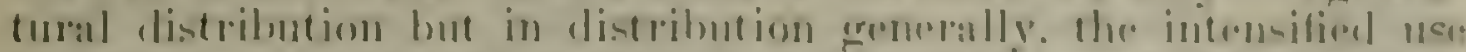

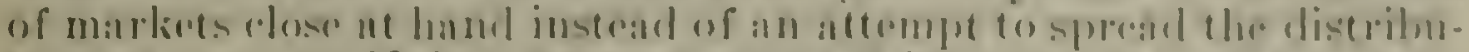

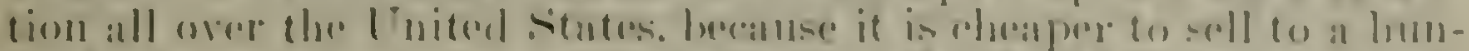

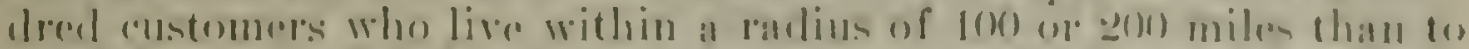

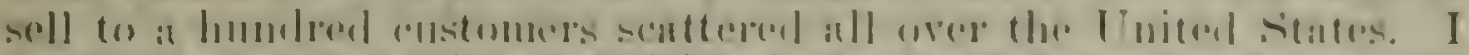

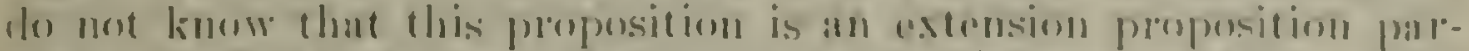

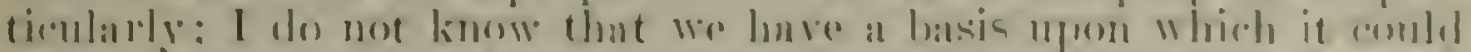
he mate fant of the extension work. but I think that is the real

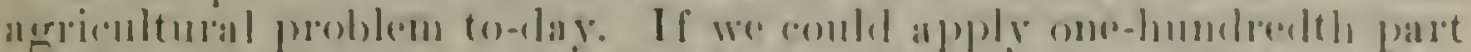

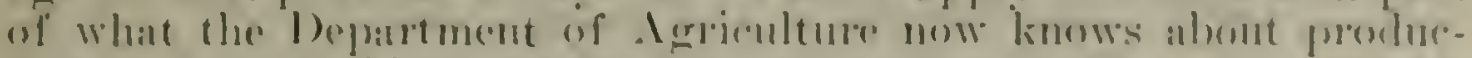

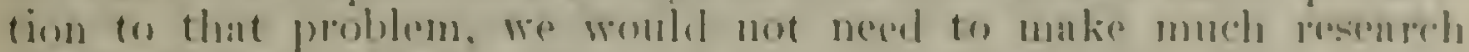
for somer time to romer.

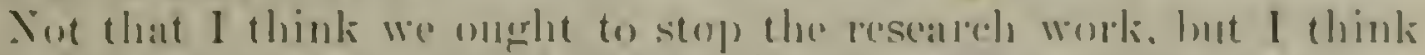

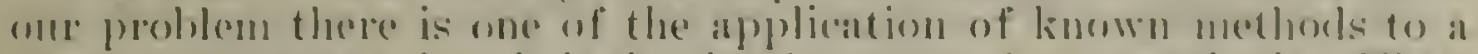

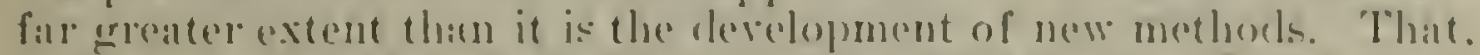
I think, is the joh which the extension serviere has. But hevoul that I think mur prohlem is balerely one of organized production.

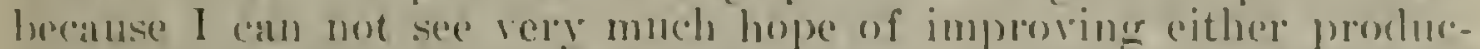
tion or distribution methols withont a someler oreanization of

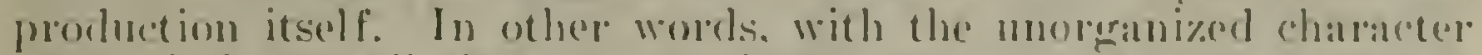
of the industry all that you grentlemen ean lo to al laldere extent is to sernel 11 ) a general hatratere. in the herpe that some of it is groing (1) hit some birt of the problem. Lou an handle at erood many individual cases. and doubtless pou do. hut ret a larere part of our eithort. I think. is wasted, heeamse we have not the oreanization of produretion to male it effective. 'That is what is in mr mind.

Mr. ('mustre. Mr. (hairman. that is an excellent idlea, and one that I think every man in the agricultural colleges will agree to.

Our arricultural colleges are doing something along that line. ire have been handicapper during the war. die to the extremely high prires and the willingness of the trarle to recoive almest anything. We de find in om districts. for instance. many vilrieties of wheat. many of them of poor quality, hecause the miller's have not been willing to stand hy the grade and reimburse a fellow a little extra for the grood guality. But to-elay the miller's are realizing that

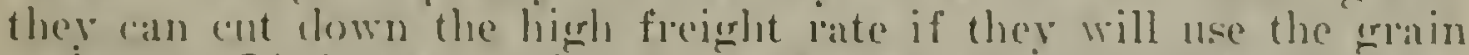
"thome. If they are geving to wase the what grown near the local mills, it must he wheit of one quality. The reason why many of the larere flome mills have heen ahle to sell theor flome in ibe Mighlle Itest is heeranse they have hern able to stamblardize their flom-one sark is rery murb the sime as the other. Put where the local mills

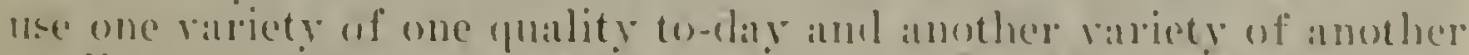
quality to-morrow one sack is absolutely ditlerent from the otherethe bialierse can not wase it.

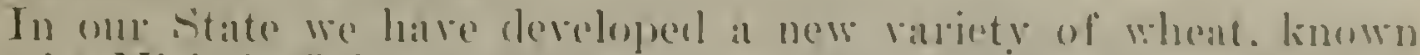

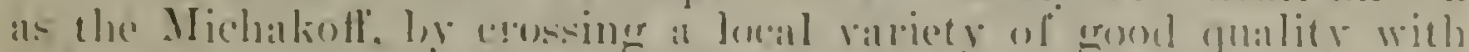

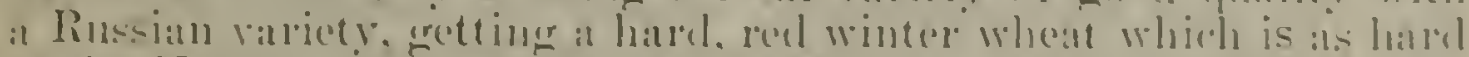

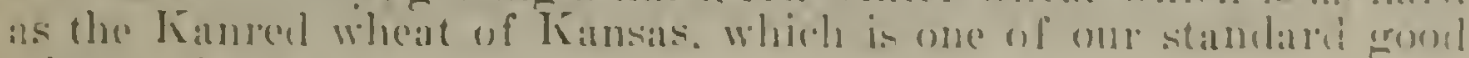
winter wherats.

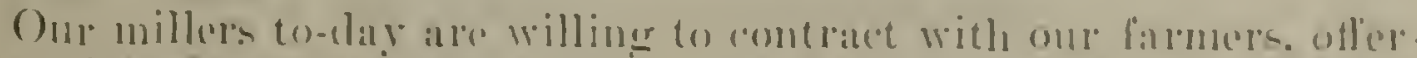

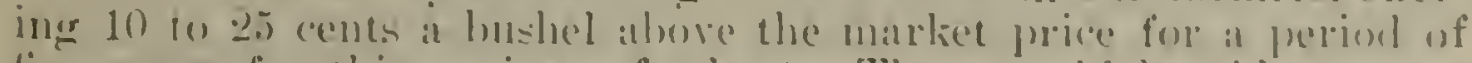
live yeals for this variety of wheat. 'They would be able to salve 
about 25 cents a bushel on freight on hard wheat imported into Indiana. The Kansas institution has done a wonderful work in dereloping the Kan Red wheat. Michigan has done the same with the Red Rock wheat, and Wisconsin and other States have put out many varieties of excellent grains.

We are in a position now to do big work, Mr. Chairman, because the farmers are realizing they must do something to help themselves. There is a spirit to-day which has not been present in any large measure heretofore. California has had that idea in their cooperative marketing. They recognized the need for good rinieties of apples and grapes in large enough quantities to warrant carload lots. They have given a demonstration of what can be done. You have emphasized one big point, which must have consideration.

Mr. Andersox. We will be rely glad to hear the other gentlemen.

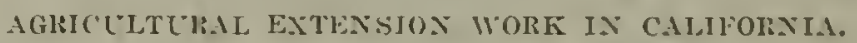

Mr. Crocherox. Mr. Chairman, I am here primarily in the interest of the Western States in this supplemental Smith-Terer item. which we beliere shomld be $\$ 1,500,000$. 'The State of Callifornia is putting $\$ 3$ into agricultural extension work for every dollar from the Federal Govermment. Eren the little State of Terada, with $90 \mathrm{per}$ cent of its land in the liands of the Federal Gorermment and 10 per cent of the land paying the entire taxes of the State, is putting up \$:3) to every dollar from the Federal fiovelnment. New Mexico, with all its difficulties, is still putting up to every dollar from the Ferleral Gorernment. I think it speaks well for the appreciation of the legishative boulies of the States and counties involved in the $1 \mathrm{~W}^{\mathrm{e}} \mathrm{est}$. The Smith-Iever let has always been manifestly inadequate for the meeds of the Sitates which hid a relatively small rum population. It is true that our populations are growing and that the number of farms is increasing. One-third of the nerl farms in the Tnited States between 1910 and 19:2) are in California. Our farms increased from 87.000 to 110.000 in that. decade. 'That malkes a great burden upon our agrieultural extension serrice.

Of the eight leading comnties in the United States in agricultural production, according to the last census, five of them alre in California: of the 50 lealing comties in the I'nited states. 16 are in Callifornia ; and yet our proportion of the smith-I.'(1) alpprepriation and of the supplemental appropliation, divied in the same

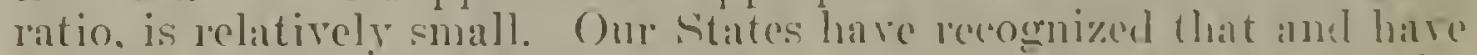
done what they could to help correcet it, hut the fuml is still inarlequate.

The State of California is putting altogether this year a total of

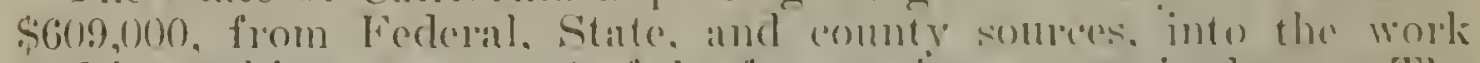

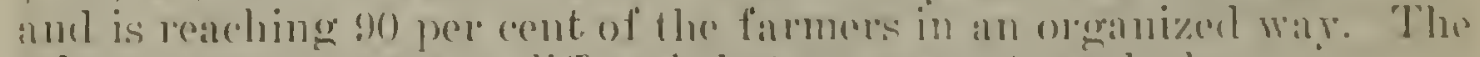

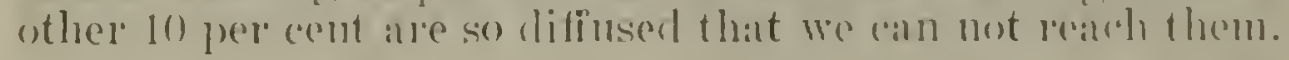

1:1.21.

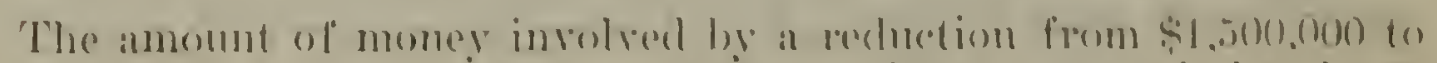

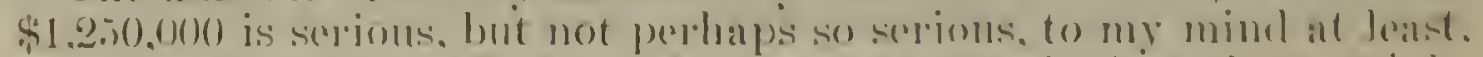

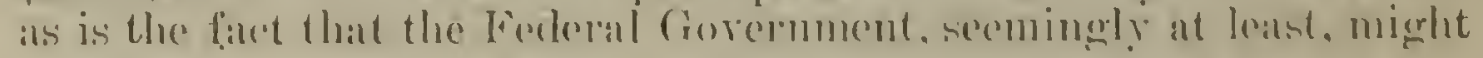


be supposed to be lessening its stupport of this enterprion. " thich the States huve so well supported.

The discomraging conditions in diflorent purts of the West which

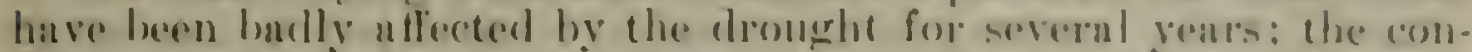

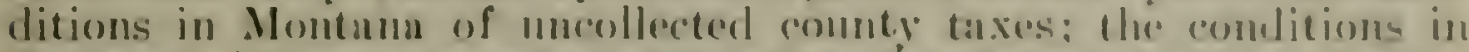
Nevada, with rrent comties with only a few farms, and the attemph (6) make farming there suecessful, and the cattle conditions. Whath lunve heen so serious, male it appear that the problem is one perhape quite as much of moral ats fimment support to this enterprise.

The llestern stutes hove met their problem as best there am. I do not know whether one nlways apprecintes how diflecult it is to enry this assistance to these people who are settling on the land and who need help in all phases of irrigated farming. They do not kmow how to apply the water to the lame. "They come from the Middle West and bustern States. and there need holp at all stanes of the enterprise. I do not linow whether it is fully apprecinted here how diflicult it is to make this work suceessful and how much serviee they need and what an expensive thing it beromes. Tiake the fuct of the incrensed cost of tronsportition. If it is true in the relattively small comnties of the highly developed states. it is cortainly far inore largely true in the big counties of the West. In my own Sinte of Culifornia one county is as large as the States of Masiachulsetts and Connecticut put together. and to attempt to hase one connty agent cover that territory is manifestly impossible. We have hail to put three men in there, and even then we are only seratching the surface.

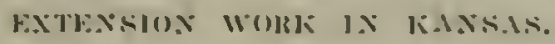

Mr. Jamme. Mr. Chairman, I am interested in this item hecanse the farmers in Kansas-and I have gone over the situation with the Representatives of Nebraska-are in a serious need of lieght. 'They are in trouble. The farmers of Kansas are looking to the anricultural colleres for help as they never have looked to them before. Many of the farm oreanizations that have endearored to function in the last four year's have had difliculties. and they are coming

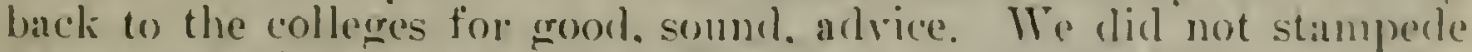
them: we tried to state the dilliculties and to present the fundamentals. and they are (oming to believe that the sleresestions they ane gretting from us are the ones that they need and should prit into use in the development of their agriculture.

lieferring to the supplemental fund I had the understanding rou have expressed. that it was merely to tide over the probol wintil we comlil get hack to reasenable prices again. But howerer that may be. the eosts of operation are rery expenesive, and we have not been able to develop the provisions of this act as it was intended they shomld be developed moler the origrinal act.

The have 10:3 connties in Kansas. Wo ale now sorving (i) of them. and there is a demand from the other connties for help. Wo hatra only heen able to reach the lemand of a few of om farmers. Wis onght to be able to reach all of oml farmers. If it is grool for some. of our farmers. for these we have leen reachinge the ones who were seeking light. We onght to push this out to the other's, now that they 
are in trouble. When an individual is in trouble he is more likely to come and ask for help. That is the case in Kansas, where we are practically at a standstill this rear. If this item is going to be reduced for next rear we must curtail our work. and it will not be a grood thing to do. If we are going to pull ourselves out of the mire, it will be clone by placing the facts in reference to their business in the hands of the farmers. I think you hit the nail on the head, Mr. Chairman. when you mentioned organization of agricultural production. I think if we conld teach the men who are producing eggs. how to pack their exgrs properly and bring then into the market in attractive containers, we would be doing a good service. Then. I think. we have to go to the business men in the cities and get them to see the light. They must be willing to pay a premium on these particular eggrs.

Tre must educate the retail men. I am spending some time in talking to chambers of commerce and rotary clubs. Members of those organizations are inviting the farmers in to have dinner, with the idea of talking these problems over, and they are getting to molerstand each other better than ever before. We should have a common understanding between the business men of the cities and the farmers before we can get what you have suggested. It has to be done through the business men and the farmers themselves. The farmers are not going to do it alone. Ther do not know how. We must have men who can come in and help us, who know how to organize, who know how to gret the products to the markets, so that they can be readily sold. We have to get at the advertising men. I am talking to the alvertising men here at noon to-day along this particular line. They have never taken that proposition into account. They have forgotten that agriculture is producing from twenty-two to twenty-four billion dollars worth of products. No one has yet thought about trying to sell the farmers goods, vet the arlrertising men have sold the manufacturers' goods. Which are sold to the farmers. I am trying to interest big business men-bankers and men of that trpe-in this problem as well as the farmers. It is more than a mere farmers' problem.

Wre are at a standstill. I hope and believe you will do anything you can to strengthen this appropriation and bring it back to a million and a half. We need to serve more farmers than we are able to serve now. 'They have come to regard us in a much more farorable light than they did five years ago. 'They are relying on us, hut we can not meet the demands on us. We are sendingr out our teachers instearl of haring them give their entire time to the instruction of students. We are carrying the instructions to the farmers, and we are giving the students the work only in a condensed form as they need it. If we can not furnish moie light on agriculture to the individual farmer's. then I do not see any salvation. It is through education that we will hare to do it. and the extension work is an educitional program. There is too much propaganda groing on, too much stufl being preached by demagrogues. We nerd to eqive the farmers sombl advice now, and we need all the money we can get for this extension service to "arry on the kind of work we have been doing in the last 18 months. 


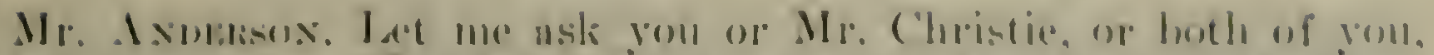
this one question: Has there bern any inclicontion of a di-imelimition on the palle of the formers in comnection with this work on ancount

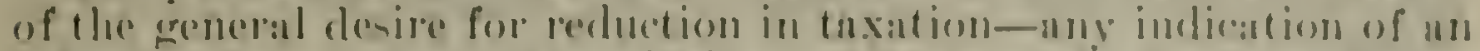
intention to colt fown the suluries or the amounts they ure upprospriating for combly arents?

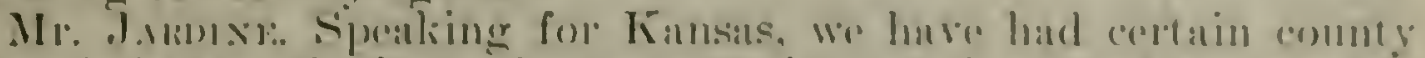

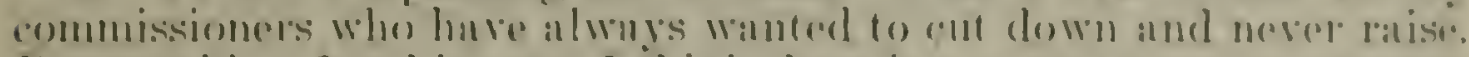
But speaking for this yentr, I think there is a morre grenerous respentser

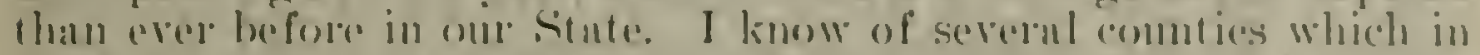

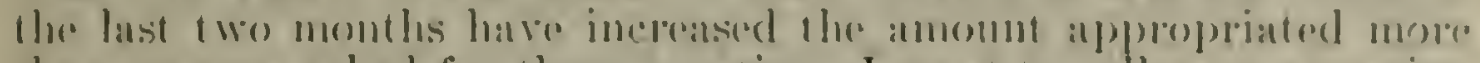

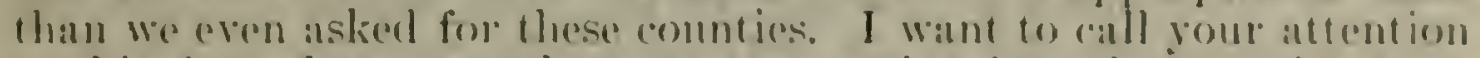
to this fatet, that erergwhere we ate putting into the counties from

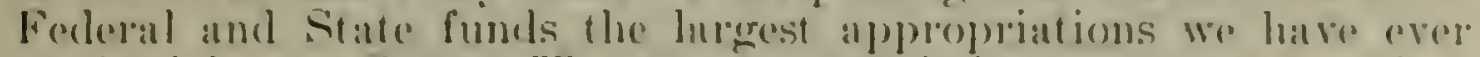
recerivel in oul state. The combly comminssioners were opposed to this proposition two or theer years ano, but they are coming buck to it now. They see the light and they sere where we have salve consesfor instance, though the elimination of erasshoppers. We distrihuted St carloads of poison in 3 (6 different comnties, and wo cheaned up the grasshoppers theorgh the county oremizations. Wro have also gone into eomties where we have eliminated the chinch huge and we are working to grether as never before. The county commissioners realize the benefits of it now. They are trying to cut down taxes, hut I do not see any evidence of it in this vork. We hat more supporters for the farm bureall than we have creve had before.

Mr. Cinsstre. Of course, Mr. Chairman, in some of the Stattes we have some people who feel that the waty to economize is to cut down on the comnty agents, hut when the matter gets to al vote on the part of the comty commissioners and on the part of the farmers themselves the appropriations in most comnties are sustained. 'To-day we have in the neighborlood of 86 county agents in the State of Indiana. and we have appropriations of money arailable in the other ficomlies, making the 92 counties, complete. While there has been somm? opposition, as naturally would be expected with the unrest which has prevaled, a majority of the people have come forward and said that we must sustain this extension work, and it stands in grool filvor.

If that answers your question, Mr. Chairman, I would like to have Mr. Wialton sily a word to you.

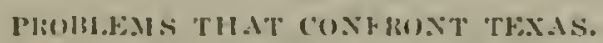

Mr. Wusox. Mr. Chairman. I simply want to point out very brefly some of the problems we have in Texas, and to speak also for the whole southern erroup of directors.

If I mnderstand the purpose of the smith-Lever Act, it was the origrinal intention when it reatehed its matmity there would be sufliciont funcls, if the statles would ollset these Federal funds, to have

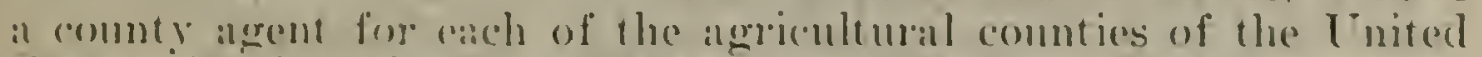

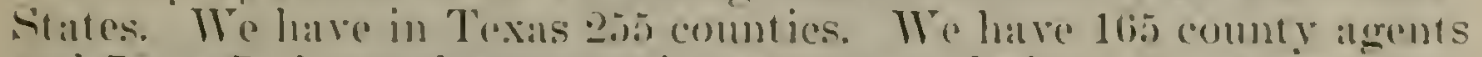

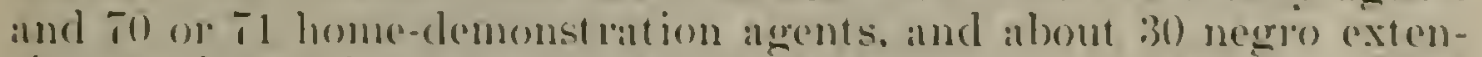
sion workers who are local assistants to the connty anents. That leares a considerible mumber of 'Texas comnties in which we do not have suflicient funds to meet the appropriations of the local bonds of county commissioners to provile agents where they are actually 
needed and where there is a demand for them. I think that the same situation applies, perhaps, in other Southern States in about the same percentage on the basis of the comnties that we hare in Texas.

I think also there is a growing demand-I know it is true in 'Texas-on the part of the people of the comnties for assistance from the department in establishing these algents to render service to the homes of the counties. I know that demand has increased substantially in our State in the last 12 months. Te are having now more requests for the establishment of the county home-demonstration work in the counties on the part of the local people, without any effort at all on the part of the institution, than we have ever hald.

\section{HCONOMIC SITUATION OF FALMER IX SOUTII.}

Moreover, the agricultural situation in many respects in the South. the economic situation of the furmer, is a very depressing one. Of the $1,500.000$ women who work in the fields of the Cnited States, about 1,250,000 work in the cotton fields of the Sonth. Somebody says that is largely a problem of the southern negro. I $\mathrm{am}$ a soitherner and have all the prejudices and opinions of the arerage Texan on that question, but that is a substantial part of our agricultural citizenry, and any work we may do in rural places that helps to improve that situation certainly helps to raise the standard of the whole citizenship of orr section.

Regardless of what the intent of the Congress might have been or those responsible for the appropriation of the supplemental fund hreetofore as to its permanency or as to its being a temporary fund. there is no doubt that we are faced with situations now that could not have been contemplated or known by those who were responsible for the passage of the Smith-Lever Act in its original form. Conditions have come about that make it inadequate to meet the situation if we are to put county workers with a properly balanced extension staff in all the agricultural counties of the Inited States. 'That is certainly true in Texas, and I think it is true the country over.

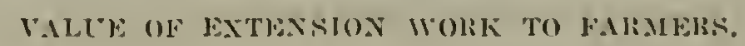

I understand it is not necessary to arene with this ammitter on the importance of the service these people render. I am sure your gentlemen realize that the farmers situation now is perhalps as mosatisfactory as it has been at any time for a decade or more. and I helieve this service oflers the best opportunity of remlering constructive service to the agricultural people. and that it is a service that helps to make the whole sitnation on the farms very much better.

That is all I care to say muless there are some gutestions you care to ask alsout the situation in the sonth.

Mr. A volmsos. Is there anything further. Mr. Christie!

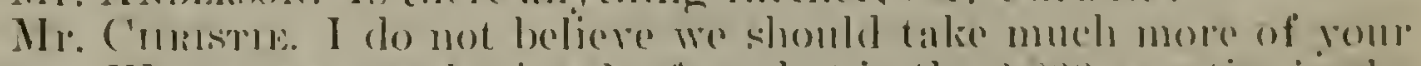
time. We want to emphasize the fand that in the $2.50(0)$ comenties in the United States wo have arents in about 2.100 of them. Wre mierht argee that we do not need agents in all of these. but we do linew it to be a fact that a larege number of comnties not pet oramiad must have help if we ale going to carly ont the program which has been 
set hefore us. This whole question has been carefully combidered he

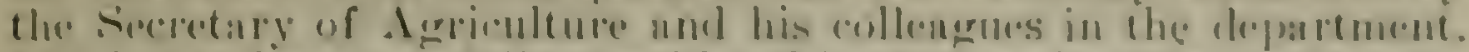

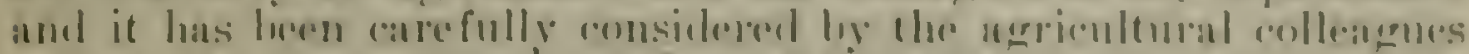

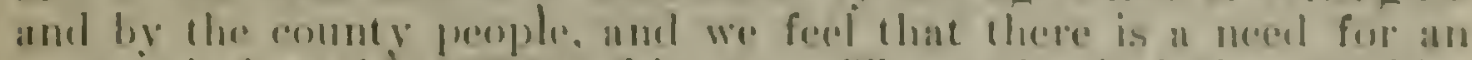

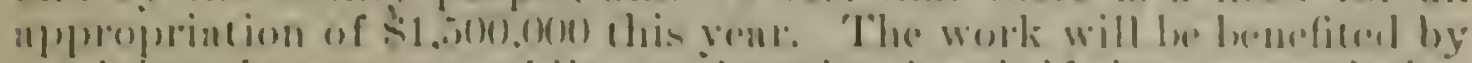
receiving that mone? while. on the other hand, if the approprintion

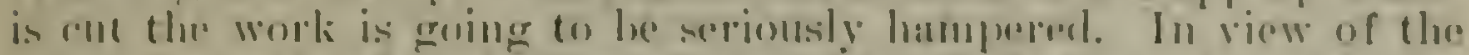
great demands of agriendture I in the approprintion will not be mate. hut that gou will give us the full :11111111.

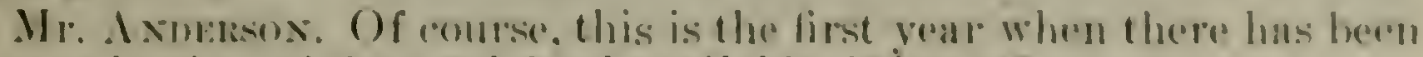
ani reduction of the total fund arailable, is it not?

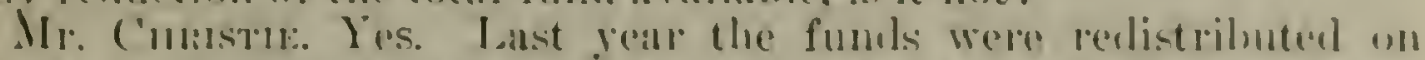
the hasis of the last census. The result was that in Indiana we went dorm on our pereentage of rurnl population. und therefore we grot at lese umount from the smith-I fever fund and the supplemental fund, making the total amount received from both funds a few hundred dollurs less than the previous year, even though the Sinith-Lever funcl hat increased.

Mr. A xumasox. The converse might be true in other places.

Mr. Cuntsin. That is true. When you take States like Ohio, Indiana. Iowa. and Illinois. some of the bigr sitates that are contributing in a larere way to the agricultural products of the country. we have received for this year but little more money that we received the yar before. So if any cut is made in the sirpplemental funds the work will he seriously imparined. If the supplemental fund is placed at $\$ 1.500,000)$, these States will receive practically the same amount of money they had last year. In some of the Wirestem States they have receiral a little nore money. hut they need it. 'They have been getting a few hundred dollars out of the supplementil fumb hecause of the small rural population. and yet they have a tremendons problem in their development work. which is making for better atriculture in the country. We are not complaining because they have grotten that money. "Tre hope they can gret more. They shouli hitre all possible consicleration.

\section{STATEMENT OF MR. D. M. GREEN, OF THE EXHIBIT SECTION.}

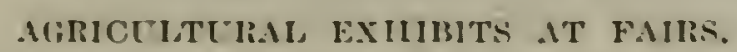

Mr. Andinsox. The next item is on page 333. to enable the Secretary of $\Lambda$ ericulture to make suitalle argricultural exhibits at State. interstate. and international fairs held within the United States, for which you have estimated $\$ 85,080$.

Mr. Grax. I have here a list of all the places at which exhibits were macle during the fiscal year 1922.

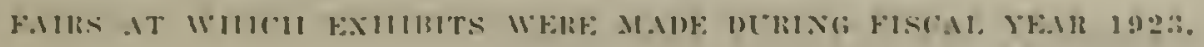

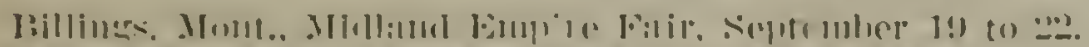

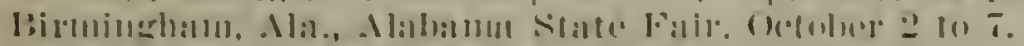

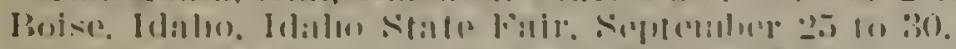

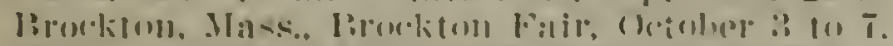

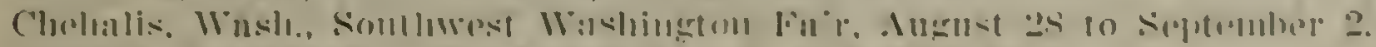

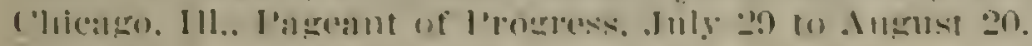

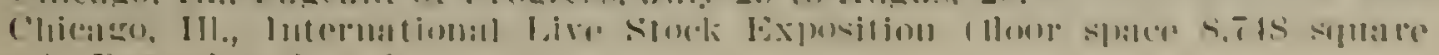
fert), Irecomber $\because$ to $:$. 
Cleveland. Oli:o.. Assuciation of lere ('ream simply Men, October 17 to 21 .

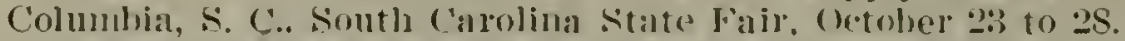

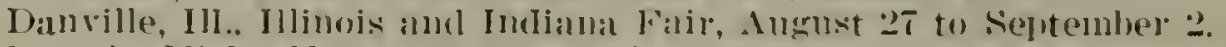

letroit, Mich., Michiquall state Fair. Seltembel" 3 to 10.

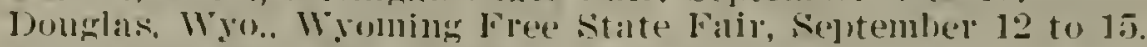

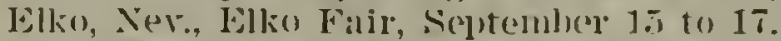

Erie, I'a. Erie's Big Exposition. Aurust 21 to 26.

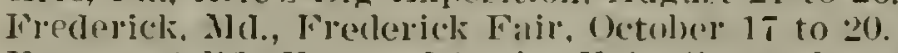

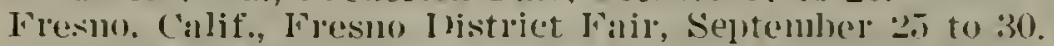

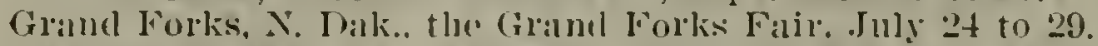

Hagerstown, Ma., the Hagerstown Fair, U(tober io to 14.

Helena, Mont., Montana state liatr. Sejutember 2-5 to 30.

Honoluh. Hawaii, l'an-Amerian Commereial Conference. October :at to 31.

Huron, S. Dak.. Sonth Dakota State Far Sentember 11 to 15.

Jacksonville, Fla., Florida State Fair and Exposition. Noventher 17 to 2.

Kansas ('ity, Mo., Heart of America Dairy Show, June 5 to 10.

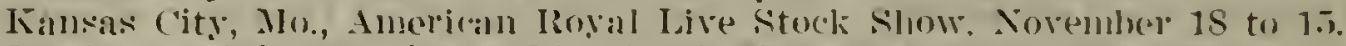

Lewiston, Inalo, Northwest Live Stock Show. Sejtember 122 to 16.

little Rock, Ark., Arkansils Sitate fair. ()ctober !) to 1.5.

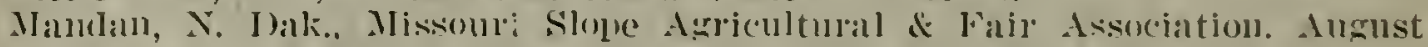
29 to :i1.

Memplis. Tenn., Memmhis Tri-stato Fair, Septomber $2: 3$ to :30.

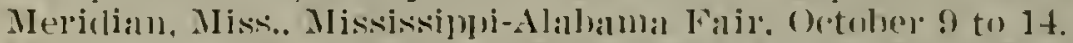

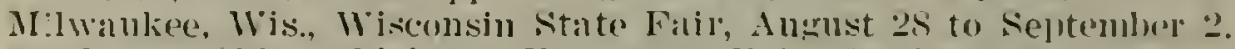

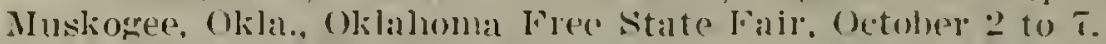

Omala, Nebr., Ak-Nar-Ben Fall Festival. Sejutenber 12 to 23.

I'hornix, Ariz., Arizona Fisir, Octoler 30 to Norember 4.

I'ortlami, Oreg., Pancific International live stock Exposition. Norember 4 to 11 .

Prescott. Ari\%. North Ari\%ona State Fa:r, octolner 19 to 21.

I'uelolo Colo., Coloriclo state Fair, Selotember 25 to 80.

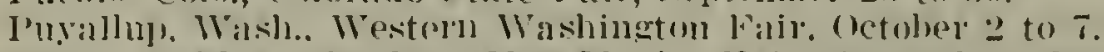

Iiaton, $\mathrm{x}$. Mex., Northem New Mexico liair. September 12 to 1.5.

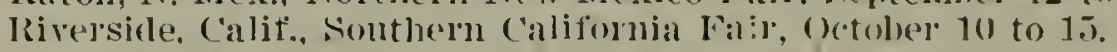

Rochester, N. Y., Rochesper Wxposition, September + to 9 .

Rome, Gal. laome County Fair. (October : 3 to 7 .

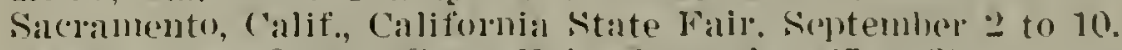

Salem, (oreg., Oregon Sitate lair. September 2.5 to 30.

Salt Lalie City, Utah, Ctah State Fair, Octolor 2 to $T$.

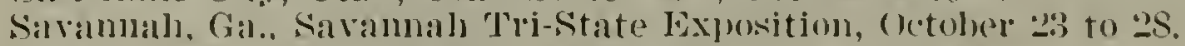

sionx ('ity, Iowa, luterstate Fair. Sephtember 17 to 23.

Spokane, Wasli.. Spokane Interstate Foir. September 4 to 9.

Springlieln, Mass. Eastern states Exposition. September $1 \mathrm{~T}$ to 23.

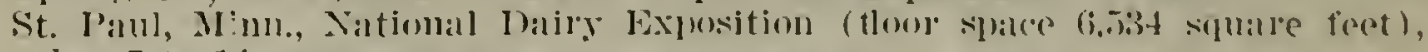

Oetoluer $T$ io 14 .

Stuttarat. Ark., Arkansas IRice Carnival. November 15 to 17.

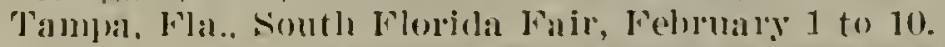

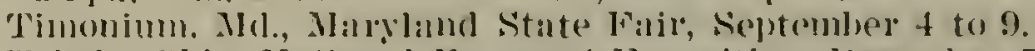

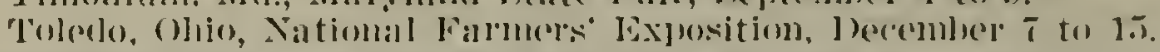

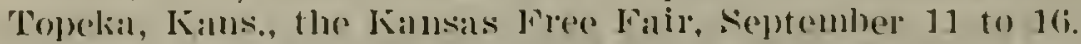

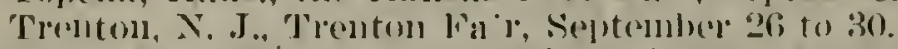

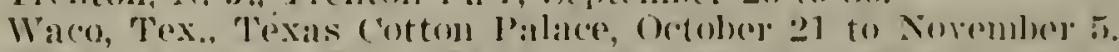

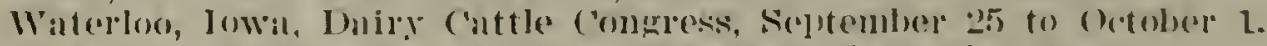

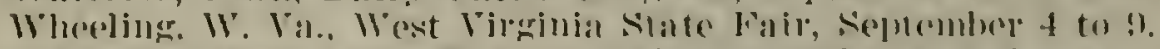

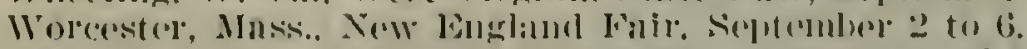

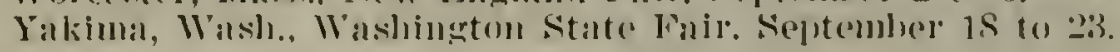

Total mumber of showing lumints, (io).

Mr. Axmbsox. Ifow many are there?

Mr. (imele. Sixty.

Mr. Axmersox. Just have them inchuded in the record. 'That will be suflicient. Were these all linro shows?

Mr. (imeses. Yes, sir: Imt most of them were State fairs. There were several special shows like the Intemational Live-stock Lxposi- 
(iom and the National 1)niry Exposition, but the majority of them were state fairs.

Mr. I voldsos. 'This appropriation apparently compres an increase

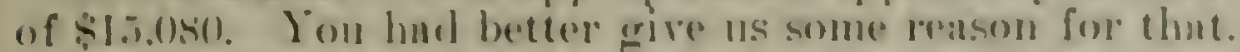

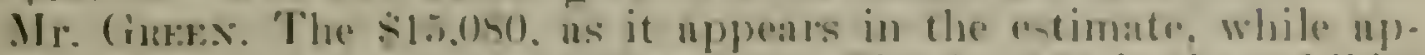
parently an increase is actually not so. The slo.(1) is the cxhibits portion of the appropriation " Feneral expenses Division of Publi.

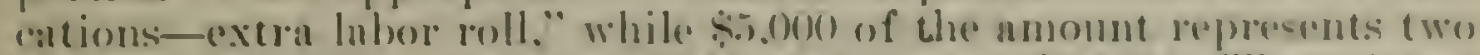
statutery positions-one at $\$ 2.06(0)$ and one at s.3.0(0). "These items

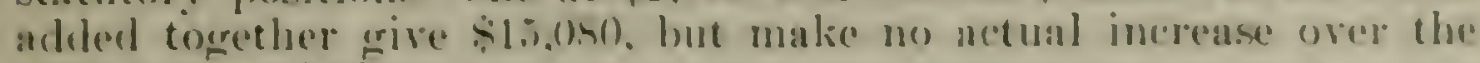

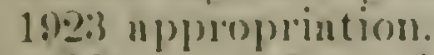

Mr. Ixomelisox. Are you planning to make any rexhibit at the National Dary Show next year?

Mr. (imax. Yes. sir: but just what it will be next year has not been determinel. It may rary somewhent in type and ilesign from this renr's exhibit at st. Panl. hut that will be deciderl later. Is Mr. Puersley previoursly mentioned. howerer. we could not build any larere exhibit than the one at this years Xational Inairy show without usiner more funds and if these were taken from our present appropriation it would serionsly hamper the exhibit work at other points.

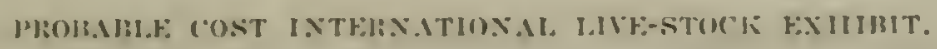

Mr. Axmasox. What amount of the appropriation was expended for the National Darry Show this year?

Mr. Gris:x. Do you mean by that the total cost in making the exhibit?

Mr. Axprasos. Yes: at the dairy show.

Mr. Grafs. Approximately $\$ 10.000$. That includes the mechanical construction of the exhibit and salary of the people during the time it was being built.

Mr. Axnensos. Do vou think an exhibit which wonld adequately represent the dairy indirstry of the Lnited States at an international dairy show could be made for $\$ 10.000$ ?

Mr. Grex.s. No, sir: I lo not.

Mr. Axmemsox. Will you tell us what it could be made for?

Mr. Grisw. Perhaps $\$ 15,(0) 0$, but that would rlepend upon the definition given "adequate." I do not know how much of an exhibit Mr. Skinner has in mind. I do not think it could be built for less.

Mr. Axprasos. Well. I have a feeling that when we have invited these people over here we onght to grive them something for their money. The exhibit ought to be one that would reflect credit not only upon the industry but upon the United States. I would not feel mrself like with holding $\$ .000 \mathrm{or} \$ 10.000$ on a proposition of that kind if it meant an adequate exhibit rather than an inadequate one to picture the industry of the L'nited States.

Mr. Grres. I do not helieve \$15.000 would build such nn exhibit as you refer to or one that would be in keeping with other things that I understand they will have here at this world's congress. I would say that such an exhibit would cost \$25,000,(100), because the exhibit we put on at the National Dairy Show this year cost us between $\$ 10,000$ and $\$ 11,000$, and I do not think that is exactly what they want. 
Mr. Ixpersox. I saw that. I think it was rery grood for its kind, but I do not think that is what they want. I wovild not think that it would be in keeping with a show in our own country where we invite competition from all the other great countries of the world.

Mr. Jurr. Ion will remember the past history on this appropriation. Mr. Chairman. Yon will recall that when the amount was $\$ 100.000$. which is the way they started out with this when it was handled by the other committee, there was a proviso in it that $\$ 25.000$ should be avalable for the National Dairy Show. That vear. as I reeall it, the department spent about $\$ 23.000$ on the dairy-show exhibit. It was next to the last year the show was held in Chicago. The next year the department requested not to tie up all that money in one show, and the cost of the department's exhibit was reduced to $\$ 10.000$. I am under the impression that this rear's and last rear's exhibit cost even a little under that amount. I presume what you have in mind now would be an exhibit showing modern dairy methods and perhaps some of the laboratory work, like the making of cheese and such as that. and that is where the money comes in. where you set up those temporary laboratories at shows like we had last year at St. Panl, and the year before at Chicago. Did you see the show at St. Paul last year. which included the small bacteriological laboratory?

Mr. Axpelisor. No, sir.

Mr. Greex. Dairy machinery, laboratory, and similar equipment is rery expensive.

Mr. Buchaxas. Somebody ought to be able to tell us what it would cost to put on a creditable exhibit at this world's congress.

Mr. Greeses. It will cost $\$ 25,000$.

Mr. Axpmisox. You cut out this language "in connection with the other departments of the Gorermment." That is for show purposes?

Mr. (inimex. Yes, sir.

Mr. Buchaxax. Yon never cooperate with any other department?

Mr. Greex. Our showings are almost entirely of an anricultural nature.

Mr. Jurr. Tre conld still cooperate with other departments if this language were cut ont, and wonld do so wherever economical or advantagreous. I never did know why that proviso was put in there.

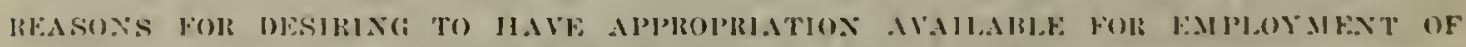

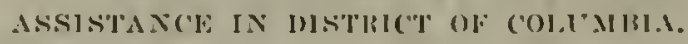

Mr. A ximisox. Fou propose to cut out the languacre "And the payment of rents" and insert in lien thereof "in or ontside the rity" of Washington." What is the oloject of that?

Mr. Grisex. Becallse the work has been considerably hampered by having part of omr work elone outsicle of the I)istrict of Columbia and the other part here. We have our arts rooms and warehouse in Alexandria and nur oflices in Washington. and it means groing hack and forth with sketrhes and supplies. hauling material, and taking people back and forth there who wish to inspect the work.

Mr. Axblisis. As the langriage now stands you can not pay for rental in the District?

Mr. Gusex. No; we can not pay rental or salaries in the District. 


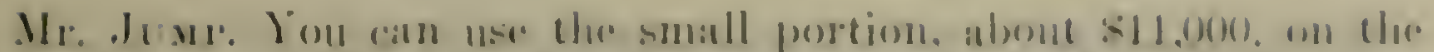

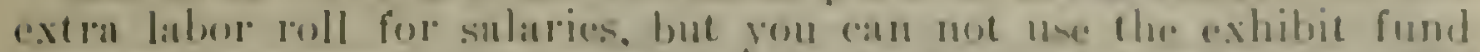

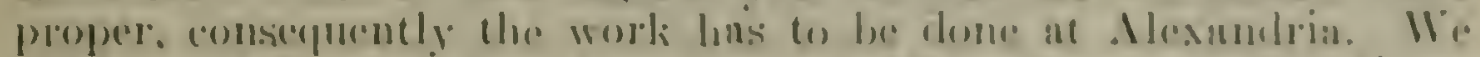

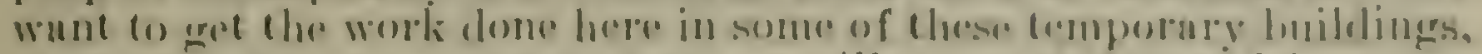
if we cant. If we can not do that, we will gon on at . I rexatidria.

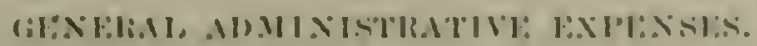

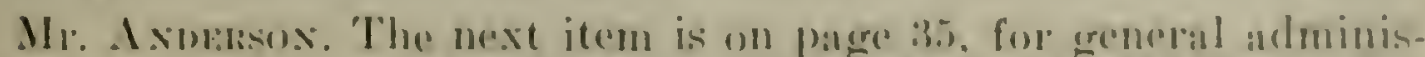
trative expenses connected with the lines of worls of the states Rrelations service, including the oftices of the direcenter and the chiref clerk. Lon propose to cut ont the lunguage which relates to the lines of work of the states liclations. Sirvice. including the oflicess of the director. the chief clerk. the oflices in charere of publication,

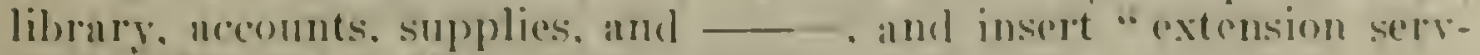
iee" in lient thereof?

Mr. Alatis. Yes, sir.

Mr. Axblesos. "There is no change in the amoment here?

Mr. Mul: No, sir.

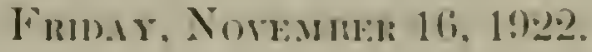

\section{STATEMENT OF MR. W. E. SKINNER, REPRESENTING NATIONAL DAIRY ASSOCIATION.}

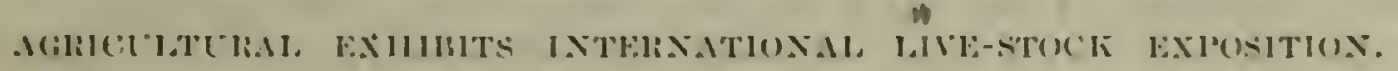

Mr. Aximesox. We will hear Mr. Skinner. Yon represent whom?

Mr. Sisxise. The Notional Daliry Association.

Mr. Arm:asos. The committee will tale up this morning the item on page :33. to enable the seeretary of A griculture to malic suitalile agricultural exhihits at State. interstate. and international fairs helal within the Inited States, etc. The estimate (alls for s.5.080. as (o)mpared with sit0,000) list reals.

Mr. Skxxm. Our interest in this thing this rear more than any other. Mr. Chairman, is that in 192:3 the Congress of the Inited other. Mr. Chairman, is that the Congress of the Initel states requested the President to invite in 102:3 the dairy interests of the world to assemble here for a world's dairy congress. And at that time we purpose making our national show international in chalateter. so as to encompass the world's industry. and we are rerre keenly concerned orer the presentation of the inchustry to be marle hy the Department of Arriculture. that it be suflieiently impressive to carry a message of significance to these people with reference to our size and importance and as to om ability to resist any intrusions while we are developing our own industry. So that I am seeking a larger exhibit. and perhaps one that will earry to some extent a different character of mesiage than that clelivered this rear at our show in Minnesota, and we are mrging upon the department the neessity for going into greater detail so as to (nhance the value of our exhibit to our own consuming population as well as the producing interests in other sections of the country than that oe'upied by the show the last two rears. 
Therefore. I am very desirous that the full amount of this appropriation groes through for that purpose.

Mr. Axibriox. Fon are not asking for an added sum above that estimater hy the department?

Mr. Sinser. $\$ 85.000$, withont any reduction. will probably take care of this work.

Mr. Bucmaxax. You say the President invited the dairy interests?

Mr. Shiscer. Yes. sir.

Mr. Buchasax. Have we extended that invitation ret?

Mr. SKIN⿴囗is. Yes, sir.

Mr. Bucmasax. Has it been accepted?

Mr. Sinvis. Yes, sir.

Mr. Armersox. Has the date been set for the show?

Mr. Snixser. Our date is fixed in our by-laws at the same time this year as last-October 6 to 13 , in 1923 .

Mi. A vinensox. Has the place been selected yet?

Mr. Skixiser. Not yet. sir, no: I am on a toir of inspection now of several cities.

Mr. Axuersox. By whom is the place selected?

Mr. Sirman. By the board of directors of the United States association.

Mr. Buchanax. There is $\$ 15,000$ extra that you want to add to these exhibits?

Mr. SKINxer. I did not know that there was anything extra.

Mr. Buchasax. I mean orer the other appropriation the precedingr year.

Mr. Sisisxer. Over the other appropriation: yes.

Mr. Buchasax. How is the appropriation this rear? Have you any unexpected balance. or are you going to have any?

Mr. SkINAER. 'That I do not know, sil.

Mr. Jrvr. Mr. Chairman. the increase in the exhibits item from $\$ 60.000$ to $\$ 85.000$ is an apparent increase only. The reason for that is that the \$15.080) is from the extra labor roll of the Division of Publications and several statutory places from the roll of the same division, and that is how yon gret the $\$ 55.000$ figure this year. It does not represent any increase. It just brings togrether all of the money for exhibits at fairs. etc.

Mr. Skixver. Will this give us, then. what we want?

Mr. Jump. That is something I an not able to answer. Mr. Pugsley and Mr. Green have more to do with the exhibits. I do not know what extra exhibits you require. and how much they would cost. The way the estimates stand now the amount passed by the Burean of the Budget is just the same as the amount this rear. If they would have to have more money than they have this year, that is something that Mr. Green and Mr. Pugsley should consider.

Assistant Secretary Pugsive. I think that conld be answered best in this way, that there can be no increase in the anomnt of money put into dairy interests this rear if the appropriation is the sume as last year, unless some other exhibit work is lessened in quantity or quality. In other words. if the money is provided as last year, there will be about as much put into the chary exhibit next year as this. But there can be no increase unless some other exhibit is robbed, if the appropriation is the same. 
Mr. Skxsor. May I ask, then, to have some other exhihit roblied! In other words. I want to make sure about this.

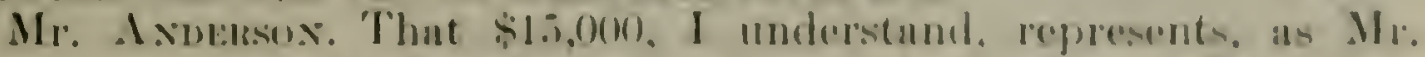
fump stutes, a transfor of anotlue item into this item. Fo it deres not represent an netual incrense in the sum uratal,le for this pure pose this year. We will go into the uclecgnary of the umomme. Mre skinner, when we grot these gentlemen up here, and tind ont about it.

\section{WEATHER BUREAT.}

\section{STATEMENTS OF PROF. C. F. MARVIN, CHIEF OF BUREAU; MESSRS. J. WARREN SMITH AND W. R. GREGG, METEOROLOGISTS OF WEATHER BUREAU.}

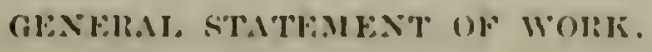

Mr. Axprasox. The next item is on puge 3i. Weather Burean.

Mr. Mamis. Mr. Anderson. I think the committee mnderstands alrealy very fully the mature of the work of the lleather Burean. that it is chiefly" a program of daily serviee to the people in the collections of observations and furnishing daily forecasts in regard to the wenther. We think there is a great economic benefit in that service und I would like to rearl a comple of letters here. very short ones, in support of that. This is a letter from the Broadway Market Co., Detroit. Mich. to the local oflicial in charge of this work. Mr. Norman I3. Congrer. and reads as follows:

Soms.s 13. Coxtikis,

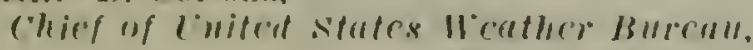
1.31: .Majestic Buildiu!n, ('ir!!.

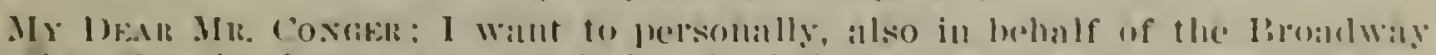

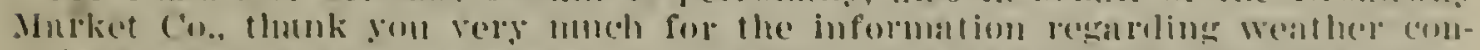
ditlons recently given us hy gon while installing a new renf on mor huilding.

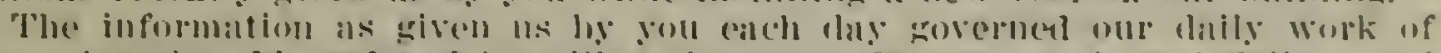
removing the old ponf and installing the new. It was worth real dollats and cents to us and we wish to express our thatuk to you personally for it.

lery truly yolls.

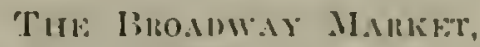

R. S. Wทrt:

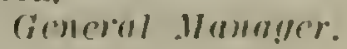

That expression, " was worth real dollars and cents to us," is a good thing. We are performing that sort of service every day all over the Enited States. This other letter is simnificant, also. This is from the Standard Oil Co.. New York City, duted Octoher $2 \pi$. 192.2, addressed to the Chief of the Weather Bureau, and is us follows:

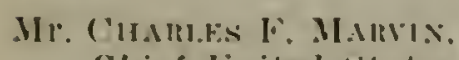

\section{chief luited sentes llenther Burenu,}

Henstim!nton, I). (".

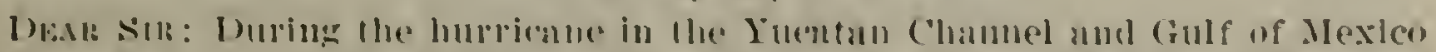
last werk a nmmber of our stenmers were In close proximity to the center of this mstulbance.

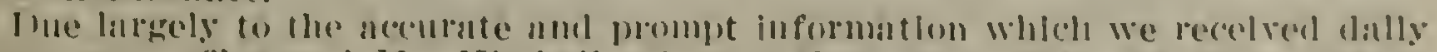

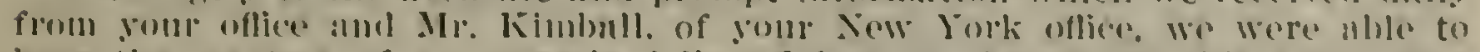
keep the masters of ollo resseds fully atrised of the course this storm was 
taking. thus enahling than to keep clear of the cent(or of the storus and perlailss silving the loss of both life alud property.

We wish to take this opportunity of expressing to rou our thanks for the valued services remberes, which alle greatly appreciated.

Youls very truly:

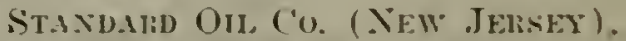

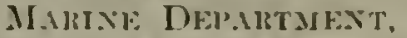

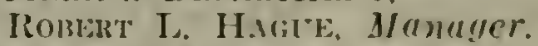

That is an ilhstration of the real benefits that come from our daily work. and every dollar of money in our appropriation. I feel, is productive of immediate economic benefit day after day.

I have prepared a written statement here showing some of the work of the burean, which I would like to have placed in the record, if you please.

Mr. Axbensox. Withont objection, it goes into the record.

BUIFF STATEMENT OF WOHK AXI) SERICE OF THE IXITED STATES WEATHER BLREAL.

The daily propram of work of the Weather Burean comprises a rery farreaching service of direct and immediate functical amb economic benetit to all the people and all the activities of the Nation. This work is based on weather observations takeu simultaneously and twice daily at ahout 200 stations in the Cuited states, so placed g(r)glatulically as to cover all sections of the comntry. and from points in Canada, the West Indies. Mexico, Central Ameriea. Alaska,

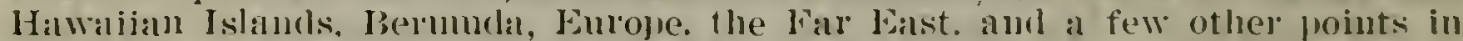

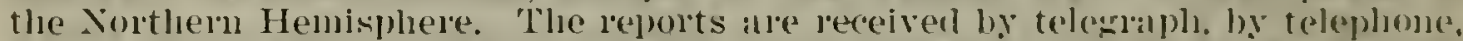
and by ralio, and are chalted at the districet forecist centers which are located at Washingtom. ("hicast), New () leans, Denver, and san Franciseo. 'The fore-

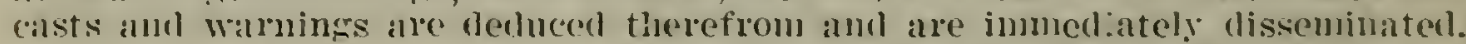
The time consumed hetween the taking of the observations and the issumgr of the forecalsts and warnings is about one and one-loalf hours. Wvery reasomalile means is utilized to the utmost to secure the immedialte and complete disseminat on of forecasts, walluings, and allvicess of all kinds.

TOPICAI, MIST (1\% MOLE IMIORTANT AEMTIRE.

(a) Inilig forecalsts and weekly outlook.

(b) Shlipler's forecasts.

(r) Warnings of Hoods and aldvires ats to sliges of jumbertant rivers.

(d) Stornu and hurricane warningers.

(e) Colli-wave watringes.

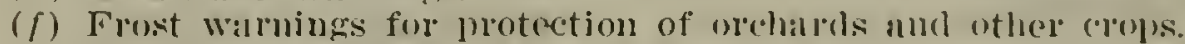

(y) Frut spray and halrest weather achires.

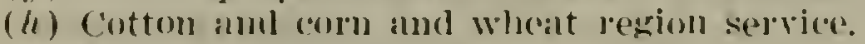

(i) Cinttle propion somicers.

(j) Weekly weather and cropl bulletin.

(li) Fire weather waning for portection of forests.

(l) Realrell and investigntions.

The foregroing services are briefly descoribed in what follows:

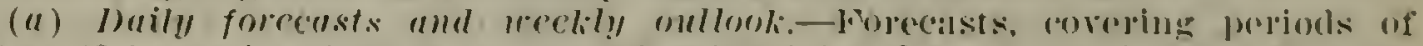

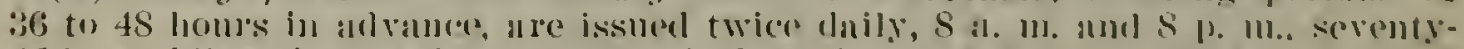

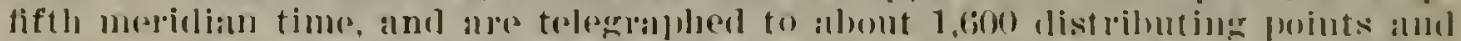

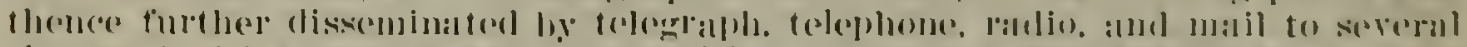

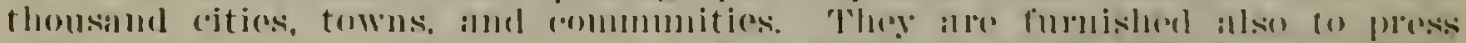

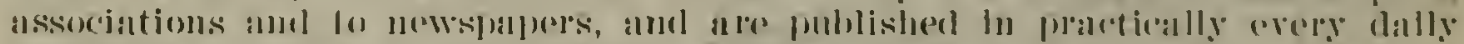

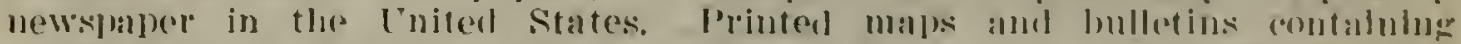

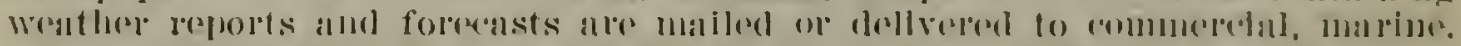

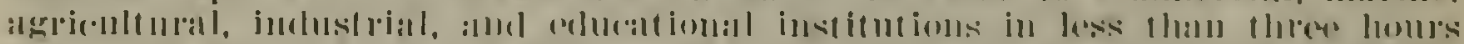

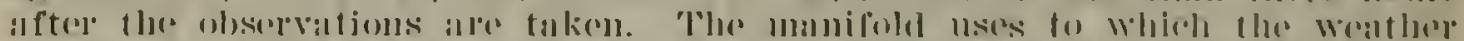

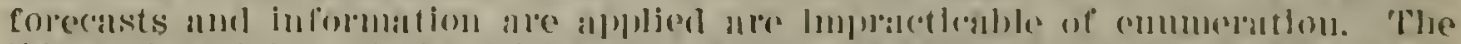

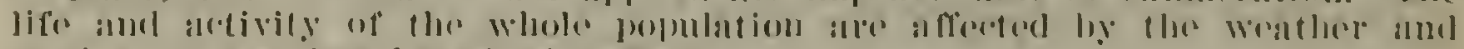

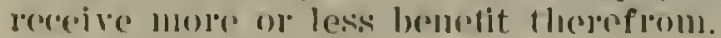

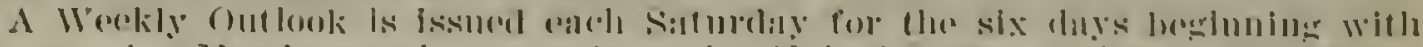

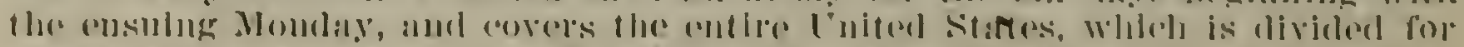

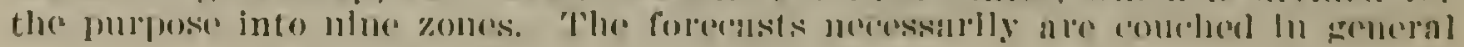




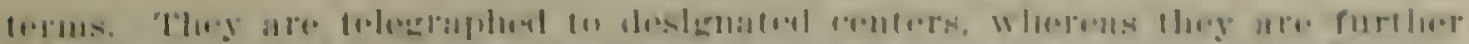

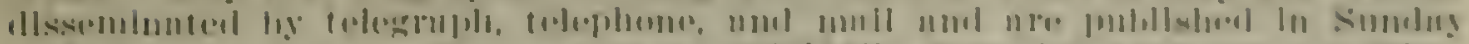

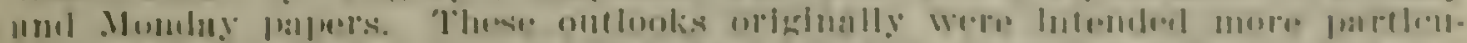

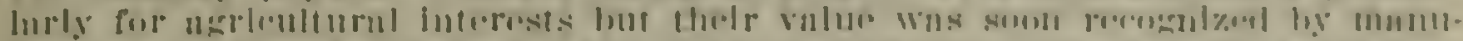

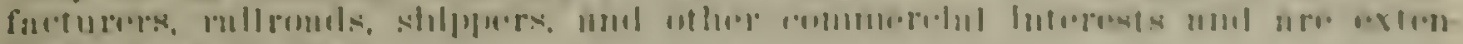

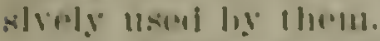

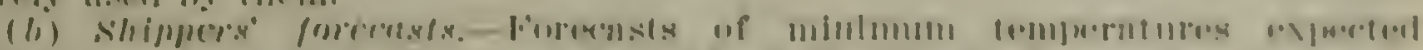

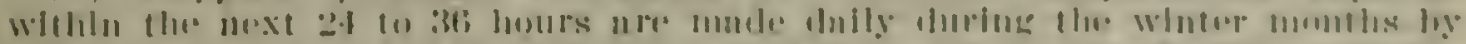

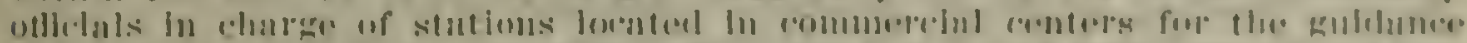

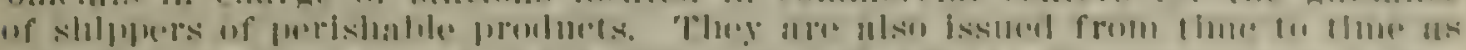

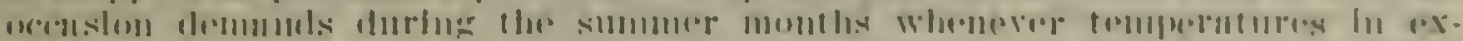

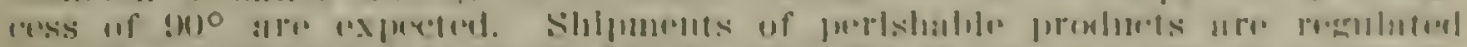

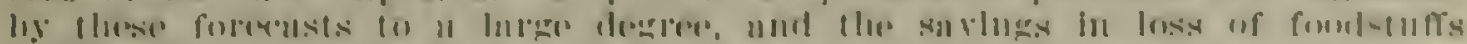

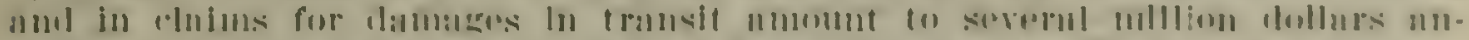

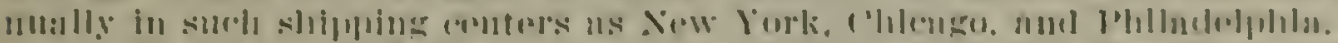

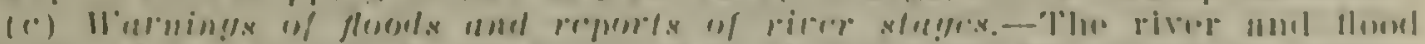

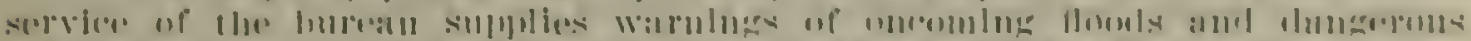
l

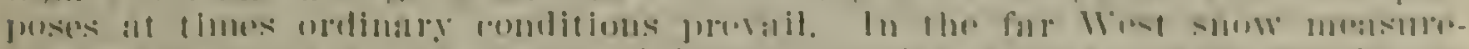

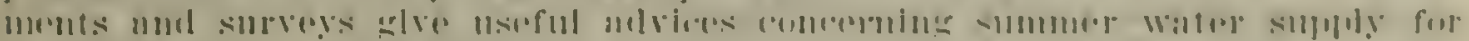

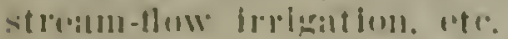

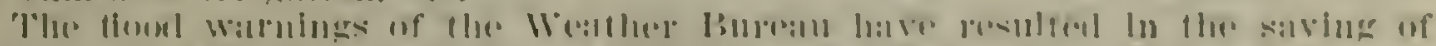

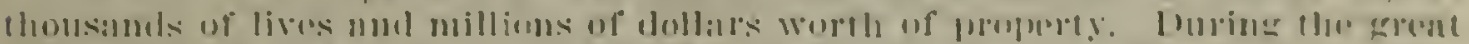

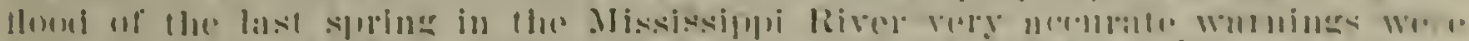

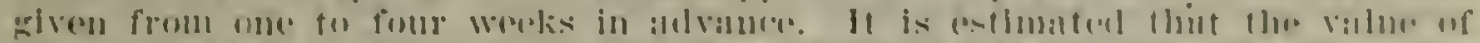

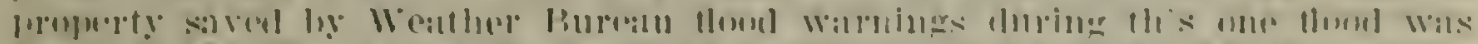

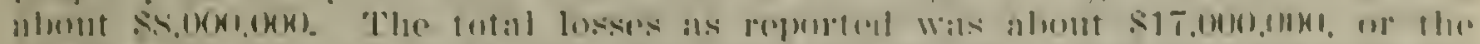

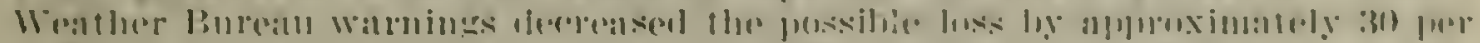
('P')

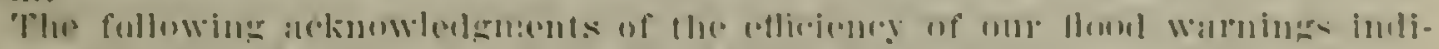

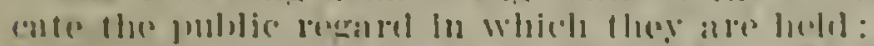

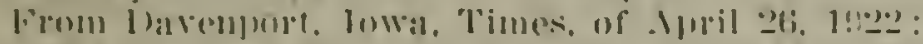

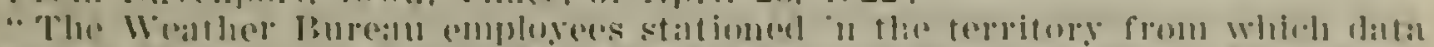

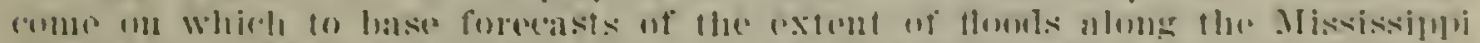

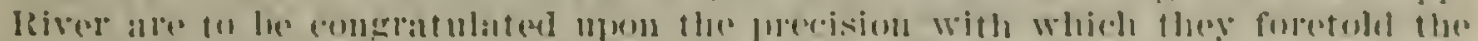

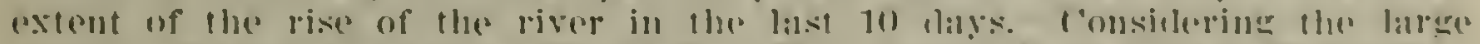

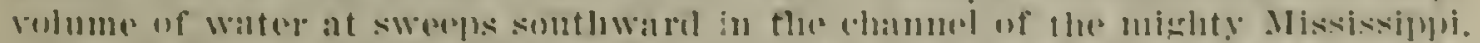

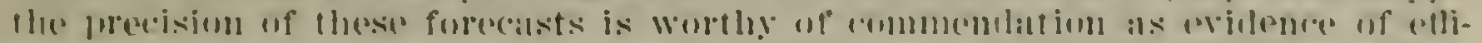

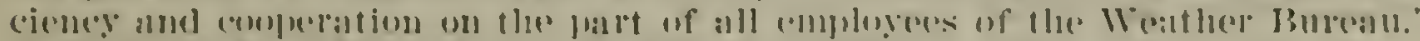

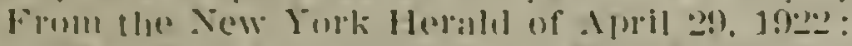

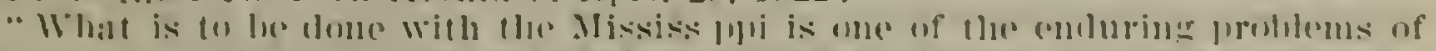

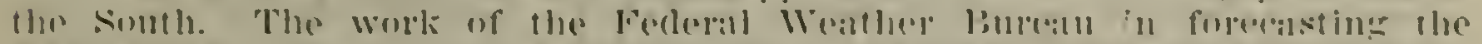

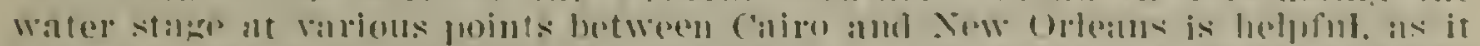

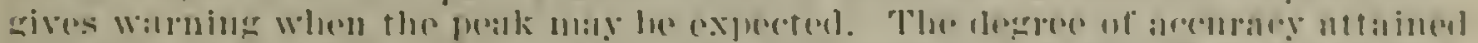

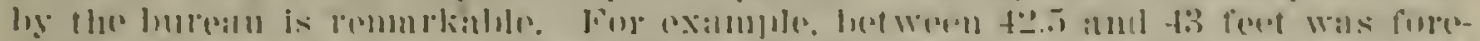

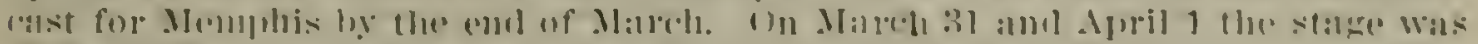
$4: 6$ feret."

fomm I1. M. (

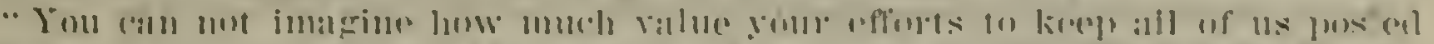
rebatise (1) risere (0)

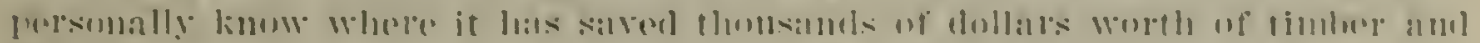
sturk."

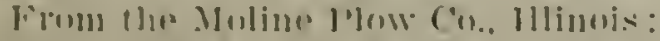

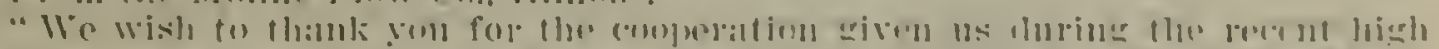

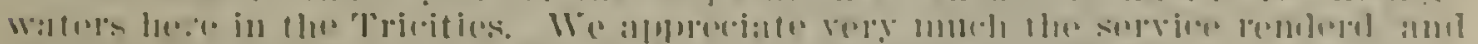

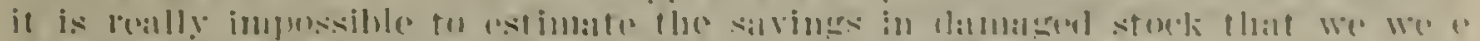

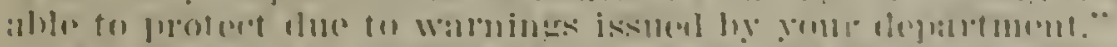

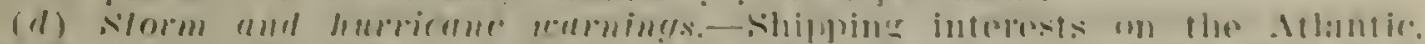

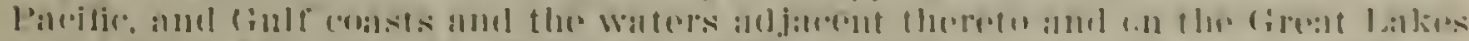

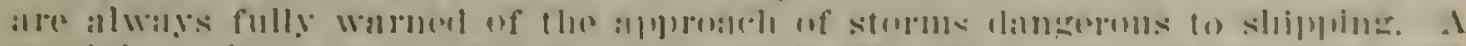

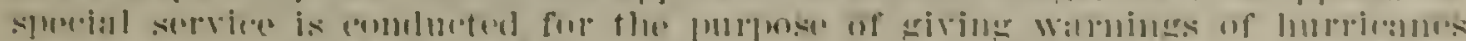

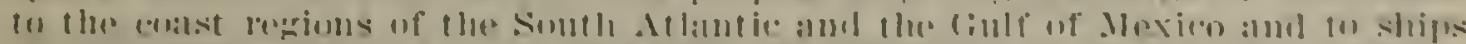
in aljatent walters ant in the (')

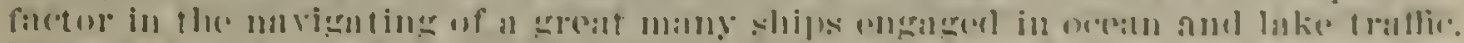

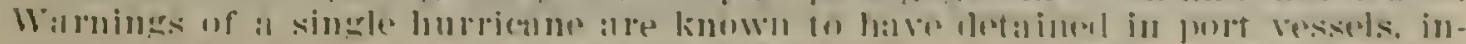

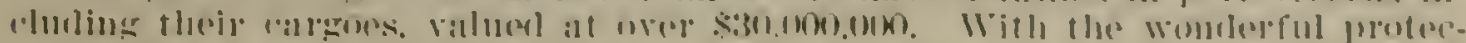

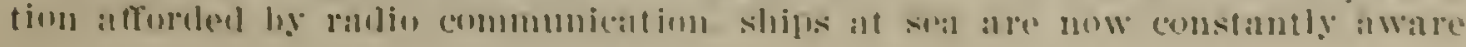


of storm conditions before then, and many instances lilie the letter from the stambarl Oil Co. can be citerl of the great economile benctits resulting from the dumicane warning service of the burean.

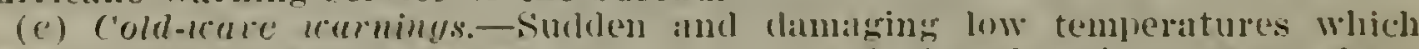

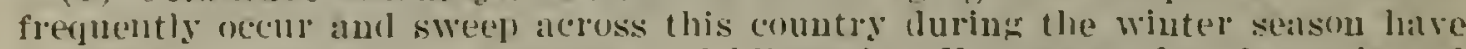
acruired the name of cold wal res and hlizzards. Furecasts of such are issued from 24 to 36 homrs in aldvance and are disseminated throughout the threatened

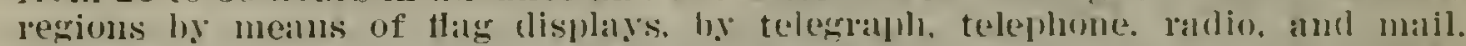
'These wannings are raluable especially to lailroills in the making up of trains and in the maintenance of schedules, to shiplers of perisholhe goods, puhlic utilities, stock rasers. citrus fruit growers, florists. and other immumerable business interests.

(f) lrost uamings for motertion of archards and other crops. - Whenever conclitions indicate the ocenrence of damaging frosts, detailen and specific walluings and alvices are disseminated hy the bureau to all localities affected, where growers are prepared to protect their colss by the varions means in vogue. In many instances industries would be too liakaldous to be profitalyle without the Weather Burean warnings. This is true especially of early trucking in the South Atlantic and Gulf States and of citrus frut production in sections of the Pacitic coast. This work has become so important in the latter districts that a trained meteorologist is assigned for a few woeks to certain localities during the elanger seison to give walnings of the minimum temperature during the night and advise as to the extent protective measures must he taken. The frost waruings also serve for the protection of sugar cane. alfalfar seed crolss. home garulens, tlower berls, etc. Alfalfa seerls are rery susceptible to clamage. and frosts are frequent aloout the time the corop is matming. It is estimated that the crop increases in value at the rate of alout sa. an acre each 24 hours during the barvesting period; if cut toro early. much loss is sustained, but heavier losses may occur from frost if not cut soon anough. The growers depend on the Weather Buratu in keeping them andsed and rigorously pusli harvesting operations when a waming is recoiren.

In the eflicient prosecution of the fruit frost work extensive temperature

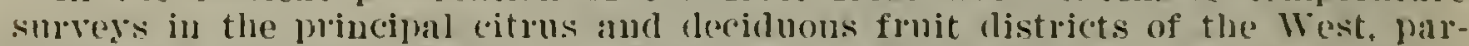

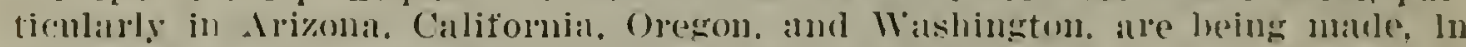
rooleration with organizations of fruit growers. as an aid in frost protection. Serere freezes occurred in the citrus districts of sontledn Callifornia during the winter of 1921-22.2. Which resulted in sreat loss to fruit wrowers, lut damuge would have been much greater hat it not heen for the special service rendered loy the Wrather Burean.

In regions where frost protective methods have been most fully derenoped and where growers are hest or ganized to profit hy the Weather Bureatu service. the work is leehl in very ligh esteens. and local organizations not only write

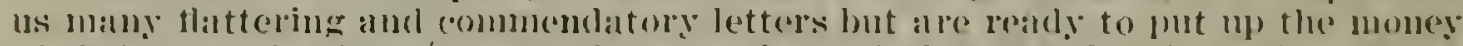

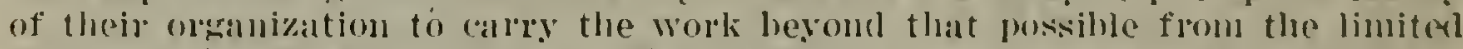
fintes of the Woather Burean. For eximile. the fruit growers of southern C'alifornia, wishing a more axtensive temperature survey and frost service during the prexent winter than the avalable funcls of the lomean permit lave matles a sum in excess of $\$ S .000$ avalable for cooperative work with the lureals, which in fact mole than equals the expenditures in the sims lowaty from (iovermment funcls.

To remove any lloulit as to the reill ecomomine hemetits of the fruit frost

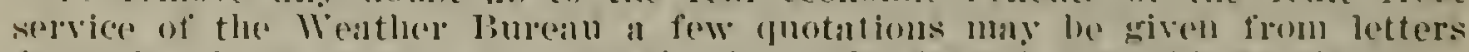

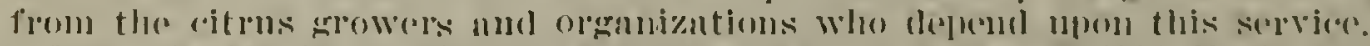

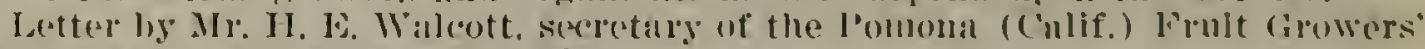

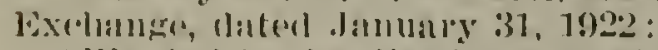

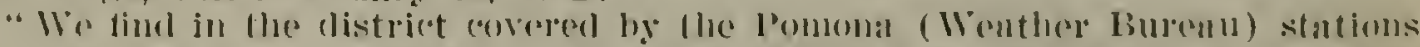

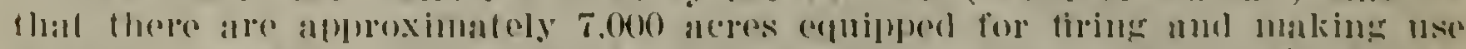

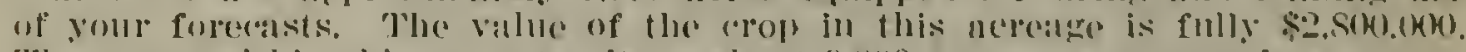

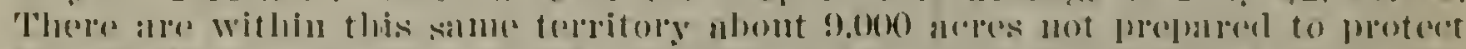

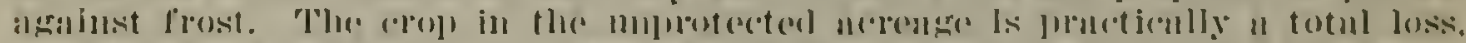

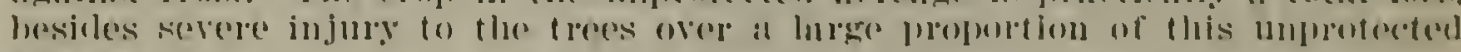
alcipalige.

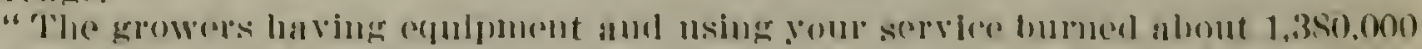

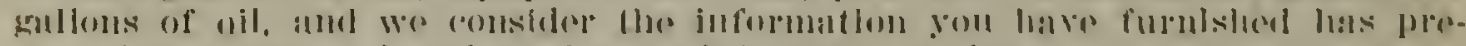

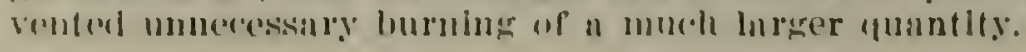




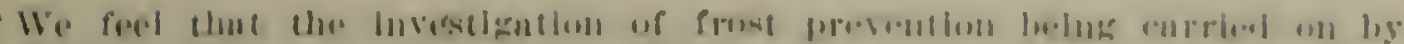

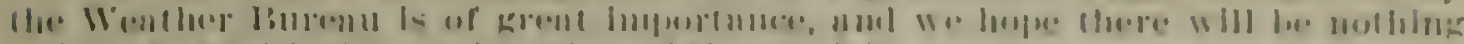

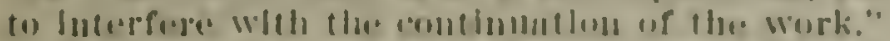

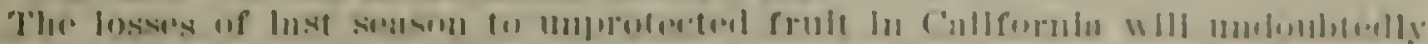

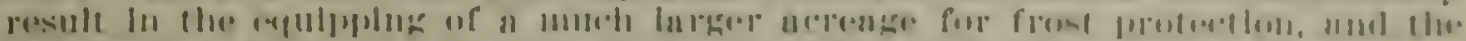

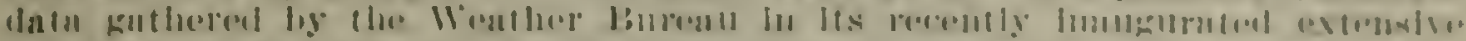

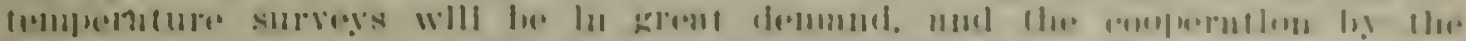

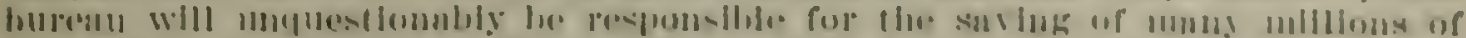

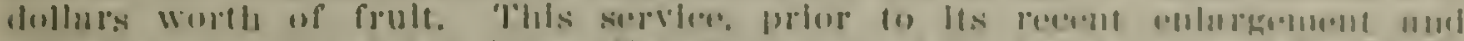

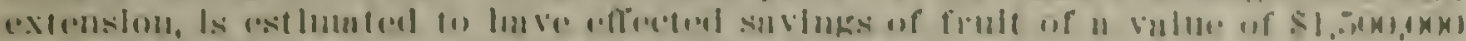

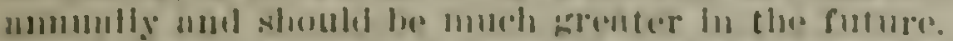

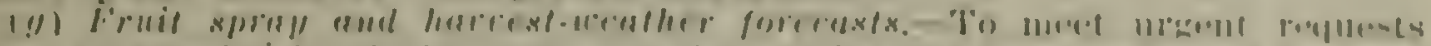

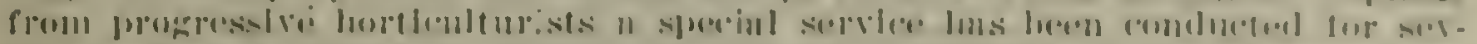
(0)

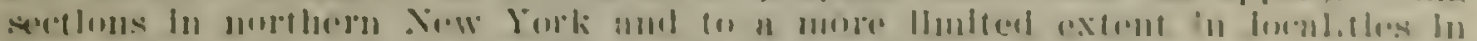

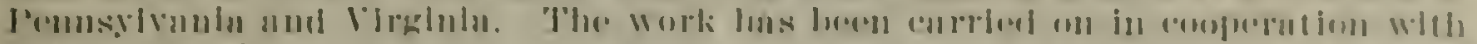

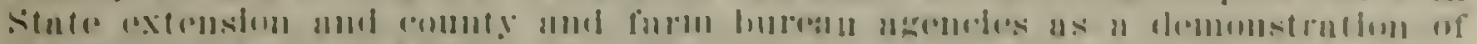

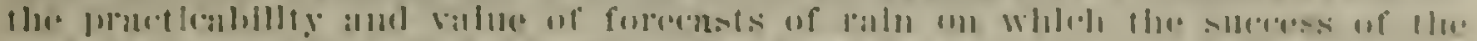

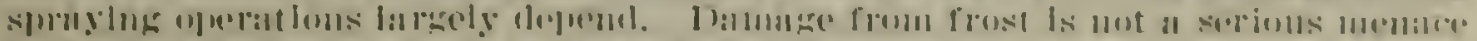

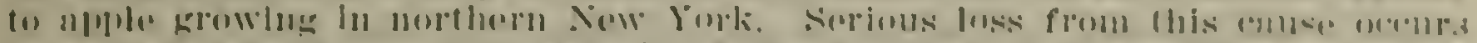

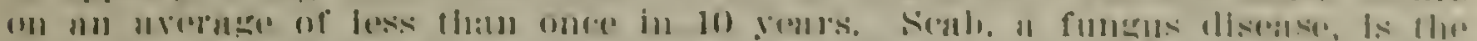

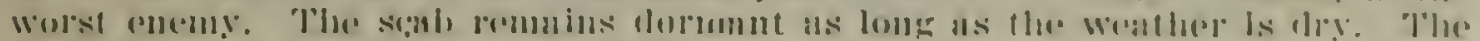

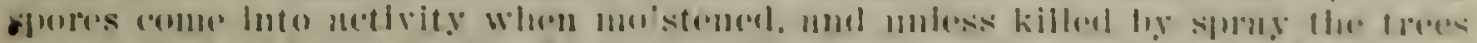

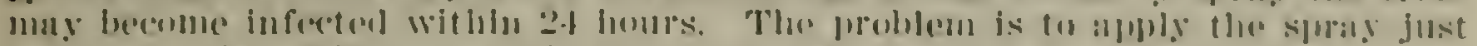

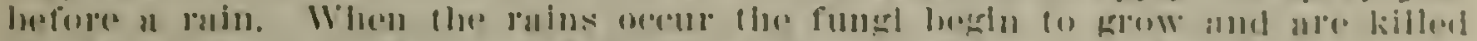

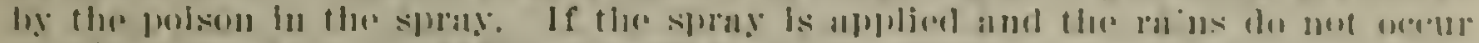

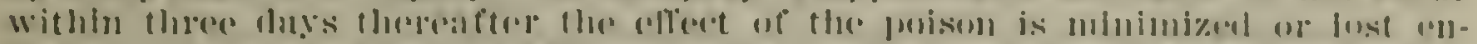

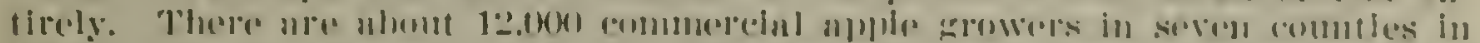

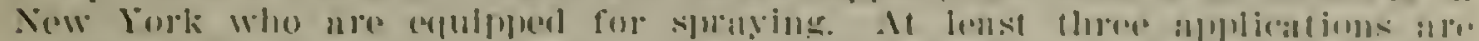

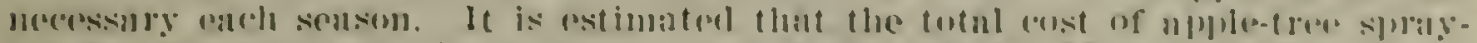

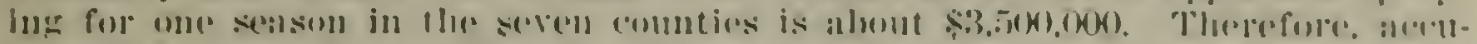

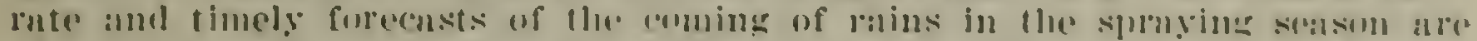

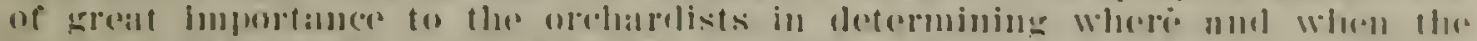

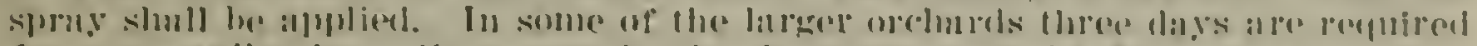

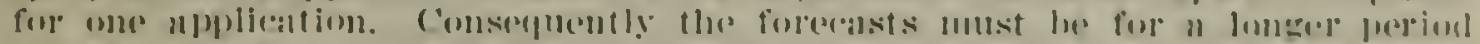

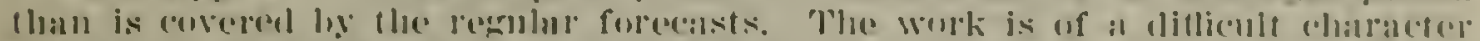

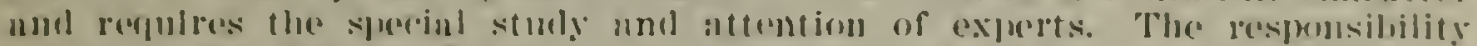

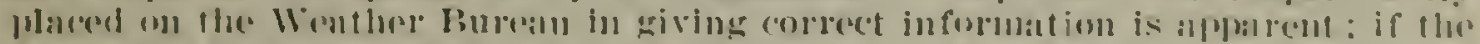

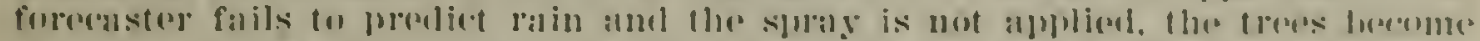

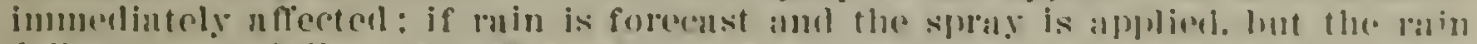

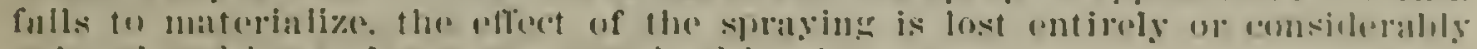

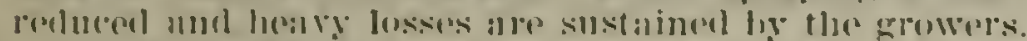

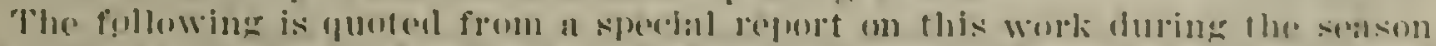

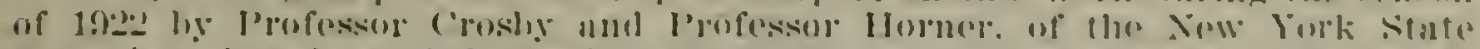

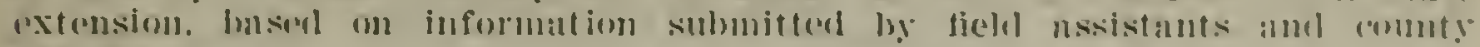
agents:

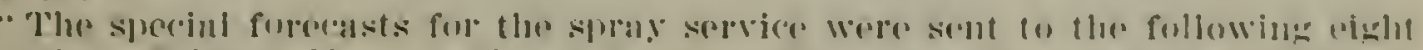

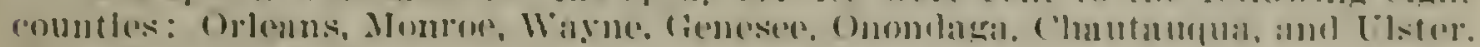

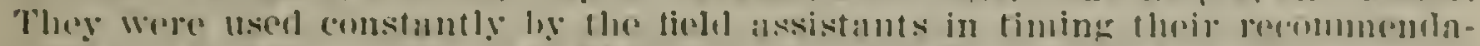
tous foj splyas. In the (a)

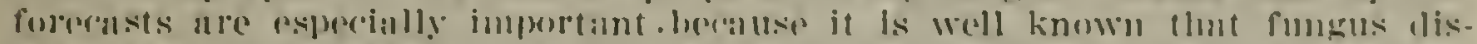

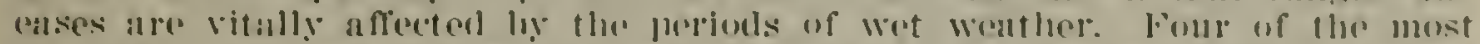

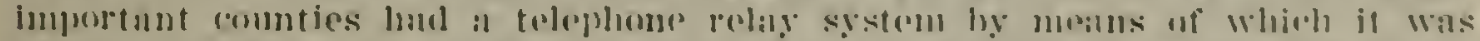

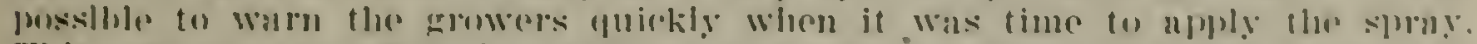

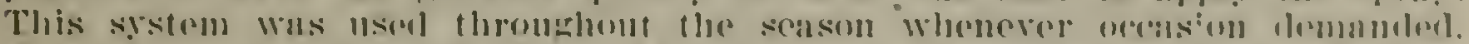

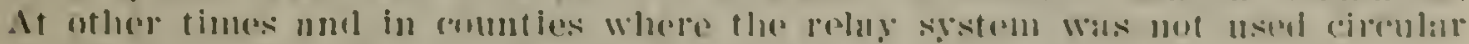

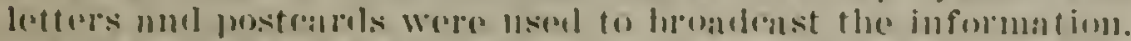

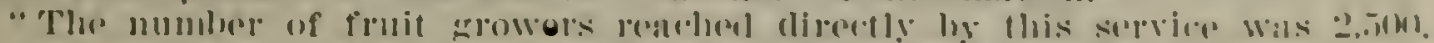

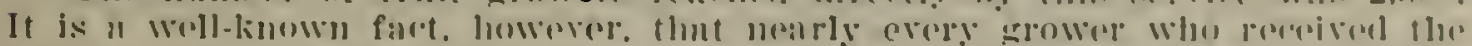

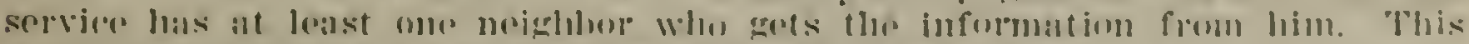

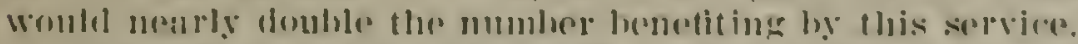

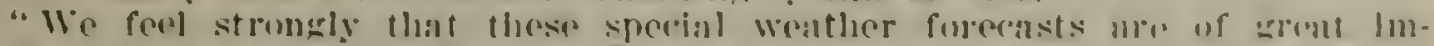

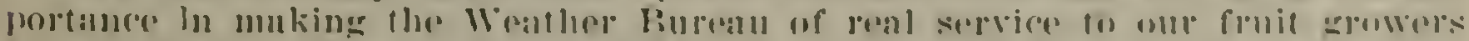

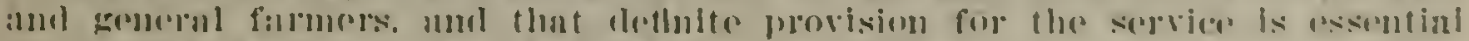
for setting the full vilue out of the lionther Burean." 
A sorue for llue special bemefit of farmers in the barresting of hay, wheat, and other crops is ronduetel in vew York state. "This work also is of a tentative and ex]erimental charalcter. and its.levelopment in Pew York and its

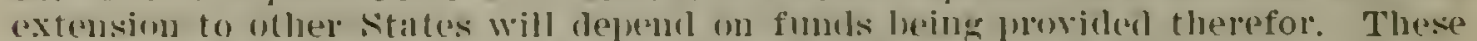
forerasts ale issued for the guidance of falmer's in lialvesting of erops liable to dlamage or loss if unfaromble weatlese ocems between the time of cutting and shocking. The predictions are not for a tixed perionl. as is the case with the general daily forerasts, hut for just as long a perion as the forecaster feels

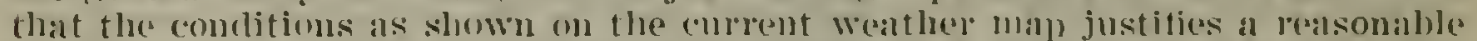
expectation of acrorales. Sometimes this perion is only for 24 hours and at others three or fomr days. Fhe progmestications are worled to apply to the

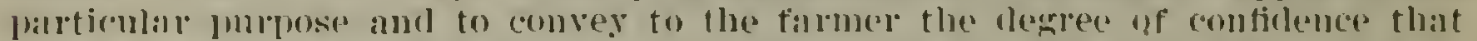

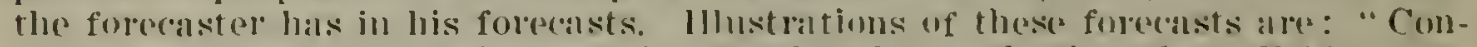

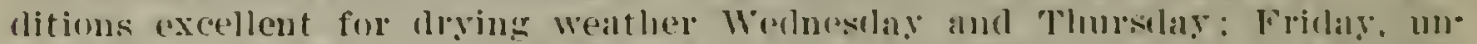

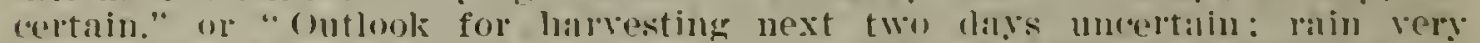

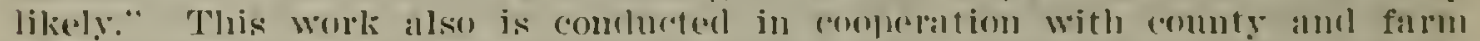
lurean agents. Who disseminate the forecasts by telephone to the indivilual farmers.

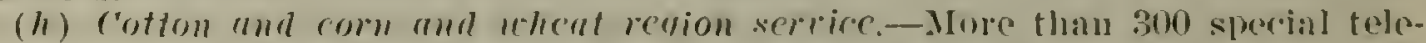
graphic stations are mantaned in the principal rom and wheat and cotton erowing states for the rollection and disemination, in the form of lailg lul-

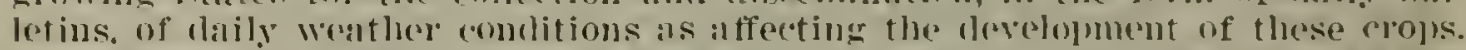
'The information is given wide distribution. the anmul value to the public being estimated at about $\$ 3,325,000$.

(i) Cuttle regfirm scrvice.-Weokly reports ale rollected and disseminaterl. showing the effect of weather conditions on runges and live stock orep the

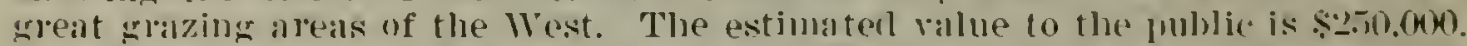

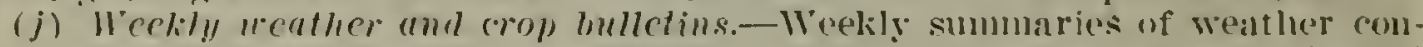
ditions and their effect on growing coloss and farming operations alle collected at the contral oflice and mulished in the dejaltment publication, Weather.

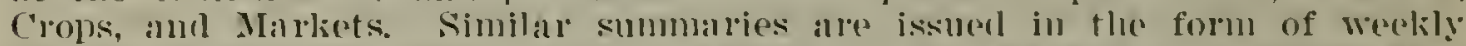
mulletins at Clicugo, coreping the principal com and what region. and at Few Orleans for the ('otton Belt. hoth issued only during the growing season. In ablition, weekly summaries are issued at the section center" of ealch state. "The estinated value of this service to the public is $\$ 1.500 .000$.

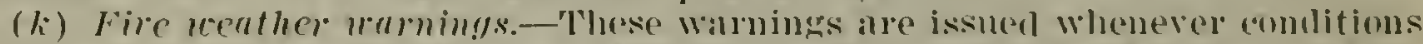
inclicate hot. dry winds which are farorable to the inception and sporad of tires in national forests and other forested regions. They are distributorl prindipally.

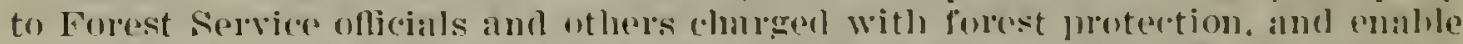
them to assmble crews and apparatus realy for action. The Forest sorvice. fire waldons, and Forestry Association testify to the great value of these walluilugs.

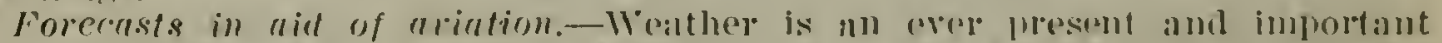
factor in successful navigation of the air. A lonwledge of existing wather

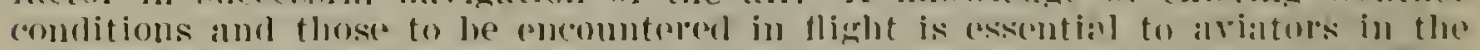

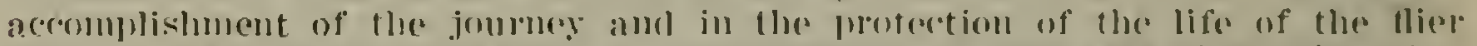

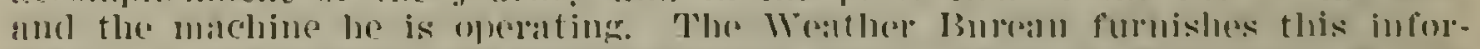

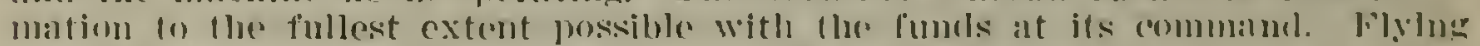

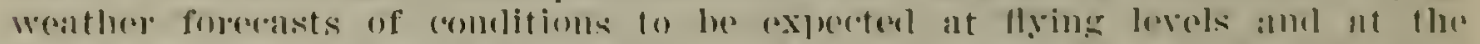

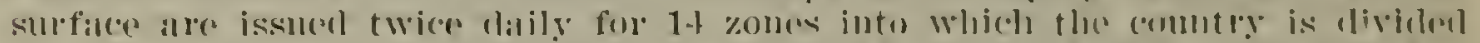

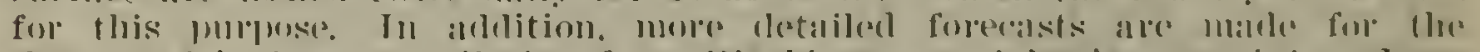

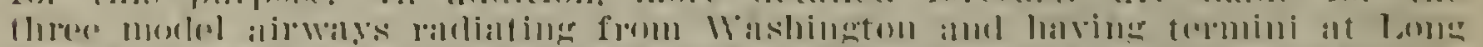

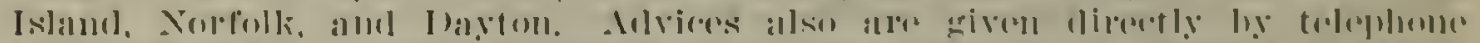

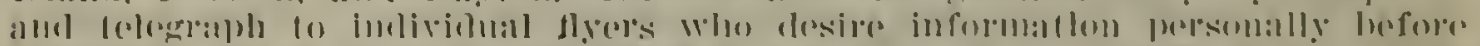

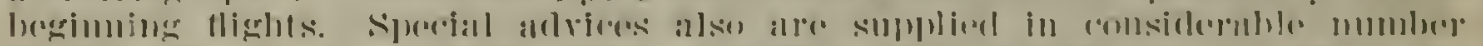

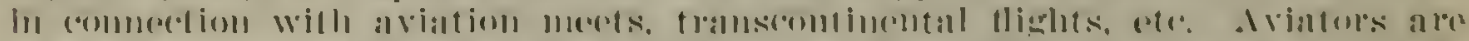

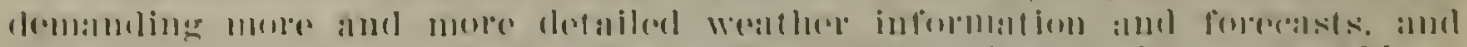

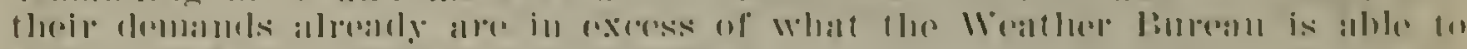

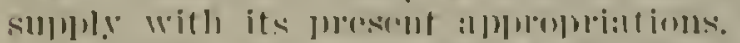

Tle

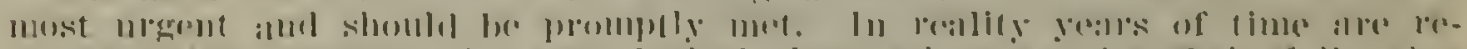

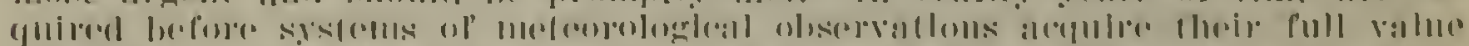

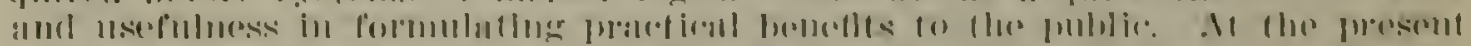

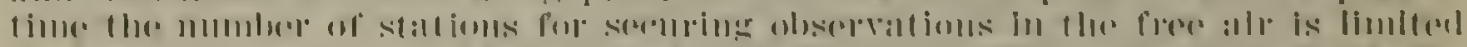

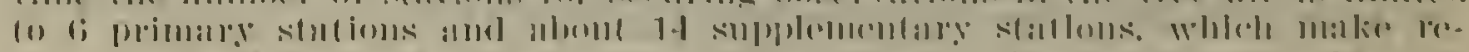

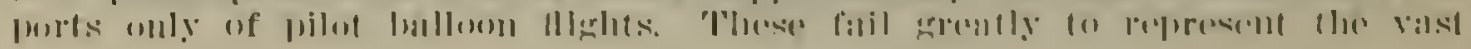




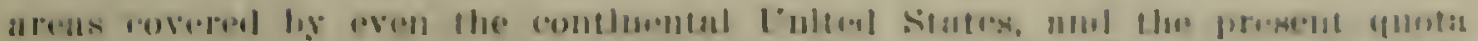

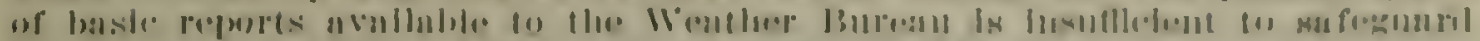

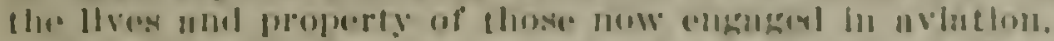

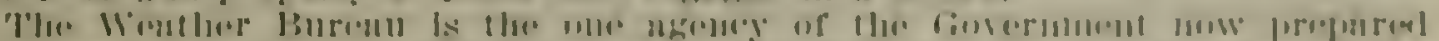

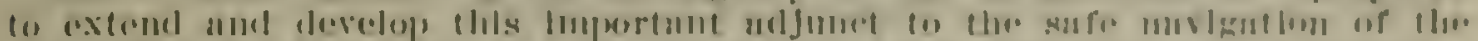

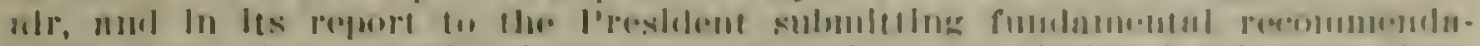

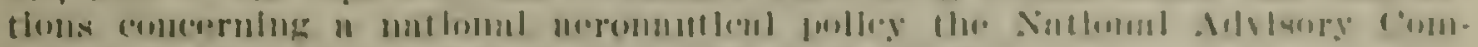

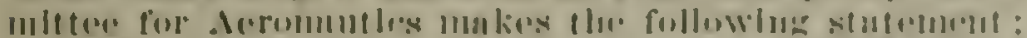

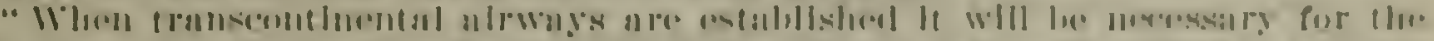

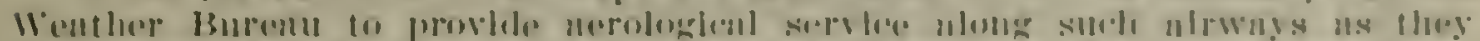

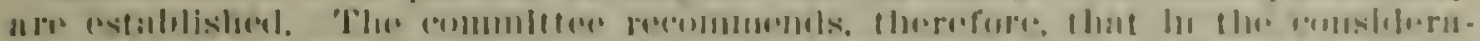
then of

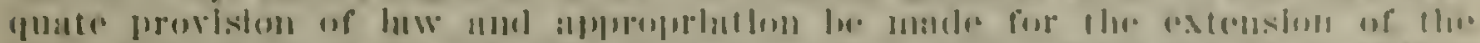

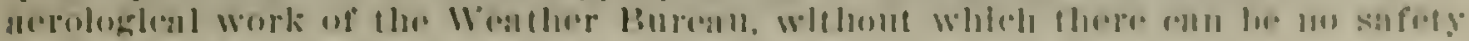

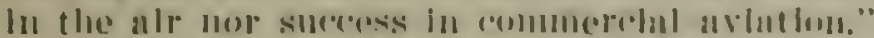

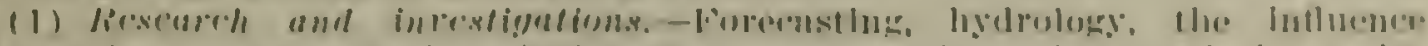

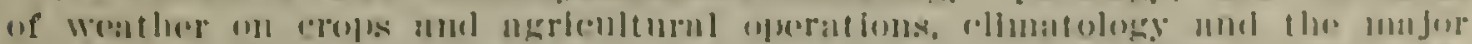

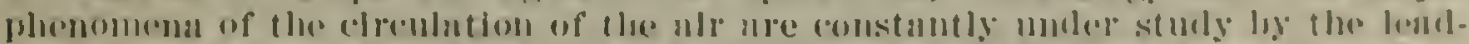

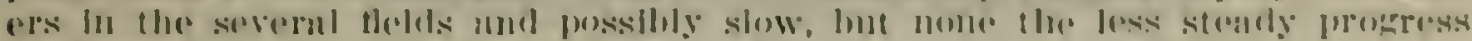

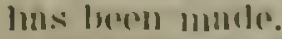

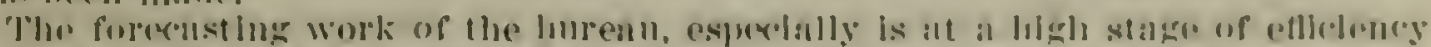

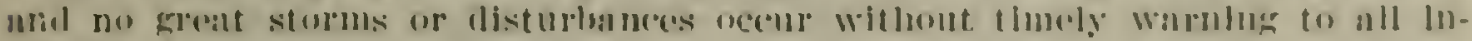

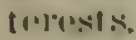

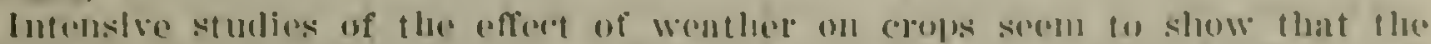

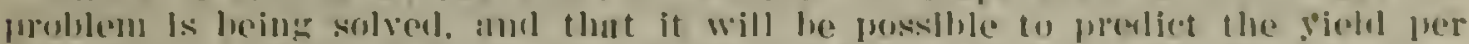

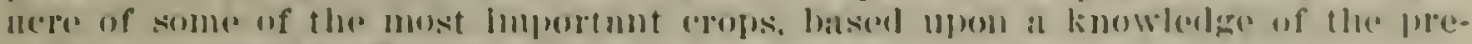
valling weather ronditions.

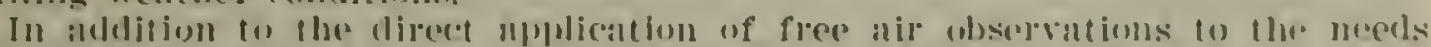

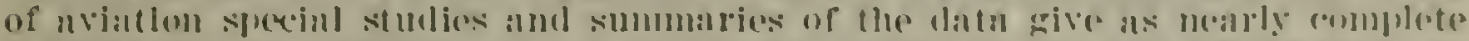

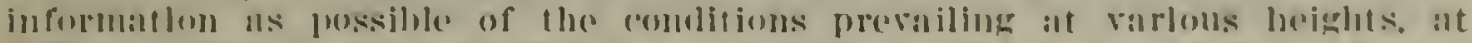

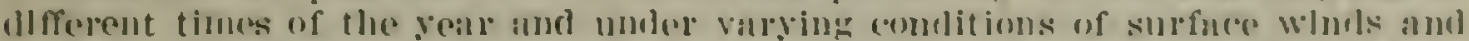

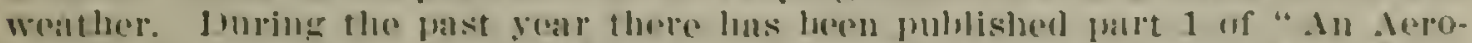

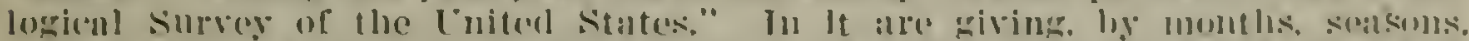

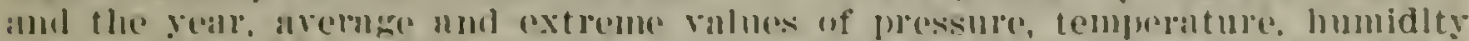
and whol for all bals of the (1)

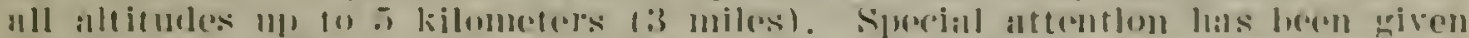
to winds, and these hate leon rolssitiel accorling to surface dirertions ant

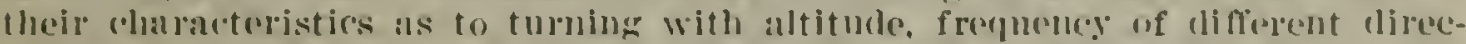

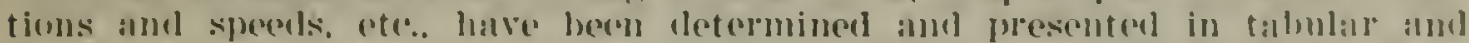

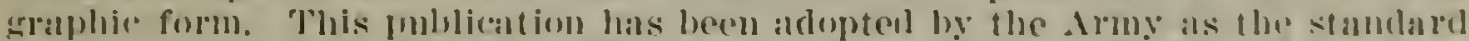

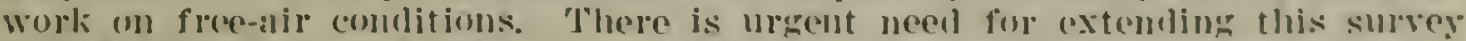

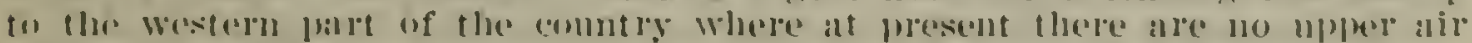
olservine stations.

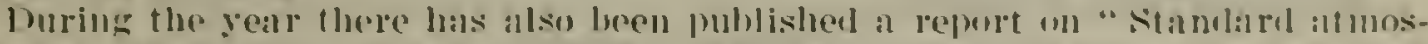

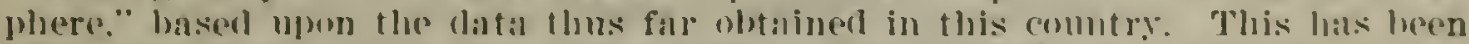

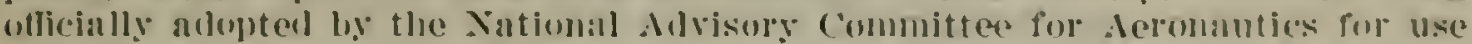
in nirejuft tests. It folms the lasis also for a levision of taloles uf hallistic

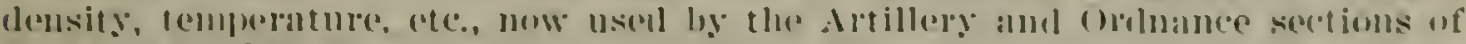
the Army and Navy.

A study of nll aviable data has been mate during the past two or throw

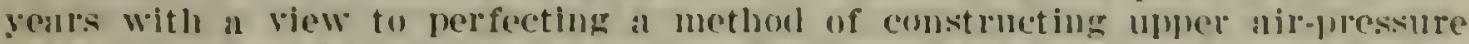
maps. This stuly has progressed to the extent that it is mus possible to

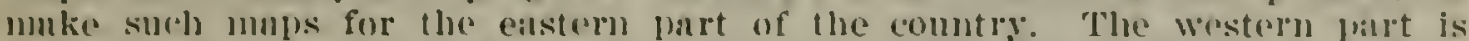
still mexplorol. In so for as the maps are roliable they will be of lletinite vilue not only in forecusting for avintim but ulso in merlicting lhe lipection

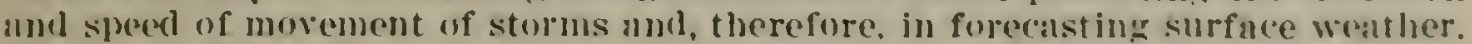

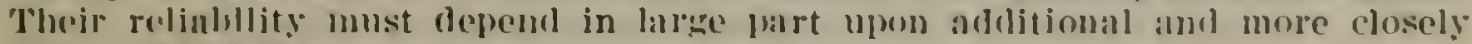
distributed clata.

\section{S.MLIlillis.}

Mr. Marix. 'The statutory roll appears on page no change in approprintion whatever. There is at change of title down about the middle of the page where one skilled mechanic has been added in lien of an electrician formerly carried in the appro- 
priation at $\$ 1,200$. which place has been dropped. The mechanic was appointed with the consent of the Civil Service Commission pending approval of this change in title.

Mr. Axdrisos. What becomes of that man?

Mr. Manix. What has happened is this: A mechanic was appointed to fill the vacincy of the electrician. He was appointed to a vacancy in the current year.

Mr. Ainfrsos. You do not have an electrician as such?

Mr. Manvis. No, sir. There is no change in the language or amount of appropriations until you come to the bottom of page 39 .

Mr. Axpersox. Necessary expenses in the city of $W^{\prime}$ ashington. etc.?

GENERAL, FXI'ENSE.

EXPEXSES IN THE CITY OF WASHINGTOX.

Mr. Marvis. There is a change there, an increase amounting to $\$ 3.000$. That is one the Director' of the Budget authorized in the estimate and is intended to cover the purchase of additional instruments and equipment. The have a stock of instruments and supplies and equipment over the country valued at over $\$ 500.000$. 'The cost of instruments has gone up rery much within the last few years, and we have been maintaining these supplies at the bureau for different stations by making a great many repairs and alterations and remodeling old instruments at the bureau. In some cases we are haring the work done ontside. This material is worn out and no longer calpable of being worked over. An increase for the purchase of new supplies was asked, and $\$ 3.000$ was granted. That is the only thing in the "In W"ashington "appropriation.

Mr. Axurnsox. May I ask you one question! The language indicates that that particular item relates entirely to expenditures in the city of Washington. Is that correct?

Mr. Manvis. Yes, sir.

Mr. Axmbrsox. This is separate from your field work?

Mr. Marmin. Yes, sir.

PRINTING OFFICE.

Mr. Animerson. All right.

Mr. Mammx. The item for printing is for the printing office in the city of $\mathrm{W}$ ashington. That is a little plant we have at the bureau for printing the inaps and other publications which can not be published at the Government Printingr Office without too grreat delay.

Mr. Axibersox. All right.

Mr. Manvix. The joint committee has investigated that very thoronghly and approved of it.

\section{HAPRALS OUTSIDE CITY OF W.ISHIXITYS.}

The next item is for expenses outsicle the dity of Washington. and carries an increase of $\$ 5,(000$. I have prepared a chart here which I would like you to look over. Under this field appropriation relat ing to the work of the hurean in forecasting the weather, ote.. we have been carrying a personnel of four or five humdred, and becanse 


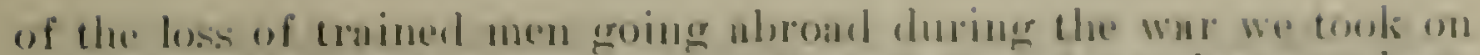
more men then than custommery hut the number of men has mow heen rerherent to the pro-war level.

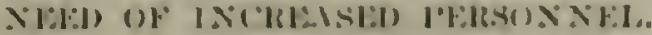

With the errowth of the Nation, the work we nre performing have-

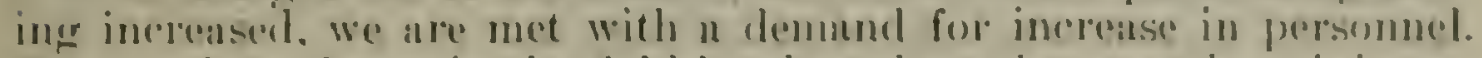
'The mumber of men in the lield has heen kept down to the minimum because of the nexessity of kerping the salary amount within the appropriation, and we are also eompetled to keep the mumber down in order to mantain un appronch to fair sularies. The Director

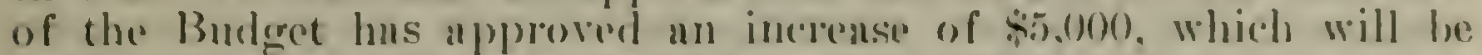
used in increasing the number of personnel in the field.

Mr. Bromaxas. Is there any increase of salury in it?

Mr. M.nivis. No, sir. It is an increase in the mumber of men.

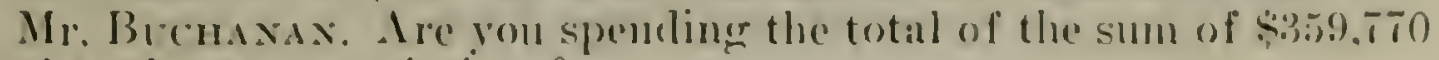
in the other appropriations?

Mr. M.nivis. The fignres you cite have reference to the fumds for statutory salaries carried in the estimates for 192:3. All of that money is never fully expenderl. Unexpenderl amounts arise from leare without pay. lipses hetween termination of alpoointments and filling of vacancies. amd places permanenty meflled, which oreasionally arise. Duringe war times, when it was rery difleoult to keep plate's filled. amounts of $\$ 5.5000$ and $\$ 20.000$ have been turned hark into the Treasury. More than se3.000 rent back in 1922. In the case of this particular appropriation for ont of Washington expenses.

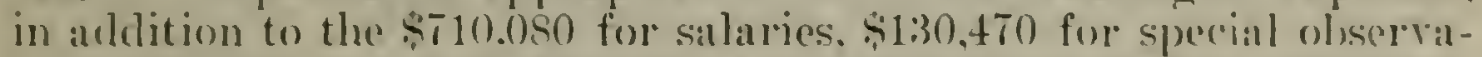
tions and reports. and sogestion for telegraphing aml tolephuning. there is a halance in the appropriation which provinles for miscellancous expenditures that is not stated in amomnt, and that hatance is inaleguate for the purchase of supplies, payment of rentals, and expenses not itemized in the appropriation. We make up the diflerence ont of the surplus in these other funds. The final unexpencled balance at the end of the year goes back into the Treasury.

Mr. Burmax. Is that a consiclerahle amomt?

Mr. Mamix. Last year we had a Budget reserve set up which practically set aside in our case a total of $\$ 26.000$ and that was exceederl by other mexpended margins that went back into the Treasury. But it meant in those cases withlolding the doing of things. Part of that. for example. was withholding inspection of stations in the field. We curtailed the traveling expenses to the minimum. We curtailed the maintenance and repair and painting of buildiners, which we own and which need repair. We put repairs off for a year. Wherever we conld save anything last year the program was to save it, but in a number of cases the necessity for expenditure calries over into this year. Some service was cut ont.

There is always a little uncertainty as to the expencliture for telegraphic communications, bedause of emergencies arising from umisual storms, etc.

Mr. Axmetsox. How many field stations are you mantaining now? 
Mr. Mamix. Te have practically 200 stations, maybe a few more. That is, regular quarters which ire owned or rented by the Government and manned by commissioned employees: but we get many reports from other sources than the regular stations.

Mr. Axnensox. Page 44, next item. for investigations, obserrations, and reports, forecasts, warnings, and advices for the protection of horticultural interests from frost clamage. 'That appears to have been eliminated. The amount is \$12,000.

FIOST WARNING INVESTIGATIONS.

Mr. Marvis. That is an item which has been omitted to effect economy in Government expenditures. If you desire. we are prepared to show you some features of the work we did with that money last year. Mr. Snith, who has charge of that work. has a few photographs.

PHOTOGRAPHIC ILLLSTIRATIONS.

Mr. Axdenson. Will you tell the committee about these photographs?

Mr. Surtr. Taking them up in their order. No. 1 was taken February 16, 1922. It shows lemon trees in a large grove near Whittier. Calif., being remored becanse of damage by frosts of January 19-26, 1922. Some cracks in trunks and large branches of trees can be seen in the photograph.

Mr. Ardinson. Could that have been prevented?

Mr. Sartu. This question is answered by photouraph No. 3, which shows a navel orange grove, near Riverside. (alif., indicating the excellent condition of trees and fruit which were protected with 407 -gallon high stack oil heaters to the acre. The entire crop of oranges from this orchard was graded "Sunkist," a grade which must show practically no frost damage.

No. 5 indicates the damage done directly across the road from the grove shown in No. 3. Practically the entire crop is on the ground and all fruit shows frost injury. That orchard was not protected.

No. T. Date, January 26, 1922: View in orange grove near Pomona, Calif. Only outside fruit. on outside, or border rows. or trees. show any damage from frost. Trees protected with 50 tall-stack heaters, 5 to 9 gallon capacity, to the acre. Temperature at check station was $18^{\circ}$ for one hour on one cold night. Fruit graded t.5 per cent loss by freezing in portion of grove where temperature records were kept. 'The work of firing the heaters was very poorly done, and there is no donbt there would have been no damage whatever if the work hat been efficiently carried on.

No. 8. Date, Jamurary 26, 1922: Yiew in same urove as No, T. showing excellent condition of trees after freez. Burning reservoir of heaters is of cast iron; 9-anllon capacity nllows long burning time, which is an important point in such cold periods as cluring the winter of 1921-22. When dangerous temperatures continued for 12 hours and even longer.

Nos. 10 and 11 show the diflerence between heated and unheate.l groves. No. 10 shows clusters of ormuge hlossoms. fresh and unin- 


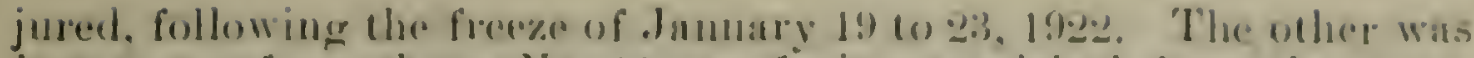

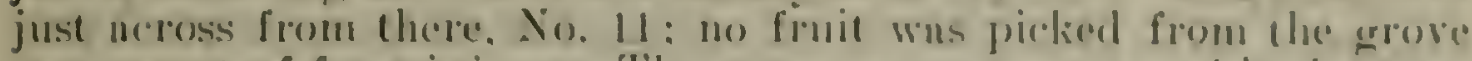
on aceount of frost injury. The grose was not protered by henters.

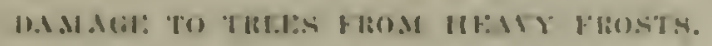

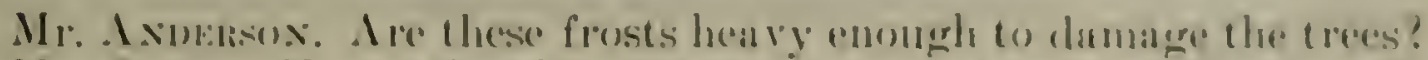

Mr. Surn. Not ordinurily, but erery fow years hard freeges will destroy a whole growo of trees. However, the majority of times they only iamage the fruit.

太̌o. 2.2 shows a great deal of frost damagere. Many humbleds of acres of oranges were in this condition. No. 2.t showis the effect of free\%.

Nos. 26 and 27 show the oranges damaged near Ontario. Calif. The team at the left in dumping a fresh lond. This cull frot is from a relatively small percentage of groves in this section where any picling whatever was done. In most of the groves no fruit was pieked, as an examination showed the loss at 100 per cent.

Mr. Axmbisox. 'This pieture. I tule it, means the fruit that was spoiled ont of that picked from the trees?

Mr. Surtı. No. They gathered it off the gromend and hanled it ofl. becanse they dirl not want to leave it on the gromul for the effect it would have upon the soil.

Tos. 31 and 32: No. 31 shows the slitting of bark becanse of the frost damage, and 322 is a grove across the roal close to the other where it was protected by heater's and was in crool condition.

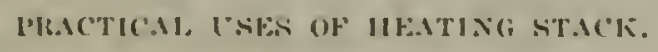

Mr. Brensax. This is not the heating stack up there, is it?

Mr. Sump. les. Those photographs show conchusively that heating is practical and will sare the fruit, and the ralue of the Weather Burean's work comes in in temperature surveys which can be made. showing the grood that heating can do under these conditions.

Mr. Axurkox. How much territory can you cover with \$12.000?

Mr. Surtr. Do you mean in acreage or heating?

Mr. Axmlasox. I mean in your general way. How expensive is the protection you would get?

AMOTNT OF THMITOKY CONER:

Mr. Santr. In the particular territory last year there was something like 7.000 acres equipped and protected with heaters. Something like 9,000 were not equipped. Of course, all those that were equipped with heaters got the warning from the Weather Burean. We had in there last year three special fiekl agents, who had special instruments for surveying temperature and who were ahle to alvise the growers, and we only hat $\$ 9.000$ appropriated last year. In adelition to those three men there. they went np to Oregion and $1 V_{\text {ins }}$ ington in the spring season, and we had sereral others in smatler sections of the comtry. I do not have in mind how much money was spent in Califormia to cover those 7.000 acres, but it was not any consiclerable part of $\$ 9,000$. 
Mr. Marvix. This $\$ 12,000$ does not cover sufficiently districts in southern California to satisfy the enthusiasm of those people down there, and they are willing to put almost an equal amount to cooperate with us in extending the work to other districts.

Mr. Axmonsox. I suppose these people. when they have these heaters, get the weather report before the frost as well as they can. do they not?

Mr. Marms. Yes, sir.

Mr. Buchasax. Can not they get it without the instrument?

Mr. Marrix. They can get the general forecast. They can not get the minimum-temperate forecast until they have men who are capable of making that survey.

Mr. Axdensox. You say temperature survey. Does that have to be made every year?

Mr. Marvix. It has to be made sufficiently long to study the conditions, and there must be a man on the ground with special training to make minimum-temperature forecasts.

Mr. Buchasax. Each year?

Mr. Marvis. Yes, sir.

Mr. Buchanas. You have made surveys in this section. I presume, in which you have saved the fruit?

Mr. Marvis. Yes, sir; surveys from which minimum-temperature forecasts have resulted in the saving of fruit.

Mr. Bucraxan. Is it required that a man be kept there each year to take the temperature or to gret any information with reference tn those survers already made to tell when the frost is coming?

Mr. Manvis. The forecaster must have a knowledgre of the current temperatures reported from the orchards in order to advise about starting fires.

Mr. Brchaxax. Current temperature each day?

Mr. Manvix. Yes, sir: whether he must be in that office or not is another question.

Mr. Buchaxas. I mean did he have to be in that State or that community to take the current temperature each day?

Mr. Mirms. That is necessary, Mr. Buchanan. The Weather Bureau man must be there to interpret the general information he gets in the form of current temperatures from all the orchards.

Mr. Buchaxax. There is nothing to keep these gentlemen in this fruit business from employing a man and in that way cooperate with you is there?

Mr: Manvix. I feel that would be a very unsucessful method of carrying it ont. You might say a ship company would pay us-

Mr. Buchaxax (interposing). No; suppose he would le moler your men?

Mr. Manvas. He would be molder our men. He womld not he in: close tonch with onr district organization, becanse while these frosts are local in many of their features they are part of a great atmospheric condition orer a large area of the comntry. This man would have to get his local maps from onr reports, eite. 'The orchardists are enthusiastic grep the service which salves a lot of money.

Mr. Axbrason. People are always enthusiastic alont things they gret for nothing. Suppose we grive you this \$12.000 and make its continuance contingent upon contributions by the people frem ont there. do you think they would do so? 


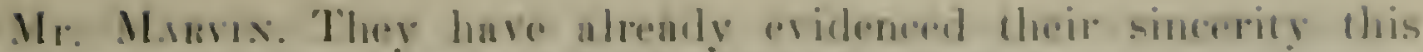
rear ly putting up about half the nomer themsolves.

Mr. Avmenses. Of course I think the renl diflionlty ahent this item is it is a special servere which applies to one indertry and a relatively small proportion of that industry. I have a froding that if an mpproprintion of that kind should lie mule it would not be innppropriate.

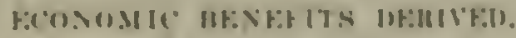

Mr. Monas. I think that is sommel. I want to say, howerer. that the burean was created for this erounmie henedit. "This as youl say is local. It is local for southern California where they are highly orcranized and profit by it. but as the season adrances these men move up into northern Califormia. ()recron, and Waslingtom, where the same work is being conducted. and in Coloralo. We are griving the sane information to truck graden communities of the sonth in Florida, and while it is local in one particular community, we are griving similar or somewhat local sepvice all over the country.

Mr. Bronasas. You are gring general information in the Sonth, as I understand it.

Mr. Manvas. We are grving general information about hurreanes, becouse a hurricane covers a large area-it is general.

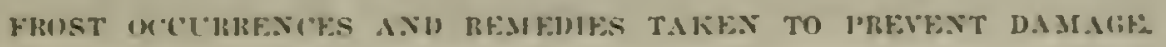

Mr. Buchasax. This is a specific locality. When the frost occurs they had better put out their heaters and prevent the frost damage. You have to take your daily temperatures, and it requires a man on the ground to do that.

Mr. Marrix. "That taking of the daily temperature is done by the orchardists. They furnish us with these local reports. Which aro used. With the telegraplic reports from the 200 stations I spoke of. in order to make the forecasts and minimum-temperatme predictions upon which successful protection depends.

Mr. A.rmassox. Perhaps we have got ton narrow a riew of what these people do. I gather from what you said. and Mr. Buchanan did, too. that these fellows went ont with their thermometers and on the basis of that they malie a forecast. From what you say, they gret these reports from diflerent aleas and other points, and they get that and put them together on a cortain date in order to determine what degree of frost there is groing to be at a certain time.

Mr. Makr.x. The Weather Buratu man eximnines the reports and makes the forecist. not the growers. The Weather Bureau man makes the interpretation.

Mr. Axprasiox. You make numerous preliminary surveys in onder to do that?

Mr. Marrax. We make numerous preliminary survers of local conditions. and it is from the meteorologist s knowledge of atmospher\% conditions that he is able to forecast.

Mr. Axmbisos. How often does that frost oceur?

Mr. Marwa. This rear we had an monsmal vear, as is shown by these photographs. Frost is an annual oecurrence in this regrion. 
I think more or less damage is done every year in the most important fruit districts of the West. Once in seven ol eight years they get a frost damage like this.

Mr. Axperisox. What I am getting at is what period of time, as a rule, do these frosts occur?

Mr. Manvis. In sonthern California in the wintertime, in the frost season, November to February.

Mr. Axpensox. You have to have a man in there, then, during the entire period of time that frosts occur?

Mr. Marrix. Yes, sir: and then up in the northern portions it is later in the season. They go up there about the 1st of March. Let me make one point, that this intensive work is not confined to the region we are talking about. This money is spent partly at some 20 or 25 other points in the United States, only not so extensively as on the Pacific coast. It is spent in California, Arizona, New Mexico. New Jersey, New England, Wisconsin, Illinois, Missouri, Kansas, Washington, and Oregon.

Mr. Buchanan. Is this amount exchusive of the salaries of the men?

Mr. Marvis. No; that is inclusive of salaries.

Mr. BuChanax. Is this $\$ 12,000$ all you ask for instruments?

Mr. Marvis. Not all of it. There are some instruments and some telegraphing that go in it. The fund is for salaries and incidental costs of travel, instruments, and things of that kind that are involved in the work.

\section{OFFICIAL TRAVELING EXPENSES.}

Mr. Axperson. Your next item is on the same page, for official traveling expenses. Is there any change in that?

Mr. Marvis. No, sir. That is for the same amount.

Mr. Axpersox. The next item is on pagre 45, for the mantenance of stations for observing, measuring, and investigating atmospheric phenomena, etc.

FOR MANTENANCF OF STATIONS FOR OBSERVING, MRASTIIXIG, ANB INVTSTIGATING ATMOSPIERIC PHFXOMENA, ETC.

Mr. Marstr. That carries an increase and cover's investigations the bureau makes in the upper-air conditions as distinguished from the service observations about which we have been speaking heretofore. The immediate practical use made of this is for flyingweather forecasting and giving information to aviators.

Mr. Buchaxax. Uppel-air forecasting?

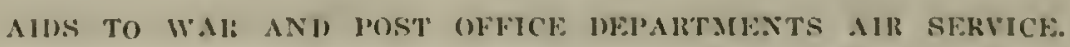

Mr. Mamix. Yes, sir; aerologrienl work, as we anll it. We have been before Congress for some renrs since the war to have the amomnt that we now have for this purpose increased. The ses,ot)(0) included in the Burlget is but a small part of that really noeded to grive us all the information we need concerning upper-air conclitions. and which we should have in order to make a tholongh-gromgr serviee, hut with the $\$ 25,000$ we hope to be able to increase the service 
to the Army and Nary and the Post Office Departanent very materinlly. I have here charts which show the arrays orer which the Whr Depurtment is now opernting from here in New lork, to Lungrley lïield, and to Dayton. ()hio. 'The seromel chare show's the

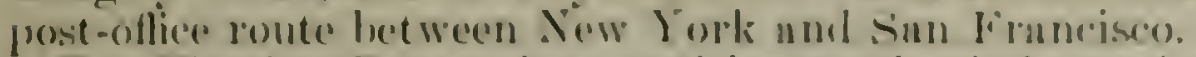

The Wenther Burean is in position to grive information nom alvice us to weather conditions ulong nir routes and is cloing so to the best of its ubility.

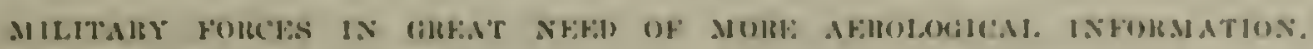

Army people are up flying very much of the time, us you know, and they need more informution than we are able to give them at the Hying stations and at posts at which operations are going on. This increase will enable us to give them additional information.

In a rerent conversution with (ienerul Patrick I was tolliner him what we would be able to do if we could gret more intensive service; that is, to get observation alongr this Lamgrley Field and Bolling Field airwing and to go to New York. I have here an extract from the Bulletin of the Balloon and Aireraft School, Scott Field. Belleville. Ill., for November, 1922. Which illustrates the vilue of our udvices to neronatio's.

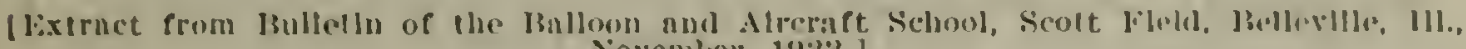
Noventrer, 1 1!2:.]

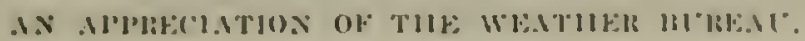

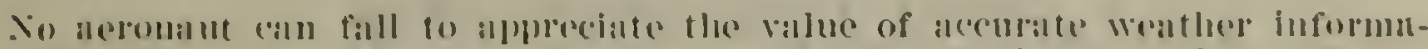

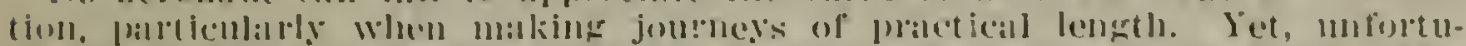

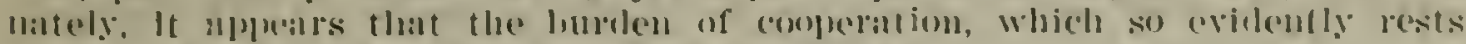

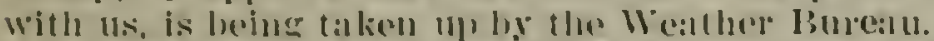

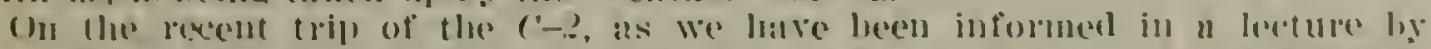

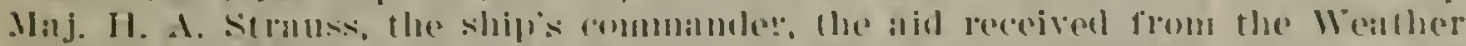

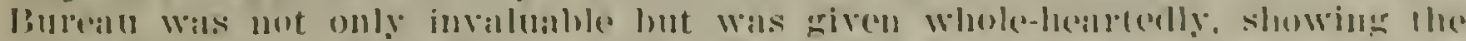

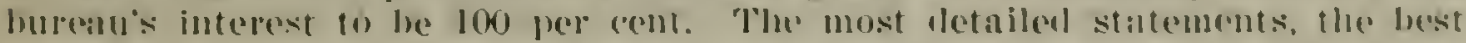

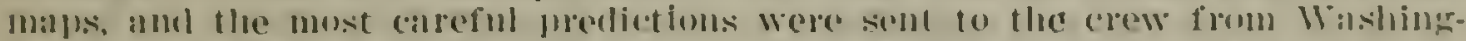

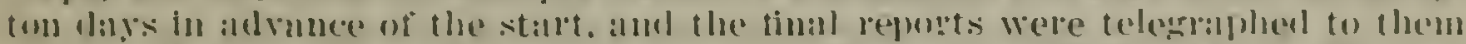

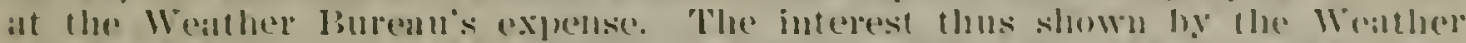

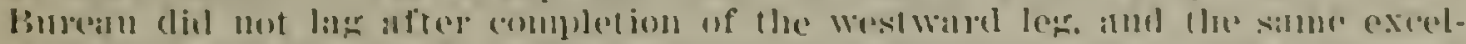

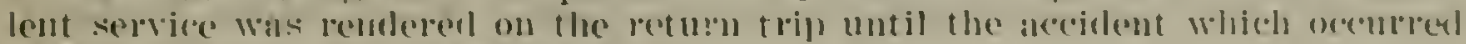
ant sill dutonin terminil(m) the tlifat.

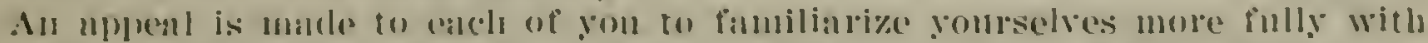

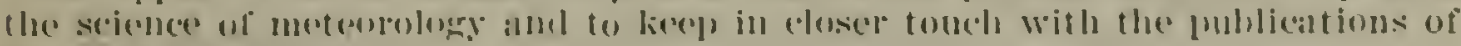
Hice Healliel Bureatu.

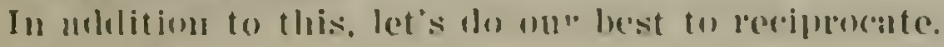

Mr. Momix. I felt that that was significant of the appreciation of the service which the aeronatutical people feel we are in a position to furnish them, and I feel it is work which means dollars and cents returned to the people.

Mr. Bı"'naxix. How long in advance can you make a forecast in the upper air?

Mr. Marix. We do not attempt it for more than est homs. amel rery detailed foreasts can not be malle that long in adrance. It is for that reason we are asking for an increase in the apprepriation. 
WEFKLY WHATHFI: ${ }^{\bullet}$ FORECASTS.

Mr. Buchasax. You are never able to make alvance forecasts of longer than 36 hours, are you?

IIr. Manvis. We are inaking weekly forecasts for anricultural interests couched in general terms. They are generally satisfactory.

Mr. Buchaxax. How often do you malie them?

Mr. Manix. Once a week-every Saturelay-and they come out in the papers all over the country Saturelay and sunday. We are hopeful with continued sturlies to be able to extend the forecasts more than a week in advance. But that is an ambition of the meteorologist. Here is an aerological survey of the Uniterl states. giving a summary of what we have clone within the past few rears. When you think of the immense territory of the Uniterl States and that we have only six of these upper-air stations you can realize what it means.

Mr. Andensox. You have only six of these upper-air stations, have you?

Mr: Marvin. We have six primary stations making observations with kites and balloons, etc. In addition to that we have nine balloon stations, sending up little pilot balloons into the upper winds.

Mr. Anderson. What do you propose to add to this $\$ 25,000$ ?

Mr. Marvis. We are going to put in some additional stations. I bave Mr. Gregg here, who is in eharge of aerological work, and I think, perhaps, he can answer your quest ions best.

ADDTTIONAL, STATIONS URGFNTII NEEDEI)

Mr. Gregr. We propose to put in about six stations. The actual number will depend upon where they are located and. of course, that will depend upon the needs of the Army. Tary, and mail air services. If the stations can be established at regular Weatlier Bureau stations now in operation, the cost will be alont $\$ 4.000$ each: but if the stations are to be established at other places than where we have regular Weather Bureau stations, we shall have to put in fully equipped new stations costing about $\$ 6,000$ each. The probability is: however, that most of them can be placed at Weather Burean stations.

Mr. Axnensox. Where they are, do you have to employ men to do this particular work as distinguished firom the ground observation?

Mr. Griga. At the Weather Bureall stations?

Mr. A xplikson. Yes, sir.

Mr. Gurag. We would have to assign one ext): man with experience in upper-air work; in addition one of the recular men already cmployed at a station would be reguires to lean the work and assist in the observation. Earch obsorvation recpuires two men.

Mr. A xumsox. IIow long are they in taking it?

Mr. Gianga. On the average an observation takes from an hom to an hour and a half.

Mr. A vollison. What do they do the best of the time?

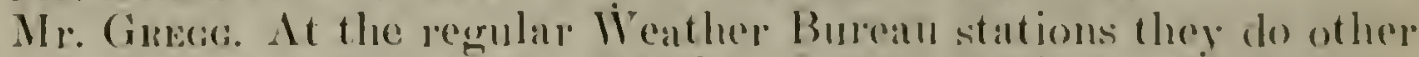
work, such as is done at all Weather Bureall stations. It the primaly stations where we do nothing but arological work we make 
observations with kites and that lakes four to live hours rach day.

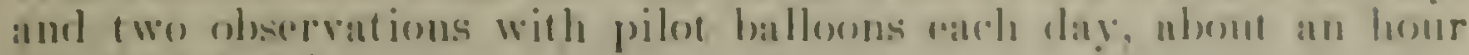
and a half emch.

I maty say, as to the time consumed, that it takes a good deal of time li compute or resher the information to a point where is is usible. The hour and a hulf reforred to is consumed in taking the observations.

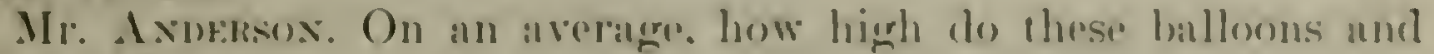
kites gac?

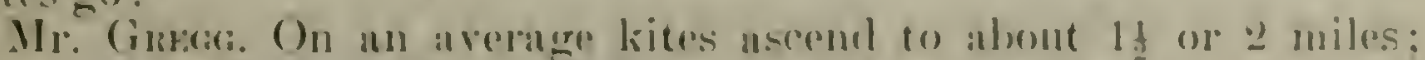
occasionally 3 or 4 miles. Balloons gro 11 p on an arerage I shombl suy $2 \frac{1}{2}$ or 3 miles. but ocensionally as high as 10 or 15 miles. Of coirse the height reached depends entirely upon the state of the sky.

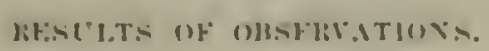

Mr. Axprasos. From these observations are you able to predict the condition of the atmosphere with respect to storms, wind relece. ity and all that sort of thing in the mpper air!

Mr. Gruce. That is the primary purpose of the observation. I might say that all these ohservations are sent to forecasting centers at Washington, Chicago and San Francisco, and forecasts for the 14 zones into which the country is divided are made and sent out twice daily by radio.

Mr. Axibasis. Apparently all this has direct relationship to your daily forecasting. What relation has it to research and inrestigation and progress in meteorological science in creneral?

Mr. Manis. That is a matter I wanted to emphasize just before I asked Mr. (iregg to tell abont the stations. The free air observations have great value and these publications are examples of the uses made of them in the study of upper air problems. 'This service for aviation is only one of the uses of the aerologrieal work. 'The data have a very important bearing upon the phenomena of the circulation of the air ont of which knowledge we hope to be able to improve our knowledge of the laws of forecasting.

Ir. Brchasax. How deep is the atmosphere? How high?

Mr. Manux. The highest points are perhaps three or four hundred miles in the atmosphere where meteors become luminous, when they penetrate the ontermost portions of the atmosphere.

ilr. Brchasax. I thought they knew absolutely the height of the atmosphere.

Mr. Manix. Well, no: it goes on and on, more and more attennited.

Mr. Buchasas. Is not there any limit to it ont there-any limit to where the air extends?

Mr. Maris. Oh, no: not exactly. It has no definite outer houndary. It is all within three or four hundred miles. This report on upper air pressure maps is one of the studies that has been mate of the free air lata in the lower layers. It is one of the mo-t important contributions to this science and deals with reducing pressure ohservation upward instead of reducing them to sen level, which is the ordinary practice. 
USE OF AIRPLAXES ANJ BALIOONS.

Mr. Anberson. Are airplanes or recrular balloons used at all in making these observations? Have they been occasionally or regularly or otherwise used?

Mr. Mamis. Very little use has been made up to the present time of airplanes for taking observations in the free air. Te can gret better results at less cost by taking observations with pilot balloons and kites, because we have better information as to the position of the balloon at the time. The instruments carried on airplanes and moving freely around have not heretofore been made useful in meteorological work.

Mr. Axuensox. I would assume, not knowing anything about it all, that to be of any value you would have to have a series of observations. It would be very difficult, I would suppose, with an airplane, and expensive as well.

Mr. Manvis. It is a much more expensive method of gretting the observation.

Mr. GregG. I may add that the principal element of interest in aviation is the wind. and it is quite difficult to make observations of the wind in an airplane.

Mr. Anderson. Which do you consider of the crreater importance under this item-the general research work in its relation to the scientific study of meteorology or the forecast which you make for air travelers?

Mr. Manvin. With respect to the increase. Mr. Chairman. we would hope out of that appropriation to derive the greatest immediate practical benefit from the forecasts to aviation, but I want to say this about the whole appropriation with its increase. It is the way we have of accumulating information which must go on for several vears before we get data from which forecasts studies can be made. The work under this appropriaiton, apart from its benefits to aviation, is a contribution to science and is something the value of which increases with the accumulation of observations. It is only with the accumulation of these observations that useful research work can be carried out.

Mr. Axuensox. When you get down to brass tacks, how extensive is air travel in this country at the present time?

Mr. Marrix. 'The travel at the present time. I think, is limited to the Army and the Nary maneuvers and to the Post Oflice Department. I think weather adrices are very important in developing aviation, and certainly this country ought not to be backward in developing civil aviation, regardless of its great need as a palt of the mational defense.

Mr. A xpersox. That completes your item does it?

Mr. Makrix. 'That is the only remaining item we have. Mr. Anderson. We would like to see this increase as an evidence of the smpport this feature of the work is gretting. beranse we feed it is important both to practical ariation and to the science of meteorologery.

Mr. Avmansox. Is there any relationship at all between these upper-a ir olservations and your forecast on the gromend?

Mr. Mamix. There is: the foreconsters depent mpon them erery day. We use these reports that we get from the stations we now have and chatrt them in the oflice on the maps for the different levels and the 
foreasters consults these charts exery day at the time of making his

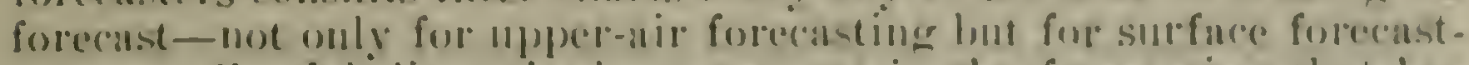
ine as well. I lielieve the improsement in the forecasting that has come nbout in the last sererul geats is partly due to the upperante data. I believe the results now attuined in forectating have never beesn surpasised.

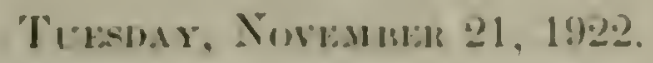

\section{BTREAT OF ANIMAL INITITRY.}

\section{STATEMENT OF DR. JOHN R. MOHLER, CHIEF BUREAU OF ANIMAL INDUSTRY.}

Mr. Axmikox. Doctor Mohler, do you want to make a preliminary statement before we start in on your statutory rolls?

Doctor Momtsis. Mr. Chatrman, I have prepared al general stalement of our work, which, if your care for it. I should like to submit (o) the committee.

Mr. A ximksux. Very well. it will go into the record.

(The statement subinited hy Doctor Mohler is here printed in full. is follows:)

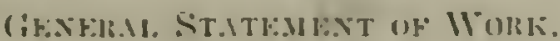

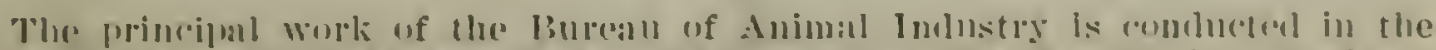

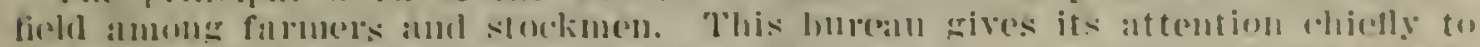

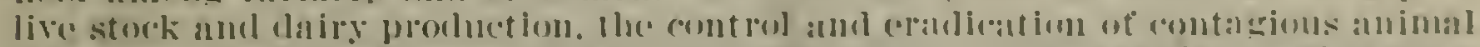

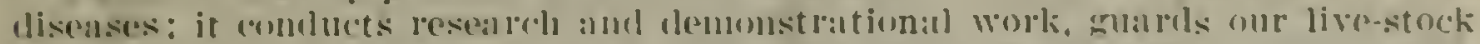

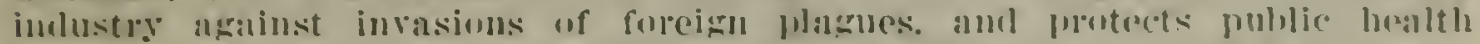

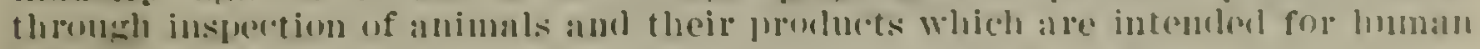
foorl.

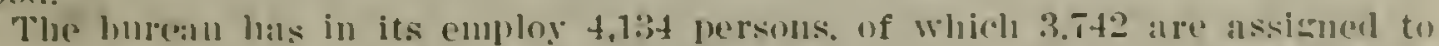

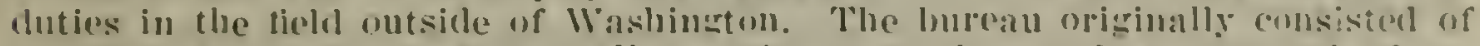

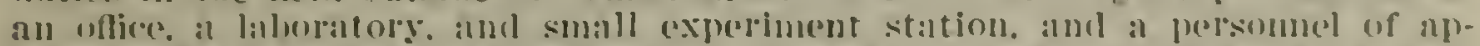

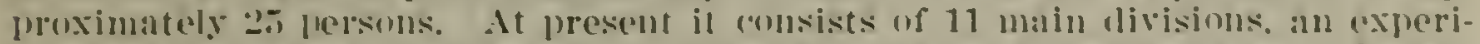

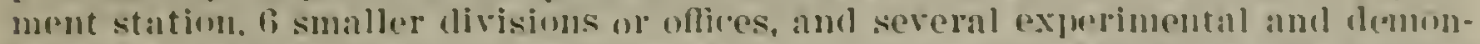
strational farms locuterl in sectloms of the comitry luest alaptent to the jurpose

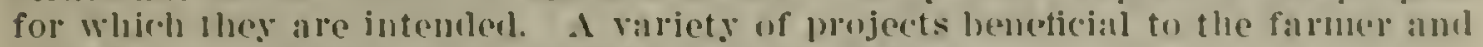
llvestock jormlucer are in prugress on these farms.

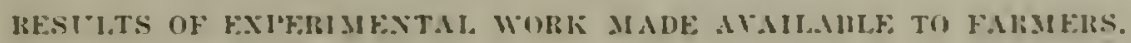

When research on nuy froblem gives encouraging results, the methon of ap-

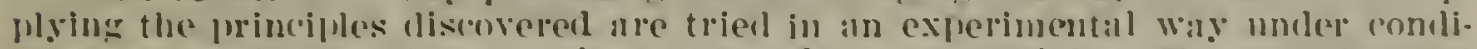
tiuns as nearly like thuse on the average fam as pussible. The cxperiunental

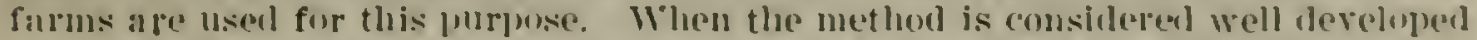
ancl suitable for general application it is male the hasis for extension work

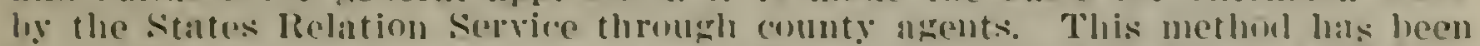
usel wlth success in preventing losses from lose cholera, ln tick eralication.

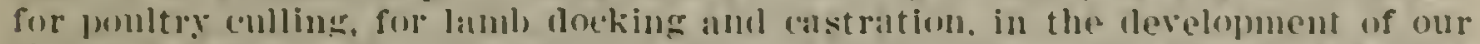

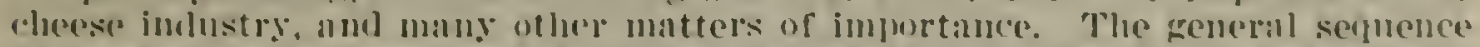

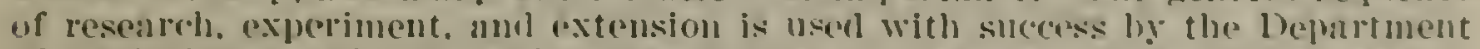

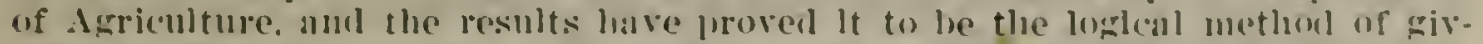

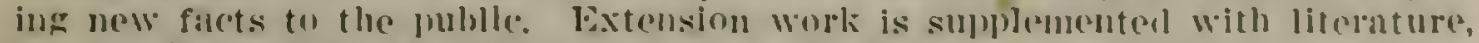
josters. lantern slicles, motion pictures. lanlio, and similar devicos.

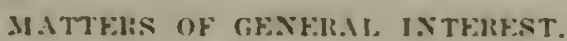

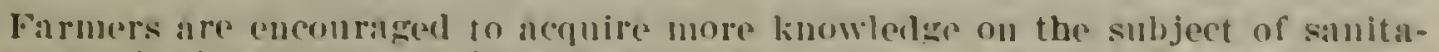

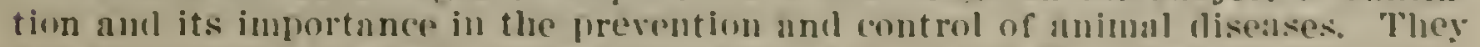

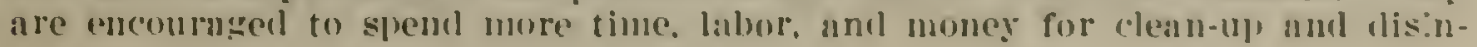


fection in froportion to the amomit they mow spend for drugs and remedies of vinious hinds and of doubteul vilue.

Live-stoek owners are urged to exereise more eare in preventing the introduction of diseases into their herds; prevention is cheaper and better than cure and eradication.

The elimination of tuberculosis from our bovine population is being pushed as rapidy as possible. The area method of eradication is the most rapid and economingl. There is need for increasing the reterinaly tield force. Loenl veterinary furctitioners latre shown themselves calmble of particibating in tubereulosis eradication work under the accredited-herel plan, and it seems desirable as eradication is extended to turn more of this work over to thems.

The burean adrocintes the eradication of ontbreaks of foot-ind-munth disease through the slaughter of all disensed and exposed susceptible animals. together with the application of quarantine, cleaning and disinfection of infected menises, and compensating the owners for animals nud other property destroped.

In the prevention of $\log$ cholera the simultaneous treatment presents anvantages over the serum-alone treatment in conferring permanent immunity and is preferable when properly aninistered by skilled operators.

The burean is endeavoring to improve reterinary service hy supervising the work of veterinary colleges and accrevliting only those thit matintain the required standard. Since the burenu employs approximately 1,400 veterinarians, it is able to exert some beneficial inlluence in that field.

The burean a ims to develop activities relating to the hreeding, feeding, and general cate of live stock in addition to conducting the discise-control work.

It is the policy to have persons working on the latger and more important practical agricultural problems to familiarime themselves thoroughly with tield conditions by spending a considerable portion of their time in the field.

Burean employees are kept in touch with agricultural matters throngh ngricultural publications and the weekly summary of editorials which ale circulated through the bureau lahoratories and otlices.

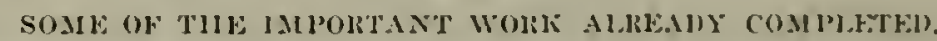

A review of the history of the rarious scientilic divisions is convincints that the standalds and policies maintained have resulted in success. Tle alctivities which have been carried to completion inclucle:

The discovery of the nature of Texas fever: how it is conveyel from infecter to susceptible bovines by an intermediate lost. Which is a tick; and the forfection of methods for exterminating the tick.

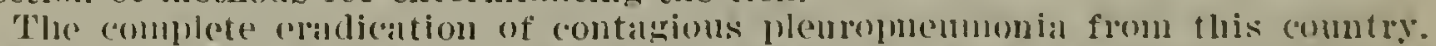
The Cnited states was the first of the latre nations of the worlel up to that time which, hatring heen once (extensively infected with plenropmemonia, was able to extirpate it.

The discovery of the cause of hos cholera, the development of antihog-(bolera sermu, thus glacing at the disposal of swine growers a reliuble arent for preventing losices fron that disease.

The erabiention of tubereulosis from live stock in tho District of Columbin. thus demonstrating the practicability of crabciting tuberenlosis from detinite arcass.

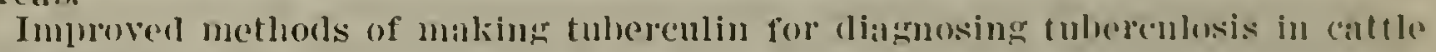
and simine.

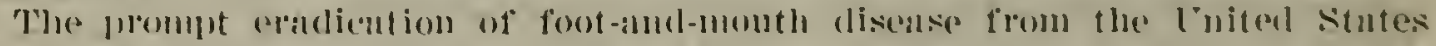
on six oecasions.

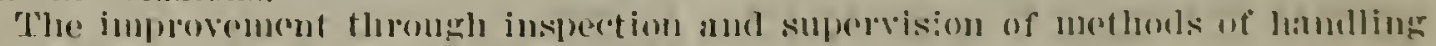
live stock in inlepstate and expunt tratle.

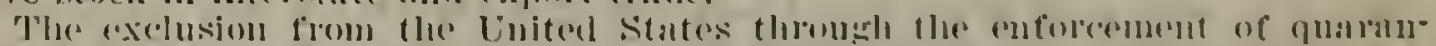

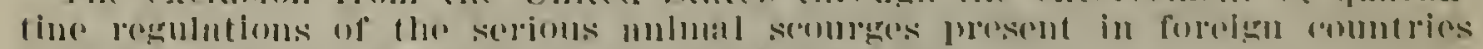

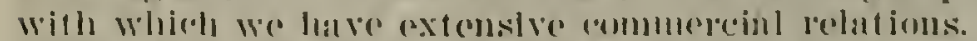

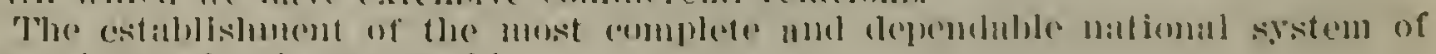
meat ins ineetlon in the worldel.

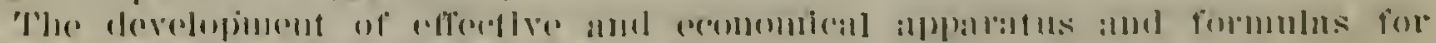
home, laboritory, mul fordory use.

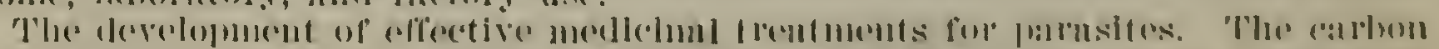

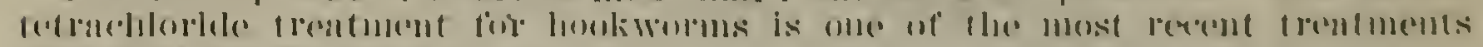

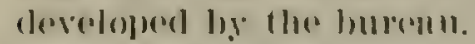


ishourtat w

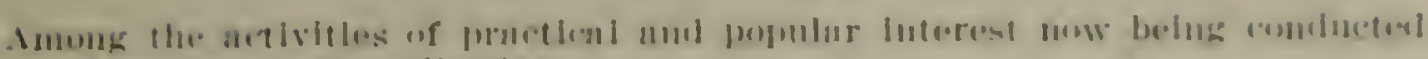
by the lurenta nare the followithe:

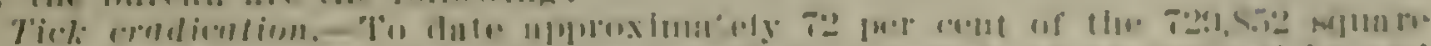

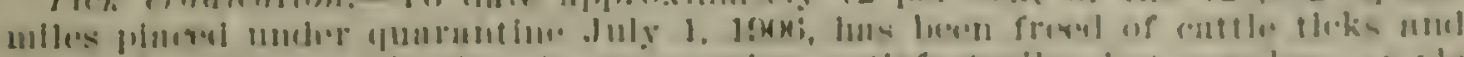

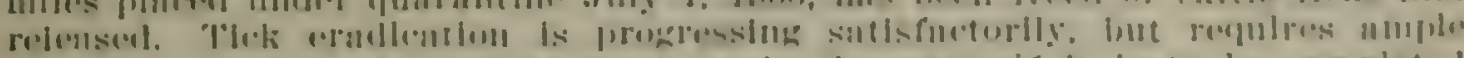

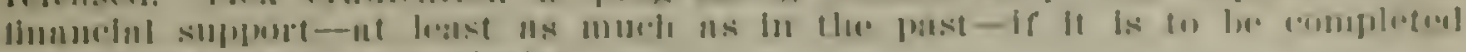

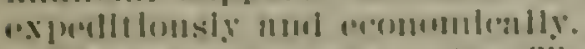

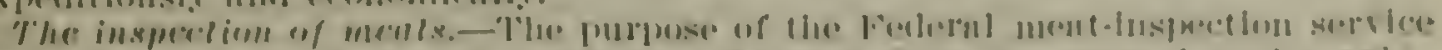

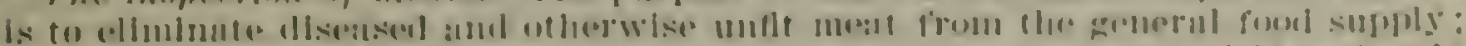

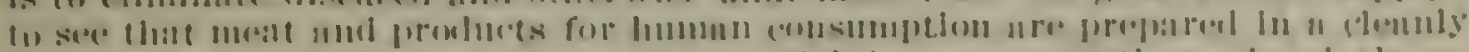

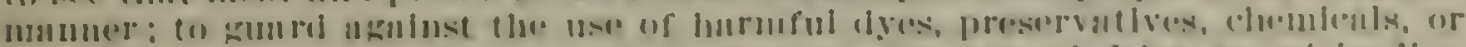

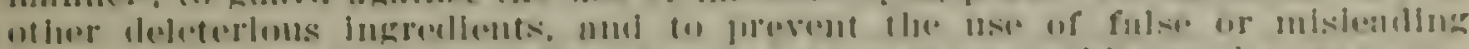

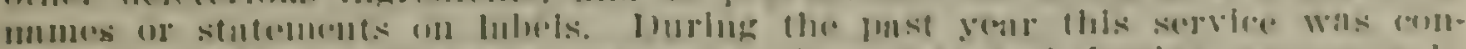

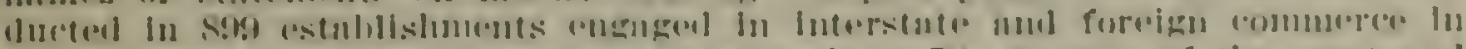

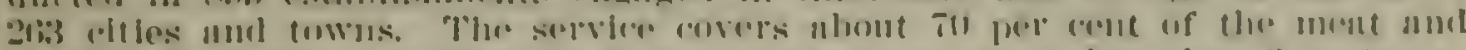

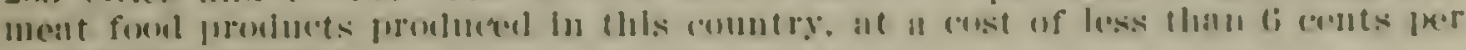

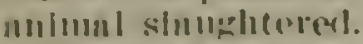

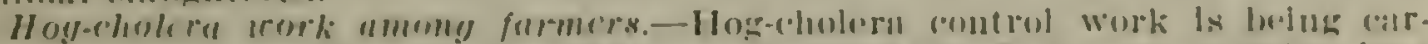

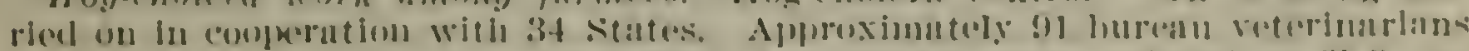

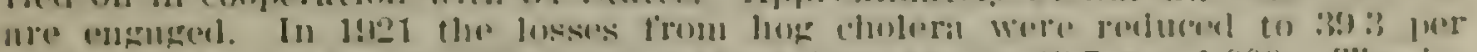

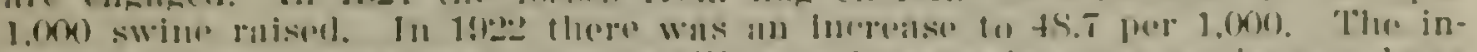

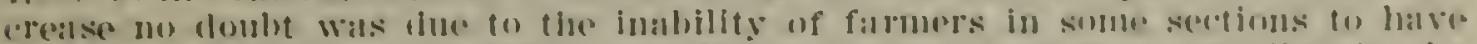

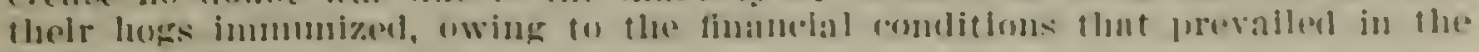
furmlng sections.

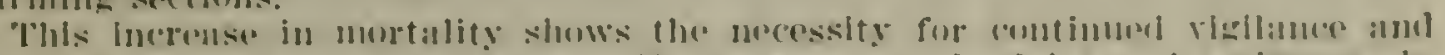

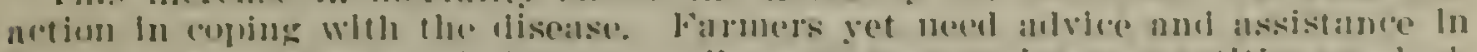

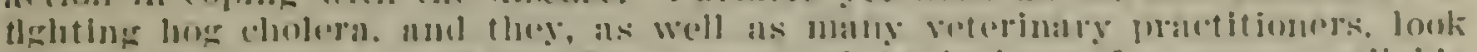

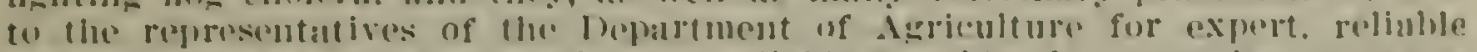

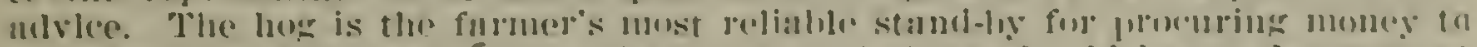

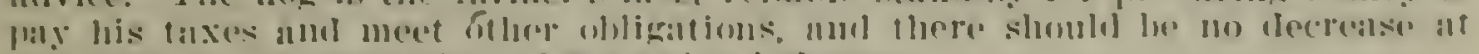
this tinse in the protertion of the swint industry.

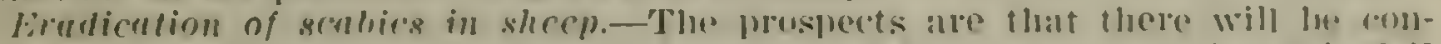

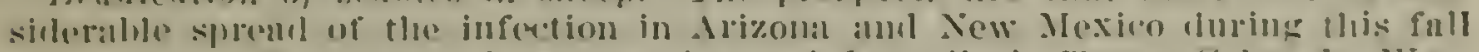

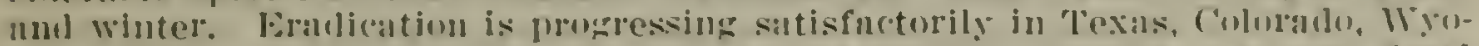

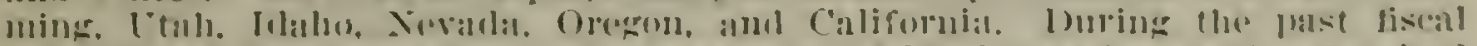

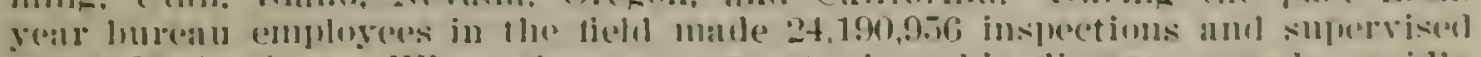

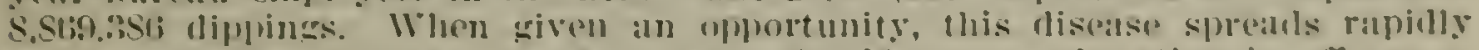

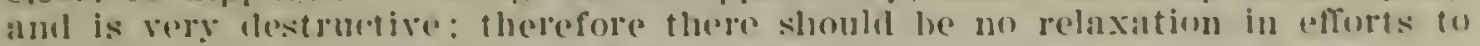

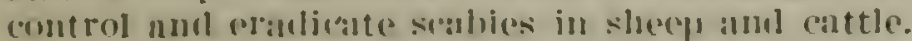

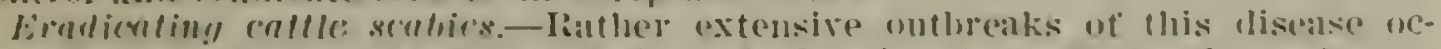

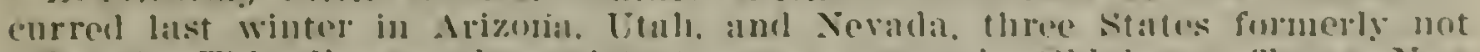
anecterl. This disealse also exists to some extent in Oklahoma, "loxas, xinu

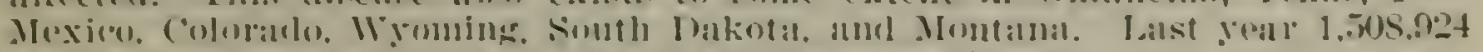

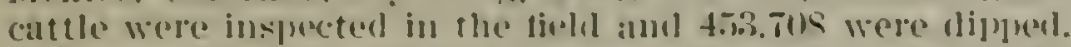

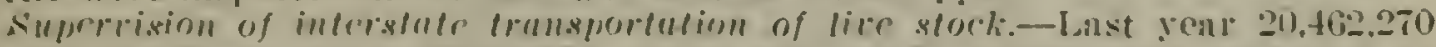

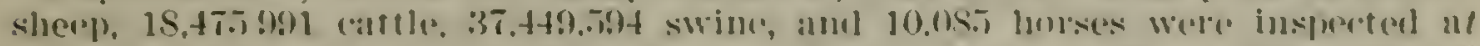

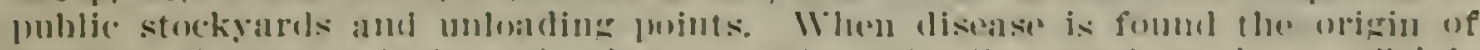

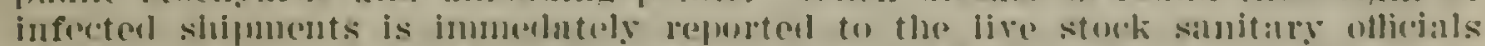

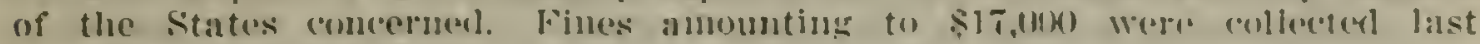
seas for viulations of the latw.

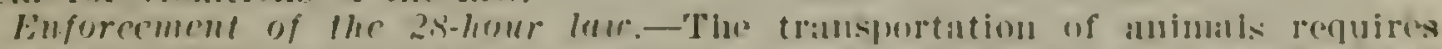
constant uttention to frevent epuelty to lhe animals while in transit. Last

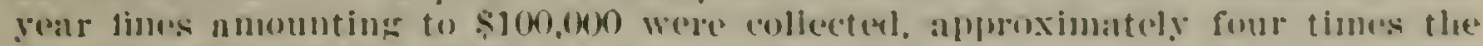
cost uf enforcing the law.

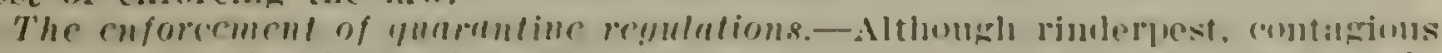

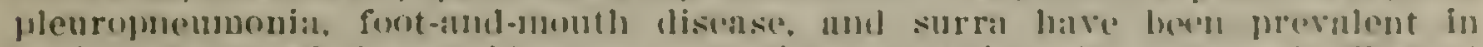

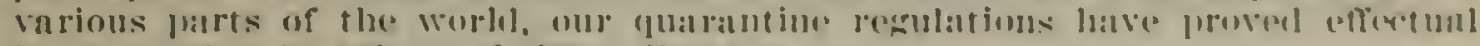
in prevouting imvingus of these liseases.

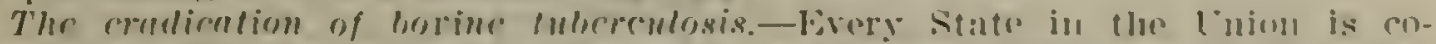
operating with the burean in this work. At prestont there aro 19,thot herds.

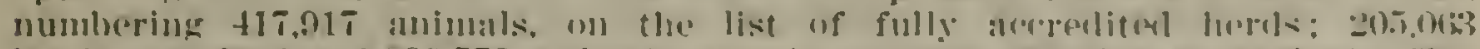

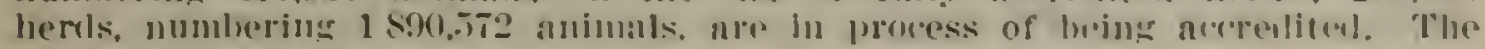

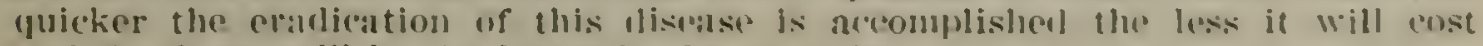
and the fewer will be the lusses in the neantime. 
Hog eholer rescarch.-It is known that this work has resulted in a siving of many millions of dollars to the farmers of the country, and it is buliered that it has been langely responsible for increasing hog production after it

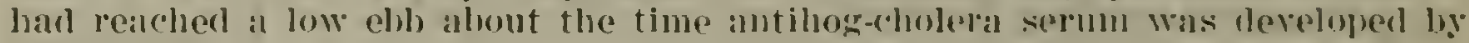
the bureat.

Inrestigations of dips and risinfectunts.-As a result of this work the inspection and quarantine work, as well as tick eladlication work, has been

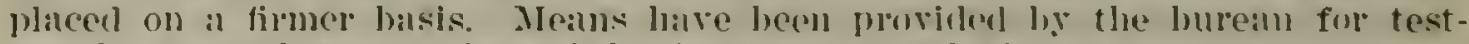
jug the strength at any time of the dip in vats reaty for nse.

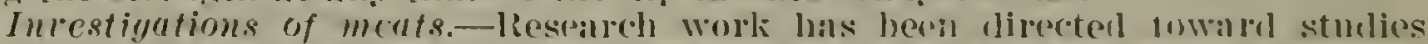
of the changes in fresh beef during cold storiage, the eftert of salting. chemingl stulies of the nutritive value, vitumin content, etc.

The profluction of tuberenlin.-The total amount of tulerenlin produced for the nse of its inspectors in the helel during the fiscal year 19)20 amounterl in romal numeless to $7.330,911$ doses. at a cost of $\$ 24,743$. The tulserulin would have cost alpuroximately $\$ 200,000$ if the burean loul heen olblineel to buy it alt mesent market prices.

The field intestigntions in the rontrol of round uolms.-In swine. stomach worms in sherep, and warble infestation among cattle are being extended.

Imestigation af animal abortion. - This work includes a study of the etiology of the disease, the development of methous of control, the difference in the valrious micoorinasms responsible for abortion among fomestic animals; and the various fhemiloal agents for the suppression of the discaser.

Imestigation of tuberculosis of animels. - This wolk includes the sturly of the camses on whide thre sprean of tuberculosis among animals depends, studies covering the tuberculin test. and other tests for tulberolusis, sturlies of the different tylus of the tubercle hicillus, their economic significance, ete.

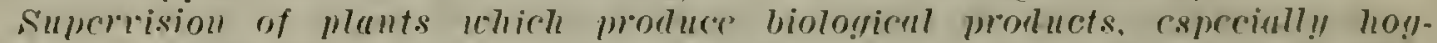

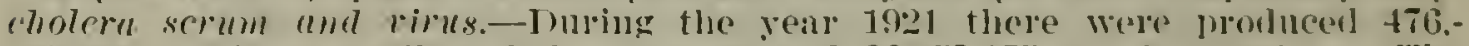

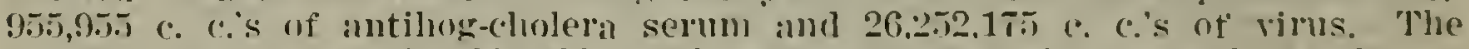

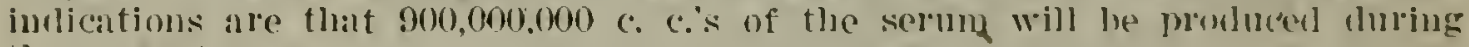
the present year.

Butter and hy-moducts.- This project is designed to incrouse the efliciency of butter making by the economic utilization of by-proulucts, inclubling the production of different kinds of cheeses and albumen jurolucts.

Comdensed mill: inrestigntions. - Studies are being malle of the factors which control the commereial quality of condensed and evaporated milk.

Nutrition of deiry corrs and secretion of milli- The ohject of this sturly is to learn more of the moress hy which the cow comverts ble mutrients of the foed into milk.

Dairy sanilation resenrob.-The object is to sturly the sanitation of city milk supplies. the factors influencing the commercial quality of milk, and flevise meats for problucing and hambling milk of superior quility.

Resenreh in animen genetics.--Fxhmustive experiments are being anducted to obtain more definite information concerning the principles of herolity.

l'he development of an Americin breesl or horses.

The rehalilitation of the Morgan hreel of lorses.

A 20-yente experiment to detrmine how the mllking qualities of cattle are tramsmitted.

Detailed experinents on inbreeling of eattle and swine.

Derelopment of a hreal of sherp alhout equally valualole for worl and meat.

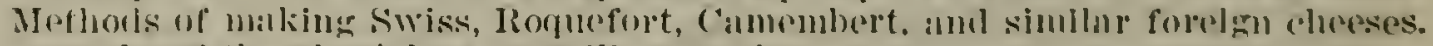
A sturly of the pligsiology of milk soreretion.

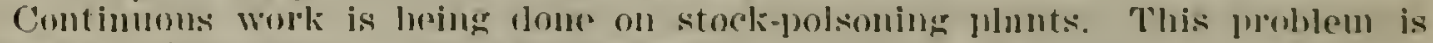
esperially lumprtant on western manes.

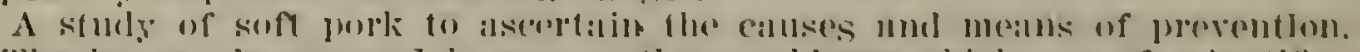

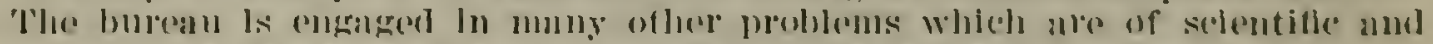

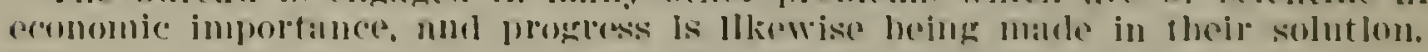

\section{SAIAIRHE.}

Doctor Monusu. Mr. Chairman, the first ehanere afloceting the Burean of Animal Industry is on pace 15 in the statutory roll. There has becn transfered from the statutory roll of the burean to the statutory roll of the Secretary one editor and compiler at s.2.20: 
that is a transfer of one mun to the seceretary ollier who will her assigned to the ofliere of editorinl and distribution work.

In addition to that change. it has bern recommonded (o drop) 2 i clerkis. laboratory assistants, arpenters, skilled laborers, mocenger bovs. and rhurwomen from the statutory roll, and these positions will be llopped on the lst of next July if approved.

Mr. A xinasos. Are there any of them racant now?

Doctor Momes. Some of them are vacant now; but the primeipal reason for dropping these positions is on aceonnt of the officioner of the other persons who are in correbnted positions and of the reduce tion of work in consequence of some reductions to be male next year.

We could, no doubt, fill these fire clerical positions. but werertheless we have recommended that these five positions of $\$ 960$ elerks be omitted.

Mr. Axmasos. Is there any other chnnge in the language of the general item?

Doctor Monras. No, sir: there is no change there.

GFNIRAT, RIPIXSL MPIROIRIATIOX.

Mr. Axmasox. And the next appropriation item is on 50 and 51 . inspection, quarantine work, ete.

FOR INEIRCTION ANIS QUARANTINE WOHT.

Doetor Mondir. This item is a general item on inspection and quarantine and covers the work we are doing on the eradication of scabies in cattle and sheep, the supervision of the transportation of live stock at the varions stockyards, the importations of animals from abroad, and other work. like mallein testing of animals going interstate. The amount requested this year is exactly the same as that last year.

IIIPING OF CATTT.E.

A widespread and prolonged dronght during the summer months in Arimona and New Mexico interfered seriously with the dipping of affected and exposed sheep. As a result the present outlook is that there will be considerable spread of infection this fall and winter in those States. In Texas, Colorado. Wyoming. Ttah, Idaho, Nevada. Oregon. and California, the other range States in which scabies is quite prevalent, the work has progressed in a satisfactory manner.

A eonsiderable number of outhrealis of the disease has oecurred in the Corn Belt States. The bureau has extended all possible assistance to the live-stock sanitary officials of those States in arresting such outhreaks. Additional employees, so far as funds will permit, will be assigned to fiold work during the coming spring in the States most urgently in need of assistance. During the past fiscal vear hureau (mployees in the fold made 2t.190.956 inspeetions and supervised 8.S6i:sisc dippings of sheep.

The work will be continued along the same lines as at present during the coming fiseal year. Further intensive work will he necessary for a number of years. however, hefore any relaxation of our eflorts can be safely peimitted. 
OUTBIEAKS OF SCABILS IN CATTLE.

Rather extensive outbrealis of scabies in cattle occurred last winter in Arizonal, Ctah, and Nevala-three States formerly not affected. As soon as these outbrealis were discovered, the bureau took prompt and vigrorous action to assist the State anthorities concerned in preventing any further spread of the disease, and at as early a date as weather conditions would permit detailed emplorees to inspect all animals in affected localities and to supervise the dipping of all diseased and exposed caltle. In Oklahoma, Texas, New Mexico, Colorado, Wyoning, South Daliota, and Montana, and other range States in which cattle seabies prevails quite extensively, satisfactory progress has been made.

In view of the spread of the disease to the three States first mentioned, however, it is doubtful whether the situation on the whole is any better than a year ago. In accordance with the usual custom, such employees as can be spared from public stockyards work during the spring months will be detailed to those sections where this disease is causing the most trouble. The inspections and dippings of cattle for seabies in the field during the past fiscal year were $1,508,92 \pm$ and 453,708 , respectively.

Mr. Anderison. Is this on eradication basis?

Doctor Monler. Yes, sir; it is on a complete eradication basis.

Mr. Axplason. And you are proceeding consistently to try to get rid of it altogether?

Doctor Monler. Yes, sir. In some States we have not had any scabies for a number of years. I told you last year, however, that since the war we have had three or four years of drought. That obtains at the present time in Arizona and New Mexico, particularly, with our sleep work, and in the Northern Great Plains sectionMontana and through the Dakotas and Wyoming-with our cattle work. When we get these droughts we are sensible enough not to insist on the full enforcement of our regulations. The ranchmen do not have enough water to spare for dipping purposes, and under those conditions we allow the cattle to go to market for slaughter without any restrictions, except to keep them from coming in contact with healthy animals.

Mr. Btchanas. What causes seabies?

Doctor Mommer. It is a small mite or parasite.

Mr. Burllaxax. It is mot a tick?

Doctor Montwr. No, sir. It is much smaller than the tick. Fon cammot see it with the naked eye. The only thing you see is the effect. where it burrows in the skin and forms little tunnels under. the surface and destroys the wool of the sheep and kills the hair on the cattle, with resulting anemia and emuciation.

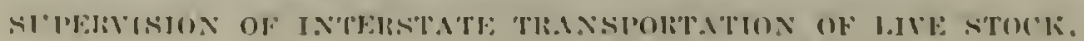

Another item in this project is the smpervision of interstate transportation of live stock. "Under this project all live stock re-

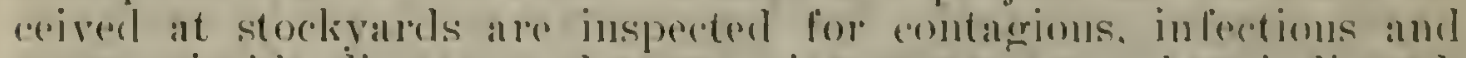

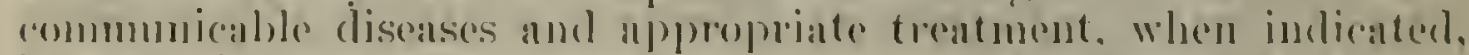

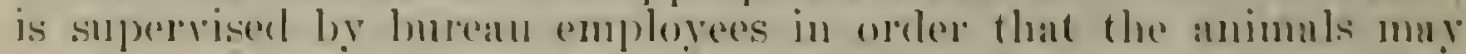

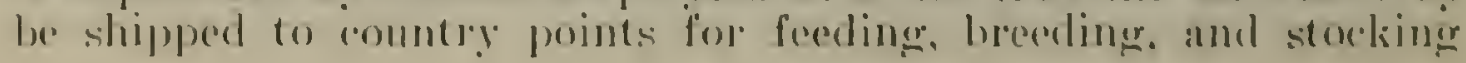


purposes. There is a tondency an the purt of many shiphers whon

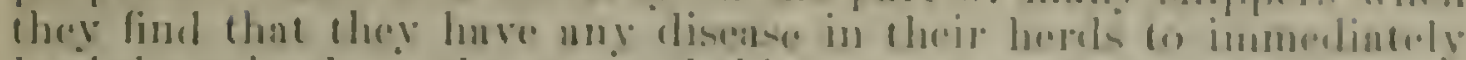
lonil the animals on the eals and ship them 10 matrere.

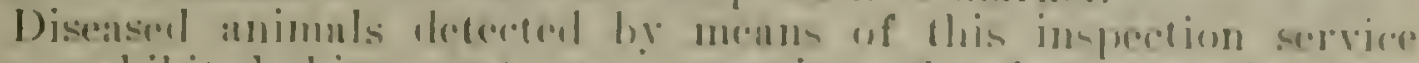

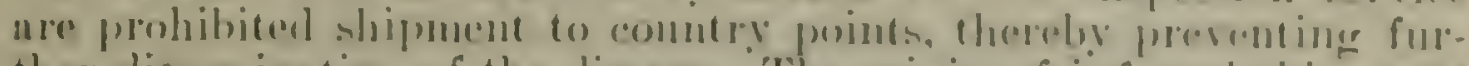
the discomination of the disonse. "The origin of infeched shipments

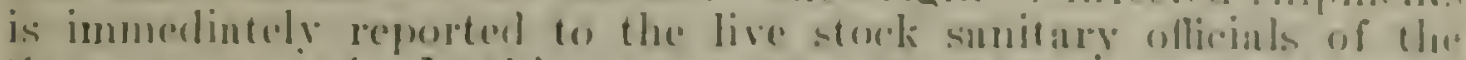
sentes concerned. In this way centers of infection are locatul nond quite ofen the spread of the ilicease from the farm or ranch where it first oredureed is prevented. The inspections mate and the treatements ancomplished at the public stockyards duriug the past var in connection with the supervision of interatate tmospertation

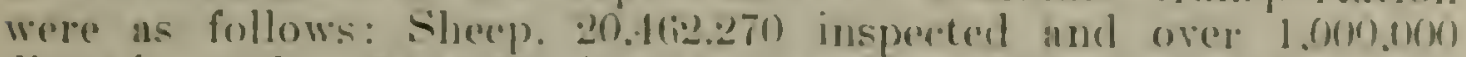
dipperl: cattle. 18.45.5991 inspected and 11.000 .000 dipped: swine. $37.0 u(1000)$ inspected and $39: 3.0(0)$ immunized against heog cholera.

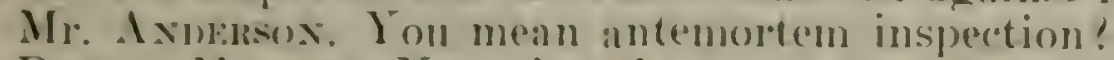

Doctor Momias. Yes. sir: these are antemortem inspections of live stock for various contagious diseases.

Mr. Axprasos. Always preliminary to inspection of shipments out into the country?

Doctor Montak. Clways preliminnry to shipments from the public stockyiards.

There were 10.000 horses inspected and 4,000 tested. largely with mallein for the presence of glanders.

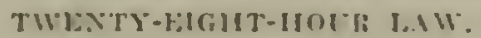

In change is contemplated in the conduct of the alministritive work to secure compliance with the provisions of the 29 -hour law. During the past rear there has been a considerable decrease in the number of violations that have been detected. Eneloretic efforts have been male to bring to trial cases covering violations that harl necurred during previous rears with the result that fines amonnting to about silun.onon were collected. approximately four times the allotment expended by the burean in enforcing the law.

Mr. Ixnmeso. Have you found that anything oljectionable result: from the enforeing of the 2s-hom law? I have understood. for example. that shipments which were coming into Chicago, where they were alpproaling the 2S-hour limit. would be held out at some way station before being shipleed into the vards. in order to avoid congestion in the vards or violation of the 2s-hour law. by reason of failure to aret them in inside the limits.

Doctor Montsal. Sro. Mr. Chairman. we have not found anything like that: in fact. we have treated this character of shipment vout are referring to with a irreat deal of lenieney. If the erew hrings the

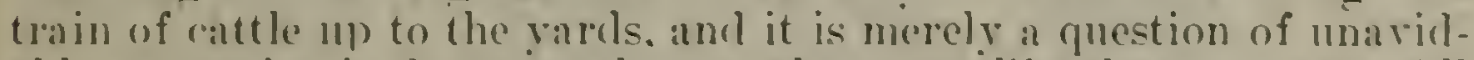
able congrestion in front, we do not take a case like that to court. . 11] duringe the -trike which buan the 1st of July. We have not stopped our mun from reportinir these cases. lnit when they were reporterl we did not attempt to have the cases go to conrt. as the officials had mo control at all of the situation on account of the strike on these railroakls.

Our ereatest trouble just now is through the Pittshurech yards. 'That is the neek of the bottle of all shipment from the Southwest. West. and Forthwest. and the roarls there at Pittsburgh have not the facil- 
ities for handling the immense numbers of animals that go through to New England points, and to Baltimore, Philadelphia, and New York from the West.

\section{DISTRIDUTIOX AND PRHPAI:ATIOX OF BLACKIAF VACINF.}

There is only one other point I would like to mention in this particular item. and that is with reference to blackleg vaccine. The distribution and preparation of vaccine ceased on the 30 th of last June. in accordance with the wishes of Congress.

Mr. Axinersox. Is it necessary to continue this language to keep it up?

Doctor Moniser. I do not think so. We have that understanding. that we are not going to go into it any further.

Mr. Axmersox. I want to ask you about this $\$ 15.000$ for keeping up quarantine stations. My recollection is that that has only been carried two years.

Doctor Monmer. Yes, sir.

MAITEX ANCE OF IIVE-STOCK STATIOXS.

Mr. Axdersor. And my recollection is that you also had about $\$ 30,000$ worth of work you wanted to do?

Doctor Monner. That was three years ago. but you know barns do not stay in repair three years. We did not have any money for the repair of those 30 barns at Boston. New York, and Baltimore for six years until two years ago, when we got $\$ 15.000$. That money was used for taking care of most of the work needed to be done it the New York station, which is the most popular of our stations: and the $\$ 15,000$ received this year we are using for repairing the eight barns at Littleton, just outside of Boston. It will not iro is far as it would have gone three years ago, when we planned for $\$ 30,000$. Those barns are affected with dry-rot: the woodwork and basement are all rotten, so that we can not use any of it.

We had to start in at the ground and put in al concrete floor and sides $u p$ as high as 5 feet in order to make any use of the barns. That work is being done now. We would like to have the station opened for the consigmment of a lot of Scotch cattle that will be shipped from Craserow on the 15th of December. The foot-andmonth disease ontbreak has greatly improved in Great Britain. and there has not been any of this disease in Scotland for live months. so we are just opening the ports of the United States to Scotch cattle. 'The importers prefer to come into Boston, hut on account of the barns not heine fixed up for receiving the cattle they will hure to (o)me in at Baltimore. Some of this $\$ 15,000$ will be used to complete the work that is now under construction in Boston, and the halance will he used at the station at Baltimore that has not received any attention sinos the war.

Mr. A volkson. How many stations have you where gou receive live aittle?

Doctor Momsti. We receive at those three points mentioned on the Athantie coast. Which are the only places where we hate guamontine stations. But oceasionally we jurevide for quarantine of eattle 
ut San linacioco. In thut rase the importer hires a stable and we kire) the animuls under supervinion.

Mr. Asurensex. The stock business in scoutand must lw about as it is here if they can afford to ship them here at present prices.

Doctor Monus.r. It is in just about the same slatere. There have not been any shipments allowed ont of England on acomint of the prevalence of the foot-and-month disense for ahout 10) months. We huve allowed some nnimals to come in from the Islands of Jersey nnd (inernsey, the first starting about the 15th of ()otober, which is the only importation that has gone through gunrantine this rear. They crime in nt. New York.

Mr. Axprasox. How long did you have to keep them there?

Doctor Monusm. Thirty days from the date of arrival. That gives un additional guanung of 30 days to the 14 days that the animals are on shipboard.

Mr. Axurnsos. What does it cost-is the feeding and that sort of thing borne by the importer?

Doctor Momer. 'That is borne entirely by the importer's. 'They have to have their own attendants, their own feed, and all supplies must be furnished by the importer; in fact, under present conditions we are requiring the importer to get all his grain and hay from this side and take it over on the boat that he is going to brings the cattle back on, so that we aroid theireby the possibility of huying luay from farms in England where foot-and-mouth disease possibly existed.

Mr. Axbersox. The importation must be rather expensive and a tedious job, then. I should think?

Doctor Monum. Only the wealthy are importing. Mr. Chairman.

Mr. Andersor. These are show stock, evidently?

Doctor Monnen. Yes. They are bought by wealthy people. who are doing the importing.

FIRAIICATION OF TUBEHCEIOSIS.

The next item is on page 53, which covers our work on tuberculosis, its ${ }^{\circ}$ control and eradication. You know, Mr. Chairman, this work has increased tremendously and I have prepared severial tables of figures which I would like to insert in the record.

\section{PROGRESS OF WORK.}

Mr. Arnvissox. I think you better make a statement: I may want to ask some questions about it.

Doctor Monn.Fr. The work on tuberculosis progressed at a more rapid rate during the last fiscal year than any previous year. During the 1921 fiscal year there were under the supervision for the control and eradication of tubereulosis 71,506 herds containing 1.19.,797 hear of cattle. At the end of the fiscal year terminating . June 30 , 1922, there were 212.152 herds of cattle contrining 2.616,39.5 head under supervision, an increase of 140.376 herds and 1.400 .598 head of cattle. In other words, the work during that fiscal rear more than doubled. 
On June 30.1922 . there were 16,216 fully accredited herds containing 36:3,902 cattle, as anainst 8.201 accredited herds containing 193.620 cattle on .June 30, 1921. an increase of 8.015 herds and 170,262 cattle.

Once-tested free herds increased from 49.814 herds containing 64.3.233 cattle to 161,533 herds containing 1.545 .183 cattle. an increase of 111.717 herds and 904.950 heads of cattle.

The eradication of tuberculosis from live stock by means of the tuberculin testing of all cattle within a given area is accepted as the best approved method of proceeding agrainst the existence of tuberculosis in live stock. While this project was a part of the original program. it could not be put into effect mntil sufficient sentiment was aroused among the live-stock owners by means of the individual accredited herd. But from present indications it is believed that area work may be carried on at the present time in practically every State.

The table here shows that the number of claims for the parment of indemnity for tuberculous cattle increased during the 1922 fiscal year by approximately 10,000 . A total of 19.597 claims were received by the department that year.

Summary of indemnity claims.

\begin{tabular}{|c|c|c|c|c|c|c|}
\hline Fiscal year. & $\begin{array}{l}\text { Number of } \\
\text { elaims. }\end{array}$ & $\begin{array}{c}\text { Number of } \\
\text { eattle. }\end{array}$ & $\begin{array}{c}\text { Average } \\
\text { appraisal. }\end{array}$ & $\begin{array}{l}\text { Average } \\
\text { salrage. }\end{array}$ & $\begin{array}{c}\text { Federal } \\
\text { indemnily. }\end{array}$ & $\begin{array}{c}\text { State } \\
\text { Indemnity. }\end{array}$ \\
\hline $\begin{array}{l}1921 . \\
1922 .\end{array}$ & $\begin{array}{r}9,925 \\
19,597\end{array}$ & $\begin{array}{l}38,656 \\
60,320\end{array}$ & $\begin{array}{l}\$ 149.65 \\
111.67\end{array}$ & 522.41 & $\frac{827,23}{23,5-1}$ & $\begin{array}{l}\text { s.54. } 15 \\
3.3 .91\end{array}$ \\
\hline
\end{tabular}

The average appraisal for tubercular cattle was reduced from $\$ 149.68$ in 1921 to $\$ 111.67$ in 1922 , an average leduction of $\$ 38.01$ per head. Owing to the falling off in the ralue of caltle. the amount of salvage for tubereular animals dropped from s.2.24 during the 1921 fiscal vear to $\$ 17 . i s$ during 1922 . an alverage reduction of $\$ 4$. (iib. but. notwithstanding that firet. the average amount of indemnity paid by the Federal Government for the 1922 fiscal year was 5.3 .690 less thin for the previous year.

AII Hlios STATES.

The legislatures of approximately 40 States will eonvene luming the winter of 1922-2:3, and inasmusch ats tuberculusis aralication work is being earried on in ench of those States and there is a continued demand for the work, it is estimated that the funds which will be made available for the next biennimm perion will increalse the present funds by at least 50 pere cent, making a total of approximately $\$ 6,500,000$ that the states will have arailable for the cooperative campaign.

A campatien for the eradication of tuberenlosis of live stork is well lamuched in every State. There are. howerer. a number of States that have made phenomenal progress in the suppression of the disease. If the work can he carried on for a perion of 10 remrs it is conficlently believed that more than half of the states will have reduced tubercoulosis to such a derree that it will no longer be a hindrance to the development of the live-stexck industry. In a great 
many of the states it will hase bero proctionlly exterminated hy that time, and it is a matter of great satisfortion that in these states that

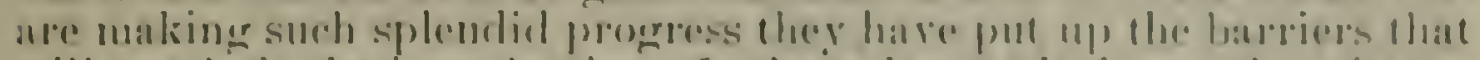

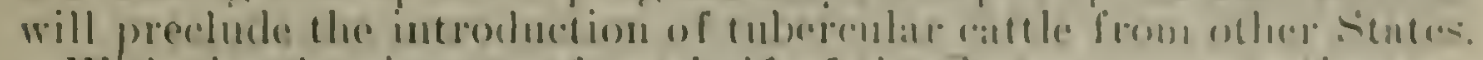

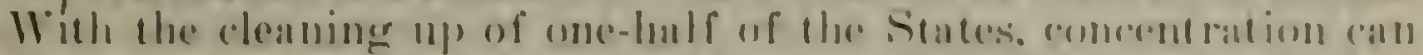
be made on the balature of the forritory in which the inferetion coists.

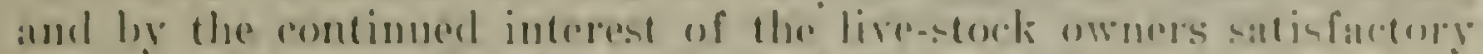

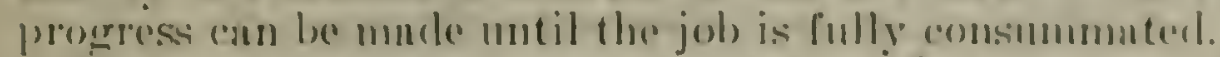

Juring the current geatr we hase macle a survey of the metire

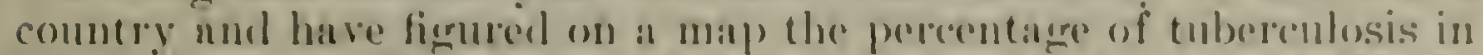

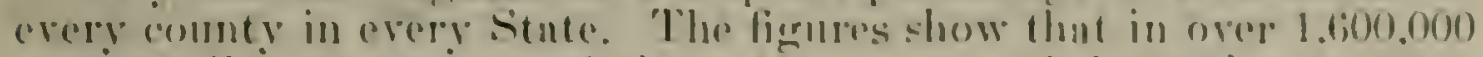

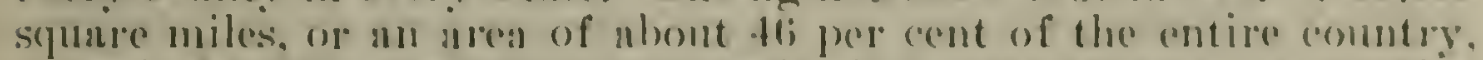
there is 0.6 of 1 per cent tuberenlosis: in 21 per rent of the romanining comntry there is 2.1 per cent of tuberenlosis: in 26 per eent of the balunce of the territory there is 4.9 pere cont of unberonlesis. In 4 per cent of the area there is over 10 per cent, while in only $1 \frac{1}{2}$ per cont, or i3.7339 squnre miles, is the disease present in orer 15 pere cent of the cattle. It a rerages about 26 pele cent in the worst inforted area.

TL"HFICUTOSIS IX IIOGS.

Mr. Axmasox. Has this eampaign reflected so far appreciably in the reeluction of tubereulosis in hogs?

Doctor Monum. To. sir; it has not. In fact, the opposite is true. There is an increase in tuber'ulosis in hogs, as firmrer ont by statisties of the vinious slanghteriner houses: but. on the other hand. there is a marleel decrease in the amount of tubereulosis in eattle. as determined by slanghterhouse statisties.

Mr. Avprasox. One of the things that I supposed-it was hoped. at least-would result in this campaign, was a reflected reduction of tuberculosis in hogs.

Doctor Mommin. That is rery true, and there is only one explanation that I can make about the increase of tuberculosis among hours, and that is that the hogs are not getting all their disease from cattle. In the last 12 months we have found a great increase among tubereulosis of chickens. This arian form of tuberculosis was known to exist in California, Oregon, and four or five of the Eastern States: but. as I said before. in the last year we have found it to exist in 24 or 25 States. especially in the Central West-in Iowa, for instance. It is a well-known fact that when chickens die on the farm they are thrown over in the hog lot, and the hogs eat them. It is equally well-known that hous are rery susceptible to the avian type of tuberculosis. We have talien tuberculous tissues from hogs and have found the avian form of the grem in those tissues. so that it looks to me as if the increase in tuberculosis among hogs is due to the increase of tubereulosis among chickens, and that the hogs are contracting a great deal of this disease from eating or associating with tuberculous ehickens.

One of the grentlemen attending the conference of I drricultural College workers here this week. told me that they were conducting an experiment at the Illinois Station with hous housed uncler the chicken roosts, with the idea of determining whether the hours would contract the disease by merely associating with tuberculous chickens. There is no doubt but what they can, beenuse we have worked that out here in our luboratory in Washington. 
Mr. A Nofrsox. Will you give us a statement showing the allotment of this fund to the States and the sums spent in the States by the States themselves and other arrencies?

Doctor Monter. Yes, sir. I have a statement of that kind.

('The table referred to and submitted by Doctor Mohler is here printed in full as follows:)

Indemnity funds for tuberenlosis eradication.

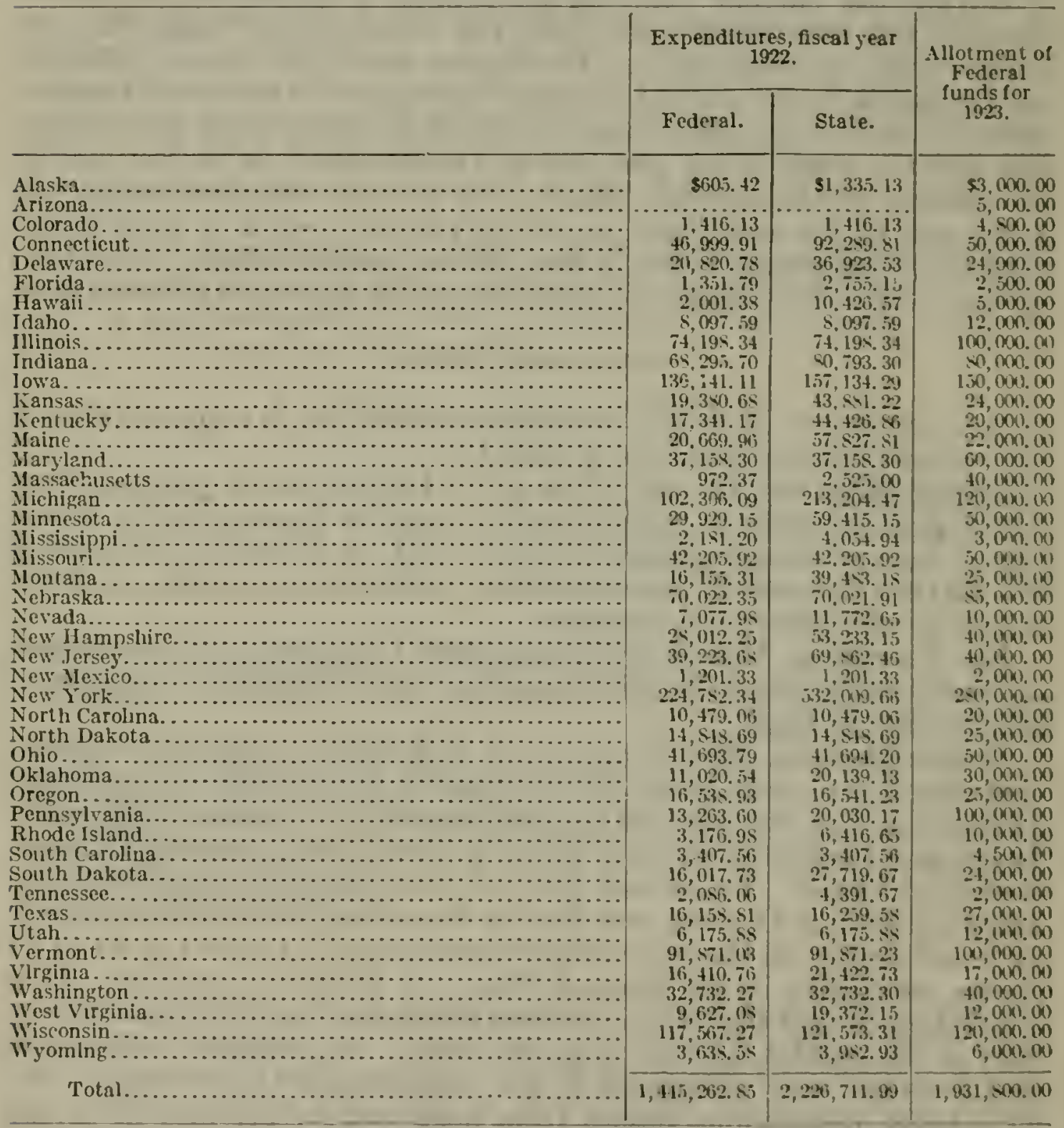

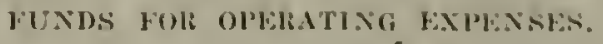

Mr. Axmenson. How is the proportion of the provision hetween operating expenses and indemnity standing up so far this gear?

Doctor Montar. The funds for operiting expenses are groing rather fast. We have finished one-third of the vear, and if we kept, up) at the same rate we have been going we would have a deficit of $\$ 90,000$. So what is happening is that we nre now starting to decrease onr forces in order to conserve the funds. Otherwise they would be exhausted in Mity if we kept on working at the same rate we have been going. 
Mr. Axmbsos, (On the ration wh wheh rom ure now working are

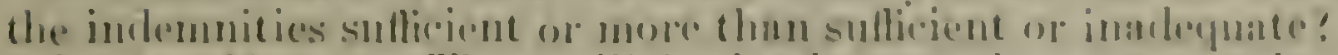

Doctor Mentas. 'They will be inndryunte. Lut mot nenply so in-

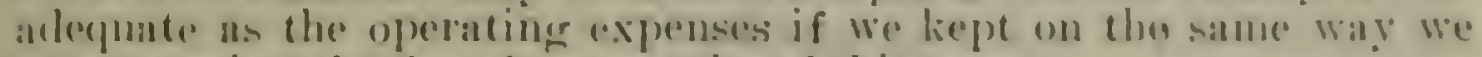
were rumning the first four mont hs of this year.

Mr. Axbatsox. What is the inducement to operate on the present bnsis with the work that is being done by the stutes?

1)octor Montsts. We are working now in all the ts states of the Union, and the Territories of Aluskan and Hawaii. Californin just cance in the linst yenr. And we are doing un great deal of this area work-in fact, we are working in fiol counties, which resluces considcrubly the testing cost per hend as well as the anome of iudennity. i whole comnty is worlied on this urea plan. The reactors nre all assombled at one point. ()ur men bring in the buyers; there is competition. They are all sold to the highest hideler. and the result has been a grent saving in the sulvage.

So we are saving considerable in that respect on on indemnity fund. But drives like that require a lot of men and our operating expenses are not going to hold out unless we reduce our force, and that is what we have been doing the past two wecks. There is, of course, a great deal of complaint from the States where we have talien off some of our men.

Mr. Axmlssux. Did you spend all of this sum-\$300.000-which was made immediately available in 1922 ?

Doctor Momssis. Nib. sir. About half of that was carried orer to this year.

M1. Axprasos. That would mean an increase in the fund this year. would it not?

Doctor Inmmin. No: because the whole amount for this year is $\$ 2.020 .700$, of which $\$ 300.000$ was a vailable last year.

Mr. A smemox. I linow: but if you spent it last year you did not spend it this year.

Doctor Moinur. No.

Mr. Axprasox. So that during the period of next year you will have more money to spend than you did this year?

Doctor Moniz. Ies: hy that amount of money-I see what you mean-we spent about one-half of that money. or a little over $\$ 130.000$, that was inmediately available.

Mr. Axnfosos. Will you get through in 1922 without a deficiency?

Doctor Mnnus. We ire going to get through without a deficieney. Mr. Chairman. But whether we are going to have to stop on the 1st of May or not I am unahle to sily.

Mr. A vimmon. That all depends. does it not. on how fast you spend yomr money?

Dortor Mommia. les: that is what I referred to a while atro. that we hat to take ofl some of onr men in order to keep within the limit-

Mr. Axinersor (interposing). What is the basis of allotment uow. 1 to 3 !

Doctor Monuse. About 1 to 2 . On the 1 st of January these 36 to 40 sitates will have their legislatures in session appropriatingr additional tuberculosis funds, and they are groing to crowl us rery hard in the spring months. but we are not going to create any de- 
ficiency. We will work along this $\$ \$ 50,000$ operating fund until it is exhansted, and then we will hare to stop. But we are trying to spreat it ont so it will cover over the 12 months and not spent it all the first six months. for instance.

Mr. Axmensox. You made that statement of the proportion of the tuberculosis in different teritories. Are your operations generally in the territories in which the larger percentage of tuberculosis maintains?

Doctor Morr.er. Yes, sir ; speaking grenerally. We have our largest force in New York, for instance, and that State has as much tuberculosis as any other State in the Union, and they are also appropriting the largest amount of money. They have this vear one and a half million dollars in New York State alone, and we have tried to put our $\$ 2.000 .000$ for all the States against the various State appropriations of over $\$ 3,500,000$. We therefore have allotted about $\$ 2$ for each $\$ 3.50$ of the State money, and that is the reason why New York State has receired more than some of the other States. because she has spent more on her own disease control.

TUBERCULOSIS WORI IX TEXAS.

Mr. Bcchanas. Is there any tuberculosis in Texas?

Doctor Mohler. Yes sir; there is.

Mr. Axpersor. Can you put that map in the record in the form of a statement?

Doctor Mohler. Yes, sir; and I shall be glad to do so.

Mr. Bucmaxax. I did not suppose that tuberculosis was in Texas.

Doctor Monuer. It is not at all extensive in Texas. but you have enough dairy herds near the larger cities of Dallas, Houston. El Paso. Fort Worth, etc., to give yon a small proportion of the clisease.

Mr. Buchanan. Around these little circles is where it is supposed to be present?

Doctor Monuer (referring to malp). Where the dots are you have less than six-tenths of 1 per cent.

Mr. Bucmanax. We have it in all sections?

Doctor Montwr. Yes; but more in certain sections, and so far as I am informed it is chiefly among the dairy cattle.

Mr. Buchanax. That is Jerseys?

Doctor Monner. Jerseys and Holsteins. Iarcrely.

Mr. Buchaxax. According to this, then. 'Texas has less than any other State?

Doctor Monnur. She has very little in proportion to her large number of cattle and her square miles of territory, but I shall be rery grad to interpret that map in the form of a table. It shows you how the dairy sections of Iowa, New Iork, and northenstern Illinois are burdened with it. 


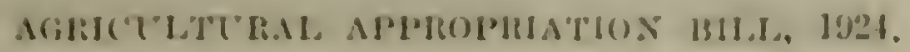

('The tuble is us follows:)

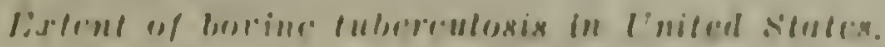

\begin{tabular}{|c|c|c|c|c|c|}
\hline Approxlmate cestrit. & $\begin{array}{l}\text { Total } \\
\text { mpluaro } \\
\text { milles. }\end{array}$ & $\begin{array}{l}\text { lor coul } \\
\text { sryuare } \\
\text { Inlless. }\end{array}$ & $\begin{array}{l}\text { Tutal } \\
\text { cattle. }\end{array}$ & $\begin{array}{l}\text { l'er revilt } \\
\text { cattle. }\end{array}$ & 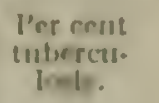 \\
\hline 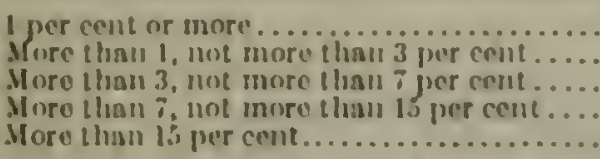 & 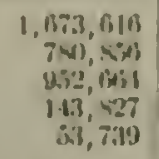 & $\begin{array}{r}\text { Mh. } 1 \\
21.7 \\
213.1 \\
\text { 1. } 0 \\
1 . .2\end{array}$ & 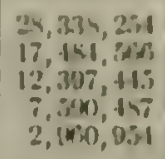 & $\begin{aligned}+1.2 \\
2 . .1 \\
14.1 \\
11.0 \\
1.3\end{aligned}$ & $\begin{array}{r}0.6 \\
2.1 \\
1.0 \\
111.1 \\
24.0\end{array}$ \\
\hline Ciramil total.. & $3,804,702$ & $(0 x) .0$ & Bs.731, 7(xi & 100.0 & 1.0 \\
\hline
\end{tabular}

Mr. Burmaxix. Is this confined to dairy attle in Texas?

Doctor Montar. Fes, sir: almost entirely.

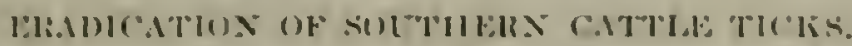

Mr. Axmbase. We will now take up). on page sti. the item " for all necessary expenses for the eralication of sonthern cattle ticks."

Doctor Minms:s. Sirstematic tick eradication in coopelation with State anthorities was conducted in quarantined counties or parishes in $T$ Stutes as follows: Mlabama, 4 comnties: Arkansas. ? combies: (ieorgia, 21 counties: Lonisiana, 7 parishes: North Carolina, 2 counties: Oklahomat. 3) counties: and 'lexas, 41 counties. Is a result of the work alcomplished, the following areas were released from I'ederal (puirintine list year:

Stales.

\begin{tabular}{|r|r}
$\begin{array}{c}\text { Coumties } \\
\text { or parts } \\
\text { of } \\
\text { countues. }\end{array}$ & $\begin{array}{r}\text { Square } \\
\text { mules. }\end{array}$ \\
\hline 16 & 5,573 \\
4 & 1,917 \\
2 & 51,227 \\
27 & 21,27 \\
\hline$\ldots . .$. & 29,563
\end{tabular}

Total area released.

Practically all of these counties released from Federal quarantine contained at the time of release a few herds which it was necessary for State authorities to hold under local quarantine on account of tick infestation or exposure thereto. 'This action was agreed upon hy the State anthorities in consideration of the release of these areas fiom Federal quarantine.

During the year final clenn-up work in released areas was supelrised in 10 States in 301 counties which had been previously released from Federal quarantine but in which some tick-infested or exposed herels of cattle still existed in limited areas.

In addition to the systematic work in quarantined areas and final clean-mp eflorts in relcased areas, a great deal of preliminary work was done in 29 counties. This consisted of community organization, vat building, and the voluntary dipping of cattle in order that cattle owners might be convinced of the effectiveness of clipping and the possibility of eradicating ticks by uniform effort. In the 
work above outlined 48,089.005 dippings of cattle in arsenical solution were supervised and herd records compiled in the field offices and reported to the department.

DIPPIXG OF CATTH.F.

Mr. Axplinsox. You saly there were over $48,000,000$ dippings of cattle?

Doctor Monlerr. Yes, sir.

Mr. Axbersox. How many times did you dip each cow?

Doctor Monter. Each animal is dipped every 14 days in a șstematic clean-up of a county.

Mr. Axprasox. For how many times?

Doctor Monles. Ther start in the spring, about the 1st of April; and as the ticks are eradicated, the dipping ceases, usually around the end of September, and sometimes as late as the end of October.

During July and August of the present fiscal year systematic dipping of cattle was conducted in cooperation with State authorities in quarantined counties or parishes in 8 States, as follows: Alabama, 3 counties; Arkansas, 7 counties: Florida. 1 county; Geororia. 15 counties; Ionisiana, 3 parishes; Oklahoma, 4 counties: North Carolina, 2 counties; and Texas. 74 counties. 'The monthly dippings. of cattle supervised by Federal, State. or county employees are as follows: July, 9,373,167: and August, 9,740.999.

During the first two months of the present fiseal year final clean-up work was supervised in conperation with State authorities in 330 counties which had been previously released from quarantine in 10 States and which at the time of their release from quarantine contained one or more herds infested with or exposed to cattle ticks. Control of these herds was undertaken by the State live-stock sanitary officials of the States involved in consideration of the release of the counties from Federal quarantine.

In addition to the systematic work supervised in quarantine areas of the States mentioned and the final clean-np work accomplished in the comnties that had been released from quarantine in those States. preliminary educational work was superrised in 25 counties in 5 States. The work was carried on in order that additional areas might be placed in a proper position and attitucle to satisfactorily conduct a tick-eradication campaign during the coming year:

During the remainder of the present fiscal year systematic final and clean-up work will continue to be conducted in the areas I have already mentioned.

COOPERATIOX WITI STATES.

During the fiscal year $192+$ it had been contemplated, if the funds remained the same as this year, that systematic tick-eradication work would be supervised in cooperation with State anthority in 13i) (counties in 8 States, as follows: Alahama, 5 counties: Arkinisas. 11 comties; Georgia, 8 cominties; Lousiana, ? parishes: North Caro-

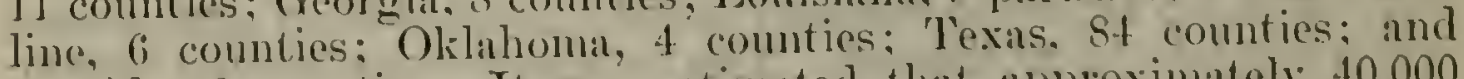
Florida, 6 comties. It was estimated that approximately 40,000 square miles of area qualrantined for cattle ticks wonld be placed in condition for release from Federal quarantine during that year. 
In addition theren the fisal elean-up work would lee contimmed in

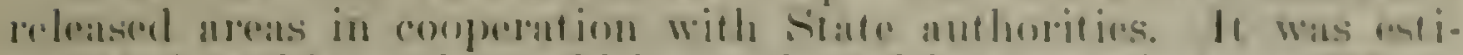

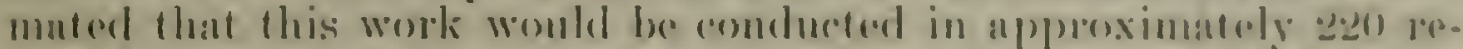
leased counties containing one or more herds qumlantined on ancount of eattle ticks at the time of their release from quarantine. In approximately 80 comonties of this mumber the work shonld be antirely completed.

Approximately the same amomot of preliminary work will be necessary during the fiscal yenr 1924 as during 1929$)^{\circ}$ in the states of Arkansus, Florida, Lomisiana, North Carolina, and 'Texis.

Mr. A xumasises. What proportion of the total area infested has heon linally cleaned up?

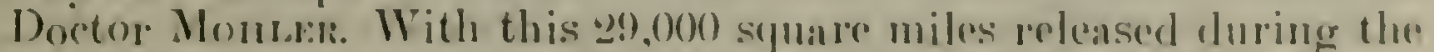

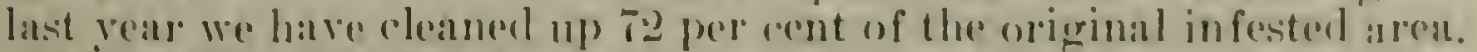

Mr. Axmatisox. I julge from rour statement that rou have to gou

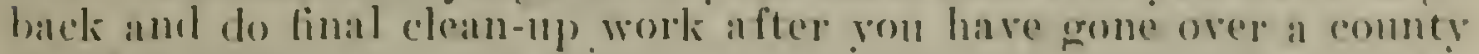
once?

Doetor Montene. Jes. sir: we never wait until we kill the last tiek to release the comnty from quarantine. We to that to grior eneonragement to the earnest men who have dipped orery 14 dats and have grotten their animals rean. We always lave a fow "bolsherists" in each county who refuse to comply with the regulations, and we consider it mifuir to the good fellows who have dipped clom to kepep them quarantined just because 2 per cent of the stockmen of the comnty refuse to do the work thoroughly. But we release a comntr only when the State's oflicials have signified their willingness to prit those infested herds in local quarantine: and they are maintained under the same conditions as if they were under Federal quarantine. We then release the other men that have clean cattle in order that they may go to the free markets withont restriction.

Mr. Axinfison. What is dome to clean up these $10 \mathrm{or} 2$ per cent that remain?

Doctor Monuris. Sometimes we have to go into court to gret those fellows to dip according to State regulations.

Mr. Axmmsox. Then there is authority unler the law of the States to require them to do it where they refuse?

Doctor Mommar. Yes, sir: that is true in all the States where wre are working. We do not have any Federal law that would rompel them to dip.

DECREISF: IX WORK.

Mr. Aximensox. To what extent will rom work be redheed as a result of this decrease in the appropriation?

Doctor Montak. It will decrease the work by about 25 per cent of what we are doing this year. We have taken up the work with the varions States ly zones. Wo have Texas mapped out into three different \%ones, dr ransas and Touisiana are mapped ont into \%ones, and the same thing is true in Georeria and Alabama. Our plan was to do a certain amount of systematic dipping work next year. having started ellucational work in these same comnties this rear. We alwas go in to (a) srstematic work one year in the connties where the prorions real we had been doing edicational work. With this drerease we will be unable to talie in any new territory. becanse the s.500.000) that will be alvailable for next year. acomeling to the proposed hill. 
will be needed to clean up the counties we have alrearly prepared. That is the only work that would be possible-to finish the systematic dippings and to mop up the territory in the districts that have been released from quarantine in order to keep the ticks in these individual hereds from spreading.

Mr. Axplissox. Do you mean there will not be any additional work in any new counties under this appropriation?

Doctor Monder. There will be very little if any additional new territory included uncler the $\$ 500,000$. It is groing to take so much money to work over the territory that has already been released and to do systematic dipping in the counties that are receiving educational assistance at the present time that we can not go into new territory in 1924. We will have to clean up the counties where we are working this year in an educational way.

Mr. A vimisox. What percentage of the appropriation is used for the new work each year?

Doctor Monler. We have never divided the appropriation on a basis of that kind; but you can readily see that we are doing somewhere around 20 per cent educational work in new territory. Then we are doing a little more than that amount of work in systematic intenșive eradication and are using the balance of the fund in mopping up in this large number of counties that were released from quarantine during the preceding year or two.

Mr. Axverson. I do not just see how that can be. I do not see how' it can cost twice as much to mop up the territory that you have been over the preceding year. as it cloes to do the new work you are doing this year.

Doctor iform.r. For instance, last year we released, as I stated a few moments ago, 49 counties as the result of the systematic dipping work of 1921, that many comties being released last December. It the same time we were doing "mopping-up" work in 301 counties that had been cleaned up with the exception of a few indiviclual herds in each county, where the States had used their power of local quarantine. Now, we have to use a great deal of care to prevent the infested herds in those particular districts from spreading the tielis to other adjacent districts.

Mr. A vmbrsox. I thought you said you left that to the State live stock and sanitary anthorities.

Doctor Monuer. We leave the quarantine to the State anthorities. The have our men back there right along to get the last tick. What we leave to the live stock and sanitary anthorities is the method of guarantine and the regulations to hold the animals in quarantine. So you see there were 49 of those new counties released. but at the same time we were working in 301 comnties after their release from quarantine, because there was some infection left behind. But we have never figured ont and never divided up the work so as to know just how much it has cost us to do alvance educational work. nor to ilo the work in the second line trenches where the 1t-day systemutic dippings oecolr, nol have we fignted out the proportional cost of mopping-up work which is the final work before the territory is entirely cleaned up of the tick.

Mr. A vmersox. You must have to go back to some of this territory for more than a year, if that is the cuse. 


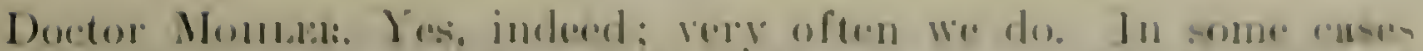

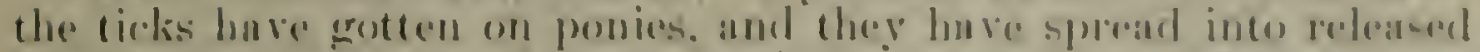
territory us the result of the horses luringing in the infestat ions.

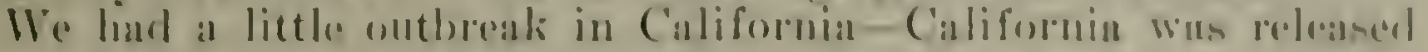

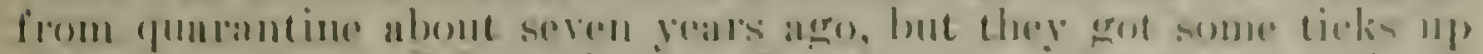
there in northern California near sacramentes. "There were only 1 H

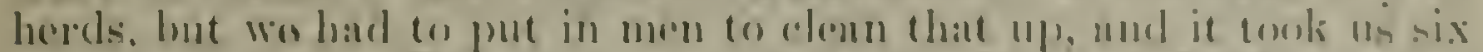
monthe to do it. That is the only time the sente of California hate

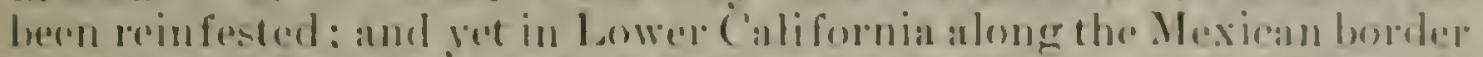
there ure ticks gralore. and it has been a constant somere of tromblile

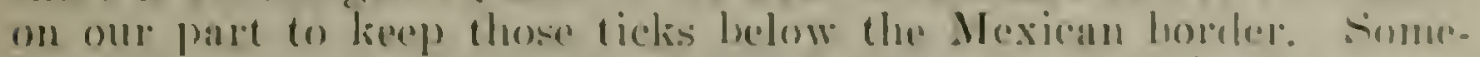
how, in some way the tieks got into that northern section last peare. and we will always hase the possibility of a recurrence of the tick in any free territory as long as the tick remains in the sonth. 'They' come in bedding, in manure, hay, straw, and varions different ways that we can not possibly control.

Mr. Bechaxas. You have a quarmatine on the importation of cittle from Mexico?

Doctor Morner. Yes, sir: every hearl of stock imported into this comntry receives inspertion along the border from Brownsville all the way across to San Diego.

Mr. Axmasox. What I can not get through my mind is if you have been doing this systematic follow-up work why you still have 300 comntires that are partially infested.

Doctor Monns. In some cimnties there are only one or two herels left that are infested, and it reguires a great dral more proportional cost to clean wp the last few herds in a county than it would a much larger territory of original infestation. It is like $100 \mathrm{per}$ cent efliciency in any line: it is relatively cheaper to hring up any ayork to the first 70 per cent of efliciency than the last 2 per cent.

Mr. Bucliaxax. When you release the counties do not the State anthorities mop up those isolated cases?

Doctor Monur.r. They work with us, but they do not as a rule have the kind of men that we have. who lnow just the strength of dipping solution required in the vats and are fully informed on the subject in general.

Mr. Bucmaxax. It looks to me as if, with nearly a year of dipping experience, the State men onght to get sufficient kinowledge to be able to make the proper solution: and after you make the solution it wonlal seem to be a simple matter.

Doctor Moruser. That may he, but after you hare a thousand hearl pass through the dipping solution it weakens and you have to have. it testing outfit to keep the solution at the proper strength to be effectire.

Mr. Bromasas. It looks to me that if you had a State man there in the business for eight months in a comnty he should be able to attend to that mopping-up work.

Mr. A sumsos. Do you have to keep one man hanging around a herd for eight months?

Doctor Jomusi. ()h, no: we have one man in eharese of two or three of these comties. Wr have only 220 inspertors employed in these 10 or 11 States. The States have 203 and the comnties hare 1.64 employees. who are practical cow men.

Mr. Bucinas. They have one in almost every county? 
Doctor Morruer. The States and counties employ almost 2.000 men, and our inspectors test the rats, supervise the rork. and direct the laymen who are reporting to them. These local fellows know the owners of the herds very well, but sometimes they do not find ticks on ticky cattle. Our men are made responsible to see that when a herd is released the last tick has been caught; that is our work. We are making great adrancement in Texas: in fact. we have made more adrancement in 'Texas in the last year than we have in the previons five years.

Mr. Buchaxax. We have a law on the statute books that if they do not dip, suit. can be brought against them and they can be fined or put in jail. too.

Doctor Monurr. That is true, and some of them have gone to jail:

Mr. Axnerson. Are you going to have to spend $\$ 500,000$ a year to keep them clean after you get them cleaned up once?

Doctor Mornuer. That territory has not been cleaned up. Mr. Chairman, as I explained before.

Mr. Andersor. Some of it must be. You have been at it for 10 years.

Doctor Monner. Some of it is cleaned up. Here is a map that will show you where it is cleaned up. There are hundreds and humdreds of counties in these 15 States that are absolntely tick free. Tou are probably familiar with this map. But there is always a possibility of reinfecting a cleaned territory.

Mr. Buchasax. You have not answered Mr. Anderson's question. When you complete the job, how much of this appropriation will be necessary then?

Doctor Momler. When we complete the clean-up?

Mr. Buchanas. Yes.

Doctor Mohuen. There will not be any of it required.

Mr. A nofros. 'That time will never come.

Doctor Monder. It came with California. Kentucky. Missouri, and Tennessee.

Mr. Andersox. If your statement made today is correct, the time will never come.

Doctor Monusk. We were working in 521 counties last year. and 220 of them were entirely cleaned up, which leares only 301 for this current vear. It certanly has been true with the Strites that $I$ referres to. All of sonthern ('alifornia from Sierra Madre to the coast was infested in 1906, and there has been only one recurrence of the ticks since that time. We think it is only fair to release a territory that is 95 or more per cent clean in order to wive some encomragement to the men that have done the wise thing by dippiner their eattle properly. The only other thing we conld do would he to hold a county in quarantine mutil $100 \mathrm{por}$ cent of the ticks lond been killed, and I do not think any sensible man would bolieve that is the best policy. It costs more money in proportion to lierp inspection on two or three infested herds in a clenn urea, but that is the only satisfactor'v and feasible thing to do.

Mr. Axmison. If it has eost $\$ 500.000$ to clean 11 p 300 combies that you have been orer three times-

Doctor Mombli. No: it has not cost that

Mr. A ximisox. It has cost too much money. 


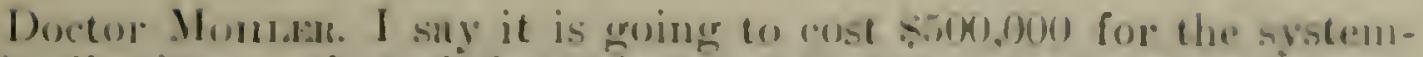

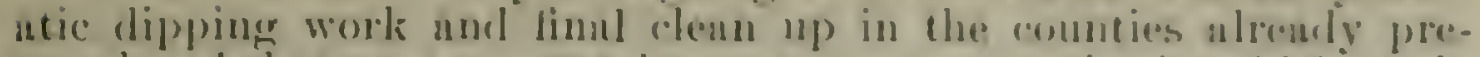
pared und that we enn not take on any new onuntes in which on do educutional work, which work we ulways plun to do a vear before we take up intensive spstenatic dippingrs.

Mr. Bucusxax. In other words, you are groing to spend the uppropriation in stnmping ont the tick intensively in certain counties and mopping up) in others?

Doctor Monter. J'es. sir; it will not do to bite ofl more than we could misticate.

We will have to stop our alvance work and clean up those comnties next year which ure cooperating with us this gear.

Mr. Bucusxas. Yon are only cutting off the eilneational work; that is all?

Doctor Monder. lés, sir.

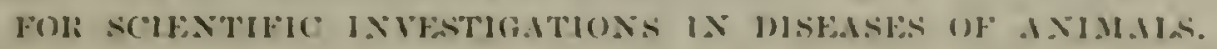

The next item I will take up is on page 6:. " Fop all necessary expenses for scientific investigations in disease's of animals." "This item covers all the investigational work we are cloing on animal diseases, investigations of tuberculin. serums, antitoxins. and other products, and remans the same as for the current year. This is the item under which we are also conducting the work on contagrious abortion.

Mr. Bromaxis. Let me ask you if there is such a thing as contalgions abortion?

Doctor Mondir. Ies, sir; that is the item which is referred to here.

Mr. Beculsax. How are abortions contagious?

CONTAGHOTS ABORTION OF ANIMALS.

Doctor Monuer. There is a germ that is the cause of contanious abortion. You can isolate that germ from the afterbirth of a cow and grow it on media and feed it to other cows that are preanant, and they will abort in four or five months' time. 'The same disease has noir been found to affect pigs. There has been more swine abortion in the last six or eight months than we have ever known before. 'The same germ that affects cattle has been found in swine. producing the same results. and we are now doing considerable work on swine abortion. We find that the living abortion raccine that we have been working on for the last two years in seren or eight herds is producing better results than any other method of treatment. We are also using various methods for the management of the herd in getting rid of the infectious material from aborting cows. We now pay less attention to the bull as a carrier. and we are gretting very satisfactory results with the combined method of herd management and living abortion raccination.

Mr. Axurnsos. At the dairy show my attention was directer to a supposed abortion cure invented by"a man whose name I do not recall.

Doctor Montar. There have been a number of cures alvertised for abortion. One man in Wisconsin used to get a dollar for an 
S-ounce bottle of fluid. We examined it and found it was 99 per cent water and 1 per cent carbolic acid. He made a great deal of money selling it to the dairy firmer's all orer the country until the department published the results. The dairy papers took it up. and now his business has ceased.

Mr. Bromasas. It did no good at all?

Doctor Momser. Not at all.

Mr. Axpensox. This man I spolse of submitted his proposition to your people. and they declined to inspect it. apparently on the ground that it disturbed your scientific work in some way.

Doctor Monder. The only thing I know about the case is that one of our men at the show brought me the advertisement of this fellow, who I understand has a very prominent dairy man in the company with him. What is his name?

Mr. Aximensox. I think his name is C'ushman.

Doctor Monler. The information was brought to me from St. Paul as an advertisement, but he has never submitted. as far as I know, any request to have the medicine tested, or anything of that kind. In those kind of cases we always ask for information as to the ingredients. When these manufacturers of medicines submit their samples to us they usually want a testimonial as to their good merits, etc., but we always request that the ingredients be told to us before we make any investigation at all. Te get those kind of letters from all over the country, probably two or three a week, claiming ''ures for tuberculosis, cholera. Texas fever, roup, and abortion. Some of the letters show such illiteracy you can hardly read them, and yet the writers believe they have absolute cures for these various diseases. I do not know the merits of that individual case, Mr. Chairman.

Mr. Axdenson. I do not know, either.

Doctor Monner. Mr. Cushman is a very good dairyman and a very fine business man. I think he is in a liank up there. too.

\section{ERADICATION OF HIOG CHOLFRA.}

The next item is on page 64 , "For investigating the disease of hog cholera, and for its control or eradication." This work is being carried on in cooperation with 34 States.

Fighty-one bureau reterinarians devote their entire time to hog cholera field work, and, in addition, the inspectors in charge of burean work in 23 States devote a part of their time to it, making a total of approximately 91 department veterinarians engaged in hog choleral work in the field this year.

State regrulatory anthorities, State agricultural collegres, farmers? organizations, live-stock organizations, veterinary practitioners, banker's, pigr clubs, live-stock owner's, and any other or ganization or individual interested and willing to assist, cooperate with us in this work.

Bulletins, articles on the diseases, and press notices of outbreaks, public addresses, interviews with farmer's in the hour lot. posters, lantern slides and moving pictures, are medimms used in our edncational work.

$A$ reterinarian is assigned to a district covering a number of counties. He keeps in close touch with the houg-cholera situation 
in his district throngh contuct with farmers, veterinnry practition-

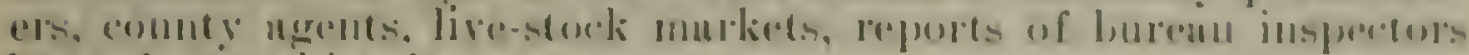
locited ut packing houses, etc.

\section{แH.1'A}

The handling of outhealis of hog choldrat in lareroly left to the depurtment and state fichl reterinurins. On recoipt of a report of an outbreak in his district the lield reterinarian procereds (1) the furm on which the disease hats appeared; he diagnoses the trouble. grves advice in regurd to treatment and the disinfection of the prem-

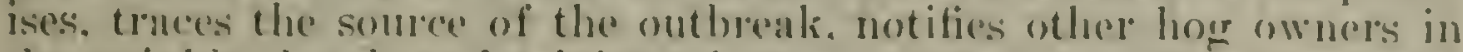
the noighborhood. and adrises them in regand to precantions and the advisability of having their herels immunized, and often assists local veterinarians in immunimg the hoess. In communities where there are no regular reterinary practitioners our field men administer the treatment themselves. Many ealls come from veterinarians who desire assistance in diagnosis or advice in regand to technique, und the farmer has come to rearad the department veterinarian ats a reliable somere of information and andrice when he is in trouble. The money appropriated for next year will be used to calry on this work alonir the same lines as at present.

Mr. Bechasax. Have you grot any vaccine or any character of medicine $t$ be administered to hogs that will malie them immune?

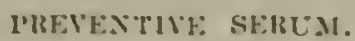

Doctor Monsus. Iors, sir. There is a preventive serum that was discorered in the burean 14 years ago. It is something like the serum that is used for diplitheria in children.

Mr. Bromssis. Is it certinin?

Doctor Monner. Yes, sir.

Mr. Brchisix. Estahlished beyond question?

Doctor Monusk. Absolutely.

Mr. Buchaxax. And any person can use it on a drove of hours and make them immune?

Doct or Mlowlisir. Yos. sir.

Mr. Burmaxas. And they can not gret cholera?

Doctor Munns: Ther (ain not get the choleral if the serum-virus treatment has been properly applied.

Mr. Bromaxis. Does it cost much?

Doctor Mombla. It costs from $1+$ cents to 2 cents a cubic centimeter. There are 40 cubic contimeters to a dose for the areragesime pir. making the cost about io to 80 cents for the serum. In addition farmer's usually employ some one to make the injection.

Mr. Bucrusax. You have to have mole than one injection?

Doctor Monter. One injection of serum and virus is sullicient for the life of the hog. but of course. When new piess are born they have to be injected.

Mr. Ixmatisox. What is the total cost-\$2 a heall?

Doctor . Monnus. It ought not to aremge nearly that much. Mr. Chamman. 'The older the pig is the more expensive it is. When they are little fellows. sucklings of $15 \mathrm{or} 20$ pounds, they an be vaccinated for 50 cents apiece. That is what we have heen trying to get the farmer interested in; instead of waiting until the pigs 
weigh 80 or 90 pounds, we are trying to get him to vaccinate them when they are small. and then he will sare half of his hog-cholera serum bill.

Mr. Axnensos. Do they die as a result of the raccination?

Doctor Monlser. No. sir. Te have vaccinated little pigs which were not more than 10 days old, right into the abdomen-put the needle throngh the abdominal wall so that the serum would go into the abdominal cavity, and they get down and suckle their mothers without showing any discomfort. We had 270 out at the Beltsville farm this spring, and practically half of them were raceinated when from 10 to 14 days old. Te did not lose one. The inference has gotten ont among the hog growers that if they vaccinate a pig before it is weaned it will not remain immune. I do not know how that theory arose, but it is absolutely without any foundation. Te tried to disprove that with these baby pigs at Beltsville, and when they got to weigh about 60 to 80 pounds we took them over to Bethesda where we do our hog cholera work. Tre placed them in contact with virulent hog cholera and we have ret to lose a single animal from this infection, showing they were made immune by being given this raceination when they were 10 to 14 days old.

Mr. Brenasar. What is the name of the preparation.

Doctor Momuse. Hog choleras serum. You inject 30 to to c. c. of hog cholera serum with 2 c. c. of the hog cholera virus.

Mr. Bucharax. They use that virus to give them al mild phase of cholera?

Doctor Monter. Yes, sir. They are then immune forever.

Mr. A xmersox. How many men have you got working in the field on the hog cholera proposition?

Doctor Montek. Eighty-one men work full time on hog cholera and about 23 work part time. All together it wonld make about 91 full-time men.

Mr. Axmfrsox. You have a reduction of about $\$ 100.000$ on that item?

Doctor Morrurk. Yes, sir: $\$ 103,980$.

\section{REDUCTIOX IN APPROPLITIOX.}

Mr. Axpersox. Will you be able to take cale of the work with that reduction?

Doctor Monr.re. Not on the scale that we are doing the work at the present time, but what I plan to do is to recluce the force in these outlying States, like Michigan. Georgia, and Filorida, and up in Montana, Washington. Idalos, and California. Instead of continuing 4 men in Texas and 4 men in kentucky. we will reduce the number there and concentrate the work on hog cholera in the Corn Belt States, where 50 per cent of the hogrs are being produced.

Mr. Annerson. Is this being carried on on an eratication basis?

Doctor Molusir. No, sir.

Mr. A vimasox. You are simply taling care of the districts where that occurs? 


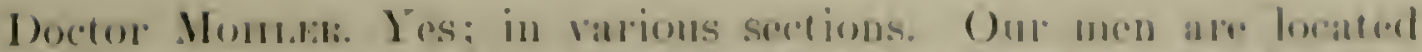
in difforent sections and they are sont to the farms where the disause oceurs.

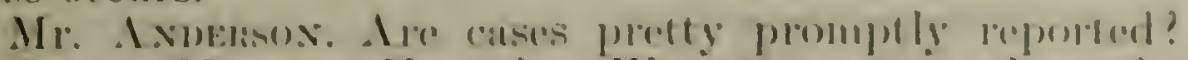

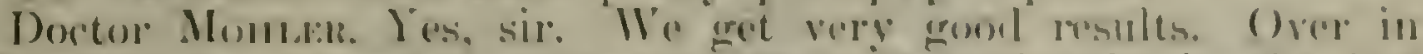
Maryland we have hat probubly 30 or to onthealis in the last three months, and the discase mever spreand from the forms where the outhealis occurred. In Michigan there has been n little momo cholem this hast fall than they had last spring: but in lown and Nebraska the comlitions are mich hettor. It raries: sometimes you will find it better in one state this yent than it wats hast yeatr. and in others you will fond that it was heter last year than it is this yeat. But we are not losing to-duy angthing like what we did fo vents arro on acrount of hour cholern. lear before last the death rate was reduced to 38 hougs per thousand. Last year it reached $4: 3$ per thousand, but that was on accomnt of the financial situation of the farmer last fall.

Mr. A xumasox. You mean t:3 hogs per thousand infected?

Doctor Monder. No: per thousand head of hogs in the comntry.

Mr. I ximasison. That is pretty high.

Doctor Monmak. It has been as high as 130 before this hog cholera serum was usel 10 years agro: but the reason for the increase last fall was on acroment of the fact that the farmer's financial condition prevented him from spending any money on serum. He let. his hous die becanse he did not have enough money to puy for their treatment.

Mr. Bucuaxix. For hog cholera you give them one dose of hog cholera sermm and 2 cubic centimeters of virus: is that it?

Doctor Monulis. Yes, sir. We have done that in hundreds of cases. Of comse if the hogs are sick with cholera before treatment. they are groing to die.

IIr. Bienasas. I mean for those that are well?

Doctor Mnntak. Ies. sir. We have on numerous occasions allowed a number of exposed hous to remain mintreaterl and an ernal number to be treated. and you cond readily see the diflerence. The untreated hogs would die, while the treated hogs remained well.

Mr. Bucmixax. It is a pretty oflective serum, then?

Doctor Momulis. Yes, sir.

Mr. Aximatsox. Ilave you any figures. Doctor Mohler, indieating what the States are spending. and giving the number of men they have employed in this cholera business?

Dexeror Monus. They are spending less than \$200,000 a reatr. and the number of men varies. 'They lave a how cholera prosimam. which is in conformity with on program. If an ontbreak oecurs they draw on the men from some other line of work, if they have no reerular cholera men. The followiner table contains this information liy States: 
Cooperition of sintes with the Burenu of Animal Industry in hor-cholera. control trork.

\begin{tabular}{|c|c|c|c|c|c|}
\hline Names of States. & $\begin{array}{l}\text { Approxi- } \\
\text { male } \\
\text { number } \\
\text { of men } \\
\text { cm- } \\
\text { ployed. }\end{array}$ & $\begin{array}{l}\text { Approxi- } \\
\text { mate } \\
\text { a mount. } \\
\text { of money } \\
\text { ex- } \\
\text { pended. }\end{array}$ & Names of States. & $\begin{array}{c}\text { A pproxi- } \\
\text { mate } \\
\text { number } \\
\text { of inen } \\
\text { em- } \\
\text { ploged. }\end{array}$ & $\begin{array}{l}\text { Approxi- } \\
\text { mate } \\
\text { a mount } \\
\text { of money } \\
\text { ex- } \\
\text { pended. }\end{array}$ \\
\hline 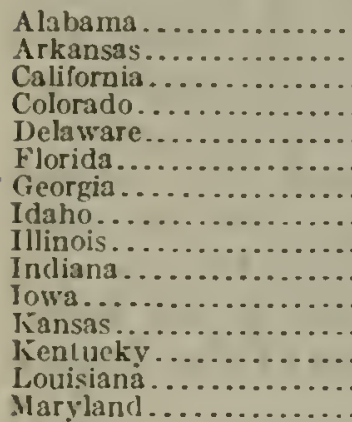 & $\begin{array}{l}2 \\
3 \\
2 \\
1 \\
1 \\
6 \\
7 \\
1 \\
2 \\
3 \\
2 \\
2 \\
2 \\
2 \\
1\end{array}$ & $\begin{array}{r}5 i, 000 \\
5,500 \\
4,000 \\
2,000 \\
3,500 \\
21,760 \\
20,000 \\
2,000 \\
5,000 \\
12,500 \\
4,000 \\
3,000 \\
4,000 \\
25,000 \\
2,000\end{array}$ & 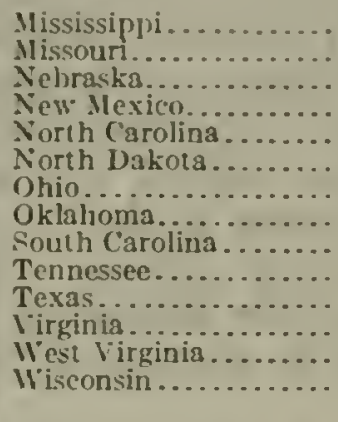 & $\begin{array}{r}1 \\
2 \\
2 \\
1 \\
2 \\
1 \\
2 \\
2 \\
11 \\
2 \\
2 \\
2 \\
1 \\
2\end{array}$ & $\begin{array}{r}s: 300 \\
4,000 \\
4,000 \\
2,400 \\
4,000 \\
1,000 \\
4,000 \\
9,090 \\
2,000 \\
4,500 \\
4,000 \\
3,000 \\
1,300 \\
4,712\end{array}$ \\
\hline Michigan & 1 & 2,000 & & $\pi$ & 195,972 \\
\hline
\end{tabular}

Some States proluce antihog-cholera sermu. while others purchase it and sell it to farmers at actual cost, including hambling.

COMIPLETE ER.LDIC.ITION OF IIOG CHOLFIS.

Mr. Ardersox. You did some eradication work in Texals at one time. Did that contemplate the possibility of complete eradication of hogr cholera?

Doctor Monter. No. sir. I do not think complete cradication is possible under present conditions. I think the cost of completely eradicating hog cholera would be so immense under present conditions that it would be extravagance to try it. It would cost a grealt deal more than probably would be appropriated. The thing to to. I believe, is what we are doing-stop the infection where it originates. and keep it from spreading all orer the comntry. Eight or ten years ago when an ontbreak occurred on one farm it spread to the whole community until a snowstorm or some change of weather conditions killed it off or it burnt itself ont: but to-day a farmer may lave hog cholera on his farm and it will be kept from spreading to his neighbors.

Mr. Axmersos. Is it transmitted by people carrying it on their shoes?

Doctor Monter. Yos; it is not nearly as infections as the foot-andmouth disease. but it is carried in the same way hy hirls. piereons. and doers. on farmer"s boots and elothing. and it is al so carried hy the wheels of antomobiles from an infected farm to other sections. It is very easily disseminated.

Mr. Ixusisox. You have to disinfeet the premises where it orenrs?

Dorotor Mlonlsk. Yo's. That is one essential thing. Our inspectors do not do that, but they supervise the work and tell the owners how

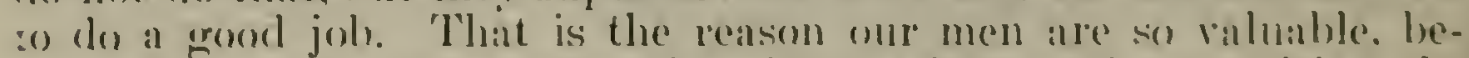
cause they cover bare territories griving andice und supervising the control of tho disease. 
R.STAMIIS WUKK.

Last year with a loug claclera foree of bo velerinarians, there were

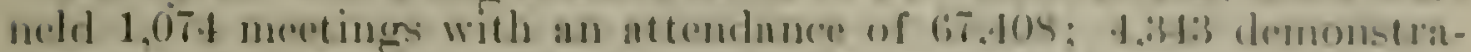
tions in the use of the preventive sermen treatment were matre. wh

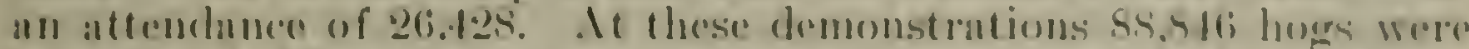
treated, t7.137 investigntions of swine disease were mude. 1.t01 in-

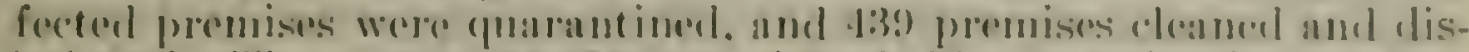

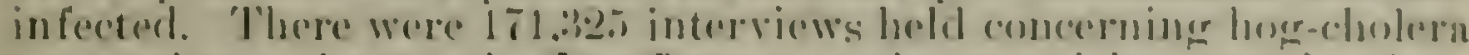

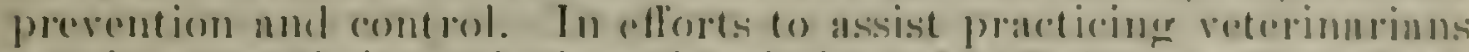

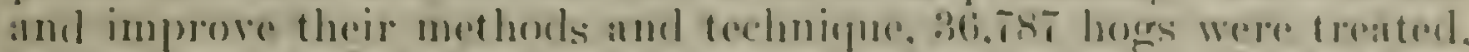
and. in sections where veferinary service was not available. 26f laymen were trained to apply the sermun treatment.

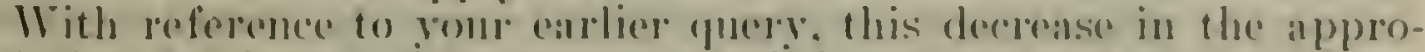
priation for hor choleris, (o my nind, is not groing to be nearly so

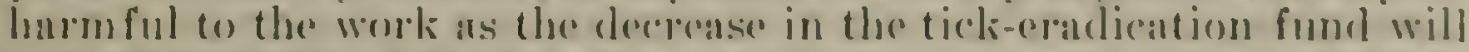
be to that work. I think we can gret alonger far hetter than in the latter case. where the erndiention methods have been perfected in such a way that four can clean the whole comuty or the whole state. for with 'Texas ferer we have an absolute and uniform method of gretting ris of ticks. Inlike with hogr-cholerat germs, we have an absolute knowledge of the life history of the tick and its vulnerable points. by which we can clean thas getting rid of this rery heary burden on the live-stock industry of those combties and states. So there is no comprorison. in my mind. between the eflect of a decrease in hour-cholera fumds and al decrease in tick-cradiention money on the live-stock industry, not only of the south but the North. East, and West. We are taking feeder cattle from the south constantly and there are groing to be all kinds of unrestricted movements of eattle between the North and Sonth when the guarantine line has been shoved into the Gult.

We had a case up in Pennsylyania the other day where ticks were hromght in with southern cattle, the ticks being so small when they left the south that you would have to have a magnifying erlass to ser them. hut when the animals got up) North for slaninter tha inspector found the ticks. Dorinir the time these eattle were on the railroal car the ticks had grown hir enough to be seen on reaching Pennsylvania. So that there will always be danger of spreatine ticks from the South to the North so long as there is a singrle tick remaining in that section.

Mr. Bichasax. You can feel them, all right.

Doctor Monms. Yes: that is true.

Mr. Buchasin. How many little tieks can come from the blood of one tick?

Doctor Mronuz. Inywhere from 3.000 to 4.000 egars are laid at one time by one fomale through her oviduct, as with poultry. These eargs later hatch and profluce the minute seed ticks. which subsefuently beeme attached to the hodies of cattle.

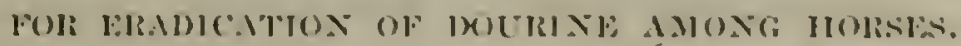

Mr. Axmbasox. We will now take up the jtem on patre biti. "For all necessary expenses for the investigation, treatment. and eraclicattion of lourine."

Mr. Bronswax. I would like to inquire as to what that is? 
PROGHFSS OF WOHI.

Doctor Monur. Dourine is an infections disease affecting breedingr horses, and is similar to syphilis in man. Continued progress is heing made toward the final elimination of this disease. A new ontbreak in South Dakota, involving about 2.000 animals. was the most unfarorable development of the year. A considerable number of riseased animals are still found on Indian reservations in Ari\%ona, but even there the number of such animals is being gradually reeluced. The work in Arizona has not progressed rery rapidly owing to the difficulty experienced by the Office of Indian iffairs in se:mling the promint slaughter of diseased animals. It is understood that this difficulty was due, in part at least, to insufficient funds to indemnify the Indians owning diseased animals. Out of 14.54? horses eximined only 243, or 1.6 per cent, were found infected and were killed.

This. Mr. Chairman. you will remember, is the same trouble that occurred last year. It is difficult to gret the Indians to carry out instructions from the Office of Indians Affairs.

Mr. Bucravas. So you just kill them when you find them?

Doctor Monler. Yes, sir. That is the only way to stamp out the disease.

Mr. Bromanas. It is like the kindred disease in the human family?

Doctor Monlew. Yes, sir ; it is.

Mr. Buchavas. Youl can not cure it?

Doctor Mohler. No.

Mr. Buchavax. Is there any 606 for horses?

Doctor Monusi. Yes; but these horses are worth only \$35 or so apiece, and while 606 might probably cure them, it is too expensive.

Mr. A xpensox. Are we going to get rid of this finally?

Doctor Montis. I expect, Mr. Chairman, that this disease will be entirely cleaned up in two year's' time. Last year I said three years. and one vear has passed, so $I$ have reduced it to two years.

Mr. A vimelisox. Yon are still insistent?

Doctor Monler. Yes, sir.

CONSTRCCTION WOHK AT BHITSIHAL, MD.

The next item, the one that ocrurs on page $6 \bar{t}$, will be lliscussed by Doctor Larson, regardingr the Beltsville dairy barn coustruction.

MEAT INSIRCTION.

The next iten is for meat inspection, on page 69. This is the lurere work of meat inspection that is beingr carried ont by the department. undere the 1906 law. 'There is a proposed decrease next rear of

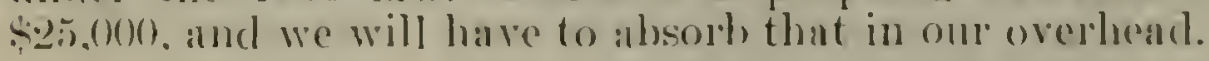

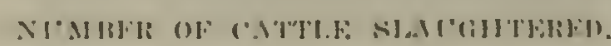

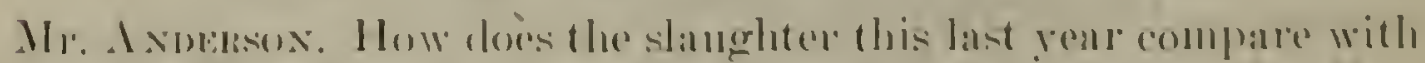
prior years!

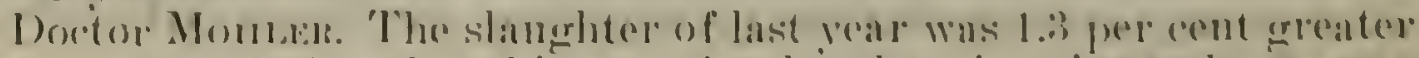

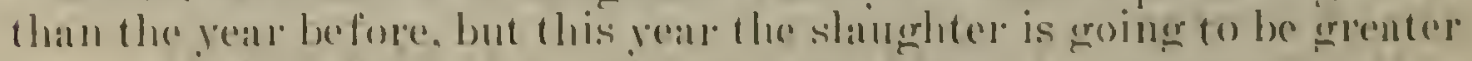


by far than any year we have had, exeept 1919, when we killed Fio.(o), (o) live sioces.

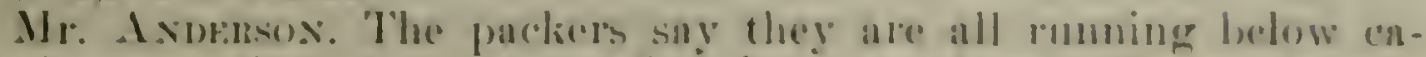
pacity and that the consumption is away down. How ran you uccomint for this increnserl slunghter in the fure of the lower cons. stumption!

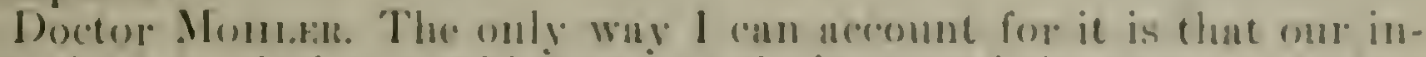
creasing populntion is taking are of the increased shungter, althomph the pere eapita consunption las decreased. 'This last yen the slumghter totaled $603,0(00,000$ animals, and that is abont 1.3 nore than the 1921 slanghter. In .June, July, and August of 192:2 the slanghter of hogs was mach higher than diring the same montlis of any preceding year. 'There are more hogs in the comntry now than there have been for several years, and the packers are slnughtering them, and alio cattle, rather fast just now. So with the prospects of increased slaughter we are gong to be handicapped by the decreased appropriation for 1924 .

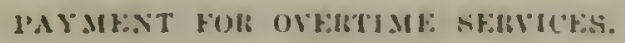

Mr. Axmersos. I have a sort of nebulous recollection of some legistation we passed. muler which the pacliers paid orertime for part of this inspection.

1)octor Mombar. Yes: that is rerre true. That was in the rear 1919. By this bill the overtime of the meat inspectors is lefrityed by the parckers. who give therr checks to the secretary of Aericul. tire. and he in turn pays the inspectors who work overtime. The inspectors are paid at the rate of one and one-half the regular pay for week diys and double pay for holidays and Sundays.

Mr. A xurmos. Did that only apply for that year?

Doctor Monder. No, sir: that has been for every year since.

Mr. A ximerson. 'That is still in eflect?

Doctor. Montres. 'That is still in eflect.

Mr. Axbrasox. How much was paid by the patckers under that last year!

Doctor Mondist. Alont $\$ 216.000$.

Mr. A vomas. There will be as much as that or more this year?

Doctor Montras. It will he al little more than that, becanse there is more killing being done this fill. and there will be more this winter than there has been for several yaurs past.

Mr. Jusu. According to my understanding of the matter, the present plan is that in a short time the department will work up an estimate based upon such realgenment of forces in the meat-inspecetion force as I octor Mohler can bring about to be submitted through the Budget Burean as a supplemental estimate. to cover the time berinning with the next fiscal reall of the money necessiry to employ the additional employees that might be required in the meat inspertion so as to do away wh that overtime. and thiss accomplish the same thing contemplated by the bill. We are not in position to make that estimate yot. but there will he something later. 
- Doctor Monns. If this bill rere reintrodnced, passed, and signed by the President, it would mean that from that date until the 30 th of June om men would have to work overtime and get no pay for it. unless we could gret some remedial lecrislation passed.

$M r$. Axumsox. They get time and a half on week days and double time on Sundays?

Doct or Mormir. Yes, sir.

Mr. Axprasox. Somebody would sare some moner if they did not have to do that.

Doctor Monsin. The packers wouli!. you mean?

Mr. Anmmison. Yes.

Doctor Monnsi. Yes, sir.

Mr. Axmersox. It would be a saving. It must cost considerable money to do this on the basis of orertime. Do you gret your recrular employees to work for regular wagres on Sunclay?

Doctor Monleri. No; not at present.

Mr. Axnmsox. So you would not save anything on Sunday work. would you?

Doctor Monsuli. In case we paid overtime. youl nean?

Mr. Axperson. Yes.

Doctor Monusk. I figrure that if we paid for the extra work we could gret along with about $\$ 180,000$ instearl of $\$ 210.000$ that the packer's pay, because the Government cloes not pay double time on Sunday or one and a laalf time for regular day work. We would employ a man at so much a month, and if the packing house was occasionally opened on Sunday he would have to le there. so it would cost the Government less than it is costing the packers: but I do not believe that it is advisable to change the orertime law until Congress provides otherwise for the extra work. When the law was passed the packers had to pay for all the orertime. and at first the men worked many extrat hours, but later. with reduction in killing. they doubled up and were paid less overtine. The packingr-house business decreased from 70.000 .000 animals slanerhtered in 1919 to (i5.).000.00(r)

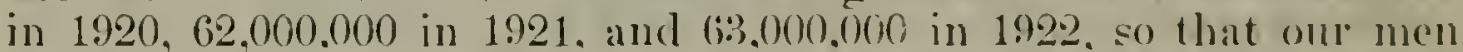
have done a great deal less orertime in the last 12 months than they did at the beginning.

Mr. Bucmaxax. Suppose this law was repealed and the department had to supply its labor, would you supply it hy means of orertime or by new employees?

Doctor Monzliz. Largely with new employees.

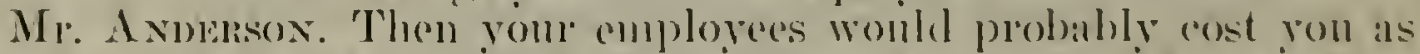
much as time and a half and overtine. beeanse you would have them on the rolls all the time, and these others wobld have just al little overtime?

Doctor Mornds. But many of the meat-inspection men who work so hard during the heary slaughter in wintertime are taken ofl the inspection work in the spring and go out and work on ticks, cholera. tuberculosis, seabies. and other seasonal work. We would not hure that peak load to carry throughont the four seasons. 
Mr. Asmansox. What I am trying to gret at is mhethere it is must economical when you have a litte overtime and pay un compleyer. that extra, or whether it would be more economical to hase more employees?

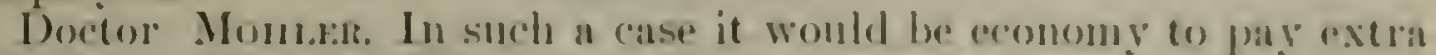

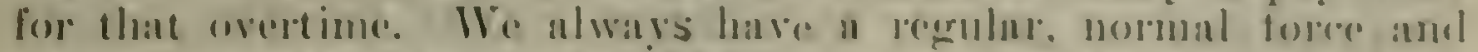
we would expect them to do a little orertime in conergencies without extrn pay. It is not a question of a litte or oceasional orertime. but where the insperetors work long hours, starting at $7 \mathrm{in}$ the morn-

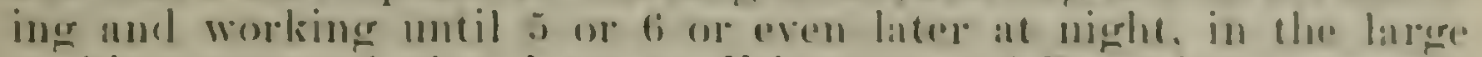

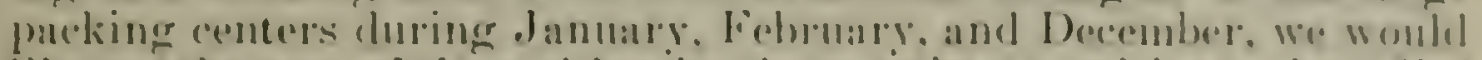
like to take eare of them either by the overtime provision or by relief employeres.

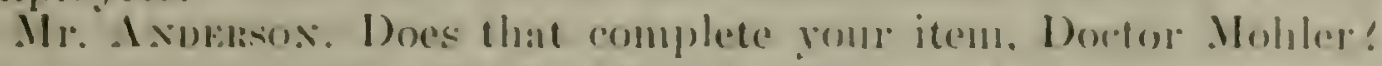

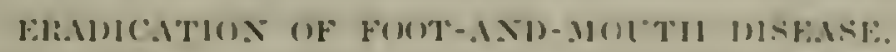

Doctor Montwr. There is one more item on page :3209. for foot-andmouth disease. which has been referred to. The assignment of experienced veterinary inspectors at public stock yards to make careful inspertions for symptoms of this discase is being contimued. Suspected cases of animals in any way resembling foot-and-month clisanse. reported as affecting susceptibile animals any where in the country, are promptly investigated by veterinary inspectors who are fumiliar with the symptoms of this disease.

At the present time when live stock is being moved from one country to another outside the usual channels of trade and foot-andmouth disease is appearing in countries formerly free of the disease, it is most important that extra precautions be taken to guard against the introduction of this disease into the Enited states or to detect the disease in the event it should obtain entrance into this country. Under this project an average of about 5,500 a month is being expended. larrely to pay the salaries of the reterinary inspectors referred to alove at public stock yards.

Iast Augrust a disease having certain characteristics of foot-andmonth disease was reported in the Island of Jamaica. We do not know low it got in there, but we found out through one of the reports of the consul at Kingston that they harl a peculiar discase which they called calf diphtheria in several of their Provinces, and we surmised it was the foot-and-month disease. We traced shipments of material from Jamaica into this country and found at that very time there were three or four humdred hides and sereral bales of sheep and goat skins on the docks at New York. In order to prevent any infection being brought into this comntry we ordered the whole careqo back to Jamaicas, disinfecterl the docks at Xell Iolk City and ordered an embargo on similar shipments. Latter on. duringe October. we learned that the discase harl finally been diagnesed as fout-and-month disease by the Jamaican anthorities. That just shows how close a comntry cain come to being exposed to an ontbreale of foot-and-month disease and yet escape. 
Tuesday, November 21, 1922.

NECESSARY EXPENSES FOR INVESTIGATIONS AND EXPERIMENTS IN DAIRY INDUSTRY.

\section{STATEMENT OF DR. C. W. LARSON, CHIEF OF THE DAIRY DIVISION.}

Mr. Anderson. We will now take up your first item on page 5S. "Necessary expenses for investigations and experiments in dairy industry," etc.

Doctor Larson. Mr. Chairman, the work of the dairy division is planned along the same general line as has been going on this past year. The appropriations are the same, and the program is the same. The work is divided into three general classes: Investigations of the production of milk; second, the manufacture of products of milk; and third, the introduction in the States of the results of these investigations.

LINES OF PRODUCTION.

Under the head of production our work is along three lines: First, nutrition; second, breeding; and third, herd management.

In the nutrition work we have made splendid progress during the past year, especially in studies along the line of mineral requirements of dairy cows. It has been found that the old standards of feeding. which have included the fat, proteins, and carbohydrates, do not satisfy milk production. It has also been found that animals may not lose in weight and may not immediately go down in milk production, but we know that some change has taken place, so that even in the next lactation period there may be a very great reduction in milk, and for this study it is necessary not only to know the milk produced but to make thorough digestion trials, and for this special equipment is necessary. We have the organization for doing this work. We have a splendid corps of investigators and we are especially anxious to have a place in which we can carry on this nutrition work.

BREEDING OF ANIMALS.

Mr. Anderson. Is this nutrition work carried on at Beltsville?

Doctor Larsox. Yes, sir.

Mr. Avoerson. Is that carried along with breeding animals?

Doctor Larson. As far as it can be. In the bresding work we ale now on our third generation of animals, in which we are attempting to establish some definite basis of improvement of our cattle. There is no known process of breeling that we know will produce animals of high production and do it minformly. We have spurts of high production, but it has nerer been unform, and we have various theories and we alde tring to work out some principles on which we can improve our catte.

Mr. Axolemson. I think there you have there kinds of hreeding?

Doctor Larsox. Yes, sir. We have the comparison of line hreeding with outerossingr; second, comparison of inhreeding with outerossingr. and third, the breceling of a pure strain of high production by eontimuous use generation after generation of sires that have proven 
ability for high production. In other words, wo believe that it is possible to use sires that have been proven as producers of a large number of animuls of high production, and conecntrute that ubility. We also have a fourth, an which we ure nttrompting to prove or disprove what is known us the "nicking" theory, hy combining blood of right distinct fumilies.

Mr. A.vilstox. What is the theory?

Doctor Latesox. The theory, which is praneteced hy most of our breeders, is that unless you use animuls that ure fairly closoly related there is danger of reducing the production of the funily. 'Thut is the genernl proction throurhout the country in buying a sire, to buy one that is fairly closely related. or that crirries some of the same blood, and not get blood that is from distinctly different families. In the Iersey brecding we have at lenst eight distinct prominent fanilies, and we are mating those in a way that will make it possible to bring together in the third generation animals with the blood lines of these eight distinct fumilies in egunl proportions. In ench generution we cain compare these onterossed animals with the animals that are bred within the families und determine whether the "nicking" theory holds good.

Mr. Bucunas. You menn eight related families?

Doctor Lansox. Eight unrelated families that are distinctive families in themselves.

Mr. Becusis. Of the sume stock?

Doctor Lansox. Of the same breed. This work will take considerable time, but we think that it is fundamental and will be very useful throughout the whole country. It is a project that a state or a breeder could not undertake. Wth our dairy cattle producing a product that last year had a farm value of $\$ 2,400,000,000$, and the efficiency of the cows that produce that product depending largely upon their inheritance for large production, we behere that these experiments should be carried out to establish methods of breeding whereby the inberitance for large milk and butter-fat production can be transmitted with grenter uniformity.

INCREASED PRODUCTION THROUGH SCIESTIFIC MA.AGEMENT.

In the manngement work it has been shown that by extra methods of care and feeding animals it is possible to incrense production 60 per cent. We have now kept a number of animals four yenrs. The first yenr we kept them under ordinary farm conditions: the year after that we kept them under what we call adranced registry conditions, or special care, and the third year we put them back to general farm conditions, and the fourth year into the adrnnced registry conditions, and we have been able to increase them as much is 60 per cent on the avernge. Now we are undertaking to determine which one of the steps in the different care contributes the most and how much ench step contributes to this incrense.

Mr. Andersos. What is the different care given?

Doctor Larsox. The general fnrm trentment includes keeping the cow in the ordinary stanchion, feeding her the ordinary feeding standard requirement, and milking twice a day. The adranced registry conditions include keeping the cow in a box stall, feeding her 
three times a day and milking her three times a day, and, in ense her production is above 75 pounds a day, milking her four times a day.

Mr. Anderson. How does the added production compare with the increased cost of maintenance on the advanced registry basis?

Doctor Larsox. We are studying ench of these steps to determine the amount of increase, as well as the net cost. We have gone far enough to say that in the East, where straw is relatively expensire, the additional bedding required in the box stall and the labor involved in putting it there and taking it away just about balanees for the increased production. The box stall, therefore, is not an economical proposition with us in the East.

With feed under the condition of prices that prevails in Maryland, where we have this farm, and with the price of milk obtaining here in the East, it is profitable to feed the additional feed that was given under the advanced registry over general farm conditions. We compared those figures, however, with conditions in one of the western farms, and it was not economienl, because the additional milk did not pay for the additional feed used. So that the feed proposition depends upon the price of feed and the market, and there are all gradations down, depending upon the price of milk and feed.

In a similar manner we are studying the various other problems of management.

Mr. Anderson. That seems to me rather out of line: an increased production of 60 per cent, it seems to me, ought to pay for a good deal of additional feed, unless the cow was starved to death first.

Doctor Larson. It does pay for a good deal of feed.

Mr. Anderson. I can not see, if the additional feed produces 60 per cent, that you would not make any money on the initial production of the cow.

Doctor Larsox. It is not only the feed that is necessary to get the $60 \mathrm{per}$ cent; I said, the hox stall, the milking three times, and sometimes four times a day, and feeding three times a day. In the case of milking we found that with cows producing a fairly good amount of milk, there was considerable profit in milking three times a day over two times. The increase in milk paid for the additional work and left some balance.

Mr. Anderson. In determining these costs, how do you get at them, all on the basis of paid labor?

Doctor Inarson. Oh, yes.

Mr. Anderson. It would not necessarily follow that the farmer who was running his own farm and not cmploying labor, could not. use a little extra energy and milk his cow three times a day and use the extra feed required to increase production?

Doctor Lanson. No; but these results are stated in terms of unit requirements; in other words, so many hours or minutes of labor during the month, and the farmer can decide for himself whether or not he will do that for 10 cents an hour or 15 cents an hour or 20 , depending upon the prices he would have to work for in order to get this return. The same is true of feed. That is riven in terms of units and not dollars, so that he can convert to his own conditions.

Mr. Axmenson. 'There is a good denl of possibility of being misled in this matter? 


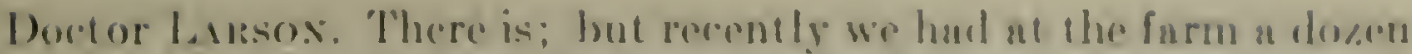
of the lending dnirrmen of this country, und this munnement work whs explained to them and they were internety pleased with it, and nre putting it into practice, much of it. Nist only is it pontise, but we have negntive results as woll. fo other worda, perople nesume that if you put a cow in a box stall you get more milk, nnd somes people are remodeding their burns on the hasis of that. It is shown that it is not economienl to do that. but people will do it where ther

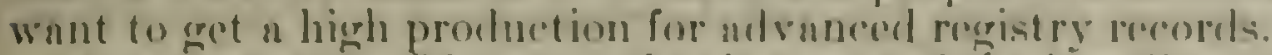

Mr. A.rofusos. Of course, that is a purt of tho breceling and solling proposition?

(1)

Doctor Lansox. les, sir. In the luborntories we are working with various products of milk, including ice cream and cheeses of various kinds, condensed and evaporated milk, and also the milk itself for direct consumption. One of the importsunt products in connection with this is the manufacture of foreign rarieties of cheese. Normally we have been importing as much as $60,000,000$ pounds of cheese, while we only manufactured $300,000,000$, and this checse that has been imported is of a kind and rnrieties that sell at the highest prices; and in these laboratories they have perfected a method of making some of these varieties as well as they are made in the foreign countries.

Mr. Axmmsox. Is it possible to find experienced cheese mukers in this country, plenty of them?

SCARCIT) OF EXIPHEXCEU MFX-CIFESE INDUSTRY.

Doctor Lamsox. No, sir; especially not men who know how to make use of these improved methods.

Mr. Axinsesox. I hare come across one or two eases in my trarels uround the country where there appear to have been failures of cheese factories, due lnrgely to the fact that the people opernting them did not seem to have the experience necessary to carry on the business successfully, and I thought that there renlly was not an ndequate supply of experienced cheese makers in the country.

Doctor Lxussox. No: I will say there were not, and especially men who could make the foreign rarieties.

Mr. Axnensox. Do they require any particular quality of milk?

Doctor Lansox. Yes; that is true especially of Swiss cheese. The other varieties do not.

Mr. Axinersox. They require a higher butter content, or what?

Doctor LAmsox. No; most of them require a low butter content. Swiss cheese is usually partly skimmed from the normal milk. In fact, you can not mnke Swiss cheese from the avernge milk in this country, becnuse it is too rich. As far as butter fat content goes, that can be taken care of, with nny of these products. Swiss cheese, however, requires a particular organism that will develop the eyes and the particular flavor that goes with it, and the laboratories of the dairy division have isolated the organism that produces the eyes and the flavor, and by the use of that organism they are able to change the making of Swiss cheese from an art into n science. Cip to this time and at the present time in most of the Swiss cheese factories 
in this country it is entirely an art, and the results are uncertain. For every hundred pounds of Swiss cheese you buy you must pay for a certain number of pounds that are destroyed that do not come out. You must pay for a certain other number of pounds that are sold below the cost of production, and probably in this country not over 60 per cent of the Swiss cheese is of high quality. But by the use of this organism they are able to get as high as 80 , and in some cases 90 per cent of high quality Swiss cheese.

Mr. Axdersox. Where does the dairyman go now to learn cheese making?

Doctor Larsox. The colleges, a few of them, are tenching cheese making. I can say in connection with this particular work that we have what is known as the introduction section. The introduction section of the dairy division is working to put the results of these investigations into the hands of the manufacturers, and it does it in this way: 'They make Swiss cheese, or any other variety. There are several rarieties of Italian cheese that sell at the higliest price, which we are now making in the laboratories. After we have gone far enough to be satisfied that we can make a particular product we go to Grove City, where we have a factory under our control, and we manufacture that product on a commercial scale; and when we hare done that we invite the manufacturers to come there and send their cheese makers there, where they can get all the information we have about the product.

Mr. Axperson. How long do they have to stay there to learn it right?

Doctor Larsox. For one variety it would not take very long. If they are good cheese makers to start with and are willing to change from their old methods, in two or three months the men can get in shape to make it very satisfactorily. We carry that on in this way; for instance, the State of Wisconsin makes most of the Swiss cheese, and they say, "Well, now, we would like to make that cheese. to make a better product," and so we enter in to an arrangement of this kind. We say to the State of Wisconsin, "We will put a man in there for one year or two years to work in five factories, not more. You put a man there to go along with this work, and at the end of that time if we have demonstrated by those four or five factories that this is the proper method, then you take it up and extend it throughout the State."

\section{UTILIZATION OF MILK AND BY-PRODUCTS.}

The work of the laboratories also takes up the matter of the utilization of milk and the by-products. We liave an enormous quantity of by-products from our creameries and cheese factories, which are not now well utilized. An example of what was done in this: In the past year the men in the laboratories have made a product known as soluble albumen. This has never been made before, and has met with considerable faror by manufacturers. 'This product is made from whey at cheese factories.

Mr. Axnenson. What is it used in?

Doctor Larsox. It is used in various food products, some of which we do not know as yet; but it is used where albumen is needed. Persons suffering with certain disenses require albumen foods, and 
we are prepuring fouds for such persons and using this produst, and ure using it in prepared flours and things of that sont used for cooking. In other words, we ne trying to utilize more products and muke them nvinilnble.

Mr. A.volsesos. I moticed you have some extension items on the question of cow-testing und bull-nsisociation work.

Dochor Lansols. Yos, sir.

Mr. Axumesos. What relution does that have to the general extension work?

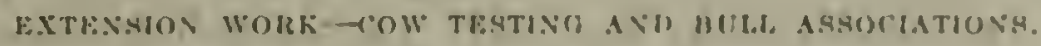

Doctor Larsox. This cow-testing and bull-nssocintion work wo hare been doing cliffers from general extension work in that we do not extend the regular nssocintion work in the States except so far as to slow the people of the State how this work can be douse. In other words, in vour neighborhood recently the romuty ugent wis not sold to the iden of a bull nssocintion. We think that is one of the best and cheapest and surest ways of improving the general cittle of this country-through the bull-nssocintion work, so our man who is in the bull-nssocintion work goes to your State extension man nnd goes aromil the county mond arranges a survey of the county and calls on a number of the farmers and he finds that they are in terested in establishing a bull association. 'This county agent did not know the constitution nud by-lnws. He did not know the difliculties of orgnnization and keeping it going afterwards, but the department man worked with this man long enough to establish an associntion. He mny do it in some other part of the State.

Mr. Ardensox. Do they not have people in the State colleges who do thint?

Doctor Larsox. They do after you have shown them how. In other words, we have men who study bull associntion work, make it a specinl study for a year or two. A college man, if he were going to drop all of his other work for a year, as would be necessary to learn all the ins and outs of the bull associntion work, could do it, but he has something else to do, and our mun establishes one or two nssocintions and goes to some other State. That is the line he is doingnot to extend it all over the State as the extension work used to be. It is simply showing the way and letting the State do the rest.

Mr. Arinersox. This fellow operates as a specialist, as I understund?

\section{CONSTRUCTION OF DAIRY BARY.}

ANIMAL NUTHTHON WOHK.

Doctor Lansox. Alssolutely. I briefly outlined the work we are doing in nutrition. 'This is fundamentil work in animal nutrition, and it is not simply fecoling animals in the ordinary sense of the word, hut it is actually detcrmining us far as possible just what becomes of these feeds and what are the precursors to milk. "We also study the blood.

They are discovering proteins, for instance, that are more valunhle than others for milk production. You may take a feed and analyze it and find it contnins a certain pereent age of protein, and tuke nnother 
one and find that it contains the same amount by analysis, but you will not obtain the same results, because this different protein has rarious amounts of amino acids in it, and results seriously on the milk. We have found that some of these proteins are necessary in some parts of the milk, and in one circulation of the blood as much as 30 per cent of some these are taken out; in other words, in passing through the udder. We are satisfied that some of these factors are limiting the production of our animals. I also said that it is necessary to get a balance of the feeds. It is not simply a problem of determining the amount of milk you get out of a cow to-day, but orer a period of time throughout the year. On simply the record of the milk production for a lactation period it is impossible, we find, to take that and learn what she is going to do the next period. We have, therefore, started what we call digestion trials in which we analyze the feed, the milk, and the urine and feces, and in that way we can get a definite idea as to what is happening to the feed and milk during this digestion period. While we are making these careful tests, it is necessary that the cows be kept away from the herd. Our barns now are used for breeding barns and we have no places for this nutrition work.

Mr. Axdersox. Will you have to buy animals for this work?

Doctor Larsox. No, sir: we have our animals increasing in our breeding herds, and we will not require additional animals for nutrition work.

INCREASE IN HERD,

Mr. Avpersox. How much has your herd increased in the last four or five rears?

Doctor Linsox. In the herd at Beltsville we have increased, perhaps, in the last four or fire rears, from $S 0$ to 1.50.

Mr. ANnersos. Do you sell any of those animals at all?

Doctor Larsox. Up to this time only those that have become sterile or unfit-unproductive. Up to this rear the foundalion stock of the breeding herd-many of them will have completed their records. We have gotten the imeasure of the foundation animals -that is, we know what they will produce, and we have their soms and daughters, so that we can dispose of those animals. We feel the work in animal nutrition is going to be handicapped very materially unless we can get a building for it.

Mr. Axpersos. $\$ 20,000$ ought to build-

VEEI) FOR LAIBORATORY BUHIING.

Doctol Larsox (interposing). It is not an ordinary barn: it is a lishoratory. It is the nutrition huilding, with places for the cattle. special stalls and deviees for making these tests. and the laboratory rooms for mixing the samples and storing them. 'This is rery intricate work. We have to be sure we are usine the same foed, for instance, throughout al whole period. 'That means that that feced is all mixed carefully in thousinds of poumds and put alwy calrefully, and the same way with the hay and other mixal feeds.

then the urine and fores are collerefed carrefully and mixed and sampled, all requiring safo and sperial teratment. "Wo have humdeds of 


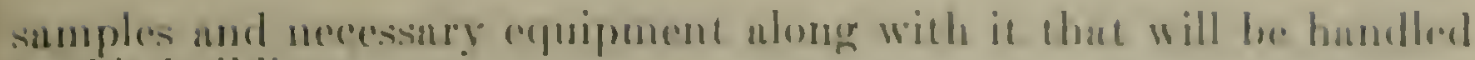
in this huildiug.

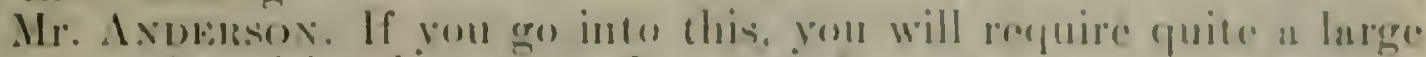
number of melitiomal mon lou, I sippposer?

Doctor Latrsox. No. sir: those hare largely heren provided for alrealy. I hope eventually we shatl-

Mr. Asmposox (interposingr). I mu skepticul uhout putting any more buildings on this Boltsvillo phare.

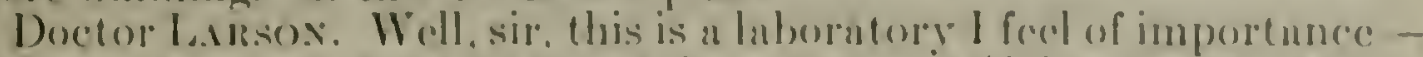

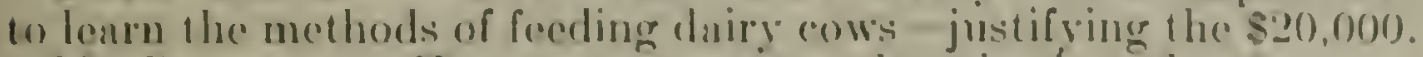

Mr. Burmasis. How many acres are there in thut places

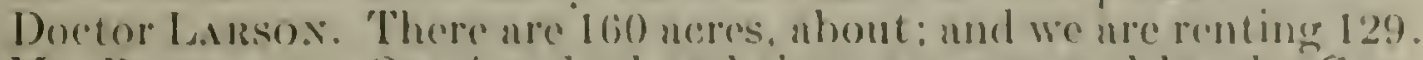

Mr. Bremaxa.x. Ono humberl and sixty acres owned by the Gor(irismont?

Doctor Istasos. Ies, sir. 'That is one of the dairy farms, upproximatoly that.

Mr. Asmbasos. Vou have gut 5150,000 worth of huildings on it now?

Doctor 1.ubsox. No: wo have only spent about hulf that amount. I think wo have very simple perminent buildiners. Nothing rlaboinite.

Doctor Montar. The farm has increased 100 pere cont in vinlue since we purchused it. It hus been a money-making propositionroc doulut of it.

Mr. Axmbssos. I should think it would be from the nmount of monoy" you halve put on it.

Doctor labsox. I think the results pry for it.

Mr. Axmersox. I think it is about the poorest land I crees sum.

LXIFIRIMENTAL PARM SELF-NUSTAINING.

Doctor Larsox. Part of it is pool. but we are rasing rery antisfactory crops on it now and lawe been for several reats. and I may say, si) far as the farm is concerned. that every year for the last soveral rears the farm itself has heon self-sustaining.

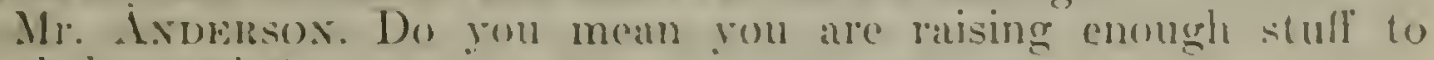
feed the cattle?

Doctor Latisox. No, sir: I mean we aro raising enough stuff to pay for the eost of producing the feed and running the farm. I mean thiv fmu itself.

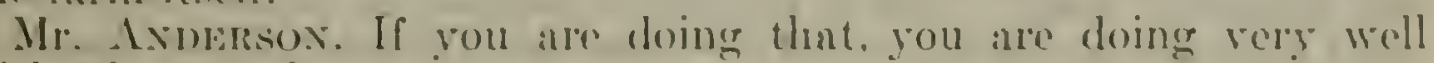
with what you have got.

Doctor Linssox. I think we are.

Mr. Bucmisis. He is just holding his own-not making anvething or not losing anything, hut just standing there.

Doctor Lamsos. Thut is right, and, as Mr. Anderson says, that is veris enod.

Mir. Ixmersos. Hois big is this harn going to he. Doctor Latronn?

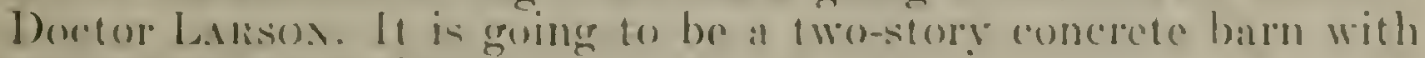
basement and one wing.

Mr. Aninilisox. Fire-prouf rouf !

Doctor Lansox. No, sir, not " fireproof roof hut it will be ceilad inside so that it will be anirly fireproof.

Mr. Buremaxis. Ceiled with wood or lumber? 
Doctor LArsox. Lsually we use metal laths and plaster. This barn will provide feed storage also.

Mr. Axinersox. Does the $\$ 20,000$ include the equipment?

Doctor Lansox. Well, there will not be very much equipment required - just the building.

Mr. Annersox. If you are going to keep all your animals there and you are going to keep all your equipment recessary to collect the urine and feces you have got to have some other equipment. have you not?

Doctor L.ıRsox. We hope to take care of that out of our regular farm funds.

Mr. Axdersox. How many animals will there be in this milk test?

Doctor Lansox. There will be about 24 in the general preparatory work going into the stalls and perhaps not over 6 or $S$ for the special digestion stalls for certain definite periods during the year.

ANIMAL IIUSBANDRY IXVESTTGATIONS.

\section{STATEMENT OF MR, E. W. SHEETS, BUREAU OF ANIMAL INDUSTRY.}

Mr. Sireets. The animal husbandry investigations pertain to all other classes of animal, except dairy animals - beef cattle, hogs. sheep, horses, and poultry. There are three items - three projects - which are being emphasized here, for which slight increases have been asked in the total 12 projects. The first one is that of genetic research. Genetic research, up until about two years ago, consisted of work with guinea pigs almost exclusively, for the purpose of working out certain fundamental principles in geneties. We believe that these problems have given us certain facts pertaining to inbreeding and cross breeding that we wish to confirm with respect to the larger animals. We have two projects-one with swine and one with poultry-which will require the services of a specialist to keep the technical and voluminous data on weights, gains, and other information until the experimental animals are mature. This will enable us to determine certain facts which have practical value to stockmen. This item provides only the $\$ 3,000$ for the salary of a specialist. There is now being spent on genetic research $\$ 10,065$.

The other item pertains to nutrition researeh, which is divided into two phuses of work. One is for the investigations with reference to meat animals, including poultry. One line of investigntion connects up with the various phinses and studies on soft pork. The other is for projects other than soft pork, which inchude poultry, animal fibers, and certain other nutrition studies to determine the values of feed in connection with other animal husbandry projects. It is not for starting new projects but for continuing projects now under way just a little further with these same animals which will reguire veri little more feod. In other words, we wish to ntilize the animals which we now have in other experiments, and the same facilities, merely (arrying them a step further to gret ont of them all there is in the way of informmlion. 'This would reguire sis,ss() for the ment investigutions, inchuding poultry and eggs. That would be nsed. $\$ 3,00($ for a specialist and $\$ s 80$ for items of equipment and haboratory supplies, and \$2,500 would be used for an assistant in the chemiral luborntory to assist with the chemicul analyses in the soft-porli work. 
Mr. Axmersox. How far have you got with the soft-pork work? Have you got anywhere yet?

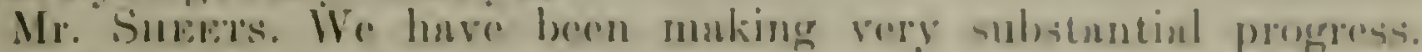
The work has been arriod on in connestion with 10 experissene stations. ulso in connection with the Institute of Amerioun .Mone Packers. With reference lo results oftained we have mude very substantial progress this your. I do not state that wo have solverel any one phase of the sofe pork problem but I belicre what work we have done will have gone a long way in throwing light on the matler when the data is finally worked up. In other words, feed represents one of the cunses of soft pork; und hougs which once become soft harden with great dilliculty. At the live stock experiment farm. at Now lberia, La, it was found that the feeding of rice products and molasses, nnd at the Constal Plans Stution, at MeNeill, Miss., the feeding of sweet potato by-products had hurdening effocts on soft hoges, and that feeds like peanuts and soy beans produce pork soft in charneter.

The other item of $\$ t,, 300$ is for making slight improvements in the abatcoir and laborntory. That is the abuttoir and laborntory where this work is done.

Mr. Axmensox. Where is it done?

Mr. SnEvrs. It Beltsville, MU. 'That is, the slaughtering work is done there. 'The hogs are shipped periodically to this station, three or more at $"$ time out of each test lot. for slaughter and general analyses. The lnboratory was not built originally for this work, merely being converted for this purpose. It is too small for handling the work satisfactorily. For instance, if we have a large hog we can not hang it up in the abattoir to cool without first cutting off its head. Whenever one is required to handle two pieces, for instance, the hog and its head, weighing them, to determine the shrinkage after cooling, it increnses the work and at the same time increases the possibility of error. What we want to do is to elevate the ceilings of the cooling rooms about a foot or 18 inches so that they will accommodate the largest hog that is likely to be killed in connecwith this work.

'There have been no modifications of the abattoir or repair' work done on this laboratory within the last six years.

Mr. Arvprsox. Where do these hogs come from?

Mr. SnEws. They come from the cooperating experiment stations. The states that are cooperating in this work at this time are Alabama, Georgia, Kentucky, Intiann, Mississippi, North Carolina, Oklahoma, South Carolina, and 'Texas.

Mr. Aximessox. Go ahearl.

Mr. SuEETs. That covers the three principal items for which we are nsking increases.

Mr. Bucnasix. The three increases?

Mr. SHlitrs. Yes, sir.

CLARK COLNTY LAPERIMETAL STATION, IDMHO.

Mr. Axpersos. Where is this sheep ranch you have? It is somewhere in Idnho?

Mr. Sneters. At Dubois, Iduho a special sheep runch. The United Stutes Sheep Experiment Station at Dubois has an aren of 
$2 S, 000$ acres of typical western grazing land that was withdrawn from settlement by order of the President in 1915. This area is sufficient to maintain the 4,000 breeling ewes which were contemplated when the project was started, but has not been realized as yet. We hare at the present time about 1,500 breeding ewes, 50 mnture rams, about 100 ram lambs, and 5.50 ewe lambs, or at total of about 2,200 head of breeding sheep on that ranch. We had expected to adil about 2.500 ewes, to bring this up to a total of 4,000 ewes of breeding age needed for the proper study of range-sheep problems. When we bring this up the returns will more than pay for the upkeep and maintenance of the station. In fact, with the 1,500 ewes of breerling age, 550 ewe lambs, and 150 rams during the last year there was a gross return from this station amounting to about $\$ 25,000$, including cash turned in to the 'Treasury' and the inventory value of young stoek added and of wool on hand at the close of the rear.

Mr. Andersox. What was the cost of operation!

Mr. SneEts. The cost of operation is about $\$ 2 \$, 000$.

Mr. Buchavix. That does not mean any improrements at all?

Mr. Sheets. That does not mean any improrements.

Mr. Axdersox. Were there any improvements made on the place last year?

Mr. Shefts. Yes, sir. We are completing the reserroir for the water supply station which has been one of the things that has been needed ever since the station was established in 1915 . Te built 12 miles of fence and added more room to the laborer's cottnge.

Mr. Andersox. If I remember aright this $\$ \$ .000$ immediately available covers the buildings out there on that sheep ranch. What are you going to do with this next rear? The chairman of the Agricultural Committee is very jealous about any construction, so I want to know what the reason for spending this $\$ \$, 000$ is.

Mr. SheErs. There is one item that has been needed and is now very greatly needed which we have an opportunity to put in in cooperation with some other ranchmen at a considerable saving of money, and that is the electric power for lights and for other power at that station. 'The neighboring ranchmen-the Wood Lirestock Co., I believe it is -are putting in their poles for this line and with our participation we will be able to get our power for something like $\$ 1,000$ to $\$ 1, \$ 00$, while if we put it in alone it would cost severnl times that.

Mr. Anderson. Where do you get the power from?

Mr. SneEts. From the main line between Dubois and Spencer.

Mr. Axdersox. Do you use it for electric lights onlr?

Mr. Siners. For electric lights, for pumping. for the preparation of feeds, for the filling of silos, and for general farm-power purposes.

Mr. Avdenson. Are you producing anything on the ranch now except grass?

Mr. Simers. We have been producing some corn and some sunflower's. 'That has been the chief task there, to get enough foed other than roughage like hay. In fact, it is the problem of the ranchumen everywhere, but we have been very suceessful with sunflowers and fairly successful with corn, and I believe as time goes on we will have gotten the land in shape in the way of stones and other obstacles, so that it will produce a little more.

Mr. Buchaxan. Is this rocky land? 
Mr. Surers. There are plenty of them there. It is volounic land

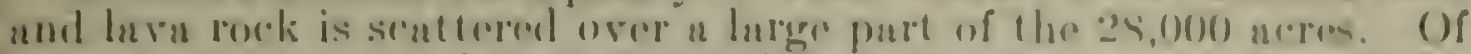

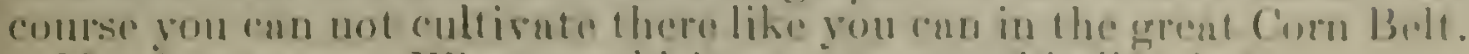

Mr. A.roressos. What would it cost to pert this line ist?

Mr. sinerers. The oldosest mstimnto is right uround $s 1,0(0)$.

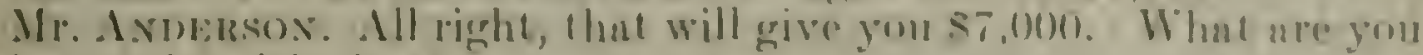
groing 10 do with that?

Mr. Surers. 'lhore is about 20 miles of fonee that ought fo lue put up to rnable us to hamblle these shere) in flocks of the propere size, for the correct conduct of the broeding and granging incestigntions.

One of the grrentest merds at that station right new ontside these other itcons is for a place for the man in chargere to live.

Mr. Axdersox. I have been hengine that, I hink, for four or live

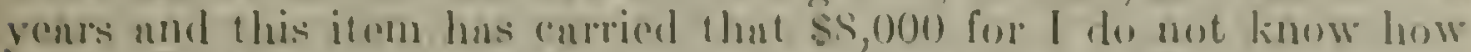
long. If that is so important why do vou not build it?

Mfr. Sukets. We have nerer hud the authority fo put up this residener for the superintendent. We have put up ons for the foremen and we put up one for the laborers-that is the laburers bunk house you might call it - but have never had the atuthority lo construct the house for the farm superintendent.

Mr. Buchasax. Where dues he stay?

Mr. SHEves. Ho stays in a two-roon slatel, with a little poreh and an oflice biack of that.

Mr. Bechasax. Is he murried!

Mr. Snevts. Yes, sir. We just lost the superintendent of this station, and it is partly due to the dissatisfaction of his family with the conditions. It has been a great loss to the station and the sheep industry that he left the section.

Mr. Axurrsox. What will this house cost you?

Mr. Snevets. By using our own facilities, as we can do (we have all the construction facilities and farm labor), we can put up a good house there to keep a good man there, and there is not anything clse to keep him, for around $\$ 4,000$.

Mr. Andersos. How many men do you keep employed out there?

Mr. Suents. During the summer season, including all men and the man in charge, we have about nine. During the lambing time we incrense that by two or three herders, as necessity demands.

Mr. Jusr. Dr. William A. 'Tinylor is here, if the committee desires to finish these miscellaneous items.

Mr. Armersox. Does this fuish animal hushandry?

Mr. Jump. I think so.

Mr. Axversos. Does your genernl statement, Doctor Mohler, cover the work done under this animnl industry item?

Doctor Monler. Yes, sir. 
Friday, November 17, 1922.

\section{BUREAU OF PLANT INDUSTRY.}

\section{STATEMENTS OF DR. WM. A. TAYLOR, CHIEF OF BUREAU, AND DR. KARL F. KELLERMAN, ASSOCIATE CHIEF, BUREAU OF PLANT. INDUSTRY.}

Mr. Anderson. We will take at this time salaries, Bureau of Plant Inclustry, on page 72 of the estimates, beginning with the statutory roll.

Doctor TAYLOR. I have a brief summary statement, summarizing the general character of the work of the burean, which it will not be necessary to read, probably, but which might in the record of the hearing be helpful, in that it covers any particular points which are not covered in the explanatory notes relating to the changes in the appropriation.

Mr. Anderson. Without objection, it will go into the record without reading.

('The statement referred to and submitted by Doctor Taylor is here printed in full, as follows:)

\section{General Statedent of Work.}

The work of the Bureau of Plant Industry is almost entirely of an investigational character, devoter to acquiring knowledge concerning fundamental principles governing crop production and crop utilization. The burean activities inclurle the improvement of crop plants by selection and breeding: the introduction of important varieties of fruits, grains, forage crops, and other plants from foreign countries: the investigation of destructive plant diseases and the development of methods for their control: and the carrying on, in cooperation with States directly concerned, of special campaigns for the control or eradication of epidemics of unusually serious plant diseases, such as hlack stem rust of wheat, citrus canker, white-pine blister rust, etc.

The burean carries on experimental work in all sections of the Lnited states, frequently upon land furnished by State experiment stations or controlled under lease, in addition to the permanent field stations, the most extensive of which is the experiment farm on the Arlington estate in Virginia. In cooperation with the Reclamation Service of the Department of the Interior, agricultural experimentation is conducted on the irrigated lands of the Government reclamation projeets. A seed and plant exchange service is conducted hetween experts of foreign countries and American experts. The bureau supervises the purchase and distribution of vegetable, flower, cotton, tobacco, lawn-grass, and drought-resistant seeds, and of bullss.

The complete activities of the bureau are too complex for detailed statement. A brief selection is here presented to show the general scope of the hureau's work: this statement is supplemental to the explanations for increases or other changes that are jresented in the estimates.

CONTROH, OH THE WIITE MINE BLISTER RUST.

White pine blister rust is a destructive plant disoase that reached Anerica about 1900. It was introduced from Europe on infected white pine mursery stock, which was planted in many places in the eastern Luitol States. In 1913 it was fomml attacking native white pines, but its wide distribution was not suspected until the late fall of 1915, when the rust was discovered on elurant and gooseberry hushes and white pines over a large area in II assachusettsand Now Hampshire. Since then practical measures have heen developed for the control of this disedse inder easteru conditions, which

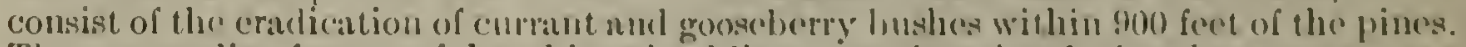
The ontstanding feature of the white pinc hlister rust siluation during the past vear was

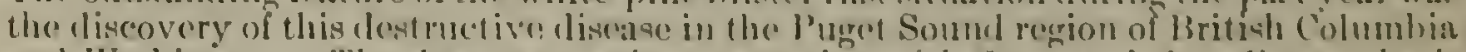
and Washington. The departuent, in cooperation with stale and ('analian an hori-

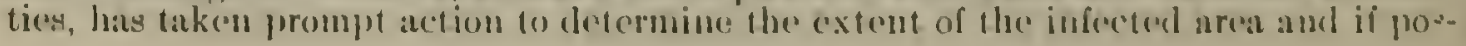




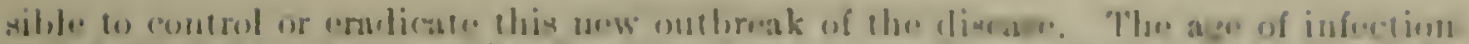

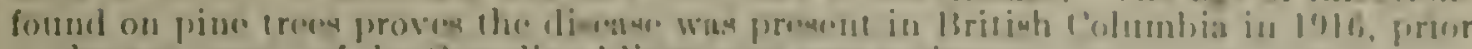

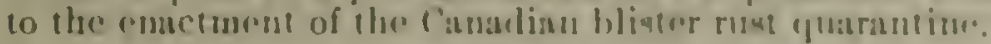

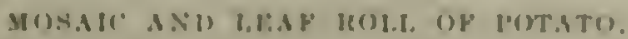

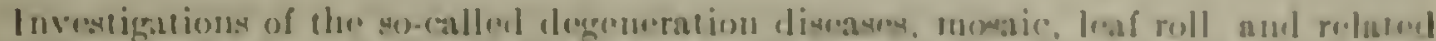

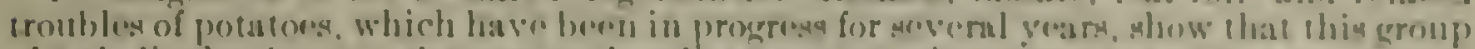

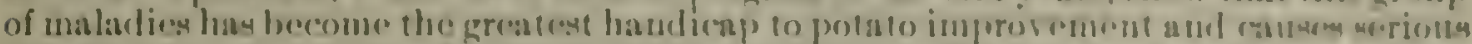

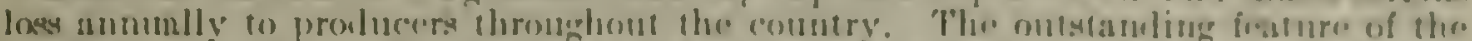

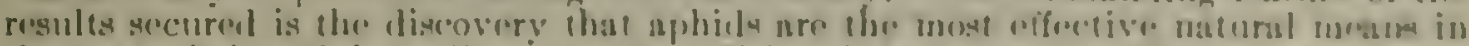

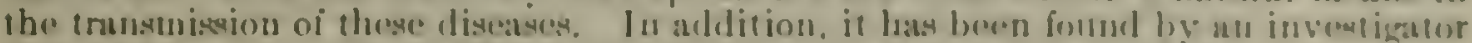

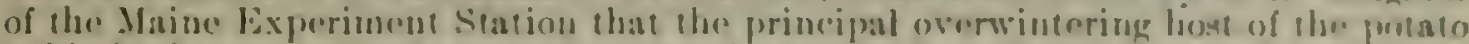

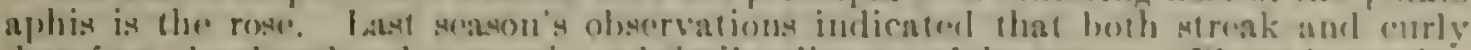

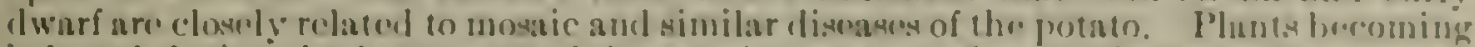
iufected doring the latter part of the growing seaton. when further geowils has prace

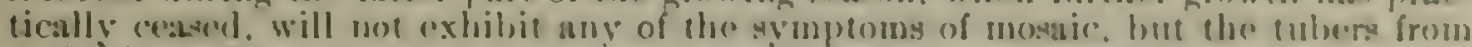

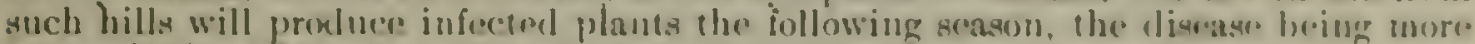
severe if the stiected stock is planted in the south. Iast se:aron's rexperimentson control of mosuic by rogning conlims previons results. showing that roguing under

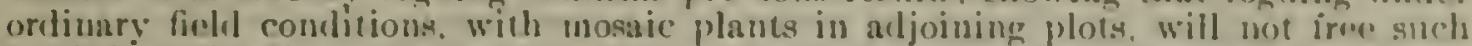
stock from the discase. hut will tend to reduce the pererntage of diseased plants, providenl it is done thoronghly and continued throwhont the season.

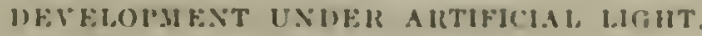

('ontinuing the investigations on the effects of the relative length of day and night on plant growth, fairly extensive experiments have been undertaken on thr rewponse of woody perennials to this inetor, especially with reference io such problems as the basis of winter hardiness, the natural distribution of plants, and their llowering and fruting habits. Application of this proress to a number of species shows that initiation of flowering and fruiting and other characteristic responsens to differences in duration of the daily illumination period are brought ahom as rearlily with arlificial illumination as with sunlight.

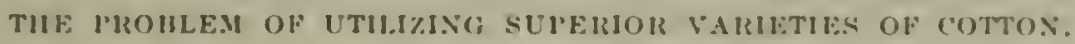

On account of the present organization or lack of organization in the cotcon industry, most of the seed is inferior, and there is no assurance of any general utilization of good varieties. Methols of breeding and acclimatization have been dobeloped and demonstrated, but other requirements must be met if a full utilization of superior varieties is to be secured. The discovery and development of a series of superior varieties, including the Jone Star, Trice, Iolumbia, If ade. Durango, and Leala, make it possible to place the different regions of the cotton belt on new planrs of improved production, and all these varieties are being grown as extrnsively as the available supplies of good seed will permit, but the inaleyuary of the present sistems of providing anuual supplies of planting seed is also being recognized and methods of improvement devised. Eilorts are being made, thereiore, in avoid the general mixing of seed at the public gins, and crossing of the different varieties in the fields. which undoubtedly are responsible for the rapid and general deterioration of secd stocks that tend to keep our producing induatry on a low plane of efliciency.

RUMHER.

The need of developing home supplies oi rubber is becoming recognized, in view of the danger of complete dependence on the remote liasi Indies for this essential raw material. It is known that several species of rubber-producing planta can be grown in the United States, if practical methods of utilization can be clevised. The central Anerican rubber tree (Castilla) is consiclerel inierior to the l'ara rubber tree (Hevea) ior the purpose oi commercial cultivation by methods employed in the Fisat hulies. but Castilla may have a sprecial value in developing rubber reserved in tropical America. Such reserves of rubber should be available in regions contiguous to the United States in case of emergencies that migh, inferiere with communication or with the production of rubber in the Fast Indies. For emergency use, Castilla would have an advantage in vielding its latex more readily. 
BINUER TWINE FIBERS.

The cooperative work with the Philippine Bureau of Agriculture to encourage the production of machine-cleanerl sisal and cantala fiber in the Philippine Islands is resulting in a steadily increasing production of these fibers. The machine-cleaning demonstrations, conducted during 1918 and 1919 with Government-owned machines, were followed by the establishment of machine cleaning on a commercial basis. During the calendar year 1920 , the Philippines produced $70 \%$ bales of machine-cleaned fiber; during 1921, the production amounted to is, 13S bales; and, during 1922, the produetion has been in excess of 1,000 bales per month. With the maintenance of the present rate of production the Philippines will produce, during the calemelar year 1922, approximately $4,000,000$ pounds of machine-cleaned binder twine fiber, ur a supply sufficient to provide binder wine for 2,000,000 acres of grain erops.

\section{SEE! TESTIKKG.}

During the fiscal year 1922 the seed-testing laboratories of the Bureau of Plant Industry received and examined 29,671 samples of seeds. Of these 17.100 came to the Washington, D. C., lahoratory and $12,57 \mathrm{l}$ to the five branch seed-testing laboratories maintained in cooperation with the State institutions. These samples represent both vegetable and field seeds from farmers, seed lealers, and investigators. to whom reports of analyses were sent showing the presence of weed seeds and worthless material, or germination, or both, as requested.

\section{CEREAL IMPROTEMENT.}

Increased yields of wheat, oats, and other cereals, as well as an extension of their range, have been secured by the introduction of new types from foreign countries and by selection and breeding work, both by the State stations and by the department. During recent years the most notable wheats are probalbly Kota, a bearded, hard red spring variety, resistant to stem rust; Kharmont, a high-yielding selection of Kharkof hard red winter wheat, especially desirable under Montana conditions; Ilard Federation and Federation, two varieties of white wheat suitable for the Pacific coast area, and the rust-resistant Durum wheats, which outyield other varieties in the spring wheat belt and are satisfactory for the mamufacture of semolina, although not for the production of first-quality macaroni.

\section{BARBERRY ERADICATION FOR TIL CONTROL OF BLACK STLM RUST.}

The campaign for the eradication of the common barberry in order to control the black stem lust of wheat was begun in the spring of 1918 and is now in its fifth year. The eradication area comprises 13 of the north-central wheat-growing States, namely, Colorado, Illinois, Indiana, Iowa, Michigan, Mimesola, Montana, Nebraska, Norih Dakota, Oliio, Soutl Dakota, Wisconsin, and Wyoming. All of these states now have enacted legislation requiring the removal of common barberry hushes. The campaign is conducted in cooperation with the State agricultural college in each of the States, with the State department of agriculture in most of them, and with the conference for the prevention of grain rust. Investigations of the time, rate, and manner of spread of rust from harberries, made during the summer, give additional evidence of the enormous losses directly traceable to individual bushes and hedges.

\section{CORN MISLAASES.}

Investigations conducted in several States on corn root, stalk, and car rots show this group of cliseases to be responsible for reductions in vield of marketalule corn, ranging above 30 per cent. Control measures are heing developed from both the standpoint of seed selection and field management. The most feasihle control measures thus far developed are careful field selection of secd corn ears before frost. proper curing and storing of these ears, and a further weeding out from this selected stock of those ears showing disease in germination lests.

\section{CIIOROSIS DUE TO MAONESIUM HFFICIRAY.}

In further work on the significance of magnesium as a constituent of fertilizers for tolacco and other crops it has been found that corn, like tolucco, dovelops chnmeter. istic patlological symptoms on certain soils when magnesium in onitted from the 


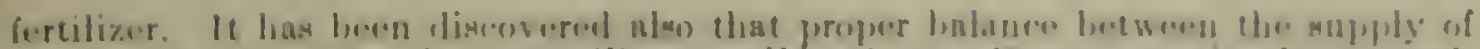

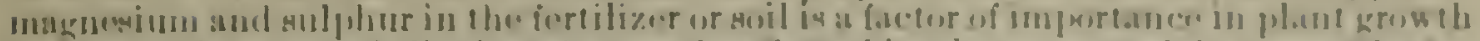

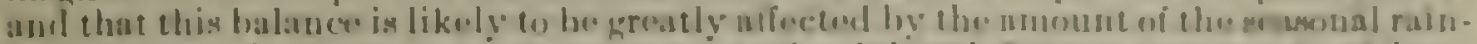

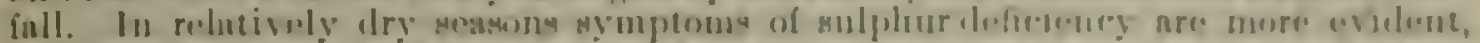

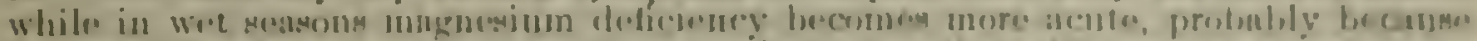

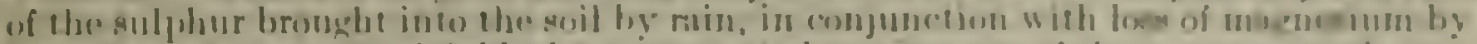

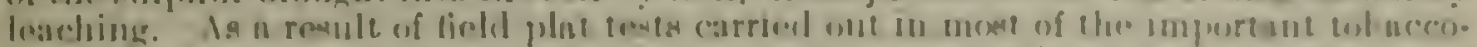

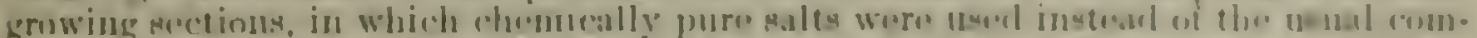

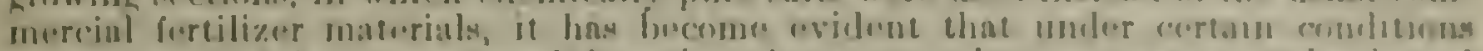

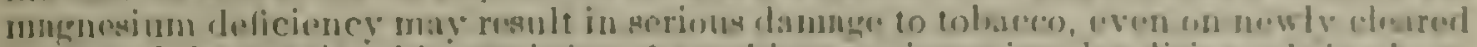

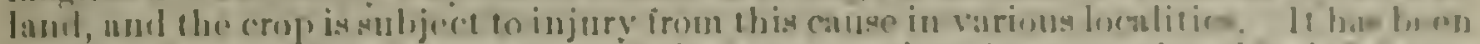

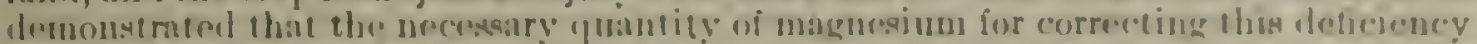

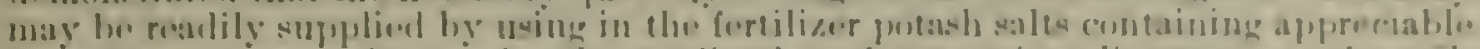

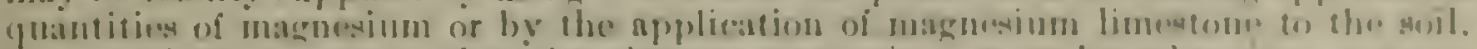

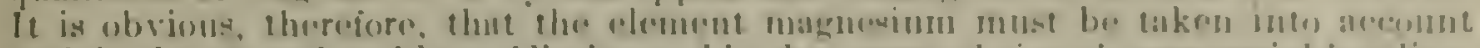

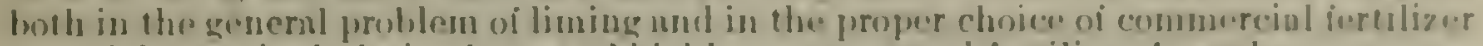
materinls, particularly in the use of highty enncentratul fortilizer formulas.

\section{MUOAII+CANE MOAAIC.}

Masaic disease of cane has bern iound in each of our eane states and creery fielul has bern inspected and the degree of infertion, if any, has bern determined and recorded. Some of the States are croperating with us in the control of the mosaic alisease in the eane areas. 'The discase has here reducerl practically to the point of elimination in parts of P'orto Rico and in the eastern aud peniusula part of forida, where roguing advocated hy the Bureau of l'ant Industry has been pricticed aceorling to directions.

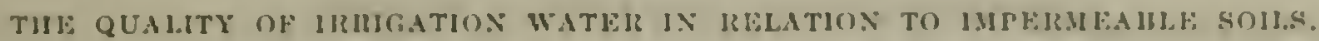

luvertigations hare been continued on the signiticaner of the salts diesolverd in irritrtion water in rendering heavily irrigated soils impers inus. The application of calcium sulphate or gypsum in small (puantitirs serves to jrevent the injurious cffects on the soil of the irrightion water that is deficicut in calcium and manesium salts. The eame trestment is often heneficial slowly and to a limited extent in correcting conditions of impermealility that already exist. When the condition of imprermeahility is serious the action of the gypsum is often very slow becase of the fact that it is not very soluble. For such conditions it has been found that aluminum sulphate is more effective than calcinmsulphate in flocenlating the soil colloils and making the soil more permeable to irrigation water.

\section{CONDITIONING OF CITIUS FIUUTS.}

It is becoming an accepted fact that some citrus fruits reach their highest edib)e quality hefore their color changes from a chlorophyl green to the orange or yellow shades of color which the consumer and the public generally have come to aseociate with a citrus fruit in good edilule condition. If such iruit is allowed to remain on the tree until it develops the desired color, it may lose in edille quality and, hesides, it may be possible to market it 10 much hetter advantage at an earlier period. This is truo particularly of Satsuma oranges and one or more early-ripening varietics of orange grown in Florida. Considerable sttention has therefore bicen given to the working out of practical methods of hastening the develojment of a ripe color of such citrus iruits. While this work has been in progress for several years, its commercial applicution has been given particular attention during the past vear. The method of procedure is to confine the fruit in a compartment which can he made practically air-tight and to suliject it to the products of incomplete combustion of kerosene or gasoline.

\section{NURFIF STOCK INVLSTIOATIONS.}

In view of the fact that this comtry has been so lependent upon foreign sources for many of its fruit stocks, the attempt has heen made to tind out whether Imerican sources of seel and Anerican-grown stocks may not be produced which will have all of the merits of the imported stocks. For apples, at least, it appears that satisfactory seed supplies can he found, and ly a new method of propagation from rooted cuttings it appears that very satisfactory type of stock probluction for nursery purposes can he very mpidly developed for certain purposes, heing probahly about as ecunomical as the production of the sectlings. Similar methods appear to be applicalule also for rose and pear stocks. 
NEW VEGETABLES.

Work on the introduction and establishment of the dasheen, chayote, and tropical yams has been carried forward and many experimenters have been supplied with material for propagation. The market for dasheens is growing, not only anong our foreignborn population who have been familiar with these vegetables in their early homes, but also among native Americans. Commercial shipments totaled about ten carloads last season. A bout 350 persons are this year growing yams experimentally and for market, from propagating material supplied by the bureau. The chayote, a subtropical vegetable of the squash family, is now produced in commercial quantities in some of the Southern States, and the department is cooperating with dealers in northern eities who desire to bring this new vegetable to the attention of the Anerican public.

FORAGE INVESTIGATIONS.

Pasture and meadow investigations are of unusual importance in that they represent under present conditions the cheapest form of animal feed. Improvements in pastures and meadows have come largely from the introduction of improved species from abroad. For example, molasses grass, introduced by the Burcau of Plant Industry in the southeastern United States from South America, is beginning to be utilized by stockmen. The Mung hean, velvet bean, and soy bean are well established and adding materially to the quantity of forage produced in the areas where grown. Investigations by the bureau of the relative value of imported red clover seed in comparison wits domestic clover seed show that, in general, the imported red clover seed is more liable to winterkillings, and also more likely to die after the first cutting following the winter season, than plants grown from domestic seed.

DEMONSTRATIONS ON RECLAJATION PROJECTS.

Demonstration work has been conducted the past year on 11 Federal reclamation projects as follows: Minidoka, Idaho; Umatilla, Oreg.: Uncompahgre, Colo.; Huntley, Milk River and Sun River, Mont.: Shoshone, Wyo.: North Platte, Vehr.Wyo.; Belle Fourche, S. Dak.; Newlands, Nev.; and Yuma, Ariz.

\section{SALARIES.}

REDUCTION IN NUMHER OF EMPLOYEES.

Doctor Thyol:. On page 72 of the statutory roll there are changes which in total involve the dropping of 17 statutory places, covering $\$ 15,900$, the transfer out of the Bureau of Plant Industry to the Secretary's roll of two places at $\$ 720$ each and the transfer into the Burean of Plant Industry from the Bureau of Agricultural Economics of four places at $\$ 1,200$ each. This transfer in is necessury to complete the transfer to the Bureau of Plant Industry from the Bureau of Agricultural Economics of the fruit and vegetable transportation and storage investigational work. 'The lump appropriation for that was transferred last year, but, through oversight, the transfer of four statutory clerical places that belonged with that work was not made. This covers that. So that the net change in the statutory roll of the Bureau of Plant Industry involves an apparent deceease of $\$ 12,5 \cdot 10$ but an actual decrease of $\$ 15,900$.

Mr. Bucmanax. These dropped places-17 of them at $\$ 900$, ne there not?

Doctor 'Tarior. 'There are seven at $\$ 960$ and six at $\$ \$ \$()$

Mr. Bucnaxix (interposing). Tou need not state thom, mess you want to give them.

Doctor" 'T'a yzor. ()ne at $\$ 1,080$, there at $\$ 1,0: 20$ onch.

Mr. Buchaxa.s. 'These aro not filled now, are they?

Doctor 'Tareor. They are places which have becil intermitently filled and racated, places whore we have had tomporary poople for 
parts of the year at varions times, and we figured that we could protect that intermittent need in other ways.

Mr. Bucmana.s. In other worda, the saluries have beren low and it has been hard to kerp anyborly in there, and those planes have been vencant most of the time.

Doceor Throors. I fair proportion of the time; some of them most of the time.

Mr. Becomaxa. And you concluded there was no use in kerping the places open?

Doctor 'Tritor. You, sir.

Mr. Becuasas. They would have been dropped whether you had any of this reorganization or not?

Doctor Trusom. They are convenient in that they do not involve encroachment on our lump fund at the times when we need people, but we ran, we fignere get ulong without them.

Mr. Axnersos. There is one item I want to ask you uhout nt the bottom of this page 72 . You have 88 laborers at $\$ 720$ conch reduced to S6. Those are two that were transferred to the Secretary's roll?

\section{FOR INVESTIGITION OF PLANT IISEASHS ANI) PATIIOIOCICAL} COLLECTIONS.

Doctor 'Tayor. Yes, sir. The next is general expenses, Bureau of Plant Industry, page 74 - the subapproprintion for investigations of plant diseases and pathological collections, including the maintenance of a plant disease survey: There are changes involving an apparent decrease of $\$ 5,000$. Actually there is no change in the amount of money that will be arailable for the work heretofore carried on. Fifteen thousand dollars is shifted from this subappropriation to the next subappropriation, that for the investigntion of disenses of orchards and other fruits, including the diseases of the pecan, as follows: $\$ 10,000$ heretofore carried by the proviso in this subappropriation for research in brown rot and kindred diseases of peach trees, and $\$ 5,000$ not specifically provided but added to this paragraph at the last session for fruit discases work. The fruit disease of the department is earried in the paragraph succeeding this, and it is desirable to have the funds there rather than in this place. It involves merely the shift of the funds to the unit where the work is done. Partially balancing this trunsfer out of $\$ 15.000$, there is a transfer into this of $\$ 10.000$ from the subappropriation for cereal disease control, which it is proposed to drop. That you will find on page 102.

Mr. Bucmanas. Let me get this clear in my head. You speak of a transfer. You do not mean you transfer an uppropriation alrendy made?

Doctor Tarion. No.

Mr. Bucuasax. In other words, you do not need so much rou have under one item and you knock that off of that item and so you have that much more on another item?

Doctor TAYror. It is not quite that, Mr. Buchanan, in that these funds will be used, if Congress approves of this shift. next rear for exactly the purpose for which they were provided and for which they are being used this year. 'The history of these particular itcms is this-on the floor of the Senate two years ago the proviso of $\$ 10,000$ 
was added for peach disease work centering in Georgia, and it was added to the wrong subappropriation through accident presumably.

Similarly the $\$ 5,000$ which is not eovered by a specific proriso was added last year in the Senate. As it stands it is out of line with the orderly character of the appropriation, and while we can use it where it is it would be better to make these changes in the location of the funds.

Mr. Bucharax. You mean you could use it where it is fol the purpose for which it was intended?

Doctor TaYlor. For which it was provided, yes.

Mr. Buchasan. But now you are attempting to get these aprpopriations that were put under the wrong subhead in the right subhead?

Doctor TaYlor. Yes, sir.

Mr. Buchanas. All right.

Doctor TAYLOR. So that the apparent net decrease of $\$ 5,000$ in this paragraph, which results from these two shifts, does not change the amount of money available for the work now being carried on. It merely shifts it to another place.

\section{FIUIT DISEASE INVESTIGATIONS.}

On page 76 the paragraph for investigation of orchard and other fruits, including the diseases of the pecan: As a result of the shift I hare just mentioned there is an apparent increase of $\$ 19.000$. And this $\$ 15,000$ is that which I have discussed: $\$ 4,000$ is desired of actual increase for enlargement of the research work on citrus fruit diseases in the Gulf States, where the work has been proceeding very efliciently and has yielded excellent results. There is need, in particular, for a more thorough study of those diseases which affect citrus fruits after harvest, while in transit, and on the market, in connection with the Florida citrus industry in particular.

Mr Bucinasas. Normally they are free from diseases?

Doctor TaYuon. They are this year probably in greater trouble than they have been for soveral years with whit is known as stomend rot, which is a disease that is not conspicunous while the fruit is on the trees, but which does produce quick decay ufter the fruit is harrested if it is not rely quickly cooled to a low temperature: and they have been having some heary losses in transit during the list six weeks. The matter has been very thoroughly considered. We lanve an excellent organization, with is temporiary pathological field laboratorr at Orlando, Fla., where we have the equipment and the persomncl, exeept that we need an additional assistant to malie this work adequately effective.

Mr. Becusaxix. Before you leare that: How hong have you had this appropriation to investigate oreharde and other fruit: this is discatses of pecinns, though, is it not?

Dostor 'Turon. This is disenses of fruits.

Mr. Bucoms.x. And disestses of the peran?

Doctor 'Trior. Yor, sir.

PECAN DISEASES.

Mr. Buchanas. Have you any bulletin on the pean?

Doctor Taruok. Yes, sir: in particular hulletins on two or thee of the pecan disenses. The disease catusing most apprehousion at present 


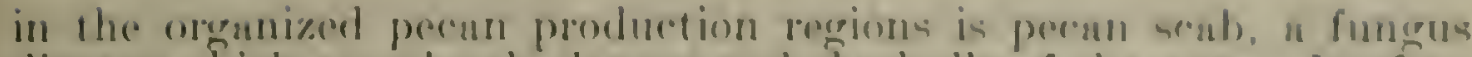
disense which uttucks the leavers und the hulls ef the nuts. It coften conseses a defoliation of the trees.

Mr. Bucmasax. You monn the onter hulls!

Doctor 'Tarion. Yés.

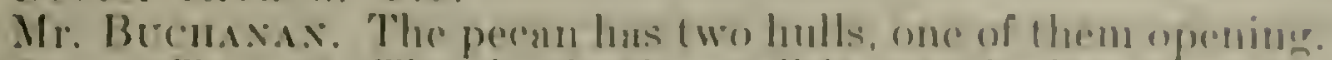

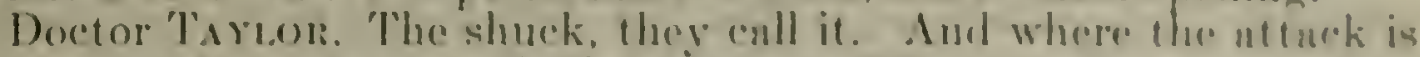
severe the fungus conses the bowning und dieting of the moler skin of the shuck, and " premature ripening of $i t$.

Mr. Bermaxis. And premature udtering of the slance to the peran itself?

Doctor 'Torron. Yós. And withount lilling: the ment dores not fill:

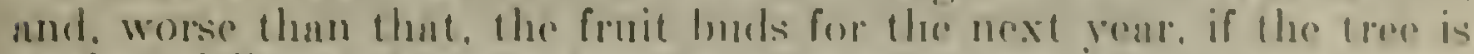
badly defoliated, do not set. so that the eflecet on the next yeur's comp is brid.

Mr. Bermasas. Do gou know the renson why thr peran is so stubborn ubout benring only orery other renr"

Doctor lortors. No one knows with exictness, hut that serms to be a characteristic which practically all of our fruit nnd nut bearing trees in the forests hare. Wo rarely get two he:try erops in surecession moler wild conditions. One of the muin purposes of oreharding and of cultivation and of spraying with the pecan, as with other tree fruits and nuts, is to steady the production by maintaining an

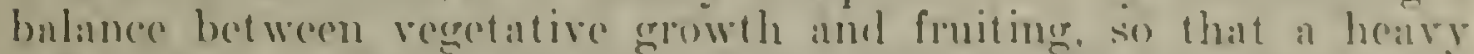
crop does not exhaust the tree heyond the pessibility of a reasomalie crop the next rear. In oreharal fieces like the prach a erond deal is aceomplished by the thinning of a too-heary crop, reduciner the loat and the draft on the vitality of the tree. With the pecon that is not princticable, and we have to aceomplish it through more affective tillage, fertilizing and spraying where a discase like scab is inrolved, to stendy the troe through its fuil-crop year.

Mr. Buchaxax. It might need inrigation?

Doetor Tirror. It might need irrigation at critical times in some places: that is a possibility.

Mr. Bichaxax. I wish you would send me bulletins, if you have them, on that. and a few copies of these bulletins on pecans, or anything else relnting to them.

Doctor Tryoor. I will send you what we have.

Mr. Buchaxax. A good many of my constituents are decply interested in that, and ours is a splendid region for them, and we are trying to grow them.

Doctor Thyor. So that the net inerense proposed here is $\$ 4,000$ for the enlargement of that citrus-rlisease work.

\section{CITTLS CANKKR ERAICATION.}

The next approprintion is page 78 , for citrus canker erndication. I will ask Doctor Irelleman to discuss that. 'There is an npparent incrense in it of $\$ 30,0000$ over the regular approprintion of last rear.

Mr. Axdersos. Fou had a deficiency appropliation of $\$ 100,000$ last year?

Doctor 'Tarook. You recall that nt the rery end of the session when the exigency developed, there was a deficiency appropriation of 
$\$ 100,000$, which made the total a mount available during this fiscal year $\$ 130,000$. So that this estimate, which is an apparent increase of $\$ 30,000$, actually involves a decrease of $\$ 70,000$ below the total available for this purpose this year.

Mr. Andersos. We will now he r Doctor Kellerman.

Doctor Kelleman. The only point to bring out in connection with this item. I believe, is that the decreases that we had recommended in early years were probably made a little too rapidly, and if we had not cut the work to $\$ 30,000$ during last year, if we had liept about $\$ 50,000$ or $\$ 60,000$ in that work, I believe it is certain that no emergency appropriation would have been necessary.

OUTBREAK OF CITRUS CANKER EPIDEMT SERIOUS.

The epidemic of citrus canker which developed in southern Florida at a town called Davie, Fla., was a direct result of inability to inspect that region for a considerable period of months. That outbreak is the only serious outbreak that we have had in the canker work during the fiscal year, although two other small outbreaks, also the result of not being able to carry on adequate inspection work throughout the territory, have occurred-one in Alabama and one in Mississippi. There is still known to be a scattering infection of canker in Louisiana, and there are some areas in Texas that are under suspicion. In general, however, the work is now in good enough condition so that we believe that we can handle it adequately with $\$ 60,000$ and also have a very small reserve that can be drawn on in case of small outbreaks.

Mr. Anderson. Is there any possibility or probability that the disease can be entirely stamped out in time?

Doctor Kellerman. In time I think that can be done. It can not be done in the coming fiscal year. The difficulty in eradicating the disease from areas where citrus is not commercial, like some parishes in Louisiana and the northern Gulf region of Texas, are the really serious difficulties in the work. I believe that within the next two or three years we can complete the eradication work of all of the areas where citrus is at all commercial; that is, in sonthern Texas and the southern part of Louisiana, below New Orleans.

Mr. Anderson. I suppose even if you felt it was completely erndicated that there would be necessity of continuing the inspection for some time.

Doctor Kellerman. For a few years it would be a very wise investment; it would be in the nature of insurance, and I believe a very cheap insurance.

CITRUS INDUSTRY PROFITABIE TO COUNTRY.

This citrus industry has undoubtedly in income taxes, in land taxes, and in other ways already more than returned to the conntry the amount of money that has been expended on it, as well as having the industry saved to the people who are growing orchands in the South.

Mr. Andersox. Do you find the owners willing to cooperate and prompt in reporting what they suppose to be the canker? 
Doctor Ketclamax. We have, I think, universal cooperntioss at the present time. It hus been very conthusiustir in the ureas in which there is a commercinl citrus indusiry, such ns southern Troxas and in the Mississippi, Alubumn, und filorida regions, where round orange or Sutsuma oranges or grupef ruit ure grown.

Doctor 'Tartor. I think it would be u fair shatement, Mr. Charmun, (o) say that there hus beren a vory murkied chunge of nttitude on the part of citrus growers as this work has progrersted. In the becrimning they were fearful of ndverse offect upon hond values und that sort of thing as it became known that their groves were under suspicion. They latre since recognized that secrecey would ultimately result in harm, and they ure nuw very frunk and pronupt to bring uny suspicious case to the attention of the specialists. So a very wholesome readjustment of opinion has developed.

Mir. Axnersox. Is the disease dillicult to dingunse?

Doctor 'Taron. 'Tu distinguish from the widely prevailing citrus scab, which is not nearly so serious.

\section{DISE.ASES OF FORFST ANI ORNAMLNTA, TRLES ANI SIIRUBS.}

On page 80 , the subapproprintion for the investigation of disenses of forest and ornamental trees and shrubs, there is no change. If propose a continuation of that work as it is.

\section{WHTE: PINE BLISTER RLST CONTROL.}

The same remark applies to the subappropriation for white pine blister rust entrol, on page 82 . The only 'hange suggested there being the omission of the provision of $\$ 50,000$ to be immediately available, which was necessary last year to inaugurate the cmlarged cducational campaign in the Eastem States, upon a basis of fullseason actirity.

Mr. Axdersox. I think you had better tell us something of what you are doing on this item, in view of the increase in the amount orer last year.

\section{PHOGRESS OF WOHK.}

Doct or 'TAYLor. This is briefly referred to in the statement that I have alreadr submitted, but it would perhups be well for me to read the paragraph for the committee, it appearing in that preliminary statement. [Reading:]

White-pine blister rust is a destructive plant disease that reached Amerira about 1900. It was introduced from Europe on infected white-pine nursery stock, which was planted in many places in the eastern Lnited States. In 1913 it was found altacking native white pines, but its wide distribution wa not susperted until the late fall of 1915, when the rust was discovered on currant and gooseberry bushes and white pines over a large area in Massachuselts and New Hampshire. Since ihen, in cooperation with the affected States, practical measures bave heen developed for the control of this disease under eastern conditions, which consist of the eradication of currant and gooseberry bushes within 900 feet of the pines. The outstanling feature of the white-pune hlister-rust sicuation during the past year was the discovery of this destructive disease in British Columbia and the Puget Sound region of sonthestern Washington. The department, in cooperation with statrand Canalian authorities, has taken prompt action to determine the extent of the infected area and if possible to control or eradicate this new outbreak of the disease. The latest information indicates that the disease was introduced into British Columbia about 1910. prior to the enactment of the Canadian blister-rust quarantine. 
PLAN OF WORK POIR COMING YEAR.

Now, supplementing this statement and specifically with reference to the enlarged program now in effect, the plan of work is this: This applies to the Great Lakes, New York, and New England white pine territory. Wherever in territory white pine is being encouraged to replace itself, to reseed itself and be treated as a timber crop for future harresting, and the local interests are willing to put their money into the eradication of the currant and gooseberry bushes which make possible the spread of the disease from pine to pine, the department places a blister rust educational agent. He is in a county, the man who does as regards blister rust control, through ribes eradication, ribes being currants and gooseberries, what the county agent does for agriculture. He works with and in many cases is quartered with the county agent. He derotes himself to the locating of the areas within which it is advisable to undertake this work systematically, gets in touch with the owners of the land, acts as n general adriser and superrisor of the actual eradication work, which is paid for by the State, the town, and by individual contributions, that phase of the work being not financed from the Federal appropriation at all.

So that the blister rust control campaign now is under way in approximately 50 counties where white pine has acquired the status of a crop, to be cared for and ultimately harrested for profit. It involves the correlation of the interest and activitr within those States of the State forestry actirities, the State agricultural extension activities, and the department's activities, the deparbment paying the salary of this special man to lead in that work.

STATES AND INDIVIDUALS COOPERATING WITH DEPARTMENT.

Mr. Bucmaxas. Is that all the Federal Government pays?

Doctor TaYlor. Yes. You will recall that previously this work in its pioneer stages was handled upon a basis of joint financing of the eradication work. That plan worked fairly well through the pioneer stages, but it appeared to us that it had reached a place where there was sufficient knowledge of the methods that needed to be adopted, and that the main job from now on is an intelligent, efficient, properly supervised leadership of an educational campangn, the bill for which, as regards the actual clearing out of these disease-transmitting plants, should be borne by the people and the States that would have the crop saved.

Mr. Buchanax. Are all those county or State local agencies responding to the terms of that agreement as carcfully and fully as is necessary and required?

Doctor 'Tryon. Very satisfactorily. I would like to say that we have not reached the poak of efficiency yet, because such a campaign takes time, particularly, Mr. Buchanan-I wish Mr. Wason were here-in a region that is as ruggedly conservative as the white pine back country of New England, where the people are of the old-time stock. 'The leaders, however, are awake, and they have come into line very satisfactorily. 'The leaders are awake, including the selectmen of the towns, who constitute the administrutive leadership in the localities. We believe the plan is somel, that it is operating satis- 
factorily for a first-yen operntion, and I am deliberntely conservotive in iny explession on that.

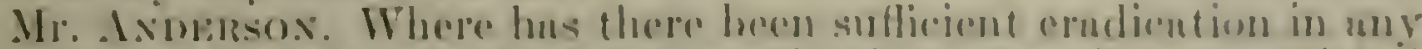
loconlity to demonstrute that the cradiention when it is completed really does der the hosiness!

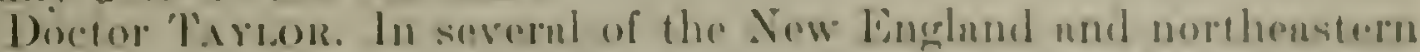
New Fork localities, where the erndicntion work was fone in ureas of comsidernble size, ns much us five genrs nero, ses thut there has beren time for new infertions if now infoctions were groing to ocente. The infertions that are foumd in those localities are proctionlly all

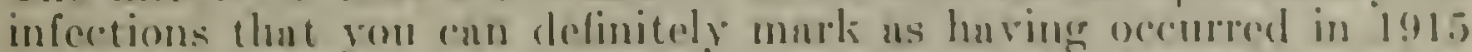
or 1916 or 1917 , as determined be the growth of the tree since that infection oceured. Of comrse, if the disense could spread from one pine trece to another pine tree, the more fact of $n \mathrm{n}$ infection being there would negutive the advisubility of such work, but with the currunts nud gooseberies out, no infection oceurs later, nul that initiul infertion. unless too severe, does not jeopurdize the future timber value of the tree.

Mr. Axmersox. Where you have them cut these gonseberries and currunt bushes out, is that the end of it: do they volunteer!

Doctor 'TArons. A second combing of the uren will probubly be necessury 5 to 10 yenrs later to uproot the very fow hushes that were missed in the initinl eradiontion, and the occisionul bird-sown seedlings that may come in. The reinspection five yeurs nfter of those enrly crudicnted arens, however, discloses a surprisingly smull number of liushes needing to come out. Of course, it all depends on the thoroughness with which the initial erndication work is done.

Mr. Becmaxa. You dig them up by the roots?

Doretol 'Tryon. Yes; they have to "ome out. 'The small ones in the locser suits are pulled out by hand. In elay soils they require grubbing, and in some arens of swmp lund some species of the wild currunts are so thickly present that it pretty nenry requires the denuling of smull nrens to get them all.

Mr. Axmensos. What are you doing in the Puget Sound ancan? Is the work being conducted there in the same way?

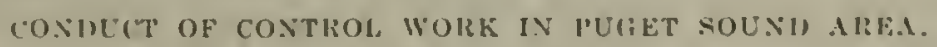

Doctor Tirtor. Not exactly. Doctor Kellerman had a glimpse of that this summer. I think his observation would be helpful.

Doctor Kridsmmax. Mr. Chairman, the work in Puget Sound region has been confined almost contirely to inspection work, the number of findings of disense inside of the United States being relatively small, the presence of the disease in the Puget Somed region, ratlieg thon the amount of it, having been the disturbing factor. At the present time it is rear that the discase has been in British Columbia for a considerable term of rears. It does not appene that the disense has been in the State of "Washington for a period anything like as long ns in British Columbin, probubly not carlier than in 1917 , ns far as Washington State is concerned, and only three diseased trees infected as enrly ne that have been found. The infections, chicefly on currant bushes, have all been found on the edge of Puget Sound or on the coist. 
That all goes to show that the infection there is of comparatively recent origin.

I would like to bring out that at the present time plans for handling the Pacific coast region hare not been decided upon. It is possible that the infections are so scattering and so recent that an eradication campaign could be carried out. That was our hope at the very beginning of the season. 'Then, as more and more counties were found infected. we became rather doubtful of the feasibility of an eradication campaign. The continuation of inspection work has not shown a very wide spread of the disease, howerer, not as wide as we had been led to suppose by the findings of midseason. 'The question of whether an eradication campaign may be feasible I believe is still an open question. An important conference is now being held, or will be held in a very short time, in Portland, at which both the Canadian and Western States' representatives and people of our bureau will review all of the information arailable, and the character of support that could be obtained from commercial holders of pine, as well as to again review the magnitude of the Federal interests in the national forests that are likely to be jeopardized; and at that time a more comprehensive plan for the future will be outlined, and if possible agreed upon by all of the parties concerned.

At the present time, you will recall, that the current appropriation is supplemented by a portion of an emergency appropriation that is available during the greater part of the present fiscal year. Approximately $\$ 100,000$ of an emergency appropriation giren to the bureau because of this unexpected discovery of white-pine infection in the Northwest, is available until March of this present year. giving us in this item $\$ 300,000$ to work with instead of the $\$ 200,000$ that is shown in the appropriation bill.

Whether it will appear advisable to ask for funds to continue some of the general eradication plans that we had at first proposed for the Northwest, or whether the campaign can not possibly be dereloped on an eradication basis and must remain on an educational basis, I think will determine whether the present funds are sufficient for all of the blister-rust work that we need to carry on as far as the Bureau of Plant Industry is concerned, or whether it would be adrisnble to provide additional funds for taking care of the Federal and other interests in the Northwest.

Mr. Andersox. How much is going to be spent in this Puget. Sound situation now for inspection and other work you are doing?

NEEI OF INCRFASED FUNDS WOR EXTENSIVL ERADCATION GAMPAI:

Doctor Kentermax. During this fiseal yenr approximntely $\$ 100,000$ will be expended for blister-rust work in the Northwest.

Mr. Axinersox. An eradication campaign, of course, would involve a considerably larger sum of money?

Doctor Kelderiax. That would undoubtedly involve a somewhat Inrger sum than we'are spending there now, although I doubt whether it would need to be very much greater. I would estimate somewhere between $\$ 200,000$ and $\$ 300,000$ an necessary for an effective cradication campaign, which would have to include scouting.

Mr. Andersos. You incan for that area alone?

Doctor Keldemsax. For the area including the States of Washington, Idaho, and Oregon. 
Mr. Anvessos. I do not quite get gou. I do not know whether

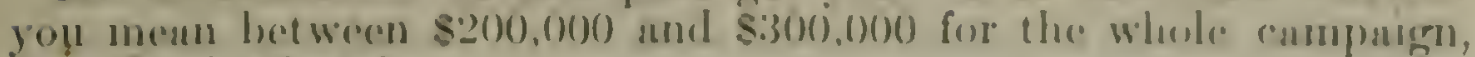
New lingland and

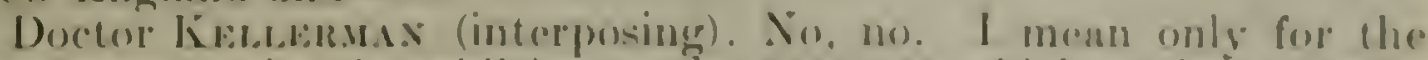
Northwer recrion, in addition to the $\$ 200,0)(0)$ which wo have ut the present time.

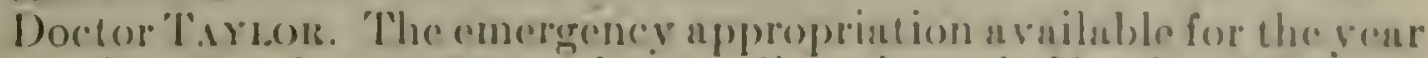
berinning Mateh 1, 1922, and cxtending through Maroh, 1923, was $\$ 150,(000$, which covers the whole of the growing senson of 1922.2 and the wintor following.

Mr. Andersox. Tell, so far as your plaus go, willout thr determinntion of the question of the policy to be pursued in the Northwest, the sum proposed is alequnte (o) continue the work?

Doctor Throri. Ies. This involves n full-speed-nhend program along the lines that we feel sure of in the territory that is ripe for it.

\section{COTTON .NI) TILCK ('IROL DISF.ASE IXVFATIRATIONS.}

The next subappropriation on page 5.4 , for the investigation of disenses of cotton, potatoes, truck crops, forage crops, drug and relnted plants: The estimates provide an incrense of $\$ 10,000$-this for two purposes - $\$ 2.500$ for work on cotton disenses. The cotton disease probably causing the henviest damage being root rot, regarding the cause of which and the methods of combating not much is known, although work has been done more or less during a considerable period of years.

Mr. Buchasax. It is as old an the cotton plant itielf?

Doctor Truzor. It is as old as the cotton plant itself, and it has increasingly become evident, as closer attention has been paid to the classing of cotton at the source, that root rot. as well as other factors which interfere with the normal growth of the plant and the lint seriously impairs the quality of the lint and reduces the value of what is harrested and baled.

Mr. Beculsax. Not only that, it cuts off its production?

Doctor TArLor. It cuts off production, and it injures the quality of that which is produced in the root-rot affected plants. It kills the stalk, the boll dries up, and you pick it and it has no staple to it. It cuuses immature seed and stops production.

Mr. Becmaxax. IIow long have you been studying that root rot?

Doctor 'Turor. In a rather broken way for a number of years.

Mr. Bucmoxas. It is a germ, is it not?

Doctor Thron. It is supposed to be caused by a fungus, but it is one of those fungi which has not yet disclosed its full life history.

Mr. Becmaxix. Has it ever been anlled to your attention-this is common notoriety clown there that the plant of sorghum planted in those patches where root rot exists in cotton in two or three renrs would destroy it!

Doctor Tartos. Fes. In fact, the only approximate control that anyoue has been nble to suggest thus far has been the use of the land for grnsses, including sorghum or other crops not susceptihle to disease, in rotation for a suflicient time to let the fungus measurably die out of the lnnd. 
Mr. Becinsax. You know the objection to that, do you not? This root rot takes possession of a patch of perhaps an acre orer there and an acre over here and another acre over there [illustrating], just in little patches throughout the cotton field.

Doctor. TaYlon. Ies; that is the difficulty.

Mr. Bucinsinas. And you would have the grass patches or sorghum patches scattered all over the field and have the exact line of the root rot.

Doctor Taroon. It becomes a very difficult thing, unless you are operating on a basis that would permit the use in other crops of the whole tract that has some bad spots in it.

Mr. Buchunan. But the spots are not sufficient, you know.

Doctor TAYLor. And that is not economically sound in many cases.

I will ask you, Doctor Kellerman, to tell the committee of one recent derelopment that you have been in special touch with in root-rot control that is interesting.

RECENT DEVELOPMENTS IN ROOT-ROT CONTROL WOHK.

Doetor Kelleman. In the Southwest the root rot has become a very serious factor in the new cotton areas, especially in these areas where the bureau has been fostering the production of Pima cottonlong-staple Egyptian cotton-that is, American Egyptian cotton.

Mr. Buchanan. That is in Arizona and California?

Doctor Kellerman. That is in Arizona and California. The experiments on the control of root rot, I believe, have progressed further than they have in any of the older cotton areas and we have had during the past two years remarkably successful control by treating infected areas of a field with a solution of formalin-that is a disinfectant used widely; it is an excellent fungicide; furthermore, it breaks down after it has been in the soil a while, so that it does not injure the soil agriculturally at all.

Mr. Buchanan. Do you apply that to the soil?

Doctor Krelermax. Yes; to date this treatment has been made only in irrigated regions, which simplifies the applieation of the disinfectant, because the area to be treated can be banked up, irrigation water run onto it, and the formalin added to the irrigation work.

There appears to be no reason, as far as we can see, why somewhat stronger solutions could not be used in connection with plowing or harrowing operations, and actually apply either formalin or some similar disinfectants in regions where irrigation is not practiced. In any case, it has been possible to check immediately, and, from some. experimental fields, to completely eradicate the cotton-root rot.

Mr. Buchanax. Have you estimated the eost of formalin per acre?

Doctor Kertermax. On a field that was hadly infected it would probably not be practicable. We have not estimated it on that basis, but on the small quantity of land that needs to be treated when infection is starting it umounts to only a few dollars per acretwo or three dollars to the acere on the lieds we have had under consideration. We find that the disease prouresses from a contrat point. 
Mr. Bucmaxis. And slowly!

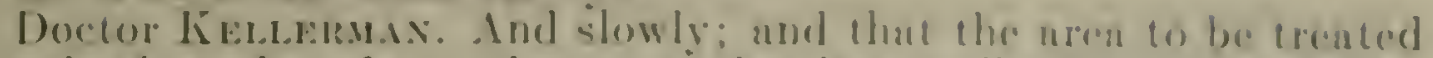
is only that redge of "y yord or more that in actualls killing the plunte: that thut is the pluce where the fungers is growing und domg its dusnage: inside of that ures or outside of that arentes trenturent is necessury.

Mr. Biecusax. Down hone the patches that die from the reot rot ure solid putches, generully.

Doctor Kestrasas. Thiut is truse, hut that is becmuso un infortions begins and sprends over a ronsiderable area, and the infected colton will die as the semson continues. Rephanted cotton in the center of the aren, howerer. will not be killed.

Mr. Bromaxax. Are you making my investigation us to the dry culture in cotton stutes proper?

Doctor keldersan. That is one of the main things that we are anxious to use this additional money for. 'This insestigation that we have been corrying on has beren calried on as a side issue to our southwestern cotton work. We have no funds, without seriously disorganizing other important projects that are riclding important results. to provide for experimental work in the nonirrignted cotton nirns.

The very uetive work on this discase has not been prosecuted duringr recent yours in the Cotton Belt, because all of the lends that have been followed have not been especinlly productive. and at the present time we hure felt thut we were getting more benefit out of the money that we were spending on plant-disease control work on other disenses than on the cotton root rot, sumetimes called "Texis root rot," beconse it is a serions matter in 'Texas.

Mr. Buchasix. I know it is. Is it in all the cotton-producing States?

Doctor Keltermax. It is more troublesome in the Southem States-in the hotter Stutes.

Mr. Buchasax. Have you ever noticed it is worse in Texas on black lund than nny other?

Doctor línllemin. I es, it is much more destructive there.

Mr. Bechasax. Changing the subject, is this fund the one that carries boll weevil?

Doctor 'IAYlor. No, sir: that is in the Burenu of Entomology.

Mr. Becussix. There is no bulletin on this get, is there?

Doctor Keflemax. A paper on this subject is now being prepared. A description of this work probably will tuke shorter space in the paper thut is prepured than the way I huve described it.

Mr. Becusas. It will be printed?

Doctor Keldemax. It will be printed rery shortly. I will see that you get $n$ copy.

I.NCREASE FOR POTATO DISE.ASE WORK.

Ductor Taron. The other $\$ 7,500$ of the $\$ 10,000$ is needed for potuto-disense work. The potnto crop is now produced under conditions so widely diverse und in regrions so farr apart and so far from the consumer, who, together with the producer. puys the freight on potatoes in mrger mensure than on nlmost uny other staple foodstuffs. becnuse of the watery chumeter of the potrito thut it hos renched a 
point where the elimination of seed-borne diseases has become vitally important.

The superficial diseases, the fungi which cause seab and troubles of that character on the skin, are under measurable control through the dipping of the seed and the aroidance of limy soils, or the omission of liming the soils immediately before the potato erop is to be grown. But certain of the most destructire diseases-and these have appeared in relatively recent times-both in Europe and this country-their control is much less well understood. They are known roughly as the virus disenses, which it is now known are transmitted from plant to plant by certain inseets, the little aphids or plant lice; and it is now known, also, that at least one of these insects overwinters on the rose. This whole virus disease problem as affecting the potato is intimately associated with the production of high-grade seed potatoes.

Much of the more southern portion of the country, including parts of the Corn Belt and most of the territory south of the Potomac River, relies on northern seed potatoes for its planting stock-Maine, New York, Michigan, Minnesota, and Wisconsin.

The strategic place, therefore, of the attack for the control of these diseases is that seed-potato-growing territory. The problem is acute also in California, where the source of supply is either the high altitudes of their own State or Oregon and Washington. A rery great interest in this matter has developed under the leadership of the Bureau of Plant Industry, which some 10 years ago suggested the idea of field inspection during the growing season as a basis for certification of seed potatoes, both as to horticultural purity as regards variety and pathological cleanness. So that there were this last year over a million and a half bushels of eertified seed potatoes produced, mostly in those Northern States.

But the situation is really critical now as regards the permanence of the eertified seed plan; it is a sound idea, one that we are confident is the only way through which these diseases can be controlled. We need more knowledge of the basic facts regarding these diseases as a basis for the field inspection upon which the certifiention rests. A meeting is to be held in Boston the last week of December of the potato pathologists and certified seed growers of the States to consider this whole question and endearor to get together upon a more harmonious and uniform plan of certification.

Mr. Bucmavas. Don't you think the department ought to be very cautious and very certain before it gives certifientes?

Doctor' TAYLOR. That is realized, and the department has refrnined from giring certificates at all covering quality or pathological cleanness of seed. We have not specific statutory authority for that. It is likely that if the name of the department appeared vipon such a certificate it would be interpreted as signifynd a gunanter of quality, which, under the present conditions, could not be given: and, accordingly, the department has studionsly and without deviation refrained fiom certifying seed potatoes or seed of any kind.

Mr. Axnersox. Where you have developed the methoit of control of the discase, do you fincl that the method is zencrally adoptedsuflicient interest is taken by the people in the production of the disease-free potatoes or other commoditios, so that you methods are adopted! 


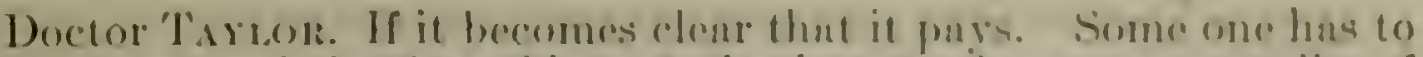
go forward and do that thing al the incrensoil raprense manully of

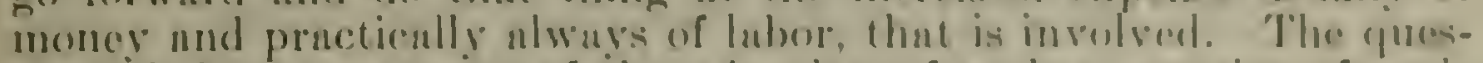

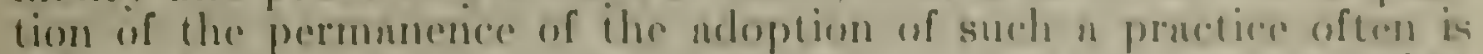
influenced by whether rery destructive semsone becur semerwht early in the iperation of the plan or not; for example, in the case of

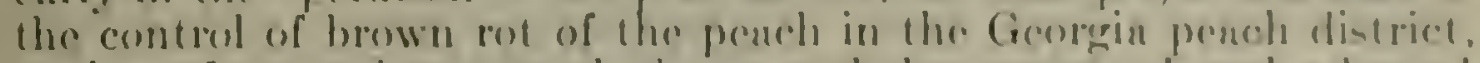

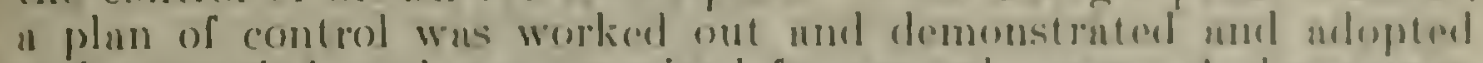

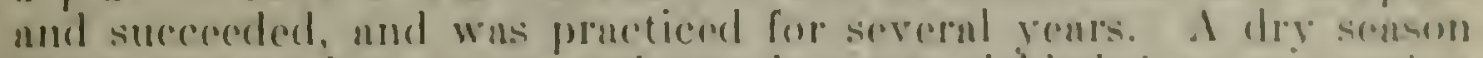
came ulong when unsprayed pench trees piodded just ar goosl a product as sprayed ones, nind there wore two or threre yours in which the wenther was relatively unfaromble for the disease. Then there came, two yens nero, a continuously showery senson in that torritury,

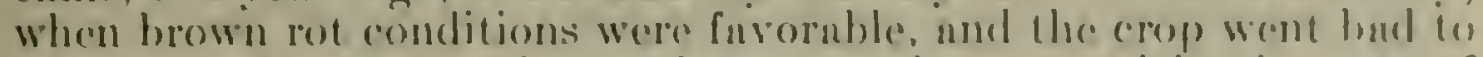
an extent that coused losies that were almost total in the cuse of large cotepprises and the growers were in a mood for adeption of better practices. The work that was put on there as a result of their nppenls for a redemonstration, with some further imprevements which had become possible through knowledge secured lnter. they adopted and this yenr alhered to a spray schedule in a very satisfuctory why and almost universally. Much depends on whether early in a campaign a year occurs when the man who does not adopt the methods does jusi as well as the one who does, becouse it is diflicult to hold him to a sehedule of incrensed expenditure and action if he cun not see that it pays.

\section{FOR INVESTGATIA TIE PIYSIOLOG OF (HOP' PIANTS.}

Mr. Anversor. Doctor 'Tnylor, you can commenee with your next itcm.

Doctor 'Taylor. The next item is on page 86, "For investigating the phrsiology of crop plants and for testing and breeding varieties thereof," in which the estimnte provides an incrense of $\$ 10,000$ for enlarging the date-production investigations in the Southwest.

DATE-PIODUCTION INVESTIEATIONS.

This is applieable chiefly to Californin, Arizona, and as " minor fenture to the Rio Grande Vulley of Texis. 'The industry is coming along in fuirly good shupe. The Deglet Noor variety is sureeding well in the Conchella Valley of California. In the great Imperial Valley, in parts of which they have more humid weather than the Conchella Valley, the Deglet Noor has not proved well ndapted.

There is now a goolly supply of oflshoots of an Exyptinn date variety, the Snidy, which is enrlier in maturing and more promising than Deglet Nool for the Imperial Valley.

We have no experimental collection there and the people are very desirous of defmite date work there. Telegrams came in this weok tendering, without cost to the department, a tract of land for that purpose in the Imperinl Valley, in the hope that this work ran go forwiturd.

Mr. Axpensos. Well, are you going out there and sturt $n$ lot of experiments on land which is furnished free, mel therely derelope a tract for private parties, or are gou going to have to buy it? 
Doctor TAYLOR. The arrangement with respect to the use of the land and the shape in which the work would be undertaken is entirelyopen as yet. There is nothing determined with regard to that. The present holding at Indio is on land which the Government holds in fee.

The larger part of the commercial scale effort, however, is handled under contracts for a period of years upon privately owned land, under contracts which reserve to the department a share of the offshoots and protect the department's right for experimental uses. In most cases the cost of the trees-that is, of the off shoots imported for those plantings-is borne by the owner of the land, so that the Government expenditure is for the expenses of supervision and 3xperimentation, such as labor, saliaries, and supplies.

Irr. Buchavax. How long do date plants last after they are set out?

Doctor TAyLor. We have not in this country had them long enough to know, but in the old World, barring destructive insect trouble, anywhere from 100 years upward.

Mr. Buchusan. I did not care anything about any specified length of time, but just wanted an idea.

COMMERCIAL SCALE COOPERATIVE AGREEMENTS FOR DATE CULTURE.

Mr. Andensox. Where the owner furnishes the land and pays for the shoots, or offshoots, or whatever you call them, for a certain period, then you turn the whole business over to the owners?

Doetor TaÝlor. Yes. In such cases, the owners bear the entire cost of the eulture and labor and all of that. That is what we would call commercial scale cooperative contract oxperiments.

Our variety collection work, however, we do maintain upon land either owned by the Govermment or by the State, so that the ownership of the trees is in the Gorernment.

Mr. Anderson. Well, what do you propose to do, to add to the work you are now doing under this? Do you have any stations in the Imperial Valley?

Doctor TaYlor. We need one station in the Imperial Valley, and we need very much an additional man scientifically trained who can be out there throughout the entire year. Our field personnel at the station has of necessity been headed by what we would call a practical man, a man who has accomplished rery excellent results, but whose full time is oceupied with the looking after the cultural details and so on. There are lines of systematic experimentation that we have to protect through the addition of a mun who is trained to do that work.

Mr. Axpensov. Are you still bringing in oflshoots orer from Egrpt?

Doctor 'Tartor. We brought some in during this last spring, a considerable quantity, most of which were finneed by the planters under these commereial scale contracts, although cortain of them were brought in for addition to our varictal collections. 


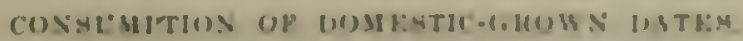

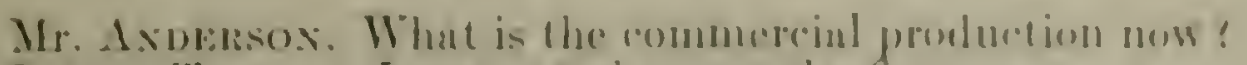

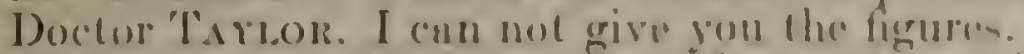

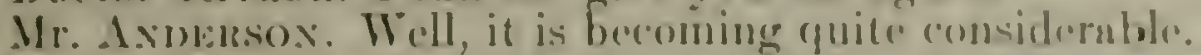

Doctor 'Tarros. (onsiderable, although not yet lume in comparison with the very heavy importations. And the production so far is chiefly consumed in the Southwest?

The cistimated production of dates in California in 1922 is $300(0) 000$ pounds. That of 1921 was estimated at 150,000 punme, the crop of that gear having beren cortailed by untimely rains.

Mr. Axprasox. It is.

Doctor T'irtols. Chicfly.

Mr. Axbersos. I have never sern ang on the mathet anywhere, and I was wondering whether the distribution had gotten outside of the distriets where they are grown.

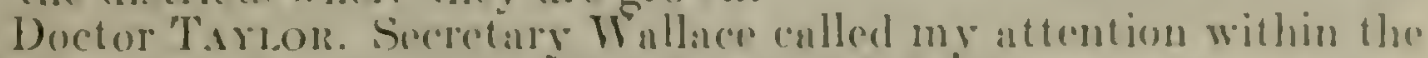
last few dnys to certain jars of funcre packerl Callifornia dutes in a fruit store at 'Tliirteenth and E' Strents Brownley's store.

A peculinr situation exists just at the moment with respect to our probable date importations this year as a result of the trouble at smyrna. The fir morement from the Smyrna district, wheh is the most important table figr commercial production districet of the world, has been seriously impaired by the destruction by fire of the packing houses, including their contents, so that the fig shipments will he subnormal.

The date importation, which in general is handled through the same channels of trade and to an extent is interchangeable with the fig, will probably be materially increased. They come from Egypt, Algiers, and Mesopotamia, and there is every indication that there will be an abnormally large importation of dates to balance this shortage of imported figs.

Mr. Axnersox. Are there any figs produced in this country?

Doctor Tayon. Yes, sir; the California fig production is increasincr substantially and-

Mr. Brcunxix (interposing). Yes, and all orer south Texas.

Doctor TAYLor. I beg pardon?

Mr. Becmaxax. There are a grent many produced in south Texas, too.

Doctor Tarlor. Yes; they are used for canning-chiefly canning and preserving.

Mr. Bíchasia. Yes.

\section{SOII. B.ICTERIOLOG A.N) PL.INT NLTIRTION INVESTIGATIONS.}

Mr. Axdensox. All right. We will take up the next item.

Doctor 'Truon. The next is the subapproprintion on page sS:

For soil-bacteriolog! and plant-nutrition investigations, including the testing of samples, promed in the open market, of rultures for incculating legumes, and it any such samples are found to be impure, nonviable, or misbranded. The results of the tests may be published, together with the names of the manufacturers and of the persons by whom the culcures were ofiered for sale. $\$ 50,000$.

Mr. Axpensox. Well, we will pass that over without any discussion There is not a change in that.

Doctor 'Taylor. So, sir. 
SOIL-FERTILITY INVESTIGATIONS.

The next is the subappropriation for soil-fertility investigations into organic causes of infertility and remedial measures, maintenance of productivity, properties, and composition of soil humus. and the transformation and formation of soil humus by soil organisms, $\$ 45,060$.

That is the same amount as was asked for last year.

\section{Page 92:}

\section{CROP ACCLIMATTZ.ATTON.}

For acclimatization and adaptation investigations of cotton, corn, and other crops introduced from tropical regions, and for the improvement of cotton and other fiber plants by cultural methods, breeding, and selection and for determining the feasibility of increasing the production of hard fibers outside of the continental United States, etc., $\$ 132,500$.

COTTON VARIETY IMPROVEIIENT WOIK.

There is an increase asked there of $\$ 20,000$. The increase is desired for enlargement of the cotton rariety improvement work, with special reference to the southeastern conditions, where, at present at least, until the prices began to go up, exceeding depression because of boll-weevil trouble and low prices and low yield has existed.

It is desired to develop at some point in the southenstern territory a nucleuar variety improvement unit for pure-seed production actirities, somewhat comparable with that which has for some years been maintained at Greenville, Tex., where the Lone Star variety of cotton has centered, which has become a very important feature of cotton production there.

The Southeast is disheartened, to an extent disorganized, in its whole cotton-production effort, and the way out appears to necessitate as one important thing the concentration of the production upon fewer rarities.

Mr. Anderson. Good.

Doctor TAYLOR. Which ean be grown, ginned, marketed, upon a standard-quality basis, and the time is ripe for that work now; we feel.

Mr. Buchanas. Do we not have many private individuals engaged in trying to get such a cotton?

Doctor TaYlor. Yes; and some with distinet success, with very marked success, and upon a fairly large scale.

Mr. Buchanas. And there are several, even, in the 'Texas territory that have varieties of cotton that is just as much in demand as the Lone Star?

Doctor 'Tarlor. That is quite possible. That presumably will be so. 'The department has no monopoly of the ability in the country in the field of cotton improvement or production. "The department has a certain responsibility, we foel, and a certain dergec of enpacity to handle and in a measure lead the wny in that work.

Mr. Buchanan. I. was just wondering whether or not in all of these things, corn, cotton, dates, and everything alse, if it would not be more desirable that the department arouse an interest in the dorelopment along an improvement, some improvement line, and then lenve it to private onterprise. 
Doctor Toroor. Thooretically, that is mequentionably true. The exuct time when the child ean sufoly be turned loose in the jungle is always a muttor of julgment.

Mr. Buchasis. (of course, I did not mern to stop the study of the problem at all. but to stop those antual farm demonstrationa and farm ownerships, or partucrship in farms for demonstration purposes. I did not mean to stop) the study in the oflice of things of that sort.

Doctor 'Tarton. I understund you. I think our minds meset on that point.

In at cuse like this, where it involves not merely the convineing of the leading minds of a country, we will say, us to the advisability of it, but it means the consincing of the arerage grower or in some way the accomplishing of practically uniform practice throughout a geographis community. It is going io take considerable time to get that idea over in this country, were we have developed an an individualistiv busis, and we have not ret learned how most effectively to cooperate, nor why rou coopernte in such things.

Mr. Bremavis. Well, in my eountry I have nerer seen a better development of enthusinsm for improving the raricties of cotton since many days, and I have been fooling with cotton all of my life. rasing it, and every farmer of any intelligence is hunting the best cotton seed and they are inguiring about them and discussing them and have pamphlets from the different cotton raising concerns supposed to put out improved varieties of seed. cte.. and one is trving one seed and one another, and there is a well-dereloped enthusiasm for improved rarieties in my territory.

Doctor Taror. 'That has been a very marked improvement in that direction during the last two or threc years.

Mr. Becmaxas. There certainly has been.

Doctor Tryor. And one explanation of that, we think, is the demonstration in the case of Lone Star, as an cxample, that it pays. and also the demonstration there of the practicability of maintaning upon a large scale, a production of pure seed that is suitable to plant in that territory.

This does not mean that the Govermment is going to maintain a continuous production of seed, but that we have got to demonstrate, convineingly, that it can be done, and that the essentials are a few things. without which effort will be desultory and ephemeral and will not maintain permanent success.

Mr. Axpersox. It is. I suppose, reasonalyle to assume that selfinterest in people will lead them to choose the best varieties and most efficient methods, but my observation is that that assumption is not a well grounded one. So, I suppose we will have to go on with the propaganda to create intelligent self-interest as long as we have any people in this country, and that is the one thing I suppose you are doing under this item.

Doctor TaYlon. Yes, sir: especially through proving by means of varieties and facts a basis for sane propaganda, and discussions. It is going to take a long time to put it over throughout the whole territory.

The illea is not restricted to cotton, by any means. It is equally true with respect to potatoes. It is almost equally true with respect to wheat, in particular districts, but the idea is sound; that is, it is economically sound, us well ns ngronomically sound. 
Mr. Axdensox. Do you have anything further on this, Mr. Buchanan?

Mr. Buclianas. No.

\section{DRUG A.ND OTHER PLANTS.}

Mr. Anderson. Well, we will take up the next item.

Doctor TaYLor. The next item is on page 94 :

For the investigation, testing, and improvement of plants yielding drugs, spices, poisons, oils, and related products and by-products and for general physiological and fermentation investigations.

Mr. Axdersox. There is no change in that item.

\section{CROP TECINOLOGICAL INVESTIGATIONS.}

Doctor Taylor. No. The next item is on page 96 :

For crop technological investigations, including the study of plant-investing nematodes.

NEMATODE DISEASE IXVESTIGATIONS.

The estimates include an increase of $\$ 10,000$ for nematode disease investigation. The need for work here has broadened, as during the last year it has become evident that many of the root troubles of peach and other fruit trees in portions of California, as well as with clover in Idaho, as has previously been known with respect to sugar beets in part of the irrigated territory, is attributable to nematodes, which previously have been attributed to soil exhaustion and other causes.

These nematodes which cause the root rot of the fig and peach in the Gulf territory, and in some places in cotton, have been proven to be destructive to many other crops.

There is one other phase that has assumed importance which only indirectly is related to plants, namely, the part that these organismis play almost certainly in the control of certain insects which damage erops, like the grasshopper.

It has been found that certain nematodes are apparently the controlling parasites, which hold the grasshopper increase in check and reduces in certain parts of the country at least the grasshopper damage to crops.

Now, the question that emerges is whether it may not be possible, through proper guidance and direction of these parasitic nematodes. to accomplish a suflicent control of grasshoppers to reduce the epidemic phase of grasshopper injury to crops. That is merely a suggestion. At present, it has not been put in effect.

Mr. Annersox. I suppose I ought to know, but will you tell us what these nematodes are? Is it a general term that covers a great variety of hugs?

Doctor 'TAYLor. It covers that group of little, but visible, organisms, sometimes known ns cel worms, of which the hookworm, which canses the human hookworm discase, is one. There is a rerr large number of species of them. 'They have not been rery much studied.

Mr. Buchanax. Are they worms or bugs? 
Doctor TaYsot: They ure worms, and they hase not heen very

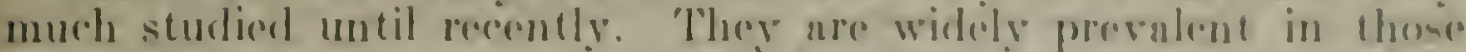
parts of the country where the soil does not freseo deep or hard in winter, so that they live through the winter.

They are troublesone in grenohouses in the North. and it has lorcome evident during this last summer that they have ohtuined lonlerement in the open erround in rarious places as fur north us the Grent Luties recrion.

Mr. Becmaxas. You would not cull a worm that is largo enomed to cut a benu stulk down a nemutode?

Doetor 'Tayon. No; these are little follows. Fon can burely soos them with the naked eye, but if you want to get their facial expresision you need a magnifying glass.

Mr. Becmaxa. Somo ure injurious and some are beneficial?

Doctor TaYrok. Sone live on grasshoppers.

Mr. Becmasas. And some of them eat other things ?

Doctor 'Taroz. Yes. 'Thant phase is very new. If I were not here this afternoon. I would be in Doctor Coblis laboratory looking over some grusshopper corpses that he has been working with.

I would like to remark that in this recent devolopment in connection with these plant-disease organisms, in the work on the nematodes affecting grasshoppers there is a close coreperation maintnined with the Burean of Entomology, and there is no overlapping or duplieation-the nematode work being done by the Burenu of Plunt Industry and the insect work by the Burenu of Entomology.

Mr. Axpersos. I do not know whether this is the place to bring it in or not, but I think that a yenr or two aro you made some estimate with respect to some work on clover. I do not know whether you even got the money or not. But has there been any developinent in connection with clover seeds?

CLOVER GROWX FIROM ELROLFAN SELL.

Doctor Taruon. There has been this rather startling derelopment during the present season, as regards the hehrvior of chover grown from Europenn clover seed imported from the Vediteranom region, where lots of seed ohtained as near to definite sources of production as we could get them without sending a man there actually to collect the seed, were planted in contract with American-grown seed plots at Arlington Farm and in severnl States, particulurly in the corn belt and lake region, where during the mild winter of a rear ago there was no perceptible diflerence in the behavior of the crep. Good stands were obtained at the seeding time in 1921. They came through the winter of 1921-22 without material diflerence in growth or stand. The first cutting of hay in 1922 was substantially alike, and it looked as though one seed was as good as the other. Within three weeks after the mowing at Arlington Farm, however, practically every plot of clover grown from the south Europenn chover seed showed a destructive devolopment of at leaf disense which before the end of the summer had killed off from half to two-thirds of the stand, in contrast with the plots from American-grown seed, which stood through in good condition, nlthough showing some slight leaf injury from this disense. This means apparently that we have got both the question of winter tenderness, which had come up before, during 
severe winters without a snow blanket to protect the plants, and we have got this summer disease susceptibility to look out for in connection with foreign clover seed.

Of course, the difficultr at present is that we have not yet developed a home-grown supply of clorer seed adequate for our needs. and so there is a continuing large importation whenever the price differential justifies.

Mr. Axpersox. I noticed this summer when I was home quite a number of clorer fields that appeared to have the leaves covered. or appeared to be corered with a sort of a white mold. A great many or some fields were almost white with it.

Doctor TAYıOR. That mildew was unusually prevalent this year. It was at Arlington Farm, and was more conspicuous on clover from American-grown clover seed than on the South European. It does not, so far as has been ascertained, through feeding tests and observation, materially injure the quality of the forage. It probably does reduce the quantity somewhat. It does not kill the plant. It appeared to be a seasonal, climatic result of weather which encouraged the growth of this fungus, previously unnoticed or unimportant.

\section{FOR STLDYING AND TESTING COMMERCIAI, SEEDS.}

On page 98 is our seed laboratory paragraph, in which there is no change in the estimates.

Mr. Axdersox. I think you referred last year to some derelopment in connection with the buying of this seed to indicate its character, variety, or something. I would like to have you tell us something about that, whether anything has dereloped from it.

Doctor TAYLor. The practical way of informing the American farmer as to what the clover seed is that he is buying, as between domestic and imported seed, appears to be through a requirement of coloring of the imported seed before entry. Proposed legislation has been agreed to in principle by the leading representatives of the importing seed trade. I believe the department has not yet submitted a specific draft of the bill, but has made the suggestion to the committee that that would seem to point the way out.

Mr. Axdersox. Admitting that the imported seed may be just as good or even better than the domestic variety, isn't the discrimination of this product upon the sole question of whether or not it is imported wholly immaterial, and amost a fictitious one? 'The man who buys seed is not especially interested in whether it comes from this country or some other, if it is just as good as what he gets in this country. What he is interested in is in getting good seed, is it not?

Doctor 'TAYzor. That is his interest. The diflieulty at present is he has no way of determining at all what the climatic enclurance of that particular lot of seed is as determined hy the conditions under which it is grown.

Mr. Avoensox. Well, as a practical matter, aside from that, it would give the importer and the furmer an opportunity to express his prejudies, well grounded or not, against the forcignil seed.

Doctor 'TaYtorr. Fes, sir. 
Mr. Axobesox. And I would imagine that it would very materially reduce the use of imported soresl.

Docetor Tareos. It would tend to encourage the preduction of an adegunte supply here, throught the dereelopment of preference intelligent proforence on the part of farmere for home-grown soest.

Mr. Axmensox. Does this ildm include your experimental imports?

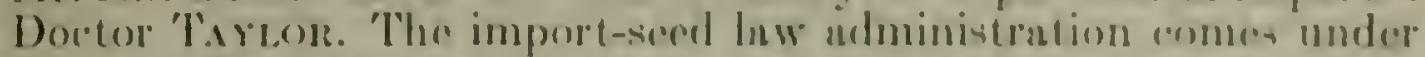
this item. This does not include foreign sered and plant introduction.

Mr. AxDissox. That is whut l wanted to know. I thonght not, but I wanted to be sure.

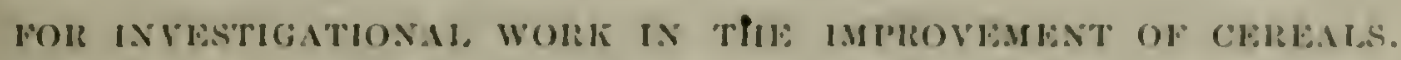

Dorfor Tarton. On prege 100 is one of the most important subapproprintions of the Bureau of Plant Industry or of the department, this being the one which covers the investigntional work in the improvement of cerenls, including corn and the methods of coren! production.

It includes the investigntional work on the disenses of the cerruls as well as on the agronomic nnd plant breeding experinentation. It also includes under the proviso the funds for the barberry eradieation compaign, now under way in 13 of the principal whent-growing States including the spring-whent States where the bhek-stem rust of whent has been most destructive.

The change in the estimate involves a reduction of $\$ 150,000$ in the money provided for barberry eradication, but un increase of $\$ 25,000$ for investigntional work outside of this proviso and the transfer from the subappropriation for cerenl-disease control previously referred to in connection with the first parngruph of $\$ 15,000$, which heretofore has been used in cereal-disease control work, und it is desired to devote that to cerenl-disense resenrch work especially.

The net change, therefore, in the money corried by the subnpropriation is a decrease of $\$ 110,000$, all of which comes out of the barberry-eradication reduction, $\$ 25,000$ of new money going into cerenl research.

Mr. Axumesox. Let me ask you if in connection with that $\$ 15,000$ which is transfered from the cerenl disease item on page 102, do you expect to continue the same work that was done under that item, or is it merely a transfer of that work?

Doctor' Taroor. Yes: work in that same general field. I will ask Doctor Kellerman to eluborate on that a little, so that it will be clenrly before the committee.

CIRLA1.-1USFASF WQIRK TIAXSFEIRRED.

Doctor Kélemax. Mr. Chairmnn, you will probnbly reenll under the cereal-disense control item there wis inserted in the approprintion this amount because of the discorery of two diseases- llag smut and take-nll, in the Middle West.

The investigntions on the seriousness and the generul spreand of take-all have indicated that it is a discase that spreads very slowly. While it is a serious disense, it is a disense that does not need to be handled ns an eradication campaign. It can not be so handled. since it occurs in several whent nreas. It is a resenrch problem rather than 
an eradication problem, and for the last few years has been handled in connection with our investigational work on cereals, the funds being retained in this cereal-control item.

In addition to that, the flag-smut problem was first taken up with the hope of the eradication of flag smut from the one county in which it was believed to occur in Illinois, in Madison County, but it does not appear that we will be able to have any reasonable success. Te are planning, therefore, to change that also into a control instead of an cradication type of camprign.

And in connection with that, also, the research development rather than the employment of inspector's or scouts is fundamental.

In cooperation with Illinois, Missouri, and Indiana we are carrving out research phases which have been deemed best here, and we hope to continue this, with the expectation of establishing throughout this region varieties of wheat that will yield just as well as those previously grown but which have a complete resistance to flag smut.

As the situation now stands, it seems to us that that is the only way that this disease can be checked or that the spread of the disease can be checked.

Mr. Axdersox. Well, can you maintain along these programs a program to confine the disease in the areas in which it is located? Is there any quarantine?

Doctor KEnlenman. Federal quarantine has never been placed on this area. Quarantines on the part of lllinois, in so far as flag smut is concerned, beyond Illinois, in so far as take-all is concerned, have been effectively maintained, with the gradual leaping out of flag smut beyond the quarantine area. It would not appear. therefore. that the quarantine policy is likely to be of any great benefit. 'The opportunity for wind dissemination. the impossibility of safeguarding, even if we knew of the distribution of spores through common carriers, motors, wagons, farm insplements, and other things that are likely to move in that general section of the country, make it now look as though the control of the discase by the substitution of resistant wheats is about the only thing that is likely to be eflective at all. Quarantines are still under way, but our expectations are that they will be rapidly loosened instead of increased in severity.

INCREASE FOR INVESTIGATIONAL WORK NEEDED.

Doetor TAYzon. The need for the enlargement of the amount arailable for the investigationnl work upon the cereals, aside from the cerenl-disease work, is acute for the renson that for severnl years past the investigational work has stood still, finmoncially, the increases of funds having been for the disease-control work. "The result is that the highly important constructive plant-breeding work has latged somewhut behind.

It is of the utmost importance that this shomld be built up. The $\$ 25,000$ involved there is desired, $\$ 10,000$ for enlurgement of the com-production work, covering this whole fichl of varietal improvement and ulaptability determinntion of corm with special reference to the Corn Belt and $\$ 15,000$ for the hreeding and int roduction of arought resistant and winter hardy type of smali grain.

One very important thing in whent production is the pushomer of winter-whent production just as far north as winter comditions permit, 


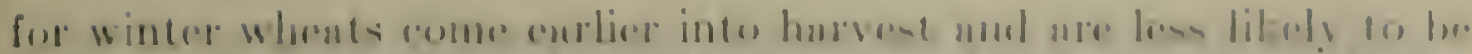

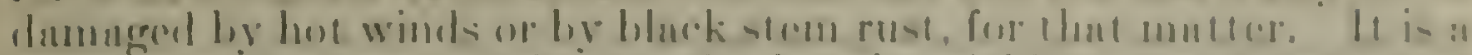

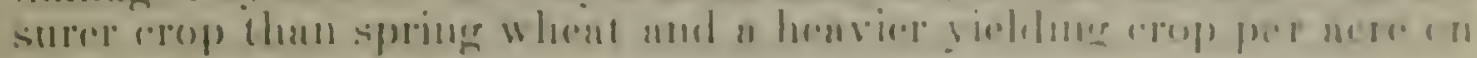
the arrigase.

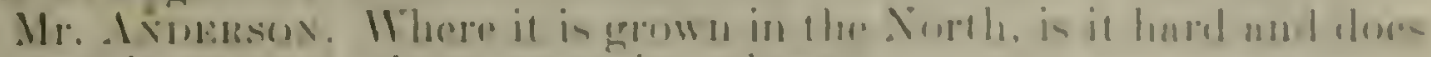

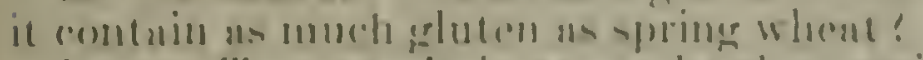

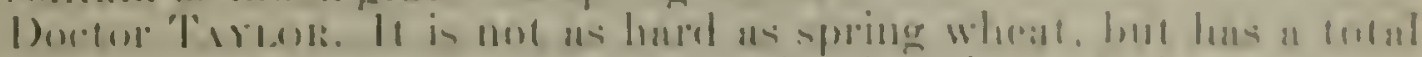

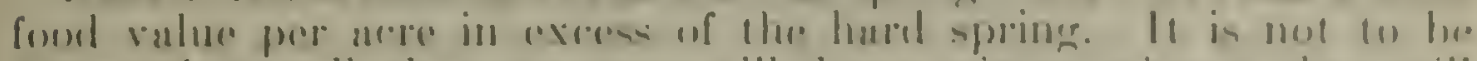
rexpectert at all that we reve will have wintere whents that will

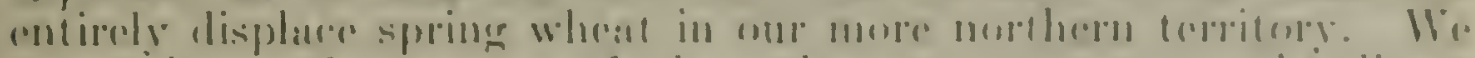

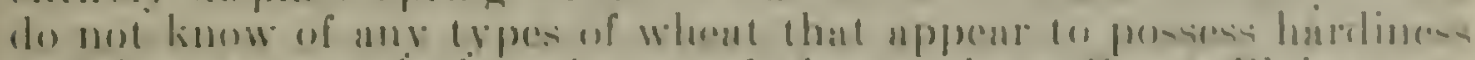

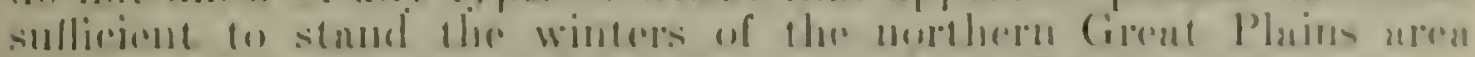

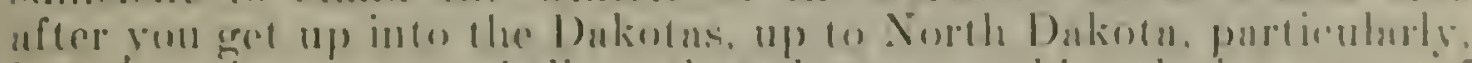

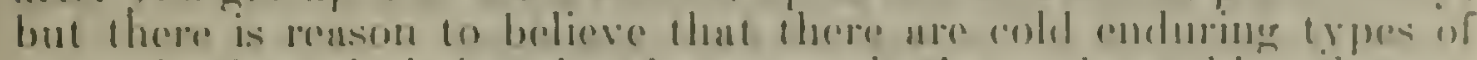

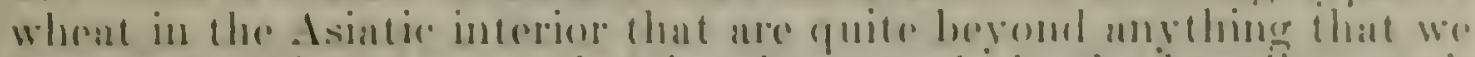
have yet. The prougress that has heen made in the breeding work

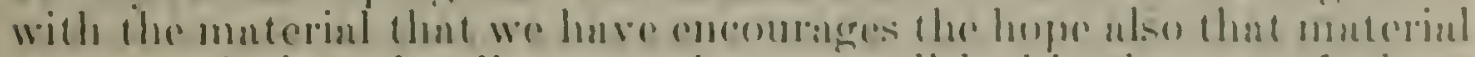

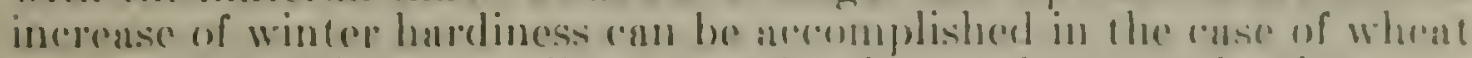
that wonlal make it possible to push winter whent prorlusetion conte-

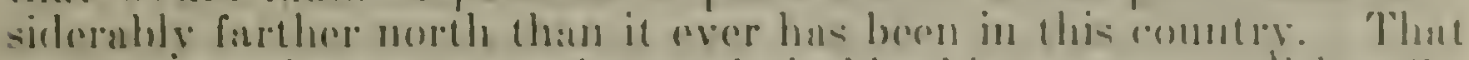
would lic an impertant and rery desibable thing to acomplish. On page 102, the cerreal disense control item

Ifr. Axumesox (interposing). Did you linish this!

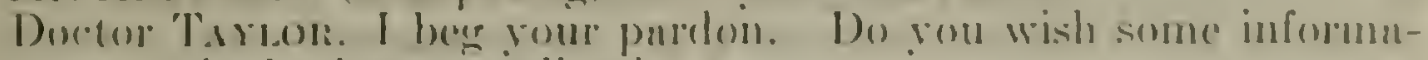

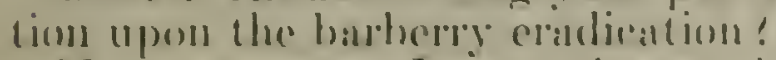

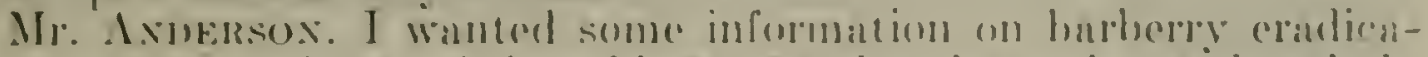

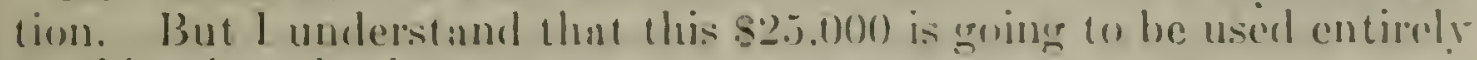
(on this whent husiness.

Doretor Trivers. On whealt and corn.

Mr. Axultesox. Wheat and corn. I want a good deal of informattion on this bathere eradiention plan.

Doctor Tareos. I would surgest that Doctor Kellerman has a map here that will help you to under'stund it.

\section{B.MRIERIY ERADICATION.}

Doctor Kesteman. Mr. Charman, the work of barberry eradicotion was considerably enlarged during the past fiscal year, heenuse of the increased funcls put at the disposal of the bureau by the last Congress. A rery small map that I have here will he the easiest way for you to visuntize, approximately, the progress of the work.

The phans of the activity have heen to center he insperetion and cralieation work in those irens where losses have been severe. where the escape of the barbery, if it oceured quite generally and there were delays in erndiention, would. therefore. result in a very much harder compungen as each rear went by. Acropelingly. the most critionl inspections and the heariest expenditures have acemred in the centrul portions of the area of the $1: 3$ States

Mr. Axurkson (interposing). Will you name the states?

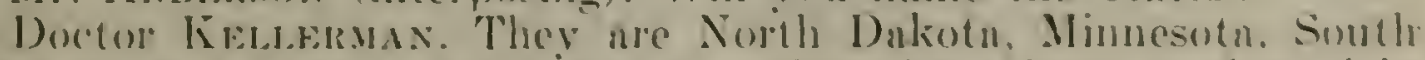
Dakota. and lowit. The inspertions there have heen conducted in ahout onc-half, a litto bit more than one-half, of the areas that we think must he very earefully inspereted and insperted on a farmto-farm hasis before we can assumb that the eradication work has been acromplished. 
A little bit more than approximately one-half of the areas of these States, more than a half of the areas of Michigan, Wisconsin, Illinois. Indiana, Ohio, and Nebraska, remain to be critically inspected.

In addition, we find that the sprouting of the barberries is a rery troublesome factor. Even after a farm-to-farm survey has been completed, we will probably have to make a reinspection a vear or two later to find the sprouts which farmers are likely to overlook.

The belief in the suecess of the barberry eradication in preventing epidemics and destructive epidemics of stem rust, I think is now practically universal.

Mr. Axpersox. Well, my observation does not agree with that at all. Of course, my section of the country does not raise much wheat. but I do not think that you will find one farmer in ten out there that takes any stock at all in your barberry business.

Doctor Kellermax. Well, I am very much surprised to hear that. because so far as I am in touch with this, which is, of course, largely second hand-I have met a few persons from where the work has been conducted, and those as a general rule, I think, are the larger farmers, and therefore they may not represent the sentiment of the farm group as a whole. But taking the Farm Bureau, which is a fairly direct representation of the sentiment of the farmers, taking our correspondents, the reports of the barberry scouts who are in most intimate contact with the farmers, I think that there is no question but that the men that we are in contact with are most sympathetic to this work, and the overwhelming majority of them believe in it.

Mr. Buchanan. Now, let me ask you a question there. How long have you been fighting this black stem rust?

Doctor Keldermax. Well, through barberry eradication, you might say, since 1918 .

Mr. Buclasin. How long have you been fighting it altogether-8,10 , or 15 years?

Doctor Kellermax. Oh, 50 years.

Mr. Buchanan. All right, then, from your 50 years of experience. has the department arrived at a conclusion that burberry eradiontion will eradicate the stem l'ust?

Doctor Kelremax. Not that it will eradicate stem rust as is disease, but that it will prevent the destructire epidemics that have caused such heary crop losses as occurred in 1916, for example.

ERADICATION OF BARBERRY OF GIREAT FCONOMIC VALLF.

Mr. Buchaxax. Then, has the department arrired at a conchusion that the eradication of the barbery hush will be itself justified, from an economic standpoint?

Doctor Kroleman. From our stuly and investigntion, that is whint we generally expect.

Mr. Becmaxas. So that whether the farmers believe in it or not. would not amount to anything except that you would have their cooperation in it if they clid. and if they did not believe in it rou would not have their cooperation, but it is up to the Govermment to go on with the work and prove it to them.

Doctor Kertesisax. It would not change our belief. Wo believe so. We are thoroughly convinced of this as a mational necessity. 
Mr. Bromanas. Yés.

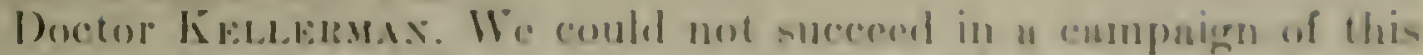
sort without nhosest the unanimons support of the furmers in the territory in which wo are carrying it on.

Mr. Becoms.s. I renlize that, und I suy if they de not beliere in it. then it is up to the Government to go im und ilemomstrate it und prose it to them and convines them of its value.

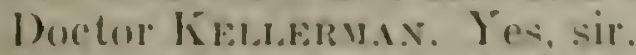

Doctor TaYoor. Mre. Antersom, I think the results of un inguniry

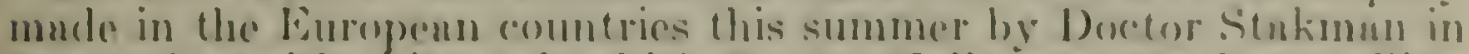
connection with this work which Doctor Kollermun hus born tolling you of, would be helpful if Dortor Kellerman will present them to ious.

Mr. ANDrison. All right: lot us hure it.

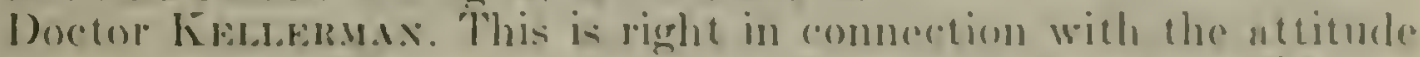

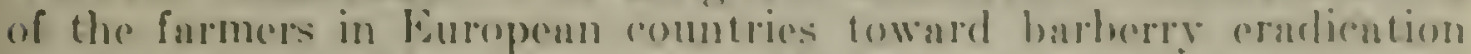
for the eontrol of black stem rust. We hase a repert here in connection with that inquiry. It has not heen isiugel in any formal publication, but I think that it is quite illuminating us to what the consensus of epinion is in those countries where they hase been at this considerably longer than we have in their eflores trisentrol the disenser.

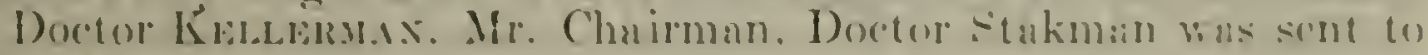
Europe- -

Mr. Avorissox (interposiner). By the depurtment?

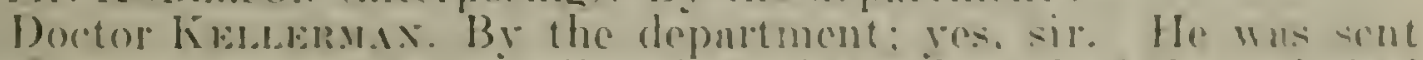

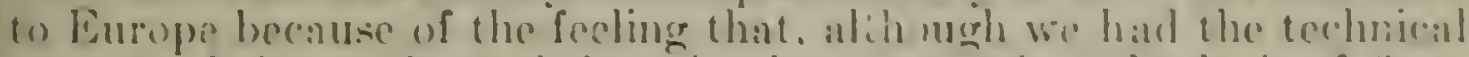
reports of the work carried on in these countries. the lacet of firsthand knowledge was a handicap) in explaining the results in these foreign countries. Denmark. particularly, hat repented musually farornble results in contro! of black-stem rust through barbery

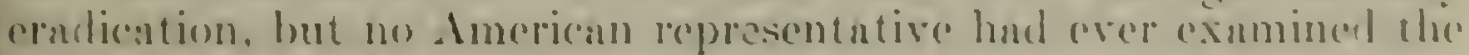
(onditions in that comntry.

Boctor stalimun male a thorough study, in so far as the seatons permitted, not only in Demmark but in France, Anstria. Mungary, und Germany, as well as England, and found that the feeling in those comntries. in western burope throughout, wis genepal. not only among the specialists but amoner the farmers as well, that the common harberry had been almost the sole cause of their serious troubles with huck-stom rust, but thant at the present time the black-stem rust wits not, and for some rears had not been a serious question, becaltse throngh the oliminntion of the eommon barberrey and in most

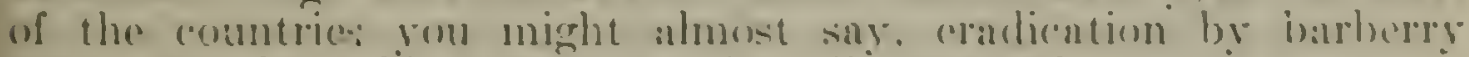
eradiention laws. black stem rust had disippenared.

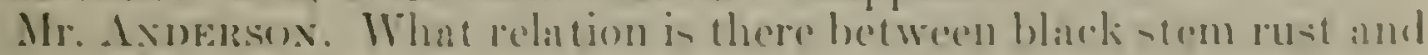
reel rust:

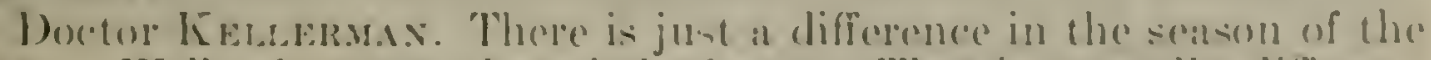

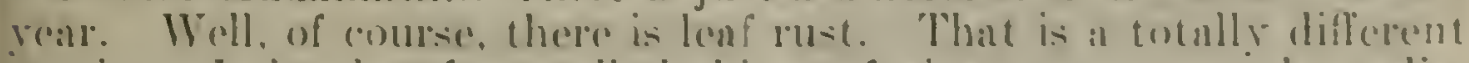
speceres. It is, therefore, a little bit confusing to try to make a ditunction betweon what is known as black stom rute wheh is at rust

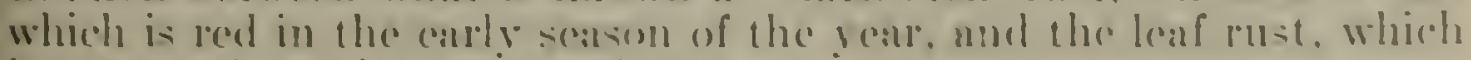
is (o)mmonly spolisen of in reid rust.

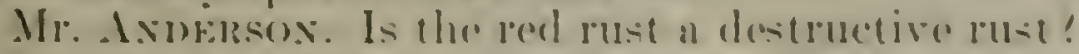

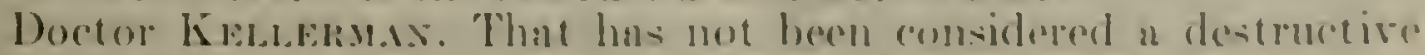

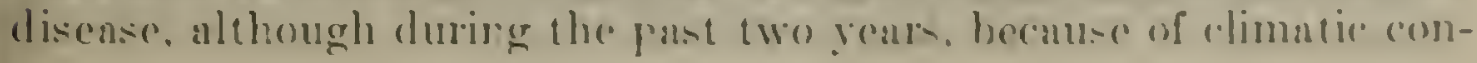


ditions and heary infestation, it has led a good many wheat growers to believe it is.

Mr. Aroterson. Mell, I think that is partially responsible for the feeling on the part of some farmers that the barberry eradication has not produced results. In other words, they make no distinction whaterer between black rusts and red rust. It is all rust and if they get this red leaf rust and it spoils the crops or damages them, they make no distinction with regard to that at all. They just assume that the eradication of the barberr has failed to climinate rust. That is my impression as to one of the reasons why the farmers are more skeptical about the relation between barberry and rust than ther would be otherwise.

Doctor Kelfermax. I think that is true, Mr. Chairman. There is one thing further. It is not only a different species of rust, but other totally different species are considered by them as stem rust. I know that farmers have considered wheat scab, which does not show any of the same symptoms except that you get your swircled grain. as rust of wheat scub infections. I know that many farmers have said all of the time that it was nothing but stem rust or haldi rust. and as such they have actually considered it, when there was not any black rust on their plants at all. And there is a very great confusion of ideas about these different diseases. but no discase hus shown the epidemic character of the black rust. There is no disense of wheat that we have now that has been able to destroy such enormous areas of grain in such a short time as during the 1914 and 1916 epidemies of black stem rust. There have been. it is true. lecal epidemies cren in areas that have been reported as cleaned up duriner the past vear. As far as 1 am aware, crery one of those arens has on recxamination been found to have been not perfectly cleancal. There is scattered an occasional barherry.

Mr. Axpersox. Has it been definitely demonstrated that if we get rid of the barberries there is not some ither plant on which this stuff will winter over?

Doctor Kelfermax. Not north of the Nebraskin line. I think that it is safe to saly that in the arerage winter the spores will not live over on other plants. In the southern plans several species of native grasses will carry the rust over winter. but in the Northern areas that we commonly refer to as the spring wheat areas black stem rust can over-winter only on the leaves of the common barberry. There are two or three species of barberry and of mahonia that (an carry the rust over winter: these are all used only as ormumentals. Genrally speaking, the common barbery is the only plant that has been widely used and the only one that has been planted moler sudeh conditions that it is begimninir to spresed as a wild plant From the standpoint of the rust-control campaign, therefore, the common harberry is the only important faretor.

Mr. Becmaxis. Is that the north Nebraska line?

Doctor Kabsamax. Yes: the spriner whent neas slown on this map) [indicating] will have epidemies of black stem rust if the batrerery is not completely eradionted. In the South the rist will winter over on Hative grasses, hut, as you know, hanels stem rust is mot a rery serious lactor on winter wheat.

Mr. Buchaxax. You say that you would not find orer-wintering spores north of the Nebraska line? 


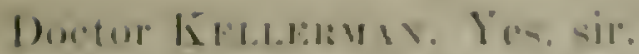

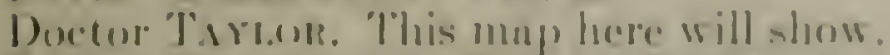

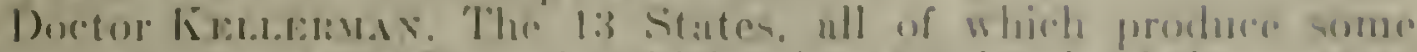
spring whent, nre llat stutes in which this antupuign is of the grentest importunce.

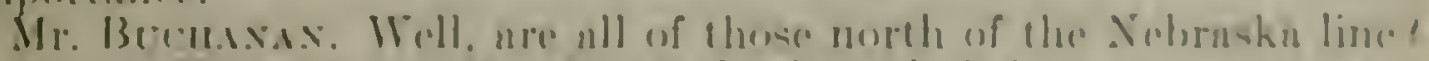

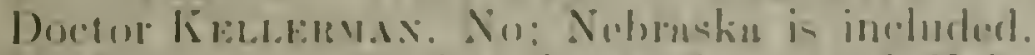

Mr. Bucmsis. Is thut the north or south Nobratin line:

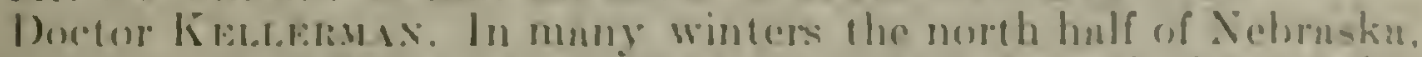

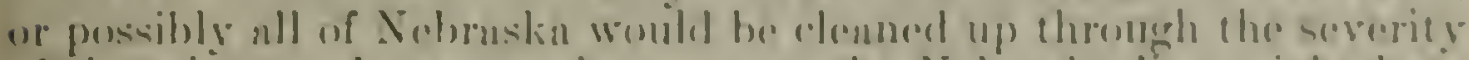
of the winter. In some winters aren the Xobruske line might he is little too far south to be the dead line on spore osereweintering, hut in that genernl anden there is a line that wases up und down from senson (1) season. In that goneral aren the eralieation of the common burherry is undoubledly u necessity if whent growing is to attuin its muxinum productivity.

There is one little comment here in Doctor sukmun's report that I would like to reasl:

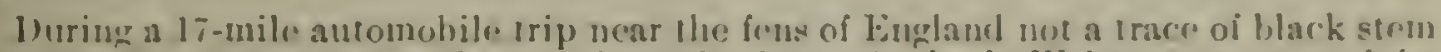
rust was fontud cxcept near fliren harberry hushes. Again, in Wiales, nol a trace of the rugt could he fouml, after driving for a great many miles, excepl on several farms where llare were harberries. In fact. the relationship here was so cloar that it was

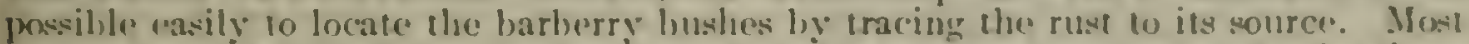
of tha plant pathologists of lingland agrce thai black stem rust can not "xist there without the common harberry. The same hing seems fo he iruc llaronghout most of France.

Mr. Buchux.s. In those countries, how do the climutic conditions compare with the elimute north of the Nebraska line, or south of the Nebraska line?

Doetor Lieloeman. The climatic conditions would be pretty much the sume as in Nebruskin, except that the extremes are not su great.

Mr. Bucmasix. Well, does it get as cold in Nebraska us it does there?

Doctor Kridfinmax. It gets colder in Nebraska. It gets colder in Nebrnskit than it does in those countries, except in occosionnl areas in northern France. It would compure pretty favornbly with Austrin and northern Germany and Denmurl. Denmank would be colder thun Nebraskn.

Doctor 'T.ruor. Their summers would genernlly he cooler than Nebraska. They are too cool for corn. They ure not as far from the ocenn as Nebraska, and they, therefore, have less hot wenther.

Mr. Bechass.. I understood the chairman to sny that there was going to be a delegntion down here to ask for n large increase in this appropriation. Is this as much as you can use economically and efliciently?

Mr. Avinfison. Before rou answer that question, let me

Doctor Kerdemax (interposing). That, I think, is a rather difficult question to answer.

Ifr. Becmasas. That is the question by which we are to be guided in making appropriations under this act.

Doctor Kentermas. I think that the question us to the extent to which it is advisable to expend money is a question that would have to be determined on other grounds nlso. 
Mr. Buchanax. It should be determined alone on economic reasons.

Doctor Kellermax. I think that there is no question but that the money that we have spent this year has been a wise expenditure and that it would not represent the most economic expenditure eren yet. We are practically certain to secure a considerable augmentation to our funds from various States and possibly private subscriptions.

I doubt if the total that can be assembled from all of these sources will be a fund that will be so large that it would weaken the organization to handle it. It is always dangerous to try to develop an organization so very rapidly that we can not select the right kind of personnel to handle the work. We have not expanded this organization too rapidly. It has never been expanded at a rate that has made it necessary for us to take anybody on whom we were in the least doubt of. It could be doubled easily without any risks of breaking down the efficiency of the personnel, and I belicve that the more rapidly we get this work done, the cheaper it will be for the country.

Mr. Bucirarax. Let me ask you this: Does the Government put in the actual habor in the field in digging up these barberry bushes?

Doctor Kellermax. No; but much of it is done by the men, because they can get the support of the farmers and get them to do the work more quickly by showing them just how to do it in the easiest and most thorough way.

WORK PERFORMED UNDER FEDERAL AND STATE SUPERVISION.

Mr. Buchanax. Are these barberry bushes dug under the personal direction and supervision of the employees of the department?

Doctor Kezlermax. In a very large number of eases, that is the case. It would be in the majority of cases, I would suppose, that the bushes are dug up under either State or Federal supervision.

Mr. Buchanax. When you say State or Federal supervision, do you mean to say that the State or Federal officers go out with the farmers and take a pick and dig up these barberry bushes, or is it done by the farmers and then do the farmers report back that they have done it; now, is that the way it is done under their supervision?

Doctor Kellerman. No; in eases of that sort the farmer and his men go out and he inspects it.

Mr. Bucranan. That is just what $I$ am trying to gret at.

Doctor Keldeman. And the inspector goes out with them and he very probably does his share of the work of digging those bushes.

Mr. Buchaxas. He could do a good deal more by superising them than sticking a grubbing pole in his hand.

Doctor Kelfermas. Except just showing the men how to do it.

Mr. Buchasan. Yes; so that if you had an organization you could do an immense amount of work in one year, with the cooperation of the farmers?

Doctor Kellemax. I think that we have pretty generally that cooperation. 'There may be some areas where that is not the case, but if so we have not had them brought very sharply to our attention. So far as I an aware, we have had during the past year enthusiastic cooperation from individuats as well as from the State representatives. 
Mr. Buchasas. Well, getting buck now to mo original question. I know nothing about the cradication of the harberry bushes. I um in favor of these nppropriations that ean be ecomomently rexpended, that will be for the benefit of the mation and the proteretion of the

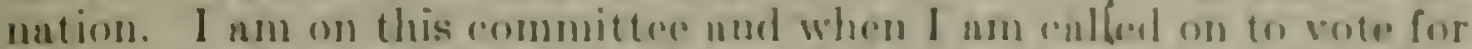
un upproprintion, I want to vote for that amomen of money that the Arricultural Department during the fisenl year ean eflicenty expend with eromomical results to the whent industry. How much is it?

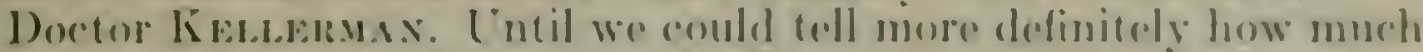
money we are going to get from the states, it would be hurd to suy, or state what our limits is. Wo can expend much more than we are expending now economicully. That l cun be sure of. Whether it is the best thing from other standpoints for us to spend that mureh on this campnign is an entircly different muttor. Wre con do n rertain amount of work with the money that is estimnted for bere.

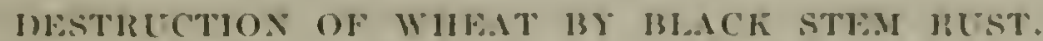

Mr. Axnfasox. What has been the maximum destruction of whent. estimated destruction of whent from black stem rust?

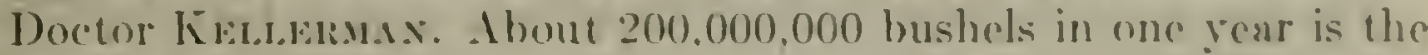
estimate.

Mr. Avipissox. Do you know of any place where you can kill off any more, or where we can sive nny more money than that, eronomicially ?

Doctor Kerdersux. I think that if we can prevent that kind of an epidemic. that it is the best that we enn do almost any place.

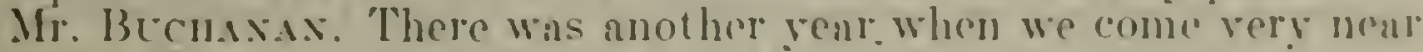
equaling that.

Doctor línlamman. Yes, sir.

Mr. Bucusax. Another vent when the loss was nearly $200,000,000$ hushols.

Dortor Keldermas. There were two veals when the lose was nearly that greant.

STATE ABW IN ERADICATION WORK.

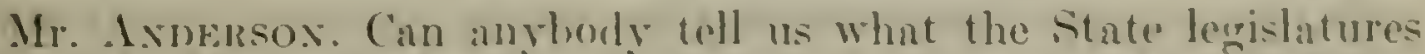
will do! Mr understandine is that it is the expectution that the 13 States-that their appropriations will posibly be about $\$ 1.50,000$, which would probubly be the maximum.

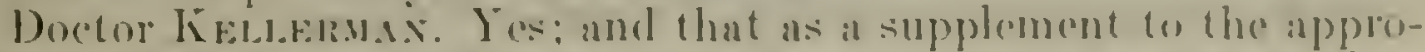
priation that we have this rear would not represent any more than an increase in the funds that could woll be put into this kind of activity.

Mr. Bucrusax. Why do you want to decrease these cestimates?

Doctor Kets.sisus. I regret to answer that wo didn't.

Mre. Bechasis. The Buleget?

Doctor Kä́d,emax. Woll, our recommendation. Mr. Buchanan. was for the sum we had this rear. That was the sum we believerd we should continue to expend.

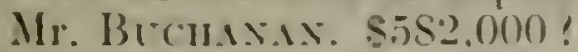

Mr. Annersos. Do vou feel that that sum would be adequate with what rou would probably ohtan from the States: 
Doctor Kestekmax. We think that that would represent a good campaign, perhaps as efficient as we could hope to muke it in this one year.

Mr. Axnersox. I understood that there was to be a conference in Minneapolis on the 9 th and 10 th of November on this subject.

Doetor Keldermax. Monday and 'Tuesday of this week.

Mr. Annersos. Was that held?

Doctor Kendemax. They held it and it was a very enthusiastic. conference.

Mr. ANonersor. Did you have any representatives there?

Doctor Krifermax. "Yes; we had three men there and both Doctor" Taylor and I hoped to get to that meeting.

Mr. Axufrson. So did I.

Doctor Kembermax. But there were too many things going on in Washington this week, which made it impossible for us to go.

That meeting was a very enthusiastic meeting in every way. The Farm Bureau representatives, State representatives, and representatives of the grain trade, as well as people that have been directly concerned in carrying on this eradication campaign, have indorsed the campaign to the utmost.

The representatires from the different States, including the Farm Bureau people, have pledged themselves to do ererything in their power to bring about liberal State support. And the entire conference, I learned just a few moments ago, unofficially, is urging more general Federal and State support for the whole eampaign.

Doctor 'TAYzon. There is erery indication, Mr. Chairman, of widespread agreement in the importance of the work. 'The vilrous persons and organizations interested hope to reduce the probability of another $150,000,000$ or 200,000,000 bushel epidemic through prompt carrying through of this eradicating campaign.

Mr. Anderson. I have always been rather conservative in rapidly expanding programs of this kind. I was a rear agn on this one, fut I feel that if this is ever going to be expanded further it ought to be done this year. We are in a bet ter position to expand now and get through with it than we ever have been or probably ever will be again, while I appreciate the need of economy.

Mr. Buchaxax. Sometimes economy ean be penny wise and pound foolish.

Doctor Keldermax. I would like to rend one other paragraph from the statement of Doctor Stakman with regard to cradiention of barberry bushes in Denmark and Sweden. [Reauling:]

\footnotetext{
Barberry bushes have been almos completely removed from lienmark, and there has not beren a single serions outhreak of rust sineo 1903, when must of the bushes were removed. The sporadic outhreaks now can essily be traced to barbere hushes which still remain in wooderl and wase lants. Nothing conld be more convincing than the contrast hetwern the rust situation in Demmark and that in sweden. In Denuark the rust dores no damage whaterer. In Sweden, on the other land, it is extremely deatructive becanse of the tremendous number of harberry hushes.
}

The reports of losses in Swoden are very much like the reports from yenr to year that ocenr in our own spring whent recrion.

Mr.Asorason. Now, will you just bricfly tell us how this work was organized this year!

Doctor Kelisemax. The work is more definitely correlated with the county agents and with the farm burems thin heretofore. It 


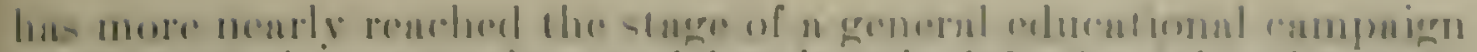

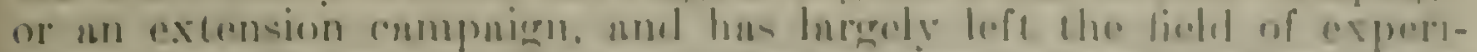
montal development. Wre ure, therefore, working und just ats fare an

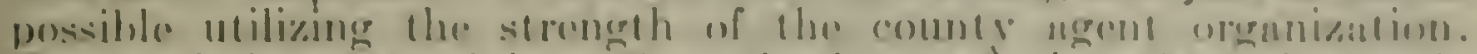

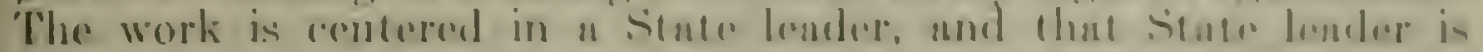

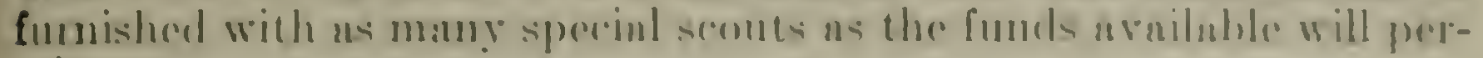
inil.

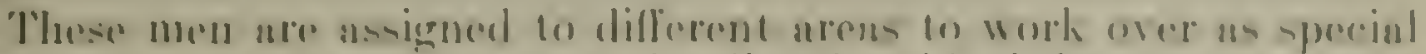

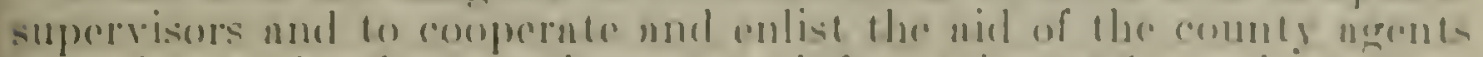
in troing to develop supplamentury information nul supplementary

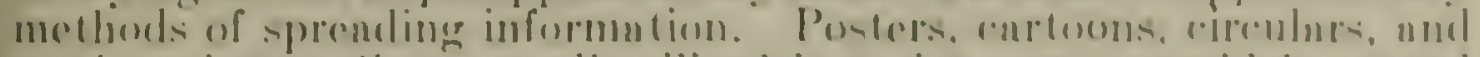
motion-picture tilus are all atiliogd in trying lo got as widely-promel as possible the information as to just what there now are suppored to do. by explaning to poople whent ther are doing, so that their work ran be devoted to seonting work. and explaining the best way of hunting for barberry bushes, showing poople where they are likely to

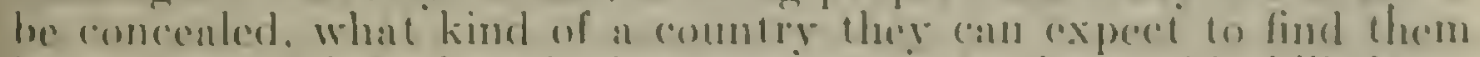

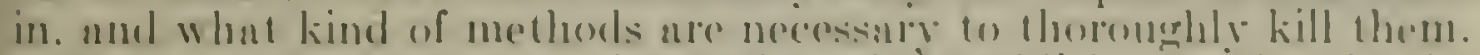

IV are doing some experimental work in actition to that in the utilization of poisons insteat of grubbing methods, in order to see whether there are ways of making aratiention work more thoresurgh and chenper, but the bulk of it is in educational and scouting work.

Mr. Anbersos. Do these scouts travel in purts, or do lhey gon alone!

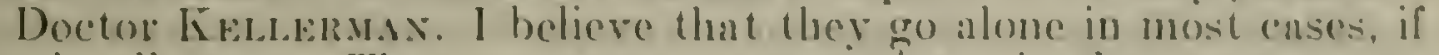
not in ull cases. They can eover more lerritory in that wy.

Mr. Axulssox. My information was last year that they were semt

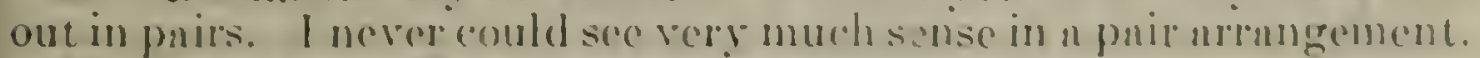

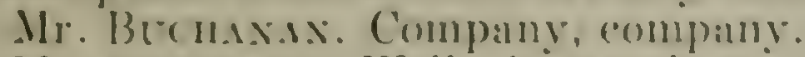

Mr. Axurnsox. Well, the waty it wis exphaned to me was that one went up and engaged the farmer in conversation at the front door while mother fellow went areumel to the hack door to see if tlare were any barberies around there any place.

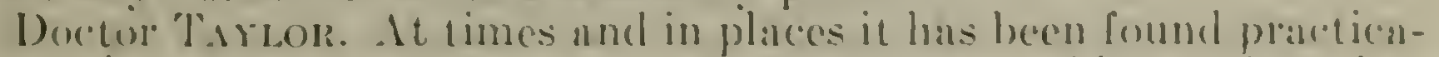
ble and exomomical to take several ont in one machine and worte a territury vitheh was remote, returning tegether in the eroning, so that in ihe morning outbound and in the evening homs-bound there

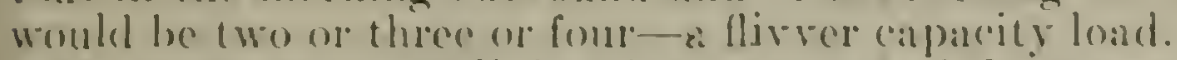

Mr. ANuresox. Wall, is this movement of these men. for instince. in at stute, is it directed he state lenders, so that you have a local leadership there which is familiar with the hocal conditions and can deal with it from the standpoint of knowledge of the loeal conditions?

Doretor 'Trion. Yes, sir.

Doctor Ketcamax. We sometimes do not hear from these men exeept from month to month, but the - nte leaders have reports from the men from lay to day.

Doctor' Tomon. In eonmection with the experimental work that 1)octor Kellerman mentioned, with reference to the investigntional work that is being done in connection with the chemical control or erndiention of the burberries. it should be understood that that is chielly concerned with those sections where there has been a rather large esenpe of burberries to rocky, rough lnnd where grubbing is almost impossible, and where it is elenr that if you ever expeet to kill out the barberries. you will need to do it otherwise thun by 
grubbing. Those areas are not large, but they are very difficult where there are rocky, rough places that are thickly set with barberry bushes. There are some such in Wisconsin. some in Minnesota, and some on rough river bank territory in lowa. In certain of those places, organized bees, after the style of the farming country, have been enthusiastically prosecuted by the communities. By the use of certain arsenical poisons and common salt, in heary applications. the eradication appears to be more thorough than in any other way.

CEREAL DISEASE-CONTROL WORK.

Mr. Axperson. The next item is the item on page 102.

Doctor Thyor. The item on page 102 is that for cereal disease control, one which it is proposed to climinate by transferring funds to these other places that have been mentioned.

The next is on page 104, for the breeding and physiological stuly of alkali-resistant and drought-resistant crops.

\section{TOBACCO INVESTIGATIONS.}

Mr. Buclianan. How about this tobacco item on page 102! Is that all the same?

Doctor Taror. I beg your pardon. The tobacco item on page 102 contemplates continuance of the work as it is. It is proceceling effectively.

FOR THE BREEDING AND PHYSIOLOGICAL STCDY OF AIKALI-RLAISTANT AND DROCGHT-RESISTANT CROPS.

The next item is on page 104 , for the breeding and phrsiological study of alkali-resistant and drought-resistant (rops. There is no change proposed in that item. That work is procceding as heretofore. The same remark would apply to subappropriation for sugar plant investigations on page 105.

\section{SUGAR-PLANT IIVESTIGATIONS.}

Mr. Anderson. May I ask you in connection with the sugralr-plant item if rou have observed any extension of the sugar-bert area in the country within the last rear or two!

Doctor 'Throor. There has been material reeluetion of acerenge of sugar beets grown in the vicinities of the sugar factories in most parts of the reuntry as a result of the unsatisfactory outcome of the crops of 1920 and $19^{2} 21$, and the deflation of price which came to a head in the contract priee for sugar beets in the senson of 1922.2 . which, of comrse, was determined last winter, when the sugar market was at its

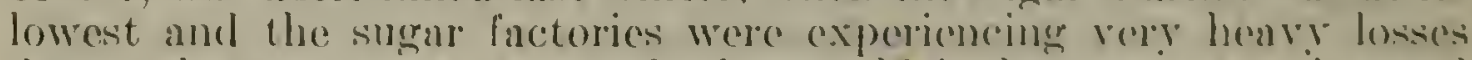
due to the war rate contracts for beets whold they were carrying and the low selling priece of sugar which they confronted. 'There was dis-

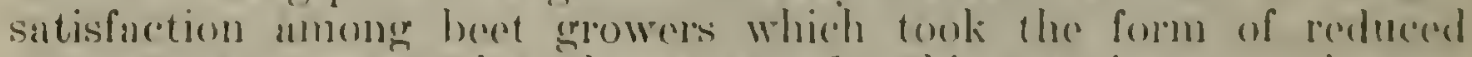

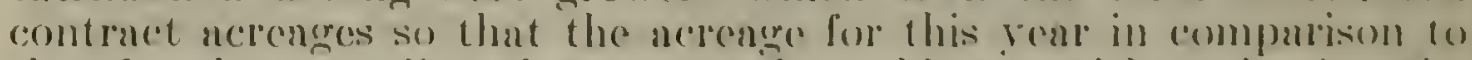
that for the preceding three yenrs, 1 would say without having the exact fignres in mind, is matcrially less. Howerer, there is contimuing interest in territory not ret equipped with boet-sugur lactorices in 


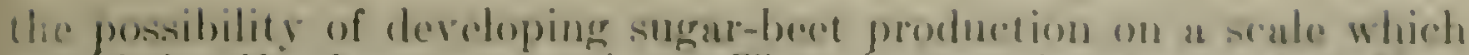
would justify factory erection. That is true in portions of New

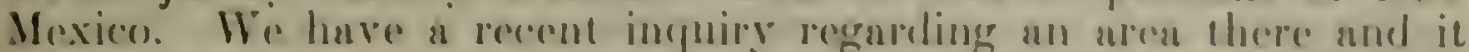

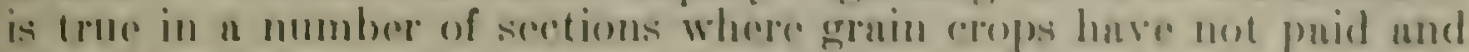

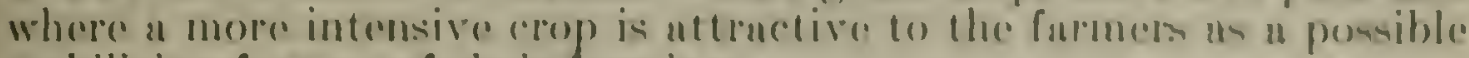
stabilizing feature of their furming.

In the irrigated regions generally, where there is not nematode infection or curly-top disconse, the interest, I should saty, is woll sustained. with indiration of a rather steady entargement of the beretgrowing aren of the country.

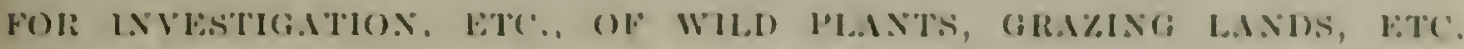

()n page 107. the subappropriation, "For investigntion, improvement. and utilization of wild plants and growing lands, and for determining the disposition of weeds and menns of their control," the estimnte provides an increase of $\$ 3.600$ needed for weed-control investigational work. The weed problem, especially in the whentgrowing territory, where the wead content of the threshed crop is an important feature in determining the grade of the grnin, needs more thorough and presistent work in the investigation of the life history of some of the weeds that are troublesome and causes pernalizations of the furmer in the gruding of lis grain.

Garlic is one of those. In the whole question of crarlicky wheat, which results inevitably in the penalization of the orower beyond the economic or linancial dnmuge that occurs, there is needed fuller information than we yet have as to the best methods of controlliner garlic in the regions where it is established. 'The sume applies for a very different reason to the spring-wheat territory with respect to the so-called wild pea. It is a veteh-a wild reteh that lowers the grate. It is diflicult of separation from the grain.

Mr. Becusax. It necessarily reduces the rield?

Doctor 'TAmok. It reduces the rield somewhat. Also it is diflicult to clenn out for milling, as well ns from seed grain.

Mr. Axnrissox. As a general thing the presence of these weeds in the wheat, for example, is it or not the result of seed that is not cleaned or is it a continual voluntering of the seed?

Doctor 'T.ryor. It sometimes is the result of continual growing of that particular crop on a given field without the rotation of a cleaning tilled erop, like corn, or more intensire farming. and while we adrocate more intensive cultivation and tilled crops in the interest of good farming generally and in the interest of weed dimination, we can not orerlook the fact that under some conditions the farmer just can not carry a large acreage of corn or of any other lilled crop. He is practically forced to enrow a large proportion of his atereage in sowed grains with the laber that he has and the market that he has. So it is important to locate the weak spots in the life history of the relatively few troublesome weeds if that can be done, to develop methods of controlling them measurably in general grnin-growing practice. That serms to be ull that the farmer can do under the existing circumstances.

Mr. Axmersox. 'To what extent can the situation be corrected by growing barley, or rye, or crops that mature earlier? 
Doctor 'Tarton. There is a possibility there in cuse of certain of the weeds that do not mature as early as these grains do. In casc of garlic, it is beeoming rery troublesome in the Mirldle West, in Missouri and Kansas. The St. Louis market during the last two or three years has been full of andicky wheat, as well as this old garrlicky country of Maryland. Delaware, an!l tidewater Virginia. The practical coritrol has got to come through deep nloughing in the fall and the planting of tilled crops with practically clean cultivation for at least one year. The deep ploughing results in a freezing and cleaning out of a large proportion of the bulbs, the clean tilling killing the remainder; the keeping of the fence rows alean als woll ats the ficlds is important, so that there will not be al reseeding of the field quickly from the fence rows.

Mr. Axpressox. How much is the wheat penalized because of garlic?

Doetor 'Tarlon. It is rather difficult to get at that, but there have been eases where studies have been made on a fairly large serale where the actual penalization that the farmer has earred has been anywhere from 10 to 15 cents a bushel. There was an estimate recently made based on a careful study of the inspection of the ports of Philadelphia, Boston, and Baltimore. where most of the wheat is exported-the Pennsylyania-grown whent-and it showed that the farmers in Pennsylvania had been penalized during the year in question something like a million dollar's merely on account of garlic, and Pennsylyania is not an important wheat-exporting State.

Tr. Axnersox. Of course, the penalization would probably be relatively greater in the smaller markets than it would be in the larer ones?

\section{DRY-LAND AGRICULTURAL INVESTIGATIONS.}

Doctor TaYlor. Yes. On page $10 \mathrm{~S}$ is the approprintion for dryland agrieultural investiuations." The estimates provide an inereats of $\$ 11,000$, and the addition of a proriso remoring this paragraph from the limitations in this act as to the cost of farm buildings. The reason for the increased appropriation is to make possible the replaring of implements and equipment and the repair of buildings on the field stations that are earried under this subapproprintion. (of these, 2 have been in operation for 15 vears: 2 for 11 rears: 2 for ! rears: 1 each for $S, 7$, and 6 years, respectirely, and during the perion (substantially the period since 1914) there has been necessarily a postponement of repail and replacements that we now have to make. Buildings need painting. Implements have been used to the limit of their efliciency, and the estimute is to corere that frature.

Mr. Axmensox. How extensive are the huildings maintaned on these dry-land stations?

Dortor 'Taroos. 'They vary grently from distincely important and permanent types of structure at Mnudan, N. D) in. where the experiment station was specilically provided for by Congress sereral pents ngo, to a trpical huilding oittit at such a fichl station as would consist of a dwelling for the superintendent, a harts, a tool house in some places a theshing building for the handling of numerous a $x-$ perimental lots of grain live or six frame buildings. whele would represent an investment of prohably ten or lwolve thousand dollars. 


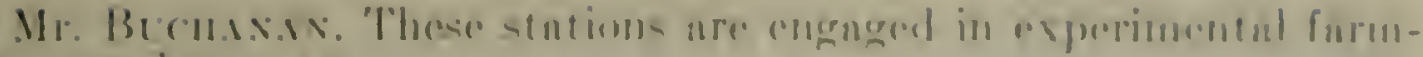
ing. are ther unt!

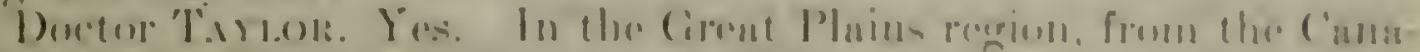
dian border down to middle weretern lesins.

1.11

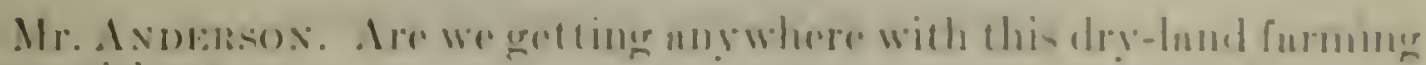
proposition!

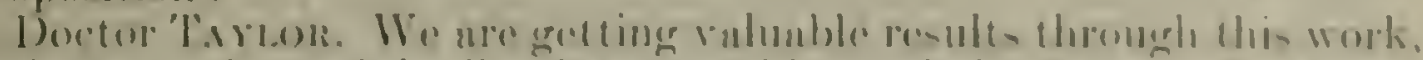

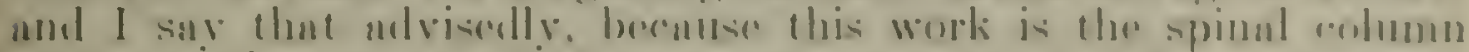
which largely sustuins all of the experimentul work of the dry-farming

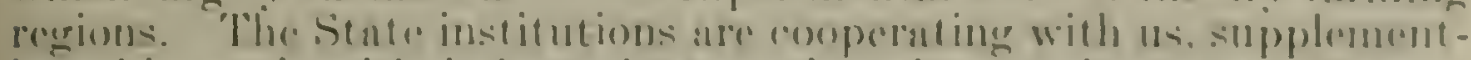
ing this work with independent stutions in rertnin rases. IFe nre

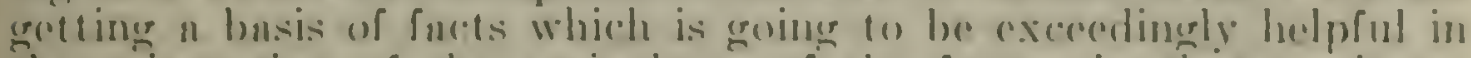
the orientation of the ogriculture of the future in that terefory. 'The sad thing is that wo conld not have hand this work dome hefere a good deal of that country was opened nud its furming begunt as it "ras, upon un cepploitutional busis in thr morlier yours.

Ir. Axnetsos. What relation will this dry-latul experimental work have on livestork rnising and fornge !

Dector Trytol: Exnetly this-the development of a permanent live-stock industry there requires a fairly constant supply of phanted formge ns woll ns aderguate grazing land and it is groing to rerguire probiably the provision of formere for the expuvalent of $n$ winter is monibs lone a part of it hot.

In other words, the nonproductive seasons in which practically no planted crops make a vield. The question ns to the acrenge unit that a farmer can hope to support his family on, the types of erops that he can afford to grow, the methods of tillage that will insure supplies of forage and grain, all have to be calculated from the data obtained by experimentation at these stations. The determination of the frequency of these is months' long periods of light productions are through these records. They are the places where, because of the continuous maintenance of the work, the facts ean be recorded and made avalable. Then, too, the prevention of irrational exploitation of these lands has got to come through the arailnbility of information of this charneter to the public.

Mr. Axnersor. It seems to me the production of grain crops in this section where you have periodic fuilures and long distances from murkets and great disadrantages in freight rates is almost hopeless: unless you can develop a live-stock industry which will reduce tho cost of getting to the marliet.

Doctor 'Turoos. The shnpe in which it has crystallized in some of our minds is about like this: That the farming of considerable areas where almost sole reliance has been placed on grnin for sale will have to be rendjusted to the basic of a live-stock industry bnsed primarily upon grnzing on opernting units hig enough to muintain a furm family. This necessitates production of sulficient supplies of formge to carry the stock through the winter and to provide a carry-over of cither dry or ensiled fornge for the bud years. Grain production is a semispeculntive posibility, the grain rop to be put in when the spring prospects look light for making in good crops. but grnin for sale not to be relied on for the support of the fomily. The grain 
crops will probably need to be regarded as an occasional source of cash income supplemental to this basic live-stock operation rather than as the basic feature of the farming. dent?

Mr. Buchasax. Stock raising country with farming as an inci-

Doctor TaYlor. Yes.

LINTATION AS TO COST OF FARM BUILDINGS.

Mr. Anderson. I notice this proviso says that the limitation in this act as to the cost of farm buildings shall not apply to this paragraph. Is that limitation carried in the appropriation bill or in the law?

Doctor TAYLOR. It is in this bill and it is a limitation of expense of any farm building erected under the Bureau of Plant Industry to a maximum of $\$ 1,500$. A considerable number of these buildings on these field stations have cost more than that and would cost considerably more than that to replace in event of storm or fire destruction. As it stands we would be helpless until Congress authorized the expenditure in case we have a fire or destruction by wind storm there.

Mr. Anderson. What would be the maximum cost of buildings to be constructed there?

Doctor Taylor. Probably under present costs $\$ 3,500$ to $\$ 4,500$ would cover all but three or four. I could not answer that more specifically than that.

\section{WESTERI IRRIGATION AGRICULTURE.}

Page 110, subappropriation for investigations in connection with western irrigation agriculture, the utilization of lands reclaimed under the reclamation act, and other areas in the arid and semiarid regions, covers the corresponding experiment work on Govermment reclamation projects.

Mr. Anderson. How many have you?

Doctor TAYLOR. I think it is seven, including the field station at San Antonio, Tex, which is not on the Government reclamation project, but is devoted to irrigation practices of similar character.

\section{NUT CULTURE INVESTIGATIONS.}

Page 112 is the subappropriation for the investigation. improvement, encouragement, and examination of the adaptability of various species of nuts, ete. 'The incrense orer the nmount carried by the regular appropriation bill of last year is $\$ 10.000$, the regular appropriation of $\$ 20,000$ having been supplemented by $\$ 5,000$ provided in the defieiency appropriation bill of June 30, to provide for a field station in the sonthern pecan territory, the mantenance of which, together with the other work, will reguire a net increase of $\$ 5,000$ for next year over the total that is araibho for this year.

PlEAN INUUSTIR.

The increase is needed primarily for work on the pecan problem in the South and the walnut and ilmond work in the Pacitic Const State- California, Oregon, and Washingron. It represents a modest 


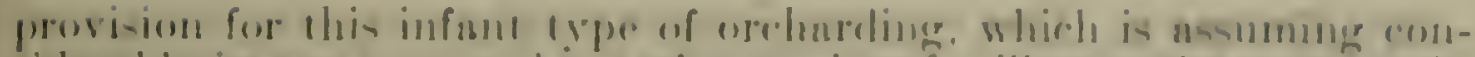

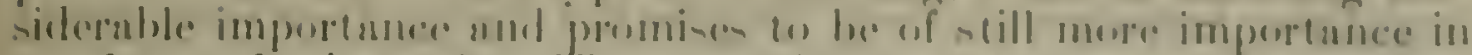

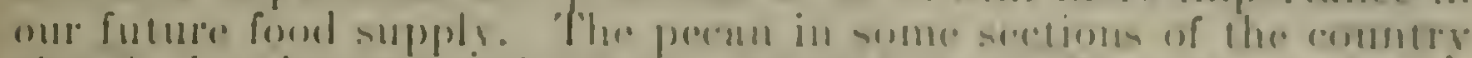

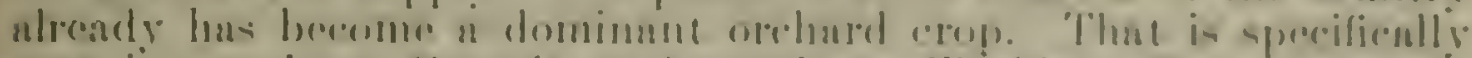

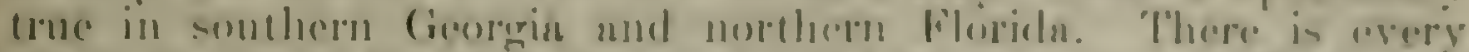

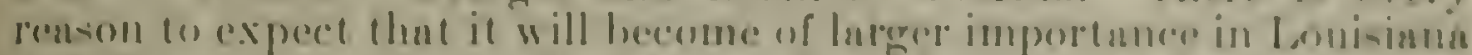

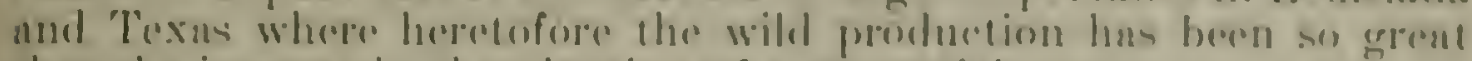
that the intrest in the planting of communereinl

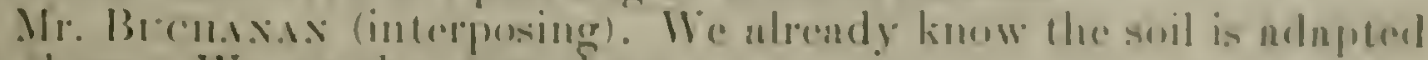

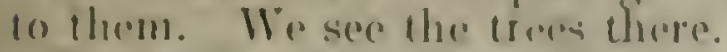

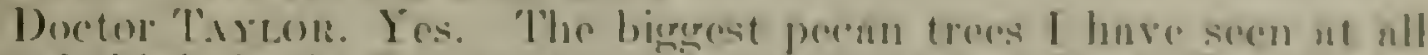
are, I think, in tho Prinity Vulley, up nom Hedley, Tos. But one of the proctical things of importance is the detcrmination of the anduptu-

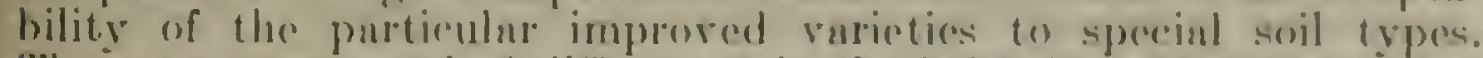

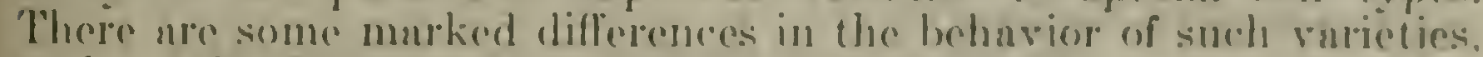

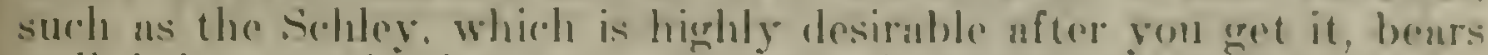
well. brings enoul pricess ete. It needs the sume sort of study us the npple, pench. pens-in fuct, all the tree fruits have reguired before thry ure shaken down into their pormanent production torritory. It is ane of the distinctly important infant orehard fentures of ciur angriculture.

Mr. Bucusxix. I think so too, and I think we know that the land is adapted to it. I know so in my section.

Doctor T.Mrot:. Of course, you have there in rour seretion the mutural pecan production to guide you. The surprisine thing is that the commereinl pecin orehurd in its most intensive form has leveloped outside of its natural territory

Mr. Becusxax (interposing). Do you know why it is? It is because it takes pecuns too long to develop into something profitable.

Doctor TAroor. Yes, sir; and that is wy, in the Sonthenst, if they wanted pecans, they had to go to work and rnise them. They could not go to the woods and get them.

FOK INVESTIGATION ANI IMPROVFMLNT OF FRUIT AND METLODS OF FREIT GROWIXA.

On puge 113, the subappropriation for investigntion and improrement of fruit and methods of fruit growing, there is nn nctunl incerense of $\$ 15,000$. 'This is required for the provision of fences. buildings, equipment for the operntion of the two experinental vineyuls which Congress unthorized the purehase of last yenr. and which no nuw goremment property, hut have to be operited he the depmetment directly insteat of indirectly thromegh coopernting owners of the Innd. These ure at Fresno and Oinkille, Calif. One is in the hot sin Jouquin linley, the rasin territory, nud the other in the cooler bny region.

Mr. Axineson. They seem to be eacting along rery well with their price without much help.

Doctor "Throk. 'They have through the unexpected developments following the constitutional amendment, up to this year, but they have had very severe losses this rear through failure of the transportation systems to move the fiesh errnpes to the liastern consumers. This work was begum lnck in the dars when wine and brundy were the principal objectives of the growers of a large proportion of ihe acreage of (rimpes. 
Mr. Axderson. This increase, I understand, is to cover additional equipment, fencing and so on, but does not enlarge the experimental station.

Doctor TAYLOR. No; it does not enlarge the area at all. 'These vineyards were established as cooperative vineyards, the labor upon which, the team power, and the buildings used for which, were secured by the department from the growers through reimbursement of the actual operating expense of labor, material, etc., to the owners of the land.

Congress decided to purchase the vineyards when the apprehended catastrophe loomed up and authorized their purchase. These are now Government-owned property without fencing or buildings and without operating equipment. This year they hare been carried along under a makeshift arrangement with the neighbors, which it is not practical to continue.

Mr. Axderson. There are no buildings on these properties?

Doctor TaYlor. No, sir.

Mr. Andersor. And no fences?

Doctor TAYLOR. I believe there is an outside fence along the Fresno property.

Mr. Axnerson. What buildings will it be necessary to erect there?

Doctor TAYLOR. It will be necessary to erect a general workshop and field laboratory building at each, and it will be rery desirable to provide a dwelling for the man in charge as there is no housing nearby in either place for such a man, and lie should be there on the place at all hours of the day.

Mr. Anderson. How many people do you have on these places?

Doctor TaYion. We have not anyone at present steadily there except near-by laborers working under supervision of an assistant in California who has general supervision over them. At certain times of the year, at the propagating times, and again at harresting time, when the fruit is harvested for the testing, there are two or three temporary employees maintained.

Mr. Anderson. You have no permanent man on either one, of these places?

Doctor TAYror. No; we have no housing whatever' on either place, either for men or for implements.

Mr. Axderson. Do you have anybody who goes out there more than once or twice a year?

Doctor 'Tayor. Oh, yes; we have the near-by laborers, who are there nearly every day, under the direction of the technical assistant in general charge of the vineyards.

Mr. Avoersox. But you have no superintendent?

Doctor TAYLOR. No superintendent there; no, sir.

Mr. Buchasax. How many acres have you?

Doctor 'TaÝor. Twenty acres at ench place.

Mr. Bucmaxax. Planted in grapes?

Doctor 'Tayuor. Yes, sir.

Mr. Buchanax. All in grapes?

Doctor' 'TArior. Yes, sir.

Mr. Buchaxas. Is there any plowing and cultivation of it?

Doctor 'TAruor. Yes. That thus far done during the transition period since the rineyards were purehased last winter has been hy hiring arrangements with near-by vineyardssts. 


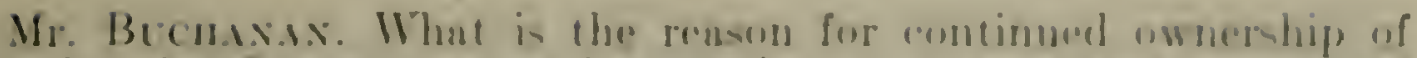
this by the Government and opreation of it hy the department?

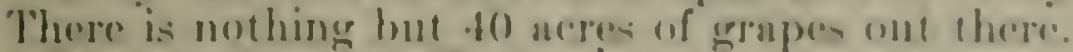

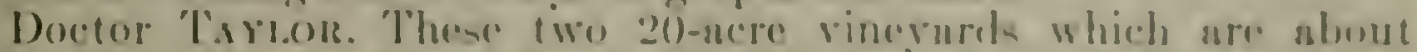

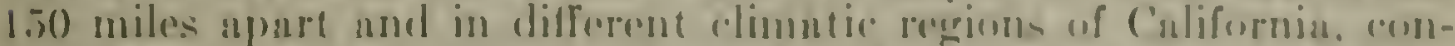
tuin at the presellt timse, without doubt, the mus comprehensise colleretion of varieties of the ()ld World trpe of grapes that exish in the world. 'They involve not merely the lesting of those sarie-

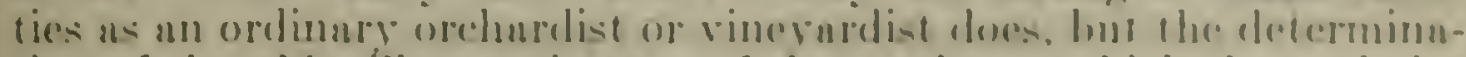

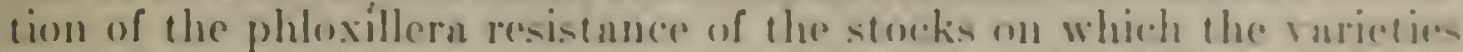

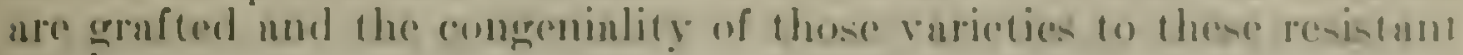
stocks.

Mr. Becmssas. Then, in short, this stock is determining the aduptubility of the varioties an this muntry and climate, und comlitoms under which those virieties an he grafted!

Doctor Tormon. Yes, sir: and the anditions under wheh the varieties can be grown on resistant stocks.

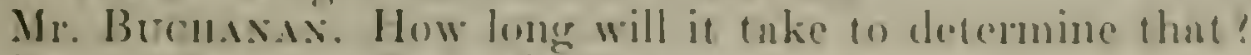

Doctor T'arom. Probably 20 years.

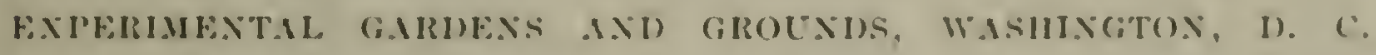

On page 115 is the paratgraph for the mantemance of the grounds here in Winhington. There is no change.

FOH HOLTICLITLKA, INYKSTIBTIOA.

On page 117 the subappropriation for horticultural inrestigntions. which includes also the technicnl studies of the physiological changes of regetables while in the processes of marketing ind storage. comries an estimnte of $\$ 1,500$, which relates specifieally to investigntion of regetnble transportation work. The questions of primary importunce may be snid to be those involved in trunsportation of northern potatoes, the whole question of production of potutoes ngainst hamful temperatures in transit in winter-harmful both through freezing. through the effect of cold in unhented cars, and the determination of the relation of the heated-car tempernture to the carrving qual'ty of the moduct where henter-car service is not maintained.

This is needed especinlly with reference to the northern Mane. Minnesota. and Dakota jotato-growing districts, and the potato produrers and shippers have-

Mr. Axumesos (interposing). We would not worry much now. myhow, as to how they hehave in refrigerator ars or other kinds of anrs if we contel get the cars. Wre will take a chunce on how they behave.

Doetor Tareon. Yes; until it enets down to nbout $2.5^{\circ}$ or $30^{\circ}$ behow zare, then sometimes there come very heary losses on aceount of freezing in transit when with the transportation chnrges already lying arninst the shipment. Confortunately these destrume freezes di not

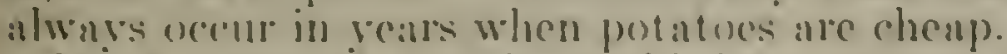

Mr. Axnersos. I notice in this item on page 113 that there is a provision for the investigntion of these physiolengionl and related ehanges of fruits and regetables during the provess of harvesting and while in commercint storage, and in the same general item appears this item on page 115. What is the difference? 
Doctor Tayon. The difference is that the item on page 117 is the work done on fruit, the word "regetable" being inserted there to make it technically legal to carry work on both products where necessary and advisable, and to simplify the financing of it. Primarily that on page 113 deals with fruit studies and primarily that one on page 117 deals with regetables. Generally the products under experiment are from different sections of the country at any one time. though not always.

\section{XULISERY STOCK INVESTIGATIONS.}

Page 119 contains the item for inrestigating and cooperating in connection with State or privately owned nurseries, methods of propagating fruit trees, ornamental and other plants, the study of stocks used in propagating such plants and methods of growing stocks, for the purpose of proriding American sources of stocks, cuttings, or other propagating material. 'This is a paragraph under which our experimental work looking toward the development of larger production of grafting stocks of fruit trees and ornamental plants in this country is being done to reduce our dependence upon inported stocks of this character from foreign countries. Such importations always, in spite of any guaranties or inspections that can be maintained, involre a certain risk of introduction of additional pests, and in proportion to the completeness of our production of our own requirements in this country are we likely to exclude such destructive pests.

Mr. Axdersox. To what extent is progress being made on the production of seedlings used in this country?

Doctor TiYror. Considerable, both as to seed-grown stocks and regetatively propagated stocks. The progress made gives promise of perhaps ultimately displacing seedling stocks for some kinds of fruit trees. For instance, in the case of the apple, through propagntion of grafting stocks of special varieties Yrom cuttings, so that in place of a rariable lot of scedling apple stocks to graft upon you may have uniformly vigorous, hardy, and insect-resistant stocks. Very distinct progress has been made within the past two venrs in that direction, particularly in case of the apple. Some of that work was done out here at Bell Station in Maryland, and some of it in Michigan. It is a field in which our men are pioneering in the expectation that some of the problems will be simplified-some of the problems of the nurserymen and the production considerably stabilized.

Mr. Buchraxas. Does the grafted or budded tree take on the hardihood of the tree from which it came or the tree on which it was budded or grafted? It produces the rariety of the tree from which it was taken, but how about the hardihood, and resistance?

Doctor 'ThYor. That is a vely eomplicated guestion. In some cases, eralting on cortain stocks increase's the haddiness of the varioty that you are propagating. As for example, the Satsuma orange when gralted on the trifolinte stock, which is what is called the hardy orange, which sheds its leaves in the winter and is distinetly hardy. will endure lower temperature than if grafted on the sweet oranges, which is the standard stock of the more southern ritrus districts.

Mr. Bechasix. Will it endure the same degree of winter as the other? 


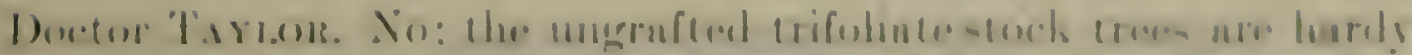

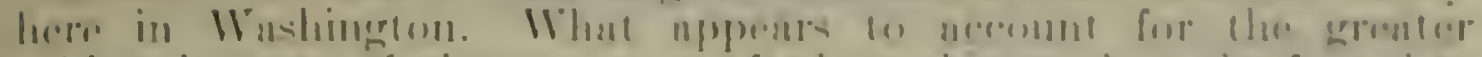

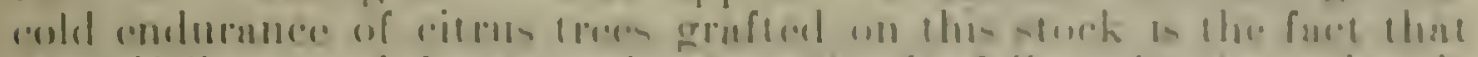

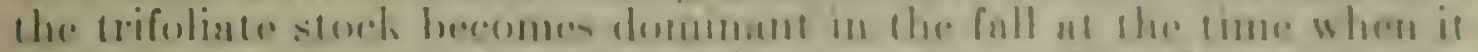

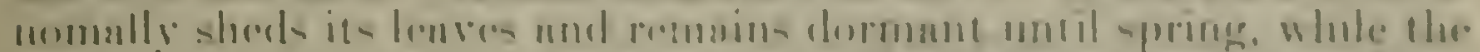

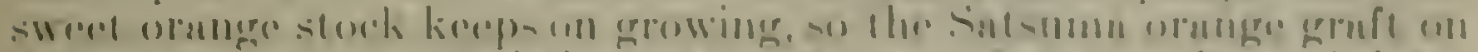

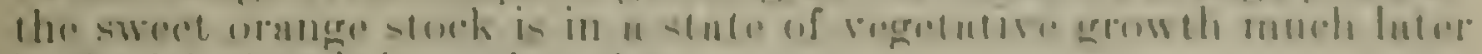
in the fall than it is an thromlure.

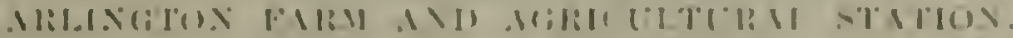

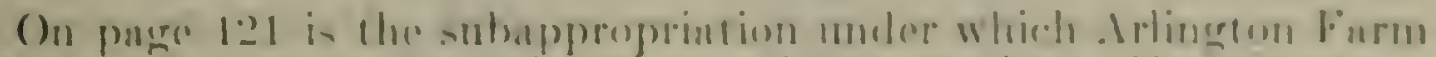

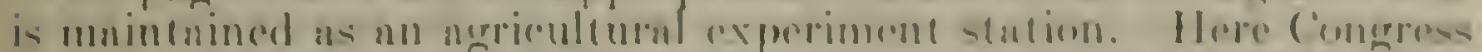

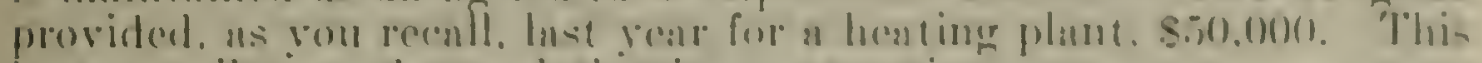

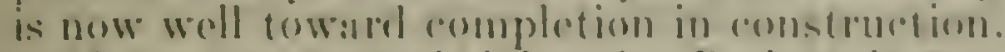

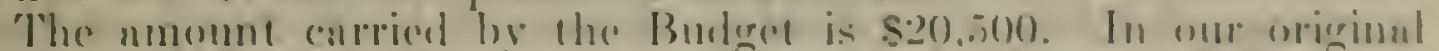

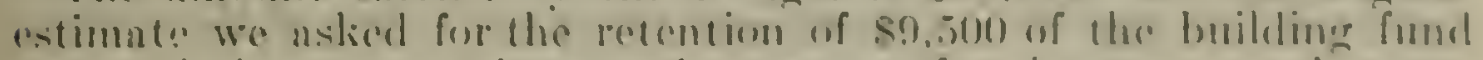

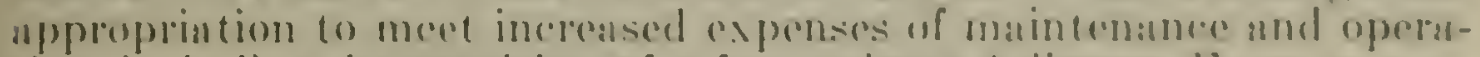

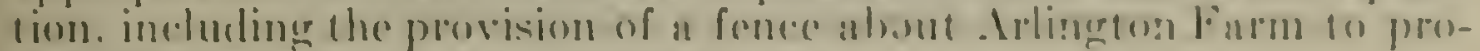

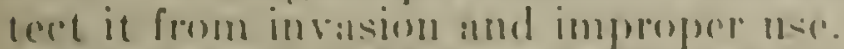

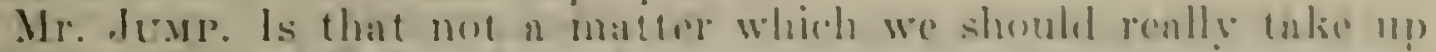
with the Burlect Burenu!

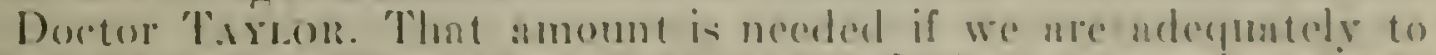
protert Arlinerton liarm as we thiuk we should from conceronchments night for purposes illeganl and destructive.

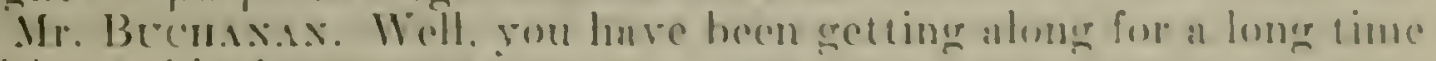
willout this, hare you!

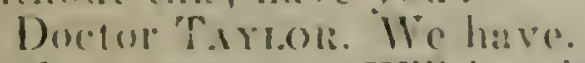

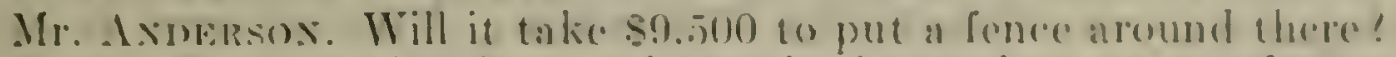

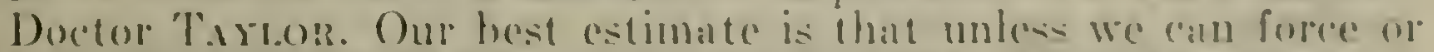

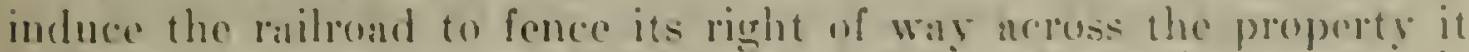
will cost apporoximately $\$ 10.000$ or $\$ 12.000$ to fonce the farm as it shomld be. "The solicitor has investigated the title to that railrombl property and we have heen advised that we ean not foren them to fence their right of way. There is a greatly increased value of Gorrenment property on the farm now, in comprisun with carlice pes:s, and greatly increased risk, due to chunged conditions.

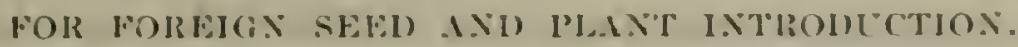

Page 123, the suhappropriation ofor investigntions in foroign secol and plant introduction, including the stmels, collection, formelesse. testingr. propargation. and distribution of raire and baluable soeds.

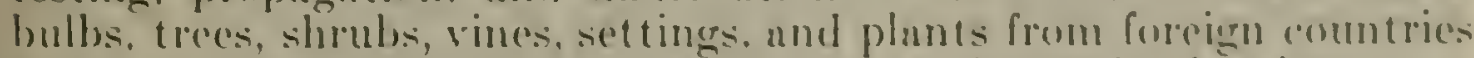
mal from our possessions," cte.. there is no ehange in thit item.

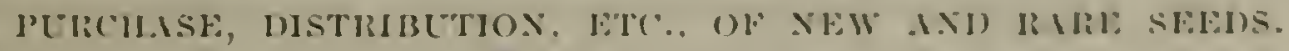

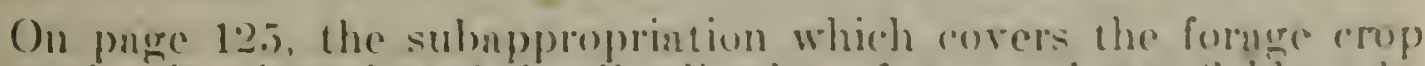
investigational work and the distribution of now and ratro liodel soods.

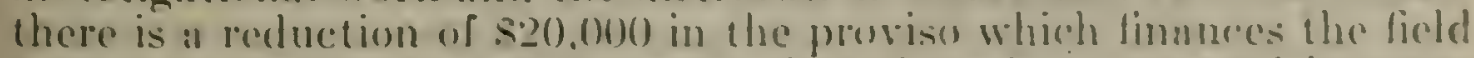
secel distributim, and at the same time there is at proposed incerase

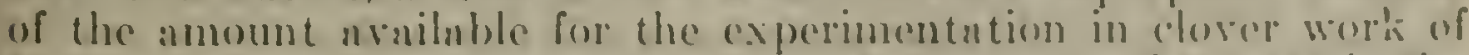
S.j.000, so that the estimate invelves a net reduction of $\$ 1.5 .000$ in the amount carred by the paragraph. That reduction is mase in recornition of the urgent need of economy of expenditure. 
Mr. Annersox. You are going to economize here at the expense of we Congressmen, are you?

Doctor TAYLor. We feel that we suffer equally in this case, eren with the Members. This work is accomplishing unquestioned and material benefit to agriculture.

Mr. Axdersox. Well, it is a perfectly hopeless proposition to spend $\$ 115,000$ getting new and rare field seeds in here and $\$ 20,000$ getting them out where they will do some good. I think it is ridiculous. If this new and rare seed proposition is not any good, let us cut it out; but if it is some good, it ought to be good enough to get it out to the people where it will do some good. It does not do any good to import a lot of stuff down here into the department, or in parts of the country where it never gets off the grounds of the Inited States. It does not make any difference to me who does the distributing. I think it is ridiculous to spend a lot of money and get this stuff into the United States and never get it out of the department.

\section{CONGRESSIONAL SEED DISTRIBUTION.}

Doctor TaYlor. On page 127 the subappropriation known as the congressional seed distribution is not recommended. The explanatory note is

Mr. ANDERsox (interposing). Let me ask you one question about this item. In the erent that the Congress, in its wisdom, should conclude that this was a desirable item to continue, would it require as much money next year to make the same distribution?

Doctor TAYLOR. I should have to get closer estimates on the prospective cost of seed than I have now. I should have to look into that.

Mr. Axpersox. I wish you would give me an estimate of what it would cost on the basis of this year and approximately what that would mean in number of packages on the basis of the quotas this year?

Doctor TAYLor. I do not think there would be a material difference unless there is some prospectire difference in the cost of labur, paper, packets, and supplies required in connection with the distribution.

Assuming that the cost of seed in 1923 will be substantinlly the same as during the current year, it is estimated that a distribution of $13,000,000$ packages (substantially the same as that of the present year) could be made for $\$ 360,000$. This assumes that the packeting, asscmbling, and mailing of the seed could be contracted for at substantially the present rate of $\$ 1.988$ per thousand packages.

This would provide quotas of 20,000 packages of regetable seeds and 2,000 packages of Hower seeds to Senator's and Representatives. Should the cost of seed and paper be slightly lower than at present. these quotas could be provided with an appropriation of $\$ 350,000$.

With an appropriation of $\$ 239,416$ (as in the fiscal year 1921), the necessary overhead cost of the packeting, asscmbling, and mailing being substantially the same as for the larger distribution, a total distribution of $\$, 5(0), 000$ packinges could be made. This would provide quotas of 13,000 packages of regetable seed and 1,000 packages of flower seed for cach Senator and Representative. 


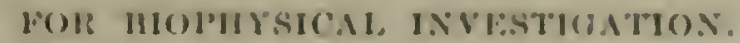

On page 130, the itcm for "Biophysical investigntion" is not chungeel.

Mr. Bucmasas. What is that? What is hiophysirnl investigntion?

Doctor Taroon. This has rather to do with the physies of life.

Mr. Buchasis. Of plant lifo!

Doctor 'liruor. Yes, sir. 'The physicul feutures of plunt growth in contrudisctinetion from the chemicinl fentures.

Mr. Bucmaxas. I thomght the rhemicul fentures determined the biolugical fontures of thom?

Doctor 'Trimol: 'This has to do with such fentures as to water requirement, the tmuspirntion and movement of the wuter supply of plants rather than to their chemical rehtionship). It is a comod word to cover a type of netivity which to a considerable extent is contered uround the devising of equipment for the actunl mensuring of the physiological processes through which phants grow, through which the wuter distribution is determined-plant growth und plicnomenn.

Mr. Axnfrson. 'This is distinetly a technical investigntion?

Doctor 'TAYors. A technical investigntion, and is of importunce becanse of its relntionship to severnl other lines of technienl biological work.

'Tuesdix, November 29 1 1922?

INSECTS AFECTING TIF PFCAN.

\section{STATEMENT OF MR. J. M. PATTERSON, PUTNEY, GA.}

Mr. Axinersox. The committee will return this morning to the three items relnting to the pecan, the first to disenses of the pecan, the second to insects affecting the pecan, and the third an item relating to improved methods in connection with the culture of the pecint1.

We will first henr Mr. Palterson.

Mr. Partensox. Mr. Chairman, I nm here representing the Xatiomnl Pecnn Growers" Ascocintion, the Georgia-Forida Peran Grower's' Associntion, and the Paper Shell Pecan. Growars' Associntion. I think that it was in Misy of this year that a committec represuting these various nssocintions enme to Washington and hud a conference in Secectary Wallaces olfice. We had suddenly been confonted with some disenses and some inseet pests which looked rery serious to the pecan industry. We (ame to Washington, and Secretary Wallace invited in Doctor Tisylor. Doctor Quaintance, Doctor Corbett, und Doctor Waite, and we had a rather lengthy conference, groing over those matters in detail. Following that conference this committere submitted to Secretary Wallate provisions eovering the matter and suggestions as to an increase in the applopriation, which we thonght we conld reasomably ank, in order to tnke cure of these troubles.

The two chief troublew we had were seab and the pecan nut ease borer, either one of which, if it continues to sprend in the groves threntens the almost complete rextinction of the industry. Ife 
understand that Secretary Wallace recommended to the Budget Committee practically the amounts that we requested should be recommended, with, perhaps, one exception. In fact. we have a copr of a letter here that Secretary Wallace wrote to Congressman Griest giving an outline of what was recommended. We had asked that $\$ 5,000$ be added to the appropriation for the oflice of Soil Fertility, which the Secretary, eridently, did not see fit to approve. He recommended \$5,000 for the office of Entomology, which covers the insect situation, and $\$ 5,000$ additional to Doctor Corbett's oflice, and $\$ 2,000$ to the oflice of Plant Diseases. Now, we are here, gentlemen, just to impress upon you, if we may, very briefly, the importance of those items. We, perhaps, understand that there is little use in talking about the addition to the office of Soil Fertility, inasmuch as the Secretary did not see fit to recommend that in connection with pecan culture. That additional appropriation was not so essential to us. The office of Soil Fertility has been doing some splendid work in connection with the pecan groves, and they have been pointing out to us the way of fertilizing to the best advantage in connection with pecan culture. Therefore, we will not ask for any consideration of that matter,

The two things that are pressing for the pecan growers are plant diseases and insects. The fungus or scab at first attacked only one or two rarieties of pecans, but in the last year or two it has attacked every rariety in some localities. It has not attacked every variety in one locality, but when rou make a survey of the pecan territory, so far as I know, there is not a single viriety of pecans that has proven to be immune to the scab. In our section around Albany or Putney the Delmos rariety was, it seemed to me at first, the susceptible variety to the scab. the scab practically eliminating the Delmos crop after three years. Doctor Waite's department has been experimenting with sprays, and has succeeded in getting some control of the scab. As I understand it, to put it briefly, the appropriation that was in effect last rear was sufficient to support one investigator on the scab, and with a small addition to that appropriation of $\$ 2,000$ they would have funds enough to support two inrestigators, because they have the equipment that the two men could use, and by that small additional appropriation of $\$ 2,000$ anded to the $\$ 8,000$ that they have now they could double the efficiency of the work of the department in that one line of investigation. 'The pecan nut ease borer began its operntions in the Monticello district some six or seven years ago. Doctor Qunintance's department did some experimental work there, and then the parasites came along and practically eliminated the case borer, and the work was discontinued. In order to make it clear. I will say that Monticello is about 60 miles south of where I $\mathrm{am}$ located, at Pitney.

That is in Florida, and the pecan nut case borer did not get ip into our district until this year. It seems that it travels somewhat like the boll weevil, and we were congratulating ourselves that it would confine itself to the southernmost border of Georgin and northern Florida. We thought that it was not going to spread further, hut that pest came up into the Putney distriet this year. Our orehards that were farthest south suffered tremenduously from that. 'To give you some idten of the damage, I will say that we have nut erroves in onir association from which we enthered last year betwern 10,000 
and s(t),000 pounds of nuts, hut this geat wo will gere frotu those groses

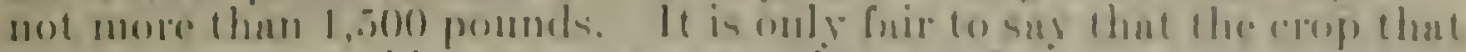

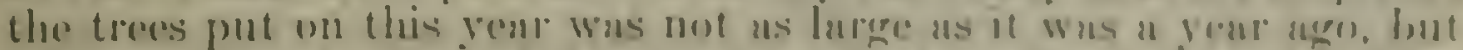

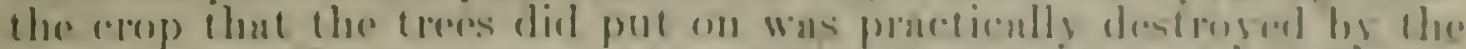

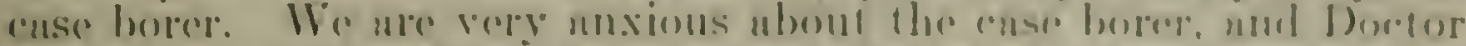

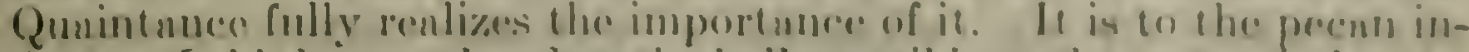

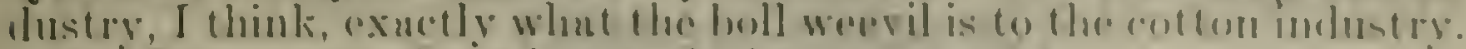

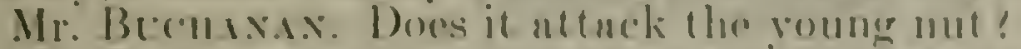

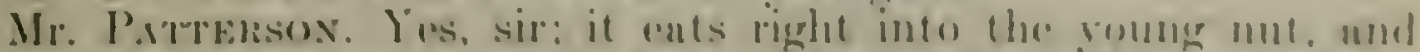

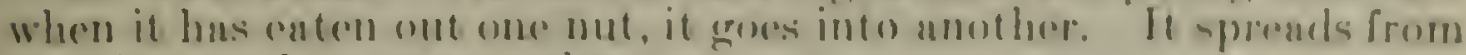
once chustor of muts in mothorr.

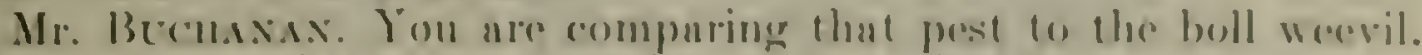
Do voll know what you ue putting us up ugninst!

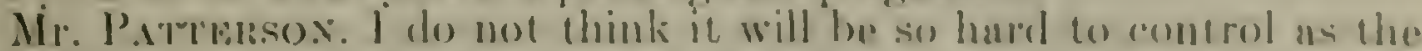

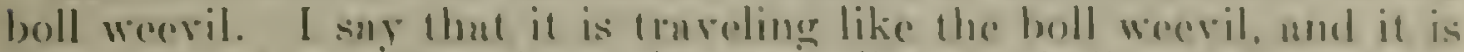

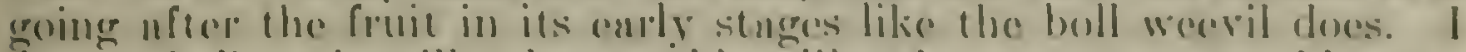
To not beliove it will tako anything likw the money ar troublo thut

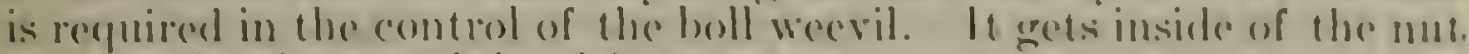
und it is hured to rench it with a spruy.

Mr. Beconsax. The boll wrevil puidehes a hole inside of the spunte. Does this insedet bole " hole into the nut, ol does it punch a hole?

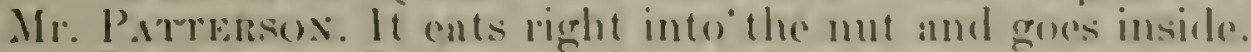

Mr. Brendxas. Like the frollworm?

Mr. P'stremsos. Ies, sir; it eats right into it. Mr gets inside of one of them and the little ones crawl out and bore into others. That is nhout ull I have to say. I wish simply to suy lo you gentlomen thut hore is a grent industry with millions of doilnus invested in it. This industry has heen going along henutifully, with increasing revenues, and it has bern rery largely taking the pluce of cotcon in certain sections of the South. Then we find the industry sudelenly throulened in this way. Wr do not ask any ereat sum of moner. and I do not believe that is necessaly, but we lo ast for suflicient funds to put suflicient investigutors in the lieds so that they inn alrive ut 4 conchusion as promptly as possible.

I have asked Doctor Tavlor if he would come over here. and I ser that he is present.

Mr. LsE. Can you give us some iden of the mannitude of the peenn industry in Georgin and the South !

Mr. Pattersos. That is hated to tell, hut l should suy there are from 75,000 to 100,000 acres of cultivated pecans in Georinin.

Mr. LA: How many trees would that he?

Mr. Parrezsox. Thiere are ubout 20 trees to the acre. 1 personally have charere of some 6.000 ncres, with 120,000 trees, and I can suy to you gentlemen that last yenr from those groves of which I have eliarge we had a vield of something over 600.000 pounds of nuts, but this vear we will hardly get 125,000 pomnds, that heing Inregely due to the scab.

Iro. Bucuaxix. Does the scub attuck the leaf or the tree?

Mr. Partrissos. It attacks the leaf nud the mut. It just eust into it and stops the derelopment of the nut.

Mr. Bucusixax. It is altorether diflerent from the other insects?

Mr. Partrasox. This is a fungus. It is not an insecet at ull.

Mr. Bucusxix. I susperet it is $n$ n insert. toos.

Mr. Patransox. It may be a microsenpic insecet. 
Mr. Buchasax. Doctor Taylor says it is not an insect, and I am willing to take his word for that.

Mr. PAttersox. If there are no further questions, I do not want to take up any more of your time.

\section{STATEMENT OF DR. WILLIAM A. TAYLOR, CHIEF, BUREAU OF PLANT INDUSTRY.}

Doctor 'TArLor. I understoor that my presence here was to be, in diplomatic language, merely that of an observer. As to this particular item not being included in the Budget, or the $\$ 2,000$ provision for this particular pecan scab, I will say that we have at present available for use $\$ 82,000$, of which $\$ \$, 000$ is deroted to pecan diseases. That suffices, in addition to the amount for field expenses that are necessary for the employment of one pathologist continuously on that work, and of one or two temporarily during the growing season. We need one ardditional year-around man as an assistant, and it will cost practically $\$ 2,000$ to get him. Then we will be in shape to hit this problem hard, and we believe we will be able to secure results that are important considerably sooner than we could with our present funds. Mr. Patterson has correctly stated the urgency of the matter. One feature that may be worth mentioning is this, that in the control of this fungi which, necessarily, must be through spray applications, we have a very narrow margin of possible success. We must use a fungicide that is strong enough to kill the fungi and yet not strong enough to hurt the trees. There is a risk of defoliaging the tree, with consequent harm to the crop. We want a fungicide that will answer the purpose under any climatic conditions. For that reason we will have to continue this work for several seasons in that same locality until we are sure of the formula and of the application schedule. It is a very meritorious proposition, and one that we will be very grad to administer if the funds are arailable.

\section{STATEMENT OF HON. CHARLES R. CRISP, A REPRESENTA- TIVE IN CONGRESS FROM THE STATE OF GEORGIA.}

Mr. Crise. Mr. Chairman, I had not intended to say anythine on this subject. I am very much interested in this proposition. however, my district being largely engaged in the pecan industry. Iudger Park's district, which adjoins mine. has older orchards. Our people are confronted with the necessity of lenrning to diversify, and many of them have begun to diversify by putting out larege pecan orchards. I believe very much in the future of the pecin industry, and I believe that if you make the appropriations here proposecel they will be instrumental in solving this trouble that has been described to rou. I hope you will give this request careful and favorable considerniton.

\section{STATEMENT OF HON. FRANK PARK, A REPRESENTATIVE IN CONGRESS FROM THE STATE OF GEORGIA.}

Mr. P.ak. Mr. Charman, the investors in these pecan crroves are not all local poople. A great many of them are from Detroit, who have bought up siacre tracts, and a number of them are from (hicinge. l'itshurgh, minl other like eities. There must be between seren and ciglat million dollars invested by these people. A good many 


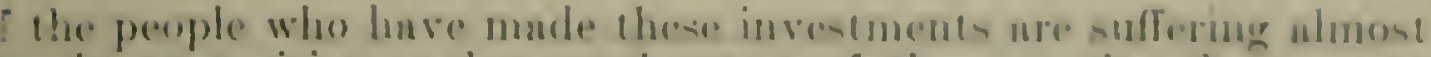
for the necessities, und " good mong of them, undere the presente

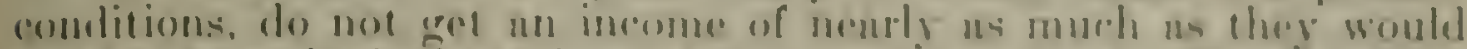
be able to muke in foretories and thinges of that kind. 'los uflow this industry to be wiperd ond fore the luek of a few dollous looke lihe.

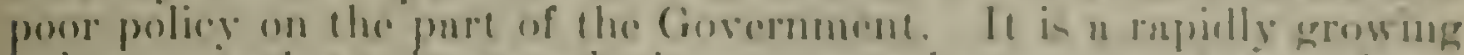

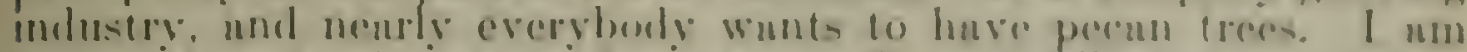

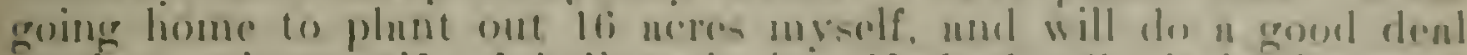

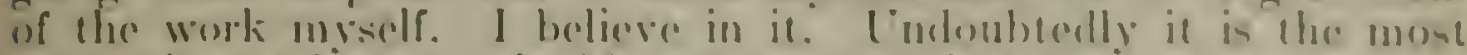
nourishing and most rulunhlo mut we hure in this conntry.

\section{STATEMENT OF MR. E. G. HESS, MANHEIM, PA.}

Mr. Hess. I nm president of the Kerstone Perme (o) und um $n$ member of the Federnl nid committer of the Nationul Pecun Growers Associntion.

Mr. Chairmun, I confered with a number of mon in the Depuremont of . Igriculture just a weok ngo to-dny. and I ulsos staw the chairmun of this committea. It is becanse of the grent importunce of giving the Department of Plant Disenses this \$2.000 that I uppear here to-day. I presented this mutter to Mr. Patterson, und thint is why he is here to-dny. It is becnuse of the need of an ndalitional seientific mun in thent depurtment, und he is needed just ns soon as he can be put on the job.

That is nll I wish to sny.

\section{Monday, Norember 27, 1922.}

INVESTIGATION ANI IMPIOVEMEXT OF CFAF.AIS.

\section{STATEMENT OF MR. HARRISON FULLER, SECRETARY AND DIRECTOR OF THE CONFERENCE FOR THE PREVENTION OF GRAIN RUST, MINNEAPOLIS, MINN.}

Mr. Antursox. We will return to the item on puge 100, "For the insestigntion and improsement of cereals, including corn, and mothods of coreal production," with a proviso that $\$ 200), 000$ shall the set nside for the lecition and destruction of the bartorey bushes and other regetntion from which rust spores oricrinnte.

Mr. Fuller. we will be glad if you will take charge of the henring.

EHAMCATION OF HAHBEIRL HCSH.

Mr. Fer.t.k. Mr. (huirman, last spring, as you know, an oreanizaltion ealled the Conference for the Prevention of Grain Rust was formed, representing the ngriculturnl interests of $1: 3$ states. including the area from Michigan, Ohio, und Indiann. West to Montamn. Colorado, and Wyoming. Representutives of that organizntion anme to Washington, and as a result of the statemonts made hy them. (ongress upproprinted $\$ 3.50 .000$ for the cradication of the common burberry bush, the approprintion being incensed from the former approprintion of $\$ 147: 200$. which had been grinted by (ongress for cheh of the three preceding rears. We come before you now to ust for an appropriation of $\$ 500.000$ for the next fisenl yenr. 
Is a basis for that request, rou alreadr have some knowledere of what was accomplished by the Department of Agriculture with the appropriation of $\$ 350.000$. and this committee will assume. unless otherwise instrueted. that you are completely informed with recrard to the manner in which that appropriation has actually been handled by the Department of Agriculture. In addition to that of course. we want to present some general considerations about the aceomplishments of the past season from the lay point of view and from tho point of view of the farmers and grain grower's themselves. In a general way, it can be said unqualifiedly and emphatically that by reason of the appropriation of $\$ 350,000^{\circ}$ the work of harbery bush eradication has been tremendously expedited. and that gains were made in attacking the problem that could not possibly have been made in three or four or five vears of smaller expenditures. We are now in a position. by reason of the fact that the campaign has progressed so suecessfully, to see the end of the campaign, and that, I take it, is something in which Congress is very much interested. You have been making appropriations now since 191S. This year $\$ 350,000$ was expended, and that has brought the campaign to the point where we can say that it is rery probable that in almost all of the States included in the barberry eradication area the necessity for any Federal assistance after two more vears will have been eliminated: and that in many of the States, as some of the gentlemen present will show you, only one more year of Federal cooperation and Federnl financial support will do the job.

During the past summer the organization of which I hare spoken has been direeting its efforts toward the dissemination of general information with regard to the barberry and the destruetion to grain which it has caused. For that purpose we have put on a widespread publicity campaign, which has brought very tangible results. In order to give you a practical idea of what we have done. I will say that we have sent out altogether about 500,000 pieces of pulblicity. including informative literature and posters. These have been distributed to the county agents, railroal-station agents, lumber rards, creameries, mills, banks. elevators, and to many individuals and other institutions throughout our area of 13 States. I careful check shows that our posters are being well displayed, and that we are getting the message across to the people to whom it is directed. In addition to that, we have succeeded in obtaining about 2.500 columns of newspaper space. 'That, of course, is publicity which reaches the individuals direct, and it shows a desire upon the part of the newspapers to cooperate with the Federal and State Govermments and with ourselves in this movement, which is exceedingly important. In addition to that wo have provided a large number of exhibits showing exactly what the barberry bush is and the damage that it cause's.

With our exhibits we have reached $10 \mathrm{~s}$ (o)mbe fairs, about 30 or 35 State fairs and sectional expositions, and such larger expositions as the Pagennt of Progress at Chicage and the National Dairy Show at St. Paul. The result of our campaign is-and we are sincerely convinced of this faret that there has been built up a widespread public sentiment, which, as you know, is the most oflective weapon in a campaign of this kind. "Wo have suceoeded in building up this sentiment by reason of the face that the fedoral Govermment was 


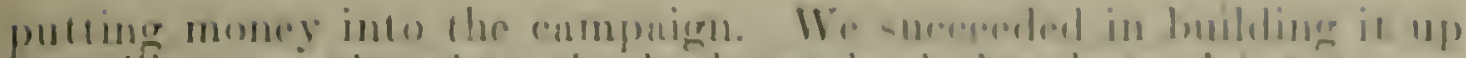

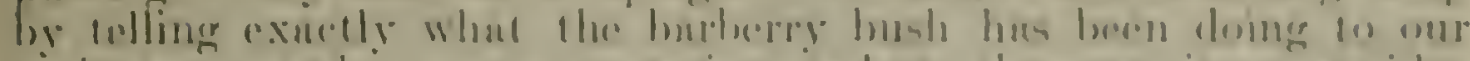

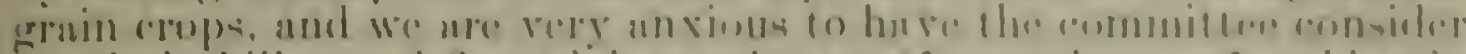

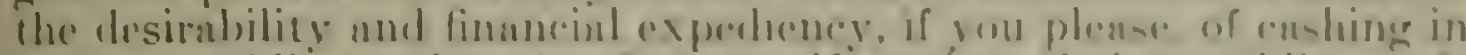

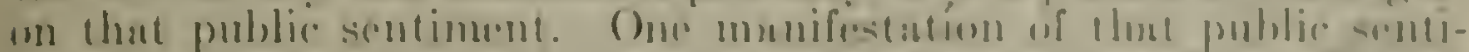

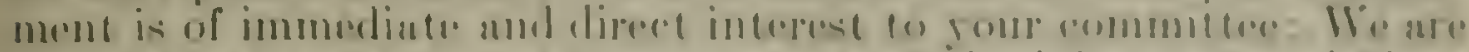

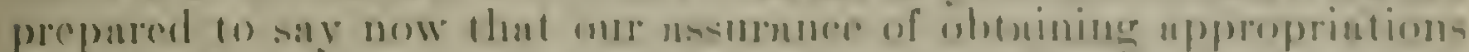

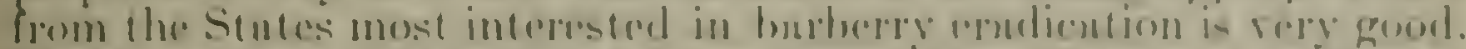

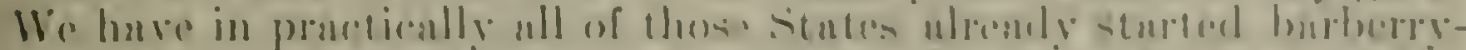

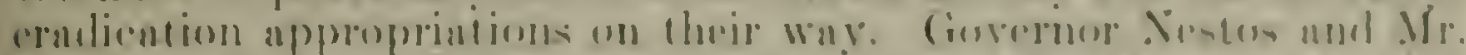

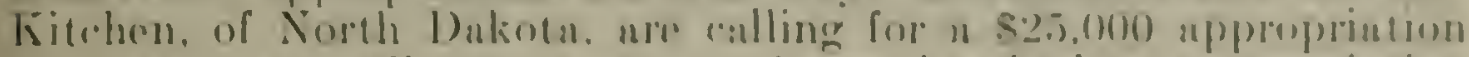

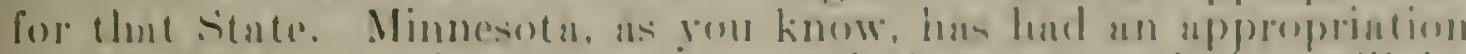

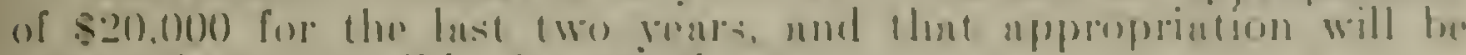

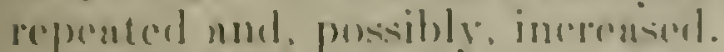

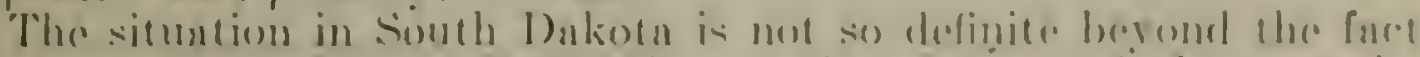

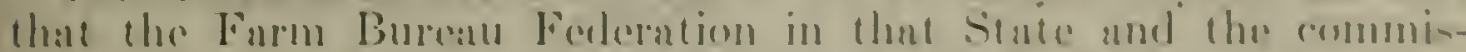

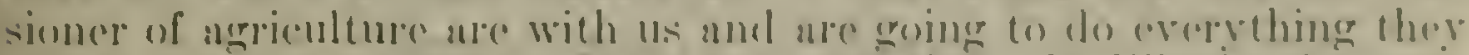

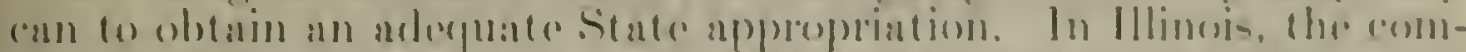

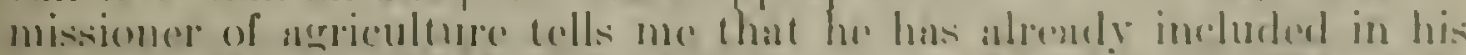

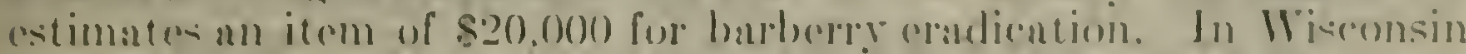

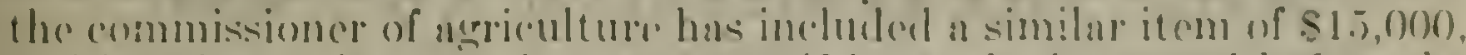

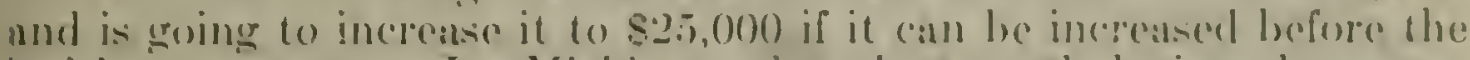
lecrishature mects. In Michigan tho plani puthologists have roquested an appropriation of 822.000 . In (Ohin the (omminsioner of ugriculture tells us that he is going to put in a re(puest for mu appro-

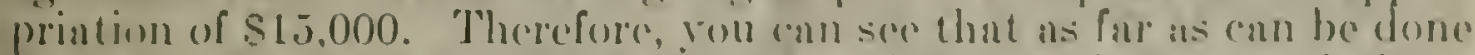
at the present time, the Sitates ilo preparing to muke mppropriations.

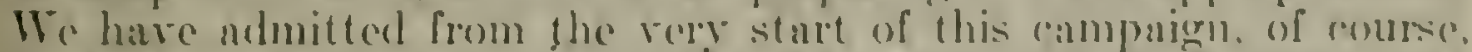
that a large portion of it should be State responsibility but we hate not mamited, and do not now almit, that it is contirely a State responsibility hy reason of the fact that it is essontially a recionnl problem. "The States nre now rendy to assume their share of responsibility and will do so at thoir no.te lorislative sessions. Your realize, of colise, that it would lo futile for me to promiso that the States are groing to do thus and so. Ill that wo (an say at this time is that the

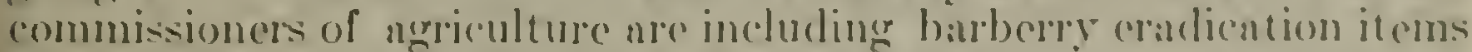
in their bublgets, and the farm bureats are doing overything they (atn to obtain those appreprintions.

Mr. I.rurtasos. Do you know what State appropriations were arablable fou this purpose this past year ?

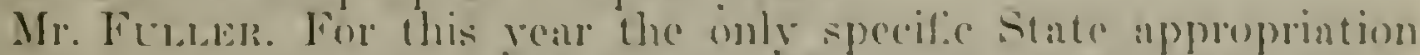

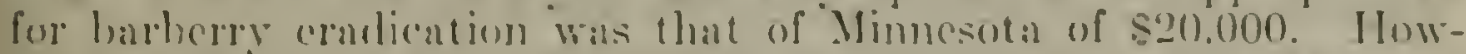

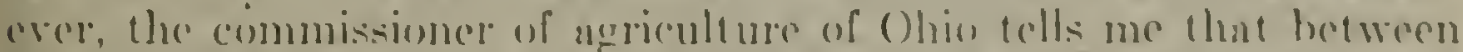
thres and live thousand lolfurs was spent in that state for harbery rendication out of funds analable for that kind of work. "The some thing is true in ofluele states. By reason of the faret that the approprintions wore not specifienlly for the purpose of harberey cradication, it is rery diflicult to make a precise answer to that

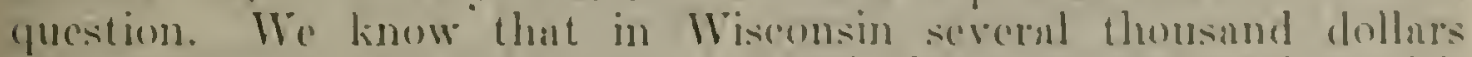
were spent he the depntement of agriculture in cooperation with

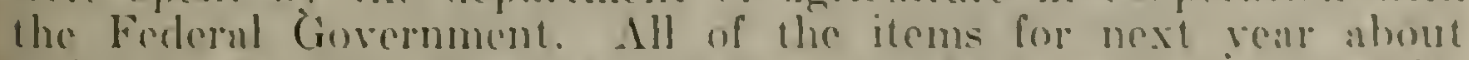
which I have becon speaking. howerer, ane to he specilic applopriatims for barbery cradicntion. Is rou understand. tho siate lecrisintures do not moet motil ufter the lsi of .tumary. and some of 
them do not adjourn until almost the 1st of April, so that the actual appropriations made by the State legislatures will necessarily be un uncertain quantity until the State legislatures actually idjourn. You are as familiar with that problem as I am, but we want to emphasize the fact that the States are ready to go forward, and the support is well organized in every State.

The other members of our committee here to-day includes the presidents of three State farm burean federations, and two plant pathologists. All of them have interesting statements to make and, if it is agreeable to the chairman, I will ask Mr. Reed, the president of the Minnesota Farm Bureau Federation, to make a statement.

Monday, Norember 27, 1922.

ERADICATION OF BARBERRY BUSH.

\section{STATEMENT OF MR. J. F, REED, PRESIDENT MINNESOTA BUREAU FARM FEDERATION, ST. PAUL, MINN.}

Mr. Reed. Mr. Chairman and gentlemen of the committee, Minnesota has rather taken the lead in this matter: That was probably because of the fact that it is a large spring-wheat growing area and has seen the damaging results of the ravages of the black stem rust more than some other areas. We have seen the rapid falling off in the amount of grain produced in the State and the hazard to which the farmers were subjected. That probably had much to do with the State of Minnesota two years ago appropriating $\$ 40.000$, to be used last year and this year in this work. With that approprintion and with what the Federal Government has provided we have made very substantial progress. There has been a very lively interest in the problem, not only on the part of the farmers but on the part of grain dealers, millers, and other's who are directly interested in the matter. However, the general public or the consuming publie of the Stute was never apparently aroused to the actunl necessities of this matter until 1921.

Much of that interest was brought about through the establishment of the Conference for the Prevention of Grain Rust, and. also. hecause of the scientife explanations given by the patholocrists of the Department of $A$ rriculture and by the pathologists in our own school of agriculture. 'Through those means the idea hos gotten pretty well known to the people of Minnesota and to all of oul people, not only to those engaged in the raising of grain or the handling of $i t$. or the manufacture of it, hut to the consuming pullie as well, that this is a very potent canse of a rery lange loss tlint comes ammully to our gran production. With thit knowledere, a very active camipaign has been carried on for the eradication of this bush. In 1918 the section of Mimmesotn in which I live. or the southenstern part of the State, was sulveyed by officers from the bepmentent of Agrienlture, and those bushes ivere removed, or the original phantings. There hus been a very henrty cooperation on the part of the farmers in this comntry, and wherever these hushes exist or are known to 
exist, the farmers are very andious lo couperule in thoid ow

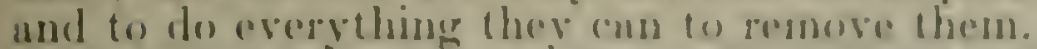

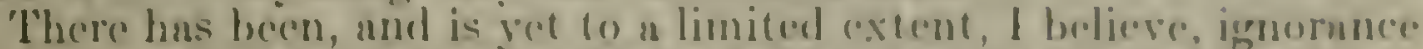
on the part of some of omi people as to the identifiention of this hush. but much of that has heren revonvend during the pant amameg hy the advereisements und publicity that have bern geven in the antuner

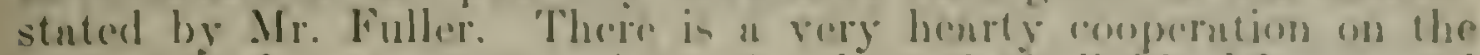
purt of the farmers in the noightorhood, on the individunl furms, und

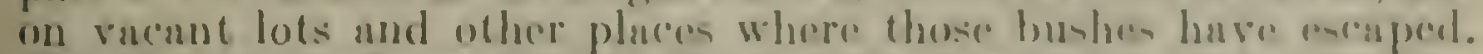

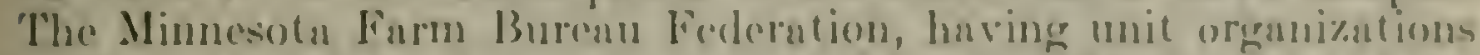

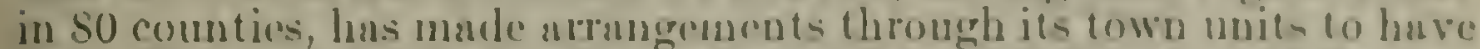
these bushes exhibited, or samples of them rohihitol, and to urge

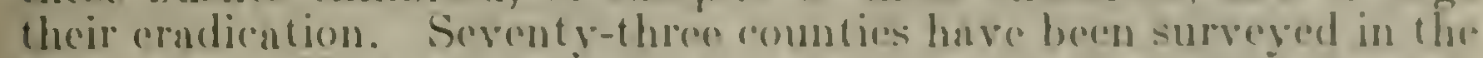
State now. 'liat has bocin done during the past five gears throush the uppropriations from the Foderal Governmont und rippropriations from the Stute, and thore has becen some research work done. We think that hy the and of the coming year, with such an appropriation as we are asking for and such as I think could be comonicully cxpended. the State will have heen gone orer once, and preblialy all the old plantings will have becn removed.

No doult there are some escuped bushes, and there are sprouts from bushes that have been removed, and it might be neressury to gover them again. We have in our State a State wered insperetur, and the counties have wecel inspecters. It is a part of thrir duty to sec that these bushes aro takon wut. Some of them work under the commissioner of nericulture of the State, and they ure given specific instructions to see that those bushes are removed; that is, vither to remove them themselves. or to see that the owners of the places where they are found remove them. As I have said, on the part of the furmers there is a very active cooperntion, hut there is a littl. different feching in the villages and towns. That refers particularly to plantings in towns and villages where the property is oceupied by tenants. They do not care to do this, but the law of our State makes the allowing of barberry bushes to grow on any property illegal. I believe thint the State of Minnesota can be looked after after the coming yeal without any Federal appropriation. I am sure in my own mind. from iny own observation, hat more has becn donc during the past year to clean up the State of Minnesota than during the four years before in which the Federal Gorernment was giving asistance.

I believe that with the cooperation of the Federaf Gorernment, a: it has becen extended during the past. year. and with the corredation of the State offorts, we can do more in one rear than we could probably do in three or four yours with a lessoned appropriation. Our people have found that this is mot omly necesiary for the state. but that it is necessary for the increased food prodicetion of the whole country. We are in a very important spring wheat crowing areas. and it is an important area in the production of other granins. I believe that it is essential to onr nericulture-not only to those engaged in farming. but thuse congaged in handling agrecultural

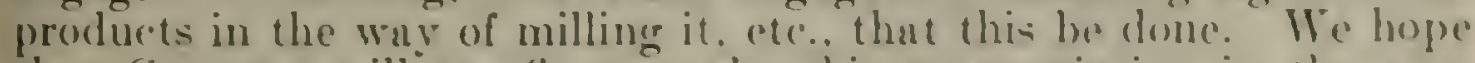
thant Congress will soe fit to make this uppropriation in the sum asked for by the representatives of the 13 Stales that formed this Conference for the Prevention of Grain Rust. 
Mr. Bechaxax. How many of those 13 States have weed inspectors, similar to those in Minnesota?

Mr. ReED. North Dakota has. I am not adrised with regard to that, but I know that North Dikota has.

Mr. Buchaxax. It seems to me that that is a highly important matter when it comes to the eradication of any specific kind of injurious bush.

Mr. Reen. Yes, sir.

Mr. Fulcer. Ohio has a system under which they have 14 inspectors, or weed inspectors. I do not think that is their title, but that is their job. They are charged with keeping down plant pests of various kinds, and they work under the direction of the Department of Agriculture.

Mr. Buchanax. Has your State a law by which you can take up and destroy barberry bushes, even against the consent of the owner of the land on which they grow?

Mr. REED. Yes, sir.

Mr. Buchinas. Without any court proceedings?

Mr. ReEd. Yes, sir.

Mr. Buchanas. You have never met with any real opposition?

Mr. ReED. No, sir; not to that extent. That has been usually met with in the case of tenants occupying property.

Mr. Buchasax. They would not care, and they would not want to do it themselves. They would not care anything about the pest themselves.

Mr. ReED. Well, if it is on town property, where the bushes have been planted for landscaping purposes, they may think sometimes that the owner would not want to have them changed, but that opposition has not been very pronouneed.

Mr. Buchanas. The question in my mind is whether they hare the proper kind of organization, such as you have in Minnesota, in the other 12 States, so that from the State standpoint it can be done. I make that suggestion because the State authority is the only one that can really supervise it if any opposition should arise.

Mr. Reev. Yes, sir.

Mr. Fulder. It might be stated that in Minnesota the law is this: If barbery bushes are found on a man's property, they can be removed without court action, and the cost eharged against him like a tax assessment, for which he would become liable. 'Throughout the entire area, I have heard of only one court ease during the entire work of the State, and that was in Illinois.

Mr. Bucidaxax. Do the other States havo such laws?

Mr. Feterer. All of the States have laws of varying clegrees of severity with regard to barberry bushes. The only law I know of that has not stood up has been the Montana law, and they are trying to get the Attorney General to render a decision that will put some teeth in to that law. In the other States the law has proved eflective, and the only court case that I know of was in Illinois. 'That was a ease where a woman was bronght into court and fined $\$ 25$ for having barberry bushes on her property. She appented the ense to the district court and the tine was reduced to s10, but it stuck.

I will ask Mr. C. W. Hunt, president of the lowa Bureau Farm Federation, to amplify the situation in Iowa. 


\section{STATEMENT OF MR. C. W. HUNT, PRESIDENT IOWA BUREAU FARM FEDERATION, DES MOINES, IOWA.}

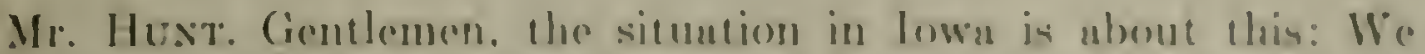

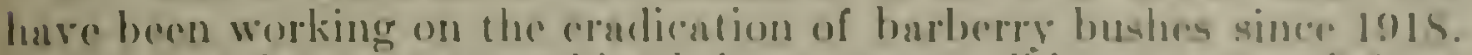

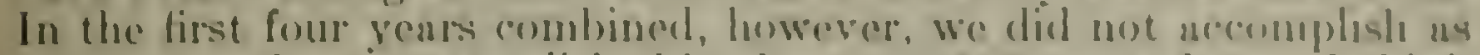
much us wo have nceomplishod in tho your 192.2 up to dute. I think there are two reasons for that increase in the sucerese of the worth in

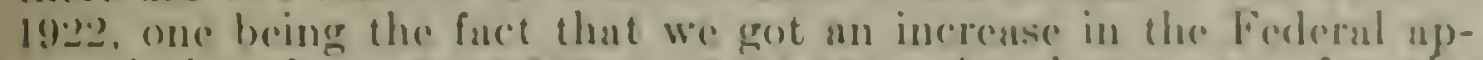
propriation from $\$ 147,000$ to $\$ 3300,000$. Inother reason for the increascel intresest in the work is the associution for the provention of grain rust. of which Mr. Fuller has spotien, and of which he is the director. In lown wo huve coopornted in the publicity work. and erory county in the State that has a farm burcum has cooperatcel with Mr. Fuller, and in that way we have spread the publicity over the entire Sinte.

Wr have given a great deal of space to it in the little puper that we publish at the Farm Burcau oflice, going into the history of the pest, and showing the need for its eradicntion. Those fwo things fonse male it possible in Iowa to do moro work in 1922 than was done in the four years preceding. The question of State laws mating it possible to erudicate these bushes where the cooperation of the owner of the farm is not given, has been spoken of here. Iowa has such a law, and I think some use was made of that law in two or three instances in the becrinning of the work. However, cluring the last two yenrs, we have had no trouble with any of the people on the farms, and the city people gencrally are getting well neyuninted with the necessity for the cridicntion of the burbery bushes. Therefore, there is the best cooperation all along the line. In the last year, 2s counties in the extreme northeastern corner of the State havo been gone over. the bushes located, and dug out. A lot of that territory Along the Mississippi River is some of the worst territory we had to surver on aceount of the limestone rock and the difliculty in getting the bushes out. We used chemical methods in some places, and cleaned up that section.

With the appropriation of $\$ 500,000$ that we are asking for here. I nm sure we (an clean up all the plants in the State of Iown next yeap. 'There ure 36 comtics vet to be gone over, all being in the southern and southeastern portion of the State. Sume of those counties along the Mississippi River are bad, just as those in the northeast corner, but we can clean them up and probably resurves the territory that has already been gone over. Therefore, it would secm to me that we probably eombl get atong without any further help after next year. Possibly we might need a litte appropriation the year following. Of course, all of you understand that we would have a good deal of resurveying work to do. mud it would be necessary to get the sprouts and secillings us they eome on ufter the original hushes are taken out. "Tho loss from errain rust in lown. I night say, is estimated nt $\$ 1,000,00(0)$ for last year.

Mr. Axnthsox. Do you mean the culent year or last year?

Mr. Hext. That would be the estimnte for 1922. The arerage loss for six years hus been about $\$ 1,500.000$. A bic percentage of 
that loss was connected with the oat crop. Iowa is not a heary wheat-producing State at the present time, due very largely to the damage caused by rust. The farmers did not know at the time that. it was connected with the barberry bush, but wheat took the rust and did not yield. They almost quit raising it, which was quite a drawback in the rotation of erops, but they did keep raising oats. They raised quite an acreage of oats, and the loss on onts from grain rust was rery great this year. The loss of wheat, of course, in comparison to the amount raised, was in the same ratio.

I just want to cite one field that came to my attention, and that. was a 40-acre field of barley. That field was very badly rusted, and they found in a $4 \frac{1}{2}$-acre tract a great number of barberry bushes-1 think something like 1,000 -in that vicinity. That 40 acres rielded 320 bushels and should have yielded 1,400 bushels, making the loss to the owner of that crop on the 40 acres something like $\$ 600$. There are other cases, of course, but that had been brought to my attention, and I mention it here to show the extreme damage of this plant.

I think that is about the situation in Iowa, and that is all I have to say, unless somebody desires to ask some questions.

Mr. Anderson. Te are very much obliged to you.

Mr. Fuller. The next speaker will be Mr. Hill, president of the South Dakota Farm Bureau Federation.

Monday, November 27, 1922.

\section{STATEMENT OF MR. W. S. HILL, PRESIDENT SOUTH DAKOTA FARM BUREAU FEDERATION.}

Mr. Hill. Mr. Chairman, I represent South Dakota, which is one of the big small-grain producing States in the Northwest and a State which has suffered millions of dollars in losses from blach rust. The work of eradication was commenced in our State in 191S, and up until the end of 1921 they had corered about 20 counties. During the past year, 1922, owing to the increased appropriations, they covered 24 counties, so that we have at this time 44 counties which have been covered.

Mr. Anderson. Was that all new work or does that include some resurveying?

Mr. Hill. That, I think, was all new work, Mr. Anderson. The entire part of the State lying east of the Missouri River has now been surveyed, but there are still something over 20 counties yet to be corered.

Mr. Bucmanax. Do barberry bushes exist in all portions of the State?

Mr. Hirl. So far they have found barberry bushes in every county they have surveyed. In some counties there woukl not be niany, but they have found some in every county.

Mr. Buchanax. How many counties have you in the State?

Mr. Hils. There are about 6.5 in the State. 'That map will show what has becn covered. 'This is the part east of the river that has been covered [indicating], and it leaves all this pald to be corered [indicating]. 


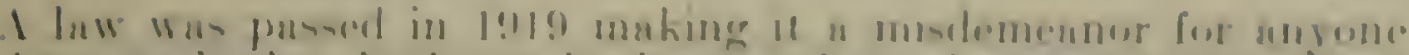

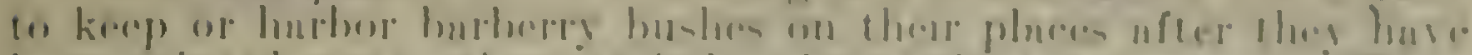

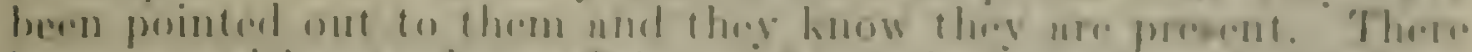

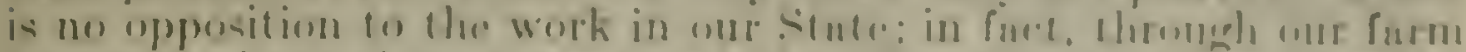

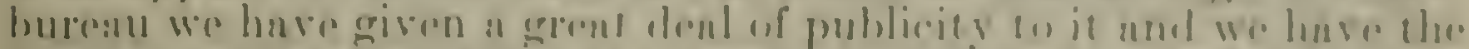

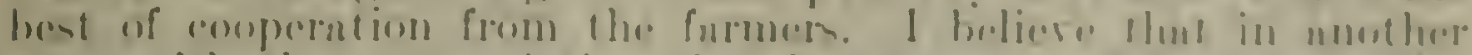

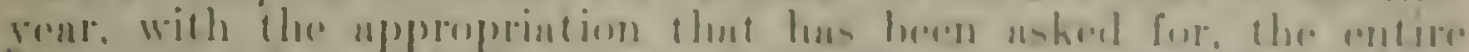

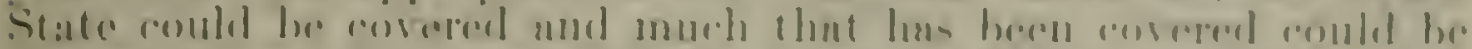

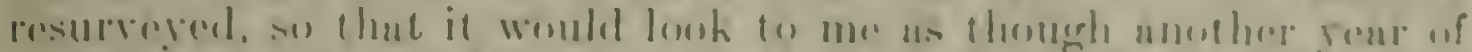

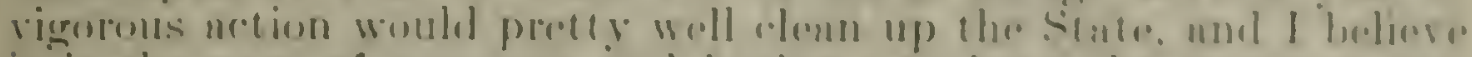

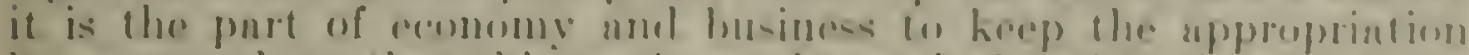

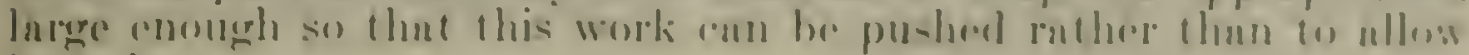
it to disige.

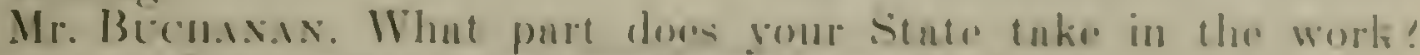
Mas bour State contributed anyluing townml it

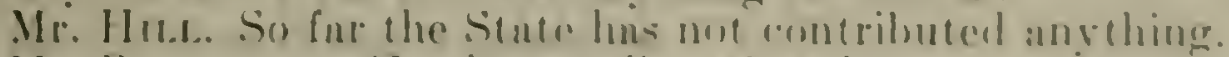

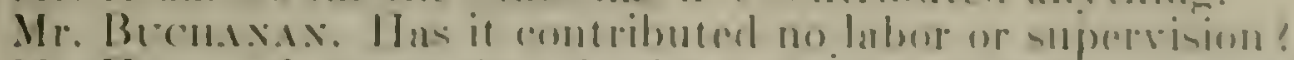

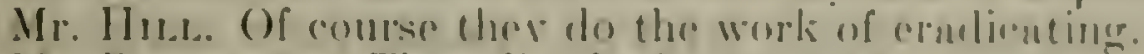

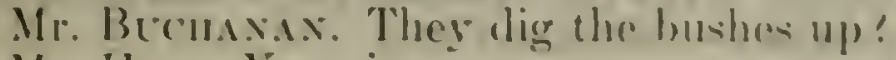

Mr. Hll.l. Ies, sir.

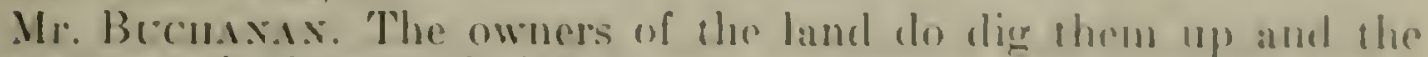
Sinte compels them to do it ?

Mr. Hnt. Yos, sir: the Stute rompels them to elo it ufrop thry have been notified that they have them an thoir plares.

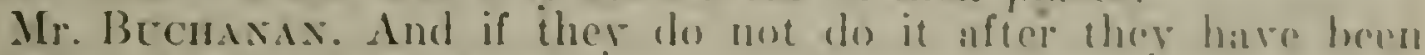
notified thoy are subject to prosecution?

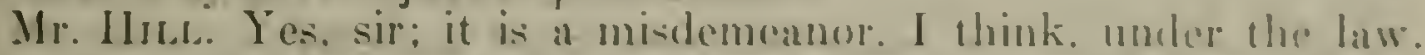
The loss from black rust this past gear has heen much losithan in other years: that may not hure been alforether on nerount of this work. hut it is a fact just the same. so that I think wo alo berinning 11) see the fruits of it.

I nm quite a lurere grower of wheat muself amel have been. I lost

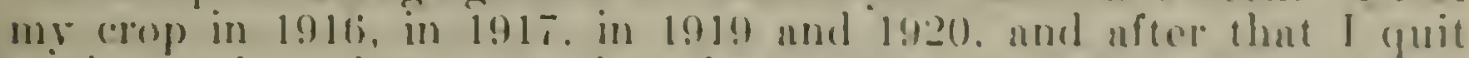

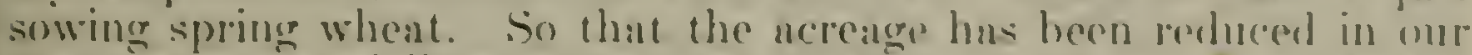

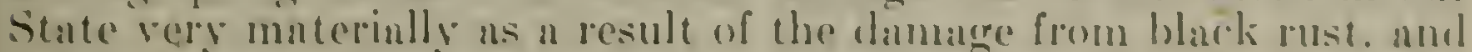
it is quite a problem with the falmers of our comntry. heomese the growing of wheat fits into the rotation of our (erops ind thry have not any other (rop) that will exactly take its place.

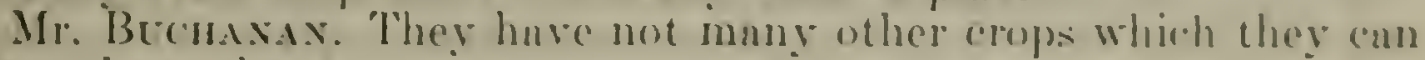
phut, have they!

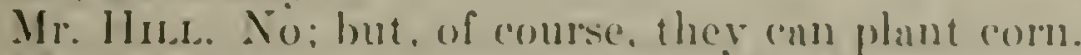

Mr. Bromasis. ('orn, wheat, and hix!

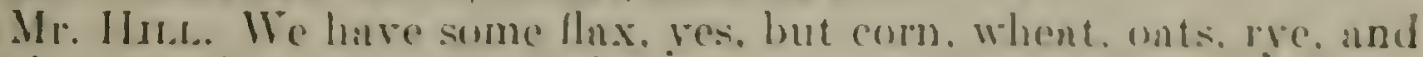
burley constitute our principal crops.

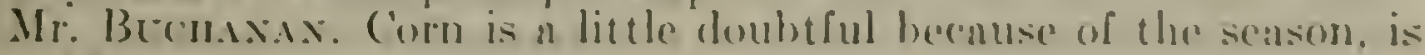
it not?

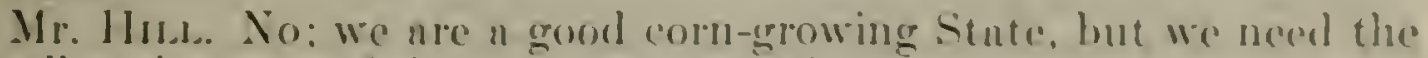
small granins to work into our ('rop) rotutions.

I think that about covers the situation in somth l)akota.

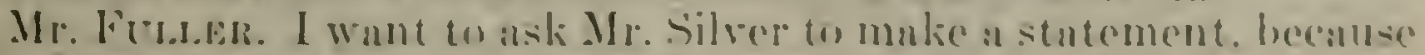

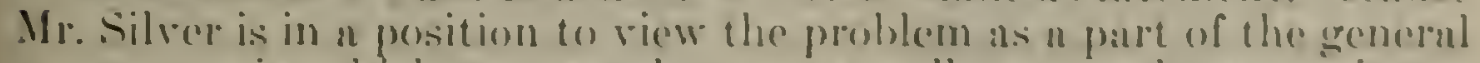

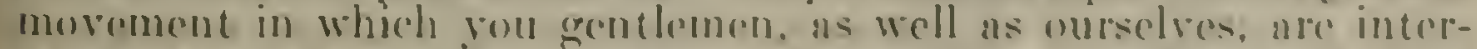
ested, numoly, arricultural devolopment mul the impleverusent of the

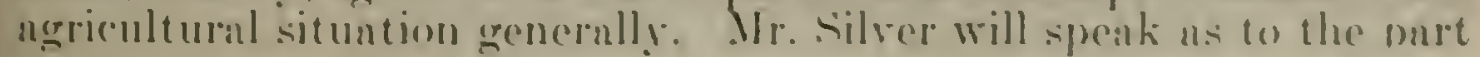


of the Federal and State campaign for barberry eradication in its bearing on the food supply of the country.

Mr. HiLl. I wonder whether I might add another thing?

Mr. Avderson. Yes.

Mr. HiLl. I just happened to think of something which occurred near my own farm. As I stated before, I have been losing my wheat crop and I seemed to be pretty nearly the first one in the neighborhood to discover black rust on my wheat, and when the survey was made this last summer barberry bushes were discovered within a mile of my farm and which, I am satisfied, have been guilty of spreading black rust on my crops. A survey had never been made in ny county until this past summer.

MONDAY, Novenber $27,1922$.

\section{STATEMENT OF MR. GRAY SILVER, PRESIDENT AMERICAN FARM BUREAU FEDERATION.}

Mr. Silver. Mr. Chairman and gentlemen of the committee: You have heard the statements of the gentlemen from the infested areas and are to hear from the technical men who will follow them. I want to add the roice of the American Farm Bureau Federation in this plea and call attention to the great economic loss that is going on and which can be aroided. The taking of plunt food from the soil, the use of the labor and equipment necessary to grow these crops only to have them lost or wasted, are, of course, serious things not only for the farmer but for the consuming public, which means the Nation at large.

The men who have testified do not come here with propaganda or with ille talk; they are here with a message right from their hearts, from the grass roots and from the basic source of supply of foodstuffs of the United States, because these black lands are the surplus producing sections of the country; that means they produce all the surplus foodstuffs that are consumed in the cities and away from the black lands.

When they have gone so far in their home States as to pass laws that give them the right to go on infested properties and take the action that is necessary to aid this eradication, and when they have made the progress these men report, it is certainly a very reasonable thing to ask of the Federal Government that cooperation which will hring about the complete eradication of this erreat pest. a pest which is causing such great economic losses in the small grains. These people are asking cooperation. 'They are not asking the Govermment to do it alone: they are asking cooperation and team work. I want to say that not only the farm burean members from these States but from other States join with those members in the infested States in askingr that you grant this appropriation and in that way assist in this cause.

Mr. Fulier. We have, Mr. Chairman, two teehnical experts as members of this committee. I am first groing to ask D)r. G. II. Coons. plant pathologist of the Michigan Agricultural Collegre, to present some additional aspects of this problem. 
M1)

\section{STATEMENT OF DR. G. H. COONS, PLANT PATHOLOGIST, MICHIGAN AGRICULTURAL COLLEGE.}

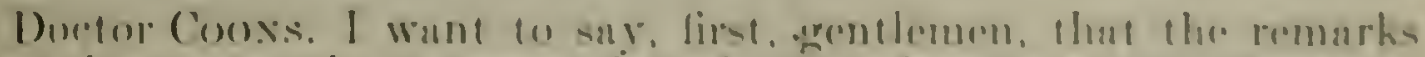
that these men who represent farm burenus have musde for their gar-

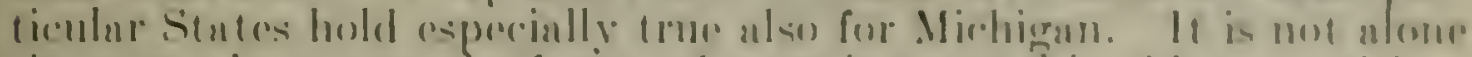
the men who ure on the furme whe are intorested in this proposition,

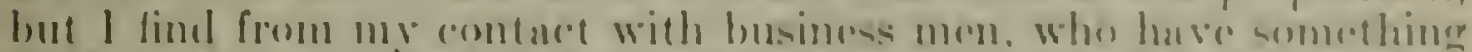
(1) do with agrionleure and who have something (1) de with thro higr

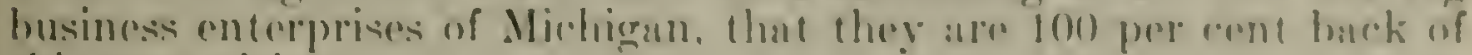
this proposition.

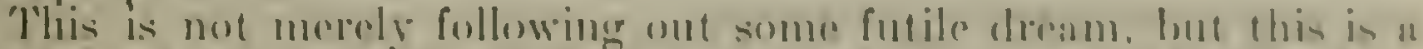

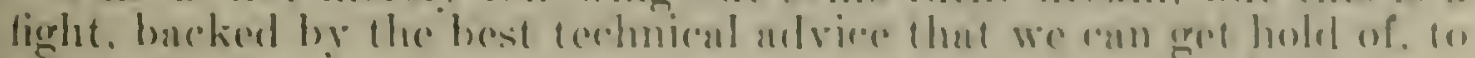

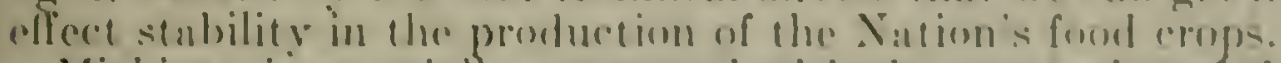

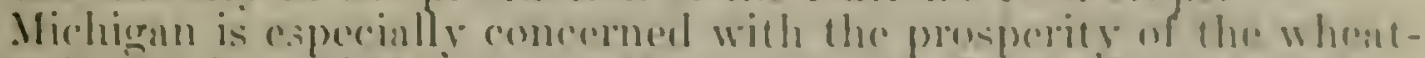
growing regions of Minuesota. North Dakentas. Sonth Dakota, and so on. Selfishly, Miehigan wonts those people fo conlinue in the whent proposition ind stay out of the potato husiness, let us say sol that

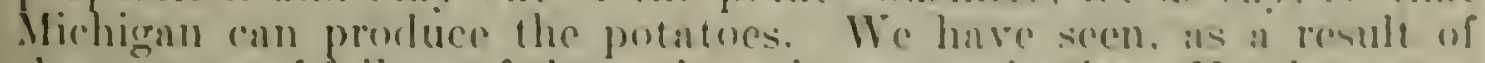
these years of lailure of the spring whent crop in those Northwentern States a tendency to go into the potato business, whirh is viewed with a grent deal of distrust and fear by the bankers. by the produes handlers, by the business mon, and by all the nerieulturul interests of Michigan.

I merely mention that as a side light to show that here is a proposition which appeals not alone to furmers. Barberry eradiention to prevent black stem rust is intensely popular with the farmers in our State, but it is also a thing which appeals to our business men as a necessury, stubilizing thing to do.

I wish, howerer, to speak chicfly as a technical mun and us a plunt pathologist viewing this eradiention program. Congress has put its hand to the plow and there is no turning back. If the job is worth doing it is well that the joh be done quickly.

You may be interested in a table of stitisties on harberry from our State, ieduced to the form of averages per comby. I find there are on an avernere of 38 city harberry locations per county and that there are t3 rural locations per county, so that this is more of a farm problem than it is a city problem.

Mr. Axubresox. You mean existing locations!

Doctor Cooss. The locations hase heen found in the 19 counties which have been survered and all have been destroged. The figures show the averacre situntion. There are also in the commes which have been surveyed an arerage of 10 escaped ancas per commty with an arerage of its bushes por escaped area. Now. then, if cradiention is to go on and if the money which has heen poured into this campnign is to accomplish its purpuse, it is necessury, it is vital, that all hasie be made and that erreat cmphusis be plated on the guteck handling of this situation before these esenped areas hecome so numerous and so large that the job of cleaning them up heromes 200 lare for us.

If this job of eradiention is not done in the next fwo to fire years it is groing to be a proposition that will cost one humdred times. at the 
rery lowest estimale, what it will enst at the present time. I tremble to think of what is going to happen to the small-grain crops of Michigan, to saly nothing of the northwest areas, if the barberry continues to increase in our dune lands and in our waste lands, which occupy so large a part of the northern part of the Southern Peninsula of Michigan.

Mr. Bechaxix. Does it increase rapidly!

Doctor Cooxs. Around a bush perhaps 100 seedlings or more can be seen readily, which represent the increase of a single vear. and if you can see 100 seedlings in an area the size of this table, who can estimate the number of seedlings that have been carried here, there. and everywhere by birds, and which escape detection? So I should say its progress is extremely rapid.

Mir. Buchasax. It will reproduce from the seed?

Doctor Cooss. Yes, sir.

Mr. Buchasax. How large are the seeds?

Doctor Coovs. They are about the size of a kernel of wheat and these are eaten by birds in the winterime.

Mr. Buchaxax. Will stock eat them?

Doctor Stakma. There was one rather interesting thing in Pennsylvania. They found that cows browsed on the herries in pastures, and, as a matter of fact, they counted about tis scedlings from a single bush.

Doctor Cooss. I would like to comment as a technical man on the method of handling this barberry erndication program. I think Congress has proceeded in exactly the right fashion in giving strong. central support to this movement, heading up the entire program, and enlisting the cooperation of all of the States in this grain-growing area, and proceeding in a vigorous, orderly fashion to cover the territory by a definite farm-to-farm survey and not being satisfied with merely telling somebody else to go and do it. With the amount of money that was spent in the first year's the progress was, I should say, slower than the actual increase of the barberry. The amome spent then was something like $\$ 150,000$.

With the amount spent this last year in the entire barberry area, $\$ 350,000$, the progress has been much more gratifying, because where before something like five counties in Michigan were covered por year by a farm to farm survey, under the apportionment given to our State, something like 15 counties were covered in this last year thoroughly and effectively. While we can not make any such farorable report as the gentlemen who have preceded me ats to the end being in sight in a year or two, at any rate we ran say that the job of covering the State of Michigan is groing to be aceomplisherl witlin a reasonable time and is not going to be dragged out over at 20-year period. My opinion, as a person dealing with plant pathological subjects, is that Congress should not think ant all of reclucing this appropriation, but should rather think of putting in more money, putting in as moch money as can be handled economically, so as io control this pest immediately.

My last statement will be a very bref one, and it will be that the common concensus of opinion of plant pathologists is that this move of eradieating the burbery is the logical and lirst step fownd the control of the black stem rust.

Mr. Buchanas. Is there any second step? 


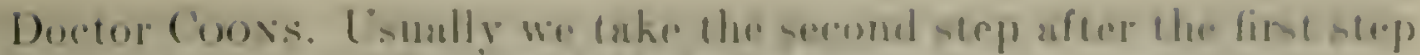
is taken. but this is the lime and the important step.

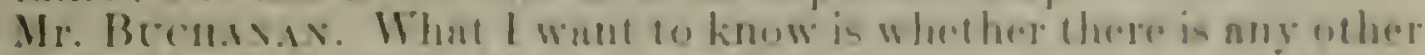
bush conceroned exeept the barberry hunh?

Doctor ('ooss. Do: there is not.

Mr. Becres.s.x. Then if wo take the first stepe, and there in ane second step, and we completely cratieate it, we are through with the problem?

Dector Cooss. We will be though with the problem as far an

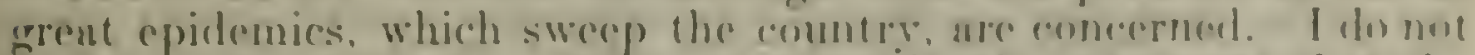
know whether anvone would want to make the statement that the rust would absolutely disappent with the erndicntion of the barberry. hut I do not believe solentists would want to got that far. You know. we are conservative.

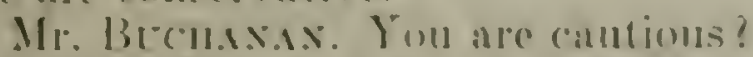

Bocerer Coose. Yes. But we believe that the eralleation of the hathery will result in the stepping of the ereat cpielemies which have herefofore swept over the country beratuse we are all romrincel that these grent epidemies start with the baberry bush and sweep over the country from the momentum they derive from this (arly start in the spring.

Mir. Futrex. The next gentleman who will discuss this proposilion will gribe rou. possibly, a more specifie answer to the question you have just put, Mr. Buchaman, a guestion which has occurred to ill of us, namely. will harberry eradication netually accomplish what we are claiming for it? Dr. F. C. Stakman. plant pathologist of the Minnesota Collecre of Agriculture, was horrowed hast summer by the Enited States Department of Agriculture and sent to Europe to find out what had been done over there. His story is of tremendous interest and has a rery important benring on your consideration of this question.

MoNnor, Novemul:1: 27, 192.2.

\section{STATEMENT OF DR. E. C. STAKMAN, PLANT PATHOLOGIST, MINNESOTA COLLEGE OF AGRICULTURE.}

Doctor Stakmax. Mr. Chairman and gentlemen, the question has awars arisen as to whether the eradication of the harberry would nbsolutely control the black-stem rust. We did not know exactly about that situation in this country hecause the experiment had never been made on a large enough seale. We did know that in certain areas where the barberry has been for yours there had been heary rust and that when the barberries were removed the rust disappeared. But there were no araibible experiments on large areas. Ife knew that some barberry eradication work had been done in Europe and that Denmark had solved this problem hy eradicating the burberries, but we did not know much about the situation in the rest of burope. So I ohtained leave of absence from the university last year and the Department of Agriculture asked me to gro over there to find out what had been done in lisupe.

I found, in the first place, that western Eiropenn countries had taken out practically all the barberries from the agricultural districts: 
that is, from the principal grain-growing districts. I found they had accomplished that either by law or just simply on account of the fact that the farmers had become so convinced that they could not grow grain where there were barberries that they took them out without the compulsion of law.

In England they have taken out nearly all of their barberries: they have never had a law, however, and it has taken them a long time. But to-day they are about 125 years ahead of us on this harberry eradication, because English farmers, about 1500 , commenced to realize that they could not profitably grow small grains where there were a great many barberry bushes. So they simply got together and started to take the bushes out and have heen taking them out ever sinee, so that at the present time there are practically no barberry bushes in the grain-growing regions of England.

In Rouen, France, they passed a barberry eradication law in 1660 , but, on account of various other difficulties they had over there that law was never enforced very rigorously. Howerer, since that time a great many of the local political units have passed eradication laws so that at the present time, as the result of these laws, there are scarcely any barberries in the agricultural districts of France. I traveled a great many miles by automobile and saw but few barberry bushes in the agricultural districts. Of course, there are still barberry bushes in the mountains, in the Pyrenees Mountains, in the Jura Mountains, and in the Alps. They are still growing some grain there but they can not grow much. However, in the principal graingrowing regions there are practically no barberry bushes. The preamble of one of the laws they passed struck me rather forcibly. That law was passed in 1891. They started it with the usual preamble, in which they said: "Whereas, it has been amply demonstrated that the presence of the common barberry is a veritable scourge to grain fields."

They said it with all of their French enthusiasm and then they went ahead and passed their law, and as the result of that law there are practically no barberry bushes in the principal grain-growing regions, although, as I say, they are to be found in the mountains.

In Italy the same thing is true. There are very few barberry bushes except in the mountains.

In Greece they are all over the mountains but there are not so many in the agricultural districts, and the same thing is true throughout the Balkans.

The old Austro-Hungarian Empire passed a law about 1895 as the result of which they have gotten rid of practically all the barberry bushes in the present States of Hungary, Czechoslorakia, and those other smaller countries now belonging to Serbia, and othercountries near there which formerly belonged to the Austro-Hungarian monarehy. The Hungarians were so firmly impressed with the beneficial eflects of that law that the present State of Hungury simply reenacted the law requiring that all of the remaining barberiy buslies be taken out, so that there are practically no barberry bushes in the territory which previously belonged to Nustro-Hungary, except in the mountains and in some of the waste lands.

In Germany the same thing has been done. The kingdoms, duchies, grandduchies, and other political units there passed laws, beginning approximately about 1865 -although there had been sone 
passed before that, 1800 and ulong about that time-requiring the eradication of the common hatherry bushes.

Denmurk, as we all know, paxion a barborre law in langs, and as

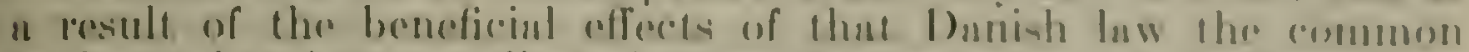

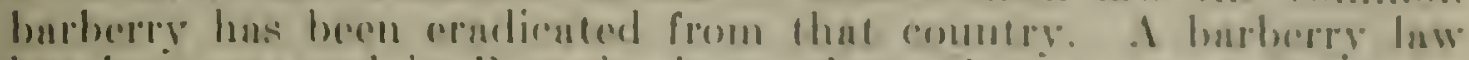

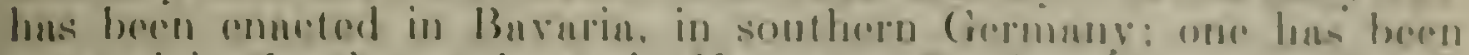
enacted in Swoden and one in Norway. So that ín practionlly all

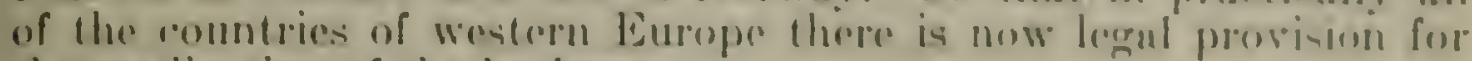
the eraliention of the buthere.

'The gurstion in which wo are particularly interested is: What han beon the result of the laking out of theise burbery bushes? In England all of the patholorists and agronomists und eron tho

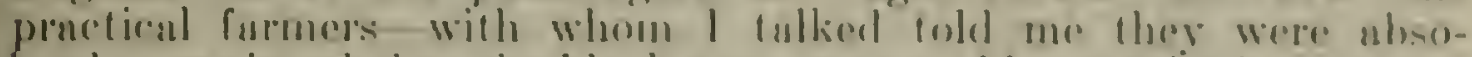
lutely convineed that the blark stem rost combl not exist in lingrand

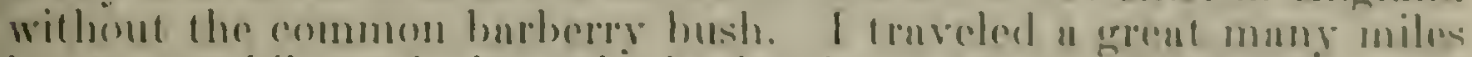

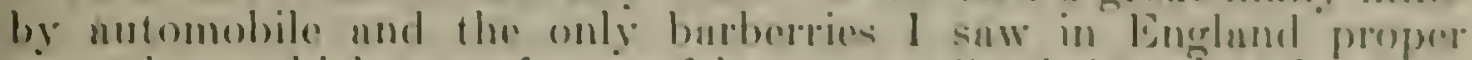
were those which a professor of botane at (ambridere Thad kept for experimental purposeses, and that was ihe only place nlso in which I saw the hark stem rust in England.

'They told me this was not an execptional year; that they had that same experienee rent ufter rent and that when they waited black stem rust for experimental purposes they had to go but to those har-

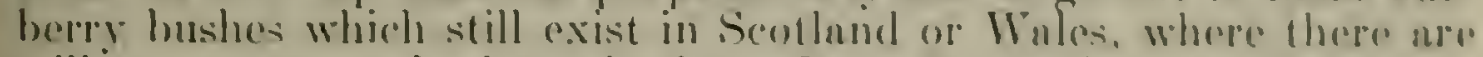
still some common barbery bushes. So, in lingland propere, they have craliented all of their burbery bushes from the agrieultural distriets and they know very little, if anything, about the black stem rust becnuse they simply do not have it. I tulked with a prominent investigntor, at Cambridge--he having studied the situntion in England for several years-and he told mo he was absolutely convinced that black stem iust could not exist in England without the common barberry.

In Wiles I made a long automobile trip and we could find no black stem lust whatever for a great many miles, and I became very lonesome. Finally we stopped at a field ind found a little on some whent. We nsed the farmer whether he knew of any buberries in the region, mol he suid he could not tell ws. We askerl him whether the knew what burberries were, and he sujel he did not, but when we neked him whether there were any pron melin in that uejghborhood-that being the Wolsh term for harberie:-he said there were. and he sajd the schoolmaster land been keeping burberry bushes right acress the rond. and we could trane the rust rery nicely from these batrberry bushes on to this farm.

We went still farther into Wales and we could find no black-stem rust at nll, except where wo found harberres and where we found them there was plenty of blnck-stem rust. There was one ficld in which it was particularly present and it impressed me very forcibly. In that field there was it very marked attnck of hack-steni rust. and nthough I rlid not know where the buberry bushes were I knew they were in that genernl region. I nsked whether they were wer in that direction and the man to whom I was talking hoked around and said: "That is exactly where they are." He wanted to know how I knew they were on that side. and the way I knew wis this: There was a very henry attack on that particular side of the erain: the gran was literally rovered with rust on that side. showing that. 
the rust had just simply been blown to that side of the grain from those barbery bushes, which were about a half mile away from this whent field, and had attacked that side of the stem. It wis a perfectly clear situation, and in Wales I became absolutely convinced that black-stem rust does not exist except where there are common barberry bushes.

I found the same thing true in France. I made a long trip through France, and I could not find any black-stem rust at all until I went up into the Alps Mountains, where there are immense numbers of barberries. I have never seen barberries more heavily rusted than these were, and this at a time when you could not find rust anrwhere else in France. We stopped at a little town called Briancon, where they grow quite a bit of rye. There they have not eradicated the barberry bushes. 'There I' saw a peasant woman, and I asked her whether they had any black-stem rust. She said they had. I asked her whether she knew what rust was, and she said she certainly did, that she was very familiar with it. I asked her whether she knew where it came from, and she said she did, that it came from the barberry bushes. I asked her whether they ever suffered much damige from it, and she said they always did. İ asked her if it did any damage to wheat, and she replied it did not, for the reason that they do not grow any wheat there, because it always rusts so badly they can not grow it. I asked her why they did not dig out the barberry bushes, and her answer was that they make a rery nice preserve out of those berries, and their rye does not amount to very much anyway. But the important thing is that in all of the great wheat-growing areas of France there was not a single bit of black-stem rust, while in the Alps Mountains and in the Jura Mountains, where there are a great many barberries, there was a tremendous amount of rust.

Even down in Spain, where one would expect the summer stage of rust to live over the winter and to be independent of the barberry, it apparently is not independent of the barberry beeause there ther have practically no black stem rust or very little black stem rust except in the mountains where there are a great many barberry bushes. All of the people with whom I talked in Spain said that the rust appeared earlier on the grain and grass near the harberry bushes, and that the rust seldom did any damage except in the immediate neighborhood of the barbery bushes or in the regions where there are many barberry bushes.

I talked with Italian agronomists and plant pathologists and made observations myself. They told me that in the southern part of Italy, where there are no barberry bushes, the black stem rust did not amount to anything, but that in the northern part of the comntry. where there are a great many barberry bushes. the black stem rust does a lot of damage. There was one interesting ('nse of harberry eratication about 60 miles southeast of Rome. In 1914 they found an outbreak of black stem rust; they looked the situntion over and found some barberies. They removed about half of them the same year, and the next year there was no rust near the place from which the barberies had been removed, but there was rust noar the remaining burberry bushes. 'They took out the remaining barberry bushes, and the next year the rust failed to develop and since then they have have had no rust in that particular recrion.

In Austrin-Hungary the farmers and others told me that they had not seen eommon barbery bushes since about 1898 , or before that 


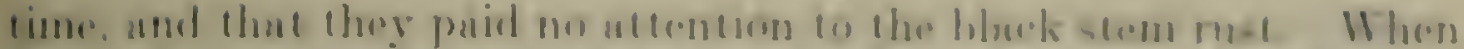

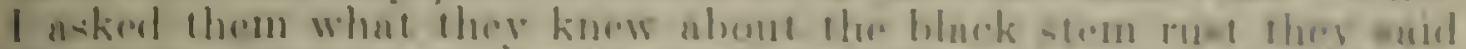

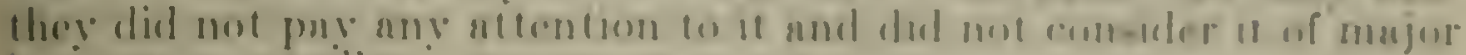
importanere at all.

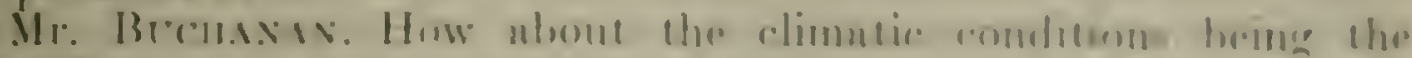
-

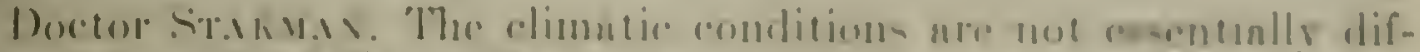

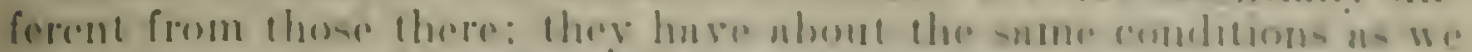

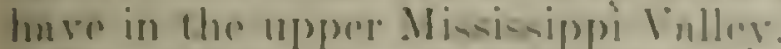

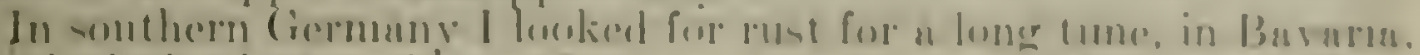
particularly, but could net fiml any 11 all: abrolutely mone. Ther tald me at their experiment station I would mot lind any and thei

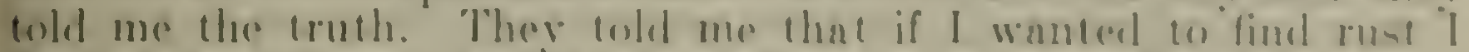

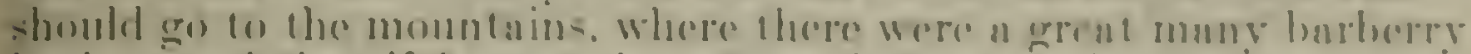

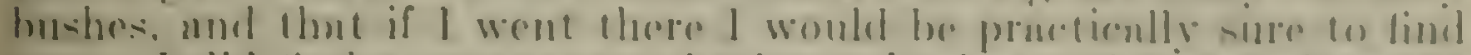

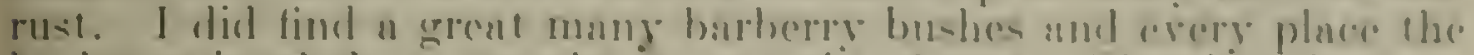

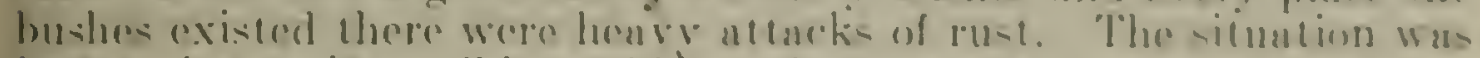

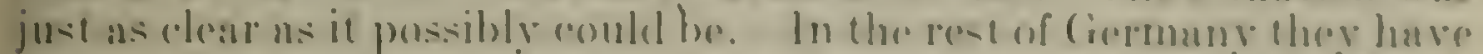

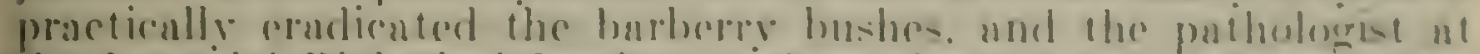

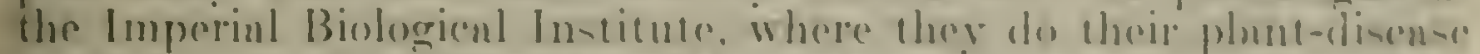

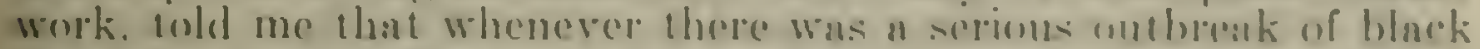
stem rust they simply went to the particulne farm or farms from which

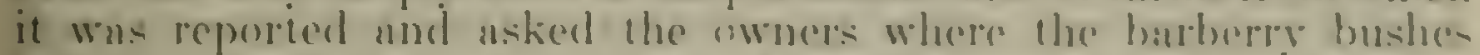
were.

If the owners said there were no barbery bushes lhey simply asked permision to look atround and they nearly alwass locited the burherry bushes. 'They cited instance after instancer in which that very

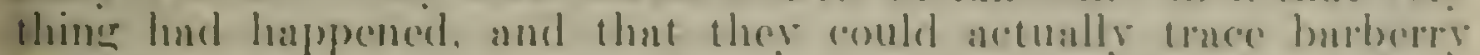

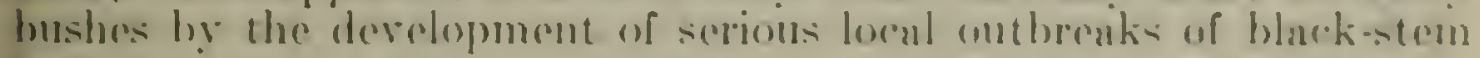
rilit.

In Sweden thes now have a law for the eradication of barbere bushes. but it has only bern in forec for a comple of years, and on

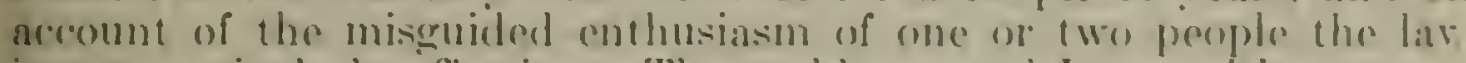
is not particularly effective. They told me. and I saw with my own rese that there is a very definte and distinet redationship between the oceurrence of hluck-stem rust in sweden and the millions of harberries along the somberistern costst und up along the pastern const of sweden. There are a great many barberry bushes in that recrion. and it is there that they suflor pinticularly from hack-stom rust. In this comntry wo think of the black-ston runt dumagring whent. but if anyboly thinks that the black-stem rust nttueks only whent and only does domage to whest he should see the siensition in

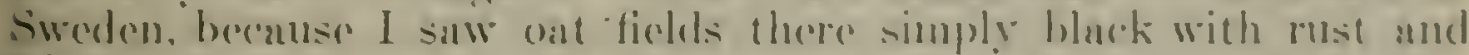
which were very seriously damated, at the same time the ridel being very erently lessened.

I saw rust over there on hluegriss and on varous other grasses on which we schlom find hack stem rust in this country. I hine never seen any rust on oats in this comntry to comparre with the sereritr of the rust in sweden. In Swoden. over townel the mountains, there nre no barberries, and barberries will not grow berenu-ce there is not an mueh limestone in the soil over there as is neeressiry for the errewth of burberies. For yenrs and yenrs swedish arrioulturise and pathol-

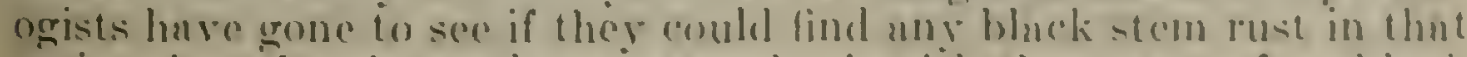
region, but they have alwars come back with the report of no blatek 
stem rust. Then they finally got a report that there was some black stem rust in one place over there and Professor Henning, of Stockholm, one of the most eminent authorities on cereal diseases in the world, went up there and he found there was a heary outbreak of black stem rust and traced it to a number of barberry bushes, and that is the only place in western Sweden where they have ret found black stem rust.

In Norway the situation is exactly as clear. Wherever there are barberries there are very heary attacks of black stem rust and where there are no barberries there are no attacks of black stem rust, so that plant pathologists and agronomists are absolutely convinced that rust can not exist independently of the barberry.

I suppose the situation in Denmark is about the clearest of any of them. They had very severe epidemics of black stem rust in Denmark in which the conditions are quite similar to those in the upper Mississippi Valley. As a matter of fact, they started a barberry war along in 1805 . The farmers insisterl that the barberry buslies be taken out but some of the owners of the bushes in the cities and villages insisted that they should not be taken out. They had a very severe epidemic every three or four years and sometimes every other year. There are records going back to 1888. They had a very destructire epidemic in 1888, another one in 1889 and still othersin 1894 . 1896,1897 , and 1901. Then they decided they had had about cnough for awhile, so the farmers insisted on the passage of a barberry cradication law and such a law was passed. Denmark is a small country. and, after the passage of that law, they cominenced the work thoroughly and they had practically eradicated all of the barberry bushes by 1904 . Since that time they have not had a single serious outbreak of black stem rust, and that is 19 years. I asked them whether they would be sure to detect an outbreak of black stem rust if they had one and they assured me they had agricultural experts in the various parts of the country who would detect the slightest attack of rust and that they are all reporting to the central laboratory, and in all of these years they have been practically mable to find any black stem rust in Denmark, although in some of the large grain areas they have found a little bit here and there and they can trace it to some barberry bush.

I made a long trip through Denmark and found no black stem rust on oats or other grains, but finally we eame near the Copenhagen municipal forest and found a trace of rust here and thera a : we rame closer to the forest, and when we got nearer the forest wo found it was pretty heary. We asked the forester whether he knew of amy harberry busihes in the woods, and he said he knew there were some there. We asked him whether they had beon rusted, and he salid they not only had been rusted but they were still rusted. Wo looked for the barbery bushes and found them, and that wat the only phace in Demmark where I could find any black stem pust, and die only damage done to grain at all was near the se commen barberry bushor.

So the situation in Europe is perfectly alear. In the lirst place. they have eradicated practically all their barbery buatas from the agricultural regious. It will be imposible for ilem to aradicate them all from the monntains, and for that reason ther will never he absolutely free from the rust, but the i do not four it like we do in this comery, They do not have the torrifice epidemies wo have in this 


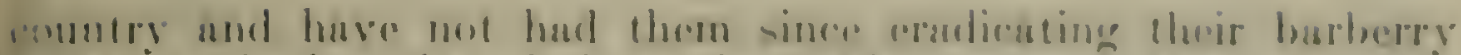
bushes. and when they do hase the black serm rost there troce it in harberry bushes.

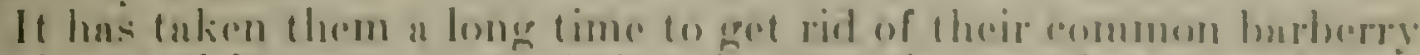

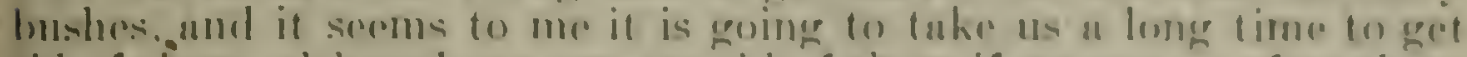

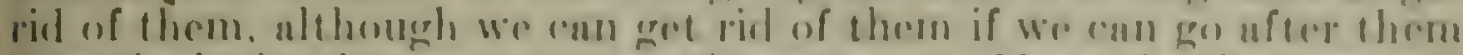
intensirely in the next two or three rears. If we do that we will ant the nimber down to surh a point that the wored inspectors and

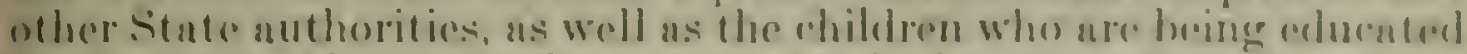
up to the needs of the farm, can simply locute and cradiente the remuining hushes.

Just one ore two things more. I want for emphomize the fanct that burope has controlled fibe black-stem rust by the eradiention of the common barbery. They do not foar the black-stem rant in western Europe and it selelom appears at all, and when it does appene it is too late to do mueh damage. If they can solve heir rust problem orere there we can do it here. The German patholugists laughed at me when I tohl them we were carreing on this campaign in the linited stutes, and they asked me why the farmers did not take out the barberry bushes. I told them some people did not believe in it: at last did not believe in it thoroughly enough to support it very rigorously, and that some people thought it was an experiment. Ther artually langhed at me and said. "The thing is absolutely settled in this country: there is nothing to it at all."

I want to cimphasize the fact that we must not get the idea that this discase is destructive only to whent. In Sweden, in the spring-wheatgrowing region and in the sonthern part of the country, it is apparently as destructive to oats as it is to wheat; it is also dessuctive to barley and ree, and so it goes as to all of our common small grains. Not only that, hut in Sweden. Where there are tremendous numbers of buskes it was even aflecting their pasture grasses. So it seems to me we are not dealing with an experiment but we are dealing with a big problem and one that has been solved in Western Europe. It is a problem that can be solved in this comntry and $I$ am absolutely and firmly convinced that the best way to solve it is by attacking it rery vigorously for the next-I will be a little more conservitive than some of these men lwo or three veal's at least. and then after that we ought to get rid of practically all of the bushes. execpt those which can be eradiented by the children who are growing up. by the werd inspectors, and by these various other agencies. In connection with that wre have got to do a lot of educational work because it is a big joh. I have not a thing to do with the barbery eradicating propram and $1 \mathrm{am}$ simply saying this because I am so lirmly convineed it has get to be done. I sincerely hope financial facilities will be provided which will make it possible for us to go ahead and solve the problem in this way. I thank you.

Mr. Axibisox. Are you familiar with what has been done in this countrit

Doctor Stansax. Yes; that is, I was familiar with what has becn done in this country until this summer. I was awa all summer. so that I have not canght up as yet with what has been done this summer.

Mr. Feteler. I have a great deal of information, in one form or another, with regard to the work done in the past year. 
Mr. Andensox. What proportion of these 13 States have been surreyed for the first time?

Doctor Stakm.x. The eities and towns have been sureyed in all the 13 States, and as far as the country districts are concerned I should say possibly about half or more: that is, as far as the farm to farm surver is concerned. May I make just one more statement? I just want to point out the destructive eflects of a single barberry bush. This is a statement made by Doctor Jackson, of Indiann. who has been one of the most conservative of the plant pathologists in connection with this barherry eradication eampaign. He says:

One thing that has greatlv interested us this summer and on which Mr. Beesrnn. our state learler, made a special study, was an outbreak of stem rust that siated from one barberry bush. It traveled in one clirection, at least, for about 5 miles. The area was nretty earefully surveyed and I have a report here containing figures given by the farmers themselves on 18 out of perhaps a total of twice that man farms. The total wheat acreage was 9633 acres. The average viold due to stom rust was 8.1 bushels. The average estimate of vield hat there been no black-stem rust was $21 .+$ bushels. The average crop this year was then 37 per cent of what it would have heen without the black-stem rust. The total lost in yield was 12.520 bushels or an arerage loss of 696 bushels. At a dollar a bushel each iarmer lost $\$ 696$ worth of wheat. The combined money loss was $\$ 12,520$.

That was rery clearly traceable to a single barberry bush in the southern one-third of Indiana. I have a great many similar cases, but I was interested in that because Doctor Jackson has been so conserrative on the thing.

Mr. Fllzer. I can answer in part the question which you just asked, Mr. Anderson. Dr. F. E. Kempton, the leader of the cimpaign of barberry eradication for the United States Department of A riculture, made this statement at our recent meeting in St. Paul:

A total of 172 counties were coverei, as against 86 in each of the two preceding years.

During the entire campaign since 1918 an area of 512 comtins has been cosered in the farm-to-farm survey. The total number of hushes found was 5.s06.titi. (If these $5,142,843$ were lestroyed.

\section{With reference to the future he mide this statement:}

A large area remains to be covered by our original farm-to-farm survey. Al the rate we went this year. it is possible that next season we can complete the surver. in Minnesota. North and South Dakota, Iowa, and Nebraska.

Without knowing how many counties there are to be cosered we could not gire you the geographical proportion which has alreacly been covered.

Mr. Axpersox. Judging from the map I have before me all of the territory of Minnesota has been surveyed, that smrey having apparently been completed this year.

Mr. Fulder. Not all of it, I think, Mr. Anderson. There are a few romnties in this area here [indicating on map].

Mr. Axmerson. But most of those on this map are murked as probably not needing surveys.

Mr. Futek. This is Doctor Kempton's map. Wo still hure a fow moments of time and I would like to make an additional statement. I want to tell yous something about the work of the oremonimtion which we represent. I told you what we hasd done in the way of sendiug out publicity material, and it will interest rou to know that we have expended in that work up lo date aboul s.50.000): we will have spent ly the lst of March ubout stio,000, and wo are planning 


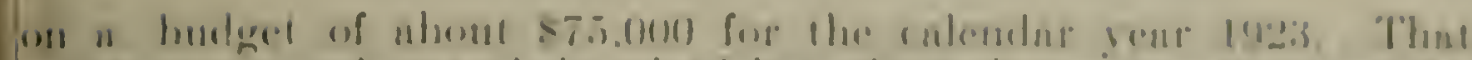

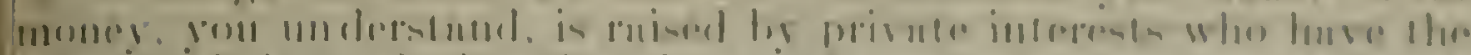

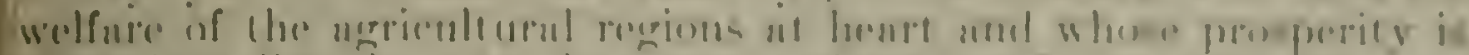

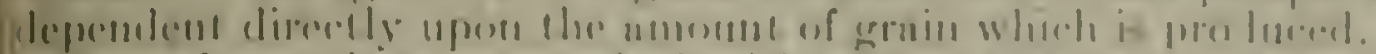

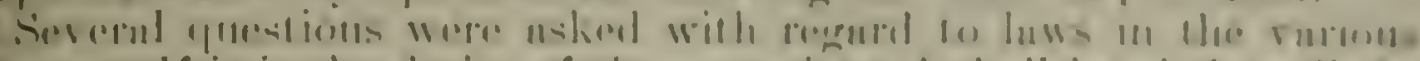

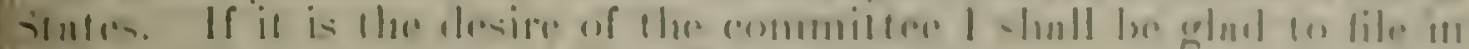

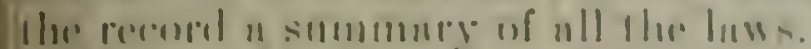

Mr. Bu+11.1

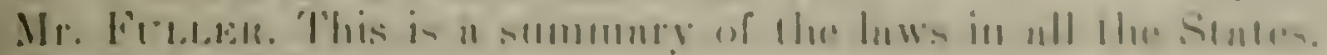
(s)ill law: follow:)

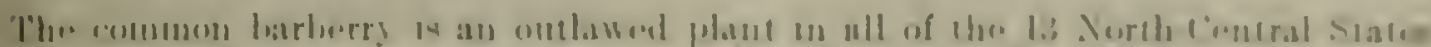

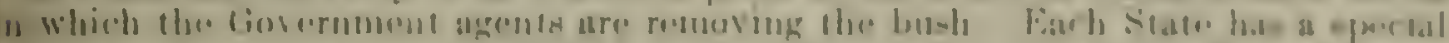

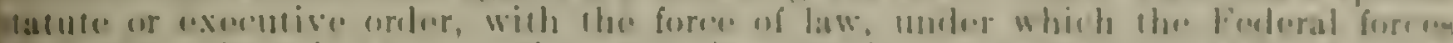

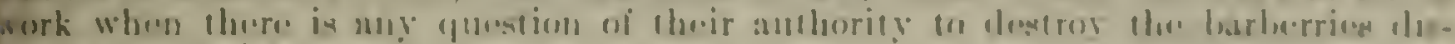

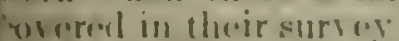

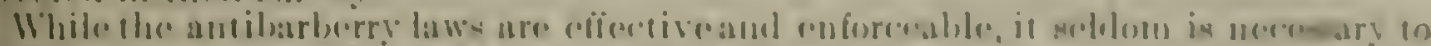

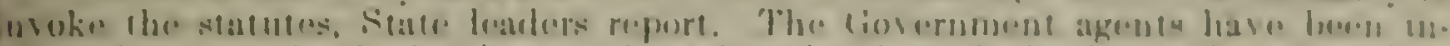

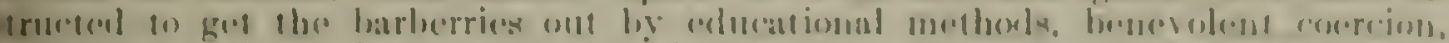

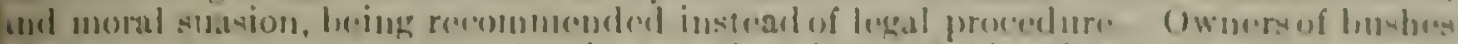

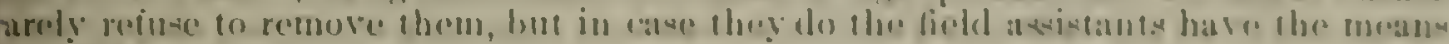
"1) (о)

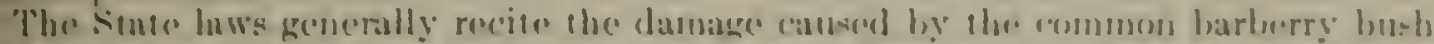

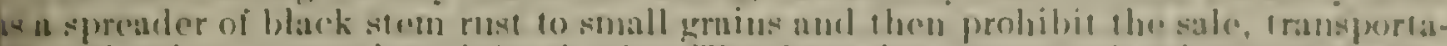

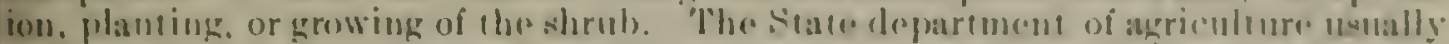

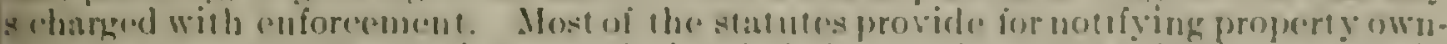

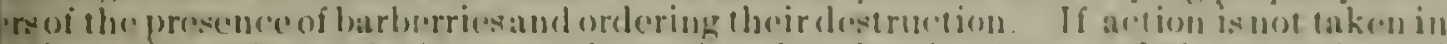

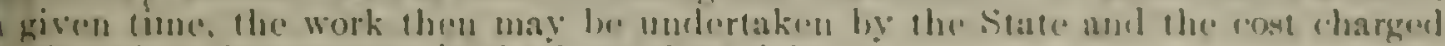
wak ugainst the property in the form of sprecial taxes.

Many of the laws, in branding the common barkerry as a prest. make it plain that the

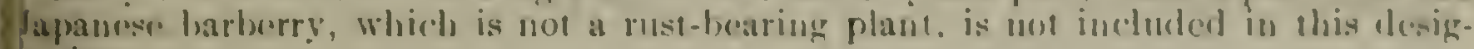
lation.

Tho Colondo regutations were ammoumed by the state ontomologist by sirture of

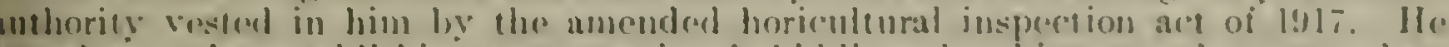
sened an order establishing a quarantince forbidding the shipment of common har-

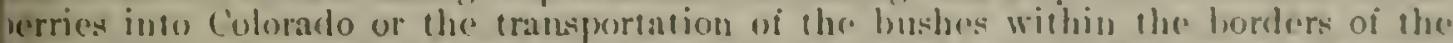
tate. The order hurther direeded the extermination of harmful barloerries wherever

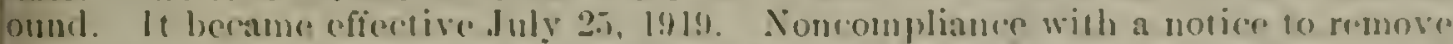

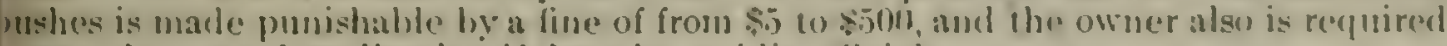
o pay the reost of eratication if elone ly publice ollicials.

Linder the Illinois plant inspection act of 1917 the state department of agriculture as isened an ollicial notice desiguating the common larherry as a pest and ordering ts cradication. The law repuires property uwners to dig uj their lushes when intructed to do so by the department of agriculture. In ease of refusal or neglect to arry unt such orders the State may lo the work amd the cost comstitules a lien against he property. Importation of the harmful harberry into Illinois is prohilited lig xecutive order and violation may he punsabed ly a line of from $\$ 500(1) \$ 5,000$. The iolation of an order to remove linshes is a mistemeanor and is punishable hy a line fífom $\$ 10$ to $\$ 100$.

The antibarberry regulations in Indiana beame effective November $29,191: 1$. hrough an order of the state department of conservation, acting under anthority of legislative act passed in I919. Wwness of Lushes were gion until December 31. !1!1, to get rid of their common and purple harberries. Posensing rust-hearing

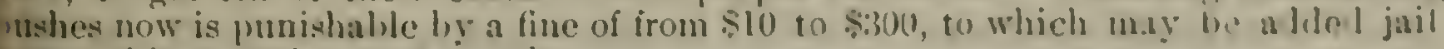
(orms of from 30 days to 6 inonthis.

The Iowa law became effective in folbruary, 1!1!?. It makes it mulawiul to sell, mansport, or permit to exist any species of the harmful harlerry. "The State rutoonologist is charyed with notifying property owners of the presencer of lushes. If they to not remose them within li days the state may do the work and charge the cest io be property to be collected as a sirecial tax.

Michigan outlawel the common barherre in a law pased in l!)!!. The satw

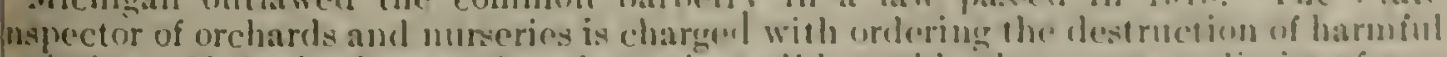
arieties. If the bushes are found growing will outsile ihe corperate limits of any ity or village and the owner of the property reluses to destroy them, the sathe may ilo

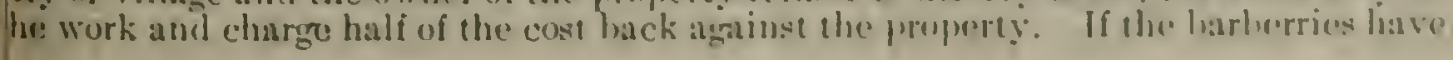


not been infected by rust spores the owners of all eradicated bushes are entitled to recompense for the actual value of the plants.

The Minnesota law was passed in 1919. It forljids the maintenance, propagation, sale, or introduction into the State of harmful barberries and makes it the duty of property owners or occupants to destroy their barberries forthwith. The State entomologisi is designaled as the enforcement oflicer. He is required to notify owners of the presence of bushes, and they then are granted 10 days in which to remove them. If they refuse or neglect to do so, the work may be done by the State and the cost collerterl from the property owner by the connty attorney. Violation of the act is made a misdemeanor.

The State board of horticulture is made responsible for the enforeement of Montana's stringent law. It provides for giving notice of the presence of harmful barberries and requires their removal within 10 dlays. If the owner does not destroy them, the State horticultural inspector may have the work done and the cost charged against the propert $y$ in the form of taxes. Vintation of the act is made a misdemeanor punishable by a fine of from $\$ 10$ to $\$ 25$. The sale and transportation of the bush is prohibited as well as its possession.

In Neloraska the antibarberry law is enforced by the sheriff of each county. The plant pathologist of the State experiment station is refuired to inform the sheriff of places where the bushes are growing. The sheriff then sends a written notirs to the property owner. If the hushes are not removed in 10 days, the sheriff may order the work done and the cost collected as special taxes. The law was passed in ipril, 191!.

North Dakota's law was passed in March, 1917, and carried the first public appropriation ever made for barberry eradication. The commissioner of agrieulture and labor was required to make rules relating to the most convenient and expedient method of eradicating rust-producing bushes, and $\$ 5,000$ was provided for the work. It also was made the duty of the board of county commissioners in every rounty to orcler and cause the eradication of barberries. Provision was made for notifving the owners of bushes who were required to dig them up within 10 days. Failing to do so, the commty. commissioners or' State commissioner of agriculture were authorized to do the work. the cost of which constituted a lien against the land. Refusal to dig the bushes is a misclemeanor, punishable by a fine of not more than \$25:

The chief of the State bureau of horticulture enforces Ohio's plant pest law under which barberry eradication is renuired. The statule contains the usual provisions prohibiting the transportation, sale, or possession of disease sprealing plants and requires removal in 10 days after notice from the secretary of agriculture. Provision also is made for doing the work at public expense if the owner refuses to do so, and collecting the cost as taxes. Violation of the act is made a mistemeanor with the maximum fine fixed at $\$ 10$. The probate court is given jurisdiction over cases arising and prosecutions take precedonce over criminal cases.

Sonth Dakota passed a law in February, 1919, making it nnlawful for any person to permit any harmful barbery to exist on his premises or to offer the bush for sale. The State entomologist is required to enforce the act as a police regulation of the State. After receiving remoral notices propertrowners are given 30 dars in which to eradicate their bushes. In ease of failure to dig them up the state entomologist may oreler the work done and collect the cost as taxes. Violation of the act is a misdemeanor punishable by a fine of from $\$ 25$ to $\$ 500$.

Babberry eradication is refpured in Wisconsin under the terms of the erop pest and nursery inspection act passed by the legislature of 1915 . The inportation of the harmful varieties is prohibited by the 19l9 statutes. Aiter forlidding the shipment. sale, or growing of the outlawed harberries the act authorizes the State entomologist to erarlicate the plants. Upon being notitied the property owner has 10 days in which to remove his bushes. After that the state may do it and charge the cost to taxes against the premises. Violation of the law is a inistemeanor. The fine is from son to 5.500 .

'The Wyoming law was passed in 1921. It contains the usual provision against transport, planting, and sale of the harmful barberries and makes it the duty of the state board of horticulture to cause the eradication of rust-bearing varieties. li the owner of the land on which the harberries are foum growing refuses io remove them within lo days after reeriving a written notice to do so the state does the work and rollerets for it hy levving special taxes against the land. V'iolation of the statute is a

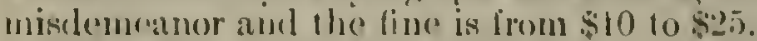

Mr. Fets.ke. I woulel like to enll the altention of the committer to the losses from black stem rust. You will recall that the statemont has beon made, hised upon figures prepmed by the plant disease survey, that the avernge ammunl loss from black stem rust 


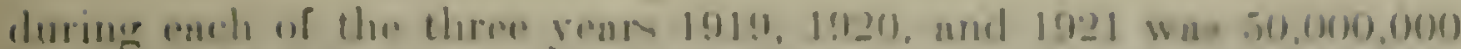

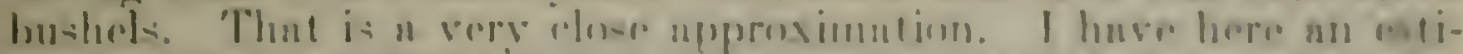

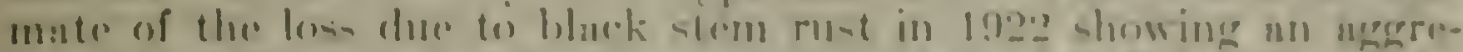

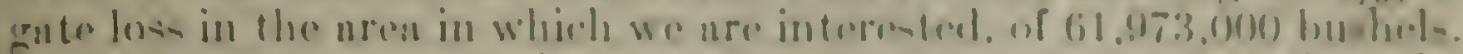

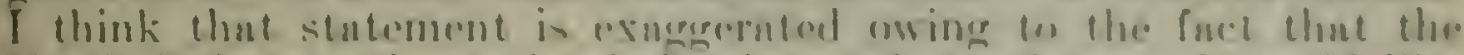
North Daketa estimule is obvions-y much ton lurges. I would like to huse this stutement included in the record. 'There figures were prepared by the plant disisase survery of the Linited staten Depurtincrit of .lgriculture.

(Said stutruent follows:)

Losses due (1) bluck stom rust in 11)!?.

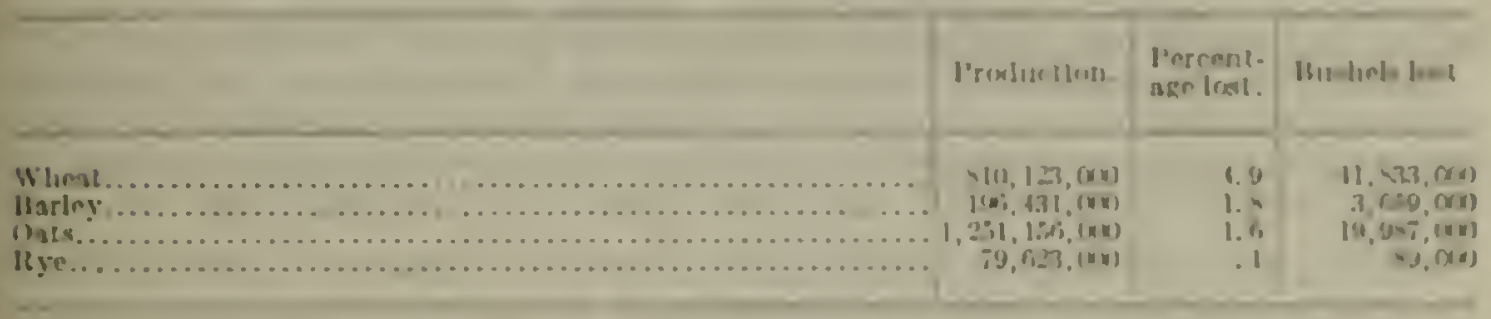

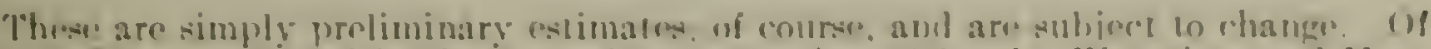

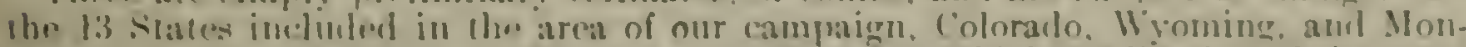
lana to not report any loss. These are the slates in which eradication of the cons.

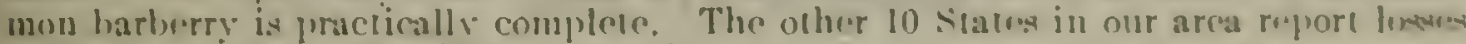

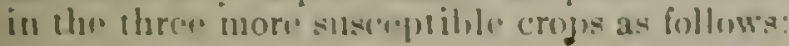

\begin{tabular}{|c|c|c|c|}
\hline & Wheal. & Barley. & Onls. \\
\hline Illinnis. & $211 . \mathrm{mm}$ & $27.100)$ & \\
\hline Imbana. & $2 \pi, 0 \mathrm{nn}$ & $\cdots \cdots,{ }_{1}, \cdots$ & \\
\hline $\begin{array}{l}\text { Juwn...... } \\
\text { Yictimil. }\end{array}$ & $\begin{array}{l}32.0 \mathrm{~mm}) \\
2 \mathrm{iv}, 0 \mathrm{~m})\end{array}$ & $281.17 n$ & $\begin{array}{l}2.1+2,(m) \\
1.102(m)\end{array}$ \\
\hline Vinnonota & 1, $50.10 \mathrm{mon}$ & iipin & 9. \\
\hline Detraska. & $x i 2,000$ & $\because 2.0(n)$ & bilfi, (m) \\
\hline Cinrth lakola & $133,211,0 \mathrm{cos})$ & $12,2 \mathrm{xin}, \mathrm{mol}$ & $111.12,(x x)$ \\
\hline Whin ...... & $721.0 \mathrm{mon}$ & 8.00 & $\because 11.07)$ \\
\hline $\begin{array}{l}\text { South Wiskola } \\
\text { Wisconsiy }\end{array}$ & $\begin{array}{l}1.168 .0 \mathrm{n} \\
179.000\end{array}$ & $\operatorname{lil}_{3 x,(x y)}$ & $\begin{array}{r}71,(2 x) \\
1 .(111 ;(x)\end{array}$ \\
\hline Tols & $3 \times 114,0 \mathrm{~m}$ & $3,1 i n, m$ & $19.917 .(201)$ \\
\hline
\end{tabular}

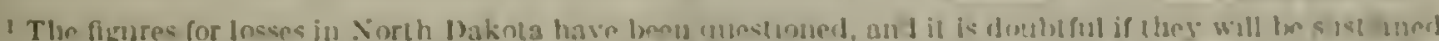

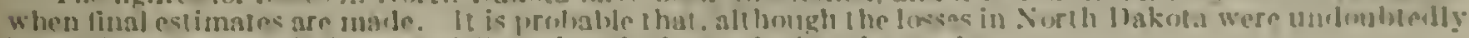

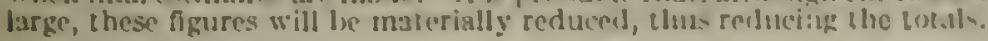

In Nebraska. Ohin. and South Dakola there wore Iozaes of rye ageregaling sti mon. This figure. alded in the tolals for whost. barley, amt nats as given. wakes a gratul total of 1 il.973.000 bushels as the lose during the past season due to black stom rust in the ares which wrare erving to free from labluerries.

Mr. Feut.en. I should also like to indude in the record the resolutions which were adopted at our meeting on the 1 th ho Norember in St. Paul, appending to those resolutions the signatures of the 3 !! delegates representing the 13 Stat (2s.

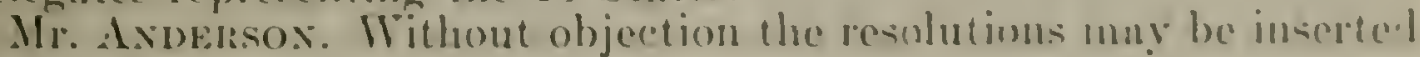
in the record.

(Snill resolutions follow:)

Whereas observarion and experionce duriug the jast year have serongly reinioreme

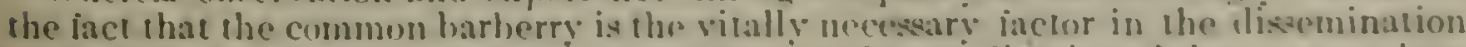
of hlack stem rust and have proved conclusivily that iroulication of the commun burberry is exsential to the continued gnowing of grain in the noth central prart of the 
United States, and consequently, to the continued prosperity of the region and the Nation as a whole; and

Whereas Congress appropriated the sum of $\$ 350,000$ for barberry eradication during the fiscal year 1922-23, which, in our opinion, has been most wisely and effectively used, with the result that tremendous progress has been made in the solution of this great problem; Now therefore be it

Resolved, That the conference for the prevention of grain rust reaffirm its confidence in barberry eradication as the solution of the problem of black stem rust; and be it further

Resolved, That we earnestly urge Congress to appropriate not less than $\$ 500,000$ ior barberry eradication during the ensuing fiscal year.

Whereas enforcement of eradication of common barberry bushes, by reason of the police power involved, is preeminently State iunction, and certain phases of barberry eradication can only be accomplished through State agencies; Now therefore be it

Resolved, That this conference earnestly urge every State included in the barberry eradication canpaign to make adequate appropriation through its legislature for these phases of the work, and to memorialize Congress in behalf of a Federal appropriation of not less than $\$ 500,000$ for barberry eradication cluring the ensuing fiscal year; and be it. further

Resolved, That the delegates to this conference pledge themselves to do all in their power to promote the most effective cooperation on the part of their respective States.

Delegates in Attendance at the Second Annual Conference for tue PreVENTION OF GRAIN RUST.

STATE DELEGATFS. •

Colorado: L. M. Taylor, secretary, State board of agriculture, Fort Collins; Dr. $A$. K. Peitersen, botanist, Colorado Argicultural College, Fort Collins.

Illinois: Frank I. Mann, representing the Illinois Agricultural Association. Gilman; O. T. Olsen, superintendent, division of plant industry, State departnent of agriculture, Springfield; George H. Dungan, associate in crop production, agronomy department, University of Illinois, Urbana.

Iowa: C. W. Hunt, president, Iowa Farm Bureau Federation, Des Moines; I. E. Melhus, station plant pathologist, agricultural experiment station, Ames.

Indiana: James K. Mason, director, Indiana Federation of Farmers' Associations, Milton; Dr. H. S. Jackson, chief in botany, agricultural experiment station, Lafayette. (Representing Gov. Warren 'T. McCray.)

Michigan: James Nicol, president, Michigan Farm Bureau Federation, South Haven; John A. Doelle, commissioner of agriculture, Lansing; W. F. Reddy, State leader of barberry eradication, East Lansing.

Minnesota: J. F. Reed, president, Minnesota Farm Bureau Federation; N. J. Holmberg, commissioner of agriculture, St. Paul; Dean E. M. l'reeman, College of Agriculture, St. Paul; Leonard W. Melander, State leader of barherry eradication, St. Paul.

Montana: A. I. Stafford, president, Montana Farm lBureau lecleration, Bozeman.

Nebraska: H. D. Lute, secretary, Nebraska Farm Bureau Federation, lincoln; Dr.

George 1 . Peltier, station plant pathologist, agricultural experiment station, lincoln.

North Dakota: Gov. R. A. Nestos, Bismarck; Hans Georgesen, president, North Dakota Farm IBureau Federation, Niagara: Joseph A. Kitchen, commissioner of agriculture and labor, Bismarck; Dean II. I. Bolley, Collegre of Agriculture, largo; Ceorge C. Mayoue, State leader of barberry eraslication, largo.

Ohio: A. E. Anderson, director grain marketing department, Ohio Farm Bureau Federation; I. J. T'aber, director of agriculture, Columbus.

South Dakota: W. S. IIill, president South Dakota Farm Bureau Foderation, Mitchell; Frank M. Byrne, commissioner of agriculture, Pierre. (Representing Gov. W. H. Melfaster.) M. R. Benedied, assistant eommissioney of agrienture and professor of farm economies, College of Agriculture, Broekings: D1. Arthur 'T. Evans, associate agromonist and (rop pathologrist, College of Agrichliure, Brookings: Dr. N. E. Hansen, profensor of horticulture, collenge of Agrieulture, Broblinges.

Wisconsin: George W. Mckerrow, president Wrisconsin liarm Burean fiederation. Madison; C. P'. Norgond, commissioner of agricultule, Madison: Dr. S. B. lianclier, State entomologist, State departmont of agriculture, Mndison: Willian .1. Walker, State leader of harberry eraticution, Madison.

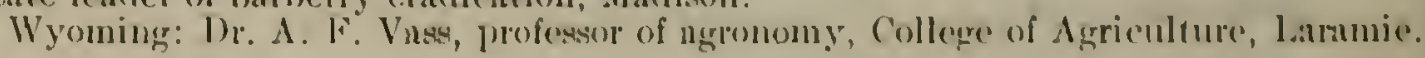




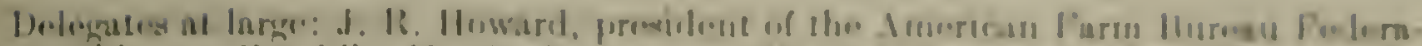

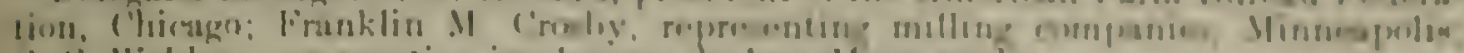

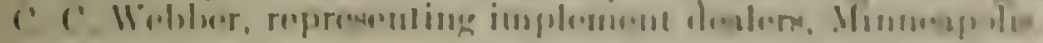

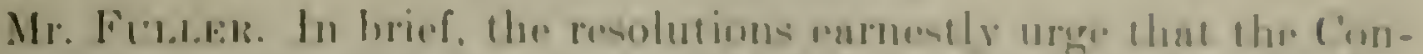
gress nppropriate not less than $\$$ iluring the ('nsuling fisoul your.

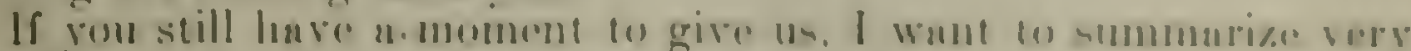
briefly whe wo holiove we hase shown.

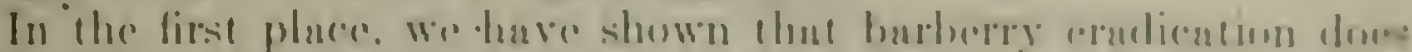
mern the control of hlack stem rast in the solution of the prohtem in which we are interested.

In the serond place, wo have shown that harberge arudiention is perferety possible and perfectly gractionble and that the spond with

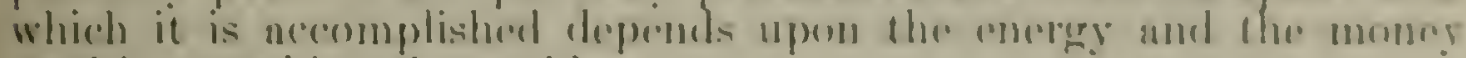
userl in attarking the prohlom.

Wr have shown, and you linver also, the statement of the berart-

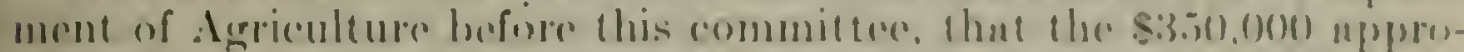

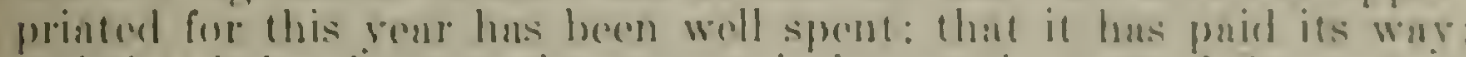
and that it has loese a wise apprepriation on the purt of congress.

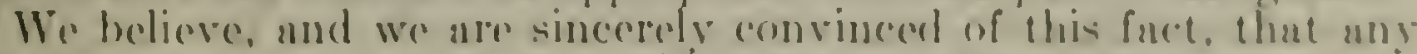
decrease in the appropration will ments, be the showing made bi

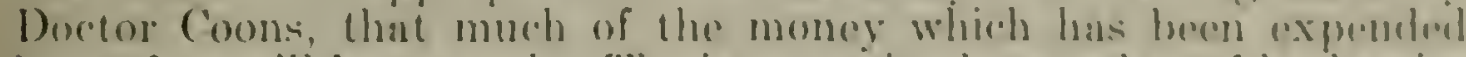
heretofore will be wasted. The increase in the mumber of batberien is such that the problem must be vigorously attacked and rapidly attacked if the barberies are not gongr (1) got away from is altogether:

We have shown that the States are realy to couperate and that they are groing to make adequate npproprintions for cooperntion with the Federal Government.

We hare shown also that this is certainly the time to wind up this job nond wind it up in good shape, hy reasion of the fact that a great body of popular sentiment has been built up and that the prople themselves are prepared to cooperate aside from state approprintions. We can not tell, of eourse, how many barberies have uctually been removed by virtue of the stimulus of our publicity campaigri. but I venture to say that the number that has come out and will continue to come out has been increased tremendomsly by rensun of that publicity.

We have shown alse that the end of the compaign is in sight. I made the statement a short time ago that about (wa) rears or more of Federal assistance would fintsh the joh, at fur as the Federal (iosernment is concemed. Mr. Reed. Mr. Mill, and Mr. Hunt hatse stated that for Minnesota. North Dakotis, and lown one more year of Fenleral cooperation will probubly de the juts.

In other words, the opportunity is presented for the Federal cinsermment to finish something it his alrealy undertaken and to hang up for itsolf a completed joll which has for its object the preserration of the food supply of the Lniterl states, in which we play so impurlant a part.

I should like rery much to supply the mombers of the commillede with any detailed information they may desire, hot unless there is a request for it here, I will prepsure it and semel it arouml to the varions members.

If there are no other questions, wo thank you for this henring.

Mr. Andersox. We ure much whliged to gou for yeur statements. 
Friday, Noveniber 17. 1922.

\section{FORES'l' SERVICE.}

\section{STATEMENT OF COL. W. B. GREELEY, FORESTER IN CHIEF.}

AREA OF NATIONAL FORESTS-RECEIPTS FROM SALE OF TIMBFR ANI) GRAZING FEES.

Mr. Axdersox. Colonel, do you want to make a preliminary statement before we take up the statutory roll?

Colonel Greeler. I would like to, Mr. Anderson.

Mr. Axuerson. All right, sir.

Colonel Greeser. I believe it desirable to give the committee a general picture of the situation on the national forests which absorb the bulk of our expenditures.

During the past fiscal year the area of the national forests was increased by 171,000 acres and now reaches a total very elose to $15 \overline{7},-$ 000,000 acres. That increase has come about chiefly through the purchase of lands in the Eastern States under the Weeks law.

The receipts from the national forests in the past rear reached the highest figure during their administration, or a total of $\$ 5,068.000$. A portion of these receipts should be credited to business handled during the preceding year; that is, the grazing business for which payments were deferred by act of Congress. On the other hand, certain grazing receipts that would normally be paid during the fiscal year just closed were postponed by authority of the secretary of Agriculture until the next fiseal year, so that the grazing receipts partially balance. The total receipts of over $\$ 5,000,000$ represent in an approximate way the growing of the national forests.

I want to call attention to the fact that the receipts have now reached a point where they nearly offset the expenditures for protection and administration. 'Those expenditures momouted last year to $\$ 5,127,000$ as compared with receipts of $\$ 5.06 \$, 000$. The are gradually chosing the gap. These figures do not include the emergency expenditures for fire lighting but are based upon the normal cost of maintaining the protective organization and handling the use of resources.

$$
\text { SALE (IF TIMHEH. }
$$

The timber businesson the national forests ast year showed in reroipts and eut substantially the same volume as durivg the preceding fiscal rear. The rut was a little over $800,000,000$ board foet and the receopts from sules of timber $\$ 1.828,000$. 'The receopts during the year reflected the ups and downs in the humber markets of the combtry and beginning lase spring showed a very rapid increase.

We marle during the year 13, list timber sales with a lotal of $2,100,000,000$ board foet. "This is the largest year's timber business we have yet had. It represents an income of a little overe $\$ 6.000 .000$ which will be realized maning within the next lo years. Many of these sate contrates extemel overe periods of severnal years.

During the lust six months the sules business has inceresed at a rery mpiel mate. The cut during the last there montles duly, Augrast, and feptember-reached manty $600,000,000$ beard foret 


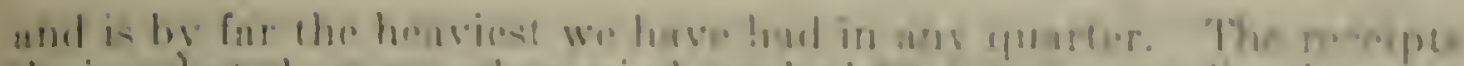

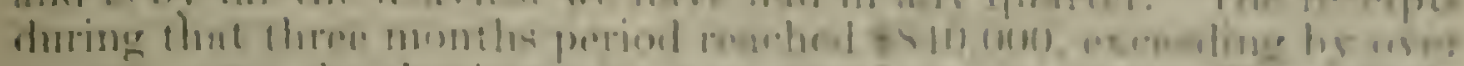

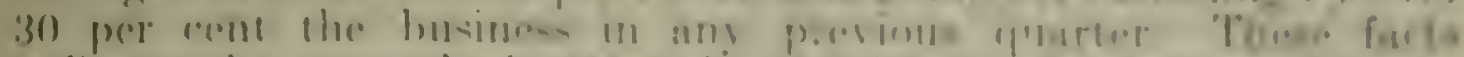

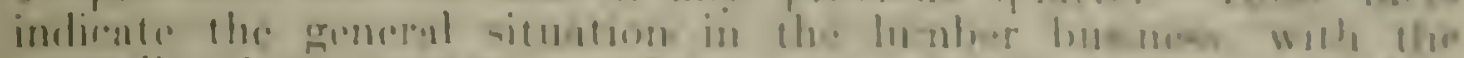

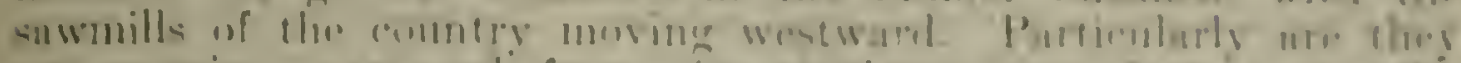

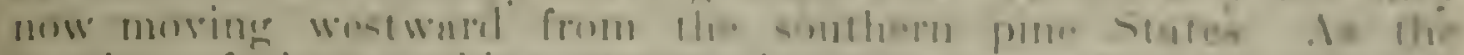

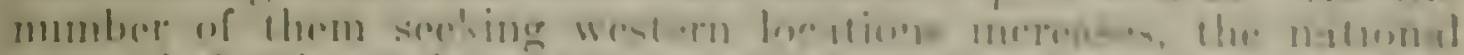

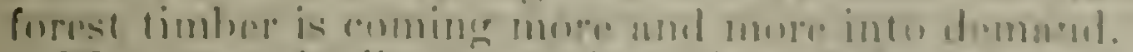

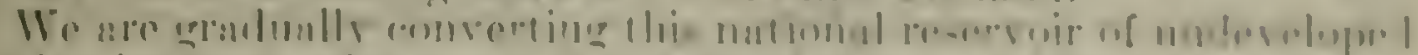
timber infe (1)

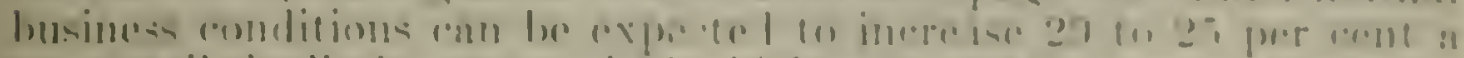

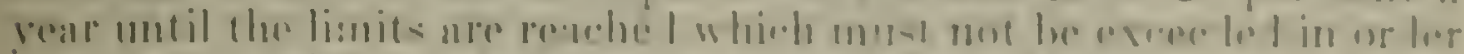

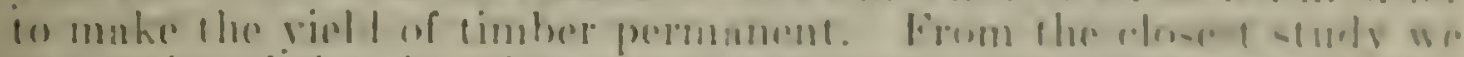

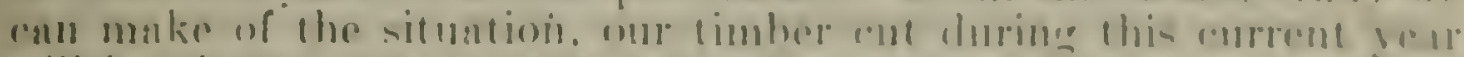

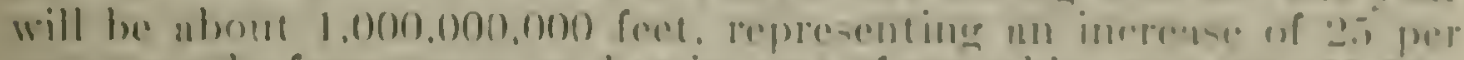

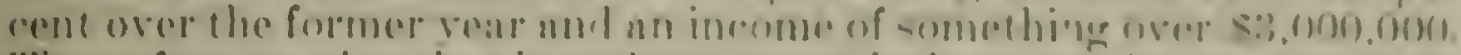

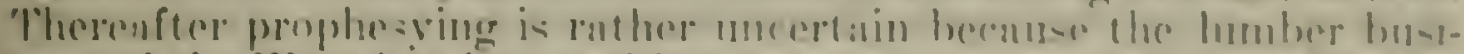

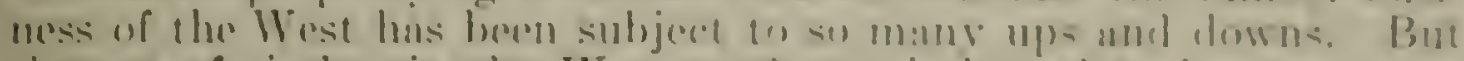

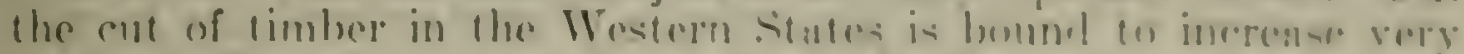

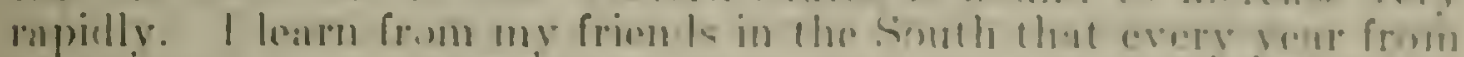

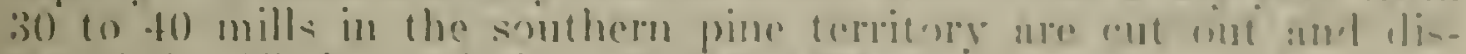

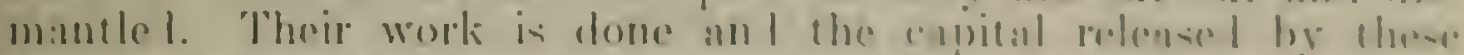

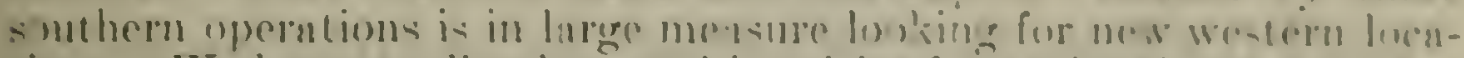

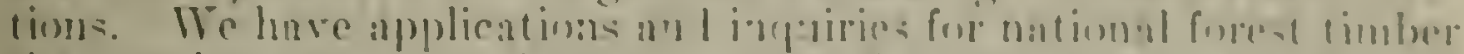

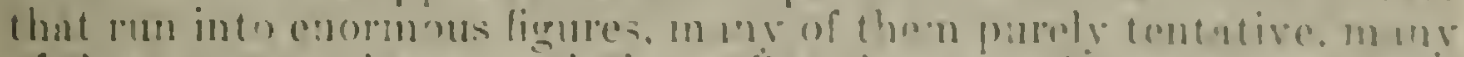

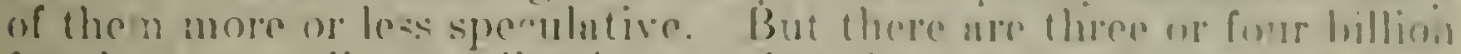

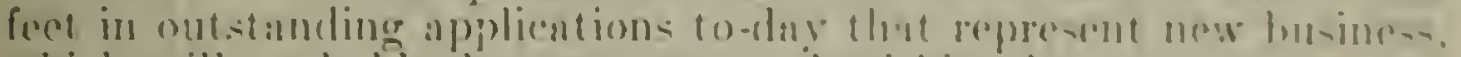
which will probably be constmmanded within the noxt one or twis lents.

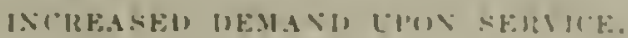

Putting eropthing together wo free the rortainty of a rupid inverse in the demands upon this service for handline ihe disposin of

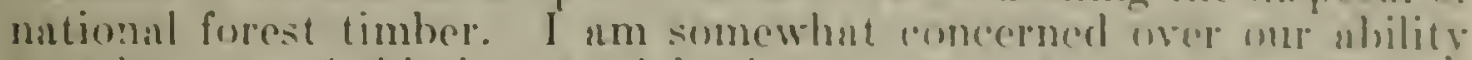

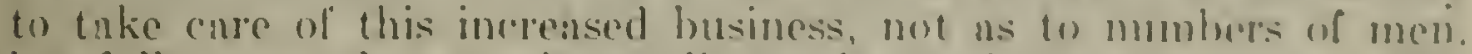
but fully as much as to the quylity and experienco uf utr mon. W0

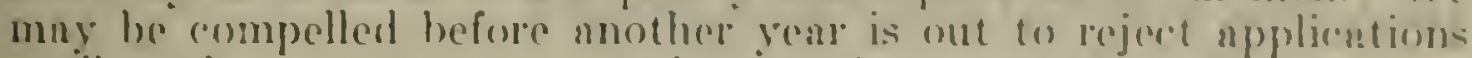
until we have gotten un oremization that cas handlo ths husinem effectively and get the results needed in roforestation in the condition in which the ground is left for future timber growth.

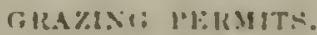

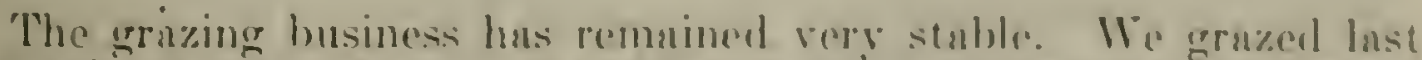

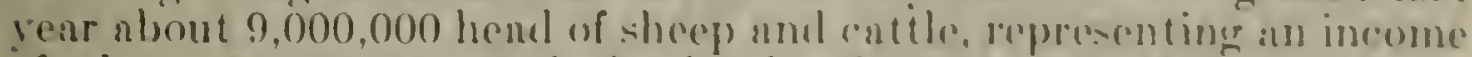

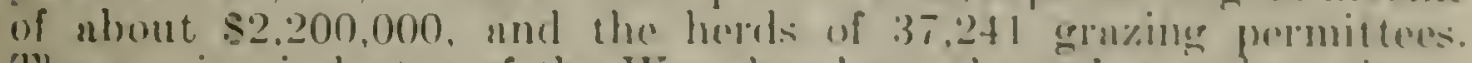

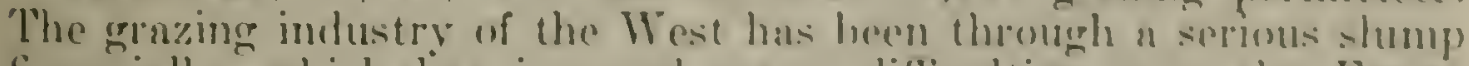

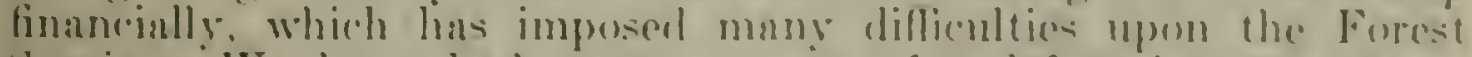

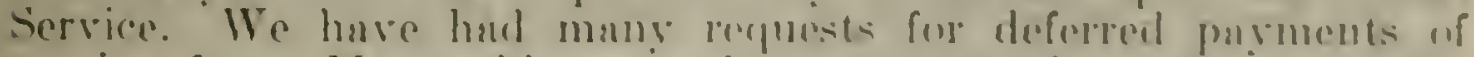

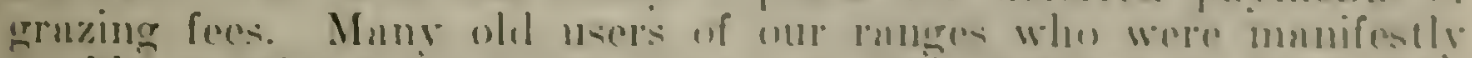

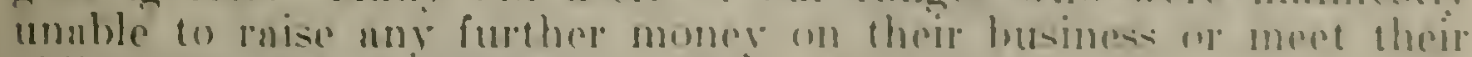
obligations to the Government ware insulverl. 
We have tried to meet this situation in a human way and recognize the acute conditions in the industry. Our deferred payments for the grazing year of 1921 have all been cleaned up with the exception of $\$ 78,000$, out of a business of $\$ 2,400,000$; and a portion of that will be recoverable without legal action. The receipts for the present grazing season will probably all be paid by the time limits set, with the exception of a very small percentage, and the great bulk of that can be recorered without the necessity of legal action, because the grazing industry of the West is gradually getting back on its feet.

Our great problem in the handling of the grazing business is the intensity of the demand for national forest range, arising largely from the extent to which the old open public range has been taken up by settlement and the fact that the absence of any regulation of the open public ranges still remaining has resulted in their very serious deterioration at many points. That is forcing a good many stockmen to seek new range and it tends to crowd sheep and cattle on the national forests and make the administration of our grazing more difficult.

I am going to speak of that again in connection with the specific item of range improvement because it is a rery practical question we have to meet.

\section{LAND PERMITS.}

I want to refer briefly to the land business, something that has not been mentioned very often in these hearings. We have outstanding nearly 27,000 permits for the use of lands in the national forests. They cover almost every conceivable variety of land use. There are many industrial establishments, sawmills and mereantile institutions, fish canning plants in Alaska, and that sort of thing, down to summer homes and small pastures used in connection with grazing permits.

This demand for the use of the national forests in varied ways is increasing very rapidly, particularly in connection with recreation. We issued last year some 1,500 more permits than at any time previously, arising largely from the demand of the people as they go into the national forests seeking recreation for permits to use small bits of land for permanent summer homes. It is a wholesome uss and I think a use that should be encouraged.

PROTECTION AGAINAT FOREST FIRES,

The fire situation during the past season has been what I would call normal or average. The large fires reported from the Westem States during the summer and from Minnesotal during the fall were not on the national forests, although the national forests shared in the greneral hazarel to a considerable extent. In fact, the national forests have fared very well this past summer considering the extent of the losses in the regions around them. That is partly becaluse of our ororanization and partly because, us our lands lie ustunly at a higher devation, they fare better in the periods of summer drovight than the lands lower down and around them.

We now have between 5,800 and 6,000 fires ench season. Duringr the past two seasons these have burned over about 370,000 atres calch year, or about two-tenths of 1 per cent of the urea of the national forests. I $1 \mathrm{~m}$ not satisfied with this showing, as l have set the gonl 
as the reduetion of our annual lose (1) one-tenth of 1 per erent of the

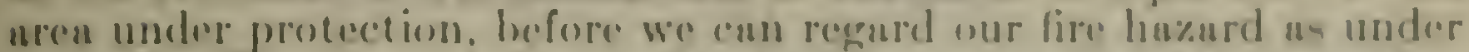
control. The damige doring the past iwo yeus has been comparatively small. It was about $\$ 212,0100$ last yenr und ubont $\$ 32.2000$ in the summer of 1!?:2.

The fouture of our fire proteretion that disturbs me most is our emergency cexpenditures and the fuet lhat we are still on at defieciency basis in meeting these roncrerneces. In the summer of 1921 we had

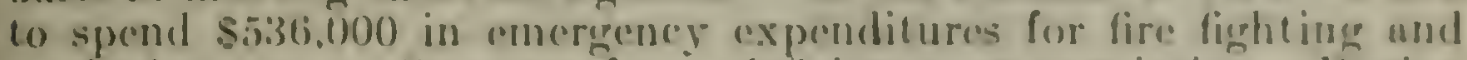
we had to go to Coneress for a deficiency nppropriation. During

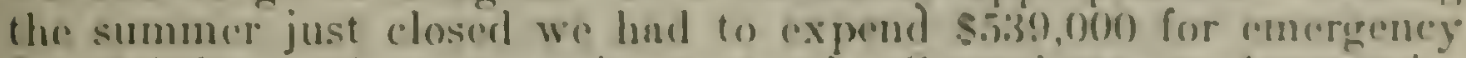
fire fighting and must again go to the Committer on Approprintions for a deficiency. Is nearly as my own judgment is able (o) size up the situation, these two summers are what we must expect us a renglar thing, and if we fure better than that in any partioular year it will be Gecouse of exceptionally favornble climatie conditions. Is far as the organization of the forest servie goes, we have got to take the 1921 and the 1922 sensons as normal. "That means that we must still remain fur too largely upon the emergency basis in handling our fire suppression.

last yenr we eot is per cent of the fires and this yenr $\$ 0$ per cent of the fires when they were still one-man si\%e, i. e., when the putrolman got there soon enough to put the fire out unaided. But the 20 or 22 per cent of the fires that got awh because they were ton big when the patrolman got there, which means in the majority of cases that we have too few patrolmen, caused these excessiro expenditures.

It is impossible to expect the Forest Serrice to keep down the number of fires without large emergency expenditures unless we ran put a more intensive patrol on all the forests. The emergeney expenditures can not be wholly eliminated but they can be greatly reduced by a more adequate protective organization. I want the commitlee to understand the situation which still confronts us in this respert and which forces us to return to Congress year after year for deficieney appropriations. That does uffect one of the changes in the statutory roll und I will speat of it when I come to it.

\section{SAIARIF.S.}

On the statutory roll 29 plines have been dropped altogether and three other cherical positions transferred to the Civil service Commission. making a net reduction in the statutory roll as compared with the current year of $\$ 21.720$. On the other hand. we huve iranferred to the statut ory roll from various miscellaneous rolls 19 cherionl positions. In every cnse. creating a net reduction in the lump sum concerned except in one item where a special increase has becn recommended. These 19 positions represent an addition of $\$ 27.700$ to the statutory roll. leaving a net increase in the roll itself of so.gso. Compuring the appropriations ats at whe and considering the reduetions in the miscellaneous items. we have cut the total cetimute $\$ 21,720$, by the 32 positions dropped from the roll or transforren we the Civil Service Commission. 
TRANSFEIR OF RANGERS TO LUMP-SUM STATUTORY ROLL.

There are no changes in the individual items, no promotions or any other changes involved except the new language which we ask to have inserted on page 135 . The statutory roll has previously included 590 rangers, at $\$ 1,220$ each. These men have all been employed for the year-long period and have been emplored effectirely. But in endeavoring to meet the situation which I outlined in connection with the increased cut of timber and also to cke out a little more leeway to meet the summer fire situation, I finally secured the Director of the Budget's indorsement on this language, which substitutes a lump sum of $\$ 200,0 \$ 0$ in lieu of 164 of these ranger positions. It provides that these places shall be carried as forest rangers, guards. or scalers at the rate of $\$ 1,220$ per anmum for periods of 12 months or less. The rate of compensation is fixed but leewar is giren as to period of employment.

These 164 rangers heretofore have been employed as assistants on our ranger districts. We have, all told, about 900 permanent ranger districts, each in charge of a responsible man for the year round. On the bulk of these districts the one ranger must handle the work the entire year with additional guards or patrolmen only during the summer season. But on certain of the busiest districts which have heavy improvement or sales work we have been furnished assistant rangers to the extent of 164 men. Some of these assistant rangers will still have to be employed the year round; but in riew of the urgency of the additional timber work I would like rery much to have leeway to reduce the employment of some of these men to 10 months, $S$ months, or possibly 6 months and use the money saved for an additional scaler or fire guard during the peak season's work: that is, during the summer when ererything is going full blast, fire protection, grazing, timber, and everything else.

What this language means is that by exercising economy we may be able to save eight or ten thousand dollars on the services of men who have hitherto been employed the year round and use that amount to reinforce the temporary men employed during the summer season. That will have to be chiefly to provide scalers to handle the increased cut of timber.

Mr. Axderson. You would not get much for $\$ \$, 000$ or $\$ 10,000$.

Colonel Grenley. $\$ 10,000$ might provide 20 additional sealers during the logging season. This is the only leeway we have got under these estimates. The Director of the Budget did not find it possible to allow the additional men I asked for in order to take care of the timber business directly, and this is the only means of meeting the situation. It will enable us to employ a few more men where most needed during the busiest senson.

\section{MARIING OF FIRE FIGHTERS' GLAVISS.}

There is come new langunge on page 140. That is the first new langunge we come to after the item 1 just discussed. It anthorizes the Secretary to use not to exceed $\$ 500$ of the funds appropriated for marking the graves of fire fighters who lost their lives in the 1910 forest fires and are now buried at St. Maries, Idaho, and also for caring for the grrares of another group of men now buried in the cemetery at Wallace, Idaho. 


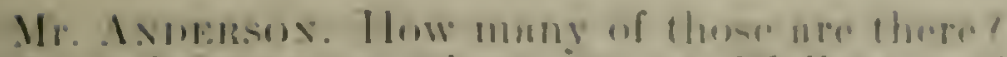

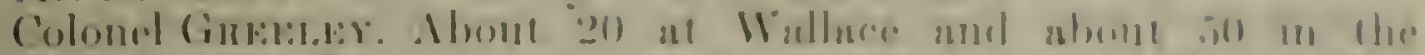

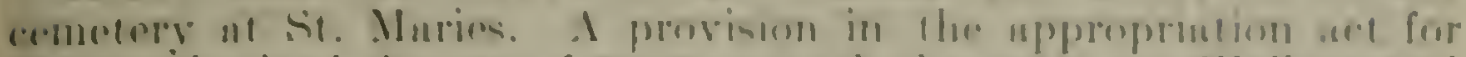

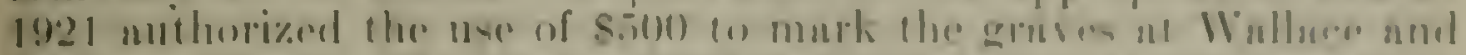

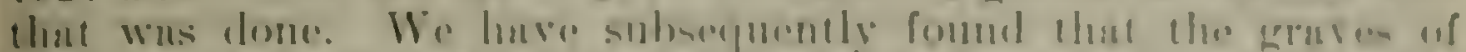

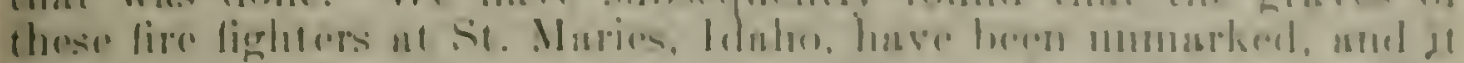

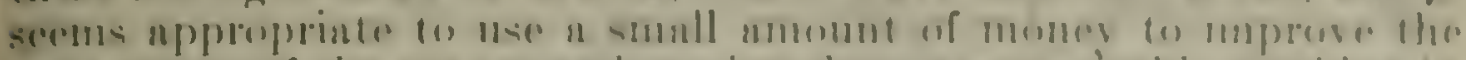

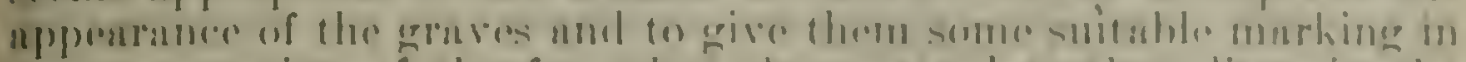

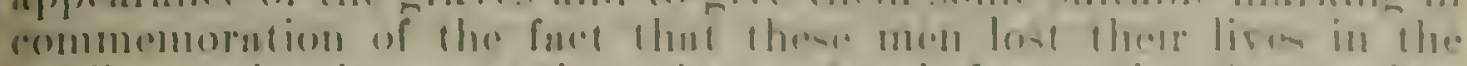

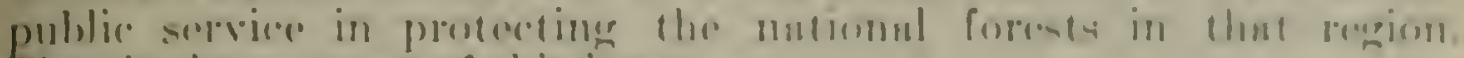
That is the porpusere of this itrm.

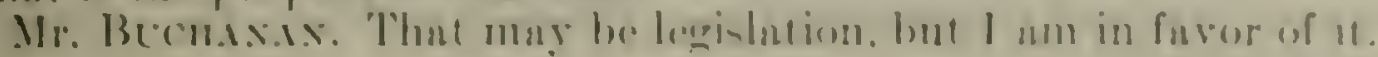

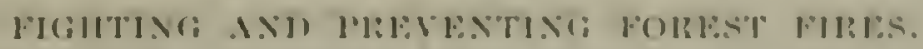

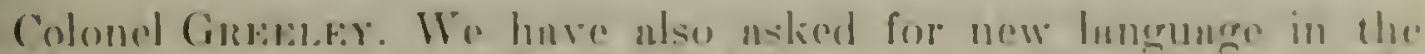

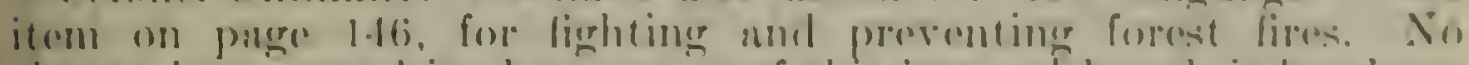

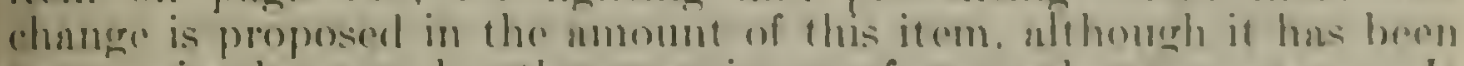

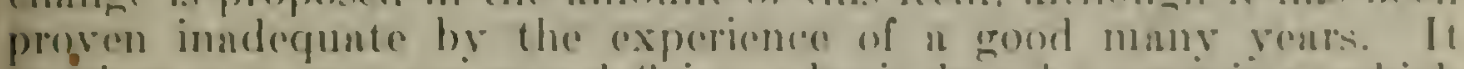

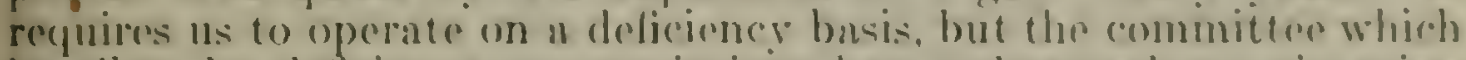
hundles the deficioney apprepriations has understoud our situation very fully and hus griven us sympathetic support.

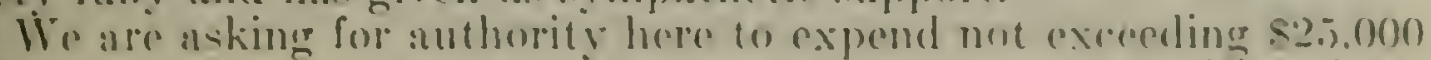

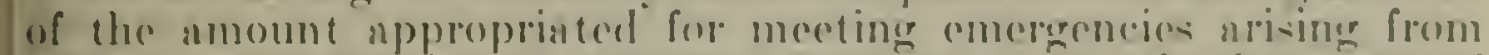

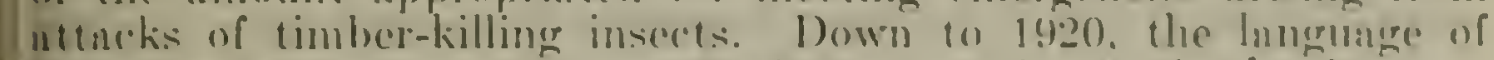

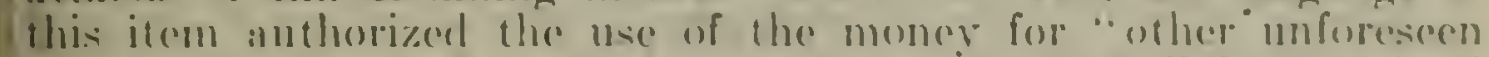
emeregrncios" as well as for fighting lires. In thr bill for the liscal

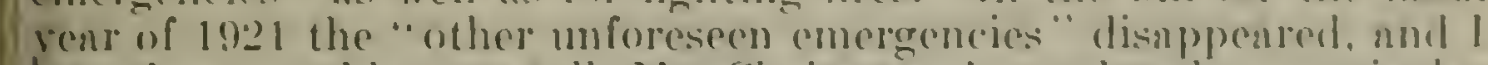
have been unable to recall. Mr. Charmonn. just why that particular lnmguage was dropped out.

\section{TIMHER-KIILING INSFCT IXVESTIGATONS.}

The sifuntion is this: Wo do not conduct mu technimal work on forest inserts, as that is done for us by the Bureatu of lintomolonge But from time to time we have these outbreaks of timber-elestroying insects. particularly the pine-bark bectles, which often assume iory serious proportions. For caimple, in southern Oregon a serions outbrali of this pest oceured last year, thr beotles opernting buth on private land and forest reserve land and to some extent on Indian reservations. The situation wats such that the state of ()peren passed a law compelling private owners to clom up their holdings muler cortuin conditions, nud Congress passed a sporial doliciency of $\$ 150.000$ to enable the Secretary of Agriculture mul the Seroptary of the Interior to cleas up the Government holdings.

'That particular situntion las been provided for, but we bave three other points to-day where the pine beetle is liable to beeome dangerous. One of them is on the Kaibah Platean. on land which lies partly in the Grand Canyon National Park and partly in the Faluab National Forest. The Forest Service and the Netionsil Parkis Service put thoir odds and ends of approprintions together lost your and sureoreded in

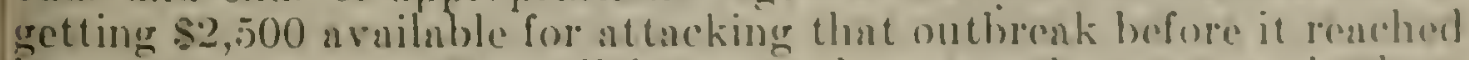
Inrge proportions. We will have to do some (ele:tn-up woth there next spring. 'Those outbrenkis oceur at one point or unothere nuspy 
every year and the situation is exactly analagous to forest fires. Ordinarily if these insects can be cleaned up promptly serious damage is prevented, but if they run on and reach what the entomologists call an epidemic stage, where the swarms multiply at an enormous rate, the damage may run up into figures that equal the damage from forest fires. We have had that happen. It happened in the Black Hills about 1900 . It would have happened in Oregon had not provision been made for suppressive measures. So we would like to get authority to use $\$ 25,000$ out of this forest fire fighting fund for such emergencies.

Mr. Axderson. This $\$ 25,000$ I suppose would be used for the physical work of suppressing the outbreak and not for technical investigation?

Colonel Greeney. No; it would be used entirely for employing labor to cut down infested trees and to carry out the physical labor of control as experts from the Bureau of Entomology direct it. 'They always examine these areas and tell us just what to do. In fact, they usually furnish a man to direct the work of suppression.

Mr. Anderson. I do not want to build up in the Forest Service another Bureau of Entomology. I can easily see that in a work of these enormous proportions there is a certain amount of physical work that is done by private owners when owned by private parties and the Forest Service must do the same thing.

FOR SELECTION, ETC., OF LANDS WTTHIN BOUNDARIES OF NATIONAL FORESTS.

Colonel Grencey. The item on page 148, the selection, classification, and segregation of lands within the boundaries of national forests that may be opened to homestead settlement and cntry under the homestead laws applicable to the national forests, etc., remains the same. Just a word of explanation may be in point. The original purpose of this item has to a considerable extent been accomplished. That was the classification of the lands in the national forests which have agricultural value and their segregation under the forest homestead law, so that they may be entered by settlers. We have classified to date approximately $i+3,000,000$ acres out of $157,000,000$ acres in the national forests and have opened to homestead entry in excess of 3.000 .000 acres as a result of this intensive classification. We still have certain areas in Alaska which must be classified and we have a certain amount of work to do in investigating appeals or correcting the original classification where there appears to be reason for reexamination.

This item also covers the cost of making survers by metes and bounds in order to permit settlers in the national forests on lands which have not vat been covered by the reetangular surveys of the General Land oflice to ofier proof ind get patents. We hine from 100 to 200 cases of that character each year and they cost us about $\$ 200$ per ease. That is a reguirement that will continue probahly for another five or six years, and then it will gradually disappear with the completion of the entries made upon these lands. On the other hand, the work of handling exchanges which is provided for in this ite 11 is one that is groing to grow into larege proportions. Last Ilareh 


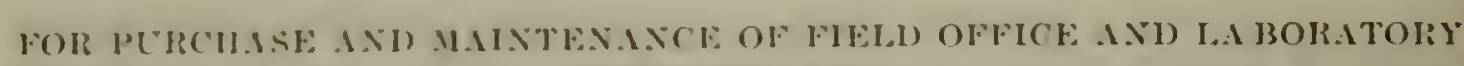
STPIIIISS, ETC.

Thore is no rhange in the item for supplies on page 151. That

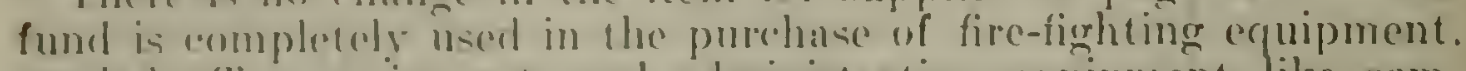

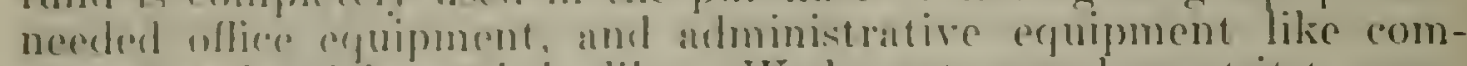

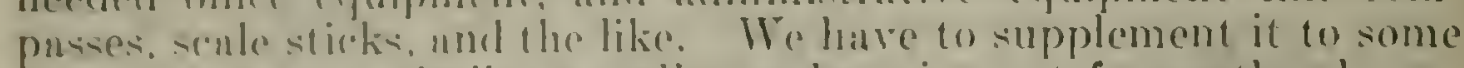
"xtont by buving similar supplies and equipment from othor humpstlut itenis.

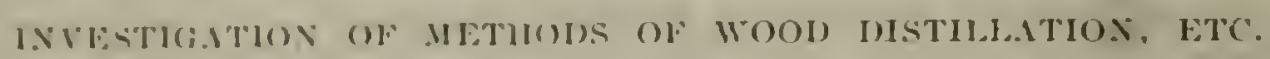

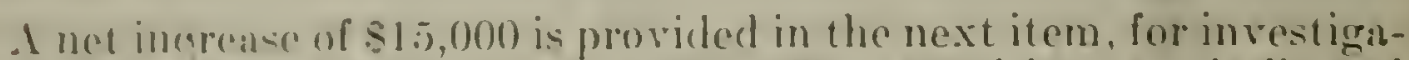

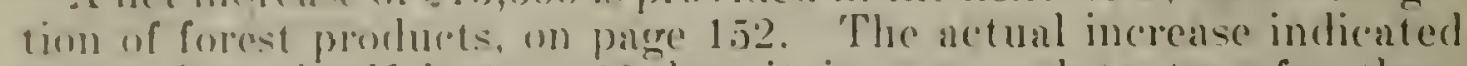
in thr itrm itself is $\$ 10 . \$ 00$, hut it is proposed to transfer three rerical positions proviously patid out of this fund to the statutory roll sol that the not incorase a valable for this work will be $\$ 15,000$.

I talie it that it is unnerossnry to go over the general scope and chaturelo of these impstigations. The increase is asked with three spocilic purposes in view. The first is to omble the Forest Products

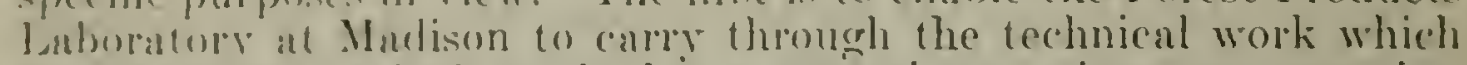
w" latro heon asked to do by a rentral committee representing lumber manufaturers and uscis which the Secretary of Commeree has ben instrumental in having estahlished. for the standardization of lumbor ervales and specifieations including nomenclature, dimen-

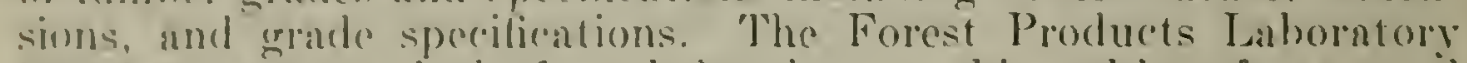
has done $n$ great doul of work bearing on this subject for a good mant vents.

Is in exmmple, on the basis of our mechanical tests of timber, the laborafory wists uble to work out a method of crinding structuril timbors of southron pine in which the grade reflects the artual stronerth and structural value of the timber. It is the so-ealled "density rule," hased upon the number of rings and the proportion of hons "summer" wond which gives the timber strongth.

"The Depurtments of Commeree and Agriculture nere now endeavoring to develop more uniform and offoctive system of grading all kinds of lmmber. A committeo of manufacturers ind consumers is covering the whole field-factery lumber, yard lumber. henry strueturest

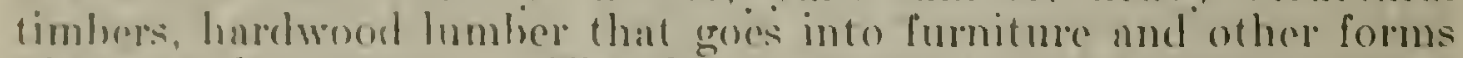

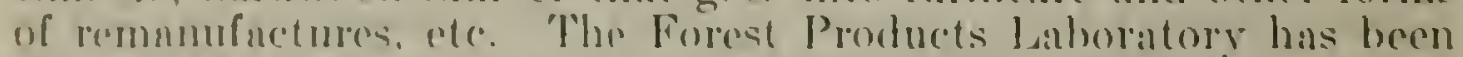

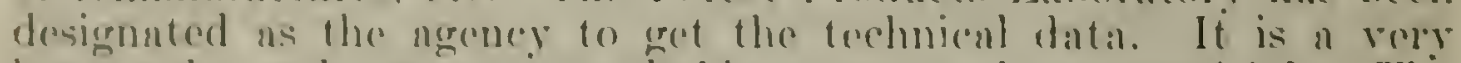

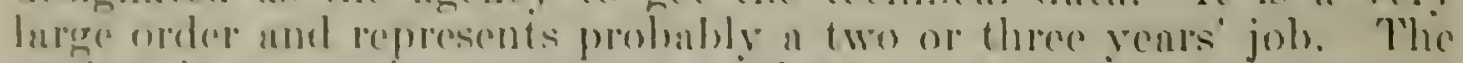

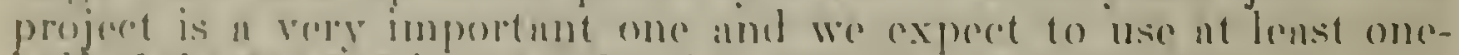
hulf of the sts.tion incerense for that purpose.

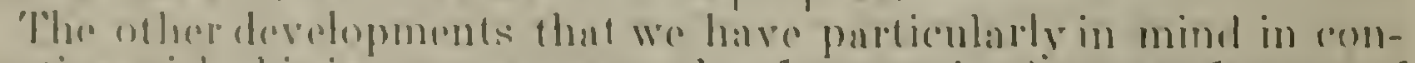

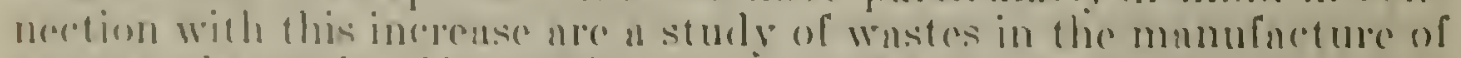

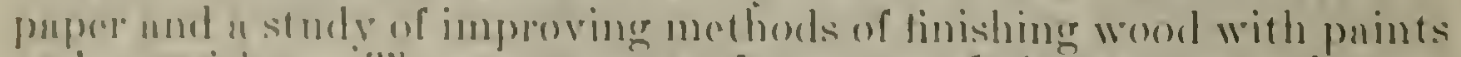

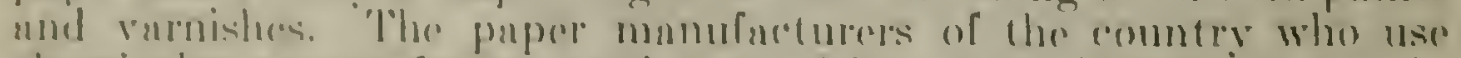

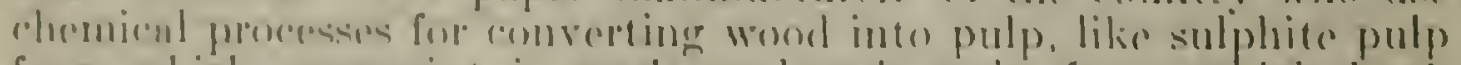

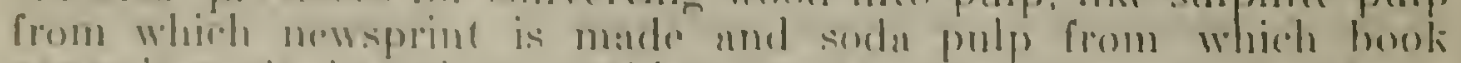

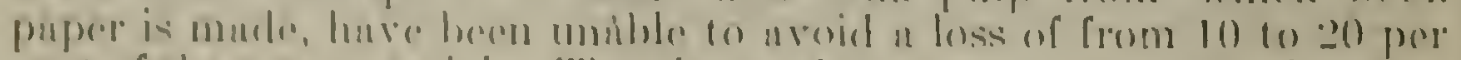

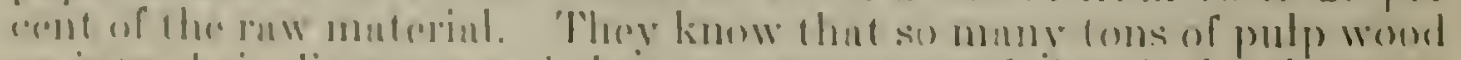

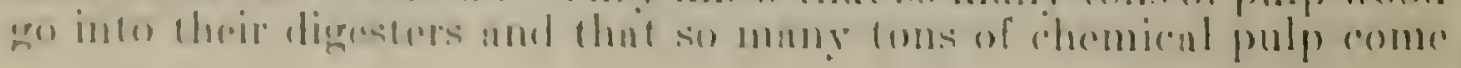




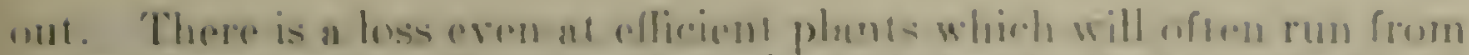

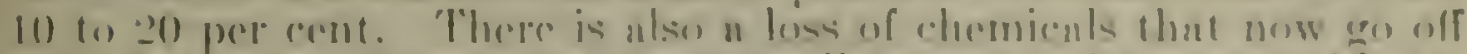

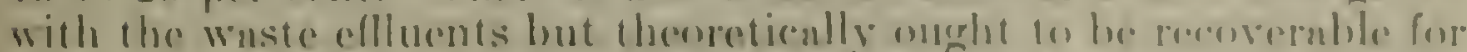

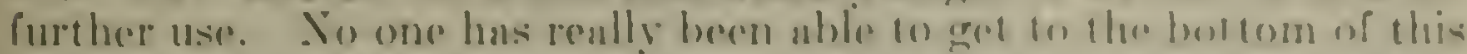
problem, and the commereint intereste purtioularly coneremerl in it

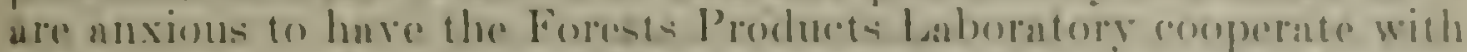
them in a joint attare. They propese on furnisti a comsiclerable

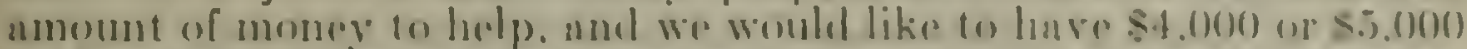

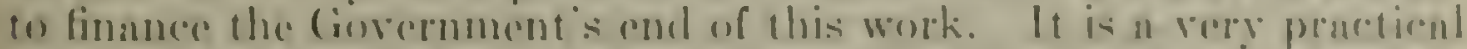
matter of ronservation berantse if these losses an be prevented it stondal mean a corresponding reduction in the coment drain upon our timber

I want to spenk in this conmertion of the extent to whinh investignliens of this charneter ought to be paid for by the (iovernenent and the extent to which they ought to be paid for hy the commeredal interest. which will bendefit from them. We have been developing

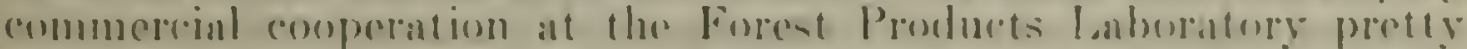
rupitly during the pust two or theee reats. on the general principle that as far as possible the industry or the egroup of mon who are eroing (1) get purticular berefit from a (iovermment investigntion meght to

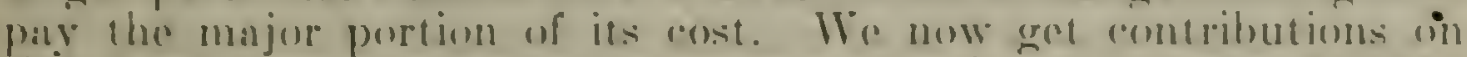

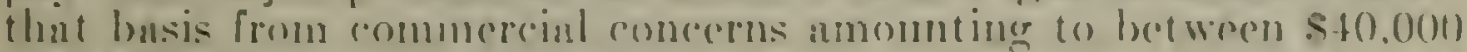

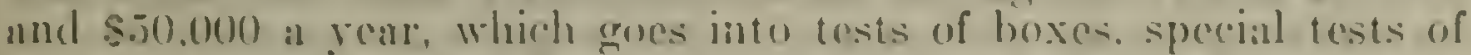
paper-making processos, oxperinents with new methorls of preserving limber. courses of instruction in lumber seasoning. "to.. in which a particular industre or group of men hare sperial interest. We are developing the idea that the wool-using industries should, to a reasonable extent, puy their war on investigations at the haboratory which arr of distinet ind immediate benelit to them.

We have gone into these two problems, the wood tinishes and studyof paper wastes, on that basis. What is required is that certain fundamental and technical investigntions in the chemistry of wombl celluluse and in wood phrsies be carried out at the Forest Products Laborators. For thit the nso of Government fumes is reasonable. becaluse it is fumclamental work having many soientile and inclustrial bearinges and possihle upplications. Other phases of these studies on the sicle of rommereval pristice, manufacturing conditions. etce. onght to be finnneed by the industries immedintely benefited.

That is all I have to say on this item unless the committee would like to see some exhibits. Here is a sheet of paper made entirely wut of cotton linters, a process developed by alie liboritory. It makes a prettr high grade of book paper. Here is a sheet marle out of ont hulls. the waste in the manufacture of oameal. The tests on paper manufacture from flas straw are going along well. We expect to have that pretly well worked out within another venr.

We recently produced a rery good paper at the laboratory by deinking old hewspapers under a new process which promises io be profitable commereinlly and effect an enormous saving of raw material. 
Mr. Axumsox. Culonel Greeley, we will take up this morning the item on puge 15i5. for experiments and investigations of range conditions within the nutionul forests or elsewhere.

Colonel Cintalery. 'This is the fund under which the Forest Service maintains its special erroing studies at the Grent Basin Experiment sution in Ltah and its studies in the practienl handling of cattle ranges in Arizom and Now Mexico, where the handling of cattle under improved mothods of rotation grazing and other improvements in runge munngement is heing worked out. The real purpose of this series of studies is to develop the scientific side of the use of the open range lunds of the West, to put the grazing industry upon a more stable hasis, and at the same time trying to get better results in kecping up) the productivity of our range lands. A concrete illustration of what this monns, something I had a (hance to cheek up) personally last summer, is working ont of a system of rotation grazing on the indiridual sheep or cattle allotments. This means that the principal foritge plants of the allotment must be determined. their seeding period and other reproduction habits established, and a distribution of the eattle or sheep worked out under which each portion of that allotment will huve an oppertunity, every three or four years. to fully re-seed with the more ralunble native phants. As a result of these scientifie studies this system of deferred and rotation grazing. ns it is called, is now in eflect on a considerable number of the runge allotments in portions of $[$ tah and other States, where the grazing conditions are most serious and the demand for the use of the range is most intense.

Another practical result of these investigntions has been working out the proper senson for grnzing the ranges of different types and at diflerent elevations. detemining the time of the rear when the formere con be eramed without serious injury. We found, for example. that a postponement of grayng of only two weeks at the beginning of the sonson may have a very mulked effect upon the net returns from the runge and its sustained productivity, becunse of the better opportunity given the forage to establish itself. It has also been possible throvigh these investigittions to establish for many of our range types the changes in plants or formere trpes which indicate deterioration of

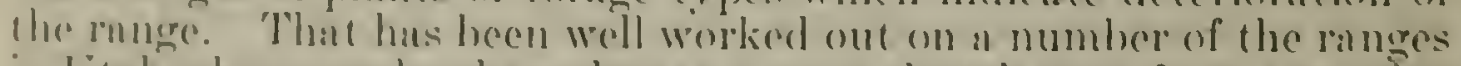
in l"tuh where lesults show that us a range deteriorntes from exeessive use the chatracter of the plants chamges: that the more nutritious

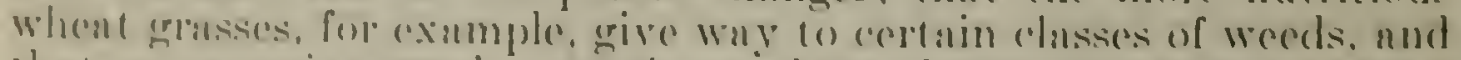

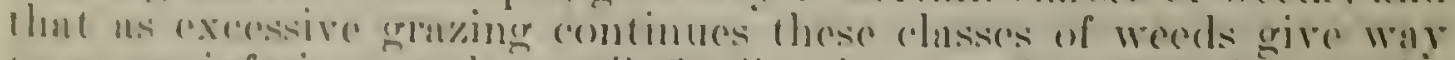

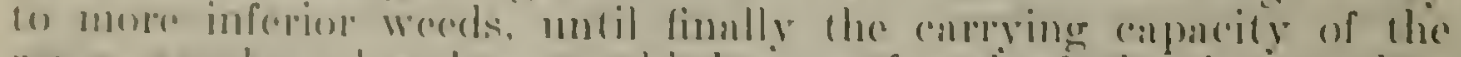

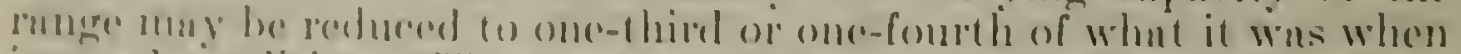
in grond comblition. These indientor plants grive the forest supervisor

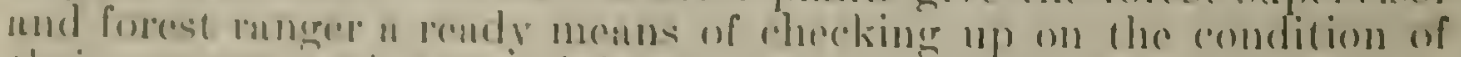

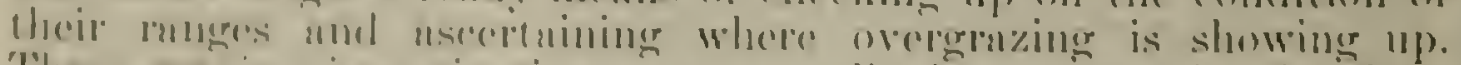

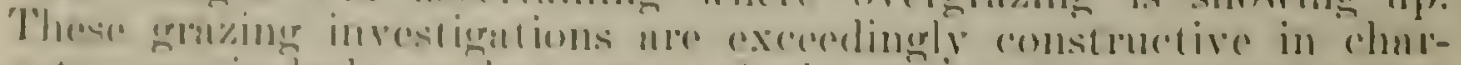

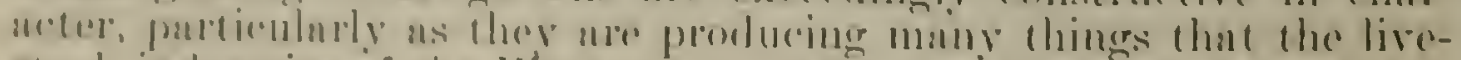

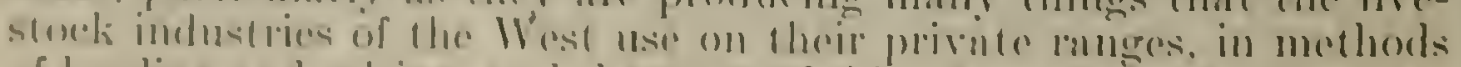

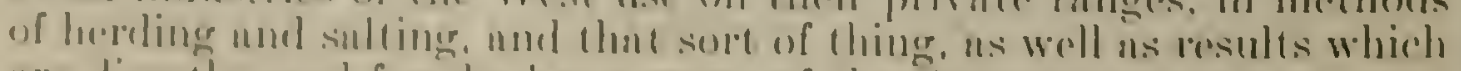

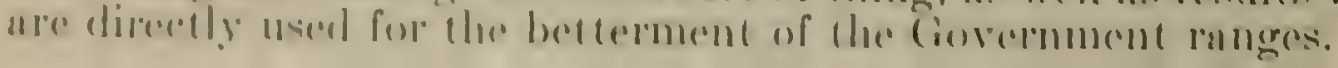


Mr. Becusas. The items call for experiments and inveatigntionnull l presume that is all that is dene, is it not?

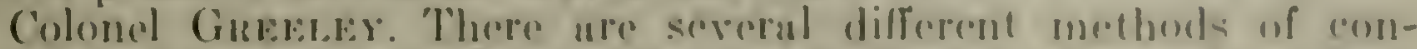
ducting experiments. One is the estublistunent of ammple plotesmall range areas perhups as hive as this room, porthup us large us a guarter seretion. These are placed under fertees. and the netual conditions of that runge and of its use nore curofully cherelied and studied from vear to your in ordere to determine the progrens of the range upward or downward and why the changess are taking phare.

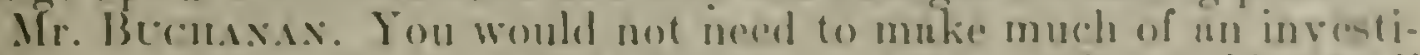
gation as to the weeds, would you, because the cattle would ent all the good grass and would not int the bad weeds, so that you wonld not have to have any study made of them.

Colonel Gubstr. The question there is to determine at what point proper use of the range gives way lo exerssive use.

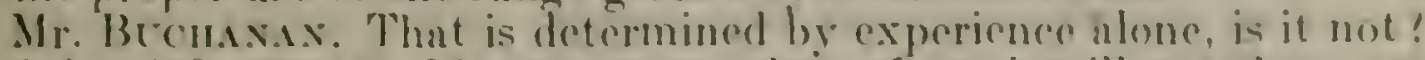

Colonel Grevers. Of course, nny class of stock will ant the most pulatable forage first. The question we ure after is at real change in the charncter of the range as the result of overerazing-something which has actually happened on n goorl many of fhose western arens.

Mr. Bucusis. Do you think the need for this appropriation will cror ceatse?

Colonel Gremery. I doubt it.

Mr. Brechass. 'Then it is like the brook, it will go on forever?

Colonel Greeler. The proposition is so big. Mr. Buchanan. that it will probably go on for al long time. It affects 125,000,000 ncres of range lunds in the national forests: it renly affects over $80.000,000$ acres of public range lands outside the national forests, and its results ure being used by a great many stock men on their own lands. That being so. I think we have got to anticipate continuing for a great many. rears what we are doing here. While we have our own land immedintely in view, we are doing for the range business of the West the same sort of thing that Doctor Taylor's work is doing for ngriculture and that Doctor Mohler's wotk is doing for the intensive live-stock inclustr.

Mr. Indrusor. We will next take up the item on page 156 , for the purchase of tree seed, cones, and nursery stock, cte.

FOR PLBCHASE OF TREE SEEI, HTC., FOK SEFDING A.II PI.INTIX.

Colonel Ginemex. The next item rovers tree planting. There is no change in the amount and no change is proposed in the general character of the work. We have about $1,500,000$ acres of land in the national forests which have been denuled by old lires and which. as far as pur present experience goes, will have to be planted in order to be restored to timber growth. With shis applopriation we were able in the past year to plant approximately 9.000 acres and to maintain the eight forest murseries. These nurseries have an annual producing capacity of hetween six and eight million forest seedlings.

Mr. Axnersos. What do you do with that many seedlings?

Colonel Grasstry. We use them all: we use about s.000).000 seedlings a year normally.

जr. Buchanan. Fight millions? 
Colund (ineley. About $\$, 000.000$. You see. we plant from $\$ 00$ to 1,200 seedlings per arere. nnd we have to allow some surplus for possible losses. I should say, Mr. Chairman, that small amounts of scedlings from one of the nurseries in Nebraska are listributed to settlers under specoial lecrishation, but the great bulk of them are used on Government lands.

Mr. Beconkax. You say you set out 9,000 acres?

Colonel Gavirey. los sir.

Mr. Becmana. And it custs you about Sls an arere to set them out!

(olonel Cinkeley. Well, it would be 9.000 into $\$ 125,000$.

Mr. Becmanis. Not quite sis.

Colous Cinkerser. It would be about $\$ 14$.

Mr. Buchusix. Yes; that is about right.

Culoncl Gimentey. That includes all the overhead costs, of course, and some experimental work that is done with this fund where the best methous haye not yet been worked out. We are doing some pouting, Mr. Buchanan, for \$5 an acre in the sandy lands of Michigan. In the Minnesota National Forest we have planted about 6.000 acres with white and Norway pine, at an arerage cost of $\$ 10$ an acre.

Mr. Bucmaxax. If it should cost more than that, I think it would be justified, and I am more impressed with this item than I was with the previous item.

Colonel Gimenry. We have planted to date about 100,000 acres in the national forests successfully. This appropriation enables us to drive away at the most urgent points but without making rery rapid progress on the big area that ultimately we must expect to reforest by this means. Some day I expect to come before this "ommittee with a planting budget and ask for approvai by Congress of a program under which these denuded lands in the national forests can be planted within 20 or 25 years. For the present we are proposing simply to continue the work on a limited scale.

Mr. Axnkisox. Are the States doing any planting?

Colonel Cimbers. Yos, sir; a number of the States have gone into planting quite extensively. Pemmsylvania. New York, and Michigan are doing a good deal of planting on their State forests. Soveral of the States. particularly Massachusets, and also New lork and Pennsylrania, are furrishing planting stock at cost to land owners within their States, who will agree to plant their lands and take good cale of the plantations. Several of the prairie States, like luwn, Nebraskin, and lllinois, are doing a good deal of work in cxprimental plantations, working out the species and methods adapted to their soil and climatic conditions. All told the amount of planting dome with State aid or under State auspices probably

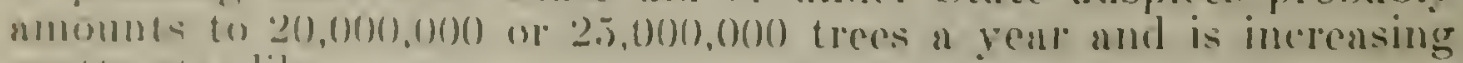
prette stomlily.

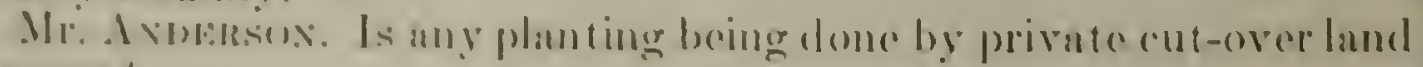

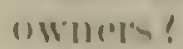

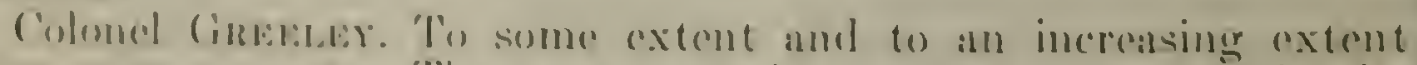

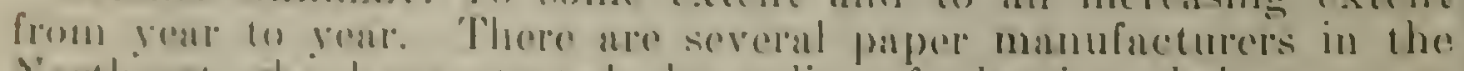

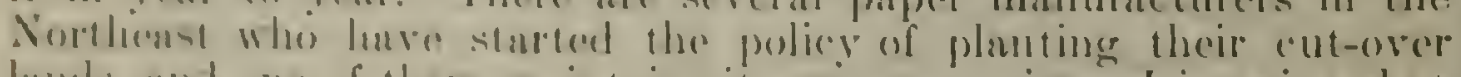

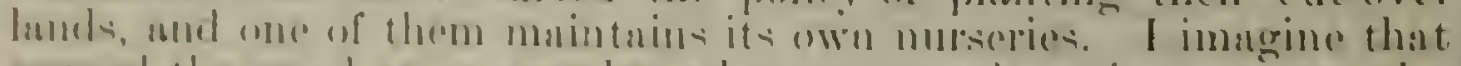

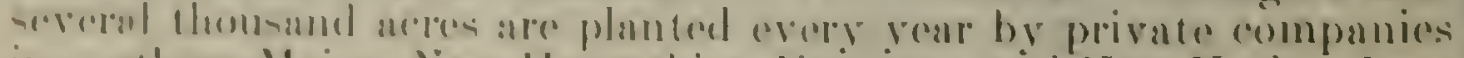

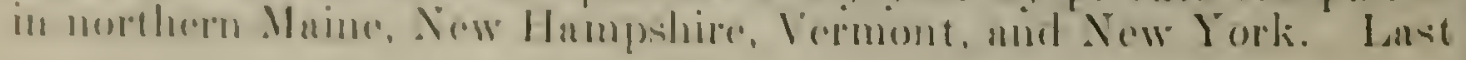


summer I risited a commercial nurtery at Keone. X. H., in the centor of the Now lingland whito-pine berte, which finds a sale for from $3,000,000$ to $4,000,000$ young pine trees covery yenr. and they are mostly purehased and planted he commercial eonecris. Firther west you find leses and less of that, but the interest is incrensing. The committee mav be interested in lenrning that within this puat rear several of the large redwool manufacturers in California liave become convineed that the plunting of their cout-overe lands is a praseticable and profituble commeroial undertaking. They are startung a planting program on a large senle. That is all 1 have to say nhout this item.

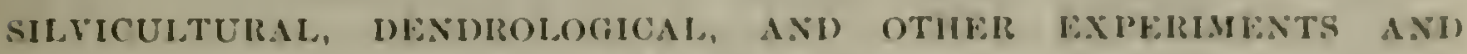
INVF.STIGATIONA.

Mr. Axpensos. 'The next item is on pacre 159 , for silvicultural, dendrological, and other experiments and investigations, etc.

Colonel Grewter. There is no change in that item. That is the item under which the forest experiment stations are maintained and the investigntions in tree growing conducted. We now have six small forest experiment stations in the South and West which are working out the problems of reforestation in their sereral recrions. Some of these stations have been in effect long enough to produce rery definite and tangible results; but others have not. The latter are producing reports on particular experiments but hare not as yet worked out the forestry science of their region.

In the Northwest, for example, the stations in Washington and Idaho hare worked out practical reforestation methods adapted to those regions, and the results obtained by those two stations are to-day the principal basis for State legislation and for the impetus given to forestry by timber associations and private concerns. They have had a very valuarle part in directing the forestry development of those regions.

Mr. Bucmasis. If they hare completed their work what is the necessity for their continuation?

Colonel Grieney. I feel there is a necessity for their continuntion, Mr. Buchanan, because there are still many questions that we ought to answer before we can call the job finished. Europe has experiment stations that have been in existence for 100 years.

Mr. Bucmaxax. You sny they hare been in existence in this country that long?

Colonel Grfeicer. No; I said Europe has forestry experiment stations that have been in existence for 100 years, and I think we have got to expect that most of these stations, not necessarily all of them, must be maintained for a long period of time to get the cumulative results in scientific observations that we need to develop our forestry science.

Mr. Bechunax. You have six in the United States and two of them are in the Northwest. If they have reasonably accomplished the purpose for which they were established, it looks to me as though you should more them to other sections and let them study the climatic conditions there, and other things, instead of letting them stay there, if they have worked out the problems connected with that section. Hare they not worked out the major problems of that region? 
Colonel Grefuer. They have worked out the problems which were of special urgency in those regions in order to get things started in the growing of timber. but there is still a whole lot of work that needs to be done on the rate of growth, the yield to be expected from secondgrowth stands, and the best way to produce timber of different species and different qualities. I think it would be a mistake to abandon those stutions for a long time to come. At the same time, there are other regions where we need to be doing the preliminary work.

\section{LOCATIOX OF EXPERINENT STATIONS.}

Mr. Buchaxax. What station do you have which is nearest 'Texus!

Colonel Gineseri. We have a station which covers the southern Pine Belt with hendquarters at New Orleans.

Mr. Buchaxax. You do not linve a station in New Orlenns!

Colonel Grender. No; just the hendquarters. The field work is done and most of the men ure stationed at points in the forests of Louisiana; one of them is in Florida; and one, I think, in Georgin.

Mr. Bechasax. What constitutes the personnel of one of these stations?

Colonel Grencer. One of these stations should normally have six technical men.

Mr. Bechasax. That is, including the overhead?

Colonel Greeter. Including the director and his assistants. 'There should also be probably two clerks.

Mr. Buchasax. Two clerks and three field men?

Colonel Greeser. 'Two clerks to six field men.

Mr. Bechasax. And one director, making nine?

Colonel Gresiny. 'That would be eight; the director, five assistants und two clerks, you might say, represent the normal organization. At the present time we have been able to give this southern station four men and one elerk; we would like to change the staff to six and extend the seope of their investigntions. 'They should cover the whole southern Pine Belt. We have another station in the Appalachinn hardwood recrion, with headquarters at Asheville, N. C.

Mr. Bechasax. Have you published bulletins?

colonel Grevery. It has published some short bulletins. Both of those stations have only been in existence one year.

Mr. Bromaxax. Has the other one published bulletins?

Colonel Gremery. The western stations have published a good muny bulletins. For exumple, we have one station in the Southwest which has published a number of bulletins; and now we lave in the Gorernment Printing Ollice a bulletin which covers all phanses of its 1) yeurs of work on the reforestation of the western yellow-pine region. It is su extremely valuable contribution to American forestry literature.

Mr. Axmaksos. There lave been several bills introduced, Colomel Grecley, providing for the establishment of a forest experimental station in the Great Lake's recrion. ('un you tell us mything about the necessity or desirability of a station in that reegion?

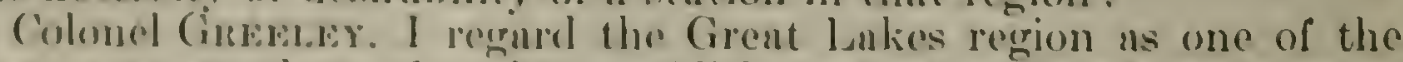
most urgent places for the estublishment of a forest experiment station because of the fact that it contuins about $60,000,000$ neres 
of forest land, the greater part of which will probubly always be forest land. It now has orer $40,00(0), 000$ acters of ent-overe land, a great deal of which has bern serionsly denudod and is procticully

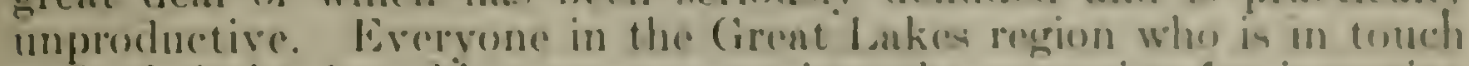
with their lnal problem now recounizes the meremity for intensive development of the right wise of their forest lands whioh are nomagricultural in character. I was called upon to meldrest a mocting of the 'Triastate Dorelopment Lengur last winter, which represents primarily the ngricultural intereste and the nericultural bouters of Ciehignin, Wisconsin, and Minnesotn. While the point of view of that meeting was primurily for agriculturnd developenent, it was plain that the Jeaders had come to realize that with their ancieultural development they must hare intedligent use of the forest lands, which form 40 per erent of their land aron, in oreler to mantain the economic welfare of those stutes.

The State of Michigan, lecognizing the sume thing, has instituted un intensive soil and connomie surver of the northern half of the State in an endeavor to get the basic fucts as to the guality of those lands und what they should be used for. Michignn has awikened to the fact that in the northern counties she lost 10,250 farms during the last decennial period; parts of Minnesota netually lost in farm population during the snme 10 yenrs. This goes to show that the economics of the fand situntion in the Lake States demand intensive forestry nong with intensive agriculture. With that enormous forest land aren, hingely unused, coupled with the fact that the Lake Stutes are strategically located to supply the whole central purt of the country with forest products, an intensive study of their forestry problens would be very well worth while. In fact. I think that in forest experiment station is more needed now in the Lake States than in ans other region, with perhaps New England coming second.

Mr. Buchasax. Have you no power under this legishntion to estublish one there?

Colonel Grems.r. We can as far as the lnnguage of the appropriation is roncerned.

Mr. Axibrensox. All you need is the money?

Colonel Grefler. I'es, sir.

Mr. Buchasax. You are not limited to Government land!

Colonel Grereler. No, sir. Is that nll on this item?

Mr. Axpensox. That is all. We will take up the next item on page 160 , for estimating and appraising timber and other resoures on the national forests.

FOR ESTIMATIN( ANI) MPPRAISING TIMBER AND OTHER RESOLRCFS ON THE, NATIONAL, FORESTS.

Colonel Greater. There is no change in the item or the amount. This fund of $\$ 100.000$ is divided between the survering and appraisn! of timber in preparation for sale and the surveying of graming lands where we need an intensive datn on the forage resources of a particular national forest. We are making fair progress in our timber surveys. We huve about $\$ 0,000,000$ neres of merchnntable timber in the national forests and about one-fourth of that has becn corered to date. Lnder this item we ne able to extend this work at the rnte o 400,000 or 500,000 acres a year, and it is only needed in the recion 
where there is an uctive demand for timber. In many of our large forest areas which ure inaccessible and shut off by topography, lumber derelopment is still a long wny in the future and no expenditure of this character would be justified.

We have applications for stumpage at the present time, many of them serious, some of them purely tentative, and some doubtless speculative, up to a total of some 9,000,000,000 feet. A part of these applications cover areas which have been surveyed in prerious vears. Approximately $7,000,000,000$ out of the $9,000,000,000$ feet. howerer. represent areas that will have to be surreged and mapped before we are in a position to fix the price intelligently and make a sale. The survey of this $7,000,000,000$ feet in itself would cost more than the entire item for a single year. It will be necessary to select out of these timber applications those which are the most promising and where a sale would be most desirable from the standpoint of the condition of the timber and confine our surreys to those particular applications. We can not at the present time keep up with the volume of applications for Goremment timber, but we can take care of the most urgent ones.

Mr. Becinisax. What is your idea as to whether we ought to be in a rush ahout selling this stumpage?

(o)lonel Greecer. I do not think we should be in a terrible rush to sell it.

Mr. Buclaxix. I am of the same opinion.

Colonel Girescer. As a matter of fact, during my two renrs as Forester I have rejected a number of applications for national forest timber. In every instance we are limiting the cut from a national forest to what it will sustain by growth and after we have reached that amount we decline further business. Take the Coeur d'Alene National Forest, in the heart of the white pine belt of northern Idaho. We have found by a close study that that forest will grow between $45,000,000$ and $50,000,000$ feet a year and keep it up perpetually. The anmual sales are limited to that amount, although we could sell out the entire forest in a couple of yenrs if we accepted all applications.

Mr. Buchanas. Do you not think the Forest Service ought to have some study made and some plan evolved by which it could determine how much ought to be sold and how much ought not to be suld in order to conserve, as far as possible, through a suflicient period of time, the timber resources of the United States?

Colonel Grebley. Our poliey is this: We have approximately $590,000,000,000$ feet of merchantable timber in the nutional forests: and we find that we can cut up to seven or eight billion feet a year and mantain that eut perpetually, probably inerensing it in time.

Mr. Bechasis. How much a year!

Colonel GnEstar. Seven or eight billion feet a year, which represents what you might suy is the interest on the capital investment.

Mr. Bi cussax. And keep it up?

Colonel Geverer. Keep it up perpetunlly.

Mr. Bucousas. Is this something which you have worked out and determmed. or ure you merely studying it?

Colonel (imblat:y: It is something we nre studying and checking ull the time; that is our best judgment to date. Our generial aim under this item and under the timber sale administration is to select the arens whereculting is most neessury ou aceount of the condition 
of the timber. 'These are all virgin forests, und a good many of them huve reached a point where the timber is cheteriorating from old agedecuving - and where to postpone cutting would be a whete. Theme are the places where we are locating new coutting operations.

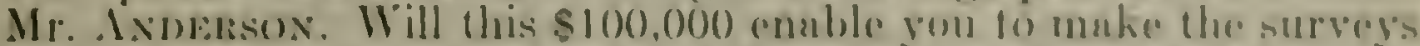
which onght to be mole to support the sales which it will be proper to consummate and which it is probuble will be consummateol?

Colonel Cirstis:y. I think not, Mr. Chairman. In my julgment, with this item at its present figure, we will have to curtuil the incense in timber sules which would be desirable and proper from the atumepoint of the conclition of the stumpuge.

Mr. Buchaxas. About how many feet have you surveged and how much will this survey?

Colonel Grist.ey. This $\$ 100,000$ ?

Mr. Buchanan. Yes.

Colonel Grasury. This $\$ 100,000$ will probably cover from five to six billion feet.

Mr. Bucanas. Then if you had a demand for what you have alrendy surveyed you would have enough to meet your "urrent demands, that is, enough for you to sell seren or eight billion feet?

Colond Grekter. Yes, sir.

Mr. Buchaxas. Becanse you have over 2,000,000,000 feet already survered?

Colonel Graerar. Oh, yes; we can meet the situation partly in that way. The difliculty urises, however, that we ought to he nble to caterid the survers inuch more rapidly than we have been able to de in advance of these applications, in order to know where the timber is that is most in need of cutting.

Mr. Bechasax. The old timber?

Colonel Gimeley. Yes. We have not been able to get a sufliciently broad. comprehensive knowledge of the entire $\$ 0,000,000$ acres, which is a pretty big parcel of land.

Mr. Becunas. Does it take this character of survey to determine the old timber?

Colonel Grewser. It takes a fnirly intensive survey, Mr. Buchanan, to determine where the old timber is and to get the necessary information for a proper uppraisnl. You see, we ure required by law to apprnise the commercial value of this stumpage, nnd with the values of some of these sales running into millions of dollars we have got to have exact dnta. It would not be right to sell the timber without it.

MISCELLANEOUS FORFST IXIVESTIGATIONS.

Mr. Axumrsos. We will take up the next item, which is on pnge 162 , for other miscellaneous forest investigations, etc.

Colonel Greeley. This is nnother item which is unchangerl. The fund is used for the preparation and editing of publications, the furnishing of information to the public and some for the preparation of forestry exhibits. A portion of the fund also goes into the preparation and printing of maps and the mantennece of statistienl records for all the needs of the service.

Mr. Bucusidax. This is used to follow up the work nlreaty done?

Colonel Greeser. Yes, sir. 
CONSTRUCTION ANH MANTPXANCE: OF ROADS, TRAILS, BRIDGES, ETC.

Mr. Axmenson. We will take up the next item. page $16 \%$, for the construction and mnintenunce of ronds, trails, bridges, ete.

Colond Gintert: Inder this item there is provision for an in(rease of $\$ 23.000-\mathrm{from} \$ 425,000$ to $\$ 44 \$ .000$. This is the item upon which the service has to rely chiefly in extending over our $1 ; \pi, 000,0(0)$ acres of land, telephone lines, lookout towers, quarters for the rancers, cabins for the shelter of forest guards, bridges, and other improrements needed in protection and administration. We ure making fair progress in the construction of these improvements. For example, we have completed 417 lookout cabins or other structures at the points where the lookout watchmen must be stationed during the summer season. We need about 200 additional structures of that churacter to complete the system. We have constructed to date neurly 28,000 miles of telephone lines to connect up the ficld fore and permit of its quick mobilization in case of fire.

We still need about 7,000 miles of telephone lines and hare other urgent improvements to build which run up to a good many hundreds of thousands of dollars. As a part of good business administration we are finding it unaroidable to spend about $\$ 200,000$ per year out of this fund on the maintenance of the improvements already constructed which, of course, reduces materially our ability to construct new improvements.

The increase of $\$ 23,000$ which is requested in this item is sought for the specific purpose of constructing more range improrements. We have been able this past year to put $\$ 25,000$ into the construction of fences, either boundary fences or division fences on our range lands, the development of water on stock ranges which. were not fully utilized because of the lack of water, and the grubbing out of poisonous plants from valunble forage land which was not being used becuuse of excessive losses of live stock from larkspur, loco weed, and other poisonous plants. I spent the greater purt of the past summer in a personal inspection of our grazing situation in the regions where it is in its most intensive form, Utah, Arizona, and New Mexico, and became satisfied, from my own investigntion and clicek upon the recommendutions I had received from muny other men in the service and outside, that the Gorernment ought to do n good deal more than we have yot been able to attempt in fencing and improving these nntionnl forest ranges.

lu dirona purticulurly wo are finding it extremely diflicult to control our ranges to the extent necessary for their protection. That is still un open-runge combry primarily. The outside pullic range has purtly disupperared on acoount of settlement, and the rest of it has.

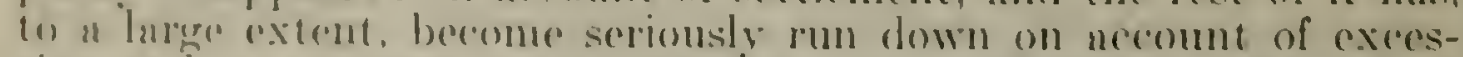
sive and unregrilated use. 'That means, from the vere muture of thinges that the live sterele on the outside ure constantly eroweding inter the mational forests. The drifting of umpermitted stock from the ontside rubeges onto the national forests is a ronstant problem which we have on cur hands. Wo can control it in part hy trespass

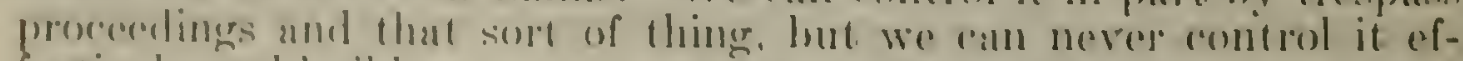
ferdively and huild up our own runges to the extent that they should be luili up until we do a lot of fencing in that country. I became persmully convinoed of that funt this pust summer. 


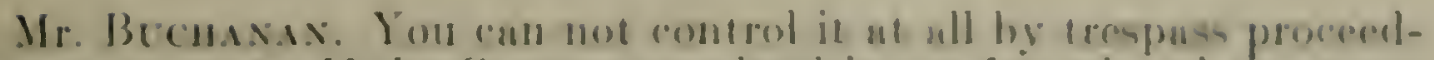

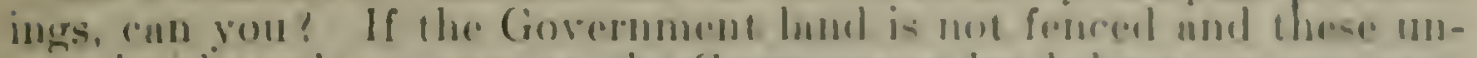

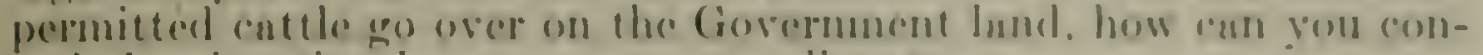
trol the situntion hy trespass procededings!

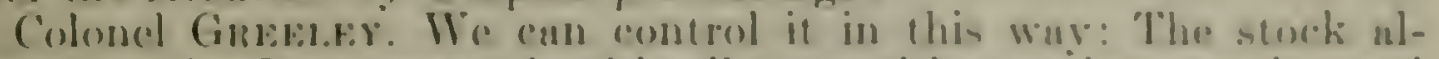

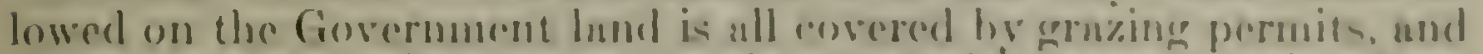
the grazing of stock in the nntionnl forests withent peranits is a trespass. It is recognized us such by the Federal courts. If gou con rateh the unpermitterl stock and identify ite ownership you hase.

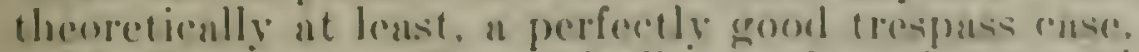

Mr. Becrissis. Theoretically you have hut practically

Colonel Gareser (intorposinger). But us a praction proposition it will not work.

Mr. Becmasis. That is hecmuse there will be a trespass here and there, and the matters will be so simull that they will not be worth the trouble!

Colonel Ginerser. Exactly. Another thing which I found from my personal inspection, and which has been checked up by our grazing experts much more widely, is the fact that we still have a good dent of range which is not fully utilized because of lack of witer. We still have muny grazing allotments where the stock crowds in uround the water holes and a lot of good forage is not utilized in outlying parts of the range because of lack of water.

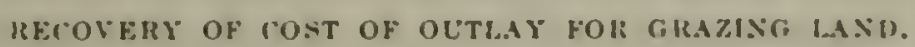

Mr. Becmaxax. How long would it take the average graming land to pay back the appropriations necessary to make those improvements?

Colonel Greeley. Under ordinary conditions you would recover the cost of the outlay in six to cight years through increased grazing receipts. There have been some striking cases where the return has been much quicker than that. To give you an illustration, on the Custer National Forest, in enstern Mfontana, we found it necessary, on account of the srift of outside cattle, to practically fence the entire boundary. We secured a good deal of cooperation from the stockmen themselves in doing that.

As a result of that fencing we stabilized the whole situation: the Government range is to-day in much better shape; the permittees are not bothered by trespassing stock; and we were able to put into effect on that forest a grazing fee amounting to 20 cents per head more than similar adjoining range was commanding. This is, notwithstanding the fact that the improrement had been partly paid for by the stockmen themselves. That forest range grazes 23,000 head of cattle, so that we now get an increased return equirnlent to $\$ 4,600$ a year, because of the construction of those improvements.

We have had cases where the investment of $\$ 1.500$ to derelop a spring has made possible a five months' range for a band of 1,200 sheep, range that fromerly was not used at all. "There are "good many cases of that charreter. In the aggregnte, they make up a situition where I feel that the investment of a reasonable amount of money in range improvements is one of the most constructire things the Government can do. It will benefit the live-stock in- 
dustry of the West very greatly. We hare had this situation: A large permittee on one of our Arizona forests, who was in the same sort of financial difficulties that many of them have been through during the last two vears, told our supervisor that in endearoring to extend his borrowings from Los Angeles banks he had been told that his credit could not be extended until his range was under fence; this was because of the experience of western live-stocks banks as to the security of cattle which are grazed on a fenced range as distinguished from those grazed on an open range.

'Thut man's range is partly in the national forest. He came to us and asked how he could get that national forest range under fence. We will probably be able to work out a cooperative arrangement with him under which we will furnish the wire and staples and his organization will furnish the labor and get that range under fence. Our land is bettered by it, his business is bettered by it, and his credit is bettered by it. It is a very constructive thing and I believe is thoroughly worth while.

We can probably get a dollar from the live-stock interests to go into this kind of development for every dollar that the Government puts into it. It is important, however, that these range improvements be owned by the Government. In the derelopment of our grazing, the necessity for adjusting range allotments and the need that occasionally happens for cutting down the large herds of an old user to protect the range or make room for the small herds of a settler, the ownerslip of runge improvements by stockmen, on Government land, is an embarrassing thing. I think our policy should be to do this work with suflicient, Government funds so that the title to the improvements rests unquestionably with the Government, and it is in line with that policy that I have asked for the increase in this item.

Mr. Buchanax. Mr. Chairman, you will notice there are some omissions in this item.

\section{CHANGE OF LANGUAGE.}

Mr. Axinersos. You are omitting the two provisos in the section because they are permanent law?

Colonel Grevisy. I think it is a useless waste of paper to put them in crery year.

Mr. Buchasan. That is permanent law?

Mr. Axpenson. Yes; we made it permanent law last year.

The next item appears to be on ynge 167.

\section{AP'POPRIATION UNDER ACT OF MARCH 1, 1921.}

Colonel Grestar. The change proposed in the item appenring on page 167 is an extonsion of the amount appropriated under the act. of Tareh 1, 1911, that may be expended in the District of Columbia. It involves no additional appropriation. The net of March 1, 1911, is the basic act muler which approprintions are not only made for the purchase of mational forests, but also for conperation with States in fire protection. Since that act was passed appropriations for land purchases have not incrensed, but the approprintions for cooperative fire protertion with the states have bern more than trebled. That 
makes it necessury to incrense, to some extent, the expresulaturen for udministrution within the Distriet of Columbin. For that renson we nsk for un extension of this limit. Wo muy not find it nereesirs to use this full extension during the present pear. furtioularly of the appropriation for land purchnses is kept on the busis reconnmesoled

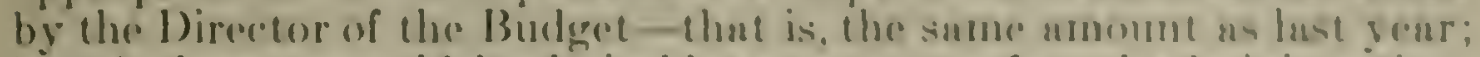
but the leeway would be desirable as u matler of good andminintration.

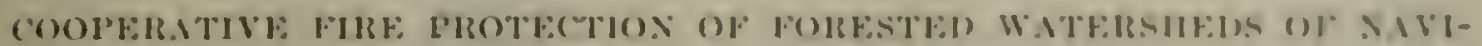
G.YBL.F: STRR.,MS.

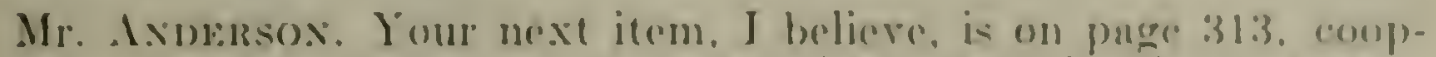
erutive fire protedtion of forested watersheds of nusigulile streatns.

Colonel Gisterser. The amount proposed is the same as during the current renr. $\$ 400.000$. Thut umount is spent in this fustion: We have conperntive agreements with 20 Stutes, eareh of which must spend at least ns much ns the Foderal Gerernment contributes und most of which spend n great denl more. These 26 stutes spent a totul of $\$ 373.107$ of Government funds for the personal services of rangers, lookout watchmen, and putrolmen who are incorporated in the fire-protection organization of the State. The rest of ndministration amounts to \$2.5,792. There was a bulanee of $\$ 1.100$ for contingencies, but since this stntement wis prepured it has heen entirely allotted to some of the States in order to meet fire emergencies. The 26 coopernting Stutes will expend during 1922 \$1, $\$ 96.000$, or about four und a half times as much as the Federal approprintion.

Mr. Axnersox. Let me nsk you there, is that for their own forest protection?

Colonel Greeser. That is on their own forest protection exchusirely, leaving out other forest nctivities. In addition to that, privite forest owners or nssocintions of forest owners will expend this yent between $\$ 1,000,000$ and $\$ 1,200,000$, or about two and a hnlf times as much as the Federul npproprintion. In other worels, leaving the national forests out of consideration since this moner is used to encournge forest protection on private lands, the total cintluy from all sources is now upproximntely $\$ 3,327,000$ a yenr, of which the Federal Government contributes 12 per cent and the States and privite owners the rest.

Mr. Becmaxax. Will you furnish a stutement showing the nllotment of these funds to the States and the amounts expended by them?

Colonel Greeler. I will be glad to do that. 
(The statement referred to follows:)

Cooperative cxpendilures in fire protection under the Works law, fiscal year 19:2.

\begin{tabular}{|c|c|c|c|}
\hline sitate. & Federal. & State. & Total. \\
\hline 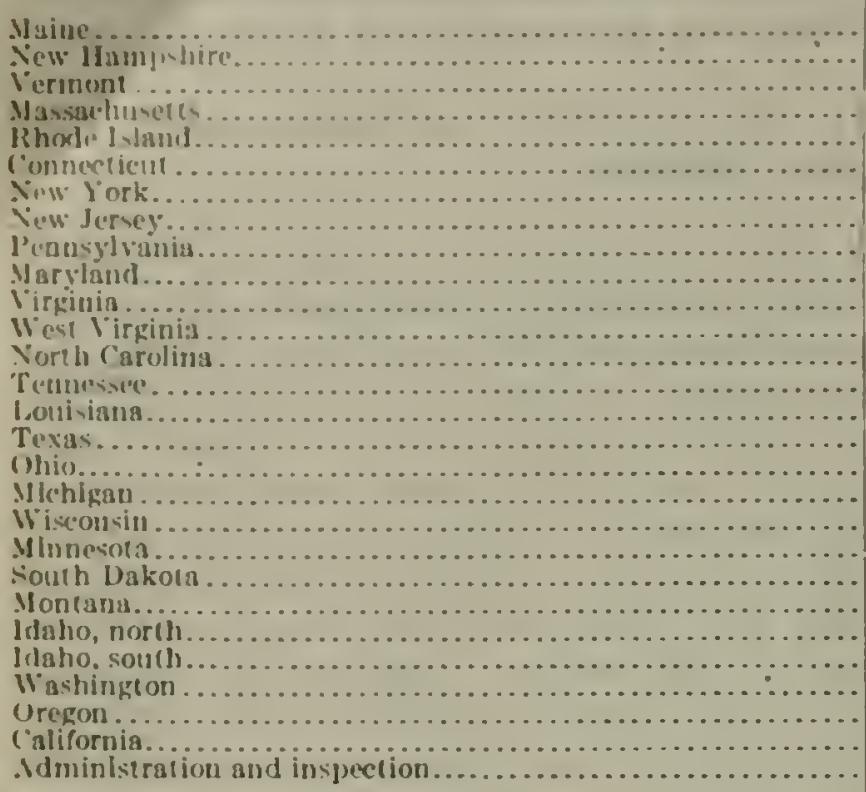 & 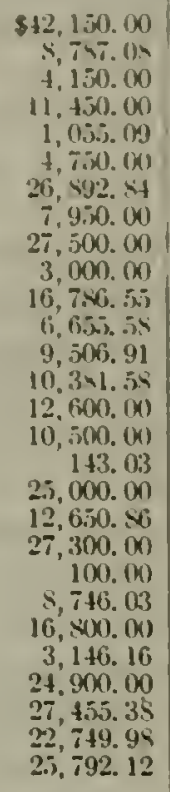 & 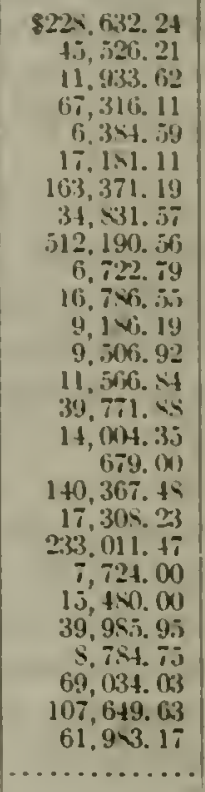 & 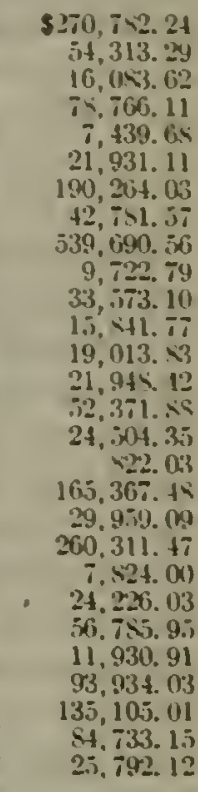 \\
\hline $\begin{array}{r}\text { Total......... } \\
\text { Enexpended talane }\end{array}$ & $\begin{array}{r}398, \$ 99.19 \\
1,100.81 \\
\end{array}$ & $\begin{array}{r}1, \$ 96,920,43 \\
\ldots \ldots \ldots \ldots \ldots \\
\end{array}$ & $\begin{array}{r}2,205,819.62 \\
\ldots \ldots \ldots \ldots \ldots \\
\end{array}$ \\
\hline ויוניה & $400,000.00$ & & \\
\hline
\end{tabular}

RFSULTS RFCEIVED FROI COORERATION WITH LOCAL AGENCIES.

Colonel Greflex: This activity, I believe, is a splendid demonstrution of what can be accomplished through cooperntion with local ugrencies with comparatively small Federal outlays. When this work was sturted in 1912 the expenditures of all the States for forest protretion did not exceed $\$ 350,000$ a yenr. In the 11 years during which this work has been conducted, and to in considernble extent ns a result of Federnl cooperation, State expenditures for fire protection have increused nenty sixfold, and the private expenditures for fire protertion have incrensed at lenst threefold. The States coopernting with the Federnl Government have increased from $11 \mathrm{in} 191^{2}$ to 26 in 1922. Thut means that in these 11 venrs 15 States which had no forest protection system have orernizged one and have qualified for ("w) repution by estublishing what, in the judgment of the Forest sorvine, is a reasomubly efliciont system for protecting their forest lumb. The ucrenge which is protected has increased from nbout

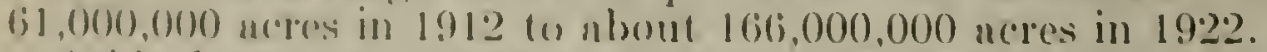

dside from the incrense in expenditures and acreage, this cooperntion hus resulted in some striking betlerments in the forest laws of

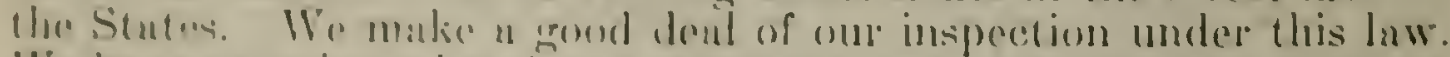

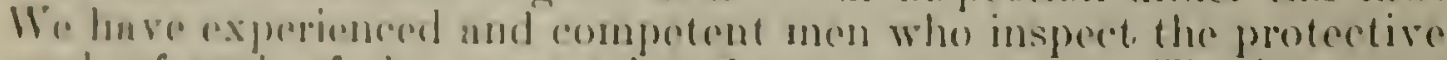

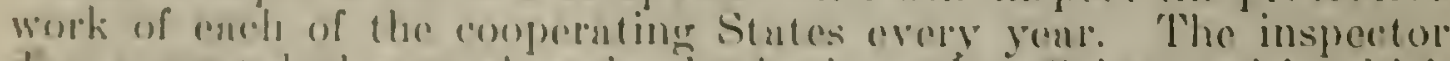

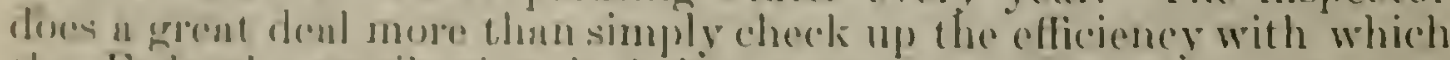

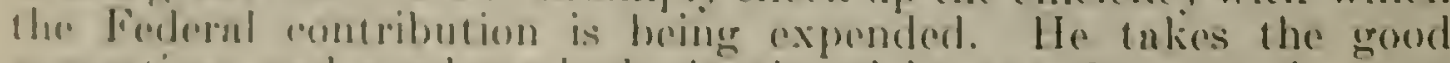
surgerstiuns und good modeds devoluped by one state to the next 


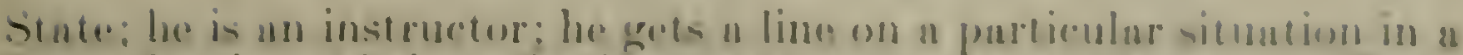

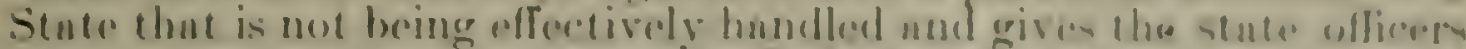

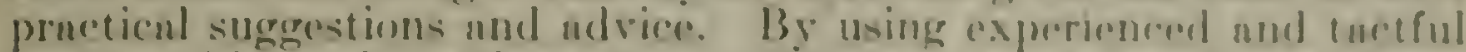

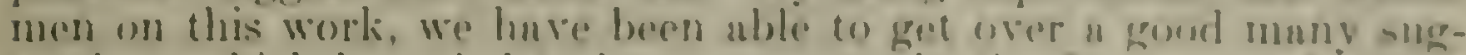

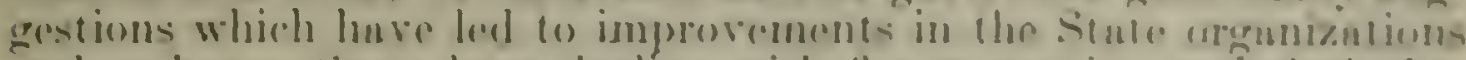

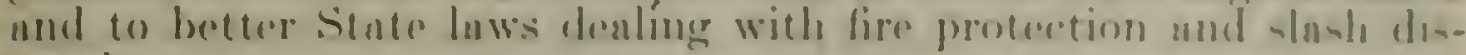
jusial.

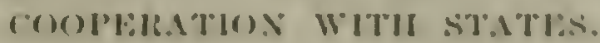

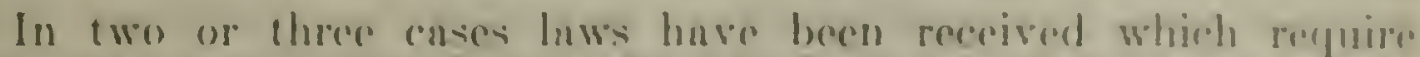
finuncinl contributions to the stutos fire-protection srstem by the

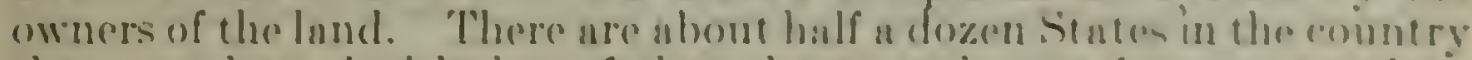
that now have lecrislation of that rharacter in anc form or another: and it represonts an important phase of this movemont for antionwide forest protection, in which the Fedoral cooperation has beon a leading fuctor. Another thing which wo have complassized in onr

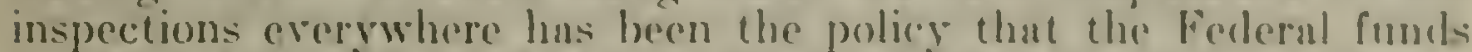
must not be used to protect voluable nereliantable timber, which we regaled as an obligation that the owner of the land should asimme. but primarily to extend the protection system ores the cut-orep lands, the denuded lauds. and lands containinger youncr growth, in which the owner may not have any very great interest.

There are enormois areas of such lands in the country which uro being held by the owners without any very tangible idru of what they are going to do with them and without much interest or concern over what happens to them. By extending the protection system over these cut-over and sceond-growth lands we are inculcating everywhere the idea that this protection is for the sake of future forest growth. From that standpoint alone the Federal cooperation has been of very great value. That is all I have to say on this item. We are still short of what we ought to be doing, but the times do not look propitious for securing an increase.

\section{ACQUISITION OF ADDITIONAI, FORFST IAAIDS.}

Mr. Axdensox. We will take up the item on page 315 for the aeguisition of additional lands at headwaters of navigable streams.

Colonel Grafery. The Tational Forest Reservation Commission recommends an appropriation of $\$ 2,000,000$ for forest purchases under the net of March 1. 1911. The item as it comes to you from the Bureau of the Budget is the same as for the present rear, $\$ 450.000$.

Uy to July 1 of this year a total of $\$ 12,57 \%, 000$ has been actually expended or obligated for the purchase of land under the act of March 1. 1911. In return for this expenditure the Goremment has ancerired title to 2,142,000 acres of forest hand, nt an average cost of \$5.5i per acre. That arerne cost inclueles the overhend ropenses, the cost of the land exinninations by apprasers, the cost of the examination of titles, which is often high on account of the exncting repurements of the Department of Justice, and the cost of cadastral surveys to dotermine the exact arog of earoh tratst.

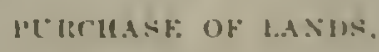

During the last fiscal yenr purchase arrecments wore made covoring $2+1,000$ acres at an average cost. for the land itsolf and excludinir overhead charges, of $\$ 3.31$ per acre. I montion that because it is 
the lowest avernge cost for which lands have been purchased since this policy began and because it indicates that the cut-over land market in the Enstern States at the present time is distinetly a buyer's market. We have to-day the most farorable opportunity to get barrains in forest hand that we have ever had.

The National Forest Reservation Commission up to the present time has approved 23 purchase units. If the committee is interested in knowing just where the are, it ean see them on this map. The purchuse mints in dark green are the ones which have been approved hy the commission and on which active purchnses are in progress. THe hatching an ench little diagram shows the extent to which the ownership of that area has been acquired hy the Government. The units indicated in light green have been examined or are under consideration, but none of them have yet been upproved by the commission as purchase areas. Before purchases in any locality are becrun, the commission must approve a specific purchase unit therein. The approval of the Geological Survey as to the beneficial relation of the forest eover in that region to the flow of navigable streams is also required.

Mr. Beculaxis. Are these all mountain lands?

Colonel Grestry. These are all mountain lands. This purchase unit covers the White Mountains in New Ilampshire. This purchnse unit [indicating] is on the Allegheny watershed, one of the units in which the people of Pittsburgh and Cincinnati are very much interested on account of flood control. These purchases [indicating] run down the crests of the southem Appalachian ranges.

TIMHER GROWTH.

Mr. Bucusix. Do these lands have any young timber growth (1) them!

(olonel Graber. They have a great deal of timber growth, both reung and old. Is a matter of fact, with our two million one hunired and forty-odd thousand acres of land we have acquired about $5,0(00,000,000$ feet of timber. Some of it is inaccessible and some of it is hand from which the better species have been culled. We have, howerer, a cond deal of timber of high commercial value. Is a mutter of fact, we ure now obtaining from these national forests " rearly income of botween $\$ 90,000$ and $\$ 100,000$ from timber sules, rontinuing ugnin the sume policy of cautious cutting and lieeping within the growing enpacity of the forests.

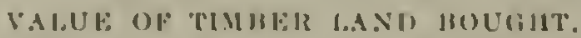

Mr. Breclasas. What perentage of the $\$ 90,000$ o! $\$ 100.000$ does: it take we get the timber out and pay the orerheal chargess! Is the work self-supporting!

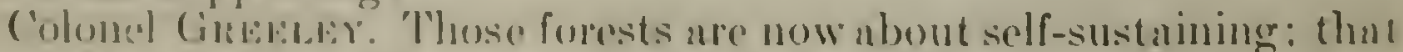

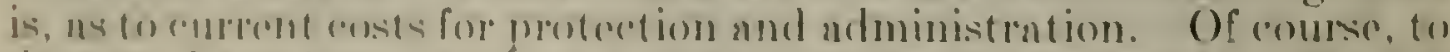

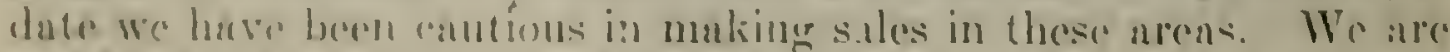
watching the watersherl situation rery dosely and we make no sules

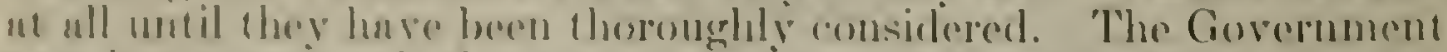
now lans a very sulunble timber proporty in thoso forests nand it has insermsed a govel deat in value sinere the land was bought. In fact.

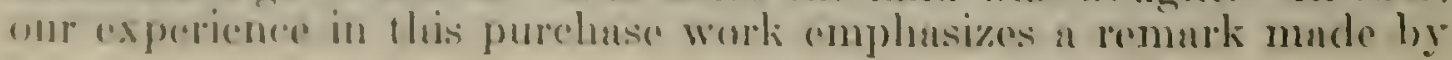


" former distinguished ritizen of rour State, Mr. (hairman, the elder Weyerhaser, who has been colled Amerien's "lumber king." He was nsterl whether he oror lost money in buying limber and he replied thent the only time he lost money wos when he did not buy cimberland. These forest lands that the Goverument has boughit since 1911 have, in the agerrecgate, alerendy nppreciated in value to a considerable degree. Two summers nero I inspected an aren in the Piegah National Forrest in North Carolina, where wo had made a sale of old pophar. onk, and chestant stampage. I found that the timber sule, which covered about one-third of one of the tructs purchused, would return more than the entire cost of the whole trues, timber und land rombined. and lenve us two-thirds of the tract still uncut.

Mr. Bucusxax. Taking all of these purchnses together, will the sale of timber pay all the overhead charges ns well as charges for enring for the land?

C'olonel Gurertr. Yes; sir: excluding churges for specinl improverments, like ronds.

Mr. Buchasas. Then the Government would get froe the growth of timber after reforesting?

Colonel Grisiry. Yes, sir.

Mr. Bucuaxas. You think it would pay all the overhend churges? Colonel Grieley. Y'es, sir.

Mr. Bucusis.. And all the Government would lose would be the interest on the money?

Colonel Grefory. That is all. The Government would get the further benefit of the apprecintion in timber values, as well as the protection of the watersheds.

In the purchase units which the National Forest Reservation Commission has approred, about 31 per cent of the area has been bought. It is our policy to have cnough purchase units within which lands may be offered to maintain a considerable degree of competition in the offerings to the Government. That is one reason why we have been able to get these lands at relatively low prices. We now have outstanding offers in these units which aggregnte $\$ 91,000$ aeres and between $\$ 5,000,000$ and $\$ 6,000,000$ in the oflered price. We ran probably get that land at considerably less than the oflered prices by making a careful appraisal, finding out exactly what there is, and then negotinting with the owner for a farorable option, with the owner knowing that his option will be considered in competition with options obtnined from other owners in that purchise unit or in other units and that only what we regard as distinctly desirable purchases will be submitted to the National Forest Reservation Commission.

FUUCATIONAL VALUE.

There is another effect of this purchase work that I want to speak of, and that is its eduentional value. We find in each of these regions where we establish a national forest and put into eflect a system of fire protection and a conservative system of cutting timber, and have rangers and supervisors on the ground, that insile of six or eight years you can hegin to see the effects upon the local people. The national forest becomes more or less a center of organied lire protection. We endeavol to cooperate with the owners of aljoining 
lands and induce them to protect their own lands. It is good business for us to do so, because if their lands are well protected our lands are sufer. Adjoining owners ask to see our timber sale contracts: they see how our cutting is done: and there hare been many cases where land owners have copied provisions from Forest Service sale contracts in the sale of their own stumpage. All of our work has a great educational value to the locality and the owners of adjoining lands.

Mr. Becmasas. I understood you to suy that 31 per cent had bern boumt.

Colonel Gremser. Thirty-one per cent of the area of these npproved units.

Mr. Becmaxis. Suppose the other 69 per cent is bought. Is the work then over?

Colonel Gresers. If the other percentage is bought, the units would be complete and the buying in those areas would be finished: ves, sir. The guestion then would be how far the Government should cxtend this policy: hut as to those specific units which the commission has approved the thing will be done.

Mr. Becustax. And on the 31 per cent how much did you say wiss spent!

Colonel Grasury. On the 31 per cent we have spent a little orer $\$ 12,000,000$. Multiply that by three and you get approximately the cost of finishing these purchase areas.

Mr. Bucuaxix. About $\$ 40,000,000$ more?

Colonel Grebler. We will not recommend 100 per cent purchuses in all of those units. probably not in any of them. There are certain lands which muy be held at such high prices that we could not recommend their purchase as a business proposition. There are certain wher lands whose owners have put into effeet a good system of protection and innagement. We do not recommend that the Federal Government buy such holdings. You might say that on the average (i) per cent would represent the completion of these units.

Mr. Becmasis. After you finish that area then would it be the policy of the department to go on to other areas?

Colonel Gresesy. I think it should be done within reasonable limits. Right in line with that question I would like to adrunce an additional jea or two. This work has been continued without a break since 1911 and the initial program has been necomplished to the "xtent of 31 pere'(ent. The showing to date makes it very clear that the ouday's for this purpose are really investments rather than exponditures, berause the Government is building up a valuable property and that moperty is enhancing in value. We rould elose out this proposition in a shori time, if Congress ordered us to do so, and "oncent with a profit over and above the entire cost of the enterprise. inchuding what has heen spent for the protection of the lands after tiey were purehased.

The present is a furomhlo time to make such purchases becnuse the fimmedial depression has resulted in a low seale of ralues for forest lands,

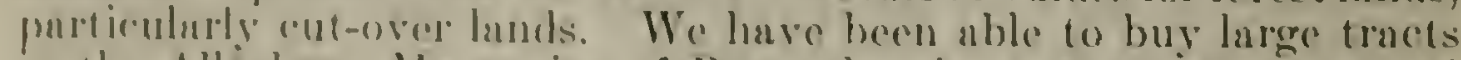

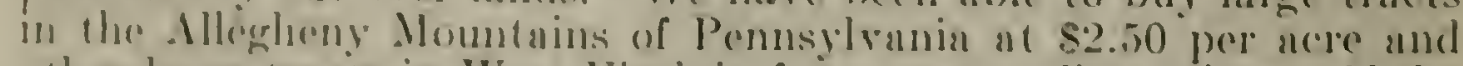
ofluer latere tracts in West Virginin for corresponding prices. If the lindernl Comermment infends to pursue this policy it probably will mever have a more favorable tima to buy forest lands at low priecs. 


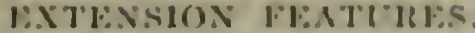

Now, in regard to its extension. Firom the standpoint of protecting watersheds. of growing timber and of giving a practieal demonstration in forestry to the prople of a region, there are certain kere areas where a smaill feederal mational forest would be rery desirable. We have not covered them all by any ments in this line if upproved units. I think it would be a very ilesirnble thing, for cxnmple, (1) have a small mational forest in the Orank Mountuins of Missomri. That is a region where there is nn enotmons uren of rough momutuin land not suited for angriculture, where the bulk of the merehantable timber has been cut and where the land is now mere or less hunging in the balunce. Much of it is burned over frectuently, is deteriornting, and is producing little or nothing. Somebody, I think, should go in there and demonstrate, in a practical way, what ans be done with that kind of land. I think it would be a good thing to have a nutionul forest or two in the mountains of lientucky, where we have none. Of course, it is a question of general policy us to how far such purchases should be curried.

The Government, obviously, em not buy any large proportion of the privately owned lands in the country, but I would faror the creation of small national forests at points where the three purposes, watershed protection, the growing of timber, und the demonstration of good forest practice give the Federal Government the best chnnce to make a ten-strike.

Mr. Bucuasas. Does renl timber grow on these mountains or just scrubby stuff?

Colonel Greresy. Real timber; the finest poplar and white onk in the world grow in the southern Appalachians.

OLYMIIC NATIONAL FORFST.

DISPOSAL OF AND PROTECTION FROM FHE: OF WINU-THIROW TIMHE

Mr. Axnzisor. The next item is on page 341 .

Colonel Grenter. That is the item which relntes to specinl protection on the Olympic National Forest. We have recommended a reduction from $\$ 33,000$ to $\$ 25,000$ for the ensuing yenr. We hope it will not be many years before this item enn disappear altogether. We hnve been uble, by very intensive methods und with fine cooperntion from the State of Washington, to enrry this Olympic blowdown through two fire sensons without any destructive fires at all. That has meant an intensive protection organization over 2.200 square miles of land, which contains more or less blown-down timber, batches of wind falls being senttered all over it. It will require approximately $\$ 22,000$ to muintain the present orgunizntion of men and equipment and $\$ 25,000$ will give us a leewny of about $\$ 3.000 \mathrm{for}$ keeping up and extending the trails and telephone lines which are $n$ vital factor in the protection of this enormous aren.

I presume the committee understands that what we are really protecting. in cooperation with the State of Washington, is one of the lnrgest reserves of timber nnywhere in the country, on the Olympic Peninsula. The Olympie Peninsula contains, I suppose, ninety or one hundred billion feet of timber, partly in Govermment ownership, but more largely in private ownership. The timber has not yet been eut 
to any extent and it constitutes, by reason of its locntion, one of the largest and most raluable reserve arens in the United States. This blow down went right through the heart of it, and in protecting the damaged strip we are protecting primarily the enormous and rery valuable timber recrion around it. With two or three more vears the growth of regetation and rotting of the blown-down timber will greatly reduce the fire hazard, and I hope we can cut this item from time to time and in the course of no great length of time absorb it entirely in our regular uppropriations.

Mr. Jump. You will observe that that item carries a decrease of $\$ \$, 000$ for 1924 .

FOR PROTECTTON OF OREGON AND CAHFORNA RAILROAI IANDS AND COOS BAY WAGON ROAD TRAILS.

Mr. Axmenson. 'The next item is on page 343. As I recall, this is a proposition that was taken over by the Department of the Interior some years ago.

Colonel Greeir. That is work which the Forest' Service has assumed nt the request of the Interior Department. The protection of these railway-grant lands, which have been rerested in the United States, was first provided for in the sundry eivil bill for 1916. In the fiscal yenr 192:2 the Forest Service assumed it at the request of the Interior Department, because a large part of the lands are intermingled with the national forests in Oregon. The actual cost of protecting these lands has ranged from $\$ 37.000$ to $\$ 43.000$ a vear, depending on the character of the season. During the last fiscal your the atctual cost was $\$ 41,000$.

An appropriation of $\$ 35,000$ means that we have got to protect the land lor less than 15 mils per acre, which is less than we can do, except in an unusunlly furorable season. The cost of protecting the nutional forests as a whole amounts to 17 mills per acre in a normal your. We repuested the Bureau of the Budget to incrense this item io $\$ 40.000$ on the basis of the arerage eost actually incurred during the pust five yenrs, but the Director of the Budget thought we ought (1) hold it at \$35,000. This means that we have got to ask for a deficiency unless we have un exceptionally farorable summer. 'The land contuins about forty or fifty billion feet of timber and is un extremely valuable property. There is no question ubout the need of sustained protection.

Mr. Axprrsox. We will take up the item on page 356 . . That is upparently an upropriation already made.

Coloncl Gravery. The item on page 356 is simply an enumeration of upproprintions previously made.

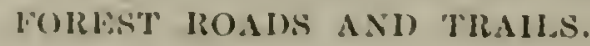

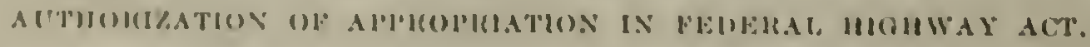

Mr. Anderson. Wo will noxt tuke up the item on page 359 , forest ronds nud trinils.

Colonel (imbialis. 'Thu jtem on puge 359 is an appropriation unchorized by (ongress but not hitfierto specilienlly made. In pussing the Fodarnt highwa uet of November 9, 1921. Congress drefined the eneneral woliev that andonriations for the construction 
of roads and trails in the national forests hould go hand in hand with appropriations for Federal aid (1) post roarls. That anet uppropriated $\$ 5.000,000$ for the fiscal yent 1922 und $\$ 10.000 .000$ for the fiscal year 1923 for the construction of roads and tmils within or adjuecint to national forests. A subseguent aret, that of June 1! 1922. nuthorized an appropriation of $\$(t, i, 0), 000$ conch for the fiscal vears 1924 and 1925, in pursuane of this same policy. The Director of the Budget now recommends an appropriation for 1924 of $\$ 3.000 .000$ out of the $\$ 6.500 .000$ which was authoriged by (ongresi. I do not know how far the commitse wishes me to gor into a diselussion of this road-building program.

Mr. Axtrersos. I would like to go into it protty thomoughly.

Colonel Graserey. It is a pretty hig subject and has been threshed out before congressional committees several times, hut I will he very glad to tell you the story if you wish to listen.

Mr. JUMP. Mr. Chairman. suppose we defer ansideration of this item until Mr. MneDonald appears in connection with the Federal nid rond item?

Mr. Axnersos. 'That will be sutisfuctory.

Wediesmy, November 22. 1922.

FORFST ROADS AND TRAIIS.

Mr. Arversox. We will hear Colonel Greeley with reference to the item on page 359 for national forest ronds.

AUTHORZATION FOR APPLOPRIATION.

Colonel Greficy. Mr. Chairman, as I explained to the committee the other day. Federal-aid legislation as expressed in the last two statutes, the Federal highway act of Norember, 1921, and the act of June 30, 1922, has recognized the need for the construction of roads in and adjacent to the national forests as a part of the Federal road policy. Sums were authorized for continuing the forest road work in the last general lecrislation dealing with this subject. to the extent of $\$ 6,500,000$ ench for the fiscal yenrs 1924 and 1925. This item comes before you now as a part of our 1924 Budget, with the recommendation of the Director of the Budget that \$3,000.000 be uppropriated out of the authorization of $\$(6,500,000$.

Mr. Axinfrsox. Was the $\$ 6,500,000$ authorized to be expended in any particular period?

Colonel Greelery. Aecording to the terms of the legislation it remains available until expended. The law authorizes an uppropriation for a certain fiscal year, to remain urailable until expended. You menn, is there a limit on the period of the anthorization?

Mr. A.vifissos. Yes.

Colonel Grencer. My judgment would be that this authorization expires with the fiseal year 1924. The authorization is made specifically for the fiscal year. Is that your understanding of it. Mr. MacDonald, as a matter of law? 
Mr. MacDoxald. I never thought of that question before. My own belief has been that those authorizations hold until expended.

Mr. Anderson. Mr recollection is that there was a three-year authorization in the general program.

Mr. MacDovatil). Yes, sir.

Mr. Axnersox. That would only carry appropriations for the three years for which the authorization was made. I was wondering whether this $\$ 6,500,000$ was carried under language which would permit making the appropriation for any one of three years covered by the generil proposition, or whether this only covered one year.

Colonel Grencey. I have here the act itself. This is section 4, paragruph 2, of the act approved June 19, 1922, as follows:

For the purpose of carrying out the provisions of section 23 of the Federal highway act, approved November 9,1921 , there is hereby authorized to be appropriated for forest roads and trails, out of any money in the Treasury not otherwise appropriated, the following additional sums, to be made available until expended, in accordance with the provisions of said section 23: 'The sum of six million five hundred thousand dollars for the fiscal year ending June 30, 1924. The sum of six million five hundred thousand clollars for the fiscal year ending June 30, 1925.

Mr. Axdersor. That only covers two years.

Mr. Buchasas. It expires with the appropriation for that fiscal year.

Colonel Greeley. That would be my impression.

Mr. Jump. If it said "during" the fiseal year 1923.

Mr. Bucmaxax. The very wording of the act, making one appropriation for one year, 1924, and another appropriation for the following year, 1925, shows that it was intended to have that for each year.

Mr. IUmr. Our impression was that they intended to make that amount of money available until the rate of expenditures required further appropriations under the authorization.

Mr. Bucnasax. It says in accordance with section 23 . What is section 23 ?

Colonel Greeswr. That is section 23 of the act of November 19 , 1921. It is a section that covers a printed page of the act. I lanve it here and will read it, if you desire to have it read.

I might say, Mr. Chamman, that in accordance with the terms of that section, to which Mr. Buchanan referred, any appropriation made for the construction of forest roads up to an amount of $\$ 6,000,000$ in any your is divided equally between roads of primary service to the States, counties, or communities in the national forest regions, und roads and trails of primary service for the protection and administration of the antional forests themselves. In other words, the legislation recognizes the two big purposes to be served by forest ronds; first, the extension of public highways, State roads, county ronds, und community ronds orer the national forests, making them contributc a reasomable share toward the completion of the public-road system in their regions; and, second, building on to that public-road syston the ronds and trails needed primarily to protect the national forests themselves mad fo devolop their resources.

Linder the terms of the law an appropriation up to $\$ 6,000,000$ is split equally betwern those two chasses of ronds. Our method of expenditure, us defined hy regulations of the secretary of Agriculture, provides for a conprerative working ont of highway plans with the Stale 
highway commissions and the Burenu of Public Ronds, which hundles the technionl enginesing fentures of this work thronghout. We develop a common plan, us far ns possible, with the Sintere and designate under that the ronds which fit into these t wo chusses.

The publie ronds which form component ports of the highusy

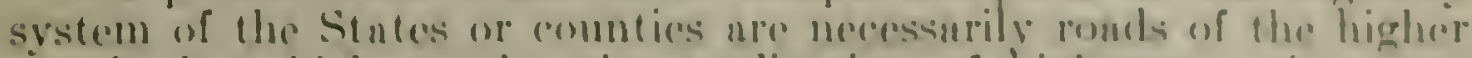

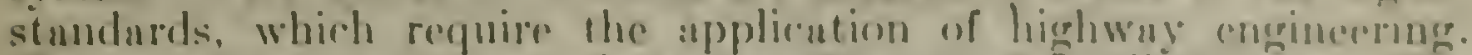
Those ronds arre buile entirely be the Burenu of Public Rosuls. The protertion and development ronds roming under the othere chasifienfion consist ludgely of rough, inexpensive rouls built ehenply fo open up our inneressible recgions in the motional foreste. 'J'hey ure rouds which do not pecpuire any partirular degres of technirnl highway skill in their construction, und ure built hy our fiedd organization of rungers and supervisurs.

Any attempt to estimate the ronds neoded to complete the publice roul system through the nutional forests and also supply the prortective fucilities required on these Goverument properties themselves ure necessarily rough und run up into very high figures. We estimnte, howerer. that nesty 15,000 miles will be necessury ultimately to romplete the public roads which must traverse notional forests.

Those 15.000 miles are estimated to cost in the neirhborhood of $\$ 112.000 .000$.

We estimate that the protection and development romls needed to open up the national forests will ultimately umount to a little orer 14.000 miles, costing about $\$ 54,000,000$, and that the trails still needed for protection and administrative purposes will run up to about 40,000 miles, with a cost of something over $\$ 11,000,000$. 'The whole program of roads und trails runs up to something like $\$ 17 \$, 000$,000 , necessurily requiring a long time to build; nnd of course containing items of varying degrees of urgency. This represents, in a rough way, the ultimate system that we must plan for. The work to date has progressed under former appropriations to a point that represents a very substantial beginning. I do not know whether the committee cares for any of these progress tables showing what has netually been clone.

Mr. Inofusor. I think it would be a good idea to put them in the record.

Colonel Grencer. They amount to a total of 4,755 miles of rourls constructed, 6,710 miles of trails constructed, and upproximalcly $S, 000$ miles of roads and trails maintained. 


\section{(The tables referred to are as follow's:)}

Construstiun, improtememt. and maintenance of roads and liails from forest road approprintions and other Fieleral and rooperative funds, by States.

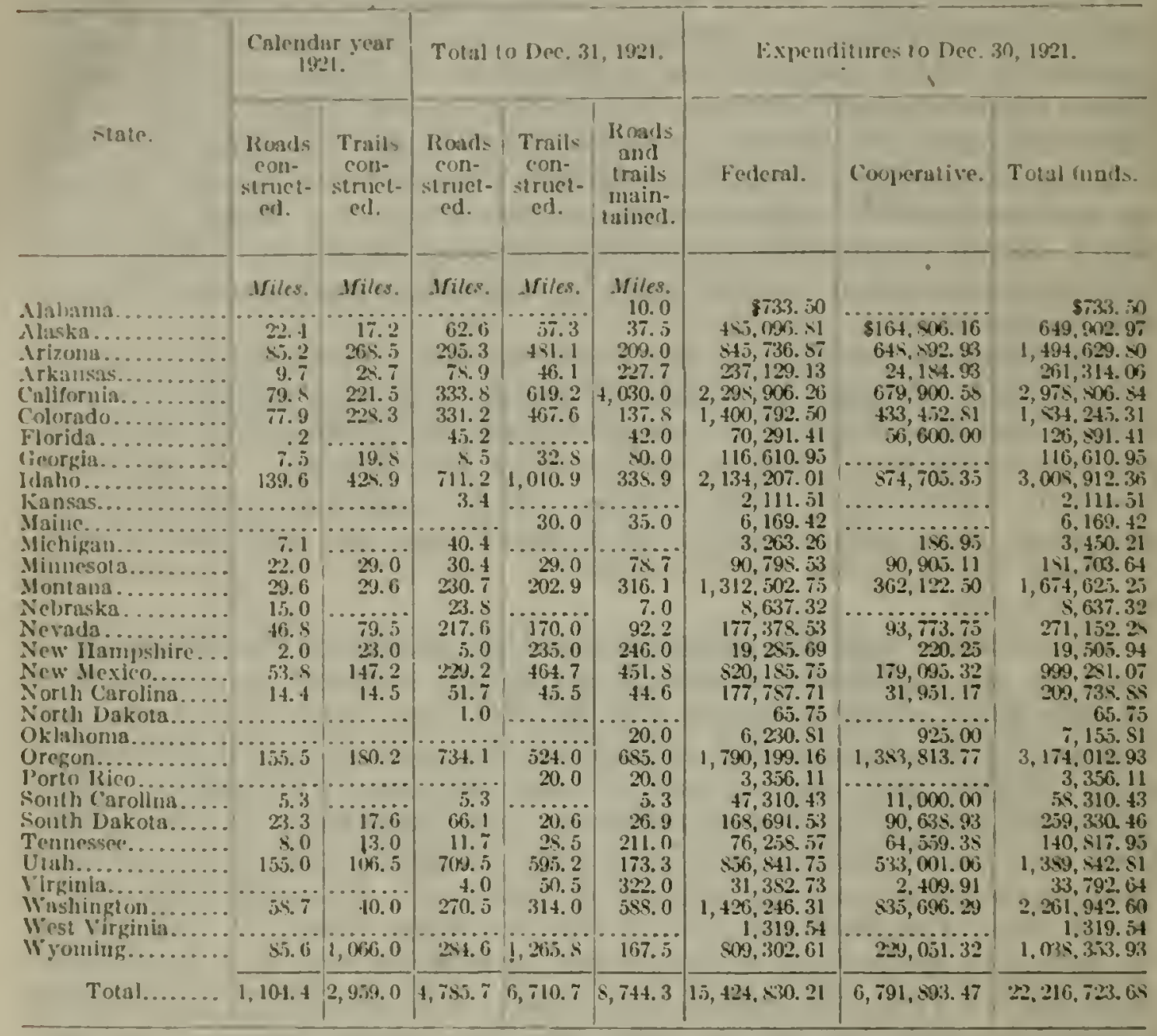

Mr. Axpersos. May I ask you whether the program you have been discussing is in addition to what has alrendy been accomplished, or does it include ronds ahendy constructed?

Culonel Grister. The program I have referred to is in addition to the milenge actually built. 'These are figures up to December 31 , 1921. There nre avnilnble for this program, however, certain amounts remaining from hast yenr's mpropriations and other unexpended bnlances of forest rond funck.

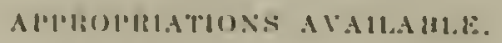

Mr. Axtrassos. Will gou make up a stutement showing the sums which you ure ut libery to spend for these ronds and trails?

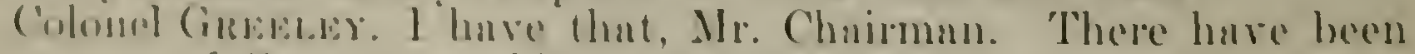
four ands of Congress making substantinl arppropriations for forest

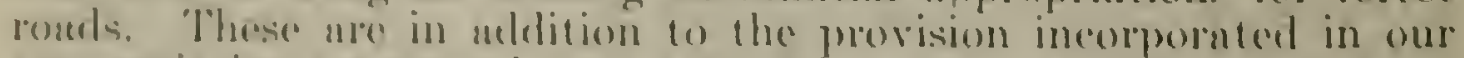

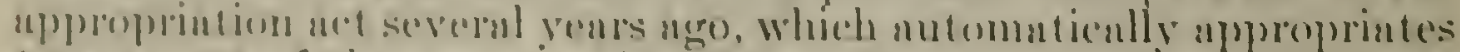

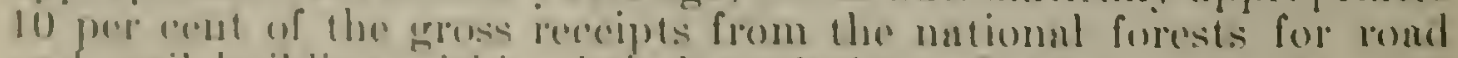

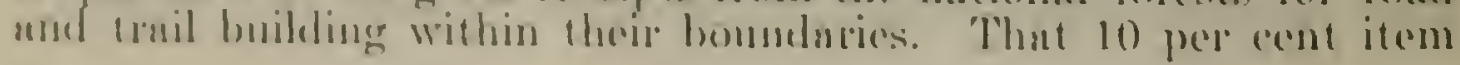


anounts now to about $\$ .50)(00)$ a yenr. Aside from that, which is a current itcm and which is almost entirely obligrated for the maintemance of rouds and trails formerly huile, we had as ailable at the beginning of this fiscal year a totul sum of $\$ 17,000,000)$ for road und trail construction. That is made up of the moxpended halamees of amounts formerly approprinted.

There is the spectal act of February 28, 1919), the fichleral forent roand construction ace as it is callonl, whose uppropriations have

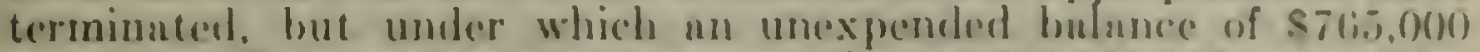
remanis. Then we hat the appropriation of $\$ 1.5,000), 000($ carried hy the Federal highway aret of last Norember, and the current appropriation which becane available under the post roads act of 1916. This aret appropriated $\$ 1.000,000$ a year for a period of ton years. These appropriations and balanes gave us, achually avaluble ut the beginnung of the fiseal your 1923, $\$ 17.000 .000$, which applies mainst the proctram I indiented. That money will be largely rexpended during the next two liscal years.

Our program to date and the program of Mr. MacDomald's organization. which handles the contracts on all of the high-standard roads, contemplate an expenditure of about $\$ 11,713,000$ during this current fiscal year out of the $\$ 17,000,000$ avalable at its begiming.

PLAX OF WOLK.

The whole point, as I see it, is this: Work of this character, to be done efliciently, requires a great deal of planning. It requires carrying on the eximmintion of projects, and their cooperative consildrintion with the State anthorities and other local agencies interested in road huilding for at least two years ahend of actual construction. We need the resources to carry the forest road program ahend at a rensonable pace, keeping the examination of projects normally $(w 0$ years ahend of eonstruction and survers normally one vear ahead of ronstruction. No construction should be ordered without advance cost estimates based upon survevs. so that all of us in the department who are responsible for this work may be assured that the money is being spent to the best adrantage.

For these reasons we need to keep two years ahend on our approprintions. That, in my judgment, is the most important fenture of this item. In appropriation of $\$ 3,000,000$ for the next fiseal yenr is less than half what Congress authorized for this purpose. It was arrived at by the Director of the Budget from this standpoint, that the rond work must be continued with reasonable provision rear by vear, so that it can be properly planned, but that in view of the present situation of the Treasury an appropriation of $\$ 3,000,000$ for the next fiscal yenr is reasonable and sufficient.

Inder appropriations at this rate, it is going to take us a good many years to complete eren the most urgent construction neeessary to develop the national forests and facilitate their protection. "The building of these roads not only has a very important relationship to the protection of the national forests but also to the derelopment of their income producing business. That was a factor which had a great deal of weight with the Committee on Roads. which originated the basic legislation dealing with this subject. 
We now have one-quarter of the merchantable timber of the country in the national forests. We could cut timber to the extent of $\$ 1 \$, 000,000$ a year at present stumpage rates, were the forests accessible. 'The opening up of these regions, through the construction of ronds. is going to cmable more and more of our timber resources to be used and to be used in a rational and intelligent way. It is going to enable the timber cut to be more properly distributed rather than concentrated at $n$ few points where there is some special industrial development. Rond building is a very important factor in the full development of these national properties to serve all the purposes for which they were estnblished.

'That is all I have to sny. I ask the committee to provide for continuing this work on a reasonable basis, because it is the steady, unbroken pull that counts on a job of this character.

\section{OTHER APPROPRIATONS AYAILABLE.}

Mr. Annersox. Are there any appropriations made in other acts which mature this year?

Colonel Grescex. The act of 1916 carries an approprintion of $\$ 1,000,000$ yearly up to and including the fiscal year 1926 . Under that act an appropriation of $\$ 1,000,000$ becomes available July 1 . 1924. That is the only continuing appropriation, with the exception of the 10 per cent of gross receipts which I spoke of and which is largely absorbed in maintenance.

Mr. MAries. You are authorized to expend $\$ 6,500.000$ ?

Colonel Gresery. The appropriation has been authorized but not made.

Mr. Mager. Is that a continuing appropriation?

Colonel Grenery. That was authorized for two specific years.

Mr. Mager. If we appropriate $\$ 3,000,000$ this year what becomes of the balance?

Colonel Greener. Well, it is simply unappropriated. Whether it remains muthorized for appropriation or not I do not know.

Mr. Magie. That is what I was getting at.

Colonel Greei.er. That is a technical question I would not attempt to answer.

Mr. Axinersox. I do not believe it continues.

Mr. Itur. If that is true, I think the Budget Bureau, in passing on these items, did not have it in mind. We receired the distinct impression, in our denlings with the Budget Bureau, that they had in mind, in recommending to Congress that merely a portion of these authorizations be appropriated, that the balance could be recommented, through the bureau, of course, and if passed, then approprinted by Congress, as it saw fit, under the existing authorizations, when the rate of cash withdrawals from the Trensury made that necossing.

Mr. Axmbasox. I do not see how that conclusion ran be arrived at moder the hanguage of the anthorization.

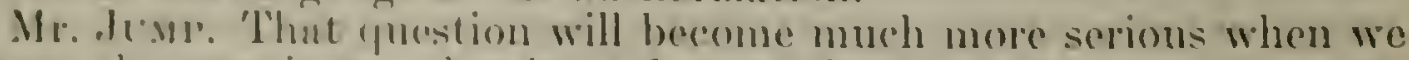
fret to the next item- thut is, so far us volume is concerned-because there, of the $\$ 65,0(0), 00(0)$ anthorizad for 1920.1 .835 .000 .000 is deferred.

Mr. A.mensox. But you huse some additional lunguage there. which, as I rereall, anthorizas you to make rontrancts?

Mr. desur. It did during 1923 and it is in lere for 1924: that is true. 
Mr. Axpensox. ()f comse thus would becone a continuing obli-

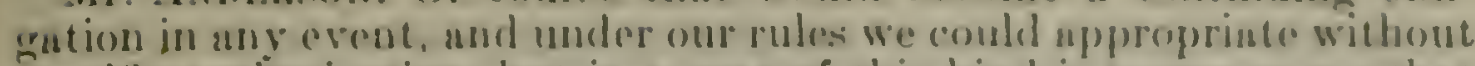
specific anthorization, but in a rense of this lind it seroms to me that uncler the lnngunge of the ace itself it simply makes a maximum uthorization which is controlling upon this committee, at least, in making the approprintion.

Vr. Tump. If that is true, thut is a terge seroun thing.

Mr. Axnensos. From a legnl point of view the obligntions of the Government mug be an entirely different question, but my iden is that so fur as the right of this committe to report un uppropriation is concerned it is an authorization for one yenr, and if we uppropriate only a part of that muthorization then the anthorization, as far as it goes, is exhmusted by whatever we nppropriate under our rules.

Mr. Mager. Yon followed the recommendation of the Director of the Budget?

Colonel Girfetar. Well, res; we followed it.

Mr. Axuressox. Or he followed you?

Mr. Marier. Sometimes the man at the bar has a very serious contention with the judge.

Mr. Axnersos. I recognize your attitude, but my feeling ubout it is that this committee, at least. is not bound by the judgment of the Bureau of the Budget as to my question of policy; if we do not think it is good business policy to uppropriate $\$ 3,000.000$ we can upproprinte $\$ 1,000,000$, and if we think it is better business policy to uppropriate $\$ 5,000,000$ we can appropriate $\$ 5,000,000$. Now, if there are any rensons why we ought to appropriate $\$ 5,000,000 \mathrm{for}$ this item I would like to have then.

\section{URGEACY DEMANDS AIPROPIATION BF CONTINUED.}

Colonel Greeler. Well, sir, may I reopen my statement? The only facts I would like to bring before the committee from that standpoint are these: We hare a long program ahead of needed roads and trails of these several clusses. There enn be no question about their urgeney, both from the standpoint of the national forests as Federal property to be protected and developed and also from the standpoint of our obligations to these States and counties to do a reasonable part townd extending their public rond system over Federal lands.

The Bureau of Public Ronds and the Forest Service together, each in their respective fields, are organized to-day to continue this work on a scale of at least $\$ 6,500,000$ a year. We expect to put through $\$ 11,000,000$ of road construction between the two organizations during the fiscal year 1923. A drop to $\$ 6,500,000$ means a rery substantial cut in the product of the organization that is now actually in existence and built up with trained men, equipment, warehouses for equipment, and all that sort of thing about wheh Mr. MncDonnld can tell you more than I can. We are orgmized and, I think, pretty well organized with personnel and equipment to do this work on a mininum basis of $\$ 6,500,000$ a year. Cutting that appropriation in two means that the organization will have to be redueed and that a loss of efliciency will necessarily result.

1 do not know that I can sar anything more than that. On the basis of $\$ 6,500,000$ a year it will take at lenst 25 years to complete the needed forest roads and trails. If that is cut in two or cut at all the length of time required to complete these necessury facilities 
will have to be extended proportionately. It is my personal judgment thut a general plan of completing these needed facilities in the space of 25 yeurs should be a minimum period and that we ought to adhere to that ruther than to extend it. On the contrary, there is the viewpoint of the Director of the Budget as to what the Federal Treasury will stand, and, of course, I can not dispute that point of view.

Mr. Annersox. I recognize the fact that it is always a question of offsetting the needs against the money you actually have. I simply wanted to get into the record the full situation, so that the committee could act upon it intelligently from the standpoint of the whole program.

Mr. Jump. In view of the question that has arisen about this item, would not this be the common sense thing for us to do: Between now and Monday have the department-Colonel Greeley, Mr. MacDonald, and myself - see General Lord and get a clearer understanding of what they had in mind. This authorization says there shall be appropriated for the fiscal year 1923, for the fiscal year 1924, and for the fiseal year 1925. I think the word "for" is the deciding factor. If it said certain npproprations are authorized "during" the fiscal year 1923, I think they would have construed it just as you have. We will go back to the Budget Bureau and see how they look upon the matter.

Monday, November 20, 1922.

\section{BUREAU OF CHEMISTRY.}

STATEMENTS OF MR. W. G. CAMPBELL, ACTING CHIEF; DR W. W. SKINNER, ASSISTANT SHIEF; MR. H. S. PAINE, IN CHARGE OF CARBOHYDRATE LABORATORY; AND DR. S. P. VEITCH, IN CHARGE OF PAPER AND LEATHER IABORATORY.

\section{SAIARIES.}

Mr. Axnersox. We will take up this moming the Bureau of Chemisty, on page 171. Do you want to make any preliminary statements before we take up the statutory roll?

Mr. CAMPBELL. I do not think any statement is necessary, but I ('un matie statements as we go along in comnection with ench parlicular item.

Mr. Axurison. Then we will take up the statutory roll, in which there uppens to be a decrense of $\$ 14,100$.

Mr. Cumplist. This is due to the dropping of 20 places. The dropping of these places, of course, is the result of a concerted effort to munfest enonomy, in erery way in the world we possibly ean. Very nuturnlly, in the development of an organization to meet current conditions, which are chunging from time to time, we endeavor to make an urrangement by brignding the work in a fashion that will lemel itadf to the (mployinent of the fewest possible men.

We liave nade a strenuons affort in that direction and have conchaded we can drepe 20 of the planes that were provided for in the statutury roll of hast year, and that will affect a reduction of $\$ 1-1,100$. 
There is another change in thut item. At the present time there is provision for nine laboratory ledpers und for one silled laborer at

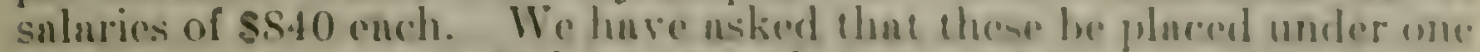
hending and given as 10 laberatory helpers or laboress, without any chunge in sulary at all. The purpuse of that is 10 mate it pusslife for us to get from the civil servere register the ype of man thet might be required for some work which we have in lie lubermforich, and we

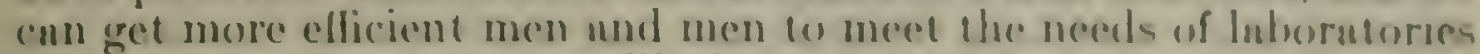
in certain sections more resdily if we do not hare the ewo lines and an nppoint them aither as laborutory helpers or laborem.

Mr. Axinersox. Are the places you hare dropped now racume!

Mr. Camplsets. Some of them are rnesut now and ull of them will be racant we contemplate by the time this bill geres into effect.

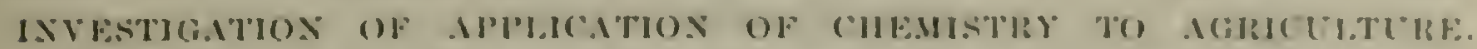

The next item is for agriculturnl insestigntions. This is a he appren-

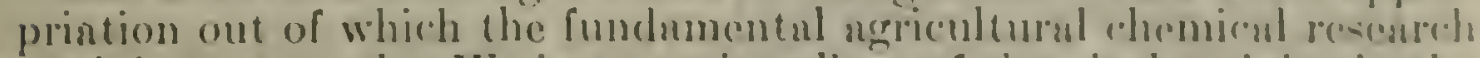
work is supported. We have various line's of cheminal activity in the field of ugriculture paid from this fund. All of these projects of work are formulated and promoted, of course, with an cye to the underlying economic signiticance of them. I inny say to you, and perhaps this would be the pertinent place to bring it in, that the work of the Burenu of Chemistry divides itself maturally inte two primnry subdivisions. The lirst is the researeh work or insestigational work, and the second is the regulatory work, such as the enforement of the food and drug act, as well as ten importation act. Now, he researeh work is of two types. First, that work which has to do with primary research in the field of agriculture looking towird cultural phases, and second, that work which has to do with the employment of chemistry in the solution of those problems which exist in manufacturing estalilishments utilizing agrieultural raw materials. In other words, it is technologieal rather than cultural, but both of which hare economic importance.

Some of the work in the technological field is supported by specific or particular appropriations. Those we will come to later. But all of the fundamental resenrch work of a culturnl kind, in which chemistry is employed in the whole ngrieulturnl scheme. is supported from this particular appropriation.

Those which hare economic signifience, illustrated in the most direct way of course, are such undertakings as the utilization of agricultural waste materinls for some beneficinl purpose. That enn be illustrated by the work which has been done in a study of classes of waste materials and their suitability and value for use as stock feeds. One of the laboratories in the burenu has been working on this thing for some few years, and bulletins hate been published on the hasis of materials which lend themselves to that use. Of course. you nre familiar with the work we have done. more particularly in California, in the eitrus fields and the utilizntion of cull oranges. products which formerly found themselves valueless and which. when they had a sale. would hring nothing more than approximately \$? as ton but which are now being sold regularly and contracted for on the basis of something like \$30 a ton. 
Mr. Bucmaxax. What use have you found for them?

Mr. Camprest. Te have found use for them in the manufacture of oils from the citrus fruits, the use of the peel of the fruit, in the manufacture of citrate of lime, citrie acid, and also their employment where the fruit is of a quality to enable its use, in the manufacture of $a$ base for marmalade. There are some several well-established factories in southern California as a result of the work we have done there.

Mr. Buchusax. What did you say was the difference between the former price of culled oranges and the price at the present time?

Mr. Campreid. Formerly, when they had a sale at all, it would be about $\$ 2$ n ton, ranging from $\$ 2$ to $\$ 4$ per ton, while now it is, in round numbers, $\$ 30$ a ton.

VAIUU: OF RESEARCH WORK.

Mr. Buchasax. Do you attribute this exclusirely to the research work of the Bureau of Chemistry?

Mr. Campibla. Entirely, because these products had no virtue, no value at all; they represented a waste material.

The work we are doing now, through the laboratory that has been interesting itself in this matter, is that of determining some plan by which we can detect, before marketing, the extent of damage that may have been done by a freez. Periodically the citrus-fruit growing sections of the country are visited by frosts, with the result that if the oranges are frozen there is eventual ernporation to a degree that renders that fruit unfit for food purposes. You will find it is absolutely dried up, but there is no indication of that fact from an inspection of the outside of the orange. Now, this evaporation does not manifest itsolf immediately. The freezing seems to produce a condition in the cell tissue of the fruit that bings about this drying out or evaporation frequently several weeks after the freezing has occurred. If that fruit could be put on the market immediately and consumed before this eraporation takes place there would be no whjection to it, but if the producing industry ships that fruit and finds that by the time it gets to the Atlantic seaconst it has begun to evaporate it not only sustains a loss which would be visited upon it through the destruction of the fruit, but in has in addition the churges of transportation, parking, and shipping. Our effort now is o work out some way, if it is practicable, which will make it possible in this industry to determine, prior to shipment and promptly ufter the frewing, whether there had been al damage to this fruit that would warrant its destruction there or the withholding of it from markets us remote as the Athntic seabound.

Mr. Bucusixa. You say you are not able to determine, under a spocific temperature, that a particular freeze has been sufficient to cause raporation. Of course, the famer knows when there has buroll a frust.

Mr. Camprisa. He kinows when he has had a freez, but unfortunaloly, Mr. Buchanan, we liml that these freezes are not universal. 'lhe colel temperature you will gete in a rertain section will not be refleceted in the matter of the fruit that is produced in that entire loculity. You will, in some sections, through a depression in the surface, lind that the fruit will bo very materinlly afferted, whilo in at more alerated lichel it will not be alfected at all. Now, the freeze 
wo had in California last year showed that this eondetion rould he ascribed to certuin localities, but that there would he proints south of some of the frozen sections where there would be no freseging, and then points farther sonth where there would be, so that prescitily the

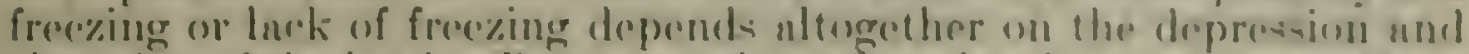
clevation of the land. Bat even where there has bern a freere, where they have had " fairly low temperature and there are indientions that some of the fruit has been dumaged, it does not follow that all the fruit on a particular tree or all the fruit in the grove will be damuged. and the question is the determinution, us promptly as posiblye. of that which has been fromen, so thut it muy he oliminated.

The only thing thent is being done by us in deteret that condition now is the employment of a plan which was devised hy the burenu based on the spereifie gravity of the fruit, but it is a plan which you can not cmploy until some severnl weeks have elupsed. 'That is just a flotation process, because after it eraporates it becomes lighter, so that the heavier oranges under this plan would go to the bottom while the lighter ornnges would flont off on top. But it takes time (1) do that: you have got to wait until nfter eraporation takes place. and that is merely a means of detection after the injury has already tuken place.

Mr. Becusax. You can do that as well by opening up your oranges, can you not!

Mr. Campret. Yes: but our experience is that if rou take a box of oranges and cut into half a dozen of them and they run bad you can go ahearl and cut 25 and they will run good, oranges taken from the same field and from the same section.

UTIL.IZATION OF แY-PIOUUCTS.

There is also reflected in the plan of utilization of waste by-products, the work the burenu has done on corncobs. I think we have told rou formerly of the progress we have made and how in that work we have found that corncobs will produce, in addition to adhesive, which seems to have commercial value, a product known as furfurnl: furfurnl is an article which lends itself to the manufncture of certain clnsses of products requiring a resinous base.

Furfurnl was un expensive chemicnl formerly, but the discovery of a supply of material from which it can be made will reduce the cost of it. It is now used in the manufacture of printing plates, phonograph records, and products of that sort. Our especini concern it this moment is the determination of just exactly the point at which the material can be used to the most economic advantage in the production of these two products, the adhesive and furfural.

We are also studying other classes of products, such as rice hulls. cottonseed hulls, ont hulls, and that elass of material which lends itself to the recovery of furfural.

\section{INVESTIGATION OF YAUPON AS A BEVFRAGF.}

Another type of work that is being done in this sume line is the utilization of casina. I spoke to you last rear about this in connection with a specific request for $n$ incrense in this bill in the amount of $\$ 5,000$ to undertake some experimental work on the use of easina for the purpose of manufacturing a bevernge. 
Mr. Bechasas. 'That is the rnupon work?

Mr. C.mprist. Yes; and I think you said that the discovery of any utilitarian purpose to which this could be placed would be a godsend to some of the southern States.

Mr. Bucnsis. I suid there was plenty of yaupon in the southern States.

Mr. Camplisu. Yes. We made an arrangement to establish a small experimental station nenr Charleston. S. C., and the work has bern done in mextremely economical way because of our ability to borrow a lot of material that wis required, and we found out that an very satisfactory bevernge can be made from this. South America very largely usés yerba maté as its clrink instend of tea. You tnke the Argentine Republic, and the supply of yerba maté is approximmtely 14:3,000,000 pounds. They produce themselves less than 2,000,000 pounds of that and they depend on the northern part of the continent for the remainder of their supply. Now, the utilization of casimu, or the youpon bush, as a beverage of the same solt as that used in South Ameriea has an economic significance which can be appreciated at once. Very nuturally, there must be determined some phan by which that beverage can be made in an economical way. One of the reasons for the high cost of tea is the fact that the leares ure hand picked in a very careful way, and an attempt to manufacture the casina product or leaves into a foundation for beverage making, in a fashion comparable to the production of tea, is something which is entirely too costly.

Mi. Br'maxis. You said they would treat them with steam and then they would break off !

Mr. Cimpresl. That is right, and that is what we are doing, but if rou treat them with steam an action takes place which prevents them from lormenting, so that what we have done with that condition is this: That by taking the small quantity of leares which can bo obtained by hand picking and rumning them through the rollers at the sume time the juice that exules from the leaves which have not been sterilized or stenmed is sufficient to infect the whole that gou run through the rollers, and thus you make possible the subseyucnt formentation that is desired in order to put the material out in the form desired; it is actunlly being put on the market now in an experimental way.

L.FATIEL ANU l'AVIR INUUSTIY.

Out of this sume fund we ne, in our lenther nud paper laborntory. giving considention to the lenther situntion of the counter. Wr renonghige thut there is a big field of work in fostering the more

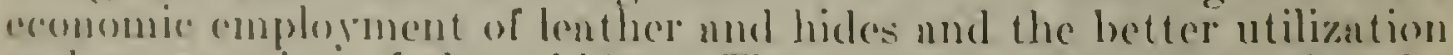
and preparation of these hides. The sprend between the price the farmer gete for hisdes and the price ut which ho has to buy lenther

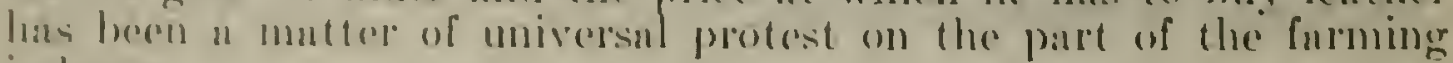
inclustry.

In the last fow youls we have issucel bulletins on the better treatment of hides: how to prepure them in a manner to get the maximum prine for them, nud alsu on the treatment and keeping of lenther. Them and serernl lines of work that onght to be laken up in comneclion with that. Wre recognize thut in this commtry the supply of hides and leather is by no menns adequnte for our demands and that 


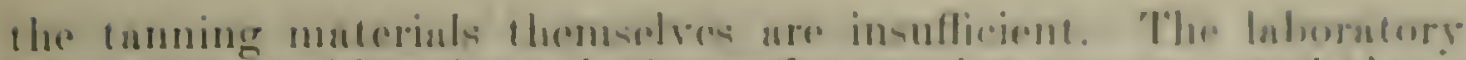

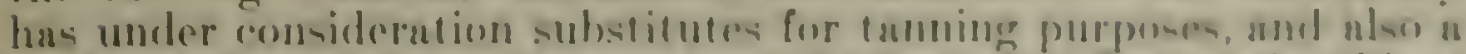
studr of the propere preservation of the lesthere One of the thinge

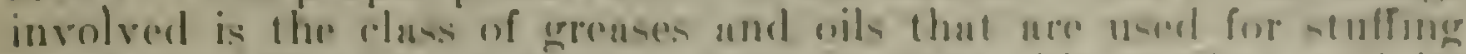
purposes. The life of leather depends upon thin stufling, and its durability depends upon that. Furthermore, the prohlens of ushemical and physeal kind involverd in leather temting, an an durability

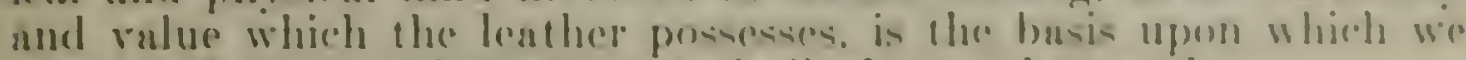
control all of onr other eflorts and all of our wther work.

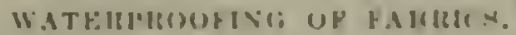

The sume lahoratory is now andirely concerned in a comsideration of the waterpronfing of fahries. These fabrics that are undel in the nature of canvas for shock and hay coverings, for horse coverings: panlins, und the like, represent in their agerecante a very matcrint expense to the farming industry. The same thing is true with respect to that section which uses certain types of fabries for tobaren growing in rertain areas. The outlay in money is considernble, and our concern has been to determme some plan by which these fabries can be made both water and mildew proof and prolong the life of the articles. As an indieation of the value of that work I may suy that the War Department consulted our hurean in connection with purchases of fabries such as we have in mind, and in one notable instance they called to our attention a saving of $\$ 24.000$ that was effected in a single purchase, not mentioning at all the adrantage they get out of the material by reason of more intensive service: that is, its incrensed durability.

STUII OF MIFFRENT TYRFS OF PROTRISS.

This fund also supports the work in our protein laborntory. The protein luboratory is concerning itself with the study of different types of proteins. We know that one of the essentials 'for animal tissue is nitrogen, and that ther get this only through the proteins they take in the form of their food. Formerly it was believed that all proteins served the same purpose, but we have shown that is not true at all. The work of the laboratory has demonstrated that there are different types of proteins and that some of them are lacking in rertain amino incids of which all proteins are supposed to be composed. We found with respect to corn that wo of the essential arids are lacking. and that if fed on rorn exclusirely an animal will not thrive and not develop as it ought to. The advantage of this is that it gives knowledge as to the defects in certain types of foods and also knowledge as to the particular trpes of proteins out of which these defects can be supplied. If rou take a corn product and supplement it with soybean menl or peanut meal, you will have a completely halanced fond.

There is a tremendous lield for development in this direction and also in the employment of certain types of our own veretable oils. the fostering of a more intensive use of them and a study of their chemical compositions. That, and the fundamental work we hure under way on crop chemistry, questions to which Doctor Skinner. the assistant chief of the bureau. has been giving his particular attention, I would like to have stated in a hrief way hy him, with your 
permission. I want to hnve him point out the significance of this work, because we are asking for an incrense of $\$ 22,500 \mathrm{in}$ it, which, in the aggregnte, will make a small appropriation for the support of the various lines of work we linve under way, especially when you recognize the scupe of the field in which this work should be carried on and consider the fundamental economic significance of it. Doctor Skinner, will you make such a statement?

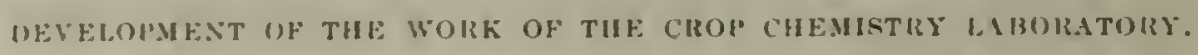

Ductor Skixxlar. A purt of this incrense will be used in the development of the work of the crop chemistry laboratory. This work contemplates a careful study of crop composition and is made desirable and necessury hy recent derelopments in agricultural ehemistry, and particularly in nutrition. by which we have been made aware of the significance of some things which have been overlooked in the composition of crops, such as the recently discovered ritamins, and the haracter and composition of the proteins to which Mr. Camplocll has just referred, and also our greater appreciation of the significance of some of the imorganic materials contaned in crops, such as iron and calcium. Heretofore research work in agriculture, especinlly in agricultural chemistry, has been aimed very largely townd increased production and without a thorough appreciation of the necessity for un understanding of what I should fike to term the quality basis. lather than the quantity basis, of crop production, using the word "quality," in the sense which I hare tried to indicate; that is, the fundimental character of the material user in its relation to nutrition.

It is rather diflicult in work of this kind to prophesy or indicate its cconomic significance, but such work is basic in its character and may be the determining factor in great economic derelopments. One thing we have in mind to do in this laboratory as illustrating the pussible economic significance is this: There is a prejudice in Lurope agrinst Amerionn com. It is beliered that the flint corn, which is grown so lurgely in South Amerien, particularly Argentimn. is of more value in feeding than our softer varieties of corn. One of the reasons, perhaps, is that in Europe practically all of the corn is used very fincly ground, while in this country we use a great deal of corn unground or cracked. But there is that feeling that our corn is inferior. In Spatin, if my memory serves me correctly, only uhout 10 pere cent of the imported corn comes from Americin, the remuinder coming largely from Arentina. Therefore we need to make a stmly to doterming, first, if there is nny real basis for the ulleged superienty of the flint corm over our varietices of eorn. If that is foumd on he true from this resenteh work, then it behooves us. rither to develop a better strain of dent corm or to undertake the production of $n$ harere amount of flint corm, especially for the expent irute. If it is found that there is nothing in the alleged superionty of the flint corn, then it will he necessary to undertake educational

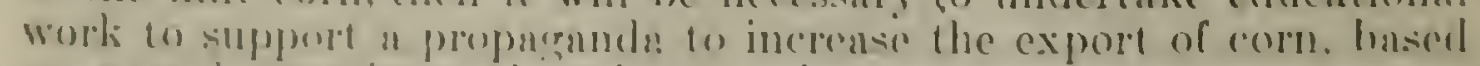

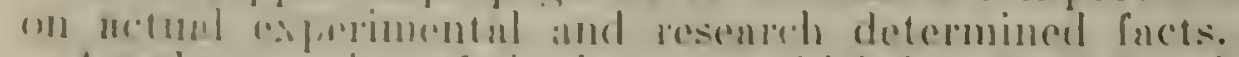

Another portion of the incersse which has been asked for will be devoted to the work of the protein laboratury that is, in expmeding that very improtant work. Mr. ('amphedl has alronly louched upun thai. The work done by this laberatory is the rery basis of a clene understunding of the needs mol the development of rational 


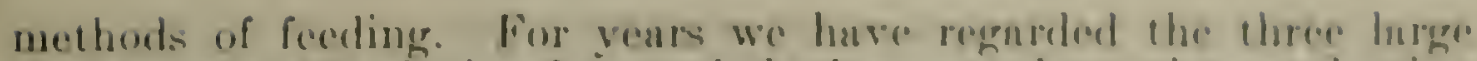

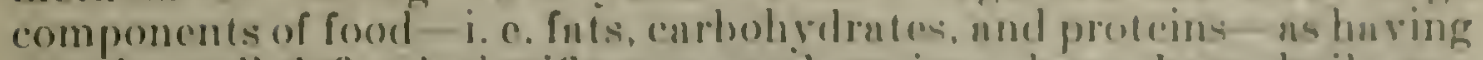
cortain woll-defined significmore, and metons huve been buile up. and textbooks have been writlen on the subject of nutrition, based on those throe proximntes of food mutcrinls. It is only within recont yeas that it has been determined that all proteine are not slike: that they vary greatly in the value of the anino-acids compese-

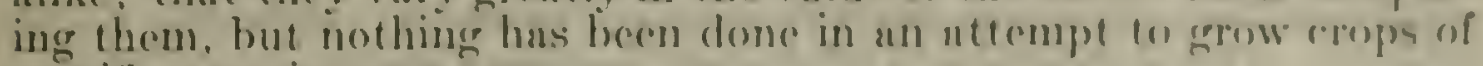
specilic protein content.

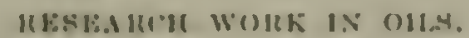

Another phase of this researeh work has fo do with oils. Here we can point with some definite signifiennee to the results of gesenreh work in an economic way. A geod many decades ngo cottenn seed was ulmost a waste product. but finully methods of relining cotlonseed oil were worked out by the chemist, nnd there wis mude uritable a great source of fat for human consumption. Back of that, however, there had been research work done fooking to the substitution in some of the organic acids of certain chemicnl elements which would change the character of the product.

The chemist who first determined that hydrogen could be injected into a molecule of oleie neid, thereby changing it into stenric ucid. made it possible to change an oil to it solid fat. The significance of that was not apparent. when it wis done, but that very thing has been worth hundreds of thousands of dollars to agriculture in this country and especially the agriculture of the South. According to the latest statisties I have, one firm, that puts out Crisco, manufactures annunlly, or did in 1916,60.000,000 pounds of hardened fat. baser on this chemical investigation. which made it possible, through a proper chemical renction, to make liquid fat into a solid muterial which could he used for shortening purposes. Of the approximately $1,400,000,000$ pounds, according to the latest statistics we have, if erude cottonsed oil, nbout so per cent is now used, either directly or indirectly, in the hardened fat preparations. This has ndded materially to the wealth of the Nation, and particularly to the woalth of the South, hundreds of thousands of dollars.

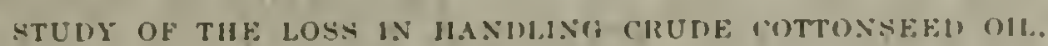

Another project which we wish to expund is a study of the refining Joss in the handling of crude cottonseed oil. The unsaturnted compounds of the coltonsed oil would theoretically account for $n$ refining loss of only about 2 or $2 \frac{1}{2}$ per cent, but, as it matter of fact, it is nearly 10 per cent, due to the fuct that there are certain physical and chemical difficulties in the matter of refining that have not yet been solved. If we could reduce the refining loss a per cent, indeed. if we could reduce it only I per rent, on the basis of $1,000,000,000$ pounds of cottonsed oil, the economic gain would be comormons.

These are three of the main projects, on which, if this increased uppropriation is allowed, we propose to concentrate. Our plan has been to concentrate on those things which scemed to have the most important economic signifiennce, and I think this statement perhatps covers sufficiently the three projects which we propose to expand. 
Mr. Avversor. I notice that you are apparently abandoning the work of the curbohydrate investigations?

Doctor Skixxer. No: Mr. Campbell will explain that.

Mr. Caupreser. There is a special appropriation for the work of our carbohydrute laboratory in connection with the manufacture of sugars and sirups, which we will come to under the particular items later on. The carbohydrate laboratory has been giving its attention, largely, to two classes of conditions. First, that which involves agricultural research primarily on carbohydrate products, and, second, the study of industrial problems with which the manufacturer is concerned in the ullization of agricultural raw materials, such as in the manufacture of cane sirup and the manufacture of sugar itsclf. Recently the work of the laboratory has been directed in an intensive way to some of the technological industrial problems because of the urgency with which a need for their solution was presented. Our force has taken that up actively and has studied on that to the exclusion of other lines of work in the belief that we could solve those problems in something like a year. So we suspended action, temporarily, on the strictly agricultural research in the carbohydrate field and employed our force on the technological matters.

If the appropriation, however, is not sufficient to make possible the study of technological problems in the way we had in mind, very naturally, a rearrangement of that project will be effected for the purpose of continuing the basic agricultural investigation which is now supported out of the agricultural investigational fund in a part of the carbohydrute laboratory.

\section{COLLABORATION WITI OTHER GOVERNMENTAL DEPARTMENTS.}

The next item is for collnboration with other departments of the Government desiring chemical investigations. The Bureau is called on in a great many wars to do work for other departments. The grentest amount of work we had to do was during the period of the war, when there was such a heary demand on the part of the Army, the Nary, and Marine Corps for the examination of supplies of food that were being purchased. While that demand is not existent now. the varintion is in degree only, because we do consult with them with regard to the specifications they issue as a purehasing basis and then make exuminations of the food upon delivery to see whether or not thry comply with those specitications and the terms of the purchase rontrincts.

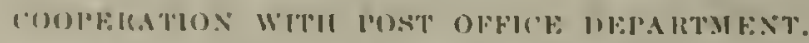

In aldition to that we are working with the Post Ollice Depart-

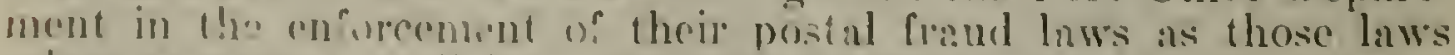
reblate to putcont molicine preparations particularly, handting those matcer's from the standpoint of the use of the mail for the purpose of effereting their sule. Most of this monery in fact, groes for that very purpuse, the Pust Office Department recogrnizing that it is not "eplipped le give consideration cither to the chenical composition 
or to the extent to which there wus frumb involsed in the therupente chains made for certain preporations und, thereforr, the P'ost Oflice Department hus culled upon the Burran of C'bemistry for ussistance in this work. Wo lase appreriated thut it was in molertaking sympathetic with the purposes of the food and ding ane itself and w\% thime used the biggest portion of this fund for that.

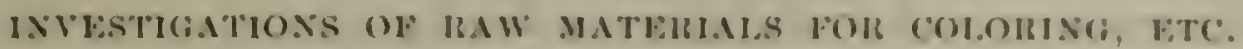

The next itom is for the insestigntion und experiment in the utilization for coloring, medicinal and technical purposes, of raw materials grown or produced in the lnited states. This is the fund that supports the work of the eolore laboratory. This appropriation was asted at a time when the department of burenu undertook to assist the color manufacturing industry in this country by a determination of methods by which it would not only utilize the intermediates arailable hut could, in fact, manufacture them and not bo dependent upon foreign soures for that supply.

That work has changed in its eharacter very materially since then. You know that some of the work of the laburatory hus affected tremendous economy in the manufacture of some of these color products or the basic material from which they are mude, such as phthalic anhydride, and its attention, instead of being given now so much to the question of tonnage production, as was the case originally, is being directed to some special phases of color work which the industry itself is not taking up. One of the grentest difficulties confronting the industry in color manufacture is some means by which there can be a definite and correct identification made of colors. It is essential to make that study from the standpoint of art and the ralue of those colors for dyeing purposes. We have been working in the past year upon methods of identification by which, upon proper annlysis, definite colors could be identified and the extent of the impurities made known.

INVFSTLATION FOR A STABLE BLLOGICAL STAIN.

In addition to that we have also been giving particular attention to a concern which has been manifesting itself on the part of the scientific world, and that is for a stable biological stain. This biological stain is used by bacteriologists, pathologists. physicians, and veterinarians in staining, studying and identifying disease-producing organisms.

That particula stain was derived cxclusively from Germany before the war. The firm that manufactured that stain went out of business as a result of the war, and, as a matter of fact, it is not being manufactured at all now. It is no longer arailable, and because of the fact that it is not a tonnage proposition. it is a question that does not in itself appeal to color manufacturers. But the replacement of that particular stain or the determination of some other stain that will unswer the purpose is of the utmost importance to the scientific world. The Burenu of Chemistry, in cooperation with scientific agencies that are undertaking to lest out the fabricated dyes for this purpose, is now trying to determine some stain that will answer that particular service. 
MANUFACTURE OF SYNTHETIC THYMOL.

There is another thing that is coming up in connection with the work of that laboratory that I may refer to here and that is the employment of cymene, which is a waste material from paper factories, as a basis for the manufacture of synthetic thymol. 'Thymol is a disinfectant that has been used extensively by the medical fraternity in this country and it also has another signifieant use in the treatment of hookworm.

This product has been brought from abrond exclusively, but we have found it is possible to manufacture from crmene a synthetic thymol which seems to have every attribute that the product that we have heretofore depended upon possesses. Thymol now sells for about $\$ 4.50$ a pound and we calculate it can be made in this synthetic fushion for about $\$ 2.50$ a pound. When you consider that there are something like 2,000,000 gallons of cymene wasted each year in the paper factories of this country and Canada the ceonomic significance of that is apparent. So that our line of work right now in this color laboratory is in specializing on matters connected with assisting color manufacturers in putting outcolors on a tonnage basis not only. but in giving consideration to those feature of color fabrication and color identification that are essential but which do not, on account of the smallness of the output, give any particularly inviting reason for manufacturers to engage in that study themselres.

INVETIRATION OF MFTIODS ANI) MANCFACTURE OF S!RLPS AND SUGAR.

'The next item is for the investigation and development of methods for the manufacture of table sirup and sugar and of methods for the manufacture of sweet sirups by the utilization of new agricultural sources.

We are asking for an incrense in this appropriation. I told you last year of the work that our carbohydrate laboratory was doing in the South in fostering the use of invertase in the manufacture of cane sirup as a means of preventing fermentation, on one hand, and crystallization on the other. 'That work has been accepted with an cuthusinsm on the part of the cane sirup producing sections that. exreeded anything we nnticipnted. In fact, lnst yenr, you may recall, that the demand was so extensive that we felt it should be submitted to the department and the department, in turn, through the Bureas of the Budget, submit it to Congress. We took it up with Congress and you effected an even greater increase in that item to meet the emergency at that time. In addition to the work on cunc sirup we are also studying, in an intensive way, some of the technological difliculties with which the sugar manufacturing interests of this country are confronted at the present time because of their failure to get a proper vield of sugur from the material out of which they are manufacturing it. You talie, for instance, the beet sugar incrests of the comntry, and outside of the State of Culifornin, and purticulury in thase sections where stornge is necessary, there is a very derided diminution in the actual yichl from what is the actun sugar in the produce itself. 'That loss, which is borne jointly by the farmer and by the munufacturel-and incidentally, in this instance 
the manufueturer himself is in most instances a farmer-has been variously astimuted at from $\$(1,000,000$ or $\$ 7,000,000$ to $\$ 10,000,000$ unnually. We have beren working on that problem in the laboratery und at this point I would like to usk, with pour prermission, Mr. Paine to muke a briof stutement with reagurd to it.

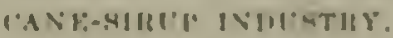

Mr. Poxfe. The cone-sirup work has for its objoct the useistance of the cone-sirup industry in the South. At the present time sugne ranc is raised gonerally thoughout Floridn, tho southern purt of South Carolina nod the southern halves of Cieorgin, Alabunu, Missis-

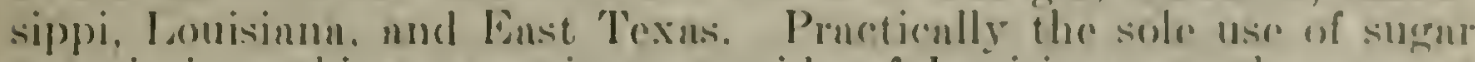
rane is in making anne sirup), outside of Louisiana, at the presint time.

Mr. Axmensox. You say that in these other stutes it is not used for making sugrar?

Mr. PaIXF. In Lonisiann it is used in making sugar and sirup. while in the other States it is in general only used for making sirup.

Mr. Bucuaxax. They muke sugrar in Texas, do there not?

Mr. Pane. I small amount.

Mr. Bucnaxax. Are not the bigrgest refineries in the United States in T'exas?

Mr. P.ISE. I do not think so.

Mr. Bechuxix. One of the biggest, nnywny?

Mr. Panve. Thare is a large one, but. I do not think it is the largest. At the present time cane sirup is made by a large number of farmers; it varies greatly in quality and has no stable and established commercial outlet; it has primarily only a neighborhood sale.

One of the objects of this work is to assist cooperative cane sirup associations in producing $"$ uniform grade of cane sirup that can be sold through regular commereial channels. We are cooperating with the farm burean federations in Texas and Alabama with the iden of assembling the sirup at central blending and canning plants for the purpose of mixing it io uniform grade and giving it sufficient trentment by the invertase process-which we have developed for presenting crystallizntion-and be able to turn out cane sirup of high and uniform qunlity.

High-grade cane sirup should have the following points of (punlity: Freedom from rrystalization, (lenrness and freedom from dregs and sediment, and attrative color and flaror and standarel density.

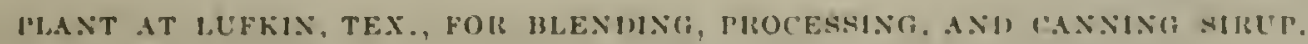

This is the psychological time to do this work, if it is ever going to be done; and if it is ever going to be done it will have to be through an organization of farmers, and it has only been in the past year or two that this has been made possible through farm burenu organizations. 'They have no facilities for the technical part of the work, and they have asked us to give them the necessary technieal assistance. We have drawn up plnus for such a rentral plant and method of procedure; and this first plant of its kind is now heing erected at Lufkin, Tex., and is expected to be in operntion in about two weeks.

Mr. Axvensox. How lnrge an investment do these plants require? 
Mr. PAixe. This plant at Lufkin will require about $\$ 25,000$ capital.

Mr. Axdersox. What would be its output, normally?

irr. Parne. They expect to handle about 300,000 gallons of sirup' this year: this is expected to be increased later to 500,000 gallons.

Mr. Axpersox. What would that be worth?

Mr. PAIxE. They should get at present prices about 75 cents a gallon.

Mr. Buchasax. In this plant you are speaking of, is it for the manufacture of some substance to keep the sirup from fermentation and from solidification, or is it to manufacture sirup?

Mr. PAxs. The sirup is made by the individual growers, the farmers themselves.

Mr. Bucinsax. I know, but what is the plant for?

Mr. Paxe. The plant is simply a blending, processing, and canning plant. The finished sirup is made in the customary manner by the growers, and the output of the individual producers is brought to this plant and mixed on a sufliciently large scale to give uniformity of quality, which they do not have now; it is then treated with invertase to prevent crystallization and finally canned.

Mr. Buchaxax. This plant, then, crushes the cane to get the juice out of it and then boils the juice to sirup; and then you mix it?

Mr. Pans. No; they have indiridual mills, just as they hare always hate.

Mr. Bucmaxas. The individual producers of the sirup bring it there?

Mr. Parne. They bring the finished sirup there.

Mr. Buchuxs. Then why could not this mixture, or treatment, or whatever it is, be made right at the mill that manufactures the sirup ?

Mr. Puxw. Because the sirup varies in quality as made by these individual producer's. The producer himself at his mill is not able to turn out the same quality of sirup constantly throughout the season, and no two growers produce the same quality of sirup.

Mr. Buchasix. Let us see about that a minute: You talie this ane and crush it and get the juice out of it, and thon you put it in the vats or pans and you boil it, and you have an instrument with which to determine the sirup-making point to which it should be boilarl!

Mr. Patne. Yes.

Mr. Buchosax. That instrument will determine that, if it is the same character of instrument in all mills?

Mr. Patne. Yes.

Mr. Bechaxas. You rould boil it down to exactly the same density, I suppose you would call lt?

Mr. Pastr. Yes.

Mr. Berondx. And why would it not be the sime!

Mr. P'axk. You get the same density, but you do not get the same quality, the sume flavor and color, becouse the flarore and color of the sirup ratres with the variety uf eane, the type of soil it is grown upon, and the facilities araibhle and care used in making the sirup.

Mr. Bermass.s. Do you recommend a treatment of the juice

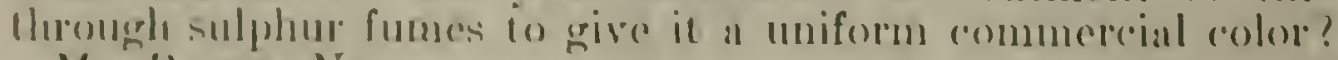

Mr. I'sist: No.

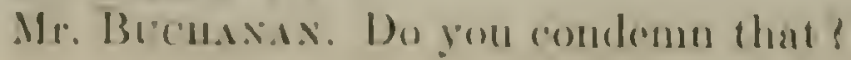


Mr. Pasx. No; we do not condenn it cither. but wo de not think it is mecessary.

Mr. Bucolixas. You have seen it done, have pous

Mr. Parse. Yes; I am thoroughly familiar with it.

Mr. Bucuanas. You know that it gives the sirup a benutiful color?

Mr. Parse. Yes. But a groat many people do not like the fluser, and I do not think the chances ure very grent for extending the market for sulphured sirup.

Mr. Bromaxax. Then it would cost \$2.5.0(0) to make one of these mixing plants. What do you do? In standarlizing the sirup), do you boil it again!

Mr. Pasce. It is only necessary to boil it a little to bring it to the proper density, in case the density is not constunt when delirered at the plant. But the principal oliject is this, to mix the sirup on $\Omega$ sufficiently large scule so that rou get " uniform product which is constant in flavor and color. Fou see, by mixing on a large scale, you equalize all those differences in the sirup. ns made by the large number of individual producers on a small seale. 'The cost of the plant is much less than $\$ 25,000$. I was referring to the cupital required.

Ir. Bucusxax. Can you not preserve the sirup from solidifying into sugar or prevent fermentation without all this standardization that roin spenk of?

Mr. Purfe. This process that we hare dereloped, which is in use in a great many mills at the present time for preventing crystallization, can be used. if desired, at the mill where the sirup is made.

Mr. Becux..x. You say "for prerenting crystallization." How about fermentation? 'That is more important than crystallization.

Mr. PAINe. We prevent fermentation indirectly by making the sirup thick. The thick sirup will not ferment is readily as thin sirup, but the thick sirup would crystallize almost solid if it were not treated by this method.

Mr. Bccusax. But you prerent the sirup souring by making it thick, and then adopt a method to prevent crystallizing into sugar?

Mr. P.Ixf. That is the point.

Mr. Skixxer. That is accomplished by the use of invertuse. 'This thick sirup would crrstallize.

Mr. Beculsu. I know that; I used to make sirup.

Mr. Skivxer. This is a method for preventing that.

Ifr. Bucnasax. I see. What do you get this invertuse from and where do rou get it?

Mr. Puixf. We make it from beer yeast, a by-product of mnnufacture of nenr beer.

Mr. Bucusis. A man could not have that thing in stock. could he! [Laughter.]

Mr. Axpressox. Is there anything further on this?

Mr. Pass. I want to explain why the invertase is used at the central plant. This is because we are going to assemble all this sirup there anyhow, to mix and can it, and that is the cheapest place to use the process.

Mr. Axifrsox. How large a production area will n plant of this size take care of ?

Mr. Puxf. It is a question of transportation costs. 
Mr. Axmensor. That is whas I am getting at.

Mr. PAINe. They are trying to get a refining-in-transit rate. They expect to get that in Texis, and that will facilitate matter's greatly.

Mr. Bucuasax. Is it possible to take this invertase and use it at a little mill in manufacturing this sirup and preserve the sirup?

Mr. PAsie. Yes, sir; they can do that. A great many mills are using it that way.

Mr. Becrusix. 'That is the practical way, and it is the only practical way.

Mr. Pinxe. I want to say this, howerer, that I am convinced that the only salvation for the enne sirup industry is through concerted netion of organizations of farmers who will get together and furnish a sufliciently large volume of uniform sirup to create a stable commercin! outlet. If they do not do that, there is nothing to be hoped for, so far as extending the market for cane sirup and increasing the acreage of sugar enne is concerned.

Mr. Axdensox. I think you are quite right. A man will go down to the grocery store and he will buy some cane sirup. It does not taste just right. Then he will go down and get unother can and it is all right. But once he gets one of these cans that is not right, he will quit buring that kind of sirup.

Mr. Bucinasas. Of course, if you want to pay for sirup produced at a little mill and ship it to a central plant and remanufacture it in order to get everything tasting just right-if you are willing to pay for that, go ahearl. But $I \mathrm{am}$ talking about the practical part of it now.

Mr. Parne. I think that is the most important part of this matter, really. In talking to farmers in Texas, a number of them told me that they would rather extend their acreage of sugar cane than that of any other crop they grow; that if they can get a reasonably stable return, there is more money in it than in any other crop they make. If they grow 1 acre or so they can sell the sirup to the neighborhood market and there is no trouble, but if a man wants to grow 20 or 50 , or perhaps 200 acres as one man told me, he has got to hare some stable commercial outlet, and he has got to sell through established commercial channels. There are a great many people who want to extend their acreage of cane. There are large areas of cut-over pine land in southern Mississippi, northern Florida, southern Georgia, and Alabama where the lumber companies are tring to find some good crup to grow on that land. They are paying a great deal of ittention to sugar cane, at the present time. There is a tendency to increatse its acreagere.

But what is the use of trying to increase the acreage of sugar enne or bother about the problems of growing it unless you ean sell the sirup! And your ann not sell it suceressfully unless foul can crente a a uniform article, and if you have not a stable, miform article you cun not soll it to (onsumers through estublished commercial channels. 'Tluat is the kery to the whole thingr.

Mr. Axmasson. 'That is the trouble, as I apprehend, with the whole agricultural situation producing something that nobody wants.

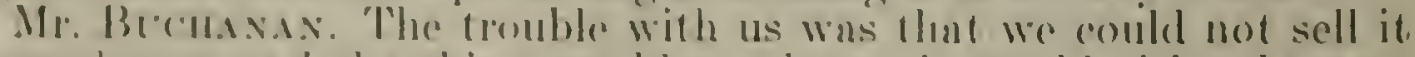
down heme, and the thing would not kecp): it would cither herome silgar or solls.

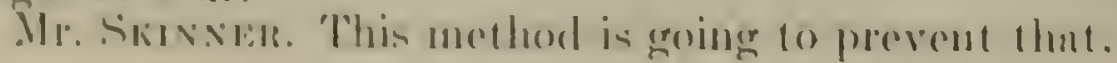


Mr. Bucosisas. If there were two or there cold montles, it would keep, but just as sonn us the wonther got warm it womld ferment or sour. That was the trouble with us.

Mr. Sasxiss. We have solved that problem.

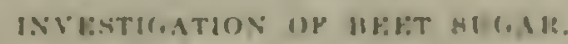

Mr. ('.smbusto. Won't you suy something. too, about the work at the heet-sterar factories, licenuse that is one of the serions problems we have to concern atrsedres with. Troll something ubout that, since we are asking an increase on this itom.

Mr. Paxk. This is morurding the winste in production of beret sugar after the beet crop is made. After the full rexpense of rusing beets has becn incurred there is a loss of something like $\$ 10.000,000$ unmunly in destruction of sugnar or failure to recover surne. I considernblo part of this loss is in fuilure to recoser sugne efliciently from final molasses. In making cane sugar they do not recover silgar from final or exhausted molasses. In the beet suenr industry they use such a process and if the process they use were perfect there would be no molasses: in other words, after recovering all the sugar from heet molasses which can be obtained by crystallization the remaining sugar can be extracted by a chemical process. In parts of California the process used is practically 100 per cent efficient. In other parts of the country there is a big loss which is due to the fact that the sugar beet does not fully mature in hardly any section of the country except southern California; also, it is stored in other sections. They must harrest the beets faster than the factory can use them in parts of the country outside of California, and pile them up, and they undergo deterioration in stornge.

There is a loss during storage of some 10 per cent of the sugar in the beet, which is lost while they are piled up. This also unfarorably affects the process of recovering sugar from molasses, so that the factories are only able to utilize about 65 per cent of the molasses for recovery of sugar; the other 3.5 per cent has to be sold for whatever it will hring. The latter has formerly been used very largely in the manufucture of mixed stock feeds.

Mr. Bucusxix. In other words, they are getting only a certain per cent of sugar out of the beet now, when they ought to get a grent denl larger percentage?

Mr. Pane. That is it exnetly. As long as they got a pretty good price for molasses for stock feed it did not make so much difference, but the price now is largely nominal and some of it enn not be disposed of at all. We huve been sturlying this problem nnd have been making considerible progress. We hope before long to have the menns of making the process practically 100 per cent efficiont.

Mr. Andeizsos. If you have got to store these beets you can not stop that, can you?

Mr. Pañ. I am referring to the recovery of sugar from molasses. Of course, they hare got to store the beets. The only thing they ean do there is to learn more eflicient methods of storage and reduce the loss there as much as possible.

Mr. Campiser.. There are some beets grown under certain conditions that lend themselves to stornge without as much loss as other types of beets in other sections. We have already made specific 
recommendations which will obviate the loss due to the storing of beets indiscriminately. This work has been directly under the supervision of Mr. Paine. They hare been concerning themselves particularly with the remoral of those impurities that are in beets or in the molasses as a result of the deterioration of the beet through storage which prevent ervstalization. The solution of that question is a complicated industrial chemical problem.

We have made splendid progress on it. We have made application for a public service patent, and we are expecting to effect arrangements by which the results obtained on a laboratory scale can be worked out in actual factory prorluction.

FOR ENFORCFMENT OF THE FOOD AND DREGS ACT.

Mr. Axnmsox. We will now go to the next item.

Mr. Campresl. The next is the appropriation for the food and drugs net, page $17 \mathrm{~S}$. We are asking for an inerease in that appropriation, Mr. Chairman. I stated to you last year that while we were asking for no increase at that period I foresaw that the approprinte representative of the bureau would come before and ask very early for an increase in the fund.

The enforcement of this law is getting more difficult and more expensive every year. That is naturally to be expected. 'The conditions with which we are confronted at the present time in its enforcement are quite different from those that obtained originnlly.

The forms of sophistication that exist now are more subtle and more devious than those that were originally encountered. The enforcement of the law does not inrolre the simple mechanical operntion of going out and collecting a sample and showing that it had been shipped in interstate commerce and in making a simple examination to prove that the product claimed to be in that pachage was not that product at all. Proper enforcement now requires thorough study to determine methods which ean be employed by these laboratories engaged in the simpler form of work, for the purpose of identifying the type of adulteration that has taken place. It is necessary, in those circumstances, to derote some of this fund to the laboratories that we designate as stafl laboratories in the bureau, which nre giving concentrated study to these types of adulteration and to the question of evolving some method by which, upon the examination of an objective sample, this form of aduilteration can be detected.

Of course, that is no simple and no easy matter. And to the extent that we cmploy money for that purpose in carrving on those various studies which are essential and which form the basis upon which all of our work depends, to that extent we withdraw from the active fiedd op arations funds that would otherwise be spent in the employment of inspectors and analysts to be stationed in our branch aboratories. Wa have a very material depletion in force, from the standpoint of ficld activity. Wro have now less than to inspectors where we formerly hat a stall of 51 inspectors. The force, as a matter of fact, if we are to mantain the sume standard of effeciency in our operations, should be increased in proportion to the increasing difliculties that we emereunter, but the comverse of that is trae now. 
In addition to looking aftere the domestie trallice we are requirod also, as you know, lo grive attention lo importations. The law applies to both import und expost trullie.

Since the war we have had really more work o do than wo had at any time previous to that, without regurd at all to the volume of food imported inte the country. Bafore that time there hasl heen something in the mature of a clasitiention on standurdizntion in cortain elasses of food products in cortuin sections of foreign contutrion from which they cance. But that was torn to piocess during the prepiod of the war, and we have found products that seromed to be made formerly in un unobjectionable way being offered for entry in this comntry with ontirely different composition from that which wo originally knew.

So the work really has incrensed rery materially from the standpoint of import control. We are not nble to meet the situntion at all with our present force, and I do not pretend to sny that we will completely meet it at all if we are granted the increase that is asked here.

I told you last gear of a visit that we had received from a committer of importers representing the import trade in New York. who had come to Washington for the purpose of seeing you and the corresponding committee in the senate to ask for nn increase to this approprintion, to be applied specifically to the Now York liekl, to increase the force and the facilities there for doing our import control work in a more expeditious way. After we explained the circumstances to them they went buck to New York. But the industry renlizes the situation and has denlt with us in a sympathetic way on the score of our limitations.

It is a serious thing when you eflect delays in import products particularly. You take the congested sections in New York, where they do not have adequate stornge facilities under Government superrision. and it is only a very short time until the elemurrage will ent up all of the importers profits. So it is imperative that such action as we do take be taken promptly if we are to give any considerntion at all to the welf are of the tride; and we do this hy using our julgment, in so far as our experience will permit, in discriminating in the cluss of products that we give attention to.

\section{MAINTENATCE OF JABORATORIFE.}

It is necessary to maintain hboratories at eertuin of the ports of the country for the purpose of expeditious consideration of import shipments. 'The overhead is fixed and definite. But up' to the present time we have not the operating funds to malie our activity economical, because it is not at all adecpuate from the standpoint of our existing overhend. If we get this money that we are asking for here our furpose is to employ it in bringing the forere up to something approaching normal, by the appointment of additional inspectors und additional chemists. 


\section{IXSPECTION OF IMPORTEI FOOD AND DREGS.}

Mr. Buchasax. Do you inspect food that is shipped in here?

Mr. Campizla. Oh, yes; imported in here.

Mr. Becuaxis. How extensively do you carry that work on?

Mr. C.MpBELL. We should do it with respect to every importation that is brought in, but we can not do it. The law itself provides that the Secretary of the 'Treasury in his consideration of products from the standpoint of the assessment of duties shall deliver to the Secretary of Agrieulture samples upon request of the latter for examination.

When this is clone, if our cxamination shows the product to be adulternted, we report that fact to the collector of the port, and state to him that it is in contravention of the Food and Drugs Act, and recommend detention of the shipment. But we should do it with respect to importations of foods and drugs at every port in the country. That, howerer, is a physical impossibility, and could not be done if the fund appropriated were multiplied several times, when you take into account the entries of all of the border ports, not only on the seaboard but on the Canadian and Mexican borders. We do have in cooperation with the customs officials what we think is a sufliciently well established plan to permit fairly reasonably aderiuate control of the importations of all types of foods and drugs.

Mr. Buchasax. You merely have an understanding, then, with the customs officials at certain ports that if any commodity looks suspicious to send you samples?

Mr. Campbeli. Our men go to the ports and they attempt to teach them. As a matter of fact, we attempt to train the customs official into a food official. You take a port, for instance, in the nature of New Orleans, or, say, Galveston, and that port will have several subports of entry, according to the customs scheme of territorial division. The oflieer that will be stationed at the Mexican border points, for instunce, will report to this collector or officer at Galveston.

We endenvor to have our laboratories established at points where the collectors themselves are located, and through their deputies arrange for appropriate supervision of all importations of foods and Irug products at these subports, and if they themselves realize the condition of the kind we have deseribed to them they forward samples to us and hold up the shipment and we make the examination.

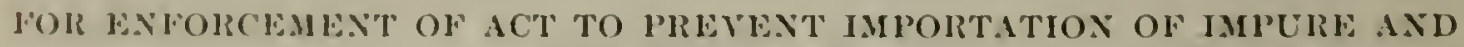
UNWHOLESOME TEA.

The next is the enforeement of the import ten act. This act and the body enforeing it was transfered from the Treasury Department (1) the digricultural Department ubout two years ago, I think. Forty thusand was lhe amount that was appropirated at the time it was in fores in the Treasury Dipartanent.

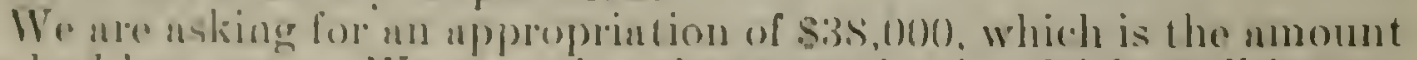
wo had last pour. Wo are using that organization fuirly well intact, attempting $i_{0}$ brigade it with our food and drug orgunization so as to make the work betweren the two, as far as it is possible to do it, 
lens expensise than would otherwiar be the cuse if they were working indepondently.

Mr. Bernsixas. Are you finding any impure imported toa!

Mr. (amplast.. ()h, yes: we found more impure imported teas

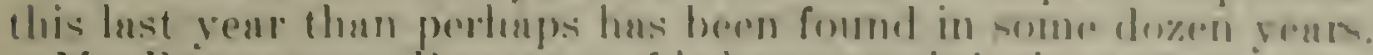

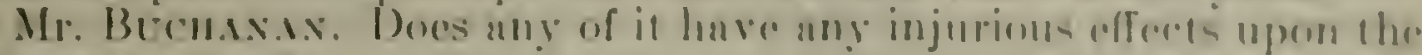
hum:n systam?

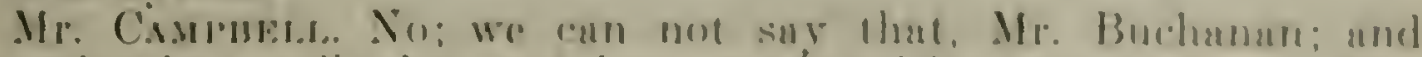
cxamination really has not boen male with that in mind. Fon know the tea impore ant is an extrousely urbitrary law. It given

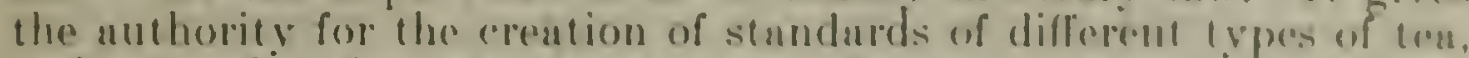
and a tea that does not compure with this standard which has beren ancered upon and set aside reither from the standpoint of the inpurities it pussesses or from the standpoint of the ("up) guality it has is not permitted entry. So the work roally is on that hasis.

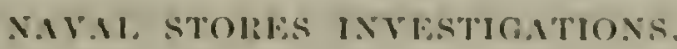

The next is the item covering investigation of grading. weighing. handling, transportation, and uses of naral stores, definite type samples thereof, cte., and we are asking for no incrense on this tem. This is an item which represents something in the nature of continuous work. Doctor Veitch. whe is chemist in charge of our laboratory having to handle that particularly, I would like to have make a statement of a few minutes length to you on that, so you can appreciate in a general way just what we are doing.

Doetor Vertci. Mr. Chairman. perhnps I can best illustrate this work by this statement: About a month ago we were asked te join with the 'Turpentine and Rosin Producers' Associntion in the inspection and study of a big lumber plant in Nabama, which for several years had not been making much money on turpentine and rosin. A party of us went there and spent about 24 hours on the joh, and we reached a unanimous conclusion that due to faulty methods of operation that company had failed to make about $\$ 24,000$ that it could have made with good up-to-date rational methods of operation and at a cost of approximntely $\$ 4,000$.

That condition exists very largely throughout the turpentineproducing belt. Many operntors are in exactly the sume condition. and we propose to be in a position to help them to elininate these uneconomic practices, to prevent their losses at the still and in the woods. and to bring their production methods and manufacturing methods up to the practice of the best operators. That will sure a considerable mount of money to the producers.

On the other hand, Mr. Chairman, we are eonstantly having problems presented to us in regird to the use of turpentinc and rosiu. You douhtless know rosin is heing more and more largely substituted for fossil resins in the munufacture of rarnishes and paints. 'This is due to the fact that these resins are hecoming searcer and hierher priced. and we ure lenrning to use rosin more successfully. modifying it to take the place of these resins with better results. But every once in a while somebody hits a smag, and they think that poithaps we can help them out. Here is an exumple of such a problem [illustrating samples of varnish to the subcommit tee] that has cone to us recently. Here is the normal ramish. for instance, that should be produced 
with a normal rosin, but when the paint manufacturer undertook to make a varnish in accordance with his usual practice from a shipment of rosin this is what he got [exhibiting another sample of rarnish], and so he asks us to try to help him solve that problem. We have not quite done that: we are on the road to it. I am just bringing this up to show you the class of problems that are constantly coming up. That fact right there [indicating] injures the sale of rosin. It injures the utility of the rosin to the manufacturer and to the user of the varnish. A varnish made like that would not be of any use; it would cristallize right out.

So, Mr. Chatrman, just along these lines-of increasing our production of rosin and turpentine, preventing losses, demonstration work in the south, and in eliminating some of the problems in the production is the way we hope to continue this work. Furthermore. we have got this question of alulteration and misgrading which we are stil! finding is exceedingly extensive. We must keep the types of rosin which we have devised in perfect condition all the time.

Mr. Andersox. Is there any legislation now which authorizes the establishment for a standard for rosin and turpentine-any method of enforeing the adherence to stindards?

Mr. Veitcin. No, sir. 'This item permits the Secretary to derise standards and types for rosin, but they can not be enforced under it. They ure only idopted by courtesy of the industry. The industry has approved them and is using them steadily, but it (an drop then to-morrow if it wants to.

ADUITERATION IN MANUFACTURE OF TLRPENTINE.

Mr. Avorison. Is there much adulteration by firms manufacturing these products?

Mr. Veircu. It is increasing, Mr. Chairman, due probably to the very high price of turpentine. Turpentine to-day is around $\$ 1.50$ a gallon in the South. By the time the individual user burs it, he pays around $\$ 2$ or more a gallon for it. That stimulates adulteration with stuff costing 20 or 30 cents a gallon, and I am sorry to say that it is inereasing some in the South, but I do not think it is increasing in the South anything like it is in the paint-using districts. In some States I have found, in asking for turpentine, that I bave been delivered mineral oil straight, without a bit of turpentine in it, under the mame of turpentine, and other places when I inquired into the matter it was stated that prices were so high that tupentine was driven off the market. Adulteration is helping to do that, of cisurs(e.

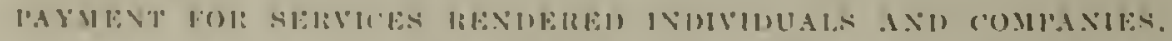

Mr. Buchaxis. When you go out and undertake the assistance of the private individual or corporation, (h) they pay any of the exponses incident tu such liclp?

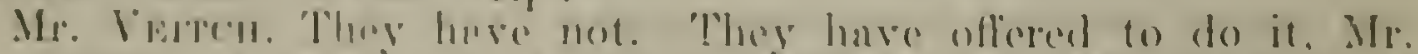
Buchanan. I do not see how we could receive it. We hase no real and hority to recerive it, and we have done this work under our genernl muthority here as a mutter of investigntion and for our informution (1) show what an be done to improse production. 
Mr. Buens.s. This serge appropriation suys " in cooperation with the imdividunls and comprinies." and I was just wondering if they ought not to puy for that serviere. You render them a ralunble -erviee when bou go there individually and supervice it and demonstrate it. I do not menn that in groting out any information or bulletins they should pay for that. But when you go there personally, or some of your men do, you supervise it nud you remler a veryo valuable service in them. It looks bike they ought to bear the expenses of that trip.

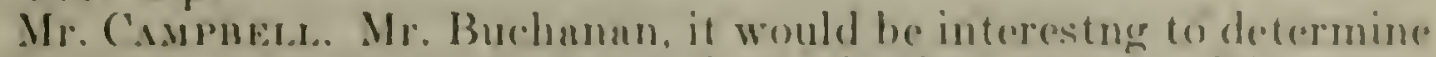
just what would be an eyuitable charge in that matter. We nppreciate that under the authority you have given us and the money rou have approprinted for the support of that work that a study of existing conditions is imperative on our part, and when we do that it is more from the standpoint of the study of the condition of the industry us "whole than in respeet to some particular individual. Saturally, rou can not get a knowledge of the condition of the industry as a whole without taking into considerntion the aggregnte as it exists on the part of individunls. And in doing that, we have been following out what we thought were the specific purposes underlying this specinl approprintion and were not disposed to consider a ihnrge.

I Saresny that the work that has been done is of sufficient interest to the indistry as a whole that the industry in most cases would be willing to incur the expenses of our service, especinlly after the service had been performed and they appreciate the benefit of it to them.

Mr. Bucanax. Would you have any authority under the existing law to make any reasonable charge?

Mr. CampresL. We do not think we have.

Mr. Bucmaxa. There is no renson why they should not pay a little, at lenst, for what valuable services they receive.

Mr. Camprelz. Of course, that is a matter entirely for Congress.

Mr. Verter. Nearly all producers who need this help are small and can not well afford to benr the expense. The work is practically furm demonstration work for the turpentine farmer. We have had this proposition presented to us within the past two weeks, Mr. Buchaman. I have seen a specification that was drawn concerning the purchase of rosin, and without our knowledge of it, that stated: In cases of dispute concerning the grade of this rosin, it shall be submitted to the Bureau of Chemistry, and the findings of the Bureau of Chemistry shall be regarded as final, nnd the party at fault shall pay such charges as the Burenu of Chemistry ma make for that work. "The question with us is, Have we any nuthority to make such a charge?

Mr. Brichasax. Wo have that being done in some other departments.

Mr. Axinfrsox. There are several acts under which inspections are made or arbitrations performed, in which one department or another aets us urbitrutor.

Mr. Bucunxax. There is some shipping act in respect to the condition of grain or fruit.

I think where a private company receives services of the Government they ought to be willing to pay a little part of the expense. 


\section{INSECTICIDE ANI FLNGICIDE INTESTIGATIONS.}

Mr. Campris. 'The next is the item for in restigation and development of methorls of manufacturing insecticides and fungicides. The work under this item has been devoted to a study of the conditions found to cxist in commercinl insecticides and fungicides that are on the market now. Certain elasses of insecticides and fungicides or disinfectants have been tested against a certain organism, upon which the standard of that product would be gauged. Fery naturally we have been curious to know whether or not it would be equallyeffective against other classes of insecticidal or fungicidal attack and to determine whether or not the standard serving as a basis for the rstimate of the ralue of this product applied with respect to its application to all classes of organisms, and we found that it has not been so in some ciases.

We have also found this, that in the class of nicotine products. for instance, the packages containing them seemed after a while to lose their poteney for insecticidal use: after a while they did not seem to possess the strength or the value that they were claimed to have originally, and we found that there was a deterioration in the product itself, under certain conditions, and gave attention to the methods under which the products should be prepared in order to mantain their potent condition for a protracted period of time.

The work of fundamental importance under this appropriation very naturally is to try to find some trpe of an insecticide or fungi(ide that will be effective in destroying the parasites but at the same time work no injury to the plant itself or to man or animal in the application of them and at the same time have the advantage of being cheap; that is the ideal product.

Mr. Becmaxas. It is rather a hard job, too.

Mr. CAMPBELL. It is rather a hard job. It is something that con not be done in a minute, but, nevertheless, we are working on that, and we do have right now under way the study of certain compounds of a chemical kind that bid fair to supplant certain types of insecticidles we have had, particularly nicotine products, that will have the advantage of being as potent as the nicotine product itself and at the same time very much eheaper.

After you work things of that sort out on a laboratory scale very naturally you lime to determine from the standpoint of the cost involved whether it is a practicnl proposition to do it on a commercial sciale.

$$
\text { investioation of Calcium arsenate. }
$$

Wo have just had this experience recently in conneetion with work that was done moler this fund. Calcium arsenate, you know, is being manufactured and shipped extensively into the Solith for the purpose of roubating the boll weevil and it hus been found that different shipments arted in different ways; in other words, the water-soluble arsenic that was found persent has been sullicient to burn the plants in a grent many cosses, nud one of our men from the laborutory made a study of that situation in the South. He found that it was not altogether chimatic conditions that wore responsible for this excessive watcr-soluble arsenice, but it appenred that some of the mineral properties wheh the plant itsolf had exusled and wore found to be in 
the dew seemed to arentuate the developmont of wuter-soluhle arsenie or that condition which is responsible for the burning of the plant.

That opers up a fundumental consideration that we hat not particularly thought of heretofore, und that is that rertuin plants

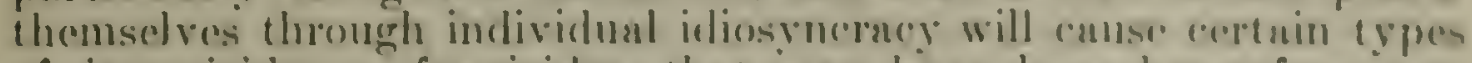
of inseceticides or fungreides, that may have been heretofore cont-

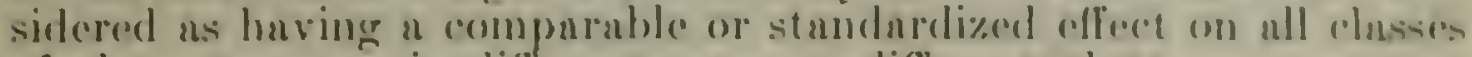
of plants. operate in different ways on different plants.

Our work on this has heren dono in a limited way mly. It has not been dereloped sulliciontly to spenk with limality ubont it.

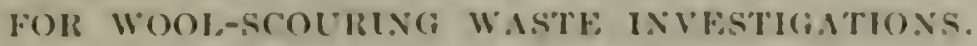

Referring to the itom on page lss for the investigation and developsment of methods of utilizing wool-seonring waste: At the time this was formulated, it did not appear that we would be able to romplete that work by the 30 th of June, but since the formulation of this estimate we have found that we could get the work through within that time, and the department has asked the permission of the Bureau of the Budget to withdraw this in its entirety.

Mr. Axuersox. We will withdraw it for you.

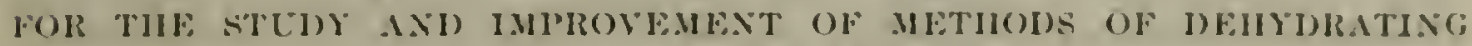
MATFRIALS LSFI) FOH FOOH).

Mr. Canplisela. The next item, page 186 , for the study and improvement of methods of dehydrating materials used for food. Thint work is continued in attempting to determine the terdnological problems involved more particularly with reference to the dehydration of vegetables. The work very largely in the past has been done in connection with fruits. The work has been concentrated in one laboratory, and that laboratory is the citrus-products laborntory in Los Angedes, Calif. We have made arangements that will make it possible to obtain the fruit at little or no cost. The attempt was for the purpose of studying the best methods for dehydration and to get concerns that were interested in having products dried to purchase those products, iurnish us raw material, and let us turn over to them the finished article, so that we could make our study in that fashion without the expense inrolved in the purchase of the material surselves and attempting to market that afterwards. which coukl not be done in a commereial wing by us, and our whole efforts have been with the purpose in view of determining what the proper technological method was, more especially in regard to what is the best method for the dehydration of vegetables.

Mr. Arisensos. Have you done anything in the way of development for a murket for these products?

Mr. Camprest. 'That thing has been urged by the industry itself, Mr. Anderson, but I can not see that that is any part of our business: and we ourselves have not at tempted to do any thing with that. Very maturally it could not be done with a fund of this si\%e, and our concern is to make arailable through the investigations that we have underway the methods which should be employed for the manufacture of a standardized article and then quit with that. 
Mr. Axumsox. What I mean is, is there any real development in the sale of these products commercinlly?

Mr. Campreds. In certain products there are. Certain products ure being put out in fairly well standardized fashion now, and very naturally the department is getting incuiries all the time where there is a desire to undertalie this on a cooperative plan by agricultural communities themselves in the establishment of dehydrating plants. But until the depurtment is in a position to prescribe the method by which this can be done and arrive at some logieal and accurate conclusion concerning the cost that would be involved and the type of supervision that should be maintained, it can not speak in a definite fashion regarding the financial adrantage that would accrue to a community from an undertaking of this sort.

Mr. Bucuaxax. When you speak of "dehydrating" you simply mean drying?

Mr. Cimprisla. Yes.

Mr. Bucmaxa. Are the markets filled with dried fruits and vegetables, or is there any considerable market for dried fruit now?

Mr. Camprisla. Oli, res; dried fruit is a pretty well established industry, but on vegetables it is hardly that, and I do not think that dehidration will ever be an industry actively supported in this country until we shall have determined some plin by which a standurdized or stabilized product can be made. The experience that the chairman indicated a moment ago about cane sirup applies precisely to this situation.

Mr. Axpensos. The next is the item on page 187 .

FOR PREVENTION OF GRAIN-DUST AND OTIER DUST EXPLOSIONS AND FIIRES.

Mr. CampBral. That is the item for investigation and improvement of mothods for prevention of grain-dust and other dust explosions and resulting fires, including fires in cotton gins and cotton-oil mills. Onr work under that appropriation has divided itself into three different classes - the work that was done and is being done in a consulting way and in an advisory capacity on, first, the threshingmachine explosions and fires, and, second, the fires and explosions that take pluce in grain elevators and in industrial establishments. and, third, our work on cotton gins and in oil mills.

By devising a mechanical separator or remover for the dust on the threshing machine, and also by making prorision for appropriate wiring to remove static clectricity generated in the threshing operntion and which was the cause of ignition in most cases, these explosions in threshing machines have been reduced to a very material (xitent. Our real problem has been in getting an observition of the precautions we have recommended. This work has been promoted very latgely by Stute augencies, especially in the region of northern Idaho, castern Washington, and nontheast Oregon. There has never heen iecorded a fire and explosion in one of the mills where the devices recommended by the hurean have been adopted.

Mr. Anmoksox. Have nny of the threshing machine companies adopted this method or deriede?

Mr. (AMrmil.. "lhey are working with us on that basis, and they molertake to manufacture the erguipment. and install it on their 
muchines and are doing that in some contes extensicels, huriug their own agents advocute the use of that in the sule of all these manchines.

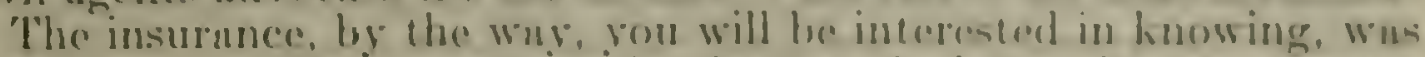
withdrawe on these mochines in that purticular region some yetare ugo -absolutely denied in every respect: and then when the insurunce companies onterent this fiedd ngain they charged prohibitive

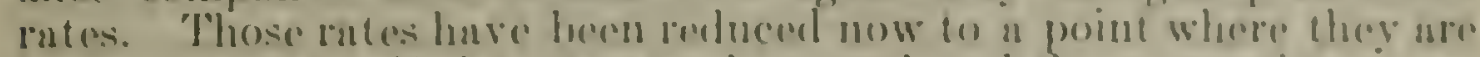
faiply reasonable if the operater has amployed the preventive nemsures we have adrocated.

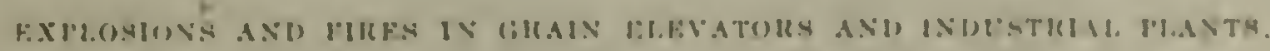

The puestion of preventing the explesions and the fires that luok place in grain elevators and industrial plants is a much more liflicult one than involved in the threshing mochines. We ure studying the causes. That involves analytienl study of all these cxplosions that take place. We attempt to do that just so soon as we possibly con, with un iden of determining what is the fundamental, responsible canse for the fire and the explosion itself. It is a simple cnough thing to advocnte the construction of elevators. for instunce, in a way so that there will be the least possible facility giren for the accumulation of dust. But we found that that within itself wili not solve the problem.

You know thnt dust with a proper admixture with air is just as explosive as gas and a proper admixture of nir. That fact has been demonstrated by the burenu, and we are concerned now-it raries. of course, with different products-in determining just what the situntion may be in a plant; that is, measuring the amount of lust in suspension in the air in rarious establishments, to determine whether or not the dnnger point is being approached in the atmospheric situation in a particular plant; we hare found out that an explosion of a violent character will take place if you have as much as one-fiftieth of an ounce of grain dust in suspension in 1 cubic foot of air.

Te nre working in cooperation with other agencies of the Government, particularly the Bureau of Mines, through their specinl interest in the prevention of mine explosions from dust, and nlso on the part of the Public Health Service for the purpose of health-control mensures as that relates to dust carried in suspension in the atmosphere of particular places.

We are now perfecting a means for the measurement of the amount of dust in suspension in the air. If that can be redueed to a simple proposition, it will be an easy enough matter for the ageney itself, for the industrial organization itself, or for the State agencies concerning themselves with this problem, to muke an inspection of an establishment and determine whether or not there is a dangerous condition existing at a particular time, and whether or not attention should at once be griven to the removnl of that condition in so far as it is possible to do so.

'There are two-as Mr. Price explained to you last renr-explosions at least that are found to take place in connection with these catistrophes, the first of which within itself is not so violent and not so significant, but it is the secondury explosion that is alwars the one that creates the damage. There nust be an ignition of the dust in some way, just exactly as there is required to be a spark in order to effect an explosion in a mixture of air and gas. 
If that thing, in the first place, could be obviated and remored, it would prevent the explosion. But so long as you recognize that in milling operations you are going to find oceasionally and beyond human prevention the presence of metallic products or mineral products that will of themselres, when thrown against machinery, ignite a spark which will of itself be sufficient to set off the explosion in that whole estublishment, you can appreciate the difficulty of attacking it from that standpoint.

One of the things that has been advanced and has been usually found to be effective, too, is what we eall the inert atmospheric control. If we could provide an atmospheric situation at the plant where ignition takes place, for instance, by the use of carbon dioxide, we would stop in that way the transmission of this flame-through the conveyor and other ageneies that get in to the bins where the dust will be found in suspension and where the extreme explosion takes place always producing damage.

Whether or not that is a practical proposition remains yet to be determined, and we are making progress in the study of that whole question through observations that are made and experimental work that is being done in the laboratories and in the establishments themiselves.

Monday, November 20, 1922.

\section{BUREAU OF SOILS.}

\section{STATEMENTS OF DR. MILTON WHITNEY, SOIL PHYSICIST AND CHIEF, AND DR. C. E. MARBUT, SCIENTIST.}

\section{SALARIES.}

Mr. Avimasos. We will take up your statutory roll as found on prge 190.

Doctor Hhitsey. There are three decreases.

Mr. Axderson. Are the places filled?

Doctor Whitser. One position of laborer is filled.

Mr. AxuERsox. But you can get along without it, I suppose?

Doetor Whitiver. Yes, sir.

Mr. Avmirsox. Then we will take up your next item, genernl ('xpense's, Burenu of Soils. Suppose you tell us a little about what you ure doing under this item on page 192, for chemical investigntions of soil types, ete.

Doctor Wintxer. Mr. Chaimun, I have prepnred a statement showing the work of the burean as a whole and if you like, it cun go) in the recort.

Mr. Axbrasox. It may go in the record.

UL:NLUA ATATL:MENT UF WORK.

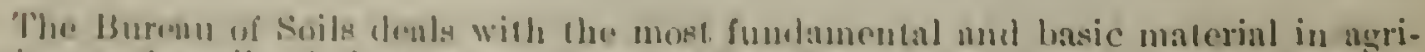

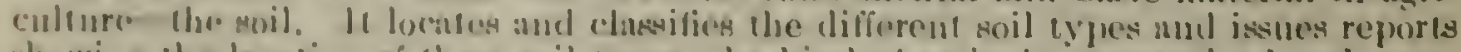

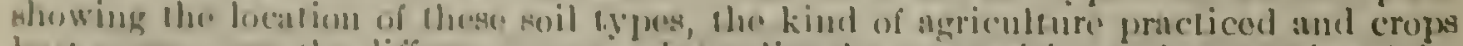

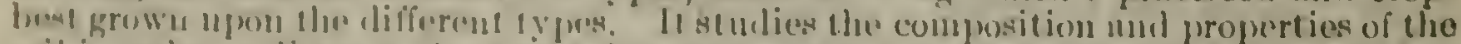
moil in order to diecover those nose umportant and corrective means to lit them better for ugricultuml ne. It investigases the fumdamental problems connected with tho 
ehemical and physical ehanacteriatice of the moil. It atulions murrom of materials

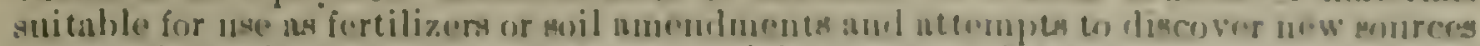
of materinl and a bether use of these materiale ut prenent known.

Soil suriey. - The soil survey is the largest work undertaken by this burean. I

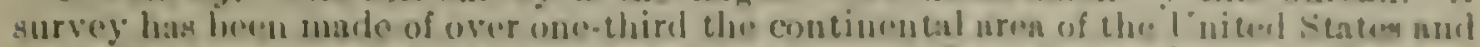

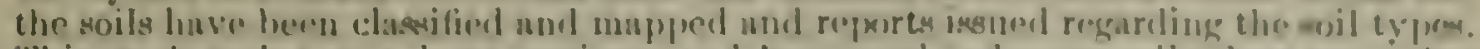

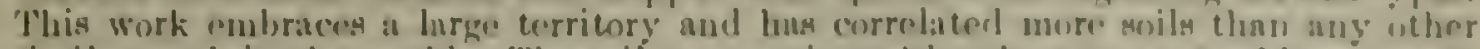

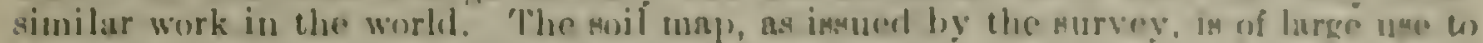
furmers or to those contumplatiug purchusing furm labls; it furvimbes fhem with a hasis ufun which to judge the ugrieultural value of such lands. 'The railronds aro uming three maje in large number in their development work, und rond ouginuon and

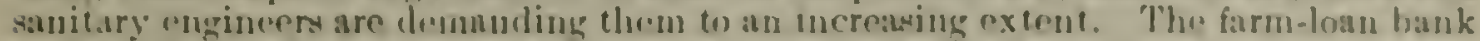
and the liveleral reserve bankes ure using them as a check in the valuation of furm lanels, foresters are cmploving them as a basis of the volue of swils when the timber has been cut. The Reclanation service is makiug use of the maps for dovelopment work, particularly in providing eflicient drainage and in the prevention of the rias of alkali: public schools of the country are using the maps for the elucation of the chil. dren regreting the physical structure and the agricultural wealth of communition. The Post (ollice Department and the Department of Justice make use of thom for runuing down iraululent land eaves. The llar College and other bureaus of tho lVar Department have used them for the selection of sites for military maneuvers aud other purposes, and investment companies are employing then in calculating risks insolved in agricultural occupation and health conditious.

During the last year surveys were completed aml begun in 6i9 conntirs in 2!) different States. The area covered hy detail survers amounted to 27.337 scuarc miles reconmaissance surveys were completed in an area comprising $15,31.4$ spuare mile. In carrying out survey work this bureat has the cooperntion of 27 states namely. Ilahana. Arkansas. California. Georgia, Jlaho. Indiana, Iowa, Marylaud, Masuchusete. Ifichigan, Minnesota, Mississippi, Missouri. Nebraska. New Jersey. Jow lork, North ('arolina. North Dakota, ()hio, Uregon. Pennsylvania. South Wakota, Temuesures. 'lexas. l'inh, West Virginia, and Wisconsin.

The Burean of soils. throngh its conperation with threse several States is able to correlate and unify the work in soil survering as nudertaken by these States. The classification and names of soil types. as adopted hy this hureait, have been followed Wy the difierent States and this burean is looked to for guidance as the leader in this work. If the soil surveys in the ditierent states are to be of any general utility there must be some contral arency which can correlate and unify then. The experiment stations ure using the soil maps as a basis for extending their work in farm management studies and in their advice to farmers as to fertilizer needs and their experimental work which is carried on in the field. In addition to this regular work of the survey there has been cooperation with the Department of Justice and other bureaus of the Govermuent where questions of soil classification and determination of lamel values has been involved. The soil maps are used by several States in determining the basis of taxation.

Fertiliser invstigations. - For several vears attention in the iertilizer investigations has been lirected to concentrated fertilizers, with the object of presenting the posihility of manufacturing cheaper materials for the farmer. The importance of this has lieen especially impressed upon us because of the cradual alsorption into feed stutis of much of the nitrogenous material that heretofore has heen used in fertili\%ers. IVe are now working along the lines of the preparation of high-grade concentrated fertilizers from low-grade or waste material, or materials not hitherto readily avislahle. The preparation of such materials is dependent upon a new volatilization process for the manufacture of phosphoric acid. With phospohric acid at a satisfactory price, there una be prepared compounds of anmonium phosphate, ammonium nitrate, potasium phosphate, or ammonium potassium phosphate, which may be mixed with ammonium nitme or ammonium chloride from nitrogen lixation products to supply the farmer with a highly concentrated fertilizer material.

The work on nitrogen fixation with which the bureau has been concerned during the last year, in conperation with the Fixed Nitrogen laboratory, has had as itsolject the improvement of processes for the removal of ammonia from the gaseons mixture atter its formation in the catalvic chamber. One of the main clilliculies in the opreration of the so-ralled llaber process is the eflicient removal and collection of the ammonia afterits formation. and in our work on this problem we have discovered certain solvents which give promise of elfecting this removal more efliciently than has heen posilite hefore. A small unit, designed for this purpose, has been constructed and is being tried ont experimentally in cooperation with the lixed Nitrogen Research lathoratory. In addition to the work of the bureau on the fixation of nitrogen from the air. work is 
being carrief on to discover methods of utilizing the various waste, nitrogenous products which may take the place of some of the more expensive nitrogen products now going into feed stuffs.

Phosphorir aril- Investigations on the utilization of run-of-mine and low-grade phosphute material have lerl to the eliscovery that these materials nay be used in a process for the volatilization and recovery of phosphoric acid. As already pointed out, the manufarture of concentratrel fertilizer material is dependent upon the volatilization mecess of unaking phosphoric acid cheaply, and by the utilization of this runof-mine material a cheaper source of the manufacture of this plosphorie acid is assured. Material heretofore of little value has been utilized for direct smelting in the fuel-fed furnace. 'This matcrial carries a low percontage of phosphoric acid and ton nuch aluminum, iron, aud lime to make it arailable for use in the ordinary manufarture of superphosphate, but these characteristics which are undesirable in manuiacturing supcrphosphates impart a good slagging puality to the charge used in smelting. These experiments carried ont with a small oil-fired furnace have been highly satisfactory and a larger and improvel furnace has been installed at Arlington and is now ready. for experimental runs. The earlier work of the bureau on the volatilization of phosphoric acid was done in an electric furnace. This methor was so successiully demonstrated that the process has been taken up by an industrial concem and iurnaces installeel at Inniston. Ala. This company is now manufacturing phosphoric acid hy this process, although all the product at present is going into high-grade chemicals and medicinal or foorl products.

Potash. - The Burean of Soils is continuing to investigate the available sources of Anerican potash, althongh at the present large amounts of German and Alsatian frotash are coming into this conntry. The former work of the burean has shown a number of different sources from which potash may be obtained, and these present a potential supply of such capacity that the emergency needs of this country could be unet under conditions similar to those prevailing during the war. when the supply of German potash was cut off. Our demonstration of available Ameriean sources of potash renders the position of this country secure in the event that exorbitant prices should be charged for the foreign material. Further research may develop more ellicient methods, so that American potash nay compete normally with that from a foreign source.

$A$ diflirulty experienced in the use of Ameriean potash a few years ago was the presence of deleterions amounts of borax in the material produced from the Searles Lako hrines. This bureau quickly discovered the source of this undesirable material and developed methods for detecting and determining the quantities of borax present in the potash. After our order designating the amount of borax permissible in potash thr companies immediately changed their methods, so that all danger from this source has been eliminated.

Chemical incestigations. - The work of the Chemical Division is closely interrelated with that of the Soil Survey and at the same time this division is depended upouf for the investigation of fundamental chemical changes taking place in the soil. I think farmers and all those engaged in supplying the farmer with practical information concorning soil management will agree with me that fundamental soil chemical investigations are required before we can give certain aspects of farm practice the scientific efrtainy ueded to make farming a less veuturesome business. I refer particularl! to the adajtation of (rop to soil and the use of lime and iertilizers.

A large munber of complete chemical analyses of soils must be made each rear if the work of soil classifiention lyy the Soil Survey is to be conducted properly. "The complur rheminal analysis of a soil is an racting and time-consuming operation, and although wo have developed rapid petrocraphic methods for the examination of certain moil comstiments. soil analysis forms a large part of the work of this division. lrom time fo lime also a consideralsle amomm of chemical soil work on special prohlems mest be dour for obher lineans in the department and for other departments of the (ii)

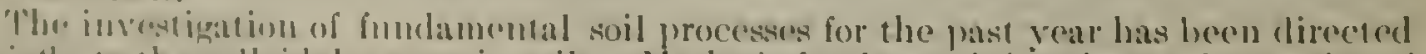

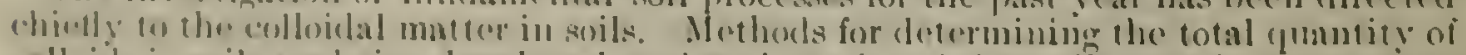

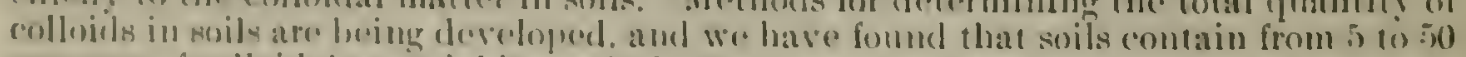

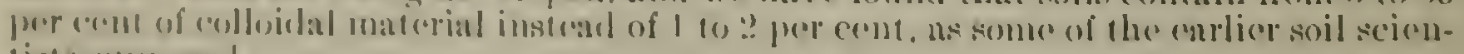
liath mapprisent.

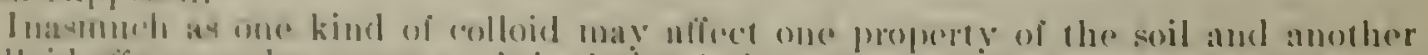

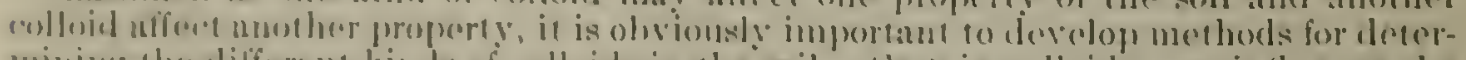

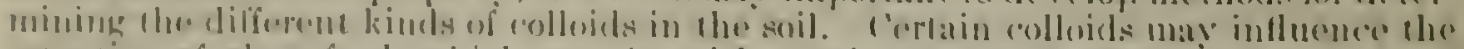

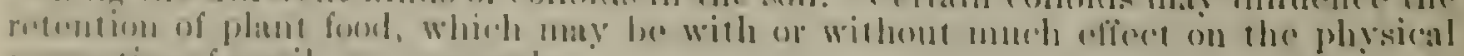

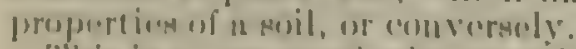

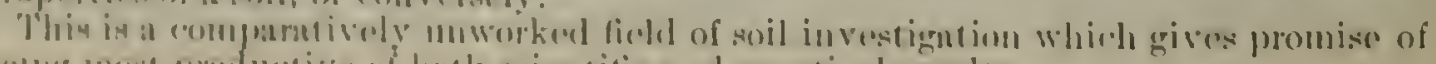

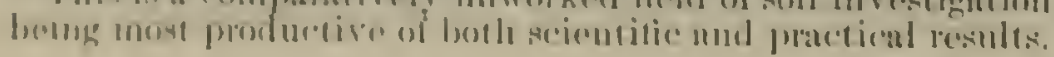




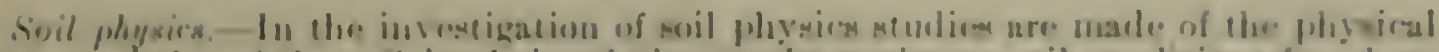

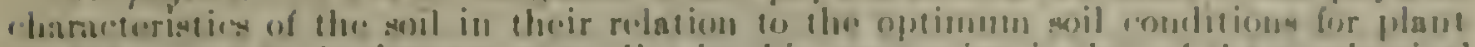

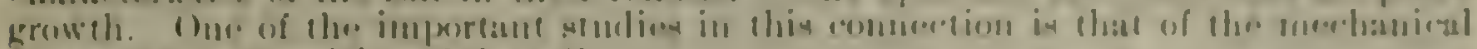
ir textural eomilposition of the eosil.

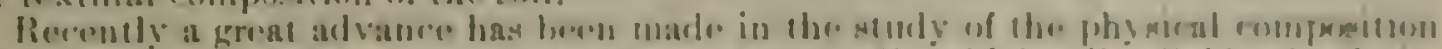

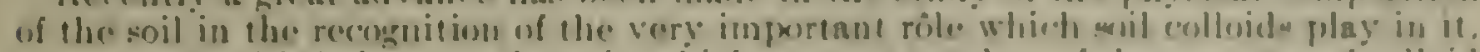

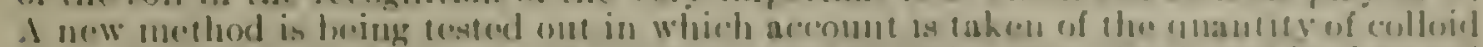

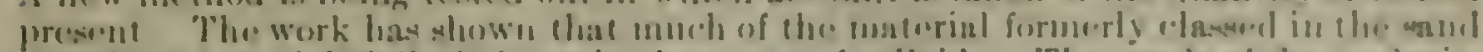

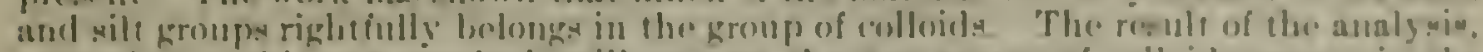

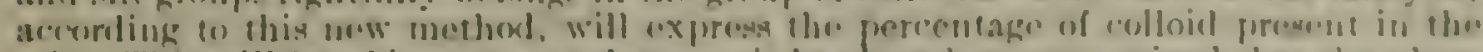

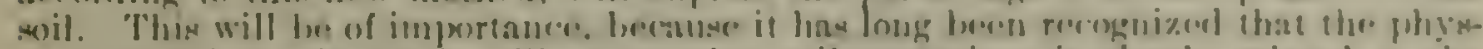

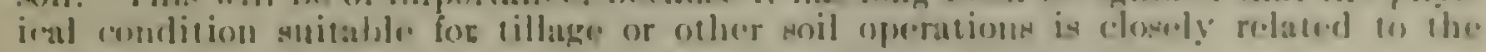
rollonil imllents.

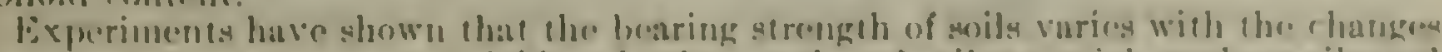

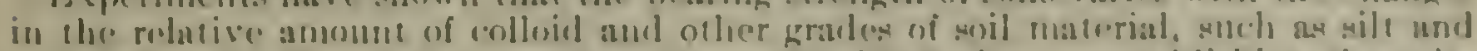

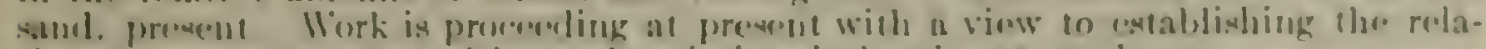
tions lectwen the eomposition and sariations in bearing strength.

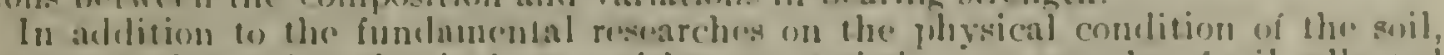
mutine unalyses of inechunical composition a re carried oni on samples of soil collected by the soil survey in order to assist them in defermining the classification of the virious woil types. Asile from the work done for the soil survey there is consideruble clemand for work by otherorganizations, such as the Geological survey, the Miseissipui

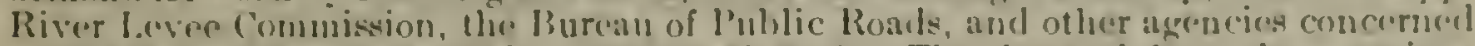
with the use of seil material in structural work. The demand from these various sourcess show the wide applicability of mechanical analysis to the practical problems in relation to the soil.

In this division there are designed and constructed special pieces of apparatus repuired for the proper prosecution of the investigations along soil hines and which have wide applicability in the study of soil problems. One such instrument rlesigned, namely, the electrical bridge, has been arlopted for use in studying alkali lands, not only in this country but in Egypt and other alkali regions.

'The past year has been exceedingly fruitful in bringing together the results achieved by the liureau cluring its (juarter century of existence into a modern concept of the soil, its various functional activities, giving us a comprehensive view of the soll, which has never heen clearly understool before.

\section{FOR ('HEMICAI, I.TVESTIGATIONS OF SOII, TYPES, FTC.}

Doctor Wurver. The work of the chemical investigations has progressed very satisfactorily. I feel that in the last year or in the ast two rears, with the discoveries and investigations wie have made of the soil colloids, we have a concept of the soil we have never had before. We have completed the separation of the functional activities of the soil into its component parts. Heretofore the world has been working along different lines of soil investigation, on chemical lines, on phrsical lines, and on practical lines, and we have been pushing each of these lines along us far as we ean. It has only been possible, since our work on the soil colloids, to bring them all together and present a fair picture of the functional activities of the soil as a whole. We know now, through our investigations, the differences in the functional activities in this soil [indicating] which is a truck soil and not adapted to general farming, and the functional actirities of this other soil [indicating] which is the strongest type of agricultural soil in the country - that is, for general agriculture - and while there will atways be ngreat deal of work to do to find the specific faults we know, in a general way. why these soil types differ.

Mr. Axversos. Can you tell us why one soil is best adapted to truck while another soil is best adapted to grains?

Doctor Wuntwey. Yes, sir. We are understanding those things in our present concept of soils. We have brought all of these things together, the physical properties, the chemien properties, and the 
biochemical changes in soils; we have shown their interrelation and the control we have of them through drainage, irrigation, cultivation, and cropping. In the chemical investigations we hare been studying the properties of the soil colloids. It is the material that causes soils to shrink or contract when dry or wet; it is the material that holds the grains together and makes them plastic or hard when dry, and it is the seat of the absorbing power of soils for moisture and for gases, and is the seat of the important chemical changes that go on in the soil from releasing the so-called mineral plant foods and is the home of the biochemical changes that are essential to a healthy soil.

Mr. Axnersox. What direction are your investigations taking now?

Doctor Wintsey. Well, we have the material out; we are writing up now and liare nearly ready for publication methods for determining the amount of colloids in soils. 'That is something we hare never had before. There are some peculiarities about the methods due to some peculiarities about the colloids, but we have methods to propose for determining the amount of colloids in soils. Then the constitution of these colloids is a subject that will require a great deal of research.

Mr. Axpersox. If I should send you a sample of soil from Minnesota what could you tell me about it?

Doctor Whitsey. I could tell you the amount of colloids in it.

Mr. Axpersox. That would not mean anything to me.

Doctor Wintrey. Well, it would mean a great deal to us in the advice we would give you as to the treatment of the soil and as to its adaptation. Of course, that is not all. I am not claiming that this is the one thing that makes soils productive or nonproductive, but it is the missing link that the world has been looking for to bring all of these properties into their proper relationship. Of course, as I mentioned last vear, we have a very small appropriation for the sturly of the chemistry of soils. We are not only working on the constitution of soils but we are working on the composition of soils nt considerable depth below the surface. We are finding more and more that in order to understand the surface soil we hare got to find out what there is in the deep depths. We have frequently heretofore worked on material at 6 feet below the surface but now we want to go 100 feet or 1,000 feet, if we can get samples. Then we are doing a great deal of routine work for the other burenus and other deportments.

Mr. Becmasas. Is it your iclea that the character of the soil 100 fect deep or jo0 feet deep has an infleunce upon the surface soil?

Dortor Wutwey. Yes; we think it has.

Mr. Buchasas. Even thomgh there are watereourses and rock betweon thens?

Dortor Wminer. Yes. We do not think it has an effect to-day, but we think it has had an effect in the past nges in modifying the present soils we are working with.

Mr. Beculanax. In pust ages the soil 100 feet down might have heon surface soil!

Doctor Marusuts. Doetor Whitney has in mind the formation of caliche, which is so abundantly distributed over Southwestern 'Texas, and the guestion has been legitimately raised us to whether that caliche, which is now close to the surface and a part of the soil, did 
not come from rery grent depths. Five hundred feet, of course is just a figure, but at least from great deptlis.

Doctor Wntrox. Wo have alkali salts which we beliero have come from a very great depth, much deeper than we have ever supposed heretofore.

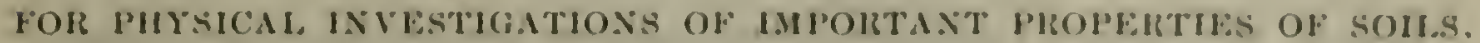

Mr. Axmirsox. We will take up the next item on page 193. Apporenty the only thing which distinguishes this from the preceding item is that this has to do with physical investigntions?

Doctor Whitser. Yes, sir: but requiring fifferent methods and different men, men of different traning, and it supploments the other. Both the chemical and playsical investigations, of course, are based largely upon our soil surveys.

Mr. Avinesox. We will take up the next item on page 194.

FOR INVESTIGATION OF FFITTLI\%ER IRSOURCES.

Doctor Whitser. For the investigntion of fertilizers?

Mr. Ardenson. Yes.

Doctor Whitsex. We have had a very favorable year in our work on the study of fertilizer stock and fertilizer materials. As I have explained to the committee, it is divided into nitrogen work, phosphoric acid, potash, and migcellaneous soil amendments, such as lime, etc., and we have made very good progress. I think I told the committee last year that we have been working for some time on concentrated fertilizers. The trade, the farmers, and the experiment station workers have all realized for a long while that concentrated fertilizers are cheaper and more economical. With the introduction of nitrogen fixition methods, which started in Germany and have been most largely developed in Germany-in the fixation of atmospheric nitrogen into ammonia gas-we have got to make certain products that are not adapted to the chemical mixtures that our industry has been putting out in the past.

They have been using a great deal of waste products, and they have been making a rather dilute form of acid phosphate. They have been muking it with 16 per cent, whereas the rock as it is in the ground carries 32 or more per cent. 'Their method of converting the rock phosphate into acid phosphate dilutes it approximately onehalf, so that we get a weaker product than we had in the mine. "Then our method of mining the rock for treatment with sulphuric acid has been a very wasteful one, because we have only been able to use the purer form of rock and have thrown on the dump about 65 per cent of the phosphorus we have mined. But with this method of volatilizing the phosphoric acid, which we have developed in the bureau. we are able to use the run-of-mine rock, thus saving the material that now goes to the dump and cutting out the expenses of the original preparation, because we use a lower-grade material.

Mr. Axnersox. Is anybody using this new process now?

Doctor Wurver. Yes, sir; there is a concern at Birmingham, Ala.. which is using it for the preparation of phosphorus, for the preparation of phosphate salts, first for food products and incidentally as 
fertilizers, but their attention has been given heretofore to the preparation of food or chemical phosphates.

Mr. Axdersox. What are you doing in the matter of nitrogen fixution?

NITLOR: PIXATION.

Doctor Wintxey. In nitrogen fixation we are working in cooperation with the fixed nitrogen laboratory on methods for recovering the ammonia gas from the gases. We hare been working on that for some time and it appears that we have a rery successful method for separating the ammonia from the mixed gases and one which I think is likely to be of a great deal of benefit in its manufacture. That has been one of the great difficulties of the past. As to potash, we are working on the possible methods of extracting potash from our waste materials, from the iron furnaces and from the cement mills. Of course, we have dropped the kelp plant. but we are working on some of the mineral sources.

Mr. Axurnsox. You have a method of recorering from cement plants now, have you not?

Doctor Wintser. Yes; we have the method. We hare made a survey of the entire industry but, unfortunately, they hare run into difficulties in the separation of the potash, which is due to methods of manipulation. If they collect the dust too near the source of the heat some of it appears to be bound up and has been reconrerted so that it can not be economically extracted. If, howerer, we allow the fumes to escape and we have a dust catcher interposed between the place where we collect the coarse dust and the fine dust we are finding that we can get a product that is almost completely usable. So that there are muny things to work out and, apparently, they rary with different localities, and with the different kinds of materials they use for cement. We are satisfied we hare a source of potash in this country if it can be produced at a low enough cost. The whole question is the cost and that means the details of manufacture.

\section{FOR SOIL SURVEY INVESTIGATIONS.}

Mr. Axpersox. The next item is on page 196, for the investigntion of soils, etc.

Doctor Wutrey. That is the soil survey.

Mr. Axpersox. In this item you have a reduction of $\$ 4 \$, 200$. What is the idea?

Doctor Wurrisy. I am unable to answer that question, Mr. Chatrman.

Mr. Axplemsox. Maybe I can derelop it. In how many States are yoll working this year?

1)(retor Wmixly. We are working in cooperntion with some 29 States. All thase states uppear to be very enthusiastic and very well siltisfiod.

Mr. Axprasox. How many will you have to cut out as the result of this redurtion!

Bocfor Wurrese. (of course, I have made no plans as to this, Mr. ('muiman. It is a cut of ubout 25 per cent in our soil survey appropriation, which would mean a cut of nearly 50 per cent in our liemlel forere. 
Mr. Axbrasox. Are these conpermting states putting up dollar for dollar or more than thint?

Docetor Wurcser. On the whole, they ure putting up more, or just about the same, I think. They put up ubunt sliso,000 last rear. I thisk their appropriation now is close to $\$ 150,000$, but not all would be used for field work, beenuse they reserve some for their luberntory investigations und thus supplement our work. They do that the sume ns we hure to curry a certain overhend here for the direction and inspection of the work.

Mr. Axul:ksox. How much of this sum is spent in the field work?

Doctor Maraste. Around $\$ 100,000$, or a litele morr. If rou will ullow me. I will say that the rest of that money is spent for informattion that is just as valunble for the soil survery as is the fichl work. for exumple, a great deal of that is spent in earying on investigations in the fietel on the soil type for the purpose of determining the reasetion of the crop to the sonl type and also the renction of fertilizer to the soil type. That is the sinte work aml, as I say of the $\$ 150,000$, which is state monery, some is spent for that, hut that is just us important for the soil survey as is the field work.

Mr. Axnersox. I will try to get at these divisions. Of the $\$ 168,200$ of Federnl money, how much was spent an field work, how much on lnborntory work, and how much on owerhesud!

Doctor Marnet. 'The Soil Survey has never equipped a laborintory. The physical unnlyses of soil sumples is done by the I)ivision of Physical investigation of soils and the chemical analysis by the Division of Chemienl Investigations of Soils.

Doctor Wurver. We spent about two-thirds of the money in the licld.

Mr. Axorrsox. I wish you would furnish me with a statement slowing the amount you spent in each State and the offset of the State moner as against that.

Doctor WuTxey. Very well.

Stulement shouing Federal and State funds expended during jiseal yrar 19?: in silutes cooperating in soil-survey work.

\begin{tabular}{|c|c|c|c|c|c|}
\hline Siste. & $\begin{array}{l}\text { Federal } \\
\text { funds. }\end{array}$ & State funds. & State. & $\begin{array}{l}\text { Federal } \\
\text { lunils. }\end{array}$ & Stole funds. \\
\hline Nabama. & \multirow{2}{*}{$54,753 . .51)$} & $\$ 3,90 \% .36$ & \multirow{2}{*}{$\begin{array}{l}\text { New Jersey... } \\
\text { New lork... }\end{array}$} & $\sin (x) 2 x$ & \multirow{2}{*}{$\begin{array}{r}8 i, 601.58 \\
1,(127,65\end{array}$} \\
\hline Arizoln. & & $1,267.00$ & & $3,7(1), 32$ & \\
\hline Arkansas. & 1007.13 & $1,0,0 \times 0.00$ & \multirow{2}{*}{$\begin{array}{l}\text { North Caroliua } \\
\text { North Inkota. }\end{array}$} & $7,359 . \times 9$ & \multirow{2}{*}{$6,113.44$} \\
\hline California. & $6,679$. .5 & 4. 404.15 & & $1,0.5 .76$ & \\
\hline Georgia... & (i, 300.70 & $1 \leq,(100),(x)$ & \multirow{2}{*}{ Ohio.......... } & $3,-\cdots,(x)$ & $1 f,(m x)$. (n \\
\hline Idaho.. & $1,517.59$ & $1,020.91$ & & $3,123 .+1$ & $11, x(x) .(M)$ \\
\hline Indisua. & 1, $46, \ldots$ & $4,91 \div .25$ & & $1,334.12$ & \multirow{2}{*}{ 1, 20i2. is } \\
\hline Jown... & $10,759.29$ & $115,0 \times 1.00$ & $\begin{array}{l}\text { Pennsylvania. } \\
\text { Soutli Dakiota. }\end{array}$ & $3,041 . v_{i}$ & \\
\hline hentucky. & 326.03 & 362.50 & \multirow{2}{*}{ Temuesse.... } & $\because 470,20$ & $2,133.19$ \\
\hline Maryland. & $3,941 . \ldots$ & $9.00,63$ & & $17,722.19$ & \multirow[t]{2}{*}{ iii), tiil. (is } \\
\hline Massachusetts. & $1,457.13$ & 763.07 & Uah. & $793 . .2$ & \\
\hline Michipan. & $1,201.25$ & $5,172.53$ & \multirow{4}{*}{ "isconsin.... } & 720.111 & riñon \\
\hline Mimnesola & $2,039.60$ & $4,962.91$ & & $6,612.34$ & $10,1+6.26$ \\
\hline $\begin{array}{l}\text { Misslssippl } \\
\text { Mllssouri... }\end{array}$ & $\begin{array}{l}3,3,7.03 \\
3,213.27\end{array}$ & $\begin{array}{l}2,04.10 \\
\times-60.60\end{array}$ & & (1:3,3in, it & \multirow[t]{2}{*}{121.13213} \\
\hline Debraska. & $i$ tini. if & $17,800,00$ & & & \\
\hline
\end{tabular}

1 Estimaled.

- Actunl fied expenses only. Dos not indude overhead, bispection aud correlation, map work, and work in nonconjeratlug states. 
COOPERATION WITH STATES.

Mr. Axpersos. Are rou now cooperating with all the States that have requested cooperntion and are willing to cooperate in the matter of finances as well ats otherwise?

Doctor WhTser. Y'es, sir.

Mr. ANDEnsos. You are now taking care of all the requests?

Doctor Wintrex. We are taking care of them but not as fully in some cases in they would desire and not as fully as their appropriations would warrant.

Doctor MARBUT. The lack, if we may put it so, of full cooperation on the part of the bureau consists largely in our having to employ cheaper men than the States employ in order to balance up the same number of men thut the States have. The States, as a rule, pay higher salaries than we do and we employ a greater number of young, inexperienced men to balance up the number of men the States put in on cooperation. The deficit lies largely in that.

Mr. Axdersox. What kind of people do you use in this work?

Doctor MARBCT. Agricultural college graduates or college graduates, usually agricultural college graduates. We hare a few men from other colleges than agricultural colleges.

Mr. Avdersox. Do, they have to have any special training in this kind of work!

Doctor Marbur. They have the special training they can get in this kind of work, but there is no place in the United States where a man con get training enough for soil-survey work to go right in the field and do perfectly satisfactory work without previous training. He must learn to do it by doing.

Doctor Wurver. And it takes two years; at least, with the best man before he can be put in charge of a soil-survey party.

Doctor Marbut. Yes; fully two years.

$\mathrm{M} \%$ Anderson. What do you pny men in the field?

Doctor Wurver. Our salaries lange from $\$ 1,320$ to about $\$ 2,300$.

Doctor MARBLT. I think there is no man in the ficld getting-even men who have been 20 years in the service-a salary of over $\$ 2,250$. Of course, they have an allowance for field expenses in addition.

Mr. Axinersos. Under this reduction what do you propose to do? Will you diminish your work in all the States or will you have to cut some of them ofi!

Doctor Wurter. We will probably have to eut a number of them off; wo will probably hare to reduce and also cut, because this is " pretty heavy cut, you sec.

\section{SOIL-SURVI\% WAIS.}

Mr. Bromaxax. Is the only result of this approprintion and this cooperation the soil-survey maps you produce?

Boctor Wurwer. Well, we produce the soil-survey maps and a report. You "re familiar with the report describing the charncter of the soils!

Mr. Buchasis. It is alluched to the maps?

Dortor Whiritr. Yes, sir. In aldition to that the States are interested beantso it gives them a basis for field experiments with

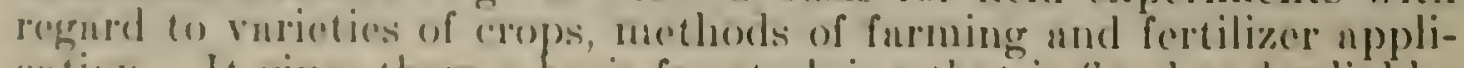
cation. It gives them $n$ basis for studying that is fixed and reliable. 
Mr. Bucusxix. Then, as I understand it, the result of this appropriation is the production of maps with the aroumpanying coxplanntions?.

Dortor Wurtist. Yes, sir.

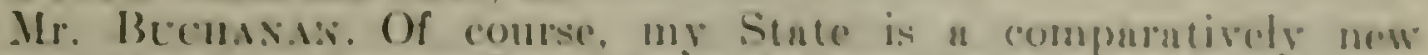
state, that is, a goung State froin an atricultural standpoint, but in these older states, where the land is frecoming imporerished by constant use, are they using these maps to any cxtent?

Doctor Wurtis:. Oh, yes; they ure using them in the obler sentes and in the Westeru and newer States. Hore is a sample map [indicoting).

Mr. Bucusin. I hare seen the maps.

Bortor Wutsey. "This is a progress mup of the soil surver.

Mr. Becus.s.s. The reason l asked the puestion was this: Mr county las been surveged and I have about five or six thensand mape of it at my home. I have mublished the fact that 1 have them

Doctor Whitsey (interposing). You only had 2,000 .

Mr. Brcmaxas. Well, it looks like five or six thousnnd. 'They are stacked up there, anyway. I published the fact that I have thein for distribution, but 1 cin not give them away.

Doctor Wurver. Have you taken it up with Doetor Younghlood. who is in churge of the Stute? He looks nfer those things in the State.

Mr. Bucusia. I have not taken it up with him, beeause the maps are on the ground and the people are down there on the ground.

Doctor Writser. I do not know what our requests are for that particular locality. In what part of the State are you-in the eastern or western part?

Mr. Buchasix. In the snuth-central part.

Doctor ManBCT. Washington County, is it?

Mr. Becmasas. We have some poor land there, too, and we are not fertilizing it.

Doetor Mariset. I think you are rnther assuming a function for the Soil Surver that is not its most important function. 'The real function of the Soil Survey maps, in adclition to giving the farmer certain information, is to furnish the experiment stations with a basis for further study or follow-up, as we eall it, of the Soil Surver. The experiment station, for example, goes on to the soils that are identified in Washington County

Mr. Bucruxax (interposing). The real purpose of the maps, then, is a scientific purpose and it is for those who are scientifically trained?

Doctor MARBCT. It is for a scientific purpose and it is for those who are scientifienlly trained, yes, and it is used by those who are scientifically trained as a basis for further investigntions in order to get information that is directly applicable to the farmer. That is the object of the Soil Survey.

Doctor Wnitses: It has a scientific basis and, as n matter of fact. the Soil Survey map is relied upon by settlers who are seeking information about new loenlities. Then, too, it is used by the bunks, the farm loan banks, and the Federnl reserve banks. I member of the Federal Reserve Bunk of Chicago was in my office last week in order to complete his list of the maps of their territory, becnuse they find those maps of rery great help to them in connection with the banking business they do. 
Mr. Buchasax. My idea is that the soil survey maps, as far as the average farmer is concerned, are a falure. Of course, if they are supposed to he for scientific men and for the experiment stations of the States that is a different proposition. If ther ure produced for the purpose of enabling the scientific men and experiment stations to figure out the character of fertilizer needed for certain lands that is another proposition, but for the uses of the ordinary furmer they we n failure.

Doctor Wintxas. Take the case of Baldwin County, Ala. Long before that mup was issued we had requests for 50 per cent more than the law allowed us. We get 1,000 copies. That means that the entire edition was exhausted in a week by reason of requests that came to us from other parts of the country, not only requests from furmers in Baldwin County, . lan., but requests from farmers in Iowa, New York, or some other section of the country, farmers who may be thinking of moring. All of the department s quota goes to incuirers of that kind. Congressmen have 2,000 copies and many of them use their quota and many of them ask for more.

Dortor Manber. Mr. Chairman, may I say a word? The timber (ruiser groes into a forest and maps the distribution of timber; he makes a map of it and that map is published. On that map should he necessarily, in order to perform his function, tell how to perform the technical work of the milling of that lumber. The Geological survey goes--

Mr. Bromax (interposing). Certainly not, and that is hardly a pariallel anse.

Doctor Marbert. It is exactly the same thing.

Mr. Burmaxix. No; that is mother proposition altogether.

Doctor Manisct. The Geological Surver maps the geology of the United States; it shows the different formations over the United States; it does not, however, go into a technical discussion of either the quurrying of the different rocks for different purposes, for the mining or for utilization at all. It is a fundamental thing, and the sume is true of the soil survey. It is a fundamental thing to be useel us $n$ busis for further work.

Mr. Bcchaxax. I would not be surprised if there were not a great many mups published at the expense of the United States which, so far as practical use is concerned, nre failures. I do not menn that scientific mon and seientific colleges would not mnke good use of then, but from my knowledge of the soil survey maps I do not believe that the averuge furmer makes use of them; at least he does not in my aection, und he does not in my eounty. That may be true as to forestry mups und us to Geological Survey maps, but as far as the uverage man is concened they ure of no use; but from a scientific standpoint, I suppose, they are all right, and it takes a scientist to minderstand them.

Doctor Marmblr. If, however, the results rench the farmers through the experiment stations, is that any argument against the fundnmontal work?

Mr. Bu'maxas. I admitted that to start with.

Doctor Wurreser. You understand that the renson you got those 2,000 copies was because the law suys you slanll have that many. Wo have nothing to do with it.

Mr. Becolaxas. I um not making uny purticular complaint ubout that, but my idea is that if they are for the use of the genernl farmer 
they are wasted. I have alroudy stuted that thene maps mighe be

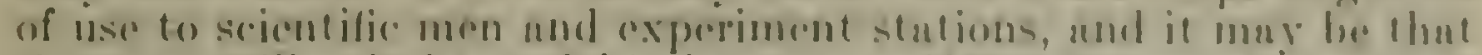
the maps will only he useful in later yeurs if they ure preservont.

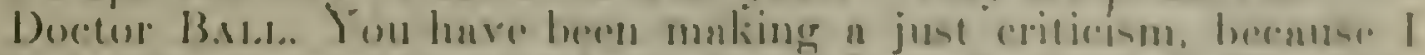
believe those maps are not sont where they should he. 'Ther are

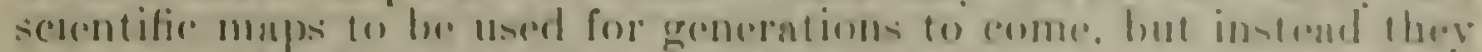
are sent out widly und distributed among furmers, politicinns, und storekrepers who ilo not know throir value.

Mr. Be(ms.

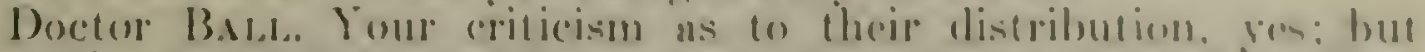
that distribution is something opere which wo have no rontrol. 'Plast distribution is madre he robson of a law passed hy ('ongresis and wo have no control over it. We would like to have it changerd.

Decter Wortexis. That is the point l was trying on make. that they go out hy law: wo do not send them. Let me say that these soil-surey maps serve a very useful purpese in the wai of stubili\%ing the values of land. A gleat many real estate dealers throughout the country are exhibiting these maps as a hasis for selling lamel and they have brought about the sale of lands at somewhat their real value. These naps huve cut out a good muny of the framdulent sules und misrepresentations. Then in some of the Stutes they ure being used for laxing purposes.

Mr. Bucmaxa. It is strange that scientific and practical minds aways come in conflict. You say these mops aid in stabilizing the values of land. There is no wy on the face of the earth of stabilizing the value of land or the products of land, because as the produets of land go up the value of the land goes up, and if they go down, then the value of the land goes down. You can not stabilize land.

Doctor Wursey. Well, relatively you can. If there is a swampy section in here [indicating] that is shown on the map: the map would show that there was this swamp there and that much of the land was nonproductive, so that now it is very difficult for a real estate agent to sell that as productive land.

FOR EXAMINATION OF SOILS TO AD CLASSIPCATION OF AGRICLITCRAL LANDS.

Mr. Axpersox. We will take up the next item on page 19s. for examination of soils to aid in the elassification of agricultural lanels.

Doctor Wnitsey. That is for the classification of agricultural lands and that hus been going on just as heretofore. We have been working with muny of the departments, the Reclamation Service, the Geulogical Survey, the Post Office Department, and the Department of .Iustice.

Mr. Axidersox. What does the Pust Oflice Depiutment have to do with the chassification of lunds?

Doctor Wurrvey. Well, they have very important functions in land frnud cases. 'They are calling on us constuntly for help in the classifieation und examination of lands to see whether the laws of the United Stutes have been broken. We have had severnl rery lurge cuses of that kind that have come up in the last few years. If have one that has been dragging for over six or eight years, and the Post Olliec 1) partment is still after the alleged fraudilent users of the mail.

Doctor Marazer. May I state that that appropriation this year has been spent largely in reconnaissance work? For exmmple, in nor thern 
Minnesota we are making reeonnaissance surveys for land classification at the request of the State to determine what is forest land and what is agricultural land.

Mr. Bucilaxax. Is it State land or private land?

Doctor MARBCT. Part of it is State land and part of it is private land. It is land. We do not inquire as to the ownership of that land at all.

LOR GENERAL, AIMINISTIRATIVE EXPEXSES.

Mr. Axpersox. On page 199 you have your general item for arlministrative expenses, which is the same as last year.

Doctor Wintrey. Yes, sir.

Monday, November $20,1922$.

\section{BUREAU OF ENTOMOLOGY.}

STATEMENTS OF DR. L. O. HOWARD, ENTOMOLOGIST AND CHIEF; DR. A. L. QUAINTANCE, ENTOMOLOGIST IN CHARGE OF FRUIT INSECT INVESTIGATIONS; MR. W. R. WALTION, ENTOMOLOGIST IN CHARGE OF CEREAL AND FORAGE INSECT INVESTIGATIONS; DR. W. D. HUNTER, IN CHARGE OF SOUTHERN FIELD CROP INVESTIGATIONS; MR. B. R. COAD, IN CHARGE OF BOLL WEEVIL INVESTIGATIONS; DR. JOHN E. GRAF, DR. E. A. BACK, DR. A. F. BURGESS, IN CHARGE OF GYPSY AND BROWN TAIL MOTH INVESTIGATIONS.

Mr. Avinersox. Doctor Hownd, do you desire to make any general stutement?

Doctor Hows BI). I have a general statement which I have prepared for the record, if you desire to have it incorporated.

Mr. ANmensox. It will be inserted in the reeord.

(iF.NEUAl, STATEMENT OF WORK.

'The mumber and serionsuess of the problems eonnected with insect damage which the country hats to confroml seem to be increasing and demand untiring woth on the fart of the ellomelogists of the feetoral departiment and those connected with the

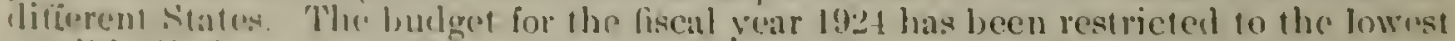
posible limit and shows a trecrase of sting from the amount appropriated for the

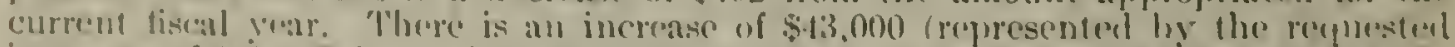

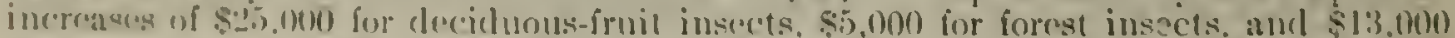

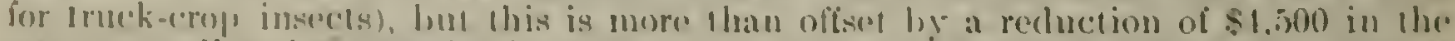

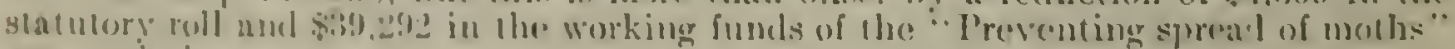
appropriation.

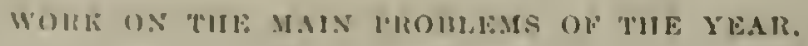

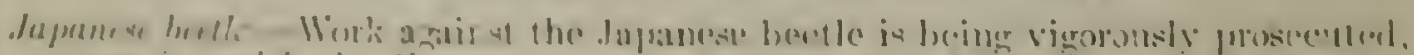

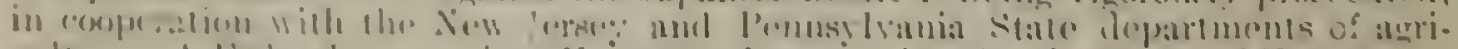

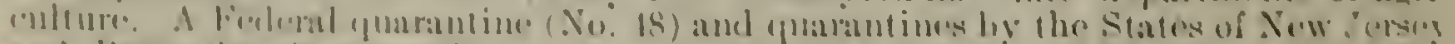

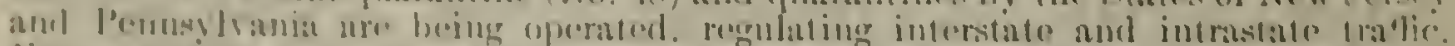

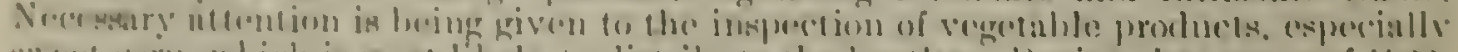

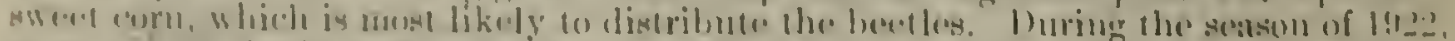

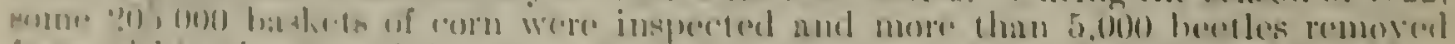

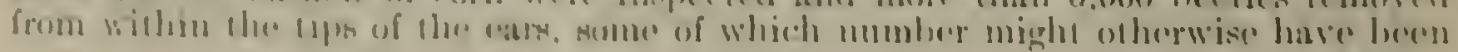




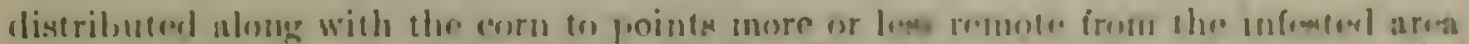

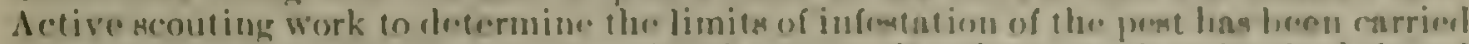

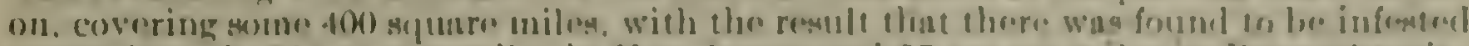

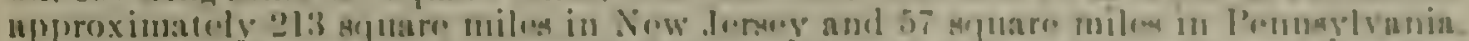

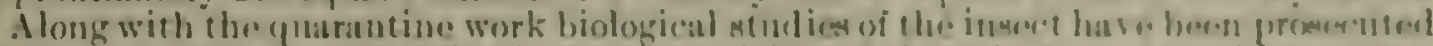

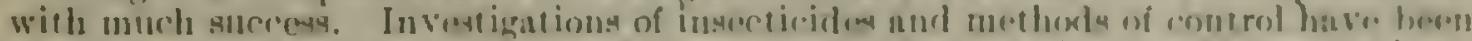

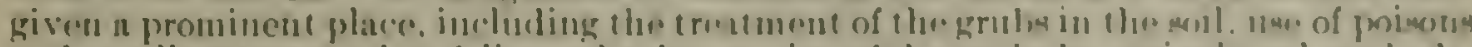

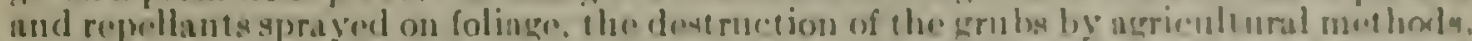

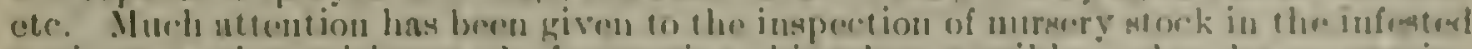

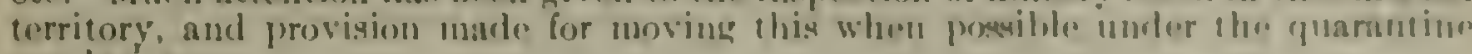
regulutions.

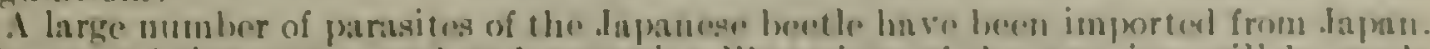

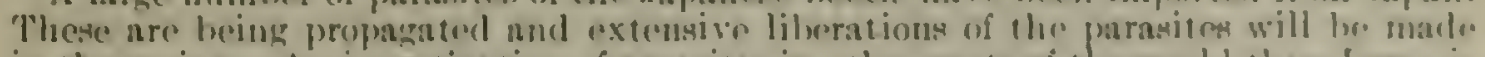
in the spring. In investigation of parasites in other parts of the world than inpan is

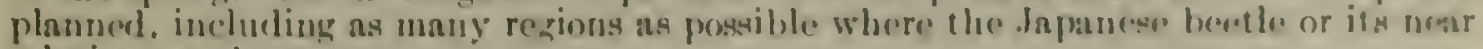
relatives aro known to orevir.

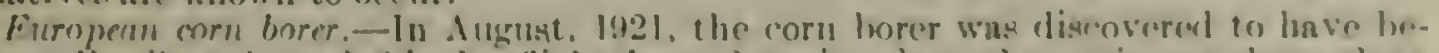
come distributed. probahly by tlight from 1)ntario, along the entiro sonthern shoro of Iake lirie in Ponnsylvanin, Thio, and Mirhigan. In ordor to study thro insert in

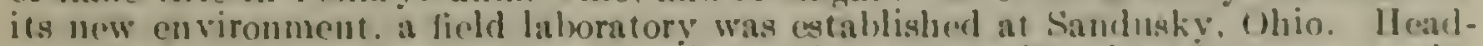
yuarters for the scouting work and the inspretion nnd certiliention of ropes were alao

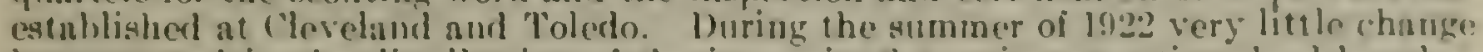
has occurred in the distribution of the insect in the regions mentioned. althongh a slight spread inte contignous territory has been observed. So commercial damage has yet hecome apparent there. hut it is feared that sorions damage to the corn crop will result within a few years if the insect is not kejt in check lig timely action on the part of agriculturnt Workers. In the western Yew York area, wear Butfalo. an extensive eastward spreal occurred durine the flight season of the moths this year. The edge of this iniested area now coincides witl the eastern border of Hyoming 'ounty. I slight increase in the amount of injury to corn was noted. Hut the losses incurrel are not yot of a very serions cluaracter. In eastern Vew York little phange has been noted. The spread has been slight and the jutensification of injury almosc imperceptible.

In Massachuselts, where the com horer has two broods per anum, a very con siderable incroasc in iujury to garden crops in general. and especially to celery, beets, and beans, has ocenrred. Serions injury lias also heren olserved un certain flowering plants growu for nurket purposes. such as gladioli, dahlias, asters, and chrysanthemums. I very marked and exfensive dispersion ly flighi luas oceurred in 1 iew Ilampsire, Rhode Island, and Maine during the late summer as a result of the dense rharacter of the infestation in the areas existing inmediately surrounding Boston.

The roseareh work on the corn horer has been vigorously pressed to determine practicable means of control, and a iarmers hulletin giving the results of these investigations is in press. This will contain recommendations for the control of the pest. chiclly by numas of changes in agronomic practice and the consumperion of the infestod crops in a manner to destroy the insects contained in them. Investigations looking coward the discovery of an ellicient insecticide are lieing conductorl. but as yet do not promise success. The fumigation of dried crops for possible movement irom the infested areas has received much attrution.

The work of introdncing the natural ruenies of the rom borer from liurope has progressed rapidly, and more than $1,000,000$ individuals of a singlo promising spocies of parasitic wasp have been liberated in Massachusetts durine the past sumnuce. It present another distinct species is bring propagated wih similar treatuent in biew.

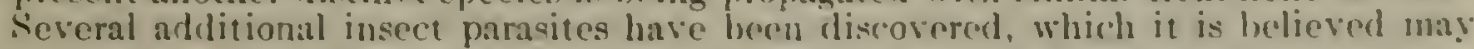
function beneficiary when introduced into Inericas.

Cotton boll weeril.- Exicellent propress has been made in the control of the boll weevil by the calcinu arsenate dust. Very many planters have used this process with profitable results during the year, and it has becu constantly simplified and cheapened and adipted to different revions. lixperinents have been made in the use of the airplane which show that in this way the amount oi poison can be cut in hali and which indicate the possible use of this instrument for dusting on large plantations or in regions of almost contiunous cotton culture und suggest that it may cone into play in community service.

The gencral feeling throughout the regions where the boll weevil has heen present for several years is one of encouragement. and it has been shown in many ("ases that by the application of cultural methods recommended by the departucut ever the small planter on comparatively poor soil uny rase cot ton inder holl wecril ronditions at a protit. 
Iccimn bean bedl.-Investigations on the Mexican bean beetle have been continued in the southeastern Lnited States, principally in Alabana. the work being spe(ially devoted to control inethods. Arsenirals of all types have been tested and will he continued in rooperation with entomologists of all infested States in relation to injury to hean plantsand to the destruction oi the insect. Biologic studies have been rontimued. a promising tachinid parasite has heen imported from Mexico, and efforts are being mallo to colonize it during the next year. The beetle. first reported in Alabama in 1920). has since in valled Georgia. Tennessee. Kentucky. Virgina, and the Carolinas. and, at thr present rate of spread. will soon reach Indiana. Ohio. and West Virginia, and probably Mississppi, hesides increasing its range in all of the States tirst mentioned. In the listancia Valley of New Mexico the ravages of this beetle are enormous and erowers arce asling the department 's aid.

Gijsy moth and brom-lail moth. - It the beginning oi the fiscal year the work was resumed with an appropriation of $\$ 400,000$, while $\$ 500,000$ was really needed to properly carry out the bureall's program of restricting the spread of the ginsy moth in fow lingland and to follow uj, the exterminative measures inaugurated in the large infosterl area in lew Jersey, as well as treatment of small colonies in New York State. Wherf additional funds became avalable on May 11 , the work was at once enlarged and vigorously prosecuted, though the results were seriously interiered with by the ahnormal heaiy rainfall during June. A colony of gipsy moths found at Greenport. Iong Island, and a small colony at Patchogue, long Island, were careiully treated and sprayed. Five small colonies in other localities in New York were carefully inspected and treated and no infestation was discovered this year. It is thereiore believed that the insect has been exterminated in these colonies. The nine isolated colonies in New Jersey appear to have been eradicated as no infestation has been found in any of them. These areas will be rescouted another season and treated if infestation ilevelops. The Somerville ( $\mathcal{N}$. J.) infestation was thoroughly scouted by late spring, though insuflicient funds made it impossible to accomplish the amount of cutting work decirable on several river lottom areas. While a large amount of spraving was done in New Jersey it proved less effective on account of almost continuous and heavy rains during May and June. 'The work, however, resulted in a sharp decrease in the number of caterpillars over the previous summer, and in no place in the State was there any surious defoliation by the gipsy moth. No trace of the insect has been fouml in the area previously infested in Pennsylvania.

On July 1, 1922, the Federal Horticultural Board placed under quarantine for the gijsy moth adclitional areas in New England, representing a total of 3,645 square miles; on the other hand, several towns were released from quarantine as no infestation was found at the time they were examined.

some scouting has been clone along the border of the brown-tail moth infestation. and as a result of this work a heavy decrease in infested areas during the year has been noted. Two thousand, three hundred and forty-two square miles have been released from quarantine, including areas in Maine, New Hampshire, Massachusetts, and Rhode Inland.

The paraste investigations have heen enlarged by the dispatch of one expert aswistant to Japan and one to Europe. These inen will make a careful study of gipsymoth conditions in these: countries and ship parasites and other natural enemies io America. It is hopuel that information may bre obtained as to the causes of the fluctuation of the insere in its original homes. which knowledge mav be helpful to us. The parasites and othere natural cuemies of the gipsy moth and brown-tail moth already

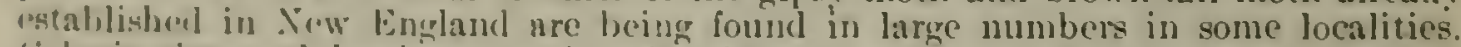
colonization work has hern continued and areas in alfinfested states received plantinger of parastes where these did not occur there before. The temperature during the winher was rxirumely low in many soctions of New England, resulting in the failure (1) hateh of many "ghe chasters of the gipsy moth. Defoliation therefore has been lous than in provious years, particularly in ihe localitios where the earg clustors were

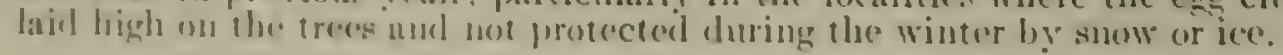

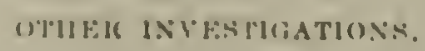

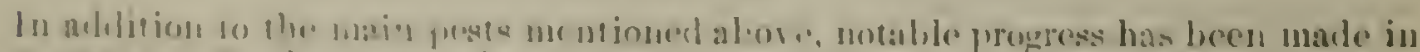

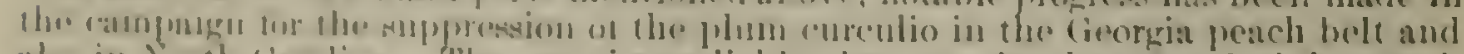

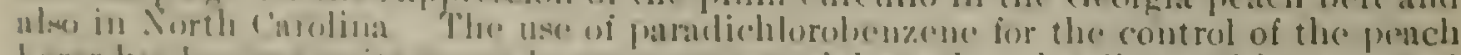

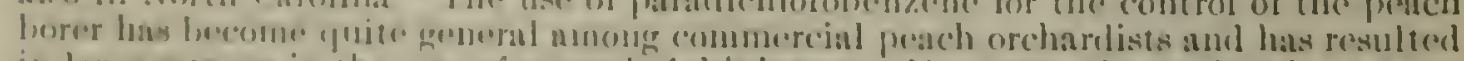

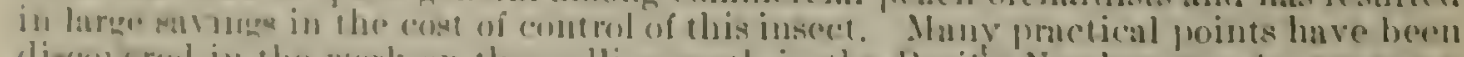
dimour red in the work on the conlling moth in the Pacific Northwest. A new spray

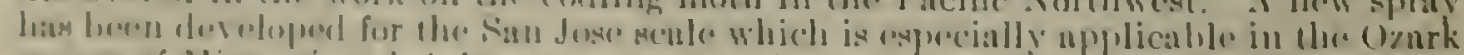

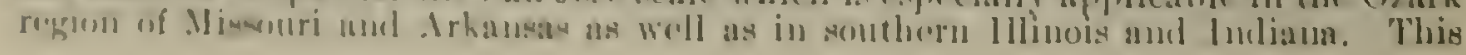




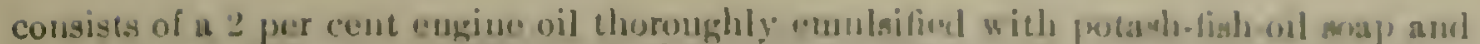

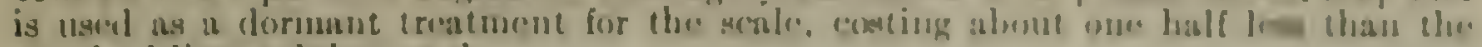
stamlard lime-suljohur wimh.

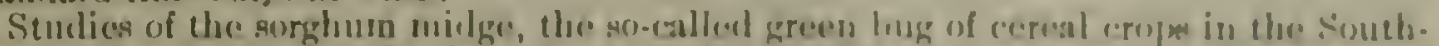

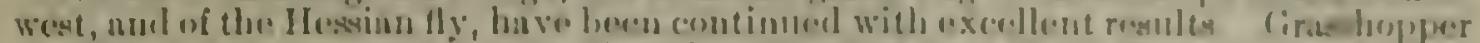

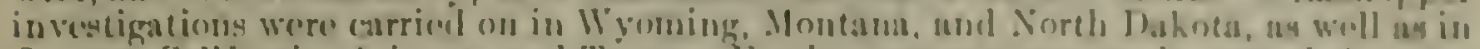

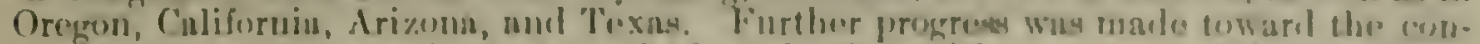

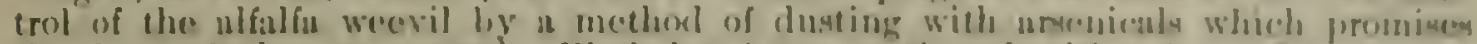

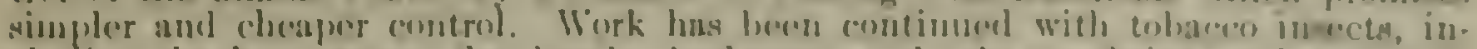

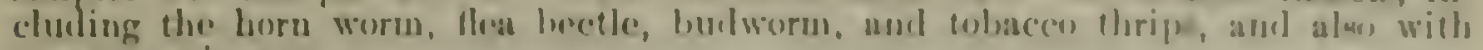
sugar-cane insects.

In foreat-insect control, a very atriking cenperntive bit of worh has lenels carrienl on

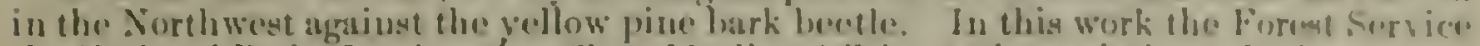

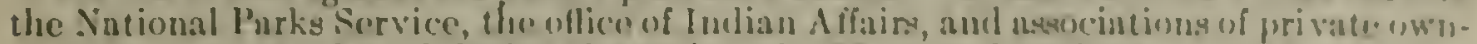

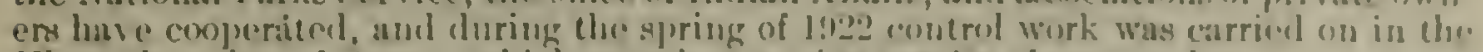
Klamath region of Oregon which promises to give results of great value.

The work on the swore potato weovil eradication has heen enntinumb in filorida, Georgin, Alabama, and Miswisuppi, with very favorable rosults in the lirut throe states. In Mississipui, however, a number of now infestations have heren reported.

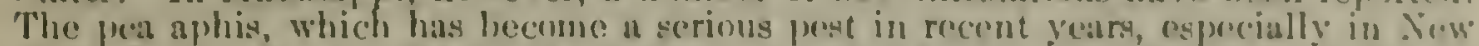
York, California, and IVisconsin, on cannery jeas, has lwen intensively studicul, aud there is every prospect of the working out of a cheat) and satisfactory incelinal for $i$ ts control. A newly imported potato and comato werevil has made its appearance in Miscissippi und is being intensively studied.

The experts engaged in the investigation of insects alfecting stored products have been at work upon the insects attacking whent, corn, and other grains in farmon' bins, warehouses, grain cars, ships, and elevators. Intensive studies have bren mate of the Angonmois grain moth, or fly weevil, that has done much ramage to the 192:2 erop of winter wheat in the Eastern states. Investigations have heen carriel on in cooperation with the Bureall of Chemistry to rliscover a more satisfactory fumigant for grain cars. and studies have heen macle of weevils attacking heans, peas, and cowpeas in storage. Insects affecting fabrics made of wool, hair, furs, and feathers have been studied.

Many important studies have leen continued with reference to bee culture, all the prohleins of importance to practical beekecping being borne in mind.

\section{TIIF: DECIR.ASIS SUUUITTED.}

The amount for statutory salaries is reduced in the estimates by $\$ 1,000$, which is explained by the fact that five preparator places at \$\$ $\$ 10$ have been dropped.

The amount submitted for the investigations of the gipsy moth and brown-tail moth is $\$ 531,000$, which is an apparent decrease of $\$ 69,000$ from the amount approprinted last winter. However, as $\$ 100,000$ of the amount appropriated last year was set aside as immediately available, on account of the lateness of the se:son only " portion of it was spent beiore the end of the fiscal year, leavingan actual decrease of $\$ 39,292$. This, with the decrease of statutory salaries $(\$ 1,200)$ is $\$ 43,192$. Which shows a total decrease of estimates from last year's appropriation of $\$ .192$.

TIIF: INCREASE.S SUIIMTEED.

Under deciduous fruit insects, an increase of $\$ 25,000$ is requested, $\$ 20,000$ of which is to provide for the strengthening of the work against the Japanese beetle. The rapid spreal of this beetle and the tremendons increase in its destructivenest during the past year have so increased the jroblem of its control that an entire reorganization of the work will be necessary. It is proposed to abandon the project of certification and inspection of field crops, such as sweet corn, etc. The area of infestation now includes so many large nurseries that the expeuse of inspecting nursery stock will require all the funds available for insepetion, leaving the increase asked for to provide for the extension of research work and the development of control measures. If the continuation of the field inspection work is to be considered, this will need to be ilone on an entirely different basis from that in effect at present and will involve much larger sums of money than this appropriation provicles.

The other $\$, 000$ of tho $\$ 2.5,000$ asked for will be expended in the investigation of pecan insects, especially the green soldier bug and the pecan-nut case horer which have recontly become seriously destructive in Georgia and Florida. This investigation is urgently demanded by pecan growers in the Southeastern States. 
An increase of $\$ 5.000$ is asked for forest-insect investigations. Of this amount it is proposed to expend $\$ 2,500$ for experiments with methods for preventing losses from timber-boring insects, including studies of the treatment of green logs with chenical mixtures and in other ways, and other practical methods of handling forest products to prevent insect damages. Work of this character was begun on a small scale in Georgia, South Carolina, and Virginia, and has resulted already in great savings in timber.

The remaining $\$ 5,500$ will be spent in a special study of insects afiecting shade trees and hardy shrubs.

Under the head of insects alfecting truck crops and stored products an increase of $\$ 13,000$ is asked. Of this amount, $\$ 4,000$ will be spent in an investigation of pea aphis injury to annery peas, which will be carried on at the urgent request of the National Canners' Association and of many yrowers of peas for canning purposes.

'Three thousand dollars will be spent in the study of the new Irish potato and tomato weevil in Mississippi. 'This is an insect pest entirely new to this country, recently. accidentally introduced, and it should be intensively studied, since it may possibly. becone a serious pest.

Three thousand dollars more of this amount will be spent in the study of insects alfecting textile iabrics. Very little research work on this group of insects has been possible up to the present time, on account of lack of funds.

The remaining $\$ 3,000$ will be spent in the study of the effect of low temperatures upon the life of insects that attack articles placed in cold storage. The department so far has been unable to give authentic data to business firms making inquiries in this dirertion.

\section{SAIARIES.}

REDUCTION IN STATUTOKY ROH.

Mr. Andersox. We will take up first the item for yone statutory roll. There appears to be a reduction of $\$ 4,200$ in that item.

Doctor HOWARD. We drop out five entomological preparators.

Mr. Ardensox. Are all of those places vicant now?

Ductor Howard. Nearly ull of them are vacant, yes; because we can not get anybody to work for that salary.

\section{FOR IDECIIUOUS FULT INSECTS INVESTIGATIONS.}

JALANESE BSEETLE.

The next item, on page 202, culls for an increase of $\$ 25,000$. 1)octor Quaintance will explain that item.

Mr. Axinessos. For what purpose do you want that incrense?

Boctor Qunistaxce. Mr. Chmimnn, that is to enhrge the work. and especiully the resenrch features of the work. The Japanese bcetle is proving to be a very troublesome insect. We are carrying on investigntions along various lines and we need additional funds to successfully prosecute these. We are hundling nursery inspection und scouting work also under the resenrch allotment. The territory rovered by the becelle is rupidly increasing, hoing now nlmost twice us muchlo us last verr.

Mr. A.mensox. 'This is the bug that attucks the soyu benn?

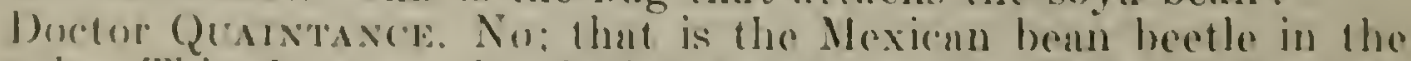
somtl. 'This Inpanose heotlo is locatod anomnd Philadelphia and andarent Now dersey.

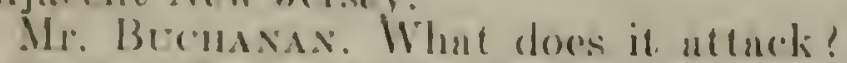

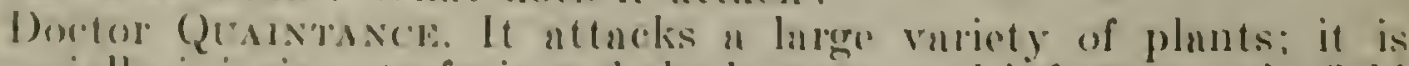

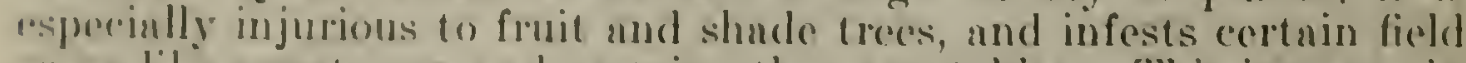

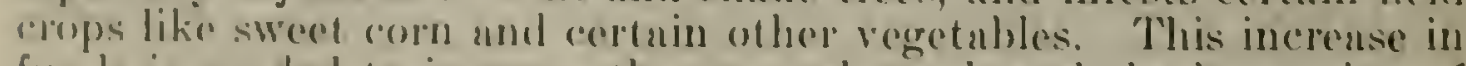
fonds is necoled fo incrense the resented work and the inspection of

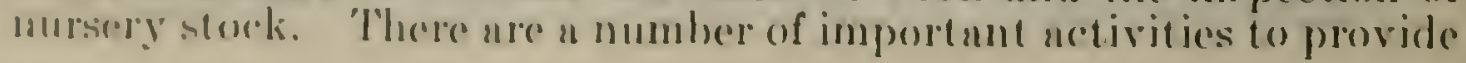


for. as additionsl seouring work, to aserersin lhe further sprosul of

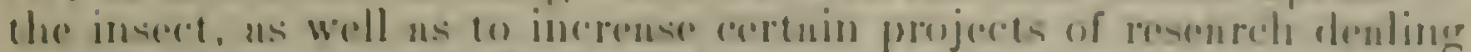

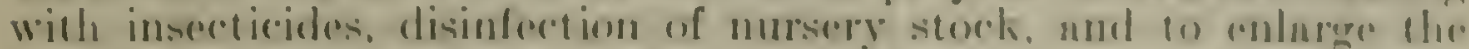

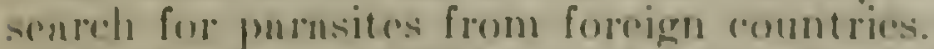

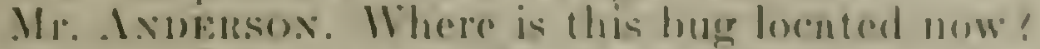

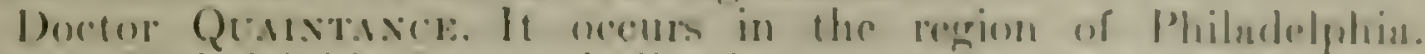

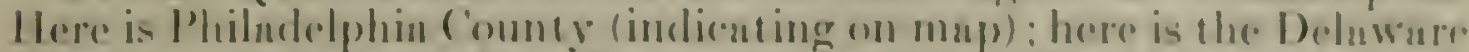

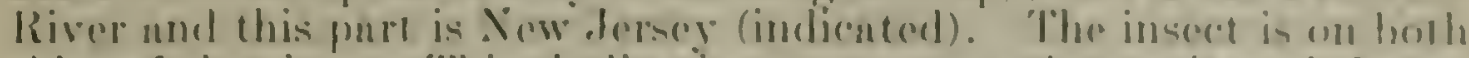

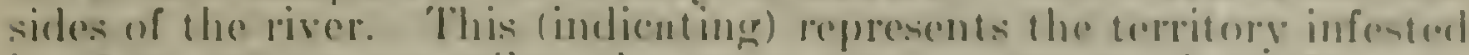

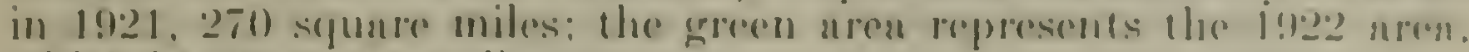
which is $77: 3$ stpunte miles.

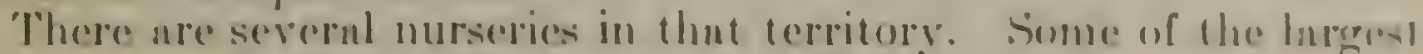

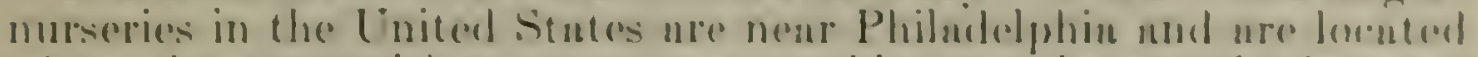
where those groenish spots mppear on this mop alose to tho infosted nren. The nurserymon themselves ne very much perturbeal ubuut

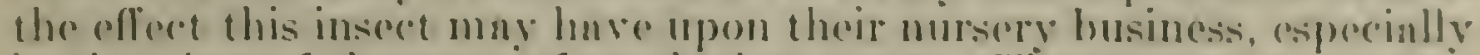
in the view of the type of stock they grow. They propannte mant ormamental plants. especinlly erergreens, and these must have around the roots a small bull of earth so that they will live when repplunted. Now, this insoet, in ono of its stuges, is n grub, dike the common white grub. It muy get into the soil urement the routs of the nursery stock. It is amost impossible to disinfect these bulls of enrth and ship them out sufoly. One important renson for usking an incrense in this item is for reseureh work to aseortain n method of cloing awny with the bulls of enrth mound the nursery stock, or of treating them so that they ran be shipped und replanted with success. We have installed in some nppuratus that lowers or rases the tempernture sudelenly. IV have been putting the plants through that. We have been using girses and solutions of rurious sorts. We have been doing this in tho hope of showing the practicability of sufely replanting coniferous stock with earth removed from the roots. It is estimated that this insect will soon nffect nursery interests rulued at $\$ 10,000.000$ (1) $\$ 20.000,000$, and we are nnxious to do something this ren for the nursery trade in that section of the country.

FFIERAL ANU STATE QUARANTIAES

Mr. Ismkisos. Is a yuarnmtine now muintnined against this area!

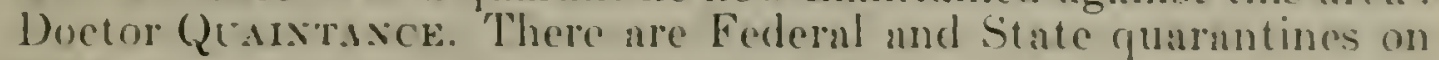
now: res.

Mr. Axurasos. How does that operate and what does it operute unuinst !

Doctor (Qtastaxce. It involves the produce likely to distribute the insect. especinlly the sweet com in this area. The udult hertlo has the habit of entering the tip of the ear: the ear when pulled ofl is sent to market in buskots. Wo inspect all of the swret corn from the territory for the purpose of preventing the spread of this bectle to distant places. but permit the produce to go to local nurkets whelo the insect occuls. Ninety per (ent of this corn goes inte the Plilndelphin marliet. We hure found some four or five thousand beetles this year in the tips of ears of swoet corn. and if we hat not fomnd them the chnnces are that some of thrm would hare been seatlered long distances. Our principal concern is to prevent the long-distance spread of the beoth. renlizing that we can not prevent its normal spread from yest to year. 
Mr. Arpersox. There is no known method of eradicating it?

Doctor Qunstaxce. No. The nature of the country in this aren is such that it would be impossible. It is thickly settled with small properties: it is a suburban district and it can not be done.

Mr. Aniversox. To what extent has it interfered with the growth of truck crops and other crops in that district?

boctor Quantaxce. It has caused a material interference with the growth of peaches and apples. The beetles are out on the wing as peaches are ripening and as early apples are ripening: the beetles collect on the fruit and spoil it for inarket purposes. Along with that they defoliate the trees, and it is necessary to protect these orchards by spraying. 'To do this, spraying is necessary at a time when it is yiute unwise to spray, hecause the fruit may carry more or less of arsenic, objectionable from various standpoints. So there is an awkwnd dilemma; if you protect the fruit from the bectle you may poison it. At the same time the beetles are attacking shade trees in various parts of the district and defolinte them more or less. We are working on other insecticides which will not be so objectionable, and we hope we can secure one that will enable us to spray the ripening fruit and not possibly interfere with its sale.

FEDERAL AND STATF CONTRIBUTIONS.

Mr. Andersox. And how much are you spending on this bug altogether?

Ductor Quarataxce. We are spending at the rate this year of $\$ 100,000, \$ 65,000$ for research work and the balance for this quaruntine and inspection work.

Doctor BAL.. You should make clear the change in program next year.

Doctor QUaIXTANCE. We are plamning to spend another year. $\$ \$ 5,000$ on research work so that the entire incrense of $\$ 20,000$ will go toward increasing that work, and maintaining the inspection service at $\$ 35,000$, the same as at present. The area infested has become so large that considerable additional money will be necessury to handle the quarmantine and inspection of field crops and prevent its long distance spread. 'That item has not been asked for yet: I think you will find a note to that eflect in the Book of Estimates. We expect that the states of New Jersey and Pennsylrmia will support the work liberully: in fact, we think that Pennsylynin will perhaps nppropriate as much us $\$ 50,000$. 'The entomologist and, perhups, other' oflicials haxe committed themselves to that recommendution.

You, probably, are not interested in the diflerent plans for handling this question of quarantine of field crops, but briefly one involves the throwing of the entire Philadelphin area open to the unrestricted morement of produce from the infested area. In that way we would be relieved from a large amount of inspection and all we would have to lewk out for would be the transhipment of the produce along the :onds by trucks und now and then by rail. Another plan would be to suatse insprection of fiedel products in the field at the souree, as we have treen deing, which we ligure would cost materially more. It is a question of the relative affieioney of the two plans and funds arailable.

Mr. Axnemson. They are able to produce (rops of veegetables and fruits aren with the progress of this bug!

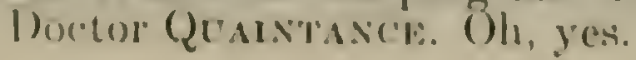




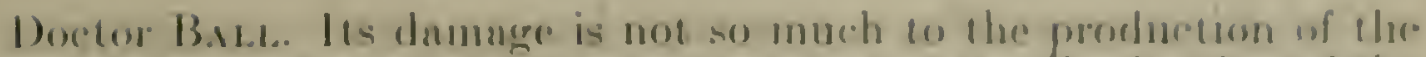
crops as it is to the sule of then on necount of the distribution of the

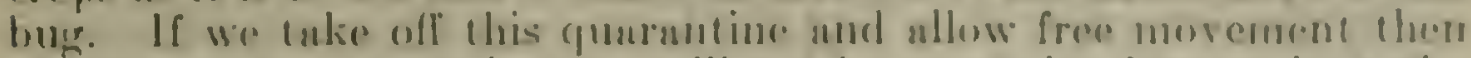

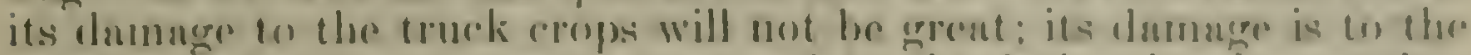

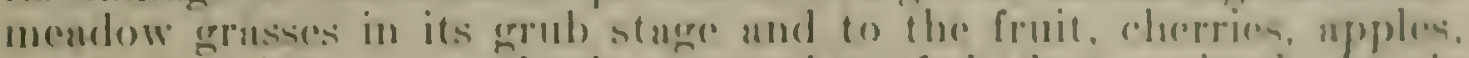
peaches. and grapes. and al large number of shade trees in the heretle stage. It does nest damage the truek to nuy grent extent but it dumuges the sule of it. The approprintion visu are leeing ustied fo comsider now rontants no item ut all for mantaning this gunram ime against truck copos but does contain money to maintain the quarantine on murery storek which will gro ull oreer the United sitnter.

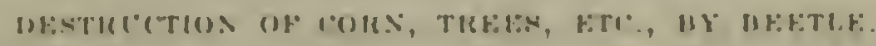

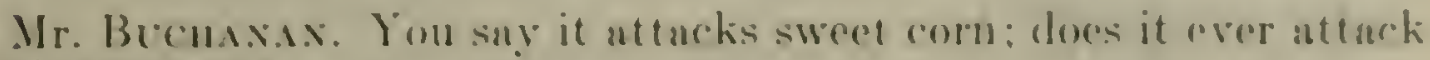
ardinary ("orn!

Doctor Quaxtaxce. To a limited extent.

Mr. Bucmaxis. Do vou hase any reason to bolieve that it will become a menace to ordinary corn!

Doctor Quastascr. I do not believe it will.

Mr. Bucmasax. It goes in the end of the enr just like the old corn worm?

Doctor QunNaxck. Yes, sir.

Mr. Brenasas. Is it like the old corn wom!

Doctor (Qumarasce. No; it is a little bronze rolored beetle. about that long [indicating].

Mr. Bechasix. Is it a worm?

Doctor Qunstaxce. No; it is a hardshelled beetle.

Doctor BAlL. It is a blue June bug.

Mr. Andersox. You say that in the beetle stage it attacks both, fruit and folinge?

Doctor Quantaxce. Íes, sir.

Mr. Axprersox. To what extent does it eat the folinge !

Doctor Quantaxce. It will defoliate trees.

Mr. Annrasox. Then it will lill them?

Doctor Quantaxce. It will kill them; yes. I have seen old apple trees almost defoliated as well as the young growth in many orehards.

Mr. Andersox. Do you have any reason to believe that it will become so numerous in the infested area that if not curbed it will destroy all the trees?

Doctor Qtantaxce. There is every indieation of that. Since the insect was found in the center of this territory it hns been incrensing at a very rapirl inte. This summer it occurred literally by the thonsands where it occurred by hundreds last year.

Doctor Bas... In the center of that area they stripped every singre lenf off of procticully every cherry tree within an ares of a mile square.

Mr. Bucmusax. If this beetle feeds on leaves, why is it mot eats. enough to poison it?

Mr. Q Q MINTANe. It is rery sensitive to any foreign matter on the foliage. and of ten refuses to eat.

Mr. Bucmaxax. Does it feed on a specific kind of trees, ar deres it food on nearly everything?

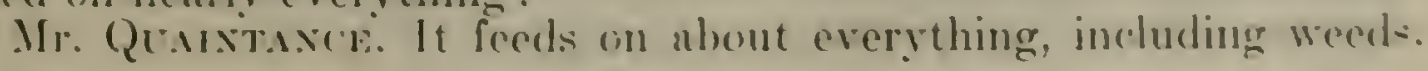


Mr. Buchasax. Has it done any damage where it came from in Japan!

Ir. Quarvance. It is held in check there very well by elimatic conditions and parasites: we have two of our men in Japan studying it.

Mr. Bochasax. Have they done anything over there trying to kill the beetle?

Mr. Qunsaxce. It is not an economic pest there, except locally and in occasional years.

Dactor BaL.. Japan has no grass lands. The white grub breeds in grisss lands.

ATTACKS FIRITS OF AI, KIXIOS.

Mr. Bucnaxix. Does it attuck fruits of any character except apples and peaches?

Doctor Quastarces. It attacks cherries, grapes, and pears, and probably plums: it will eat almost anything. Our records of its injuries to plums are meager, because plums are not grown to any crent extent in the area.

Mr. Bechasas. You think, then, if it lives in Japan it will live in nearly every section of the United States?

Dortor (joantance. There is every reason to believe it will spread in every direction.

Mr. Bronasix. Its greatest damage seems to be to grass: is that it!

Doctor Quantaxce. In golf courses it eats the grass, especially on the putting greens. where the turf can sometimes be rolled up like a blanket.

$$
\text { PECAX INSHC:Y WOKK. }
$$

Doctor How.snn. There is another slight increase in this of $\$ 5,(000$, Mr. Chairman.

Doctor Quarasce. That is an enlargement of the pecan insect work in the South-in Georgin, Florida, Alabama, etc. There have uppenred there recently two serious insect pests of the pecan: One the su-ralled southern stink bug, which is a green foul-smelling bug thut lreeds especially on the cowpeas, grown largely in the orchards for soil improvement purposes. They eut these peas for forage or they die down and the bug migrates to the peenn trees and punctures the muts which at that time are still tender. The result of the puncture apparently is to conse dwarfing or doterioration of that part of the kernel in the shell - the ment-thnt was punctured: and hast your and the yenr before there was a very heary loss reported of this peroling charatere. The nuts looked all right and wore sent out (1) the trade, and then the complaints anme in, and the brokers and growers were quite at a loss to deteret the trouble and stop it. That is one of the inserets that the peran growers hatre made representutions (1) the deprertment about.

Amothere is a small catcrpillar, the larra of a little moth, that appesus in the spring about the time the little pecans are formed. It beres into the muts and the nuts fall, and the injuries have been rery sorere in the somblamst for a couple of years and is on the increase. This insere hos berol quito bad in Texas and some reas destroys the bulk of their crop on the river bottoms. In Georeria we think it quite posible to stop thut troublo hy spraying. 
Mr. Beomanas. Yon have got a hard jol, to spray pecan trees.

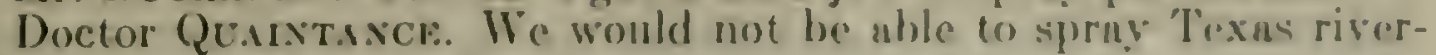
bottom trees economicnlly.

Mr. Armensos. Have you linished with your increases under thin item?

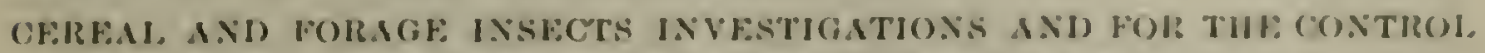

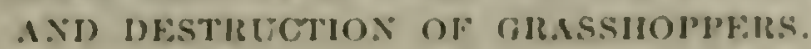

Doctor Hownus. 'There is no increase asked for under the next item nor under the item following that. Of course, if you wish to ask auy questions wo ure here to nnswer them.

Mr. Anversos. Have there been any serious outhreatis of the Hessian fly this last yoar?

Ire. Waltox. No: there have not been any sesere outbreats during last year.

Mr. Becriasas. What does it attack?

Mr. Wartox. It attacks whent, ree, and harley.

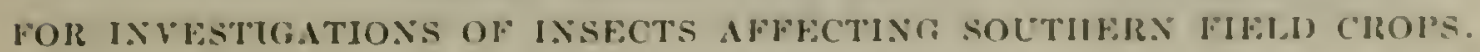

Mr. Axmprsos. The next item is on page 206. investigntions of insects affecting southem field crops, including insects affecting cotton, tobace. rice, sugar eane, etc. Does this item on page 206 include cotton boll weevil?

Doctor Howard. Yes, sir.

Mr. Bucisasa. What have you been able to do with the boll weevil?

Doctor Howard. I will ask Doctor Hunter to tell you about that.

PROGRESE OF THF, BOLL-WFEVIL CAMPAIGN.

Doctor Huxten. Mr. Cond is the man right from the firing line, and he could answer questions more specifically and more directly than I could. Howerer, a large part of the eampaign this year was in testing out poisoning in different localities. A number of problems have arisen with reference to the local conditions and their effect on this process of controlling the weevil by poisoning. In your State, Mr. Buchanan, of 'Texas, in 1921 we had a number of experimental areas where the applieation of the poison was made by our men. In all eases the results were suceessful: that is, an increase in the crop was obtained that more than covered the cost of operations.

This year we had no specially supervised experiments in 'Texas. but a great many farmers all over the State applied poison. 'Toward the end of the season we made an effort to check up, to get some reading on the practical experience of these farmers.

In every case in our publieations and in letters and other communications we have emphasized the importance-this applies more especially to 'Texas, but applies more or less everywhere-of the necessity on the part of farmers providing some elieck area where the poison is not applied so that they will be able to figure nut what results they actually obtained.

In Texas we maile an effort to get a complete list of all users of calcium arsenate. We succeded through the jobbers and from other 
sources in obtaining a list of 110 users. We had an agent risit each one of those farmers senttered throughout the State to find out what results they had obtained, whether they had provided checks or not. Unfortunately in only 29 out of the 110 cases had the farmers provided checks. So there was no direct reading of the results they had obtainel. In 28 out of these 29 there was an increase in production ranging from one-serenth of a bale up to fully a bale to the acre.

Mr. Bucmaxan. They did report an increase of a bale to the acre, did they?

Doctor Hexter. Yes, sir.

Mr. Bucinanax. I am afraid there is another Ananias Club down there.

Doctor Hunter. Some of them were your good citizens in the county of Hidalgo. I hare a full record that I will be glad to place in your hands.

In the majority of cases the farmers did not provide checks; they did not seem to realize the importance of doing that sort of thing.

Mr. Buchanax. Does the cost still remain about $\$ 6$ or $\$ 8$ an acre?

Doctor Huxter. It seldom goes as high as that.

COST OF POISON PER ACRE.

Mr. COAD. The averages from costs from the rarious points this year vary somewhat from the States, but around $\$ 2$ to $\$ 5$ an acre. I do not believe we hare any over $\$ 5$ an acre for seasonal treatment.

Mr. Brchasax. Is that poison applied with the big machines?

Mr. COAD. Every type of machine available is included in the records. For example, we have very excellent work-

Mr. Bechasax (interposing). How many applications?

Mr. Cosn. Well, it varies even on the same property. For example, you take a single property and in striking your areringe (1)1 the place some land may receive one or two applications and another part as much as six applieations. You will find it costs right around-_-

Mr. Buchasax (interposing). I am not talking nbout the cost per acre of one application or two applications: I am talking about the cost pere acre with one or two applications that are essential to get the desired results.

Mr. Cosn. Yes, that is what I whs talling about, the season's treatment, in other words.

Mr. Brollaxas. (One or two applications is not a season's treatment, is it?

Mr. Coan. It is for some lands; yes. Take, for exmmple, ngrent denl of T'exas area, and sometimes in Louisinnn and Mississippi, you have some ureas adjoining timberland or gins or points of hibermution, from where the holl weevils come out after hibermation that mar require four to six npplicutions. Other areas adjoining those will tuke perhaps hut two to four: other areas infested only late in the senson reyuire one or two applientions merely to protect the young loils.

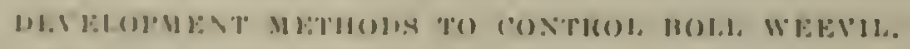

Mr. Buchaxas. Has the depurtmont given any consideration to the recommendntion of this filoridn miversity? 


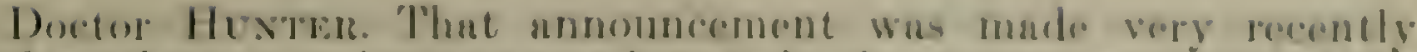
and marks a very important advance in the control molbods of the weevil nnd brings up a mumber of guestions whinh need to be investiganted with a grent denl of corre. Undoubledly u very important adranee has been made in that work, but there have beren points ruised by the author of the bulletin himself ubout the upplienbility of it to other conditions.

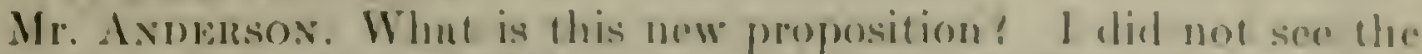
bulletin. I got a circular on it, hut l dicl not got the bulletis.

Doctor Hoxter. In brief, it is simply this: J J ant the rotton about the ordinnry time, and do nothing towned the control of the botl weevil until nhout the sth of June, under Floridn comditions, where all of the weevils that have pussed through the winter huve amerged und made their way to the fields. Buring the weeks immedintely preceding the sth of June the rast majority of those hibernatine weevils will die: that is the nutural course shown by a very laren number of observations which have been made. Conseguently. about the sth of June there will be a very smull number of weevils in the fields, and those that are there will be dying rapidly. Somo will be depositing their eggs. At this low cbh in the reproduction of the weevil all such weevils as are in the plants at that time ure picked off by humble and the fruit on the cotton phant is also remored.

Mr. Buchasax. All of it?

Doctor Hustrer. All of the fruit, gotting the remaning hibermuted weevils, those that huve come over from last year and cutting off the brood for next year for that season by pieking the progeny, eggs or grubs in the squares. The third step is to apply a poison to the plants immedintely after they have been stripped of the fruit, the idea there being to get such straggling weevils as have missed the process of hand picking.

Mr. Axdirsox. Do the fruits sot again after being picked ofl these cotton plants?

Doctor Huster. Yes. The process in Florida shows that this plan of stripping the plants has a remarkable eflece in acederating the process of fruiting a little later.

Mr. Buchasax. That would depend on the chander of hand. It might facilitnte its going to stalks. On some lunds it would be rery injurious-on rich lands.

Doctor BALL. 'This new method has been very successful ounder the Florida conditions, that is, conditions in which they rase a relntively small amount of cotton per acre. On account of the low cost this is in method that appenred to be peculiarly adupted to arens that hure smaller production.

Mr. Axpersox. I think it would be somewhat expensive to go around and pick off the bugs and fruit.

Doctor Howard. It costs about $\$ 1.50$ an nere.

Mr. Bucinasax. The reason that is not so expensive is that a cotton plant about that high (illustruting) will hare 1 or 2 squares of fruit on a stalk and " person (an go along with a sack and pick them off.

Doctor Hexter. One hund picks ensily over an nere a day.

Mr. Buchaxas. Oh, yes. 'There would only be 1 or "2 squinres on a stalk. They do not look nt these squares to sue whether there are bugs on them, but just pick off anything in the squmes. 'These squares are supposed to have been punetured by the weerils which 
have come out of hibernation. The only question in my mind is that ther will have to strike the ficld at the right time or the next square will be punctured, too. It would not be more than three or four days until another syunre would come on.

FOIR INESTIGATIONS OF INSECTS AFECTING FORESTS.

Mr. Axderson. Now please take item on page 209.

Doctor Howary. An increase of $\$ 5,000$ is asked for there, Mr. Chairman, of which it is proposed to spend $\$ 2,500$ in experimental work and methods of preventing losses from timber-boring ins ets; the other 82,500 for shade tree protection. I have no argument to make beyond the mere statement that the funds are required for the work proposed.

Mr. ANDersox. Is there any emergency existing in this timberboring matter?

Doetor Howard. Nothing special.

Doctor B.1LL. It is a subject that has been almost neglected. The timber is growing rapidly in ralue. There is a possibility of using methods which could not hare been employed when the stumpage was cheap. So there is an opportunity now to save timber that could not have been saved heretofore.

FOR IXVESTIGATONS OF INSECTS AFFECTING TRLCK CROPS, FTC.

Mr. Axnersox. On page 211 you have an increase?

Doctor Howand. 'There is an increase there of $\$ 13,000$. The first two expenditures under that increase will be $\$ 4,000$ in the inrestigation of pen aphis injury to camnery peas. And one of $\$ 3,000$ to the new Irish potato weevil in Mississippi. Mr. Graf who has just come from a peal aphis conference, will be able to explain those items.

PEA APHIS INJURY.

Mr. Girsw. 'The pea eanners recently had a meeting at Chicago, and repuested the Burean of Entomology of the department and the intomologists of the interested States to attend this conference and tell them about the control of pea aphis. The insect has been injurions in, this comntry for about 20 years, and in that time several remedies have been tried out, with the result that nieotine has become the arecepted remedy. The cost of nicotine on cannery peas has been so) great that most of the eanners, or growers who are growing the produce for the canners, would rather take a chance of getting part. of their (rop through without treatment than the spending of a largo amount of money for treatment in the licelds.

The troutment of annery peas by either spraying or dusting is very diflient where they have been hrondeasted. Some experimental work was attempted this year in cooperntion with the State of Wisconsin, using the newly prepared nicotine dust. The results are of scientific value in showing the possibilities of this remedy, but not. "mongh has beon done to show its practical possibilities.

'The pora uphis is the mest diflicult aphis to control with either sprity or dust.

The plan for next year's work, which has been apploved by the canners and by all the entomologists attending the conference, was to 


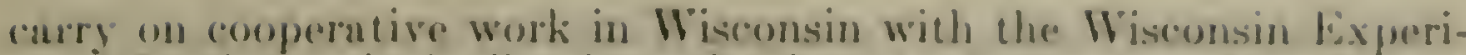
ment station, principally uleng the line of adupting remedies for use in cannery liclels. The lateger part of the work wemlal be carried on in IViseonsin, although the surrounding States-Indiana, Illinois. Michigan, and Minnesola are plnuming to give all the conperative assistance possible.

Doctor How ans. How about the California work on this same proposition!

Mr. Girar. The Culifornia work will be continued. hut the situation is entirely different in the West. Pens are planted in rows nurl con be trouted with sprays. Some additional hiologrical work will he fonc in un attempt to discover the sourec of infestation in the spring. Apparently in the Middlo West the aphis must migrate from wila fool phants to the peas. In (alifornin they are apparenty present (1) the pea plants just as soon as they come ont of the ground and loreed up slowly, and the work in (alifornia will be largely an attempt to determine if thero is not some hope of stopping the early infestation and thus let the peas get ouough of a start so a reop min be grown with few or no insoretiode trentments.

IONT OF TIRHATMEST I'RIR ACIRF.

Mr. I.vorasos. What is the cost of treating an nere of peas with the nicotinc dust?

Mr. Gratr. Rowed or hrondensted peus?

Mr. Axmbison. No: blondeast. Mow do you do it?

Mr. Grar. That is a difficult question. It is just about impossible to spruy these fields with our present efuipment. In the ense of dusting, one ('nn use n duster mounted on nn automobile truck and equipped with a ranvas trailer to hold the dust in the plants long enough to kill the uphis. This is the reason we ure working on dusts inore than other remedies.

I should say that spraring the brondensted pens would cost about st to $s 6$ an reve and would hardly be effective on uccount of being a downward spruy instend of underspray.

Mr. Ininersox. Will this dust get down undernenth so as to kill the bues undernenth the lenves?

Mr. Cirar. Yes, sir. We have had very good results so far as the killing goes. The only sticking point has been the cost thus far. This canvas trailer is fastened to the rear of the truck, and it nlso serves to drag many of the aphids out of the plants and drop them down on the ground, where they are readily killed by the dust.

'The strength of the wind at the time of dusting is an important eonsideration. If the wind is too strong, it swerps all of the dust out of the plants before it has time to kill the insects.

POTATO WFEVI, IX MSSISEIPI.

The other item eovers the new potato woreil in Mississippi. 'This insecet was discovered last springe.

Mr. Buchasix. Tho Irish potuto!

Mr. Grat. Ies, sil\%. It moly exists, so fur as wa know now in about 100 square miles in south Mississippi. Ono of the growers fonmel that his tomato and potatu plants were boing entirely destroyed. He could not find the insects causing this injury. since they foed only at night and hide under clods or trash in the daytime. 
They are entirely different from any insects we hare on either of these plants at the present time. It is ipparently the same as the tomato and potato weevil proving so destructive in -Australia, and this is the only place it has been reported in the United States.

Mr. Buchasax. Is it a worm!

Mr. Grar. No: it is a beetle. But the grub also feeds at night. like the beetle, and hides in the daytime.

Mr. Buchusax. It is like the old bean worm?

Mr. GraF. No. Eradication was first considered but this was dropped on account of the diffieulty in finding the insects. This small appropriation is just to start the cooperative work with the State of Mississippi to try to learn something about the insect so remedies may be developed.

Mr. Bccilixax. The probabilities are that that insect will not thrive in the cold potato climate in the Linited States, if it comes from Australia.

Mr. GraF. It is difficult to foretell how injurious an insect may become.

Doctor How ARn. He does not come from Australia, Mr. Buchanan: it is a curious thing that they were imported into Australin from South America. The insect is a native of the slopes of the Andes in Peru and Chile, and probably was a direct importation from South Ameriea, probably in ship supplies in some ship landing at a Gulf port.

Mr. Axnersox. Do they raise many Irish potatoes down there!

Mr. Graf. No, sir. It has just appeared on some of the smaller plantings and is not yet in any important potato producing district.

Mr. Anderson. Do they raise tomatoes?

Mr. Grak: Not in large quantities, but large plantings exist ut Crystal Springs within easy reach.

Mr. Andersox. Do you know in how large an area it infests?

Mr. Graf. We do not know much about that. It was found in about is or 6 towns. I would say of hand that about 100 square miles are infested. The difliculty of inspecting makes it impossible to furnish an exact statement of its occurrence.

Mr. Axpersox. Does it spread rapidly?

Mr. Grak. We do not know anything about it.

Doctor' Howann. 'There are other portions of that $\$ 13,000$ not yet explained. The $\$ 3,000$ to be spent in textile fibers, and $\$ 3,000$ on low temperature studies as to the life of moths in furs and the life in cold stornge: If you wish any further informntion, Mr. Beck will toll you ubout it.

TEXTLL FAHUC STUHL:

Dortor Brok. Textile fabries rolates to the work of the injuries by mothe to manufacturers of upholstery and other fabric manufactures. surch us those who put out these mohairs, and besides, the silk mills throughout the country and woolen manufacturers, and all these who store riw worol.

During the past wor or three geass we found that there had heen a considerable umount of damnge to raw wool in storage by these mothes. But the demund for information from the fabrice concerins hins increased considerably this last year on aceount of the development of chemiculs for moth prosting fubries, the attempt being to 
moth proof fubries by giving them a trentment before they go out to be made up into clothing, and we have spent a gerod dent of time so far this rear in dotermining whut effect these troutmonts have. We have besen doing it he taking money from cortuin other uppropriations.

Wo have found that there are some trentuents one treatment consists of a rombination of aluninum sults and elocelricity. which secms to be verve good: und nnother one which is less proming but being advertised considembly by certuin firms.

So far we call not earry on this work satisfuctorily. Wo ought to make a thoroughgoing study of ull these tests - a thorough bioforerient study, and study of control methods.

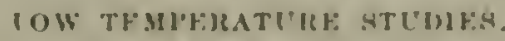

Low temperature work has chiefly to do with the value of cold storige protection of fondstuffs. The development of cold stornge hus, of eourse, been phenomennl in the pust few years, but the department has not the information it ought to have to tell cold storage lirms or brokess or farmers who handle large stocks just how long they would huve to keep their commodities in cold storage before they can issue those stocks und guarantee them to be free from living insects.

Beans and pens are in cold stornge now, und we are frequently usked how long to permit them to stay in cold stornge nt $36^{\circ}$ before we con guarantee the bean weevils to be killed. We have found that information now, but the last call was from the dried-fruit industry to find out how long these "Sun Maid" raisins should stay in cold storage at $32^{\circ}$ before the insects in them are killed. Of course, it is un cxpensive treatment-cold storage-and they would like to remove them from cold stonrage as soon us they can. Now, practically, they are held in cold stornge throughout the summer, just to protect them from the insects.

Mr. Axinfersox. How long does it ordinarily take?

Doctor BECK. Well, in connection with the insect for dried fruit. we have not any idea, but judging from the work that has been done with other inserts. we think that at $32^{\circ}$ the majority of the insects ought to be dead in about three weeks. Other forms, which are much more insistent, we have not information on. The big warehouse compsnies want information on the length of time they must keep the clothing-furs-in cold storage at various temperatures before the moth is killed.

We found, in connection with that, than full-grown elothes moth will live-may remain alive-in cold storuge one and a half years. and come out in fairly thrifty condition.

Mr. Bucmaxis. What temperature kills them?

Doctor Beck. That is what we are trying to find out. We know that many of them will die at temperatures averaging in the vicinty of 40, but we have had a cood many in cold stornge here in Wishingt on for one and a half years at a temperature ranging from 26 to about 50 and down, but averaging ubout 36 . It is a verv interesting piece of work, and the information will be very practial to all persons interested in the cold-stornge concerns. 
FOR INVESTIGATIONS ANI DEMONSTRATIONS I. BEF CULTLRF.

Doctor Howard. The next is bee culture, Mr. Chairmin, in which there is no increase requested.

The work of this section is chiefly concerned with investigations of problems of importance to practical beekecping. All beekeeping practices rest on al linowledge of the hehavior and physiology of bees and as a result the investigation of the office follow these two main lines. I detailed study is being male of the temperuture and humidity of the colony throughout the active period of the year, as influenced by external factors, comparable to the work done a few years ago for the winter period. The work on wintering revealed the desirability of certain important modifications in beekeeping practices, and the work for the active season was undertaken in the expectation that it also would yield important practical results. It is too early to report the exact bearing of this work on beckeeping practice for this part of the year, but it is evident that it will furnish cxplanations for certain phenomena now observed but not understood. A study is being made of the factors influencing the rearing of brood in the colony in the early part of the year. One of the most important problems of the beekeeper is to get the population of the colony to the highest possible point before the heary secretion of nectir begins and this study is undertaken to determine what factors inHuence this increase. From the information gained it is expected that detailed information will be arailable to the beekeeper which will enable him to have all his colonies to the desired strength at the right time. If this can be accomplished it will materially increase the production of honey per colony and thus decrease the cost of production.

In connection with the study of wintering it was found that certain honeys cunse an abnormal condition of the bees, commonly known as dysentery. To determine the exact cause of this condition a series of experiments was undertaken to determine the utilization of various carbohydrates by the bees. It has been found that the dextrins in honey are the chief cause of this trouble, and as these substances are found to a dangerous degree only in the darker honers, it is possible for the beekeeper to prevent this condition merely by examining the color of the honcy available to the bees during the winter, as in case it is dirk to supply the bees with a small amount of sugar syrup after all gathering of nectar has censed. I change in the behavior of the bees in sterace in the full which has been observed makes it possible to prevent ilysentery without removing the dangerous honey from the hive, but merely by supplying a better food for the period of the winter, lanving the less desirable honey for spring use, when it is entircly safe. This will remove a serious source of winter loss which was not fully controlled by the usual winter care advocated by the publication of the bureau.

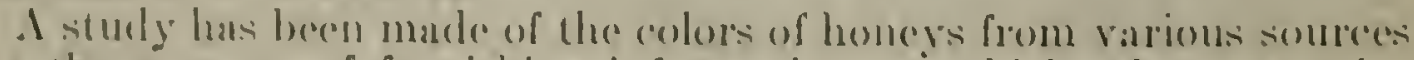
for the furpose of furnishing information on which adeguate coler standards for homer mug be defined. This will prevent the confusion which is mess so often cexperieneed in the wholesale selling of honey.

Thu discase of beres still demands attention. Special work has

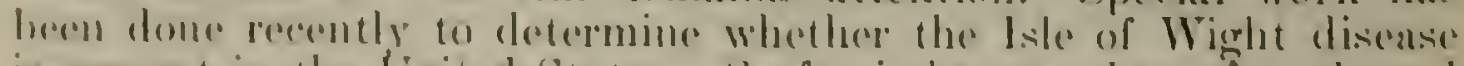
is present in the (onited Stutes. So far it has mot berol found, and 


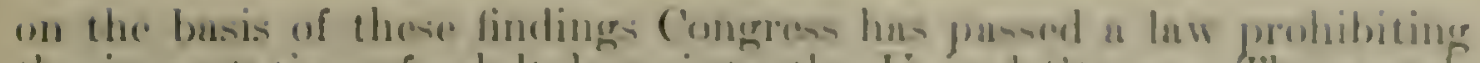
the importation of adult bees into the linitul sisem. The soarefo for this disense will be contimued to make sure that the disanse is

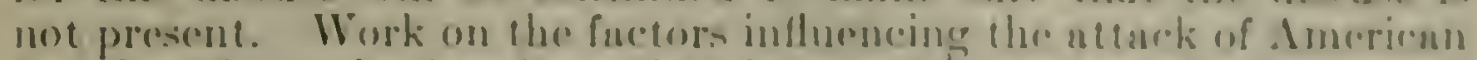

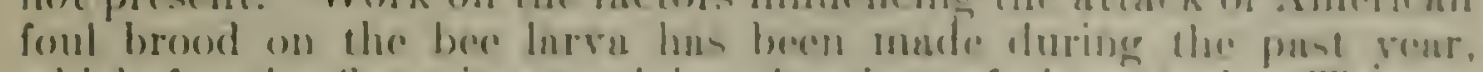
which for the lirst time explatin the lime of the nttack. The ons-

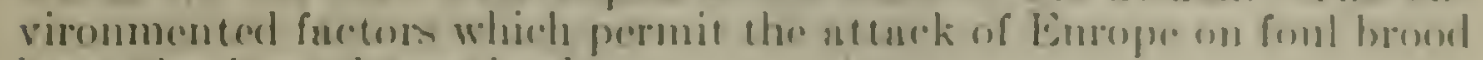
have also bersh determined.

Detniled instruetions for the ganthering of the muximum homey-erop) have bern prepured and published for there of the main heney recrions

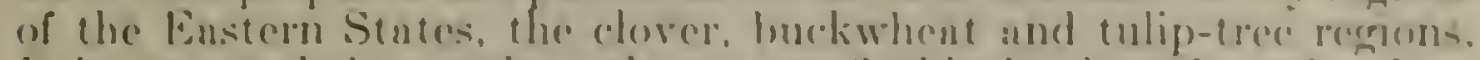
It is expected that such work muy profitably be done for other heekeeping regions of the country, thus making the recommendutions of the department more specific for the various parts of the country.

The demonstration work in heekerping has been reduced, the work having been turned over to the severn! Stutes as soon ns they were able to continue without the help of the burenu. Work is now being continued in only three States. This work has resulted in a grent advanee in beckerping in rurions. Stutes and has been a most profitable line of work.

The work in bee culture denls with those problems which most closely nffect the beekeeper in maintaining his prorluetion. Following the recent decline in prices of honey, the beekerper is in need of specifie assistance in order to prevent a loss of the increase in honey production which oceurred during the war. The work now under why is chosen so as to be most serviceable in muintaining this growing branch of agriculture.

FOR IXVESTIGATIONA OF INSECTS MFECTIS(; CITIES ANI) (OTHEL TIBOPICAI, ANI SLRTIBPIC.M. PI.ANTS.

Mr. Aromersos. What is the next item?

Doctor Howarn. There is no change in the next item, but we suggest taking out the item of last yenr of which $\$ 10,000$ will be immedintely nribable for comphor scule.

CAMPHOR SCALF INVESTIGATHOSS.

Doetor (Quastaxes. Cnmphor scale was discovered two yenrs ato in New Orleans in the shade trees on the streets and in the parks. It hus since been found in Mississippi at four pluces in which it has been believed to be eradicated. But it is also foumd in the citrus belt of Alabama. Mobile, and Grand Bay, the Satsuma recrion. The Sutsumn industry in that territory is developing very rnpidly. The scale seems to hive come over on shipments of commercial nursery stock from Japan direct ubout 1911 or 1912 , and has gotten quite n start in a few orehnrds. It kills the small twigs of the citrus trees. but especinlly incrusts the fruit. so that the fruit should not be marketed. It is practically worthless if the scale occurs in any quantity. We hud a hearing to-day before the Federal Horticultural Board us to the advisability of Federnl quarnotine on this scale.

We are having the fullest cooperation with the States involvedLouisiana, Mississippi, and Alabama. The citrus industry of Florida, Texns, and Californm is much exereised over this insecet and has put in force effective quarantine mensures. 
The insect attucks some 150 different sorts of trees and plants, including a good many of economic importance, as the Japanese persimmon, the peean, rubber plants, roses, pench, plum, and the like. We do not know, along with its further spread, whether it will becomo an important pest in the Georgia peach belt or not. The inseet is too new to enable us to surmise what it may do.

We have a laboratory in New Ortenns where the insect is being given carceful consileration, is a study of its parasites, its methods, and rate of spread. Lxperiments are being made in the New Orleans territory and also in the citrus area in Alabama with spray's and other methods of control.

Wre can report distinct progress in our knowledge of the insect itself und progress in developing control measures.

Mr. Buchanas. What does it attack!

Doctor Quan'taxce. It attacks many linds of plants -

Mr. Bucraxax (interposing). No, no; does it attack the limbs or the fruit?

Doctor Quaxtaxce. It attacks the twigs and leaves and fruit of certain fruit-bearing plants at lenst. It is especially noticeable in camphor trees. It attacks the small branches, which die very guickly. It first was discovered by reason of injury to these trees in New Orlenns. Our men working in Japan are going to send us some parasites from Japan if possible. 'They have one or two now under cultivation.

Mr. Axmersox. Are there any developments under this item worthy of note at this time?

\section{FOI AIMNISTRATIVE AND MISCELIANEOUS EXPENSES.}

Doctor Howand. I think not. The next is general administrative expenses - no incrense.

FOR PREVENTING SPREAD OF MOTTLS.

Then comes page 211 , prerenting spread of moths.

Mr. Axpersox. There seems to be a slight reduction.

Doctor Howar1). It is reduced from $\$ 600,000$ to $\$ 531,000$.

Mr. Axinerson. I think you better tell us something about the status of this moth proposition.

(iYISY ANI) HROWX-TAIL HOTHS.

Mr. Bungess. The gypsy moth and brown-tail moth activities have been carried on along the same lines as during the previous your, with the exception that somc foreign work has been attempted to bring in purasites to work on these species. As you know, the work is divided into three sections. One section linndles the scouting and border work to determine the area that is infested and to carry on clean-up work along the border territory. Practically all of thrit work is dons in New England, with the exception of the work that is done in Now Jarsey. where the moth was found a little over two yemise nero.

The New Enghand work along the border was held up for a time Inst spring bocouse our funds were very low until the approprintion passed, and then the force was incrensed as rapidly us possible, but injury resulted before that work could be resumed. 
The Now Jersey work was continued throughout the winter and very good results have been secured.

Mr. Avibuson. Is the New Jersey business on an eradication basis !

Mr. Bukgess. Yes, sir. Only a fow hundred caterpillars were found Inst summer and the scouting work this fall has not progressed far enough to give a good idea of what will develop, but wo do not anticipate as much infestation as there was last year.

ATIVITI:S IS IR:W JRIKH:Y

Doctor Howari). Let me interrupt you long enough to ask Doctor Ball to grive his impressions of the elean-up in New Jerser.

Doetor Bard. 'That was one of the most surprising things I have erer seen in the insect line. There was an area there in which they had lilled practically every tree over a large district, and were depleting the trees around there in a greater circle.

The moth had sprend for nearly 200 square miles, and they sturted in a yoar ago, and when they sprayed the first time there the caterpillas fell off and just practically covered the ground, just mande in bed of caterpillars on the ground, and this year they could unt find caterpillars enough to feed the parasites on the whole area. Of course, this eradiention in New Jersey, as we have toid you all the time, is a hopeful proposition, but not an absolutely sure one. I feel rery much more hopeful of it than I did before: and unless crerything at the present time is deceptive the outlook is grood.

Mr. Annersox. Do you continue the spraying just the same when you find the caterpillais or not?

Mr. Burgess. The operations in certain ureas depend on scouting work done in the winter, and if we find infestation in a locality during the winter, we sprny that locality and a good belt surrounding it.

Mr. Axnersox. Are you pretty certain to find them, if they are there?

Mr. Bungrss. Reasonably certain.

Doctor Bata. If they were there in any numbers. they would be found.

Mr. Burgess. If they are in any wy numerous, we would find them. There were also in New Jersey eight outlying small colonies that eame as a result of shipping trees from these badly infested areas before the infestation was known. Those have been cleaned up, and no infestation was found in those areas last vear or this rear. We will follow up the scouting of those areas another year to check up so as to be sure.

There were also three areas where infestations went from that main area into New York State, and those have been cleaned up in a similar way.

I.FFF,

Aside from the New England and New Jersey areas, there are two small infestations on long Island that have been given very careful consideration this year. I might say, howerer, that we depended to a large extent in these infestations on spraying this spring, and we had a very unfavoruble season for spraying. "There was a great deal of rain and we did not accomplish as much by 
spraying this spring as in an ordinary year. The results have been reasonably good in those sections, however. But we expect to find some infestation there this fall and will have to follow the matter up.

MrTIODS USFI) IN F.XTERMINATIXG IXSECTS.

Mr. Annerson. Where did you say you depended on spraying? Do you use any other method?

Mr. Burgess. We destroy the egg cluster's where they are found, and the egg cluster is about as big as a quarter of a dollar, a buffcolored patch, hid on the under side of the branches or tree trunks at the foot of the trees. It is treated with ereosote whenerer found. We do not serape them from the trees, beeause if we did we would seatter the eggs, but they are treated right on the tree surface with ereosote, so that they are killed completely.

Mr. Buchanas. One treatment kills a cluster, does it?

Mr. Burgess. Yes, sir. The scouting in New England developed an increase in area in the southern part of the territory, Connecticut and in the Massachusetts; and with very nearly the same area infested in Vermont as in the previous year. The infested area in New England on the western border, the new area, is very lightly infested, and we are carrying on scouting and clean-up work in a strip approximately 25 miles wide from Long Island Sound, up through Connecticut, Massachusetts, Vermont, and New Hampshire.

Mr. Axperson. You do not do any spraying exeept along the border in the New England section?

Mr. Burgess. No, sir. And then in the areas where there is the greatest likelihood of infestation by wind spread, exposed areas where the caterpillars might blow long distances, and a great deal of the work there in these lightly infested areas can be done by creosoting. There have been this fall two towns in New York State over the Massachusetts border, in one of which there was a cluster found and another one in which two egg clusters were found, New York State is very much interested and very much concerned as to what the future developments are going to be.

QUARANTINE WORK.

Another branch of the work consists of quarantine work. All of the infested territory in New England is held under Federal quarnmtine, and all products likely to enrry the moth to other parts of the United Stutes must be inspected before they proceed.

'The Now York and New Jersey arens nire held under pun rantine in couperation with the States: the areas are so small that it is possible to handle them by an arangement with the States. It has been done in that way and very sutisfactory results have been secured.

Doctor Howsins. 'The commiter will be interested in henring you cover the hrown-tail moth situation.

Mr. Bereiss. I will spenk of that shorty. The experimental work corors difineme lines of work, designed to develop better field methods and to bring in and disseminate the natural enemies of the erpey moth. A grent denl of work of that sort along the parasite line was done a number of years ano, and wo secured from Burope and from dapan somo of the most ronspicuous and easily eollected pnsusiles. They were hrought into New England and have heen 
libented in different lonenlites in the infosted uren Their life his-

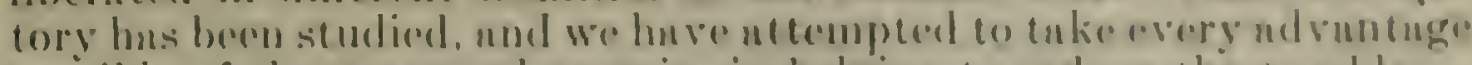

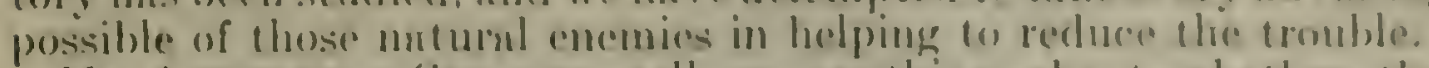

Mr. Asmensos. Cin you tell us nnything nhesut whether lhery huve any offect or not?

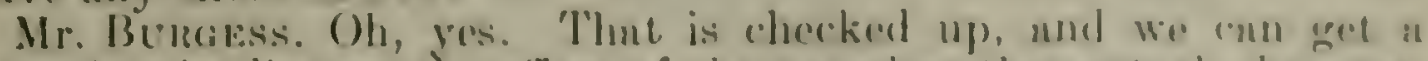
very definite line on the effect of the parnsites thut nthek the reggen,

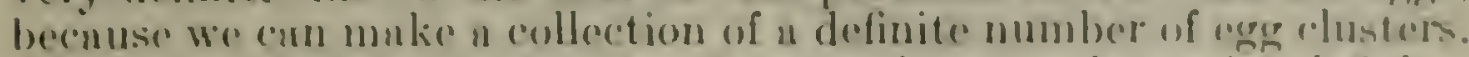
We know definitely the number of erges and we con determine definter ly the parnsitism of the egres. But it is 1 geod dent more difficult to deformine the benefit thit is derived from purnsitism of the cuterpillnrs, herenuse in a good muny of these conses purnsitism is likely to be quite locenl. nul there nre some species that muy be very uburdont in one loculity and muy not be in mother.

The purnsitism has incrensed, nud there nre some olements, such as the offect of extremely cold winters that reduce the number of egg clusters in difforent yours. But, unfortumntoly, the exgy chusters thent ure protected by snow or iee are not killed of by the extremely low tempernture.

As I suid. the most ensily collected parnsites from ubroul huve been secured and hrought in, but there ne some others that we have records of that are npparently abundant only at specinl times-that is, when the gypsy moth is prirticularly ubundant in some loculitiesand those are species that we would like to hring in, becanse we wunt to get all the help that we possibly enn, and for that renson work was taken up this summer in Europe and in Japun ntong that line und some interesting information was secured. One shipment of pnrasites was sent over from Jupan; it is the most diflicult to bring those living things through in good condition: owing to fnilure in the proper icing between Senttle and Boston the grenter portion of the individuals in the shipment died. But we did secure some breding stock, and it has been placed in the field, particularly in southern Mussachusetts and Connecticut. We also sent some down to New Jersey. We hnre made it a point in that New Jersey work to send parasites from New England down into that section, pnrticularly those purasites that can muintain themselves on other hosts hesides the grysy moth.

They will not only be bencficinl in curtailing the increase of the cotepillars, but if there are strny caterpillars of the gyps moth, it. will give the species a chance to do some good work and help) along the ficld work, that we are trying to do.

IROGRESS ON TIF, F.TERMIXATHA OF BHOWX-TAH, MUTH.

Doctor llownd spoke about the brown-tnil moth. Wo have done some work on that insect. The maximum aren of spreat of the brown tnil moth was in 1914. It was in nbent half of Mnine, thrersquarters of New Hampshire, one-hulf of Vermont. three-fuarters of Mussnchusetts, the whole of Rhode Istand, and one-third of ('onnectieut, also it small section at the end of Long Istand. This yeats our recorel indicates that there has heen 1 grent reduetion, from year to yenr, which amounts to fir per rent of the nren, hased on the mximum for the vent 1914 .

Mr. Axpersos. What is the brown-tail moth? 
Mr. Berowss. The brown-tail moth is a moth that came orer from Europe. It is abundant in Europe.

Mr. Annersos. Where is the infestation here!

Mr. Burgess. It is entirely confined to New England, and at present it is known only to occur in Maine, New Hampshire, and Massachusetts. There are no infestations known at present in Vermont. Connecticut. Rhode Island, or Long Island, so we feel that progress is being made with that insect.

Dortor Howand. Those insects are mentioned together in this item relnting to moths. Wo have only two more headings in the buck of the book.

Mr. Axinersox. You are providing here a reduction of $\$ 69,000$. What is the basis of that reduction!

Doctor Howard. The fact that you gave us $\$ 100,000$ to be made available last rear, and we did not use all of it, and it went in as \$5.50.000, and the Budget Bureau scaled it down.

\section{PREVENTIOA OF SPREAL OF FUROPEAT COR.T BORER.}

Mr. Andersos. We will take up now the item on page 224, the Eurmean corn borer.

Doctor Howand. We ask for no increase there. The European eorn borer sprearl into Rhode Island and Maine this past year and made a slight spread along the southern border of Lake Erie. but the work we are carrying on is the same as last year, and I do not know if you want any further word on it or not

Mr. Ainersox. I would like to know what the status is now.

\section{PROGRLSS OF WORK.}

Mr. Wartox. This small scale map shows distribution of the corn borer. The situation in the western end of this infested area is much as it was last year. There has been no important change. There has been very little spread there [indicating on map], although there has been a little spread in contiguous territory.

Mr. Axdersor. Let us finish with that. What are you doing to ('onfine it to this area?

Mr. Watox. We are enforeing interstate and intrastale quarantines.

Mr. Axunsos. How is that canried out?

Mr. Warrox. This work is curried out he the inspection of all arops rexept corn, which is not permitted to move outside of the infested area in any circumstances, except in shelled condition. Thut quamutine, of course, is applieable to the entire infested area.

Mr. Anofrsox. What is heing ane in the area to destroy the insert?

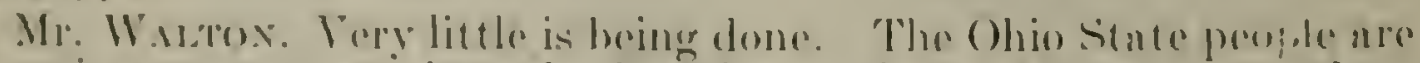
carring on $"$ sumpaign of erluention to indues farmers to ndopt methods which will redene infestation. 'This is so rery slight ut the

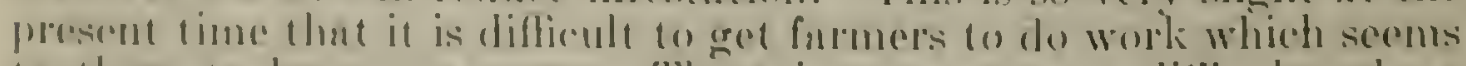

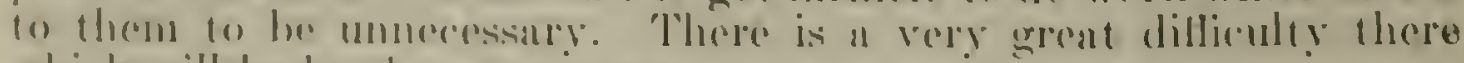
which will be hasel to overeome.

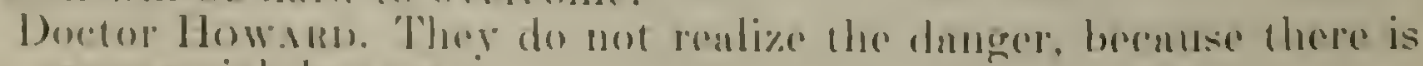

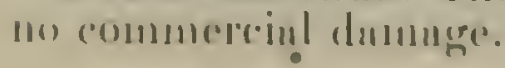




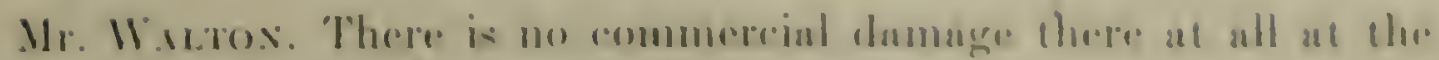
presient timte.

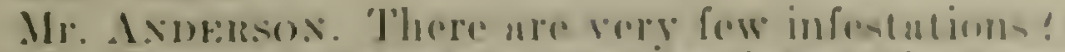

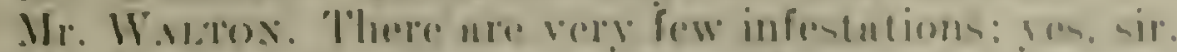

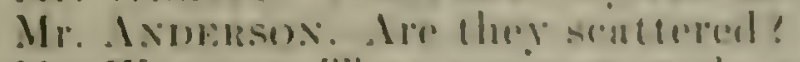

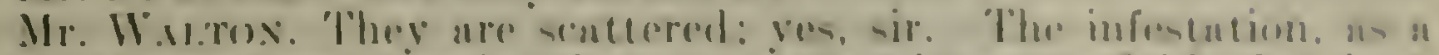

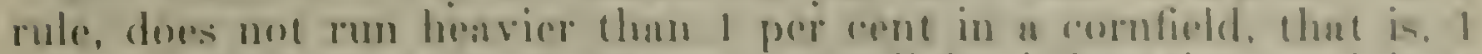
raterpillar in I stalk in 100, "rery slight infentution, and it is almust impossible to find it.

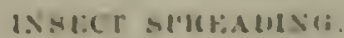

'Tu ero on with the distribution of the insect, there hus been as general spread to the morthenstward, in the general direction of the prevaling wind. Must of this hus beon in contiguous territury. There has been no commereial spread, or long jumps, but a sprend by flight of the moth to the north and northenstward.

In the western end it is nergligrible, hut in the western end of New Fork there has been a considerable spread from the west, extending to the eastward edge of Wyoming county. The spread there this rear equals the contire aren of infestation that hand oceurred during previeus years.

Mr. Anemsox. Is the infestation there light!

Mr. Walton. Yes; but it is not as light as in Ohio and Michigan. There is some apparent injury, for instance one shipment of sweet corn was taken to a canning factory which had 7 per cent of the ears infested, but that was from a single farm.

Mr. Anofissos. What would you do in a cuse of that kind!

Mr. Waltox. Well, they rejected his corn.

Mr. Axoensox. That did not kill what was in it.

Mr. Whrox. There is no way of killing it when it gets in an ear of com. exeept taking it out and smashing it, but the commercial injury is so slight it is hard to get farmers to act. The New York people are doing what they ('an in the way of education, and we are receiving active cooperation from the State people, the New York and Massalchusetts people.

In the eastern area of the infestation in New York that is shown by this red area-the in jury is very slight indeed, although the insect has been there for a good many years. These areas, rou understand, are areas of one generation of the insect. one generation per annum.

Mr. Axmensos. When you say "these," what do you mean?

Mr. Waltos. Eastern Now Yurk, western New York, this corner of Pennsylvania [indicating on map], the northern part of Ohio. and the southeastern part of Dfichigan.

Mr. Axinersos. Is that only 1 year old!

Doctor Ban. One generation in a vear, and orer in Massachuselts it has two.

Mr. Waltox. I was gromg to say that it had two generations in Massachusetts, so that the insect increases twice as fast in the New Enghand area as it does in these other areas.

Doctor Howann. There is extraordinary damage in New Englanel this year, is there not? 
Mr. Waltox. In New England we have a great increase of injury to garden crops. At the time this infestation began in New England, not when it began, but when it was discovered in 1917 and 1918, there was a great deal of early sweet corn raised in the eastern New England area, and as the injury by the insect increased, farmers began to discontinue growing it, because it was unmarketable, and the consequence has been that the corn borer entered these other crops-celery, beets, beans, and rhubarb-and at the present time the infestation in these crops is very heary. There has been a good deal of commercial injury this fall.

Doctor BALL. Tell about the injury to corn.

Mr. WaLTOx. The injury to corn was so heary that the sweet-corn farmers have practically ceased producing it, except for local consumption.

Doctor BaLL. Tell about the injury to corn in Canada.

Mr. Walton. Well, we had not been discussing the Canadian infestation. That is outside of the United States.

Mr. Buchanas. I would like to know what damage it does where it has a foothold.

Mr. Andensox. Please finish with the New England business first.

Mr. Waltox. I was about to say there has been a grent deal of spreal in New England this year, because of the densely infested condition of the older territory. There has been no clean-up there for two vears.

Dictor HowarD. The weed areas are full of them.

Mr. Wartox. The weed areas are full of them, and there has been a great flight of the second generation moths, which occurs during the last week in July and in early August, and the insect spread up the Merrimack Valley to the center of New Hampshire, and they have flown along the Maine coast for a long distance. There is the heaviest infestation in Massnchusetts and New England this year that ever has existed.

Mr. Avinersox. Is there any clem-up work, or anything in contemplation there?

Mr. Waltox. 'The commissioner of Massachusetts is endeavoring now to secure funds for that purpose. He thinks he can get $\$ 100,000$, hut he wants the Federal Government to help him.

Mr. Axiserson. Is the Federal Government doing any clenn-up work ut ull in Mussuchusetts?

Mr. Waltox. It is doing no clean-up work in Massachusetts. The funds ure insulficient for that purpose.

Mr. Axinksos. You are merely attempting to muintain a qunranline?

Mr. Walsox. We are merely attempting to mantain quaruntine, seouting and limiting the nrea of the infestation.

Mr. Axmersox. I would imagine the clean-up of the aren in which the woods and crops are infested would be a very diflicult matter.

Mr. Waitos. Yres, sir. It does not mean erudication. It means "reduction of the intensity of the infestation to perhaps reduce this great migration of moths.

Mr. Axmensos. Has uny mothod been worked out by which that an be acemplished! 
Mr. Watton. Yes.

Mr. AxDensox. Is it practiral!

Mr. Wartox. Yes; it is costly, but it con he clone.

Mr. Avorersos. Plense toll us whut it is.

Mr. Watros. Burning over the weed areas at the time when the weeds are in a dry condition. That can be done.

Mr. Asnersox: Are those weeds burned with un oil burner:

Mr. Wastos. Yes; they are burned with oil burners, and there also has to be a fire protection to control the fire after it gets started.

Doctor B.1s.. It could be done if they went at it in a commercinl way, but the destruction of weeds would be chaner by a chemical process. Burning the weeds will of ten incrense the erop the next vear. If we do it by chemicals it would climinate that.

Mr. Axmensox. Can they destroy it with chemicals?

Mr. Wartos. Yes: sodium arsenite is used, which is very effective.

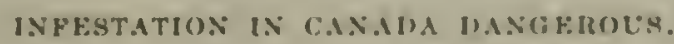

As to the Canadian condition, a very intense infestation of the corn borer was discovered near St. Thomas, in southern Ontario, in 1920, and since that time this infestation continued to exist, and became very much more intensified in 1921. There was rery serere injury to corn. Some of the flint cornfields were an entire loss. Since then either the insect has spread, or the scouting work has been much more effective, and it has been found that practically the entire southern half of the Province of Ontario is infested with the inseet. They have the largest single area of infestation on the American Continent. This year the injury in the center of that area is not so grent as was the case a year ago.

Doctor BaLL. They cleaned up the cornstalks orer the heavily infested area last year.

Mr. Waltow. They cleaned up, and the Canadians believe that a large portion of that reduction of the infestation has been due to delay in planting corn to a certain date, a date beyond which the moths will have died off.

'They do not raise much corn for grain purposes. It is largely a forage crop. It is raised for silage. They can delay it when it is planted for silage. Whether or not that would be applicable to Ohio and Michigan conditions remains to be seen. Probably it will not be. except to a limited extent.

POSSIUIITY OF INSFCT SPREADING ALL OVER TIF UNITED STATES.

Mr. Axinensox. Have we got a prospect of getting this bug all over the United States in due time?

Mr. WaLtox. It looks that way, ulthough perhaps the spread will be slow. In the meantime we are bringing in the natural enemies from Europe. We liberated 1,000,000 of one species in Massachusetts this summer, and several other species, which promise equally well will be liberated later on.

Doctor Howand. We are making a more intensive study of European parasites than erer before. It the laboratory in the south of France they are studying the life round of every parnsite.

Mr. Axdersox. Where does this com borer exist in European countries? 
Doctor Howamo. All along the Mediterranean.

Mr. Axpersos. Do they raise corn there?

Doctor Howard. Yes.

Mr. Axinersos. Do they raise it suecessfully?

Doctor Howam. Quite successfully; yes. In Italy, especially, the corn borer oceurs in almost every cornfield, and does not have an appreciable effect on the erop.

Mr. Anversox. Does the spread of the borer rary from year to year under different climntic conditions?

Doctor Howanin. It does; under different seasonal conditions, you mesn!

Mr. Avinersoi. Yes.

Doctor Howard. It does, unquestionably. We have records of its damage in Besarabia and 'Transylvania which show a severe damnge: but there is no record of severe loss along the Mediterranean, and we tmuk it is controlled by parasites, and that is the reason we are over there trying to get them and bring them over here and reproduce the entire environment of the insect in this country.

Mr. Ardersox. In bringing them orer is there any danger of bringingr bugs that are harmful?

Doctor Howard. Quite the reverse. They are so well known in their habits and relations that there is no danger whatever. In fact. it might interest you to know that one of the parasites we brought over for the European corn borer we expect to be a very efficient enemy of the native cornstalk borer in South Carolina, and it is a parasite of the sugar-cane borer in Louisiana, and we have liberated a large number of them in sugar-cane fields in New Orleans this past. year, and it will serve, possihly, a triple purpose we hope.

STATE COOPERATION.

Mr. Axversox. Will you give us some idea of the prospects of offsetting funds appropriated by the States next year?

Mr. WAlToN. I can grive you the figures on the amount that the stites furnished this year. Perhaps that would interest you. I have no figures on what they may furnish next year.

Mr. Axinerson. 11 light, go ahead.

Mr. Watox. The States fumished this venr, for the cooperntive work, " otal of $\$ 49,700$. This is distributed is follows: Michigan. $\$ 4,000$ : Ohio, \$11,000; New York, \$15,000; Massachusetts, \$15,000: Sew Humpshire, \$2,000; Muine, \$2,000: and Vermont, $\$ 700$.

Mr. Axmersox. 'They do not seem to be rery scared up there.

IIr. Waron. Wither that or they are very poor.

boctor Howam. Massachusets is thoroughly scared now.

Doctor Bs.1.. It had not been in Vermont until this yent, and only in the edge of New IImmpshire.

Mr. Axwersox. Is the amount requested suflicient to mantain the work on your present hasis!

Mr. Mstres. Yes: without the conduct of the thorough seoutiner work in the Mississippi Vulley states, which should be done to determine whethere the insere is present or not. That we an not do with the present funds. Wo had to negleret that during the present fiscul yemr. 


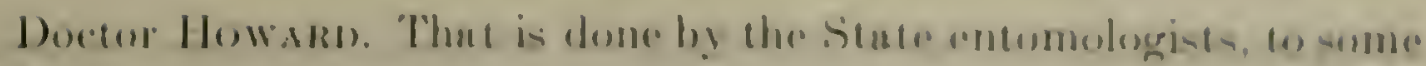
extent.

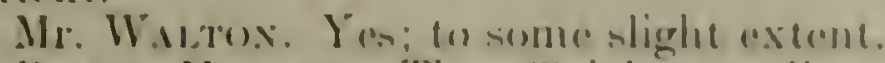

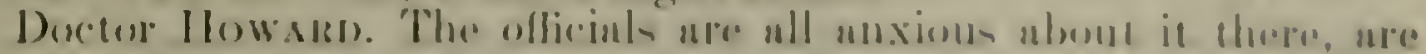
Hore not!

Mir. Wharos. Yes.

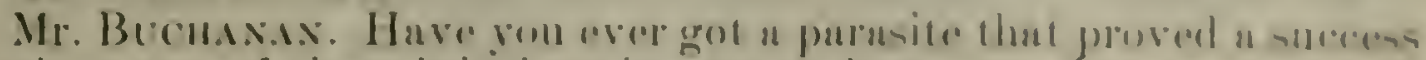

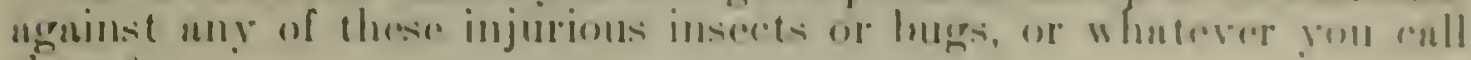
them!

Doctor IJow:urn. Oh, yes: a grant many limes.

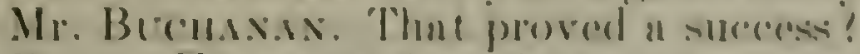

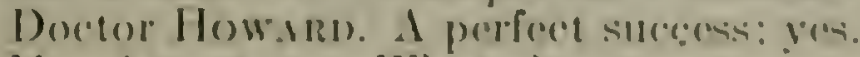

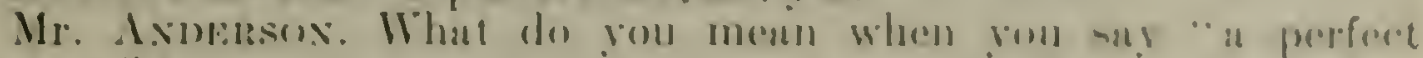
surcess" !

Doctor How.unt). It absolutely controls the insiect

The most fumous one is the Australian Landy Bird, to kill off the white seale in California. That scale made its nppearance through being introduced aceddentally into conntries nll over the world.

It always calused alarm, and they have sent to California for the Australian insect und it stopped the damage.

I got a letter to-day from south limnce which says that scale is distributed along the Riviera, and the insect we sent over there to fight has done perfoet work.

Doctor Ball. 'Take our nutive insects, like the grass hopper. Ninety per eent of the control work is due to purasites. After vou have a plague, 90 per cent of the egrgs have of en been found destroved by parasites. If it was not for parnsites, our native insects would be as serious " pest as new ones, and that is why the new ones are a very serious pest, for they leave their parasites behind them, and are brought in alone. Our native insects, in many cases, are not so injurious, because they naturally developed a suflicient number of parasites to keep them in check.

Doctor Howard. I have seen 90 per cent of the egges of the Army cotton worm destroyed by parasites.

Doctor B.a.L. You have seen outbreaks of the raterpillar in the northern country that stripped the leaves of the trees. The next year there will not be one, because the parnsites wiped them out.

Mr. Becusax. I have seen them to a limiterl extent. It may be that parnsites hold them down.

Doctor Bals. Plant lice are regularly controlled by parasites, and if th were not for these parnsites we would not have any" plants left ut ill.

Doctor How und. You refer to imported parasites!

Mr. Burgess has pointed out that the range of the brown-tail moth has been reduced by severnl thousand square miles, and that is partly due to the work of the parasites we brought over from Europe, from 1905 to 1910 . This natural method of control is fascinating, because it is so cheap.

Mr. Buchasas. Yes; if we con get it.

Mr. Axuensox. Take up the next item on page 226: the spreal of the Mexican bean beetle.

Doctor Howakd. Mr. Graf. 
CONTROL AND PRFYEXTION OF SPREAD OF THE MEXICAN BEAN BEFTLE.

Mr. Grar. Any statement we might make on our last year's work with the Mexican bean hettle would be largely a statement of the progress of the insect, rather than of our own. It is still spreading.

Mr. Axnersox. I think you had better begin at the beginning and give us a history, hecause we will hear something about it luter on.

OENERAL STATEMENT OF WORK.

Mr. Grar. This insect is probahly Mexiean in origin. It has been in the Rocky Mountain region, in Arizona and Colorado, for about 50 years.

In 1920 some specimens were found in Birmingham, Ala., its first uppearnnce in the East. The insect was found to be distributed in 13 counties, centering on Birmingham, with an area of about 4,500 square miles. The following year 1921 found it in five States, orer an area of 45,000 square miles.

Mr. Axpersox. What States did you find it in?

Mr. Graf. Alabama, Tennessee, North and South Carolina, and Kentucky, but the main infestation was in the northern part of Alabama, northern Georgia and eastern Tennessec, with just a few counties in the other States.

At the same time a great many tests were made with rarious arsenicals in an attempt to develope a control for the insect. It was necessary to work out entirely new dilutions of poisons since humid climate in the East of ten eauses severe plant injury.

Our standard arsenical, lead arsenate, caused a great deal of injury to the plants. We found calcium arsenate and magnesium arsenate were relatively safe; the only trouble with calcium arsenate was that it was unsafe to apply the arsenical strong enough to control the insect. Where many insects are present it is difficult to save the plant with any poison and much additional work is necessary to obtain a safe and sure remedy.

'This year the work on insecticides was continued. Seouting was stopped on account of lack of funds and we have no exact iden of the infestation except that it is within about 50 miles of the Ohio River and moving north rapidly.

This blue line [indicating], which shows the infestation for 1922, is very inaccurnte, because we depended on correspondence almost altogrether. If the insects spread during the past rear in the same direction that it sprend in the two previous years, it ought to be in Wost Virginin. We are not snying it is in West Virginin. It has not been so reported, but it is continuing its sprend very rnpidly.

As fur as recommendations for control go, we hesitnte to recommend machesiun arsenate, becnuse of its injurious effect on pench folinge.

Mr. Avibresox. What do you mean?

Mr. Cimal. Il anused much injury to peaches. It burns the

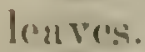

Doctor Howant). The pench is extremely suseeptible. Is a bean us susceptible as the pearoli?

Mr. Cinse. It is to some but not to others. We have always betioned that the soluble arsenic content of a poison is what couses the damage, but the other chemirals in the insecticide also have some 
action on the plane. The lead and magnesiom have 1 grent deal in do with it, and it is ruther diflicult to say a poison will burn one plans becouse it has burmed some other plant:

The beno is supposed to be more tender to arsenimals thun a prench. but us far us magnesium is concernod it is more harly.

Wo have mado arrungenents to have muguesium arsernale lestol under all conditions this rear in the West nond North, and should have some ulditional informution on this point somen.

Ifugnesium ursenate is only manufactured by one compung, and it is doubtful if a stable formuln has been devoloped. This work recpuires many losts in different distriots in order fo low certain of insect control without plant injury.

The insecticide phase of the question is still largely unsolved. A mun was sent to Mexion this your to continue investigntions of purusites, and he collected and shipped a large number of the parasites of the Mexienu ben beetle from nent Mexico City. Alout 3,000 of these beneficial inserts have been received and an attempt will be made to colonize them noxt yent. It is still too early to predicet results. This material was carefully watehed and all secondary purusites were destroyed.

Mr. Gisar. Secondary parasites are the ones that kill the beneficinl purasites.

Mr. Arversox. Are the infestations on the edges of this center as heavy as they were in Birmingham?

Mr. Graf. Yes, sir. One of the most noticeable things is that the most complaints come in from the north boundary of the insects. Is it goes further north it is becoming more injurious.

Another thing is the infestations along the southern edge is becoming weaker, but whether it is the level country, the absence of hills for hibernating the insect, or whether the climate is not suituble, is something we can not tell.

Doctor Howarn. Does it fly away to a distance to hibernate?

Mr. Gral. In New Mexico, it was found in the woods $7 \frac{1}{2}$ miles from the nearest heans, and that is as far as we looked. I would say 20 to 40 miles would be within easy rench.

Mr. Axifersox. Does it attack anything except beans?

Mr. Grar. In the East it feeds on all cultivated beans, cowpeas, soy beans, and other legumes, and to a limited extent on the flowering beans, but it is a primary pest only, as we think now, on cultivated heans.

Doctor HowarD. Does it not affect the wild cucumber?

Mr. GraF. No, sir; that is another insect. The insect is apparently changing its habits a great deal. We thought we knew something about it after it had been in here a year. We thought it would be possible to grow early beans in Birminghnm this year. The Italinns tried it the previous year and quit. The beetle was two or three weeks late last rear, and some of the people grew early beans successfully. The Italians noted the success and tried to plant a very large crop of beans slightly later and they were all destroyed. In the fall it was expected the inseet would be injurious until the 1 st of September, hut it had disappeared from the fields on the lst of August, when the weather was very favorable for further development. 
We found them hibernating in the woods, under the moss and lear ves. when the temperature was $S 2^{\circ}$ in the shade, at a time when they had in the previous vear caused serious damage.

Doctor Howiris. Isn't that characteristic of the family?

Mr. Grar. Most of the ladvhirds hibernate early, but they did not do it in Birmingham the previous year. 'They changed their habits.

PIRUPOSED ACTIVITIES.

Mr. Axokssox. What are you proposing to do next year!

Mr. GraF. We are proposing to continue the work, following it north a great deal more closely. Te about concluded from our insecticide tests on beans that it will be necessary to derelop al sepalrate formula for benns in different hatitudes. We think we can use a stronger poison on beans in the Northeast than in the Southeast. If that is possible, it will be easier to control. It is dangerous to put the arsenate on the plant in a high concentration: that is, high enough to kill the insect-at the present time. We planned to do some work in the West, but it appears that part of the appropriation is stricken out, so we can not carry that out.

Mr. Axprasox. What do you mean "in the West"!

Mr. Grar. In the Rocky Mountnin regions, New Mexico, and Colorado. The benns are a lower-priced crop there. Injury occurs over a short period, and water is so scarce that they can not spray conreniently, and the wind is so high that they can not dust.

Mr. Bichavax. He got you there.

Mr. Grar. He has, unless we can develop some mechanical control.

Mr. Axinersox. Go ahead in relation to that.

Mr. Grals. The main producing States of the North are Michigan, Wisconsin, New York, and New Jersey. New Jersey produces mostly green beans; that is, beans for canning, and from the present trend of infestation it threatens these and other States. The States further west will be free a great deal longer than New York and the rest of the States on the castern seabonad.

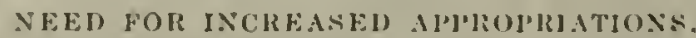

Mr. Axumbsox. If you had more money, what could you do with it?

Mr. Cirse. Wo would start work in the West prineipally on a mechunieal control. Those people ont there are fighting a hopeless fight. "They can not choose theje planting time. They have to plant when the moisture is in the soil; they have to plant so as to he sure of arobiling frosts. They have to plant in certain fertile vallers neme the surrounding hills, which furnish hibernating guarters forl the inserets.

'Flere is appurently no way they can aroid having a creat denl of inseret damagre.

The cop value will arerage in Now Mexico about s12 per acre ored the cost of production. That mons that direct control with inseceticides is just about out of the question. Wo are trying to figure out "Incelandical contrivance to knock some of the bectles ofl the plants in the course of their cultivating the crop. They cultivate from two to four times a seasone, and if we could reduce the beetles to some extent, without any astru expense, it might provesufliciont to save 
the crop. The beans mature rapidly, and if the beotles are only partially reduced the beans might pass the critiond period safely and

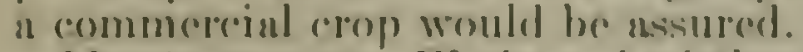

Mr. Axmaksox. We have had them a long time out there. What can we do to stop them from getting in the besu producing seretions of Michignn!

Mr. Grat. Wo ran not stop them. We have given up the idea of thut.

Mr. Axmersox. What can we do to find ont! What ran we do when they get there?

Doctor Howand. That is what we are doing undere this appropriat tion.

Mr. Axmeksox. Have you money enough to do it?

Ih. Ginar. In the enst the work could be expedited with additional funds both as regards the development of remedies and the surver to determine the best localities for growing beans.

Mr. Andersos. You feel your work in the east is us offeretive us you ('an do it?

Doctor Howard. $\$ 25.000$ is enough, it seems to me, to follow up our studies. although a larger nmount would of eourse permit more extensive resenteli.

'Tlesum, November 21, 192:2.

\section{BLREAL OF BIOLOGICAL SURVEY.}

\section{STATEMENT OF DR. E. W. NELSON, CHIEF OF BUREAU.}

\section{SALARIFS.}

Mr. Arvensox. Is there any preliminnry statement rou want to make, Doctor Nelson, before you start on the statutory roll?

Doctor Ner.sox. The work of the Biological Survey has to do with the wild hirds and mummals of the country, the general conservation and utilization of the useful species and the control of the harmful unes, including the administration of the Federal game laws.

Mr. Axmensox. We will take up your statutory roll, on page 229. There seems to be a small increase.

Doctor Nessox. There is an increase of the statutory roll, which is compensated for by a corresponding decrease on the lump fund appropriations: it is merely a transfer.

Mr. Arvensox. All of these chunges involve transfers?

Doctor Nessox. Yes: except two which we dropped as noted on puge tt of this explanatory statement.

Ilr. Axmensos. Then there is a net decrease on the statutory roll?

Doctor Nbasox. Yes: of $\$ 2,700$ through dropping two clerks: then there is a change of the title of photographer, changing it to photographer or clerk, with no change in salary. Otherwise, the salaries stand as they are for the present year.

Is anything further desired on that itein?

Mr. Ixnelsos. No: I think not. 
MAINTENANCE OF TIE MONTANA NATIONAI BISON IRAgE AND OTIELE RESEIRTATIONS.

Doctor Nessox. 'The first appropriation item is that covering game and bird reservations, page 231 .

'This is for the maintenance of the Montana National Bison Range and other reserrations, 69 birds and big game reservations, of which live are mostly, at least, for big game. We have about 40,000 acres under fence. These 40,000 acres are distributed in five reservations. Within these fenced areas we have on the National Bison Range in Montana 462 bison, 325 elk, and 75 deer of two kinds, and 14 mountain sheep. On the Wind Cave game preserve, South Dakota, we have 92 bison, 149 elk, 20 antelop; on the Niobrara Reservation in Nebraska, we have 41 bison, 54 elk; and on the game preserve in Sullys Hill National Park, N. Dak., 11 hison and 50 elk and 5 deer.

A large number of these reservations are without regular warden service. Some of them are so small that they do not warrant it, and as to others the funds available do not permit us to maintain a warden. We have wardens on the more important ones, and in the maintenance of the big game reservations we have the upkeep of resident wardens' quarters and of fences, with necessary repairs. In some places new fences must be constructed to take in unfenced lands at: the animals increase in number.

WINTER ELK REFUGE.

In the winter elk refuge at Jackson Hole, Wyo., we have about 2,000 acres of land, largely under fence, where we provide forage for the southern Yellowstone elk herd in the winter. 'This herd lives in the summer in the southern part of the Yellowstone and adjacent national forests and in winter the animals come down into the Jackson Hole country, in the valley of the Snake River. Formerly these elk used to pass on south into the plains of Wyoming, but that country has been occupied by settlers and by stockmen, and is fenced. $A$ t present the elk are stopped when they get down in the foothills, as they have no outlet. 'The result is that they have insufficient winter range, and in order to keep the elk alive they must be fed hay during severe winters. That is the object of this rescrvation, where we cultivate about 300 acres of hay land, raising between 600 and 700 tons of hay a yeur. Occasionally we have to buy additional hay. The elk, in numbers ruming anywhere from 4,000, 6,000 , or more. "ome down into this valley in winter and are fed during hard seasons.

Mr. Avdersox. Does this appropriation cover only these five refuges or reservations?

Doctor Nezsos. It covers those and the 64 bird reservations.

WAIIIEN SERVIC.

Mr. Axnerson. How do you police these bird reservations?

Doctor Nessos. By wardens. At the more important ones we latre a warden sorvicr.

Mr. Avmersos. How do you police the ones where you do not have the warden services!

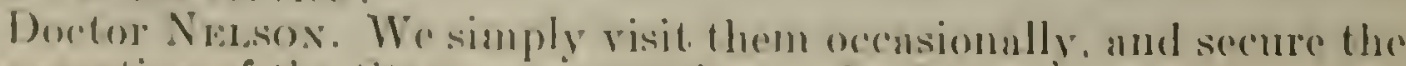
conperation of the State gune wardens. In Lonisiana, for instancer. 
the State gane oflicials have a bout remising urenond the month of the Mississippi, and as some of our reservations lie off the coast in this vicinity, they have very kindly agreed to belp police them during the breceling season.

Mr. Hexnerson. A number of Reclamation Servior men ure aleo male deputy wardens without salary.

Doctor Neasox. Tes; the Rechunation Service has mon in change of the rechumation rescrvoirs, a number of which nre bird reservations, and they net ns wardens. Wo get quite a lot of conperntive service of that kind to help out.

Mr. Asuressox. (n these bird reservations, for cxumple, I understand that it is not permissible for a man to have a gun. ammunition, or any other firearms of any sort: is that correct?

Doetor Nersox. That is, you mean the perple are not permitted to go on-

Mr. Axueksox (interposing). les.

Doctor Nelsox. No: there is no shooting permitted, except at two places

Mr. ANinersox (interposing). Not only no shooting permitted. but you do not let them on there with a gun at all?

Doctor Nelsox. No; a man is not permitted to go on there with in gum, unless be is a Government hunter killing predutory animals.

Mr. Andersox. Is that done by law or regulation of the department?

Doctor Nelsox. That is by regulation. 'The Secretary of Agriculture is authorized to make proper rules and regulations to protect the reservations and to make them fulfill the purpose for which they were establisherl.

Mr. Hexilersox. The law prohibits interference with the birds on the reservations, their nests and egers.

Doctor Nezsox. We do not interfere with the fishing, for instance, as long as it is done nccording to the State laws. 'The Big Lake Reservition, which is one of our important reservations in Arkansas and a rery great resort for wild fowls during the migration season, is also a very popular fishing ground. There is a lot of commercial fishing there, and we give anybody a permit to fish as long as he complies with the State fishing laws. I might say, in this connection, that the work of our wialens on the Big Lake Reservation has brought about an observance of the State fishing laws of that locality because as soon as a man violates the law we reroke his permit.

This affords a strong incentive for the fishermen to aroid riolating the requirements of the State laws.

\section{INCIRASE IX GAME.}

The big game on these feneed reserrations is increasing rnpilly. We are now working out a system whereby we can take care of the surplus, and the indientions ure that there may be a surplus of game to be marketed which eventually will fully take care of the expense of caring for these places.

Mr. Axpensos. Have there been any apparent increases in the number of game birds?

Doctor PFusox. Migratory game birds, you mean? 
Mr. Axderson. Yes.

Doctor Netsox. Very great increases. That we will take up later: when we come to that item.

Mr. Axpersox. 'The next item is on page 232.

\section{SLLAYS HIL, NATIONAL I'ARK GAME I'RESERVE.}

Doctor Nersox. For Sullys Hill Reservation, N. Dak., there is an appropriation of $\$ 5,000$, which has been continued for some years, for purpose of caring for this reservation and for making certain improvements needed for its proper maintenace. These improvements are now in an advanced state, and the place is rery popular with the residents of the surrounding country. Owing to the fact, of which you probably are all aware, that North Dakota is a rather flat country and here is a little hilly region bordering Devils Lake, with a small tract of woodland on it, it makes a very popular picnic ground and resort for the people of all that region. I am told that they come from as far as 200 miles away to have picnies at this place, and on pleasant days hundreds of people come there. In addition to maintaining the game there we are trying to accommodate the people. We have built a woman's rest house. The are also putting in a little water service, so that the people who come there can get water easily. and a parking place, as well as other simple improvements.

Mr. Bucluxis. Is this Government land?

Doctor Nelsox. Yes; it is owned by the Government.

Mr. Buchasax. Do you call that a game reserration?

Doetor Nelsox. Yes: it is a game reservation.

Mr. Bechasax. What sort of game?

Doctor Nersox. Buffalo,. elk, and deer.

Mr. Buchasax. Is it fenced?

INCREASE IN NUMBER OF BUFFALO.

Doctor Nelsox. Yes. It might be of interest, before I leave this game reservation matter, to state that in the United States at the present time there are nine Govermment herds of bison containing 1,146 animals. There are also a considerable number of private herds, so that the bison, all told, in the United States number about 3,527. In Canada they have over 6,000, so there are now in existence in North America approximately 10,000 bison, whereas a few years ugat they were on the verge of extinetion.

Mr. Axmensox. They are not very far from it yet $-10,000$ is not very many.

Docetor Nrasox. Well, it is enough to be encournging, in view of the fant that the bison bread in captivity just as freely as cattle. They have increased from a little handful to $10,000 \mathrm{in} \mathrm{a} \mathrm{comparatively} \mathrm{few}$ vents, and they are seattered over Canada and various purts of the Cinited States, so that the future of the bison is pratically assured. They can be maintained and will be mantaned.

Mr. Bucoux... Do they got as gentle as cattle!

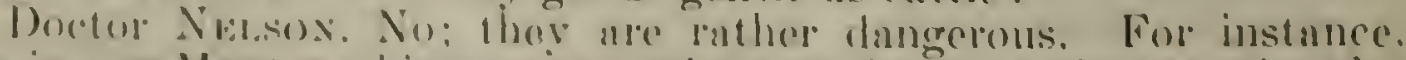
up in our .lontuma bison minge, where we have nearly soo, they let yon ride up to within a short distance of them, but if you get on foot ihey ure likely lo rome after you, purticularly some of the cows. 
Some of the old cows are more vicions than the bulle. Wo have found that on severul of the reservations where there nre bison the cows are inclined to be more anvage thun the bulls.

Mr. Beonswis. If they were handled properly they would get gentle like entele?

Doctor Nassos. Oh, yes; they would; they could be made gentle.

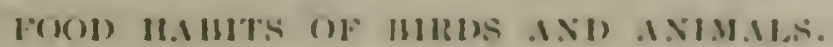

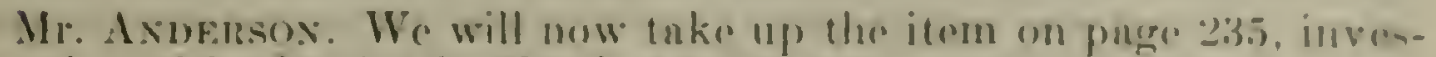
tigntion of food unimnls. North Amerien.

Doctor Netsox. The main work under this upproprintion is that of eontrol, lesisening the losises due lo deplededntions of prodatory wild unimals, such as mountain lions. wolvers and others. on live stuck. and the destruction of cropse and fornge by rodents. There is a grent variety of these numals.

PRFIITOKY A.IIMA WUIK.

In our predntory nnimal work, which I will take up first, we are maintaining un orgnuization throughout the western United States, with an inspector in charge in ench State. and under him wo have employed hunters who ne poisoning and trapping and shooting these predntory animnls.

During the last yenr we nctually took the skins or senlps of nearly 31,000 of these unimals, in addition we put out an enormous number of poison buits. which, judging from the number of animals subseguently found by stockmen in the ranges, undoubtedly resulted in the killing of more than is 0,000 additional coyotes and bobents.

Mr. Brenasax. You do not spend any money on juck rabbits and ground squirrels?

Doctor Nersos. Yes; and later on I will tuke that up.

Mr. Bechasis. All right.

Doetor Nes,Sox. Our men put out 1,229,000 poison baits during the year in their campaigns against the predatory nnimals, and the number killed was very grent. We received fron the skins of these animals, which are Government property, $\$ 34,202$, which, added to that previously received, make a total of $\$ 2 \$ 3,000$ that we hare turned into the Trensury for the skins taken by our hunters.

Mr. Axdersox. How many animals do you say you killed this yenr?

Doctor Nersox. We actually took the scalps and skins of 30,986 . and in addition the use of more than a million poison baits resulted in killing an enormous number of additional animnls, of which we get reports from the stock men who find the dead animals senttered over the range. The reports in mnny places are that the coyotes and other stock-killing animals have practically disappeared, so that stock men are able without losses to run sheep, for instance, in open grazing.

With respect to our work in western Texus Mr. Hudspeth informed me that he considers that the predutory work in that region has added $\$ 5$ or more an ncre to the value of the lnnd, owing to the freedom with which stock can be grazed. It does not require the same number of herders as when predatory animals are present. 
Mr. Axnensox. Has this work got to be kept up on its present basis indefinitely!

Doctor Nersos. Apparently it has, at least until the animals are destroyed. Just as quick as you stop this work the animals breed back and become so destructive that in many places it puts the stock business out of commission. In northern California, for instance. ther had stopped growing sheep in some sections owing to the depredations of corotes. Since we began working there they have started again to grow sheep, and we have reports from various places that if this work was not being carried on it would be impossible to continue growing live stock, particularly the smaller stock.

COOPERATION OF STATES.

Mr. Buchasax. Before we went into that business, some of these States were taking care of themselves. Now, the Federal Government has gone into it, and they just withdraw and turn the whole thing over to the Government?

Doctor Nersox. No: the States are putting up money: for instance. their cooperative funds for 1922 for this work in the States amounted to $\$ 196,405$.

Mr. Buchasax. Prior to that they had rewards offered at so much per scalp?

Doctor Nelsox. Since we have shown the superior effectiveness of the work as we are doing it, many States have ceased to rely upon the bounty system.

Mr. Bucuinax. That is just what I told you.

Doctor Nelson. I beg your pardon.

Mr. Buchanan. 'That is just what I said, since the Government hus taken it up they have stopped.

Doctor Nelson. But they are nppropriating money in place of the bounties.

Mr. Buchanas. Oh, yes; two or three dozen States appropriate $\$ 100,000$, but we appropriate $\$ 502,000$.

Doctor Nelsox. The $\$ 502,000$ is not appropriated for the predatory-unimal work alone. For the predatory-animal and the rodent work combined the Government puts up about $\$ 400,000$, and the States are putting up upproximately $\$ 1,000,000$ in coopcratire funds. They are contributing practicaly two-and-a-half times as much as the Federal Government.

\section{FXPERIMENTS AT DENVER LABORATORY.}

We have established in Denver a laborntory where experiments are being made in developing an improved type of poison, which is combined in such a why us to make it palntuble to predatory unimnls.

There hus been grent difficulty in the use of strychnine, which is the man poison, owing to its bitter taste. The predatory animals ure rery nente in deteeting it, and when they take the buit in the mouth and notice the slightest. bitlorness they drop it. Wo nre working out a method whereby the purticles of strychnine are conted and disenised in such a way that the development of the tuste is swoyed until the mimnls swallow it, and we uro getting exceedingly effective results. Wo have found that the plan on which we stmed the tapping of predatory nnimals requires too large a body of men. 


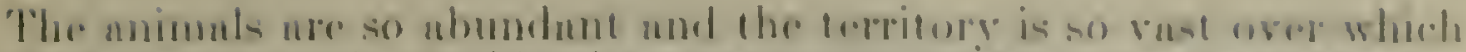
they ronm thut it would enke an nermy or control theme in thes was

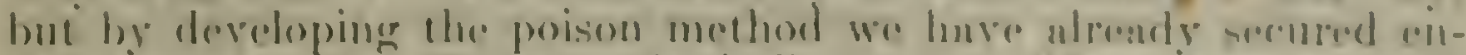
cournging results. These resules indicole thut with n compuratively small forere and with the coeperation of the stockmen nnd the locen

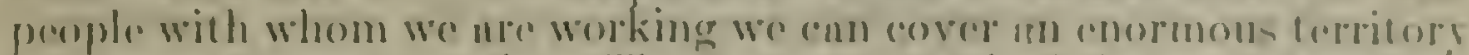

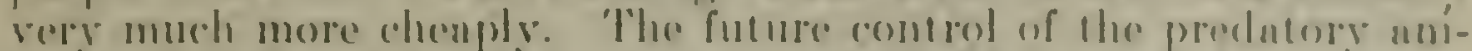

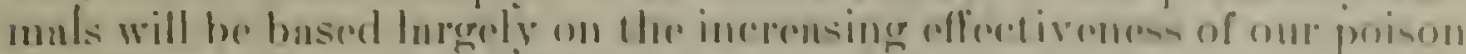
('numpuigns.

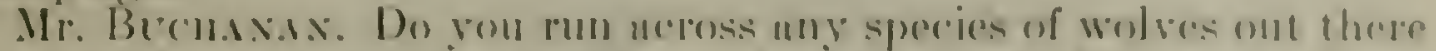

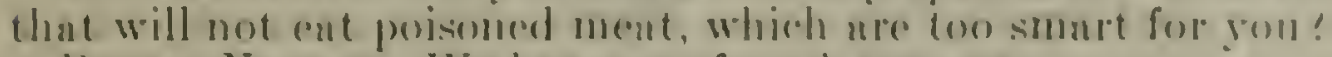

Dortor Deasox. Wo hase mot found my ret.

Mr. Becmaxis. Do you not find those which will not eat meat?

Dortor Nessos. I do mot think we hase evere run nerose one that would not take some mat. Wo have poisoned it mumber of old wolves.

Mr. Bechasas. Loboes!

Doctur Nersox. Yes; that have rum for many years.

Mr. Bermax. Some of them ure so smat that they will not eat dend ment; it hus got to be whrm.

Doctor Nersox. These little buits that we put out ure fixed up in "tompting way, just a little bit that is dropped, very corefully prepared, and they will pick it up. A wolf that will not touch a dead carcass is likely to piek up one of these baits.

Mr. Anofrsox. How mung men have you got employed in this work now in the field!

Doctor Nessox. Wo hare 160 in our regular organizations, and the number runs aver 200, necolding to seatson.

Mr. Becussas. 'Two humdred altogether!

Doreur Nersos. About 200.

BOUNTY SYSTEM FOR PREDATORY ANMALS.

Mr. It:Mr. Going back to Mr. Buchanan's question of a few minntes ug(). lar mny watut you to put in the record il statement of the obsintratums of the department which have demonstrated the lessor degree of elfertiveness of the bounty system in comparison with the system which you are using.

Doctor Nersos. The bounty system nganst predatory animals hats been in vogure ever since the einrly settlers ('ame to the eastern Lnited States. and it has always been honerombed with fraud. It gives opportunity for the rankest kind of frnuds and it nevel definitely controls predntory animals, becaluse it is for the interest of the bounty hunters not to exterminnte the animals from which they geet al returin anch rear.

Mr. Anuersos. They had to leave some breeding stock?

Doctor Nessox. They did. Our trappers have found muny royotes with a trap mark high up on one leg, showing that they have been raught und freed. A mark high up on the leg of a coyote indirates that that mimal has been calught and turned loose: and our mon have caught muny female coyotes with that mark on them. Many of the trappers have tolk us that they never killed at female, becnusis that would be cutting off their business. 
Montann in 18 yenrs paid about $\$ 125.000$ a year, which made an augregate of ahout $\$ 2.000,000$, and at the end of that period it had practically as many wolves and coyotes as it had at the beginning. The expenditure of that amount of moner ought to have killed every predatory animal in the State of Montana.

Mr. Tum. 'The bounty hunter's also get the least destructive animals!

Doctor Nersox. A bounty hunter can not afford to persist in trying to destroy the very cumning, experienced predatory animals, particularly wolves and certain coyotes, which have become very suspicious and have evaded capture for years. We will, when necessary, keep a man for months on the trail of a notorious stock killer until we get him. 'There have been bounties offered of $\$ 500$ on a single wolf, and the bounty hunter goes in and spends a month or so and quits, because he can not afford to keep after' him. But we put one of our men in there, and he follows that animal until he gets him, and in that way we have destroyed in South Dakota one wolf that had a record of about $\$ 25,000$ worth of live stock it had killed on the range.

Mr. Buchinan. How much was the reward offered for that wolf?

Doctor Nelsox. They had offered up to $\$ 500$ reward for him.

Mr. Bucmanax. I have heard of even as high as $\$ 1,000$ being offered for a big lobo wolf.

Doctor Nelsox. Our men have killed a lot of those notorious old animals; and last spring they killed a big grizzly bear near Williams, Ari\%, that had a record with the stockmen of having killed during its life some $\$ 25,000$ to $\$ 30,000$ worth of stock.

CONTROL OF RABIES.

In addition to hunting the animals because of their destruction of stock there is the control of rabies. Rabies started in the West in 1915, when it spread to five States-northern California, Oregon, Idaho, Nevada, and Washington-

Mr. Buchasas (interposing). You do not mean the first rabies started in 1915 in the West?

Doctor Nersox. Oh, no: I mean this epidemic I am speaking of. It became so severe that those five States urgently asked for an appropriation to do something to help control it, and an appropriation wus made. We organized the work along the lines mentioned, with inspectors and paid hunters, and before we got thoroughly going rabies had spread into Utah, but we stopped it there, and we have held it ever since.

'There have been several outbreaks. Last year there was an outhreak in Wushington, and it sturted to spread again, but we concentrated hunters there and suppressed it. What we do is concentrate u lot of hanters with traps and poison to kill the predatory animals. In that way we clean up the animals which serve as earriers of the dismase in that district, and that stops the spread of the rabies.

Mr. Bucusas. Wolves, principally?

Doceter Nezsox. ('oyotes and wolves: ves. But evory earniverous mimal has it skmnks have it, cats and dogs have it, und they pass it on to cattle, sheep, and horses, all kinds of live stock.

Me. Bucruas. If you kill out the jack rabbits. you will not have uny remedy for mbies- nuy c'ure? 
Dortor Net.sos. Why?

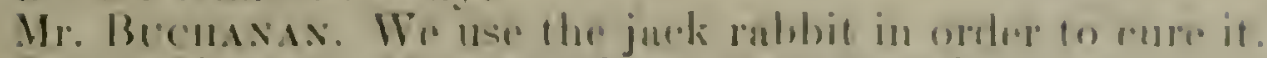

Doretor Nessos. Wr use poismon: that rurm it.

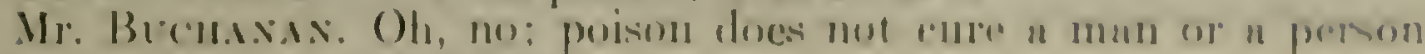
who is bitton, who rontracts robias.

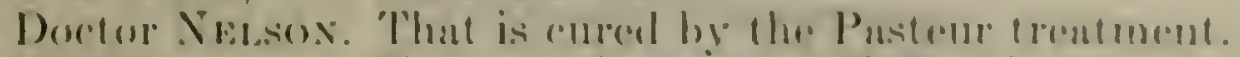

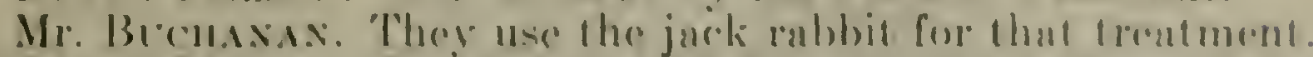

Doctor Nessos. In this outhreak I have just spoken of, which wr. have suppersised, there is an offecial record of 2.151 peeple that have bean hitten by rabid animals in that forritory, 59 of whom died. The way it was going the disense would have spread over the entire

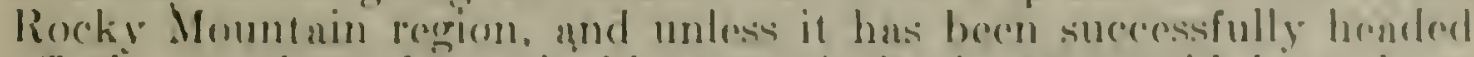
off the number of pereple hilton and the losses would hase heen tremendons.

Mr. Brorns.s.s. Do you know it is the hat thing in the world when we lose a case of rabies if the person will got to the institute right away?

Dector Nessox. I know it. The trouble is that people have as little wound, and they do not think anything of it, nnd they let it go until it is too late. But they have learned their lesson in this territory. and they do not lose any time in getting to a place where they an be treated.

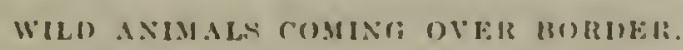

One thing rou alluded to, Mr. Buchaman, is the fact that in southern New Mexico and Arizona-I am not sure whether the same thing happened in southern 'Texas or not - wolves are constantly comingr across from old Mexico. The stockmen along the border report to our inspector the arrival of wolves. During the past season in Arizona over 30 wolves came across, and were reported on the stock ranges bordering Mexico. Our men killed all these except one which got away and returned to Mexico. Not one of them got more than 2.5 miles north of the border. That I cousider was a pretty effective record. They actually got the skins of these animals. They came in packs, one pack consisting of seven, and they claned them up very promptly.

You see these anmals make kills and leave tracks, and the storkmen find them right away after they come over. There is a very big reselvoir of wolves in the Sierra Madre Mountains of old Mexico. and if they were not stopped they would keep Arizona and all that southwestern country full of wolves. We are lolding them down by killing them promptly after they come across the border, before they have time to become established and breed.

In addition to the saving of live stock, the predatory animuls are also extremely destructive to game of all kinds and, naturally, the killing of such a large number of them saves a very great amount of game and has a great influence in increasing the supply.

In Michigan, the conservation commission asked us for assistance in organizing a predatory animal service under the State grame commission, to help suppress the wolves which wore destroying deer on such a large scale in the northern part of the state. We have had a man there, and the ollicials appenr to be very apprecintive of the work he is doing in tenching the Stute wardens. Who are 
special men appointed to work with him. They learn how to handle the work of killing the wolves, by trapping and poisoning. With this instruction and direction of its men the state is enabled to handle its problem.

\section{DESTRUCTION OF RODENTS.}

The destruction of rodents is a part of this work. The losses from rodents of diflerent kinds amount to about $\$ 500,000,000$ a year, according to the estimates that have been made after careful investigations, and there are many sorts of rodent pests in every State in the country.

In the West, where the dry climate is especially suitable, the injurious rodents are inuch more abundant than anywhere else-prairie dogs, jack rahbits, gophers and quite a variety of others, and various kinds of ground squirrels. The organized campaigns, with the special methods of poisoning that we have developed, have convinced the peoplo of the effectiveness of the work to such an extent that during the last vear about 105,000 farmers and stockmen cooperated, and \$799.974 was expended as cooperative funds in these campaigns. They put up for this rodent work about five times as much as the (ivisernment.

Mr. Axdersox. It must be more than that, if it is $\$ 700.000$ ?

Doctor Nersox. Yes, it is $\$ 799,974$.

Mr. Axblssox. According to your figures here, you are spending about $\$ 12 \$ .000$ on that.

Doctor Nezsox. On the rodent work?

Mr. Annersox. Yes.

Doctor Netsox. Yes; the cooperative funds amount to about six times as much. Some of the States are making direct appropriations which have to be spent in cooperation with the Biologieal Surver.

We used 1,000 tons of poisoned grain, and 757,000 pounds of bisulphide of carbon, a fumigant which is put in the burrows. 'That was used by the cooperators and the survey combined.

During the course of the work we have poisoned over $10,000,000$ acres of Federal lands, and under personal direction or in cooperation over 93,000,000 acres of private land.

Mr. Axornsos. 'That is altogether, during this period of operation?

Doctor Nassox. During the time since we began in 1916, over 103,000,000 acres, in which the majority of these animals have been destroyed; they have been either ground squirrels, pocket gophers, or prairice logs.

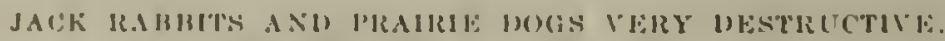

Mr. Bucmaxax. What is your objection to jack mbbits!

Doetor Nissox. They are terrilically destructive. where ther incrensin as they do, and in one instance we killed over 1,000,000 jack rabbits in castem (Oregron by poisoning.

Mr. Bromasas. Destructive of grain, you nean?

Dector Nasox. They concentrite on the errain. When the grass dries up in the summer and the grain is growing in the arid Wost. (hut will be the one grens spot in the whole reerion, and they concentrate for miles aromot, mod in many plases they have netually destroged in

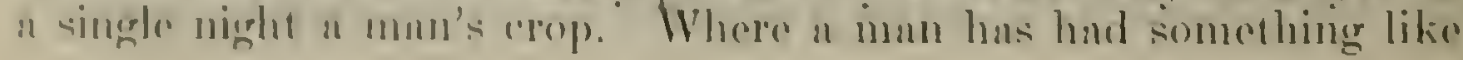


30 or 40 or 50 acres they have just simply cleaned it up in one night. The jack rabbits in northern Nevada and also in Esculante Valley, in Utah, haye actunlly caused the settlers to ahundon their ranches; they could not ruise crops.

Mr. Buciasax. There has been many ane there.

Doctor Nis.sox. After the poisoning campaign in northern Nevala, the people have gone back and there is a prosperous community there now. We have poisoned the rabbits and shown them how, and they are able now to go ahend.

In the ease of prairie dogs, they concentrute about the farms and ure exreedingly destructire, and they ulso occupy un inmense aren. Over 100,000,000 aeres are oceupied by prairic doge in 12 western Stutes, and they prohably destroy 25 jer cent of the forage in the country they occupy. In some places they take it practically ull. They concentrate about the cultivated arens to such an extent that they often destroy the fields, and occasionally they clean up so that the man abandons the cultivated lands. In other places they take nnywhere from 5 to 50 per cent of the crop, and in many julnces, before we poisoned them, they were unable to grow crops at all.

It will interest you, no doubt, to know that we have made a final clem-up of the prairie dogs in one area in southern $\Lambda$ rizona, about 110 miles long and 15 to 20 broud. It was a very rich valley bottom. in which the prairie dogs were enormously abundant, and it was like a desert. They had destroyed everything and kept the vegetation right down to the bale ground.

Mr. Buchasas. I know all ubout those crentures. They are fit for nothing on earth except to ruin the country they make a town in. They have a regular eity of prairic dogs.

EXTHACTS PROM LETTEUS OF PERSONS BENEFITEN BY TIE CAMPAION AGAINST PRFD.ATOIRY A.NIMALS.

Doctor Nelsox. Mr. Hugh Campbell, president of the Arizona Wool Growers' Associntion, wrote a letter August 3. He sars:

On June 23,1922 , the last prairie dog was exterminated from the counties of Cochise and Graham. This was a result of three years' united effort on the part of over 800 stockmen and farmers cooperating with two experts of the Biological survey. In area 120 miles long and from 10 to 20 miles wide was actually cleared of this pest.

Three years ago when I visited this district I rode through mites and miles of prairic dog infestation, and bare, denuded lands lay on every side. To-day, after these pests have been exterminated, the grass is knee high. Fat stock and fertile farms are to be seen on every hand and a prosperous community is in the making. where heretofore at least $5,000,000$ prairie dogs had their way and forever held in check the development of that fertile valley.

It is estimated that the increased forage now made poswihle will support at least 5n,0no head of sheep, and farmers are now growing alialia and grain on ground which was formerly so heavily infested with prairie dogs that it was quite impossible to raise anything.

I think there is a good exumple of direct benefit derived from that work.

We hare also cleaned up four counties in Kinnsas. We organized there, or suggested to the State agriculturnl college, which is eooperating with us, that they begin on the eastern border of the prairiedog infested area in Kinsas and elean one county after the other. moving west each time, in order that they may make a final clean up. They have been fighting prairie dogs in Kansas ever since the farmers of the State went in there, and they still have them. By 
this method of starting in definitely on the eastern border and just going west they will finally eliminate them from the State. When they get a county clenned it is cleaned; there is no way of reinfesting, except from the west, and they will keep pushing that line to the west. As I say, during the last year they cleaned up the prairie dogs in four of the Kransas counties.

In northwestern Arizona for some years now-the last 10 years or more-the prairie logs have been extending their range several miles a year into new territory, going west. We have cleaned up a belt along that western extension border of over 50 miles long and about 5 miles deep, and are going to stop that western extension. At the same time we are carrying on the general work of destroying the animals elsewhere.

Mr. Charles Springer, who was chairman of the Council of National Defense in New Mexico during the war, and who is one of the largest stock and land owners in the State, became very much interested in our work at the time of the war. In the food-saving campaign he backed the intensive work we were doing in helping to destroy prairie dogs in crop areas. 'I asked him in a letter if he had ever made any estimate of the effect of prairie dogs on the grazing industry in New Mexico, and he wrote that he had; that when he became chairman of the Council of National Defense for New Mexico he had taken it up with his county chairmen, and they had made a survey of the State. He states liere that-

In the 50,000-acre unit now being investigated and treated-

That is where our men worked-

in the Moreno Valley in Colfax Connty, the prairie dogs destroyed nearly all of the grama crass and I believe the damage to that range amounted to 75 per cent. Generally the damage done by prairie dogs in the infested areas with which I am familiar ranges from 40 to 50 per cent to 100 per cent. I have seen in Rio Arriba and Sandoval Comnties, and in some of the other counties, large areas rendered practically worthless for grazing purposes by these pests. It is safe to estimate that the annual damage marle to ranges in New Mexico has amounted to destroying the grass on more than fi, 000,000 acres of the very choice graxing land of the State, the areas selected and infested ly prairie dogs being generally the best grama grass flats and draws. Opinions differ as to the number of acres of grazing land required to support one head of cattle.

In ('olfax ('ounly on the grama grass ranges, where there is much rough. unproductive laud. We generally estimate that it requires 20 acres, one year with another. for rach cow ol urown bovine animal: and as the lands infested by prairie dogs are very much botter than the average, I believe it is safe to estimate that the $6.000,000$ acrise rendered worlhless by them would support $\$ 00,000$ hearl of eattle or more than $1,500.000$ boarl of sheep.

That indientes his opinion us to the damage. Considering the fact that New Mexico is one out of 12 or 13 States that have prairie docts. if you ger rid of the prairie dogs in all of the States we figure that froin could add more than $1,000,000$ head of cattle to the range in the West from the incereased forage aloure.

In this commedion, I have here a photograph of wheat from a

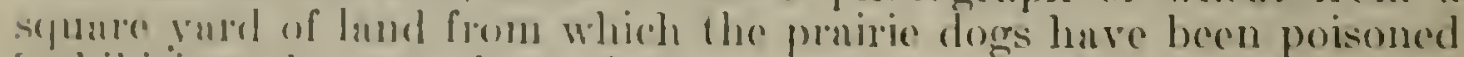
[ahibiting phologringh to the subeommittec], and here [indienting] where the pratrie dugse are operating, which is also a square yard of

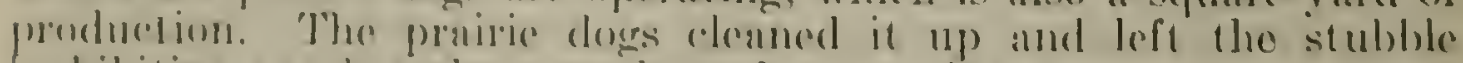
fexhibiting mother photograph to the anmmittee).

Here in morthern Drizonn we fenced a small aren with pruirie dorproof fence. Then we put stocki-proof fence on another area right

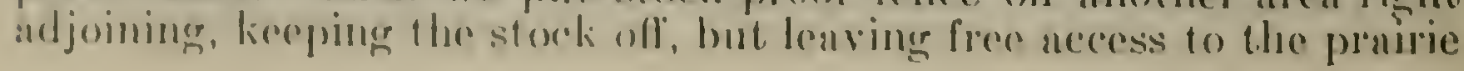


dogs. In the aren in which the pronirie doge were formed ont there was the growth of the fornge (indienting on photegraphla and here on the ontside, where the praire degs, but no contele, were preminged, that was the growth [indienting). Thut is a proctionl illustration of what these unimuls do.

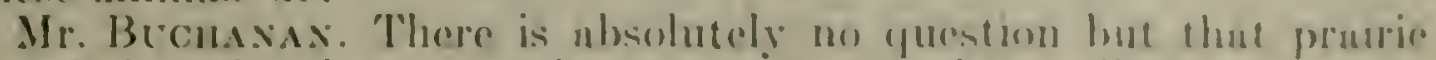
dogs, when they have a settlement or town they call them prairiedog towns - are absolutoly destructive of agricultural vereotntion, und they render the land practioally useless. F have seen rant terrigory just nbundoned on acrount of pritirie doess. There is no guestion ubout that.

Doctor Nessos. The object of this redent work is to reontrol, and eventually oliminute, these pests, and it is a long job, becumse they cover such a tremendous aren. It is a job that simply has to lice continued, and while it looks like a long joh there is one concouragring fenture, however. You have things like insect pests which are so numerous and which are spread over such an area that their extermination becomes a practical impossibility. All that (an be done is to try to hold them down in their destructiveness. The prairie dog can netunlly be eliminuted and done with forever. The only thing is, it requires "long, continued, patient, organized campaign.

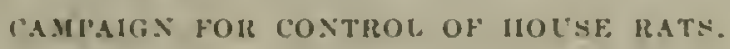

House rats: We are also having a large campaign for the control of house rats all over the country, and there is a very great interest in that work. At the present time there is a campaign groing on in Portland, Oreg., under one of our men, which is getting rery grood results. They not only destroy the rats but they establish methods of rat-proofing and start rat-proofing campaigns and cleaning up of trash piles nnd climinating the places where these pests live. In that way they innugurate a permnnent riddance.

In Texas in one county last year-Denton-there was a campaign ngainst the rats led by one of our men, and by actual count 253,000 rats were killed. There is a population there of about 36.000 people, and evidently the rat population was very much more numerous than that of the people.

The rats are exceedingly destructive of crops and food of rarious descriptions as well ns goods of every kind, and nlso ('nrry diseases. and are a menace from that point of view.

I might state, in connection with the rat work, that during the last year we had 325 recuests for information and nssistance from 42 States in regard to rat work and 76 requests to help in campaigns in 26 different States for the suppression of the rat nuisunce.

FIR-FALMING INVESTIGATIONS.

We are also carrying on investigations into fur farming, and have an experimental fur farm in $\mathrm{New}$ Tork State. The fur-farming business has increased and become very profitable. and there are now over 500 silver fox farms in the truted States. With about 12,000 foxes, and an investment of ubout $\$ \$, 000,000$. There are fur farms in 25 States: there are also about 200 or more fur farms in Alnskn. 
We have experts at work investigating rarious phases and furnishing the information which is needed to help the people handle this business in the most eflective way. It is an entirely new type of business and the people going into it naturally have no accumulated knowledge to fall back on, and we are trying to assist them. Judging from the appreciation that they are sliowing, we are proving very helpful in building up the business along the best lines.

Mr. Axpersox. Are you getting any action out of this knowledge obtained at the experinental farm?

Doctor Necsox. Yes; we are getting a great lot of informntion on the hundling of the parasites and diseases and methods of taking care of them. and one of the interesting things we have discorered there is the breeding season of the marten, the American sable. Heretofore, for years they have been trying to breed martens without success. They had the idea that martens bred in January and if put together at any time except the breeding season. one of the pair would kill the other, and so they held them apart. So they would keep them apart all the rear unil January and then put them together. 'They got no results.

Our man tried putting them together in the summer. and they mated, and two diflerent years we have got young. 'They uppear to mate in August and carry their young for about eight months, that is, so far as the present indications go. A neighboring fur farmer in New York tried the same experiment and got the same results.

We thus appear to have solved what was thought to be an impossible matter; that is, the successful breeding of the marten in captivity. We have harl three successful breeding seasons, and there seemis to be no doubt but that they can be successfully bred in captivity. So the marten is one of our valuable fur animals. This is quite an important piece of information.

IXVESTIGATIONS OF FOOD HAIITS OF HIRDS.

Another item under this same appropriation is the investigation of the food habits of birds, and the experiments and study to control losses to agriculture by bird pests, such as blackbirds, crows, and others. In some places they become tremendously destructive. 'The work that the Biological Survey has been carrying on ever since its origin, of studying the contents of birds stomachs in order to determine exactly what the birds eat at different times of the year. has formed a basis for a large part of the protective legislation for useful birds throughout the United States. All the States base their appreriation of the value of birds on these researches. which are still going (1)11.

'There is a curious thing, and yet a thing not unexpected, and that is thut hirds with the changring conditions and chunges in agrieulture, "hange their habits lrequently, and birds that are usually harmless may become quite harmful at certain seasons, particulaty in connection with the destruction of fruit.

'There are other protected hirds, such as herons, that destroy fish on a larege scalc.

Bnder the law, us rectards migratory birds, the Secretary of Agriculture has the anthority to issue perrinits to destroy protected birds whore they ure destructive to agriculture or other interests. We 
investigate eomplaints, and whore waranted, tho secreturv insues the neressury permit for tho destructions of threse pests.

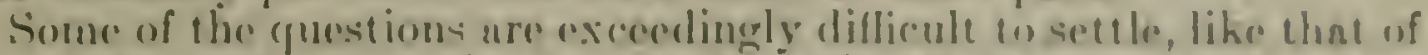

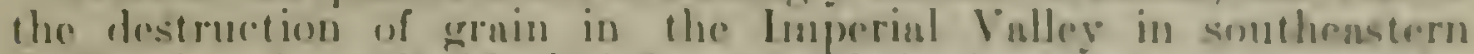

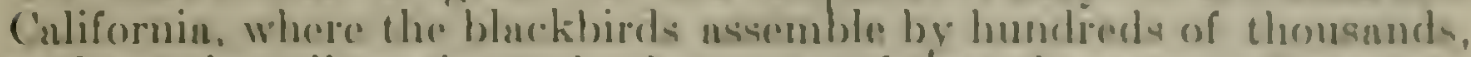

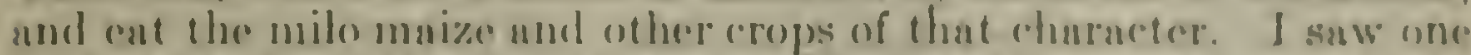
field of 1 (io) acoes that they had notmally clemued up so the owner dirl not rut the roup).

Mr. Buchasin. How do gon destroy those hirds!

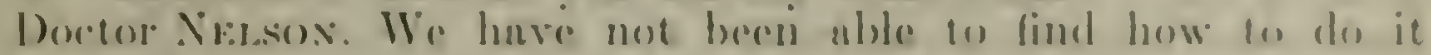
siccersinglis.

Mr. Brocis.s.s.r. I expect I have seon a million in ono drover: the whole country hack with them.

Doctor Xrisox. Ocrasionally wo can poison these hirds on a

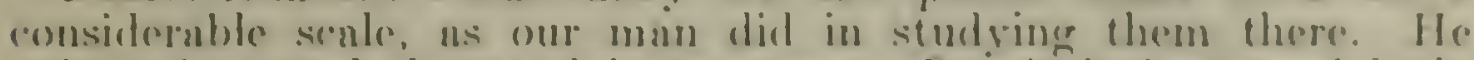
poisomed sereral thomsund in one cuse. But it is just geod lurek. berenuse the flocks are irregulare in thoir movements. and there is no tolling whele they are aroing to rome next: it is a shoer necoident if they come te it poisened field.

Mr. Br("Haxix. Do you ever poison muy ducks?

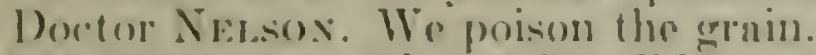

Mr. Brons.s.s. I know, but did you erer put out poison for dueks?

Dortur Irosos. ()h, no.

Mr. Brochiss. They do in some places, do they not?

Doctor Inesox. I never heard of it. Wilel ducks?

Mr. Bucrinan. Yes.

Doctor Nersox. I never henred of it.

Mr. Buchaxix. Ducks do go into the linkds mul tear the shocks lown.

Doctor Trasox. I never hemed of poisoning them.

Mr. Bucmasix. I heard they did in Canada.

\section{FOR BIOLOGICAL, INVESTIG.ITIONS.}

bortor Xrasox. The next item is for biological investigntions, which rover the technicnl, scientific investigntional work of the burcun. forming the fundamental basis for our ceonomic work. It is noressary to study the rarious animals from a technical point of view in order to determine what they ne, the different species of hirds and the diflerent species of maminnls and their distribution and rhuructeristics.

In commection with thut, one of the forms of netivities we are pushing is the bunding of migrntory birds to study their flight-their lines of truvel. I prent many people are doing this work voluntarily. I think there nre over $400 \mathrm{in}$ different purts of the linited Sintes who are cloing this roluntary work. We supply the hands and the lilanks for records. and they do the work. 'They irap the birds in wire t rups or nets, and put an aluminum band on one leer of ench hird. 'This band has an inseription on it to return to the Biolocical survey. Washington. and when anyone erots one of thrse hirds. the hand is romoveril and muiled in.

Mr. Axmrasox. The bnud having a serial number, or something of that sort? 
Doctor Nelsox. Yes, sir: they hare a serinl number. It is proving most interesting. We are getting very extraordinarily interesting results, which will increase, of course, year by year, because of the accumulation of the birds banded.

We get quite as unexpected information as we did in regard to the ducks banded near salt Lake, in Utah. Afterwards one of those ducks was taken in central Californin, another one was taken orer in Kansas, another one in Arizona, and another one in Alberta-at evers point of the compass from that center. The ducks went enst and west across the mountinin, which was quite surprising. That wis something we had not suspected, and is very significant, because it means that these great marsh centers, such as the Bear River marsh. at Salt Lake, form reservoirs from which ducks start and supply the surrounding States in every direction. Before that we had always supposed ducks flew north and south; we did not suppose they were flying at right angles to that course.

Among the scientific researches are investigations in response to inquiries from different governmental departments and from the States, and we have the cooperation of a large number of people in connection with that work.

INVESTIGATIONS RELATING TO FORAGE OF LARGE GAME ON NATIONAL FOIRETA.

We are also investigating the relations of large game to fornge on the national forests in order to work out a system whereby a certain amount of large game can be maintained without seriously interfering with the grazing industry. At its last meeting the National Live Stock Grower's' Association passed a resolution asking that the Biological Surrey and-State officials handling matters of that kind institute an investigation in order to determine what can be done in the matter of maintaining game in connection with the grazing industry. We are carrying out that work as rapidly as we can.

We huve recently investigated the situation on the Kaibub Plateat. in northern Arizona, which is a Federal game preserve and national forest, where the deer have increased tremendously. 'There nre now not less than 20,000 deer there, and our men have made the recommendation that about 2,000 bucks be killed next fall, if possible, in order to relieve the pressure. The deer are incrensing to a point where before long they will eat themselves out of fornge. They will not only eliminate the live stock, but will eliminate themselves, and some pratetical outlet must be found to take care of the surplus.

Mr. Axnensox. We will now take up the next item. on page 2 ft).

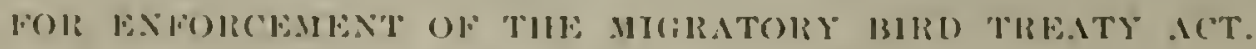

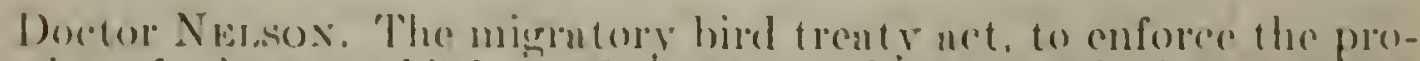
tection of migratory birds. We have 28 fully paid, full-time wardens and several humdred wardens on a mominal sulatry who can he used

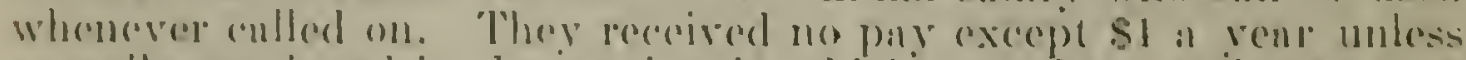

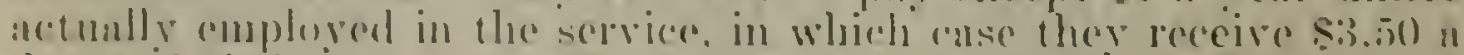

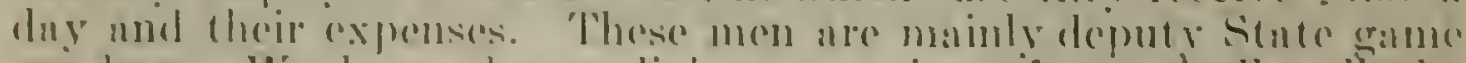

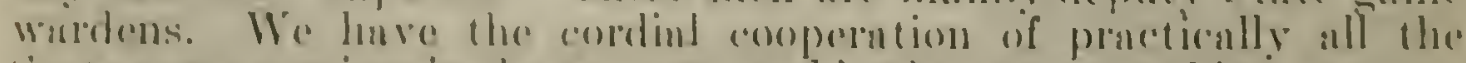

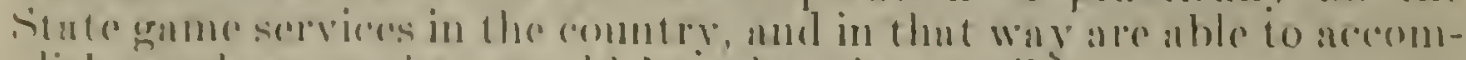
plish much more than would he otherwise possible. 


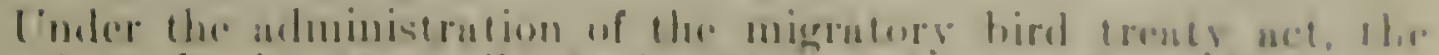

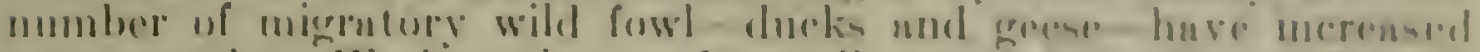

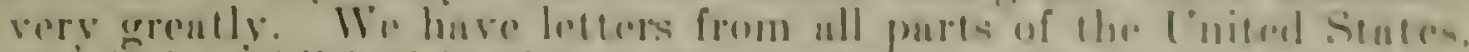
and it is published in the sporting mognginm repoutedls, Ihus tho

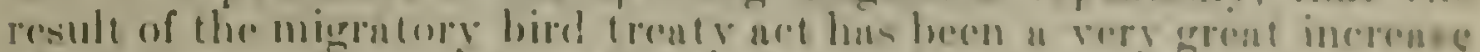

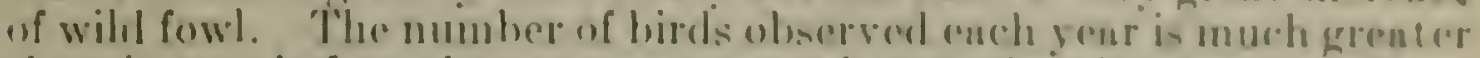
than it was before thut net was passed, and that incremse his loren

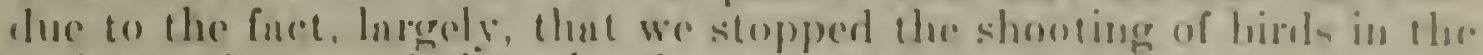
spring and stopped the sale of entme.

The destruction of game by wholesule sealo was endorl, and breenling supply of birds which had survired the fall homting and the winter were enabled to get back to their breeding gromols.

The need of protertion of this kind is shown by the fure that the birds were decrensing vory rupidly at the time this trenty wis nearstiated and the law passerl. The sportsmen of the country renlized that unless something of this kind was done the migratory wild fowl would be exterminnted in a comparatively few years.

Last yenr there were more than 4,000,000 hunting licenses issued by the different States. Adding to that number those who hunted in States where a license is not required-and those who are cxempt from taking out licenses through ownership of land or other causes it is estimated that a total of over $6,000,000$ people hunt each year in the United States. It is obvious

Mr. Anderson. The woods are full of them.

Doctor Nissox (continuing). That the game has to be protected. becaluse in some places it is fairly mobbed. It is generally concederl among sportsmen and those acquanted with the subject that this migratory bird treaty act has been one of the most sucressful ronservation laws ever passed by Congress. It has demonstrated its effectiveness in the recognized increase of birds.

IMPORTATION OF FORFIGX BIRIS AXI) MAMMALS.

In connection with this work. we also supervise the importation of foreign birds and mammals for the purpose of keeping out destructive species, and we are successful in that. The mongoose is the most dangerous of all animals if it should get a footing in the United States. It is a little animal from India. wensel-like in its habits and terrifically destructive. They were imported into Jamaica and into the Hawniian Islands, and wherever found they wrenk havoc with all ground-frequenting birds. Mnny of our ground-frequenting birds are game birds, and they would be wiped out if the mongoose became established in this country. They would do well in the southern United States and they would wipe out all quail, grouse. and wild fowl that nest in the ground.

Mr. Axnersox. How do they get imported intu the country?

Doctor Nessos. People bring them in. They know that they are great rat killers, and so people, ignorant of their habits and what they have done in the countries where they have been introluced. think it would be a fine thing to have them kill rats.

There is a real danger that these animals might be introduced in some areas and spread all over the tropical and other wam parts of 
the American continent. We are constantly guarding against their importation. 'They are coming in every litile while, and when they come in we switch them off and either have them killed or sent back to where they came from.

\section{INVESTIGATION OF REINIEFR INIITSTR IN MASKA.}

The Chammax. We will now consider the next item, page 442 .

Doctor Nersox. 'Those are investigation experiments in connection with reinder and the protection of the land fur-bearing animals in Alaska.

The reindeer in Alaska were first introduced in 1892, and up to 1902 they imported a total of 1,280 animals. There are now 200,000. perhaps, reindeer in Alaska, in addition to 100,000 or so that have been killed--the offspring of that one thousand two humdred and odd. This indicates that conditions in Alaska are extremely farorable to reindeer growing. They were imported for the benefit of the Eskimos, but gradually they have, of late years particularly. drifted to some extent into the hands of white men. So that at the present time two-thirds of the holdings in Alaska belong to the natives and about one-third belong to the white men who are beginning to develop the business on a commercial scale and to export the curcasses.

Up to 1920 nothing had been done in the way of scientific study of the reindeer business in Alaska or of conditions on the rangewhat the range would support and how it should be handled. In 1920 Congress gave an appropriation to the Biological Surrey to begin investigations of that character, and I went up to Alaska with some experts and established them at an experimental station on the coast, where they are now conducting investigations. The preliminary results have been published in a bulletin published recently, which is the first bulletin of the kind. It contains a comprehensive survey of the reindeer business and points out what is needed to conduct it suecessfully. 'The conditions under' which the reindere' business was conducted in Mlaska were very erude, but they have already begun to take advantage of some of our suggestions and report surprisingly good results as the outcome.

We have found that there are at least $120,000,000$ acres of hand in Alaska that are suitable for reindece grazing. This area would accommodate in the neighborhood of $4,000,000$ reindere. These animals breed very rapidly. They begin having young when they are only a year old, and at 2 years nenrly alwals have young, and they raise a large per cent of ealres.

The ment is of excellent quality, but the animals are small. The carcasses of the animals that have been shipped average about 150 pounds anch. In Mlaska there is a larere wild caribou, which is another nume for the wild reindecr, individuals of which are snid frequently to dress by actual weight from 300 to 400 pounds, in contrast with 150 pounds in the case of these imported reindeer.

We completed in August a trap corral in McKinley Park, Alaska, where we propose to capture some of these big young bulls and put. then with the reinderer herds for the purpose of grading them up) 


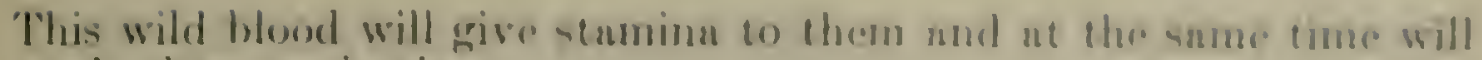
gracle them up in size.

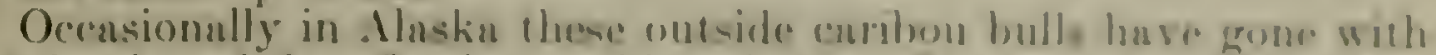

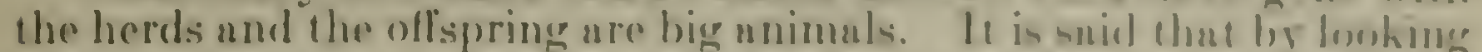
nt a reinderer herd you can tell the half breeds by their stnuding up ubove the others. There is no question that bo preporer soldection

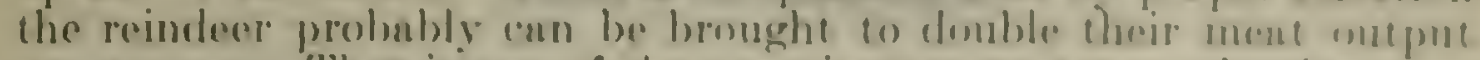

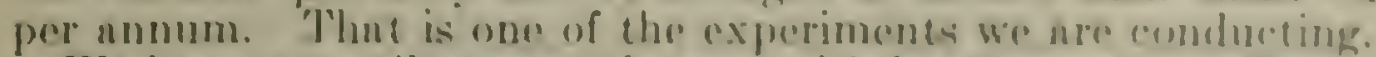

We hare a small power schooner with hendquarters ut Dorme thut our mon use to visit the reindere herds ulong the const of the Irofore and southword. They are nlso making n definito, rorreful sturly of the forage plants ased by the reinderer and the distribution of thene plants. It the sume time they ane studying the churacteristies of the country, in order to work out a method of allotment of gruzing land. for the purpose of nllotting these reindeer herels definite urens just as is done on the mutional forests. They nhearly huve llant worked ont over a considemble aren. nud as soun us Congres's pusses the necesenry legislation allotments can be made. That will be a rery grant holje to the business, beenuse at present they nre nlmost walking on ench other's feet, and herds are interfering in a very durimentul wny. There is a lot of mixing up of reindee belonging to different owners and this results in henry losses.

In addition we have the supersision of land fur-bonring unimals in Aluska and are mantaining warden service. We have u patrol bont in southenstern Maska and are trying to prevent the overkilling of fur-bearing animals.

The fur-bearing mnimals from Alaska afford a return of more than $\$ 1,000,000$ " yeur, and it is of great importance that the killing hy poison and killing ont of season of these animnls be restricted in order that the output caul be maintained.

Mr. Bechaxa. Ought not killing hy poisoning be prolibited!

Doctor Nersos. It is prohibited.

Mr. Buclusax. Fou used the word "restrieted" unintentionally. I suspect.

Doctor Nersisex. About poisoning!

Mr. Bichasix. Yes.

Doctor Nessox. We restrict the killing. but step the poisoning wherever we can. No poisoning is permitted.

Mr. Becmaxa. I did not wint the record to go down that way.

Doctor Messos. Is there anything further in regurd to this item?

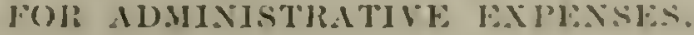

Mr. Axumesox. I think not. Now take up item at pher 2.4.

Doctor Ni:sos. There is no incrense here. It is just the conduret of the routine business of the office. Conless you huve some inguiry there, 1 do not know that there is anything to be said about that. 
Wedisday, November 22, 1922.

\section{DIVISION OF ACCOCNTS AND DISBURSEMENTS.}

\section{STATEMENT OF MR. A. ZAPPONE, CHIEF OF DIVISION AND DISBURSING CLERK.}

Mr. Axnensox. You have un item for salnries for which you are asking $\$ 59,420$, and you have some increases in this roll.

Mr. Zappone. Mr. Chaiman, before taking that up, I have a brief statement here in regard to the work of the division which I would like to put into the record.

Mr. Andersox. You may read it.

\section{GENERAL STATEMFNT OF WORK.}

Mr. ZAPPonf. The Division of Accounts and Disbursements, in accordance with law and regulation, pays accounts submitted by the various bureaus, divisions, and services of the department. Accounts are cxamined to ascertain that approvals are genuine, that extensions and additions are correct, and that there are appropriations out of which they are legally payable.

A cashbook record is maintained of all individual payments, and ledger records are kept of disbursing and appropriation debits and credits of all funds of the department. Through the use of a card index duplicate payments are prevented and a ready reference to payments is avalable. The division also supervises the placing of funds to the official credit of temporary special disbursing agents and other fiscal officers of the department, and after making a record thereof transmits their accounts to the General Accounting Office. It receives and accounts for all moneys due the department from various sources; makes advances of public funds to employees for the payment of their expenses while traveling on officinl business; maintrins a record of liabilities and disbursements in connection with purchases of lands under the Weeks forestry law; keeps the departmental record of amounts withheld from employees' salnries under the provisions of the retirement net of May 22, 1920, nnd. under the direction of the Budget officer, assists in compiling the annual estimates of appropriations. Miscellaneous financinl reports are prepared from time to time as required. During the fiscal year 1922 this ollice nlso received and deposited in the Treasury all the collections of farmers' seed grain loans, and muintained the file of notes and mortgnges and a detailed record of the repayments thereunder.

\section{S.II.ARILS.}

There is an incrense in the estimates of $\$ 3,600$ to provide for three udditional employees at $\$ 1,200)$ cnch. The sulary roll has incrensed only $\$ 9,(55)$ during the nine-yent period from 1915 to 1923 , inclusive, with an increase in the number of employees from 32 to 38 , most of which increase was ullowed by this committee during the lnst two years. During the snme period the upproprintions of the department iarried by the acrieultural ace have uncreased from $\$ 20,000,000$ to upproxiniately $\$ 3(1,000,000$. In addition there have been large ap- 
propriations carried in specinal nets that lawe loen pasted by Congrem from time le time. such as the permanent approperintiofi for meat inspection, for the nequisition of lands under elue II costa forestry law. the seed grain lonns net, nnd the acte for Federal nid to the striles in the construction of ronds, amounting anmually lo millions of dollens.

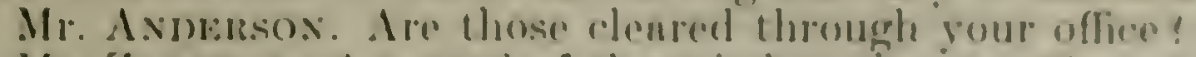

Mr. Zsaproxe. A recorel of them is kept in my ofliee and all of the aceounts are paid there.

Mr. Axuresos. For fioderal aid for ronds?

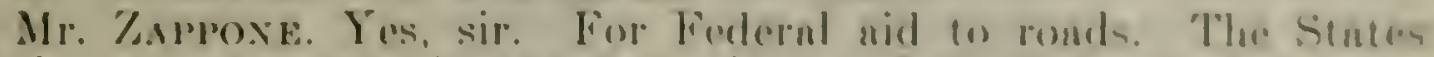
make the puyments in the first place and then the meoumte are submitted and refunds mole hy the Government for sol) per cent of the work done. 'Than work is enntralized by the Burean of Publice Rouds in Woshington, and the aceosuts are scheduled to me for parment like othere aceounts of the department.

Mr. Axversox. Is thent true in the rase of the nid given through the Smith-Lever Ant?

Mr. Zappose. That is not true in the case of the Sinith-lever nid. Those appropriations are adraned directly to the stantes hy the Secretary of the Treasury and payments ire made by the sintes. However, the requisitions for funds puss through the secetury of Agriculture to the Treasury Department as required by the law.

Mr. Axnersox. The bosklesping that is done in comnection with those funds is not handled in your olfice?

Mr. Zaprons. No, sir: except to set up the amounts in my ledger: all the work is conducted by the States Relations Service. Ther have a detniled record and must have in order to keep in touch with what the States are doing, and to enable them to prepare the annunl report which they have to submit to Congress in regard to the funds.

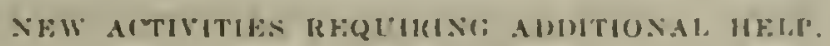

The additional appropriations mentioned hare added largety to the work of the office. The accounts and ehects hnve incrensed during the past year about 10 per cent. The number of employes in the department during the past year has also increased about 1,000 , from about 19.000 on October 31 last year 10 nbout 20,000 on October 31 this year.

Mr. Avdensox. Where does that increase come in; under the grain futures act!

Mr. Zappose. A large part of it was in the Bureau of Agricultural Economies, due to the errain futures net nnd other new activities. also to additional legislation Congress has pussed, such as the packers and stockynrds net, operation of the Center Market, and the seed grain lonns aet. 'Then the fixed nitrogen laborntory was transferred to the Department of Agriculture from the War Department.

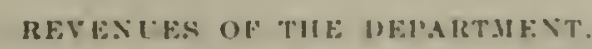

The revenues of the department are also increasing numually. During the fiscal yenr 1922 the revenues for misecllancous receipts afone nmounted to about $\$ 5,000,000$, and repayments to the appropriations about $\$ 3,000,000$, making ubout $\$ \$, 000,000$ in all.

Mr. Axdersos. I wish you would give us a statement of the rereipts and the sources from which they come. 
Mr. Zappone. Such a statement has been inserted under the office of the Secretary.

CLASSIHICATIUN OF ALL EXIENUITURES.

Mr. Axdersox. Anything further?

Mr. Zappose. During the present fiscal year a new activity has been added to the work of my office; that is, the classification of expenditures in accordance with certain objects of expenditures prescribed by the Comptroller General in Bulletin No. 1 issued by his office on May 11, 1922.

The Secretary felt that he would like to hare a centralized record in the department of the objects of expenditures as prescribed, and to do this I put in four punch machines, a tabulating machine, and a distributing machine similar to those used in the Census Office for compiling the census. The vouchers are coded by the bureaus and are sent to my office for payment. After payment, they go to these machines, and the rarious objects of expenditure are recorded.

In two or three years from now, I hope to be able to make statements of expenditures under any class or object of expenditure, as prescribed in the bulletin, for the entire department. That is the adrantage of a centralized record.

The bureaus are keeping a similar record, but they only show the hureau end of it. That is all that they will have. For instance, if you want to know the amount of the expenditures for fuel for the entire department, or for ice, or for stationery, or any of the fixed charges, it can only be obtained by calling on the various burenus for it. But sometimes this information is required quickly, and, by means of these machines, it can be turned out in a few hours. You simply run the cards through them and there are no mistakes. They are practically infallible. The cards are run through twice, and the results balance. If they do not, there is something wrong. I think that is all.

S'TATUS OF WORK.

Mr. Buchasax. What is the condition of your work now; is it current!

Mr. ZAProne. It is not current. My work is slightly in arrenrs just now. It is due to the stress of woik at this time and more particularly to the large number of financial statements and other data that we have had to prepare, most of which has been for the information of the Budget Bureau. In conducting its work the Budget Bureau necessarily requires considerable data and this lns imposed udditional work on my oflice and other oflices of the department.

$\mathrm{Mr}$. Buchasas. The reason that it is not current now is not duo (1) al lack of two or three employees, is it?

Mr. "Laproxe. No; I asked for more but that is all that was allowed: however, I hope to get up the work with the three employees requested and such additionul help as I may be able to get from the bureaus in the way of temporury details.

Mr. Becmaxax. So you usked for more employees than are in the estimate and the Burean of the Budget cut them ofl?

Mr. "aniosis. Well, ther were not allowed.

Mr. Jusp. The truth of the matter is that with reference to the Division of Accounts, I have never seen a year since 1 have been in 
the department that there hins been so much astan work of this erpe.

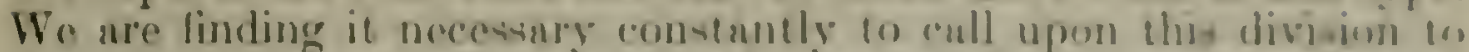
compile stutements of various hinds, nearly ull of them complicnted

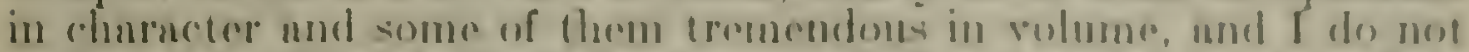
see how his wlice has done the work with the foree that it hus. As as

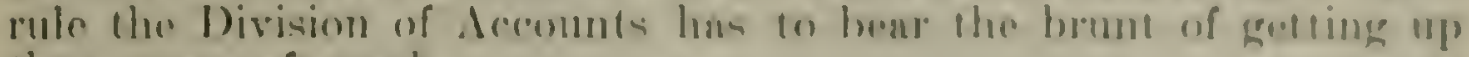
that iype of work.

Mr. Axmbsos. We will enke up the question of the library.

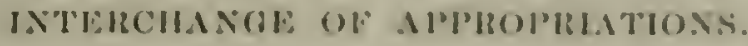

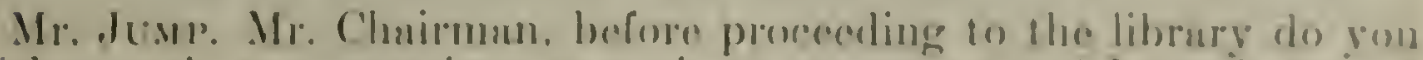
wish to usk any questions as to item ou page 310 "Interchange of uppropriations" " That is the 10 per cent trunsfor prosiaion rolating to the general expense items.

It is merely a repetition of the langunge courreol in this gent's hill.

Mr. Bucunisa. You had that up last year?

Mr. Jemr. It is the same thingr. The sume lungunge is submitted.

Mr. ANDERsox. I think that there is no necessity of groing into that. My recollection is that the charman held it in order last year. so that I think there will be no yuestion sbout it.

\section{REIORT ON PER IIEM RATKS ON TRAYKA.}

Mr. Jump. The report on per diem rates, ete., on travel-din you wish to ask any questions on that?

Mr. Anderisox. No.

Mr. Jusp. 'That is all, then, before we come to the librury item.

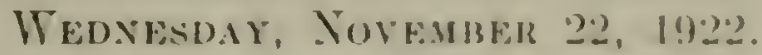

\section{LIBRARI"}

\section{STATEMENT OF MISS CLARIBEL R, BARNETT, LIBRARIAN, DEPARTMENT OF AGRICULTURE.}

\section{S.MI.1RII:S.}

Mr. Axmensox. The first is the item of sularies. lour statutory roll this vent culls for the same amount as lust yent?

Miss B̈ABstetr. Yós, sir.

Mr. Axumsor. The next ifom is:

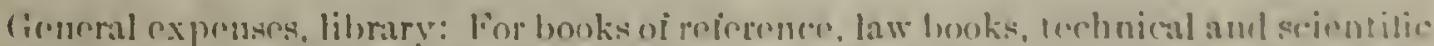

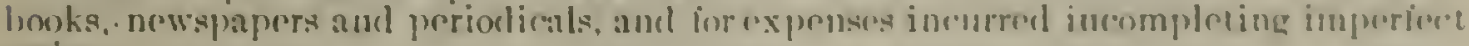
series.

And so forth. You have this yenr s.25,000, and you ure asking for

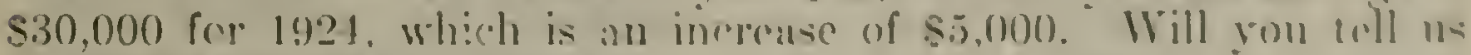
ubout that increase, plaise!

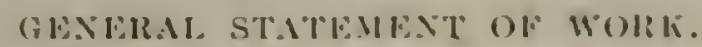

Miss B.ır.tert. The reasons are guite fully given in the explumatory notes accompanying the estimates, but I have prepared an additional statement which I shoulal like to grie, if you hare time for it. 
Mr. Andersos. We will be very ghat to have it.

Miss BarNetT. The library of the Department of Agriculture is a scientific and technical library. It comprises approximately 165,000 volumes and receives currently 3,000 periodicals. 'The subjects which it covers are the subjects under investigation by the department. The question is sometimes asked, Why is it necessary for the Depurtment of Agriculture to have a library? Why can it not get all the books it needs from the Library of Congress! With all its great resources it is impossible for the Library of Congress to eare for ill the specinl needs of the various departments. Its resources must be supplenented by the libraries close to the work of the departments and bureaus. A very large part of the books contained in the library of the Department of Agriculture are not arailable in the Library of Congress nor in any other library in the country. This is especially true of foreign agricultural books, for the Library of Congress does not attempt to cover in any adequate way the ficlds in which the department is especially interested, namely, agriculture and the related sciences. But cren liooks on these subjects. if contained in the Library of Congress, are not duplicated in the library of the department inless they are frequently needed or are of special interest. It must be borne in mind, moreover, that the Library of Congress serves a very large clientele and that it would be decidedly unwise to delay the work of the clepartment because of the inability to obtain promptlithe use of books which are essential in its investigations. However. the resources of the Library of Congress and of other Govermment libraries are always taken into aceount, and it is the policy of the library of the department to aroid unnecessary duplication.

All the cirilized countries of the world have made great progress in agricultural research and instruction during recent years. It becomes more and more important for the investigators of the Federal Department of Agriculture and State institutions to keep track of this progress. 'This necessitates a constantly inereasing expenditure for bockis and periodieals in which the results of such work are given.

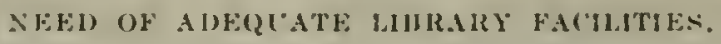

'The importance of adequate library facilities to a rescurch institution such as the Department of Agriculture ann not be too strongly rmphasized. If the library is wenk or inefficient because of inadequate resources or by renson of an insufficient or poorly trained stafl. the work of the department is bound to sufler. All effective researeh must be bused on what has ulready been done in the same field. unless a great deal of wasted effort, loss of time, and duplicution are to result. Testimony bearing upon the importance of adecgunte library facilitios in resenteh work is given in a paragraph of a recent report of the Department of Agriculture of the L nion of South Afrira deploring the lack of proper library facilities in that department. It says that "in many cases members of the stafl" of the departurent who have to investigate particular inportant problems find therig work doubled by hack of dnta already published in connecetom with sinilan important probtems in other countries. In many "ases they lanve to spend six months of salariod time and considerable

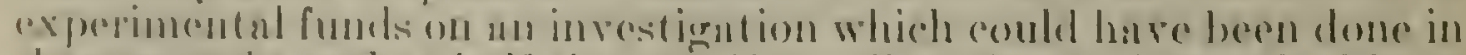
three monthe and at half the cost if a woll-ecquipped library hand been within rench. 


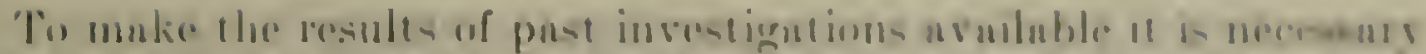

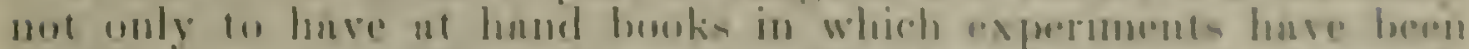

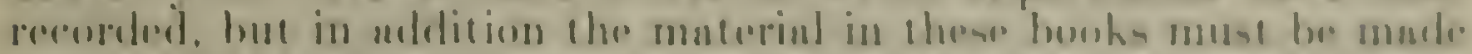

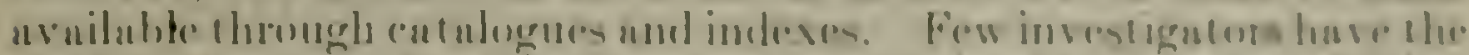

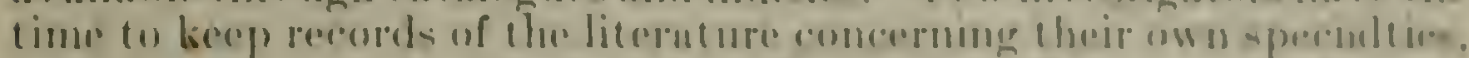

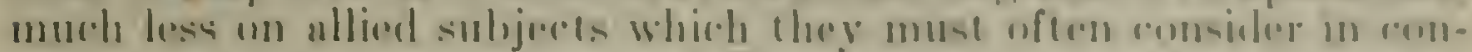

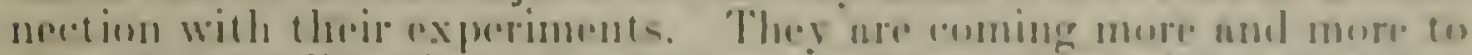

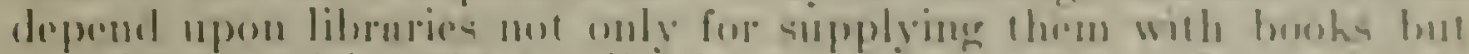

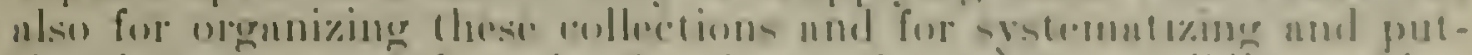

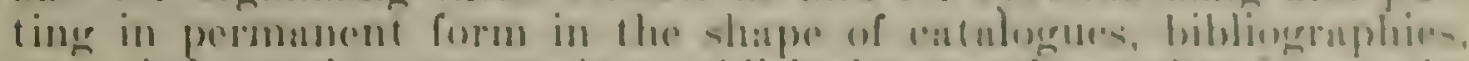

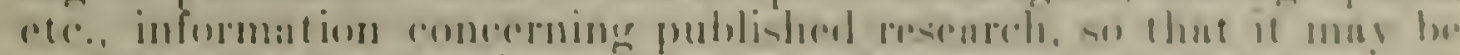

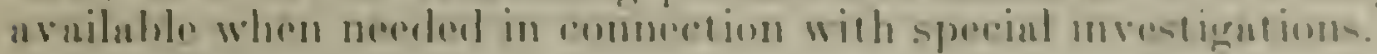

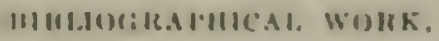

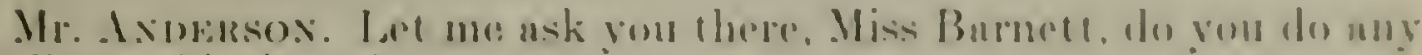
bibliographical work!

Miss Barserts. les: we do. Is an illustration of l/w hime of

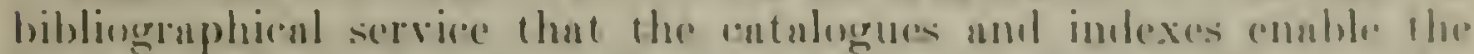
librury of the department ar gire may he cited the resume of the results of price lixing theough to centuries. prepured by the lihruring of the Burenu of Agrienltural Eeonomics, wheh wo especially useful in commetion with the National Agricultural Conference lust pent. That is just one of a number of examples wo conld give.

Mr. Axinzasox. You get requests from prople in the department (1) work ont nll muterial in the library, specifying mutrial upun specinl questions, or relating to particular investigntions?

Miss Bansetr. Yes; that is what we try to do. Wo maintain "

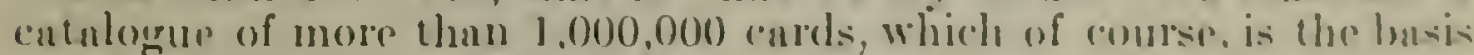
for all of our bibliographicial work.

Mr. Axuersox. I suppose that inchudes, of rourse, sulyject indexes and author indexes?

Miss Barsetr. Yes; both subject nnd anthor indexes.

The library is an essential and important part of the equipment of the department and as such can not be impaired without sirrous los: to the work of the department. It must keep pace with the growth of the department and keep in elose touch with the growth if acricultural work nll over the world if the investigntions of the depurtment and of the afliliated state institutions ale to be arried on to the besit adrantage.

CUST OF I'FRIOHIS.ML.

Lnfortunately the support given the library in the past few reas hass been most inaleguate both for salaries und for books. In irder to muke this elenr it is only necessiry to review briefly the library's upproprintions for the past seven yesis. from 1917 to ilute. a poriod in which the work of the departmont hus ereatly expamled. In $191 \mathrm{~s}$ the clepartment appropriation was \$25.929.113. For $192: 3$ it is $\$ 36,774,173$. an increstse of 30 per eront. In 1!917 the tolal apporepriation for sularies and general rexpenses of the library was \$19.5201.

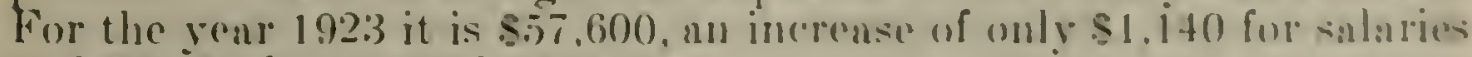
and $\$ 9,000$ for greneral expenses.

The total increase in the library nppropriation during the seven vears umounts, therefore, to only $s s^{140}$, or approximatoly if per 
cent. On the other hand, the cost of books, periodicals, supplies, and equipment during this period has increased from 30 to 200 per cent. To give only one or two examples, the Rand, McNally \& Co, atlases have increased in price in the past seren years from $\$ 16$ to $\$ 35$ a copr, and the Official Railway Guide. for which some 30 subscriptions are needed in the rarious offices of the department. has increased from s9 to $\$ 1$ s each.

Mr. Axpresox. Is that paid out of the library uppropriation?

Miss Barserty. That is paid out of the library appropriation.

Mr. Axinersox. Why slould it be paid out of that appropriation?

Miss Barnett. Weli, you see, under a law passed by Congress in 1898 it is illegal to use any part of any appropriation for the purpose of purchasing books and periodicals which does not specifically mention books and periodicals. The library appropriation, with one exception, is the only appropriation for the department which can be used for the purchase of books and periodicals.

For the reasons that have been explained, the increase of $\$ 7,000$ in the book fund in the past seren years is more apparent than real. It is in fact insufficient to cover the loss in the purchasing power of the dollar. Furthermore, due to the present system of business operation in the department the library is now called upon to pay from its appropriation for services which were formerly rendered the library by other offices of the department without charge. It must now pay for expressage, for its trucking service, for its multigrnphing and mimeograph work and for its shopwork, all of which work wis formerly paid for from other appropriations of the department. These expenses have still further decreased the amount arailahle for books.

NEED FOR ADIUTIONAL ASSISTANCE.

While the estimates for this year include no changes in the statutory salaries, it is necessary to say a word in regard to them, as they furnish additional reason for the increase in the book fund. In the appropriation for 1917 there were 33 positions on the library statutory roll. In the appropriation for 1923 there are only 2S. Seren of these positions were cut of in the appropriation for 1922, and no provision for them was made by an increase in the fund for general expenses. In fact, this fund was decreased by $\$ 600$. In the approprintion for 1923 two additional places were restored to the statutory roll, making 28 in all, as compared with the 33 in 1917. As the work of the library has much increased in the past seven years, it was quite impossible for it to carry on the work required of it with a decrensed forec.

It was also impossible to provide for all the positions which wero dropped from the statutory roll by carrying them on the fund for the general expenses of the library, without reducing the book fund (6) such an rextent as to hamper scriously the work of the department. In the rmerereney it was necessary for the library to ask the help of the bureas in earrying the salaries that were not provided for on the statutory roll. Their help has also been necessary this rear. It will he secon, therefore, that the $\$ 5,000$ increase in the past seven years has becen entirely inadeguate to cover provision for the five positions dropped from the statutory roll, for the increase in the cost of hooks, periodicals and supplies, for additional shelving that is 


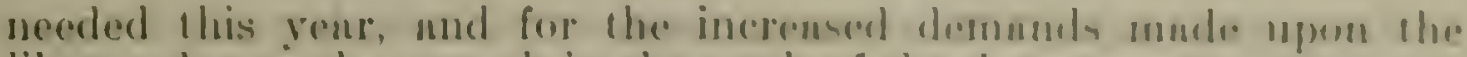
librny due to the growth in the work of the depate mente

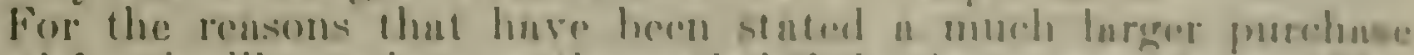

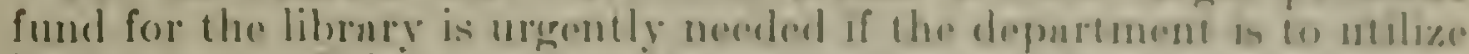
in the most efficiont manner the money uppropronter for invelightions and he in a position to coopernte effertis.ls with the stnte institutious, which nuturnlly look (1) the Depnrtmont of Agrieulture as hendyuarters for information on agriculture sum the lonlted nota and scioncess.

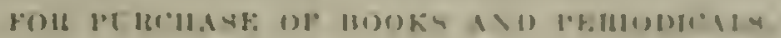

The $\$ 5.000$ increase in the astimates at approved by che Budget is $\$ 10,000$ less than the estimates presented by the department. On nceount of the errent need for additional funds it is ureently recommended, with the approval of the office of the Secoletury of Inricuslture, that the following provision be inserted in the lithrary approprintion:

Provided, That hereafter adlitional fundly irom any appropriation of thre drepartument for general expenses, may with the approval of the Sirefetary of Igriculture, lee iranuferred to the appropriation for the general expenses of the library for the purcha. ni looks and periorlicals.

Such a provision would supplement the library approprintion and make it possible to meet the special, unformeen and (xtruordinary needs of the burenus for books and periodicals. In othor workl: when a new line of work is undertaken by the depurtment the literatture on which, as represented in the library is inadecunte. it womld be possible for the burenu to transfer to the library some of its fundsfor the purchase of additional books and periodicals needed in the work. For example, it would bo possible to trinsfer funds for the purchase of extra copies of such reference books ins attases und dictionaries and the Oflicial Railway Guide, needed for oflice use which do not however add to the permanent resources of the library.

'This provision would be of ureat service to the department and is enrnestly recommended in addition to the $\$ 5,000$ inceresse contaned in the estimates. The bureaus hare often expressed dissatisfaction over the fact that they can not buy books and previodicals from their appropriations, especially when they have greatly needed duplicate ('opies of reference books which the library with its limited appropriation was unable to buy for them. They have stated that they would be ghad to use their funds for the purpose, but they have been umable to do so because of the law previously referred to which makes it illegal to purchase books and periodieals from uny uppropriation not specifically mentioning houks and periodicals. "The proviso recommended for inclusion in the library approprintion wubld make it possible to meet the needs of the hireaus and ret would not destroy the present unity of the library orgunization of the depirtment.

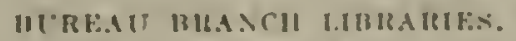

Mr. Asumersox. Are libraries mantained he any burenus of the department?

Miss BanXeTt. The books ure purchased by and recorded in che main library, but the diflerent bureas mantain what we call branch libraries. 'They pay for their assistants. 
Mr. Axdersox. Well, you hare branch reference libraries in some bureaus?

Miss Barnert. les.

Mr. Axdenson. In all!

Miss BARNetT. Not in all of them.

Mr. AxDensox. Not in all of them?

Miss BARNETT. In some of them.

Mr. Anovesox. And where you have them, the cost of the library. if you have one. Whatever it costs. other than the purchase of books, in connection with its mantenance, is borne by the bureau itself !

Miss BarNetr. Yes.

Mr. Jusp. But the books are all catalogued in the main library.

Mr. Avmrisox. I understand that. How is your appropriation for general expenses now divided between the purchase of books and the employment of personal service?

Miss Barsett. At the present time?

Mr. Avintron. Yes.

DETAILS FROM OTHER BUREAUS.

Miss BarsetT. We estimate from this appropriation we will have to spend about $\$ 3,000$ for personal services, beenuse the other burealls now ure carrying assistants for us that we can not carry.

Mr. Buchanan. $\$ 3,000$ for personal service?

Miss Barnetr. Yes; for personal services. We are keeping down just as low as possible the expenditures for personal services from the book fund.

Mr. Axpensox. Now, with regard to this $\$ 5,000$ increase which is proposed in this item, do you expect to use it for additional service or for the purchase of books?

Miss BARNETT. I would like very much to have that reserved just for the purehase of books and periodicals, but unless we can get help again from the bureaus in carrying some of our present salaries it wili be necessary for us to use some of it also for salaries.

Mr. Axmenson. Are there any details now from the bureans in the library?

Miss Bametr. Yes.

Mr. Axinerson. How many?

Miss Barnetr. Al present we have seren, as follows: One from the Secretary's office, at $\$ 2,000$; one from the Division of Publications, at $\$ 2,000$; one from the Bureau of Public Ronds, at $\$ 1,600$; one from the Stutes Relations Service, at $\$ 1,400$ : one from the Bureau of Biological Survey, ut $\$ 1,200$; one from the Division of Publications, at $\$ 960$ : and one from the secretury's oflice, at $\$ 900$. The amount of the salures carried last yenr by the bureans for the library was approximutely $\$ \$, 000$.

Mr. Axterssos. Is that in addition to the people they arry in theil own librurics!

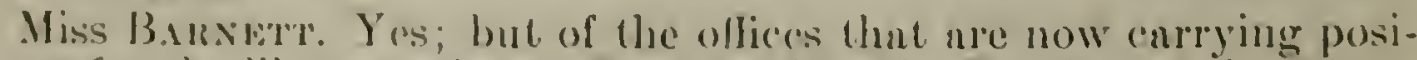
lions for the library only the Burenu of Publie Roads and the Sitates Rolations Service maintain branch libraries.

Mr. Itusp. Do you not think that it would be a grood policy, Mr. ('hairman, fo have an understanding that if the incrense of $\$ .5,000$ is granted to the depurtment, that it is to be used for books exchusively 


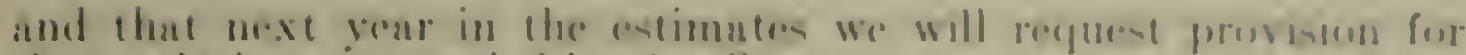

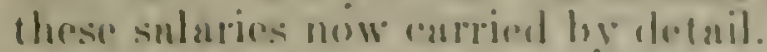

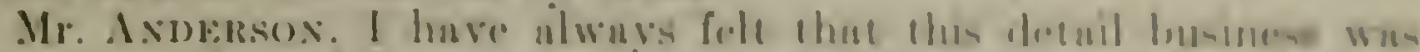

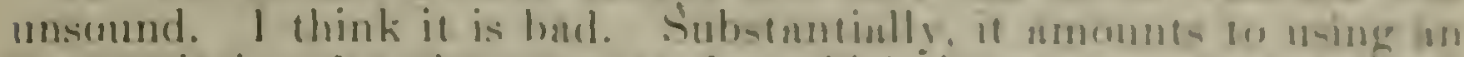
apporepriation for the purpone for which it was not metended. I

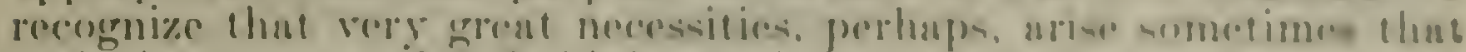

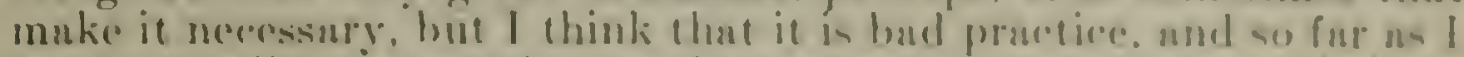

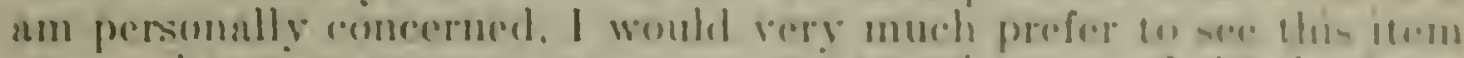

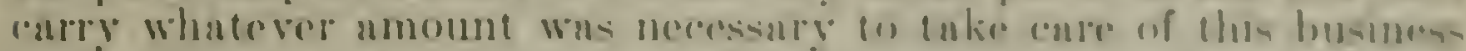

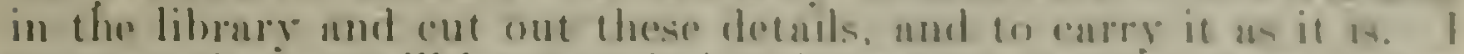
suppose that wo will huve lo do it this way for the noxt vear. but as

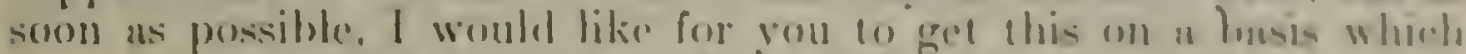
reprosents what it actunlly is. I think that that would he the loret thing for everrobedy concerned.

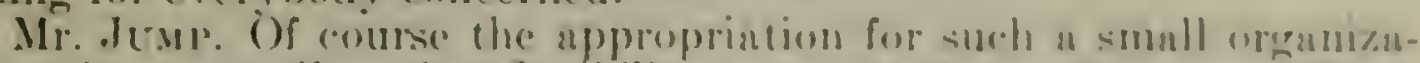
tion deses not allow dor flexphility ns in the larger huranus. If an emergency arises here, they do not have any hrgo hump sum to turn

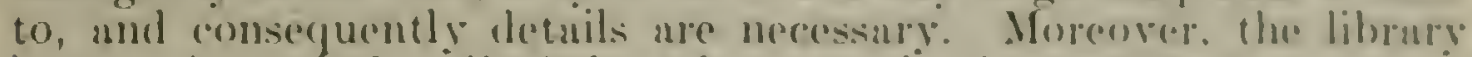

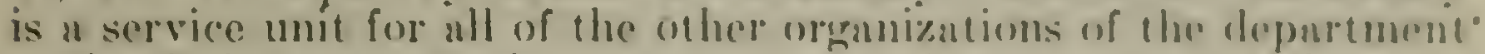
so that it does not seem improper to use the lump fumls uf the huroums to this small refent for parmont of a dirocet seprico to the same. bureums.

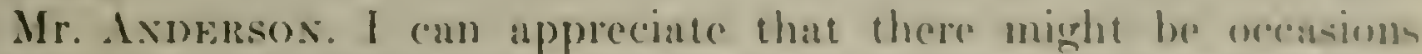
where details would be necessary. pertapps, under somo coreumstances: but where you have a permancint cletail, as you apparently hure hre, carried on the rolls of other hureaus, I think it is bad practire.

Miss B.nRxiot. Unfortunately. they have not been permanont. Sometimes the details have only been for a period of threo month.

Mr. Arnersos. Well, it amounts to the same thines. execpt that the money is seattered around a little more. and just that much is used anเาiัay.

Mr. Itum. We hava been able to do it like this. Mr. Chairman: In the division of publicntions, for instance. we had an editor who went on leave of absence for sereral months, due to illness. Nuw. we had a library employee we were able to carry on detail from publications by using the statutory place of that man while he was on leare without pay. Our being able to detail that position helped to just that extent in this particular branch. Of course, we huve had a number of lines of work added without corresponding incressis in the funds arailable for the library service. I refor to such additions as the packers and stock yards act. the mpoin futures act, and fixed nitrogen research laboratory. which, as its name implics. is particulary a research branch. and so on: and all of these things that have been added have increased the demand on the library, and it las been very helpful, really necessary. in faet, for us to hinse this much leewis:

Howerer, next year wo can come to the committee, if you desire, with a complete revision of thut situation and providis for threse employees.

Mr. Axnersos. I would like to see what it womld lowk like. 
Wednesday, November 22, 1922.

\section{BLREAC OF PLBLIC ROADS.}

\section{STATEMENT OF MR. THOMAS H. MacDONALD, CHIEF OF BUREAU.}

Mr. Axnersos. We will now take up the Bureau of Public Roads statutory roll, on page 250.

Mr. MAcDonidn. Before taking that up I have here a statement showing the general character of work of the bureau which I will insert in the record.

\section{GENERAL STATEMFNT OF WORK.}

The operntions of the Bureau of Public Roads are administered under two majol divisions-first, the highway division and, second. the agricultural engineering division.

Under the first division the major activity is the administration of the Federal highway laws and the appropriations which have been made for carrying on cooperative road work with the several States. The construction of highways in the national forests in cooperation with the Forest Service is also handled under this division, as is the research work in highway engineering and highway economics, the distribution of war surplus, and the informational and educational activities incident to, and a necessary part of, the responsibility of leadership in the tremendous program of highway improvement which is going forward in the United States. This division is operated through six subdivisions, i. e., highway administration and engineering tests and research, war materials, highway transport and economies, informational and educational, and control. This last subdivision handles all of the accounting and fiscal records required in connection with the apportionments to the States and the disbursements to them for work which has been performed, and all other fiscal records of the buresu.

Under the second division, agricultural engineering, the major activities are those in connection with carrying on resenrch in the ficlds of farm drainage, farm irrigation, and other engineering problems in connection with the utilization of hand for agricultural purposes; studies of the proper design and resenreh in the prineiples underlying suitable farm structures for eflicient farm service, and the proper housing of farm animals; the distribution of the results of ressurch and investigational studies upon these subjects through technicul and farm bulletins, farm power studies involving both animnl und mechunical power; the use of explosives for land clearing and utilizution. 'This division is administered through threo subdivisinns dranguge, irrigation, and form engineering. Practically all farm enginecring problems and services for the Department of Agrientture are grouped under this division, and the opportunity is thiss given to renperate to a greater or less extent with many other bureats and divisions of the department. There are many researeh problems anguging the attention of the department, which involve sometimes in a major and sometimes in a minor way, ongineering principles, repuipment, and design. 'The attention of the committee 
is directed to tho fure thut tho most notuble nolvaneres whoh havo

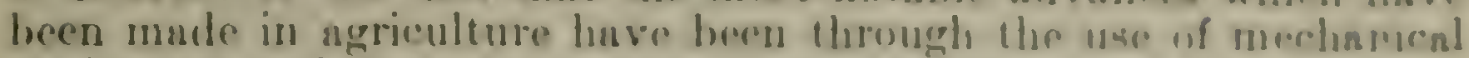

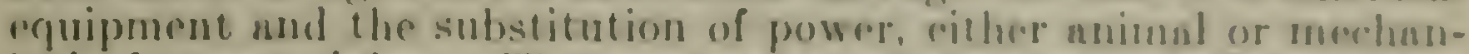
icol. for mun labor. 'The production of the imdividunl has horen

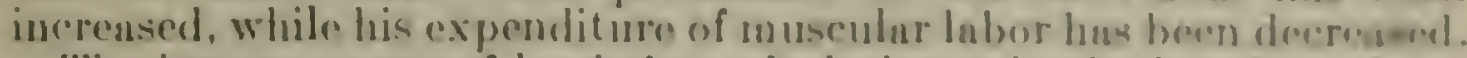

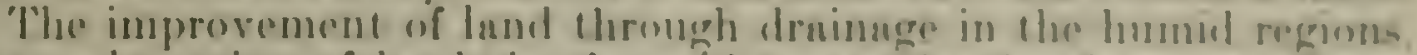

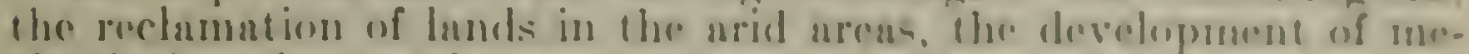
rhanienl equipment for and application fo farm comblems. have all

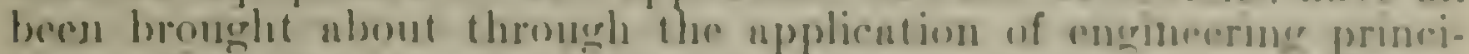

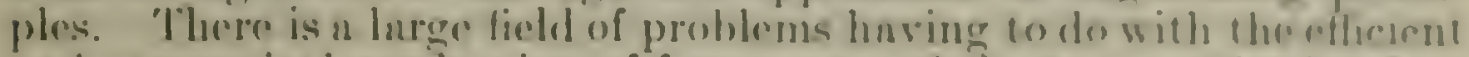

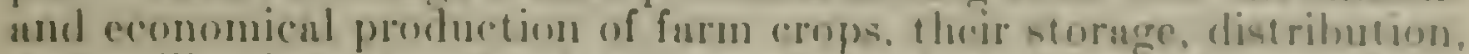

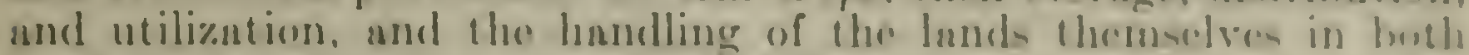
the humid mod ard regins which involve the principlos which mos

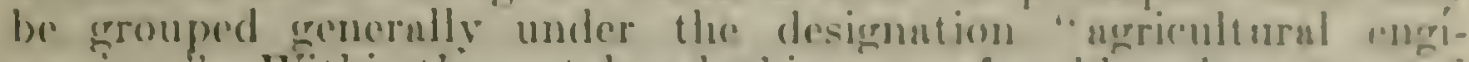

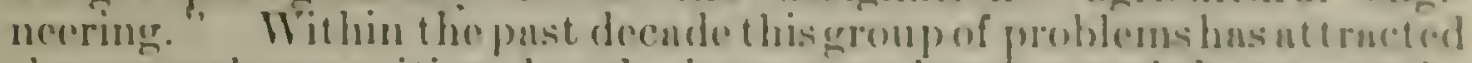

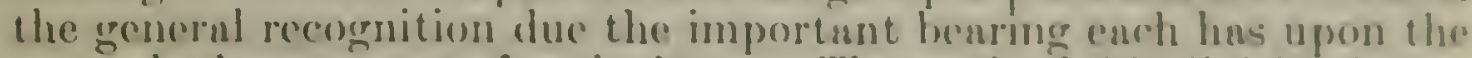
generul advanerencent of agriculture. 'The work of this alivison in the department has not becn expnuded in keeping with its importance. The appropriations are being maintained at n doud levol, which will not nllow its expunsion, and hecumse of the incrensed cost of rarrying on work now as compured with the pre-war level it is impossible t) produce results eonsistent with the needs of the times. Muny highly important resenrches are being carried on without adopunio persomnel or facilitios.

Among the outstanding results which have been or nre being secured through the netivities which the hurnu is enrrying on. either through cooperution with the individual States or indrondrntly, the netunl completion of rouds is perhaps the most importmet. During the past fiscal year more thin 10,000 niles of highwnys of all t.pes were frought to completion. 'This does not mean thit all of the work on the 10,000 miles was done during the year, but that this milenge was brought to actual completion during the yenr.

The progress in highway researeh has been notable. The burenu has carried on an importint series of tests on the impact on road surfaces, and other studies at Arlington, and a number of cooperntive resenrch projects have been instituted with State highwny departments, Stute edueational institutions. and other ngencies. "The bureau is cooperating with and supporting the National Research Council, in establishing a nutional research progrum on hicplisn: ('nginecring and economic problems, which shull be so coordinnted that attention shull be given the major problems, but that duplication of effort shall be eliminuted. The bureau is also cooperating with the State highway depurtments through the Americun Issociation of State Highway Officinls, in the work of developing and standardioing specifications, design, und practices for modorn bridges and highways.

The attention of the committer is directed to the fnet that in highway transportation we have a tremendous new foree in the economic and socinl life of this Nation. which has not yot becouns stubilized, whose limits are not yet known, and whose ramificntions touch the whole fabric of our ariculturul, industrinl. mal social life. The building, maintenance, nnd operntion of our highways ure an integral part of highway transportation and, in fuct, become the controlling element of the utilization of this form of transportation. 
The carrying on of extensive and detailed stụdies of the present and possible uses of the highways, and the accumulation of essential economic data must be considered a necessury and rital part of the activities of the bureau.

It is my personal judgment that the major problens now confronting us with reference to the highway program are, first, the annunl rate at which new construetion should be undertaken, second. the financing of the costs of construction and maintenance, and the distribution of these costs, and third. the relation which highway transportution should oceupy and maintain to other forms of transportation.

SAIARIES.

Mr. Axmersos. 'There is an apparent decrease of $\$ 9,840$ in your statutory roll?

Mr. MacDoxalm. 'That decrease, Mr. Chairman, is due to the dropping of these places, all but two of which are not now filled.

Mr. Andersos. Can you get along without these employees that have been eliminated without any detriment to the serrice?

Mr. MacDosald. All but two are places which may be eliminated.

FOR ROAI MANAGEMFNT ANI FCONOMIC STIDIF, OF HIGWAY CONSTRLCTION.

Mr. Armersor. Your next item appears to be the one an page 253 :

For inquiries in regard to systems of road management and eronomic studies ol highway construction. operation, maintenance, and value, either independently or in moperation with the State highway departments and other agencies. and for giving expert advice on these subjects, s660,800.

Mr. MaDoxגin. The bureau is asking for no change in that item. Mr. Chairman. We are asking for the same appropriation that we had during the previous year. Last year we did not use all the funds. because we have been carrying on the work largely with personnel cmployed part time by the L'niversity of Wisconsin. This year we have oreanized it on a full-time hasis and expect to use the entire fund.

Mr. Axoersox. Will you tell us something about what you are doing and propose to do under this itrm?

Mr. Macboxalds. Ender this item the bureau proposes to (ary an a study of highway transportation extended along the same lines we have already becrin. Fol example, in Connecticut we are carrying on a full year's study of the trallie over the highwnys. The plan corers the whole state, including the traflec entering and lenving the State, als well as the local trullide within the State. In detail, it is

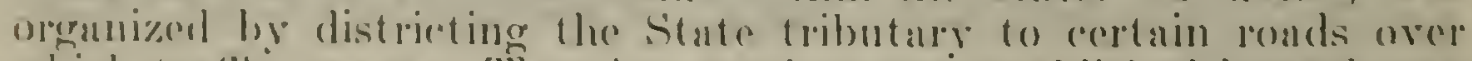
which traltic passes. Then key stations are established in cach one of these distriets, and full datia of the trattie units is taken hy the liold connting purt y'.

Mr. Axmeasox. What do you mean by "units"?

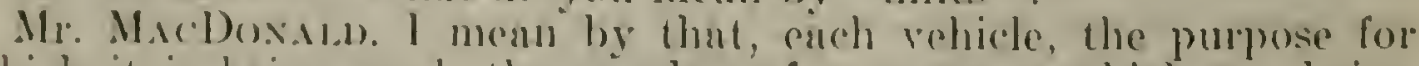
which it is boing used, the number of passengers which ure being corried, ar the frevight and the eharacter of the freight that is heing curried and its destimation. 


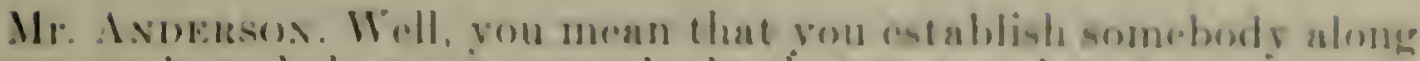
these ronds and they stop ererybody that comes atong?

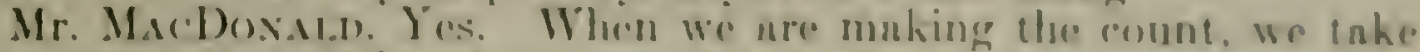
the entire data with reforence to the traflic that is going oser the rouds. These counts are taken in conpereration with the State haghway department, which has anthority over the traffic, but we have systematized the operation to such in axtent that it is gomible fo take the datu rery quiekly. This relates to the taking of the traflie romen. There are other stutions estuhlished. fewer in number, at

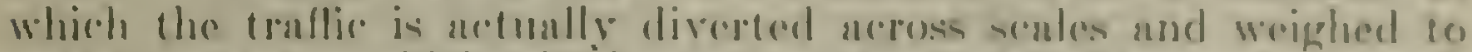

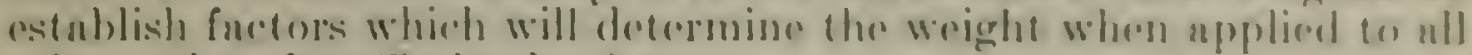
wher units of trallie in the state.

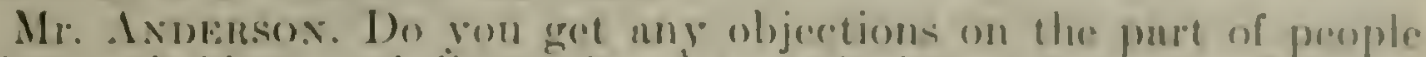
who are held up and diverted and are asted fore informution?

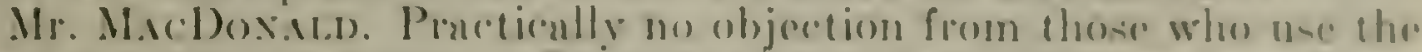
rond in a propere mannos. There has been soms objection from thons.

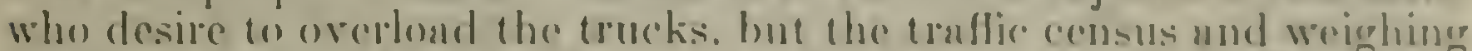
has had a very snlutury oflecet in the regulation of such trallie on the ronds. For example, we found in the first trafler ecusus that pertung

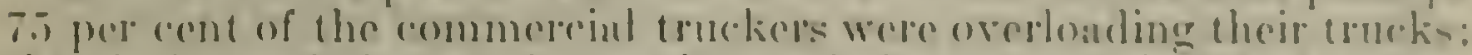
that is beyend the rated capacity. und they were doing that apparently as a menns of incrensing their rompensation without recented to the detrimentul offect upon the rouds. Since seales were instulled und the trallie eount has been going on, the overlonding hus decerased to a hurge extent. In other words, it has resulted in restraning the trallic to the lecral londs, and upparently the imestigation has guined farol from the better elass of truck operators and truck owners. Truck manufacturers particularly ure upholding it.

I may say that the scinles ure installed by the state. We do not contribute to this expense. Half or more thun half of the expense of the census will be paid by the State.

Mr. Axmensox. In how many places is this truflic census boing inkin?

Mr. MAcDoxim. We are carring on this complete count in Connecticut. We have an informal agreement with the Massnehusetts Highwny Department, and we hure been curring on a less extensive surver there. We have during the vear taken truflio counts on the county hasis in 'Tennessee. nnd we have un extensive Stute-wide traflic census now going on in Califomia in cooperntion with the California Ilighway Department. We expeet to add during the coming renr similar studies in one or more typical ngrieultural States. "Thesese studies when completed we feel will give us it fair picture of the various typical traflic conditions which exist in the Lnited states.

Mr. Axumesox. What is this investigntion the basis of - I mean. what do you expert will come out of it in the wy of concrete results:

Mr. Mliclboxulu. Two rery essential things will be mutured out of such studies: first, the principles of recrutution of traflic on the highwys, so far as the use of motor trunsportation for the morement of commodities and pissenger's is concerned: nut, second. the form. or licenses. which may fairly be charged for the eperation of mofos vehicles upon the highwars.

These ase ewo immediately impostant mutters in connection with the operation of our highways the one of louding. speests. and othere propere regulations, und, the other the fair charges for the usse of 
the roads. Yet, this and other similar studies are basic in laying the foundation far the whole consideration of the economics of bighway transportation.

Mr. Axuersox. Has it been shown that the orerloading of truelis beyond their rated capacity has had a detrimental effect upon the roads, as well as upon the trucks?

Mr. MaCDonatD. Yes; in my judgment. that has been shown, as applied to the heavier trueks; that is. the detrimental results to the road are more pronounced if the heavier trucks are overloaded than if the lighter trucks are overloaded. but in my event, there is a more detrimental effeet from overloading a truck of any capacity, than from the same loaid carried upon a truck properly designed to carry that load. This is due to the impact. of hearilyloaded wheels upon the roads. It is possible to multiply the statie load, that is, the load of the truck standing still by seven, if a large obstruction on the road surface oceurs. Which drops the lond on the highway. The average equivalent impact of the moving truck measured by the load of truck, stationary is about four times the latter and it does not require a very large obstacle to produce a very considerable impact, varying with the speed of the truck.

There is a long and involved task ahead of us to detrmine the relation between the motor vehicle and the road, but during the past year much progress has been made.

Mr. Axderson. Well, it would seem from that statement that the smoother the road and the better condition that it is kept in, the less will be the upkeep?

Mr. MacDovald. That is very true, sir. That is one of the reasons why road maintenance becomes so absolutely important. In accurately circular smooth wheel passing over a perfectly plane road does not produce impact, but even a half-inch difference in the surface of the road, with a solid rubber tire produces considerable impact. On the Bates experimental road test in Illinois where the weaker stretches of road were actually tested to destruction, after the break started, it progressed along the road as much as 30 feet a day. Up to a certain point, the road carried the load, but as soon as the first break occurred, then the breaking down of the section oceurred at the rate of 30 feet a day.

In addition to the traffic studies under this item, which we propose to carry on, we are making an analysis of highway finance, including the problens of the raising and expenditure of funds for highway purposes in the States, to determine the principles underlying the proper distribution of the cost between the several sourcr's of revenues.

J.AW: RERULATING TRAFHC.

Mr. Buchasax. Let me get back to your first proposition for just "minute. Yon are taking the census of the amount of traflice eroing oree the rouds in rednin states, the weights of the trucks, with un idea, I suppose, of a law linting the nimount any truck can carry or any velielo cun canty?

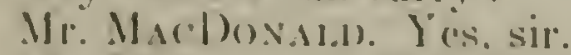

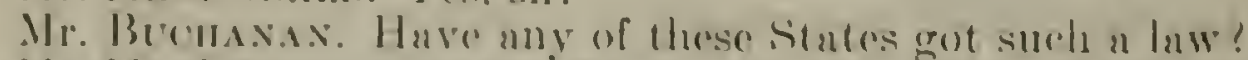
laws.

Mr. Mact)oxilds. Practically all of the states lanve regulatory 
Mr. Becmaxas. I um talking ubeut the woight of trache now.

Mr. Macloosuld, lese sir.

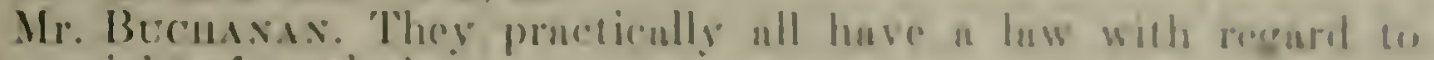
the weright of truclis?

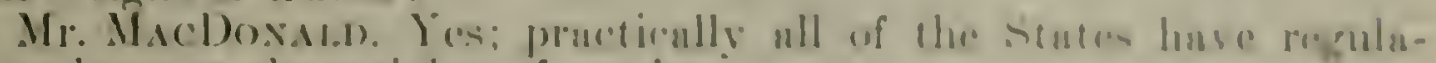
tory laws on the werights of truckis.

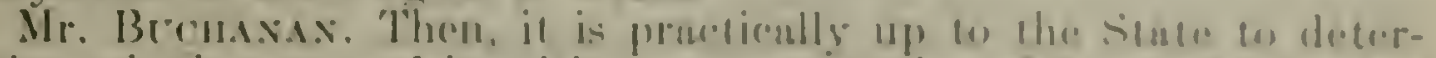

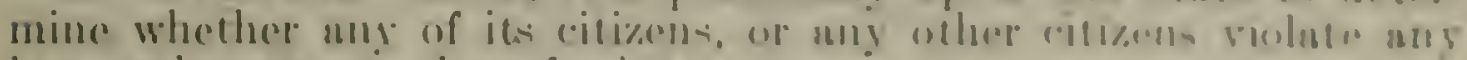
law, and proserente them for it!

Mr. MacD)(onate. Yos, sir.

Mr. Bucons.s. 'Thut is a criminul statule, is it not!

Mr. Maclosinero Yes. sir. No, if yon lake the cold law for it. I suppose that would not be true; but these laws upe not the reasule

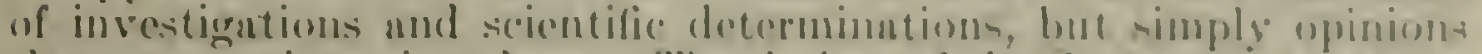
that wore written inte laws. The desiren of the situten nre to seroure a law that is based upon careful and arecurate studios.

Mr. Bromavax. "Then, this is true, is it not. Hout you are taking a census of the traflic, and so forth, with a view of urriving at what ought to be the law !

Mr. MacDonat. Yes, sir.

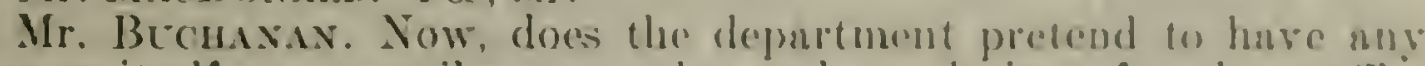
power itself to preseribe any rules und regulations for the traflic, or ns to what shall be the londs for these trucks!

Mr. MacDonalde. It is a part of our duty under the law to inveritigate and make recommendations as to the regulations which should be minde oflective.

Mr. Anderson. Yes: you have got that power.

Mr. Bromasas. 'That is what 1 am trying to get ut.

Mr. Andersos. You have that power.

Mr. Becmasas. What I am trying to get $n$ t is as to whethel you have any power to prescribe trallic regulations or not.

Mr. MacDos.ne. No, sir. Not to prescribe reculations.

Mr. Axdersos. You have power to matie investigntion and recommend regulations us to what the rules and regulations ought to be.

Mr. MacDosate. Yes, sir: that is true.

Mr. Buchasax. Now, you say you have no powror that is, unless that power is conferred by an ict of (ongress. Do you think that this is a subject as comes under the juristiction of a state?

Mr. MacDoxaldo. Te hare no power under an ace of Comgrese to prescribe these rules.

Mr. Buchavan. Have gou ever thought of the question, then. of the Federal Government regulating the traflire londs on ronds where Federal money groes into the road?

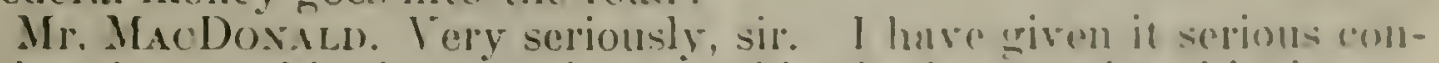
siderntion, yet 1 hesitate to place any thing in the perorel at this time.

Mr. Bucimsax. There is no use of hesitating. We have got to face it sooncr or hater. It is a matter that we hare got to consider sooner or later, and there is no use of hesititing. We might just us well come right out and consider it now.

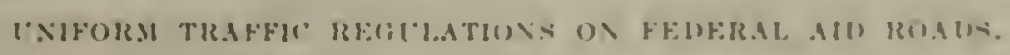

Mr. MacDoxated. Under that assumption, it is with the iden of ultimately lixing uniform trallic regulntions, that wo nre comping on these studies in the varions parts of the country. Ifo holieve 
that those reculations will necessarily vary with different sections of the country. For example, in an agricultural State-I have recently been over a number of miles of roads in Texas. where, I believe. henvy truck traffic should not be allowed: that is. the heary truck traffic necessary to the industries of the New England States is not necessary in large areas of 'Texas, where on many miles of highways there are sparsely settled agricultural communities only.

Mr. Bucuaxi.: Certain stretches of highwas that are not built for heary trucks?

Mr. MicDonatid. No: and even though these roads were built for heary truck traffic, there is not the traffic to demand heary trucks. but rather trucks of the lighter type. The passenger cur truffic is important.

Mr. Bucnaxax. And the heary trucks result in serious injury to the roads?

Mr. MacDoxald. If they are loaded to the point of causing a break in the surface, and then erery rehicle becomes a destroying agency: but until that break does occur the road serves the traffic without serious deterioration.

Mr. Buchavax. Then, my understanding of these studies that are being conducted, both with regard to the weight of the trucks and the amount of traffic, and so forth, is with the ultimate object of presenting to the people, or to Congress, the question as to whether or not there should be rules and regulations established by the Federal Government, either by Congress or by the department, with the authority of Congress, as to what traffic is going to go over the roads that the Federal money enters into the construction of throughout the Union?

Mr. MacDoxal. Ýes.

Mr. Bucranas. With an idea of uniformity of traflic regulations so far as possible.

Mr. MacDoxald. Ies, sir; but I should like to qualify it to this extent, that we are approaching that end by these cooperntive studies with the State highway departments of some of the States in which this problem has become acute, with the idea of establishing in those States, as nearly ideal laws as possible. in order that through and from actual experience the proper legislative authority will be able to fix wisely regulations in all States.

Mr. Axnessox. In my part of the country, which is, as you know. largely agricultural, the thing that is tearing up the roads more than trucks, hecause we do not have a great deal of truck traffic at present. is the big busses that run up and fown some of our highways, making regular runs of 150 or 200 miles a day, earrying 15 or 20 or 25 people.

Mr. Macbowar. Over gravel roals, particularly in dry seasons of the year, the antion of the tires of heavy, fast, busses is to ravel the topi surface rery rapielly.

Mr. Becmaxax. You alre speaking of gravel rouds? Has the department come to any definite conchusion as to gravel roads being built by boud issues liy comnties, the bonds being issued for 30 or 40 sears; is that not absolutely unceonomiant?

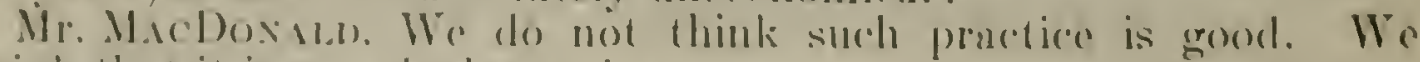
think that it is rory bad practicer.

Ifr. Bucousin. "That is all that I want to know, all of which ngrese with. 


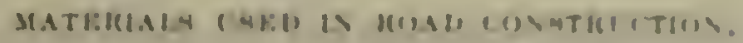

Mr. MacDoxus, I may say, Mr. Chairnan, that we have a grent many miles of gravel and madum ronds in the vorions sentes that are sulliciently strong to carry thie present traflice, hut the grentest deteriorntion, us you suggest, is the raveling and subsequent loses of matcrial from the surface; particularly furing dry sensons. In some places, a top of bituminous matcrial is being llaed anceresfully over the old gravel or macadam roud.

Mr. Axdersox. That produces a rough surface when it bregins en brenk up, doesn't it!

Mr. MacDoxaldo. You are spenking of the oiled gravel ronds, I beliere. The oiling of gravel has generally not proven suceosful. As soon ns the surfuce begins to ravel, it becomes very rungh. I referred to the pructice of laying down an inch and a hulf, two inches. sometimes four inches of bituminous materinl on old rompucted gravel or macadnm rondways. However, it is doubtful if we will be able to use that construction in the northera states where there is much moisture and frost. In Texas, and in some of the southern and southwestern States such as Ari\%onn, where there is no deep freezing, combined with a grent deal of moisture in the gromd. that type of construction is preserving old gravel and macarfam rouds at a very rensonable cost as compared with the cost of the modern pared highways.

Thut, I may say, is one of the objectives that we are continunlly striving for, the building of chenper types of ronds that will economically yet successfully carry the traflic.

Mr. Bucinsas. Well, don't you think that the sooner we come to concrete as a base of public roads, the better for the Stutes, comnties, and Federal Government, and that these (three) other types of roads never last half the length of the life of the bonds that are issued, and that in ease of bond issues for construction, that any road that does not last for the life of the bond, is a failure?

Mr. MacDowal1). But there is a great disclepuney now existing between the milenge of improved roads in the several States and the number of automobiles and motor vehicles that are needing to use them. You see, our registration of motor rehicles has passed tho ten million mark, and it has only been within the past four years that we have carried on a large program of highway improvement and the task of bringing these roads up to a fit condition for the motor vehicle to use is a tremendous one. Tho give highwiy service it has been necessary to recogni\%e the great demand for road mileage.

Mr. Buculsas. Well, what is your ideal road; concrete?

Mr. MacDoxat.d. No, sir; I do not think that concrete is neessurily the ideal rond, because I can not disassocinte ideal fentures of road construction from their cost, and if we ean get a cheaper type of rond that will serve the traffic

Mr. Buculaxix (interposing). Let me put the question differently. What would be the best road, regardless of the cost?

Mr. Andersor. Regardless of the cost?

Mr. Buchanas. Yes.

Mr. Axprnsos. That is not a fair question.

Mr. Buchasix. I do not mean an impracticable road or a road being built in a community that is not able to maintain it, or 1 do 
not mean an impracticable, theoretical Ltopian road, or an ideal that can not be realized.

Mr. MacDoxald. There is no single adequate answer to that question.

Mr. Buchasax. Well, there ought to be.

Mr. Anvensox. Would not the answer to it depend upon the locality, the quality of the soil, and drainage?

Mr. MacDonald. Yes, sir.

Mr. Axprisos. And the amount of traffic would be one of the elements that would enter into it.

Mr. MacDoxald. To answer such a question fairly and practically I think that you would have to ask it about specific roads.

Mr. Buchixax. No; can you not make a concrete road, on any ground, and can you not without any great cost? It will cost a fittle more on some grounds than others for the foundation, but I can not see anything impracticable about the question. Here is a county that may issue two or three million dollars worth of bonds on the determination of bettering their roads, and I would like to know whether it would be better for them to put in a concrete road, a gruvel road, or make - take the road that you were speaking of a while ago-gravel road with a surface on it. Now, that is not an impractieable question.

Mr. MACDoxald. Let me answer that from the viewpoint of practical experience. I do not care to put any particular county in the record.

Mr. Buchasax. You can put my county in if you want to. We recently had that problem up, Washington County, Tex.

Mr. IlACDonald. There is a county that issued bonds to build roads. They issued bonds in large amounts - $\$ 2,000,000$ or $\$ 3,000,000$ on two different occasions. They have constructed concrete roads only, and they are very good roads, but they have located some of them close together, within a half mile of each other.

It is my judgment that in that county-and we find now, with the prices of agricultural products dropped to a fraction of what they were when the bonds were issued, the people are finding the taxes to support the cost of those roads, along with the other expenses of the land itself, a difficult finaneial problem. I have been over thint system of roads, and it is my judgment that they were right in building concrete roads on their main arteries, but thint every traffic demand could have been satisfied on their side roads if they had built gravel or some lesser cost ronds.

Mr. Buchaxax. That is the answer to my question, the main arteries should have been built of concrete. "You feel, then, that the earth roads are not satisfactory?

Mr. MacDoxald. Not for important roads, except in what we might call the plains regions where there are large arens, which are dry, are not subject to the action of frost, and where the soils are sundy.

Mr. Buchanax. In other words, except in the regions where we luve maturul rouds?

Mr. Macl)oxard. Well, I think that is a rery good answer for it. When the cratlic is too heary in such localities for the nutural soil I believe that a crushed stone or gravel rond protected with a bituminous surfuce will prove sntisfactory. 


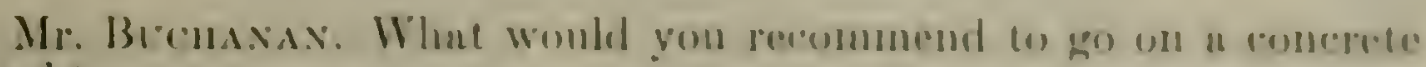
rond?

Mr. Macl)osals. Nothing, unleas und until some surfacing is demanded.

Mr. Blocusina. I ast that guestion for information. In mas own

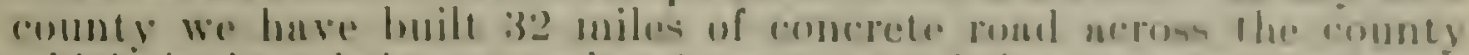
which is just being completed now, nnd I just wanted to hous whether you thenght it was esserntinl to hare any surfuce.

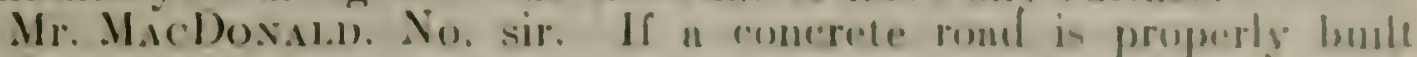

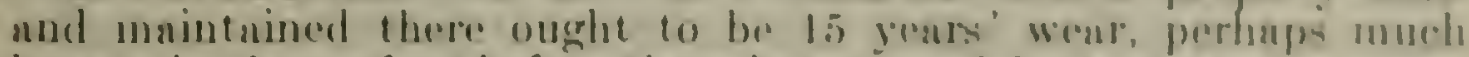
longere, in the surface hefore there is any need for a now lopp.

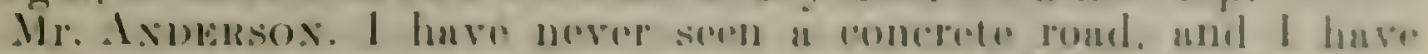

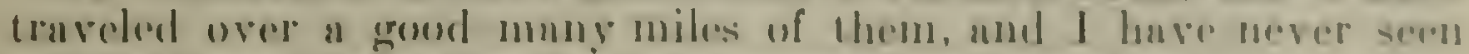
me that would stand up foi lis years without an surfuce.

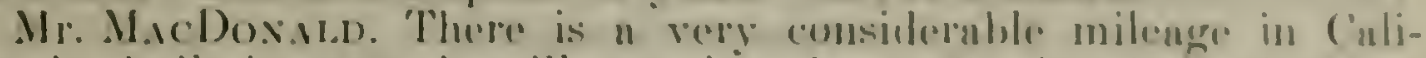
formia, built in 1!00!, is still carrying the trullie, hut it is ulan true that some of the roads there hive heen repopped. The tirit eonrerete rouds were not of the sume gunlity as the best ones are now.

Mr. Axnessox. Well, I have not done nny traveling in California. which is perhaps the reason I have not seeri any. I have nevere gren ond that has stood up for 15 years, and 1 have traveled fo).000 miles of highwing during the last s yours.

Mr. Macbosals. Mr. Chairman, if we are not getting l.j yeas sorvice or more ant of the modern type of paved reads we nire not building as good ronds as we ought to build, and as can be buile with the material which wo have to use.

Mr. Becmasax. All right; I have taken up too much time on this. 1 guess.

Ifr. MacDoxald . I think that covers, in a genernl was, this topic, Mr. Chairmun.

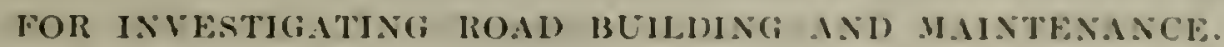

\section{Mr. Axpemsox. Your next item is:}

For investigations of the best methorls of road making, asperially hy the use of local materials: for studying the types of mochanical plants and appliances used for road hudlding and maintenance; for studying methods of roal repair and maintenance suited to the needs of difierent loralities; and for furnishing bxpert advion on these subjects, \$\$7.,060.

Perhaps you had better make a complete statement on that, as to what you are doing and expect to do.

Mr. MicDosiln). Lnder this item we have been making a number of studies of the use of local rond materials. for eximple, in the Southem States, the use of sand-clay roads. We have found in the Southern States the need of a great deal of pionering work, that is the clenning, grading, draining, putting in the subdrainnge where necessary and building the brideres and colverts. This character of work has reguired the available funds mol has necessitated our using local cheap materinls for surfacing, such as the sand day and op soil. We also have been coopernting with the State of Califurnia, and the Columbia Steel Co., in the P'ittshurgh. Calif., tests. In that project a circular track was constructed, and loulded trackis operatorl over the track. Different designs were used and both plain and reinforcel concrete sections. The trucks were opernted orer the 
track until sections of it were destroyed. A bulletin is now in process of preparation which will probably be ready this month, giving the results of the tests.

The State Highway Department of Illinois, also, built an experimental stretch of highway and raw truck traffic of controlled weight over it. The results of such tests and studies are leading to very material modifications in designing paved rondways and these modifications I believe will result in better roads, at perhaps a lower cost. It is estimated that new principles of design adopted in Illinois may save $\$ 1,500$ per mile in the cost and yet result in a more satisfactory and stronger road. The Bureau will cooperate with the Illinois Highway Department in carrying forwurd this study.

ROR INVESTIGATIOAS OF THE CHEMICAL ANI) PIYSICAL CHARACTER OF ROAD MATERIALS.

Mr. Andersox. The next is on page 25\%, "For investigations of the chemical and physical character of road materials, for conducting laboratory and ficld experiments and for studies and investigations in road design, independently or in cooperation with the state highway departments, and other agencies," and so forth. 'This is your laboratory item.

Mr. MicDoxald. That is the laboratory and also research item and we are omitting it from the appropriation requests of the Department now because under the Federal highway act, provision is made for carrying laboratory testing and investigational under our ndministration fund. The allotment of this item comes out of the administrative fund this year. I shall be rery glad, if you wish, to go in to the character of work we are carrying on.

Mr. Anverson. I think that we would be interested in your statement about what is being done under this.

Mr. MacDoxald. We must recognize the fact at this time that the whole science of modern road building is in the making, and because of this fact we are proceeding on the theory that the more extended the investigational and research work that the States and the Federal Government carry forward during this period the more eflicient will be our use of the materials which are available for road building and the better will be the results which we obtain from the use of those materials. The science of highway building has many phases, all involving technical and detailed studies from which the practical results may seem to be only slowly developing. Not only is this true of the bringing to life of new principles, but also in establishing procedures to insure the application of knowledge already secured. For example, to control the quality of the materials going into Federal-aid projects the bureau does not attempt to make the tests in a central laboratory, but in cooperation with the States we do atfempt to insure uniform standards of laboratory tests and practices, then uniform specifications for testing materials and the making of check tests. 'That is, the burean keeps in close touch with all of the Stute haboratories in which the actual tests of road mutcrials are made, and by constant cooperation and frequent check tests lielps to keep the work of the stnte laboratories on a uniform basis. The bureau and the severnl state laboratories frequently make tests of the same material to compare methods and 
results. Also testing engineres from the burent sion the stute Inborntories and the state tosting congineces vicit the laboratorion of the burent. In this way a neeresury result is heing grmolublly

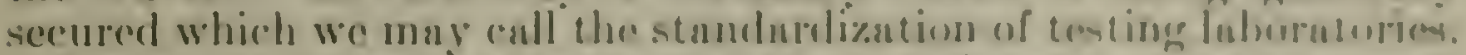

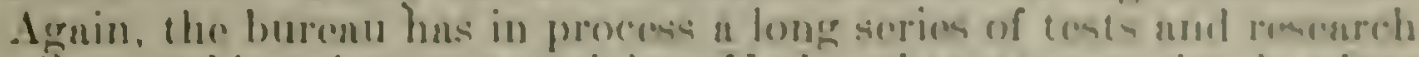
studies on hituminous materials. Cinder that as a major hemdong we are studving the shoving of bituminous pasements und other properties of hituminous surfaces. Wo are working on lente for the volatilization of petroleum products, the consistency" of tum, and other tests which we are trying to bring down to the point of standatrelisation for general use all orer the country. Most of this work is in conjunction with the A. S. T. .I. These are only indicative of the great muny paths there are to follow during this perios of desclopment of modern rond building. The resentehes of the hurenu on monbituminous imnterials nod me thods of testing are cxtensire nud include the studies of the resistance to went of concrete ngergegntes, the determination of deleterious substances in conscrete nergrespntes, the net ion of alkali upon concrete, the use of blast-furmace sligg for concrete nggregntes. and a very extensire study of subgrades and subgrade materinls.

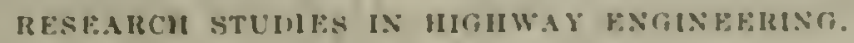

The bureau has endearored and is endenroring (0) stimulate resenrch in the field of highway enginecring, and in this connection has afliliated with the National Resenreh Council, whose artivities we are supporting in its efforts to establish a national program of highway resenreh.

From the Nationnl Resenrch Council there is a bulletin just now arailable which outlines a very long series of tests and resentches which nre now going forward all over the Lnited States in the highway field, a complete census of highway resenrch projects. In most of the major research projects the Burenu of Public Ruads is either coopernting or is carrying on the tests independently. The burenu has taken the position thint there exists in the State highway departments and at the colleges and universities of the country lnboratories. plants, and equipment which nre being used only to a partial capacity. and that without large additions to already existing plants and equipment it is possible to obtain a greater output from these laboristories. In many of them assistnnts are arailable who are not cmployed during vacation periods or who may be empleyed only part time with the colleges. In order to stimulate resestreti and to make use of existing facilities the bureau has entered into conperative nereements with n number of universities, including P'urdue, Mnsinchusets Institute of 'Technology, lowa State College, and other universities: also State highway departments, including the (onnecticut state Highwny Department, the Callifornas State Highwa Department, the Illinois State Highwy Department, and others.

It is our judgment that the funds which ane being used for rematech purposes are perhaps the mest productive and that this wert should go forward on nu incrensed senle continually. It is only through painstaking and exhatustive research that we shall arrive at determinations of the best derigns for highwnys and the best use to matie of materials: in thoir building. 
Mr. Anderson. I have noticed a very considerable variation in the character of the ronds resulting and the methods adopted in putting gravel on them. Have there been any experiments which have developed the relative strength of the road resulting from different kinds of gravel or methods which are more successful in putting them on, or do you simply use what you can get?

Mr. MacDoxind. The bureau has been making a very extensive sericis of studies of the beharior of gravel roads; in fact, some very good studies are now ready for publication. It is true that in the building of grarel roads on many of the main highways we hare used the local materials which could be secured at the lowest cost even though not first class in quality. In such eases it is not expected to maintain the gravel surface indefinitely, but it does proride a temporary wearing surface while the newly built road grade is becoming compacted. As soon as the road bed is ready, or as soon as funds are available, pared surface is placed. If it is the intention to maintain the gravel road, more care is used in selecting and preparing the material.

Up to the present time in most of the States the Federal-aid work has been almost entirely on the main roads of the country, either construeting or reconstructing them. It is not pliysically practicable and funds are not available for building only pared roadways, thus we have been earrying forward the grading, draining, and preparatory work in adrance of the more durable forms of surfacing. $\mathrm{It}$ is possible to do this type of improvement on a larger mileage each year than it is to follow up with the construction of pared-road surfaces. Also, it is in general better engineering if traffic conditions can be met to build the roadbeds some time in adrance of the surfaces, and that plan has been widely used in all of the States where it is possible to obtain local materials for interim use, such as grarel, sand, clay, and similar materials. The difference in the service to the public and the saving in the cost of maintenance is considered to offset the cost of applying materials of this character.

The probabilities are, Mr. Chairman, in answer to your question. that the differences in results which you observe on different grarel roads, while partially due to the kind of materials used, are in a greater percentage of cases due to variations, first, in the character of the subgrade, and, second, in the traffic.

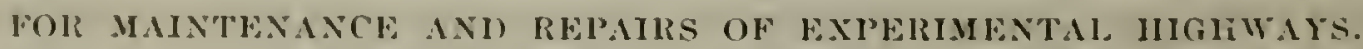

Mr. Axmersox. Your next item is for maintenanee and repairs of experimental highways. I imagine that is a good deal of a misnomer. is 11 not?

Mr. Macl)oxall. No, sir: our expenditures last reall were all on experimental highways that we had built, although our principat expenditure was on the Mount Vernon road leading from the pared road into the grounds at Mount Vernon. That road was originally built as a surface-treated gravel rond, and we have found it necessary, with the heary traflie which has beren dereloped, to recrade and

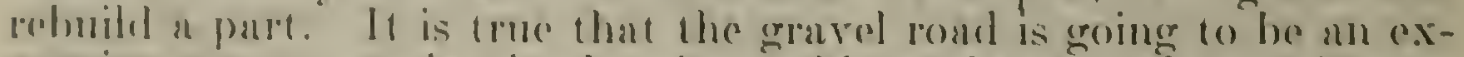
pensive type to maintan, hat it would not be possible within any 


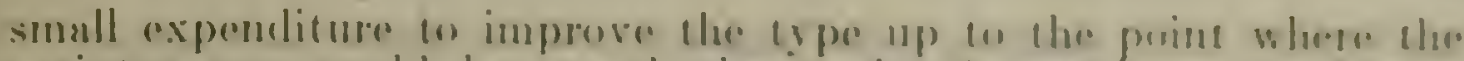

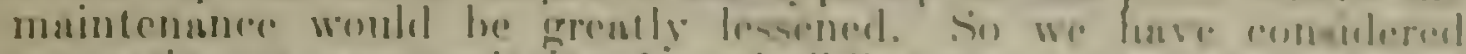

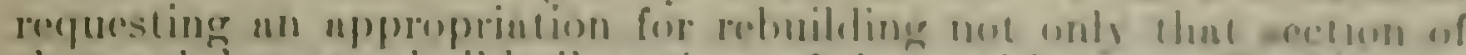

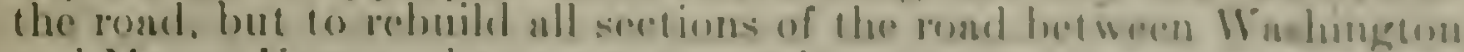

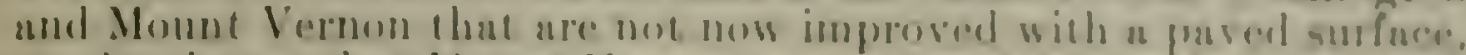

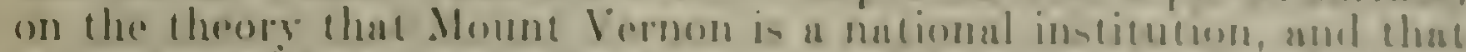

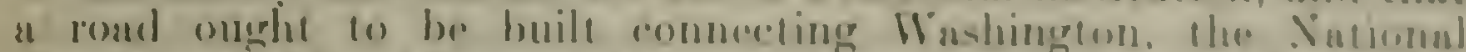

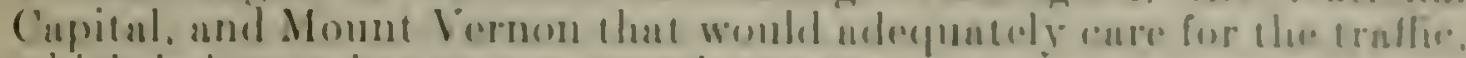
which is increasing $n t$ " tromendous rate.

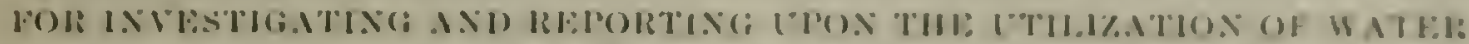

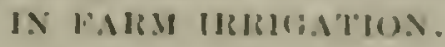

Mr. Axnsosox. lour next item is for investigntine und reporting upon the utilization of water in farm irrigution, including the bert methods to apply in practice, ate.

Mr. MacDoside. The work in irrigntion is corried on under the Division of Agrieultural Engineering, and in the pstimntes submitted to your committee there are no increnses in $n 115$ of the items ullowed. The approprintion for earrying on the work in irrigation is the sume as the amount we had last year, and is pructically the same nmount it has heen for the last live years. It has ureriged about $\$ 50,000$ per yenr.

I may say in connection with all of our work in nericultural onginecring we are endeavoring to get away from the class of activities which may be termed service or extension, such us the sending out of engineers to give advice on specific prohlems and to concentrate on the resenrch problems entirely. In future probably is per cent of our activities will consist of resenrch work and only 25 per cent of service or extension. During the war there was a large demand for service work, but since we have taken the position that State organizations, where the States mnintnin organizntions, should do this work. We have cooperative ngreements with several of the western States, including Californin, Neranda, Utah, New Mexico, Colorado and Texas. There will alwars be the exception of giving andrice or help where there are lurge problems involving the specinlized knowledge developed through resenrch and investigntionnl studies. To abandon these lines of activity entirely would throw us out of touch with the practice and prohlems of new irrigntion and drainge development and render it diffieult to plan and carry out research work in such in way as to be of the greatest benefit to water users.

Mr. ANDEmsos. If my recollection is rorrect, this item does not have to do particularly with the mechanical operations. but rather with the agriculturnl operations?

Mr. Macl Doxald. It has to do with the agrientural operations: that is, a study of the use of water in irrigation. It does not conflient with the work of the Reclamation Service. In fact, it is the only service of this eharacter which the Federal Government is rendering the very harge number of people who are aperating irrigated lands that have not been developed by the Federal Gorernment hut by private or community enterprises. I helieve that the Federal irrigation projects include about 10 per cent of the total irrigated hand. 
STUDY OF WATER REQUIREMF.NTS OF CROPS.

One of the projects which we have under way now consists of a study of the duty of water, or the water requirements of crops. We are making a comprehensire study of the results which have been obtained over the past 10 or 15 years, with the idea of publishing a series of articles on this particular subject, which, in my judgment, is the most important subject we have to deal with. A large amount of unpublished data has been and is being accumulated, the publication of which will prove valuable to State officials in apportioning the flow of streams, to courts in settling rights to the use of water. to engineers in determining the capacities of irrigation channels and structures, to canal managers in framing water-right contracts, and to farmers in growing crops.

Another project is the percolation of water through earth dams. Any loss of water through the retaining structures, if it can be aroided ought to be avoided, and this project involves research in reference to the best types of earthen dams to build, the kind of eore walls. and the parements and drains necessary as a part of those struetures.

Another subject is the water-holding capacity of irrigated soils. This subject involves a study of the movement of water downward through soils and subsoils by the action of gravity and also the distribution of soil moisture in all directions by the action of capillarity.

There are also studies now in progress dealing with drainage structures for irrigated farms. This will embrace the principles of design which practice and results of experiments indicate to be the most satisfactory in reducing cost and increasing efficiency of the rarious structures used in drainage systems.

\section{HYIRAULIC EXPERIMEXTS}

In cooperation with some of the States we are carrying on a number of hydraulic experiments, chiefly for the purpose of developing instruments for water measurement and also for measuring evaporation.

Mr. Anderson. Has there been any development of economical pumping machinery?

Mr. MCCrory. We have made a study of the cost of pumping and have also a bulletin on the sulject of pumping from wells for irrigation rendy to submit for publication. There has been a considerable increase in the effieiency of deep-well pumps in the last 10 or 15 yenrs; in fact, irrigating pumps generally have inerensed in efliciency considerably in the last 10 years. Fully 30,000 pumps are now supplying water to more than a million acres of land, much of which is in crops of yery high value. We estimate that not less than 70 per cent of the irrignted lands of the coustal region of sonthern California, comprising the highest priced agricultural lanids of the West, are watered by pumping plants.

Mr. MacDosane. Wo have heen making a study of the cost of developing irrigated farms to the point of profitable returns. The cost of stormere works, distributing systems, and other features of the irrigation systems of the West, and the average cost of such construction, as an ucrenge cost araninst the lands serred are definitely known. Our study is bringing out the interesting fact that the origriand cost of placing water on the land is only a portion of the cost of bringing that farm up to a state of productivity. 


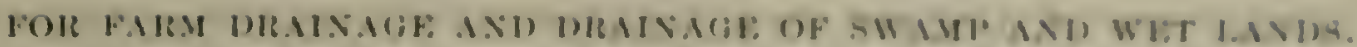

For farm druinage we are asking the same approprintion that we have for this yent. In our resenreh work we nre atturking in few of the outstunding problems - those which are the foundusion of effective nut eronomienl druinnge.

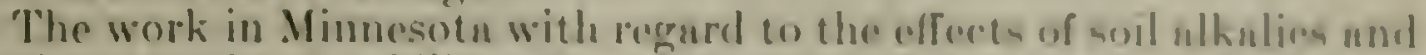
neids upon the clurability of concrete tile is being continued in conpserntion with the College of Apriculture of the University of Mennesetn. and the Stute depnrtment of druinage and waters. Definite progreas is being made on this projert. Largely as a remult of this work in Minnesota concrete tile munufartured in the sinte has improved in quality When the work was begun large tile did nor ineed the absorption requirements of the Amerienn Soriely for Testing Mnterinls, i. e., 11 per cent. 'Tests of 1 ist tile mule by 17 plunts during the past rent showed that about one-half of the plants are now mnking tile areraging between 6 ind 7 pere cent ubsorption. The work we nre doing in Minnesots is receiving the cordial support of the tile manufacturers, who fully apprecinte tha necessity of researeh in order to improve the quality of tile made.

During the lnst fiscul year" an engineer was stutioned at ('npe Girardenu, Mo., to make is systemntic study of the flow of water in a large floodwny that is a part of the Little River draimage distriet. Vnfuable information was secured ns to the elements that affect the flow of such channels. 'The use of floodways in connection with large drainage undertakings undoubtedly will incrense and reliable information as to the flow in such channels is essentinl to their proper design.

The eflect of tile upon the ground winter table has received the attention of the burenu for several years. The purpose of these investigations is to nequire $n n$ adequate bnsis for determining the proper depth and spneing of drains in the rarious soils. A study with regard to the effect of tile in the sundy soils of the constal plain of North Carolina was completed lnst renr und a report prepared. 'The opportunities for study along this line are as numerous ns are the types of soil and the inrintions of rainfall, and the work shonld he continued.

The study of the use of sedimentation basins as a meane of prerenting the deposit of silt in mnin dramage channels in the Micldle West has been continued. The purpose of such basins, which are constructed in branch drains, is to entch nud retain silt whshed down from the hills before it renches the man chunnels. The subject is 1 very important one ns it is believed that the proper location and construction of such basins will help to solve the silting problem which at present is a very serious one.

At the reguest of interested Inndowners a study was made as to the possibitity of dmining suecessfully certain impervious soils by the use of tile in the Yazo Delta. Miss. The landowners chumed these soils could not be successfully draned. Our investigntions. however, showed that the difliculty was largely improper design and construction.

In cooperntion with the Ofliee of Furm Managenemt and Farm Economics, a study has been completed of the eronomice results that have been obtained in wo drainage districts in North ('arolina. 
The behavior of drainage pumping plants in Texas and Louisiana, the operation of which had previously been studied by the bureau. was investigated in order to determine how the different types of plants were working, what diffieulties were encountered, and what changes should be made in the reeommeneled practices.

In our drainage work wo are emphasizing research-the study of the basic problems of farm drainge. I fee! that the instruction of the individual farmer in his specific problems is a matter that can now well be left largely to the State Extension Service. We are, nevertheless. carrying on some extension work in cooperation with certain States that arree to benr a part of the expense of such work. 'This year we have such agreements with Alabama, Arkansas, Georgia, North Carolinn, West Virginia, and Tennessee.

FOR INVESTIGATTIG FARII DOMESTIC WATER SUPPLY AXD DRAXAGE I)ISPOSAL.

Mr. Axpersos. Your next item is for investignting farm domestic water supply and drainage disposat.

Mr. MacDonal. That request remains the same as this year.

Mr. Axdersos. What is this item particularly directed to?

Mr. MacDoxald. I should say the major studies we wish to carry on under this item are two-researches with reference to farm buildings, particularly barn ventilation, and storage houses for different kinds of crops; and farm power studies.

We believe that, from the agricultural standpoint, one of the greatest advances that we will have to make in the future is in connection with the storage of what we regard now as perishable crops over a length of time so as to depress the peak and distribute such crops over a longer period of time.

Mr. Axversox. Do you have reference to farm storage or commercial storage?

Mr. MacDosald. Particularly to farm storage, but I assume the principle would be applicable to either. I had reference particularly to farm and community storage, such as tobacco barns, and potato, apple, and fruit storage facilities. We have made considernble progress in the successful storage of sweet potatoes, and the tobacco crop seems to offer similar desirable fields for study.

The burenu is concerned in establishing the principles of design which should underlic the construction of buildings for specinl unricultural purposes, believing that if these principles are est nblished any arehitect of builder can use them in producing satisfactory buildings.

Circut yeurly losses aceur in tobneco barns during the firing and curing of the crop due to improper ventilntion or improper construction. There is atso room for improvement in the nrrangement of these barms by which considernble saving in labor may be made. It is axpereted thet this work will be done in cooperation with the Burenu of Plant holustry nud with one or more of the agrieulturnt collegess in tobureor-growing stutes.

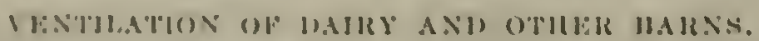

In the rentilution of duiry und ofher harns there is need for further inventigation. We lave ulsendy prepared a bulletin based on 


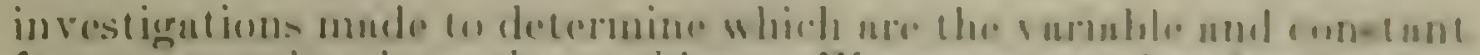

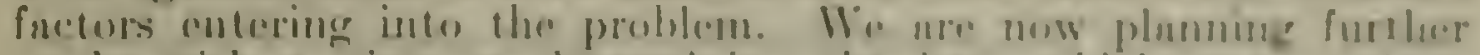

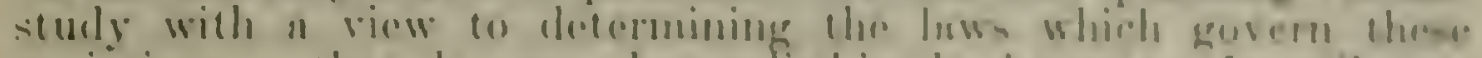

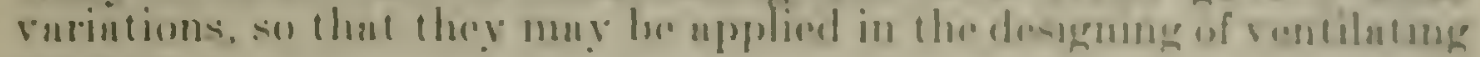
sistellis.

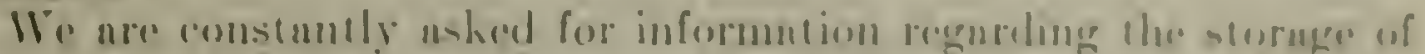
potatoes, apples, ind other prodects. In couperation with the

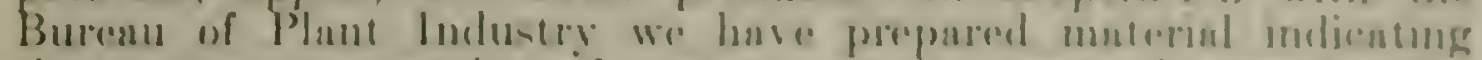

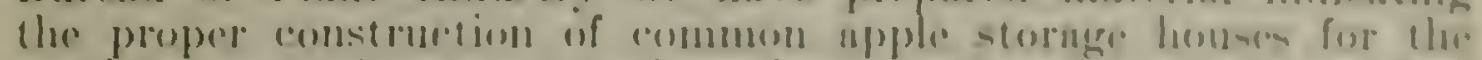

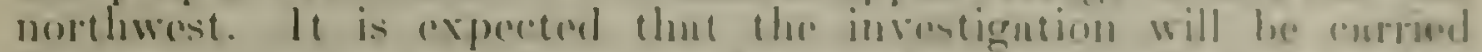

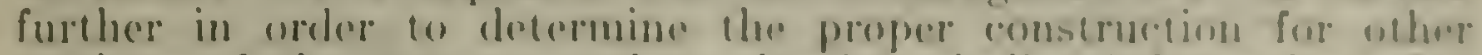
sections of the country and le develop siusine information wats respect to the stormege of other erops.

Inother investigntem which is thought alvisnble is thut molneing to silnge pressures. The size and haight of silos have grently incroused. introducing new problems in the design of siles which will withetumel the inerensed pressures. At present there is no dolinite information with respect to this. There have been fuilures dere to improguere construction: in other instnnces an unnecessurily expensive deign has been used. The development of silnge prickers has mude it possible to store "greater quantity in the same silo but this mean an inerensed but unknown pressure. In view of the fuet that silos are incrensing in number at the rute of from twenty to forty thousand "yenr, the result of this investigntion should bring about in reduetion in the number of fallures and a saring in material.

The transportation and handling of fruits and recgetubles involve muny engincering problems which are yet to be solved. It is thought the precooling of fruits offers a menns of reducing losses in transportntion and storage. In cooperntion with the Burenu of Plant Industry it is expected to continue investigntions now under way in order in determine the effectiveness of precooling.

It is planned also to undertake further investigntions relntive to the factors that grovern the design und operation of enr-henting sytems, with the object of developing a more ellicient system of heating cars used in the transportation of perishnble foodstiffs. and to thus reduce the henry losses which oecur at certain seasons. The problem of a sut isfactory henter cor is of grent importance to potato growers in the North and to fruit and regetahle growers throughout the onums?.

Similnty the refrigerator cur, so necessury to the suecessultraniportation of perishables during warm weather. is still susceptible fo great improvement, although a great deal of work hos bern done along this line. It is believed that the losses which ocente eneh yent justify a consiblernble expenditure to redure them.

The farm power sturlies outlined hy the farm power committee of the department have heras continued. In couperation with the Bureau of Animal Industry nnd the Otfiee of Furm Maniegement and Farm Economies a study of the cost of power on farms in the winter wheat belt in Nebraskn, Knnsus, and Ok hamoma, was male. liecords were secured from $3.5 t$ farms where tratetors were used, and from s. farms where horses only were used. I complete reserd of the work done with both horses nud tractors during the reare precesting the investigntion, nul information from which the enst of wing the fractors and horses could be determined. Were ohtained from dach farm. A record of the changes in the operation and arganization of 
the farm after the purchase of tractors, and statements from each farmer coneerning the advantages and disadvantages of a tractor on his farm, were obtained. A summary of this investigation has been published.

Several vears ago information in regard to the experience of farmers with motor trucks was secured from truck users throughout the United States. The experiences of farmers in the Corn Belt and in the New England States were compiled as department bulletins. During the last veal the farmers whose experiences were reported in these publieations were agnin circularized. and the information secured is heing prepared for publication as farmer's bulletins in order that the experiences of these farmers with motor trucks, which now extend over a period of several years, may be arailable as a guide to other farmers contemplating the purchase of motor trucks.

In cooperation with the Bureau of Animal Industry a study is now in progress which has for its object the determination of the amount of power developed by horses and the ways in which this power may be utilized most efliciently in farm operations. It is known that many of the hitches used at the present time result in a waste of power. and it is planned to determine the effect of various factors on the efficiency of hitches and, if possible, to develop better hitches. The importance of increasing the efficiener of animal power may be better appreciated when it is known that with some common hitches used for plows the work of one horse is used, overeoming side drafts. The amount of horsepower used on the farms of the United States is equal to 80 per cent of the total horsepower used by all other industries combined. Information of great value to all farmers could undoubtelly be secured if these investigations could be prosecuted vigorously with an adequate foree.

The investigation now heing carried on in cooperation with the Bureau of Entomology relative to the control of the cotton boll weevil will be continued. A new phase of this work is the introduction of the airplane in dusting the cotton fields with poison. Experiments already made indicate possibilities that make it highly desirable to (onntinue the investigation. Results of an mexpectedly gratifying charneter have been obtained, but whether the airplane can be used rommereially is yet to be determined.

\section{SURPIULS WAR EXIPOSIVES.}

Mr. ANuERsox. Your next item is for superrising the preparation. distribution, and use of picric acid, trinitrotoluol, trojan powiles. and such other surplus war explosives as may be made avalahlo for use in clonding stumps and stones from acricuiltural lands.

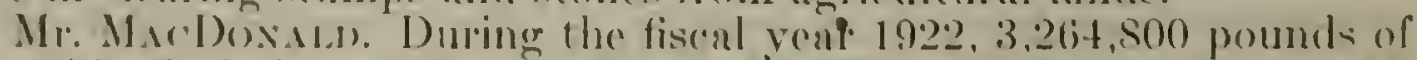

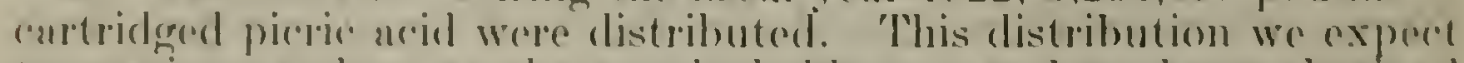
to continue as longe as the supply holds out, and we have obtamed mothing lost faromble reports from the farmers who have used the matcrial.

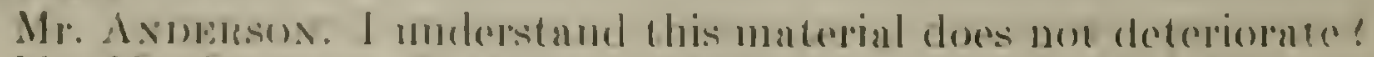

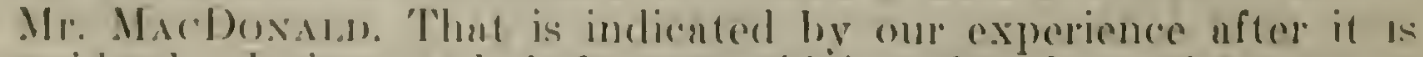

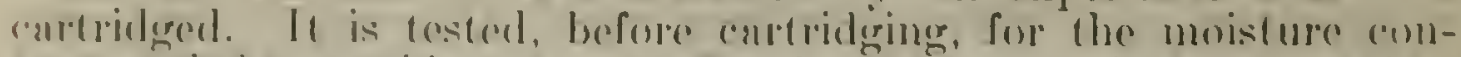

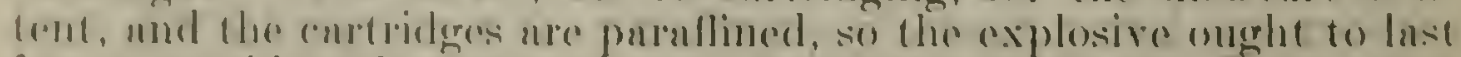

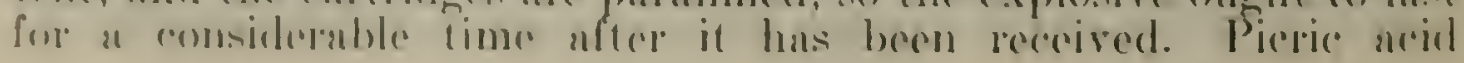


recquires a somewhat hearier detomator than 'T. X. 'T'. or other commercial explusires.

An interesting side light ont that dentribution in the fuet that thin supply has beren available to the furmers at a rery meninul come

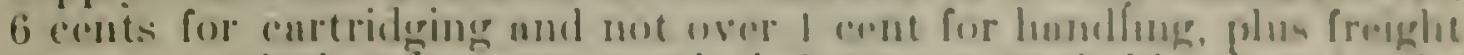

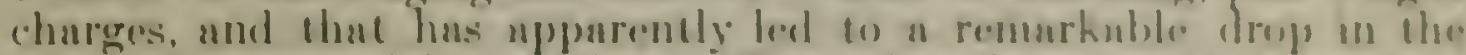

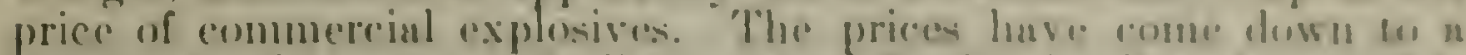

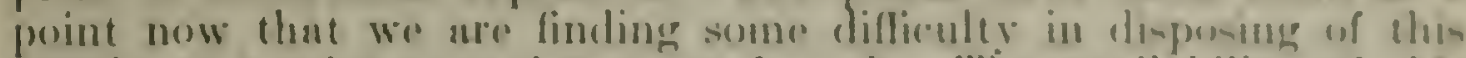

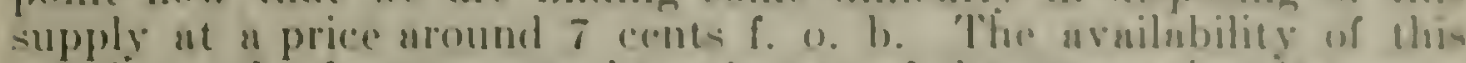
supply to the farmers may be only one of the coulem, but it a crue that the prices of commercial explosibes hus come dewn he very much lower levels.

Mr. AxuErsos. How much of this explosive is left?

Mr. Macboxisto. It is now about $4,000,000$ pound-

Mr. Asmensos. At the rate you have been grong gon will gent rid of it in ulout a year or two?

Mr. M.ı(Doxild). Yes, sir.

FOR GE.NFRAI, ADMIXISTIRTIVF, F.XPF.NSF.S.

Mr. Arinemsox. There is no change in pour item for general administrntice expenses?

Mi. MacDositn. No, sir.

\section{FXCHA.IGF, OF PDSSENGFH-CARRMTNG VEHICI.KS.}

Mr. Annemsox. We will next take up the item on pare 322, and particularly the provise which relates to the exchange of passengercarrying vehicles.

Mr. MicDositn. With reforence to the anthority requested under this item to exchange used passenger-earying vehicles or parts for new vehicles, we now find ourselves confronted with this situntion: Linder the nets of Congress which turned over to the department for distribution to the States certain surplus war equipment suitable for roud-building purposes, the department is authorized to retain for use in its rond work not more than 10 per cent of the equipment. That included all kinds of equipment, such as trucks, automobiles. tractors, tents, and miscellaneous equipment of all kinds. All of the passenger motor vehicles which were taken oser had been used. The have received only cans which had been used to a consideruble extent and that had not been well maintained. as you would expeet under the then existing conditions, so in ntemping on use these rehicles-and I may say that the distribution started nearly four vears ago-we find these vehicles have deteriorated to an extent that it is very expensive to mantain them.

We have no authority to tracle these in for new relictes that could be opernted at less expense, and no nuthority (1) pay the difference between their trade-in ralue and the cost of new ears. We have also taken over from the War Department a considerable amount of spare parts. All of the nonstandard motor rohiche parts were declared surplus by the War Department and turned over to the Department of Agriculture for distribution. There had been large purchases made of spare parts, so that along with the motor vehicles, spare parts became surplus sometimes out of proportion to the number of vehicles to be maintuined. We now fincl that some of the munufacturers are rather anxious to trate for some of these spare parts in exchange for new motor vehicles; that is, an 
exchange at cost price can be made. Whether that is due to the fact that the companies are no longer making these particular parts and need them for the repair of the older models still in use or not I do not know, but the proposition would be in the interests of economy.

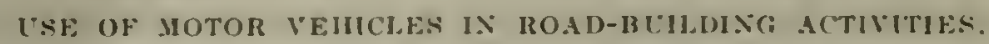

'The use of motor vehicles is absolutely essential for the economical and eflicient conduct of the road-building nctivities of the bureau. The number of engineers assigned to each State to give general inspection to the conduct of the Federal aid road projects is very limited, and each man is expected to cover a large territory and keep in personal touch with all the projects in that territory. Also. the building of forest highways is dependent upon motor transportation. Many projects are built far away from railroads and from the necessary supplies. The efficiency of the work of field surver parties, inspection engineers, superintendents of construction. and, in fact, of the whole organization of the bureau engaged upon road work is predicated upon adequate transportation over the highwars. In Washington and at several points in the field we have established shops in which we are attempting to repair and rehabilitate these used machines, so that they can be distributed and used in the service where needed. Many of the machines taken over are fit only for such salvage parts as may be secured from them. Our principal use is for cars of the latter type, such as Fords and Dodges, except where it is necessary to send out a larger party on surveys, and we believe that a real saving can be made if authority herein requested is granted.

The number of cars in actual serrice varies from month to month. depending upon the amount of road building that is going forward, the number of survey parties in operation, and the number of forest highwny construction projects. Our Norember report shows in actual operation 64 Fords and 63 cars of other makes in use on gencral operations, and 48 assigned to specific projects. Because of the age and the use which has been made of these cars, we estimate there should be at lenst a 30 per cent repheement during the fiscal rear, and we request therefore specific authority to expend not to exceed $\$ 29,000$ from the administrative Federal aid fund for this purpose.

Mr. Axnersox. Do I understund that this proviso upplies only to pussenger-carrying vehicles which were turned over by the War Depurtment and retaned by the Secretary of Agriculture for use in connection with highway work!

Mr. MacDosall. Yes, sir.

Mr. ANmbsos. Were there any passenger vehicles turned over to the Stutes?

Mr. Macl)(nsalu. Yées, sir.

Mr. Axmensox. But this does not apply to them?

Mr. Macl)oxilw. No, sir; such vehirles belong to the severnl states and are subject to the jurisoliction of the state highway departunents.

Mr. Axmenson. Gun you gripe us an idea as to how many machines "are involved in this proposition? As far as this language goes, they ure nll involved.

I con see where manchines which have been operated for two or three yrams, and probubly were not very good when you got them, 
have deteriorated 10 a proint where the uphore in vors gerout. Dow, it

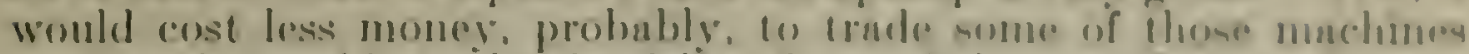

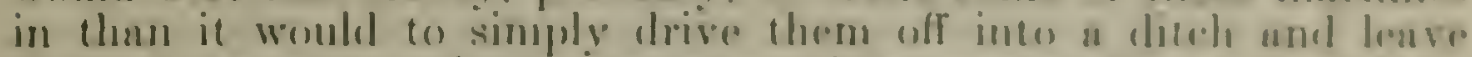
them, because you should get as moch salvage value ue there is in them. That is a perforety molerstamelahle propusition.

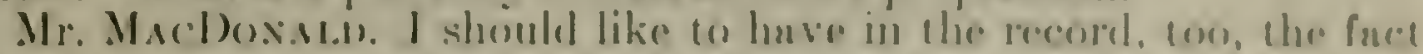
that this transportation is ahsolutely necessary for the arrsing on of our work. I have just investigated some of cur opremitoms in

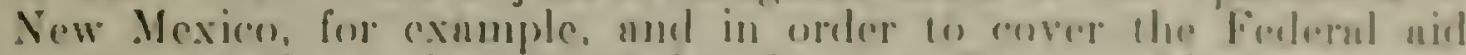

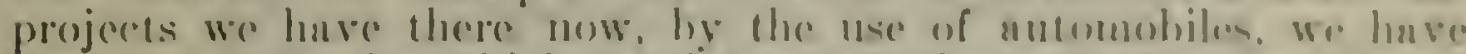

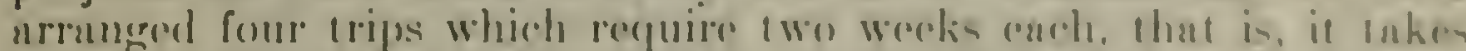
cight woeks to cover the projects which ure going on there mew. These projects could not be covered if we attempled to use trian sers. iere, heratuse it deres not exist. The sume thine ws true in the nat ional forests. The ronges of momutains, as goul know, run lurgely morthonst and southwest, and the forest aress onecupe largely the niountuin ranges, while our transentinental highwnys run from the enst w the west, so that we have inherited with the antional forests the linbility of building through the worst sertions of land that are encountered: that is. erossing the mountain runges: the valleys fying in hetwoon ure not in the forest reserves, but the forest reserves lie on the mountuins and we are rumning at riegh ungles of them and crossing them at the best passes we can find. So that transporation is not only absolutely necessary from the stundpoint of arrying on the work, hut from the stundpoint of suring as much time us possible, especially where the ronds are open for only af few momtls throughout the rear.

Mr. Annersos. Are these cars used by your supervising engineers inspectors, ete. ?

Mr. MacDonario. Yes, sir.

We have been administering the Federal road and since 19)11i and we have never bought one new antomobile for that purpose.

Mr. Andensos. We understand what you are trying to get at and when we come to write up the bill we will put in what the commithe is willing to carry.

What is to be said about the second proviso!

Mr. Jump. When Mr. Reese was here he fully explained that proviso and I will merely reiterate what Mr. Reese said the other day. We would like to secure authority to use severnal of the secomil-hund machines which the Bureau of Roads has taken orer from the War Department for the ordinary work of the departmont in Wishington.

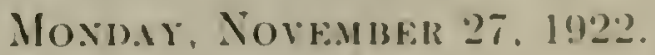

\section{COOPRRATIF, CONSTRUCTION OF RLRA, POST ROALS.}

Mr. Axversox. Mr. MacDonald, we will anke up the item on page 360 with reference to the construction of post ronds.

Mr. MacDowald. Mr. Chairman, under the rarious federal aid road acts the department has been carrying on rooperntive rond building with the several States, and the milenge of hirhways which have been completed and pnid for under the several acts providing Federnl funds, by States, by types, and by liseal years. is shown on the table which $1 \mathrm{~mm}$ submitting for the record.

(The tuble referred to follows.) 
$\vdots$
$\vdots$
$\vdots$
$\vdots$
$\vdots$
$\vdots$
$\vdots$
$\vdots$
$\vdots$
$\vdots$

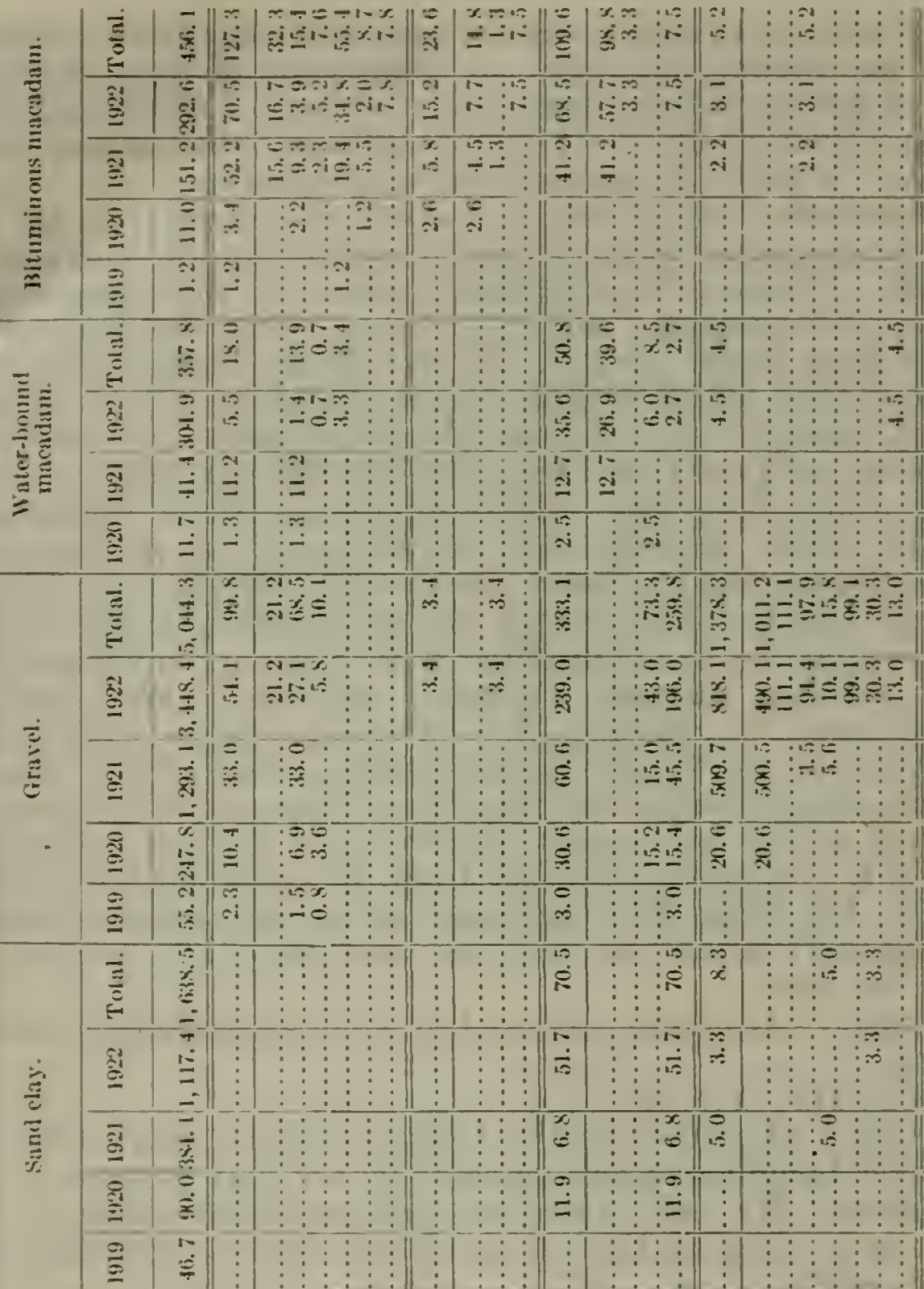

$\Sigma$

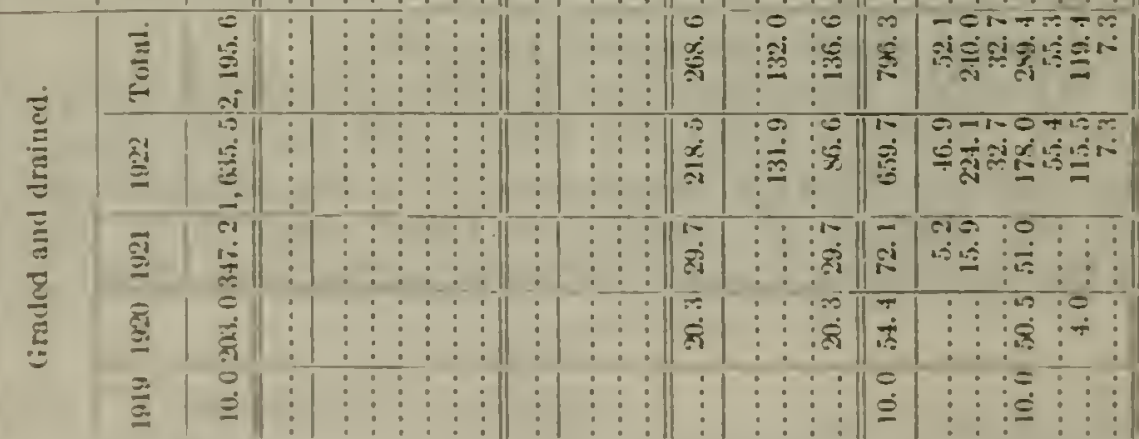




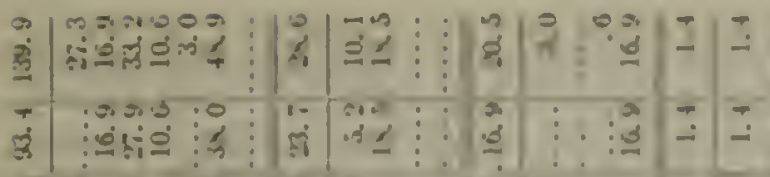

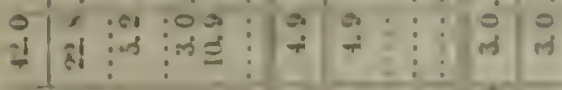

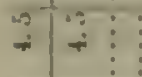

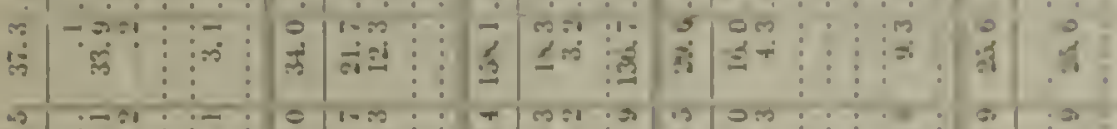

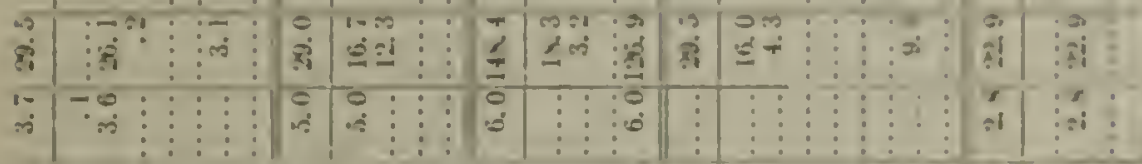

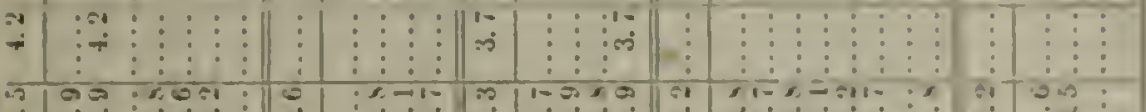

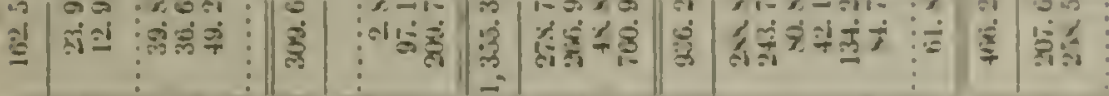

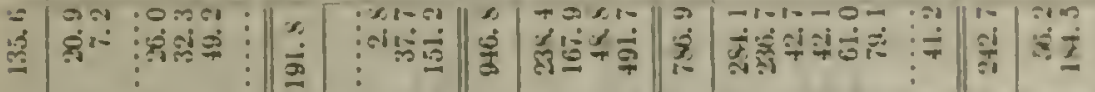

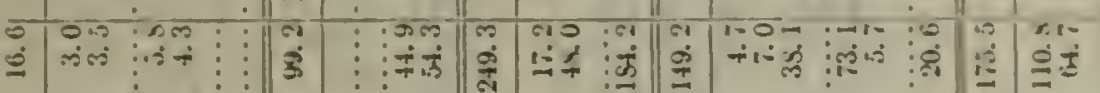

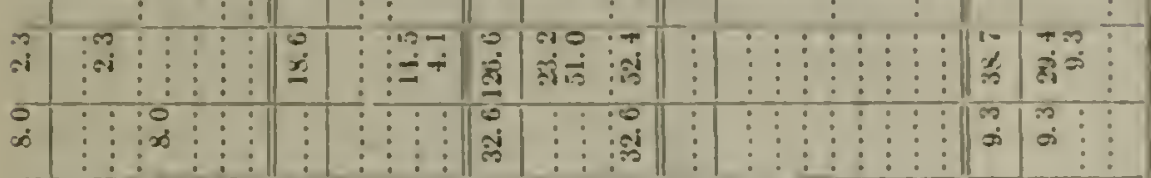

苛

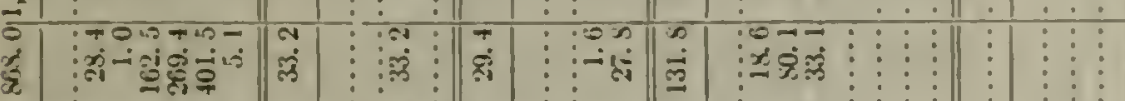

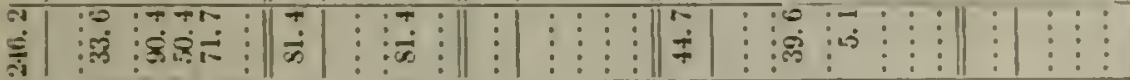

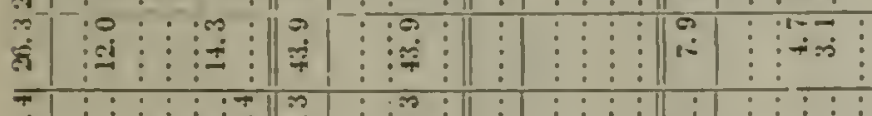

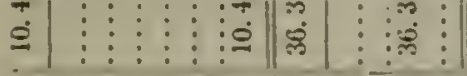

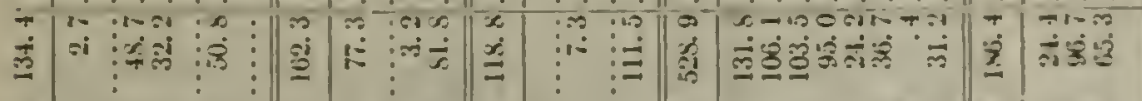

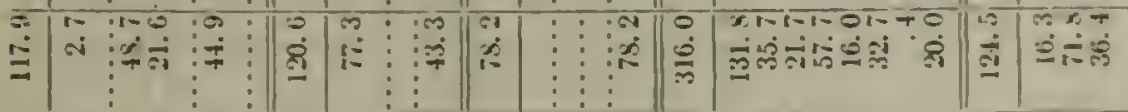

勿

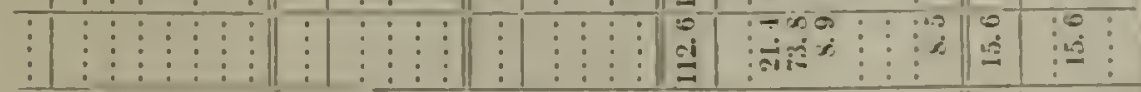

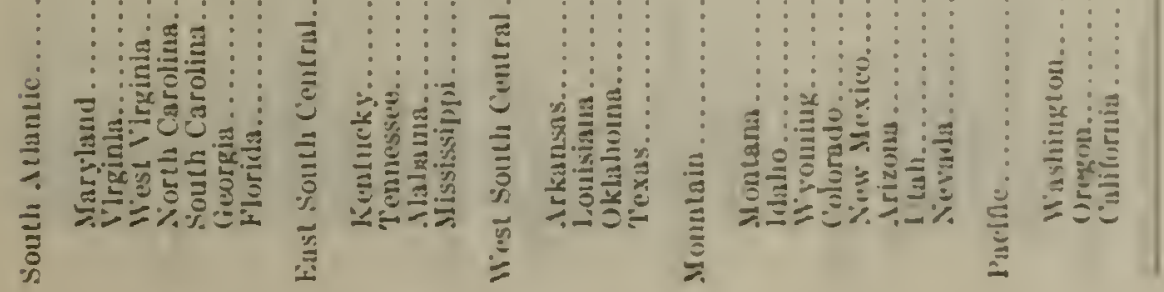

$20028-22-24$ 


\begin{tabular}{|c|c|c|c|c|c|c|c|c|c|c|c|c|}
\hline \multirow{6}{*}{ } & $\stackrel{E}{E}$ & $\stackrel{\overrightarrow{0}}{\ddot{*}}$ & 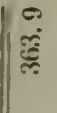 & 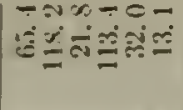 & $\dot{8}$ & @Ẹ & ai & 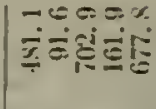 & 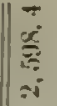 & 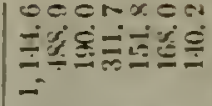 & $\begin{array}{l}\stackrel{0}{E} \\
\text { a }\end{array}$ & 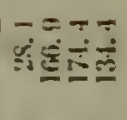 \\
\hline & 离 & $\begin{array}{l}\frac{-}{0} \\
\overrightarrow{1} \\
0\end{array}$ & $\frac{10}{\pi}$ & 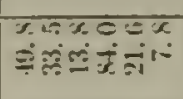 & $\frac{\infty}{2}$ & 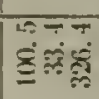 & $\|$ & 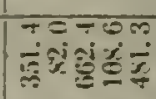 & $\frac{1}{3}$ & 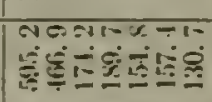 & de & $\therefore \rightarrow$ \\
\hline & $\overline{\hat{\underline{\varepsilon}}}$ & $\begin{array}{c}0 \\
0 \\
\dot{0} \\
\delta \\
0\end{array}$ & 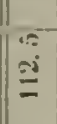 & 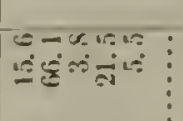 & $\overline{\vec{B}}$ & 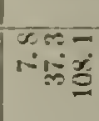 & $\begin{array}{l}\|= \\
\overrightarrow{0} \\
\vec{c}\end{array}$ & 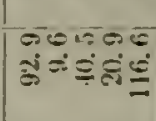 & $\overline{\bar{O}}$ & 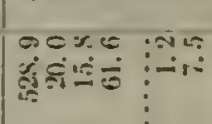 & $\stackrel{4}{\stackrel{4}{*}}$ & $\stackrel{\Phi}{\circ}$ \\
\hline & 春 & $=$ & รi & & 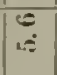 & \begin{tabular}{c:c}
$\infty$ & 0 \\
\hdashline$i$ & $\vdots$
\end{tabular} & $\|$ ? & $\overline{\dot{\Delta}}$ & $\overline{\div}$ & 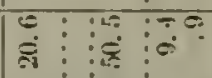 & 8 & \\
\hline & $\stackrel{9}{\Xi}$ & 焉 & $\stackrel{2}{\Xi}$ & 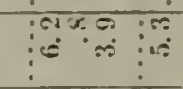 & $\overrightarrow{a i}$ & & $\|$ & 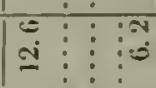 & $\|$ & 10 & $\dot{\square}$ & \\
\hline & $\frac{\infty}{9}$ & si & $\mid \begin{array}{l}a \\
\text { a }\end{array}$ & & & & 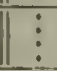 & & $\vdots$ & & : & \\
\hline \multirow{5}{*}{ 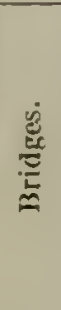 } & $\dot{\delta}$ & 4 & 19 & & $\vdots$ & & 11 & & $\Xi$ & $\because$ & $\dddot{1}$ & \\
\hline & ह & $\begin{array}{l}0 \\
\vdots\end{array}$ & !? & & $\vdots$ & & 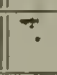 & & $=$ & $\div$ & $\overline{\bar{s}}$ & \\
\hline & $\overline{9}$ & m: & 19 & & $\bar{\vdots}$ & & $1 \%$ & & $1 \vdots$ & & is & \\
\hline & हิ & $?$ & $\bar{\vdots}$ & & $|\vdots|$ & & : & & $\vdots$ & & $?$ & \\
\hline & $\stackrel{9}{\Xi}$ & $?$ & $\vdots$ & & : & & 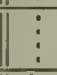 & & 1 & & $\because$ & \\
\hline \multirow{5}{*}{ 总 } & $\dot{b}$ & $\stackrel{0}{\varepsilon}$ & & & มี่ & & $5 i$ & $\mid \begin{array}{l}0 \\
0 \\
\dot{s}_{1}\end{array}$ & 事 & 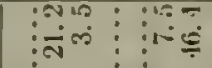 & $\underline{\Xi}$ & \\
\hline & हู่ & $\begin{array}{l}0 \\
0 \\
0\end{array}$ & & & $\vec{a}$ & & $\stackrel{\bar{i}}{=}$ & 递 & $\frac{5}{3}$ & 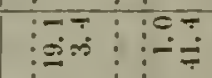 & $\overline{\dot{C}}$ & \\
\hline & 힘 & ث. & $\vdots$ & & $\infty$ & 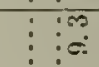 & $\bar{m}$ & 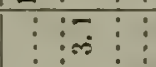 & $=$ & & $\ddot{0}$ & नुं \\
\hline & है & $\frac{n}{i}$ & & & $\mid$ & & \pm & & 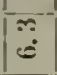 & & 7 & \\
\hline & $\frac{9}{3}$ & 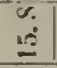 & & & $1 \vdots$ & & is & & $\begin{array}{l}\infty \\
\infty\end{array}$ & :-i & 1 & \\
\hline \multirow{6}{*}{ 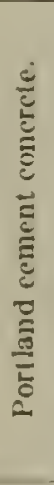 } & $\stackrel{\equiv}{E}$ & $\begin{array}{c}0 \\
i \\
i \\
c i \\
c i\end{array}$ & E⿱ & 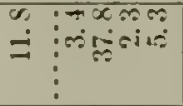 & $\vec{i}$ & 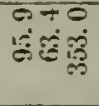 & 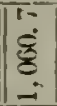 & $\mid \begin{array}{lll}01 \\
8 \\
\dot{0}\end{array}$ & 这 & 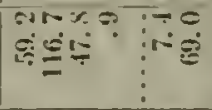 & จุ่ & ज: \\
\hline & है & $\frac{1}{52}$ & 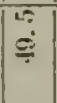 & $\begin{array}{l:c}\infty & \infty \\
= & -\infty\end{array}$ & $\overrightarrow{0}$ & $\begin{array}{l}n=0 \\
\sin \pi\end{array}$ & 宓 & 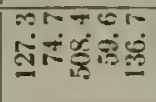 & $\overline{\vec{C}}$ & 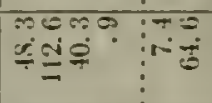 & 象 & 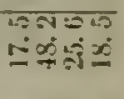 \\
\hline & $\bar{g}$ & ט. & $\because$ & $\vdots \overline{-i} \overline{-} \overline{-}$ & $\Xi$ & 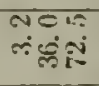 & $\stackrel{12}{\varrho}$ & 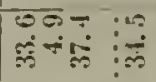 & $\stackrel{0}{0}$ & $\because$ & $\frac{1}{x}$ & $\begin{array}{l}\div= \\
\div=\square\end{array}$ \\
\hline & हो & क्: & & & $\approx$ & & $\overrightarrow{0}$ & (־- & & & एँ & : \\
\hline & $\frac{5}{9}$ & $\begin{array}{ll} & =1 \\
& =1\end{array}$ & $\therefore$ & & -i & & $\begin{array}{ll}m \\
m \\
m\end{array}$ & & & & 5 & \\
\hline & $\stackrel{s}{\underline{S}}$ & "ே. & $\left|\begin{array}{ll}a \\
8 i\end{array}\right|$ & {$\left[\begin{array}{cc}0 \\
\vdots \\
\vdots\end{array}\right.$} & $\bar{\vdots}$ & & $\vdots$ & & $\vdots$ & & $1 \vdots$ & \\
\hline \multirow{6}{*}{ 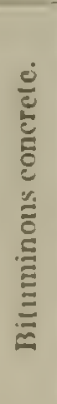 } & हैं & $\ddot{\bar{\varepsilon}}$ & $\mid$\begin{tabular}{ll}
81 \\
3 \\
\hdashline
\end{tabular} & 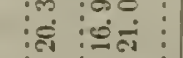 & 8 & 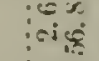 & $\vec{i}$ & 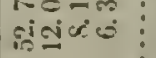 & $\left|\begin{array}{l}n \\
\dot{n}\end{array}\right|$ & สู่ & is & : \\
\hline & 칠 & है & 至- & $\vdots^{0}:$ : & $\begin{array}{l}01 \\
2 \\
2\end{array}$ & : & 票 & $\begin{array}{l}E \infty \\
\infty\end{array}$ & $\stackrel{0}{\Xi}$ & 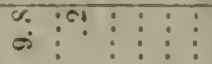 & $\begin{array}{ll} \\
= \\
\end{array}$ & : \\
\hline & $\overline{0}$ & تే: & 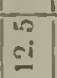 & נחיר & m. & 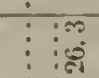 & $\begin{array}{l}0 \\
0 \\
0\end{array}$ & $\begin{array}{l}\because \infty \\
\because \quad: \infty\end{array}$ & $\stackrel{0}{=}$ & 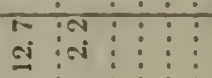 & $\overrightarrow{\tilde{\partial}}$ & in \\
\hline & 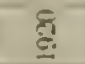 & É & $\begin{array}{l}1 \\
\therefore\end{array}$ & : & & & s. & $\vec{\circ}$ & $\vdots$ & $\vdots$ & $\stackrel{2}{\square}$ & \\
\hline & : & : & $\therefore$ & 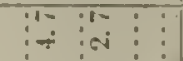 & & & & & $\vdots$ & $\vdots$ & कर & \\
\hline & $\bar{\Xi}$ & $\oplus^{\circ}$ & & : : & & & & & & & $\vdots$ & \\
\hline
\end{tabular}




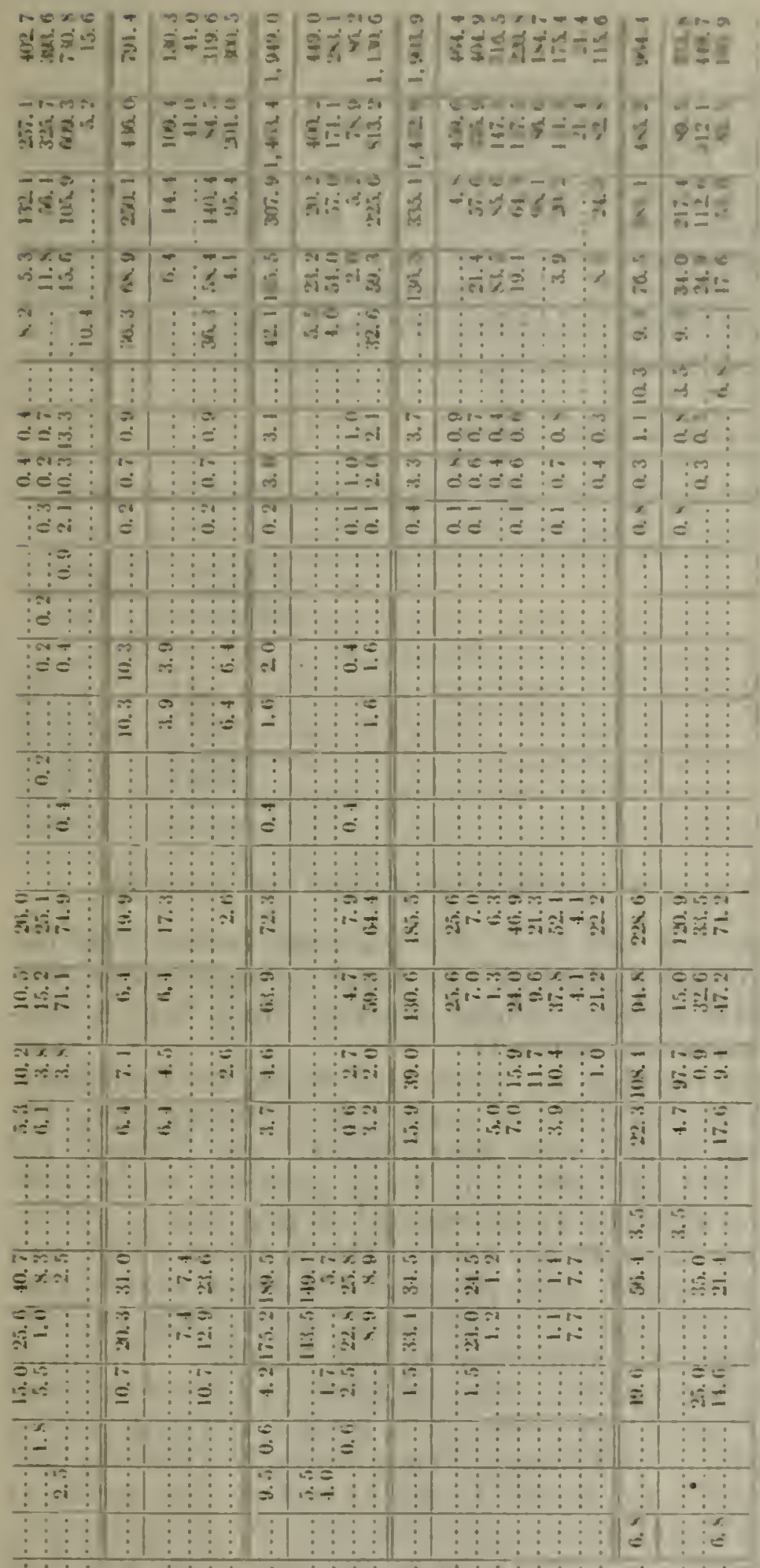

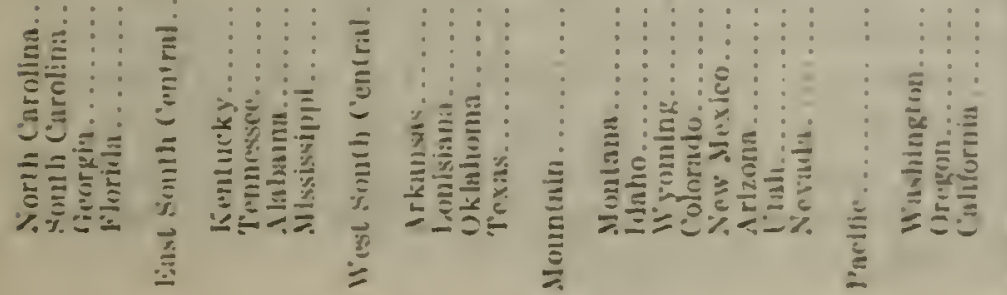


TOTAI. MHEACE. COMHLETED.

Mr. Axdersos. What is the total mileage?

Mr. MacDonatr. The total mileage of all types completed during the fiscal year's 1917 to 1922 , inclusire, is 25.844 . Of this 13.355 is for projects completed and entirely paid for, 4,362 for projects completed but for which final parments have not been made, and 8,127 which is the equiralent completed mileage of projects under ronstruetion. I also submit the following summary of the Federal aid roal mileage of all types completed by fiscal years, and of the parments made to the States during these years, with totals to July 1. 1922.

(The statement referred to is as follows:)

Summary of completed Federal aid road mileage and of payments made to Stutes.

\begin{tabular}{|c|c|c|}
\hline Fiscal year. & $\begin{array}{c}\text { Miles com- } \\
\text { pleted } \\
\text { during year.! }\end{array}$ & $\begin{array}{c}\text { Federal aid } \\
\text { paid during } \\
\text { year. }\end{array}$ \\
\hline 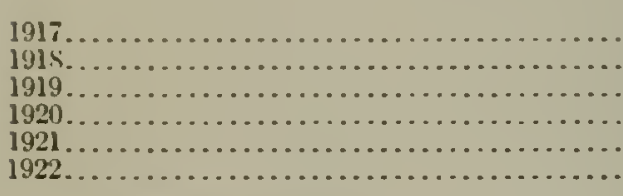 & $\begin{array}{r}4.2 \\
105.3 \\
1,345.0 \\
4,979.0 \\
9,781.0 \\
9.3 \times 6.0\end{array}$ & $\begin{array}{r}\text { None. } \\
125,466 \\
2,702,215 \\
19,593,430 \\
55,974,305 \\
5 \times, 216,123\end{array}$ \\
\hline Total to July $1,1922$. & $25,44.0$ & $166,911.552$ \\
\hline
\end{tabular}

1 Includes projects completed and equivalent completed mileage of projects under construction.

Mr. Axderson. Can you tell from the material before you the total mileage of completed highways, the total mileage under construction, and the total mileage under contract upon which construction has not yet been commenced?

Mr. MacDonald. On October 31, 1922, that being the last statement I have, we had 14,706 miles of road under construction, the total estimated cost of which was $\$ 261,330,000$; the Federal nid allotted amounted to $\$ 115,214,000$, and those projects under construction were reported as being an average of 59 per cent complete, varying by States from 32 to $\$ 3$ per cent. The projects which had becn completed, but on which final payments had not been made, amounted to 5,129 miles, of which the estimated cost was $\$ 76,151,000$, and on which the Federnl aid amounted to $\$ 34,172,000$. The projects on which construction had been completed and all pnyments had beon made amounted to 16,235 miles, at a total estimaled cost of $\$ 2 \$ 3,330,000$ and on which the Federal aid amounted to $\$ 120,046,000$.

Mr. A.Nmbrsox. What I am trying to get at is how rou arrive at this estimate of $\$ 30,000,000$ for the next fiseal year. Suppose rou toll ws what the situation is and what the requirements are and then you can figure out the $\$ 30.000,000$ afterwards.

Mr. Macboxaldo. Mr. ('hairman, I will endeavor to hoil this down to a renly comprehensible statement. There are two questions involved. One is the necessity for authorizing the apportionment (1) the stutes of the $\$ 65,000,000$ which have beon nuthorized for "uppropriation for the fiscal rear 1924. The other yuestion relates to the muking of un uppropriation to apply on the anthorization. Briefly the status of the funcls is as follows: 


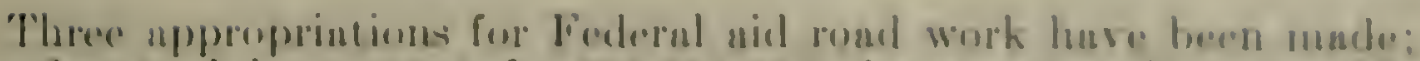

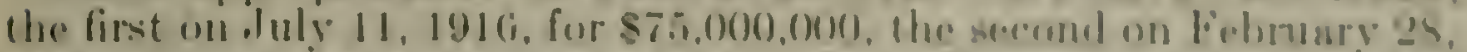

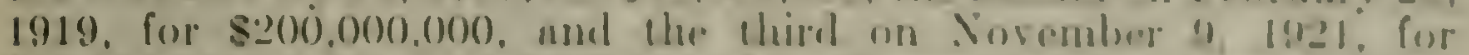

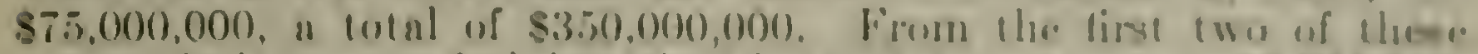

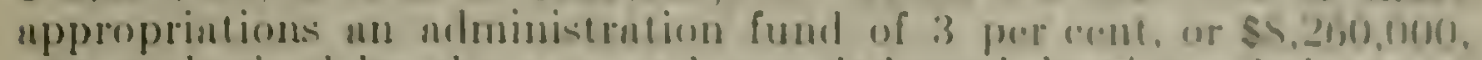

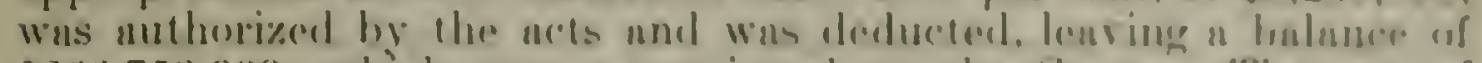
$\$ 26(6,750,000$, which was apportioned to the States. The and of

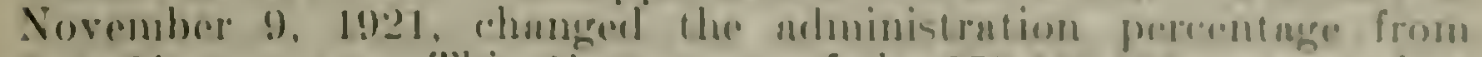

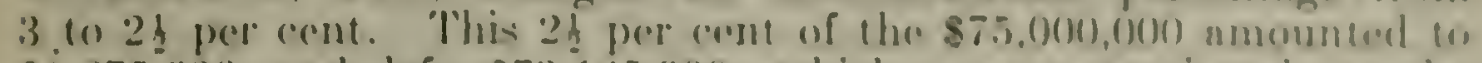
si.s75.00) and left $\$ 73,125,000$, which wos upportioned for the

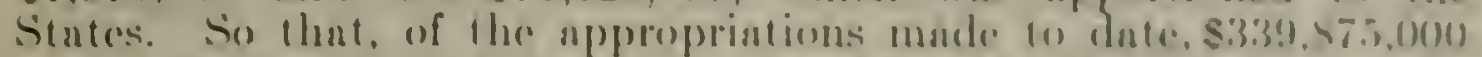
have been apportioned to the states and $\$ 10,125,000$ rotuined for the

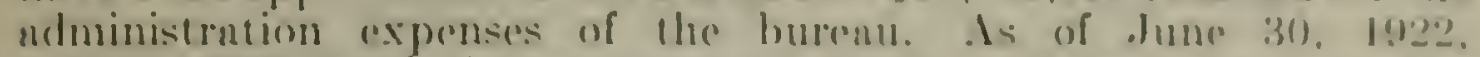

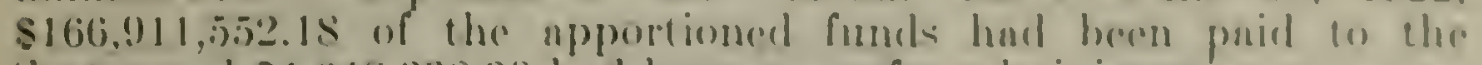

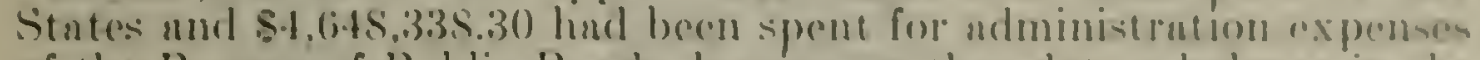
of the Burenu of Publice Roscls, lenveng on that duse a balanee in the upportioned npproprintions of $\$ 172,963.445 . \$ 2$ umel in the ndministrntion fund of $\$ 5,47(i, 6(i) .70$.

The net of dune 19.1922. mande no uppropriation. It nutherized an uppropriation of $\$ 50,000,000$ for the fiscen year 19223. $\$(05,0(100,0(0)$ for 1924, and 575.000 .000 for 1925. It authrirged the secretary (1) make npportionment for 1923. This ant also directed the Secretury to act upon projects submitted ngninst the 192:3 npportionment and stated that "his approval of any such project slanll be decmed a contrnetunl obligntion of the Federal Goremment for the paynent of its proportionul contribution thereto."

Contrnctunl obligntions of the sort referred to in the precoding parngraph have nlrealy been entered into with many of the states, and with the exhaustion of the upproprinted funds apportioned to these States there will be no funds to pay rouchers rendered by them on account of construction work done under the terms of these contractunl obligations.

It would appear at first thought that the upportioned balnuee of nearly $\$ 173,000,000$ shown above should be sufficient to matie payments to the States for a considerable period. Howerer, the rash balnnees to the credit of the individual States are not in such amounts as to permit this, the laggard States having rolntively Inrge balaness and other States which have been more active in rond building having small balances. Under the law, as interpreted by the solicitor of the department, the bulnones not immedintely needed in some States muy not be used in other States. For eximple. let us anke the States of Arkmnsas, Georgin, Idnho, Illinois. Iown, Mane, MnryInnd, Minnesota, North Carolina, Oregon. Pennsylynain, and West Virginis. On July 1, 1922. Idaho had a cash bulance to her credit of $\$ 1,153,000$ nut hand completed work unvouchered to the amount of about $\$ 115,000$, which if puid would redure here bulanere ns of that date to a little orer $\$ 1,000,000$. During the lisenl your 19:2.2 she was paid in round numbers $\$ 1,600,000$ from the Federnl Trensury. If during 1923 the state does a similar nmount of work we shall lack over $\$ 500,000$, or ubout 80 per cent of her $192: 3$ npportioument, of having enought to pay her or a larger nmount if the unvouchered amount is reduced. In Iowa this is 100 pore cent. In like manner we shall have insufficient funds to pay Illimois, Maryland. Minnesuta. Oregon, and the other sintes mentioned. nnd in orider to pay during 
the fiscal year 1923 the States in a position to render vouchers for practically the full amount of their 1923 apportionment we need an immediate approporintion for all the States of the $\$ 50,000,000$ authorized for 1923; nlthough in the States of Alabama, Indiana, and Missouri alone we had a total balnnce on July 1st of nearly $\$ 21,000,000$, a balance which judging by our records of the past will not be entirely used in these States until some time during the fiseal year 1926, and under the law as interpreted none of this balnnce can be used in any of the other States. I hare here a blue print showing the condition in each of the States which I would like to insert in the record.

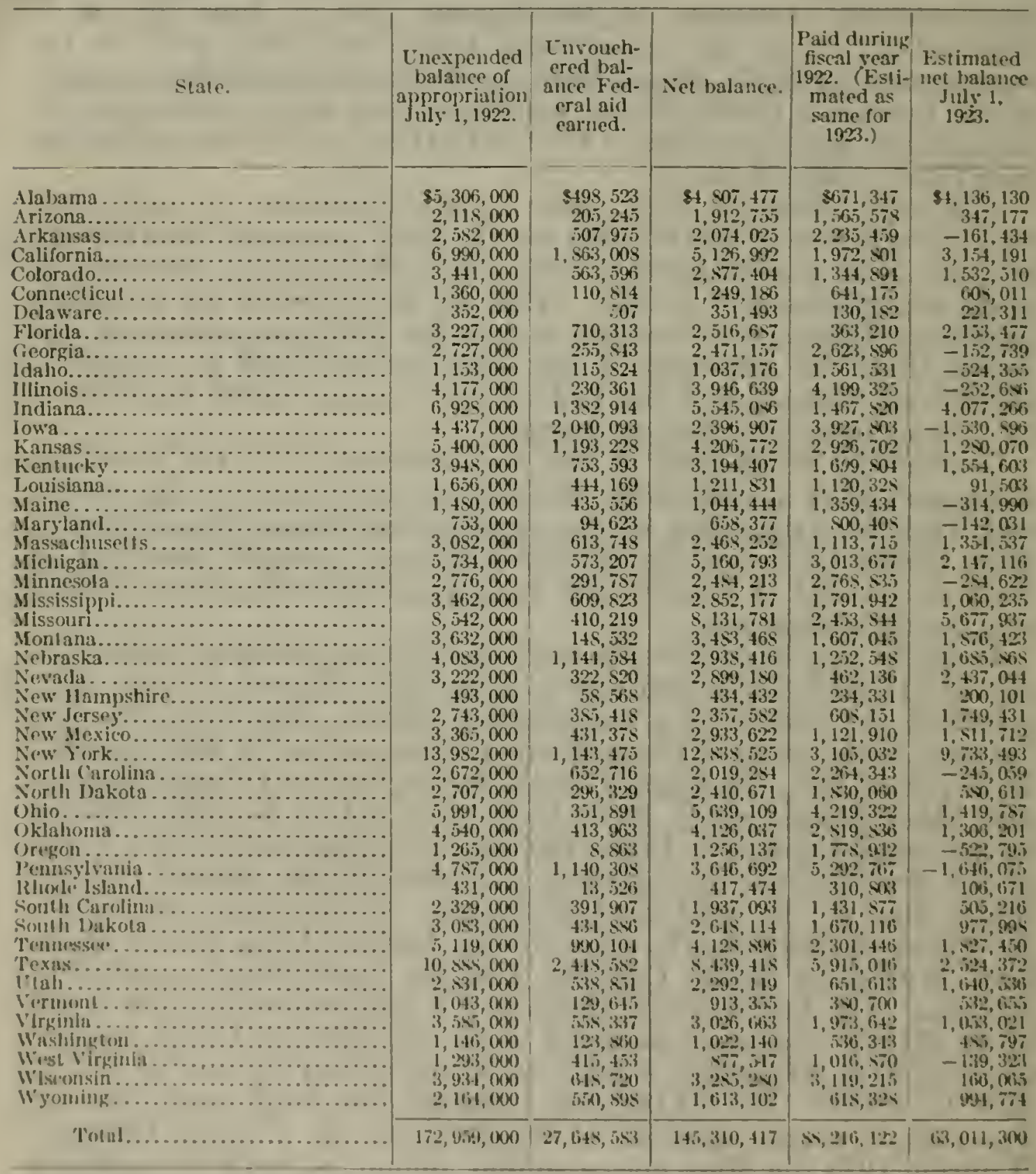

For the fisenl yenr 1924 conditions similar to the nbove will render necessury un uppropriation of the full momont of the 192.t fiscal yetre mihorizntion for paynent of vouchers during the fisenl yenr 1924, nsimning that Congress, in the mentime, nuthorizes the upportionment of the 1924 anount alresty athorized hy it to be appro- 


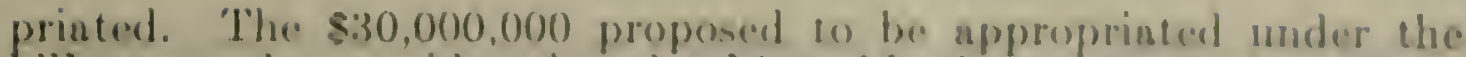
bill now under considerution should cumble tho pumment of vemelsers

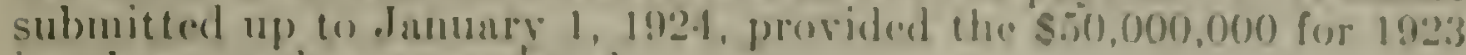
is subse(puently upproprintod.

Relutive ho ilw question of anthorizution for the upportienument of

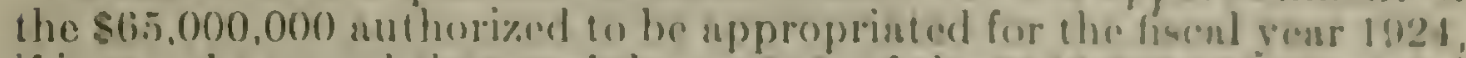

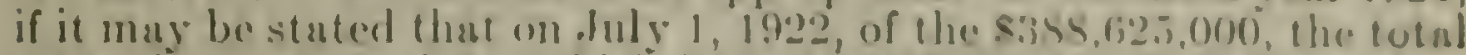
apporliomment to date (whichi includes $\$ 18,7.00,00()$ for 19.23 spportioned but not yet uppropriated). $\$ 91,(i) 6,079$ remained unohligntod.

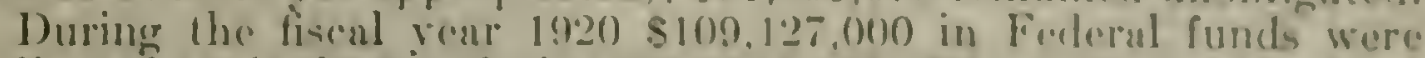
obligated to the States, during 1921 s $\$ .1,115,0) 0$, and during the fiscal year 1922, $\$ 49,000,000$. Had not progress been represafed during $1921 \mathrm{by}$ tho appronching axhustion of apportionod funds the whligution iluring that year would undoubtrolly have pussed $\$ 100,000,000$. Arain dering the fiscal your 1922 it is estimntod that locderal nid road work was repressed to the extent of upproximutely $\$ 50,000,000$ becusse of lack of a congressional appropriation to continue the work ut the sume rute us in 1920 and 1921 . This is indicated quite plainly in the chart which I have here showing "Progross of Fedroral wid roud work."

The best evidence wo have indicates that the States would normally easily absorb upproximately $\$ 100,000,000$ a year in fecloral aid with a yearly appropriation of this amount and at the rute nt which funds have been obligated in the past the funds now npportioned will all be oblignted, averaging all the States, considerably before the end of the present fisenl yenr. Any delny there moy be in nuthorizing the apportionment of the 1924 funds will act is a repressive influence. On October 31 of this vear the States of Maryland, Washington, and Oregon had obligated practically all their apportioned funds and must await further apportionments before they can proceed with their normal Federal nid road program. The chart also shows conclusively that construction parallels obligation at an avernge interval of approximntely six months which is the time taken in the survey and preparation of plans and estimates.

As an explanntion of the term obligated which I have used I will state that the initintory step for the improvement of a Federal aid road project is by the State in the submittal of a project statement wherein is adequately described the location, nature, and expected cost of the improvement proposed. This stutement is submitted through the appropriate district office of the bureau and from tho district office after proper field and office inspection and examination, it is forwirded to bureau headquarters in Washington, where after further scrutiny it is transmitted to the Secretary of Igriculfure for action. If farorable action is aken by the Secretary notice of it is sent to the State highway department and upon such fivorablo aetion it is considered that the Federal Government is obligated to the extent of the nmount of Federal aid stated in the mpproved project statement. 'The ageregate of these mpproved statements m a State, as modified by any amendments there ma be mado as the work proeceds, constitute the aggregnte of obligntions maninst a State's apportionment and when the total of the obligations reach the total of the apportionment the normal procress of the siates Federal aid rond activities is of course interrung matil a new aunor- 
tionment is made. This interruption means a serious disturbance in the organizations of the State highway departments: a reduction in force and dismissal of trained men who may not be arailable when the program is resumed.

STATE REQUIREMENTS.

Mr. Axdensox. Is there any way of knowing whether any one particular State expects to put on an average program or more or less than that?

Mr. MacDoxald. Ies, sir; we obtain estimates from the States as to their requirements and as to the program which they expect to put under way. While we secure these estimates from them, we are governed to a large extent by our own records of what has been done in the past. We maintain for each State a eurve similar to the chart I have shown for all of the States combined, which shows the progress at which their work is put under way and completed, and by extending those curves which show a rather constant performance, State by State, we are able to arrive at approximately what we think a State will do in the way of putting funds under construction for the suceeeding year. Te are willing, of course, to admit that one State, or two or three States, may rise above the line of the curve by making an unusual effort to put a large amount of work under way, but the 48 States are so balanced in that respect that we find our figures are quite dependable. By ruming out the curve on the 48 States, and making a composite of the whole, we beliere that we have a rery accurate forecast of what we will need from the standpoint of total funds for the succeeding year, and, in fact, we have projected what we believe the total program will be for the next two years. We have done that from a careful study of the curves of past performance.

Our conclusions as stated above are that there should be an immediate appropriation of the $\$ 50,000,000$ authorized for 1923 , an immediate authorization to apportion the $\$ 65,000,000$ authorized to be appropriated for the fiscal year 1924, and an immediate appropriation of $\$ 30,000,000$ from the $\$ 65,000,000$ authorization to be followed by an appropriation of the balance of the authorization by January 1 , 1924. This program, however, will not enable the States to proceed on so extensive a road-building program as they have been carrying during the last three fiscil years.

Mr. ANomesox. Even with the $\$ 30,000,000$ appropriated?

Mr. MacDoxald. With the entire $\$ 65,000,000$ appropriated, there would not be a sufficient anount to pay the States the sums that we paid them during the past fiscal year. 'That is, there is no question but what a number of States, proceeding as in the past, will need to draw their proportion of the entire $\$ 65,000,000$.

Mr. Axulersox. 'The question seems to be whether we are to leave in the Treasury a considerable sum of money which is not drawn by some of the states, while there may be a deficit in the amount which will bo drawn by other's.

Mr. MAcl)oxal, . That, of course, would automatically take care of itself at the end of ench three-yenr period. That is to say, Congress las fixed a three-yent perind iluring which States can take up each appropriation. I inyself think that is rather too long a period, and I opposed that length of time when the legishation was proposed. I do mot linow why it was fixed at three yenrs. States which do not take 


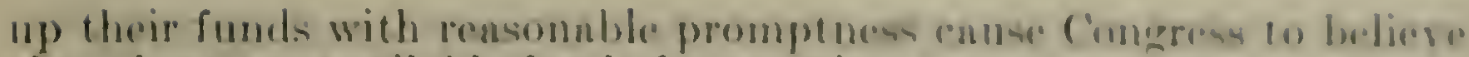

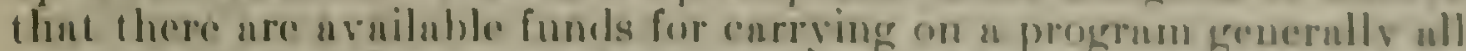

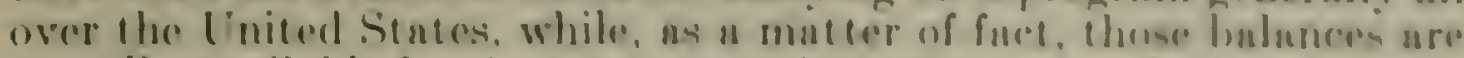
netunlly aveilable for the most part within a verve few Sintes.

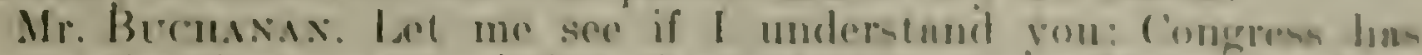

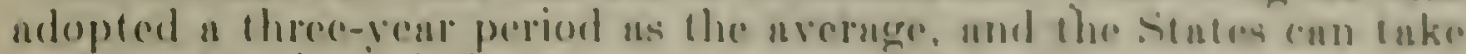
theil proportion of the momey npproprinted within that prerion of tiino!

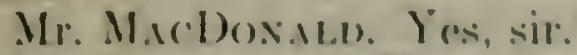

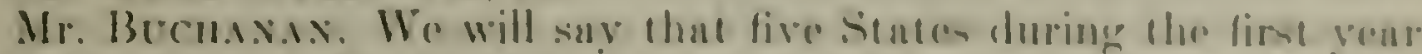

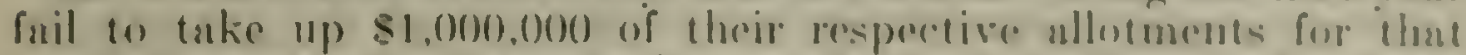

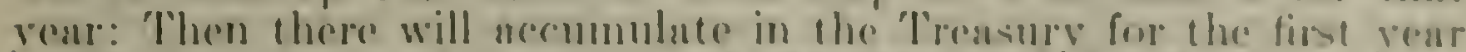

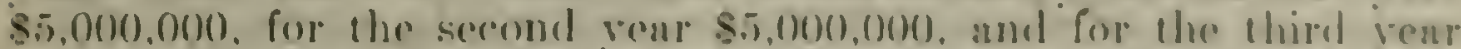

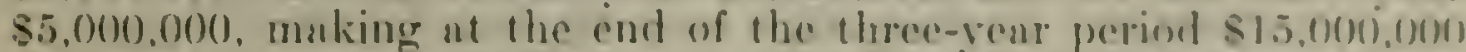

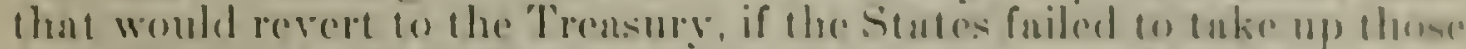

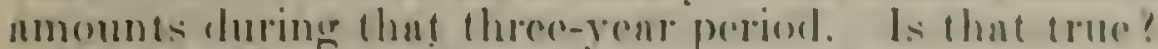

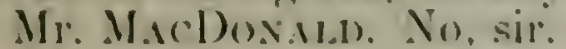

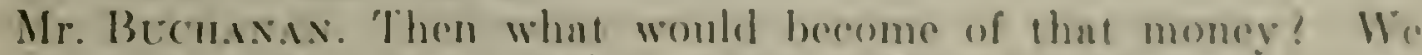

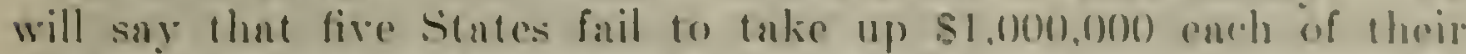
allotments for the therevear periol. and I want to linow what heromes of that $\$ 15,000,0(0) 0$.

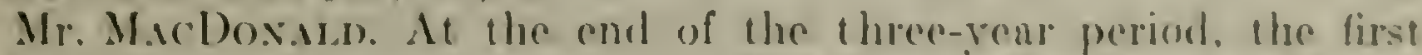

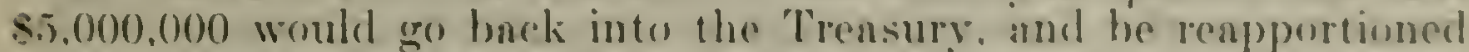
monom the States that had erone ahead. It wombl be lost for that individual State. Lut not lost to the total fund.

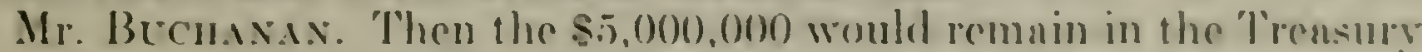
for three veratsa?

Mr. Micl)osidn. Yes, sil.

Mr. Bucmans. Before it would he allotted wo the other Situtes?

Mr. MacDoxali). Yes, sir. Then the next sij.(0)(0).0(0) womlet he aribable for the nest three-rear period.

Mr. Buchasis. Then it would be reallotted at the end of the fourth vear?

Mr. MacDonatio. Jes, sir.

Mr. Bucus.ix. And the last $\$ 5,000,000$ would be roallotted at the end of five rears to the other States that took their approprintions?

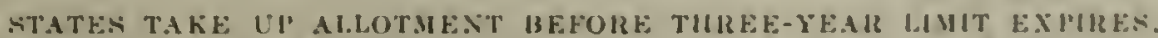

Mr. MacDosin. Yes, sir. What actually happens is that tho States can be three rears behind, but if they put in their project ngreements and huve their contracts signed up by the end of the fiscal year during which that particular nllotment would lapse. they ran continually hold on to their funds. They ran work two years behind the arerage, and still hold their funds. There have berin no funds to lapse for any. State yet, and I do not think there will he. because all of them nre procecding at a sufficiont rute to come within the three-year limit.

Mr. Bucusxax. The provision requiring that proceclure is embodicd in the law?

Mr. MacDoxiro. Yes, sir. Taking the halaner which we should bave in the Trensury at the end of this fiscal year. and assuming that a)] the States draw all of the Federul nid that thoy have ormed. and we think they will carn as much ns they did last yent, we would 
have a total of $\$ 63,000,000$, but here is Alabama with $\$ 4,000,000$, California with $\$ 3,000,000$, Indiana with $\$ 4,000,000$, and New York with $\$ 9,000,000$, or pretty nearly half of the funds in those four or fire States, the rest of it being distributed in small balances. These balances are based upon the assumption that the payments during 1923 will be the same as for 1922 .

Mr. Axdezson. They will not do that, because your authorization for this rear is not as large.

Mr. MacDoxinn. The authorization for this year does not have anything to do with what the States are going to draw. Of course, it has something to do with it, but a large part of the program for which they actually pay out the money is based on former apportionments, and out of the apportionment that will be available for this year of $\$ 50,000,000,1$ assume that probably $\$ 26,000,000$ will go over for the program next year.

Approximately, we estimate that there are 20 States that will need their apportionments of the $\$ 65,000,000$ during the fiscal year 1924 . 'Those estimates are as close as can be made without knowing whether' the States will take up the entire amount of our indebtedness to them, or whether they will carry on the same-sized program as they have on an average cluring the preceding years. If all the States were operating on the same basis, then any balance which we have remaining in the Treasury would all the time be prorated to the States in the same proportion as the funds are originally appropriated, and then the total balance would mean something, but as it is, the total balance means nothing whatever.

Mr. Axpersox. You are dealing with two things here?

Mr. MacDoxalu. Yes, sir; that is true.

Mr. Andersox. One of them is the authorization. Now, it seems to me that you have language here which continues your authorization, but so far as this committee is concerned, we have nothing to do with that except as the authorization creates un obligation which has to be paid out of the Treasury this year. What we want to get at, if we can, is this, I think: Assuming that this nuthorization will be made in accordance with the provisions of this section of the law, what additional sums will be drawn from the Treasury in addition to those already appropriated, and those which must be appropriated for this year?

Mr. MacDoxicn. It is this fiscal year that we are talking about.

Mr. Annenson. I mean the next fiseal year.

Mr. MacDoxat,. Assuming that that authorization would carry sullicient authority over into the succeeding fiscal your, or that the Appropriations Committea could npproprinte the balanee of it, I holieve that the $\$ 30,000,000$ would be sufficient until January 1, 1924, but I can not granrantee that it would be.

Mr. Axmmsox. Of course, that is not a matter of very great consecpuence, perhaps, because the next session will be next December, if we do not have one carlier, and, as long as you cau create obligations, the mere appropriation of the money is relatirely a small thing.

Mr. Macl)oxis.s. I ngree with you thoroughly on that. However, to cret some safuruard, if it were specified by the committee that the $\$ 30,000,000$ conll be used to take up obligations as they came in, it would be well. 
Mr. Andersox. Leet me nak you the quention that I asked Mr. Jump a while ago. which question did not go into the recorsl, but which, perhaps. will clarify the situation. The gurstion I want to ask is this: Suppose there is nuthorized to be experded $\$ 80,000,(x) 0$ for the next fiscal year, and you apportion that w the states, lherebs creating an obligntion on the Treasury for its parment, and wapperse we appropriate $\$ 30,000,000$ ns being the sum wheh will be aretunlly withdrawn from the Treasury as a conseguenese of these obligntions: now, must that $\$ 30,000,000$ be npportioned in the sume rutio us the original $\$ 60,000,000$ was apportinned, or run that $\$ 30,000,000$ bro drawn upon in the proportion in which the states have artunlly done their work?

Mr. MsclDoxalus. Well, I would judge thut undere our present procedure we would only pay nut in proportion.

Mr. Avuensos. There is this distinetion between whut rou have been doing heretofore and what you are doing now: Heretufure you have had the actual money approprinted.

Mr. MacDonalio. les, sir.

Mr. Asurnsox. Consequently. theme was no distinction betwern the appropriation and the authorization, but it was all ine thing. If rou did not spend it in one year, you could take it up in the next. Now. We have made a change in that situation somewhat. and we have made an nuthorization upon which you can crente obligations. The question which arises seems to be perfectly simple. If you tuke the money out of the Trensury in the ratio in which you hrise made the allotments to the States, then you are going to have a certain amount of money in the 'Trensury that lies there obligated until it is expended. In the other case, rou have States that will have money coming to them that you will not be nble to pay, although it wis allotted to them under the authorization, becuuse you have not the cash. The question is whether this $\$ 30,000,000$ can be allotted as a fund out of which you can pay obligations that arise this year. without respect to the allotments created under that authorization. If you can, it will take much less money than would be required the other way.

Mr. MicDoxald. Myown judgment is that that is the way it should be handled, and I know of nothing that would prevent your putting language into the law that would allow that procedure.

Mr. Buchasas. How about the law on the books now or the regulations of the department? Can you not do that now? Suppose we gave you $\$ 30,000,000$ in the way the bill reads, and suppose some States enter into contracts and complete them, while some other states do not. Could you not take all of this money and pay the obligations of states that did complete their contracts, learing the others that did not complete them obligated under the bulance of the $\$ 65,000,000$ ? Does the law provide that the cash approprintion shall be allotted in aceordance with the original allotment of the \$6.5.000,000?

Ir. MacDoraci. I think that it would be ruther better to make it clear in the law, if possible.

Mr. Becuasax. This is not a legislative committee.

Mr. MacDosico. I think the secretary should have authority within his diseretion to so use the appropriation.

Mr. Axdensos. It seems to me that it gets down to a fairly simple proposition. We have authorized $\$ 65,000,000$, and we must pay 
that some time, but we are only going to pay $\$ 30,000,000$ of it this year. It is not quite as simple as that, because you have some hangovers, but that is what it amounts to in the aggregate. is it not?

Mr. MacDosalm. Yes, sir: I believe that it would be possible to provide for the use of the fund in that way. The total $\$ 65,000.000$ to be apportioned, and $\$ 30,000,000$ approprinted to apply to all of that apportionment as the obligations come in.

Mr. Andersox. Ies, that is the proposition.

Mr. MacDoxiLn. I suppose there is no possibility of getting any assurance that Congress would act promptly when we had expended the $\$ 30.000,000$.

Mr. Axprasox. I assume, and I think it is a perfectly sound assumption. that Congress, having authorized the Secretary of Agriculture to incur certain obligations which mature in the future. and Congress haring appropriated in its best judgment and in rour best judgment the amount. which would be required for this fiscal vear under that athorization, if the developments were such that is larger amount was required, it would recognize that clearly an at deficiency under our rules. If your department were to spend more thim $\$ 30,000,000$ during the next fiscal year upon that authorization already made. it seems to me perfectly clear that that would be a deficiency.

Mr. MacDosalns. Assuming that that plan could be carried out. I think it would be preferable to piling up the appropriation.

Mr. Axinersos. There is no use in appropriating $\$ 65.000,000$ or $\$ 50.000,000$ for the next fiscal rear if your actunl obligations will (all for only $\$ 30,000,000$ or $\$ 3,5,000,000$.

Mr. MacDosald. I agree with you and with the Director of the Budget on that.

Mr. Axnersox. I suggest that you put some of those tables in the record, so we will have complete data before us.

Mr. MacDonals. I will do so.

\section{PRONKION FOR OBLIGATION OF BALANCE OF ALTIORIKATION.}

Mr. Bucmaxax. You have a provision here in this bill which provides for the obligating of the balanee of the $\$ 65,000.000$ that we are authorized to approprinte. Now, that $\$ 65,000,000$ has been allotted in a rertain proportion to the different States. What reason hare Fou to believe that all of those States will be ready to enter into obligutions such as would continue the power of Congress to appropriate under the original authorization! Some of them may not be ready within the fiscal renr, and, that being the ease, we would lose the power to appropriate under that original anthorization the stis,$0(0),(0)(0)$ that is. if some States were not ready to enter into obligatoly contrals within the liscal rear.

Ifr. Macl)oxald. It is my understanding of the languane of this anet that it rhanges that status in that we are authorized to enter into (onl ractual obligntions.

Mr. Becmasix. The proviso reads:

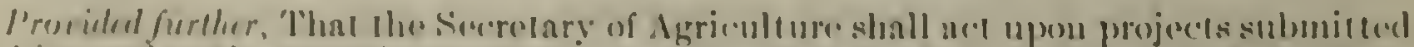

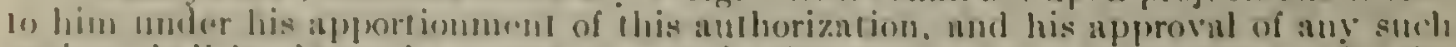

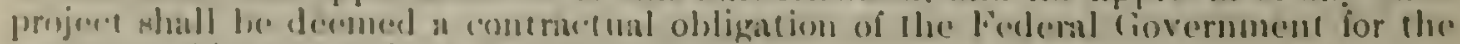
pablutenl of its pouportional (ontribution therefo. 
So that the States. or all the statem, will have to loe prepared and ready to submit to the Secretary of Agriculture a proposition for the improvement of public highways, and you must be ready to to it

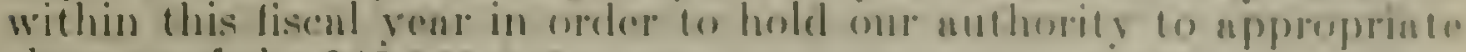
the rest of the s(io, $000(1),(0) 0$.

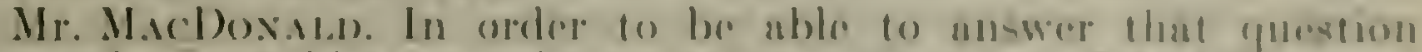
correctly, I would hase w know if that is the viewpome of this committee ioward such an anthorization. I was goine on the thenes that if the stis.000,000 is apportioned as the anthority would be given under this are, and a considerathe portion of the states will artunlly phaee their full apportionments, or their full share of the apportionment, under contract, and that the Sererenry approsers their projects, or if, say, hulf of the States did that within the fiscal reare then the remander of the $\$(65,0000,000$ must be uppropriated either during the fiscal year or during the following fiscal rear. or clse we break faith with the balance of the Stater.

Mr. Bucnox.s. 'That is true; it must be rither during the fiseal year or the following liscal year, but suppose it is not oblignted during the fiscal year, will Congress then have the power to appropriate under that original act nuthorizing $\$ 65,000,0(0)$ for this fiscal year?

Mr. MacDoxild1). I am assuming that (ongress will have, having authorized the Secretary to enter into contructunl obligations.

Mr. Buchasis. They must actunlly enter into contracts.

Mr. Axnmasox. But not within the fiseal year. necessarily.

Mr. Bucusax. You may be right about that.

Mr. Jume. This morning Mr. Mnel)onnld and I mised that question with General Lord, and he called in Judge Wnich, the former Comptroller of the Enited States, who is now a member of the Budget staff. While it was recognized that the question was solely one portaining to the rules of the House, concerning which the executive officers of the Government are not authorized of competent to rule, the opinion of Judge Warwick, informally expressed to us, of course. Was that this proviso in the estimates about the $\$ 65,000,000$ apportionment and subsequent obligntions to be entered into under it would perpetuate the anthority to report out appropriations in Inter fisenl years, wherens the original act, as we understand your view of it, might not do it.

Mr. Axulesox. Entirely aside from the question of the time it is whligated, my impression is that where Congress has authorized the Government to enter into an obligation, and that obligntion has been entered into as a fixed contimuing work, under our rules no question would arise under this provision at all. I do not think nny question would arise under it at all.

Mr. Jury. In other words, it does not seem that congress would authorize the Secretary of Agrieulture immedintely upon the passagere of this act to apportion the full authorization of $\$(65,000,000$ among the States and then do other than honor the whligation. regandless of whether the fisenl rear had expired or not.

Mr. Becmas.s. I do not know what wonld be the construetion of this langunge, but I do not believe that this provision extends one inta the power of Congress to appropriate under this authorization muless the projects have been approved within the time that congrese authorizes the making of the appropriation.

Mr. Jenp. That is the whole question. 
Mr. Buchasas. We can not authorize a department to enter in to a contract after the time has elapsed when we are authorized to make the approprintion.

Mr. Jump. Do you not think you have extended the time?

Mr. Bucmasas. If he approves the project, he can extend it to eternity-that is, if he approves the project during the time that we are authorized to appropriate.

Mr. Jcmr. If there is any doubt, why not put in an additional sentence specifically extending the time of the authorization?

Mr. Bucunsax. Possibly it should be extended for the three-yent period.

Mr. MacDoxalu. We have a general law providing that funds apportioned under the federal highwa net are available for three yenrs.

Mr. Chairman, the other day we had a hearing or a partial hearing. on that provision of the law authorizing us to exchange passenger rehicles, and I am prepared to insert the figures, or to go into that question, if you desire it.

Mr. Avpeirsox. I do not think that will be necessary.

Mr. MacDonald. I find that it will be necessary for us to have for the next year or two, and, perhaps, longer, in the neighborhood of $\$ 29,000$ to replace cars, or authority to use up to that amount. This is in addition to the amounts now shown in the bill. We have 17.5 ('nrs in use.

Mr. Andersox. I suggest that you have the solicitor or somebody draw up a provision authorizing you to use that amount out of some appropriation.

Mr. MacDonalo. I will do so.

\section{Monda, NoveMBer 27, 1922. \\ BUREAU OF AGRICULTURAL ECONOMICS.}

STATEMENTS OF DR. H. C. TAYLOR, CHIEF; MR. LLOYD S. TENNY, ASSISTANT CHIEF; MR. WILLIAM A. SCHOENFELD, DIRECTOR OF MARKETING RESEARCH; MR. WELLS A. SHERMAN, SPECIALIST IN MARKET SURVEYS; MR. W. F. CALLANDER, IN CHARGE OF DIVISION OF CROP AND LIVESTOCK ESTIMATES; MR. J. CLYDE MARQUIS, DIRECTOR OF MARKET INFORMATION; MR. H. S. YOHE, IN CHARGE OF ADMINISTRATION OF UNITED STATES WAREHOUSE ACT; MR. C. W. KITCHEN, SUPERINTENDENT OF CENTER MARKET, AND MISS EMILY E. CLARK, JUNIOR ASSISTANT IN MARKET INFORMATION.

(MENTHA, CHATACTER.

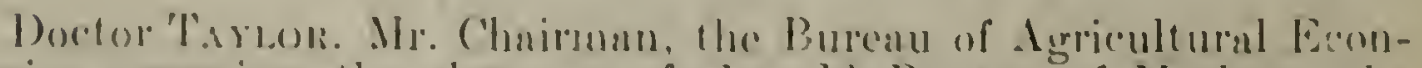
omices comprises the elements of the old Burean of Marleets, the Burenu of Crop Estimates, und the Offiee of Farm Mannerement

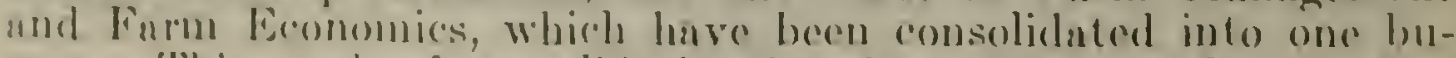
remu. 'This work of consolitation has been going on for about " your and a half in areordune with the autherity in the appropriation 


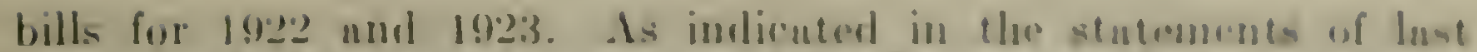
year, the first consolidation, that of the Burran of Markets and the Burenu of Crop lestimntes, mude posable the throwing logether of $n$ part of the administrative suetims last renr. that is. of mail and

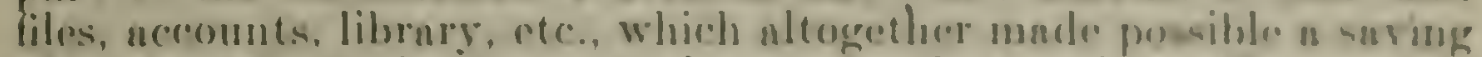
of about $\$ 30,(000)$ in the genernl expense of operntiens. "Then, when the Oflier of Furm Mnnugement and firm fermonices was ronsolidnted with the Burenu of Markets and ('rop) listimntra, a similar saving was made through the further enusolidation of those serviege units of Farm Management and Farm Feonomies with the larger orgnnization; so that there has been a sinving in the general overhead by those two steps in consolidation of approximntely $\$ 600.000$. A part of this was taken out of the statutory roll and a purt of the saving was offected by trunsferring certain cinployee who had participated in the general administrution of the hirenus to seientifie work.

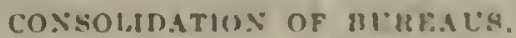

More importnnt, however, than the finnneial savings is the increased efliciency or effectiveness of the marketing work of the department through this consolidntion. There are three ways, at lenst, in which this consolidntion has incrensed the effortiveness of the work. In the first place, that has been done by bringing together the working units of Crop Estimates and Farm ifanagement. For example, the erop estimating machinery of the old Bureau of (rop listimutes has proved exceedingly useful to those who are working on farm-manngement problems by providing a menns of guthering some general informution to supplement the detailed information that was being gathered directly from the farmers by those working on the problem of cost production and farm organizrition. Detniled cost nceounting work has been carried on on a large number of farms in different parts of the United States for the purpose of securing the bnsic elements of cost in terms of the mnterinls and litbor entering into the cost of producing erops. 'Those figures hecome of greater permanent value when supplemented from year to your by specific information that can be gotten through (rop estimitors with regard to the changes that have taken place in the cost of those minterial elements of cost-that is, changes in the cost of labor in the production of whent. and of supplies, such us binding twine, etr.. thut may change from year to venr. Another example of the benefits derived from this closer coordinntion may be illustrated by the work in livestock estimates and live-stock marketing.

By bringing the live-stock marketing section in close conjunction witl the live-stock estimating section, they hure proved to be mutually helpful, and are cooperating very closely, so that the information that is secured in (hicngo, for instunce, by the live-stock marketing division supplements materinl that is collected in the field by the live-stock estimating group in innking a dotermination of what has actunlly taken place: that is, what comes into the market is a check upon estimates of what wos behind the murket. Furthermore. the materials that are gotten through crop estimntes with regard to what is probably behind the market this year is rorr helpforl io those who are interested in that problem from the marketing point of view. and who are interested in knowing what is coming into the market during a giren season. 
Another way in which the consolidation has proved especially helpful is by bringing together the people working on the economics of of production and the economies of marketing and talking over the various problems that they jointly have to work upon, each gets the point of view of production and of marketing, and not simply the point of view of production or the point of view of marketing. We come to see more and more that many of the problems of marketing arise out of conditions in the field of production and, on the other hand, many of the questions that the farmer needs to have answered before deciding what to produce have to be answered by those who are working in the field of marketing. The biggest change that has been brought about in the work of the combined bureaus and, particularly, with regard to the marketing work, is the introduction of more economic research.

Iore effort is being given to the thorough understnnding of the economic forces that influence the market movement of farm crops. A study is being made of what happens to each of the principal crops from the time it leaves the farm until it reaches the consumer. For exmmple, take wheat: We are interested in making a study of what happens to wheat at the local station as the farmer and the local buyer get together and agree upon a price at which the whent shall be sold, and the extent to which careful grading of the grain is taking place. Then, we are interested in the financing as well as the actual movement of the grain, both in the loeal and in the central markets, following through in detail ererything that happens to this whent, including the financing and the grading of the wheat, from the time it leaves the farm until it reaches the mill, with a riew to making a clear picture that will be a basis, first, for educationnl work, and second, for a proper adjustment of our grain grades, in order that through a proper adjustment of grain grades and through the education of the furmer to look after his own interests, the milling value of the wheat mny be more perfectly reflected buck to the farm. An exumple of one thing that has received a great deal of attention is the "Know your wheat" compaign, which has for its purpose tenching the farmer to know what he has to sell in order that he may sell it more advantageously. It has the further office, howerer, of stimulating him to produce a thing that is of higher intrinsic value in the market. Work along this same line is being carried on in the field of cotton marketing. In the past it was the rule for cotton of different grades and staple to be sold, by the smaller farmers in particular, at the average price in a given community without. remald to the diflerences in ralue.

Erlucational work has been earried on jointly with the extension services in the various States, to help the farmers to know the value of what they are producing, and, in turn, that hus had a very benefiernt influence upon the farmers in selecting varieties of cotton to grow that will demand better prices. We hope to organize the researeh work in surh a way as to form the fomdation for improving all of the services and the regulatory work. In a gencral way, Mr. Chaimnn, he ceftert has been to make the resenreh work of the hurenu follow up und actually further lle work that was so well begun in the fiedd of murketing and credit by the eloint Commission of A grricultural Inquiry. 


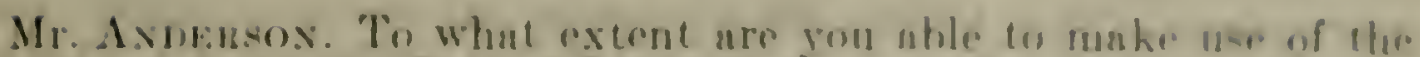
studies made hy the Forderal Tindo ('oniminaion!

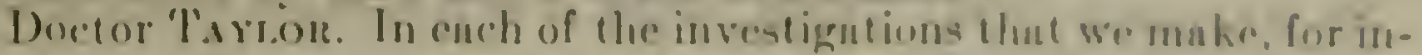

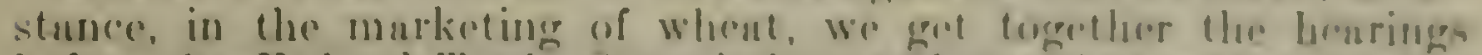
before the Federal Trald Commision, and use that material in so fur us it unswers the question thut mereds lo be unswered. 'Thkore for example, the gurestion of the extent to which grain is actunlly solyt by grade ut the locent stations. We find information there. lint wo

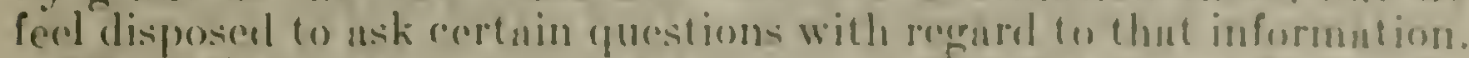

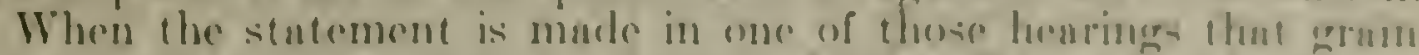

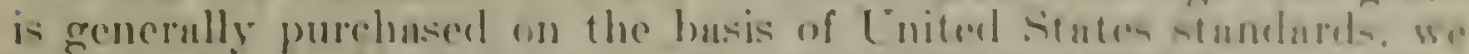
want to know what artually truncpires at the local station- whether ull of the necessury work is performed to usecertuin necurately whut the grade is, or whether they roughly determine it as U. . . X Oo. I or U.S. No. 2. Our impression is that, while it is quite enencrally bompht on the basis of those grades, in many instanees the grader are nen hy any means accurately determined at the local slations.

Another way in which the work is benefited ly the consolidntion is

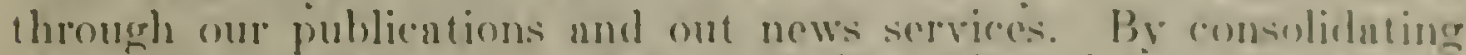
the news or information serviees of these three burents into one. and kecping the farmers informed about the eronomic problems of both production ud marketing all the time, we ure able to make the work more offective. It is true that it is very often not production news so much as markeling news that the producer is interested in, beconuse he is adjusting his production to market ronditions. Furthermore, it is often mive that it is not so much what is hitppening in the market that the market man is interested in, as in what is happening behind the market in production. and we are kecping the whole field of marketing and production before our minds in sprnding out information. We believe it is more effective than where thuse who are interested primnsily in production ure giving out information for the producer and where those who are interested in marketing are giving out information for those who are interested in the hundling of firm produce.

With this genernl stutement, I would like to pass on to the specilic items of appropriation.

\section{S.ILARIES.}

Mr. Axmersox. Suppose we take up the statutory roll on page 2ug?

Doctor 'Taytor. I would like to have Miss Clark rover the statutury roll.

Miss Crank. We have $\$ 965,440$ on the statutory roll now. There is an npparent incrense on this item of $\$ 11,990$. but an aretual decerestice of $\$ 30.260$. The nppurent increase is calused by the transfer of th employecs, with salaries angeregating \$1S.T(1), from the lump-sum roll to the statutory roll, and the transfer of one aceomentant atul boukkeeper from the oflice of the Secretury to this bureatu.

Ir. Axmbasos. Where did those trinsfers come from?

Miss Cr.ark. They cume from various lump-sum rolls of aur burenu, and I have a second table here corering that. The tranters were as follows: From furm manngement and practice. S9, - i2); from market distribution and farm production, Slo,7so; from erop and 
live-stock estimates, $\$ 1 \$, 000$; from market news service. $\$ 3,600$ : from enforcement of the Lnited States cotton futures act, \$3,000; and from the administration of the United States warehouse nct, \$3,600.

Mr. Axdresox. What I want to get at is how those places arose under those lump sums?

Miss Cuark. Those places are new appointments made since the last transfers to the statutory roll, but they are very largely offset. by the places we are dropping. 'They are offset, first, by the transfer of one executive elerk at $\$ 2,250$ and one telegraph operator at $\$ 1,400$ to the office of the Secretary. Four clerks of clnss 1 are being transferred to the Bureau of Plant Industry, which were omitted aceidentally last year. Then there are dropped from the roll 45 places with salaries aggregating $\$ 30,260$. All of those places are rither vacunt or are filled by employees whose services can be dispensed with by the end of the present fiscal year.

Mr. Axdersos. What $I$ am getting at is this: You set up a situntion last year which made the statutory roll and the roll under the lump sum. 'The supposition at that time, I assume, was that the statutory roll that was then set up was set up with reference to the clerical requirements in connection with those lump sums. Of course, if that assumption is not colrect, we must come to a different. conclusion. If it is correct, what I want to know is where the occasion for those clerks arose. In other words, if the statutory roll, when you got those appropriations, was properly apportioned to your lump sums, there would have been no occasion for appointing new clerks to be paid out of the lump sums.

Miss Clark. We increase the statutory roll only by transfers from the lump sums-that is, by the transfer from the lump sums of clerks who are already in the bureau.

Mr. Axdersos. I understand that, but that is a continuous process, apparently.

Miss Clakk. It is a continuous process. This looks like more of an increase however than it is. There is a net increase of only $\$ 11,990$, and we are dropping more places than we are ereating new ones. There are 45 places that will be dropped, and only 40 new places to be ereated. 'That makes this readjustment necessary.

Mr. Axbersox. What was the total increase in the Bureau last year, exclusive of the statutory roll? Do you recill?

Miss ('anks. The total increase to the burenu was approximately $\$ 136,000)$, and of that just about $\$ 36.000$ was on the statutory roll. 'Thare is a need for readjustment as the clerionl roll is consiantly changingr. We lost nearly 25 per cent of our total clerical roll by termuntions, through resignations, and otherwise, and we have had new uppointments. For that renson we have difliculty in keeping the clerical fores adjusted to the statutory roll. Every yent there nre upt to be some new trunsfers. When there is an increase in the uppropriations, it has not been the custom to ask for new statutory places. It has been the policy not to ask for statutory places until the arkis ure in the hurenu, working on a permanent busis. Then Wre usk for the statutory places in the estimntes for the coming rear. "There is only one othere chunge in the statutory roll. We are asking that the designation of nime machine operators be changed from matchine operators to machine operntors of clorks. There is no change in the sulary that is requested. It will give a dittle more 


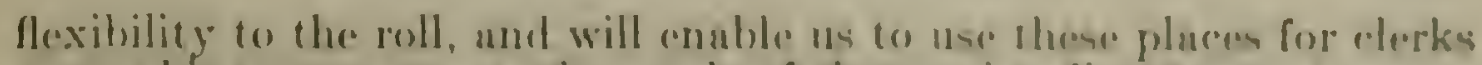
or muchine operators ns the needs of the serrioe diethte.

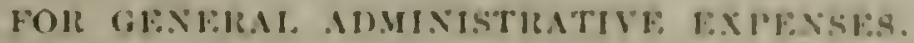

Mr. Axnensos. Your next item seems to be the genernl uduiniatrative item, in which there dees not appenr to bre nuy change.

Doctor Tarom. There is no clange in that.

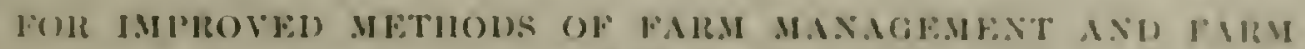 f'llictorick.}

Mr. Andinsox. The next item is on puge 273, to investigute nut roconarnge the moption of improved methods of form management and farm princtice.

Doctor Toriton. There is a decrease in the lump sum, hut a corresponding incrense in the statutory roll, so that the tolul amome is the sume.

Mr. ANonstons. Suppose you give us a brief stutement of what is boing done under this item bow.

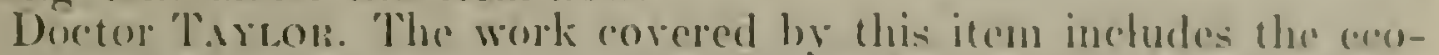
nomices of agrieultural production. This is included under two chasses or headings. first. the study of the basis of production, und then the organization of production. Under the hend of the bases of production we have the stidy of land economies or the land bases of production, farm population and country life and agricultural finanee.

Under the hend of land economies we are proposing to expend the same amount as for the current rear, which is sti.too) for the lump sum and $\$ 27,520$ on the statutory roll, making a total of $\$ 92.820$.

I.A.I) VALUATION:

One of the lines of work of very great importune at the presone time, corered hy this subdivision, is the question of lnnd ruluation. The work has been done on the basis of questions that wore put in the last census schedule for the special benefit of our bureau. and by sperial studies in the field, with a view to determining the wny in which land is being ralued and the relntion of hud values to the einrning power of the land, as well as to increments that have been adderl (1) the value of the land. The joint-stock land banks, the lederal form loan hanks, and the farm mortgage bankers have heen very much interested in this piece of work in the last renr. berause the question of the size of the loans rests back upon a proper vuluntion of land. They recognize that there has not been any seientific method of land valuation developed in the pust and this oflort to derelup a scientific basis of land valuntion urouses a rery grent interest on the paut of these money lenders. It is also of rerregreat value, if applied properly, to those who are buying land in order that the prices paid maty properly eorrespond to the earning power of the lind.

Mr. Axdensox. Has this item any relation (o) the cost of production studlies?

Doctor 'Turen. Yes. This has a very important applieation to the cost of production studies, because in the past we hare had to take the land ralues given by the farmers. 
Mr. Axpersox. I did not mean particularly this land raluation item but this item of farm management.

Doctor TaYlor. Yes; because whether or not you are going to operate a farm for profit depends upon buying the land at a right price and heing able to borrow money on it up to a fair valuation.

STUDY OF RELATION BETWEEN LANDLORD AND TENANT.

Another problem that is being covered in this section of land economics is the question of the relation between landlord and tenant. Since two-fifths of the farms of the Cnited States are operated by tenants this becomes a rery important matter, because the relation between landlord and tenant has much to do with the trpe of farming and what the tenant is free to do in the management of his farm.

Mr. Buchasax. Do you mean you are making a study to ascertain what that relation is?

Doctor 'TAYon. Yes; and the relations which are successful and lead to good agriculture as well as the relations which tend to retard good farm management.

Mr. Buchaxax. Then you propose to publish a bulletin on that?

Doctor TAYLOR. Yes; a bulletin has just recently been published on the relation between landlords and tenants in the black prairie of Texas.

Mr. Buclunax. Does that bulletin state what the proper relation should be, in the opinion of the department?

Doctor 'TAYLOR. It shows the relations which are proving successful and profitable.

Mr. Bucilaxax. Have you found a general class of relations that are successful?

Doctor TAYLor. Well, of course, there is more than one factor. It is a proper form of contract along with good people that makes the success.

Mr. Buchaxax. Have you found, in the relations between landlord and tenant, where a good tenant is not successful all the time?

Doctor TAYLoR. There are certain methods of renting land that discourage good tenants, so that a good tenant will tend to disappear or go some place else if the methods are not proper. So you usually find the good tenants and the good methods of renting going togrether.

Mr. Bucmanax. What I want to get at is this: What general service is rendered by this inrestigation? Do you hope to change certain of the relations between landlord and tennint that have heretoforce existed, or what?

Doctor 'TAYron. 'To give the best possible information to those who make inquiry and are studying the problem of improving the relations betweeni landlord and tenant. Hundreds of people are continually asking questions on this subject, and what we are doing is bringing together the information which is useful to those who are wantint to improve conditions. Where there is a good system of temancy there is a better chance that the temants will be able to rise to the position of land owning farmers in the conrse of time.

Mr. Becmoxas. I fram it will be a long time.

Doctor 'Taruots. Of comrse, in the South it takes a good deal longer with one class of population than it does with another. 
The yuestion of colonization has loen takon up. In a large number

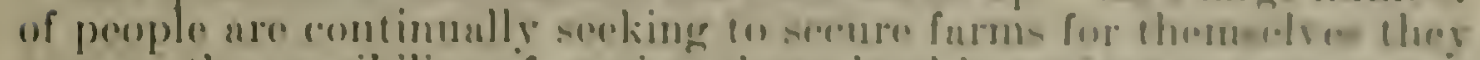

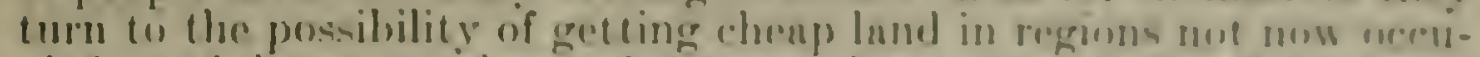

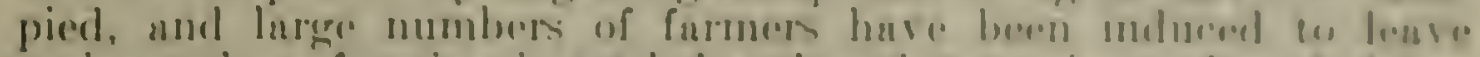

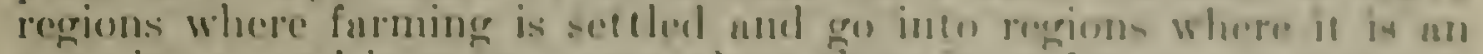
expreriment und in musy asses whore there is mo future opprorturits.

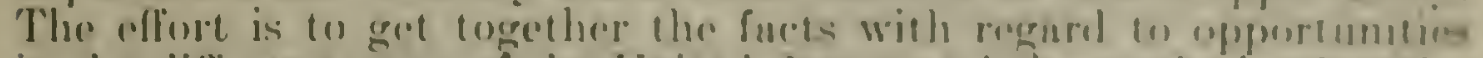

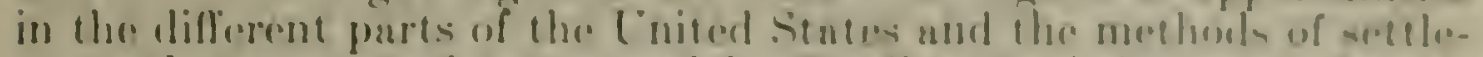

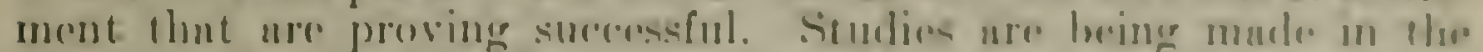

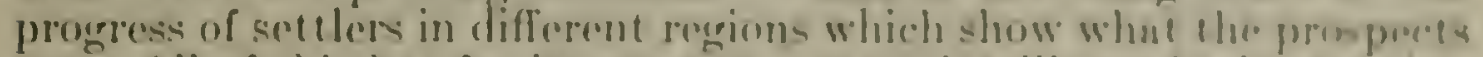

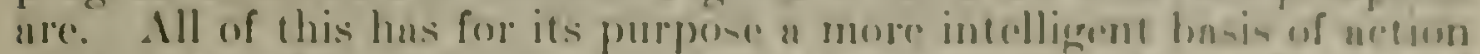

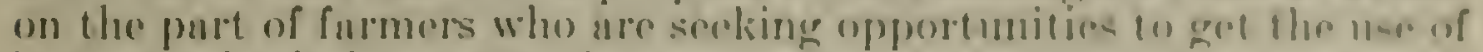
land us a hasis for production.

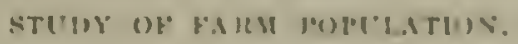

Another purallel line of study. which is hasie on furm orgunizution. is the study of farm population. which has heon earred wn within the

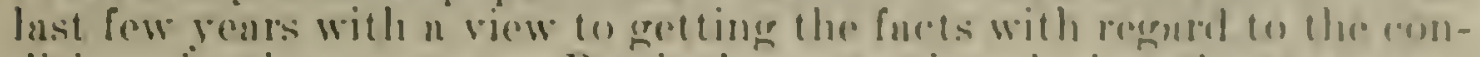
ditions in the country. Particular attention during the pust venre has been given to an unalysis of the farm population. Intil the last census, the rensus of 1920 , 110 had neser hud any information with rearard to farm population as such. Rural population, which is a very diflerent thing, has been tahulated. By spercial arrungement with the Census Buresuan indientor was put in licfore the name of onch person to designate whether or not they lived on farms und whether or not they workerd on falrms.

On the basis of this an experimental study has beron male in dight counties in the United States for the purpose of showing what is Iruse of the farm populntion in comparison with other crroup of populat tion. This gives the same facts with regard to the people on farme that we have been getting in the past with regurd to the eity popmlation, and also gives essentially as gend information with lenurd to the people on farms as it does with regurd to the lise stock on furms. Now, wo have been hearing a great ileal from time to time about the shifting of population and how the mantenanes of the right $19 p$ of people on the farms is essential to the future of gond angriculiure. This for the first time gives us the becinnings of the detailed facts as to what is there and, on the basis of future studies, it will show the trends that are taking place.

Mr. Axmersox. What does it show in general, so far as yuu hato gone?

Doctor 'Taruon. These tabulations are just being thrown in shaph now; they are just getting through the machine work on the atumlntions. 'They show, for instance, in Dane County. Wis.-one uf the counties chosen-facts as to the question: "Is illitracy more common in farm families than in other fumilies?" And it has becn shom that there is six-tenths of 1 per cent less of illiterncy on farms than in the country as a whole.

Mr. Axnensox. In that county?

Doctor' TAYlon. In that cominty, yes. It shows the oceupations of the people who live on the farms and a rather high percentuge of people living on the farms who work at other things and bring income into these farm homes. Of course. that includes the selool-feachers. 
It also shows the ages of the people on the farm, the extent to which the work is done by women and children, and the extent to which the work is hired.

Mr. Axpensox. That is all very interesting, but what I am trying to get at is: What do you do with this information when you get it, and of whint practical ralue is it?

Doctor Tarior. When we are studying the question of farm production through a series of years mud wint to get at the trend of what is taking place, and if the trend is in the direction of depleting the human basis of agricultural production and we want to know what steps to take to maintain the human basis of production, then this analysis is helpful.

Mr. Avidersox. Well. to discover trends you have to have some information over a series of years?

Doctor Thyor. Yes: but in the meantime it is important to know more than we do about the people who lire on farms.

Mr. Axdersos. Do you expect to continue this orer a series of census periods?

Doctor 'TAYor. The expectation is that when this is tabulated and put in shape so as to show the significance of it-and it has not yet arrived fully at that stage-the probabilities are that there will be enough people who want this information that the Bureau of the Census may be asked in the future to include this analysis in their regular work, and if that can be brought to pass-

Mr. Buchasax. (interposing). Then, is it the purpose to do this work through a series of years and have the Bureau of the Census make it more complete?

Doctor Tirton. No; that is not the idea. This work is being done now in cooperation with the Bureau of the Census in order to ascertain whether or not this will answer the questions that many people are interested in having answered, and if it does it will get information that will be wanted. It is considered rery much more economical to experiment in eight counties at relatively small cost. and have the experimentation carried forward by people who understand what they are trying to get than to start in at once and make the whole tabulation without the preliminary experiments.

Mr. Buchasax. How much of this appropriation is spent on the census proposition?

Doctor Taroon. This whole question of farm population?

Mr. Brciasax. Not the cost of production, but on farm population!

STANHARIS OF LIVING ANU TIE, ELEMENTS OF COST IX TIE FARU FAILY.

Doctor TAYror. $\$ 25,000$ is being expended on the whole question of farm population and comutry life, but only a small amount will be recuired to complete this census study of farm population.

Another line of work which is being earried on under this same heading of farm population and comtry life is the standard of living and the elements of cost in the farm family.

Such a study is just being completed in Livingston (ounty, N. Y.. which shows the elements of the farmers' standard of living, the cost of food, clothing, rent, and various personal cxpenses, and general cxpenses for education, alrancement, etc., and the part of this which 


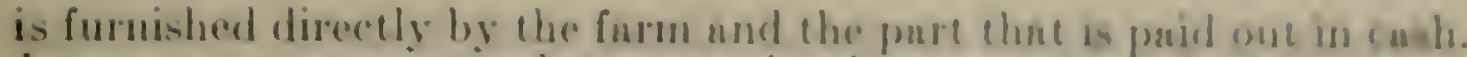

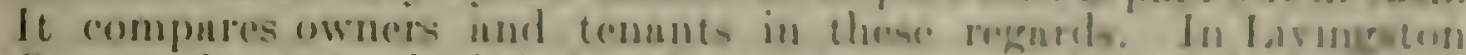

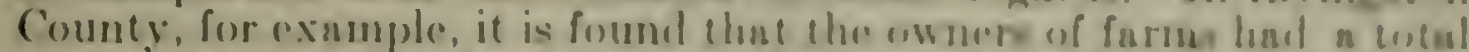

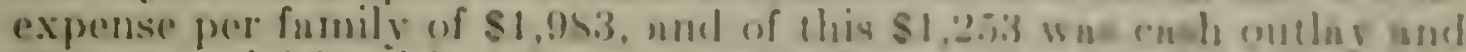

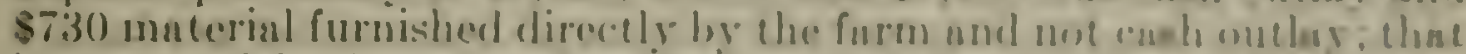

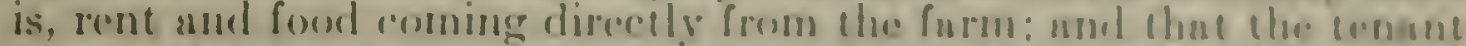

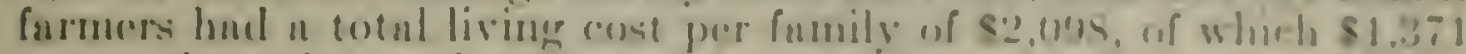

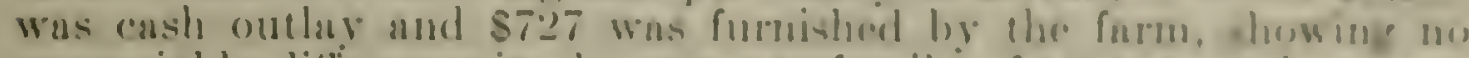

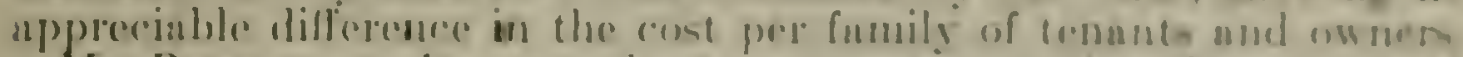

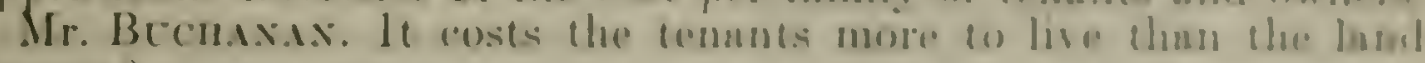
owners?

Doctor Tarion. Slightly in thros instunces.

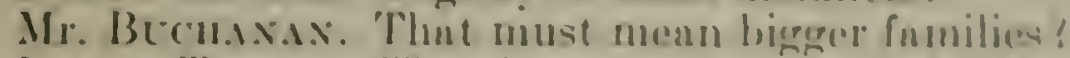

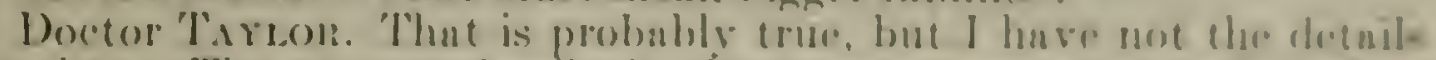
on that. The avernero family in this surrey amounterl to 1.1 whers we took the whole family, but when we conk the whole houschold, including the hired help, it unounted in t.s por family: but it is tho 1.1 thut is concerning us.

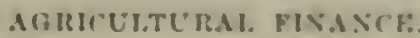

Another busic line of work is that of cupital or ngricultural finance. In this division, in which $\$ 25,600$ is aslical from the lump sum. The topics covered include a study of fire insurunce, hail insurance, and the rarious kinds of crop insurance-the forms of insuranee und the cost of securing insurance of these diflerent forms. Mlso a sturly of the different forms of eredit. Particular attention has beon given to the credit associntions in the various States. Fhere are now $1: 3$ States that have laws providing for credit ussociations. nud there are some 300 credit unions now operating in the Lnited States. but comparatively a small proportion of them among farmers. I study is being made, porticularly in North Carolina, to get the results if what has happened there and to lenrn to what extent credit associations huve been bencficial. Studies have ulso been made and reports published on bank loans, mortguge lonns made by bankers to farmers, and then bank loans made to farmers on personal credits. The attempt in this division is to get together the best possible infurmatiun on questions of credit and insurnnce as they aflect the farmer. "There are muny demands mude upon the men in charge of this work for information and for help by the farmers' cooperative insurance counpunies in the different parts of the country, especinlly ut their unnul meetings, where the representutives of lurge numbers get together and talk over their problems.

\section{COST OF PRONUCTION AND FAlBM OHGANIZATION STUHIES.}

Now, Mr. Chairman, having covered brielly these studies of the instruments that are busic to production we come to the question of cost of production and furm organization, which is the gathering of the facts which are basic as to the right orgunization of the furm. Cinder this heading we are expending $\$ 55,027$ from the lump sum for the cost of production work and $\$ 53,200$ from the lump sum for the farm organization work. While I speak of these two items as separate. ns a matter of fuct they ure very closely associated und the work is being carried on in the closest possible relution, because the major 
purpose, as we see it, of cost of studies is an analysis of the farm business as a basis of better farm organization, although it is recognized that studies in connection with the cost of production and marketing are important with relation to tarlff studies, and the 'Tariff Commission is asking us for the results of our cost of production studies and cost of marketing studies as a basis for some of their work.

Mr. Arofisox. Are these cost of production studies being earried on in the same way as formerly?

Doctor 'TAYror. Yes, sir; the cost of production studies are being carried on in the various parts of the United States, and, so far as possible, in cooperation with the States, so that each dollar we spend on cost of production work results in $\$ 2$ being expended for work in this ficld.

I would like to give you a brief statement of what is being done in the way of cost studies. We are making beef cattle cost studies in a number of places, the cost of fattening beef-cattle on corn farms, the cost of fattening cattle on the pastures of Kansas, and also the cost on ranges. All told there are 750 farms and ranches on which these beef-cattle cost studies are being made.

Mr. Avonnsox. Do these figures show any substantial reduction in the cost of production as compared with, say, 1919?

Doctor TAYuor. A very marked reducton in cost due both to the fact that the feeders are bought at a very much lower figure and to the fact that the feed is very much cheaper at the present time than it was.

Mr. AxDersox. Do the figures show that any considerable portion of the stock on these farms is produced at a loss?

Doctor 'TAYlon. The figures for the last winter are showing very satisfactory profits but the figures for the earlier period, when the feeders had been bought at higher prices and sold at lower prices, and when very high-priced corn was being fed to them, show definite losses, but those ligures, when put in the form of returns for the corn fed to them, simply show that the man did not get as much for his corn when fed to cattle as the market price for corn indicated he might be selling it for, although we recognize that if all of it had been put in the markets the price of corn would have been difierent.

Mr. Axnersox. I have the general impression that the farm situntion to-day is worse than it was a year ago, but if your statement is correct - and I assume it is - that general impression would not seem supported by the facts.

Doctor Thruok. The impression that the farm situntion is worse than it was is based upon the fact that while the elements of cost in the producing of eattle are lower, so that when you figure the relation between cost and price there seems to be a marerin of profit. it is ret. true that the purchasing power of the farmer, hased upon a comparison of the prices of the various things the farmer has to sell with the prices of the things he has to buy, is down in the sixties. The studies ulso incluele farm practices and feeding practices on these farms, so that the studies are not confined simply" to the question of the elements of cost.

Mr. Axberson. To what extent, for example, are the feeding practices with reforence to logers fairly standard?

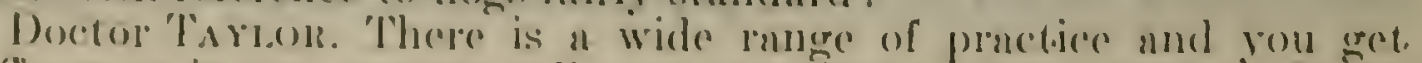
differensers in cost contesponding more or less to those manges. Some. 


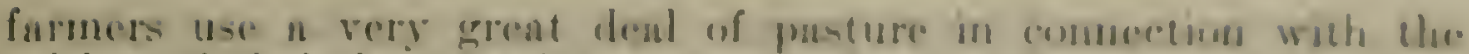

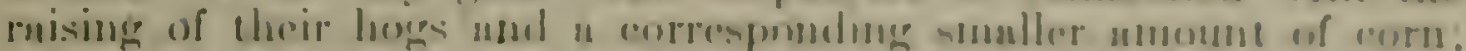

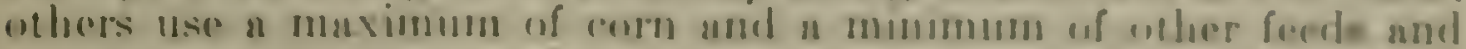

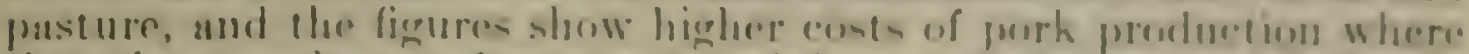

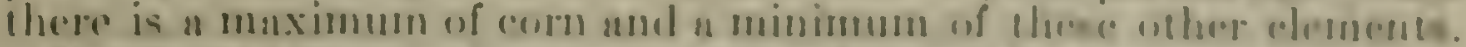

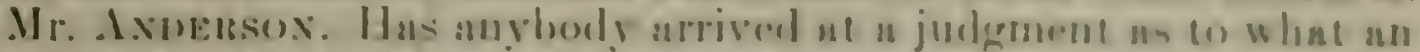

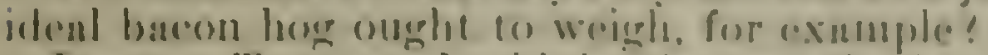

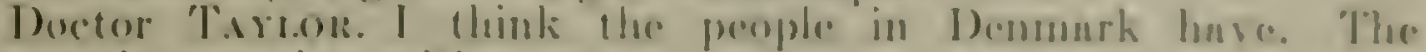

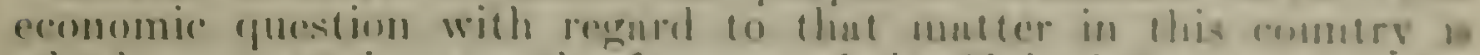

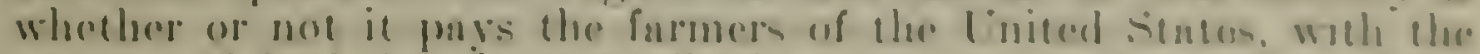

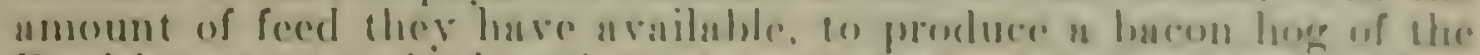

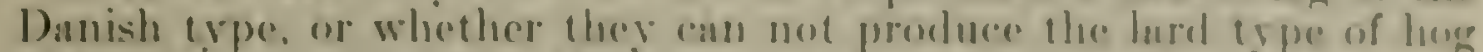

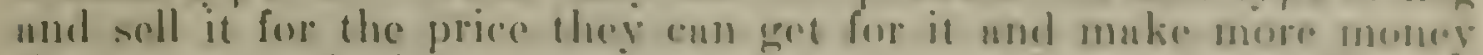

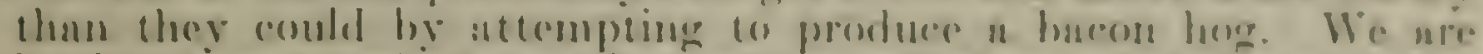
hoping to got hasic ligures here which will show what tho situntoun is in thut regurd.

Studies are being made of dairv farm mameroment and rome of

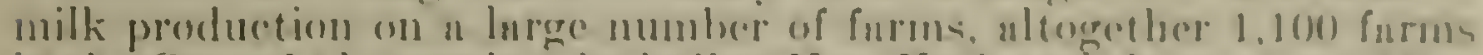

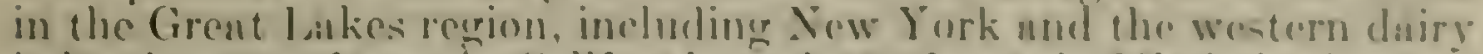
holt: then l60 furms in ('alifornia nnd 200 furms in Mi--is-ippli.

Mr. A.vomisox. This is somewhat aficld, hut is this the itron molor which farm powere studies have hoen marlo?

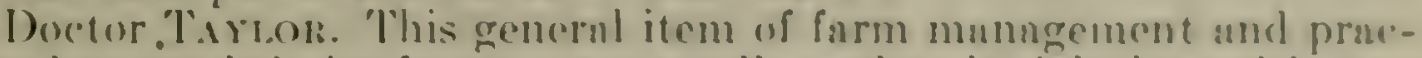
tice has carried the farm power studios that is, jointly- with two other hurenus.

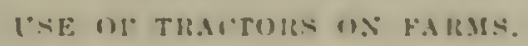

Mr. Axmersox. Have you renched nuy conchusion us to the economical use of the farm trinctor?

Doctor 'Throols. The figures for the Corn Bele and for the Whent Belt show that the aretual eost of getting the work done-the plowing. the pulling of binlers. and work of those classes-is somowhat greater when done hy truetor than when done ho hores on the basis of the price of horses and the cost of feeding that has ofunined in the last two rears and the cost of tructors and the cost of oil. kerosene, and gasoline ns they have obtained in the lust wo yeurs. I comparison, when male. shows that unless there are economies and adrantages in getting the work done more quickly and just at the right time in order to counterbalance this extra iost. it would look as though it were better to use horses.

Mr. Axmkrsox. Is not the situation, as a pructical matter. usually this: I man has about so many horses which he uses, and when he gets a tractor he is not able to reduce his horse power very much?

Doctor Tarton. I believe that one of the reasons why the tractor hos not proved more profitalife to many formers, particularly in the corn belt, is that they need their horses for cultivnting their corn and nt threshing time and that there are too many horses standine idle when the tructor is nt work. We expected. when we went into tho wheat belt, that the facts would show up somewhat differently. hut there they have to have their horses at threshing time, and. as a matter of fact, they huve not redueed the number of horses on the furms us much as would secun to he necessury to reduce the lotal cost where they have tractors. The facts seemi to indiente thut whero they have tractors the total farm power cost is greater than where 
they do the whole job with horses. We asked questions intended to bring out the compensating advantages, but I think the studies we have thus far made do not properly measure the question of compensating adrantages.

Mr. A.Inessox. I suppose there is some compensating advantage in the greater speed with which certain operations are performed, and perhaps the consequent savings in losses of crops due to that fact. Suppose a man has a wheat field that is ready to cut and perhaps it is overready; he might save some loss if he could get at it quickly with a tractor. but I doubt very much whether those adrantages offset the increased cost in most cuses.

Doctor TAYLor. It seems to me that the way in which the farmers have registered themselves on the question of tractors in the last year, and the small number they have bought, seems to check pretty well with the results we secured and published.

COST OF GIROWING WHEAT STUDIES.

Other lines of cost studies that we have carried forward are the cost of growing wheat in the principal wheat regions, including studies of 900 farms, and the cost of producing cotton on 640 farms in specific localities of the different parts of the Cotton Belt, and the cost of growing tobacco in Virginia and Kentucky on 180 farms.

Mr. Axderson. Do these studies derelop any adrantage from feeding grain crops to cattle and hogs as compared with straight grain furming?

Doctor TAYLor. You mean a comparison of that kind?

Mr. Anderson. Yes.

Doctor 'TAYur. In the Corn Belt of Illinois and Iown during the period of very ligh prices for grain the profit went toward grain farming, but during the last two years it has been distinctly in faror of those who were feeding their crops to live stock, owing to the wide difference between the price of corn and the amount of pork or beef that could be produced from the corn. That, of course, depends upon the trend of the prices of the two things, but this is true: in comparing Iowa or central Illinois, for example, experience hus shown that to the extent that the corn is sold the farmers, in the very rich counties of central Illinois, hare seemed to hold up their yields pretty well from year to year, ma by reason of being close to the Chicago market they find it is more profitable to sell their crops.

Mr. Axmensox. 'That is probably due to the freight rates?

Doctor 'TuYor. 'That is onc importunt item, and the reason they can continue to do it is that they have a very rich, deep soil there that will stand that kind of thing for a long period of years. On the other hand, the yield per acre is better in that country on the farms where they have been keeping cattle. 'Take the large farm that used to be owned by Sam Allerton, and owned by his son at the present time. They continued to feed cattle there much longer than their neighbors beculse they were interested in the cuttle business, and yet they finully broke over und commeneed selling corn becnuse it imale them more money, and the yields from their hand are npprecinbly ligher becanse they stayed longer in the onttle business.

It is donftful whother in any of these ases adequate considerntion is being given to the question of permanency of yields and that a too shore time point of rew is taken by the farmers. 


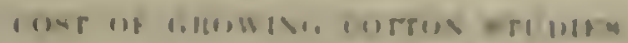

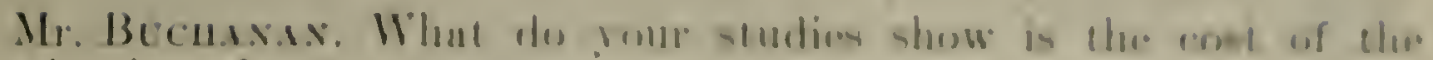
prosluction of roteron!

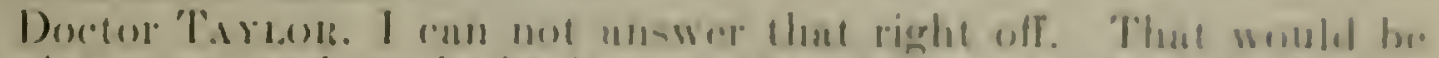

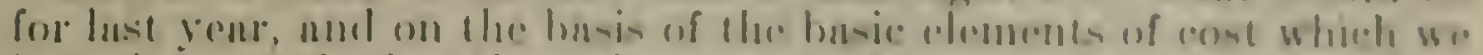

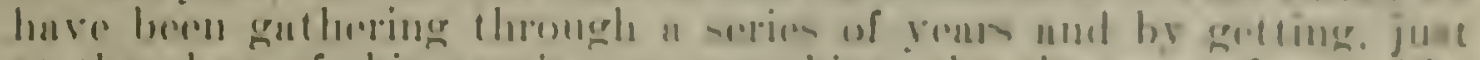

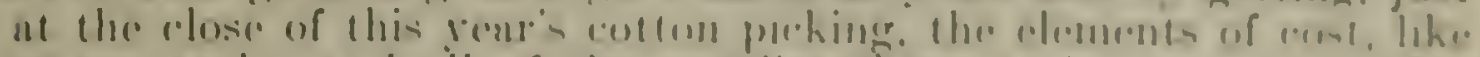

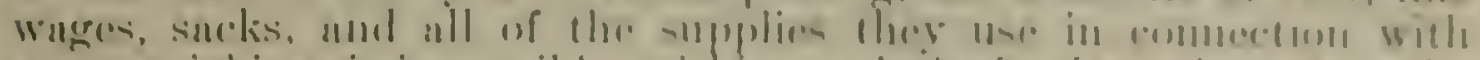

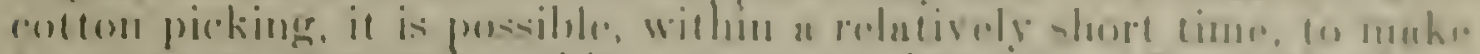

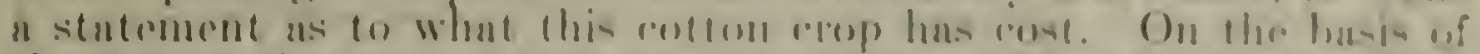

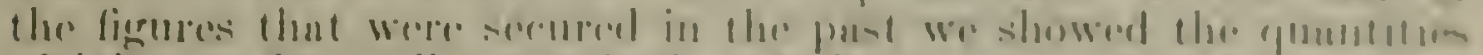

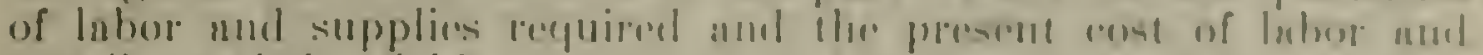
supplies and lhe yidel.

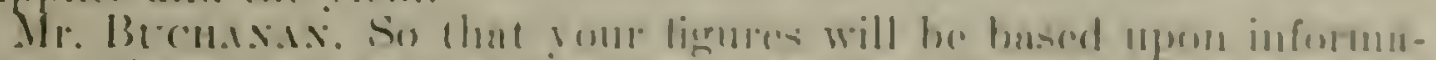

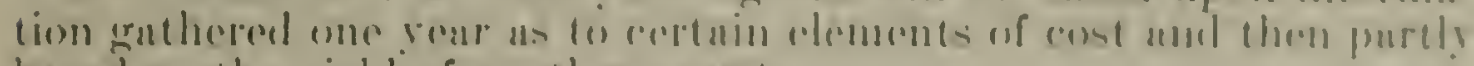
bised on the riedil of anuther rent?

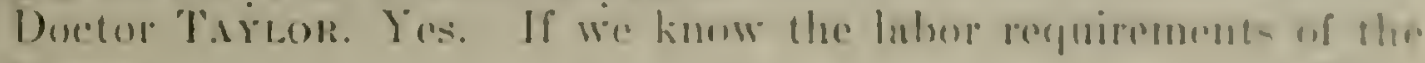
(ल) -

Mr. Buchonax (intopposing). As gou know, in some gram it lakes a great deal more to cultivate cotton than it tukes in others, ncoopling to the seasons.

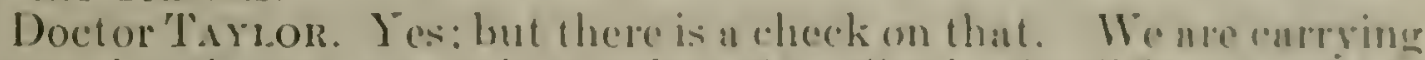
forwned ench yenr a cert nin mumber of studies in the different recrionto give us a line on that. Lutess we can get our busic figures in sinpe so that we enn use them ns the hasis for culculating present (u) - and as a basis for changes in elements of cost the ligures are nlwoys uhl.

Mr. Bucumas. Do you figure wheat on the same basis as collon!

Doctor Tarton. Yes: rach year we figure on the cost uf whentbut $I$ have not the ligure with me although I con get it for you for this past yenr-by the same method.

Mr. Buchasis. If you have figures at the oflice on the cost of pronduction of whent for this yen, cotton, robacco, and any uther stuple commodity you have been investigating, I wish you would put them in the recoril.

Doetor Tarlor. I will be glat to do so.

Trend of production costs for selcided stuple farm products.

[1913 cost per unit eyuals 100).]

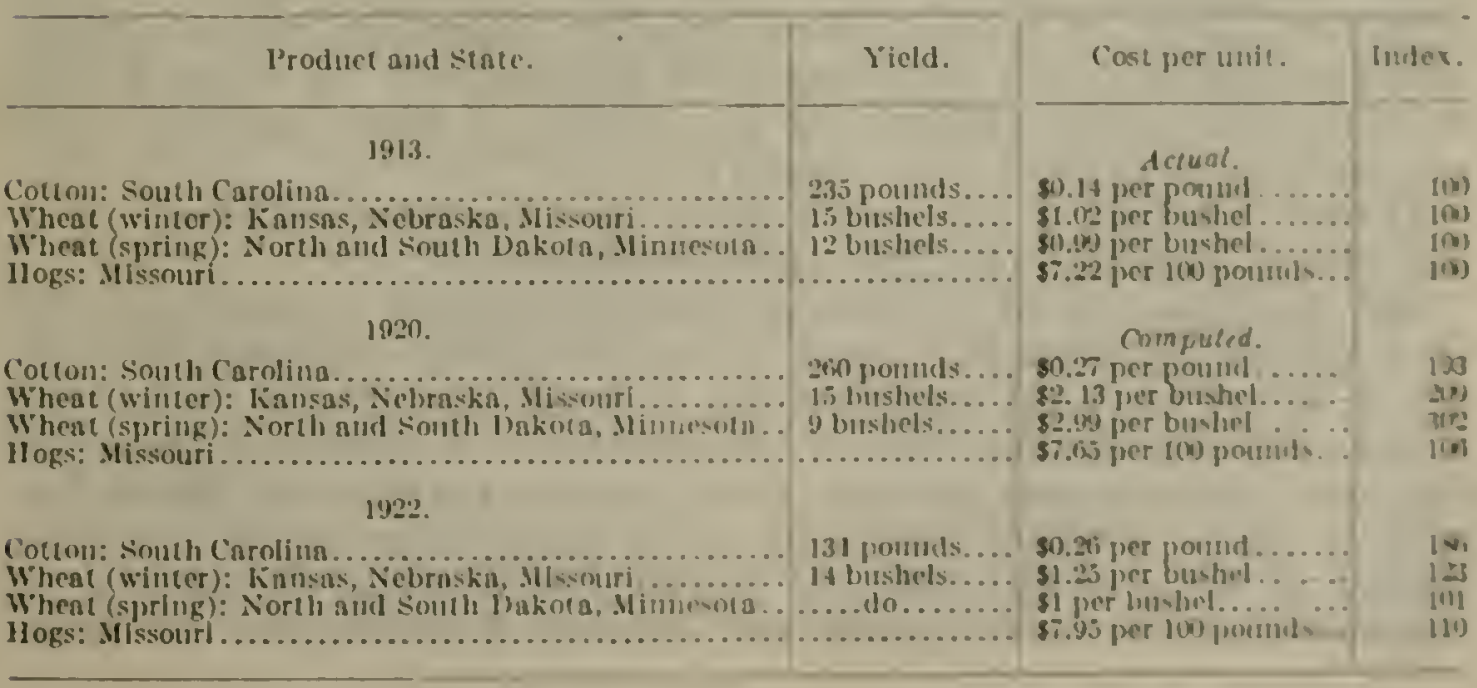


Studies are also being made on the cost of producing rice on 200 farms in Louisiana and Texas, and the cost of producing sugar bects on 200 farms in the State of Washington and on 75 farms in Colorado. Studies this year for the first time are being made on the cost of producing cane on 50 plantations in Louisiana.

Mr. Buchaxax. Sugar cane, I suppose?

Doctor 'TAYron. Yes; sugar cane.

FARM-OPERATIONS STUHES.

Mr. Axpensos. To what extent do these studies cover the cost of farm operations and the farm as a plant unit?

Doctor 'Thron. 'They include a complete statement of the inventory - that is, the land and the equipment - and of the labor that is put in, so that we have a complete statement for every one of these farms showing the total expenses and total income ind then the part of this that is expended upon the particular erop in question, like rice or sugar beets or cane, and the income from these particular crops.

Mr. Axpersos. What I am interested in finding out is this: Here is a farmer who is running a diversified farm operation, feeding cattle and hogs and producing the necessary feed, ete. Now, is the whole operation, the way he is conducting it, a profitable operation or is it not? If it is, does it pay him a return on his investment and a reasonable return for the labor risk and management or does it not?

Doctor 'TAYLor. Well, that varies greatly. There are some farmers who are making very satisfactory incomes in terms of dollars, as good as they made before the war, while there are others now; as then, who are producing at a loss, and you get a very large range in cost from those who show a loss and from those who are getting a very satisfactory profit.

Mir. Axmensox. Are these differences traceable to differences of methods or are they due to a difference in managerial ability?

Doetor 'TaYlor. I should say that fundamentally they ure due to a difference in managerial ability which manifests itself in the way in which he carries on his business.

Mr. Axulisox. Have these experiments been conducted on specific farms for some years?

Doctor 'Thyor. Ýes.

Mr. Andmison. Where these studies have been carried on on one farm for a series of years do they show nuy improvement of method and manarerial ability resulting from the studies? In other words, (1) they tulie these stullies and as a result of them improve their practices so as to get better results?

Dortor 'Taron. I cun not muswer that question ofthand. If I hat Mr. Wileos here he could probably answere it.

Mr. A xursisox. I have assumed that information in regard to cost (an a sperific fam onghte to lead to the climination of waste and the use of hetter methods which would, at least, produce for the farmer at more uniform income year in and year ont. I suppose a farmer is like uny other husiness nim and that there are certnin considerntions.

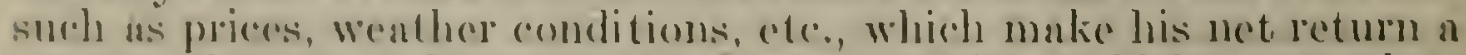
mutter of more or less nps and downs, hut it would be natural to suppese thut the insestignation mol definte determinntion of costs, 
arising from the use of certain practices, would reanlt in a more uniform income for the farmer rather than a larger percentage of return one year and less in another.

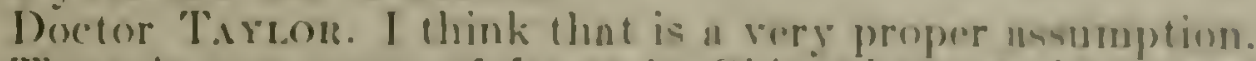

There is ance group of farms in Ohio where wo huse studied the same farms for Sor 10 yenrs. Our objective is not simply en study the cost of production, but the organization of those farma, and we have gone back every year and given 11 demomstration of the reanles. showing the why in which the men were farming who were making the mest money und the way in wheh those men neve farming who are making the lenst money. I have seen letters from men in that recrion making stutements us a the very grent bendit they have receiverl, nnd I think from that rexpion or the Indiann region, where similur studies have ben made, it would be perforely easy to work out a stutement of the progress; but there ure a number of items that have to be taken into account, namely, the trend of affnirs with regard to the elements of eost and the pries the furmers are eretting for their products, which would make it rather diflicult a show stintisticully just how much the farmers had benefited.

Mr. Livmasox. I nm far more interested in this cost of production business from the standpoint of farm organization than 1 am from the standpoint of arriving at an actual or more or less thoretical determinntion of what it costs to raise a bushel of wheat. Such ficrures us apply to the whole country, I assume, would be more or less instructive: but the practical application is that of farm orgnnization and farm management, and if as a result of a series of cost studies there has been no development of farm methods which enables a farmer one vear after another to eret better returns than formerly as a result of better managerial methods, then there is nothing in it.

l)octor Tayzor. What you sny is entirely true, but, us I say, I have not the statistical measurement of that benefit. However, I have no question about the benefit and the benefit is not simply to the farmers on our farms; the records are kept and analyod and this material is the basis for the educational work carried forward by county agents for the benefit of all the farmers in a community.

Mr. Buchasis. No proper study of cost production could be made unless based upon proper form manngement. 'They go hand in hamd; they are linked together, and no cost of any stundard commodity would be of any ralue unless that cost was computed upon the basis of proper farm management. The fuestion is: What ought these things to cost to produce under proper farm mantugement? They have got to go hand in hand to be of any value whatever.

Doctor Tirzon. You will be interested to know that in the study of the rost of production of cotton, in Sumter comnty, Gas. for instance, the cost was found to be very different on different farms; and the pratetiees different on different farms. For instance, the cost of production of eotton was less on farms where they were producing more velvet bens and more hogs and had introdured these other elements.

Mr. Becmaxix. That is all true: but the question is what is the cost, the avernge cost, of the production of a pound of eotton, under proper farm munagement, farm orennization, or what does it cost 
to produce a pound of cotton or a bushel of wheat under proper conditions, the average cost throughout the United States, under proper farm management and farm organization. Now, that would be a valuable fact.

Doctor TAYLOR. We are trying to ascertain that, and also what would be the proper type of farm management. I take it that that is in line with your remark.

Mr. Buchasax. Yes; so that they can improve their methods.

INVESTIGATION OF MARKLTING AXI IUSTHIBLTTIG OF FARM PRODCCTS.

Mr. Axpersox. We will take up the next item on page 275 , "For acquiring and diffusing among the people of the United States useful information on subjects connected with the marketing, handling. utilization, grading, transportation, and distributing of farm and nonmanufactured fruit products, and the purchasing of farm supplies," etc.

Doctor TarLor. I shall ask Mr. Tenny to present the statement on this item.

Mr. 'Texir. This appropriation corresponds somewhat to the one that Doctor Taylor has been discussing. in that it is an appropriation for the study of the whole ficld of marketing and distribution of firm products:

There is an apparent increase in this appropriation of $\$ 79,220$ : but due to the transfer of eight employees to the statutory roll with total salaries of $\$ 10,780$, there is an actual increase in the it $\mathrm{cm}$ of $\$ 90,000$.

PRORIRES: OF WORK.

This appropriation is used to cover the resenreh study of the processes of marketing and distribution. beginning at the farm and movine through to the terminal markets. or practically all of the work that is done in methods of marketing. The work that is done in studying the costs of marketing. and practically all of the work that is done in standardization of farm products and live-steck products, is done under this appropriation. This is chiefly a research fiedd, but the language of the appropriation is sufficiently broud, so that in connection with tha extension sorvice we do a considerable anount of extension work also moler the appropriation. 'This work is divided into a number of rery well-defined projects, and to get the story of the whole appropriation it is necessary to take up the individuial projects.

"The first one is entitled "Cooperat ire purehusing und marketing." There is no change in the amount of the allotment that we are proposing for this project. 'The nature of the work in cooperative markinger as I think was brought out hast gear, has been considerably changed within the last two gents. and now we are devoting practically all of this allotment to what might be termed economic studies of cooperative marketing.

These studies took the form first of an investigation of the locenal phases of couperative marketing. and that work has been carried on and brought, pretty nenty (1) a couclusion, with a bulletin that han just reenently beon published on the lewal phases of rooperative ascereintions. There has been a very wide demand for this bulletin, 
and I anticipate that in spite of the face that it las loren insued only six weeks, we will be out of the printe in a very shore time. Thís

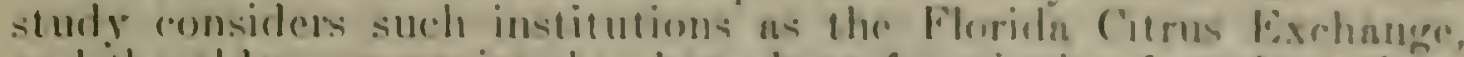
and the older companies that have been fonetioning for a long time. and the cooperative methods used in theil orgunization.

This study will be contimed so that so far us the legal phases are concerned, we will hase a very complete set of fares amil a vers good

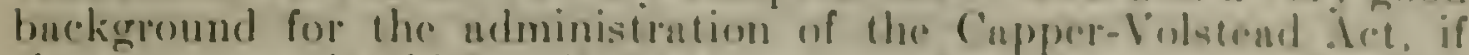
the sereretary should find it noressury to take noy netion unerer thas lıw.

Mr. Axprasos. To what extent me the various States enareing speconl laws which cistablish the learnl contity of these conperativen und lie liabilitios of the mombers?

Mr. Troxy. Why, I shoutd say that during the last three years approsimntedy 20 states have pissed now lecpisation delining the ficld of cooperative marketing associations. Many of the other States had satisfuctory haws prior to that time, and, as I recall, there are only a rery small number of States now that have not geod hase laws for the operation of eopperative usserentions.

Mr. Becmaxax. Do those laws excmpt the imblividual members from individunl linbility?

Mr. 'Trisy. You mean state the huties of the nssociations?

Mr. Buchasax. Are they put on the same basis as corporntions?

Mr. "Texis. Yes: practically.

Mr. Buchasas. Itith a corporation, individual members are not individunlly responsible for the acts of the corporation. What I want to know is do those laws exempt the individual menbers of the cooperatives from individual liabrility?

Mr. Traxy. Yes: in pructicnlly all cases, especially the newer laws.

The second line of sturly being instituted under this cooperative work is what might be termed "economic study." We are collecting information regarding the $100 \mathrm{or}$ more outstanding suecessful conperntives, and by "outstnding" I imply especially those that have been operating for a comparatively long period. Ind we are getling a great denl of valuable information regarding these ussociationswhether they are stock compmies or nonstock companies: the number of members that they have; the ammual turnover; the kind of contratet that they have between the member und the nssocintion: their sales policies and methods of financing: and all other factors that enter into the successful operation of their business.

We are colleceting that, first, by correspondence: but we are taking a few, as the men are able to take them up. and makine a very careful analysis of them and publishing these individual studies.

The first one is on the press now, and that is on the American ('ranberry Exchange, which is an old organization. We have male a very cureful economic study of that organization. us to how it functions over a period of years and what it has accomplished, and I feel that these individual studies will be of rery great assistance to other people who nre interested in organizntion work.

1 second sturly is now being put in final form. that of the California Fruit Growers lixchange. ('alifornia. That has operuted for 20 years, or thereabouts, doing about $\$ 25,000,000$ of business anmally. And just as fast as wo (an we want to take up some milk-marketing studies, some cooperative tobarece and cotton assorintions. livestock associations, and studies covering the entire agricultural fieled. 
STUDY OF COOPERATIE ASSOCIATIONS.

In connection with this project we are making for the first time in the history of the department what might be termed an associative statistical and historical study of cooperative associations. Emphasizing what Doetor Taylor said in the beginning by taking advantage of the consolidation, we use the crop estimate people in collecting these data. Through this organization we have people in practically every town in the Lnited States who have sent us the names of every agricultural cooperntive association in their district. We got about 35,000 names from these reporters. Then we circularized those, and we reduced the number to approximately 10.000 by elimination, where we found any duplication-where locals are branches of centrals, and so forth-so that at the present time, we have a list of approximately 10,000 associations in the United States. That work is not completed, and we do not feel that that is necessarily the total number. And then we are getting more information reiarding the amount of business that these associations are doing, and other information of that character.

The third project that is also economic, under cooperatire marketing, is the study of cooperation ahroad. We have had a man for six months in Denmark studying the big developments of cooperative marketing in Denmark.

Mr. Axpersox. That is about the eighteenth time that has been done.

Mr. Texry. It has never been done by the Department of Agriculture.

Mr. Anmersox. It has been done by a lot of other people.

Mr. 'Texvy. The changes in Europe especially in connection with cooperative marketing have been very rapid since the war. That would apply more particularly to the other powers in Europe than to Denmark, hut it applies also to Denmark.

This economist is now in England finishing his studies of the relation of the English market to the Danish cooperative morement.

Mr. Axinnsox. Is he studying the cooperative buying organizations in the labor unions?

Mr. 'TENTY. No; simply studying the distribution of Danish acricultural products in England.

Wo have also hat a man working on information a vailable recrarding cooperatives in Russia. He spealks and reads Russian fluently, and has been ahle to gret a great deal of valuable information through so that we are actually getting a very up-to-date picture of the cooperative morement in Russia.

Mr. Bucrasax. Do you think that you can get any information from linssin!

Mr. 'Tkxy. Russia has some of the very laterest cooperative movemonts in the world, and it is the eonerinsus of opinion now, eren among Rossians, that the cooperative movement has heen the one thing that has hedel Rossiat forrether even to the extent that it has

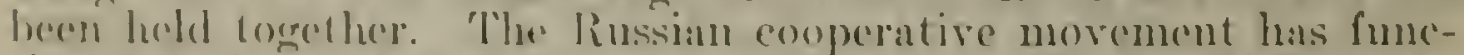
tioned during practically the entire time of the Russimn difleculties.

Mr. Burmaxis. It mist he al good one. then.

Mr. Thasy. I think that will be suflicient for those projects unless there ure somo questions. 
Mr. AxDERsos: Well, this conperative marketing an Ru=ia, I nhe it, is not the Bulshevik movemont ut ull!

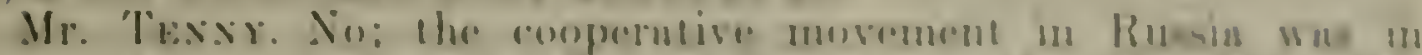
existruer long hefore the Bolshevik gevermment. 'The Bul-hersh

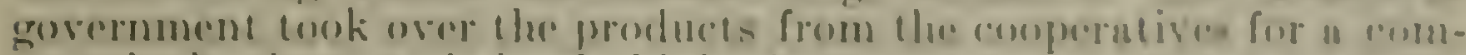

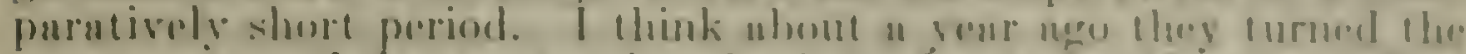

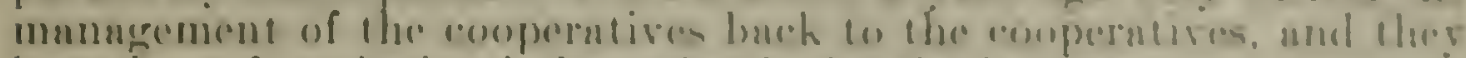
have bern functioning independently for the lant sent.

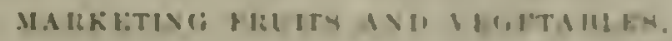

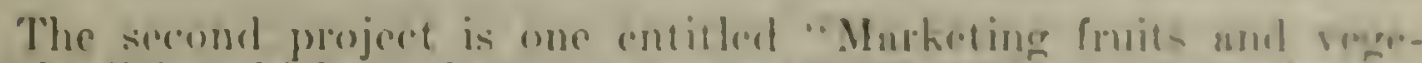

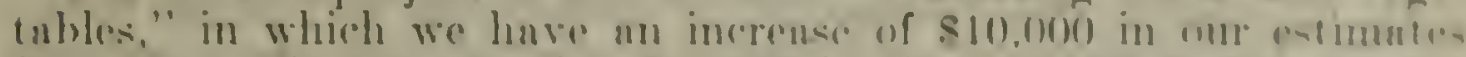

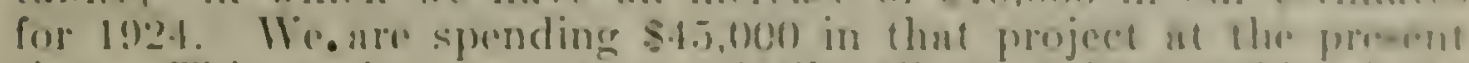
lime. This project corers practionlly all, as I have said, of the

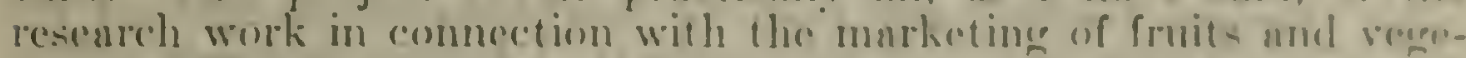
tables. This hos been largely in the past resenreh work on stumbroli-

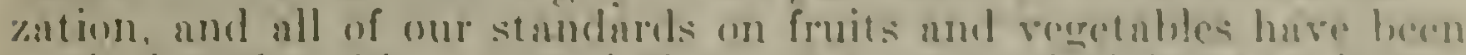
worked under this appropriation. A very murked incrense in the

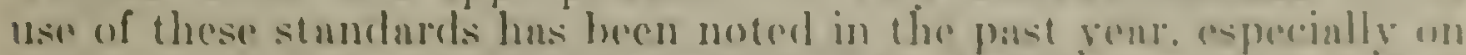

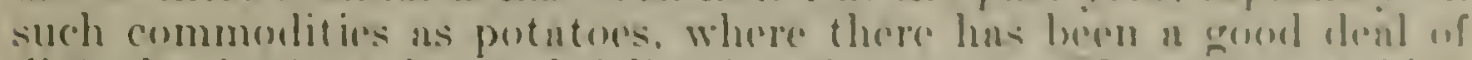
difleculty in finnncing not delirering the crops. Wo me now asking for the increase lareoly for the ecomomic lines of work. Wre ure making a complete pieture, of the hundliner of a mumber of our fruits and regetnbles from the producer to the consumer, study ying especially such questions as in one particular ense, the use of the publie auction. We are in that conse making complote studies of all phases of the auction trate in the larger cities: the relation of the aucion and receipts at terminals to the finaneing of the crops and methods of finnucing in their relntion to the metheds of markoting. with the iden of ultimntely having a very clenr picture of all of the thines involved in so far as we nre ahle io work them out in connection with our hig fruit and regetable crops.

Mr. Axdersox. 'To what extent does this study enlighten you as to the terminal-handling situation?

Mr. Texry. In this particulnr project we are not spending a great deal of money in connection with the terminal handling. In cooperntion with the farm people we are studying finnnces. In this project we are in Boston, New York, Philadelphia, especially, and also to quite an extent in Washington, studying terminal fucilities and terminal handling. 'That is largely being financed, however, through the cost of market studies.

MARKET PRICES AND TILASPORTATION.

The fourth project is market price trends and transportation. I am omitting the costs of marketing and will come back to it. Wre are now doing the same work that we have been doing in the nuture of service work for the rest of the department in that contrncts must be made with a large number of railrond people in order to get the information that is needed for market morements and market prices.

In connection with our live-stock morement, which is being developed to a much greater extent than it has been heretofore, our transportation man is now in the field making those contracts to get the $22025-2:-26$ 
information that is needed with regard to the morement of lire stock and lice-stock purchases. We have also undertaken during this year some increased work on the relation of trunsportation to agriculture. We are getting, of course, some very marked changes in agriculture in different parts of the country, lue to the increase of transportation charges, so we have selected one man, a trained economist. to derote his entire time and attention to these studies on the relation of the change of transportation rates to agriculture.

There is an apparent decrease of $\$ 2,500$, or thereabouts, in this, but there is a transfer of two statutory positions that will make the same allotment for next year that we have for this year.

Mr. Axmensos. Are you able to get enough data with regard to the relationship of prices to transportation and location of agricultural products to arrive at conclusions?

Mr. 'Texwy. I would say that the work has not progressed far enough yet for us to determine that fact. I believe that it is safe to say that a considerable amount of data can be made arailable that should go a long ways toward answering some of those questions.

COTTON HANDLING AND MARKETING.

"Cotton handling and marketing" is the only cotton project in the bureau in which we are asking for an increase, and in that there is an increase of $\$ 10,000$. This is the item under which we aim to hare a campaign on "know your cotton." through cooperation with State extension services. We have a large number of groups of farmers in the various parts of the Cotton Belt that employ a grader themselves. We cooperate with them in selecting the grader and in secing to it that he does grade the cotton and give the staple on it according to the United States grades. This is a means of training the farmer to know the actual value of his cotton.

Mr. Buchinay. 'To know the value of his cotton?

Mr. Texsy. 'To know the value of his cotton, and we think that with the big cooperative mevements in cotton, whether they are successful or whether they do not suceed, the farmer must know what he is producing and the value of the thing that he is producing. This also goes back to the point of showing where our marketing work links up very closely with our productive work.

Mr. Bechasan. Let nie ask you one question there. Have you ever given any thought as to whether or not the department oughit to make stuple in essentinl ingredient in its grades instead of making it soldely upon trash and color of cotton, or foreign substance and color of coitton?

Mr. Trexy. That matter, of course, has been given very careful consideration.

- Mr. Buchavax. Staple is the most valuable element in cotton.

Mr. 'Texsy. But, of comse, cotton is sold now not only on its grinde but on staple.

Mr. Buchanas. Yes; cotton is sold on staple. Now, the buyers have boen buying from the farmer, distegarding staple and buying the ecoten on the color and foreign matter in it. By that method the farmers have been beat out of millions of dollars, the cotton farmers. temunt farmers and othors. I can name a lot of them right now that hase been beat out of a lot of money. They are getting wise to it 


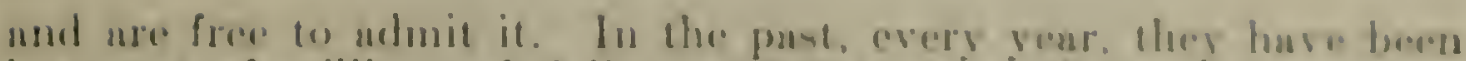
beat out of millions of dollurs and they kiow it, and the rotton buress are berenting rich at the farmess expente.

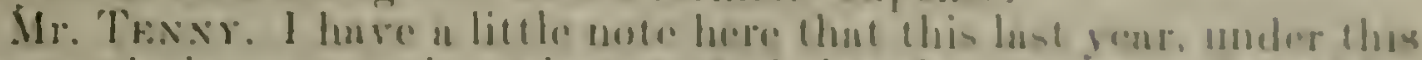

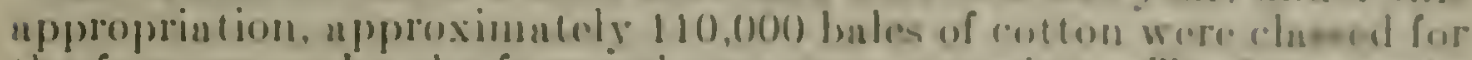
the farmars, or by the farmers own representutive. The incerente in price to the furmer in marketing. not only aceording to the grade of their cotton, but by staple, which they do now moter thes methed

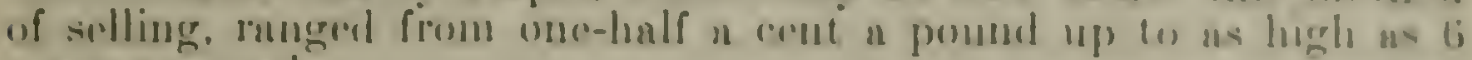
conts $n$ pumal.

Mr. Axmassox. How and you determine that!

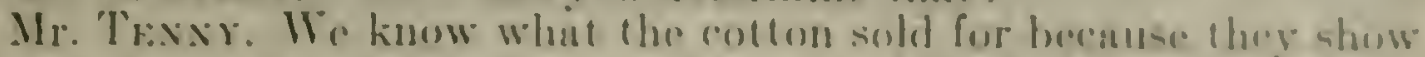

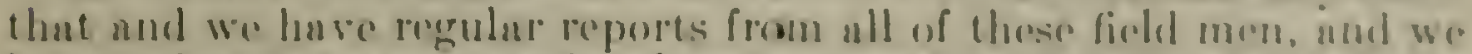

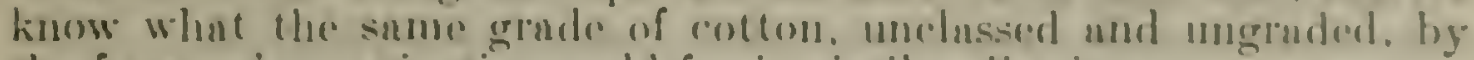
the farmerse organgalions sold for in imilar distriets.

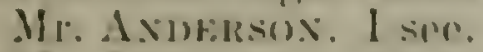

Mr. Bechisas. Not wuly that, but the farmers pertanpe have hat their coten elassol and then go around without lesting the husers know that they have hat it chased, and ask the bugres what they will give them for it. 10 make them a price, and then ifferwarde they will sell it at this higher prices, after letting the buyore guote them in price. They have bern swindlod for years and years on that.

Mr. Texir. There is no question nbout the truth of that.

Ilr. Becomis. Ahiolutely mot.

WFATHFIUNG AND HANDLING OF COTTON.

Mr. Thasy. The second study that is being conducted under this project is the wne on weathering and handling. So much of the cotton is hnolled at the production points, especinlly, witlout warehousing facilities, that we are anxious to know not only the physicul loss. but what spinning losses nre.

Mr. Bechasax. Well, you have a great many facts on that already, because in pust years you have been giving that considerable study:

Mr. Texir. But we are still conducting those experiments and especially emphasizing the effect on the spinning quality of that cotton.

The increase will be very lurgely used, if granted, in studying the economics of the cotton murket.

The cooperative morement has progressed rery rapilly throughunt the Cotton Belt, and we desire to get a complete picture of the cinton marketing and the place that the cooperative is pluying in it ut the present time and that it proposes to play in it.

Mr. Axmensox. I do not know very much about cotton, but where these cooperntives hundle considernble quantity do they sell on the exchange or do they market direct to the spinner?

Mr. TExxy. They market direet, not only to the spinners. Imu to the cotton faetors. "To the best of my knowledge, they do not sell a pound of it on the exchnnge. 


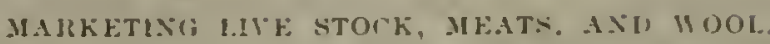

"Marketing live stock, meats, and wool" is our next project. There is in this project also a small increase. The marketing work in live stock has progressed very rapidly during the past two venrs. It has been a tremendous task to arrive at the grading of live stock and live-stock products, especially the meats. This work started with the meat end of it - what constitutes the higher qualities of meats-and from that end has worked back to the kind of animal that produces that meat. We are now getting the manuscript in final form to put out these first statements on the grades of live sturk and live-stock products.

'The same thing is true with wool. We have for the last three years done a great deal of preliminary work on wool grading. Te ire now having public hearings in connection with our tentative wonl erades. We had two public hearings on this last week. At the hearing in Philadelphia on Thursday of last week the fact was brought out that we must do some additional research work. is there was a very strong demand there for the grades to show, at least, the English Bradford count system. Inasmuch as 60 per cent of the wools that are used in this country are imported, they felt that it would be very greatly to the adriantage of the American wool industry if the same grades could be adopted for at least the mill end of the business in this country.

Mr. Avmersox. What is this Bradford count system! What is it the busis of?

Mr. Texry. Theoretically, it is based on the number of hunhs of garn that can be spun from a pound of wool. That idea. howerer, has been largely lost, and SO's will actually not spin $S 0$ hanks of yarn, but the wool originally classed as SO's is still called SO's. The system runs from about 32 's up to 90 's, the coarser yarn being 32 's and the very fine yams being about 90 s. We recognize that the English system probably would not do for the producing sections, but we are in hopes that they will at least try the arrangement. 'The suggestion was made by the mill trade that we can bracket certain of the erroups into fines, quarter-bloods, half-bloods, three-eighths, and so forth. so that we can have a comparison between the grades suited to the needs of the mill, which are very complicated and which rery closely rescmble those of the English system, and the grades that the producer's know now.

That is going to require some little additional work before we are realy to put out our tentative grades of wool.

I might say in connection with our live-stock work, we are really hoping that the grades of live stock enu be so specifie that buying and solling mey be done through specifientions as well as through personal inspertion. A mumber of cooperative associntions in the enstern half of the United States that buy large numbers of foeders every your, eren during the last year, bought their feeders on specifications. and they have been entirely satisfied with the practice, nud of course. it sared the tavef exprenses and salary of a man eroing out into the western ranges and selecting the feeders for finishing work in the east.

We are also doing a great denl of work in the field of retailing meats, some in cooperntion with other ngencies and some of it indeperidently. 


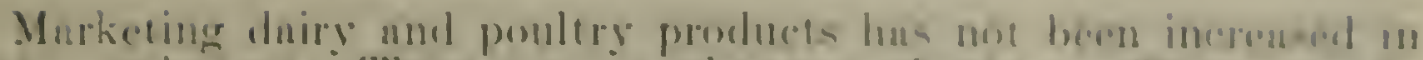

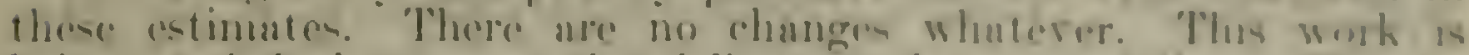

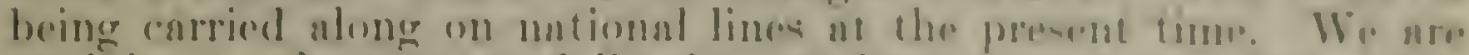

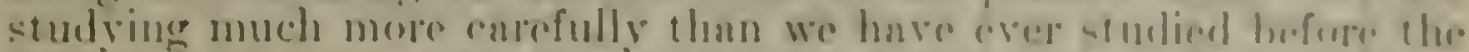

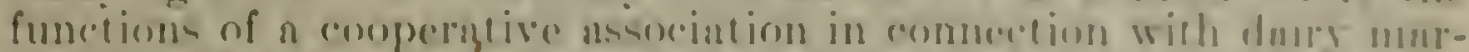

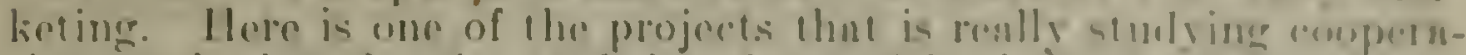

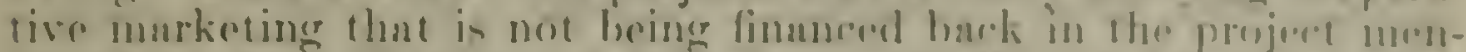

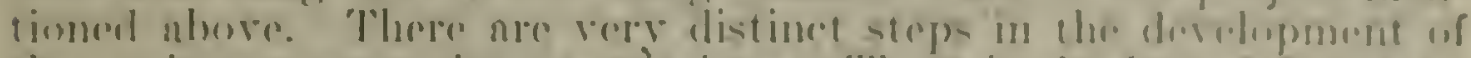

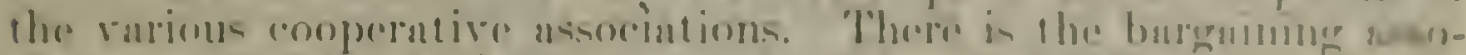

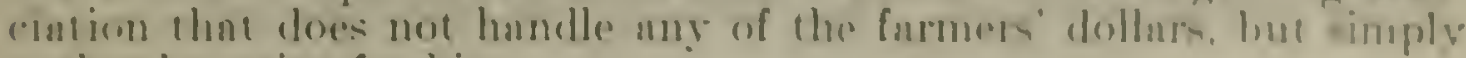
make langrains for him.

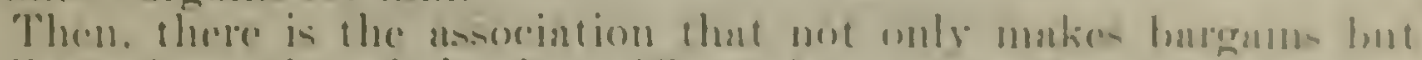

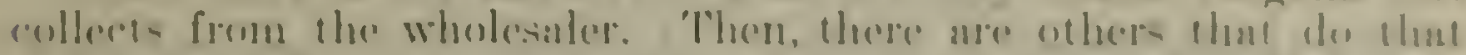

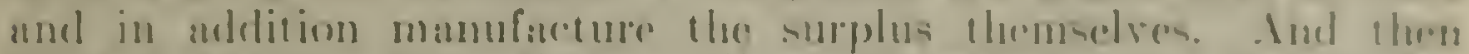

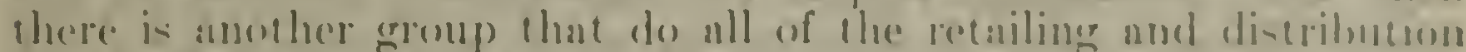

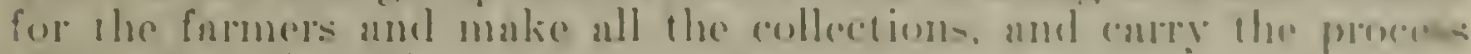
alt the wa! thromgh.

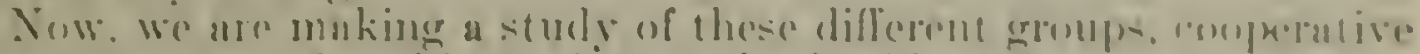

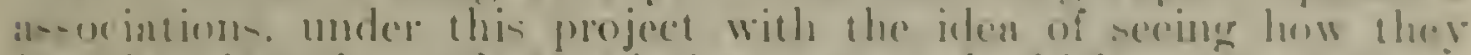

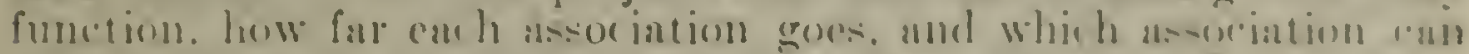

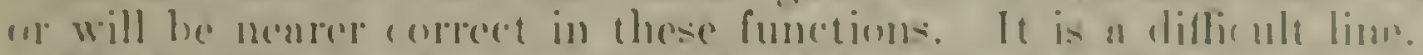

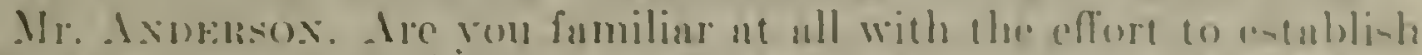

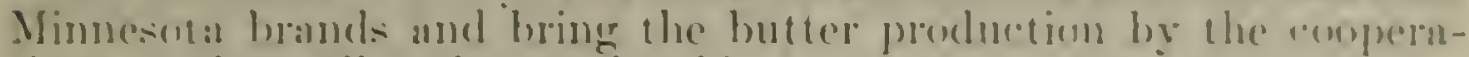
iives up there all under ons hend?

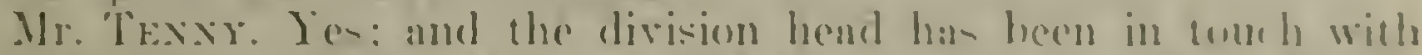
these peop)le. hus heen out there and had a mumber of ronforemens with them, and l think has hecn in Now York alin.

Mr. Axnsssox. Are they making any hendwa!

Mr. Tr.s.s. I have not hened a thing about it for the last three (1) four months. I am not sure whether that is going through or mot.

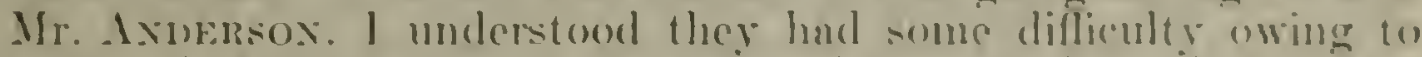

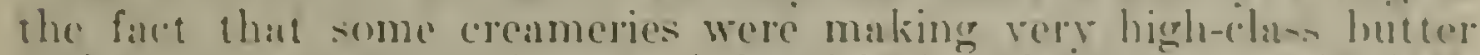
und gotting a promium for it, und they folt ilat if that was d:ablished. the effect wemlel be their premium tis the arerage of the whole state. That was ane of the retarding inlluences.

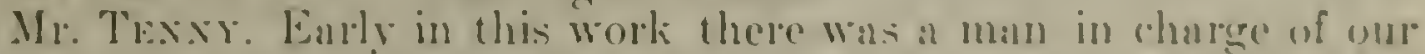
dairy marketing division who was stronery impressed with the idea that they (ould not attempt to actually soll in New York. hut that

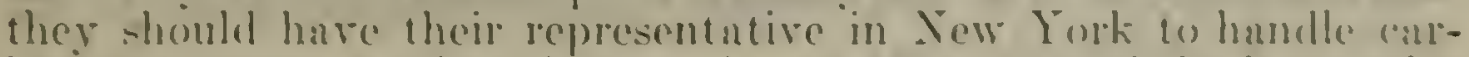
lonil shipments. so that they would get advantuge of the latrere sales operations and then ihey (ould still have the adrantage of the different concerns, in case there was nny preminm. Lut let the actual solling of the lutter come nlong as a lnter clevelopment: but at that timo there was yuitr an element in the associatums wut there that wore not satisfierl without going the whole way.

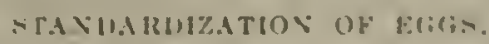

We have been doing much work in the last rear in tho stambaldization of ecress. Very little work has hoon done up to this last rear on that. but this reat we have done a ereat ileal of work on tho

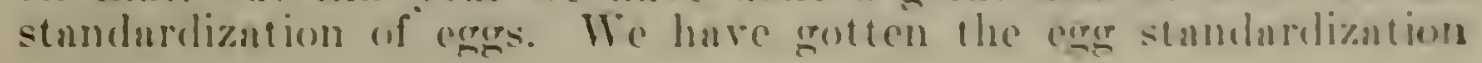


work to a point where we liave been able to grade eggs by our tentative standards. Under a cooperative arrangement made with the State of Missouri, a number of egg graders are employed by the State of Missouri, but under our general direction, as our grades are being used, and 90 carloads of eggrs were actually graded at the rarious shipping points in Missouri. We were thus able to tell how the tentative grades worked out, and we have found that they worked out satisfactorily under commercial conditions. We want to continue that work and go further with it, and see just what the additional processes involved are in carring those standards for egers through to the terminal markets. That work has not been done yet.

MARKFTING OF HAУ, FEED, AND SEED,

The eighth project is entitled, "Marketing hay, feed, and seed." That project is increased this year in our estimates due to the very great demand to the markets for the standardization of hay. We have been working on standardization of hay for two years and have completed standard grades on timothy, elover, and clover and timothy mixed hay. Hearings have been held in the last three months, and beginning with the 1st of January, nearly all of the large hay associations in the eastern terminal markets have agreed with us to present to their membership, with considerable assurance that it will be adopted, the plan of having hay sold in these big terminal markets according to United States standard grades.

So while we have no compulsory grading law on hay and are not asking for any, we feel that the grades on hay are going to be adopted almost universally in a comparatively short time.

All of this work has demonstrated the need for additional work on such hay as the western hay, alfalfa, particularly, and wire grass hay, of the liest, but the appropriation up to the present time, has allowed only for that being done on timothy, and that must be continued. We must do a great deal of work also in getting reindy for our hay grading classes, because all of these eities will employ, jointly with us, official hay craders, so that the hay will be graded aceording to the United States standards.

Now, it takes about five weeks to train these men in grading hay. according to United States Standards, and it requires a great deal of hay to use in their laboratories.

Mr. Anderson. Are you making any investigations as to the marketing conditions of hny?

Mr. 'Thasy. Yes, sir.

Mr. Axmersox. I have heard a great deal of complaint.

Mr. 'Trexy. I do not have them with me, hut we have two or three bulletins on hay marketing that have been very well received indeed.

'This allotment is nlso incrensod with the idea of doing some little work on the intprovement of the foed market. 'There is at great deal of interest in the standardization of feeds and the standardization of methods of selling ford, and the human aspect of it, and they are very important in addition to the biologie aspeet which we recognize should be taken cate of by Plant lndustry. 
The next project that is scheduled in the book in houmn ws "Mar-

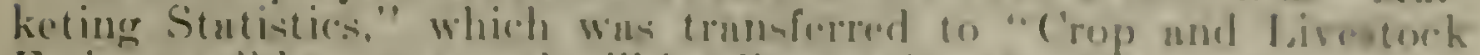
Estimutes." last year und will be dincused under thut approprintion.

HAILATIVG INIGILUTION.

The next item is entitled "Market information," \$17.0001, whele in just the snme as last yenr. There is nn nppurent dererense of s:3.000),

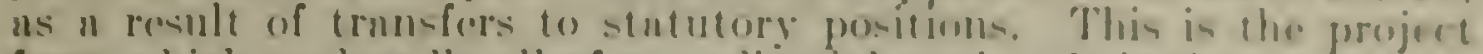
from which we handle all of our editorial work. It is simply routine work in comncetion with colitorial work in the hurenus.

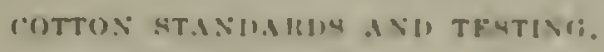

"Cotton standards nud testing," is the next itcm. This really should be merered with the other projects on cotton, an it is administered nll in the sume division. Tt is the enontinuntion of the work that we were discussing there. One of the things that has heen studied, for instnnce, under this projoct, is the possibility of improving the sumpling of the bale, or the classing of the bale, hy tnking -nmples nt the grin. The busis of this work is checking up, really, the mothod of taking samples from the bale, and we are finding that it is possible to get a more aceurnte iden of what is in the bale if it wore possible to grude it at the gin.

Mr. Brocusax. Further than that, it prevents a great deal of los.

Mr. Texsy. Yes, sir.

Mr. Bermaxax. The practice of ripping a bale of eotton that lone [indicuting] and tenring out two or three pounds not only renslis in the loss of cotton, but a lot of foreign substance gets into it, and causes that much tare. I belicre, or loss.

Mr. 'Texyy. Ies. This work is also the line of work that we do in cooperation with Plant Industry in the production of new varieties of cotton, where our burenu eonducts the spinning tests on those new varictics.

As I think we announced last year, work was started on new standards for cotton, certain groups of new standards. Those will be effective in August, 1923.

We are making spinning tests also of ull those new stundardis and determining the percentuge of waste or loss in the different stundards.

STATE: COOHEIRATION IN MAIRKETIAR WOIRK.

"State cooperation in marketing work," is the next itcm. Is I outlined a yenr ago, our program in this project has changed rory materially. Originally, this was a project for the employment if joint ngents in various States. The iden of cooperating with mon did not prove successful, and. therefore, we hegan about is menthe ugo to change this orer, nnd wo are now conperating with the States on projects. We ure entirely sntisfied with the me arrangement. That project is conductiol rery laresely in conpremtion with our other projects. It covers resenreh nind extension work especially. It gives us a fund from which we onn make experiments where a State munifests n desire to conperate on some one of our 
rarious projects. Now, that may be in the cost of marketing: it may be in a study of terminal marketing. such as we have in Massachusetts: it may be a question of standardization of tobacco, as is the case in about six of the tobace States. where the States are very much interested in the continuation of the work and where we have a special fund that we can cooperate with the States on those various projects. I do not think that it is necessary to go any further into that, because it is not a project by itself any inore.

\section{GRAIX INVESTIGATIONS.}

The next is "Grain investigations." which is the last of these, with the exception of one which was transferred to Plant Industry last year.

Standards have been arrived at for corn, wheat, and outs. That has been done in the past. Standards for flax and rice are being worked on, and they are practically completed. Standards for ree and harley are also being developed. That work is all of our standardization work.

Our research work is paid from this appropriation. In addition to that standardization work, there are three lines of work that we have given special emphasis to in the last year. One is the grain cloming work, and if you do not mind looking at these samples. I would like to have you see the results of this cleaning work. This [exhibiting sample to committec] represents on the left the wheat as it was originally threshed, and it has been sold through the channels of trade in practically all the Northwest. So, our idea has been to derolop a cleaning machine which ean be attached to the thresher, working automatically with the thresher. The second sample of wheat shows what is accomplished by the eleaning method, and the other two small squares show the material that has been taken out.

Now, those three different types-you will notice the information at the bottom of this one [indicating] that as the wheat has been threshed, there is 9 per cent docknge on which freight was paid, and on which all the marketing processes were paid. After using the clenner, that dockage had been reduced to less than 1 per cent in this particular sample. The percentage of foreign matter in this sumple [indicating] is reduced only slightly. The totul foreign matter before cleaning in this sample [indicating] is $9.6 \mathrm{per}$ cent. The total forcign matter after cleaning is 1.3 per cent.

Now, on the basis of these. and on the inspections that were made in Minnesota inspection points, we have estimated that in the course of the year 1921, 9,500,000 bushels of foreign matter entered into commerece.

Mr. Axmensox. What is the effect of this cleaning on the grain. on the whent?

Mr. Trovr. Woll, up in the right-hnnd corner, you will notice the chanere.

Mr. Axmerson. I see. That is what I was looking for.

Me. 'Troxy. In this particular sample, after cleaning, No. 1. which woighted is $\frac{1}{2}$ went up to 5! pounds. Often it rases the grade.

Mr. Bucusas. Ordinarily, what is the difference in price between No. 2 and No, 3 whent!

Mr. Traxy. The difference in price between No. 2 and No, 3 whent nveruges between 2 and a cents per bushel. 


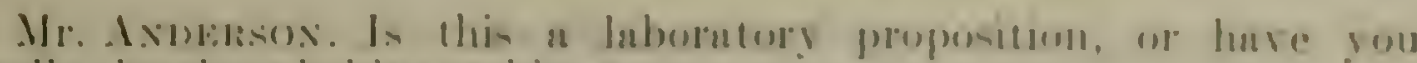
renlly developed this mochine!

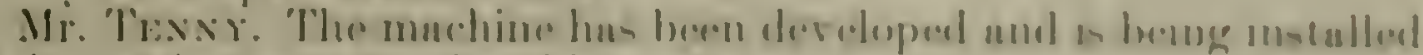

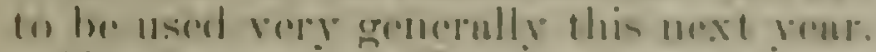

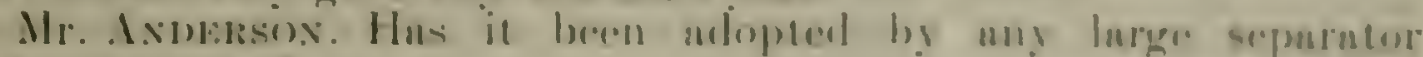
monnfacturus?

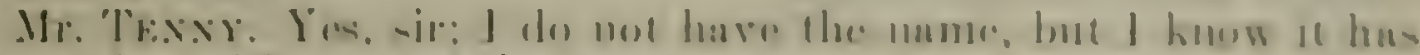

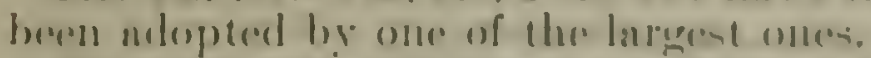

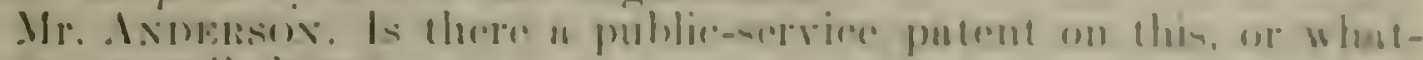
r.er rom coll them!

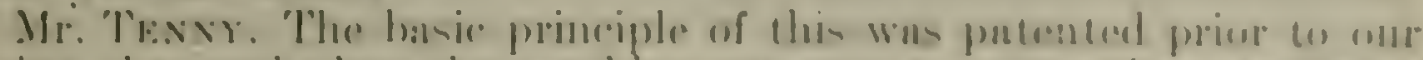

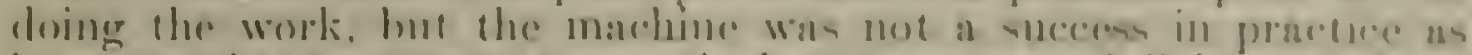

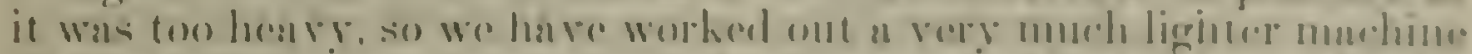

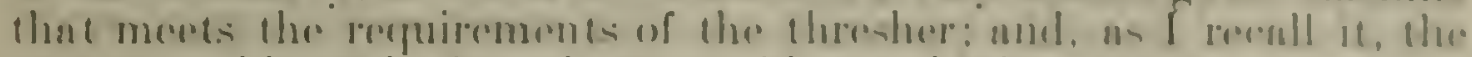

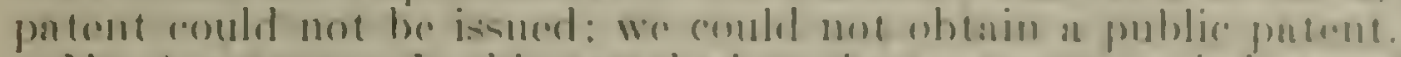

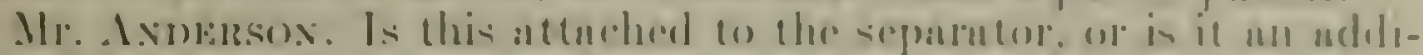
tionsul machins!

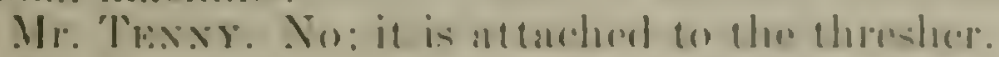

Mr. Bromaxis. It is mate a part of the thre-hore?

Mr. 'Texsy. It is antenched to the thresher: ress sir.

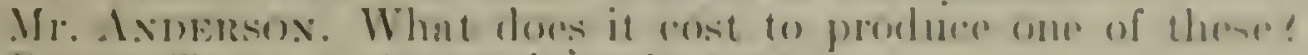

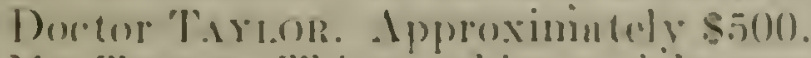

Mr. Traxy. This machine weighs approximntely foto pound-

Your enn see that this was an important part of our "Kow rour whent" campaign, and it is impertant to the farmer in improving his whent after he does know the imperferetoms in it.

Now. a similnr line of work is heing carried on in the southwestern territory, where we had heat damages which we have found during the hast two years has inereased to a point where it affected the marketing of the wheat rery serionsly. Our laboratory experiments show that this is due primarily to the fact that whent is being cut and threshed and in the farmers harns hefore it is quite mature. It is apparently mature, and when we eut it and put it in bundles it had an opportunity to go through that last ripening process.

Now, sinee they have adopted the hurry-up methods. in order to produce another crop after eutting the wheat in that country, this heat domage is developing.

Mr. Bucnasix. 'They do not leare it in the shock long enough!

Mr. Trexis. No: and they are developing methods of threshing directly in the field. topping and threshing.

Mr. Becuasax. Clipping it?

Mr. Thesr. Yes, sir. Of course, all of this wheat work we carry through our baking tests. and determine the eflects of heat damages and the relutive amounts of heat damage on the brend, by haking. and we have arrived at a point now where we cun say that wheat. that is damaged above a certain amount, is proctically useless for bread making at all and must he used for feed purposes.

The third study is our economic study, which Doctor 'Tnylor touched upon, and which probably needs no further elaboration. We are making, and during the next year, we propose to make a complete study of the maketing procesises involied in the handling of wheat, particularly. 


\section{COST OF MARKETING.}

Now, I would like to ask Mr. Schoenfeld to cover the one project that we have omitted, the cost of marketing. Mr. Scheonfeld is in charge of our resenrch work and this costs division is operated almost directly under his supervision.

Mr. Sciobsfind. Doetor 'Taylor has outlined the lines of study we think are necessary in the marketing processes.

Bofore we ean ittempt the solution of problems encountered in the marketing of agricultural produets, it is absolutely necessary that comprehensive studies be made of the various steps, processes, channels, and functions involved in the marketing of commodities. Along with such steps it is necessary to measure the costs of these various steps and to ascertain from these studies which are economic or not economic, the very items pointed out in the cost production studies.

Before it is advisable to make such detailed cost studies it is desirable to study margins or charges exacted, rather than to plunge into detailed cost studies, which are time consumers and expensive and which do not always yield what is winted.

After we have studied these margins and have segregated them so as to be able to see the margin for the man who handles the commodity at the point of shipment, the transportation agency charge and the terminal marketing margins, then we are in a position to approach the whole problem of costs in a more logical manner.

During the present and last fiscal year, a comprehensive study of the costs of marketing live stock was started in the corn belt and was continued into the present fiscal year. 'This study has been extended so as to include the territory in the South and West. The data secured is now being tabulated, and is practically ready for publication. We have found, however, in these data, certain factors which were entirely unlooked for in our preliminary cost studies. It will be necessiry to go back and determine just what the causes and conditions were back of these factors.

For exnmple, in our live-stock marketing study we find that where there are mixed shipments of hogs, shipments in which cattle or sheep) were in the same car, that universally the number of crippled hogs and dead hogs was higher in such shipments. We find, also, thint the number of crippled hogrs is higher in the winter months and late fall months than during Ifny, June, and July. It will be necessary to ascertain the reasons for these losses, and, as pointed out by Mr. Anderson in his reference to our cost of production studies, cost studies should indicate the losses with recommenditions ns to how to nooid or reduce them where possible.

We have found, for exmmple, that where it is popularly assumed that marketing margins of certain agencies were high, that these mnreins might be low in comparison with other agencies that take at lankere propertion of the spread between consumer and producer.

Mr. Axulksox. How far have you gone along with this margin study?

Mi. Scmonsmoto. In some commodities-potatoes and onions, applos, and in some of the duiry commodities-we have merely rompleted surh studies of matginis from the producer to the con-

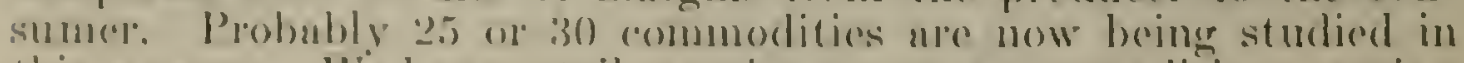
this munuer. Whe huve retuil matrins on some commodities covering 
a long period of time: that ss, a pretiod of a vour and a half to ewo years. I $\mathrm{am}$ coming to the part which will probubly answer your question. There is grent difliculty in going back to orighnal records.

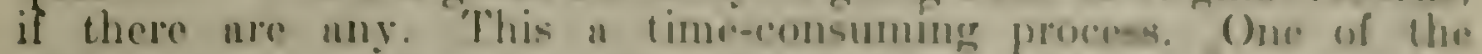
problems wo have is to piek out retallers who ure open-minded enough to open their books, and if they do not linbe books, or reecords, or papers, give us information so that we can use their data from which to derive service matreins.

Mr. A.rurissos. When you uttompt to get threse figures, do you take the individunl denlers, or do you uflempt to get volume trinsaction which will givo you a gencral uveruge?

Mr. Schoportets. Yes; we are getting at it in that way. Wretry to take typical cstablishments. I will use us un illustrution a study on whicli we ure now working. In Beston wo hase unken exchasive retail trade stores; the midclle type of retnit establishonent und the low-priced cash and corry; (chan and hargain counter establishments. We take this as being typieal of a cress-secetion of the retail business.

Mr. Avolissos. Thut is in the meat tracles!

Mr. Scnobstan. So: we are making the studies with fruit und veretable and dairy products retuilers. In Buston we have started on the ment trade, and also in (Chicure. I will dwell on this later on. In Chicago we are working with the lictail Butehers' Associntiun and are cooperating with it in grotting costs of retniling ment.

As I have pointed out, we are having difliculty in getting satisfartory records. Where retailers are willing to cooperate, we find that their records are not in such shape that they can be used. For instance, they will record a sale of apples. Thrit may mean anything from westeri boxed apples to eastern barreled upples, or it may mean ungraded apples. Records are seldom kept of the grades or standards.

In the Pacific Northwest we are making a study of the cost of marketing boxed apples from the time they leare the orehard to the terminal end. We are getting cooperution in Philadelphin and Boston, Chieago, and New York City from some of the local resenrch agencies in the study of the terminal distribution of apples and other fruits and regetubles.

This work is necessary, more necessury than some other types of market research. We can not go to a library or to a dofinito alerency and collect this information. It is necessary to go to the books of various marketing agencies, work with them. and oser a lone period of time. For such type of work it is not ndvisable or practicable to use unt rained mon. It requires men with a darge amenunt of tact who can handle rather delicate situntions constuntly arising and who can see the facts when they uppear. The ordinary man trained in accounting is not completely fitted for this trpe of work. He must have in addition to his training in aceounting a broad. common-sonse training in business practice. He must sece hings that an ordinary accountant would orerlook The aceountant usually seres the ligures before him and roes not alwars sore the molated furcs. For

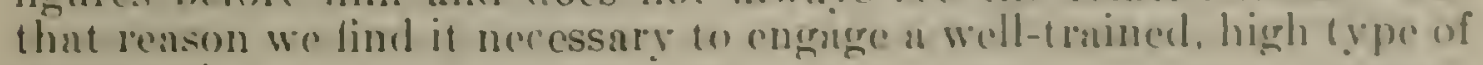
pel'sonnel.

After wo have mate margin studies then we hope to proesed with rather detailed cost stucies. Wre are continuing some of the studies in the reent marketing of live stuck. It the recpuest of the Master 
Butehers Association of Chicago we are coopernting with the Northwestern University in making detailed study of the accounting methods and sistems used by the retailers of Chicago.

Mr. Axnersox. To what cextent is this done in connection with, or do vou use the figures of. Harvard Lniversity?

We are making cost studies of the marketing of Maine, Wisconsin. Michigan, Massachusetts, and Minnesotat potatoes, which are continuations of the work started last rear. We are covering the entire costs from the time the commolity leares the producer to the time it reaches the consumer. We are finding quite al lit tle interest in this subject, and are getting plenty of offers of cooperation, some of which we find it necessary to turn down. In some places agencies that are anxious to do this work are too anxious to prove that certain types of midtllemen are entirely unnecessurv. wong. or dishonest. That condition of thought is disastrous in good research. Where that ocrurs, of course, we have to clecline the ofler of cooperation. We are trying to get others to cooperate with us and to look at facts as they ire.

is Dortor 'Taylor pointed out it is rontemplated that a complete study of marketing agricultural crops. smeh as grain, fruits, vegetnbles. dairy products, cotton, wool. and live stock, will shortly be made. Aloner with such study should gat) the study of costs of marketing. 'The marketing picture is not complete without such studies. The alppropriation increase of $\$ 28.000$ is to cover the study of market marerins and costs of these commodities.

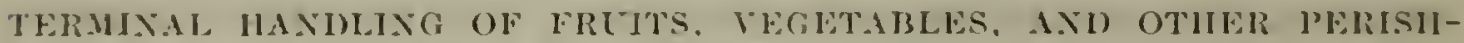
ABLLS.

To grive an illustration of some of the things which cost studies are developing: In cooperation with the port authorities of New York ('ity we are making a study of the terminal handling of fruits, regetabiles, and other perishables. The have found, by studying the custs of hamdling of eommodities. after unloading on the Manhittan terminal piers of the Pennsylyanial and Erie railroads, that the cost. of handling of crates of commodities from the piers to the roadway, (1) marginal way, as it is called, that the charge may be as great is the entire freiglit cost from the point of production to the Manhnttan piris.

Mr. Axpensos. Ineluding the freight!

Mr. Sonoserest). The eharge for hauling from the pier to the road way, a distance of 400 feet, may be as great as the freight charges from the point of production in the West or the South to the Manh:1ltan piers.

Mr. Annersox, I do not dombt it a bit.

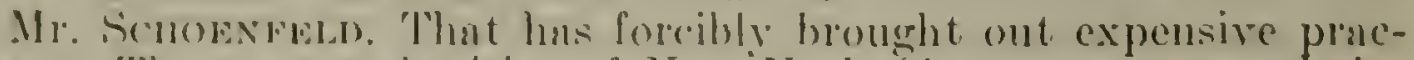

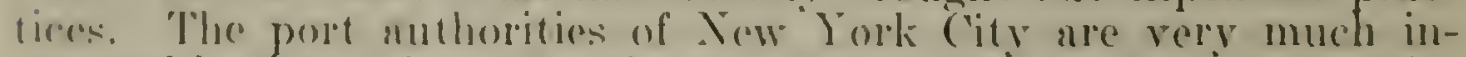
terestod in that point. It brings ont the necessity of regulations for thre trominnl hundling of fruits and vegetables in New Fork City.

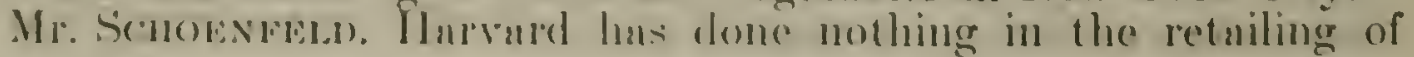
mints.

Mr. Axuszsos, I know but hey hase done n lot of work in other retuil work that could he used in comnection with the retail of meats? 


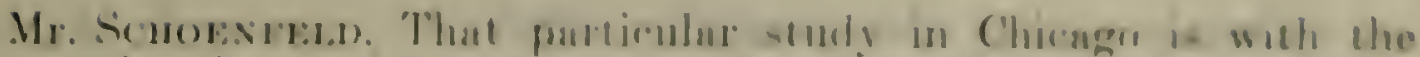
muster butchers. I might any in that ecomection that ande of the

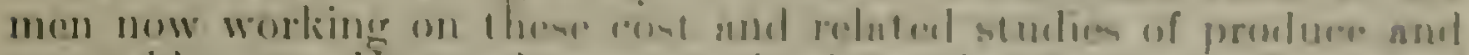

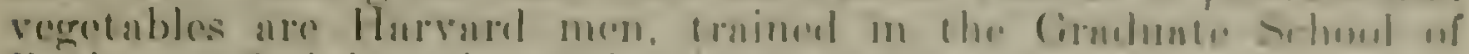

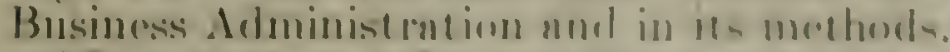

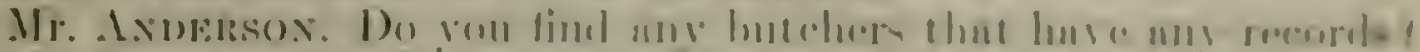

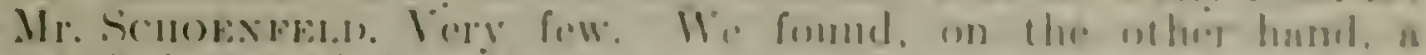

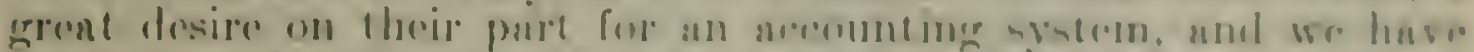

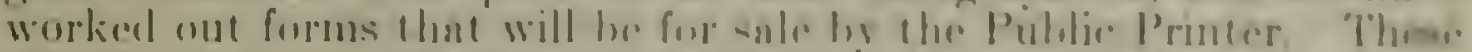

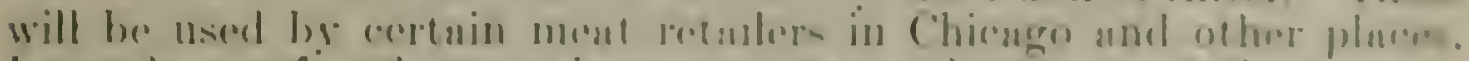

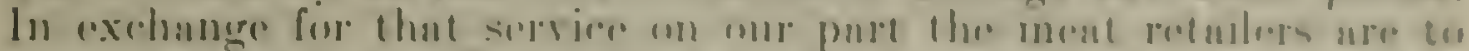

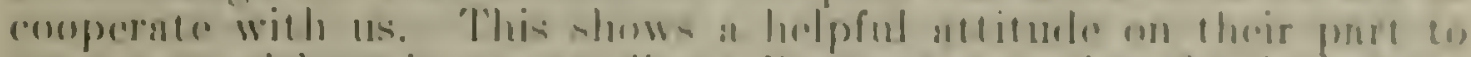

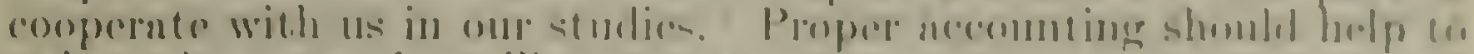
reduee the roots of rentailing meats.

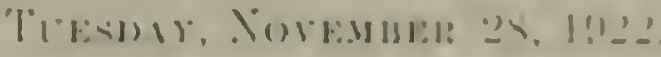

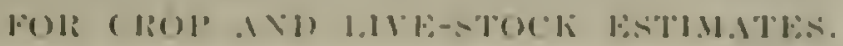

Mr. Axmersos. What is the mest item?

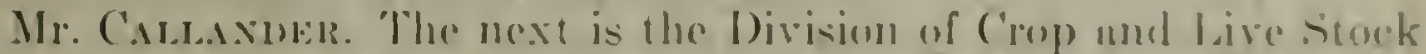
Estimates of the Bureatu of Agricultural beonomics. The total allotment of lump funds to this division for the current yeatr anomonth to $\$ 301.600$ : an appurent increase of $\$ \mathbf{s} .0(0)$ is included in the estimate. There are some transfers a the statutory roll which make- the real increase in the estimates for this division s.j,000 for the liseal forar

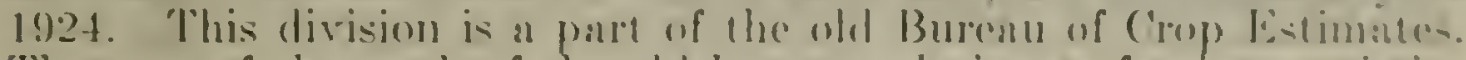
The part of the work of the ald burenu rehating to foregrs stati-tices has been put into another division. which will he taken up immediately after I get through. This division is coming to be the principal datagathering machine for the whole bureau. It is not cons doing the regular crop estimating work. hut it is cooperuting with the Form Management and other divisions in gnthering economie data. There

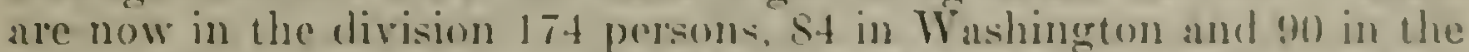
field. Of the 90 persons in the ficld, about $4 S$ are angreuldural statistieians who have been appointed as a result of civil service examinations: 2 are live-stock specialists, and there are about to rlerks. The division has ollices in 42 states nt the present time.

The New England Stutes are combined; Kintucky and West Virginia are considered as one unit. and Utah and Nerada are considered as mother unit. In cach of the other States the division has an office with a statistician in charge. There ne now nbout 260,000 volunteer crop correspondents altogether. Thut makes nu nverago of ubout 10 for erery agricultural township in the United States. Of that number, 26,000 are township correspondents-that is, one in each township, who makes monthly reports direct to Winshington. There are 28,000 correspondents called field nids, 1 in ench towmship practically, who make reports on the ficld stutistician in cach state. There are 2,700 eounty correspondents, 1 in ench of the ngricultural counties of the United states, and in some of the more important counties there me 2. Ench of those county correspondents has a corps of reporters who report of him. and he compiles his reports from what they send him and somels them to Wishington. There 
are 30,000 live-stock correspondents. This is a new work that is being developed this year, and we expect eventually to build the number up to 60,000 live-stock correspondents. This does not include the 300,000 farmers who are reporting through the rural carriers of the Post Office Department. Then we hare 50,000 other correspondents whom we call individual farm correspondents. They report to Washington for their own farms only, covering acreage, production, and matters of that kind. Te liave another 50,000 farmers who report in the same way to the field men.

This duplicate system is used so that one may be used as a check upon the other. There are 6,300 special cotton correspondents, 3,800 honey bee correspondents. 7,500 special data correspondents, 2,000 maple-sugar correspondents, 13.000 truck crop correspondents, also 2,500 canners', associntions correspondents who report every year the total amount of fruits and regetables canned. Practically all canners ure on this list. During the present year, 3,000,000 schedules were sent out from Washington, and at least $3,000,000$ more from our ficld offices. From these returns, during 1922, about 45,000 separate and distinct estimates were made on various factors relating to the crops and live stock.

Six thousand of these estimates reluted to live stock, and 12,000 to prices; the balance related to acreage, condition of crops, and yields. The truck-crop work in the field is carried on by two truck-crop specialists. The work on truck crop in Wnshington fits in with the other crop work, and is done by the same people, so that the cost of it here in Washington is relatively small. Nearly half a million truck schedules were sent out this last yenr, and 79 separate and distinct reports were made on truck crops.

\section{COOPERATION WITI TIE STATES.}

All of the work of the division, wherever possible, is done in cooperation with the States. We already have arrangements with $2 S$ States. The States are Alabama, Arkansas, California, Colorado, Idaho, Illinois, Indiana, Iown, Kentucky, all of the New England States, Maryland, Minnesota, Missouri, Montana, Nebraska, New Jersey, Michigan, New York, North Carolina, Ohio, Oklahoma, Utah, Virginia, and Wisconsin. The States are putting into this crop reporting work somewhere between $\$ 75.000$ and $\$ 100,000$ a year. That is an estimate, of course. Some of the work is mixed in with other State work, so that it is hard to tell how much the States are putting in. 'These cooperative arrangements are extremely benefieial in two ways: First, they have eliminated duplicate reports in many of the states and the single report that is now made has been strengthened. It has bern possible to merge the elerian holps. the reporters, and the funds. In practionlly every state where these cooperative relations are in ofleret the work is going along in a rery satisfactory way and we are able to get much more detailed inforimation concerning each individual state than was possible before these cooperative arrangements were made. Second, it lans kept down the expense to the Forleral Govermment of doing the (ereprepeporting work. 


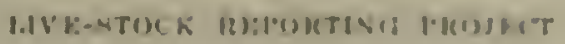

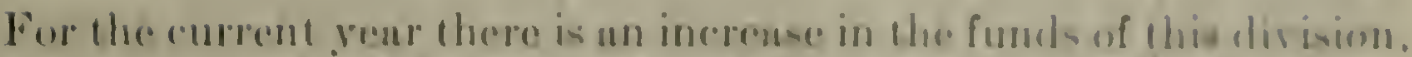

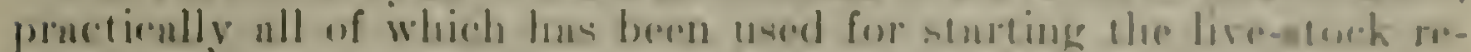

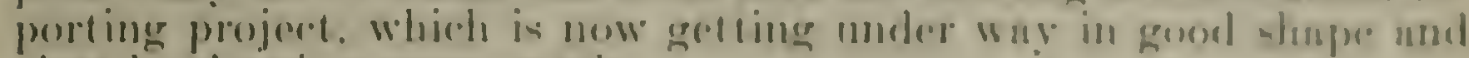
alrendy showing soms results.

I might say that up lo this your the lise-stork work of the disirion

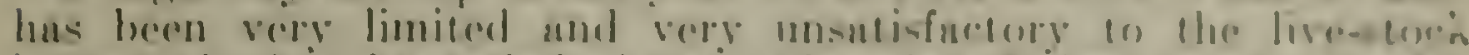

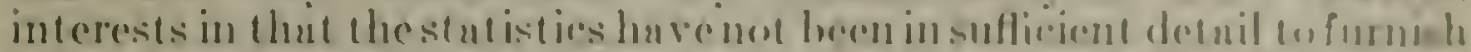

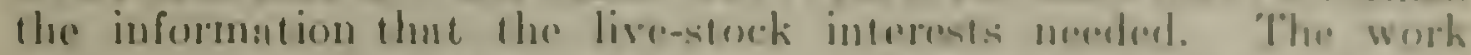
included up to this yeur simply 110 ummul estimate of the momber of live stock on farms. bused on a pereontuge molhod of mlimsting. laking the census us " basis. The mortuliry of live stoch has ulse been estimnted. the report being simply nn index mumber sluwine

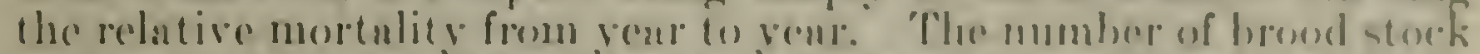

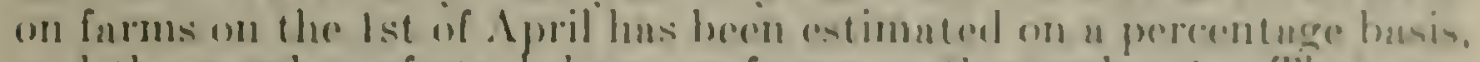

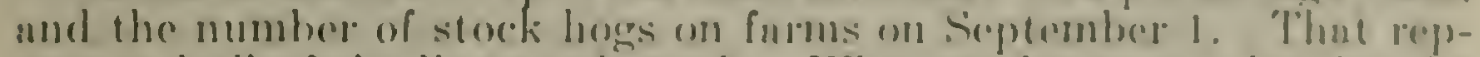
resented all of the liverstork werk. Whan we begnen to plun for the new work it was found that there were so many demands for werth is

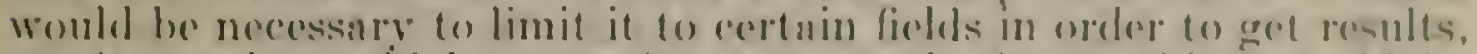
or the work would be spread out so muld that nothing would be aceomplished. Two conferencess were held, one in rhicago in May. and the other in Denver in July, at which were present a mumber if live-stock producers and representutives of liverstock nsineintions, rnilronds, and other orernizutions.

In addition a number of men who could not be present, like representutives of the 'Texns Cuttle Assuciation, for instunce, scud letters sugeresting what they wanted in the way of service, and hused on the mectings in Chicngo and Denver n rather elaborate progerum of what the live-stock reporting service should include whs outlined. We ascertnined directly from the people who nre rnising stock what they wanted. Mr. Bixby, Mr. Tomlinson, and some of the other livestock assuciation mon told us what they wanted, und our program is lurgely bised on what these men said wins needed. The progrnm as now outlined includes the following things: First, an offort will be made to make the Junuary 1 estimnte of numbers on forms more accurate and have it give more details than in the past. Heretofore the division has simply reported the number of cuttle und milk cows, sheep, swine, and horses, but nothing as to nge or sex. This year will be the first nttempt to sepnrate the clnsses of cuttle into steers. bulls, nud cows und calves, and. if possible, muke an estimnte ns to the number of steers of lifferent nges. Tho informution will be gathered in severnl ways, the principul one of which will be to get reports from thousands of individual rnnches and furms. telling just what they have on their own farms, in the way of stock of various chasses and ages, and from these reports work uj rntios which will be applied to the totals.

Four recionnl live-stock men huve been put into the field and serernl assistant live-stock stutisticinns huve been ndded. We now have a live-stock statisticiun in 'lexas, a recrional live-stock statisticinn for Arizonn and Now Mexico, a regionnl man in Denver, with an nssistant. one in Wyoming, who covers the Wyoming-Nobraskn-South Datota area, one in the Grent Basin nren, with hendyuarters at Sult Latio City, and through an arrmgement with the Liro-Stock Marketing 
Dirision one of them in California will do considerable of this work in Californin in addition to his work on the marketing end.

Then a live-stock specialist has been put in Iowa, one in Illinois. and a regional live-stock specialist has been stationed in Chicago, who has his oflice with the marketing division. The lire-stock reports are to be cleared through the Chicigo office to a large extent, where they will be combined and fitted in with the marketing reports, so that the whole projeet of reporting on the markets. reporting on the receipts of livestock at various stock vards, and the estimates which this Division will malie will be one and the same project. 'There will be close cooperation between all the lines of live-stock work, which. we think, will improve the service. Then an arrangement has been made with the Post Office Depart ment to make a semiannual pig surver. One was made last spring which was very complete. The returns from the 17 states in which we made the survey included about 10 per cent of the farms, and from the statistical standpoint a sample of that size is abundantly large enough to give a picture of the whole: in fact, we think the number of reports could probably be cut down to 5 per cent, which would be much less expensive and still obtain a very exact picture of the whole. At the present time another survey is in procress, and we already have in about 200.000 schedules from all over the country. I noticed this morning that something like fifteen or twenty thousand have come in from Iowa.

Mr. Andensox. Are these sehedules pretty accurate and do the farmers make them out carefully?

Mr. Carlender. They are made out for the most part by the rural carrier himself; he asks the questions and fills in the answers. just like a census enumerator. Those are the instructions, at least. which go sut, and each earrier is instructed to piek a section out of his route of 10 consecutive farms. He is instructed not to select his farms, bat to take every farm as it comes, regardless of size or ownership, until he gets 10 reports. From these reports we hope to be able to work out the ratios. For the first year the information is not particularly valuable, beeause we have no comparisons that are satisfactory; but beginning with next spring's survey we will have comparisons, and I feel that these pig surveys are going to be of great assistance in showing trends in hog production, and I think, based on these survers, it will be possible to forecast very necurately and a good many nonths aliead what the supply of hogs for marketing is going to be.

I believe these estimates can be made very accurate, because we have as a check the receipts at the stockvards as woll as railrond movements, and we are arranging now to get from the stockyards and from independent packing plants which do not get their stock through the yurds direct the state of origin of all the stock coming to their phants, so that we will be able to forecust how many pigs Iowa. for instance, will produce and eheck the forecists from the netunt records of what go to market. Based on the surveys and eheeks we will be able to forecast after this coming year, I think, how many pigs we may expect from any State during a season. I doubt if we can estimate very closely the number to be marlieted in any ono month, but for a seasom I think we an forecast quite aceurately.

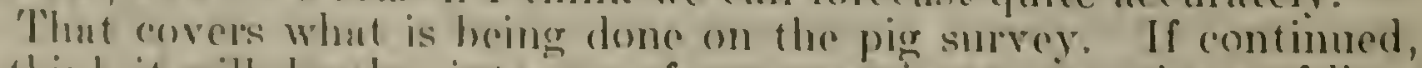
I think it will dovelop into one of out most importint pieces of livestock reporting werk. 


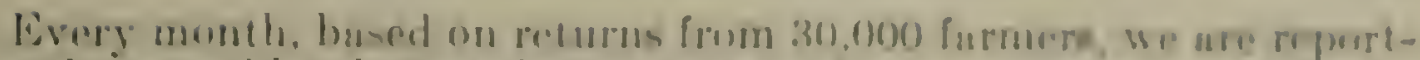

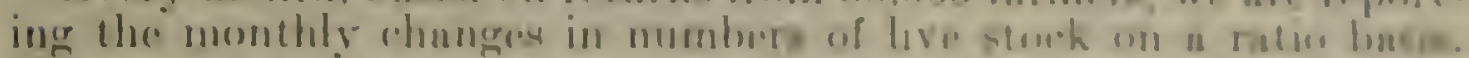

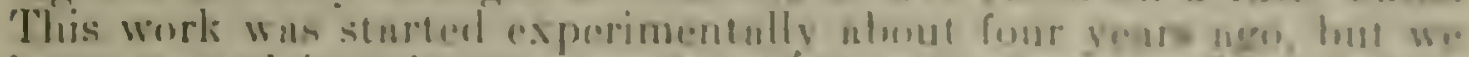

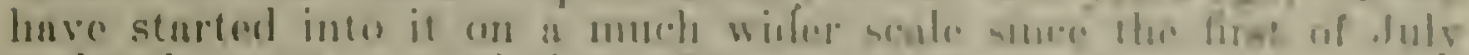
under the new npproprintion. Thume menthls chaneres.

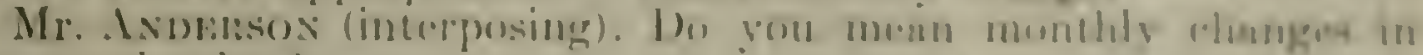
hog production?

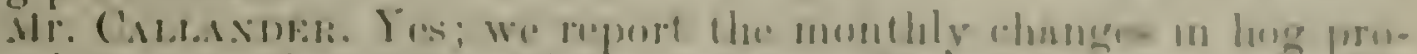

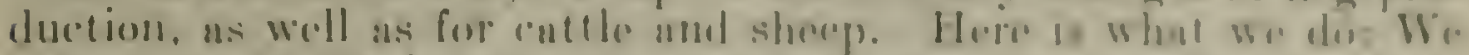

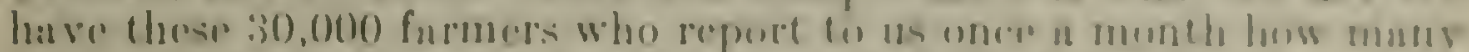
catele, sheep. and swine ther have on theig farms on the tat if the month and low many at the chese of the month; hess mats wer. bort doring the monih, low many wore sold, and how mas were

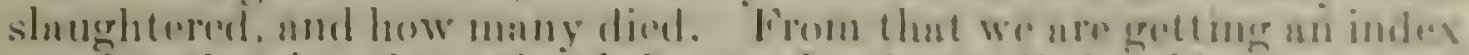
number showing the ratio of the nmmber born, dienl, sold, purchased. and slancritered benrs to the totul number on the farm. It in really n sort of beokkecping aceount. 'This work will be expanderl erentidally to include about 60.000 farmers reporting ances a month an lo what happens on their farms. 'T'hat will reve us a very splendid index and even the experimental data that has come in so far hase been very valuable on hoges, being borne out by the receipts at the stockvarits. We ulso nsk how muny sows are breal each month, and we hive found quite a correlation between the number of sows bred and what goes to marliet some monthe latre. Wo fool thut is goning to become a very important index for the future and enable the livestock producers to get a picture of what is happening and thereby determine whether they should increase or decrense their herels; in fact, some of them are already using the data, but we are not giving much publicity to the work until we can develop it further.

Mr. ANurssox. When they get to using it, that will modify your returns, will it not?

Mr. Caldander. The thing about it is this: A great mase of famers will probably not pay much attention to it. at least for sume yours. but there will be quite a pereentage of the farmers who will prolit ly it from the start; enough to end to stabilize the morement io market.

\section{FARM PHICES OF LUF: STOCK.}

Then we are estimating the farm prices of live stock. We have been doing that for a great many yents nnd, of couse, will continue.

We are also planning to make and we are making right now the report output will come out on December 10 -an estimate of the number of sheep

Mr. Avnersox (interposing). Before you go into that, I have always had a great deal of doubt about the ac'uracy of your extimate of farm prices, and I would like to know how you get ai them?

Mr. Caldavider. We do not say they represent netual prices, but our contention has ulways been that they give us the trends from month to month and from year to year. "They nre goten in this was: We have a corps of price reporters and the number lons up (1) 1.000$)$ per State: in some States we have as many as 1.000 reporters who report the average farm prices that are bieng recoised in their territory. Now, what makes the figures nppear to be off somedimes is that these figures come from importing arens as well as from areati 
of surplus. In other words, here is an area-and I will take potatoes as an example-that only produres about one-fourth of its potatoes and has to import all the rest: the price of potatoes in that area is very much higher than it is in unother area which ships out potatoes and that natumlly raises the average State price. We have been thinking for some time of trying to work up a system of price reporting which would give us the price in surplus areas in addition to State avernges. You see, now there is one average for a State which also includes the prices in areas which import. Whether we ran work out something or not $I$ do not know, but that is what causes the prices to seem too high when you take an average for a State.

Mr. Axversox. How do you weight these prices when you come to get an arerage for the whole country?

M̂r. Caldaxier. We weight by production. The prices for ench State are weighted by distriets for some crops and by counties for others: we use nine districts in each State for weighting purposes. and we weight the price for the State according to the importance of those nine districts, and then we weight the price for the United states by relative importance of each State. Of course, greater aceuracy could be secured-but it would inrolve a great deal more work - if we weighted each State by counties for all crops. Most of the prices for the principal crops are weighted by county.

Mr. Axmersox. Do those weighted figures continue the same every reall!

Mr. Caldander. No: they are adjusted from year to yenr.

Mr. Axmerson. To the production!

Mr. Callander. Yes. sir. Returning to our live-stock work, as I just stated, we are going to issue on about the 10 th of December the first estimate as to the number of eattle and sheep on feed in the Corn Belt. and in the case of sheep the number. also, on feed in the Greeley and Scotts Bluft area in the West. Our men are working on that now.

\section{PASTUIE AND FEED CONDITIONS ON THE RANGF.}

We are making monthly reports on pasture and feed conditions in all the range States: also on the condition of live stock and livestock prices on the range. Those reports are coming ont once a month. We began in September-and we are about half throughto compile a complete record for three years back, from railyond data. of the number of hearl of eattle shipped out of ench station and shipped into anch station in all States from Ohio west. A number of railroads have been lind enough to furnish the dat a free of cost but for some we have paid the actual derical expense required in compiling the information. We feel we must have these data ns a busis before we can make intelligent live-stork estimntes, berause we ure planning, us soon as we ran get these data worked up. compiled, and thrown into counties und recrions, to estimate live-stock supplies and forecust the probable market morements of stock from dillorent arems.

Mr. Axmeksox. Do you expect to get these railrond data erery Y'al!

Mr. Cartaxinen. Yors: wo hope to be able to make such an arrangement with the ruilroads, in fact. a number of them have alrendy "greed to furnish it to us monthly hereafter. We have that matter 
up sow with the railronds informully und quite a number of the hig ronds honse agreed to furnish this information to us monehly hereufter: it mans guite a bit of expense to them but thes hase ugreest to furnish it. The ruilrond and stockyned data will uftord a louis which will enuble us to foreenst that out of n cortuin uren there is going 10 be shipped: so mung hend of eattle or so many hend in storek of moy other knd: in nddition we will hase the sibserpuent rnilrond and stockinad records as to the actual moroments lo use ns a rebeck nguinst our estimntes, und we ought, ats time gorse on, 10 inatir more nind more necornte forecists of the morement.

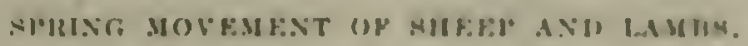

Ono litule piere of work which has attracterl quite a bit of altention and interest is one phun to estimute the probuble spring movenuent of sheep und lambs from Culifornin, . Iri\%onn, Kenturky, Pennester, West Virginia, nol Virginis. The mosements from these uress eome very elose together in the spring and anty summer, und when they overlap they hurt the sheep morket.

Wo will first show how many hend are likely to come out of emels of these areas. We have the machinerg in motion and I think we

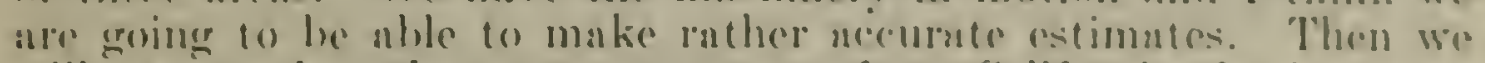
will report when the movement starts from C'ulifornin, for instance, and when the movement starts from these other arens, nud arranese with the storkind companies and railsonds o muke workly reporte,

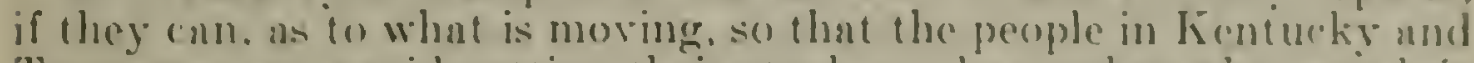
Tennessere can aroid getting their stock on the murket when stork is roming from (alifornin or vice versa. There is a great denl of interet in that partic ular project at the present time, beratuse when that slore all comes in at the same time. especially into the Jerery City market which happens frequently, the price goes to pieces.

Another report on the program is an estimate of the calf and lamb crop in the range States. so that we may have a long time view of what the future supplies.

I might suy that in nll this work we have the live-stock nsocintions back of us; they are helping us. their membership is reporting and their leaders are hncking us up in the work.

Mr. Axuersox. Probubly they will feel differently ubout it when they find out what rou are going to do!

Mr. Caldaxisen. The things I have mentioned are the thinges the live-stock prople hore asked for and we are trring to shape our projects in the West and Middle West to give the producers what they want.

\section{WPECIAL IREIPUITS.}

Then there are $"$ grent many other special reports rehting to localizer urens that we are planning to make, but it is hardly worth detailing them here. For instance, an estimate of prospective mosioments of gruss-fat entele from southern lexus will be mule in fideruary; an estimate of lamb erop of californin and early lamb crop of Arizoma, nlso Ilaho and Colorado, will he made in Mhreh: repert on condition of pusture in Linnsas Flint Hills short-granss areas will be mate in Mareh: that is very important to the people who bring cattle from fexas and put them on the Flint lills pustures: the 
morement amounts 10 about 150,000 or 250.000 head, that being the number brought in there in the spring. The prospective morement of crass-fat shecp from west Texas will be estimated in March. Another report on the condition of Kansas Flint Ilills and short-grass pastures will be made in April. An estimate of fat cattle movemerit from California will be made in May. An estimate of number of cattle which have gone from the Southwest States to Oklahoma, Kansas, and other northern pastures will be made in June: that will give an index as to what fat stock will come from those areas in August. September, and October. Estimates of the probable number of fat and feeder lambs available for shipment from Arizona, Idaho, Wroming. Montana, Colorado, and New Mexico during July and August will be made in June: that will give an index as to the supply of feeder lambs for the corn belt.

$A$ estimate of the number of grass-fat cattle coming from Montana, Wyoming, and South Dakota, ete., to marliet. That will be a general inquiry which will be made in July. An estimate of the ealf crop of Texas, New Mexico, and Arizona, which will be made in September. I have already mentioned, I think, some of the other things we hare already started and I will not go into them again.

$$
\text { COOPERATION WITI LIVE-STOCK ASSOciations. }
$$

I have also mentioned the cooperation we have with the live-stock associations, and I might say that we hare been directly helping these associations. We are helping through our work to put the feeders in the Middle West in touch with the people in the West who have the feeders to sell. We are doing the work in this way: We get these men to report to us and tell us how many cattle or sheep of different kinds they have; we are turning that information orer to the associations and the associations are drawing it off and sending it out and then handling the business themselves. Just recently we hare helped to locate pastures in Texas and some other areas for the cattle which were starving in New Mexico. We have done quite a bit of that indirectly and as an incident to our other work. We do not consider it a part of our work but we help wherever we can.

Mr. Axdemson. The information is there, and there is no reason why they should not have it?

Mr. Cillavibr. That is true, and we are making the greatest possible use of the information we are gathering.

CROP-WOHK STUDIES.

I have not mentioned anything about our erop work, but that has gene on about the same, anil we are spending about the same amount of money this year as usual. However, I might say this: We have just put into the Washington ofliee one of our experts from the ficld, who has made ono of the best records as to devising new methods and betfer methods of crop estimating.

During the hast your or two we have devised improved methods of estimuting arerenge, which is our greatest problem in crop estimnting. If we can goet the nereage aecurntely, the rest is rathere easy.

So we hase, within the last year or two, been experimenting, and now we have worked out two or three new methods of estimating 


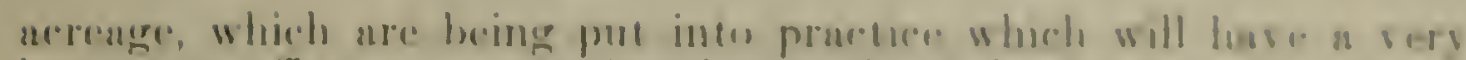

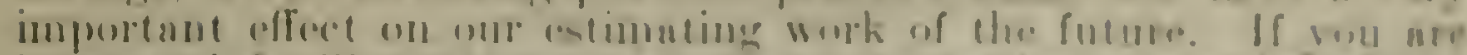

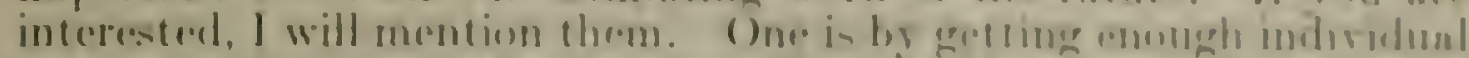

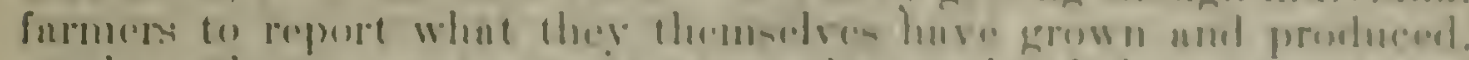

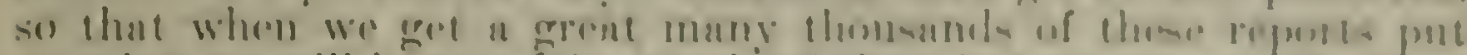

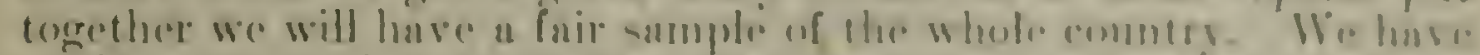

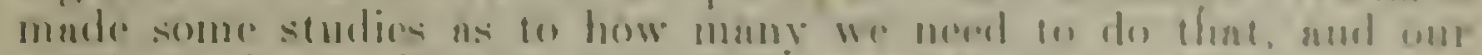

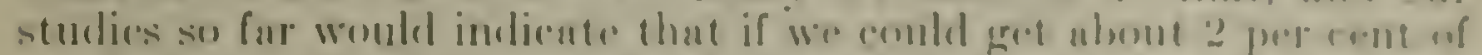

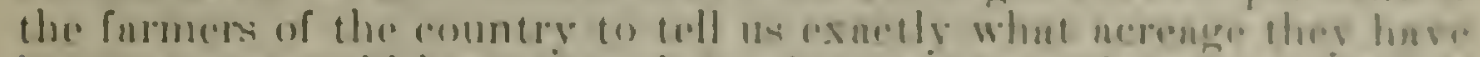

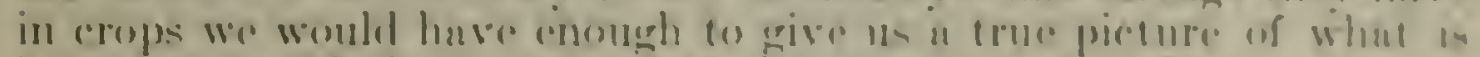

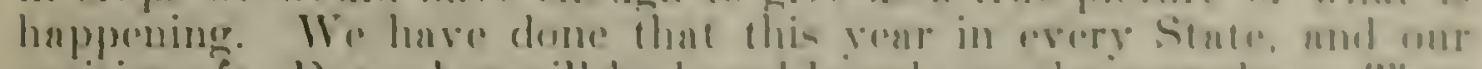

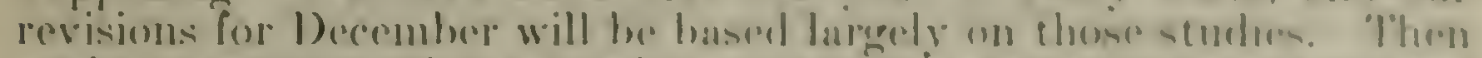

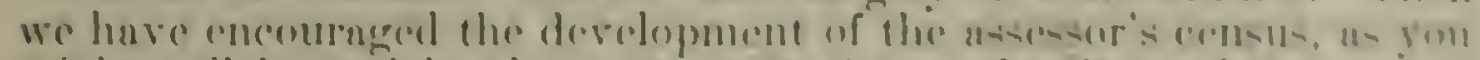
might call it, and in ubout 15 or 20 stotes the stules have puirel

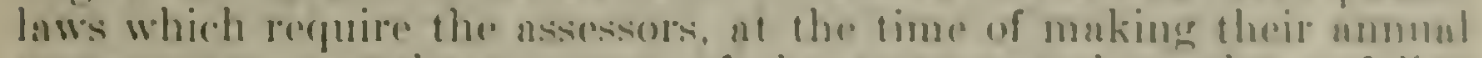

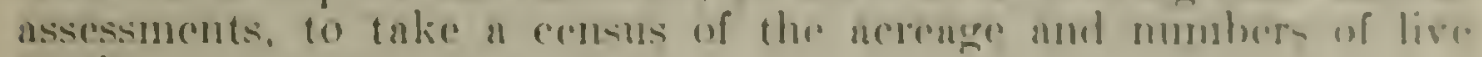
stork.

In about four States the data have become so necurate that we foed it is really better than the Enitod States census so for as ncrenger is conecrned. That is especinlly true in Wisconsin: in Minnesenta thiyear they noe taking it for the first time and it is extromely snliefuctory: Vichigan has an anmual assessors' census as woll us lowa. Nebraska. Missouri, and Colorado. We are anxious to sece und are encouraging the pussige of state laws which will give ne cemans in every State. Then we have also. following out the suggestions made hy i statistical committee of cxperts who inrestignted our system last winter, started a system of field counts, as we call it, that is. each of our field statisticans takes a certain line of milrond or certain rond and he covers that same area each vear. The arangement now is that he will take enough of those rouds in his State to grive a goont cross section of his State and will count the number of fichels of ench kind of crop along those ronds, making an exact record crery year of what changes have taken place. In the case of fields that nire not of good shape or are of odd sizes we are trving the experiment of count ing the kind of crop that is opposite each telegrapla pole. We find the field count is a very satisfactory way of estimating the changes in acrenge from year to yenr in the East and South, but it is not so satisfactory in the West.

Some of our men are quite enthusiastic about the merarary with which changes in acreage can be determined by counting the lieds from year to yenr over exactly the same area. In a State like (ienria. where it has been tried out to the greatest extent, it takes about 4,000 miles of roud, covered year after yenr in exactly the sume way, to determine the change that has taken place during the vear. I might say that last year in South Carolina our statistician covered about 3,000 miles of roud and estimated the cotton crop based on his survey. His estimate was about the same as that finally determined in December after the ginning returns were nenty all in. All of the other sources of information gaver a much lewer nereater than his survey, but us it was a new experiment he was to trust the results. 
The increase for the coming year will be used im part to strengthen the livestock work. The division simply can not begin to meet the demunds on it for livestock information; it is expensive to get railrond data and other information of that kind, and we want to put on about two or three more men to strengthen the service in the Corn Belt States. We were only able this year to put on two livestock men in the Corn Belt besides the regional men in Chieago.

We have allowed extra money for clerical help and the travel expenses of our Corn Belt men but we had not enough money to put on more assistants there this year. There really ought to be four more men in the Corn Belt States. Another man is needed in Texas. We find that one live-stock statistician, with an assistant, is not enough by any means to cover the State of Texas. There are two or three well defined live-stock areas there and we want a new man to put in the Panhandle area, and at the same time have him cover a part of Oklahoma. We also need a man in the western part of Nebraska and South Dakota, as well as eastern Wyoming, to help the regional man there So we are estimating we will use about $\$ 14,000$ of this, if we get this increase, on that part of the work.

We can not undertake dairy work this year because the funds will not permit it. To start on a project of estimating milk production and changes in dairy needs would take as much more money, probably, as it would to handle the meat animals, to which we are limiting the work at the present time. An increase of $\$ 11,000$ is asked for to strengthen the Washington office. We have put one more man in this year, but our weakness, if we have any-and, of course, we all have that-is that our Washington office has not had enough trained statisticians to handle the information that comes in from the field.

Mr. Andersox. Do you mean you want these men to act as interpreters?

Mr. Calmander. I mean that we need additional men to interpret the information that comes in, to study its weaknesses and improve the methods of getting it. We need a cotton statistician in the Washington office who will help and who will study new methods of estimating cotton, which is a tricky erop and it is very hard to get good results. He will give his whole time, practically, to a study of whit we have been doing in estimating and to the devising of new methods. He will also visit our various cotton States and help the field men improve their estimates, and he will also be in a position to furnish anything in the way of cotton statisties which may be needed at any time.

Mr. Axmersox. What do you do in securing statistics and what is the difference in what you do and what the Department of Commeree does?

Mr. Calianiser. The Department of Commerer simply reports the amount of cotton ginned. They bearin in September and periodically make reports metil the lst of December. They have paid reporters who go to the rins and report the actual number of bales grimned. We hegin estimating in June; wo estimate the condition on the lst of Jume and then on the lst of July we estimate the acerage of (a)tloils.

Mr. Becousas. Do you not start in by estimating the acreage planted in cotton! 


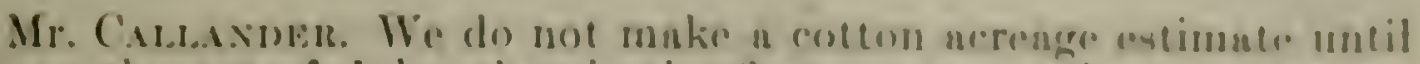
about the lst of July: that is the lirst acronge estimate: then wo estimnte the condition, and from these iwo facturs forcenst what the

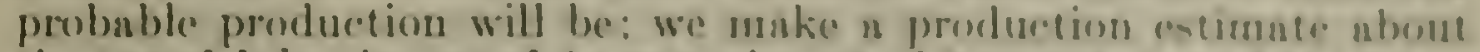

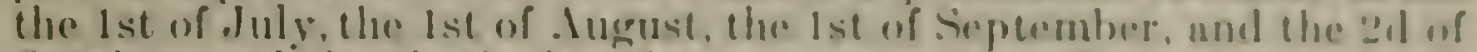
October, and that is the hast forerast wo make. Fou sere, nearly all these reperts have been male before the Deparement of Comsunere has begun to make ginnine reports in the full. Thorl a finnl astimate is made in December, about the 12 th of December. We hase been accumulating data for sevornl vears with a view to making nnedher forecast in November, nnd I thisk we now have sulliciont dnetn en begin this coming yenr to make one more additional colten foreenat in November of each year. There has been quite a demund for thase becatue there is quite a gap between the estimute mude on the zal of October and the linal production estimute will be in December.

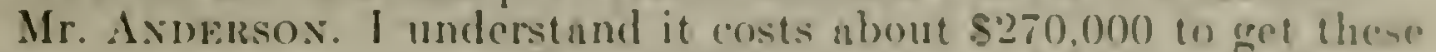
cotton ginning stutistics. Do you think you could do it any chenper than that?

Mr. Caldanisk. Well, I think we have the machinery and that we probubly could if it were given to us.

Mr. Bucluxax. The most of that is paid out in wages to the cotton stutisticiuns in each county, is it not?

Mr. Caldaniner. I think so.

Mr. Becmasas. Have you anybody now employed who could take up that work without much extra expense?

Mr. Cardaxder. We have men in every county and I think we could probably arrange to get it. Of course, we have a head man-a statistician-in ench State who is familiar with conditions in his State, and we get that sort of informution from other sourees, that is, not on cotton, but we get similar information on some other products by getting reports direct from the people who ure doing the work through our State statisticians. As it is now, the ginniner reports are, in a way, a check on the other, and it is very desirable to have not only an estimate of what the probable production will be. but a report of the actual amount ginned. We have estimated that we could make the ginning reports for about $\$ 100,000$.

Mr. Bechasas. When you make your estimates after the ginning statistics come in you have those ginning statistics to take into consideration in making your estimates?

Mr. Callander. Fe only have them for one report and that is the December report. At that time we do take into consideration the ginning statisties, becnuse the crop is pretty well ginned by that time. as a rule, and this year a grent deal of it is ginned.

In addition to this cotton statistician we want to put $n$ grain man in the office who will specialize on grain stutistics and methods of estimating wheat and corn. Up to this time we have only land Mr. Murray, the chicf statisticinn, and one other man, us statisticians in the Washington office. 'The information comes in from the field and it has to be rushed through, and there has never been enough trained people in the Washington oflice to properly handle the matcrial. We want, if possible, to strengthen the Waslington organization by putting in at lenst two more statisticians than we hare at the prescrit 
time, and we feel that the results to the whole service will be very beneficial.

I have already mentioned the fact that since the amalgamation of the bureau with crop reporting the machinery. the field men and the volunteer correspondents, are now being used for other purposes as well as crop reporting. We are not using the same people, but we are building up lists of men who report only on special subjects because we do not want to overburden our regular crop reporters.

MARKETING STATISTICS.

Doctor 'Tarror. Mr. Tenny will discuss the item relating to marketing statisties.

Mr. 'Texwy. This is the item I mentioned yesterday as being transferred from the marketing and distribution funds last year, $\$ 23,400$. This is used exclusively in the compilation of fundamental marketing information. It includes holdings in cold storage; it includes the movement of cars from shipping points, and some price information as to the various commodities.

Mr. Axnensox. Do you get figures yearly, weekly. or monthly as to the loads and unloads of fruits and regetables?

Mr. 'Texis. In the larger eities we get daily reports as to the loads and unloads of fruits and regetables.

Mr. Anderson. 'That information, I imagine, gives you a fairly good index?

Mr. Texwy. Yes; it does. In addition to that we have coldstorage reports on 35 commodities. To show the completeness of these reports, we are cireularizing monthly 1,206 cold-storage plants.

Mr. Anderson. Do you include public and private cold-stornge plants?

Mr. 'Tenvy. Yes: 1,191 of the 1,206 are giring us replies monthly, leaving only 15 out of 1,200 that fail to reply, so that we feelour storage reports should be very nearly accurate.

Mr. Axnerson. Are these reports ever checked up?

Mr. 'Tensy. Through personal risitation?

Mr. Anderson. Yes.

Mr. Texwr. Oceasionally an individual one, but not universally so. The man who has this in charge is right now making a visit to six or eight of the lurger eities for the purpose of getting in touch with these cold storages and finding out how well their reports are manle. Of course, that does not mean that he goes into a storage house and makes a count or goes through their books, but he is cindeavoring to get the attitude of the people who ne making the reports, how they are making them and the data from which they draw of the reports. We are also making cold storige reports on fish. One hundred and ten concerns are on the mailing list and the average for the last six months has been 107 reports, lenving only three that have failed to report.

Wo are making cold storige reports on apples, butter, rheese. eggrs, fish, ice rrean, lard, live stock, live-stock slaughters, cold storage holdings of mucats, condensed and evaporated milk, oleomargarine, and the cold storage holdings of poulter, as well as yuartorly reports on wool. We are handling a portion of the wool reports. the remandere being hamelled by the Department of Commerees and we are 


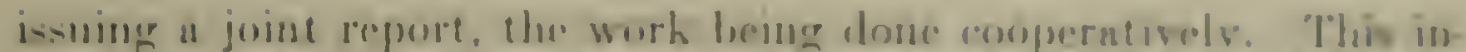

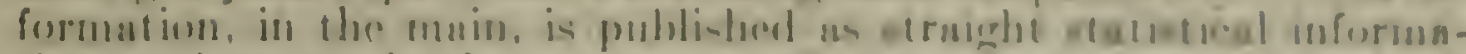

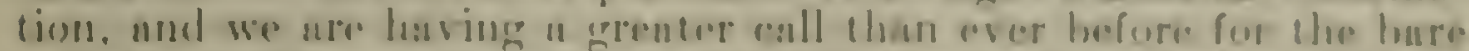

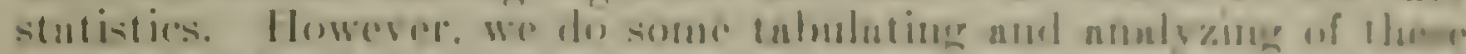

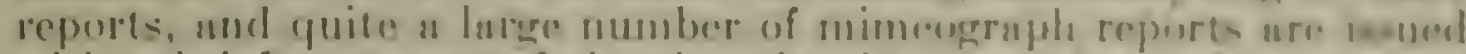

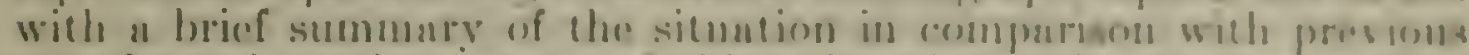

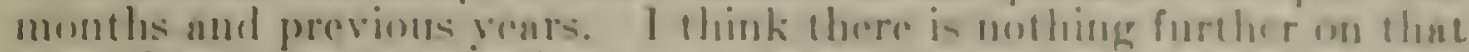
ilcul that I rale (1) mintiun.

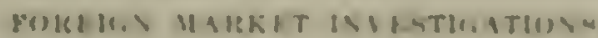

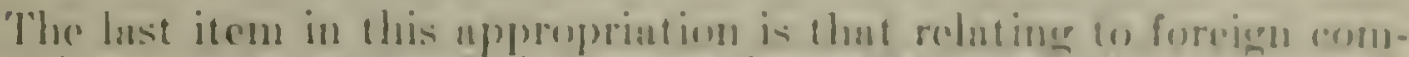

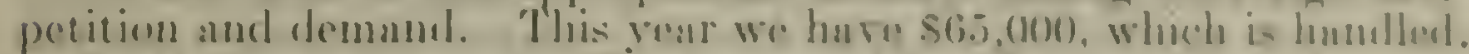

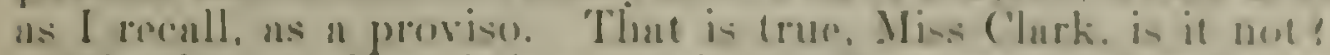

Miss (lank. Ins; it is a proviso to the mppropriation for apop and livesterok estimntes.

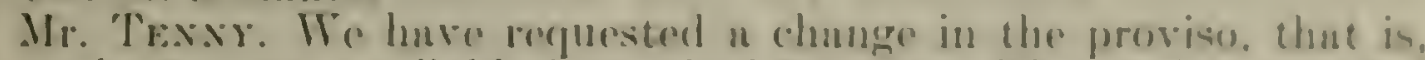

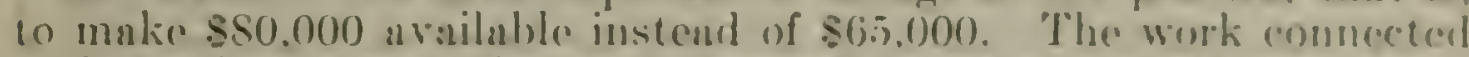

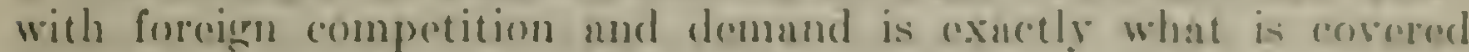
in thut houding and nuturally divides itsolf into i wo linss of work.

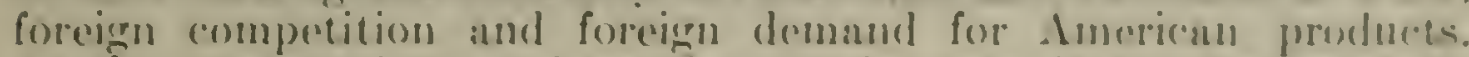

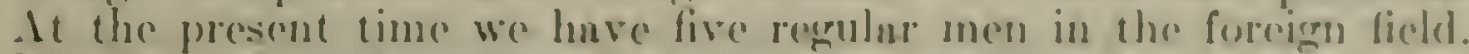
Mr. Foley is in London, whero ho is in touch with representatises from the whole of the British Empire. In addition to heoping in touch with the dovelopments in the Britisle Empire Mr. Foley has made seroral other studies. Last vear we had a request from tho almond judustry for informution regurding competition in the nlmond industry nud this mimeogruphed circular report was guten out. We have in the files n number of letters from the almond associntion of Culifornia commenting most favorubly on thut report and telling us it is just the information they want in shuping up thoir industry and their sales policy. Mr. Squires is now in Gromany. In Germany we are studying the development and conchach of the live-stock industry there, with especinl reference to the relution of the German live-stock industry to lard substitutes. Germuny wis one of the largest buyers of lird before the war and we are now studying, in a rather critical way. the lurd substitues that are being used in Germany. with especial refelence to the question of demand for our own products.

Mr. Andensox. How is this foreign work organized! Do you hnve representutives in the foreign countries who stay there the year around?

Mr. 'lexsy. These I lanve mentioned are in the furcign commeries most of the time, but not neeessurily in nny one comntl\%. Mr. Squire was originnlly in London. Mr. Squire was in the Fuglish countries with Mr. Foley, mol when the need nrose for making an study in Germany we sent Mr. S(puire to Germany. He will ulso go into Poland and cover "number of those central Guropena countries in making the special studies we want mule. Mr. Michad is still in eastern Europe, in the Bulkan comntries, and has becu making a rery cureful stuly of cereal production. We have this month. Xorember, issued u report on rereal production in lugoslisin, und that report indicates the charneter of the studies these men are making. Mr. Bulloch is still in Argentina, hut will return very shorty to the 
Washington office. Mr. Bullock has been studying particularly the statistical work in Argentina, with the idea of getting better statistics out of that country, which are very important from our standpoint, as it produces much of the same products we are producing and those products come in competition with our agriculture. He has also been studying the live stock industry in Argentina to a considerable extent. Just recently we have sent Mr. Lively to Manchuria.

Two things are particularly in our minds in this work in Siberia and Asia. First we want to get a clear picture of the competition that is coming from there on cereal production, and then we are proposing that he shall go over into certain parts of China to study the cotton production in that country. Something over $1,000,000$ bales of cotton enter into commerce from China, and it is our desire to know more about where this cotton is produced, the conditions under which it is produced, the labor conditions that make the crop and the whole economic aspect of the production of cotton in China.

Mr. Anderson. What I would like to know is whether that is something which will become a mere matter of history and which can be embalmed in some library, or has it some relation to what we are doing?

Mr. Texwy. Through our press service these reports are being given the very widest distribution and they are angle from the point of view of being of assistance to American agriculture to-day and in the future, but primarily with regard to the development of our agricultural poliey for the future, because if China has the possibilities of producing a certain type of cotton and not another particular type that fact is of very great importance in all of our agricultural work in developing the cotton business in this country. I am using that simply as an illustration. The review I have given covers the work of individuals. In addition, we are getting a great deal of statistical information direct from the countries, analyzing it and issuing it in connection with the crop reporting information. We feel it is just as important, with the channels of trade open as they are now, for us to know what is being produced in foreign countries and what is being done with it as it is to know what is being produced here and what is being done with our home production. So all of these men and all of our correspondents are working from the angle of being of the greatest benefit, from the statisticnl point of view, to our agriculture.

Mr. Avpensox. What is the situation now with reference to securing prompt statistics of European production and consumption? My recollection is that those statistics have come in as a rule six months or a year after they could have been of much use. I am interested in knowing just what is being done with a riew to getting those statisties more promptly.

Mr. Trexv. The statistics of crops and live stock and live-stock products that we are able to gather from initial sources are cabled, and are handled just as expeditiously as our own crop and live-stock reports.

Mr. Axumasox. Do they come directly from the country concerned?

Mr. 'Thexy. Yes, sir; we are getting them that way, and we are also gotting them two weeks or so later from the institute at Rome. Wo fure a number of other reports. We are issung weekly this 


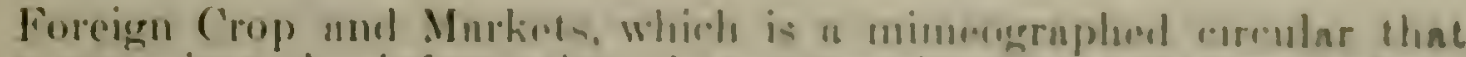
summarizs's the information that romen in during the work from foreign rountries.

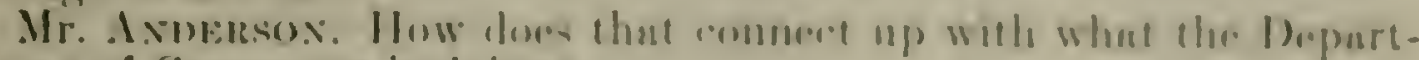
mont of commereo is doinger

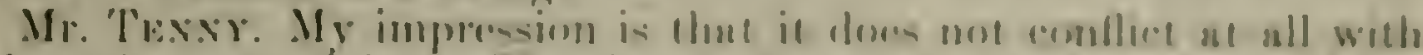

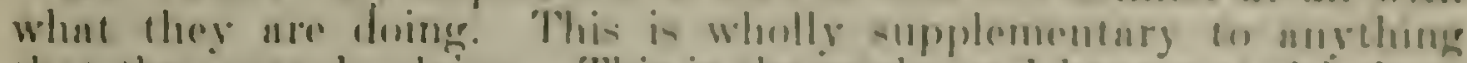

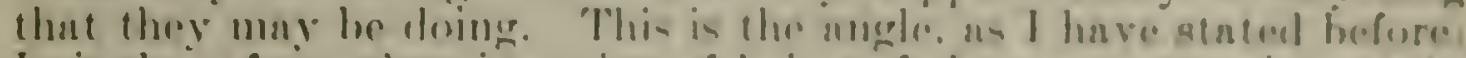
It is done from the viewpeint of heing of the grentest ansistanes in shapping our own nericulture. and is meressury in oreler lo develop

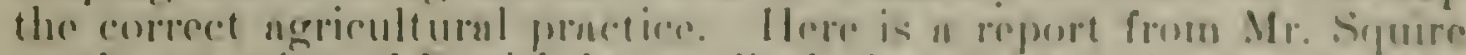
on the question of Danish buend displaneing the Imerienn product in

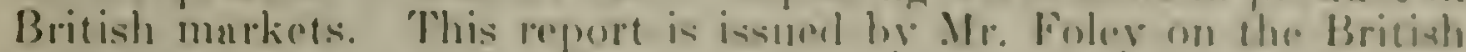
npple market, and it has hen usenl he proctionly all of the apple

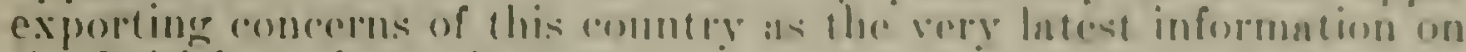
the British apple market.

Mr. Axthemsox. How many prople have you in gour division!

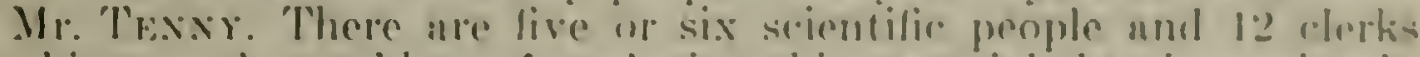
working on the problem of analying this muterial that is coming in from foreign countries nnd getting it ont from weok to week so that it may be useful.

Mr. AxDEzsox. How many people have you in foreign countries?

Mr. Texwy. There are five.

Mr. Andersox. Are they all in Europe?

Mr. Texxy. No, sir; there is one in Asin, und one in south America. The others are in Europe.

\section{FOR MAIRFT IASIFCTION OF PFISISAHLF FOOIN.}

Mr. Axnersox. We will take up the item on page 2S1, for (mabling the Secretary of Agriculture to investignte and certify to shippers and other interested parties the qunlity and condition of fruits, vegetables, poultry, butter, hny, and other perishable farm products.

Mr. Suemax. Mr. Chairman, we have here nn estimnted inerease of $\$ 100.000$, which it is proposed to expend in the following proportions: For the innuguration of hay inspection work, $\$ 40,000$; for poultry and eggs inspection work, $\$ s, 000$; and for further work in the inspection of fruit and vegetnbles, $\$ 52,000$. The hny work will be entirely new. The approprintion, howerer, for the last three years, I think, has carried authority to inspect hny nlong with those other products, hut no nddition wis made to the nmount carried in the appropriation and no hay inspection work has been done.

\section{HAY INATECTION SERVTCE.}

Hay standardizntion work has gone forward, as Mr. Tenny explained to you, under the marketing und distributing item, or through an nllotment from that item, and now the department is in a position to go nhead with the nctunl inspection work. The hay exchanges of the country have taken a most lively interest in the work. und apparently hine heen cutirely converted to the idea. Ther now have men in traning with the department who are to be used as inspectors to be empleyed jointly by the han exchanges and the department. They are to be emplused umber the supervision 
of the department in the application of the recommended grades for timothy and clorer mixtures.

Mr. Avinensox. Will any change he made for those inspections?

Mr. Sintrux. Yes, sir: a charge will be made for the inspections, but how nearly it will come to making the work self-supporting, we can not tell in advance. It will have to be tried out. We will have to experiment with that as we go along, just as we did in the case of fruits and regetables. As you will remember, the fruit and regetable inspection work during the first year was a free serrice. In connection with the fruit and regetable work, during the fiscal year ended June $30,1919,14,493$ cars were inspected, and no charges were made until October of that year. Then we began with a fee of $\$ 2.50$ per car, and that fee was continued through the next year, or the year ended June 30, 1920. During that year 25,4SS cars were inspected at a fee of $\$ 2.50$ per car. Then the fee was raised to $\$ 4$, and the interstate limitation was put on by Congress. Then the number of inspections dropped to 23,877 . Then in the fiscal year enderl June 30 , lnst, the inspections went up to 31,207 , at a fee of $\$ 4$ per ear. Therefore, as you will see, we have progressed from no income at the beginning to a point where we have returned to the Treasury in the last fiscal year $\$ 12 \$, 627$ out of an appropriation of $\$ 175,000$, making the scrvice about five-serenths self-supporting. ITe are running at just about the same rate this year in our work in the cities. That is a digression from the diseussion of the hay work to a discussion of the fruit and vegetable work.

Now, the same policy is to abtain in the hay-inspection work that has obtained in the fruit and regetable inspection work-that is, to start with fees that the people will pay and then work it up as nearly to a self-supporting basis as possible. When we come to the question of the inspection of fruit and vegetables, I would like to go into that matter further, and see whether the committee has the idea that we should raise the fee so as to make the work entirely self-supporting. or until we reach the point where the decrease in business balnnces the incrense from higher fees, or whether we should aim to keep the work popular, even at the expense of a small part of the appropriation. It is a question right now whether we should raise that fee to $\$ 5$. If the fee had been $\$ 5$ last vear, and if we had had the same number of inspections, we would have been only $\$ 15,000$ short of turning in the full amount of the appropriation to the 'Treasury.

Mr. Axinssos. If I understood Mr. "Temmy eorrectly, those hay standards are still in a somewhat experimental stage.

Mr. Smbkmax. "They necessarily are in an experimental stape mal they reaneth the stage of demonstration in actual practice. 'The hay uscociations of the country have genepally aceepted and approved this proposition, and wish to put their business upon the basis of the recommended hay grades, so far as timothe and clover mixtures are concerned. Most of the work remains to be done with reference lo prairie hays and alfalfa, so that the hay-inspection work contemplated

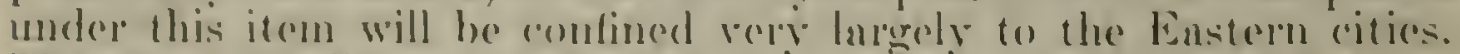
The ment andully in traning now sire expected to work in Boston. New York. Philidelphia, and Richmond. Ya., with one operating fore in Washingtor, who will he uratable for inspection work at Wushinglou and in Alexandria, where the hay laberatory is located. 


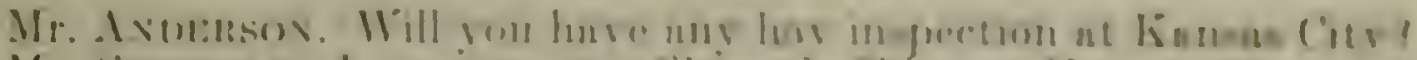

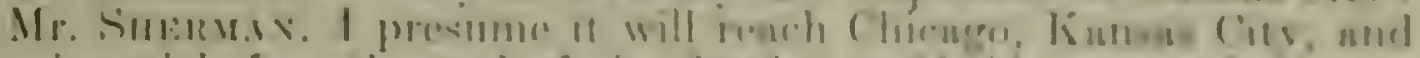

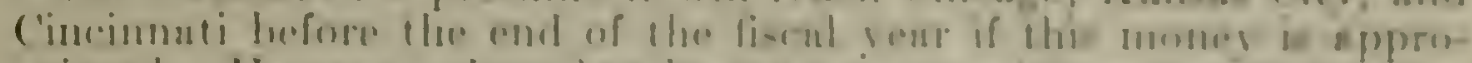

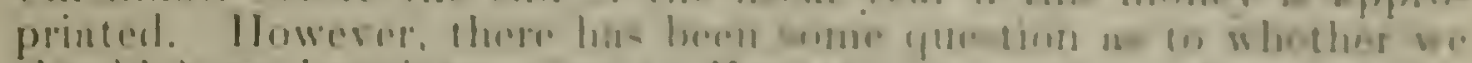

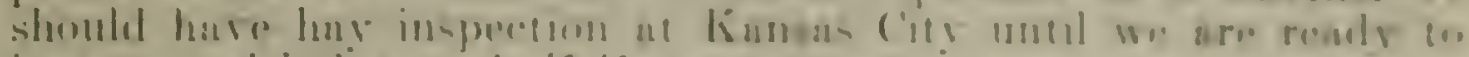
inspret provirie ling nud ulfalfu.

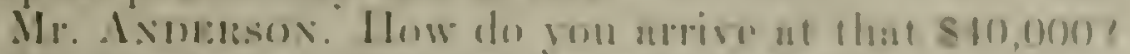

Mr. SHeksas. That is purroly an intmante.

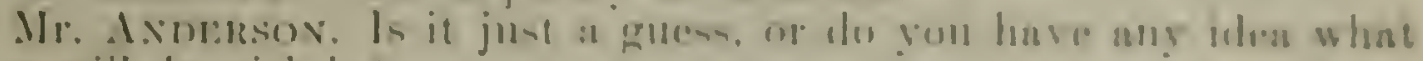
you will do with it!

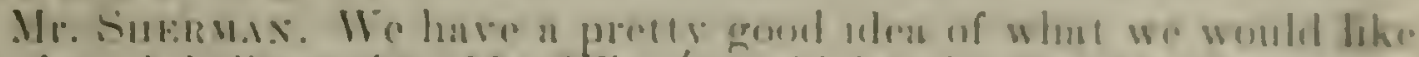

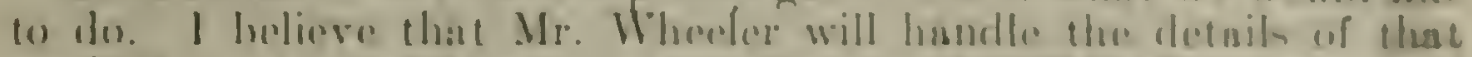

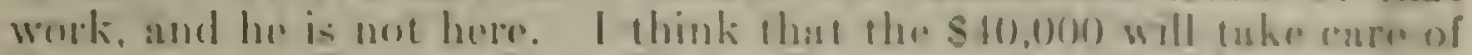
the work in Boston, New York. Philadelphin, Wohineron, and

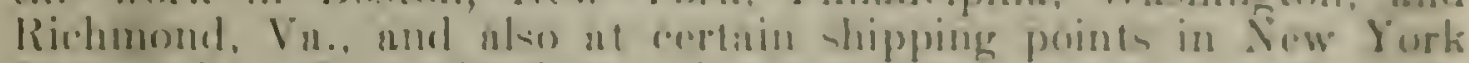

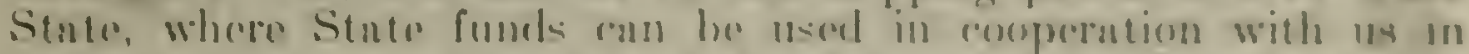
making this sorvide arnilable at the shipping emel. It mas ulat be

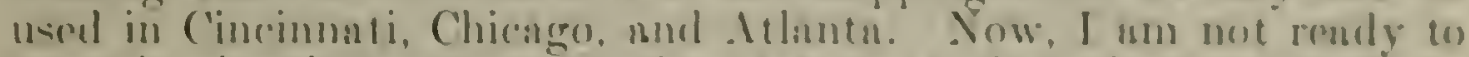
commit the department to the statement that the work will be enrrien on in all of those cities doring the antire fincal yeme on this $\$ 10,000$, buesuse it would secm to mo that that would bo more than we could rensombbly hope to curry aut, but those points I hase mentioned nre points where we expect to begin work, and it will be dome pretty llearly in thent order, su far as the moncy will go.

Mr. Arnersos. I think you had beter furnish us with a statement showing where you propose 10 put those men, whint saluries gou will pay them. nat when you expert to junt them on.

('The stutment referred to is us follows:)

Salaries:

Estimate colering hay inspection.

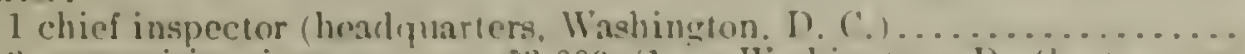

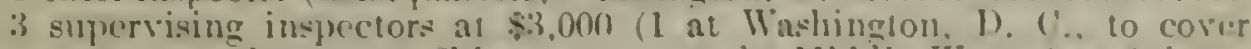
castern matkes: I at Chicago to cover the Jidille riest: I at . Itlanta

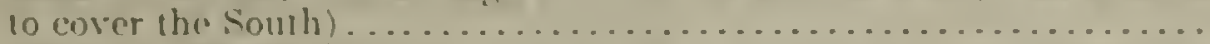

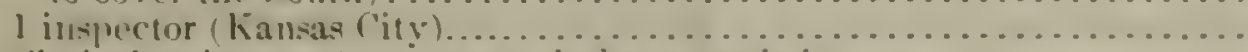

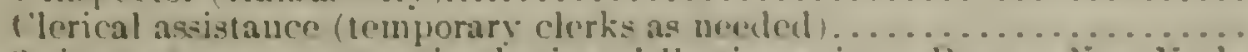

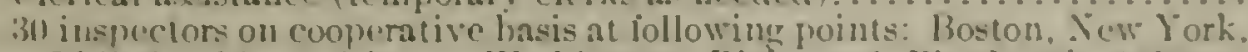

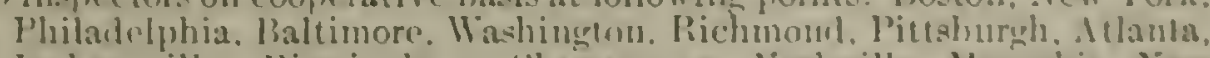
Jacksonville. Birmingham, Chaltanooga, Nashville. Momphiv. Jiew

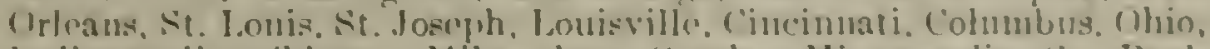
Indianapolis. I'hicago, Jliwauker. Smaha, Minmeapolis. SI. Paul, Wuluh, shipping points in New lork and Virginia, and also in Uhio, Indiana, and Michigan, if possible.

Stationry and oflice supplies. . . . . . . . . . . . . . . . . . . . . . . .

Telephone, tolengrah, freight, express, ilmyage, itc. . . . . . . . . . . . .

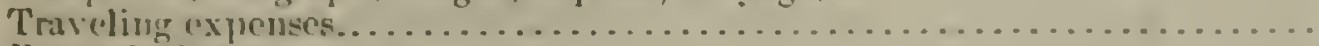

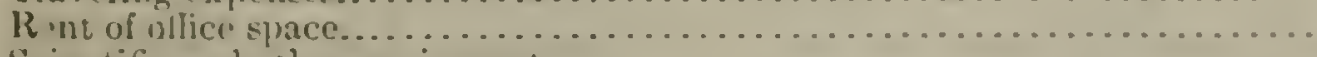

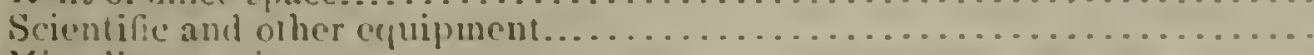

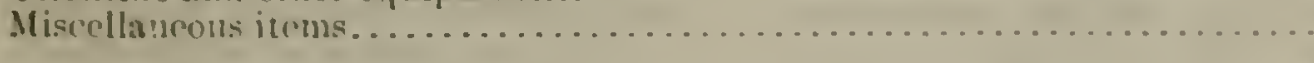

$411,(x)$

Ii his appropriation is grantod, armugements will be male to starl men in taining for iuspectors on July 1, and within six weeks of that time, the dopartme-nt will lie ready in get the service inder way in all of the cilies shown shows.

Mr. Smermax. There nre five men in truinge mus.

Mr. Trass. The only armengement that with be mole until the 1st of tuly will be to put these mon in at $\$ 1$ per year, which is simply

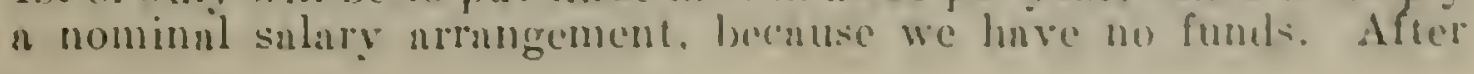


that time, if the funds are available, we would like to pay them not less than $\$ 100$ per month, and in some cases it will be a little bit. more than that. All of them will be cooperative men.

Mr. Anderson. That is, purtly paid by States?

Mr. Texry. In some cuses partly paid by States and in some cases partly paid out of inspection fees that are collected by hay exchanges.

Mr. Andersox. I do not see how rou can charge an inspection fee on the side of the Government where the men are partly paid by the Government and partly paid hy the States.

Mr. Texiy. The way it is handled is that the fee will be charged and collected through the hay exchanges, and the part of the salary that is not paid by the Federil Government will be paid out of those fees. In addition to the amount that will be paid these men out of the fees, a part of the fee will also come to the Federal Treasury to cover the approximate cost of the service to the Federal Treasury. We will have to pay our proportion of the salaries out of the appropriation, but out of the fee will conne into the Treasury an amount approximately equal to the amount paid from the Treasury.

Mr. Shemmax. Of course. if such agreements are made, you can provide for the reimbursement of the Treasury with much more accuracy than from the fors. which, in turn, are dependent upon the flow of business. We hare a rather profitable arrangement that I would like to explain to vou a little hater with reference to shippingpoint inspections of fruits and regetahles, in which the States guarantee to us a return of the salarices that we have to pay.

POLLTHY ANI) EGG WOIR.

It is the purpose to allot $\$ S, 000$ of this increase to poultry and eogre work. Mr. 'Tenny has spoken to you with regard to the progress that has been made in the derelopment of egg standards. The people who are handling the poultry and egrer work realize that it is of very little use to recommend egg standirds or grades unless rou are ready to put on the inspection service and demonstrate whether or not they are heing used and lived up to. If rou simply recommend certain grades, they will be adopted in both the western malkets and the eastern markets, but you will still have those questions and differences of opinion between shippers and receivers until rou put on Federal inspectors. Therefore it is expected that if this increase is granted about $\$ \$, 000$ of it will be used for poultry and egrg work. That work will be dome in the hig cities. like New York, Boston. Philadelphia, and Chieago. In New Yorle Cits, we will sas, there will probably be a certain number of inspections of live poultry. They will have the same ald guestions that have been agitating the poultry trade, of the orerfereling of poultry hefore putting it on the market. They are still huving a great deal of difliculty with that, and they want federal inspection (o determine whether or not pondtry arrives in a proper condition to he placed upon the market.

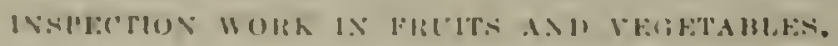

Uut of tho $\$ 100,(000$ incrouse askod for, it is proposed to allot

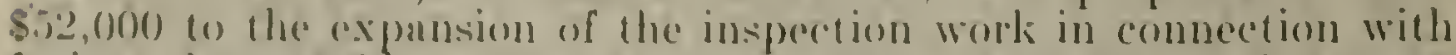
fruit and veretubles. I have just reviowed the work to dato. Is it has heen handled in the past, the inspections have grown from 


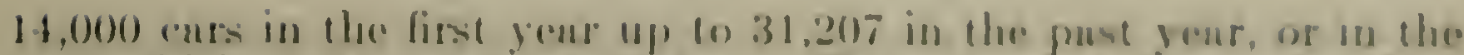

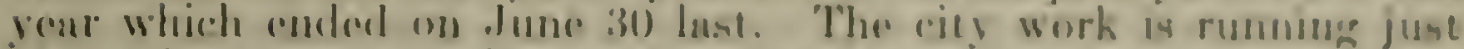

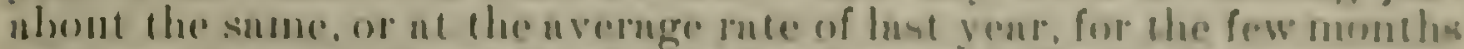
we hure passed through of this fisenl yenr. The only new work that has come on as in the citios is the inspection work that we

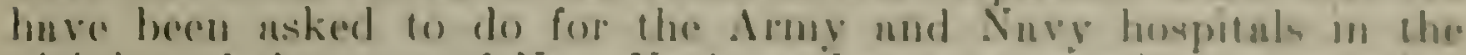
ricinity of the port of Now York, nnil we ner now junt complestug

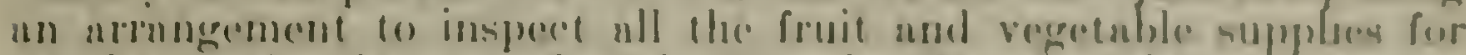
the flece under the eonteol of the Shippine Bond, wheh will invelse

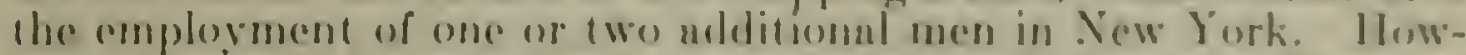
evere the will be poid for hy trunsfor of funds from the shipping

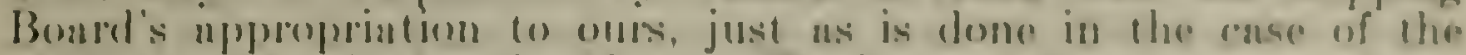
work that we do for the Nary. Wo lanve right men mow giving full time fo the inspection of sipplies for the Nave, und the salaries of those mon are reimbursed to us by a trunsfore of funds from the Nay apporomintions to ours. For thut renson, if you look nt our pay roll, it might uppeas that wo ure carrying 1 rather latge forese for: the amount of insperetion work we nre doing. hust a number of these men are renlly being paid by the Nary, and they constitute no donin upon this approprintion.

Just ut the present time there is an extra demund in the port of Now lork on the purt of exporters for the inspect ion of commodities groing ahroate, purticularly of apples, which work we hove not heen uble to do. heenuse of our innbility to put on any more men. The inllexibility of the service is a rery serious hamdieap in some respects.

Last rear, ns rou nre nware, the House amemeded the langunge of this item. providing that inspect ions mieht bo molde of these products whon offored for interstate shipment, or when recoived ut such important central murkets as the Secretary of Agriculture may from timo to time designate, ete. I nm not sure whether the conmitter renlizes just what they did to us when that chunge in lungunge took place, or whether they thought they would multiply our fied hy 10, 20. w 100 . As a mater of faret, you multiplied our lield rery nenrly one hundredfold, but as you know, there was no incrense made in our approprintion to mect it. Therefore, we have had the delightful outdoor sport of seeing how many hricks could be mode without straw. You muy be interested to know that from the lst dny of duly to the 15th day of November we had inspected at shipping points

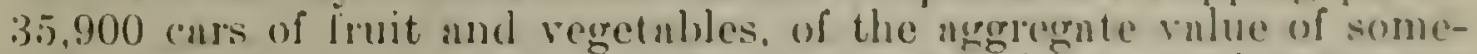
thing orer $\$ 24,000,000$. That is to say, we had inspected more cors at the shipping points between July 1 and November 15 than we had inspected in the comse of the entire preceding lisan genr.

Mr. Axolersox. How did you do it?

Mr. Sinemax. On the 11 th day of oune I started mysolf on a tour of the state capitals, visiting the commissioners of agriculture and the people who have authority to do those things in the sentes. and also those who have some noney fo spond, and especially those who have anthority to use the money that they muy muke in such enterprises. I was fortilion hy a series of opinions from the solicitor"s office as to whent sort of harenins we conble enter into under thant item. I had a series of eonferences with commissioness of angiculture, the murket men in the stutes, and a geosd muny with the attormess general of the Stutes. 10 see how we could lit the state law into the federnl law and work up a cooperative algeement under which this 
work could be done. In some of the States they had unexpended balances in their agricultural appropriations that they were grad to put into this work as a matter of experiment and as educational work. They were willing to do that whether they could get the money back or not, and in those cases that was the measure of the amount of work that could be done. In other States they were alrealy operating inspection services, and they had authority to use fees for the support of such work. In those states we had a rehatively simple proposition.

IVe worked nut agreements with 18 Sitates. Some of them have operated for a few months. or until the State money was gone, and some of them will operate throughout the fiseal year. As I have said, we have 18 cooperative agreements with States for shipping point inspections, and in mnyy vital particulars absolutely no two of those agreements are alike.

Every one is different from any other-that is, as to the method of making application of the funds, the division of the money, the method of emploving the men, etc. However, in every case we held to two or three basic principles. We hare held in each case that a reasonahle fee must be charged and collected, approximately sufficient to cover the cost of the service rendered. We have allowed the States that wanted to put money into it to fix the fees, and in some cases they lave put in a seale of fees that would not make the work selfsupporting, but in those cases the States were willing to inrest a certain amount in it for educational purposes. We have also insisted that the inspections should be on the basis of United States grades, and that the form of statement concerning any matter of grade should be a form that we approved.

We hope next year to bring about an almost absolute uniformity in the form of the certificate and in the nature of the statements made, and we expect to do that by having all of the certificates printed here at the Government Printing Office. They will be printed in such manner that each State can run in the State name under that of the Department of Agriculture, with sufficient room alongside the citation of our authority for them to eite the State authority.

Mr. Axmensox. How is the certificate signed?

Mr. Sinmmax. It is signed by the inspector, who states that he is anthorized by the acts cited to inspect and certify both on the part. of the State and of the United States. He holds a license card signed by the Secretary of $\Lambda$ griculture and countersigned by myself, or by the supervising inspector, authorizing him on belalf of the Secretary to inspect under this act. Therefore, all of those shippingpoint certilicates are joint State and Federal certificates. Where no one in the State hus authority to do this work, we can not operate, because we have no money. We have the authority but have no moncy. If anybody in the state has the authority and the money, we rain cooperate with them.

Mr. Axulirsos. How are those shippiner-point inspections enrried out! I suppose that in the case of many commodities it is a seasonal proposition.

Mr. Surkmax. Yes, sir; in some anses it is sensonal, and there will be mo ocension for the work cxeret during a few works or months. In those coses there will be no premanent siate organization to handle it. 


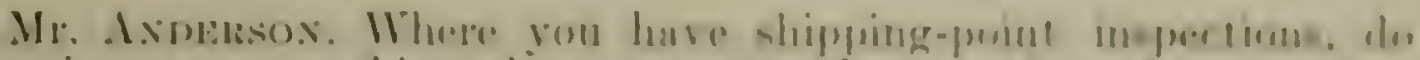

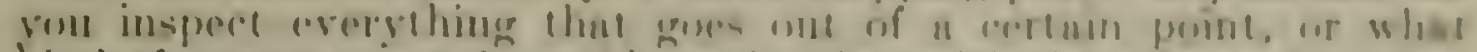
kime of nerangentent do you linso for that with the theppere?

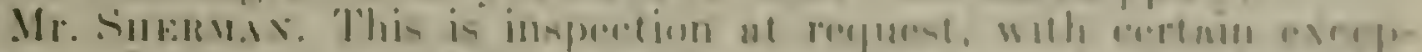

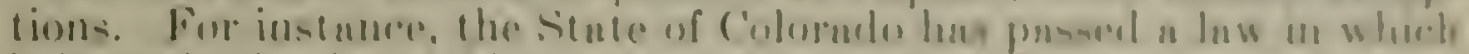

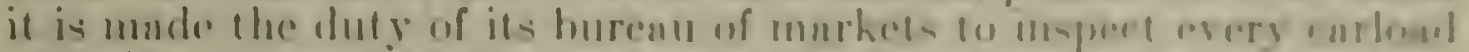

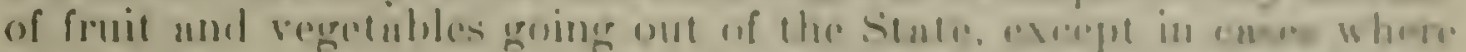

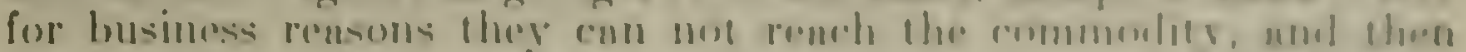

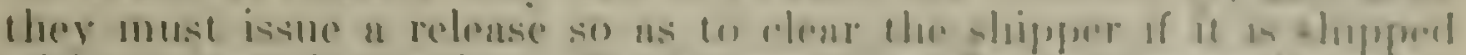

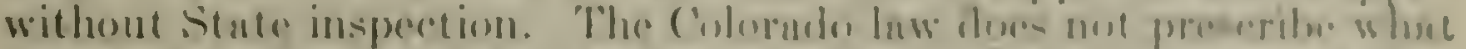
a man muy ship or what he muy not ship. nond it does moe prestalse any grade that he must conform (o, but providen thent he molat hase. the inspection male and the cortifiente pust in the cor showing the result of the inspertion. For the purposes of thin insmedom, the State bureatu of markets has adopted nll the grades we have recommended for froits and regrobliles, and they have drawn up therr own where we have not mude recommendations.

Now, the law having repuired the State agency to do this work, we recognize the state as an interested purty with reforence to corres shipment of fruit and vegetubles made out of the State, und our ngrerement with the State burenu of markets in Colorndo prosides that we will jointly with the state, and at its rerguest, made a ferderal inspreretion of every car of fruit and vegetables that the State nerency inspects. The State nuthorities have divided up the territory intos six districts. under six supervisors.

Mr. Axbersox. Do you menn by that that you have wo in-peretions mude?

Mr. Snenmax. The same man mukes the inspection, und there is only one inspection. There is one operntion und one certificate is issued. In that case legally we do not know the shipper at all. and we only know the State of Colorado. The shipper must submit to the inspection and the shipper is delighted to have the Federnl certificate added to the State certificate, which he must accept and pay for.

Mr. Axdersox. I should imagine that it would be a prettr expensive proposition to make an inspection of every curlond of fruit and regetables shipped from the State of Colorado. Are those cars concentrated at gateways?

Mr. Suermax. No, sir; they have a complete system rovering the entire State. They have divided the State into six districts under six supervisors. Out of the fees that they collected last rear from this service they sent the supervisors of those six districts to (hichan, and we gave them there our regular course in inspector training, say. for a month. Then we made them cooperative employees under the State law. Unfortunntely they could only he paid $\$ 1,500$ a vear, and it is not to be expected, of course, that they can hold good men at that salary. Therefore we made those six distriet men cooperntive employees nnd added $\$ 300$ a yenr to their sularies. We made them United States food products inspectors under the law and anthorized them to inspect commodities received in their markets. just as our men do in New York and Chicago. For instance, they can make inspections of shipments coming into Grand Junction from points outside of the State. In that connection, we were able to 
reestablish the Federal inspection at Denver, which we had to talie out of the State after the war. 'therefore. as I have said, we have those six well-trined men, and under them there are inspectors who are inspecting the ears from day to day. Those six men are traveling over their territory all the time. 'The local inspectors under those men inspect practically all the fruit and regetables that come out of Colorado and issue C nited States certifieates allong with the State eertifieates.

The State pays us as our share of the fee collected 2.5 cents per car. The State of Colorado has inspected, or we have inspected jointly with the State of Colorado, between the 1st of July and the 15th of November, 13,342 carloads, or a little more than one-third of the total shipping point inspections in which we have participated have been right there in the State of Colorado. The State, having statisties of the shipments orer a period of years, knows just ahout what it has to do. and can apportion its men in such a way that they can handle the work. They ean take men on and drop them off so as not to have a large idle force. They have adopted fees running from $\$ 3$ per car on potatoes up to $\$ 5$ on hoxed fruits per ear. On that seale of fees, the work is entirely self-supporting, and the 25 cents per car that they pay us returns to the 'Treasury just about twice the amount of money that we are putting in the State in the way of contribution to the salaries of those supervisors. Therefore, we will come out of the shipping point inspection work in Colorado with ahout from three to five thousand dollars a year above our expense's.

Mr. Axpersox. Under this increased appropriation, then, you would eontinue to make cooperative arrangements with the States?

Mr. Shermax. To some extent. Let me explain another cooperative arrangement that we have with the State of California, where the work is entirely voluntary. There is no State law requiring anybody to submit to inspection, although that is not exactly true with reference to apples. They have a special mandatory law with reference to apples, which makes inspection almost compulsory, or the shippers think so anyway. Generally speaking, the inspection in Californin is on a purely voluntary hasis, and the State is out soliciting business all the time for its inspection service. In Callifornia, by the way, we inspected 9,407 cars between .July 1 and November 15 , that being the second largest number of cars inspected for any state. In California we also have an agreement that our share of the fee is to be 25 cents per car. That State will make no inspections without the participation of the Federal Government, and we have made three men in California cooperative employees and have contributed to their salaries. One of them is the chicef of the bureau of standardization of the State department of agriculture, and he represents us in the supervision of that work.

Basically, that is not a desirable armorement, and we slowuld lave a man who is a full time and full salaried Federal man repressenting us in California in the supervision of that work, and working jointly with the State men. The state men, of courso, should be paid entirely by the state.

It is not at healthy arrangement to have the Feoleral supervision in any territory entirely in the hands of a man who recejves the major 


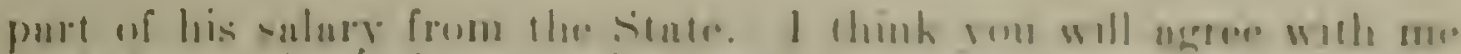

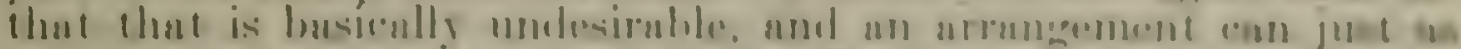

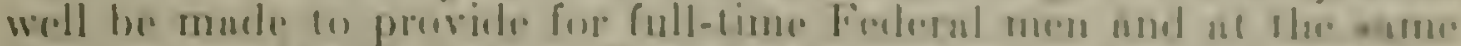

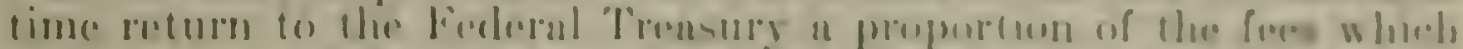

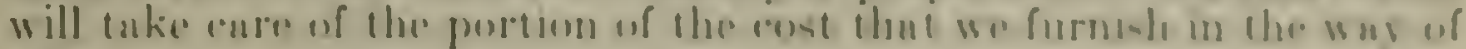
sularins.

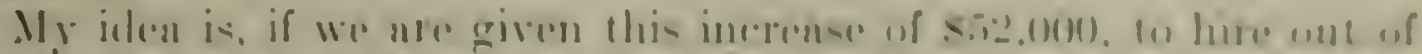

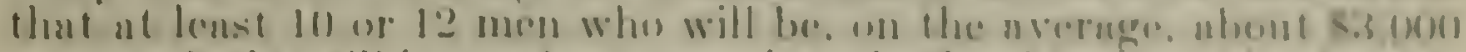

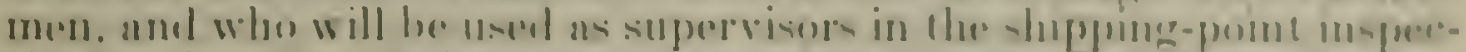

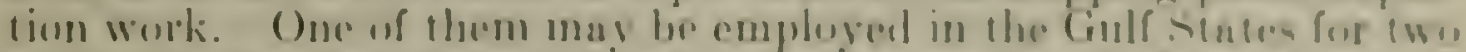

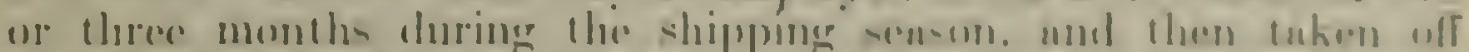

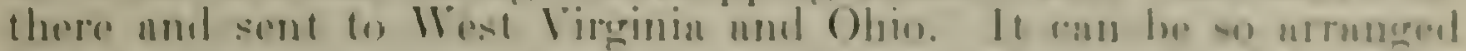

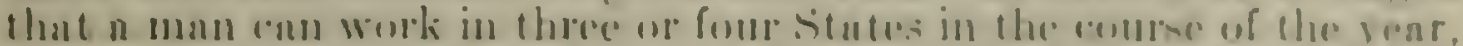

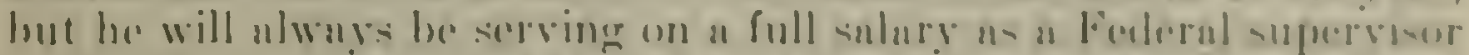

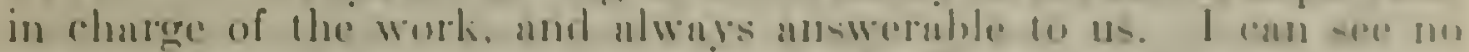

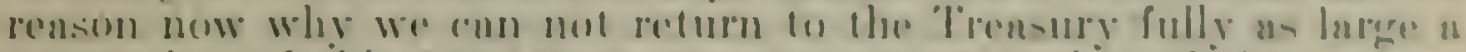

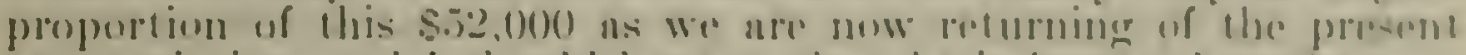

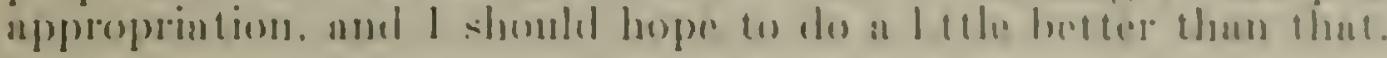

\section{INSTRETION JOUNT.}

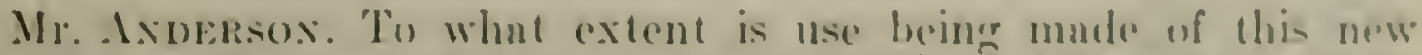
langunge nuthorizing inspections ut points which mag he convernicht! reached!

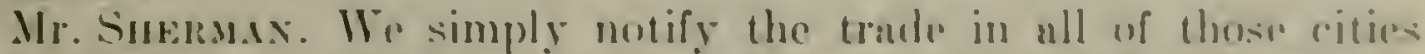
that there is no longere nny limitation as to plates, and that mur inspectors will orn muyhore within a day's journey of the places where

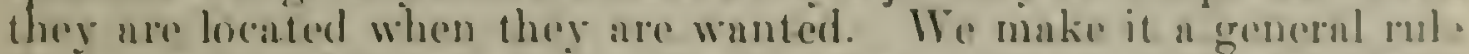
that the insperetor will not go so far uway from his post as to kerp) him orernight. In several instances it has hoen nocessary to somil a mun out from Chicager. for instnnce, on work that will tuke a loneror time than that, hut, ns u generul proposition and as an administrative matter, wo say that they mu go anywhere within a day"s jumrury of the places where they are locinterl.

Mr. Axnersox. Is there considerable inspection work of that -ort ut points any from the desiguated points?

Mr. Surrusix. There is a groud deal of it in the uererregate, but it is fairly well concentrated, I would say. For instance, thr deturnta

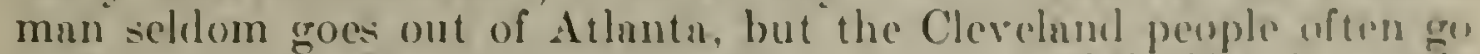
to Akron. The Detroit inspecters go to 'Toledo, and the Teslede people are exercised ovel the fact that they have to pay the arfaro of tho inspectors from Detroit down to Toledo mul back nenin. Tho Iow York inspectors make inspections all nromd Sow York, and mp inte

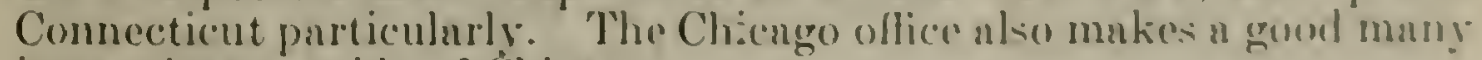
inspections outside of Chicingo.

Mr. A.nerrsox. Do you have any inspertions mate of shipmonte out of the larger citics as well ns inspections of shipments in? Fur instance, at Chicaro, do you hure shipping point inspoctions of shipments out of Chicuga as well us inspertjons of shipments (e)ming inte) Chicago?

Mr. Sinemax. I do not think we have hat nuch uf that this yenr. but we have had that sort of inspection work at Chicago in wo wr

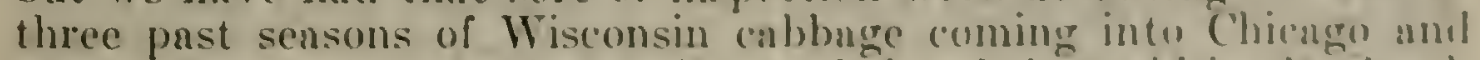
being stopped there for inspection, and then being sold in the suluth 
on the basis of the inspection at Chicago. We inspect a great many onion sets also in Chicago. There seems to be large quantities of onion sets produced in the areas close to Chicago, and they are shipped out through Chicago houses that handle them. For that reason we have a good many onion set inspections to make there.

We had cooperative agreements, for the inspection of potatoes only, with the States of North Dakota, South Dakota, and Montana, each of those States having a certain amount of money available in their acricultural appropriations with which they were anxious to secure inspection work, largely as educational work, as well as a service work. In ench case, the service was offered until the State money was gone, and then it was dropped. For instance, in North Dakota we inspected 222 carloads of potatoes, in South Dakota 306 carloads of potatoes, and in Montana only 70 carloads.

The machinery was set up, but, as you realize, this year has been an exceptionally hard year in which to support a thing of that sort in the case of potatoes, because everybody had to consign his potatoes, and, of course, the man who consigns his potatoes does not care much about the inspection of them, because he knows that when ther get into the market the buyer will form his own judgment regarding them anyway.

In normal rears, I think, the potato inspctions at the shipping points would be by far the largest single item, as potatoes are by far the largest single item in the market. This year, outside of Colorado. where everything has to be inspected, I presume the inspection of apples will run almost as heary as the inspection of potatoes, although in Idaho, where the inspection work is entirely voluntary, we have inspected over 6,000 cars of fruits and vegetables, more than half of which consisted of potatoes.

Mr. Andersos. When you inspect a car of apples, do you open all the boxes?

Mr. Sinermax. No, sir; all of the inspections are made by sample. Usually in a car of apples that will mean ahout 10 boxes if they are of one variety and size, but if rou have four or fire different sizes in a car, or four or five different varieties in a car, we have to inspect the usual run of samples for ench size and for each variety before we can issue a certificate covering the car.

In the case of a carload of sacked potatoes, the rule is to inspect as many as cight sacks, and if from that inspection we find the condition running fairly uniform, we will assume that we have the average of the enr - that is, provided we have taken the eight sacks from all parts of the loarl. If we find an irregular condition in the potatoes. we gro a littlo further. When we find a range of as much as 12 per cent betwern the best and poorest sacks of potatoes in a car, we do not certify that as a first-grade car, but we say it is an irregular car. We may say, "A majority of the sacks up to grade, with some showing 15 per cent defects." or we mav say that they do not meet the requirements of the Enited States No. I grade on aceount of the excess of defects. We may say that they run from 3 pere cent to 15 per cent defective, or mostly 12 per cent defective, or something like that.

In New York we had a situation in which the State thought that they could put up ahout $\$ 2,000$ to do this work. 'They were to employ three men, and we were to furnish a supervisor. "The fees were divided between us, we taking 50 cents per ear and taking chanco 


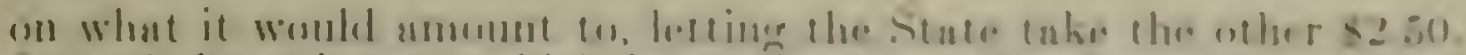

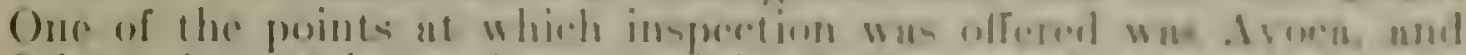

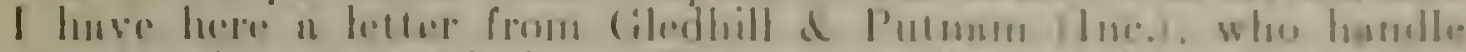

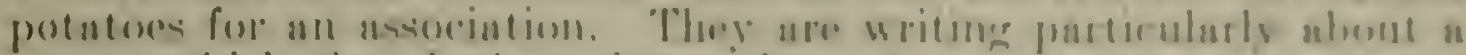

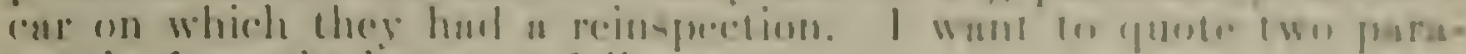
Erraphs from the littror, as folltums:

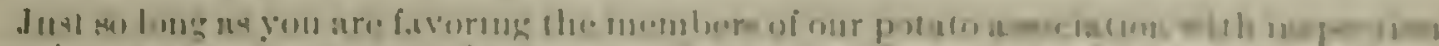

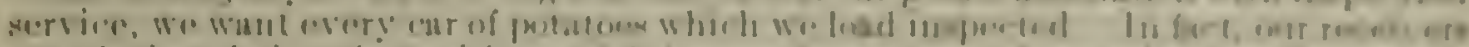

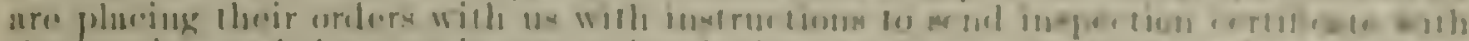

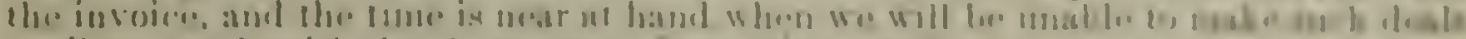

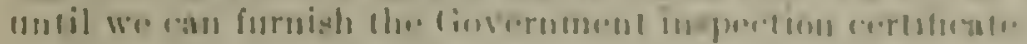

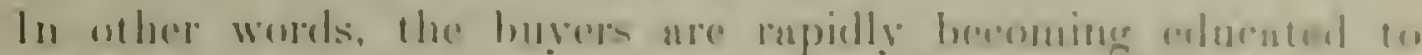

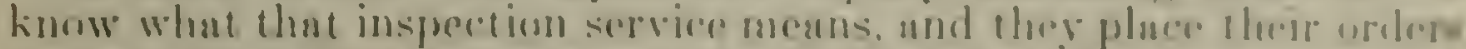

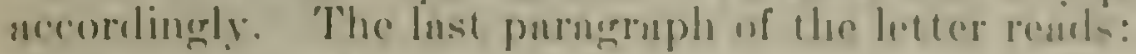

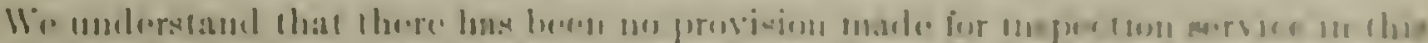

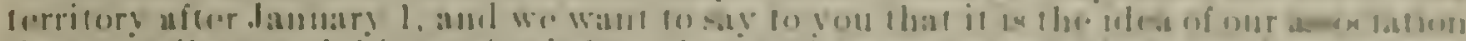

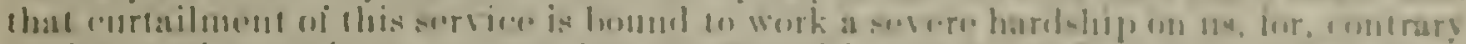

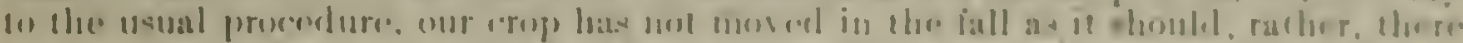

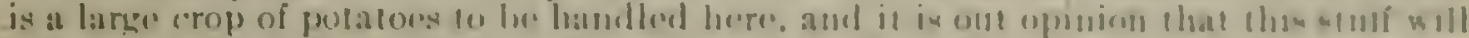

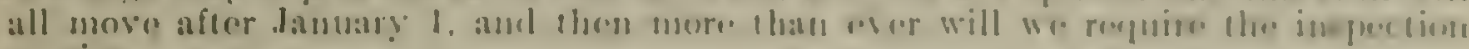
arvice.

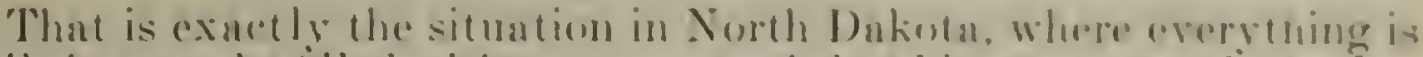

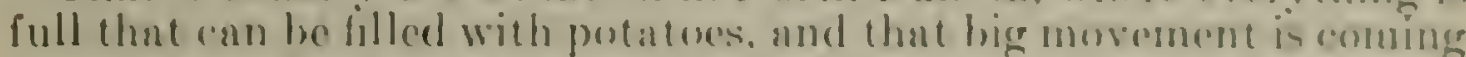
on after the State has expended all of the moner that it has fore the

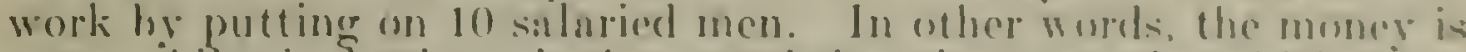
gone, white tho fousiness is there, and there is nu way hy whele thome fees com now he colherted and the expenditures recesuped. In (iolorado, California, Idaho, and the State of II nshingente where the work is supported hy the fees collected, we have sullicient clasticity to tuke care of the business ns it comes. () course, that would he a thoroughly satisfactory situation in places where we have a persunnel that wants to cooperate. hut in other places where the focs can mut bu rexpended we run right up against this situntion of getting the trado educated up to the servere nnd making the busines: men dependent wit the service, and then having to withdraw the scrvice. "lout is the only ground on which we are open to any honest criticism.

Congress has asked us to gu into this business and to lender at business service. 'This is a service that can he sold like life imsurance, but you must show that it is a goud thing. Ifter the husinesis man is shown that it is a grond thing. he wants it. Then the huriness men begin to build up their husiness upon the busis of this inspertion service. Then if the comdition of the market is such that it berounces easy to sell at the shipping points. it becomes exeoodingly impontune for those people to be ahlo to get the service.

As we are situated now, wa ure ntterly holpless. and I think bull must realize that, as a pratetical proposition. We must mortguge or obligate nearly all of our appropriation within the lirst throe months of the liscal your. We have pressure now from coitios like "Toledu, Ohio, Des Moines, Iowa, I lartford, Conn.. San Intonio. "lox., and Wichita, kans., where there is a demund for inspertion. und ther are too far from points where we have inspection serviro ntroudy established.

Is a practical mutter, we must hy out our program at the hournning of the tiscal year and provide for the axpenditure uf most of our money. 
Then, when a situation arises like this export situation in New York, where there is a volume of business that we should handle. if we are to handle this husiness as we would handle a private business. or if we are to make an income when it is possible to make money. we should have the funds arailable. We should handle our business in just that way, so as to take adrantage of the conditions. but our pay roll is sucli and our balane is sueh that we do not dare to put on two men in New Yurk, eren though they will carn a profit for the Treasury. 'That is in a place where we have rent already paid and where we have statutory d lerks at irrned, and where we have ererything neres-ally, cxept the additional men to do the additional work.

'T his shipping point situation in western New York is duplicated right now in dozens of plares all orer the country. Men siey to us.

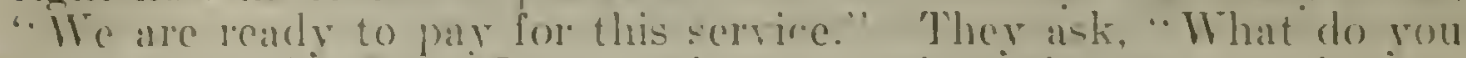
- do with the fees?" We can aly say to them that we put them in the Treasury, and if we tell a good enough story to the committee they may add something to the fixed amount that we can spend nexit veali.

Mr. Axpersox. We seem to be keeping pare with you as it is, as nearly as I can figure it out.

Mr: Silemax. I do not think we can find fault with the way the committee has treated this project. We are placed in a situation where we have to compete with private agencies. Te have private adgencies competing with us all the time, and we have had a private agency to take some railroad business away from us this yenr. Last rear it was our service, and we inspected 5,196 cars in P'hiladelphia last veals.

Mi. Macies. What did you charge for that inspection?

Mr. Snerias. St per ('ar.

Mr. MageE. What does the private ageney charge?

Mr. Sulksux. The private agencies will charge whaterer price they have to make in order to get the business under contract. We were olfered the business of one of the large railroads.

Mr. Magel:. What do they charge for that service?

Mr. Silmuax. They charge all that the tratlic will bear.

Mr. Mncies. That does not mean anything. What do they ordinarily charge!

Mr. Snerman. So far as I know, they have no ordinnry charre. They mule contracts.

Mr. Macies. That does not indicate anything at all. Do you know whether they charge $\$ 10,825, \$ 1$, or $\$ 2$ as compared with your rharere of st per car! I ask for that as a mattere of information, and if you can give it, I would like to have it in tare record.

Mr. SinkrMa.. In some case's one agency is inspecting for \$2.50 per ('il.

Mr. Maglik. What is the highest amount that you linow of any privato anency churering?

Mr. Sharsix. I would not like to quote anylondy becanse we are deperdent mpon somebody's word for it.

IIr. Mstivis. You have at pretty geod iden of it, have you not?

Mr. Susksax. There is a man inspereting at Minneapolis -

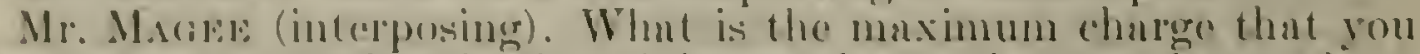
know about and what is the minimum charege that you know about made he private arencies?

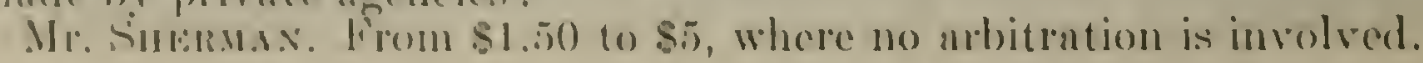




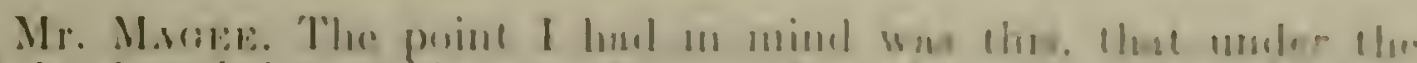

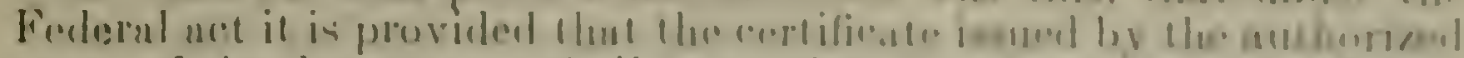

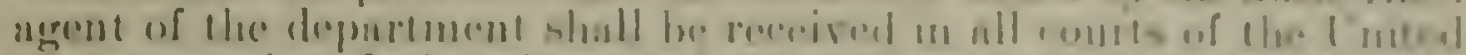

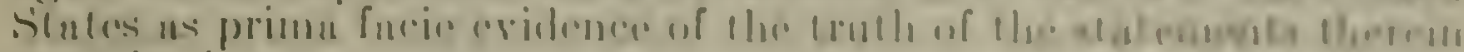
rontuinterl.

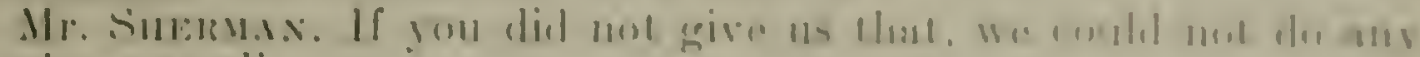
busingis 11 all.

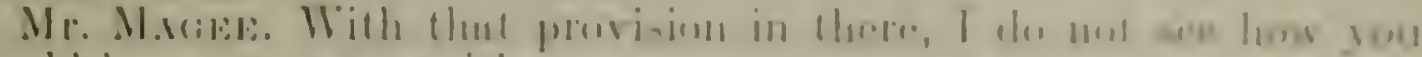
combl lowe nuy comsurtitim.

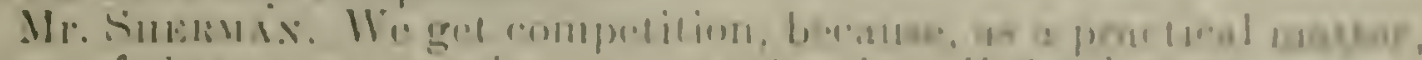

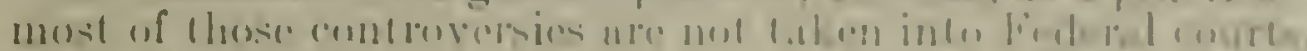

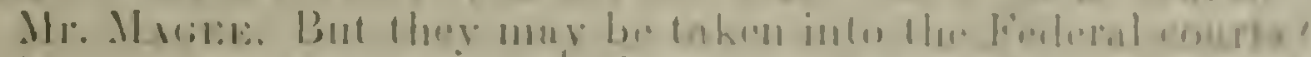

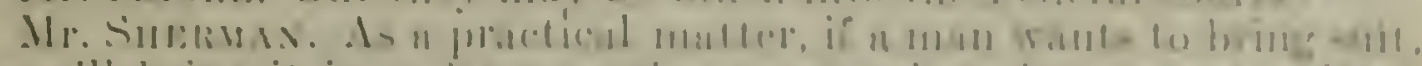

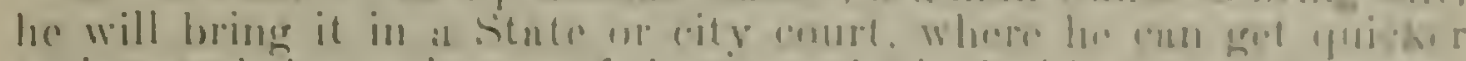

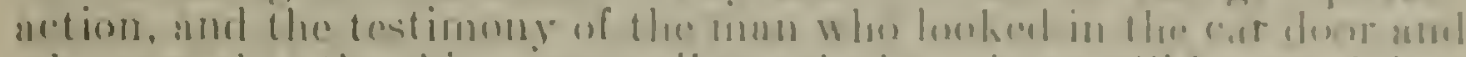

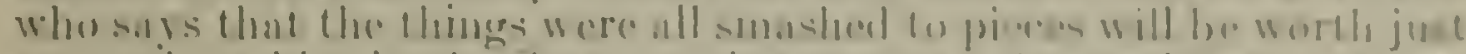

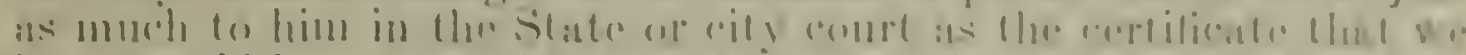

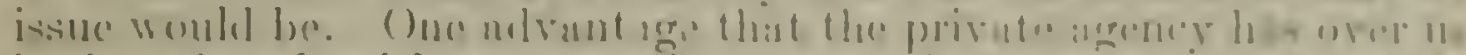

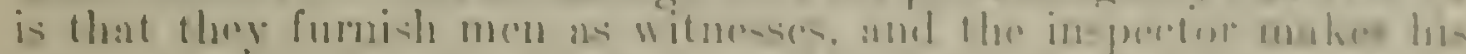

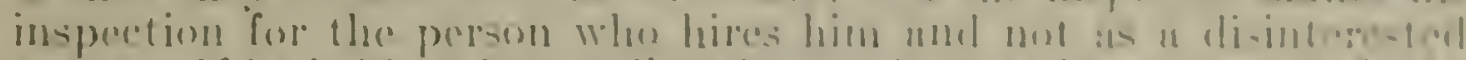

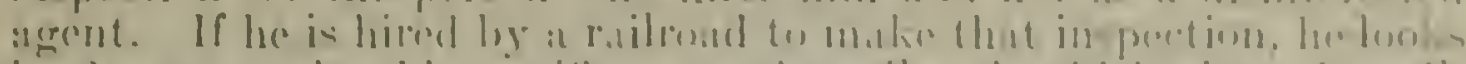

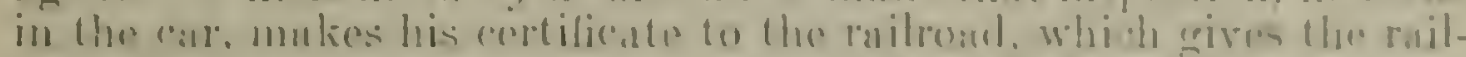

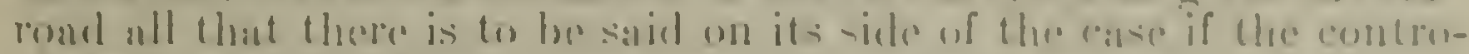
versy is cinmind inter court.

Mr. Axmbesox. I gromed the impression somehow that some of these peope who malie contrants eovering an certain large mumbler of inspect ions made them as low ats S1 por catr.

Mr. Sneman. I think rery likely they do. I do not know what the private ageney ollered to do the irork for the l3. At (). Rathond for.

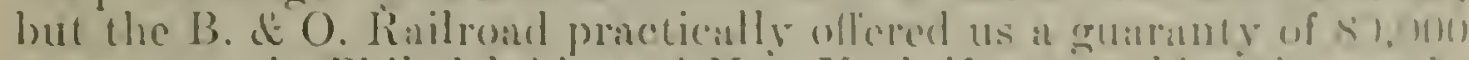
cars a roar in Philadelphia and New York if wo Would niake a substantial rerluetion in the fee. They expected to gret it dene for $\$ 2$ per ear or less. We understeod that this private neroney had oflecend to

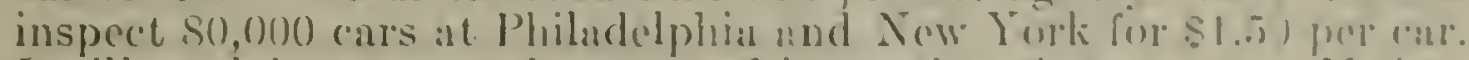
I will exphain to you what sort of inspection that menss. If they find out that we have inspected at carr, they gor in and looks at our erertificate, and they will always trail us. They will never malso at statcement which disigrees witli our inspection. but their inspeetion in for the purpose of furnishing evidence to the person who employs them.

Mr. Mhaes. I understand that, hut I rew it from the shandpoint of the shipper and not the transporting agency. It seems to me that with a fee of 54 a man who exereised crdinary prudenere would hardly take the chance of missing a federal cortilicate.

Mr. Snfman. That is true. I think I am sufe in suying that these private inspection agencies have nlmost no business from the producers and are almost never employed by a shipping association.

Mr. Axbersox. It is practicilly all rathomel inspection?

Mr. Sunmax. It is railrond inspection and inspection for the receiving interests.

Mr. Mager. That is the way it impressed me, that you would not have much competition from the producers.

Mr. Shemas. No; not at all.

Mr. Macee. But what the transporting ageney might do is another thing. 
Mr. Sulermax. We have no competition at the shipping point.

Mr. Andersox. I am not quite satisfied as to this hay business.

Mr. Shermax. May 1 say one more word on this matter of elasticity, although I think you see the point all right! I was going to say that it is not necessary to make all of the income from the service rexpendable in ordere to take care of that situation. 'The first $\$ 10,000, \$ 20,000, \$ 30,000$, or $\$ 40,000$ of fees could be hold in the

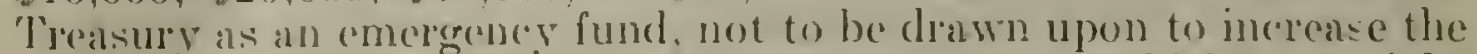
permanent sulary roll but for the specific purposes which rou might designate, in order to take care of work that would develop during the verall.

Mr. Avmbrox. You will have to set the that with the Burlget oflicer.

Mi. Snlkmsx. Of course we never put it up to him.

Mr. Andemsox. I think it is the policy of the Appropriations Committre, and I presume the Budget Bureatu too, to oppose rerolving funds. We could not do it without its being subject to a point of order any way, and I think it is a rather bad policy.

Doctor 'TaYLok. Mr. Tenny will say something more about the laly ituation.

\section{HAY-INSPECTION WORK.}

Mr. Texw. All I can say is that the demand for the hay-inspection work is very strong. As Mr. Sherman has said, we have simply estimated, to the best of our ability, what it is going to cost to take care of the cities which have already indicated a desire for hay inspection work. We have estimated it on the basis of earrying a substantial portion of the salaries of the inspectors in these different cities and then have provided for from two to four supervisors, depending on the number of eities that actually take the work.

Mr. Anderson. In how many cities do you think you will have inspection!

Mr. 'Texry. At the present time Boston, New York, Philadelphin, Chicago, and Richmond have written us, and we have princtically arived at a tentative agreement to undertake inspection work in those rities. Cincinnati, St. Louis, Atlanta, Baltimore, and Pittsburgh have been considering the matter but have not arrived at any definite decision.

Mr. Anomersos. 'Then you have five cities in which you feel confident you will be able to establish it?

Mr. 'Twoxy. Yes, sir; five cities that have assured us that they want the inspection work, and the matter has gone so far that men representing those cities have heen and are in the city taking the hnyinsprection course we are giving.

Mr. Axmbron. Will you be able to get this started immediately ufter the lst of duly?

Mr. Thexy. Yes.

Mr. Axpmasos. Wo will next take up the item relating to the market news servier.

MARKLT NEWS SHRVICH.

Mr. Marquis. The murket news service approprintion involves no increase, as you will note, but there is an apparent decrense, due 10) Iransfor of three clerks to the stutulory robl. That fund is devoted to market news projects in four principnl lines, live stock and meats, 


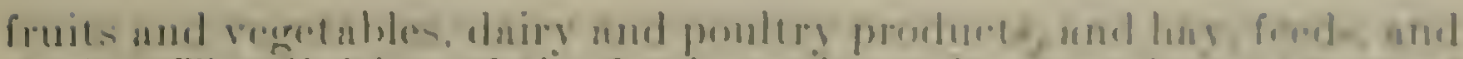

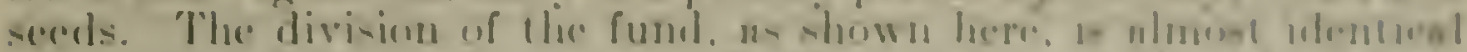

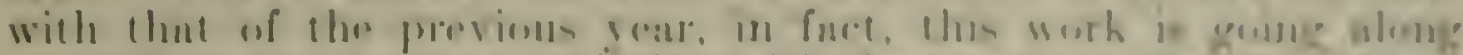

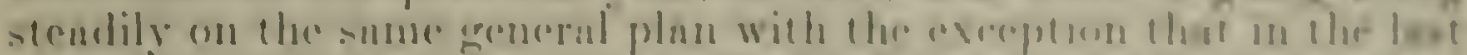

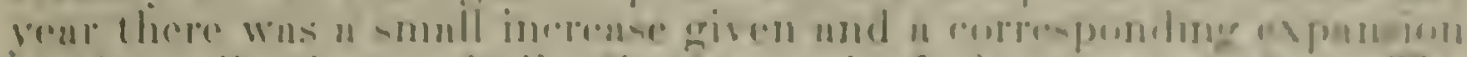

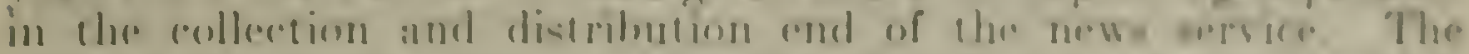

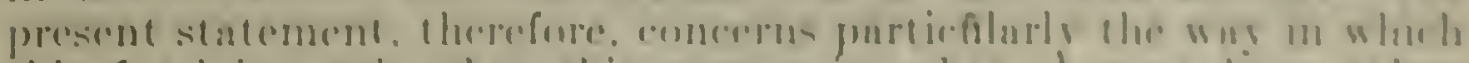

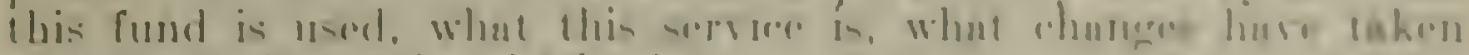
phere and the reanles ohtuined.

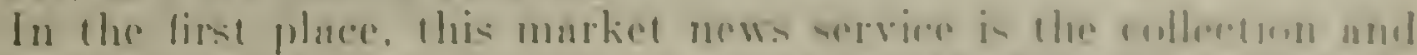

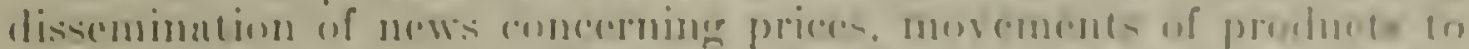

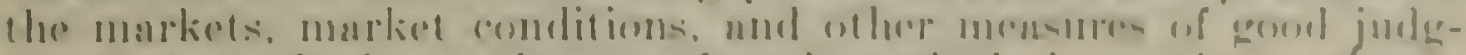

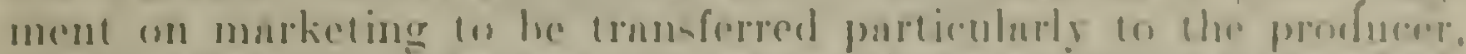
ulso to serve the trade. and also inform thut purt if the trade whech

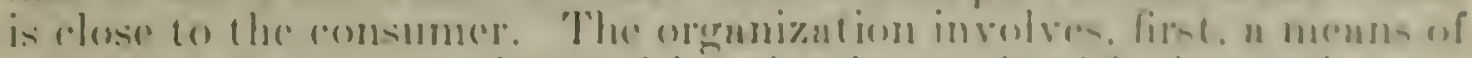

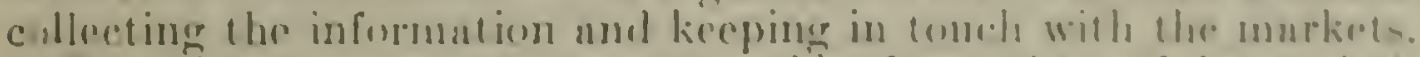

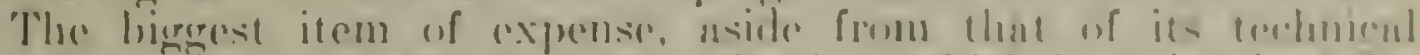
persomel, is the mattep of communication, which in matntamed he

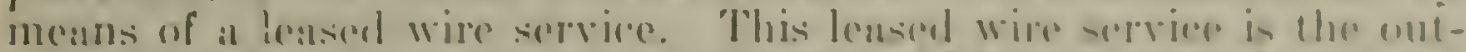

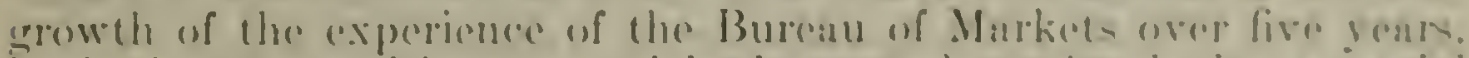

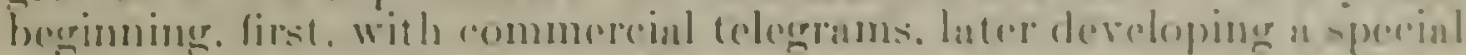
arrangement with the lolecraph companies to lease a wire at half the rost of commereial ralles and to utilize this wire to the naximum umder the supervision of our own staft. This wire at the presont time connects the principal atgricultural markets, beginning with Buten on the east. Now York. Trenton. Philadelplian, a connertion lo

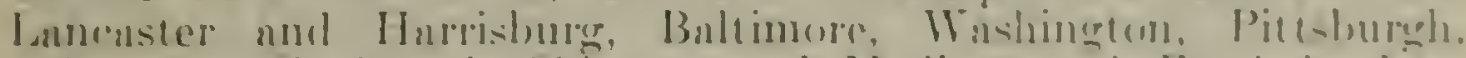
Columbus. C'incimnati. ('hichugo, and Madison and Fond du lase, Wis.. Minneapolis and st. Patul in the Northwes. Then there is a southern and western branteh connecting st. Lonis. Jeflerson ('ity.

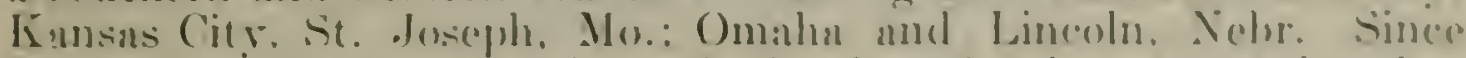
september 1. in extension of the leased wire connection has been made to Fort Worth. Tex., nnd on to Austin. There is no leased wire sorvice to ang other points than those I have named: there is no connection to the Southeastern States or farther wat than Lincoln. Nebr. You may recall that during the war, at the maximum expansion of this service under the emergencre funds a complete national sistem was laid oun.

Mr. Axinerson. Where did it go in the Southeast?

Mr. Marquas. Here is a map showing the maximum devolupment on December 30, 1!)1s. It that time there was a hrumeh whoh

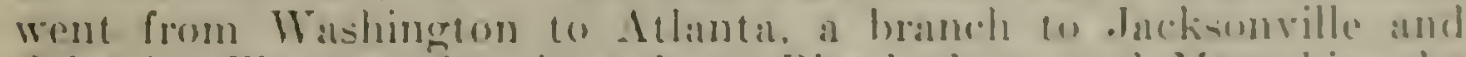
Orlando, Fla.. another branch to Birminghum and Memplis. The

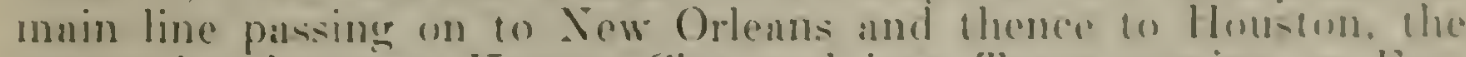

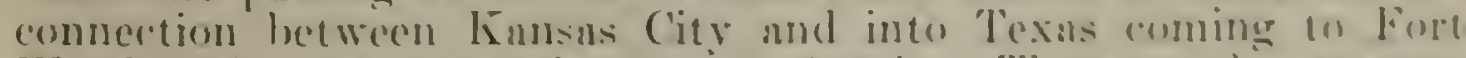
Worth only and not ersing on to Austin. Then on the western cirenit the leased wire went west from Kansis ("ity w Domer. w

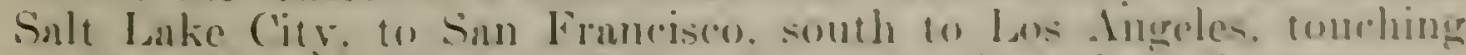
at Fresnes and Turlock in (nlifornia, with a branch to sacranento:

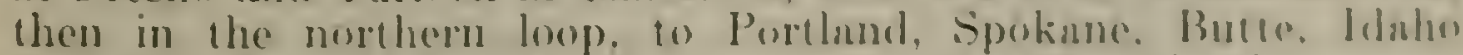
Falls, Greeley: (olo.. and hitching in with the other vireuit.

Mr. Axurbsox. But that service was mantaned for only a relatively short time ! 
Mr. Marques. That wis maintained for about a rear and a half and was discontinued when the appropriations were readjusted at the end of the war. Ilere is a statcment which shows the amounts carried for the work. It reached its maximum development in 1919, when the enerener funds amounted to $\$ 1.114,000$, combined with the rerglatr funds of $\$ 2.54,580$. malking at grand total of $\$ 1,368,5 \$ 0$. In 1920 there wats a reduction to 8497.920 ; in 1921 another reduction t) $\$ 103 .(120)$ : then in 1!)2.2 to $\$ 390.160$, and last rear there was an increase of 820.000 to $840 \mathrm{j},(100$, and then this rear it is the same The figures represented in this ippropriation are $\$ 3.600$ less, due to changes in the statutory roll.

\section{DEMAND FOR NEWS SERVICE.}

Mr. Anterson. Is there any demand for the extension of the leased wire selvice?

Mr: Marquis. During the past year there has been a strong demand for the market-news scrvice. As we have observed, the demand for marliet new's is greatest when prices are low or falling. Farmers are not particularly concerned about prices as long as they are high and sut isfarto $y$. 'They are not searching for a market, and they are not so much interested in the choice of markets with reference to which will pay the best pric s, but when prices becrin to go down, then comes the call for more market information. The result is that we have had a greater call for information of this charaeter during the past 12 inonths than in the past, due to the low prices. The farmers s'nisgr markets wished to know the diflerence in prices at various markets, the.best time to s 11 , and the danger of grluts: also to linow the r lative prices for valious qualities of products. All of these tuings have tremendously increased the eall for this sort of informatit n, with the result that we have had frequent requests to extend tuss service into areas that are removed from our regular lines of conmunication.

Mr. Axmerson. Is this service maintained with respect to all these various commodities -hese stock, fruits, and regetables-or only as t) so the of thent?

11: Ilurze s. IIl of t.re iour principal lines, live-stock meats. fruits and riguta les, diry and poultry products, and hay, feeds and sededs, are in luded, and that includes a raliety of reports which go all t.ae waty aroul the spread 1,1 price quotations to market movenents, t te entire range of varions ninds, grades, and qualities, and any other news that beats upon the mariet situation.

The leased wire furdusnes the most reliable means of connecting our odices ar the coltection oi information, and I wontd like to show you the way that is usid inost edectively. On the leased wire connecting these points, when now a.nounts to 3,300 miles, 2.,600 up to

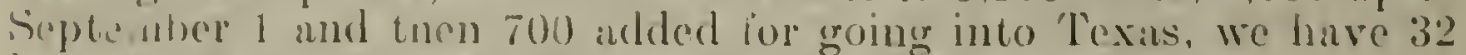
bralle. oflices. linese ollices are in constint communication for 12

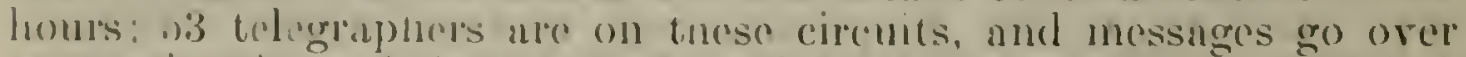
tuese wires hy code in the most eondensed form possible. Here is a record showing that from if a cloces in the morning until $6 \mathrm{p}$. m., and every mimute during the day, there is a scries of code messages of varions sorts gening hrough. We make the best possible use of the ti ne. 'These messurges are not sent in hull but in code letter and 


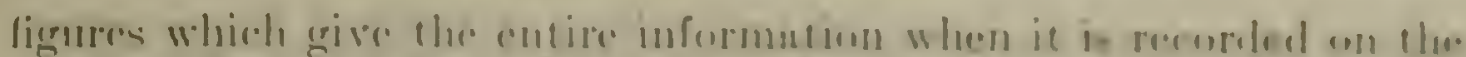
specinlly prepared forme in all the ofliere that are oll the wire at that

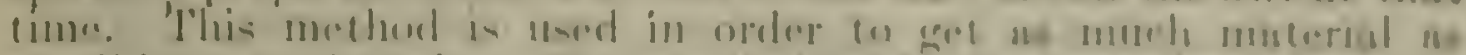

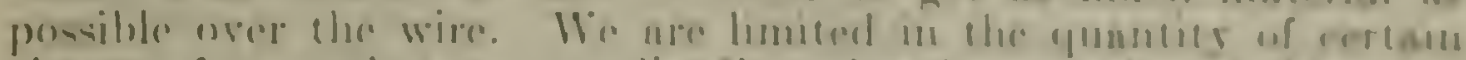

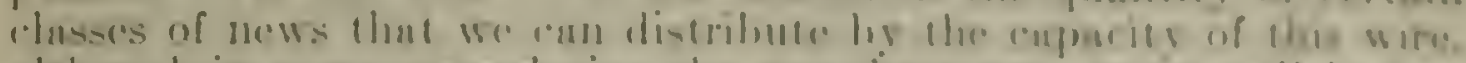

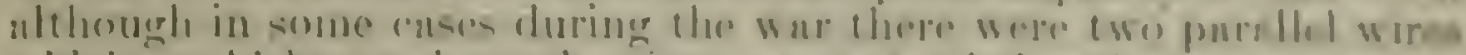

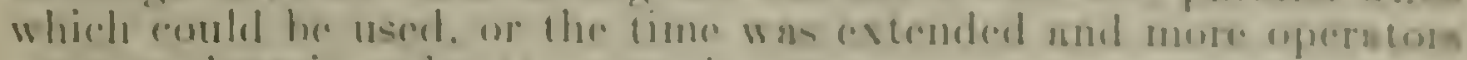
were on duty in ordere to arme the mas.

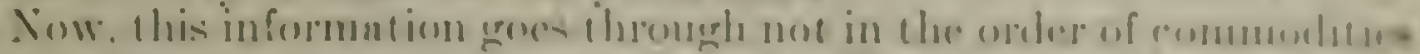

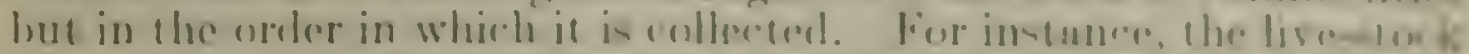
information fromst. Punl was the first on the ware on the parth ular

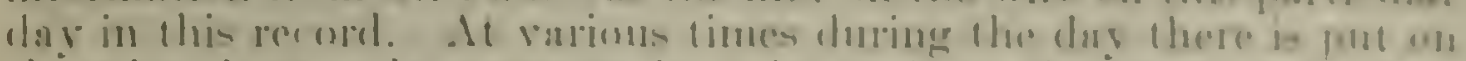

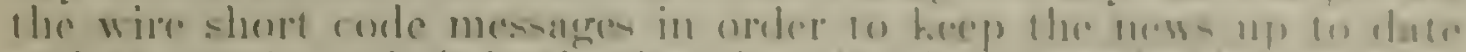

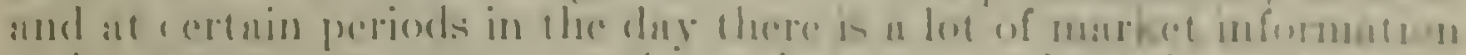

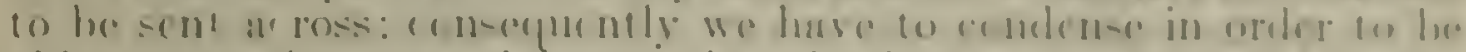

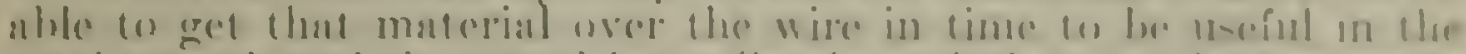

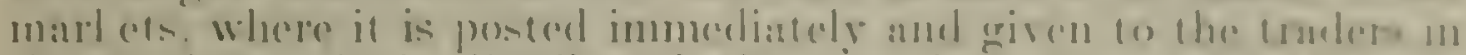

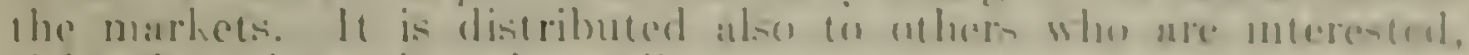
cithere tolegraph or be radio.

the siope of these reports is inc reased con-inlerably by the tom-

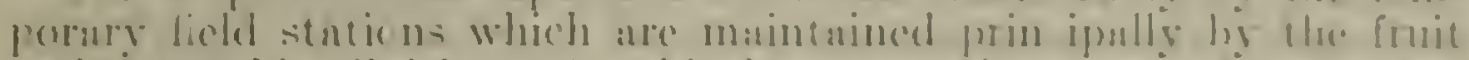

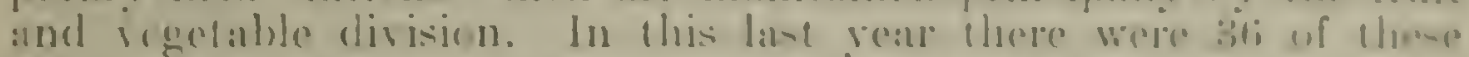

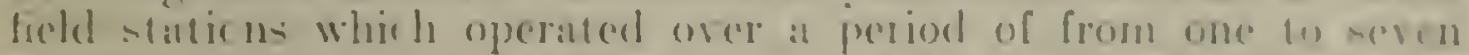

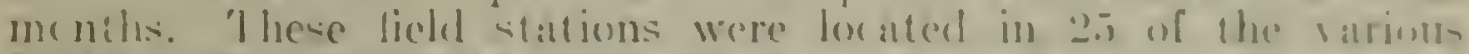

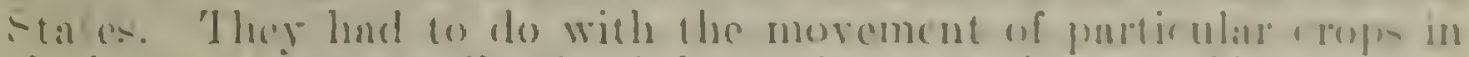

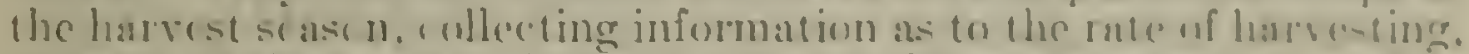
the atc of ship nont and the qualitios of the grouds going ont, and in tunn linging hath intermation from the general mathel for thene

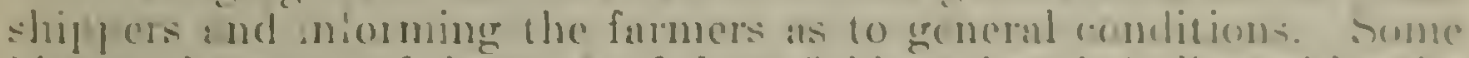

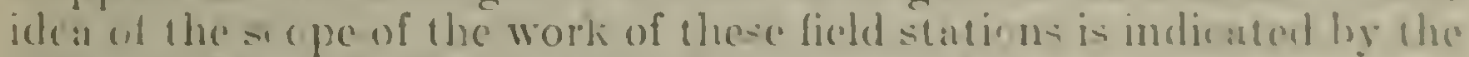

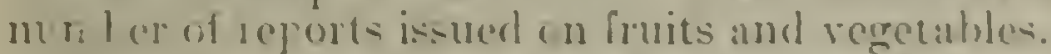

In the general marliet stations about fire and a yuarler million reports were issued, and in the lield stations ubout one and at half

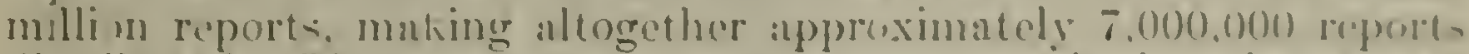
distributed. Thare reports are sent out not only in mimeograph form, which are mailed, such as these samples show, but are relensed at various points to the press. Ont serrie ties together all of the variou- means for the distribution of news, and we have particularly had increased demands from various publications for murher iaformation and market reports. Within the patst few monthe wo have been asked to furnish to the Asinciated Prosis addutional repores which heretofore they have gathered from their own sourees. They tell us that the Federal Govermment reports are now being rewarded is standard: that the public has come to recard them us unbianed and as being the best sourec for general matket informntion. 'Therefore they prefer, wherever possilite, to take our reports and distribute them rither than to eollect information through their oun marnet reporters.

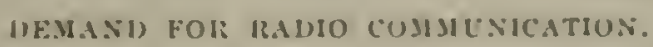

There has also been a greatly increased domand owing to the development of radio communication. Sinces a year ago, when - wme prediminary tests were being made as (1) the iso of radio in connection with the post oflice radiu stations, this work has dereduped 
until there are at the present time covering the United States some forty-odd broadeasting stations which take popular market news and distribute it direct to the people: who have recaiving outfits, and these broadcasting stations-which broadcast by telephone rather than by telegraphic code-in turn are rapidly developing until ther can pick up the general market news which is distributed from high-powered naval stations. Through cooperation with the Navy Department we are sending from the high-powered naral stations at . Prington and the Great Lakes station at Chicago. at several hours during the day, condensed market reports which are pieked up by these forty-odd stations throughout the Enited States, turned into telephone radio reports, and giren further distribution. This map indicates the manner in which the country is being covered by radio, on a regular schedule, at the present time.

This radio eommunication has greatly extended the possibilities for the clistribution of market news to the producer and to the small primary markets. It has not as ret proven so valuable in the collection of information, because with radio there is no chance to check back doubtful messages or to confirm any points that may need confirmation. On our leased wire, if there is anything that appears to be doubtful, the operators can easily get in touch with the sending station, confirm the message, and he sure of the result. With radio that is impossible, but for rery quick service at the rery minimum of cost it is unequaled. Te hare been able to distribute our news to hundreds of thousands of people throughout the country by means of the radio that otherwise could only get it through the expensive method of either telegraphing or telephoning. Consequently we are continuing our work in a more or less experimental way. and these experiments are relatively inexpensive because of the cooperation of other branches of the Government. The Burenu of Standards has lent its aid in the development of receiving apparatus and in tests of receiving apparatus to encourage the use of radio. The Post Oflice Department very generously loaned its facilities in order to make them of use. All of this radio work has been conducted at the very minimum of expense and the maximum of promise of results. There are yet many problems to be worked out, and the States are going at those local problems. All of the work being ane has for its end the securing of effective distribution over certain areas.

() all the elements of cost involved in this work the grentest, of comrse, is that for the technienl men who gather the news. The gathering of market news involves the use of men traned in a knowledge of the particular product they are covering, whether it is live stock, fruit and regetables, or dairy products. It involves a knowledge of grades and standards in order that they may know what they are gnoting prices upon. In many commodities, which we have not yet begun to quote fully the problem is, first, to get uniform stamdards to apply in rarious market in order to determine what is a comparable price of one market with another. 'Things which have the same names are not always the same things in our agricultural markets; consequently, thi price of a prime article in one marker is not the price of a prime article in mother, so that the problem in a proper news service turns on the question of classes, mames, stamilards, and designations; consequently this work improves as the mon improve in experience and as our grade and standard 


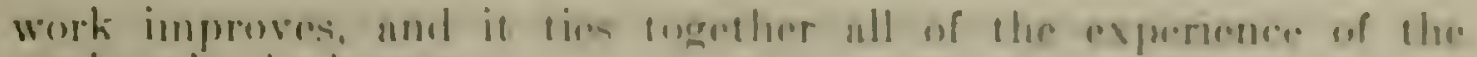
werkers in the human.

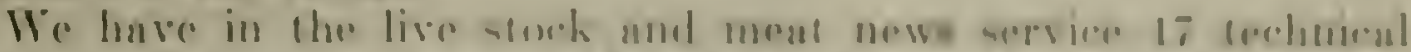

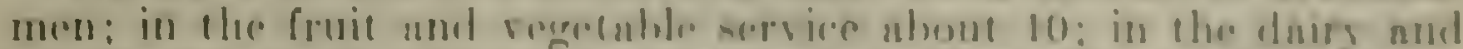

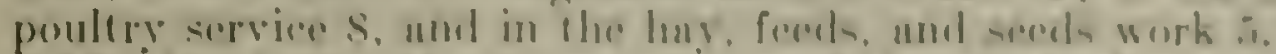

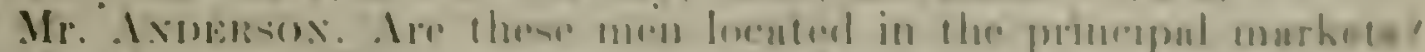

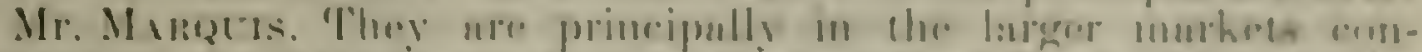

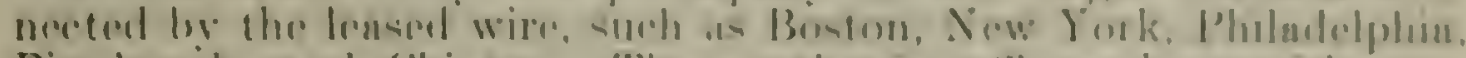

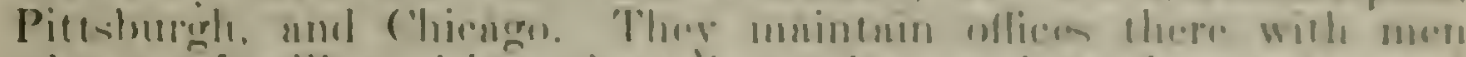

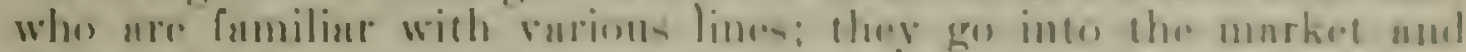

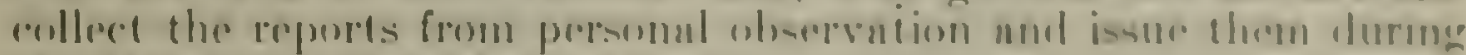

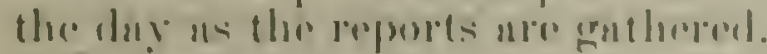

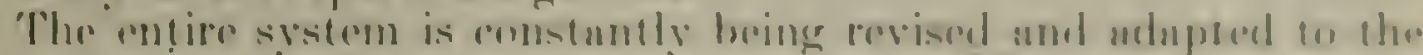

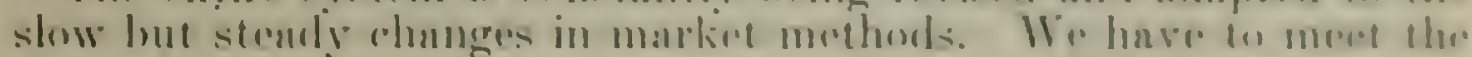

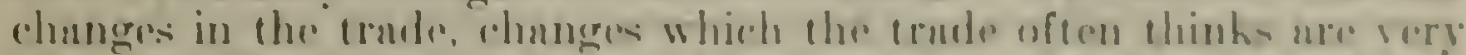

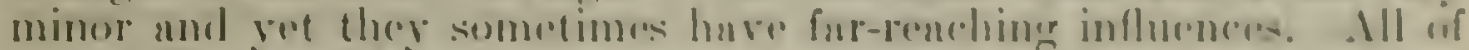

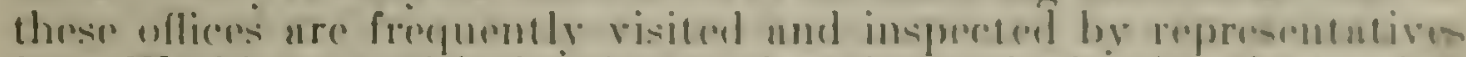

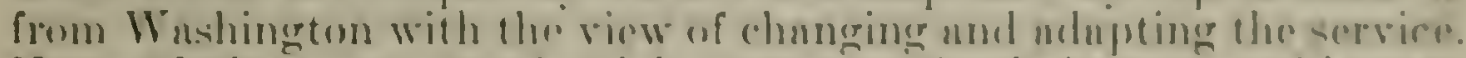

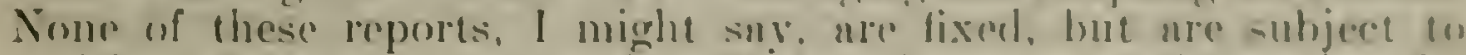
levision at comstant intervals. Mailing lists arre made up for the ficld stations, for instanee, ut the beginning of n senson, these lists heing made up of poople who make application for the servier. When the season is over those mailing lists ure lilod and uro not usod again, but new lists are male out for the next season. We are constantly revising our lists and sending our material only to the pospplo. who repuest it. In that way we aroul the waste involved in sending material to people who have no pnrticular use for it.

One other point which I might mention is that the commoreial organizations are showing a growing interest in the ralue of martet reports gathered by the Federnl department. I might cite us un instance that in one of the large live-stock markets the commision men were, up to a few months ngo, ench distributing once a weok a market review of his own preparation, but they have recently stated that they would like to all join together and through their organization send out one market report prepared weekly by the markot reporting servico, and have that report coincide exactly with the Govermment reports which producers are recoiving by radio and otherwise. As soon as this broadensting station was developed there came a call for market news, hut privately collected murkut news brondrasted generally and without any check upon it was regurded as of less value than « Government report which they could stute in broadeasting was the oflicial Gorernment report, and thereby create confidence in the material that came through the nir and where there was no opportmity to check back. 'The result is that most of the market reports that are now being brondensted, dealing with commodities on which we collect complete reports, are Goverument reports. However, that does not apply to grain in certain loculitiss, where we do not have a complete grain market reporting service. It does not apply to some other commodities which are reported locilly. but in a gencral way the reports gathered by the Federal Goverinment have shown an increase in faror in the past year on the part of the press associations and commercinl organizntions.

Mr. Axdersox. If there are no questions we will ake up the next item, enforcement of the United Stutes cotton futures net. 
Mr. Texwy. This is an appropriation for the enforcement of a definite law. No increase is asked but there is a slight transfer to the statutory roll, leaving the amount actually the same as the appropriation of this year. 'The only thing of very great importance in connection with this appropriation is that there is an unusually heary demand on the department for the preparation and distribution of official cotton standards. For the last year or more we hare been developing some new cotton standurds on some of the main grades of cotton. Those have been promulgated to be effective in August, 1923, and naturally all the people who are going to use those standards are going to want new sets of standards. We are, therefore, securing a considerable amount of cotton and equipment for the purpose of getting these sets ready to go out.

Simply to show the progress of the work, the hoards of examiners at New York and New Orleans have classed 234.14S bales of cotton. During the year requests for reclassifying were filed on 43,384 bales. Of these 43,384 that were reclassified the grade was changed somewhat on 3,724 .

We are maintaining the same machinery in the Cotton Belt for arriving at the price of cotton at points of origin and the differences in price of the different grades of cotton as provided for in the law.

Mr. Andersos. Are you doing any investigational work under this item?

Mr. Tenvy. None.

FOR LNFORCEMENT OF TIIE GRAIN STANINARS ICT.

'The next item is for the enforcement of the United States grain standards act, and the same appropriation is asked for the coming year that we have for this year. During the present yenr we have not quite as much money as we had last year. which has necessitated the readjustment of our work somewhat. Te have eliminated 4 field offices, having now 34 field ofticers instend of 38 . We are taking care of the work in one of these places. Atlantal, Gil., through the oflice of Federal gratin supervision at Nashville. In the other three eities where offices have been eliminated a Federal emplovee has been left to supervise the inspection, but without expense to the Government other than his salary.

'This is a rompulsory piece of legistation and this appropriation is used entirely for the enforement of the law. The enforement of the law necessitates two lines of work. First I might say that the inspretion work is not done by the Federal Government in this grain stundards work.

Mr. ANmerson. Is that univorsally true!

Mr. 'Twaxy. Yes. The original inspection work is not done by' the 1)rpartment of Agriculture.

Mr. Axbersos. Do you have any insperetors who are not licensed by states or hourds of trade?

Mr. Texsy. No; we have none. The work we have to do is, first, to suprovise the inspectors who an amploved by the states and boands of trade. Second, the law provides that if any sthipper recrivere, or interested porty desires to appent from the granle ussigned 


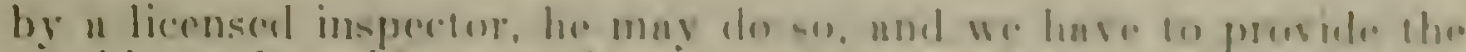

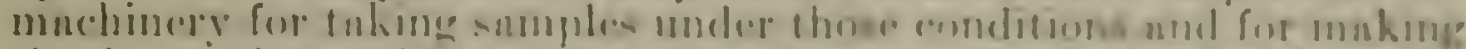

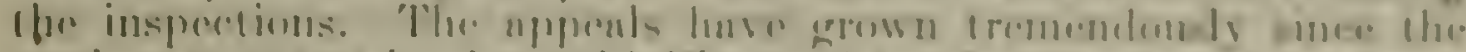

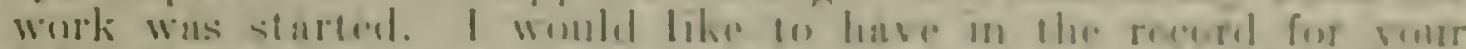

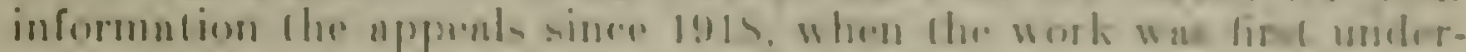

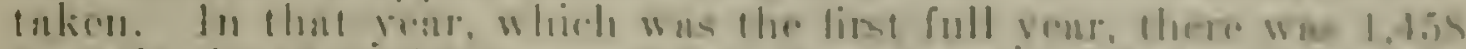

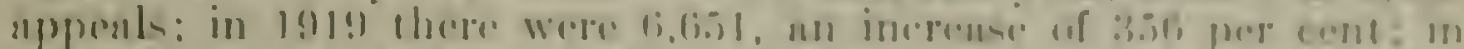

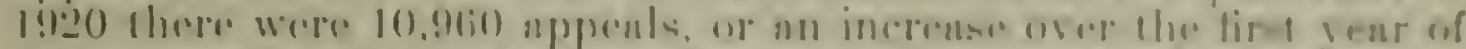

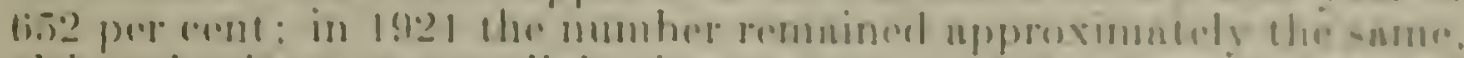

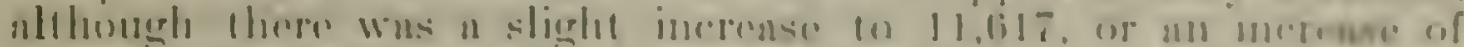

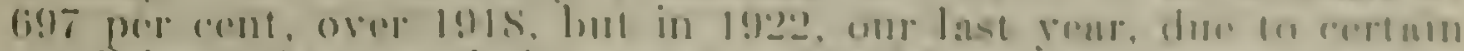

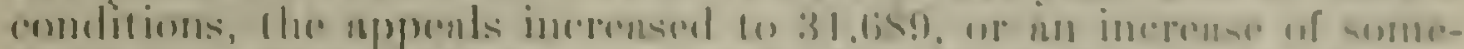

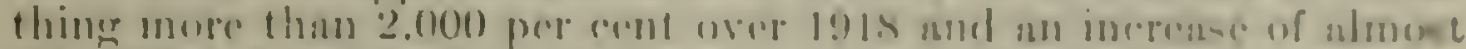
3000 per rent olver lasit your.

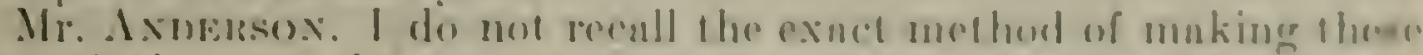

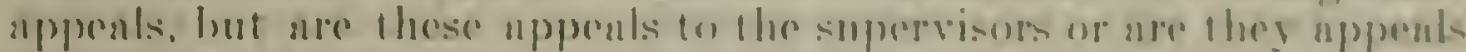
10 the secoretare?

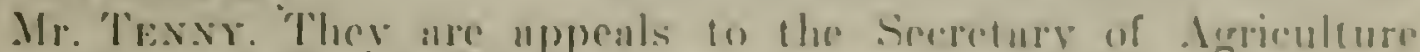
through local oftices of Fidernd grnin supervision.

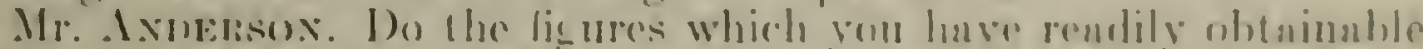
show the number of enses in which the ernde wis ruised nnd the number of cinses in which the grate wats lowered!

Mr. Trexir. Yes, sir.

Mr. Axnensos. I would like to have that information.

Mr. Texsy. Very well, we will furnish it for the recold. This incrensed number of appeals is simply un indiation that the purty interestod desires a Federnl rertilionte.

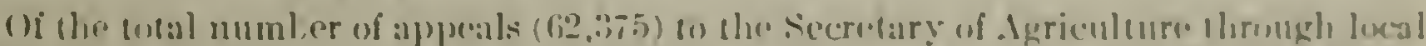

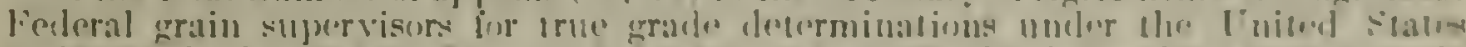

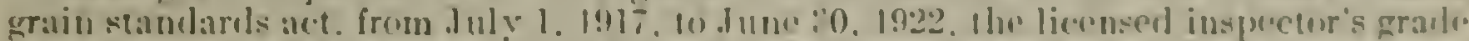

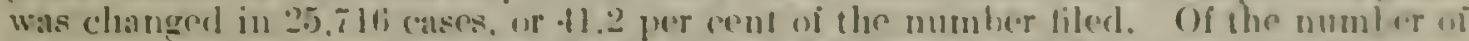

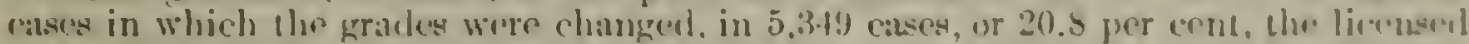

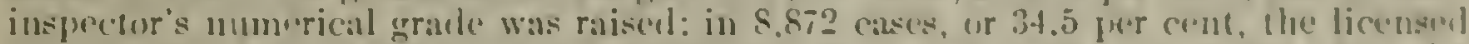
inspector's numerical grade was lowered. and in 11.495 casts, or 44.7 per erent. the licensed inspertor's mumerical grade was not changed, mut the "grade dosignation" was changed becanse of a rifference helween the inspector and fiederal grain super. visor on factors of grade designation such as elass, subclass, culor, Ireaterl grain. ic. In

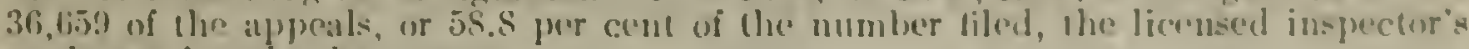
gra le was bound to be correct.

Oi the 192,355 nppeals tiled, 30,012 , or 49.1 per cent, wore taken frum 'inhound' in. spections. and 32.36 i3, or is 1.5 per cent, from "unthomel" inspections.

All of this appropriation is used for the enforement of stumdards of shelled com, wheat, and oats; we hare other grndes that are rendy for promulgation but they an not be officially promulgated without the enforcement net forthwith becoming operntive, entailing upon us the need of doing the supervisory work and the nppenl work, hut which we can not do.

Mr. Avonesox. What are the grains for which you have standards but which have not been promulgnted?

Mr. Texsy. Rye, milled rice, grain sorghums, barley, and flax.

Mr. Asorissos: Are there men qualified to make these insperdions in the erent they should be promulgated?

Mr. Bestery. If I understond rour question, it wis whether the inspectors in the country are rendy to take these stundurds and upply them.

Mr. Anderrsox. Yes. 
Mr. Besley. Yes, sir; they are, with the exception of milled rice and with an additional rescrition on the grain sorghums. In the markets where they handle grain sorghums extensively they are equipped, but in certain other markets they would not be.

Mr. Axpersox. Do the standards which have not been promulgated require specialized equipment?

Mr. Besley. Only to a rery minor extent. For example, the sorghums would have to have a special set of sieves of certain sizes, but that is practically the only additional equipment.

Mr. Trasy. We have a number of urgent letters from foreign govemments for grades, particularly on rye. I have mislaid those letters, although I have them with me. But one is from the German Gorernment to the embassy here and one from a large importer in France, particularly urging that grades be established on rye, so that the importations can be made on the same basis as these other grains. They claim that the present methods are unsatisfactory and that they are not greting uniform deliveries.

\section{FOR ADMINISTRATION OF UXITED STATES WAREHOUSE ACT.}

Mr. Avinerson. We will next take up the item for the administration of the United States warehouse act.

Mr. Tolfe. This estimate, which is for administering the United States warehouse act, carries an increase orer last year of $\$ 16.400$. We shall quite likely use this additional money to place an additional man in our Raleigh office, from which office we cover Virginia and the Carolinas: one additional warehouse inspector to work from the Atlanta office, which serves Georgia, Florida, Alabamn, Mississippi, and 'Tennessee; and an additional inspector in the grain territory extending from the Mississippi to the Rocky Mountains. Then it is contemplated to open an oflice at Memphis, which will mean placing one additional inspector and taking from the office or inspection force of the Dallas and Atlanta offices certain men and adding them to the Memphis force. It also provides for adding four clerks, two of whom will quite likely come to the Washington office, due to the increased amount of work, which I will show you before I finish; and one to the Denver oflice, which is to be opened. We now have a man working from that city but have not established any oflice headquarters. One clerk will he needed in the Memphis office, which will be opened probably after the 1st of July.

It is hardly necessary for me to tell this committee what the purpose is of the warehouse act. It was passed six years ago. Primarily its purpose, in a word, is to aid in orderly marketing and in producing or bringing forth an instrument which can he used for eredit purposes when the products are in storage. My understanding of the history of this act is that in the first few years after its passage this committee, and Congress in general, was quite discouraged with what was being done under it; discouraged with respect to the nanner in which the furmers themselves, who were supposed to be using it and for whom it was passed primarily, were nvaiting themselyes of it, and discouraged also with respect to the manner in which the warehousemen were responding to it.

To derelop a credit instrument proporly und make it of the grentest use-and in this instance it huppens to be the warehouse receipt - it 


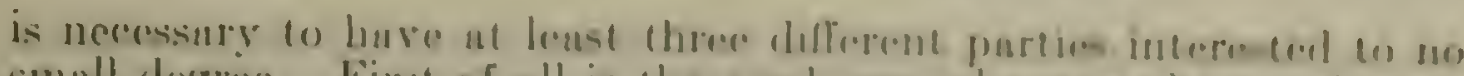

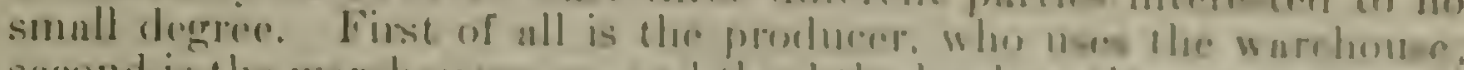

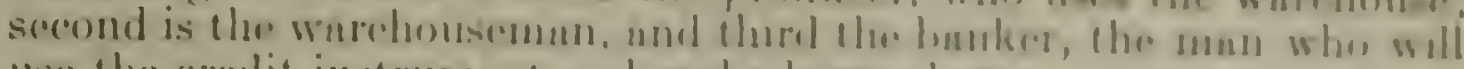

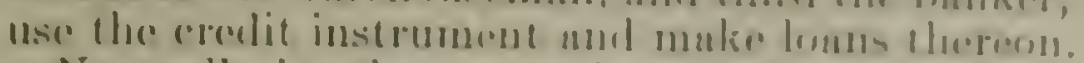

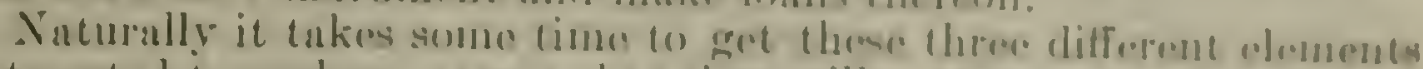

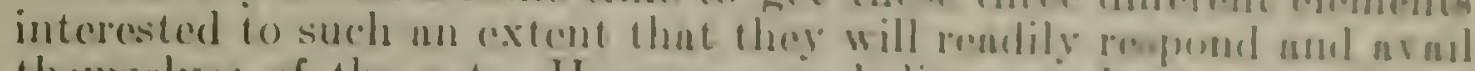

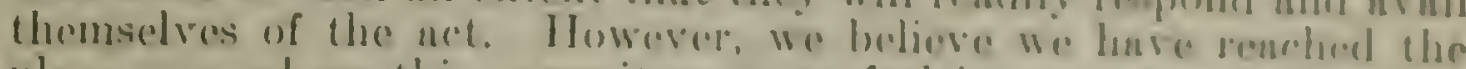

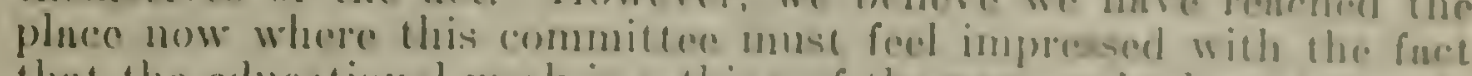
that the educentionnl work is a thing of the pant and where dermands

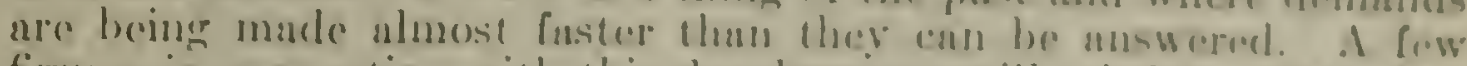
figures in connection with this devolopment-will reinforer the point.

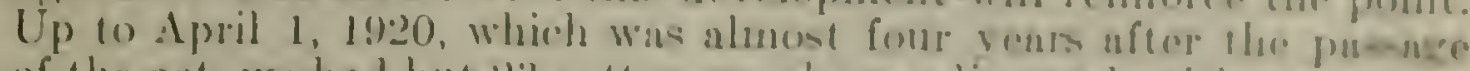

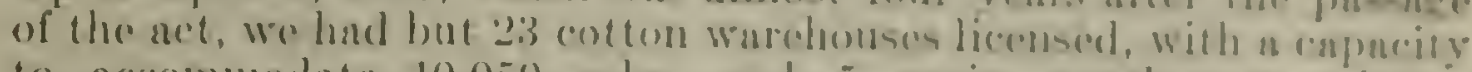
to acrommodate 10,050 sales, mel it grain warchomate, will a capacity to necommodate 136.000 bushels of grain. Whe hat mo

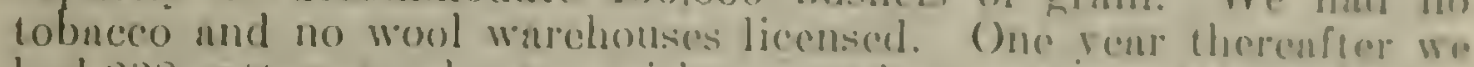

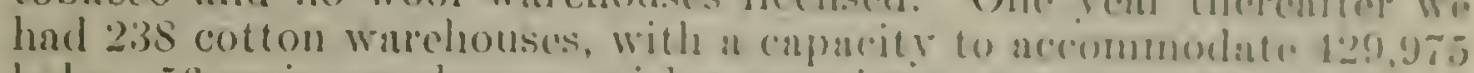
hales; 56 amain warehouses, with a capracity to accommolate 2. 105. 100

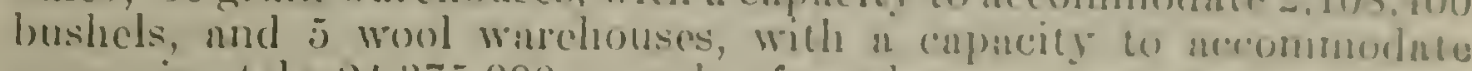
npproximately 24,375,000 pounds of wool.

Up to the ist of May of this rear the figures showed 265 reotom

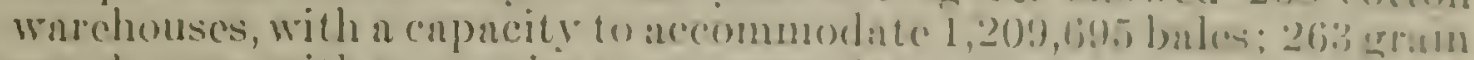
warehouses, with a capacity to accommolate approximntely i i, su(1), (10)

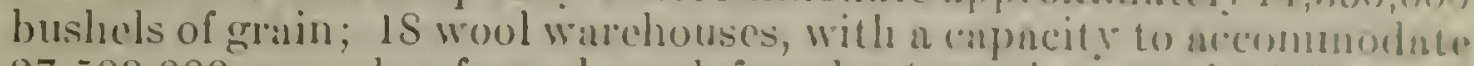
$27,500,000$ pounds of wool, and for the fust time we hat licellored tobacco warchouses - 1.t-with a capacity to accommodate about

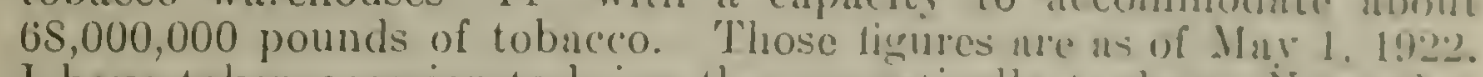
I have talien occasion to bring them practically to date Nubromber 20 - so that the committee might sec that progress is still hoing made. We have now 400 cotton warehouses, with a capacity to accombudate $2,000,000$ bales of cotton; 215 grain warehouses, with a capacits to

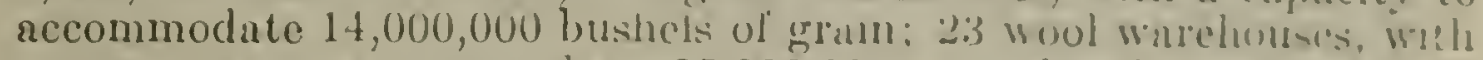
a cupacty to accommodate 25,000,000 pounds of wool: and $5: 2$ tobacco warchouses, with a capacity to accommodate $2.25 .000,000$ pounds of tobacco.

TEIIMINAL WAIREIIOI SES.

Mr. Ardensox. Have any of the warehouses which have been preriously licensed withdrawn from the system!

Mr. Ione. Oh, yes: there are cases of withdrawing. suspending. canceling, and perinitting the licenses to expire. I hecusc is only: issued for a period of one your. It ma interest you to knum just why warehousemen permit their liecnses to expire or why they are suspended. Conditions change from year to year with respect is the advantages to be gained in storing ob not storing products: also the development of the cotton cooperative movement and other eouperative movements has some efiect upon it. You will notice from the figures which I gave you that we have about $2.500,000$ penumb lons of licensed capacity for wool than we had on May 1. That is the to the fact that one of our licensed wardususmen, who whe operating fire large wool warchouses in Chicugro last yent, found that this your, with the increased price of wool, that the famers wore solling ihoir wool quite freely" as it was clipped and there wis tho excasion fortore, 
and as these warehouses which he had licensed were in leased buildings he decided he could not afford to take the risk of a loss this year, so he did not renew his licenses when they expired: in fact, he asked that some be canceled. The same thing is true of grain. In grain we had one case where a warehouseman had 68 licenses last year and this yenr, due to cooperative movements in that particular section and the morement of grain for export, he did not renew his licenses on more than about 34 . His warchouses were in leased buildings and he could not afford to take the risk of a loss.

Mr. Axderson. Are these terminal warehouses as a rule?

Mr. Yonf. No; ther are practically all at country points. We have not gone into terminal territory as ret. We have one rather large warchouse, which is terminal in nature, at Davenport and another at Fort Worth, with a capacity to accommodate about $1,000,000$ bushels. We have one at Mansfield, Ohio, and we have now pending an application from the Mill and Elerator Association of North Dakota for the licensing of the warehouse at Grand Forks, which has a capacity of about 2,000,000 bushels. If we once begin to get applications from these terminal warehouses, it is going to make very heary inroads into our appropriations, because it will practically mean that we will have to station one man continuously at such terminal warehouses.

I do not know whether the committee would eare to see how the work is going with respect to the large warehouses, but your inquiry with respect to terminal warehouses prompts me to place in the record some figures with respect to how the large cotton warehousemen are arailing themselves of the act. As you probably recall, in the first few year's most of the cotton warehouses were owned by small operator's, but now we have a great many ranging from 4,000 bales' capacity up to 165,000 bales. I shall be very glad to give the clerk the figures to place in the record.

('The figures referred to follow:)

Number and eaparity of warehouses.

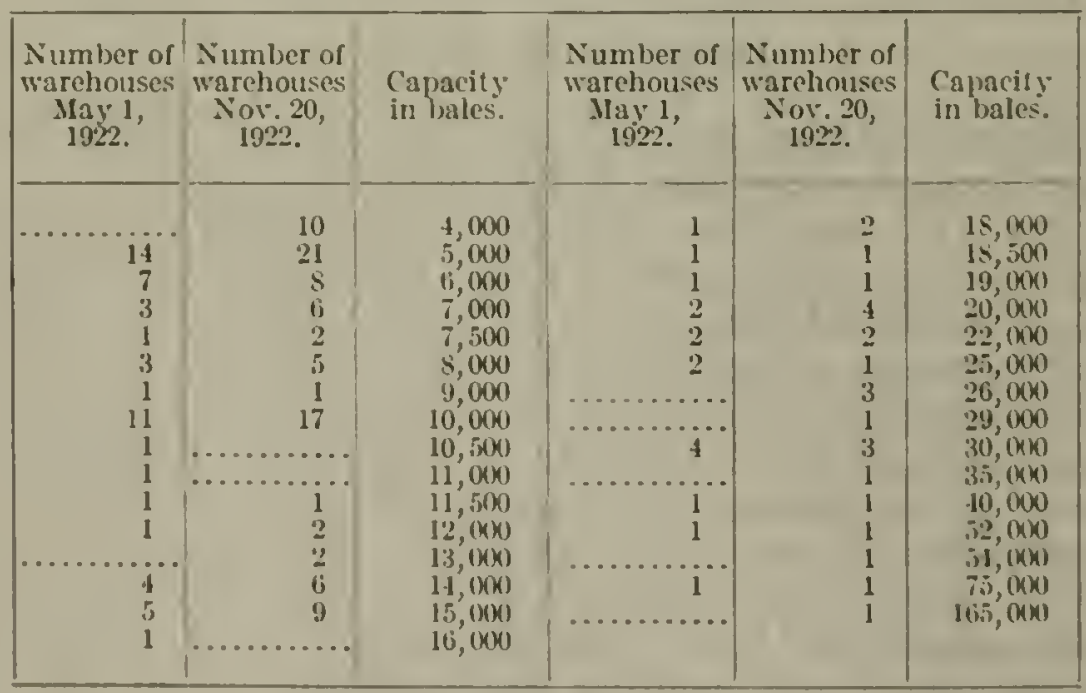

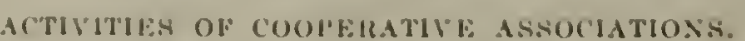

Mr. Yone. I might state thut the tremendous increase in this work in the last two years, and particulurly in the past. year, is due, in inensure, to the influence of these cooperntive nssocintions. Tnke 


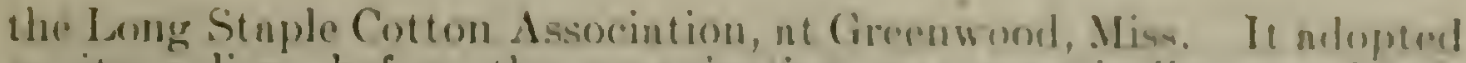
ats its policy, before the orgnnization was practically completerl.

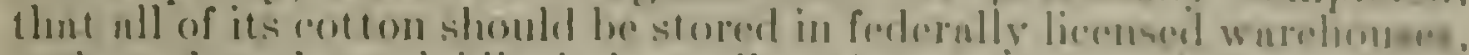
und to show how rigidly it lins ndhered to is policy, it has refuesel to place any cotton with uny warehousement muleses thes berome

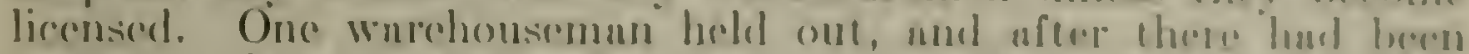

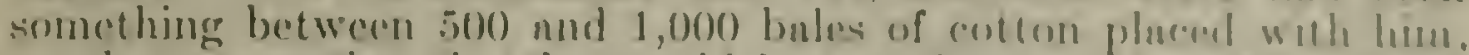

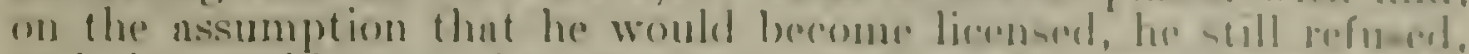
and the president of the association sent a raft down the rover, or

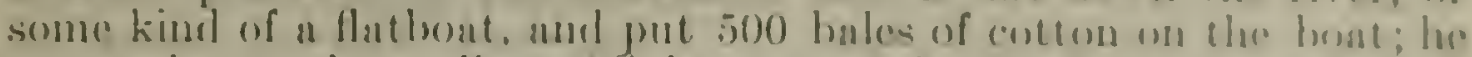

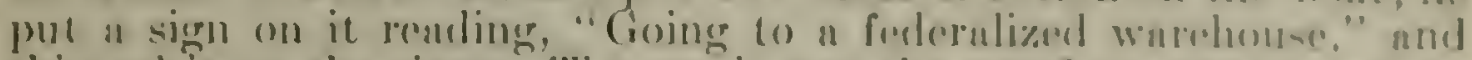

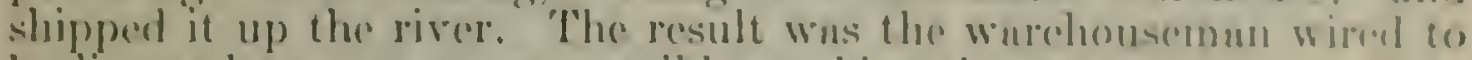

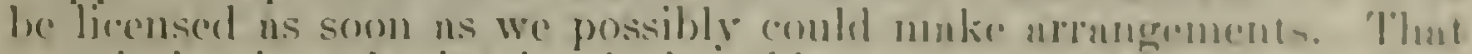
nsiseciation hus nbsolutely, during this rear and lnst your, put ull uf its cotten in liernsed waredususes. The sume thine is true of the North Carolina Cotton Girower's dssoriation, and the drkansas Cotton Growers Association, and prantirally revery ane of the cintions are in some measure using linensid worohuses, althongh

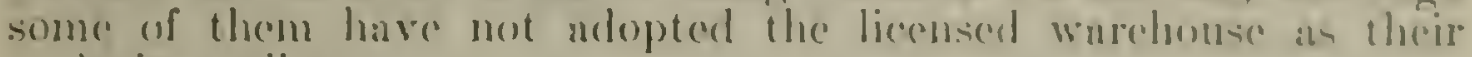
ixilusive policy.

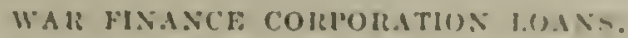

The werk of the Wall Finane Corporation in this councetion hus undoubtodly beren expedited considernbly as far ns making loante lo

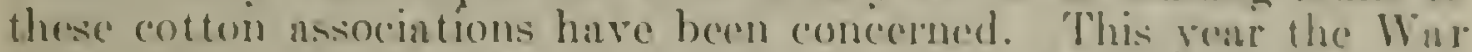
Finance Corporation hos had applications for loalns from practically evely one of the cotton errowers' associations. 'The North carelina Cotton Growers' Associntion has applied for $\$ 10,000,000$ : the Sonth Carolina Cotton Grower's' Associntion hats applied for $\$ 10.000,000$ : the Georgia Cotten Association has applied for S5.000,000): the Alabamar Farm Bureau Cotton Association has applied for $\$ 3.000,000$; the Staple Cotton Cooperative Associntion has applied for $\$ 7,000,000$; the Arkansas Cotton Growers' Association has applied for $\$ 7,500,000$ : the Arkansas Farmers Union Cotton Associntion has applied for $\$ 1,000.000$; the 'Texas Farm Bureau Association has applied for $\$ 9,000,000$ : the Oklahomn Cotton Association has applied for $\$(6,000,-$ 000: and the Arizona Cotton Associntion has applied for $\$ 1,200,000$. In ench one of these applientions, and as a part of the ngreement with the War Finnuce Corporation, the stipulation was made that ts collaternl for lonns the War Finance Corporntion would aceept, without further question, Federal warehouse receipts, but that if receipts issued by any warehousemen who wre not operating under the Federal act were presented as collateral the Wir Finance Corporntion would reserve the right to inspeet and pass upon the receipts issued by such warehousemen. In other words, it placed the Federal warehouse receipts at once on the basis of being an acecptable piece of paper to the War Finance Corporation without any further considerntion.

Mr. Axuflssox. If I remember correctly, all commodities that nro placed in Ferlernl warehouses have to be inspected and clnsied bofore they go in?

Ir. Yont. The law originally provided that the grade should bo stated on every reccipt. Then a year afterwnrds, I think, it was amended to read that the grade should be stated on every receipt 
issued for nonfungible products unless the depositor requested otherwise, leaving it optional with the depositor as to whether the grade and class should be stated. In that connection it is interesting to note that the depositor is fast getting to the place where he is having his grade placed on the receipt, but it should be pointed out that the option is only with the depositor and not with the warehouscmen; in other words, if a depositor says nothing with respect to grade, it must be noted on the receipt.

Mr. Axuersox. Do these warehousemen maintain inspectors for determining the specific grades or do they have Federal inspectors?

Ir. Yonc. No; they have their own graders and inspectors: in fact, we will not license a warehouseman until he has satisfied us that he has someone who is capable of grading under the law, and provision is made for licensing inspectors. The same is true with respect to graders.

In administering this act and in our relation with the War Finance Corporation we have recognized that, of course, the War Finance Corporation could not very well say it would not accept as collateral any form of warehouse receipt uriess it was issued by a federalized warehouse, and to meet the War Finance Corporation in that respect we have assisted in a great many instances by giving information with respect to the warehouses which might be used but which were not licensed. as well as information as to the-management and financial responsibility of the warchouses, and in a great many instances we have undertaken to supervise and inspect nonlicensed warehouses which might be used by different associations.

\section{APPLICATIONS FOR LICENSES PENDING.}

Mr. Anderson. How many applications for license liare you pending now not acted upon?

Mr. Yone. I should imagine not more than 15 or 20 that have not been acted on as far as we can act. By that I mean to say that a considerable number of other papers must be filed besides applieations. These are cases where the application had been hled, and we have not had an opportunity yet to make inspections of the plants, or where the warehouseman has not been able to file a bond, or because there is some other difficulty in the way.

\section{WAREHOUSE RECEIPTS.}

It has occurred to me that, perhaps, I can best show the growth of the work and the result of the work of the department with the bunkers, in getting them interested in these federalized warehouse receipts, and getting them to the place where they fully appreciate what the receipts mean, by reading to the committee a few extracts from the minutes of the Anerienn Bankers' Association, which was in session the other week at New York. 'This part of the minutes is a part of some resolutions prepared by a subcommitteo of the committer of commerce and marine of the association. It reards in part as follows:

Roblizing thr great importance of enahling the farmers to market their crops more

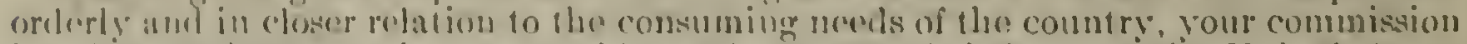

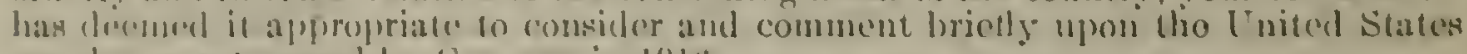

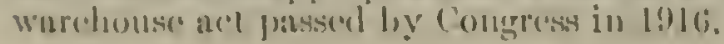


At this print the commitere incluiled some ligures showsme the progress thant lud heen mude, und it grones on en says:

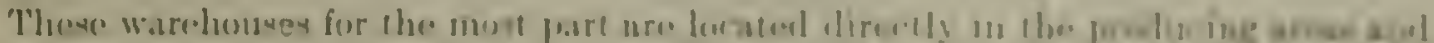

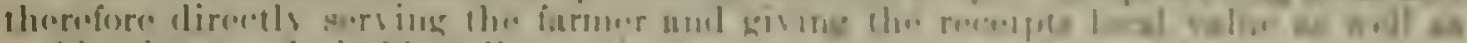

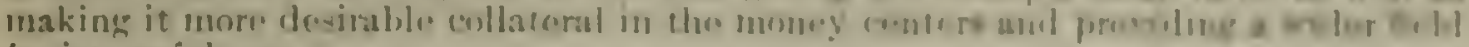
for ils ilucofulingess.

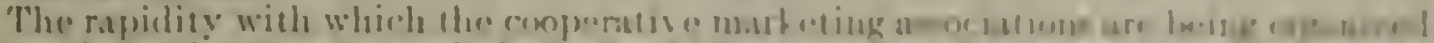

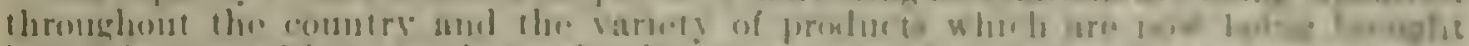

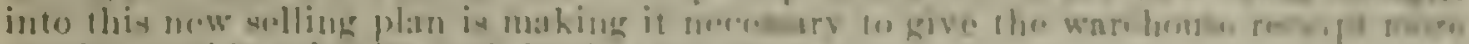

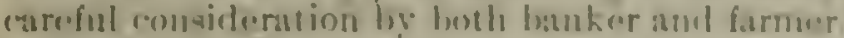

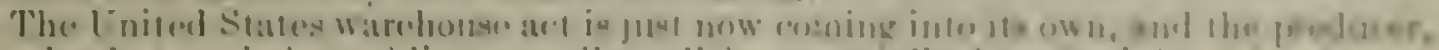

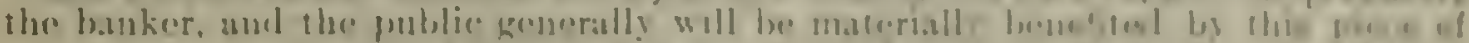

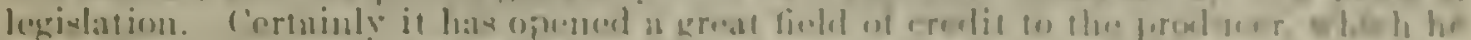

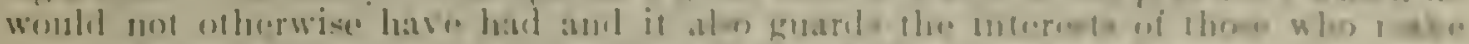

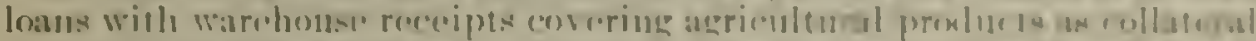

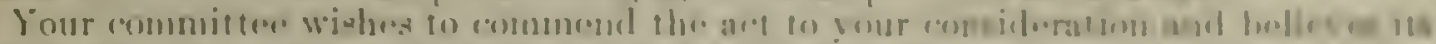

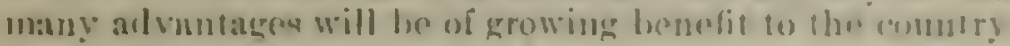

In this connection, to slow the committor low elemely we hare worked with the Whr Finanere Corporntion. I would like to inclurle in the record a Ietere signed by the munueringe directore of the $1 \mathrm{H}^{\circ}$ Finnne Corporntion, rending as follows:

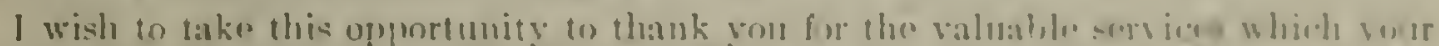

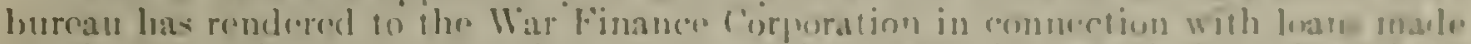

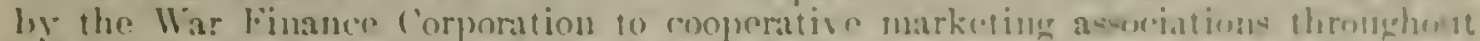
the Unitwl Statrs.

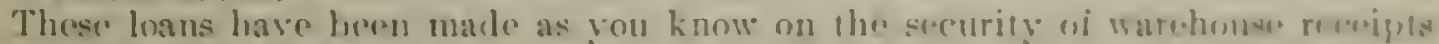

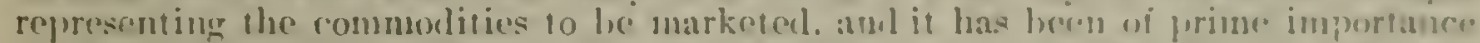

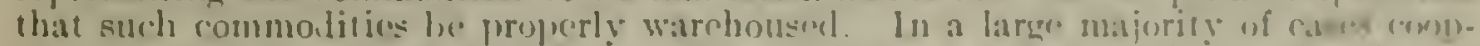

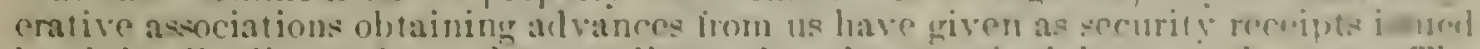

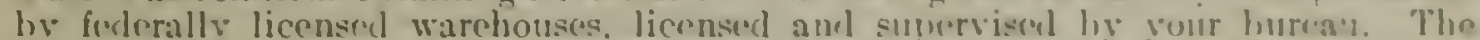

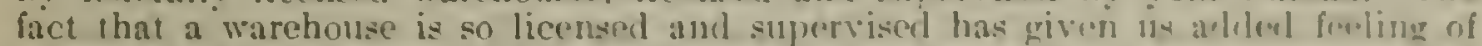
security and an assurance that our intrerst in tho socurity us lseing proprorly carml for. and the integrity of the warehouse receipt respected.

From my experiesece in the work of the llar finanes fonmeration. J helireve that

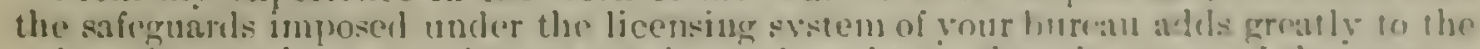

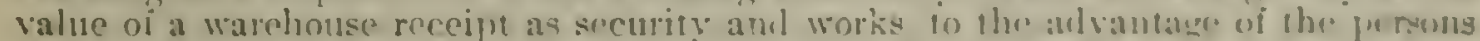
or institutions which lend mones on warreholsse receipt secterity of the owner of the

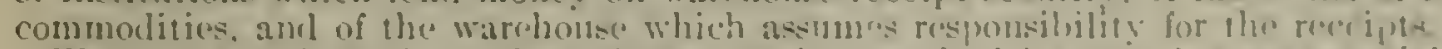

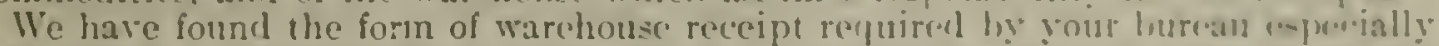
valuable in connertion with our loans. In ronnection will mur rotion lasus. in instance. the warchouse receipt issued by federally licensed warchonsca cortifien on its face not only the number of bales, but the weight, grarle, and sitaple ol the ovton such certification alles greatly to the value of the roceipt as collatrial.

Mr. Chairmnn, it is not necessary, or I do not believe it is necessury. to burden the record to show the progress we have bech makine under this piece of legislation. but as you can ensily apprecinte the usefulness of it will depend in large measure upon the nttitule which the bankers may take towarl the federnlized warehume recipt. Therefore, I would like to put into the record part of a letter from the recent governor of the Federal Reserve Board, rending us follow:

I think it is recognized by banks and other financial institutions that warehouse receipts representing readily marketable nonperishalle agricultural commonlities properly warchoused are a lesirable kind of security for hank loans. It is apparent. of course, that some warchouse receipts are more desiral, le than nihers, and that the degree of desirability is dependent upon a number of iactors. includrol mume which are the form and legal effect of thr receipt. the guestion of whether or not the isuning warehouseman is licenserl. bonded. and operated nurlur loderal law or a staten lan furnishing proper safeguarls, and is supervised and examined ly compotont uflucials with a view to the protection of the public. the roputation and financial respunsibility

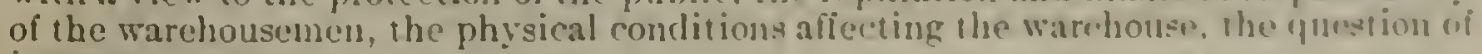
iusurance, etc. 
Crenerally speaking, there can be no doubt, I think, that warehouse receipts isued by warehousemen licensed and bonded under the Lnited States warehouse act will be considered by bankers as more desirable collateral security than those issued by warehousemen who are not licensed or bonded under any State or Federal law.

There are a great many other statements which I might place in the record, but I think these will suffice to show that the Federal reserve banks, the War Finance Corporation, and all those who hare to do closely and intimately with the granting of credit to farmers based upon products when they are in storage are fast reaching the point where they respect more highly the Federal warehouse receipts than almost any lind of receipt issued by warehousemen.

\section{INCREASE IN WORK.}

Mr. Axderson. You appear to be anticipating some increase in this business. What is the basis upon which you anticipate an increase?

Mr. Yone. The basis of our anticipation is the realization of the past two years, and the further fact that we know that there are a good many warehouscmen not now in the system who expect to come in next year. I am quite confident that we shall see just as much of an increase in the licensing of cotton warehouses, or in the demand to be licensed, next year as we have had in the last two years. We have been told that the 'Tobacco Growers' Cooperatire Association of the Connecticut Valley intended to use licensed warehouses exclusively this next rear. We are quite confident that there will be a hig increase in the licensing of grain warehouses between the Mississippi River and the Rocky Mountains, as well as in the Northwest. In fact, the estimate which is before the committee is not in line with our anticipation of what the needs will be. Our anticipation is based entirely upon what has taken place in the last two years, and upon what we have pretty concrete evidence now in definite expressions of intention on the part of those who have warehouses.

Mr. 'TExxy. The committee should realize that this work involves the making of reinspections, and the more wilrehouses that are licensed, the more reinspection work has to be carried on.

\section{FOR ENFORCEMENT OF TIE STANDARD CONTAINER ACT.}

Mr. Anderson. The next item is for the enforcement of the standard container act. The current appropriation for this purpose is $\$ 3, \$ 00$, and the estimate for 1924 is $\$ 5,000$.

Mr. Sulimax. The estimate for the enforement of the standard container act is $\$ 5,000 ; \$ 1,200$ of the amount previously approprinted or allotted from the original appropriation of $\$ 5,000$ was set aside for one statutory platee, and the lump fund was reduced to $\$ 3,800$. That has been the amount of the lump fund, I believe, for the last two seusons, perhaps. 'Thut is no lonerer suflicient to carry the salary of one techuicul mun in charge and his necessury travel, if he is to do the work that he should do under this approprintion. As a matter of fuct, another mun from the grades and standard work has been obliged to give a part of his time to this work.

Mr. Anmenson. You have only one on this job?

Mr. Subruax. Only one mnn is giving his whole time to this job. 'There ure hundreds of manufacturers making these contuiners, all of 
whom are under the provisions of the uet, and the net, of courese, in order to be effoctive, must be enforeded ut thre facetory. Niow, the fuctories are not making us any toouble, becuuse the farcurios that are making these packages that are userl in intratate commurren wane to comply with the law. It is contiroly a malter of testing the new forms that they put in, or of lesting the samples that they arond in to us, nnd in visiting the new men and in visiting the factories at times when they put in new muchinery, with which they huse trouhle, and with which they are not turning out strielly standard contuiners.

Mr. Axidensox. What does this contniner net cover!

Mr. Sulkmax. It cover's grape baskets, berry boxes, and tills.

Mr. ANibrasos. 'That is all?

Mr. Simemas. Yes, sir, that is all, hut, us a multer of fact, the sume manufacturers who are making ('limnx grupe baskets are nlan mannfacturing strawberry and ruspherry boxes and tills, und a good many of them are also inanufacturing the round stave bushel busket, which is eoming into very genernl use. They send us all those parkuges in order that they may know whether they are making standird bushel baskets, or not. They do not want to muke nonstandurd packages, especinlly those covered by pending legislation.

Mr. Andersos. In this work you have to cover (ontuiners that renlly are not covered by law at all?

Mr. Sinermax. We hnve to do some work on contuiners that are not covered by the law itself, and the same man is working on both.

\section{FOR COMPLFTION OF WOOL, WORK.}

Mr. Axpersox. The next item is on page 29., for the completion of the wool work.

Mr. SHeryax. Under this item we are asking for $\$ 3,000$ less than you gave us last year for this work. The collection and distribution of excess wool profits have reached the point where our speed is dependent entircly upon the speed of the courts. We have distributed practically all of the money which we have collected, that can be distributed, except certain funds that were paid under protest, and which we can not disburse until the courts have decited certain pending cases. We have actually disbursed and sent hack to the woolgrowers between three and four hundred thousand dollars. non in doing so we have accumulated an undistributable fund in the l'reasury, for which no growers can be located, amounting to over $\$ 100.000$, which amounts to more than all that has been spent in the entire course of the collection and distribution.

Mr. Axpersox. How much have you in process of liquidation or held up by suits?

Mr. Sinmax. We have over $\$ \$ 00,000$ in sight that has not been collected, but it is not all in suit. That is, in some of those cases we still have assurnnes that the amounts will be paid whenever the amounts can be arrived at. In some cases there are estates to be settled, and the executors assure us that they will settle with us whenever they get through settling for income taxes, etc.

Mr. Axpersox. Suppose you give us the exact status of the matter, or furnish a statement showing how much money his been collected. what amount has been disbursed. ete.

Mr. Simbrax. I will do that. We have that statement crely week, and I can give it to within seren days of this time. 
PRESENT STATUS OF THE COLLECTION AND DISTRIBLTION OF EXCESS WOOL, PROFITS TO NOFEMBER 2.5, 1922 .

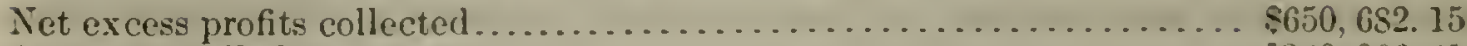

$\Lambda$ mounts mailed to growers............................. $5360,066.41$

Undistributable (growers unknown) ........................... \$106, 795. 37

Total number of checks mailed.......................... 105,570

Balance in hand is held under protest or is composed of partial payments on pending cases or sums in process of clistriluution.

Total excess profits ascertained and uncollected............... \$\$16.056.07

Total excess in hands of solicitor or Department of Justice......... 615. 198. 87

Fixcess pending uncollected in our hands.................... 200, 857.20

This sum is covered by excess profits due from estates which are in course of settlement, the executors of which have promised settlenent without suit; cases in which partial payments have been made and notes given for balances due; and a few in which attorneys for the dealers have assured us that settlement will be made without suit whenever the exact amounts due under the regulations have been agreed upon. A few of these cases are still open because of unusual conditions surrouncling the dealers' business which caused him to deviate from regulations in lanclling the $191 \mathrm{~s}$ clip, resulting in erroneous audits of the reports originally subinitted. There are in all only 21 pending eases, which have not been pewsed to the solicitor for legal action and their number is decreasing almost monthly.

Jore than 5,000 dealers participated in the handling of the 1918 wool clip. Final settlement has been made with all but 78 of these firms. Imong these 78 , however, are several firms whose excess profits were large. From one of these firms we are demanding over $\$ 295,000$. Their attorneys have stated that they will appeal this case to the Inited States Supreme Court before they will make parment.

Three United States district judges have overmiled demurrers entered by defendant wool dealers claiming that the regulations were invalid and that the Gorermment was without right to bring suit for the recovery of these so-callel excess profits. Three other United States district judges have heard arguments on similar clemurrers. One has rendered no decision, another has expressed the opinion that the Government has a legal and binding contract with the dealers but that it is misappropriating the moneys leceived or is recovering them for an illegal purpose. He has witheld decision as to whether this fact established a condition which is open to demurrer. The third judge expressed the verbal opinion that the contract, evilenced by the acceptance of a permit, was binding, promised to render his judgment on a stipulation of facts submitted by the Government and deiendant and, at the request of the Government, to put his opinion in writing, which thus far has not been received.

Mr. Anderson. Have any of the lawsuits been tried?

Mr. Snermax. In several cases argument has been heard on demurrers. In nearly every case the defendant has demurred to our complaint, and has alleged that the Government had no right to maintain a suit. There have been three decisions by United States district judges, the decision in each case upholding the Govermment's right to sue. Arerment on similar demurrers has been made before three other judges, who still have the matter under consideration and have not handed down decisions.

Mr. Axmelson. You have had no adrerse drecisions?

Mr. Summan. No, sir. We have, however, an expressinn of opinion hy Judge Martin, of Boston, that in his mind there is no doubt that the Government has a leanl and binding contract with the denlers, hut that there is mo doube in his mind that the purpose to which the money is beiner devoted is wholly illegal. So he allowed the guestion to be rearened as to whether the illegal purpose for which the money was being collected and expended was at matter open to demurrer. On that point he has not rendered a decision.

Mr. Avoleson. What is the basis of this reduction?

Mr. Submax. The basis of this reduction is the relense of auditors from the work. 


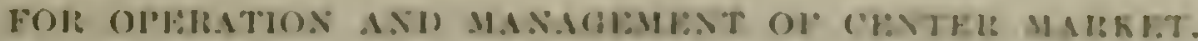

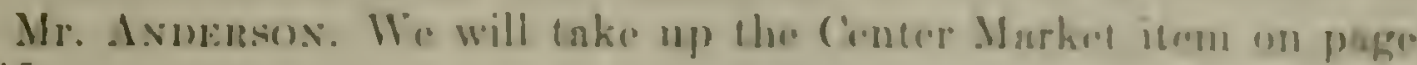
$3 \cdot 1 . \overline{1}$

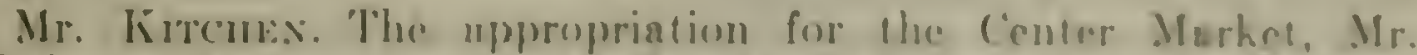
('hairmmn, covers an estimate for the lime time that the Gioserre nent has ever netunlly opernted the place. The law truneforring

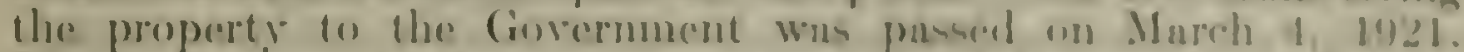
That act provided then a commision should be uppointed los the President to make o valuation of the phyirent innprosemente on the land. und the eommission was uppointed on the the of (Octriber. 1921. The commission completed its work within six montha. as

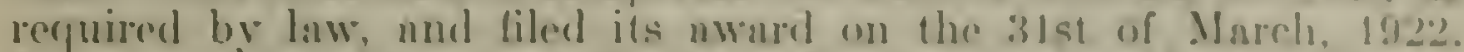
The award amounted to ș(io):2.00. On the lat day of April if this yenr, the Department of Agriculture assumed control of the property and took over the mangement of it. Wre are operating a lurge busness institution. Before taking it over, we had to draw rules and regulations. which we have done, nud wo had to change the nocounting svstem so ns to conform th the liscal reguirements of the 'Preasury. We put nll of the termuts under lense. and other contrnets were mude. One of the difficult things that we had to handle was thant ist the time we took ower the property the coli-storage warehouse was pructically filled with perishable eommodities. All of those necounts hand to be liquidated, and the stornge due the market company had to be paid to the market company, and that due the Government had to be collected as it became due.

SANITAIR CONUITIUNS IMY'lRYF:1).

We started out in the operation of the market itself, lirst, Io improve the sanitary conditions, and we hase had a general (clenn-up). We have panter the reiling in the interior court of the B street wing. and we have painted the interior of the bowling alley completely nnd the side walls of the auditorium. Te have also remodeled the public toilet facilities at considerable expense. In connection with the sanitation work, wo have issued regulations corering the handling of meats, and have employed a ment inspector by transfer from the Burean of Animal Industry to protect the public against the sale of impure or unwholesome ments. The duties of that inspector are also to make sure that the utensils and equipment used in handling meats are kept in a thoroughly clean and sanitary condition. The cold-storage warehouse is operated on an nearly a commorcial busis as is practicable under Government control. We receive commodities for stornge from tenants and from outsilers, and the storage is paid on the bisis of the established rates.

OPFIRITION OF IBLSINESS SKLF-STYPOITIVG.

I am glad to inform the committee that the operattion of this business by the Government is entirely self-supporting. I have a statement here covering seren months, or from the time we touk the property orer, showing our receipts nmount to $\$ 139,219.23$, negainst an expenditure of $\$ 109.087 .56$. The expenses show a balance in the Treasury of about $\$ 30,000$. At the present rute of expense and income we will take in nbout $\$ 240.000$ this yenr. Our approprintion 
is $\$ 165,000$, and barring unforeseen accidents, we probably will not expend over $\$ 155,000$ for the reason that we have been asked to set aside about $\$ \$, 000$ as a reserve. Of course, that may be spent in case we have serious accidents.

Mr. Axmersox. How does that $\$ 240,000$ receipts compare with the receipts of the market under prirate management?

Mr. KItchex. As nearly as I can find out, it compares almost exactly. You may remember that when I made a statement before the committee before, we estimated that the receipts would amount to $\$ 258,000$, but I am not now prepared to say that that was correct. The Market Co. operated the Center Market and the Washington Terminal Storage Co. as one corporation, and in the appraisal hearings, considerable difficulty was encountered in separating the activities for the two plants.

We have issued our leases for the same rates. Our storage rates in some instances have had to be lowered, because they have lower rates, and we have had to meet their competition.

So I make a conservative statement that our income probably would not be more than $\$ 5,000$ less than theirs, and a margin of that kind could be accounted for by natural changes in business conditions.

The handling of the auditorium under our management is more productive than it was under theirs.

Mr. Andersox. You are still maintaining the auditorium?

Mr. Kitcilen. Yes.

Mr. Anderson. Is there any change in that situation?

Mr. Kitcires. We have kept the auditorium and rent it for special occasions, so that it can be available for use by the department for any purpose desired.

AUTIORITY NEEUEl TO PAY CLAIMS.

We lave rum into some difficulty in operating a business concern, due to the regulations of the Government, and we will hare to ask for a litule additional authority to carry us through.

Since the estimates were made we have presented to the comptroller two small chaims for damage to goods in cold stornge. One is for $\$ 12$ and one is for $\$ 17$. And when we drew this law in the first place we inserted the word "chaims," but the comptroller feels that payment of these claims is unauthorized, so I have some language liere which I will present for your considerntion.

Mr. Andrison. Well, this committee, of course, has no legislative jurisdiction. 'There is no objection to it being submitted, but I do not think that we can do anything with it.

Mr. Kutchex. Well, how are we going to pay the elaims?

Mr. Axiblisox. You will have to ask the authority of Mr. Haugen's conmittee, the Committee on Agrieulture, 1 guess. Well, go whend and present the proposition anyway, and we will deal with that lat (ol on.

Mr. Kircurs. Well, the proposition is this, that we would like to huse made a part of the appropriation anthority the following lungunge. After the word "made" insert the following: 


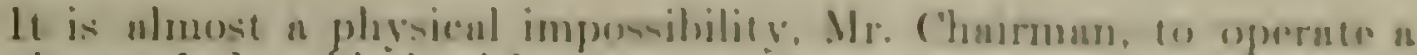
business of that find withont somer provision lo more these small damngr claims. It is customary on the operation of commercial stornge houses that if an! goods are damegerd by the negligenere of the company that the company will make good, and if fred that having banded sovernl humber lhomsand dollars worth of goush an and out of storage, during lhe last seron monthe, und has ing pro-

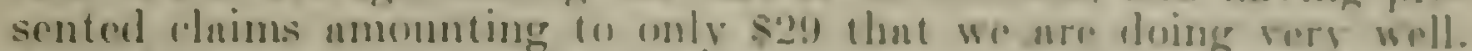
And if we are not given nuthority to pay these linge chans these fellows will sar that the (iorermment is not responshlo and thes will

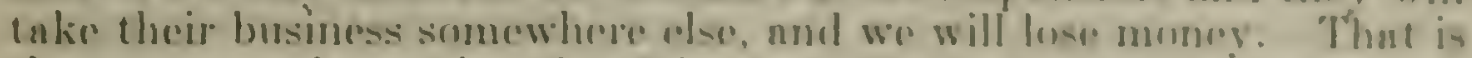
the argament for puying the claims, nus if this is not the proper enm-

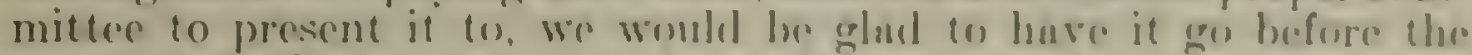
proper committer.

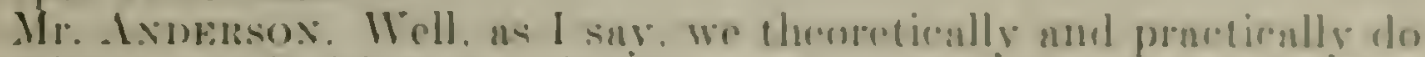

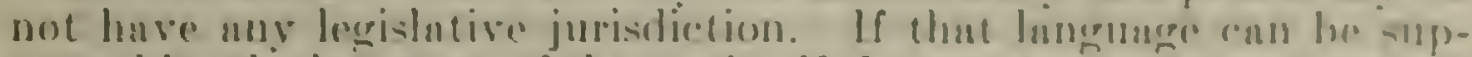
ported hy the language of the ane iteolf I suppose we can appropriate for it. The real fuestion from our point of view is whether the langenge of the nets anthorizing the operation of the market hy the Secretary of Agriculture furnishes sullicient basis for appropriations to pay claims of this character. I would imagrine thut it did.

Mr. Magis. Are you given power to tnke gonds in stornege!

Mr. ANDERson. Ýes.

Mr. MAGEe. I should think that there would be the implied power to pay for any dumages.

Mr: Ardersox. Let me ask this question: Is the comptroller's decision based upon the language of the approprintion. that it dnes not give authority?

Mr. Krtcnkx. No: the principal argument is this:

The general policy of the laws of the tritud Stales is neainst axumplim of liability for damages indefinite as to annount. If damage claims growing wat of willfil

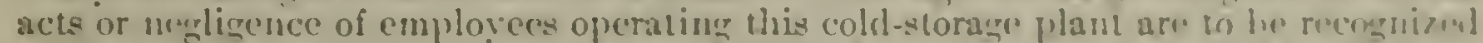
and paid. There should be specitic antlorily of law for such payment. with suth restrictions and limitations as congress mag soe fit to inpose. Is lhe law now rands payment of the claims is unauthorized.

I just got this on Norember 23. It has been pending for some time.

Mr. Jump. Mr. Chairman, could not this language go in in the form of a limitation as to the anount of clains which the secretary could pay?

Mr. A.viersox. I should think so.

Mr. ItMP. It could specifieally provide that the amount "shall not exceed" so much.

Mr. AxDersos. I judge from what has been read that the comptroller's objection is that the language of the appropriation does not authorize the payment of the claims.

Mr. Kitcula. The basic law, howerer, gires the secretary of Agriculture the following authority:

The Secrotary of Inriculture is herehy anthorizel, ont of appropriations na fo by

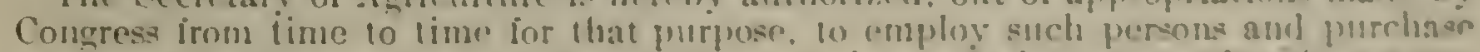

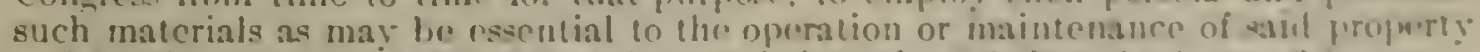
and for the proper managrment and control therrof. rll stat. 1111, sere "-

It seems to me that the payment of these conims would be a proper authorization be the comptroller.

Mr. Magef. What is the specifir nmount of the clams? 

$\$ 29$.

Mr. Kitcines. We have only had two elaims, and they amount to

Mr. Mager. You recognize that umount as just?

Mr. Kitchex. Yes. We secured all of the necessary supporting statements before they were sent to the comptroller.

Mr. Axdersox. The whole question is on the legal aspect, as to whether you have authority to pay them, rather than upon the validity of the claims?

Mr. Kítchis. They are absolutely good claims and I recommended that they be paid: but these being the first ones, naturally we made a test cise of them, and put the proposition up to the comptroller. We can not afford not to pay these claims.

Mr. Buchasas. Have you any records upon which you could base an estimate of the total amount of chams that might be allowed during a fiseal year, or what they would amount to!

Mr. Kiтculis. Well, these two claims occurred in May, I believe, and we have not had any since. Now if everything goes well, we might go through a year and not have a claim. On the other hand, some experienced man might quit and we might get more claims in it month than we had had for two years.

Mr. Jump. Something might happen orernight, and we would have more claims the next morning than we might have in two years with good luck.

Mr. Krtchex. Yes. I serious mechanical accident might produce large claims.

P believe there was some other language, also.

Mr. Armerson. There is some new language proposed in the estimates.

PUICHASE OF NFCESSARY SUPPLIES AND FQUIPAENT.

Mr. Kitcues. Yes. 'The other change that we would like to have is after what I have just suggested. We would like to have the words-

I'rovided, 'That the Secretary of Agriculture may purchase necessary supplies and equipment for use at Center. Market without regard to awards made by General Supply Committec.

We have felt justified for asking for that for this reason, that we are operating a busines institution and competing with other business institutions, and in buying supplies and materials we freguently find that we can buy cheapere in the open market than we can through the (iemeral supply (ommitter entracts, and for that reason we would like to have authority to buy either through the Gemeral sup-

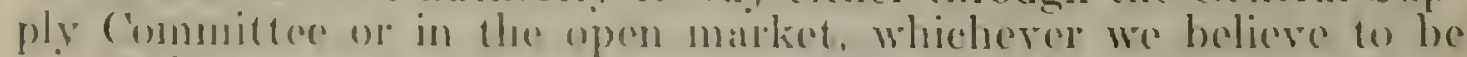
mest advantageons to the Gescroment: but in doing that we would

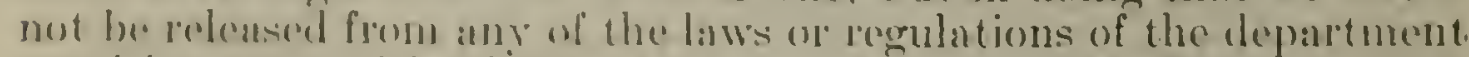
mepuiring compertitive bids. Any purchase under the Department of

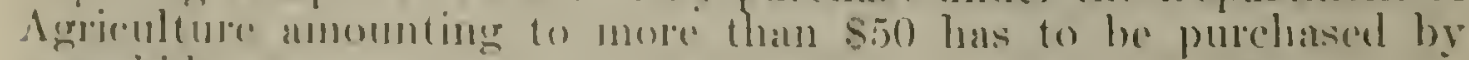
"Ir)' bids.

Mr. Mncile. Open bisls!

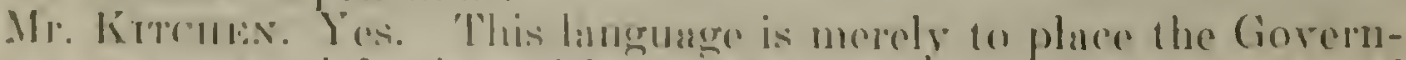
ment on an equal fenting with privinte industry in the operation of this plunt.

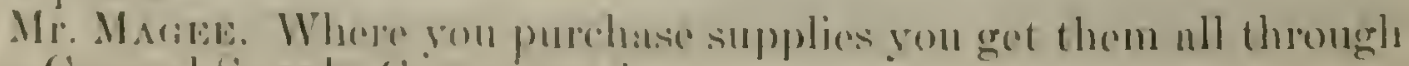
the (ioneral Supply Cimmotloe? 


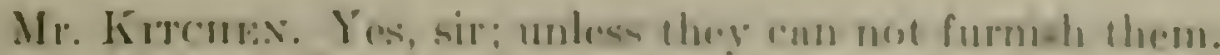

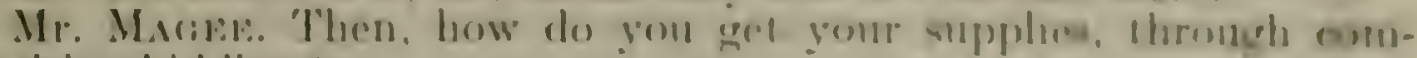
petition bidling?

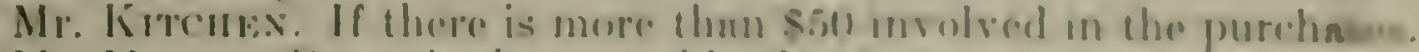

Mr. Maciser. Dores the lnw provide thut!

Mr. Kitchiss. Yó.

Mr. Macist: This would be in direct conflied with the law no it now

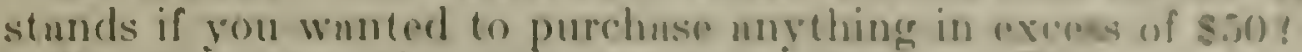

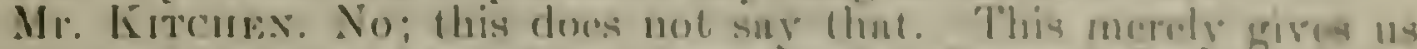
mutherity to purchuse rither through the Genceral supply ('ommittor

Mr. Macres (interposing). Woll, whut I um tulking nbont is that if you did not wish to purrehse through the Gonerisl Supply (iom-

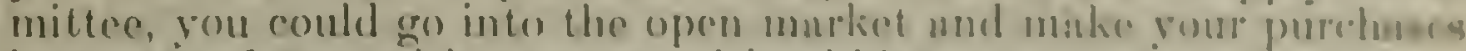
in exeress of $\$ 50$, without rompetitive hids!

Mr. Kircum: Well, we could not muless-

Mr. Magre. (interposing). Woll, if ('ongrens should mopt this lungunge, you could.

1fr. Firrenex. It is my understanding that the busic luw of the Asriculturial Depurtment-

Mr. Jime (interposing). Both the law mal the regulations of the depurtment require that we obtuin competitive hids for nne purehases in excess of $\$ 50$ in the Department of Aericulture in lin-hingenn. except in eases of emergency or cuses where competition enn not be obtinined.

Mr. Mages. And if Congress should udopt this languater, rou would not have to do that?

Mr. JUMl'. The hunerunge proposed would not affect that at all, becutse the recrulations promulgated hy the secretary of Agriculture and which are in the hands of every purchasing officer provide that any purchase in excess of $\$ 50$ must be by compotitive bidding. except as I stated a moment ago. "The only thing that this language does is to avoid the necessity of purchasing under the Gencral supply. Committee contrnets so far as Center Market is concerned.

Mr. Mages. I do not see where this has anything to do with the regulations of the Secretary. It sitys:

Protiblu, 'That the Secrelary of Igriculture may purchase necresary" suppliw and

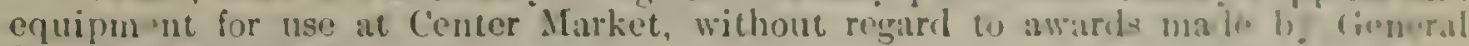
Supply committer.

Mr. Jump. They would not be relieved by this langunge from the restrictions imposed by the Secretary, beciuse they would continue to be enforeed and ure not affected liy the proposed change.

Mr. Macier. You do not think that the renulations of the Secretary of Agriculture affect the law as enacted by Congress?

Mr. Jesrm. Not if the two are related. hut in this instance rou de not have that. This merely relieves the Center Market from the obligation it now has to purehusing all of its supplies possiblo throuph the General Supply Committee's contracts.

Mr. Mager. Are you a lawger!

Mr. Jusr. No, sir.

Mr. Magir. Well, I am, and I think thut I cun tell whint the English longunge menis when it is clent. This lunguage reads:

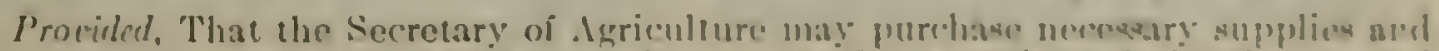

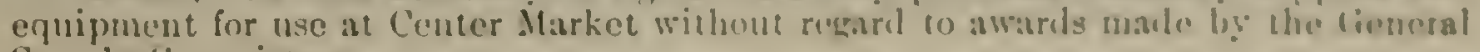
Supply. Committee. 
My legal judgment is that if Congress enacted this language, that you could make all of your purehases without regard to the terms laid down either by the General Supply Committee or anybody else.

Mr. Andersos. As I understand, the regulations of the department require competitive bids for all purchases in excess of $\$ 50$, under departmental regulations, and that those regulations are based on the statute. Is that correct?

Mr. Jump. They are based on the statute: that is correct.

Mr. Kitcins. When we talked this orer with the solicitor, when this appropriation was being considered there, he stated that if this were approved by Congress that we would be bound by the $\$ 50$ limit and we would hare to secure competitive bids for any purchases orer that amount.

Mr. Buchanax. But the position taken by my colleague is that this is legislation in this bill and that it modifies the statutory law and should come through the proper legislative committee.

Mr. Magee. Yes.

Mr. Buchanax. New legislation.

Mr. Mager. New language.

Mr. Axdersox. 'There is no question about that.

Mr. MageE. If this is put in, then the amounts in excess of $\$ 50$ would not come under existing statutes.

Mr. Buchanax. That is the regulation.

Mr. Mager. I understood him to say that it was a statute, that there was a statute requiring them to secure competitive bids where purchases execeded $\$ 50$ in amount.

Mr. Axpersox. That, of course, is where the purchases are not made through the General Supply Committec.

Mr. MAgres. Whether it is a recrulation or a statute, I do not know.

Mr. Krrcuex. I do not know whether it is a regulation or a statute: but l know that we have to do it before we can get purchases approred.

Mr. Junr. The law, the regulations, and the policy of the Department of Agriculture are not to permit any purehnses in excess of $\$ .50$, without competitive bids, unless there is an emergency or some other extenunting circumstance, which makes it necessiry to purchase a certain item. I will have the law covering the matter looked up and a statement inserted in the record.

The law (Rev. Stats. sec. 3709, p. 733) reacls as follows: ". 1ll purchases aud contracts for supplies or services, in any of the departments of the (iovernment, rxcept for personal services, shall be made hy alvertising a sulficient lime previonsly for prepresals respecting the same. when the public exigencies do not repuire the immerlate delivery of the articles, or jerformance of the services."

This provision of the law was amended on Ifarch 1. 1899 (30 stat. 1. 957) hy pro-

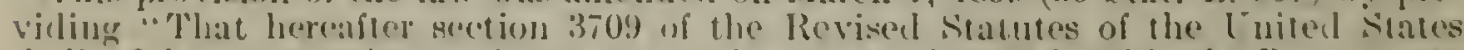
whall uot be construed to apply in any purchase or service resolered in the Department of Agriculure when the aggregate andunt involved does not exceed the sum of $\$ 50 . "$

Mr. Marer. The point that I am making is that Congress enacts any lexgislation which is in conflict with the existing legishation, and it is necessary to construc the langrange of the act, the last enacted lungunge would rescind the prior enactment. Now, if we are going to adepe this law here providing anthority for you to purchase in this manner, you migrht still purchase through the General Supply Commillece, if you did not have atuthrity to make these purchinses in excess of 850 willout competitive bidding. 


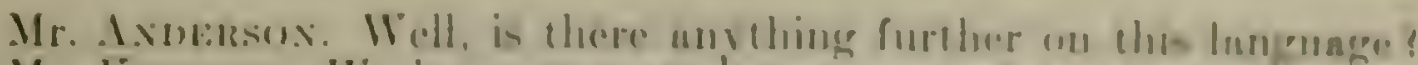

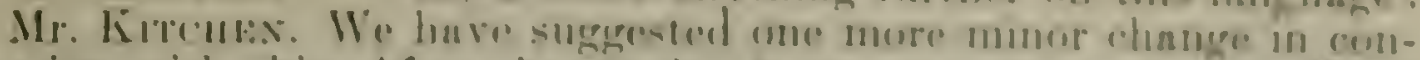

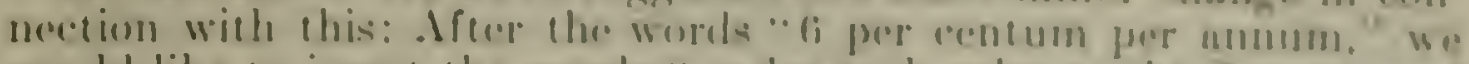

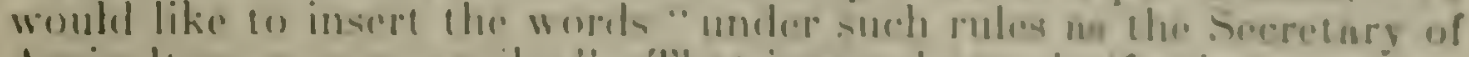

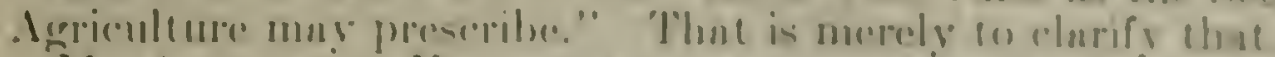

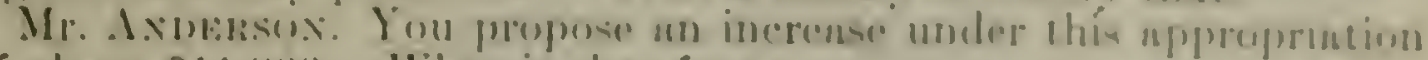
of nhout $\$ 11,000$. What is that for!

(2)

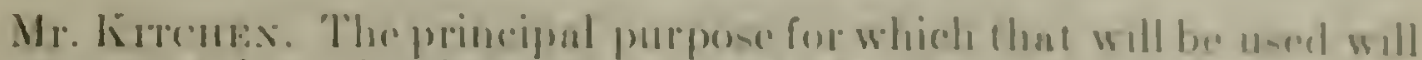

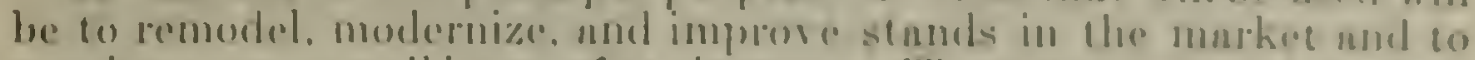

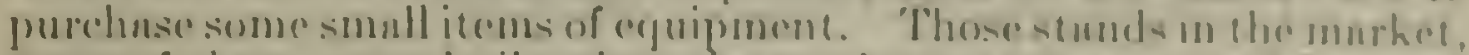
some of them. Were built when the market was construeted in lsiz,

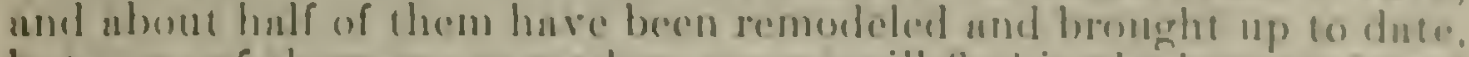

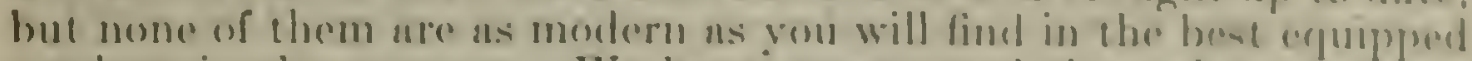

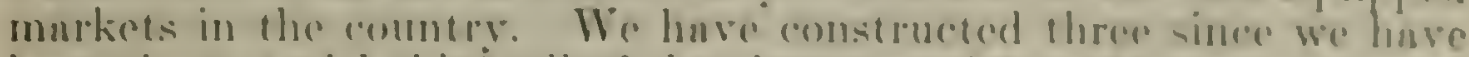

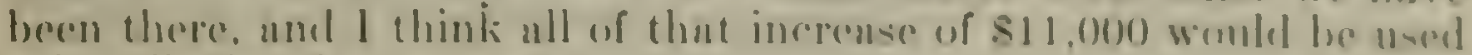
primarily for that purpuse.

Mr. Armessox. Lnder new equipment?

Mr. Litens: Wherever we improve the stands and improve the equipment, we increase the rent 20 prer cent.

Mr. Magra. And rou say that you are taking in $\$ 210,000$ and your (x)enses amount to about $\$ 160.000$ !

Mr. Kiтchis: Approximately $\$ 160,000$.

Mr. Maties. And the Govelniment owns the property?

Mr. Kitcuex. I would like to add to that statement that

Mr. Matibs: (interpusing). Does the Govermment own the property?

Mr. Kitchex. Yes.

Mr. MAcire. Buildinges and all?

Mr. Kitchis. les.

Mr. Macise. Have you made any allowanes for deprecintion or anrething of that sort?

Mr. Fitcus. If we tuke in $\$ 240,000$ and spend $\$ 15,000$ for operating expenses. alterations, improvements, we would have left $\$ 85,000$. The taxes on the land and the bulding and the water rents formerly paid by the prirate corporation amounted to $\$ 25.000$, and adding that to our opernting expenses would bring them up to $\$ 180,000$. lenving $\$ 60,000$. And then I figme on the umount of the award, which whs $\$ 960.000$, interest at the rate of 5 per cent, which would amount to $\$ 4 \$ ; 000$, and still leave us a surplus of $\$ 12,000$. I figure that he improvements that we hare made to the building will offset the depreciation.

Mr. Mager. What ubout repairs as necessny'

Mr. Kitcusix. Well, I say the repairs and improvements which wo make would add to the capital account and oflset depreciation.

Mr. Magre. Do you figure on any insurance, toon?

Mr. Kitcul:s. We have not figured insurance.

Mr. MageF. What would rour insurance mount to?

Mr. Kitcuks. I do not know what the insurance would amount to, but the figures certainly do show that we can make n return of between it and $j$ per cent on the amount expended by the Government, allowing for taxes and all.

Mr. Magfe. Taxes and whter rent would be how much? 
Mr. Kitcinex. Twenty-five thousand dollars.

Mr. Magee. That would make $\$ 155,000$ plus $\$ 25,000$.

Mr. Kircirex. Which would be $\$ 1 \$ 0,000$, subtracted from $\$ 2 \cdot 10,000$ would leare $\$ 60,000$.

Mr. MAGEE. The interest is how much ?

Mr. Krtcines. Forty-eight thousand dollars.

Mr. MAGEF. You figure that at 5 per cent?

Mr. Kircinis. Five per cent on $\$ 960,000$ would be $\$ 4 \$, 000$. Subtracting that from $\$ 60,000$, leaves $\$ 12,000$.

Mr. Mages. Do you know what your insurnnce would be?

Mr. Kitcirex. No: but it certainly would not be more than that. We will check that item up, though, to make sure.

Nоте.-As nearly as can be ascertained, the amount of the fire insurance premium paid in the past on the Center Market property was approximately $\$ 5,000$ per annum.

Mr. Trixy. I want to make one statement about that $\$ 11,000$ increase. If we have anything to do with the market we are going to get that baked goods stuff under cover and-.

Mr. ANDisison (interposing). That what?

Mr. Trexy. Bakerl goods, pies, cakes, that is now handled out in the open market. That has got to go under glass cases, and we are very anxious to have an increase to take eare of the amount of improvenients necessary.

Mr. A YDersox. llow much would be involred in that?

Mr. Texsy. Mr. Kitchen, can you give an estimate?

Mr. Kirtenex. We have not prepared an estimate on that. Stands already built have cost us about $\$ 1,000$ apiece.

Mr. MAGEE. How much?

Mír. Kitcinex. About $\$ 1,000$ apiece.

Mr. Aximsox. You said that you inereased the rent 20 per cent when you made improvements. 'Twenty per cent on what?

Mr. Kirchex. Over what it is now, to reimburse us for the improvements. I feel that it is only proper if we improve a man's facilities to let him pay a little more. It is only fair if we improve in man's facilties that we should be reimbursed gradually for those improvements.

Mr. Axdision. Are there any further questions? If not, we will take up the next item.

Mr. Jusr. Doctor Ball and Doctor Langworthy are here to present the estimates of the Bureau of Home Economies.

'Tuesday, November 2S, 1922.

\section{BURFAU OF HOME ECONOMICS.}

STATEMENTS OF DR. E. D. BALI, DIRECTOR OF SCIENTIFIC WORK, AND DR. C. F. LANGWORTHY, CHIEF, OFFICE OF HOME ECONOMICS.

\section{Mr. Axmerson. 'The next is the Burrau of Home Economies:}

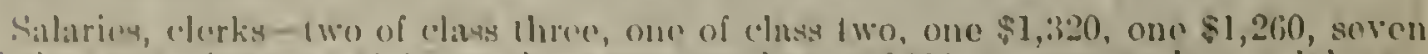

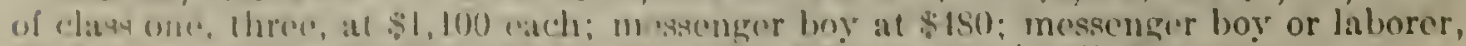

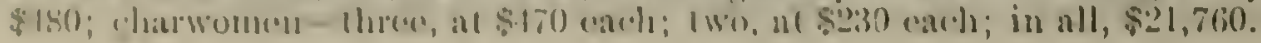




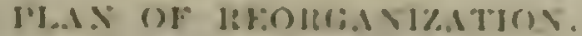

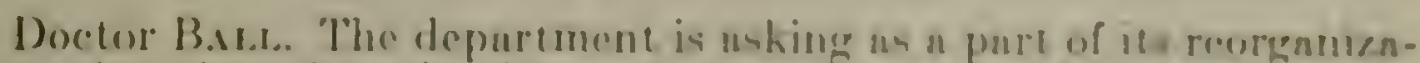
tion plan that the scientifie und rementefl work wheh whe formerly incerporated in the states Relations Service be remored and that the work in home economies be muld an indepondent huresu.

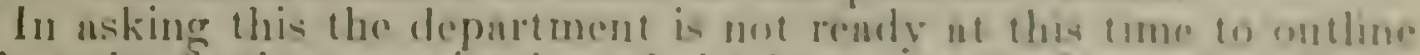
what the final reoremention of the home ieonomies work will lee. It is the intention of the department to cenll in 1 commenteon of esprerts on the diflerent phases of the sulnject und to ask them to conanler the orginization of a progrmm of development of this worh and to ery and fit that work into the present orgunization of the Depurtment if Agriculture. In its brondest nspects a home economices department

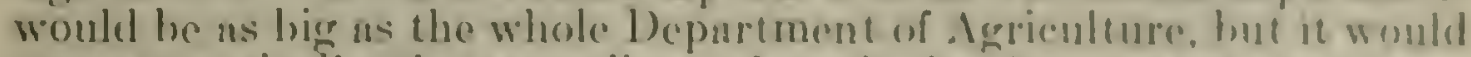
cover practically the snmo lines of work the ilepurtment nuw deses: so instead of organizing home eronomics $u=$ a burenu corering ull of those phases of the work the idea would be to make the Burenu of Home Economies the center organization which wonld conpernte with the other burenus to make the full and complete ficld of woman's work.

For instunce, we have in the Public Rouds 1 division of nerieulturat

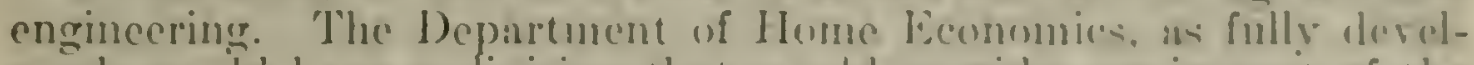
oped, would have a division that would consider equipment of the lome, especially the muchinery of the kitehen, and that work contd be handled in cooperation with the Seientifie Lingincering Divinion with special upplieations to the wombn's problems. 'The same thung is true in the nutrition work. There will be cortain phasen of the mutrition work which will be purely related to the ford of man. but in a very lange pereentage of nutrition problems there will be no difference in methed or upplication between the sudies enrried on for the benefit of man or the denestice mimals. 'Therefore it is probable that most, if not all, nutrition work cexeept sperial ataptiations in foods and cooking. would be handled couperatively under the Burean of Home Eeonomies.

In the same way we would find that as you organiog and deredep the home exonomies work, eombining it with the work of ugrienlenre. rou would find a very small amount of it neederl to haves sperial developments of its own. It simply means organizing that work and applying all of it to the problems of the home. There will he certain other phatses in which there will be no change needed and the worts will be eontinued as at the present time.

Mr. Becustr.s. What platses are not receiving attention now?

Doctor B.a.s. I would not say that there wila any particular phases receiving no attention; but take, for instunce, the equipuments. which is probably one of the phases in which substantial alvances could be mate-

Mr. Buchaxax (interposing). Equipment for the home?

Doctor B.st.. Equipment for the home: the mechanical applianees in the home are receiving pructicnlly no uttention at the presont time. The mujor research problems of the Ollice of Home lisenomics up to the present time hnve been the nutrition problems und the textile problems. This work rested liarerely on the utilization of agricultural production and so, of course, the mutrition and textile problems 
came to be the major fenture of the work. Home economics from the standpoint of our institutions, from the standpoint of building up rural communities, has a much broader scope than that. The agricultural economists would like to have us change the name and make a division of home cconomics, involving the economic factors. This is a phase of the work that has had little development.

Mr. Magee. 'This is new?

Doctor BALL. This will be one of the features to be developed.

Mr. MAgeE. You do not have an office of home economies now?

Doctor BArL. It is now under the States Relations Service.

Mr. MageE. Then you would take it out of States Relations Service and make a bureau of it?

Doctor BaLL. Yes; take it out of States Relations Service and make it a bureau. The Secretary has already announced that he proposes to put at the head of this work a woman of outstanding research, ability, and of national reputation.

Mr. MAGEe. You are asking for the same appropriation for this year?

Doctor Batr. Yes: and in asking for this we do not wish to be misunderstood. We are not ready at this time to outline any program of derelopment of this work. 'This is a continuation of the work that is now going on, with the hope that we will be able to strengthen this work where it should be strengthened. and probably eliminate certain work which should be eliminated.

'The work, you understand, has been dereloped under States Relations Service, and the development of it has been along the lines helpful to extension, but the Secretary is coming to fecl that the real function of the Department of Agriculture is in the resenrch field, as the States now hare well-dereloped extension programs.

Doctor Langworthy will discuss the organization of the bureau and the work to be done.

GENERAL STATEMENT OF WORK.

Doctor Langwortmy. Speaking for the present organization: As I recall it, Mr. Chairman, the appropriations for the Office of Home Economics have been made to enable the Secretary of Agriculture to study the use in the home of the agricultural products for food, clothing, and other purposes, and labor incident thereto. 'The work of the oflice has been organized along those lines.

Nearly three-fourths of the total sum appropriated for the Office of Home Economics $-\$ 50,000$ for each of the last two fiscal yearshas been expended for work concerned with food and its uses in the home. Aluch of this is technical laboratory work and all of it. generally recognized as highly desirable. Some of the work is an upplication of statistical methods to problems of dietetics, with the result that rational or "balanced" food selection can now be offered to home makers in nontechnienl as woll as technical terms. In other words, food selection and meal phanning can now be easily discussed with an necuracy formerly dillicult except for the expert student. Such a generalization has been often attempted, but never in so workable a form as thint provided by the Oflice of Home Eeconomics. Attention has been given to devising graphic mothods of summarizing und presenting such data. 


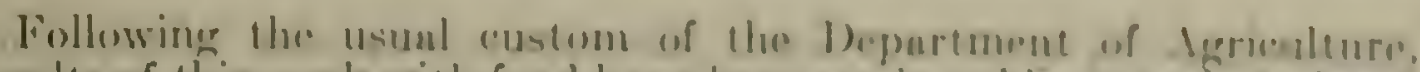

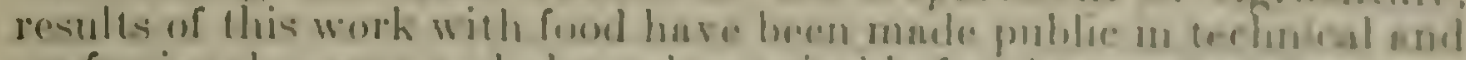

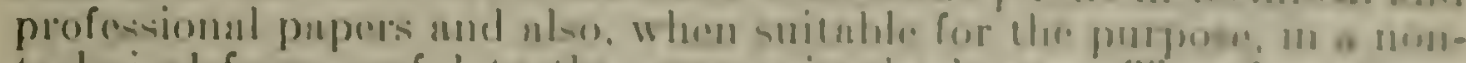

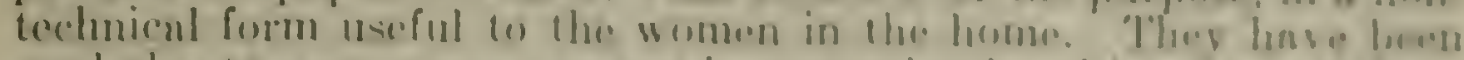

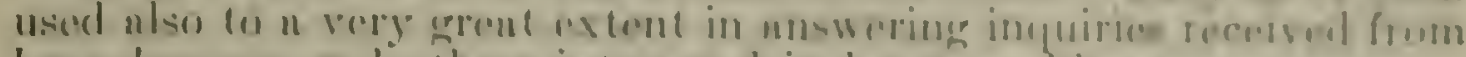
housckerpers and whers interented in home pomblene.

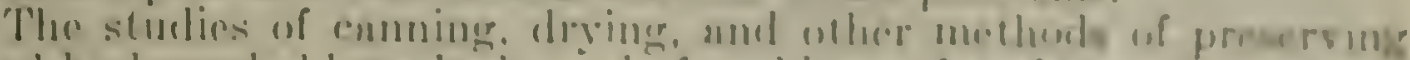

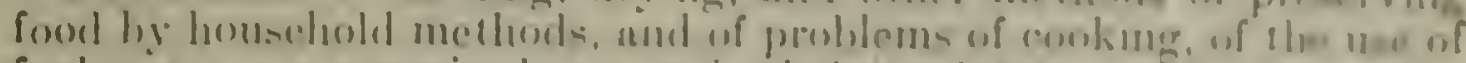

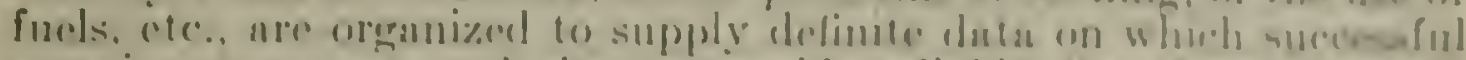

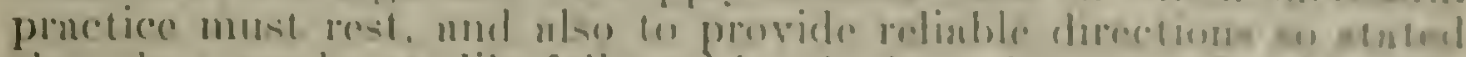

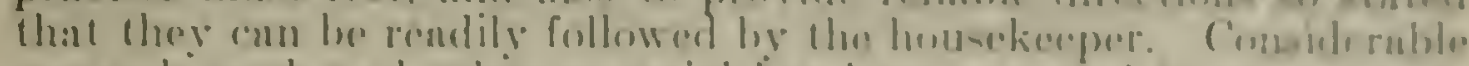

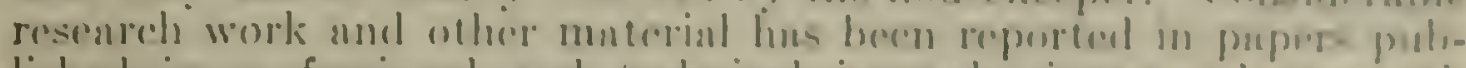

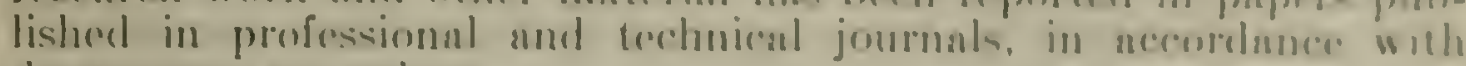
department procedure.

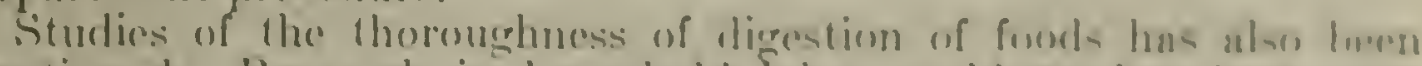

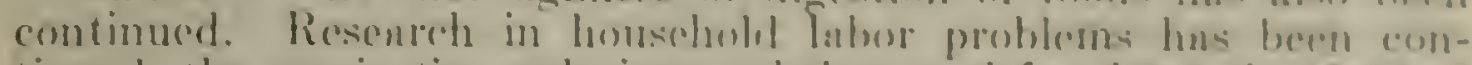

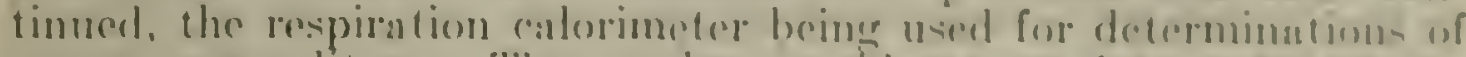

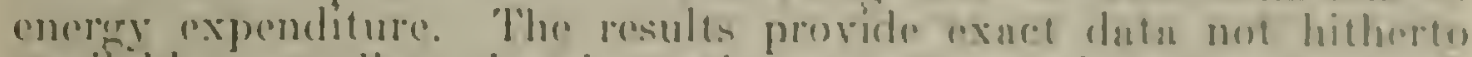
availible regarding the demands on a woman's strengetl which houschold tasks involve. Without such data one ran not decoms in telinite terms the important gutestion of work in the home. The

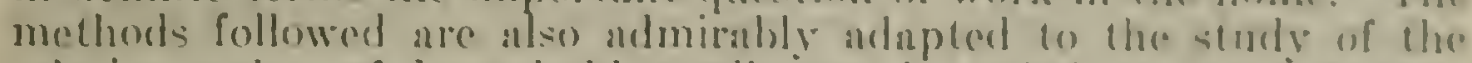
relative value of heuscholel applinnees intended as lubor sarers. In fact, it is hard to say how such guastions cant he studied an fincy should be without such measurements.

The use of houschold equipment for the purpose of saving lator wis included in this problem, the outeome leeing that a wonking surface too low or too high to lit the housckeeprer wins foumd we cause a greater expenditure of energy than the use of une the right height: that is, one on which the hind will rest lighely when the arm is dropped to the side and the fore-arm ratised fo in anerle of $1.0^{\circ}$ from the body. The manufactures of sinlis and kitehen fables has been cquick to take up this conclusion, as have the housekecper and the tencher. Besides this there is, of course, al firld in housiohuld labor for the engineer and the mechanician. The plan of work in the Depmetment of Agriculture, as Doctor Ball has pointed out, proviles for this elsewhere, along with problems pertaining to rentral heatiner. water supply, sewage disposal, and other engineering questions related to the home.

There are other phases of houschold manigement regardine which we have been collecting information, partly from laboratory studjes and partly from surveys and statisties of netunl home practier. Closely related to these nre the problems of economies in the home. These have beem studied chicfly by means of survers and the anily-ie of statistical data which are provided by them. It is diflieult an sis parate the farm and the home in considering these questions of the manugement of income in the farm home, and so it is natural that in survey work and interpretation of statistical results we should have been working in cooperntion with the Burenu of Agrioultural Eeonomices.

The wise use of money is an important household manacement problem, and this question has received consideration, particularly with respect to the wise selection, suitable care, and repair of waring apparel, furniture, and other articles of personal and houscholit 
equipment. In so far as possible. laborntory studies have been made of the materials and operations involved, and critical examination made of available literature, and as a result some information has already been made public and considerably more awaits publication. A practical outcome of such work is that it enables the housekeeper to sare money by prolonging, without undue labor, the usefulness of clothing and household equipment. For example, good household ways of mending china and wood have a technical as well as an economic interest. 'To learn why some cements, for instance, are superior to others in mending porcelain will take one far into physics and chemistry.

STUDIES OF THE ORIGIN AND DEVELOPYFNT OF TIF IOME AND ITS EQUIPMENT.

The Office of Home Economics has done considerable work in the collection of material for the discussion of important problems such as the origin and derclopment of the house and its equipment, of the manners, customs, and social usages, since these in great measure determine the distribution of the income in household expenditures, and are equally important in the discussion of the whole question of household management. The time arailable for such work has been limited, but nevertheless it has been carried on to such an extent that some generalizations at least can be made.

Special equipment, such as apparatus for the study of accelerated wear, is a mecessity if one is to study the question of relative durability or wearing quality of textiles and other materials. I believe that all who are familiar with the problem would agree that the development of such devices is time-consuning and costly and that nothing of the sort has yet been prorided which is entirely satisfactory; and, furthermore, that it is not possible to discuss such questions except relatively until such measurements are possible. It is a step forward in the march or research to reach a point where one can see the way. That point has been reached and useful work can be done. The cost will be considerable in terms of money, and it seems to me that the derelopment of such equipment might suitably be a cooperative project in which several Gorernment agencies should unite.

In the experimental work carried on with food, mention should be made of the study of food storage problems in which the respirition calorimeter is used, at kind of work which is highly technical. How(vere, it provides data inmediately useful to those interested in commercial cold-storage problems, and also which will prove rery important in the questions of farm and home stornge. The case is it parallel with that of canning, piekling, and brining, and dehydration of ford, projects which demand and are receiving special study from the wholesule or manufacturer's standpoint, from the hoviselold stamelpoint, and in some calses, at least, from the farm standpoint as regurds quantity. While it is true that in such cases the fundamental biologrial, cherinical, and physionl principles can be studied independently of the upplication, wherever facilitios are arabble, the appliention of the principles and experimental study of the procodures pequisite in each case are of errent value. Since procedures and apuipunent desirable diflere with the guantities of matrial used, there is as distinct a fichl for such study and resenreh on home problems as there is for these which concerin the latge manufacturer. 


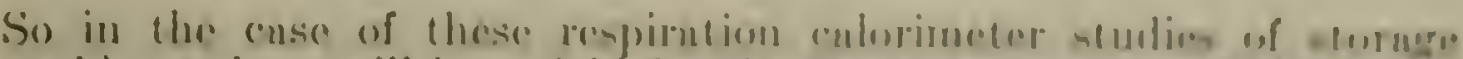

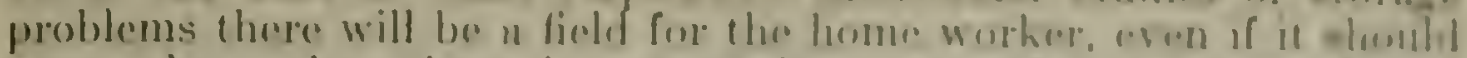

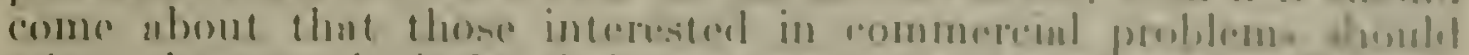
adopt these mothods for their own purticular lios of work. There as no doubt that they ure applicable to problems of home mentape of

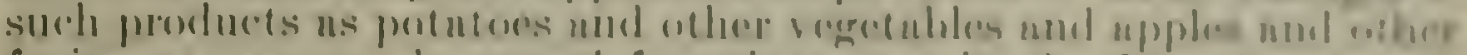

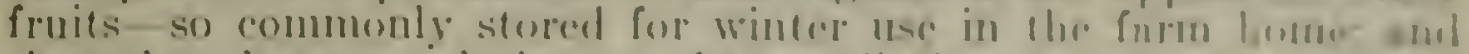
that they have a rolations to the ventilution and hundlioge of the

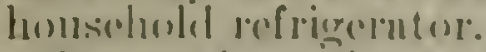

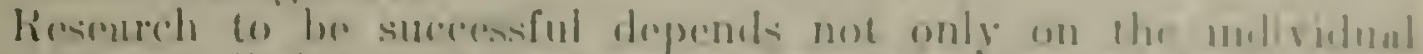

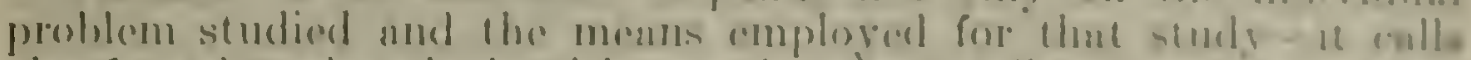

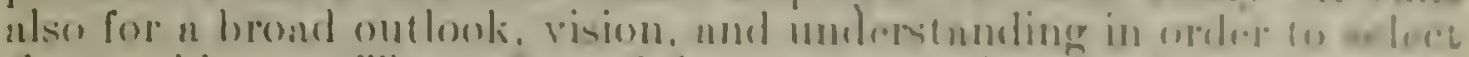

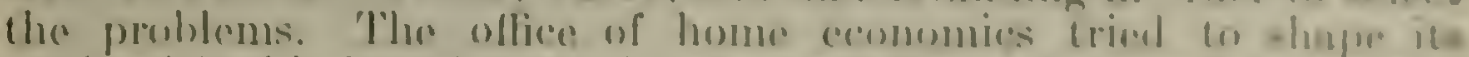

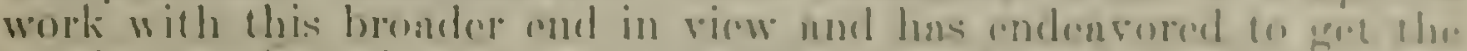

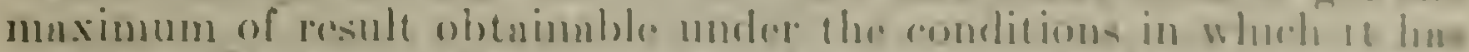

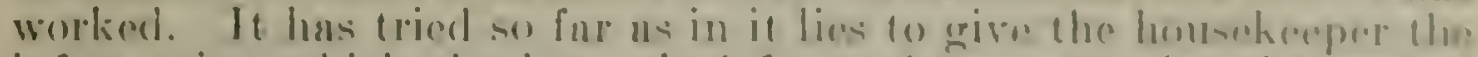

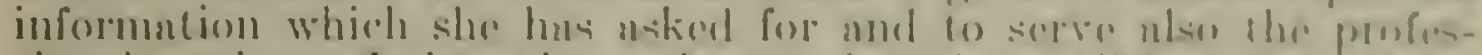

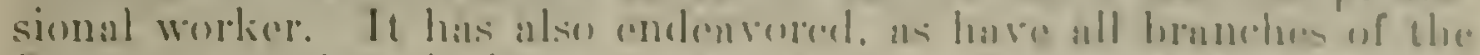

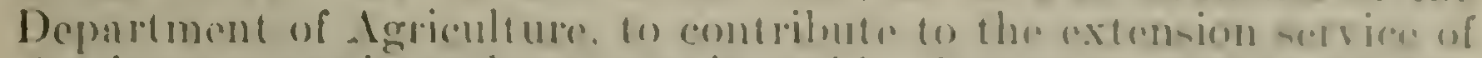
the department in such wats as it could. But orere and boromel this,

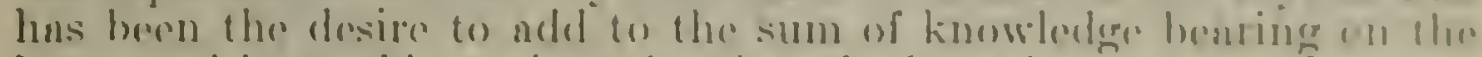
home and its problems, in order that the housedinemer mas the more ansily nchire a hetheresult.

Thiat we huve been suecessful in some of our efforts I think is borte out by this simple illustration.

'The study of food preparation has not had for its purpore the preparation of dalectable dishes. alehough that is semethiner that $10 \%$ could always do and plense a rery largi publice, but it has hud this. to find the principles upon which the preparation of food hould he based, not only that a pulatuble dish may result, but alio that it lirger part of the food vilue may he conserved.

And we hare also tried to find some way of making sure that the housckeeper could choose the foods to form a "well-bilanterl" diet. as people like to call it, so we could give some atriere to the homerkeeper which would not repuire detailed information in physiologry and chemistry of food and nutrition to enable here to pick the fonds to enable her to take care of her family and not result in ill hendel.

Mr. Buchas.x. There is administered under the Dapartment of Lahor the maternity bill, thut carries on work along the sume lines that you have outlined. Is there any duplication of work as lectwern your departments?

Doctor Laxgwontur. There is alwons friendly relntions betwent this work and that we have carried on, but we ilo not do anyehing that is as intimate in the relution to the home as the maternity hill.

Mr. Becmaxas. Do they talie adrantage of the information that you nre able to give them?

Doctor Laxigontur. I am sure I am right in snying that they tuke advantage of such information as we have puhlisherf, but before it would reach the person to be benelited, under the maternity bill the facts would be restated.

Mr. Buchaxax. But what I am trving to gret at. I would like to see whether these investigations, or what not, scientilie facts, truths, with regard to nutrition as applied to the young mother nond the child, or young mother, during the prenat al dags before chilalbirth, I woukl 
like to find out whether your bureau is undertaking to corer that subject, or that bureau is undertaking to do it, or whether the two bureaus are undertaking to corer the same subject.

Doctor LANGwontry. No, sir: we have never done that.

Mr. Buchasax. Well, it has been done in other instances, and I was wondering whether there was any duplication of that work in your bill.

Doctor Lavgworthy. It would not be done in the office of home economics herause all of those problems are involved and are connected with the study and practice of medicine; and we would not undertake work in such a field. So far as I am concerned, that work would not be considered in connection with the office of home economics. The work in connection with the feeding of the expectint mother, and the feeding of the young child, and the feeding of the mother and her child after the child has been born, has so far received attention in the Children's Bureau-all that it has receired in the Government so far as I know, unless the Public Health Service may have done something.

That reminds me: There has been a publication, that I recall, Mrs. Max West is author of a bulletin on feeding young children. In it she made some statements with regard to general nutrition, and she sent the manuscript down to us to see if she had stated them well. As a special subject of research I am sure that I an safe in saying that there has not been any such duplication as you feal.

Mir. Bucrianax. My object was to ascertain whether or not in the erent that would be gone into, if you have the facts already, whether they would get the facts from you, and use the information you have already collected.

Doctor LAxgwortmy. Yes, sir; the Red Cross is an organization, an independent organization which has always worked with us in the wiay you suggest.

Mr. Buchinax. The Red Cross is not trying to build up an orginzation, especially, like some of these Government bureaus are. I think without any question, some of then are, and I would say that all of them are.

Doctor LANgwontuy. I can only speak, of course, for myself. As I say, if you left it to me to decide, I should not want to take any of their functions, in any way, and if 1 had a piece of information and they asked for it, I would give it to them. Would not that bo about what you would naturally expect?

Mr. Buchasax. That would be what I would expect.

Doctor Liseworemy. Ios; that would be just the way I would ferl about it.

Mr. Bucmasix. I guess it is our duty to see that there is no duplication.

Doctor Laxgwortur. We have always thought that the relation, the friondly relntion between individuals and between bureaus in at depatment, and between diflerent departments, was one of tho very sat isfuetory things about eurrying on the work.

for instance, the study of the use of home equipment and textiles, which is enrried on to some extent by the Burean of Standards, but for entirely diflerent purposes - they hare instituted it from a manufucturing and trade stundpoint - hus yielded materind which eould be interperefert in homsehold troms, and that wo have tried to grot and 


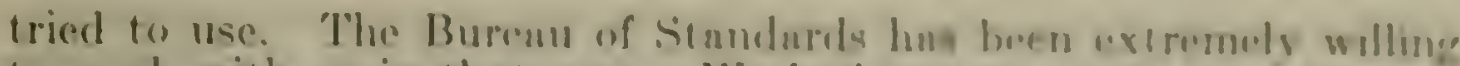

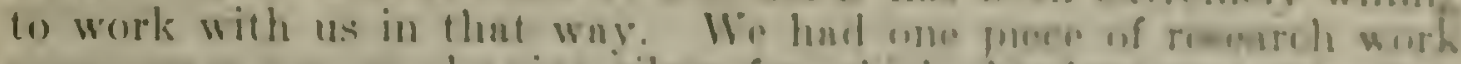
some years ngo on clenning silvere for which the departanens has no

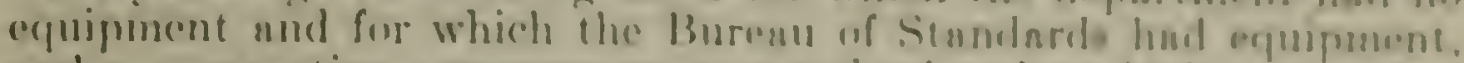
and a cooperative arranerement was arrised at he wheh cene worther

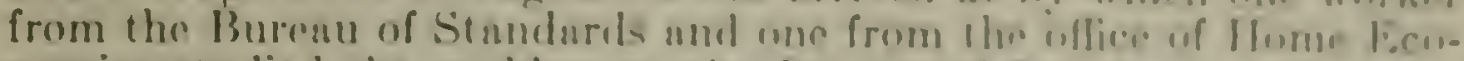
nomics studied the problem at the Burente of Sembelurels. Thus wo

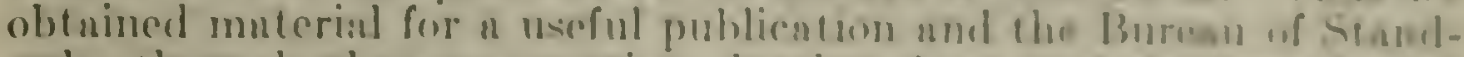

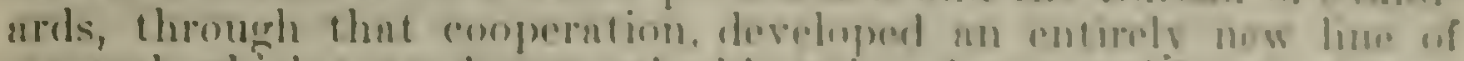

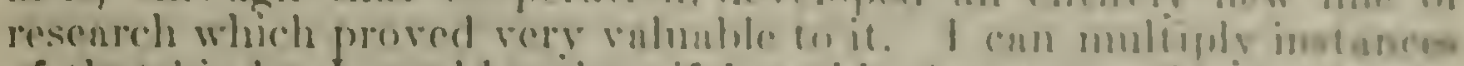

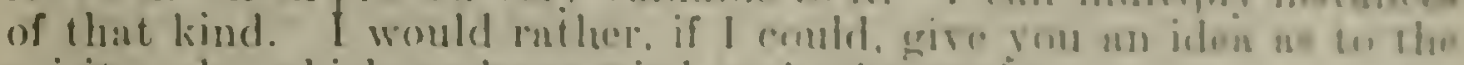
spirit under which we have tribed un to the worl.

\section{SHLMUI:S.}

Mr. Axumesox. Very well. Now, on phere 297 you has a sentupurs roll, which I nssume is inade up entirely from the frumser form thates Rolutions Service.

Doctor Laxgwontry. It is the sume in content us han buen in States Relations Service. There is no escential elunge und it ensers the same projects.

Mr. Axmersox. Now, you propose in your eronerul laneusure in

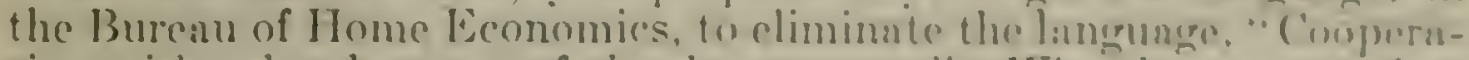
tion with other bureaus of the department." Why do you "ont that out?

Doctor Barl. Simply becuuse it is unneressary. 111 hurimus cooperate. The langunge is not neerssnry. It might be neresentr in providing for cooperation with other ilepartments, bat it is nut necessary liere.

Mr. Avmersox. If there are no further questinns on this item, we will take a recess until 10 o'clock to-morrow morning.

Wednesdx, Norisurar 29, 1922.

\section{ENFORCEMENT OF INSECTICIDE AND FLNGICIDE ACT.}

\section{STATEMENT OF DR. J. K. HAYWOOD, CHAIRMAN OF THE BOARD.}

Mr. Axnersox. Doctor Haywond, we will take up your item on page 300 , for the enforcement of the insecticide ant.

Doctor Harwood. Mr. Chairman. I have a short prepared statement, which presents this matter in a comcise wns and I beliere it will make the discussion shorter if $1 \mathrm{am}$ permitted to submit it.

\section{GENEIRA STATHMHT OF WOOKK.}

Mr. Axprasox. You may proceed with rour groneral stntement.

Doctor HAYwoon. The insecticide and fungride bond. composed of four scientists representing the Bureaus of (hemistry. Plant Industry, Entomology, and Animal Industry, and working in couperation with those bureaus, was oreanized in the department to nsisis the Secretary of Agriculture in the enforcement of the act. 
The inseeticide act places upon the department the responsibility for preventing the manufacture, sale, or transportation of insecticides and fungicides (including disinfectants) which are below the strength claimed for them, which will not accomplish the results promised. which are injurious to regetation when used as directed, or those which fail to comply with any other provision of the act. the purpose being to require that labels shall contain only truthful statements and that the materials shall not be ndulterated. The products designed for the use of farmers, fruit growers. market gardeners, and stock and poultry raisers constitute the most important class which comes within the purriew of the act. Products used to rid the household of insects, and disinfectants, germicides, etc.. used to kill or combat bacteria, also come within the srope of the work.

The act has been in effect since January 1, 1911, and its enforcement has resulted in greatly improving the quality of proprietary insecticides and fungicides and in making the labels truthful representations of their efliciency.

The industry legulated by this act has experieneed a tremendous growth, with a consequent increase in the work of the bonrd. It has developed from a side-line business to one attracting the investment of a large amount of capital and the erection of many plants for the manufacture of an increasing variety of preparations. 'Through the eflorts of scientific investigators new methods of controlling insects and fungi have been dereloped and the industry is of constantly increasing ceonomic importance. The overcoming of losses to crops and animals through the application of proper remedies has come to be regarded as an important part of commercial farming and stock raising, and the use of the materials controlled by this act has consequently become more general and the tonmage entering interstate commerec is now very large.

Another important result of the enforcement of this act which should receive considerable emphasis is that it has proved to be a potent aid in the endeavor of the department to introduce new remedies. By involing its provisions it is possible to materially assist other bureaus of the department in the introduetion of new methods of control treatment, by preventing the sale of materinls which purport to be of the standard recommended by the department, but which, in fact, are less effieacious and sometimes positively injurious. By inspecting the mnterial offered for sale in the localities where other bureaus are attempting to introduce new control methods, it is possible to prevent to a large degree the failure of the control treatment, which would follow from the use of materials not up to the standard.

'The board is giving special attention to:

(1) Campaigns designed to improve the quality and labeling of Bordeaux mixture and Bordenux-lead arsenate mixture.

(2) Campaigns ngainst hitherto monsperted inserticides and funcicides fulsely daiming to control the cotton boll weevil and falsoly claiming io control many inserts and plant disenses by inocuIntion into the tree or by absorption through the roots or seeds.

(3) Campanigns arainst insect powder aclulterated with powdered laisies.

(1) Campaigns nguinst disinferennts which are adulternted or the labels of which benr falso and misleading claims. 


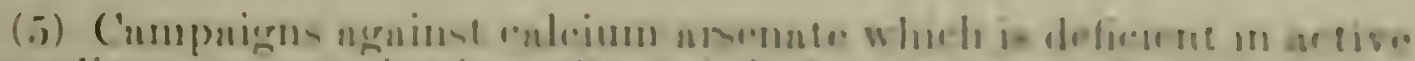

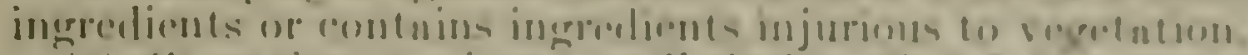

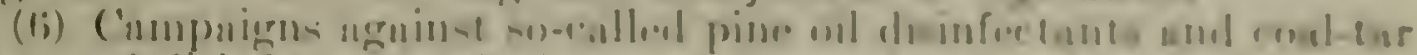

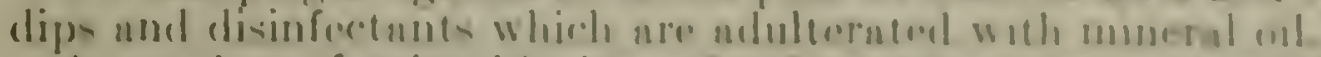

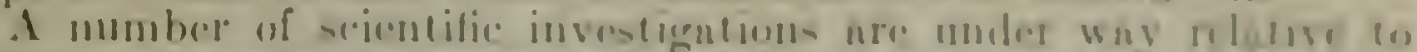

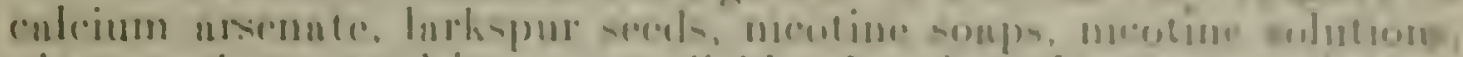

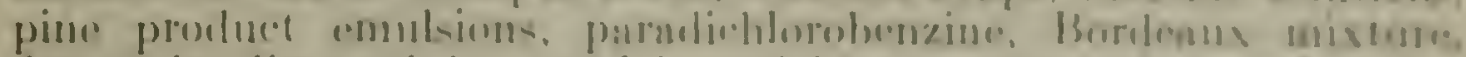

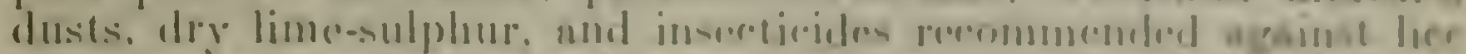

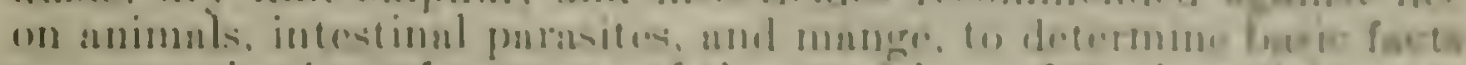

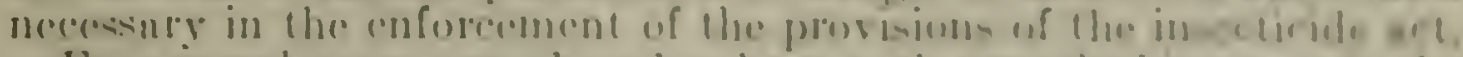

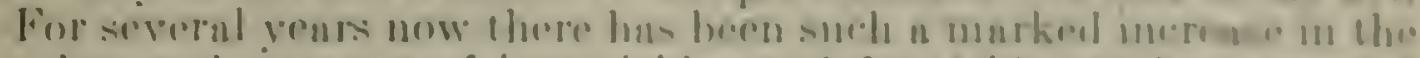

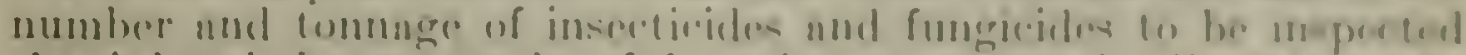

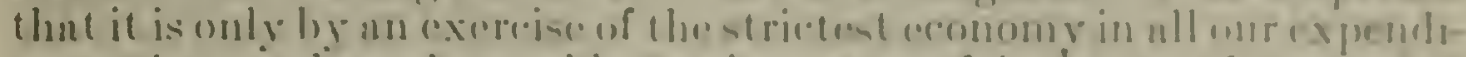

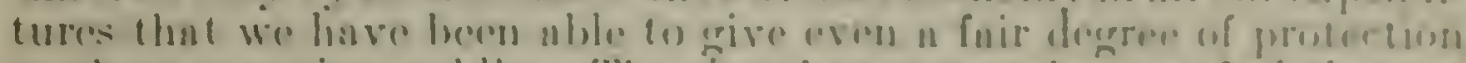
(1) the eousuming publie. The time has come when we frot that wo would not be doing our duty if we diel out frankly state fo fors that

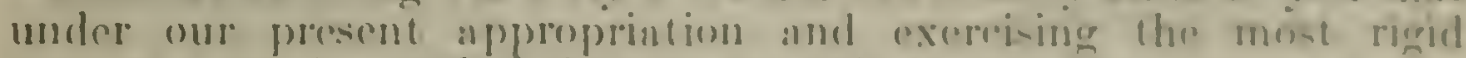

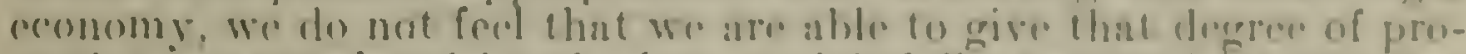
trection contemplated by the haw or rightfully appected hy the ronsuming public.

\section{S.II.IRIr:s.}

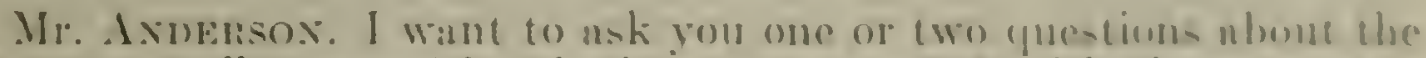
stitutory roll, cosered by the itom un puge 3010 . The itrm appents to be the same, with the execption of the droppring of one me-enger bor at $\$ 4 \$ 0$ und one at $\$$ stio.

Dortor Horwo(o), les. sir.

Mr. Arinessor. Are those plates vacant now!

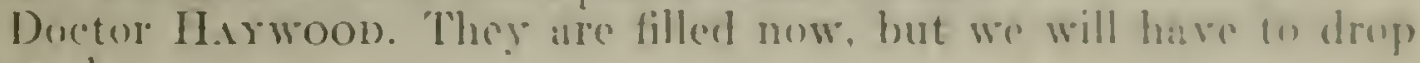
those boys.

Mr. Ainbssox. There are no dhnges in your genernl expense item?

Doctor Harwoov. There is no change whntsoesere in the rest of the approprintion.

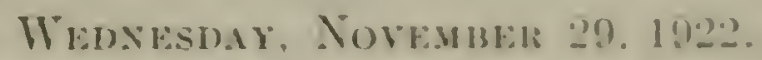

FEDERAL, HORTICLLTERAL, BOARD.

\section{STATEMENT OF DR. C. I. MARLATT, CHAIRMAN OF THE BOARD.}

Mr. Axnensos. Doctor Mardatt, do you wish to make a genern! statement before we take up your statutory roll!

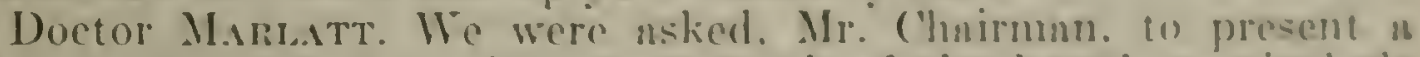
statement of the more important work of the honrel. particularly with reference to the items of the approprintions. I have such in statement here, which I would like to submit for the record. It contans information that maty be of use to the committer, eovering the genernl work of the board in its more important phoses.

Mr. Axnersos. You muy submit that for the recoril. 


\section{(The statement referred to is as follows:)}

\section{GENERAL STATEMENT OF WORK.}

The Federal Horticultural Board is the agency for the administration of the Federal plant quarantiue act of $A$ ugust 20,1912 . This act has for its objects:

(1) The prevention of entry into the Cnited States of new and important insects or plant diseases injurious to agriculture, horticulture, and forestry.

(2) The prevention of spread in the United States of any such pests which may have gained more or less limited foothold.

(3) The control and, if practicable, the eradication of such pests, either directly or in cooperation with the bureaus concerned.

'To give such protection now involves the administration and enforcement of some 22 foreign and 15 domestic quarantines.

$\Lambda$ somewhat detailed record is given of these activities in the annual report of the board now in press. This special report for the information of your committee covers the subjects of more general interest and of immediate injportance. These are: (1) Control of important new plant pests, such as the pink bollworm, corn borer, pine blister rust, etc, and (2) the port inspection service for the enforcement of the various foreign quarantines.

\section{CONTROL OF LMPORTANT NEW PLANT PESTS.}

The Department of Agriculture is now attempting to prevent the spread and in come instances to cradicate a number of important introduced pests which still have a rither limited foothold. These include, among insect pests, the pink bollworm of cotton, the Furopean corn borer, the gipsy and brown-tail moths, the Japanese beetle, and a number of minor enemies. Among plant diseases similar control is being attempted in the case of the potato wart, white-pine blister rust, citrus canker, and certain discases of small grains. The present status of the more important of these will be briefly summarized.

The pink bollworm.-This is probably the worst known enemy of cotton, and had gainel limited footheld in Texas, Louisiana, and New Hexico. The possibility of eradi ating this pest is better now than ever bef ore. No infestation by it was found in 1921 in 1 ouisiana, nor has there been any reappearance determined so far this year, and Lousiana may be looked upon as substantially, if not entirely, freed from the pest.

In Texas, as to the older infestations in eastern Texas, but a single infested boll containing a single larva of the pink bollworm was found in the large Trinity lay distri.t in 1921. There has been no return of the pest in the Ilearne district since the original (deanup in 1917, and this area may now be released as alsolutely free from the pest. In the western areas of infestation in the Pecos Valley and in the Rio (irande Valley near El Paso, noncotton zones have never been estallished, and the pink lullwom reappeared very scatteringly in 1921, as was to have lieen expected. As ling as the witcome in eastern 'Texas was incertain, neither the planters nor the State anth rities have been willing in these western areas to abandon the growth of cott $n$ in an elfort to eompletely eradicate the pest, but if it can be held to these western are:s, which are separated by wide and uncultivated and fairly desert tracts frum estern cotton cultivation, they will present very little greater risk than occurs from the pink bullworm in Hexico.

The situation in New Mexico in the Rin Grande Valley and in the upper Pecos Valley is similar to that in western Texas.

The mly new onthraks.hy the pink bollworm during 1921 were two very incipient infestatinn in Ellis and (iraysun Connties in northern Texas, originating from shipments of see I frm ('arlshad, N. Mex., made prior to the determination by the department of infostation at the latter point. 'These new outhreaks were immediately' and vienronsly taken held of by the state and Federal authorities and thoroughly

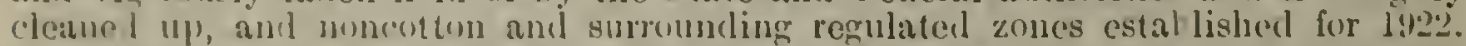
No infestation of the (rop) of 192: near these points has so far developed. They present a sitnation mome serions than was ll earne in 1917, which was completely eradicnted with one year's ('leasurp.

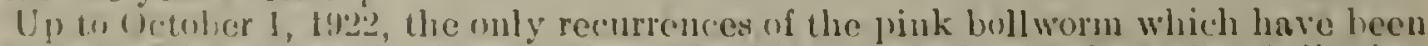

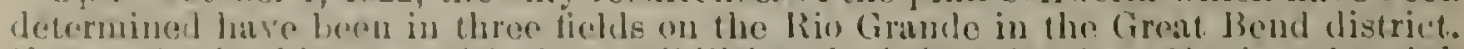

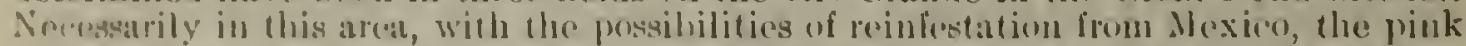

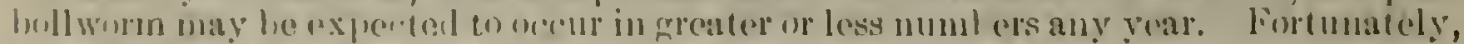
this areat is a iely unimportant cotton district and is isolnted from chther cotton regions. As a hasis for the linowledge of the present status of this post, very intensive inspec- 


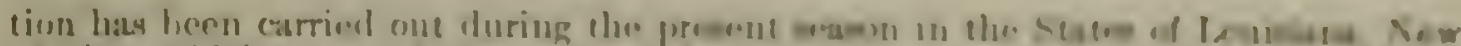

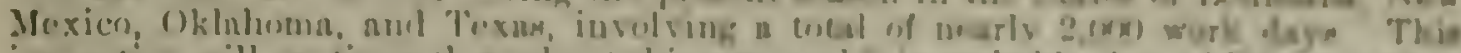

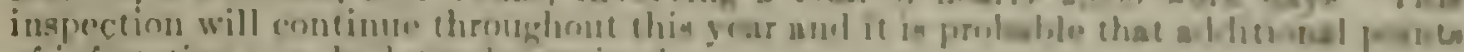
of infestation mov bo later determinesl

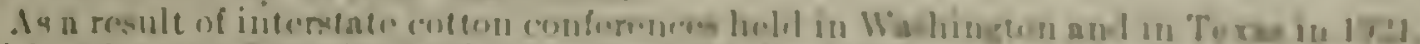

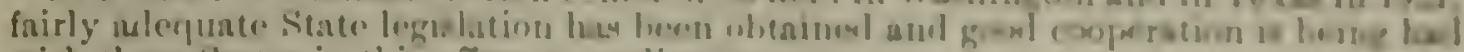

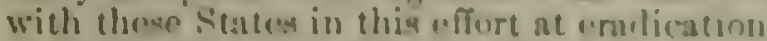

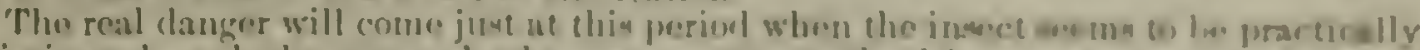

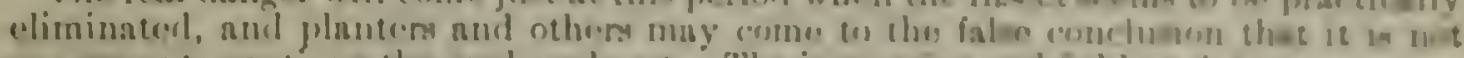

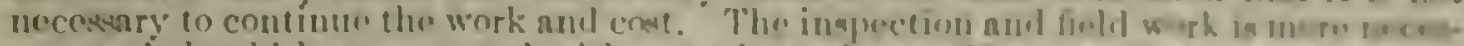

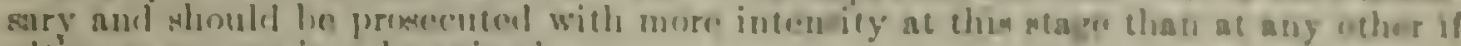
ultimute succesen iq to log gained.

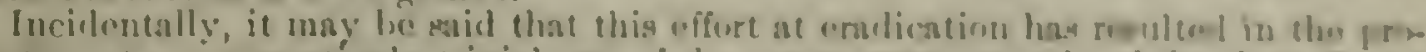
teetinn at a comparatively trivial cont of the colton crop uen only of the throse fanes muceruet, but probahly of the entire South, ant whatover the sutcome of the afiert

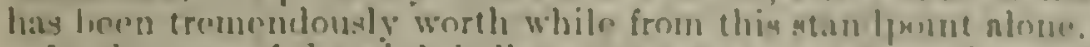

In the casn of the pink hollu orm wo are now mlomptime to do what wa ne fured in the case of the holl wervil in spite of the pointing ont of the ruecenty by the department at that time, nearly 30 years ago.

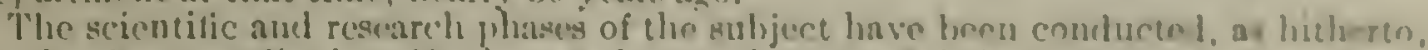

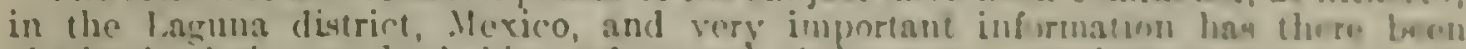
olitained relative to the habits and control of the prot. One important renent entcome of this work is the determination that the yotk bollworm can nut at a rule.

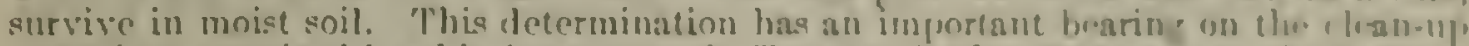
operations practiced by this department in Trxas and others states b. 1.. the detrurtion of all standing and seattered cotton and holls has undouliemlly had intw-lo of itw

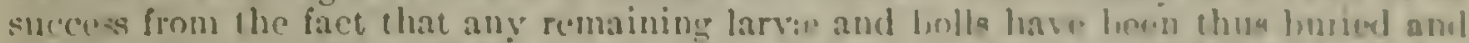
hase perished in the moist voil. It has been shown that with inf aterd holle os hurtwe

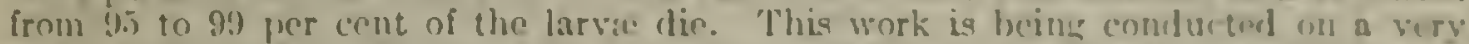
small appropriation $(\$ 5,000)$, but it is very dewirable to consislerably evtend it, and a fund of $\$ 11,000$ was requested for next year $(19231)$. This increaste way un approred hy the Budeet Bureau.

The corn borcr. - The administration of the corn-borer anproprintion has bern assigned to the Bureau of lintomology", but in cooperation with this hoard an in "fuarantine features. 'There has heen no new outhreak of the corn borer this year. In other words, this pest is still limited, so far as is known, sulstantially in the areas determined lait year, these representing for the most part areas of nriginal inferation from liurope in 1909 and 1910 , namely, the New Vingland area, the eastern and western Vew York areas, and the (intario aren, from which latter it has aplarently spread, as determined last year, to the southern and western shores of lake larie. There has leen during the year a local but limited natural spread of the insere in the case of each of these areas.

It would appear from this record that the quarantine and control measures ralu. guarding the movement of products from the known infested area have provented wi 'e jumps of the insect. 'the funds avalable, however, for this work have hern entirely inalequate for general surveys of other states or areas and no positive rlaum is male that the department. now has information as to the existing dictributon of this pest in the I'nited states.

It is very important that the corn-borer work should he continued. Shere in no question ai all as to the importance of this pest of corn. It is a nuw pest aml will lic an adelitional burden on this crop. During the present year it has maintaibul itwolf about in the same status as previously in the known areas of inirstation, there beat certainly no increase of elamage in the western areas of invasion in New Jurk. l'onns.l. vania, (ibio, and Ilichigan, and, in point of fact, in these areas no commerrial dande has ever resulted. 'The extensive damage which the insect frofuenty excasions in

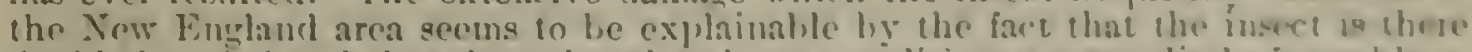

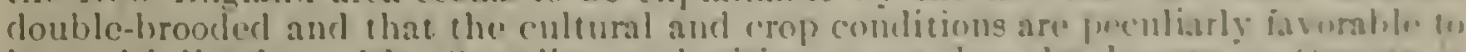

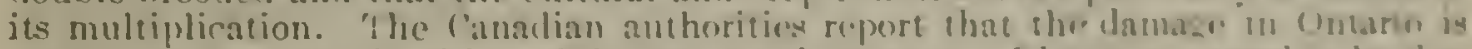

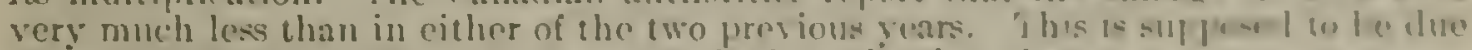
to better cultural ennditions and also to the late flimeing of eorn.

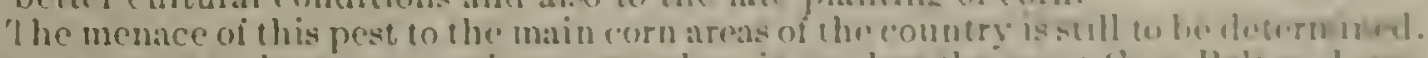

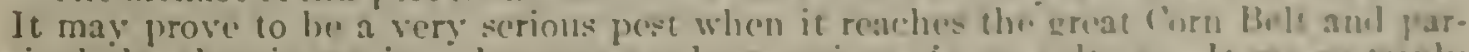
licularly when it gete into the more sonthern regions of corn culeure. It ra nersubly alway have a very serious phase in conuertion with table corn for mmolnate wh-

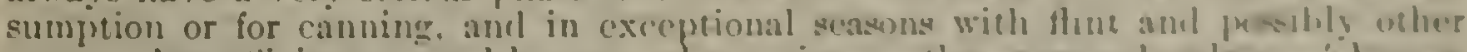

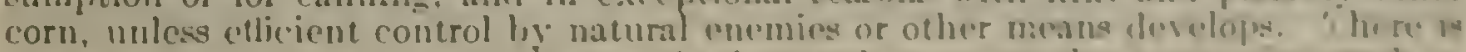
therefore every reason to continue and adequately support the quarantuse worh w prevent spread. 
The effort during the current year to livide the cost of the work between the States concerned and the Federal Goiernment has been only partially successful. Fairly adequate support and cooperation has ben oltainel from approxinately half of the States concerned and varying support mor or less inadequate from the other States. It becomes, therefore, a fuestion to be seriously considered whether in a menace of this kind, which affects the whole comnty, protection should be jeopardized by conditioning the necesary quarantine and inspection work on the support of any . State or States ont of a series: in other words, the neglect or failure of any state may negative both the efforts of other States and of the liederal (iovernment.

The situation is very similar to that in Texas 30 years ago when the boll weevil first appeared, and when it was neither possible to arouse the Texas Legislature nor the farmers to take protective action which at that time would have been a fairly easy and simple proceeding. In other words, it has repeatedly proved difficult to get a State where an insect has not yet reached the stage of causing material damage to become sufficiently interested to cooperate in iunds and work. It would scem clear that the necessary control messures should be instituted in connection with such State until such time as the State has hecome fully aroused to the need ly educational and other means.

The Japanese betle. - The Japanes heetle quarantine fund is also being administered by the Bureau of Entonology, the board cooperating in quarantine features. It seems desirable here to emphasize the belief of the board that this pest is one of the most dangerous insect introductions made in many years, and threatens large future losses, particularly to fruit and forage crops. to the latter as a grub infesting the soil. This beetle seens to he still limited to the original area of infestation, except for the natural spread of some five miles a year. In the center of this area, where the insect has become most abundant. the damage to foliage and fruit is rery alarming. The ease with which the insect may he carried with produce is also a very disfuieting feature: for example. during 1921, out of some 200,000 baskets of sweet corn moving out of the district and subject 10 inspection, upwards of 5.000 beetles were removed. The insect may be carried by almost any of the farm, garden. florist, or nursery ploducts moving out of the district and in addition is a strong flier.

'The yuarantine and rontrol work against a pest of this kind can be justified only by the repression of spread and lessening of damage secured. There is no question ait all but that this pest will in time spread throughout the Tnited States. The prevention of spread is of immediate value and gives a period during which the insect can he studied and its means of control more iully determined, and more particularly affords opportunity for the introduction from its original home of natural enemies. From this point of view the department would seem iully justified in maintaining for the present the fuarantine and other control of this pest which is now in operation.

The gipsy und broun-tail moths.-The quarantine control of the gipsy and hrown-tail moth is in cooperation with the Burean of Entomology of this department. The quarantine on account of these two pests hats been twice slighty modified during the year. The quarantined area has becn extended with respect to the gipsy moth, but with respect to the brown-tail moth it has been possible to reduee very materially the area quarantined on account of this insect.

The new areas determined as infested in New Jersey, New Jork, and Pennsylrania in 1920-21 remain as iormerly under the control of State quarantines, no federal action having been taken, inasunch as these State quarantines are being administered in active cooperation with the oflicers of the l3urean of Entomology of this department. 'Tle scattered points of invasion in Ponnsylvania, Now York, and New Jersey, which resulted from the big central roleny at someville, N. J., have been apparently eradiratcol. The Somerville colony his boensubjected to thorough clean-up and cuntrol work now for two seations, and the outlenk is gool for the eradication of this pest in Now Jersey.

'Two new points of infestation were defernined during the year on long Island and thre chatu-up of these areas is actively under way in cooperation with the State oflicials.

Jnspertion of products likely 10 disseminate the gipsy moth has been continued in New England and in New .ersey in cooperation with ihe State authoritios and shipments have berol wafeguarded hy careful examinations.

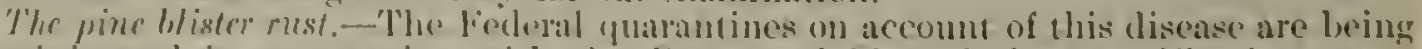
alminimtred in conpreration with the liurean of Plant Industry. The impottant. development in the white pine bliser mas situation was the discovery in the fall of

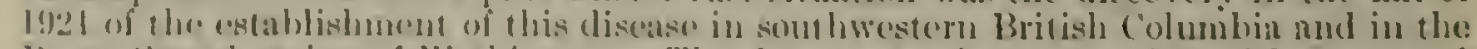
l'uget somed region of Washington. The department in cooperation wish state and

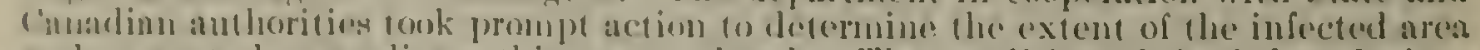

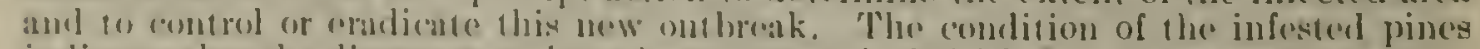

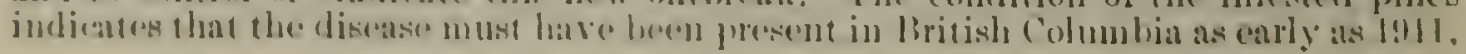




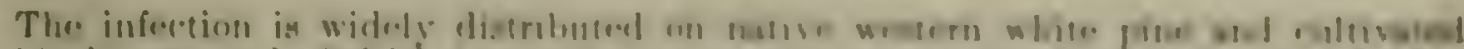

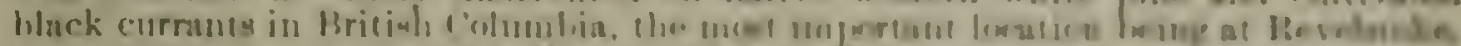

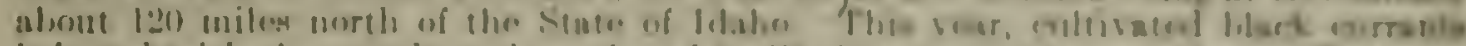

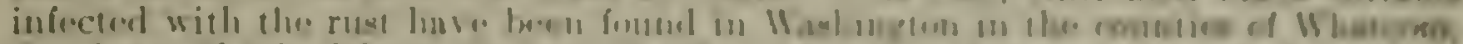

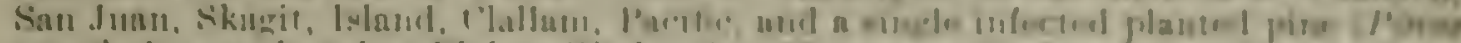

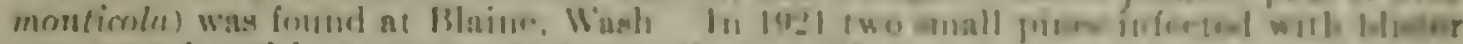
rust were foumd in a Mursury ut Mound Veruen, Wa=h

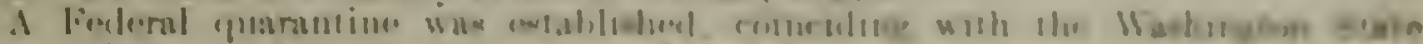

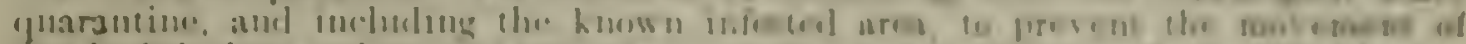

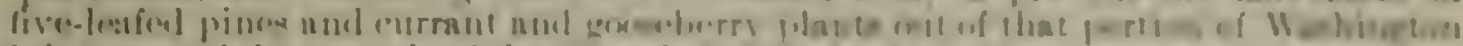

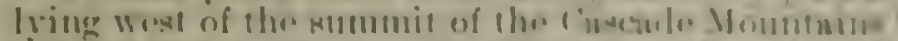

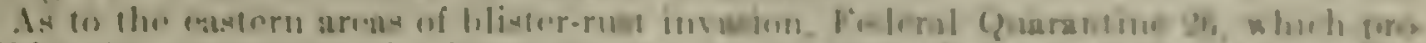

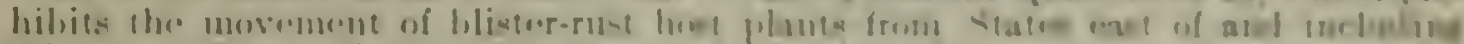
Minmenta, I

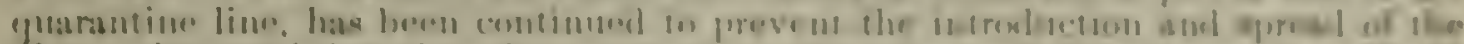

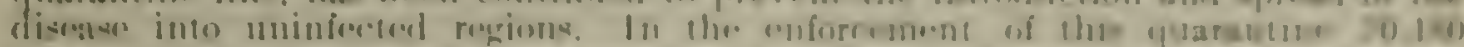

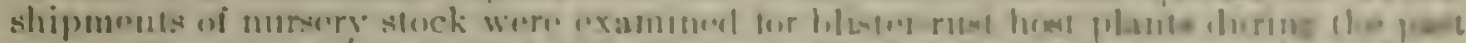

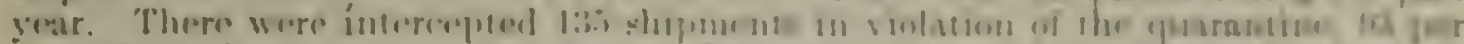

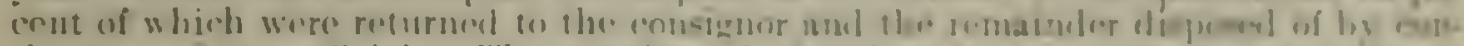

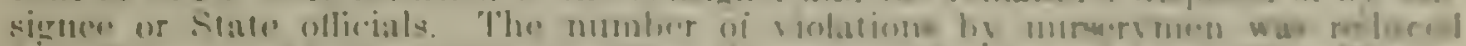

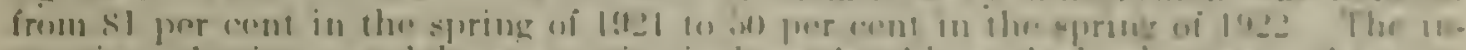

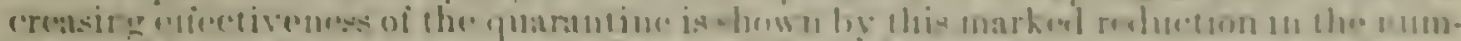

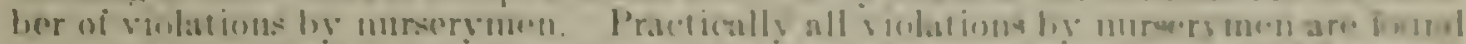

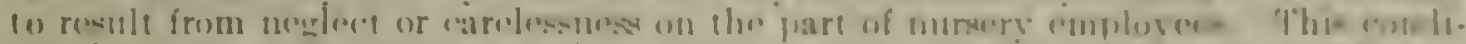

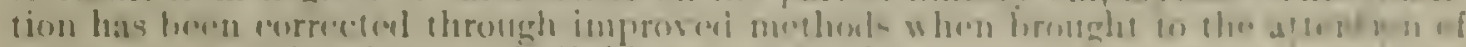

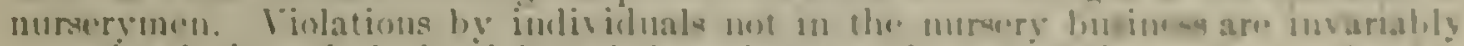

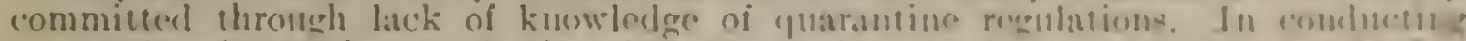

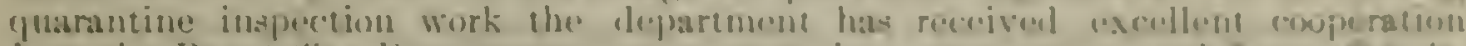

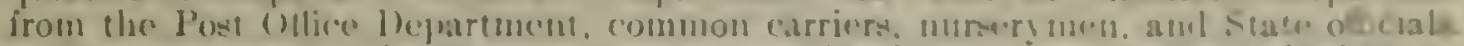

The poluto uart.-The liuropean potato wart is still reatricted in the linited s tatem

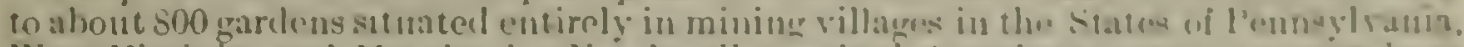

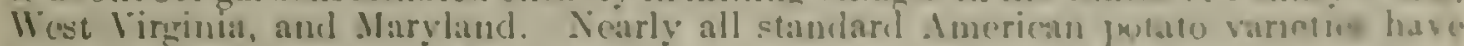

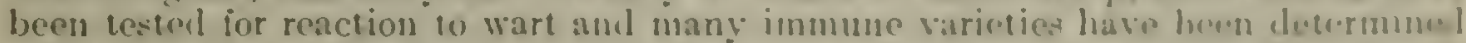
so that this disease does not now have the menace fo this country which it oriemally had. In the invaled districts these immune varieties are now for the mer purt being grown under regulations enforeed by the states concerumb and the denter from these distriets is thus being very ereatily minimized.

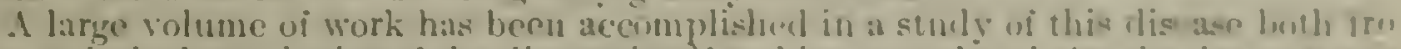
the technical standpoint of the disease iteelf and its cuntrol and alen the deu rmmatum of the reaction of varieties of potatoses in it as to immunity. It is propkes d, alf r the

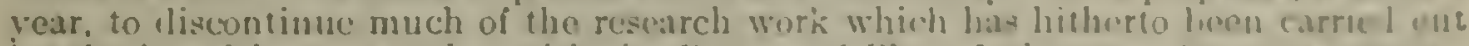

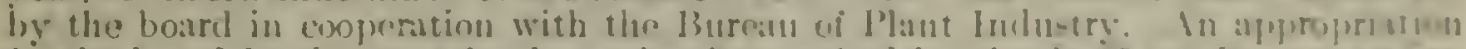

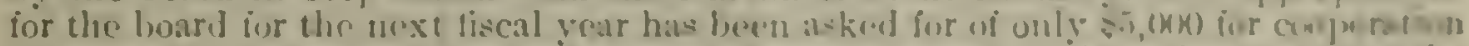

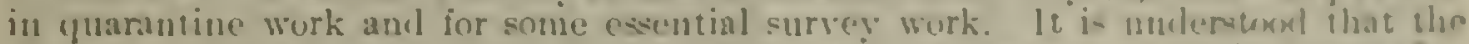
Bureau of Plant Industry will continue such tedinical research work in monecrion with the disease as may be necessary.

The hoard loes not ieel. howeser, that the time has cumc "hen it is cither uners.

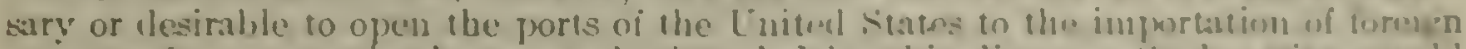
potatoes from countries known to be invaled by this disedse. Such action wull probably result in the extension of this discase to protetically all the jutato resten in

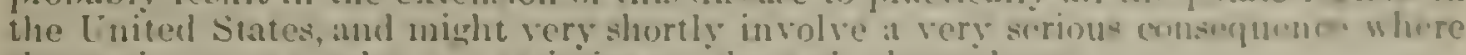
the noniminume rural groul) varicties are the main dependence.

IOATE: SCALU: I:HADRATIUN.

There are approximately 20,000 imported date jolluns mow plantol in orcharls in Caliornia, Irizona, and Texas. These special date dietrick include (isuchella and

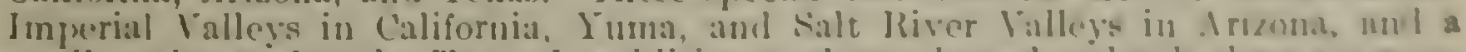

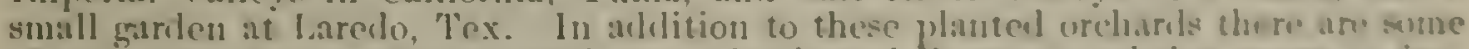

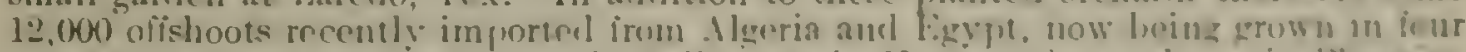
quarantine nurseries-iwo in Inclio. Calif., one in Yuma. Irix., and nne in fhemir.

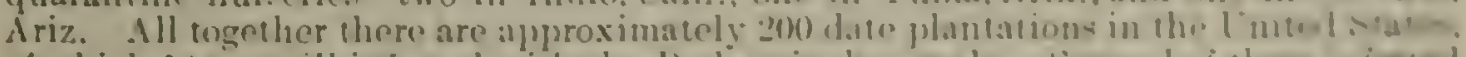

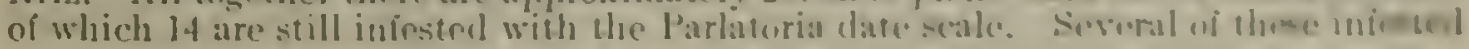

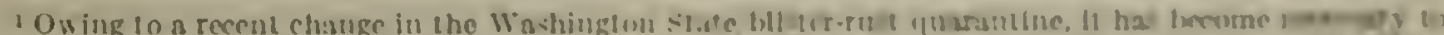

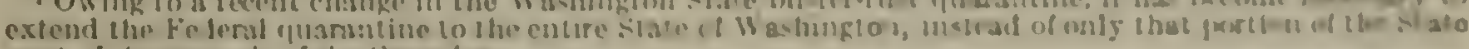
west of the sumunit of thr ('asiondes. 
orchards have been almost completely cleaned up during the year, but others are still seriously infested, and among them are hali-a-dozen orchards which contain large-sized palms which require repeated treatments over a considerable period to thoroughly eradicate the scale.

The 12,000 recently imported ofishoots are all under close observation, and many of them are likely to develop scale infestation later on, even if they are now apparently clean, and these plantings must, therefore, be kept under observation for a considerable period of years before the plants can be taken out of quarantine and distributed.

More than 100 of the date plantations in the United States have been completely: cleaned up within the past eight years by the methods now being followed, and it is believed that the remaining infested groves can be similarly cleaned up within the next few years.

The Parlatoria scale is so destructive to the date palm that the experts of the Burean of Plant Industry and all others who have studied the matter agree that dates can not he grown in this country profitably unless the Parlatoria scale is completely eradicated. The whole fruture of this pronising industry', which is so admirably adapted to the irrigated valleys of the Southwest, is, therefore, tied up with the success of the Parlatoria eradication work. Several million dollars have already been invested in date culture and the industry is a rapidly growing one.

During the past year a very eflicient corps of date scale inspectors has been trained. and rapil progress is being made in the work of eradication of the scale. The State and county oflicers of California and Arizona have given most thoroughgoing cooperation in this campaign of eradication.

\section{PORT INSPECTION SERVICE.}

Of particular importance at this time is the strengthening of the port of entry inspection service for the enforcement of the various foreign quarantines. This service is the first line of defense and represents a very important and rapidly growing activity. The enforcement of foreign quarantines must primarily be carried out at the ports of entry of the United States. It involves the inspection, in cooperation with customs officers, of vessels arriving from foreign countries for the purpose of excluding plant pests with plant material brought as cargo of such vessels or by passengers or crews. In the case of Mexico, it involves the control of freight and other traffic between that Republic and the United States, and control to a much less extent on the Canadian border.

Two States, California and Florida, on account of their very important fruit interests, are giving most valuahle conperation aud aid in such port inspection work. 'The State of California is spending in this work approximately $\$ 100,000$ a year to protect her great fruit inclustry, and by collaboration this department gets the advantage of this work at trifling cost. Florida is in a similar status. No other states are taking this same sort of action and the protection at the other ports of the lnited States is practically limited to work of the Federal Horticultural Board of this department.

The importance of this work may be illustrated ly the following typical instance: The examination of the personal baggage of a passenger landing at Baltimore from Brazil clisclosed in one of his boxes some fifty-odd packages of Bra\%ilian cotton seed all infested with living pink hollworms. The owner proposed to take the materinl to the cotton section of Mississippi for planting. Had there been no inspector at Baltimore, this entry would probably have resilted in the establishment in that State and in the snith of the worst known enemy of cotton, and would possibly have mullifecl all the eftort which has heren going on now for several yeass at great cost (1) control and eradicate this post in its present rather limited footholet in lonisiana, 'fexas, and New Mexico). This is only one illustration of hundrods during the vear of the interception of pests theatening many of the major fruit and liedd crops of thr Nation. These intereptions hat ve inchuded such important pests as the corn horer, ritus canker, pink bollworm, rarjous brujt llies, including the Mediterranesu, potato wervils, and suany of hers of hoth known and unknown poszibilities. $\Lambda$ total of $3: 97$ dilierent kinds of insect pests late been thus intercepted and identi-

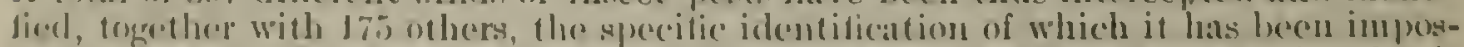
sible to mahe. 'This servior is now much mudermatnned and long hours are involved, und at importan ports only partial inspection can now be made, and other ports aro without any proteretion of this sort. Whitherer.

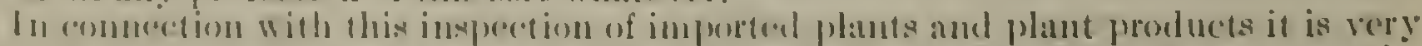

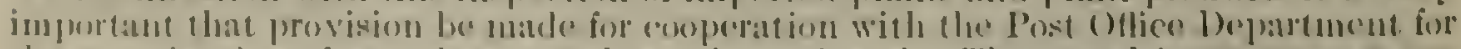

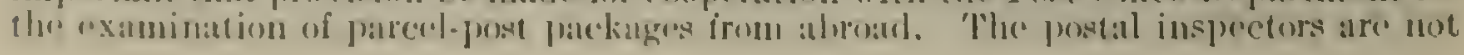




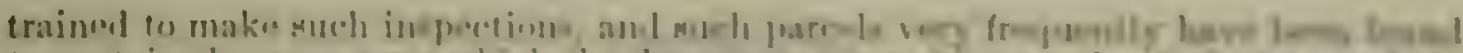

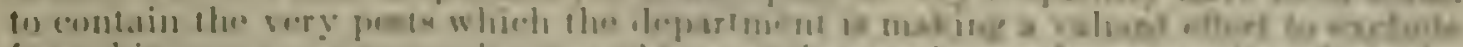

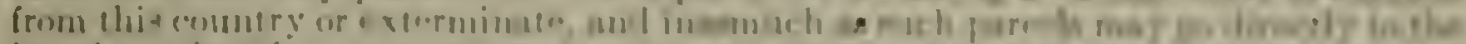

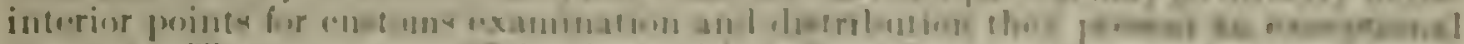

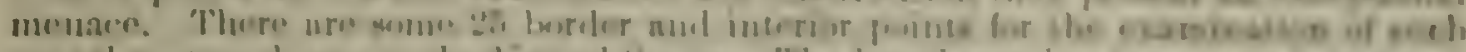

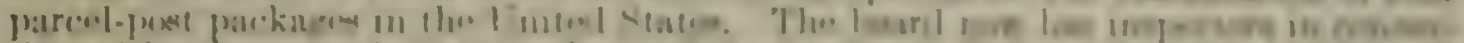

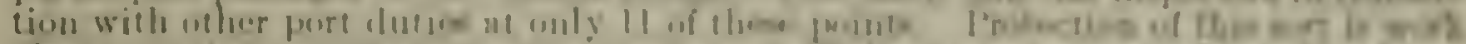

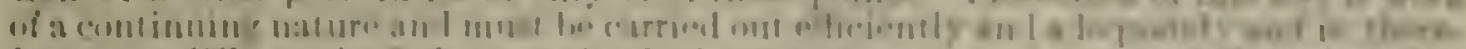

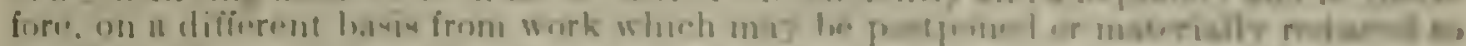

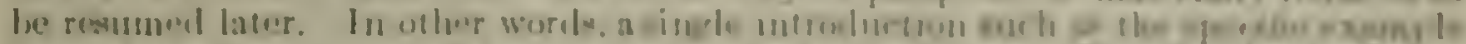

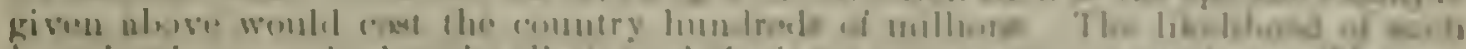

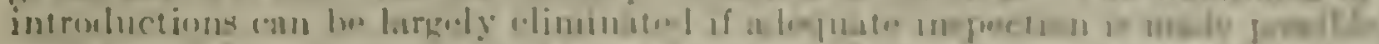

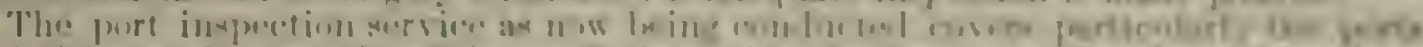

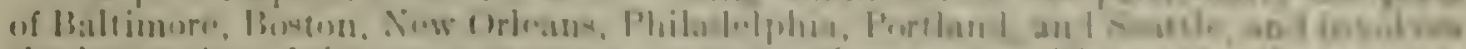

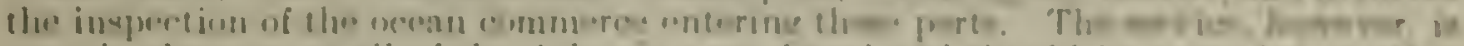

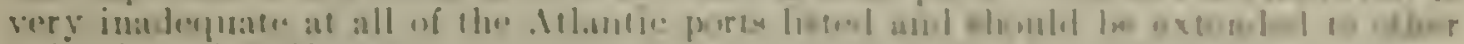
Allintire and rinlf porpe

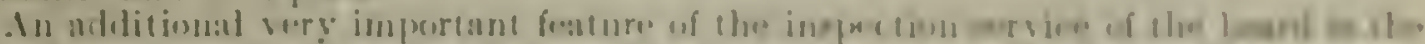

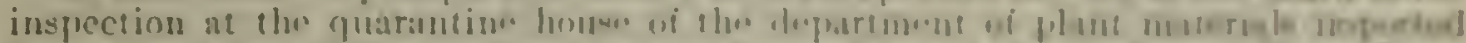

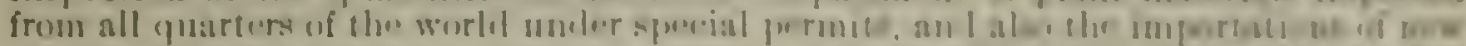

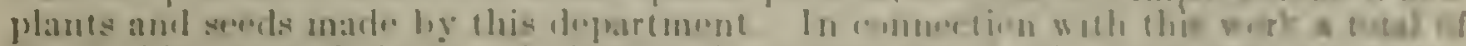

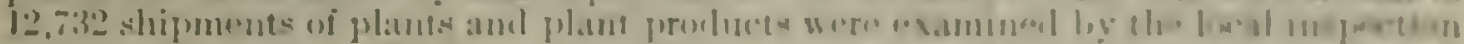

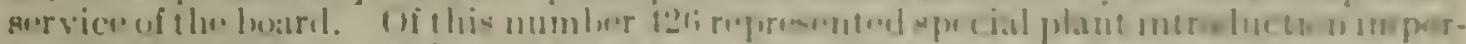

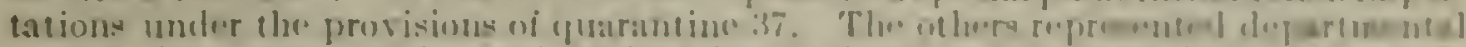

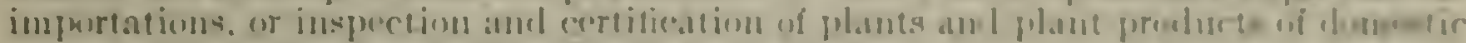
origin arriving in or las ving the Jristriet of tolumbia.

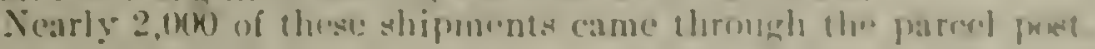

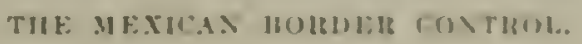

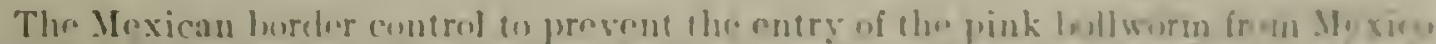

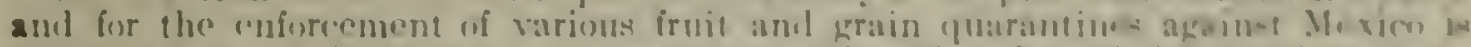

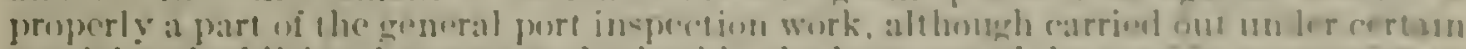

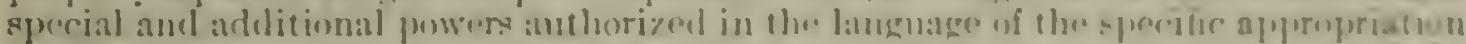

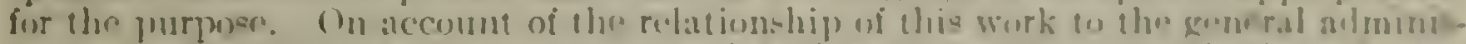

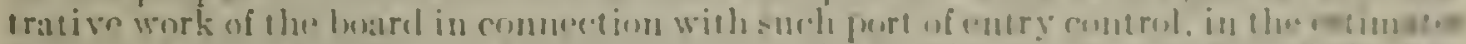

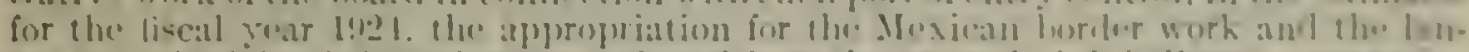

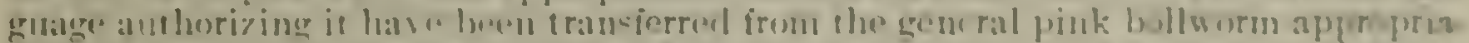

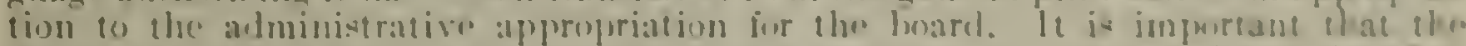

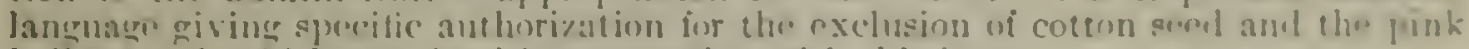

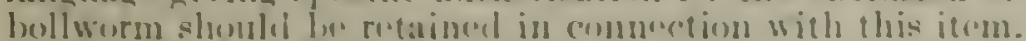

The presention of the movement of cotton and cotfon semd irom Hexien into slle

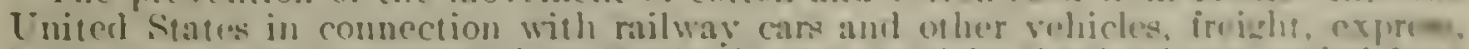
bagnge, and other materiale from Mexico has involved for the liseal yar mulel June

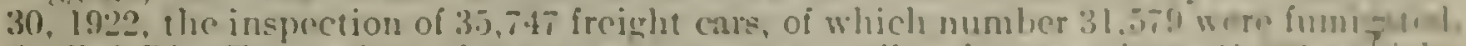

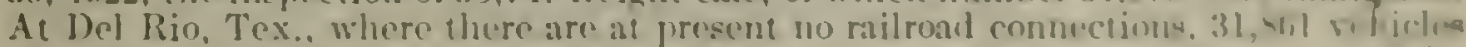
of various descriptions were examiued. lig of which were fumigated on acenum of the presence of cotton seed at the time of inspection.

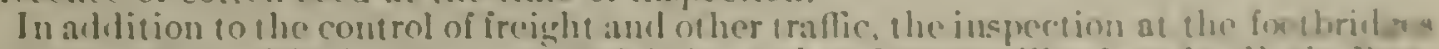
in conperation with the customs oflicials located at Brownsille. Iarewe, liaple l'as.

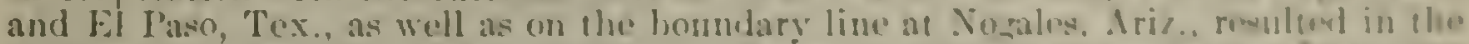
interception of a total of 5,511 pieces of comraband natorial during the last firal your

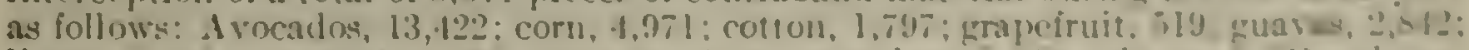

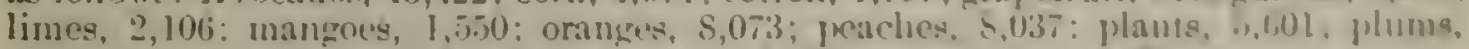

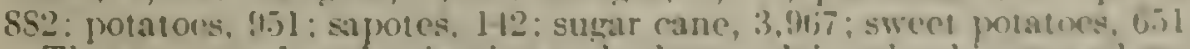

The amount of car funigation and other work involved increased wery crondy during

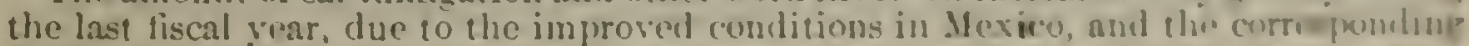

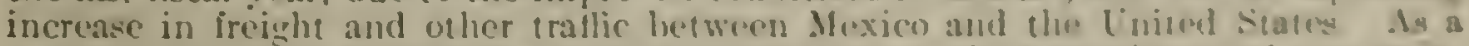
result of this, it hecame necessary to call upon congress for a enpllememal appropination, and s, 0,000 was so appropriated in connection with the urgent deferemeg lill

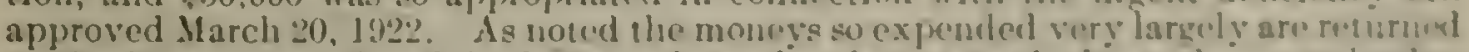
to the Treasury of the inited states from the charges mado for such car and ofher fumigation-cliarges based on the cont of chemicale and labor involved. Fumparton fecg amounting $10 \$ 126,350.50$ were collected and turnol into the Trosury. 
Mr. Andersox. We will take up your statutory roll on page 304. It appears to be the same as before, except that you drop one clerk of class 1 , and one messenger or laborer at $\$ 720$.

Doctor MARLATT. 'That effort to reduce the statutory roll, I think, has been explained.

Mr. Axderson. 'This was in accordance with the general policy?

Doctor MamLatT. Yes, sir; it was in accordance with the general policy.

\section{FOR PLANT QUARANTINE WORK.}

Mr. Axperson. We will take up the item on page 305.

Doctor MarlatT. The portion in italies on page 305 is transferred from the pink bollworm appropriation, which comes later on under the miscellaneous items.

Mr. Axpersox. It brings the language of the appropriation up into this general item?

Mr. Marlatt. Yes, sir. It is very important that this language should be preserved substantially as it was, because it is under this language that we have authority to control the border situation between Mexico and the United States. We have not that authority anywhere else. We do not have it, for example, under the plant quarantine act.

Mr. Axnerson. There is no change in the language. It is the same as it was in the other paragraph.

Doctor MAnLATT. Yes, sir. It should be changed rery slightly in the way of punctuation, as I have indicated here in my copy. "The item includes a series of statements separated by semicolons, and this addition should be separated in similar mamer by a semicolon. I have inserted the words "provided that" here [indicating] to make the statement a little more logical. If there is objection to these verbal changes you can accomplish the same correction by simply putting in at dash instead of the semicolon following the word "thereof." "Then there would be no change in the language at all

Mr. Axunesox. I do not think there will be any difficulty about that.

There appears to be an increase of $\$ 70,000$, as shown on page 57 of the notes.

Doctur Mandatr. This increase is explained in part in the notes submitted with the estimates. The increase of $\$ 70,000$ includes really two items, one an increase of $\$ 50,000$, for the Mexicun border control explained in note (b), page 59 of the "explanatory notes and statements," and the other $\$ 20,000$, explained under note (a), for the extension of the port-inspection service of the board.

JNCIRASE FOIR PORT INGIECTION SIEITIL.

The arrument for the port inspoction service, I think you know. This service is a very essential part of the administration and enforcenent of some 39 quarantines. The principal item of expense is in connection with the conforcement of foreign (quarnutines at the ports of entry in tho United states. Wo have to maintan at these ports inspectors adequate to curry out the inspection necessury 
under the quarantines, and particularly in relution to produce that sre imported in quantitios. For instines, we inspect and heinfere all importod cotton, and that hus amomed to nenrly 600,000 bales in one year. The arerage is nbent 300,000 bules a ronr. 1t is one of the large items of import of the linited senters. Ill of ihat cotsen must be disinfected moler our supervision. Simblar inspectum upplies to all other foreign plant prosluets that are under restrotion. It meludes nuscry stock, "grent mung fruils. some grains, corm, and cereals from tho (ricent, all of which requires inspection and oms of it disinfection. Wo have had to supplement the funds for thut purpose

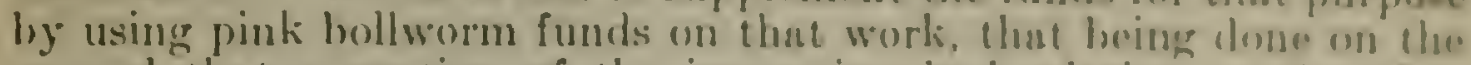
ground that a portion of the inspection had relation to the pink follworm.

Mr. Axnerson. It secms to me that the combining of thone l appropriations is a rather doubtful proposition. I suppose there is a certain nmount of relntion between the border control work und the genernl inspection of importntions of nursery stock. but I think it would be better policy to mantain this whole border businesi ns a separate item.

Doctor MandatT. That is a matter about which I do mot foel very strongly, Mr Chairman, but the argument for the changer is a perfectly good and logieal one. 'The horder control work botween the United States and Ifexico relntes not only to the pink hollworm hut (o) a number of other quarantines. It is paid for out of the pink bollworm funds, but the men are there, and enforce locally other yuarantines, such as quarantines against corn. Mexicnn fruits, cke. Tliese men, who are being paid out of the pink bollworm funds, ure, as a matter of fact, enforcing along the border half a do\%en other quurantines. A considernble percentage of their work has relation (1) the general port of entry enforcement, and the rest is closely related, and that makes it entirely logical and proper to transfer this whole Mexican border work to the administrative work of the hoard. It is work in port that will necessarily have to go on even after the pink bollworm work has stopped.

Doctor $B_{A}$ LL. If we get rid of the pink bollworm, this work of inspection would have to go on just the same.

Mr. ANinersos. I understund that, but it would be upon an entirely different basis.

Doctor BALL. Do you mean the work on the border?

Mr. Arderson. Yes.

Doctor BaLL. It would be very much the same.

Mr. Axbersox. Including all this fumigntion of railrond cas, and that sort of thing?

Doctor MARLATT. It would reduce the expense very much.

Mr. Avoersos. But that is distinct from the pink bollworm proposition.

Doetor BaLL. Suppose we should eralieate the pink bollworm, and it looks as if we would, we would still have to maintain the horder inspection, including the fumigntion of cars and eversthing of that kind. What we would like to do would be to have our booklecping show the amount of money spent in the erndieation of the pink bollworm, but after that work is finished, we must continue forever at the work of keeping pests out of the country.

$22025-22-31$ 
Doctor Mantatt. This work of port inspection inrolres all the United States, but the cost as to California and Florida is borne by those States. California is spending about $\$ 100,000$ in port inspection work, and the Federal Government gets full advantage of it by using the (alifornia men. Florida is spending about one-half as much as that in protecting her various ports. and again we get full advantage of her work in the same way. These expenditures indicate the importance which these States attach to that sort of protection. 'They do it on account of their great fruit interests. which are, perhaps, the greatest in the world-certainly, those of California. Other States have not the same reasons for port inspeetion in an immediate menace to fruit or nursery interests. or at least do not realize it in the same way. The result is that few of the other States are doing much, if anything, in that sort of work, and the Federal Govermment is earrying out most of the port inspection work that is heing done outside of California and Florida. We are not covering the ground hy any means. We corer certain Pacific ports north of California, New Orleans, and in connection with the pink bollworm, some of the Gulf ports of Texas and the Mexican border ports. We cover also the principal northern ports, such as Boston, New York, Philadelphia, and J3altimore. We have one man at Philadelphia, and one at Baltimore. The work is undermanned, and the men are working overtime, frequently 12 or more hours per day. They are enthusiastic young fellows and they are able to to do it. It is hard work for them. and we ought to have more men. They realize the responsibility of their jobs and are trying to keep plant pests out of the country.

As an illustration of the value of this work I want to tell you of an inspection incident that happened last spring. A gentleman returning from Brazil, through the port of Baltimore, brought with his personal baggage among other things a'small box. Fortunately, we had a man at Baltimore, and the box was opened and found to contain a lot of small plants and wood specimens and some 59 packages of seed cotton and cotton seed. Prnetically every one of those packages contained living pink bollworm larve. This man's purpose was to take these packages of cotton seed to his home in Mississippi for distribution and planting. The carrying out of his purpose-it would have been carried out if it hud not been for the department's inspector-would have eaused a vast loss to the cotton erop of the South through the introduction of the pink bollworm. It would probably have amounted to hundreds of millions of dollars, und when I say hundreds of millions of dollars I menn two or three hundred million dollars amually. That would have been the cost to the cotton crop of the South. We have many other equally typical cases. We are intercepting that sort of thing all the time. At ports like New Orlenus, where many interceptions are made, and where, on account of the favorable climnte the danger of establishment of new pests is great, the inspectors go through the passengers' baggage and examine it along with the examination of the customs service.

Examination is also mate of the storeroom on the ship, where the ship's stores ure kept, and of the personal affects of tho crew. Vurious fruts and regetables are often found, and in them fruit flies and other pests. Such supplies and stores must be promptly destroyed, and sonnetimes it is necessury to disinfect the ships. 'This work does not. 


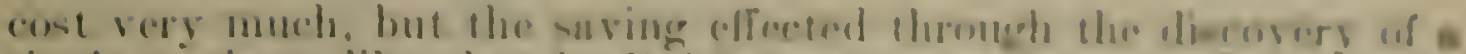

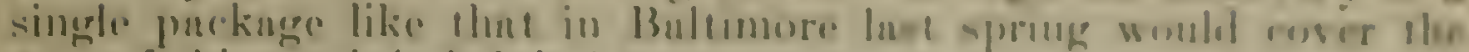
cost of this work indefinituly.

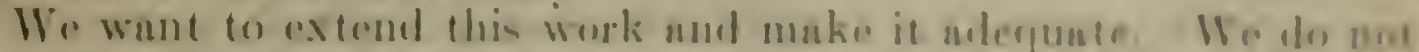

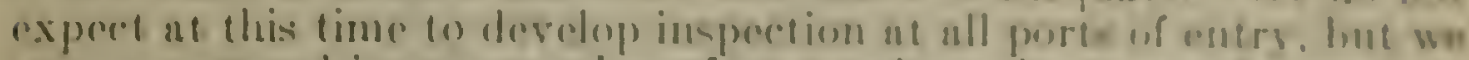

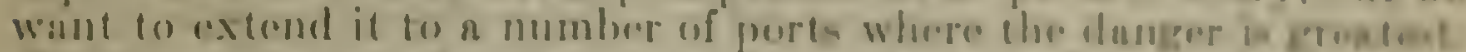

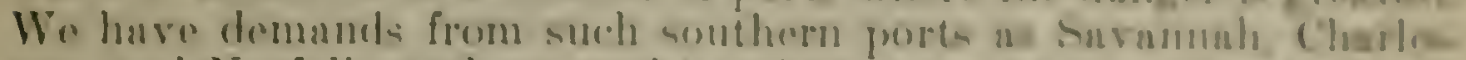
ton, and Norfolk, and we ought to have mon at ull of theme plate.

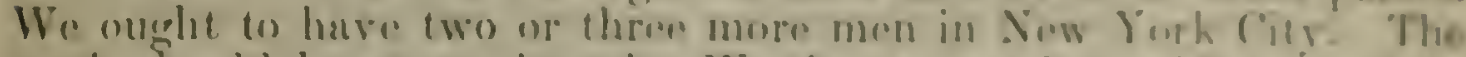

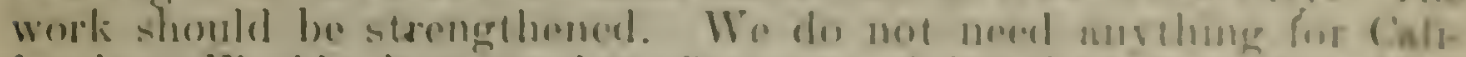

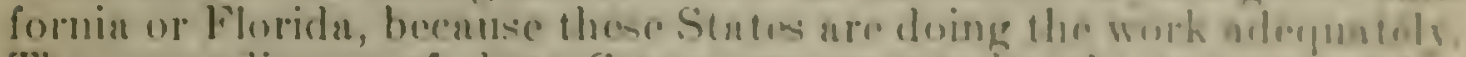
The expenditures of thesse States are overe twice the armonst of the

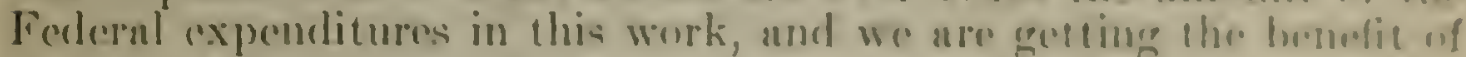
their inspretion.

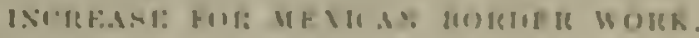

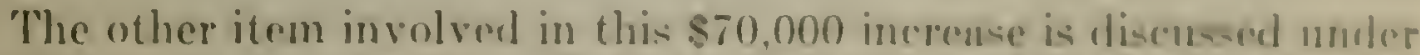
explanation (b), page i9. Thant has relation to the Mexionn lubler work. The cost of this work, as has hen explnined in prosious years, is dependent upon the nmount of trullie thint goes through the various ports. The very much improved situation in Mexion in the last year or 1 is montlis has greatly incrensed that traflice, which means that so many more cars, so much more freicht, and so murch more passengers' buggage rrossing the horder must he examined and safeguarded. 'The cost of this work, so fur as any neressary disinfection is concerned of freight cars, freight, and bignguge, is covered by charges made for the work. The price is fixed to eover, as alusely as we can estimate it, the cost of the lahor involved in eperatirig the fumigating plants and the rost of chemicals. The hig cost is for chemicals, sulphuric acid and cranide. which we buy in carlued lots. That cost, however, is covered back into the 'Treasury, so thut it does not represent an actual loss to the Government.

Mr. Axdersor. Have you any figures as to the receripti from this fumigation and inspection work last year or so far this year?

\section{RECEIPTS FIOM 1NSPFCTION \&EIRICE.}

Doctor MantatT. I think they ure given in the statement which I submitted. They amounted io $\$ 126,000$ for lnst year. We hul to get, as you recall, an emereney incrense of $\$ 50.000$ to carry the work through last year, and this year agnin wo will have to usk for an emergency incrense of $\$ 50,000$, ind to avoid that next yenr, 192 t, the increase is now put into this appropriation.

Mr. Axdersox. And that mukes the approprintion for this particular work the same as the amount expended this your?

Doctor Manutat. Yes; the same us the amount expended last yenr and the nmount that will be expended this vear. I have drafted an item for an emergency increase to cover ihe balance of this year. 'The work now is a $\$ 50.000$ higgel job than it was iwo years ago.

The thing I want to emplansize most in conncetion with the committee's hearing to-day is the need for strengthening the port of entry inspection for the enforcement of these many foreign plant quarnatines. 
Mr. Buchaxax. Have you any specific insects or injurious animals for which your inspectors are looling and hare you any specific ones by name?

Doctor Marlatt. Yes. Each one of these quarantines relates to a specific pest, that is, most of them relate to one pest.

Mr. Bucinanax. According to what country they come from?

Doctor Marlate. According to the country and the product. For instance, we have grain quarantines against pests that are preralent in trans-Pacific countries, and we control the entry of all grain from trans-Pacific countries on account of rarious grain diseases.

Mr. Buchavax. What do you watch for at the eastern ports?

Docior Manlatt. At the eastern ports we control the entry of cotton on account of this pink bollworm. We control the entry of all the fruit which comes to us-that is, we regulate it and see that proper safeguards are taken in connection with its entry-all of the fruit that comes to us from the countries and islands south of us, that is, from Cuba, the Isle of Pines, etc., and from all the Central American countries.

Mr. Bechasax. In other words, they have some injurious pests in comnecion with fruit in those countries which we do not hare?

Doctor MarLatT. There are two or three quarantines involved in that. Some of them relate to certain fruit fiies which occur in the West Indies, Central America, and in Mexico; others relate to other insects-for example, one to what is known as the black fly, which is prevalent in Cuba and the Central American countries and which would be a very serious pest to all the citrus cultures of the south and, perhaps, to the Pacific coast later on. 'Ihese quarantines, therefore, have for their object the prerention of the entry of some known specific pest or pests. Incidentally our inspectors ure on the lookout all the time for things that are not known and not expected.

Several of the worst pests which have come into this country are pests that we did not know anything about beforehand; they come on us as a surprise, but if our men are there they are competent to detect many such pests. For example, the chestnut bark disease, the citrus canker and corn borer were surprises of that kind, but if we had had our existing quarantines in force 15 years ago instead of 10 years ago we might have excluded some six first-class pests, such as the citrus canker, potato wart, oriental fruit worm, Japanese beetle, European corn borer and the camphor scale. 'This last is a new and very dangerous scale for the South; not only for camphor und many other plants but for citrus orchards. It got in during the period during which we were trying to get plant quarantine legislntion. It took four yenrs of effort to get this legislntion, and during that period the six very important pests enumerated got in when we had no control and no means of lieeping them out.

FOL LXTLIRINATION OF THE POTATO WART.

Mr. Avplasor. We will next take up the item on page 307 , to enable the Secretary of Agriculture to meet the emergency caused by the establishment of the potato wart in enstern Pennsylvanin, and to provide means for the extermination of this disease in Pennsylrania or elsewhere. 
Doctor Marustr. The potates wart is oun of the prese that gent in during that poriod just referred to: as a matler of fact, it carne in the year hefore the lecrishation was pasted by Congrow. That wan $n$

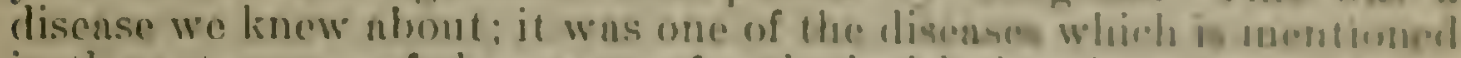
in the net ns one of the rensons for the legielneton, but the autheraty came a little too late. The plant quaruntine net became haw in August, 1920), but this pest got in during the precoredtune wituter through a large shipment of potatoes from Germung, whoh were distributed to mining districts in Pennsplvania. Whas Virgina, and Mnryland. This disense has been under insestigation by the hourd since 1920) under specifie approprintions. So far no the work of the boned is concerned, it is now possible to relinguish the apporopriutun except for a rery minor item. This is done for the rensen that we have completed what we believe is the necosenry investigntional und control work which should be done by the depurtment int this ime. The work that should be enrred forward now is such work that the States can take care of, and they have expressed their willinguent to do that. If they did not do it we would have to kesp the work gening. but Pennsylvania has her own internal guarantine which is giving as much protection as we could give with a similar fordernl cyun runtiuse. Maryand has promised to take similar action. 'The experimentul work under this appropriation has been earried to such un extent that it can be rery much reduced, but it is necessary, as staterl in the explanation which you have before you, to continue certain phan of the work, and for this purpose s.r, (1)00 is asked.

Mr. Bucmaxax. Are you destroying the wat and geteng rid of it?

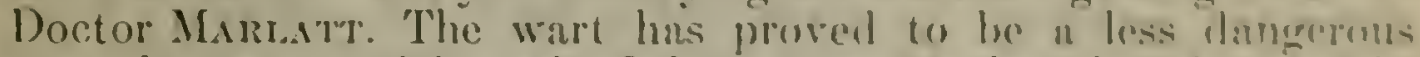
disense than was anticipated. I do not want to be misumelersoul in that. It is just as dungerous as we anticipated for a coltuin group of potatoes-i. e., for what is known as the rurnl grenup of potatore. which are grown largely in the central portion of the countrs: lhat is, in New York, Ohio, and through that districi. It is very destruetive to this rural group of potatoes and that includes miny of mur best potatoes, grown over considerable areas. Most of the bariotien of potatoes in this rountry, howerer, are immune to the di-cise: that is, other than the rural group, and particularly the potateses grown in the northem sections, in Mnine, northern Sew York. Michigan, Minnesota, cte., and the potatoes grown in the south. During the course of these years of investigntion pruetically nll the potatoes grown in this comtry have been tested and muny important rarietics-I should say 70 or more-are substantiully ob nhiolutely immune to the disease. That has rery much simplified the contrat of the disease, and it has also relieved a great deal of fenr which th. disease gare potato growers when it first came to this comutry.

What the States are doing now in all these distriets-nnd they ure all rather limited districts and not commercial potato-growing districts - is to require the householders to grow immune rarieties of potatoes. The experts do not believe that it is possible to entirely eradicate the disense by that means, but at least it proctically climinates the risk of the carriage or spreal of the discase.

Mr. Andersox. This disense is carried in the soil!

Doctor Mardatt. 'The disense remains for sereral years in the soil, and it affects also other plants than potatoes. These other plants are affected much less than potatoes, nud this disense mon not he de- 
tected in them, and yet the disease may be there, just as doctors tell us that we have all the germs in us that most people die of, but we do not die-all at once, at least.

It is possible that this disense may attack plants and not be recognized, but it is known that if susceptible potatoes are planted in an invaded district within eight years the disease will probably appear again; in other words, when you onee get it into a district it is very doubtful whether you will ever gret rid of it. We do not feel that the time has yet come-and we have not done it - to open our ports to foreign potatoes from countries where the disease exists, because that would mean that the whole country might be flooded with potatoes that might carry the disease. We are maintaining our potato quarantine against foreign countries where the disease is known to occur, in spite of the fact that we know the disease exists in limited districts in this country. These districts are, however, not trade districts from which potatoes are exported and they are of little danger to the country as a whole-that is, immediate danger. Furthermore, the movement of potatoes from these districts is prohibited and controlled under State quarantines.

Doctor BALI. That is exactly the same policy which England and France are carrying out at the present time; they have such disease districts and they are holding the disease there.

\section{FOR ERADICATION OF THE PINK BOLLWORM OF COTTON.}

Mr. Axderson. We will next take up the item on page 331 , to enable the Secretary of Agriculture to meet the emergency caused by the existence of the pink bollworm of cotton in Mexico, etc. Doctor Marlatt, I think, perhaps you had better tell us, somewhat in detail, what the status of this pink bollworm is, as we want to keep track of this fellow.

Doctor MARLATT. I have covered that subject in the statement I have submitted, but I will be glad to abbreviate it and repeat it. I have a very hopeful report to make on that pest. I am sorry I can not say, as I did of the potato wart, that we have found any cotton that is immune to it or any district in America that is going to be immune from that pest. In other words, the menace of this pest to the American cotton crop is the same that it has been before, and it is therefore worth our while to continue every effort humanly possible to keep it out and to complete the eradication which now seems to be in a very favorable status.

Iast year, and I mean by that the crop year of 1921 , but a single piuk hollworm in a single boll was found in the large Trinity Bay district, where the insect first got its big foothold. A considernble portion of that district was maintained as a noneotton zone in 1921, but a considernble portion of it was planted, and in the planted areaatl of which was under thorough inspection - but a single infested boll was found containing a single pink bollworm. 'That was mighty encouraging, and that result has come about from the work the department has done in that district since 1918 , aided, in lare measure, by very favorable climatic conditions, which have helped out the fight. Even when the State failed to come forward, as it did for a year, with full cooperation, it so happened that that year was a year of floods throughout that district and cotton failed to grow; it was drowned out 
and destrored, so that there was rery litele neroner in coteon in the district. Thant was a lucky happoning and junt at the time when it

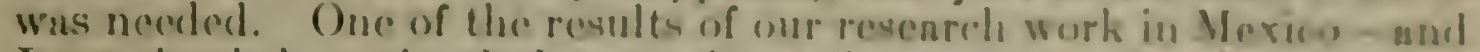

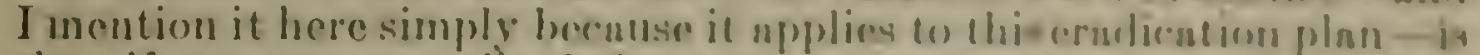
that if you remose all of the cothon phanes and all of the surfues materini you con get and burn it, which is the process wo follow. the only remining poink bollworms in the lields will be thesen that wre in thosoil.

They are pressed in with some boll that falls down and gers crowilad

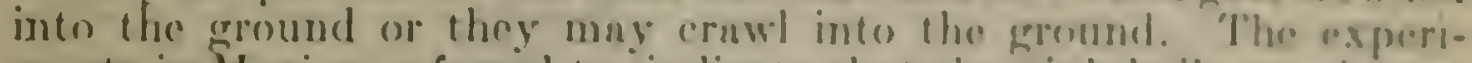
ments in Mexico, referred to, indieate that the pink bollworm lursue will not survive in moist soil but will survive in dry soil. In cusech 'Texas, during the winter, there is more or leas rain und the wiil is moist so that with the clenn-up and the subsecpurnt death in the sol of the balance of the larvie, due to moisture, it is possible to do pretes effective eradication work ns the results have secuned to demonstrute. The only unfavorable factor in that year, 1920, was the discrovery of two new points of infestation in two countices in northern trexus. Immediate steps were tnken to clenn-up these districts and the State having - in the meantime given us n good law and good cooperation-established noncotton zones in these counties, und full control was immediately put into effect.

Mr. Bucmaxax. Have you traced the origin of the infestution in those counties?

Doctor Manuatr. Yes; we know the origin of it in those places.

Mr. Bucmanas. Where did it come from?

Doctor ManLatT. It came from seed from Carlsbarl, N. Mex., before the infestation at that point was determined. Not only did that seed go to those two place but it went to mnny other places in Texas and everyone of these places has been under the most thoroughgoing inspection for two years, but no pink bollworm has been found at any other place, so that by this time we feel pretty sure that these two places were the only ones where it got n foothold. In explnnation it may be said that the infestation at Carlsbud was juit heginning, and the chances are that practically all of the seed from Carlsbad was uninfested.

COTTON 7.NES FREE FHOM FUITIIR INSPECTION.

Mr. Bucinasax. You sturted this work in $191 \mathrm{~s}$ and ut that time you did not have full cooperation but since then you have hal it. Now, have any cotton free zones been released under your inspection zoning system or transferred from the cotton free system to your inspection system?

Doctor MAnLATT. A good many: most of the zones which have been established have been so transferred, and I will come to that in a moment.

To complete what I was saying about these two counties, and the present status in Texas, no infestation has been found the present year, 1922, and the inspection has been so thoroughgoing that we believe we are safe in relinguishing all noneotton zones in Texns for 1923 but still maintaining the districts under regulation so that we can control the movement of the cotton. It is all shipped out of the country. 'There will be a clem-up' this fall in the two northern counties as an additional precaution. 
Louisiana, as you recall, had three parishes under noncotton zones for two years, that is, in the southwestern part of the State, and there has been no reappearance of the pink bollworm in those parishes during that time. The discovery of the insect at Shreveport was the only other point in Louisiana. We investigated other points under suspicion, but without finding any infestation. No reappearance of the worm has been found in the Shreveport district for two years; in other words, we have had two years in Louisiana without the pink bollworm, and for 1923 the formerly invaded districts will be under regulation only.

Texas, as already noted, has been free from the pink bollworm with the exception of one speciment last year, now for two years. But this applies only to the eastern area. There is a western area, which is entirely separate, in which the attempt to eradicate the pest has been postponed, not necessarily abandoned, but postponed for reasons I will mention later. The outlook is now most encouraging where work is being done, both as to the main portion of Texas and as to Louisiana. The danger comes just at this time when the work seems to be approaching completion, namely, to have it understood that the cost will be fully as great now as before, because it is essential to keep up the same amount of inspection for one or two year's more. To materially reduce or to relinquish inspection work because success seems in sight would mean the loss of the opportunity to eradicate this pest. I do not think I need to enlarge on that because you can see it as plainly as I can present it.

This appropriation is for 1924 . which means the crop year after the next, and we do not know what we will have to expend but we have every reason to believe we will have to maintain inspection, and this is the chief item of cost, even if there are no new outbreaks. in the most thoroughgoing mamner for at least that period. Thereforce, we are asking for the same amount we had last year, less the amount that has been transferred. We look upon that appropriation, as I have said before, as an insurance fund, and I lo not use that term in its ordinary signification, but as a fund to be used if needed and we believe it probably will be needed. We have turned back into the Treasury, in former years, very condiderable sums, where the money was not needed; in other words, we only use what is needed.

You understand, I think, the arrangement which is made in this appropriation for the cooperation of the States with the Federal Ciovernment as to reimbursement to farmers in noncotton zones. The amount of such reimbursements this year is not very great.

Mr. Axinenson. Is that now permanent law?

Doctor Mardatr. It is in the language of the appropriation net. You will find that at the bottom of page 333 , "of which sum not to exceed $\$ 200,000$ may be nvalable for reimbursement." etc.

'The nature of the reimbursement is specified in Senate joint resolution No. 72, upproved August 9, 1921, and I think perhups that is rontinuing legrislution.

Doctor BarL. It is as it applies to the pink bollworm, but it would not be uvilable for any other insert.

Doctor Martary. Oh, no; und as it is tied up with this appropriation, if this appropriation should lapse I suppose that resolution would be functemless.

Mr. Axmezson. What is the difference between the approprintion carried on page 331 and the uppropriation carried on page 333 ? 


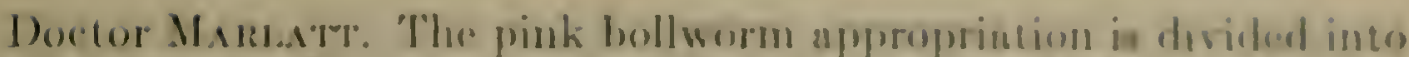

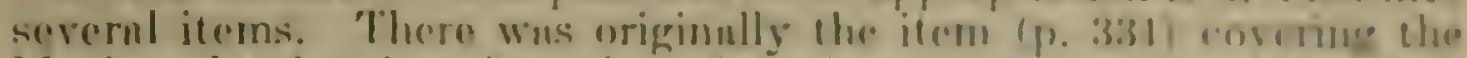
Mexican border situation; then there is no item on page $3.2 \mathrm{z}$ whe ha coress the surveys to determine the netual distributson of the punk

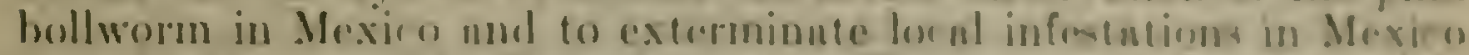
near the border of the linited states. This appropriation was orzes-

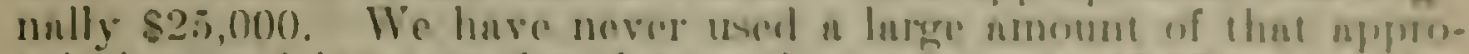

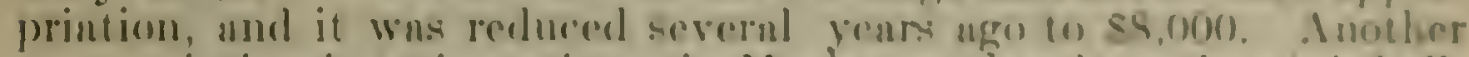
approprintion is 60 investigate in Mexico on elewhere the pruk boll. worm $n$ a basis for control mensures. That rosers the tee huient resenreh work which we are carring on in the lasgum dietrut. - Mexien. where the piork bollworm is most abundant. Thant is its renter in Mexico.

Mr. Averersox. And the inspection work is paid for out of the item corried on puge 333 ?

Doctor Mariatr. Lxactly.

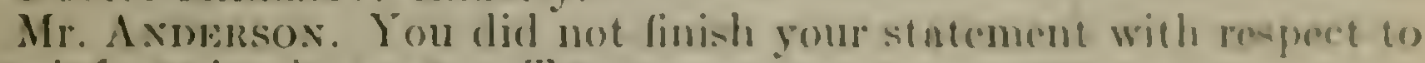
the infestation in western 'Texas.

\section{INFFETATION WORK IN WHTEI:N TEXAS.}

Doctor Mardatr. There are four points or districts of infestation in west Texas and New Mexien, namely, the important cotton producing area in the Pecos Valley in westem 'Texas; a sinilur area much farther north in the same valley in New Mexico in the vicinity of Carlshad: the unimportant Grent-Bend district, the growth of cotton in which is confined to a few trivial ficlels at the bases of the hills: and the much more important and recent cotton derelopment in the Rio Grande Valley southenst of El P'aso in 'Texas and northwest of it in New Mexico.

The invasion of the Pecos district in west Texas was due to cotton smuggled across the horder from Mexico in the Grent Bend urea. The invasion of the Carlsbad distriet was apparently from seed from the Pecos Valley in Texas, and the invasion of the lil Paso region in 'Texas and New Hexico is traceable directlyto infested cotton seed brought to the immediate border at Junrez in freight cars and in comnection with traffic, and probably ehicfly by flight of insects across the river. These sources of invasion, particulary for the Great Bend district and the El Paso region, will continue is long as the insect is abundant in Mexico, and no permanent control can bre ecrtainly effected until cooperation with Mexico leads to joint action by that country with the United States. The establishunent of noneotton zones, therefore, as to the districts along the Rio (irande inmediately bordering Mexico is a rather useless procecding under present conditions. The establishment of noncotton \%ones and attempted thoroughgoing cleanup areas in the Pecos Valley in Texns and New Mexico would be possible but the planters of these arens have not been willing to forego the one crop which is their main staple and the State has not been willing to enforce a noncotion zone as to these areas. As long as the whole projeet of the eradication of the pest in enstern 'Texas was somewhat on trint there was perhaps some justification for this point of view.

As a result of conferences held in 'Texas, on which are bused the present control operations in eastem 'Texas in full cooperation with the State and under adeguate State law, it was decided that for the 
present these four areas in western Texas should be excluded from the effort at eradication, but that these areas should be quarantined and thoroughly controlled and all cotton produced therein should be fully safeguarded both as to local utilization and with the requirement of export under safeguards of the lint.

An important consideration in reaching this decision is the fact that these four areas are all widely separated from the great cotton areas of central and eastern Texas by stretches of semidesert or grazing country, and these areas, therefore, represent perhaps no greater menace or risk to eastern Texas than does Mexico itself. Their control places them, therefore, practically in the same status relative to other cotton production in the United States as though they were part and parcel of Mexico. Ultimately, when the full clean-up of eastern Texas and Louisiana has been completed, it would seem to be highly desirable to take up certainly the Pecos regions in Texas and New Mexico for similar clean-up. Any permanent eradication of the pest along the Rio Grande in the Great Bend district and westward, as already indicated, must be dependent on the cooperation of Mexico in similar work with respect to the contiguous cotton areas in that Republic.

Mr. Anderson. Can the movement of the crop be controlled with any certainty from the regulated districts?

Doctor MirlatT. Mr. Chairman, I think we have methods of controlling all the movements of cotton grown in these western districts; at least, there has been no infestation which has come from any such movement, and we think that it is pretty adequately safeguarded. It amounts to the prohibition of any movement of cotton seed or seed cotton whatsoever from these districts. The cotton lint is under control until exported. It moves from El Paso or from the Pecos district or any of the other districts directly to the port of export and that means usually the nearest port of export, Galveston, Texas City, or Houston, and these are also within a regulated zone. If it remains at these ports for any length of time it is kept under control in licensed warehouses until it is shipped abroad. Some of the cotton that is shipped abroad may come back, but if any of the cotton from regulated districts comes back to this country it is treated like foreign cotton and must be fumigated as a condition of entry unless it can be shown that it is more than two years old. The insect will not remain alive in the boll orer the second year; that is, beyond the second yenr.

IEIMUURSEMENT TO FARMFIS IN CLEAN-UP CAMPAGN.

Mr. Annerson. I would like to ask you if you ean give us any idea how much of the $\$ 200,000$ which is available for reimbursement has been expended or is likely to be expended this year?

Doctor MAriat'T. I have a statement which indicates the expenditures under this item for the year 1922; that is, the one that is just completed. We spent $\$ 20,000$, taking just the large figures, in cleanup work, at a cost of $\$ 4.50$ an acre; that was the arerage cost. That compures with a cost of about $\$ 9$ or $\$ 10$ m acre during the war poriod, when labor was scarce and high. We have been able to reduce this cost lurrely by contructing for the work with farmers, which was not possible in the old days because the bovs were all away and we hud to hire lnbor, transport it, feed it, and house it. 'The cost 


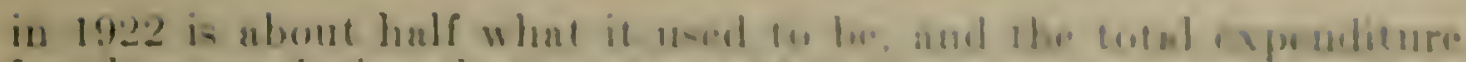

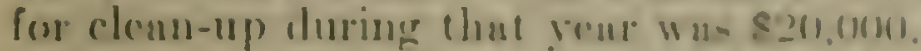

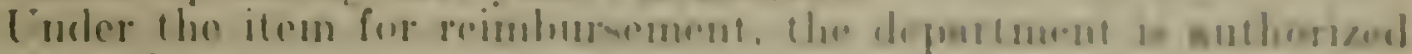
ta (ixpromel

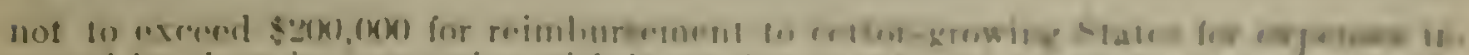

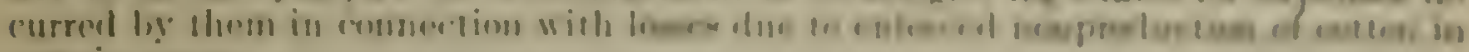
cerrnill zoncer

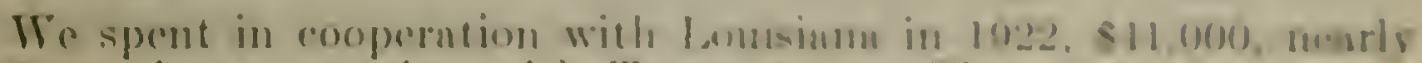

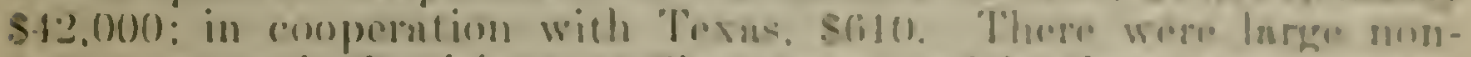

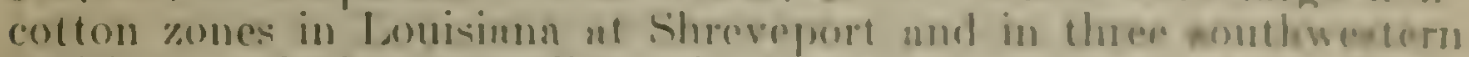

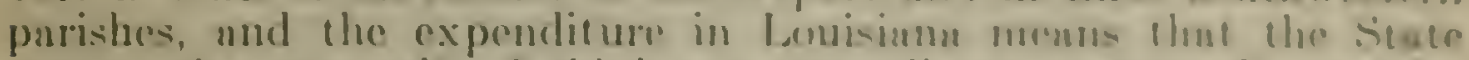

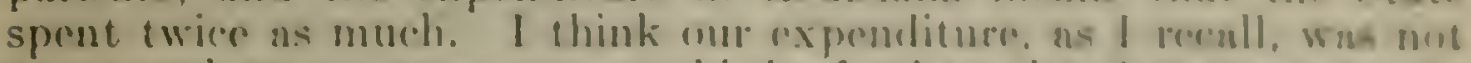

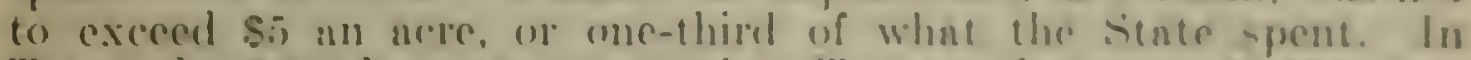

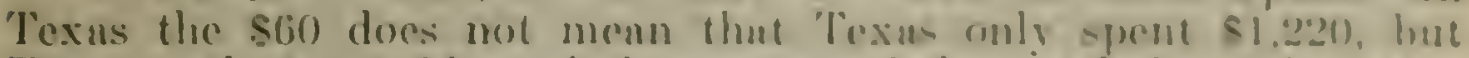
Texas made most of here reimburstement of phantion heforo this reasolution was passed and it was decoded that it wos mot rotronetior. so

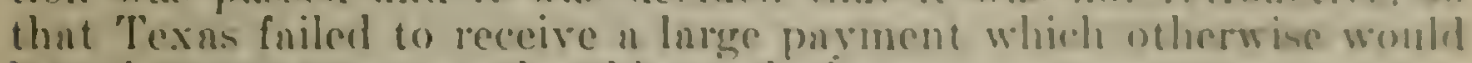
have been necessar under this resolution.

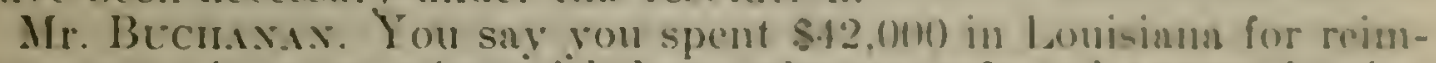
bursement in comnection with losses due to cuforecel nomprodurtion of cotton?

Doctor Mani.itT. Yes; that was reimbursement to the furmers and represented losses due to the establishment of noncotton mones. That means that the State must have spent twice as much under tho terms of the resolution. I will be very glad to submit this data for the record.

(Said data follows:)

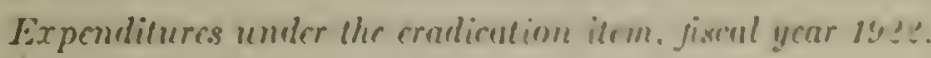

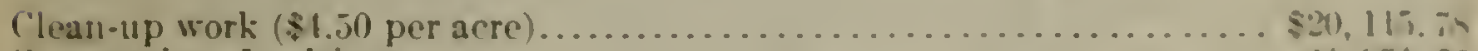

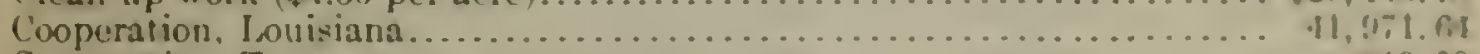

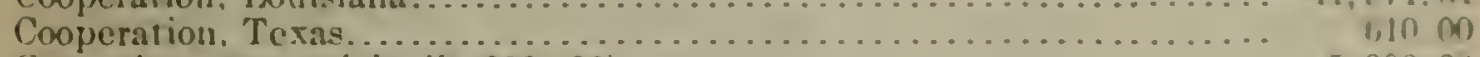

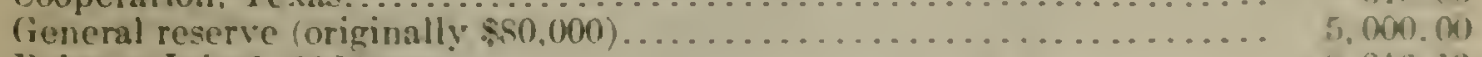

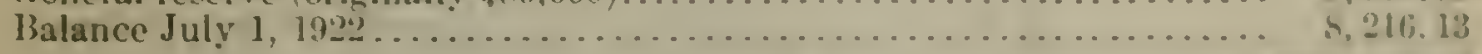

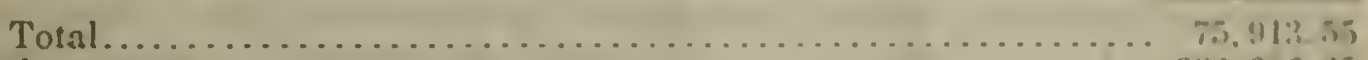

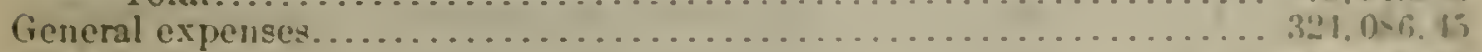

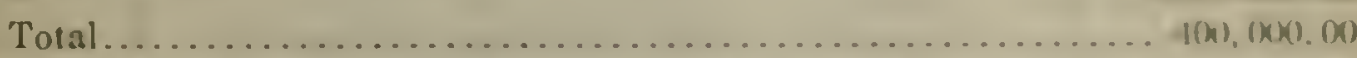

Doctor MAnutat. The plun for 1923 is not to declitre nomeotton zones for any of the old districts in Texus nest year. but all will be maintained ins regulated zones. We are groing in make the try-rut of growing cotton in all of those anens next year.

Mr. Annersos. Then is it going to he necessary to contiune this $\$ 200,000$ ?

Doctor Mariatt. New infestation mave hetermined betwern now and January. This is the best season for surve! work. We nro doing rery intensive surveying work througlout these states just now, nud that work will be contisucel until the land is plower up for next year's planting. and there may be findings fotwoen am and then. 'The designation of that sum for reimhursement is of no specinl significance, becunse it is spent, us indientod. (1)!ly where nerded. For instance, this yenr we spent $\$ .42,000$ (1) of the $\$ 20(0,000$ : tho rest is available to gro buck into the Treasury if it is not rocelend for other purposes. 
Practically the full amount of the approprintion is needed for continuing work, and if all of this $\$ 200,000$ had been spent for reimbursements it would have been necessary'to come to you for a deficiency in order to carry out the other work. In other words, that $\$ 200,000$ could not be eliminated from this appropriation and allow us to do other necessary work.

Doctor BALL. There was no appropriation; that was simply an authorization to spend that much out of our regular appropriation.

\section{FOR ERADICATION OF THE PARLATORIA DITE SCALE.}

Mr. Anderson. Your next item is on page 338, eradication of the parlatoria date scale.

Doctor Mariatt. You will find a full statement of the work on the parlatoria date scale in the explanatory statement which I have submitted. Briefly, this work has for its purpose the eradication of the parlatoria date scale.

This scale came in with date palms many years ago, before there was any date industry and before there was any realization of such a possibility and before there was any realization that there was any danger from such an insect-in fact, it came in unknown and unheralded. It is now believed that the success of the date industry in this country is dependent on the eradication of this scale: in other words, if this scale persists and becomes a burden on the industry, it will prevent its growth and establishment. The experts of the Bureau of Plant Industry, who hare been especially interested in the matter, believe that this scale can be exterminated. 'There were some one hundred infested plantations at the beginning and there are 14 now. The work of eradication is being pressed to the fullest extent of our means under the appropriation, and the outlook is very favorable for the extermination of this scale. The department is now supervising and making the importations of new material from abroad; all of this new material must be safeguarded and held in quarantine for a period of years before it is distributed to planters. That is all covered in this work and the continuation of this appropriation for the completion of this work is apparently essential for the future of the date industry - an industry for which the department is peculiarly responsible and in which it is much interested. It has been a department project from the beginning and is very promising.

Tuesdar, November 21, 1922 :

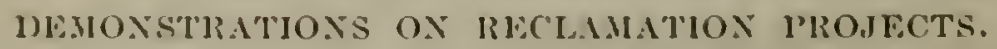

STATEMENT OF DR. WILLIAM A. TAYLOR, CHIEF BUREAU OF PLANT INDUSTRY.

Doctor Tartor. Under the head of demonstrations on reclamation projects the anricultural development work on the Government reclamation projects is prosecuted. This constitutes the grenerul unricultural extension work there, comparable with the type of work which within the States is corried on under the Smith-lever Act. From the berinning this work has becn maintained by the Federal 
Government because of the relntion of the setelere on the projects to the Federal Goverument as dehtors to it for the constructons cese of the irrigntion works. The approprintion for the currymg on of this is $\$ 39,000$, and there is mo incremere estimnted for the comme senr. The work is under way on some 10 of the projects. On certan of them it is only for a part of the gear, those heing the newer projects of the Milk kiver Valley section of Montum, where n gool deal of difficulty has been experienced in getting settlers started in irrigntion.

"The work covers to a considerable extont the comonrmerment of live stock utilizntion of erops grown on the project. It developer rather carly in the oceupution of the projects that the production of perishuble crops, such us potatoss nul fruite, while sureresful from the stundpoint of qunntity, was unprofituble becouse of the long distance from the murkets. Settlers were therefore eneourneged to swing buck to the production of nffalfa and olluer foruece crops and concentrnte these into dniry products and other figher-priend commodities, such as beef, mitton, and wool.

Mr. Axinesisos. I hure understood thut people on these projects are principally men without menns and they huve had consulernble difficulty in procuring money or credit ?

Doctor TaYion. That is true, (o) a certain extent, but bueiness men and bankers as a rule have cone to a realization of the somndness of live-stock development there and better credit conditions now exist. As the projects become more fully occupied und profitable credit improves, as it becomes possible for settlers to pay their bills. The demonstration work is very useful in this field. It is producing excellent results and the proposal is to continue it on the same hasis during the coming year.

FOR EXIPLIMENTS ANI DEMONSTRATIONS IN IIVE-STOCK PJODLCTIO: I. THE CANE SUGAR AND COTTON DISTIICTS OF TIE UNITIP STATES.

Mr. Jump. On page 317 is the next item, for experiments and demonstrations in live-stock production in the cane sugar and cotton districts of the United Stntes.

GENERAL STATEMENT OF WORK .

Doctor TaYlon. The puragraph on page 317 for experiments and demonstrations in lire-stock production in enne sugnr and cotton districts of the United States is a feature of work which has been under why for severnl years, which had as its objective when innugurated, the encouragement of live-stock production especially in the cane-sugar territory in the State of Lousiann. The cane-sugnr district is essentially a one-crop district. If climatic conditions ure adverse to cane the farmers are left in bad slanpe. If sugar prices aro low the cone growers suffer. 'The most promisung method of dirersitication there to get the region off of the single crop busis has nppeared to be through five stock. The problem is a difficult one from the live stock standpoint, for two rensons: One, the wetnesis of the larger portion of the acreage nvaluble, which lies low nud the other is the prevalence of live stock discases and live stock damaging insects. It is a territory where live-stock development has not oceurred except 
to a restricted extent in the form of semiwild cattle, which range on the cane brakes and paille finne or maiden cane pastures of the lowlands along the southern Louisiana coast. It is a line of work which the department and Louisiana Experiment Station have prosecuted in cooperation, and the department has considered it a worth while work looking toward the future relief of the sugar territory from the single-crop handicap which it carries. In its present loeation the work is expensive per unit of operation and per unit of achierement thus far.

The site of the field station where the work is located was made available to the department by the State of Louisiana, it being a portion of one of their penitentiary farms of which they operate several in the State. The place is well equipped with buildings. It is well stocked with mules and horses, cattle and hogs for the experimental work that is being prosecuted, but it is expensive and in the interest of rigid economy of expenditure the estimates proposed the determination of that work at as early a date as it can be done advantageously.

Mr. Andersox. Is it so expensive as to indicate that live-stock production in that section is likely to be, under normal conditions. so expensive as to be unprofitable!

Doctor TAYLOR. I think not, under rather better soil conditions than those which exist on this particular site. 'There is a great deal of conparatively unutilized land in the region which will afford range for supplemental feed. There is also in the region much land better adapted to forage crop production under tillage than is this particular site. However, there has developed during the past three or four years a strongly marked tendency under the prevailing economic conditions to substitute rice for sugar cane, these wet lands proving more profitable in rice than they have in sugar or in the forage crops, than it is necessary to grow for silage or for hay.

Mr. Andersos. Does the Govemment own the buildings?

Doctor TAYLon. The Government owns the buildings. The title is in the form of a deed from the penitentiary board of the State which holds the penitentiary farm, to the Government of the United States for use for this purpose.

Mr. Andersox. Conditioned upon your use?

Doctor 'TAYLor. Conditioned upon that use as far as the lands themselves are concerned. The other property would be disposed of, I take it

Mr. Axdezsox (interposing). They would not be of much value without the land, would they?

Doctor 'Tarior. Apart from the land; that is true. The above stutement applies, I believe, except with regard to a little entrance plot deeded to the Gorernment by the parish in order to give entrance to the experiment farm without having to go through the penitentiary inclosure. This would also revert.

Mr. Buchanan. As a matter of fact, these buildings are not of much vulue to anybody, but they aro fine buildings?

Doctor' 'Tarion. For the purpose for which they were planned. 'They would not be of much value except for that purpose.

Mir. Buchanas. And that purpose is a failure?

Doctor 'T'sYion. I would not be willing to acknowledge that Mr. Buchanan. 
Mr. Bronısis. I anแ.

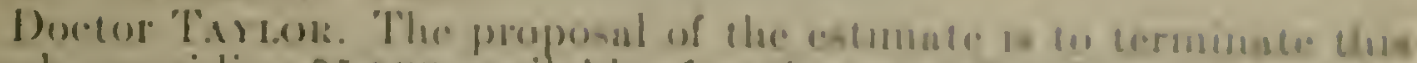

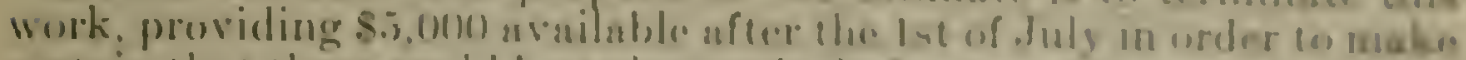
cortain that there could be a thorough clesing up of the work, wothene Waiste.

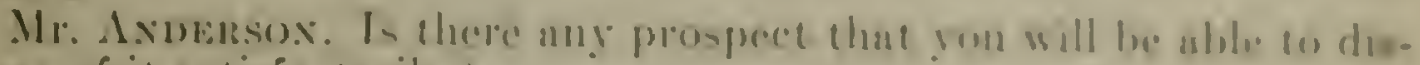
pose of it sutisfactorily?

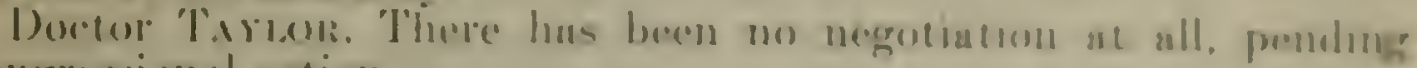
congresisional action.

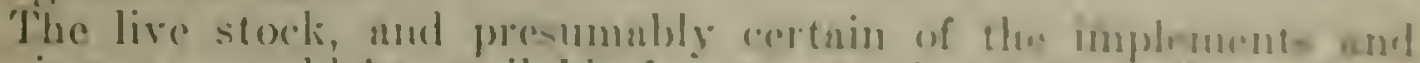

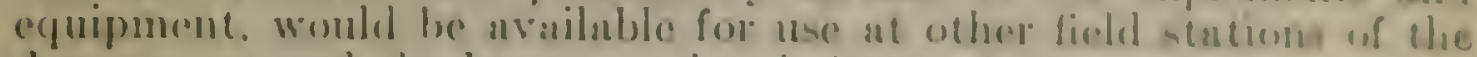

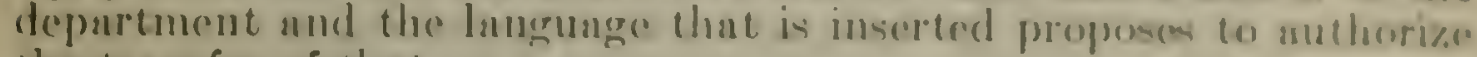
the transfer of that.

Mr. Axmbasox. I understand the water is pretty chene undere the soil there?

Destor 'Tareon. "The primary dilfienlty is the very obstinute retention of water through the wet tines und the lomerh and quick baking of the soil in dry times.

Mr. Bechaxix. Does salt water get up there anough to buther it?

boctor 'TaYoon. It lies sufleciently nbove and sulficiently far from salt water so that there is no trouble of that character.

Mr. Bucusxix. You have no drainage?

Doctor 'Taroon. There is drninge crough for an cordinnry quality of agricultural soil. but this is a very toumf, tenacious, und stubhorn soil to handle except when the season turns just right.

Mr. Bucmaxix. Is it black land?

Doctor 'Thyon. Yes, but not black waxy. It is very different, diflicult soil, except the arens along the bayou frontage, which are very productive, whether in crops or in pasturage.

Mr. Axnrnsos. How much lnnd is there in that tract!

Doctor TAYlor. In this tract approximately 500 acres, with 500 acres of the penitentiury farm adjacent used for a rough pasture umler a lease contrict.

'TLEstr, Novimbr: 21. 1922.

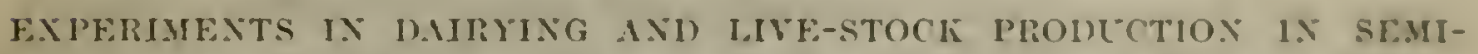
ARID AND IRRIG.ATED IISTRICTS OF THF, WESTERY INITII STATES.

\section{STATEMENT OF DOCTOR C. W. LARSON.}

Mr. Axnersox. Experiments in dairying and live-stock production in seminrid and irrignted districts of the westem Lnited States.

Doctor Lansox. For the diary work we have (wo stations-one at Huntley, Mont.. and one at Jirdmore, S. Dak.. and we are asking for the sume as for the past sereral years. In addition to these dary farms the Animal Hushandry J)ivision is carrying live-stock work at these two or three other forms in this same erencral recrion. I have a statement here of the actual experimental work going on at Hunley and at Ardmore. I coun put that in the record. If you want to sare that time.

Mr. Avnensox. All right: put it in. 


\section{HUNTLEY FIELD STATION.}

The Huntley field station, establislied in 1909, is located on the Huntley reclamation project, near the town site of Osborn, Mont. It comprises 300 acres of public land, of which 140 acres lie above the irrigation canal. The work of the farm is under the supervision of the office of western irrigation agriculture, the office of dry-land agriculture, the biophysical laboratory, and other offices of the Bureau of Plant Industry, the dairy division and the animal husbandry division of the Bureau of Animal Industry; and the Montana Agricultural Experiment Station is also cooperating in the investigational work with field crops and hogs.

The dairy work at Huntley began in 1916, and consists of investigations of problems encountered in establishing dairving in the irrigated sections, particularly with reference to the effective utilization of the forage and grain crops produced in those regions. A herd of purebred Holsteins established in 1917 now numbers 50 head, and the animals are being used in the dairy cattle breeding experiments. In this connection bulls are loaned from this herd to farmers on the project with the object to determine the transmitting ability for production of these bulls. At the present time 34 farmers on the Huntley project, owning over 200 cows, are using bulls from this herd.

The following are some of the experiments conducted at this station:

(1) The maximum carrying capacity of an irrigated pasture for dairy corrs. To determine the number of dairy cows that can be maintained on an acre of irrigated pasture. Four plats of one-quarter each were seeded with a mixture of smooth brome grass, orchard grass, tall fescue, perennial rye grass, Kentucky blue grass, white clover, and alsike clover. The four plats are fenced into two half-acre lots which are pastured alternately.

(2) A comparison of the carrying capacity of thiree mixtures of pasture grasses under irrigation for dairy cows, the following mixtures being used:

\begin{tabular}{|c|c|c|c|}
\hline & \multicolumn{3}{|c|}{$\begin{array}{c}\text { Rate per acre of sceding, } \\
\text { pounds. }\end{array}$} \\
\hline & $\begin{array}{l}\text { Mlixture } \\
\text { No. } 1 .\end{array}$ & $\begin{array}{l}\text { Mixture } \\
\text { No. } 2 .\end{array}$ & $\begin{array}{l}\text { Mrixturo } \\
\text { No.3. }\end{array}$ \\
\hline 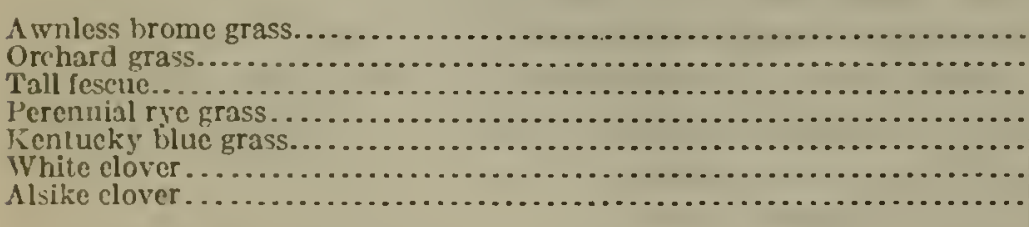 & $\begin{array}{l}2 \\
5 \\
3 \\
3 \\
4 \\
2 \\
2\end{array}$ & 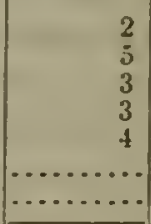 & $\begin{array}{r}\because 5 \\
3 \\
3 \\
4 \\
2 \\
2\end{array}$ \\
\hline Seed per acre.................. & 21 & 17 & 16 \\
\hline
\end{tabular}

One-half of these plats are being top dressed with manure each year and compared with those without top dressing.

(3) "he feeding of dairy cow's on roughage alone as compared with roughage with liberal grain feeding, and with limited grain feeding to determine the economy of production of these tro methods of feeding.

\section{ARIMORE FIELD STATION.}

The Ardmore field station was established by the Bureau of Plant Industry in 1911 and dairy operations legan in 1916. 'I he work on the farm is under the supervision of the oflice of dry-land ayriculture, the dairy division, and the animal husbandry division of the brueat of $I$ nimal Industry. I here are 1,200 acres in the farm, of which 353 are used by the dairy division for corrals, permanent pastures, and crop land. 'the dairy work consists of investigations of problems encountered in establishing dairying in dry-land sections, particularly with reference to the effective utilization of fortage and grain crops produced.

'I he herd of pure-l,red Holsteins established in 1917 now numbers 41 head, and they are beine used in the dairy cattle breedimr experiments.

the following are some of the experiments in progress:

(1) l'asture experiments: (a) Nalive pasture composed of buffalo grass; grama, and wheat grisses; (b) strect clover; (c) bromo grass; (d) slender wheat grass. 


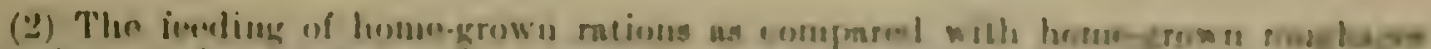

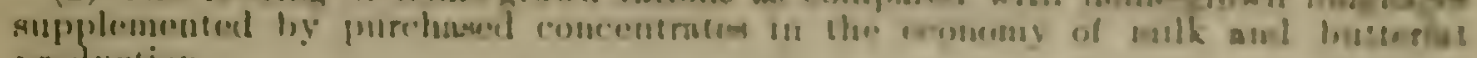
prosluctions.

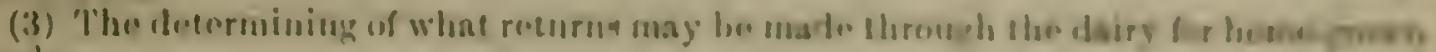
piveds.

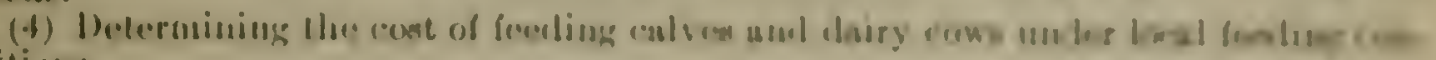
ditions.

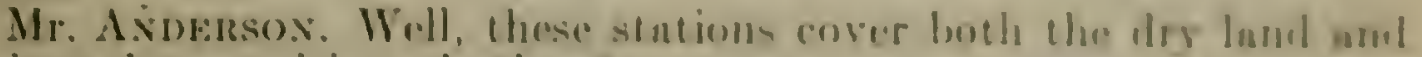
irriguted propositions de thry?

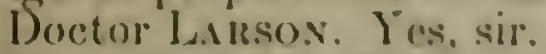

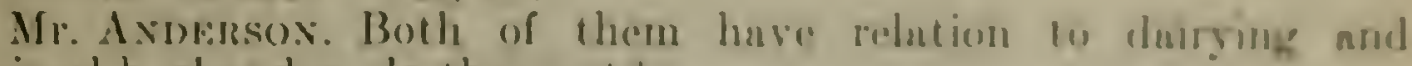
animal husbandry, do they not!

Doctor Isarsox. Yes, sil. J'hrem is mo rhnuger in this itern.

Mr. Axurasox. Is this work donc in colluhoration with the Buroun of Plunt Industry?

Doctor Larsox. Oh, yes, sir. They grow the crops and the farma were originully astublished by that hurratu.

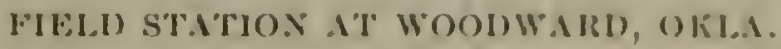

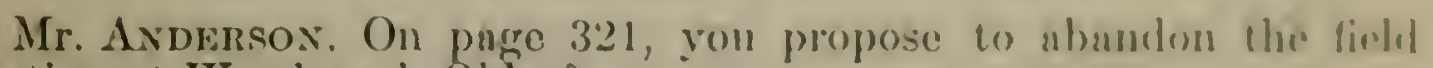
station nt Woodwarl, Olilar?

Doctor Larsox. Yes, sir.

Mr. Avingrsox. Will you tell us why?

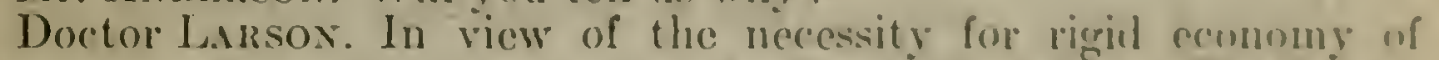
expenditure the discontinunuce of the livestock work nt Woulwarl, Okla., is contemplated, except to the catcont that it can he done in connection with the adjucent dry-furming licld station muintuined by the Bureau of Plant Industry moler its sulapplopriation for inrestigntion and improvement of methods of crop production muder subhumid, scmiarid, or dry-land conditions.

Mr. AxDERsox. Is this station at Wuodward!

Doctor Idursox. 'This station is ut Moodward, Okla.

Mr. Annwrsox. Wis this proposition origrinally intended to bo a separiate station?

Joctor Larsos. 'This Woodward station?

Mr. Axurissox. Yes, this live-stock proposition!

Ductor L.irsox. Yes, sir.

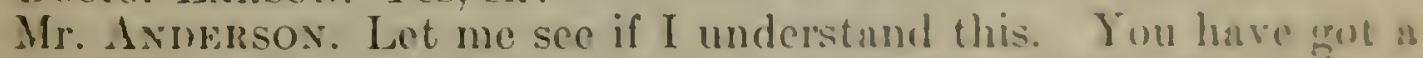
plant at this station now. That is, this proposition was of T) a live-stock proposition in addition to thut?

Doctor Larisox. Yes, sir.

Mr. Axumbsox. Sepmrate from that?

Doctor Lansos. Adjoining it and maintained by lle department under the supervision of the man in charere of the dry-lumd farm.

Mr. Anderson. That is exactly what gou propose to do anyay. is it not?

Doctor L.srsos. No. 'The idea of the wolding of this stafoment was to provide for the possibility of calrying this on wn 2 smaller seale and perhaps in cooperation with the State.

Mr. A.Nmensos. What will you do if lhis goes oul?

Doetor Idarsos. The will be obliged to move the hord alsen lacro and discharge the herdsuen, and the farm will revert to the city of Woodward, Oklı. 
Mr. Andersox. Where is your nearest lives-tock station to Woodward?

Doctor Larsox. 'The ones at New Iberia or Ardmore would be the nearest, so far as dairy cattle are concerned.

Doctor Monter. 'There are only about fifteen eattle there now, are there not?

Doctor Larson. Fifteen head. This was a special item put in in 1921.

Mr. Axpersox. I never was for this farm, but it is there and unless the work which would be done there anyway is done elsewhere there might be some reason for continuing it.

Doctor LARSON. The partieular region is different from the other dry-land regions where we are working. They have a particular situation in there, pasturing of their wheat crops and information along that line is important at the present time, to know whether or not it is advantageous to pasture their wheat crop in the winter time-winter wheat-and that is the experiments we have there now.

Mr. Axderson. Can it be maintained on its present basis for $\$ 12,500$ ?

Doctor Larson. Yes, sir; it can be maintained for less if necessary.

Mr. Anderson. That was your estimate for last year; $\$ 6,500$ is what you expended.

Doctor LaRson. That is what we are rumning on now. It can be run on that another year.

Wednesday, Novenber 29, 1922.

ENFORCEMENT OF THE PACKERS AND STOCKYARUS ACT.

STATEMENT OF MR. CHESTER MORRILL, ASSISTANT TO THE SECRETARY OF AGRICULTURE AND IN CHARGE OF PACKERS AND STOCKYARDS ADMINISTRATION.

Mr. Anderson. We will next take up the item on page 348 , for the enforcement of the packers and stockyards act.

Mr. Morrill. In order to put before the committee an accurate statement and one of which it can make use, I have written out a brief statement which brings the work of the packers and stockyards alministration up to date from the point where the first annual report leaves off.

GENERAL STATEMENT.

The annunl report has not yet been released for publication, but the Assistant Secretary has authorized me to furnish to each member of the committee a copy of the ammual report, which will show from the beginning of the work under the packers and stockyards act the methods of organization, the subject matter covered, the extent of the work that we have to do, and what we hand done up to the end of the last fiscal yoar. The subsequent statement in tyewritten form brings it up practically to the present time, and I will furuish a copy of it to ench member of the committee.

Now, at the present time wo have 79 public stockyard markets in 71 rities in the United States that ane subject to the jurisdiction of 


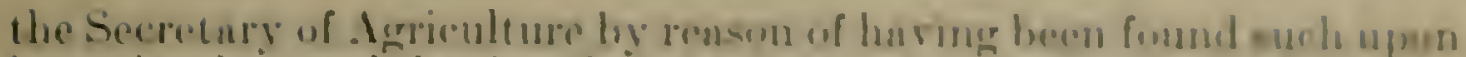

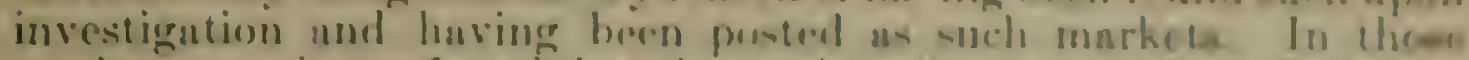

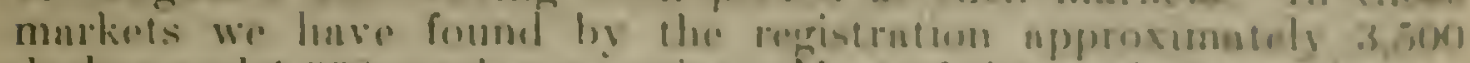

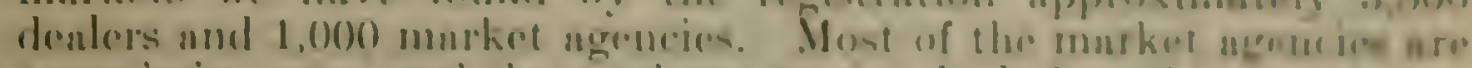

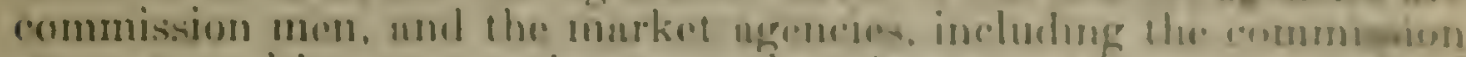

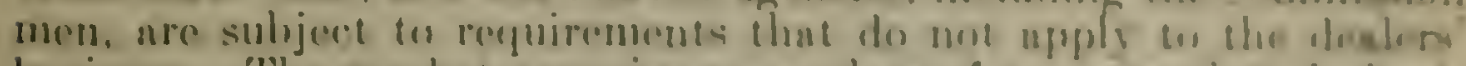

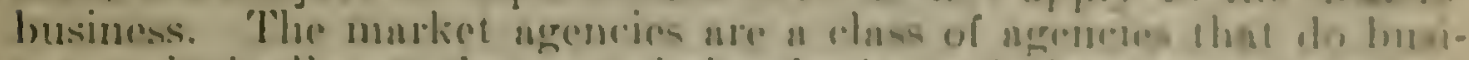
nese principally on the rommincion basis, and thes are negureal on file with the Socretary of Igriculaure their sedechlules of rates, cherses.

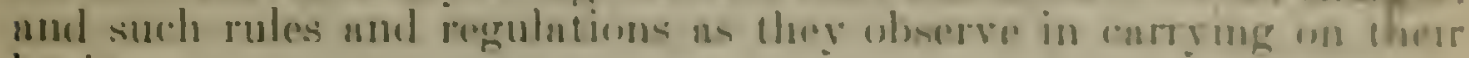
business.

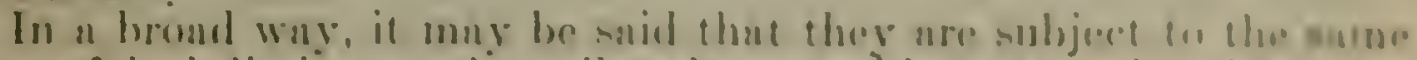

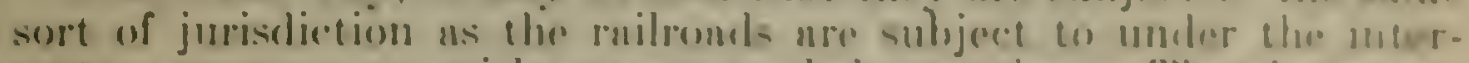

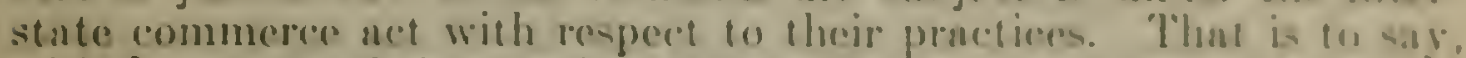
with respect to their practices, they most be nomlineriminatorg arid

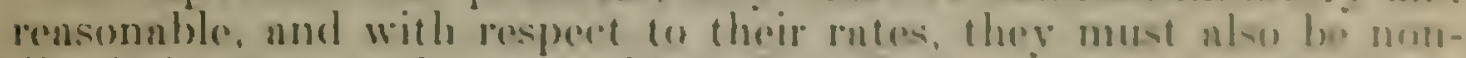
discriminutory and reasmable. The Department of dericuleurs does not make the rates in the beginning. Ther file the ranes und publish them, and they ne subject to investigntion. explamblom.

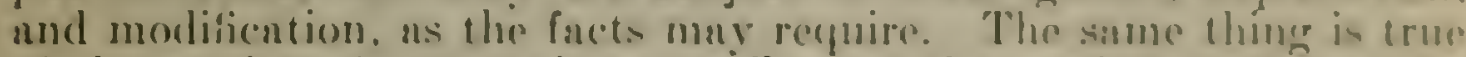
of the stockrarl rompunies as woll is of the market mencense In order to deal with the physionl aspeets of the markoting of live stock. as we found them at the stockyards, We have suprepioum at 20 of the cities where there ne stockinads. Tlase supervinurs are resident in those markets, but from time to time, by asignment or special instructions. they go (o) other yurds for the purpone of dealuner cither with special guestions that may arise, or for the purpose of remuining in the markets for a longer time in order to berenme thoroughly acruminted with the conditions and to see that the various agencies subject to our jurisdietion thoroughly understand whut we are experting of them under the parekers and stochyouds

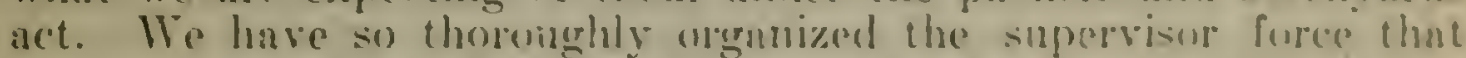

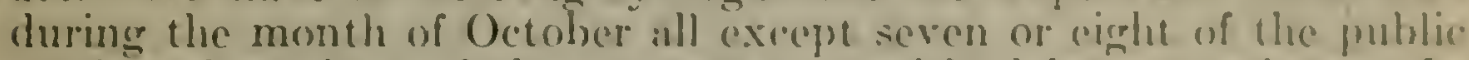
stockyard markets of the country were visited hy supervinom. In addition to the stockyard companies and market agents and doulers opernting at the stockynds, we have, of course, the packers, who operate both within and without the vards.

So far as their operations in the yards are concerned, they are denlt with in the same way as other operntions in the yurds are dealt with. Then we have certain other operations that must be deale with specially, such, for example, as you will note from reading the annual report and that supplemental report. For instance, there is the question of discrimination in butter fat prices, which arose during this yeur, several complnints having been male ngninst ane or I wo large packers upon the ground that in their huyge operations at country points they had discriminated between country points amd had also been guilty of unfuir competition. Such matters us that require specinl investigation. So fur we hare found the complanins to be unfounded. In one particular case that I have in mind the man that made the complaint was found to be the man who started all the trouble. He started a rate cutting.war and disl some improper advertising, and the packers simply met the competition. Other aspects of the packer work, other than those specinl matters, cume up from time to time, more particularly the matter of studying their 
accounting systems and arriving at an ability to determine what are the true costs in the packing industry. In that we have been delayed for several reasons:

First, because during the first year of our operations, we found that we were in competition with almost everybody else to get auditors, and it was virtually impossible for us to get more than just a few auditors to deal with the pressing questions in comnection with commission rates and similar matters. It has only been during the last two or three months that we have been able to go into the field of accounting to the extent of getting enough auditors to organize a force that would look forward to a study of the accounting systems. It seems that during the past few months there has been a sort of let-up in the demand for accountants, partly due to the summer season and partly due to the commercial depression, and through the medium of civil-service examinations we have been able to get hold of a number of men who seemed to be very competent, so that the work of studying the packers' accounting systems is now started. We have been under a good deal of pressure in the last few months, and are right now, on account of complaints having been filed as to commission rates. We have tagken those complaints and have been working up the information, but at the present time we have the question of reasonable commission rates to determine at Chicago, St. Paul, Omaha, Kansas City, Fort Worth, Denver, and Portland. We have also the question of certain stockyard charges to determine at Peoria, Ill., Omaha, Nebr., Chicago, and Milwaukee, and in a number of yards the companies have taken up with us informally the matter of certain changes in their rates, knowing that if they were to present the proposed changes formally they might run up against suspensions.

During the early part of the administration of the act there were a number of reductions in stockyard rates particularly, but recently, on account of the rery great adrance in corn, there has been an attempt, which looks almost like a concerted movement, to raise the rates on corn in the stockyards generally. Chicago, Milwaukec, and Buffalo have proposed an increase of 15 cents per bushel. We have suspended the Chicago and Milwakee increases, and they are awaiting a hearing now. At Buffalo there is a slightly different condition of aflairs, because of the fact that when they increased their corn rate, they reduced their hay rate, and it may be that they have an equity that is different from that of the other yards. In addition, a number of the yards have introduced a new charge this yenr that had not previously been made, called a "reweighing charge." That is a churre which is imposed upon speculators operating in the speculntor division for the service of weighing their animals.

'That is sometimes known as a rewrighing charge and it is sometimes known as a second weighing charge. That is to say, the speculator's buy the bulk of their animals from commission men, and in the past the stockyards have been supported almost exclusively from yardige charges and feeding chareres imposed upon the first handling through eommission men. plus a feeding charge to the speculators, bit without any yurduge charege to the speculators at all. "The stockyurd compunies liave concerved the idea that that is a discrimination, and it also menus a possible inclease in their revenues. The question that we are trying to work out now is how to deal with the reweighing 
charge so as to do equity nomong ull the ponplo involved. Sot all of the stockyard compunies hase mude the chatge. Sorme of them take the view that the specoulators division is something to for momeaned in the markets, and that they are justified in not imporemg thre sume charges upon speculators that they do upon ol hers. There. who are propesing to increase the rnte take the other riew - thane in that the support of the gard should cono from all alike, regnrellowes of whether they are necessury to mantain the murket or not. . Ill of that work in connection with commission rntes has simply taken all of the tume of the anditors that we could get logether, plus is good muny tomporary people to get up the necessury statistienl infornution wn inarket conditions. It will be some time hefore we and dispore of all of those cuse's.

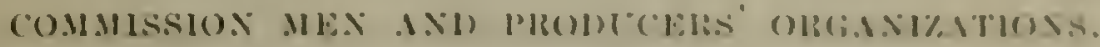

Fortunately. in one respect wo hase hrought about a comblition of affairs comparatively recently where for the first line, so far as we know, the commission men and the produces's urentization- have becon willing to get fogether in the same roum and tulk were the commission rates. They are doing it hesanse we arre placing our representatives in the conferences for the purpuse of purticipating in them. Formal complnints were fited. als at matter of fact. he the Western Producers' Isseriation at six of those matrents. When those formal complants were filed, we took up the matter with all of the organizations concerned for the purpose of getting them together on a method of procedure which wonld eliminnte the technical requirements of what would be almost a court hearing in the presentation of the evidence, as well as the employment of lnwers and things of that lind, and within the last two or three dnys we have received advices from all the marliets except one. snying that they will join in this informal method of having two of ime represintatives, the head of our rate division and the hend of our tracle practices division, act rirtunlly in the capacity of arbitrators. "The idcea we have is to deal with the subject from the purely practionl stamblpoint and to have the procedure stripped of all technicalitics and of all the legal recpuirements that lawyers might impose, for the purpose of getting down to what will be al commission rate that will be acceptable to everybody concerned, as is purely practical mnter. We think that that will go a long was towned getting rid of the commission rate question in the future when it is worked out, because. one of the conditions of the stipulation that the purties are nirreeing to is that the commission men will anecept whaterer condusion is reached as a result of that conference, and that they will put it into effect without appeal to the courts.

\section{TRAINING OF JRESONTER.}

In building up the kind of organization that we have in the yards, of course we have had to build almost from the bottom, taking men who knew nothing about the packers and stockyads net. but who were acquainted with practical marketing conditions in the yards. We have had to train them up, nnid, in order to bring about solichurity and uniformity in the organization we have a system hy which every 
supervisor reports once a weck on everything that he has done, on every question that has come up in his experience, and either the disposition he has made of it or the disposition that he wants to make of it. The reports of those activities have been summarized and furnished to all of the other superivsors once a week, so as to keep them in line with every thing that is going on. During the last two months we have.summarized and used the reports in the Department that could be given out to the public without a breach of confidence, or without starting any trouble with any particular yard. The statements in the monthly summary, of which I have the last one here, are framed in such a form as to describe just exactly what we are doing at the yards during the month. I have brought copies of the monthly summary, because from that you can better visualize what we are trying to do.

Mr. Anderson. When a question arises as to rates, would the parties hare to come to Washington for a hearing, if the ordinary procedure were followed?

Mr. Morrill. No, sir; we hold the hearing in all cases in the market where the question arises. We do not hold hearings in Washington at all. I do not see where that would do anybody any good.

Mr. Axdersor. I do not either, and that is the reason I asked the question.

Mr. Morrill. In other words, we want to get the facts, and the place at which to get the facts is in the market where the question arises. You can hold a hearing at the market, and bring in everybody you need and hear what he has to say, and then send him back to his work, just as you do here in your hearings. He can remain if he wants to, but he can go about his business as soon as he has said what he wants to say. The Government bears the expense of its own travel, and the market agencies are relieved of that expense. They get their hearings right on the ground where they have the evidence and the witnesses. If the hearings derelop that ther need something else, they can go out and get it. For cxample, we held a hearing in one market recently, and the man who made the complaint presenterl a case which seemed very meritorious. It was a thing that involved a question that was fundamental in the making of rates in stockyards, but, as a matter of fact, for various reasons the people who had a like interest decided that maybe it was not the best thing for all concerned. They had reasons for thinking that it was not good business. When our people arrived at the yard and found that condition, they simply went out and grot the people who knew the facts and brought them in and had them make their statements so that we would be able to decide the case on its merits. We resort to just as little formality as possible to get along with and keep the record clear for legal purposes.

Mr. Andenson. I think that is a very sound practice.

COMMISSION RATES.

Mr. Monnus. The amount of the appropriation provided for by this estimate is precisely the smme as we have for this year. There is no change in it. If you do not mind my taking your time, I might mention one thing thint we are doing. or have done, in comection with those commission rates that is of a cood deal of interest to us and is going to be of a good deal of interest to the commission men. 
Before we knew that those complaints would be filed, we startuel in to munlye the commission men's operations in five tvpienl merhete for the purpose of determining just how they got theor revernue and for what purposes they expended their mones, has ong in mind the

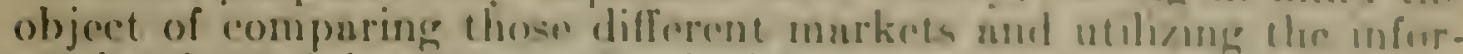
mation in arriving at sound principles to cover ond future rate de. terminations. What we would like to do would be to hase some fundumental facts that will shorten the rate work later ous. For that purpose we selectod Pitshurgh, St. Paul, Omahn, Fort Worth, and

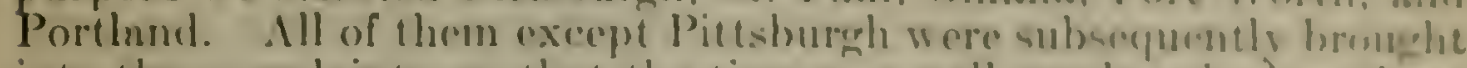
into the complaints, so that the time was well emplosed whers thate markets wore selected.

Now, by taking the conditions at those markets nn interentume connpurison can be male. We will take Pittiburgh. Fort Worth, and Portlnud; and, roughly spenking, they are in one erous, while si. Paul and Omaha are in another crouid). At Piltshureht there nre II) commission ngencies, at Forth Worth 1:3, ancl at Porthnts, of whith 6 were in continuous operntion during 1921. At St. Panl there are 31 commissior agencies nul at ()maha 51. In hoking orer their figures we find that at Pitshurgh their neruece not return to the owners is 60 per ecent of the ineone, at Fort Worth? mere cent, at Porthnd 37 per cent, at St. P'als 27 per rent, and at Omaha 34 per rent. Omalna and Portland operate on practirally the same bercentage. We took the arerane net return to the owners withoul regaril to the perentages. and we hive an areruge net roturn in Pittshurgh of $\$ 23.000$. as acrainst only $\$ 16.0(0)$ in () muha und $\$ 1.00(0)$ in Fort Worth. Now, as a matter of faret, in cramining the exp phe

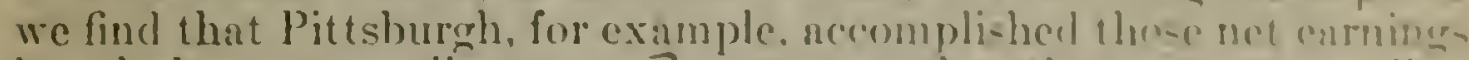
largely by not spending so much money as the nthers or met span line so much money in advertising, solicitition, or anythine ole hur 'ly. Practically all of the items of expense were erreatly betow thes of any other market. Now, of course, all of these thinge alre afforic l he the volume of business, and we have not completed unr star ist inal information on the volume of business. That is being wortic i up nus. to apply those figures to the volume of husiness. In interesting thing about that is the way they distribute their in and when they get it. Among other things, in the course of this compurion, we will be able to show just how the conperative enterprises vor sing in the sume markets get along as to expense, and as lo const per catr, pher hanl. or per pound, as compared with the olel line anenceins. In wther words, we will probably get something that is fant rather than conjecture on those points.

Mr. Axnersox. Of course, to really furnish much of a ha-is for comparison. I assume that those fignires would have to he dweited into volume of business in some way, so ats to gere at the rest per ear. per liead, or per pound.

Mr. MonmL. Fes, sir: and we are taking all theer of those things. We are going to work it out per conr. per hemd. and pre pound, and then we are dividing it by species, of courso. 'lhen, we are lahin. into consideration just how much money they spend for end clasi of expense, solicitation, advertising. ete. Sime of them sprent at great deal more for advertising then others. For instance, in some markets a great deal of money is spent for market papers. The secretary of one exchunge told me list winter that many shippers 
get seren or eight copies of the same market paper from commission men. Of course, things of that sort ought to be eliminated.

Mr. Axpersox. It is not the commission men alone who are doing that sort of thing.

Mr. Morrill. Of course, we happen to be dealing with that particular problem. I do not contend that that is the only place where we will find it.

Mr. Andersox. Will you use the entire appropriation this year?

Mr. Morrill. Yes, sir; it will be used this year. We did not use the entire amount last year: We used $\$ 174,000$ out of the $\$ 200,000$ provided, but this year, on account of all of these things coming up at once, and the necessity of employing a great many temporary people, we will use the whole amount.

PROCEEDINGS TOUCHING THE PRACTICES OF PACKERS.

Mr. Anderson. Have there been any proceedings begun touching the practices of packers?

Mr. Morrill. No, sir; there have been no formal proceedings except one. There was a proceeding instituted by the Kansas City Livestock Exchange against Armour \& Co. and the Fowler Packing Co., of Kansas City, on account of the fact that Armour \& Co. operated a yard known as the Mistletoe yard at Kansas City, not far from the public yard, where they bought live stock that had been shipped direct to the Fowler Packing Co. at the Mistletoe yard, and not passing through the open yard. The operations in the Mistletoe yard were limited exclusively to hogs, and to persons or shippers out in the country who were in a position to supply the kind and quantity of hogs that the Fowler Packing Co. needed for its operations. The Fowler Packing Co. is largely an export slaughtering plint. In that case, it was complained that the maintenance of those yards operated as a depressing influence upon the public stockyard, and, also, that the yard was, in fact, a public stockyard market and that it ought to be brought under Title 3 of the packers and stockyiuds act.

We held quite lengthy hearings on that matter at Kansas City. Twelve days were consumed in the presentation of the evidence on both sides. We found that there was no possibility of the two sides getting together informally, because there was a question of principle involved, and it was looked upon with a great deal of concem all over the country as involving the question of whether packers might buy direct from the country instead of through the public yards. We found, in the first place, that the Mistletoc yards were not, in fact, public stockyards, but simply receiving yards for shipments sent in from the country yards, where the grading, docking, or pricing took place for the purpose of closing the transactions. The prices at the Mistletoe yand were based upon the prices of the same day in the public; stockyards market of Kinnsas City One of the complaints was that because of the fact that the Fowler Packing Co. was owned cxclusively by Armour \& Co., and, therefore, was merely a department of Armour \& Co., the receipt of those hogs in the Mistletne yard took that amount of hogs out of the public yad and gave the buyers of Armour \& Co. a certuin power that they should not possess in the public yards. There was not any evidence brought forth to substantiate that. We were unable to find facts in the evidence to 
substantinte the contention that the operations of . Imonur of (as,

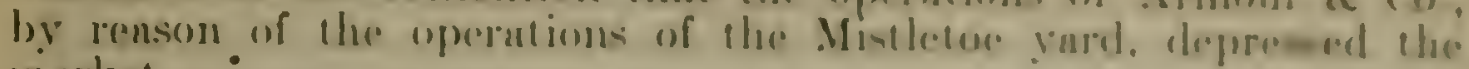
murtiet.

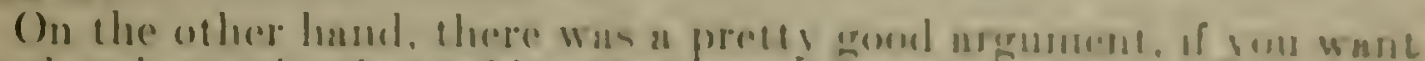

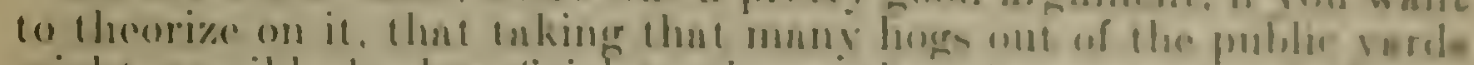

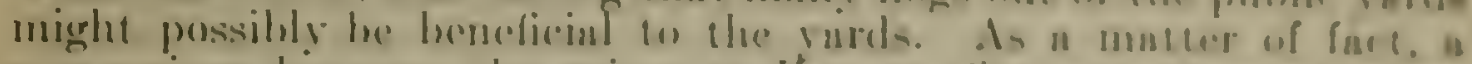

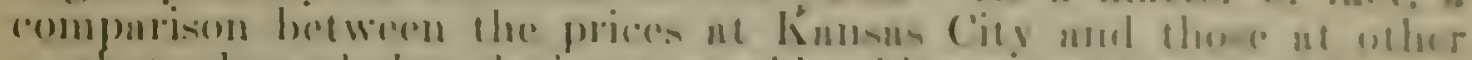

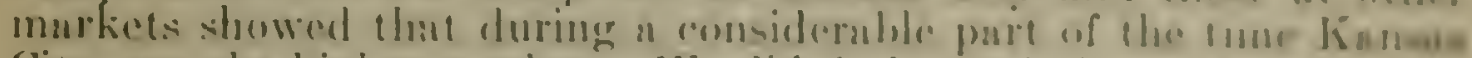

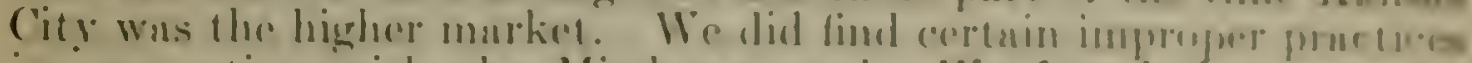

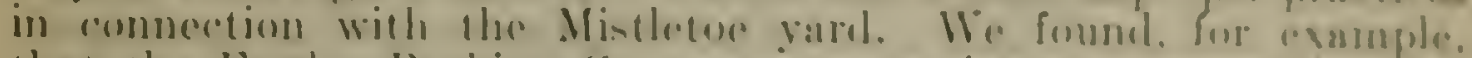

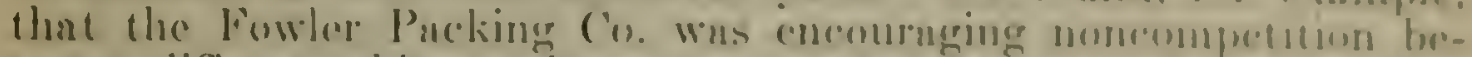

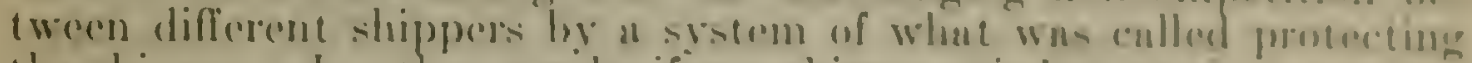

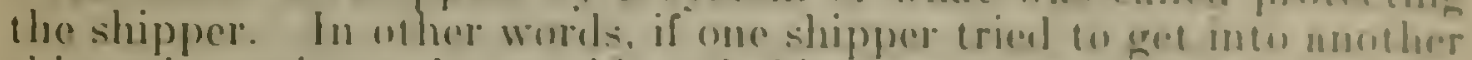

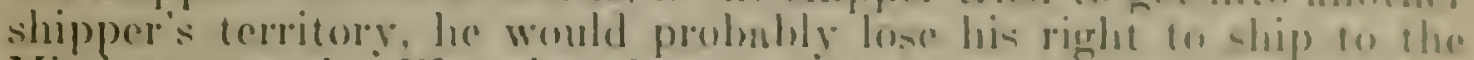

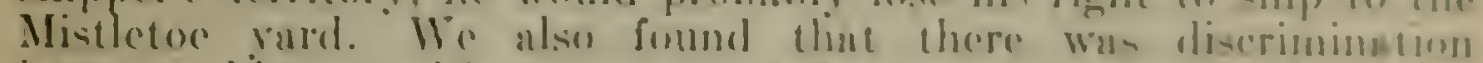

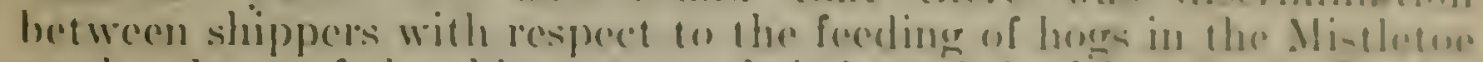

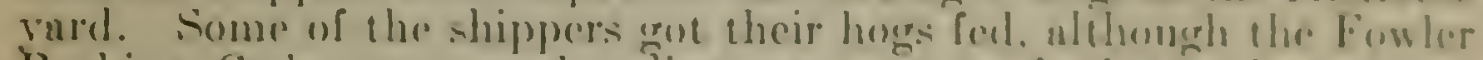

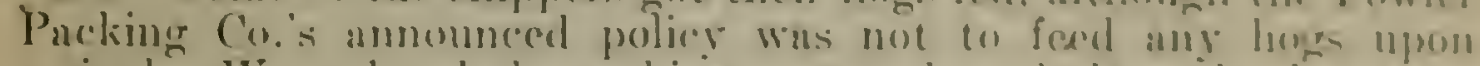

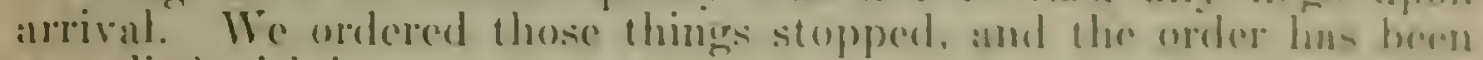
romplied with in every respect.

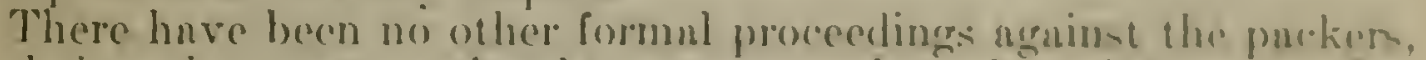
and the other matters that have come up have bern informal. For instance, there has beren the mattere of the butter-fat diecrimination, und also the matter of the nmount of huttere placerl in butter cartuns. There was a complaint that a big pucker was puttine 1.5 ounces of butter in an ordinary pound carton and simply stumping l.5 cumeres orer the pound on the label. There wins no difference in the size of the carton. We got together all of the big packers and represemtatives of the American Creamery Butter Manufacturers und uther on the question of whether that was a desimble business pronetice. 'They agreed that it was not and they stopped it immediatcly.

Mr. Axnersos. Was there nny difference in the price of this 15 -ounce packinge and the pound packige?

Mr. Momant.. There was not, so fnr ats we could find. By thut I mean that while probably the pneker sold it at a price slightly lese. so far as wo could ascertain, the retailers might or might not have sold it for less. 'The ground of complaint secmed to be that other people who were trying to sell straight pound packages were not uble to make a go of it, and were complnining that it whs unf nir competition for somebody else to sell 15 -ounce purkages. Fot only- dill they ngree that that particular practice should be stopped. hut they acresid upon the principle of the standard size conton-m other worle, that there should be no devintion from the puarter-pound, half-pouml, and pound sizes. Recently I made some inquiry regarding it and I am unable to find that the agreement has beon departed from answhere, although, from our understunding, there were several million pounds sold previously in that manner. As I have sabl, we ure ntlempeing to work on the matter of the necounting systems now.

\section{FAFORCBMST OF THF GRAI HUTULE IC'T.}

Mr: Axpersos. The next item is for the enforement of the grnin futures act.

Mr. Monkild. The grain futures anet, ns you have it before you, takes the place of the future trading act of August 24, 1921, the 
operation of which was virtually suspended before its effective date. In May, 1921, the Supreme Court held that that act, which was passed under the taxing powers of Congress, was unconstitutional as to its regulatory provisions, leaving in effect the tax on puts and calls and leaving in effect the section authorizing the Secretary of Agriculture to carry on investigational work, without power, however. to compel members of exchanges to disclose their books or to make reports. Immediately after that a new bill was introduced in Congress under the interstate commerce power, based upon the theory that those transactions on the Chicago and other boards of trade are so closely interlocked with interstate commerce that they are inseparable from it in effect and that anything which operates atrersely upon the price on a futures exchange-and by "adrerse" I do not mean necessarily downward, but either downward or upward, contrary to the normal operations of the law of supply and demand-would necessarily operate adrersely upon the cash grain business of the countrr. Upon that theory the bill was reintroduced and was passed the bill containing, as to its substantial provisions, virtually a repetition of the provisions in the act that was declared to be unconstitutional.

Mr. Axperson. Did the second act repeal the taxing provision of the lirsti act?

Mrr. Morrili. No, sir.

Mr. Axderson. That is still in force?

Mr. Monnill. Yes, sir. That section of the first act was not affected by the decision of the Supreme Court. That has been virtually self-operating, because the exchanges have stopped that practice so far as we know. If they are doing anything of that kind now, it is under cover.

Mr. Axderson. I judge they have, because they are making such an awful holler about it.

CONSTITUTIONALITY OF NEW LAW BEFORE COURTS.

Mr. Morrill. By reason of the similarity of the prorisions of the two laws, outside of the legal question, the same exchanges are subject to the new law that were subject to the old one. There are 11 of them -2 at Chicago, and 1 each at Milwaukee, Duluth, Minneapolis, Kansas City, St. Louis, Toledo, Baltimore, Los Angeles, and Sin Francisco. Not all of them deal in all kinds of grain, and some are more limited than others. 'The Chicago, Milwaukee, Duluth, Minneapolis, Iransas City, and St. Louis exchanges brought suits to test the constitutionality of the new law, but all of them have been suspended in the lower courts now, remaining in their original status as a temporary stay against the Government, except the Chicago suit, where, when the question of granting a temporary restraining order came up before the district court a few weeks ago, the court on its own motion dismissed the bill of complaint of the Chicago Board of Trade, denied the injunction, and granted an appeal to the Suprene Court of the United States, and on Monday of this weck a motion was presented to the Supreme Court to advance the hearing of that case. The Government, of course, is very anxious to corperate in gretting it decided prompt $y$. The other cases will await the disposition of the Chicago Bond of Trade case. 


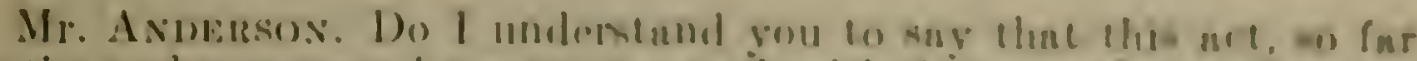

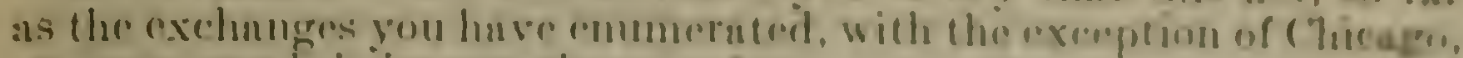
are concertued, is inoperative now?

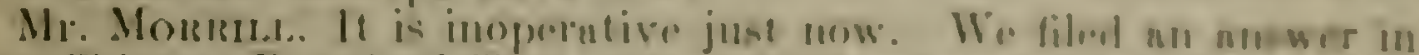

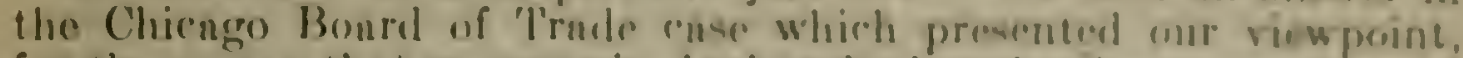
for the reason that we were in doubt whether the (invernument rould nfford to admit any of the sllecrutions in the hill of complame filed by the Chiengo Bourd of Trude, and beenuse the Chienge Bomal of 'Trucle attempts in its bill of compluint to negutire the allogations

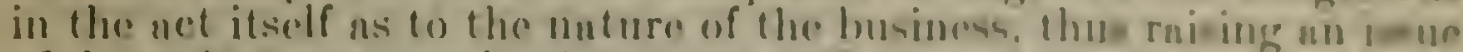
of fact; but upporently the court ut Chicuge took the viros thint it might be possilhe for the Supreme Court of the linited stuen to in he sufficient judievint notice of the fucts to puss upon the bill of complant without a henring. As a muttor of fact, a henring in the lower cours.

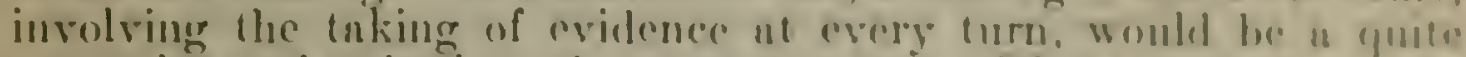
cxpensive and quite long drawn out mutter. Wro huse continumels during the past your kept a man at Chienge und Minnenpoli-, in unfliipation rither of litigation or of enforeconent of the law, gottine therether all the information that he could get us to the eperntion of both of those boards of trude, using the records of the Buroun of Internal Revenue to a considerable extent. und thus getling urquainted with the various commission men and other trublos on the

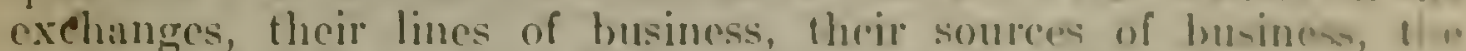
methorls that they employ in doing busimess, ete.

Mr. Axuensos. Th whint extent has the prohibition of pule nod calls redueed the number of transactions or narrowed the market?

Mr. Monmla. We have no record of the number of puts and enlth, but that does not affect the transactions in the pit at all. The put and call transactions were outside of the pit. I do not ser that the climination of puts and calls has in any way nurrowed the markot, nor that it has in any way operated to the disadruntuge of the market.

Mr. Andersox. I have recently had a mumber of men (o complain very bitterly because of the alleged eflect of this act on the markit. But I do not sce how that could possibly happen.

EFFECT OF ACT ON TIF MAIKET.

Mr. Morini.r. I have some concrete facts on thut subject that I think will answer your question. Or men have been at work getling facts, and I think something con be said nbout that. Taking the Chiengo Board of 'Trade, the total number of hushels of whent futures sold during the eight-month period in 1922- lhat is, during the first eight months ending with August-were $, 5,04(1,122,000$, ns compared with $7,784,822,000$ bushels for the sime periul in 1921. That is an incrense of approximntely $300,000,000$ bushols during these eight months.

Now, as a matter of fact, our figures up to date indicate that in all futures-that is, including corn. onts, and other grain- there has

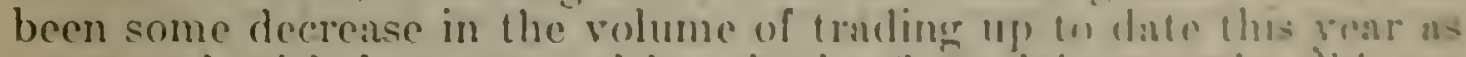
compared with lnst yenr, nlthough the liset ejghe monelse fid not show any decrease in wheat, but, on the contrary, show ard an increase. We think, however, that that is not due (o) the law. Wi, think al-o that there are a good many things bring saicl about the law by persons 
who have, perhaps, not read the law at all, and who do not know what it provides. As a matter of fart. what this law does is to say to those exchanges. "You must operate under the supervision of the Federal Government, and you nust see to it that the prices on the market are not manipulateil or controlled, that there are no attempts to corner the market, that there shall be no dissemination of false and misleading information about the crop and market conditions, that you keep adequate records showing all the facts of transactions, and that you shill make such reports as the Government may require from time to time showing how the business is going on, plus a requirement that you must not discriminate against cooperative associations of producers solely upon the ground that they are paying patronage dividends.

I think that is a fair statement of what the law requires, and I do not know of any reason why anyone should look upon that as an extreme exercise of gorernmental power, or as giving power to do anything that ought not to be done. The grain futures act is a means by which the Government will be enabled to say what are the facts as to the amount of business, and how it is conducted on the exchanges, and will be able, if necessary, to formulate a basis upon which to prepare legislation that will get at the real needs. In other words, it puts the Gorernment in a position to get the facts.

Last year the case that was brought before the Supreme Court was taken up in December and decided in May, and this year it is up in November, and I see no reason why the Supreme Court should not decide it as soon or sooner than it did last year, particularly because of the fact that last year it was apparent that the decision was delayed by reason of the child labor decision.

Mr. Axplizsox. That would mean, then, that if the decision was favorable to the Gorermment's contention, the enforcement of the act would begin about the time the appropriation for the fiscal year covered by this estimate would be available?

APPROPRIATION FOR 1924.

Mr. Mormul. Yes, sir; it should be in full swing by that time. The estimates presented to you now are precisely the sime as those for this year.

Mr. Axpersox. And your plans will be the same?

Mr. Monmil.. The same plans will also apply. I see no reason to alter the plans, because there has been no alteration of the conditions that would require a change of the plans. We are expending approximately $\$ 30,000$ this year on investigational work and in getting up all sorts of information that will be of use, both in connection with the litigation in the Supreme Court and in connection with giving the work active supervision when that time comes.

Mr. MacieE. Do you expect to spend the appropriation of $\$ 103,600$ for this fiseal year?

Mr. Monmil. I drew up the estimates, at the time they were drawn up, upon the hasis that the same estimates would be required from the standpoint of giving supervision to the principal markets and getting up the information that will be necessary from the investigntionul standpoint to support the conclusions that the Sereretury of Agriculture might draw from the economic standpoint.

Mr. Máes. That does not nnswer my question. 
Mr. Axurksos. I understomed you 10 sat that of the approprin-

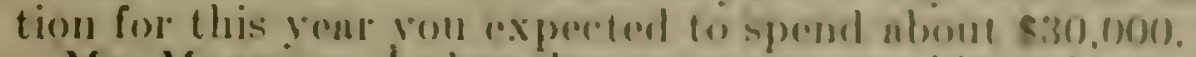

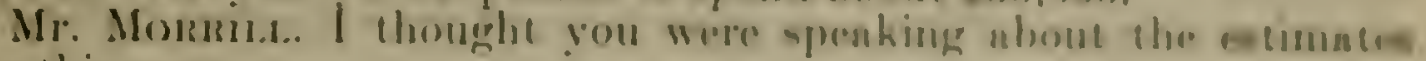
for this ront.

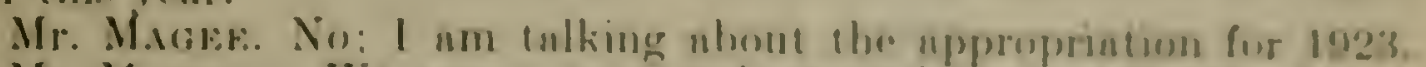

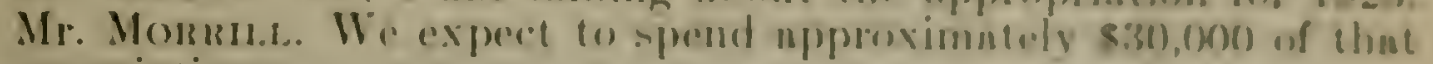
npproprintion.

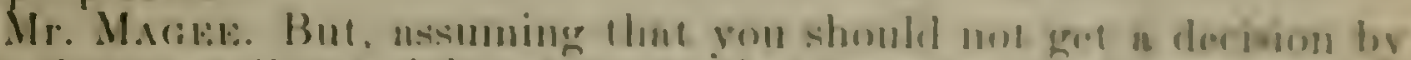

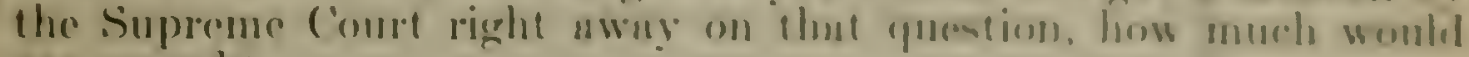
youl spent?

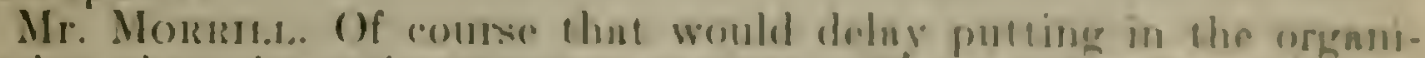
zation that the estimntes contemplute. Wre would not pout in the orgnnizalion thut the estimntes contemplute unlese the suprome Court should held the law to be constitutionul.

Mr. Magis: Jou could hardly justify the upproprintion of nns

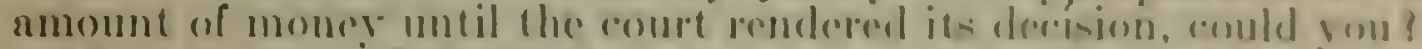

Mr. Monmm.1. Only in the why we ure doing it unw, ly putsing ourselves in a position to hold our own in the litignton mol in

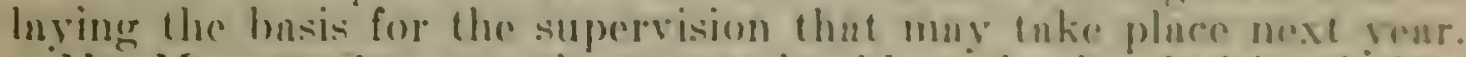

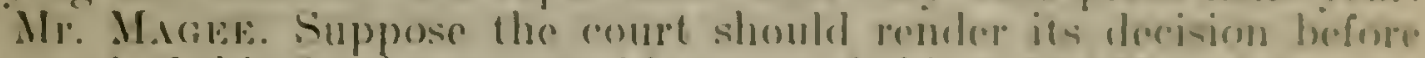
the end of this fisenl year, would you need this $\$ 103,100)$ to take rare of the act for 1924 ?

Mr. Monzin... Yes, sir.

Mr. Macer. Suppose you should not get n decision!

Mr. Monzar.. If we should not get a decision, it would be lestened by the length of time that the decision was delayed.

Mr. Mater. If the decision were molverse, you would not need the money at all?

Mr. Monrne. No, sir. In that rase we would mot spend the money at all, beconse if the decision should be arlverse, I um inclined to think that it would wipe out the whole law. That was not the ease in the decision on the other law.

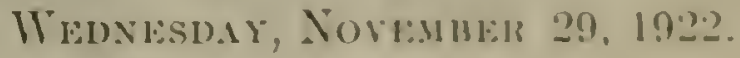

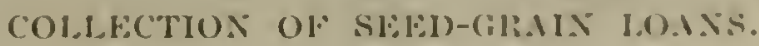

\section{STATEMENT OF MR. LEON M. ESTABROOK, CHAIRMAN SEED LOAN COMMITTEE, UNITED STATES DEPARTMENT OF AGRICULTURE.}

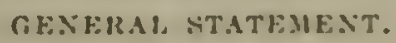

Mr. Estabrook. Mr. Chairman, continued drought in the Northwest over a series of years cuused such finnuncint distress, especially to the furmers who were mable to make crops. and who foumd it necessary to mortgnge all of their ussets, that in the spring of 1921 many of them were without seed or money or eredit with wheh to buy seed. Congress made an appropriation of $\$ 2,(1)(0,0)(0)$ in the sprime of 1921 , and a further npproprintion of $\$ 1,300,000$ in lhe spring of 1922 , to meet that situntion. Of the $\$ 2.000,00()$ aratable in 19291 there were louned ibout $\$ 1.94 .5,708$ to 13.93 .5 furmes in the States of Idaho, Montnm, North Dakotn, and Washington. In the spring of 1922, from the $\$ 1,500,000$ appropriated for soed-gran lous, there 
was loaned about $\$ 1,481,787$ to 11,968 individual farmers in Idaho, Montana, North Dakota, South Dakota, and Washington.

Mr. Anderson. What was the maximum loan allowed under that law?

Mr. Estabrook. $\$ 300$.

Mr. Anderson. In both cases?

Mr. Estabrook. Yes, sir. Most of the loans were for considerably less than that. The applications were scaled down to make the money go as far as it would. In the autumn of 1921 an attempt was made to collect the loans that were made that spring, and again in the autumn of 1922 we have carried on a most energetic campaign to collect as many of those loans as possible. Up to November 4 . 1922 , we had collected of the 1921 loans $\$ \$ 22,00^{7}$, or 42.3 per cent of the amount loaned in 1921. Up to the same date, namely, November 4, 1922, we had collected of the amount loaned in the spring of $1922, \$ 450,662$, or 30.4 per cent of the amount loaned in the spring of 1922. If those figures are totaled it will be found that in 1921 and 1922 we made 25,903 individual loans, amounting to $\$ 3,42 \overline{7}, 494$, of which there has been collected to Norember 4, 1922, $\$ 1,272,666$, or 31.1 per cent of the total. That leaves outstanding and unpaid and yet to be collected $\$ 1,123,703$ of the 1921 loans, and $\$ 1,031,125$, of the 1922 loans, or a total of $\$ 2,154,827$ for the two years, or 62.9 per cent of the total amount loaned yet to be collected.

I have here a statement showing the number of loans and the amount collected in 1921 by States and counties, and a further statement showing the amounts loaned and the collections to November 4,1922 , by States and counties for both years, with a summary of all.

Of the $\$ 2,000,000$ appropriated for seed-grain loans in 1921, $\$ 1,940,002.20$ was loaned to farmers, according to this statement. and $\$ 52,464.98$ was used for administration expenses in making and collecting the loans, leaving an unexpended balance of $\$ 7.532 . \$ 2$ to go back into the Treasury. Of the $\$ 20,000$ arailable for administration expenses of the seed-grain loan appropriation for 1922, $\$ 19.509 .4 \mathrm{~S}$ was actually expended; $\$ 2.61$ remains as a liability, making the total expense $\$ 19,512.09$, with an unexpended balance which will be returned to the Treasury of $\$ 487.91$.

INTEREST ON LOANS.

Mr. Andenson. Do these loans carry any interest?

Mr. Estalmook. 'They carry interest at the rate of 5 per cent.

Mr. Anderson. Have there been any instances in which interest las been paid!

Mr. Estabrook. There are a good many instances in which interest has been puid. A complete record of that is leept in the seedgrain loan oflice at Grand Forks, N. Dak.. but the stntement from that oflice to which I referred does not show the interest collected.

Mr. Andersox. What chance is there of collecting the remainder of this money, or some portion of it?

Mr. Estabrook. The collections are coming in at the rate of 815,000 per day. At the present time they are running around seventy or cighty thousund dollar's per woek: It raries from week to week. We had expected much lareger retmins because of the grood crops. The North J) alota (reps this year were 27 per cent better 
than they hud been for a series of gense, mol the r rope in Jlontana

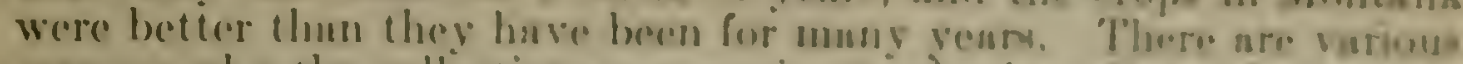

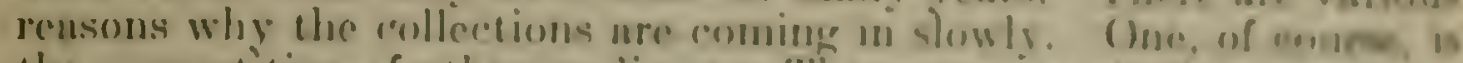

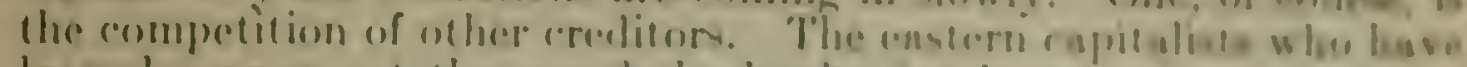
louned money ont there and the banks, implement companos, and

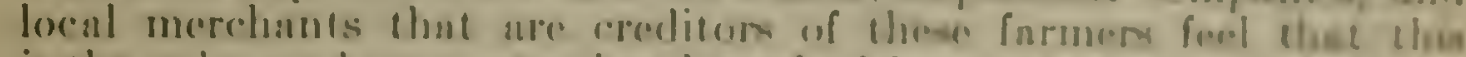

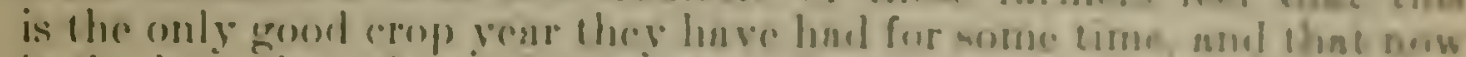

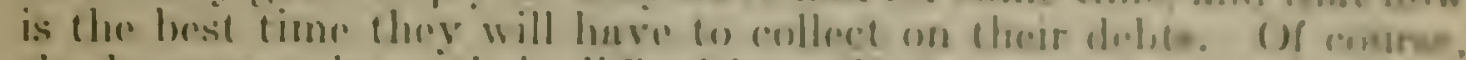

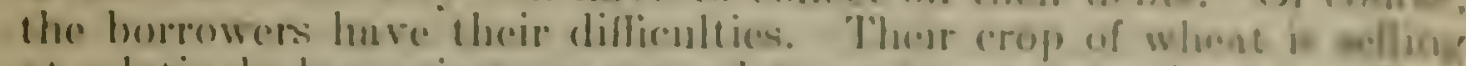
at relatively low prieces, or around so or 4.5 centa per huebol They

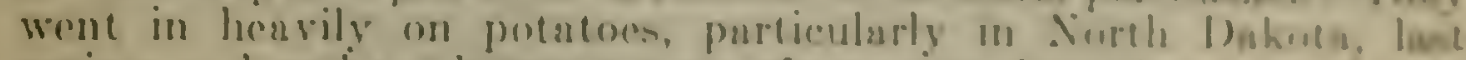

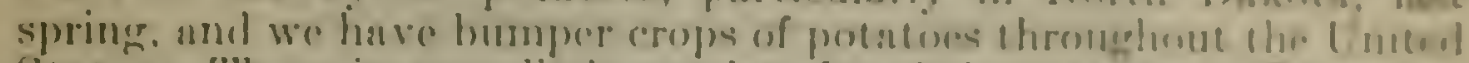

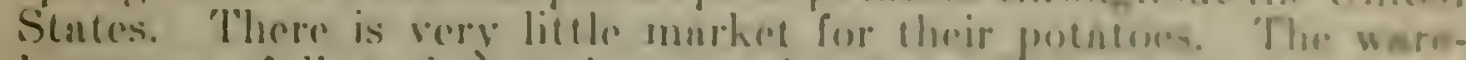

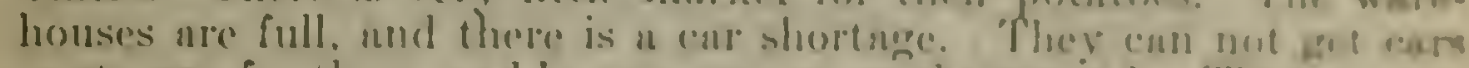
or stornge for them, and buyers ure not on the gronind. Thes no not

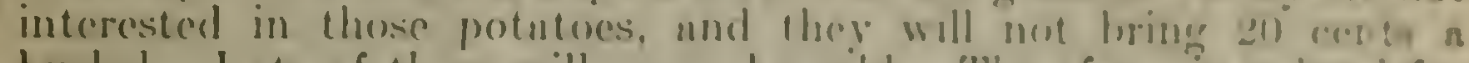
bushel. Lots of them will never he silld. Therefore, it is hand for

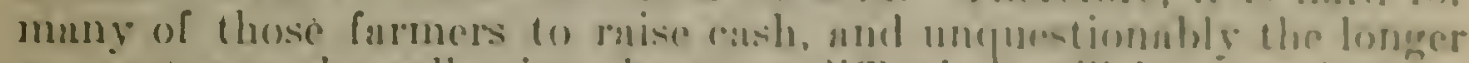
we postpone the colleretion the more diflienlt it will be in collect.

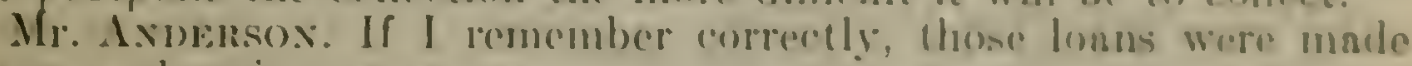
upon secel-gruin mortenges.

Mr. Estannook. They wore covered by sped-grain moreguges.

Mr. ANInERos. In arery case?

Mr. Estanzook. Yes, sir.

Mr. Axmensox. In that erent, it would secm then where a man made a (rop suftieient to pay the lonn, the money conld he collerend

Mr. Estambook. We can enforer those 1922 mortanges, heranter we lave the 1922 crop to fall back on, and we are presing those rers virorously. It will be much more diffecult to collect the unpand 1921 lomis.

Mr. Axnersos. Of course, there the security is ermene.

Mr. Estabmook. Yes, sir. We tried to eret is many renewal mortgages on the 1922 crops covering the 1921 loans as we could, but many of the 1921 borrowers did not respond. fniled w arrange for the cxtension of their 1921 lonns with a mortgnge on their 1922 crop.

Mr. Becnaxax. How much of the money lonned in 1921 lnve you collected in 1922?

Mr. Iistabrook. I can not gire you the exact figures. We har the sect-grnin lonn office at Grand Forks to telecriaph cach Monday morning their collections for the week, and they follow that up with a written statement. The weekly collections for the werk ending October $14 \mathrm{rm} \$ 31,316$ for $192 \mathrm{i}$ secel-granin lons as compared with $\$ 61,000$ on 1922 louns. Or about hnlf us much for 1921 as for 1922. For the week ending October 28 there were collereted practicully $\$ 27,000$ on 1921 loans, and $\$ 71,000$, or more than twice as much, on the 1922 loans. For the next werk the collertions were $\$ 37,000$ on 1.921 lonns and $\$ 71,000$ on 1922 lonms. It is running at about that rate, or nbout twice as much is being collected on the 1922 lonns as on the 1921 loans. Whereve we conn. we tre applsing any remittances that come in on the 1921 seel-ersan lons, with the iden that we will stand a better chunce to renew the 192.2 Ionns with security than the 1921 loans. 
Mr. Buchanas. A great many of those loans in each year were made to the same people, were they not?

Mr. Estabrook. Some of them were, but it is hard to say just how many.

Mr. Magee. How was the 1921 crop?

Mr. Estabrook. The $1921 \mathrm{crop}$, as a rule, was a partial crop failure.

Mr. Magee. What was the percentage?

Mr. Estabrook. I do not recall just the percentage, but there were several thousand farmers out there who made no crop at all.

APPROPRIATION ASKED FOK COLLECTIONS OF LOAXS.

We are asking for an appropriation to continue the work of collections in the next fiscal year of $\$ 20,000$. It is a question of just how vigorously Congress wants the department to press these collections next year and how much money it will take. We had an emergency appropriation of $\$ 50,000$, beginning with July of this year, for collections. Up to June 30,1923 , we have actual liabilities and estimated liabilities amounting to $\$ 37, \$ 46$.

Mr. Axderson. Out of the $\$ 50,000$ ?

Mr. Estabiook. Yes, sir.

Mr. Andersox. This is in addition to the $\$ 19,000$ you spent?

Mr. Estabrook. Yes, sir. Apparently we will have about $\$ 12,000$ to turn back from the 1923 , but $\$ 20,000$ will not enable us to carry on as vigorous a campaign next year as we are carrying on this year. $\Lambda$ the present rate of collections we will exceed $\$ 1,000,000$ in the next two or three weeks, so that for every dollar we spend in maintaining a force of ficld agents up there and in sending out circulars we get back many dollars in collections.

Mr. Bromakis. Next year you will not have any sccurity whatever, will you!

Mr. Estabrook. We are preparing to renew loans where the borrower can submit satisfactory evidence that he is unable to pay his loan, and in such cases will take a mortgage on the 1923 crop.

Mr. Buchanax. Will you renew the mortgages?

Mr. Estabizook. We will extend the loan and take a mortgage on his 1923 crop.

Mr. Buchasax. So that you will have some security next year to proceed on?

Mr. Estabrook. Oh, yes; surely.

Mr. Mages. Provided they will give security?

Mr. Estansook. They will not get an extension of their loans unless they give a mortgage on their next yoar's crop. We are meeting with this little difliculty: The banks are pressing for payment and pointing out to the borrowers the fact that the Govermment only charges is per cent interest while they are paying a very much higher rate on their other loans, so that it is to their adrantage to pay off their other debts and let the Government indebtedness stand. 'Then, too, here are many people who advise the borrowers to simply lold back, saying that it is only a question of time when Congress will cancel these foans and they will not have to pay them.

Mr. Buensass. It was pretty late when we made that appropriation. Do you linow what pereentage of the farmer's had already been 
supplied with soeds ut the coppense of bankers and how murle of thie money went to the hankers?

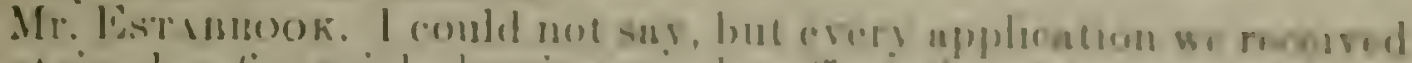

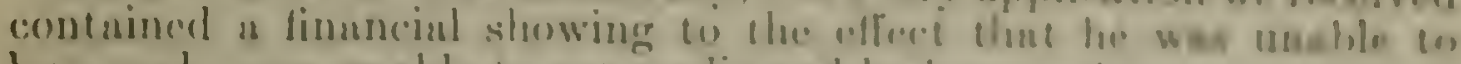

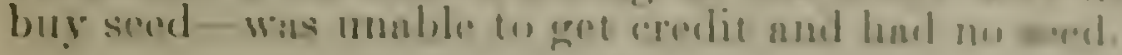

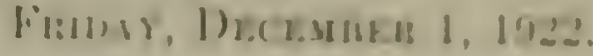

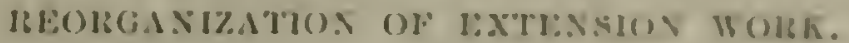

\section{STATEMENT OF HON. HENRY C. WALLACE, SECRETARY OF AGRICULTURE.}

Mr. Axdrason. Gentlemen of the cemmutem, the Secretar of Agriculture is here this morning, and I an sure the commithe will be very oflud to henr any statement thut he cares to make with res prect to the Budget or any items in it.

Secretnry Watsace. Mr. Chnirman, I hure nut enme with the thought of taking up much of your time. I gather that rour hearings have been satisfuctory with the various people from the department. They have gone into the mutters in which they ure particularly interested and about which they are well informed with reapect to the detrils. I will not undertake to go into those mutters. but there are one or two subjects that I want to mention. 'The lirst is the reorganization of our extension work. I simply wish to sur that we have not submitted that plan to you without very full considerntion of it ourselves. That is to sny, we have not casunlly lonked over the present organization that we have there and decided that n new one would muke it a lot better, and worked up a scheme from that standpoint, but we have given time to this plan which is now submitted, and we ure very much convineed that it will bring about economy in the way of expenditure. It will not only resule in economy but in very greatly incrensed efficiency in the ndministration of the work. That is really the chicf argument for it - the increased eflicieney with which the work may be conducted, rather than the umount of money sared, although there will be some very substantial savings as the result of that better system of organization.

I am very fully persuaded that that reorganization plan in u wi-e one. You will notice that we are asking for two places with salarie of $\$ 5,000$, ane for the director of the extension work, and the uther for the chise reditorial man. "That proposed direcetor of cestension work would correspond to the director of scientific work and director of regulatory work, which positions you luve ulready andiorized. Under the close personal direction of in efficiont mun, iur retension work ean be immensely strengthened. Wo have hand the majur attention of such n min on that work during the pust your, numl, an a result, I think wo have made a very substantial improvement in the administration of the work. That has been dene. hewever. hargely through the close personal attention given to it hy disistant secoretury Pugsley. Mluch more could have heon accomplished with the ty gre of orgmization we are now asking. Iho had had large experience in 
extension work before he came here, and, in fact, that was one reason why I was particularly anxious that he should come-that is, because of his experience in extension work and publication work as well. He has given the major part of his attention to that work. and, as a result, we have made real progress under the present plan, but it has been working toward this reorganizetion all the time.

ORRA.IIATIOS UF A STRUNG PULHIATION SEIRICE.

The other position for which we are asking a salary of $\$ 5,000$ is for a man who will be, you might say, a managing editor or editor in chicf of the publication organization. Our work in that respect has never been as strong as it should be. 'The salary for that position has been, as I remember it, but $\$ 3,000$, and when you reflect upon the amount of money we are expending and the tremendous importance of our publication work, the manner in which the publications are put up, and the manner in which the material is presented, I think you will agree with me that we really ought to be able to pay $\$ 20,000$ or $\$ 25,000$, if necessary, to get the right sort of man to do that work. Even at that, he would sare us money. I suspect that if we can get a really capable man for the amount suggested here, and I think we can, and give him six months or a year in which to get thoroughly acquainted with it, we will be able to make a saring of from $\$ 50,000$ to $\$ 100,000$ a year in our publication work. That would be just my guess from my knowledge of the publishing business. He will be able to save on what you might call the mechanical side of the work, but, more than that, he will be able to save in the manner in which the various publications are presented. He will be able to sare in the matter of pages.

We have made sereral substantial savings, for example, during the past year just from understanding the mechanics of the business. The Printing Office can print most economically in certain units of folios, and we found that there had been a great mass of waste through the sending out of publications that might run over that profitable unit just one page. In that case, it might be necessary for them to add three other pages, or, in some other cases, seven pages, and all because there had not been close cooperation between the one who prepared the manuscript and the man who did the actual printing.

Mr. Jiccinas. That is, in the matter of printing units?

Secretary Wablace. Yes; in the matter of the mechanical priniting units, and the editor is the man who should look after that. For instance, we will say, a publication would make 17 pages, but a competent editor could rearrange it and eut it down so as to get it. within the unit of 16 pages; or, if it should run 19 pages. he might print a 20 or $2 \cdot 4$ page pamphlet as a result of that arrangement. There is great waste in that respect. There would be a question of whether it could be reduced to 16 paces, or, if that could not be done, how those additional pages could be used to the best advantage so as (o) get somethingr out of them instear of wasto paper. It is important that we hare a capable man at the head of the editorial work, and I mm very anxious that this position shall be authorized. I know that it would be in the interest of econonty and of the eflicient romduct of our business as well 


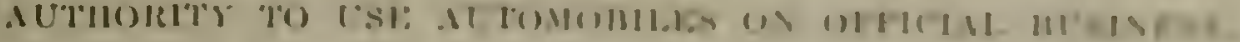

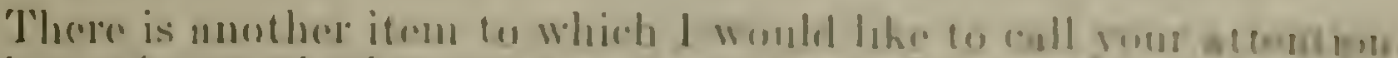

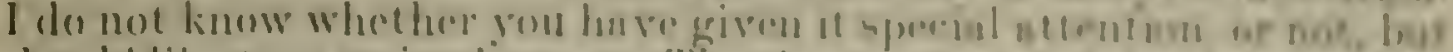

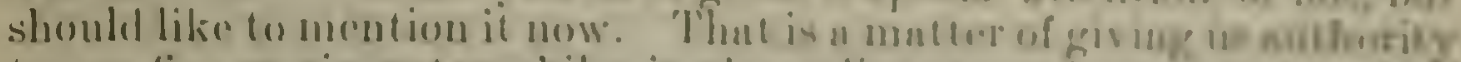

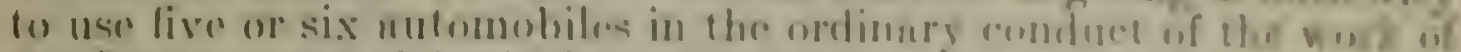

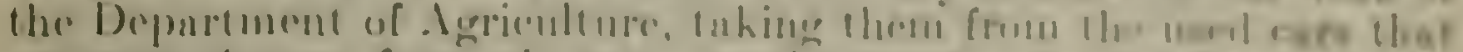

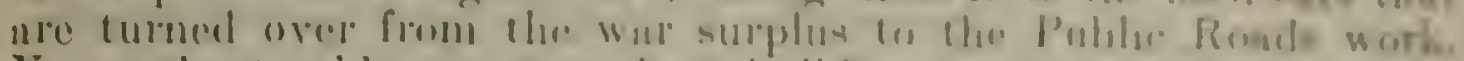

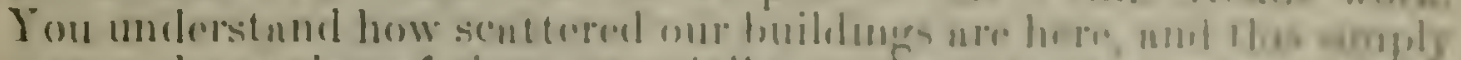

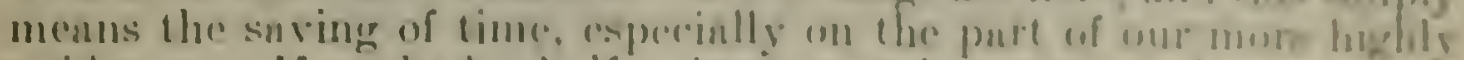

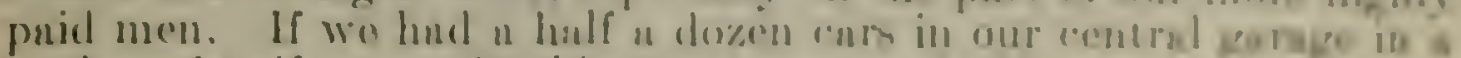

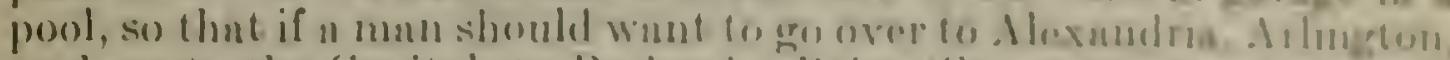

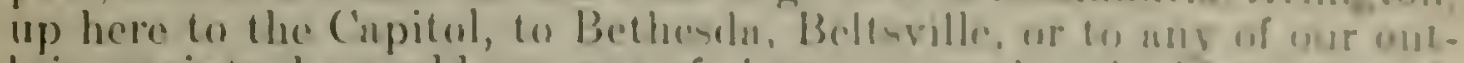

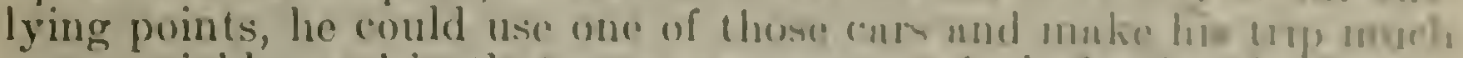

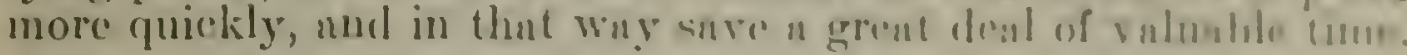

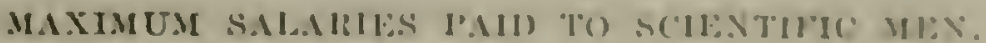

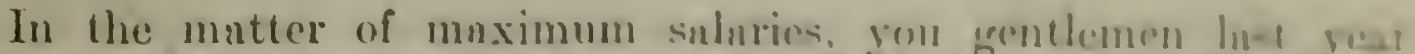
nuthorized nn incrense in the mnximum which might lu puil to scientific men. I secured this morning in memornulum of the ne. we have mude of thut nuthority, und I find that under it wo nre currs ins only 6 men nt $\$ 5,500,1 \$$ at $\$ 5,000)$, und !) at $\$ 1, \$(0)$. F'rom that you will see that we have not nbused the authorization that you grove us. The eflect of this has been tremendously helpful. It wis notion to the people all down the line that there wis an opport unity lo advance up to $\$ 6,500$, us they becmme gunlified to fill tho-1 puitioms. and it has contributed in a most helpful wa to build up the mornte of the department. In the first plnce, the mere recounition of the importance of scientific work by the increase of this maximum huhad $"$ very fine effect on all of our depurtment people. I lut of them have felt $n$ if Congress and the hends of the Gurernment departments had just gone nway und forgotten them. A lot of them huve been giving their lives to scientilic work, and they lonk npon the action you took last yeur as a recoguition of the inportaner of the ir work. Doctor Ball will spenk to you more in detnil nbunt that. I want to cxpress my appreciation of your netion in regnud (n) thisalary limit and my acknowledgement of the helpful effect that it has been to us.

I think our budget carries a request 10 authuri\% us an increwn. slightly the number of places to which we mny puy uf few of the hiefler suluries, and Doctor Ball will speak to you about that also.

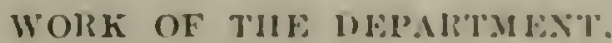

On the whole the department peuple during the pant year hase. I beliere, done very meritorions work. We have sut biens ahle per come to you mol ninke reports corering n number of definite thum completed, or as many things completed ns wo would like en repurt.

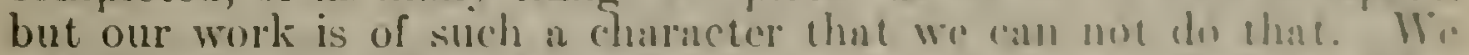
can not go out and at the end of a calendur year suy that we have

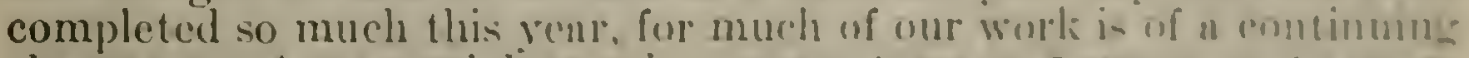

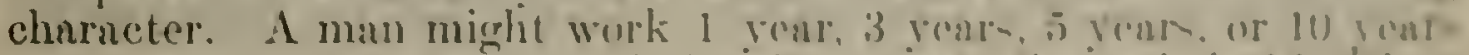
on some agriculturnl problem beforr it comes te the period of fruition. but I have been very much plensed during the past yenr with the 
manner in which our people hare carried on their work. I think we have expended the money that you gave us list year to good advantage and to the benefit of the country.

I think that is all I have to say, unless you wish to ask me some questions.

Mr. Anuensox. Mr. Secretary, I would like to ask you one question: As you have obserred the development of the department and its relation to agriculture generally, what is your opinion with respect to the probable necessity of larger appropriations to reduce the hazards to plant life from plant diseases and insect pests?

INCREASEI) APPROIRIATIONS.

Secretary WaLdace. Gentlemen, I think you had as well make up rour minds now that there will be a necessity for probably steadily increacing appropriations for such purposes as the chairman has mentioned. That is to say, as our population grows and our agriculture becomes more intensive, and as the means and necessity for communication with the outside world increase, the number of injurious insect pests and plant diseases will increase right along, and we are going to hare a constantly inereasing fight against both plant discases and insect pests. That probably means steadily increasing appropriations for this purpose, or for eradication and permanent control measures.

Mr. Bucilavas. Is there not a mistake made in the department in rccommending only certain amounts, about as last year, especially in places where you have educated the public sentiment up to the point where there is enthusiastic cooperation on the part of the people in your cradication work? Where such a public sentiment exists, would it not be a better policy to use all the money necessary while the sentiment is good, because then the department could use its funels much more efficiently in stamping out or eradicating the insect pest or discase, rather than to continue it from year to yenr? If it is continued over a long period of years, will it not cost a great deal more money? For instance, in the matter of black rust in whent, our hearings show that the sentiment is in fine shape to cooperate with the department in stamping it out.

Secretary WaLLACE. Yes; but that is a little different from other (ampaigns, because in that case the cradication program is clearly indicatrel. In other cases it becomes largely a matter of continuing control. or in eflort to check or retard the spread of the pest rnther than to cradicate it. In the case of black rust in wheat, we have a straight eradication program.

Mr. Bromaxas. Thuse are the eases of which I am speaking, or those in which there is a reasomable hope for cradication.

Sircetary Wablace. Then it becomes a question of low much money, assuming that you have the money araibable, ean be spent in a theronghly eflicient. manner. That is the only question to be determined. there.

Mr. Buchaxax. I entirely ngree with you.

Mr. Axulison. We are very much obliged to you for coming up, Mr. Secoretary.

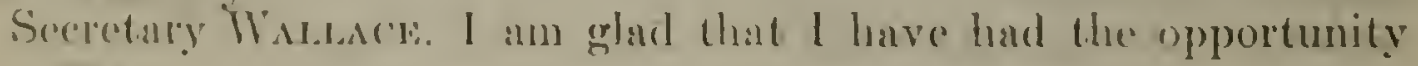
to ("omene. 


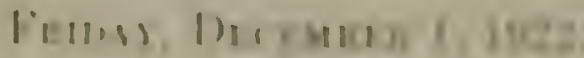

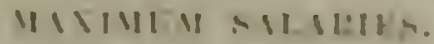

\section{STATEMENT OF DR. E. D. BALL, DIRTCTOP. OF SCIR.TIIIC WORK, DEPARTMEYT OF AGRICULTURE}

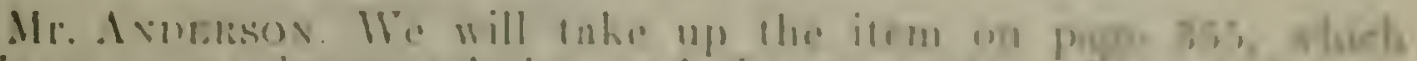

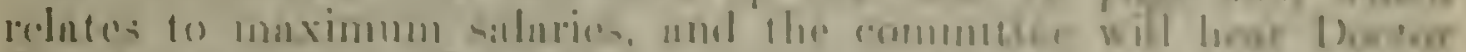

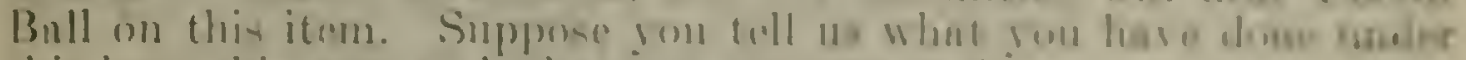

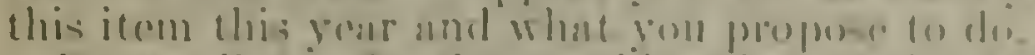

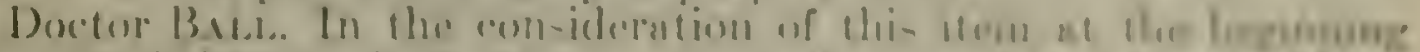

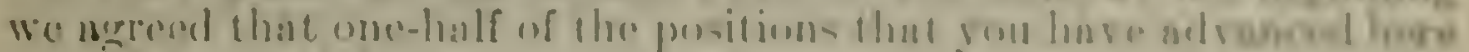

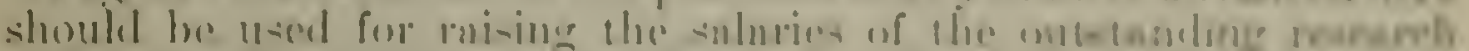

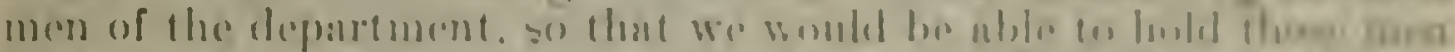

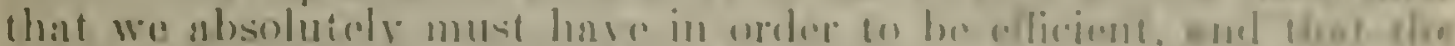

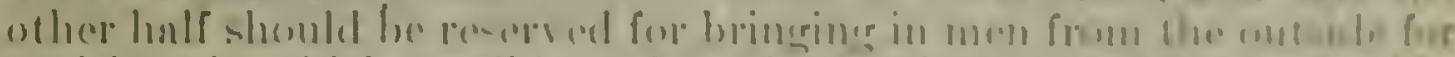

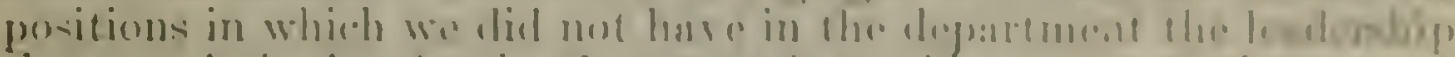

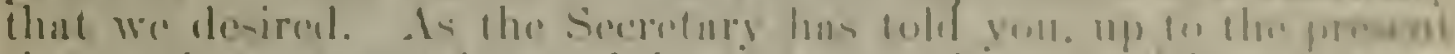

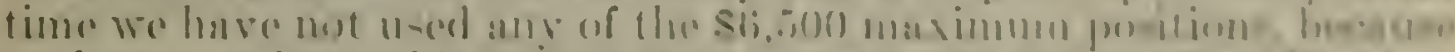

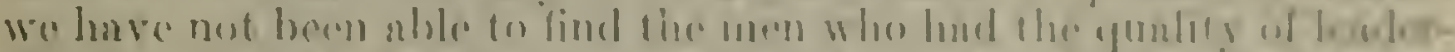

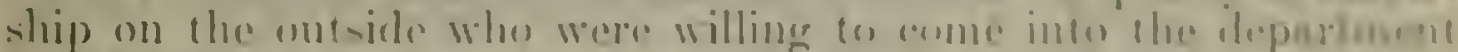
for $\$(0,50)$.

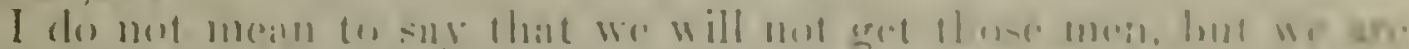

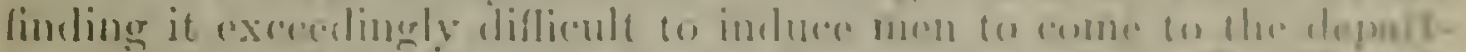

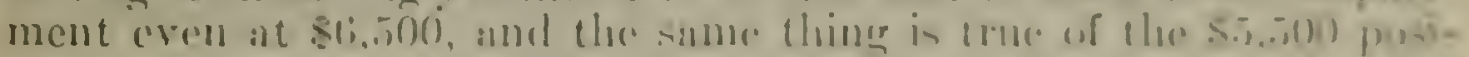

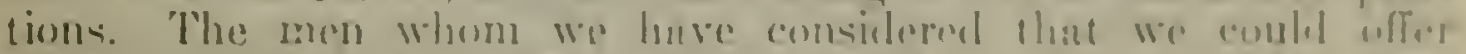

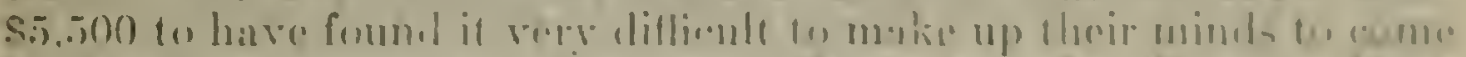

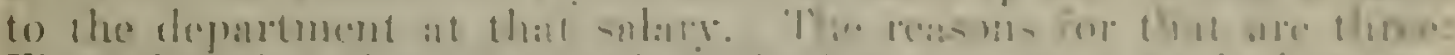

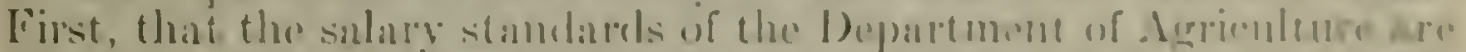

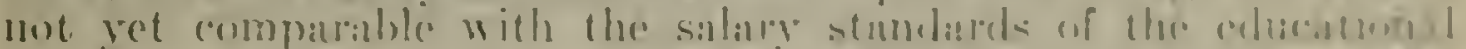

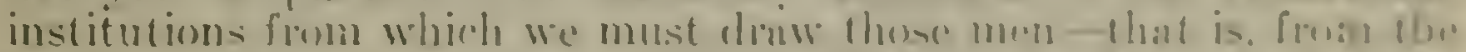

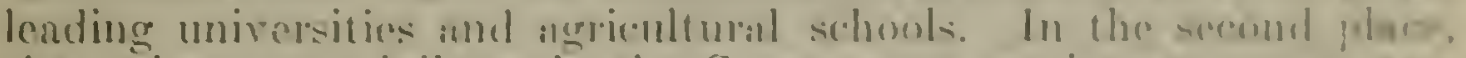

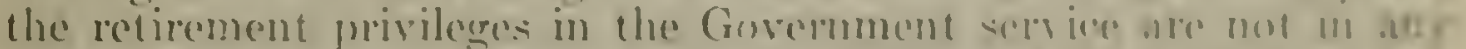

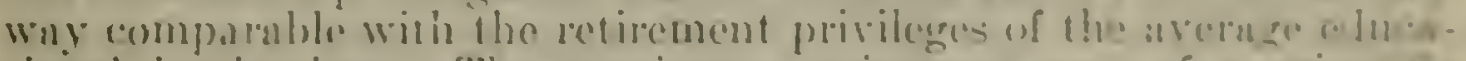

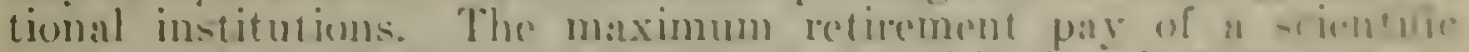

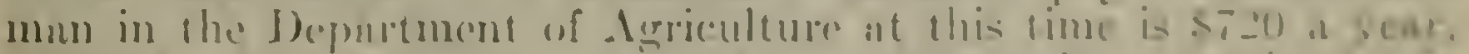
while the average retirement pay for at porfesine in an matiantum in

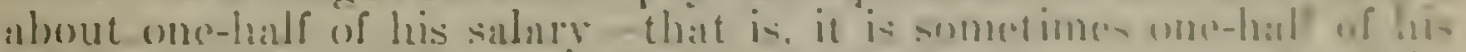

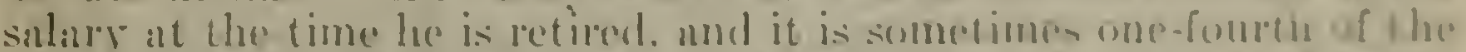

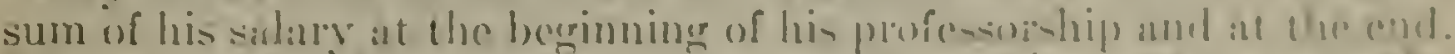
In any event, it is mush higher than the resirement pas on the departiment.

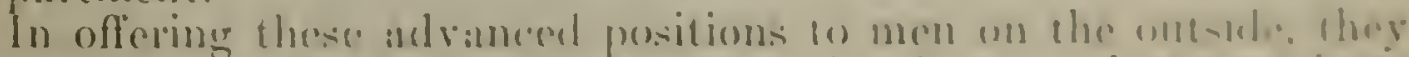

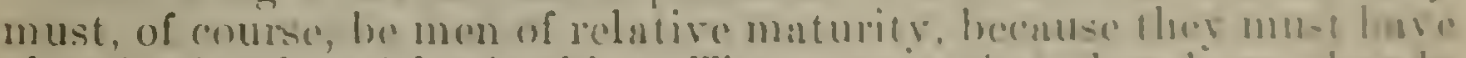

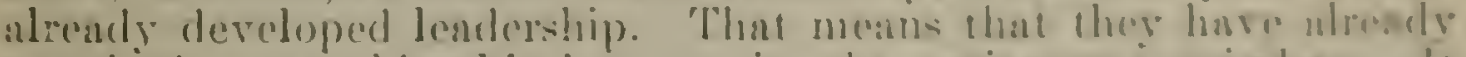

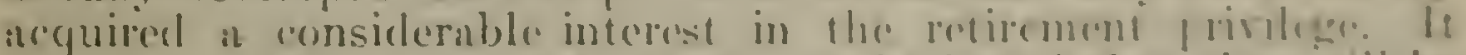
means, in other words, that it will not be long before thes will be

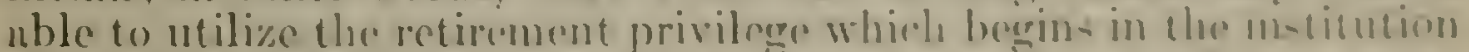

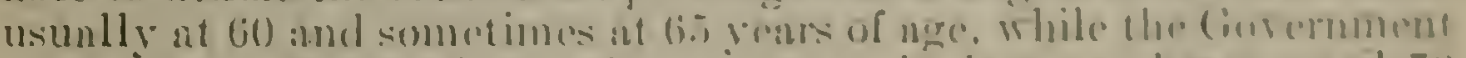

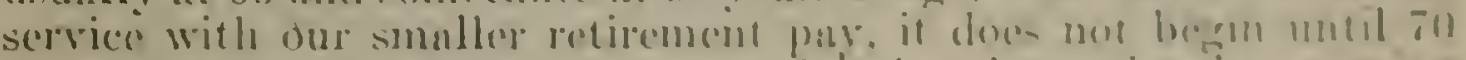

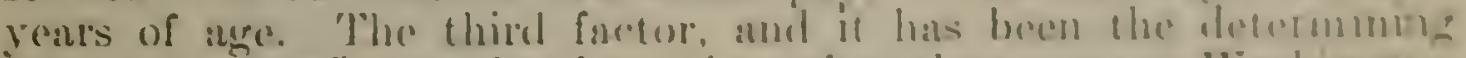

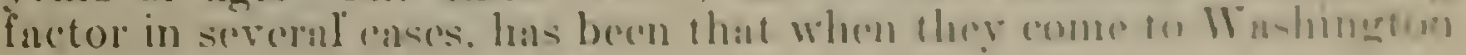


to investigate the cost of living they decide to stay where they are. I want to put this before rou simply so you can understand the problen we are facing. If the Department of Arriculture is to use efficiently and economically the money that is appropriated, we must have men of vision, men of ability, and leader's in their lines to carry on the work: so that this one little.item here on this last page is more important from the standpoint of the future work of the department than much that precedes it. I hope and anticipate that that situation will be finally relieved by the reclassification system, but the Department of Igriculture can not afford to simply mark time until such time as the reclassification becomes available to us.

Mr. Magee. Does the reclassification bill take care of it?

Doctor BALL. The reclassification bill, of course, would abolish this legislation.

Mr. MAGee. Will it give you sufficient salaries to get the men whom rou hare in mind?

Doctor BALL. That, of course, I can not say, because the reclassification bill has not been formulated yet.

Mr. MAger. But there is a reclassification bill pending, is there not?

Doctor B $3_{A L L}$. It is pending, but with three changes in salarics, so that none of us have any iclea what the prorision will be.

Mr. Magee. How do the salaries there compare with the salaries provirled in this section of the bill?

Doctor BALL. Is reported out of the Senate committee and under the consideration of the Appropriations Committee of the Senate at this time the salaries would be rery helpful to the department. I think they would reasonably meet the situation.

Mr. MAGEe. How do they compare in particular instances with these salaries?

Doctor BALL. They are very much better than these, because you have here a limitation of $\$ 5,000$, and in the present bill there are only 11 positions above that.

Vir. M.1GEe. What is the maximum?

Doctor BALL. $\$ 6.500$.

Mr. Mager. I mean in the bill.

Doctor BALL. I can not tell you exactly. It is above $\$ 6,500$, probably above 87,000 as a maximum for scientific workers, and approximately $\$ \$, 000$ for administrative heads. They recognize administrative heads above scientific work.

Mr. Axumesox. The Secretary made a statement in regard to the number of places that harl been used. Hare you those figures?

buctor Bsis.. I have them in detail. The Secletary had them summarized, and I will put the summary in the record.

\begin{tabular}{|c|c|c|c|c|}
\hline & $\$ 1 ; .501$ & sin, $; 00$ & $B,(1 M)$ & 4.400 \\
\hline 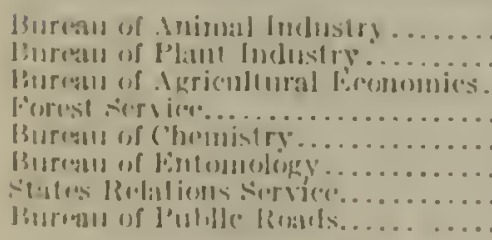 & & \begin{tabular}{c}
$\frac{1}{2}$ \\
$\frac{1}{2}$ \\
\hdashline
\end{tabular} & $\begin{array}{c}1 \\
1 \\
1 \\
1 \\
1 \\
2 \\
2 \\
2 \\
2 \\
1\end{array}$ & $\begin{array}{l}2 \\
0 \\
0 \\
5 \\
0 \\
0 \\
0\end{array}$ \\
\hline 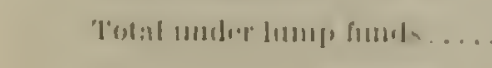 & Xime. & ii & 19 & 8 \\
\hline
\end{tabular}




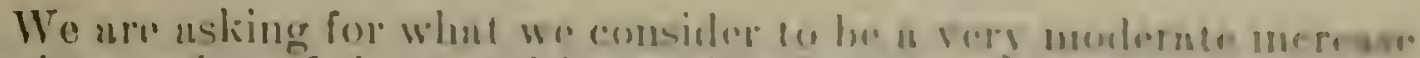

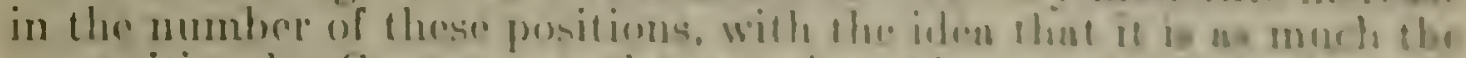

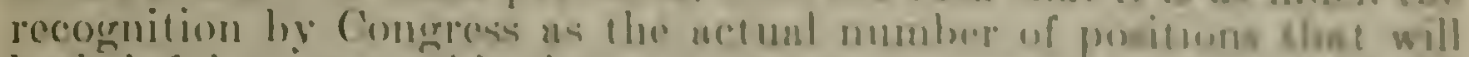

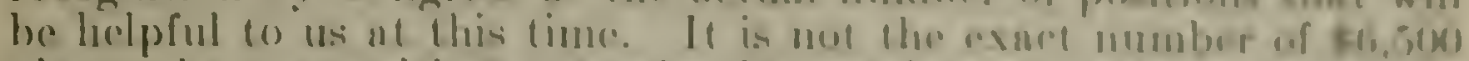

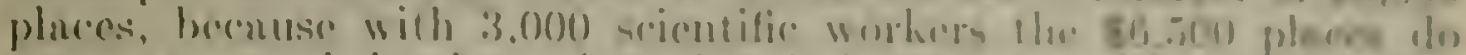

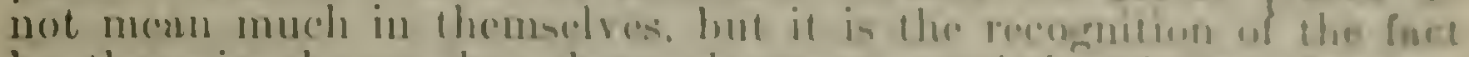

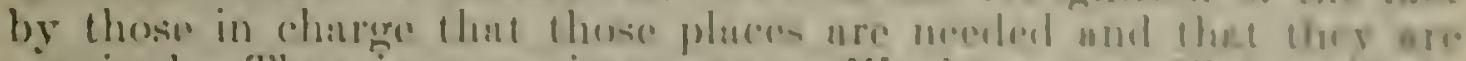

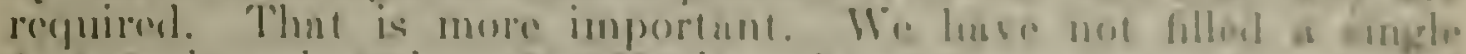

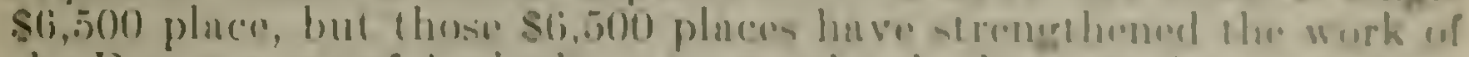

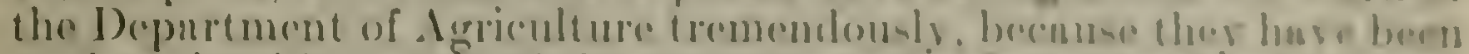

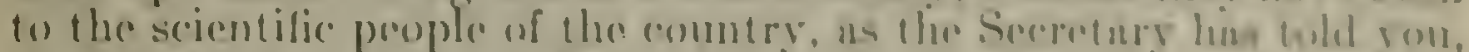

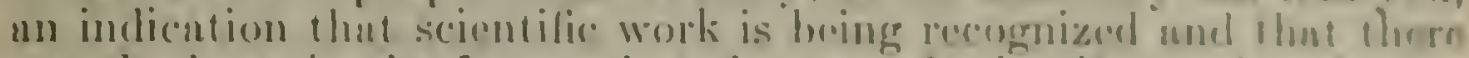

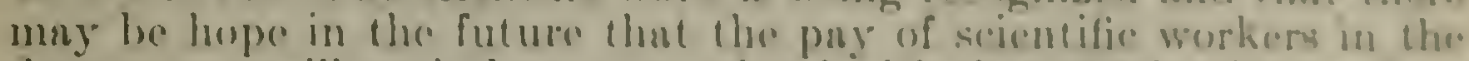
departmont will nernin bo put on a lovel with that of sciontifire worhers in other institutions. Tha sciontific workors of the dopenrtunont of

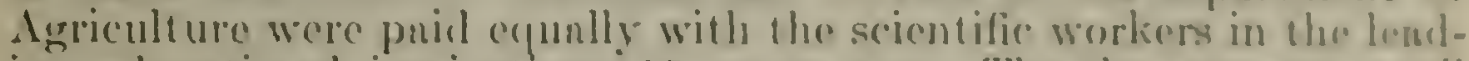
ing colucationul institutons 15 gears ago. 'Jhe doparmont, until last your, had hud no raises during nll of tha poriod in which tro. mendous udranees lund been made in other lines.

They wore getting seriously discourngerl, and to the point where

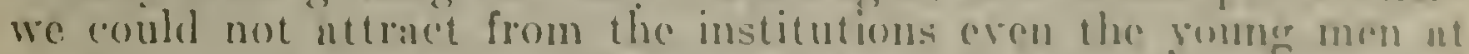
very murb higher sularies than wo wore justificed in puring fo mon of that charueter, becanse there was mo future. 'lis illumilnto: Wo hal a maximum of $S t .500$ up until last Iuls. Mo oflered five wall

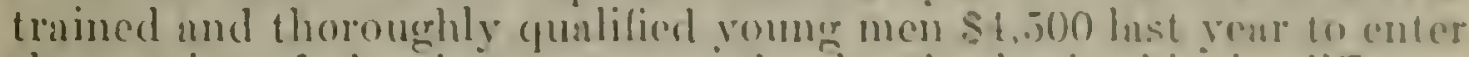
the serviec of the department and tuke the leadorship in dilforent lines, but evory one of those men refused to aceept such n po-ition becuuse $\$ t, 500^{\circ}$ wis the maximum and there was no future for them.

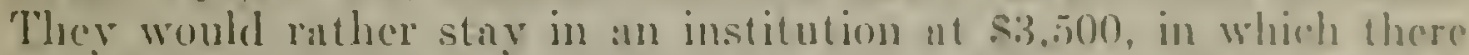
was an opportunity to work up to $\$ \$, 000$ or $\$ 10.000$. Howovere, this vear it numbel of those sume men hire alecepted those positions ut the sume sulury simply hecanse the Governmont hal ni leat indicated that theie would he an opportumity in the future for them. The result of this work has hech to help us matolially in gettinger gend

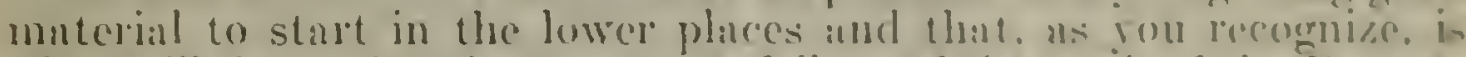
what will deternine the suceess or failure of thw work of the f)epartment of Igrivulture in $1005^{2} 20$ yeirs from now.

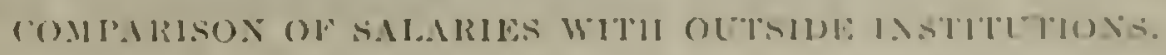

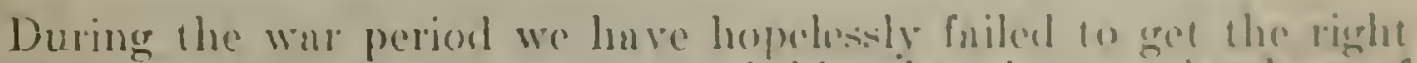

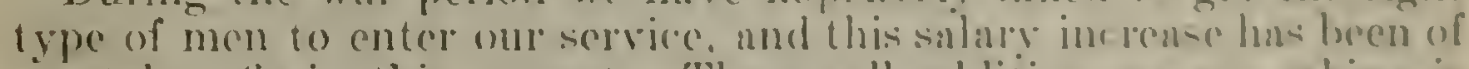

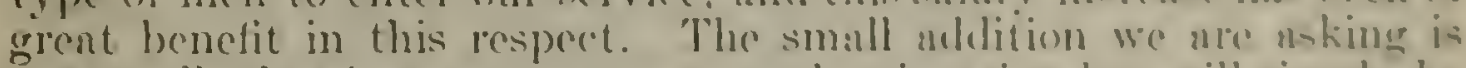
not at all what is neressary lo moed thr situation hut will simply bo an indication of the somtiment and will he holpful to 11. I gas lust year aomparisoms with a good many of the colugutional in-titu-

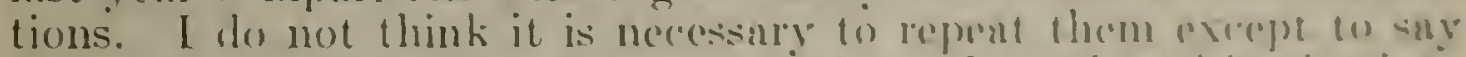
that in the leading colucational institutions. Iho comburel in-litutions

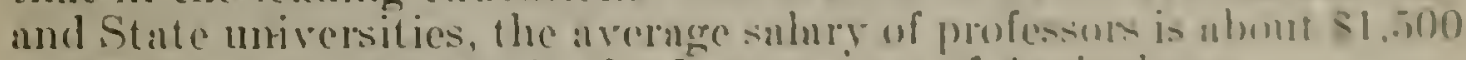

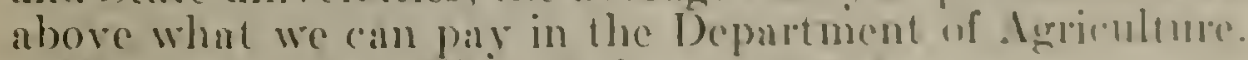

Mr. A.jolinsox. Mhat is that arerager!

Doretor B.w. 'Whe urernere sulary!

Mr. Ixverisox. Yes.

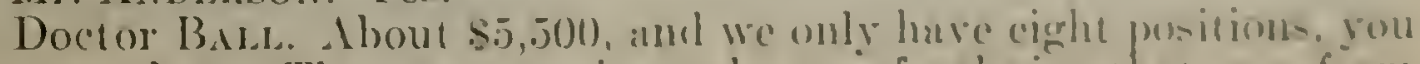
sec, at that. That arergac is made n! of salurio that rum froms 
$\$ 4,000$ to $\$ 10,000$. Now. uverages are deceptive, because it is not the arerage man who leads the work, it is the exceptional man, and all of these institutions have maximum salaries which are up to $\$ 7,500, \$ 8,000$, and $\$ 10,000$, and they are thereby enabled to hold the exceptional men by using those maximums.

During this year we have lost a number of our strongest men to other governments and to other institutions. On the 1st of January one of our strong scientific men is going out as the dean of one of the agricultural schools. 'That is good. We want to have the Department of Agriculture workers change back and forth with the State institutions; it should be so. But we want to be in a position to take them the other way. We offered the dean of a college a position with the department, but we could not get him; we simply can not get the learlership we want under the conditions that exist. We have no hope of getting a man who holds the position of dean in an institution, and yet those institutions are in a position to offer positions to our men. Five or six of our men have had an opportunity to accept deanships, but the fact that recognition was made of the possibilities and opportunities in scientific work in the department this year probably sared all but one of those men from aceepting the offers, while if our maximum had ramained at $\$ 4,500$ we would have lost sereral of those men.

Mr. Wason. Do you not think that if we made the salaries in your department comparable with the salaries of the large endowed institutions of the country you would still find the same embarassing situation of being unable to draw leaders from those institutions that you find now?

Doetor BALL. We would have difficulty, but we would be able to draw leadership from those institutions not quite as farorably located as to salaries. There is a wonderful opportunity for a man in taking charge of a great national project, but that does not make up for inability to keep his family in decency and comfort. If we could pay enough so that a man could live in Washington comfortably, just reasonably comfortable, the same way he can live in these other places, I would have no fear of our inability to get that leadership, but we must reach that point. We do not need to bid against commereial salaries and that would not be necessary. Then, some day we must consider the question of better retirement privileges for scientific men.

The present retirement net, as you understand, is entirely based on the great body of elerks; it was not intended especially to corer scientific men. It is fairly adequate for the arerage saluries of the clerical force, but it is absolutely inadequate as to scientific men, so that the first need is a good salary and then good retirement privileges. When that day comes, the Gorermment will have no trouble in holding leadership. I hope that the day will come when men will be moving back and forth freely between colleges, universities, and the Department of Agriculture, but we must have the day come when it is not all a movement out and not a movement in.

Mr. Buchanan. Have you any ielen as to how many scientific: investigators you have in the department?

Dochor Bas. We have apploximately $3,7 \cdot 10$; at least, that is the estimate made a year ago. () that same basis of liguring, all the other Government departments together lave about 3,200 . 
I.)

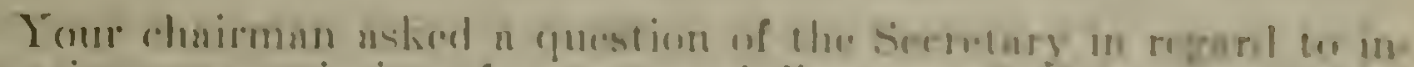

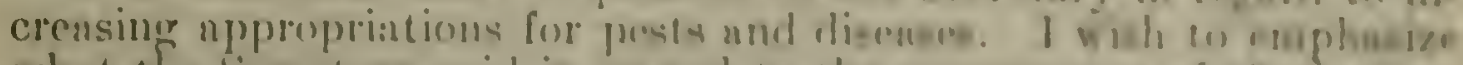

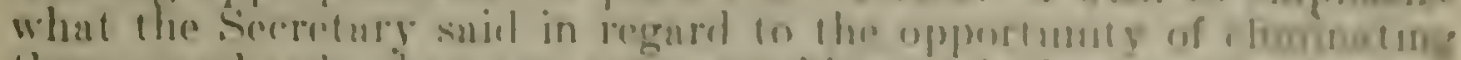

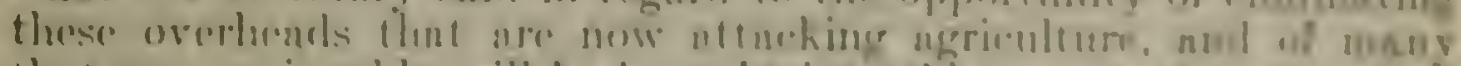

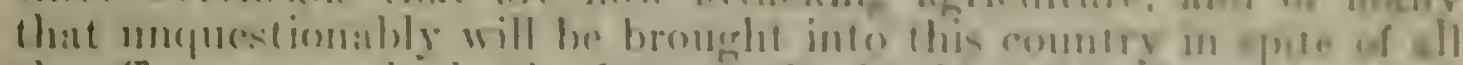

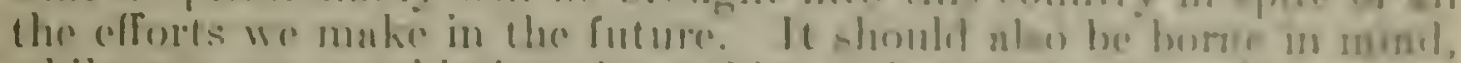

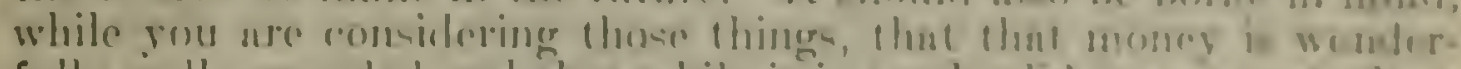

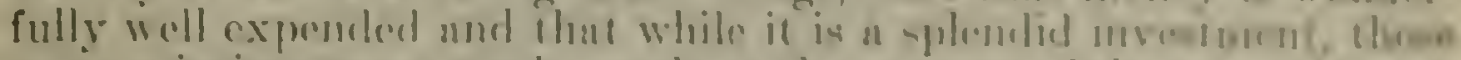

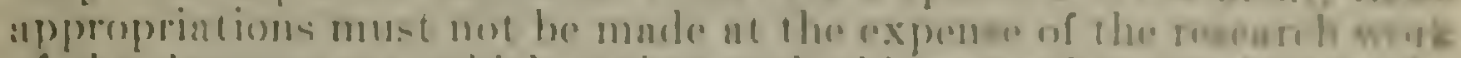

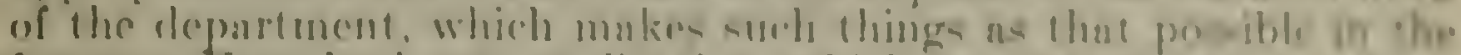

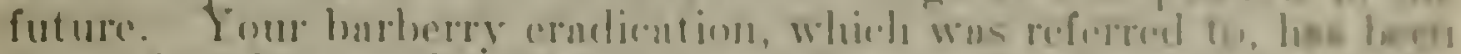
a wonderful example of what a small umound of mones soent for

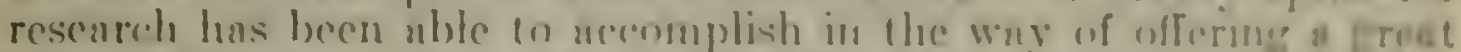

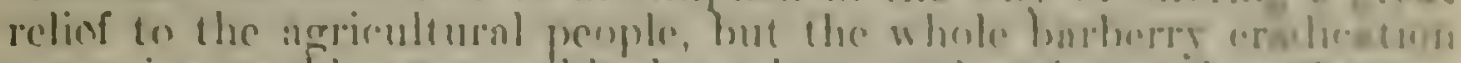

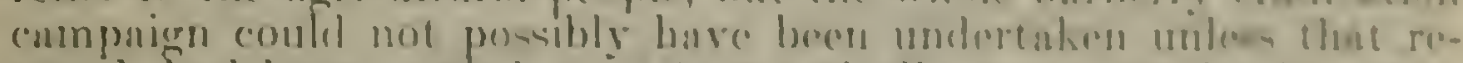

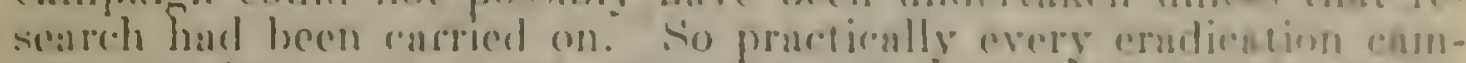
paign is the result of resonerele that must be corriosl on beforeband. Then when it comes to a point where you conn crmelessle a pw-1 ur n

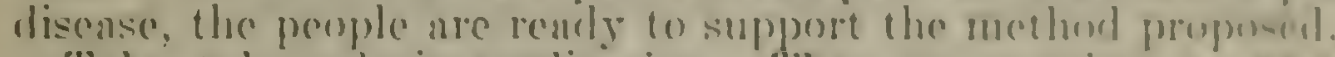

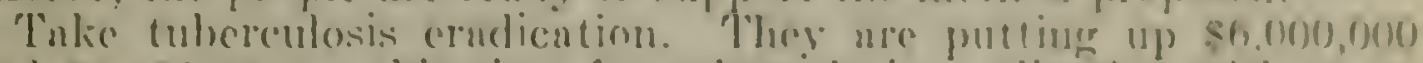

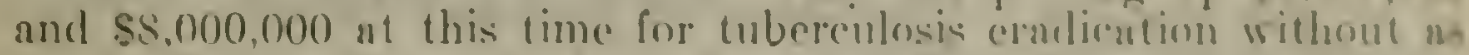
much ceffort on the part of our depurtment or of your committere an

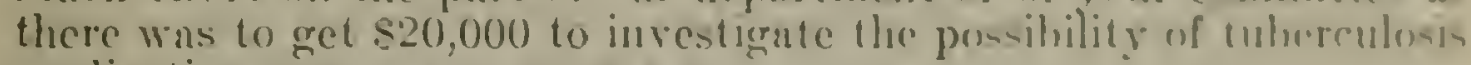
eradication some seven yests ugo.

So I want to emplasize at this time that this is a rery much reeluced budget, reduced as compared with last year and very mush reduced us compared to the growth of work in argiculture in the Nation-that is, every year ngriculturnl production is increasing: it is incrensing in complexity, and it is incressing from the standpoint that ranch addetional law passed by Congress fooking toward the relief of agricultural conditions has placed added duties on the department, sin that at the snme time the burlget of the department is increated it is incrensed by the nddition of new duties much more lnrgely than it has been by an increase of work in comnection with the lincis alrendy being carried on. So in this budget we have tried nll the wiy through, by as much reorganization as possible, to emphasize the research feature, to hund orer to the States the demometration and extension work and to kecp that which is absolutcly esential for national develupment in the way of mantenance of research intact. While this does not represent a hueleret comparable with the derelopement of agriculture as a whole or the complexity of ugriculture an a whole, it does represent what the conditions at this time warmmt. I think that is all I have to sny.

Mr. Les. Fou have discovered that the babery is not the unly source of rust, have you not?

Doctor BaLn. No: it is just the eontrary. They have alwas helieved, up until within the last 10 years, that while the rust went from the wheat to the barberry and back to the wheat that it nleo lired orer the winter and was able to go right from the wheat to the whent, so that the harberry wis not necessn'y. The fundanental discorery which was made wis that in the northern part of this country. from Kentucky and Kiansus north, in the grent whent-growing region, this 
pest was not able to live orer the winter and infect the growing wheat except as it went through the barberry.

Mr. LeE. Then if you destroy all the barberries you think you will have no more rust?

Doctor BALL. If we destroy absolutely all of the barberies in the northern region, then all of the rust they could have in the northern wheat-growing section. would be what blew up from the southern region, where it can live over the winter.

Mr. LeE. 'There was something said here last year to the effect that some other growth or host plant caused the rust.

Doctor BALl. That is in the South. The funny thing is that in the South the barberries do not carry the rust becruse, you see, it lives over on the wheat and does not ordinarily form the stage that goes to the barberries. So that in the South the barberries are not the carriers, but in the North they are the only carriers of rust. That is something which was not known before and it is the reverse of what was taught us in the beginning.

Mr. Buchanax. A gentleman appeared before us who had been sent to Europe to study this condition; he made a very thorough investigation, as the result of which it was demonstrated that in the colder climates the rust is carried only through the barberries.

Mr. LEe. I was in doubt about that because there was something in the hearings last year to the effect that they thought they had discovered some other plant.

Doctor BaLL. All of us thought that, but it has now been demonstrated that the barberry is the only carrier in the northern section of the country. There are hundreds of other opportunities to take from agriculture overheads it is now carrying, like the rust, as soon as our scientific work is carried to the point where we fecl sure we have the method necessary and the money necessary. Te are hoping to be able to obtain money rery soon to make a test of the possibility of getting those warbles out of the backs of cattle. There is no question but what it would not cost much more to take those warbles out of the backs of cattle than is represented in the damage they do in one year, and if we expended that amount of noney for two years, or possibly three years, we would be rid of that pest forever. "That is only one of a large number of plant diseases and insect pests which, when the time becomes ripe, we will be willing to say we will undertake to eliminate.

Fridis, December $1,1922$.

NEW IBERLA (LA.) EXPERTMETAL, STATLN.

STATEMENT OF HON. W. P. MARTIN, A REPRESENTATIVE IN CONGRESS FROM THE STATE OF LOUISIANA.

Mr. Axmensox. 'The committee will return to page 317 , the item reluting to experiments and demonstrations in lire-stock production in the came-sugrar and cotton districts of the United States, for the purjose of heraring Somntor Ransdell and Congressmm Martim, in whose distriet, I assume, this station is locared.

Mr. Marerix. Yos. 


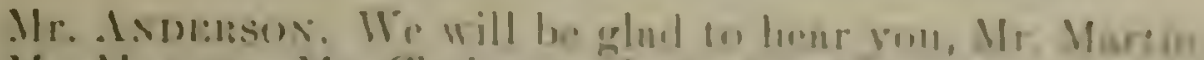

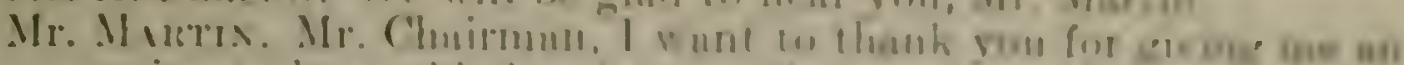

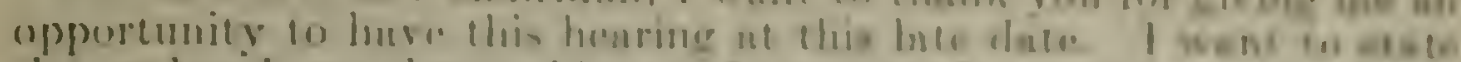

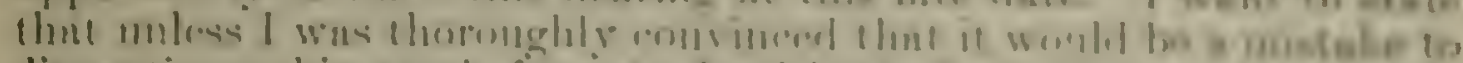

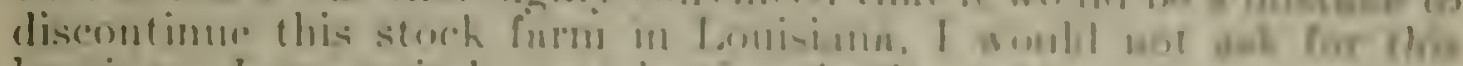

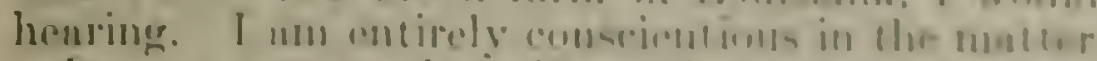

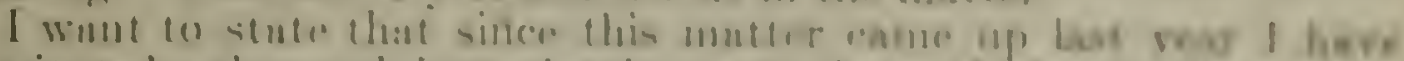

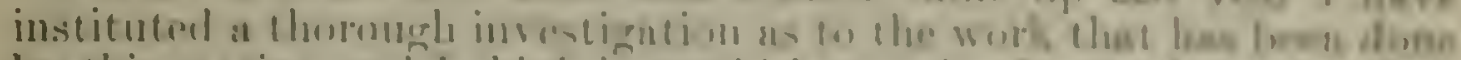

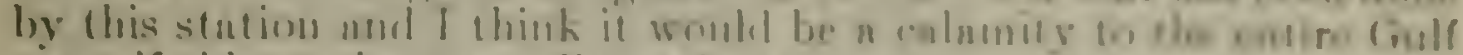

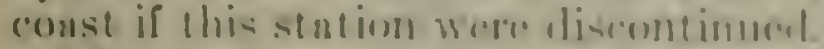

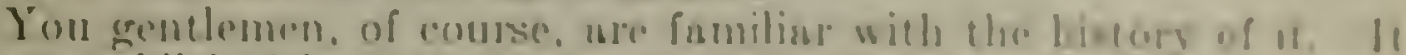

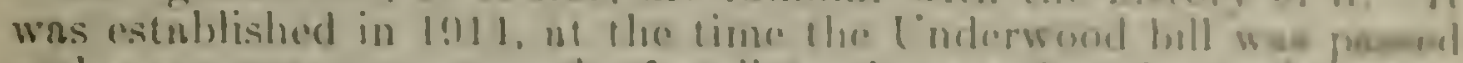

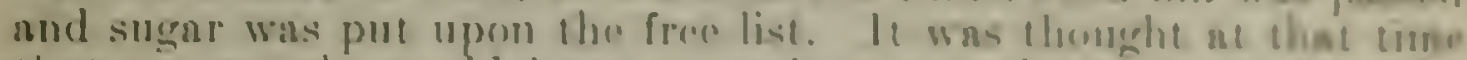

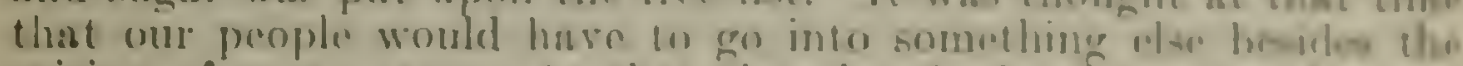

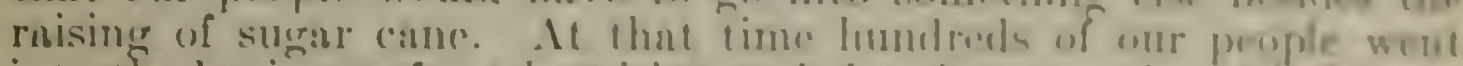

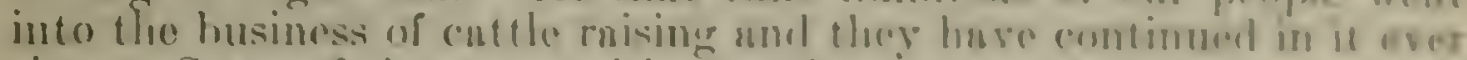

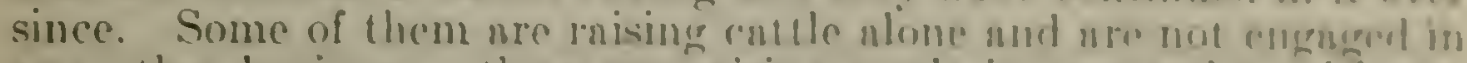

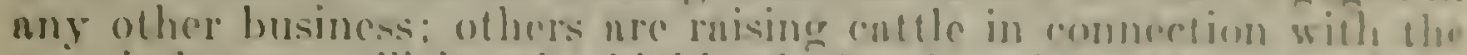

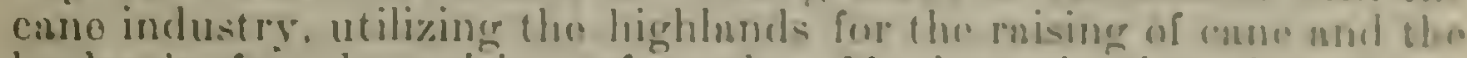
lowhnote for the mising of cuttle. My insestiention shoured me

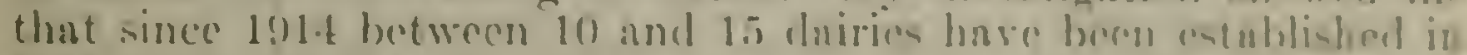
that section of the romitiy.

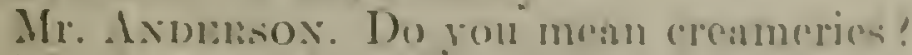

Mr. Martes. No: dribies for thr purposit of shippung milh and

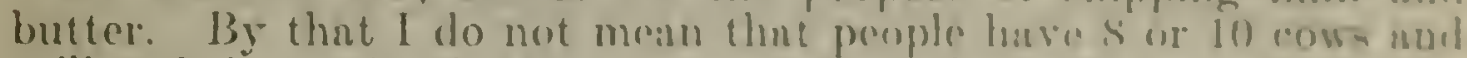
utilize their surplus for the purposo of supplying thr mathots in the

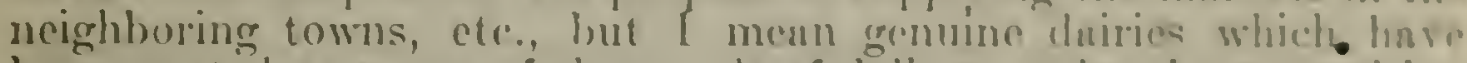

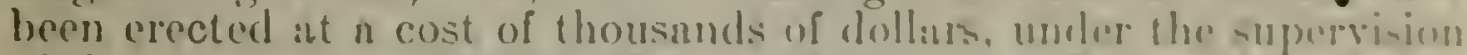
of the bond of healih of the State of Louisianit. Many of the huild-

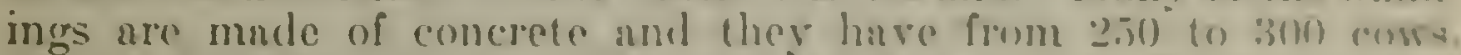

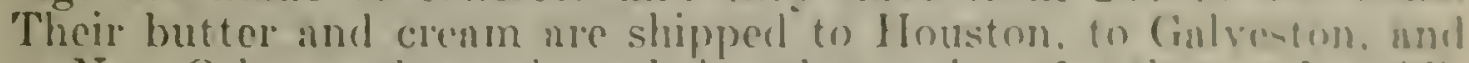
to New Orleans, those planers hoing the markefs for them. In meldi-

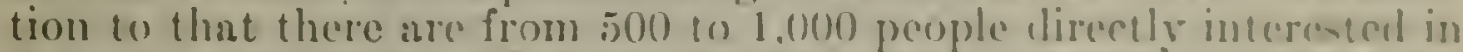
the rasing of eatele. I want to state thut lust berir. nt the time

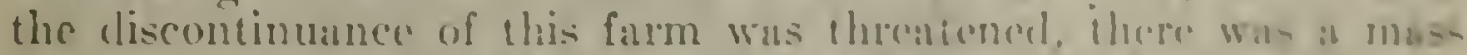
mecting called in that secolion and they passed as sot of remolutions.

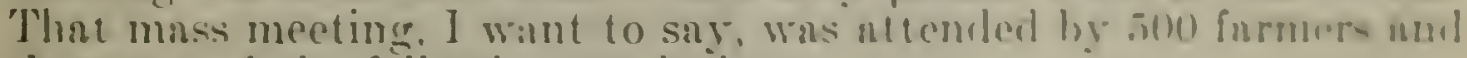
they passed the following resolutions:

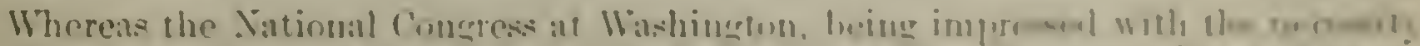

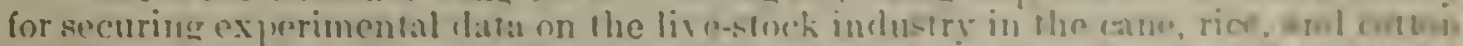

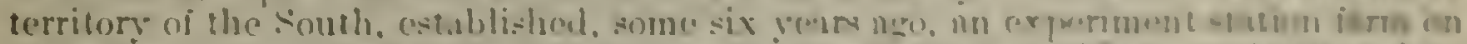

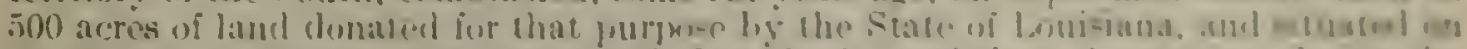

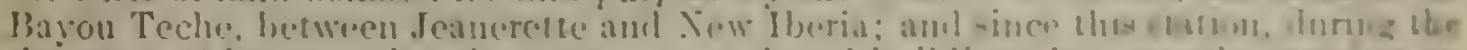

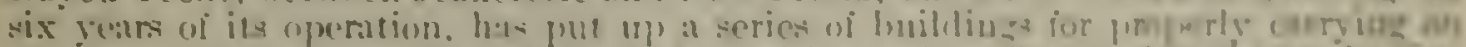

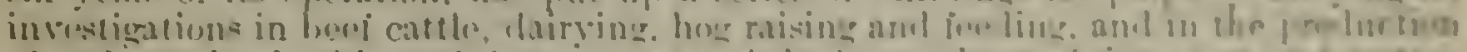

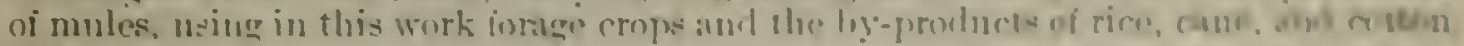
anil

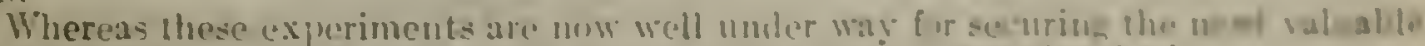

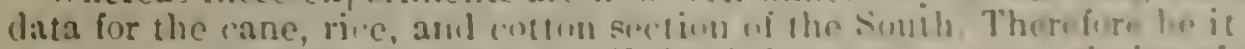

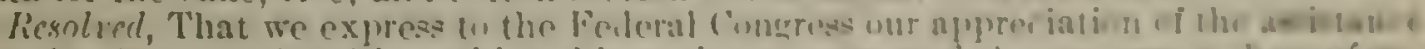

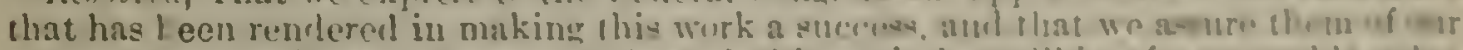

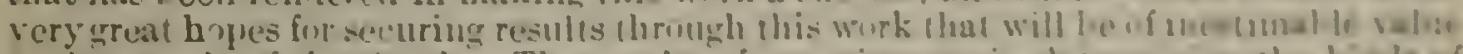

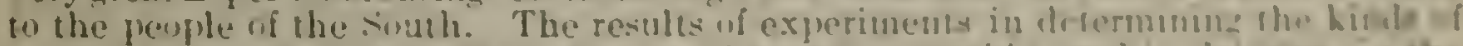

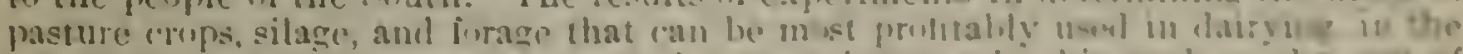

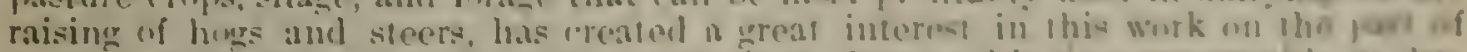

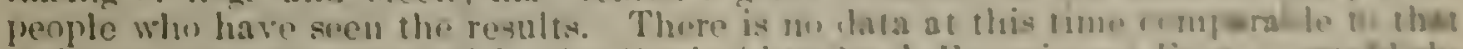

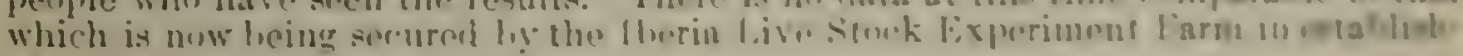


ing the feeding value of the by-products of rice, sugar cane, and cotton in the punduction of live stock and live-stock produr'ts; therefore be it further

Resolved. That we earnestly request our Representatives in (ongress tw urge upun that body the necessity for placing the Ileria Live Stock Experiment Jarn on a hasis that will insure a continuation of these investigations for at least several years to come.

These resolutions were passed too late last year. Mr. ('hairman, for me to present them to the committee.

Now, gentlemen, I want to call your attention to some of the work that this farm is loing. I have in my hand the lirestock 'Reporter' that is printed at Fort Worth, Tex., and I want to read this to you for the purpose of showing that Texas is directly interssted in the maintenance of this farm. It is the only stock furm on the Gulf coast; they are making studies in other portions of the country but there is no other farm of this kind on the Gulf coast.

TFXAS ATEKHS, FINISHEU IN JOULNIANA, THEX SOUH HERL, MAKF BIG HETCLI.

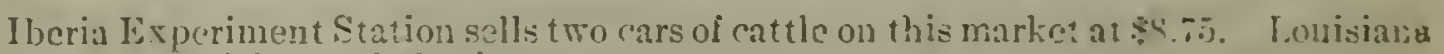
offers goorl fiell for cattle business.

Two cars of fed steers from the lberia Experiment Station at Wranereter. La., tinished for the purpose of determining the food value of different rations and also to afford a comparison in gains between native Lonisiana cattle and those of betrer breeding from other States, were sold on the Fort Worth market late Saturla! at \$8.75. a new top for the year.

Mr. Axuelisor. What is the date of that paper?

Mr. MARTtx. 'The date of the papel is Monday, May 1, 192.2.

The steers averaged 962 pounds and were purchased by swift cto. All were drohorned.

J. R: Quisenherry, live-stock specialist in cliarge, who accompaniel the elipment to market, explained that one car consisted of hereford cattle purchased last spring

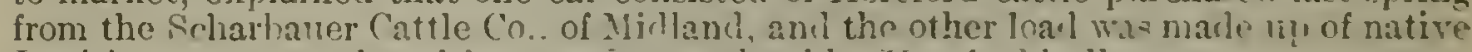
Louisiana steers procluced from grade cows brerl by fiereford bulls.

Results of the experiment were favorable to the native Louisiana catile. It the completion of the test they ontweighed the Texas steers, and they made fasier gains both when on grass and when on feed. However, the Texas-raised cattle inade splendill allvancement, regardless of the fact that they were taken to strange pastures where conditions were inuch changed, the country being low and marshy, and their performance was most creditable as well as profitable. The experiment tends to shor that Texas cattle are well adapted to the Lonisiana climate, and, when properly handled, will make gains similar to those of the native Louisiana steer. After all expenses had been figured, freight charges from Midland to Jeanerette and then lack to the liort Worth market included, the Texas steers produced a profit of around \& per heacl.

That Was the result obtained from stecrs shipped to the Fort Mrorth market after having been fattened on this farm. I want to state in connection with this, that luring this same year they had something of a drought in 'Texus and humdreds of enttle were shipped to the low lands of fouisiana and put on what is hnown as paye Finne hay, which grows wild in the lowlanels. They were all taken to lonisiana, fattened there and sold on the malket at a good plofit.

In commertion with that 1 want to tell you ubout some other work

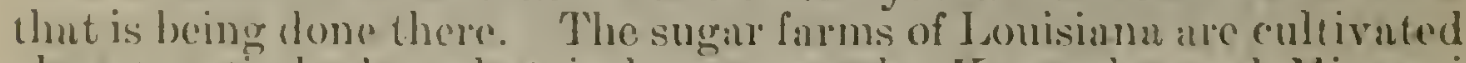
umost (unturly by what is known as the Kontucliy and Missouri mule. I do not know whether you know them ol not hut they aro rery latge mules, and it takes a very large mulo to hrouk up the stilf land where ranc, corn, and eotton are grown. The price of these mulcs rums from \$2.) to $\$ 300$ apicee, so that this fanm has heon experincuting in the rusing of mules and they hove found that just as liuc mules can be raised in that section, just as lalere and give just at 


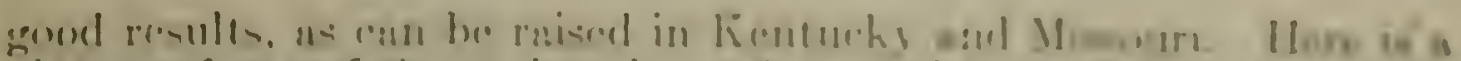

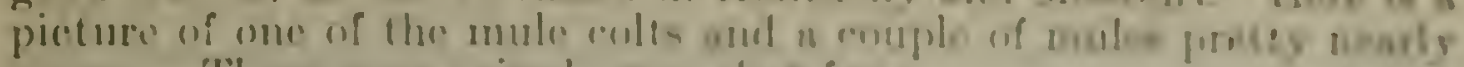

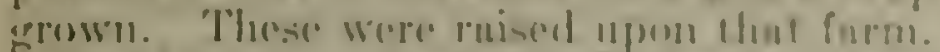

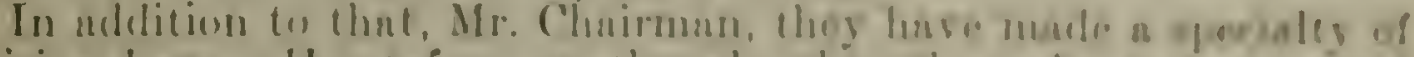

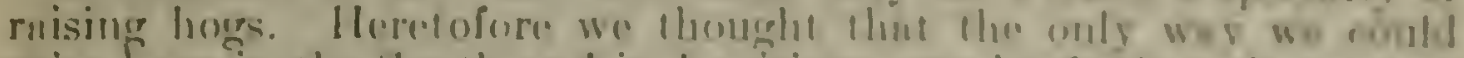

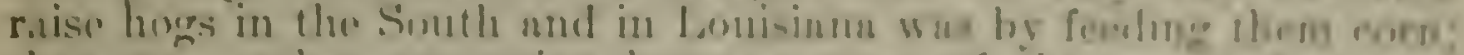

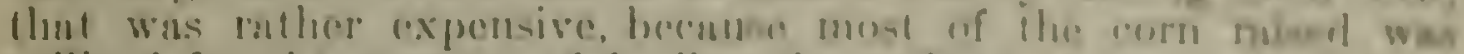

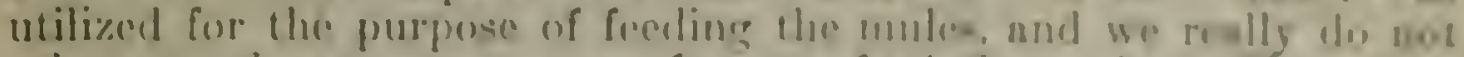

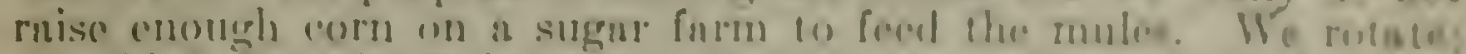

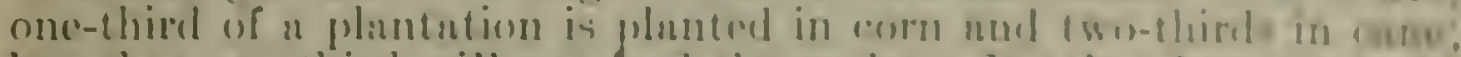
but that one-third will not fored the mules. It takes from lo we 20 )

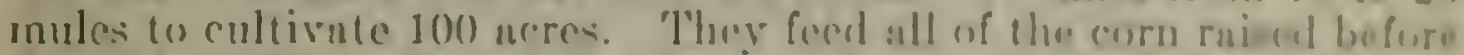
the end of the your and then have lo huy sume freed of sume hind.

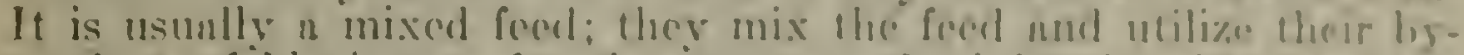
product of bhekstrap for the jumpose of mixing it with plon ford.

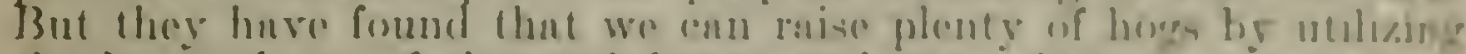

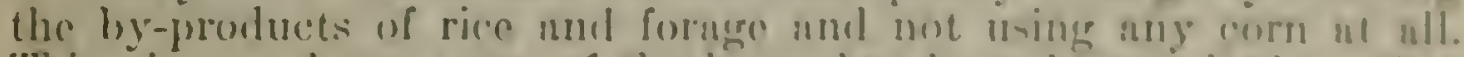
This pieture sluwes some of the lings that lawe lwen raised on that furm in that why und, gentlemen, you can sere the condition they are in.

Now, Mr. Charimun, I want to direot your attention to the was in which the results of the experiments on this farm nre dieneminutoil smong the farmers. It is done in two wiys. In the first pluce, about twien a year they hold what lhey anll at fockd day; penple from all over that section ginther on that farm and the superintentent of this farm and Doctor Dodson, who is a member of the committer appointed by the Secretary of Igriculture to help run the furm, exhibit the cattle, give lectures to the farmers. and tell them if the results of the experinents. In addition to that the State of douliainn. through its experimental stntion, puts out a bulletin ino or throv times a year giving the results of all of the experiments as the the feeding und the rasing of cattle that have been conducted on this furm, and these bulletins are generally distributed throughout the cattle-raising sertion. Besides that they have hoys rlulie that ure interested in the rnising of conttle and pigs: they bring them down 10 the farm and lecture to them. Here is a picture of one of the burs clubs on that farm. Here are some more of the entele that ure an it.

Now, Mr. Chnirman, I wnnt to make this statement: W"hen I hrard that the Department of Agriculture hat recommended the diecontinunnce of this fnrm Senntor Broussard, Somater Ransdell, and mysolf went to see the Secretary of Agriculture, Doctur. Mohler, and Doctur Taylor, to find out whether they hind made such at recommendation. Every one of these gentlemen said most positively they had mot: that they had included in their recommendations ihe experimental farm at Iberin and that they were strongly in faror of its cont inmanee. that it had done good work, but ther said that when they went hefore

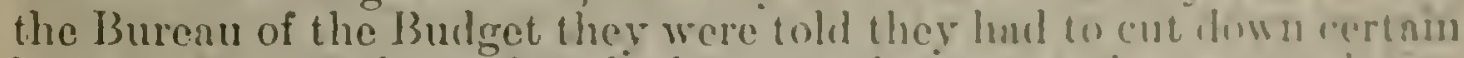
items. Among those they lial to ent down was the uppropriation for the cattle tick and the nppropriation for how cholera; fhen they were told that they had to cat rown certan of these mperimental farms, and they said they recommended the discontimumen, I helieve, of two, oise in Oklaliomn and the farm at Lew Iberis, for the reason that the financinl returns of thee furms were nut ecpual to those of other farms in the country. 
Now, I want to state that so far as the New Iberia farm is concerned the returns have areraged between $\$ 7,000$ and $\$ 20,000$; the arerage, I should say, was between $\$ 13,000$ and $\$ 14,000$ from that farm, and I think you will find that in 1922 there was an appreciable increase in the returns, so thit this amount must be taken from any appropriation that is made by the committee because that amount is returned to the Treasury. But, Mr. Chairman, the good that that farm is doing in that section of the country is certainly worth moro than $\$ 20,000$ or $\$ 25,000$ to this country. I think if you could see the interest the people in that section are taking in stock farming and the great number that have gone into the cattle business-and I hare stated that there are between 500 and 1,000 actually engaged in the business-and the dairies that have sprung up all over the country, I do not think you gentlemen would entertain for a mivute any suggestion of its discontinuance.

Now, Mr. Chairman, if there are any questions that you gentlemen desire to ask in regard to the operation of this farm I will be rery glad indeed to answer them.

Mr. Axdersox. I have the impression that the people not only in Louisiana but throughout the coastal plains area of the South ought to have considerable help with their stock problems, but along with that, so far as this particular station is concerned, I have the impression that the station is not well located.

Mr. Martix. Well, I know how you got that impression, becauso you were kind enough to tell me last year, but I want to state that that is a mistake. To begin with, I want to describe to you the country down there. This is located on Bayou Teche. Our country is all alluvial. The highest point there is not 10 feet abore sea lerel.

Senator Raxsoell. He means land that has. been made by the overflows of the Mississippi River.

Mr. Mhrtis. When you begin at the Teche the land is rather high; then it begins to slope back and reaches what is known as the swamp. 'The front portion of that land will grow anything in the way of corn, hay, oats, alfalfa and clover.

Mr. MaGee. Is it black soil?

Mr. Man'Tx. No; that is sandy soil; but when you go back you gradually get to the black soil that is subject to orerflows. 'That soil grows a hay which, in food value, is way beyond eithre alfalfa or clorer. It is a hay known ns paye Finne. It grows in abundance where the soil is damp; it grows wild down there but it ean be transplanted. You can dig it up by the roots, transplant it, and it will grow very well in other places.

Mr. LAw. Is it anything like Bermuda grass?

Mr. Mantix. No; it is not. The enttle will go up to their stomachs in mud to at this paye Finne hay and get fat on it in the winter. tou do not have to feed them when they eat paye Finne hay; you do not have to feed them anything at all but let them feed on this paye finne hay, because it grows as well in the winter as in the sillimmere.

Sonator R.axsmes. Toll them about the factories which are making paye Finne feed.

Mr. Marts. We have two factories down there which, since this "xpcrimental station has established the value of this paye Finne hay, are manufucturing a mixed feed the base of which is paye 


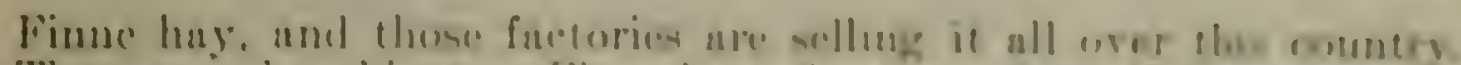

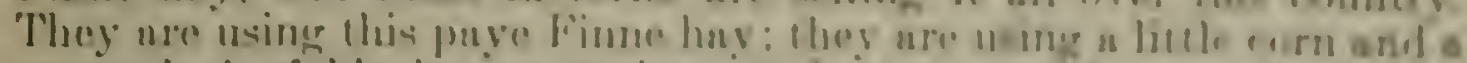

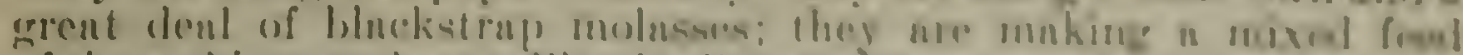

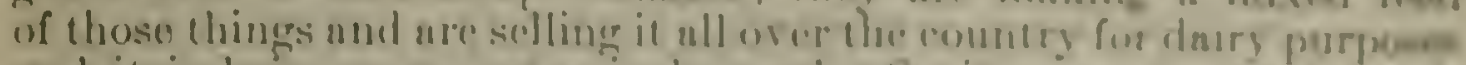

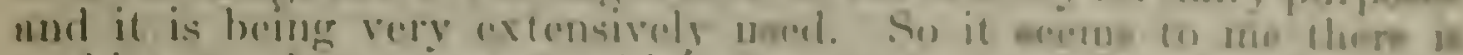

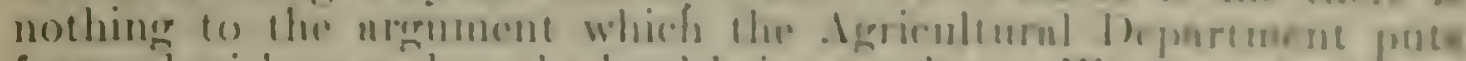

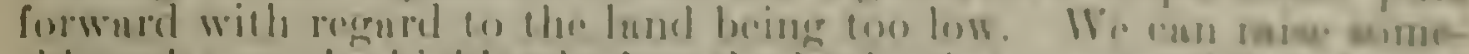

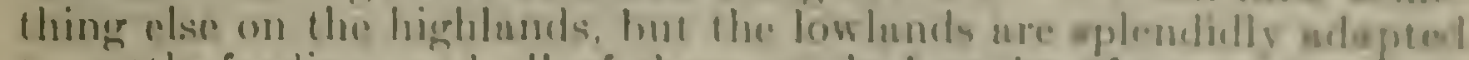

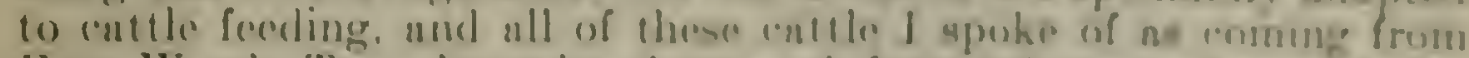

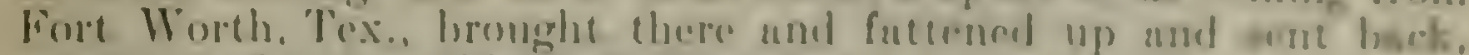
wre turnod ont on this pay loinmo haye.

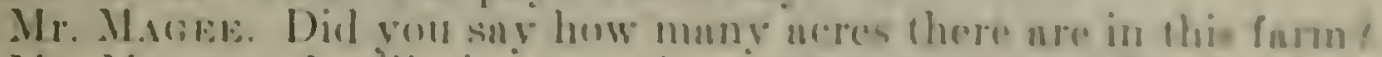

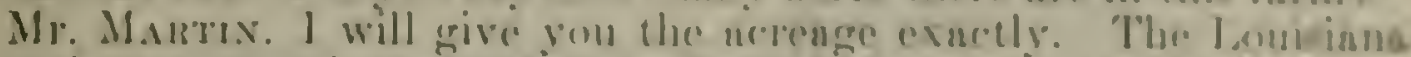

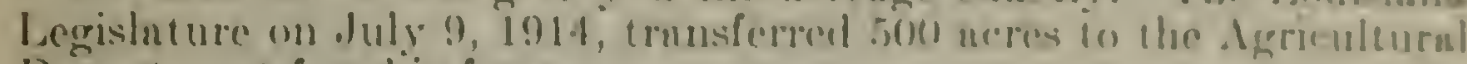
Depurtment for this farm:

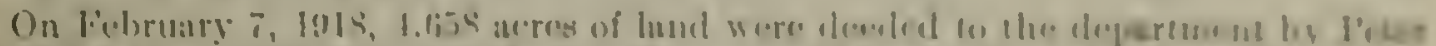

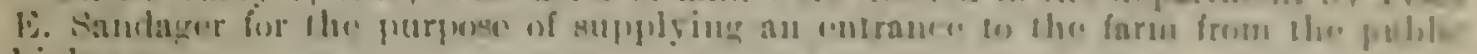
highway.

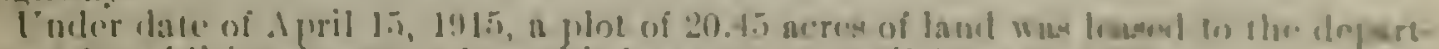

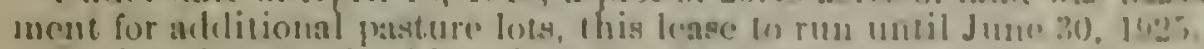

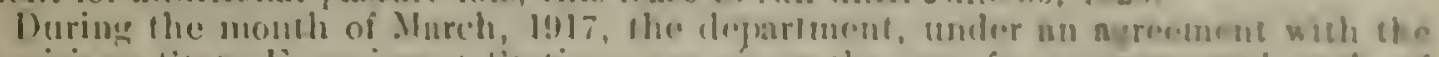

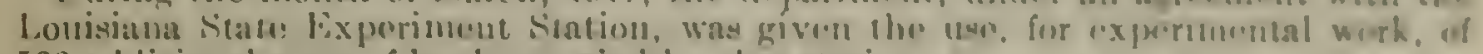
500 alditional acres of hand occupied l,y that station.

So there are at)proximately 525 areses.

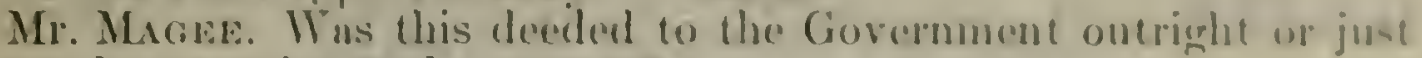
given for experimental purposes?

Mr. Manter. It is given hy the Stato for just us long us the (iove ernment wants it, free of nny changer.

Mr. Magks. Are these 500 aleres or more mode up of sundy lumb and alluvinl hund?

Mr. MLartix. 'This farm takes in both.

Mr. Magre. In what proportion?

Mr. Martix. I should say that ahout 300 neres nro samdy and about 200 acres in the lowlunds. The Bayou Toche runs for a erent many milos. I made a mistake in the number of neres in this farm. It is 1,025 ncres but the ploportion of black und sandy lumd is the samile.

Senntor Broussaru. It rums for S0 or 90 miles.

Mr. Mantix. And this samo stretch of land goes right ulonge there. All of our country is built up of buyous- Bayou "lecho. Buyou la Fourche, or somo bayou; the land being on the bank of thro loupou, runs back and fimully reaches the swamp. 'The live stove; huildings. and machinery on that furm nre vulued ut about $\$ 70,000$. Theres are some very fine buildings on it, and these would have to be torn down and would go to waste in the revent the Govermment disomtinued the farnt.

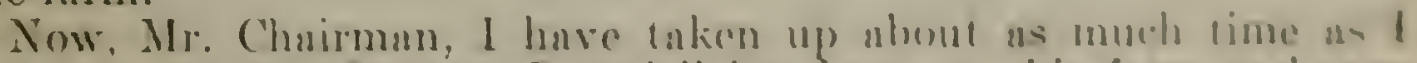
feel I mught to. Senator. Ransdedl has bern un this farm and -con the work: Senater Broussurel lives within a mila of thie farm mol is himsolf a cattle rniser. Ho has a caltle furm within a milo or wo

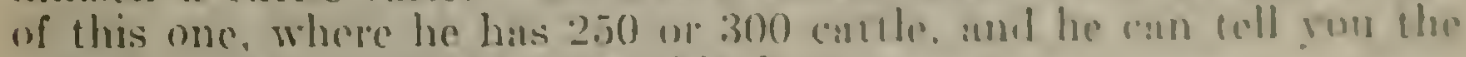
results he has ohtuined from this farm.

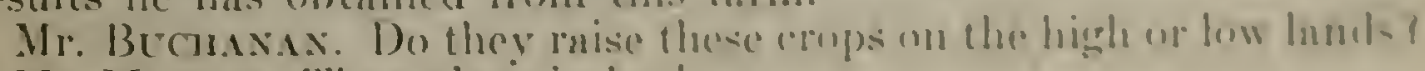
Mr. M.иттx. 'They planit in huth. 
Mr. Buchavas. Is there any question or difficulty about the drainage of these lands?

Mr. Mantis. I know there is not in connection with the land on which this paye Finne hay grows, because that raises itself. As to the other land, there is natural gravity drainage back toward the low lands; the drainage is toward the swamp and not toward the bayou.

Senator Raxsnerc. Has it not the same drainage that the sugar lands in that entire section have?

Mr. Martin. 'The same kind.

Senator Ransoedic. As I understand it, these lands have the same kind of drainage that the lands have which are adapted to the growing of sugar cane and other crops.

Mr. Mantis. Dr. W. R. Dodson, the dean and director of the Agricultural Experimental Station in Louisiana, and who is one of the committee in charge of this station, has wired me that he has forwarded a statement setting forth the important work being done by this farm. Let me say that Doctor Dodson is most highly thought of in the State of Louisiana and his done a great cleal in the way of getting our people interested in cattle raising. His statements ean be absolutely relied upon.

I would now like to have you hear from Senator Broussard.

\section{STATEMENT OF HON. EDWIN S. BROUSSARD, A SENATOR FROM THE STATE OF LOUISIANA.}

Senator Buocssard. I do not know what particular facts you would like to inquire about, but I would be pleased to answer any questions the committee desires to ask.

Mr. Lee. 'Tell us about your farm.

Senator Broussard. I am very familiar with this particular land; in fact, at one time this plantation, before the State acquired it, was owned by my father-in-law. This land is just alongside of and was taken from the convict farm, what we call the Hope State furm, which is a convict farm.

Senator RANSDell. How far is your home from this farm?

Senator Broussand. I live at New Iberia, which is about 6 miles from there, but I was born and brought up just 4 miles from there, in another direction. I might say this, that the Hope farm is the one farm belonging to the State that has always paid; it palys money every year, when other farms have lost money oceasionally. There is some black land in this farm; in fact, if you understand the alluvial formation, the highest points are next to the streams and all the lands drain away from the streans. The land close to the streams is usually very smoly and then it changes until in the rear it gets to be, in some places, black soil.

Mr. Las. The black soil is more productive, is it not?

Senator Bnoussands. It is at rertain seasons of the year, when you get much better results than you will from sundy soil.

Mr. ANmerson. The difficulty the department presents, as l understand it, is that this bhack soil, pmrticularly at certain limes of the yonr, is very wet, nud that it is rery diflicult to get on it in order to (1) the necessury work in prepnring it for crops, and that it has a tendency to becomo very hard when it dries. and that the enenseguence 


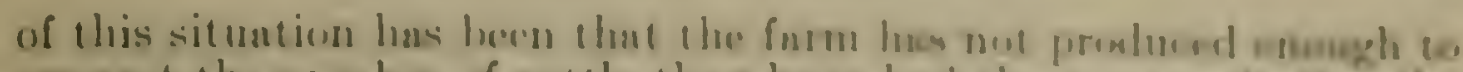

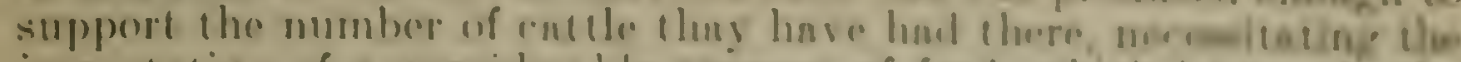
importution of a con-idernble nniome of foed whis h hes made stie

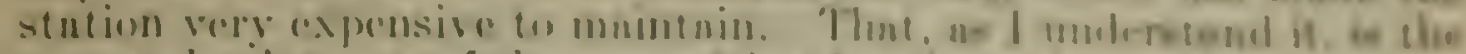

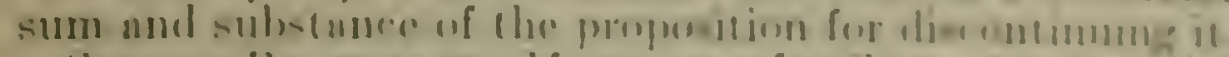

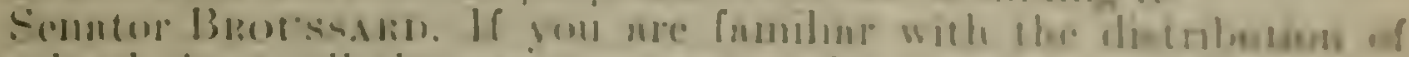

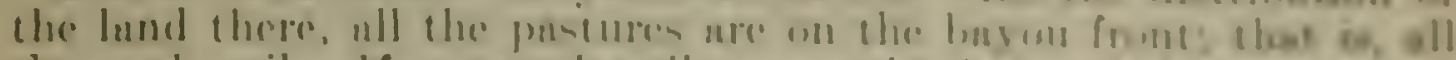

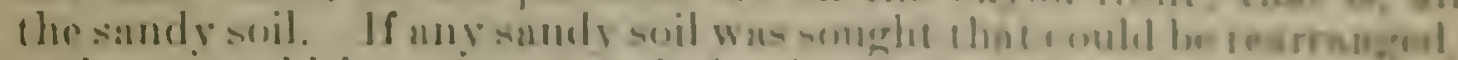

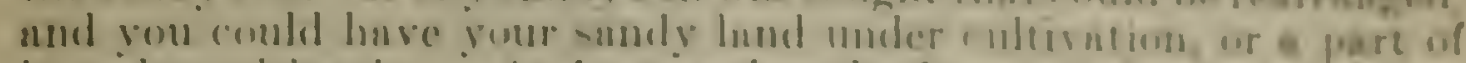

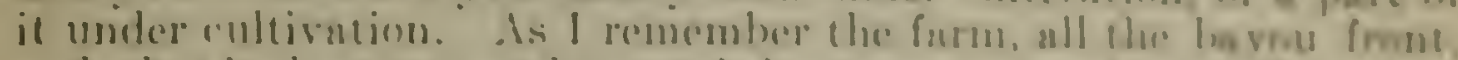

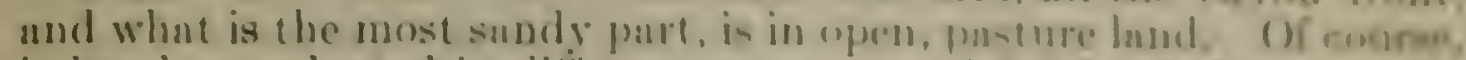

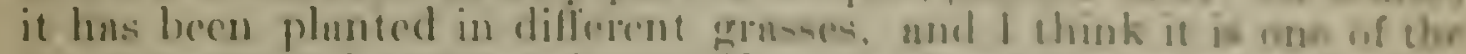

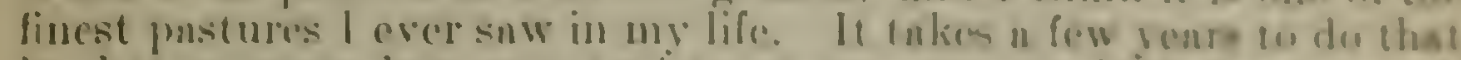

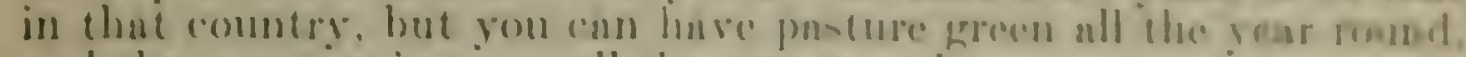

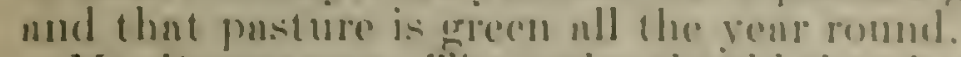

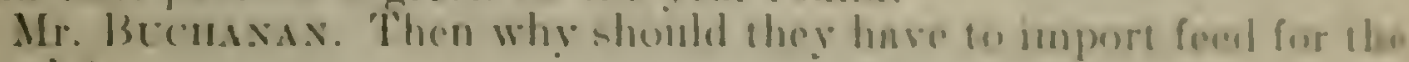
itorelk!

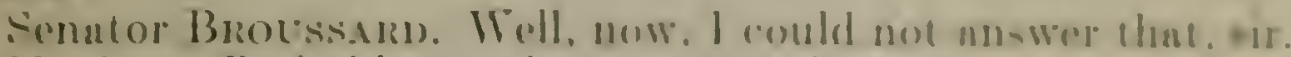

Mr. Lese. Probubly you have too much storek for the ar renge.

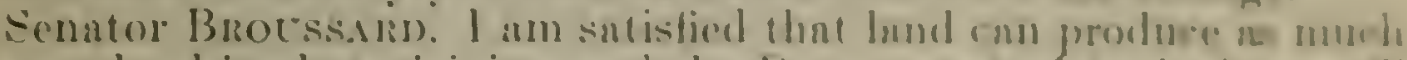
ns any land in that vicinity, and the Department of A griculare wall show you thent those lands ire the mest produrtive lnseds in the sinte

Mir. Axinerson. How much land is there in thi-section whula is of the same general character as this farm?

Senntor Brovssard). All of it is of that sume generul character on that side of the bayou. On the other side the sandy formateon extends up to what was formerly an old lake bottom thine has heen drained, and all of thut is sandy:

Mr. Averrson. Your statement that all of it $i=$ of the sume ganeral character means something to you because gou are familing with the territory, but of course it does not convey invelhing 6 mo bermuse I am not. In acres or square miles how inuch of that cerritory is of the same generial character!

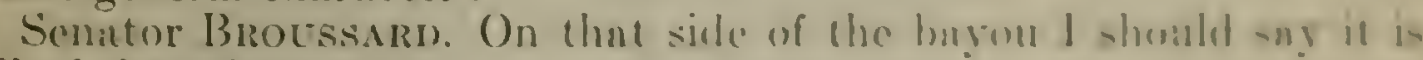
nll of that character.

Mr. Axbersos. I do not know whether that -ide of the buscu hat 4) neres or to square miles.

Senator Bmotssand). What we you trying lo gre! The aren of land of that kind in thr State!

Mr. And trsox. In generul terms: yes.

Senator Brol'ssinn). Or do you menn in that rommy y

Senator R.x.sibrato. He means in the State.

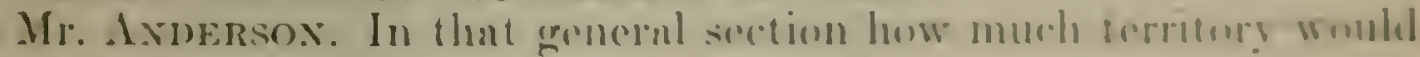
there be?

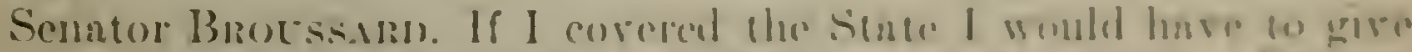
you a largere ligure than if 1 coverest the county ar parials. Dh som want en know what proportion of the lands in that conutes are the way?

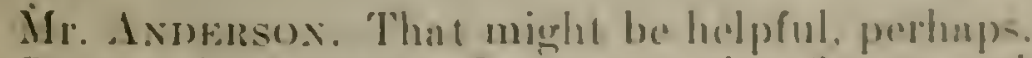

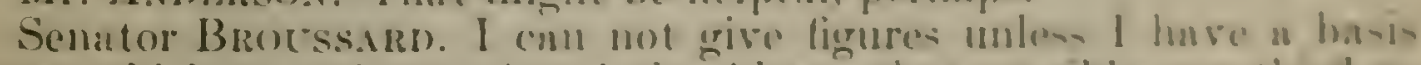
upon which to estimate, but 1 should sis that per-ibly onse-thed or one-fourth of the hands are that way.

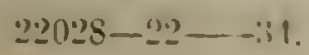


Mr. Buchanax. About how much is that in aeres! Just guess at it in acres or square miles.

Senator Brocssard. In the parish?

Mr. Buchasax. In the parish and in the State.

Senator Broussann. I would not know about the State, but in the parish I have given the proportion of that character as one-third or one-fourth.

Mr. Becmanax. Would that be 1,000 acres?

Senator Broussard. 'There are something like-I do not recall now the exact acreage of that county.

Senator RAxsDeLL. Are there not a great many acres of land of that character in adjoining parishes?

Semator Broussarn. Yes, sir.

Senator Raxsuell. Thousands and thousands of acres of the same general character?

Senator Brocssani). All through the State, hut I would not know the proportion in the different parishes.

My. Bucmaxax. You ean readily see our idea. You want to hare an experimental farm on a certain character of land in order to see what it will derelop, and it is necessary for us to know about how much land there is.

Senator Brocssard. I think Mr. Martin has already testified that there are about 300 acres of this land, that is, sandy land, and that the other 200 acres are black lands. Now then, I would say that possibly one-third or one-fourth of the lands of that parish are just of that character, I mean, of the character of the black linds.

Mr. Buchanan. How large is the parish?

Senator Brotssarn. It is about ten miles long and about eight miles wide.

Senator Raxsperc. Nay I say that fully one-third of the lands of the State of Louisiana are of this same character, and the same problem you lave in raising eattle on this farm is the same problem they have all over southern Louisiana.

Senator Broussarn. Not only as to the black lands but it is the same problem they hare on the Gulf const. We have different types of land; we have these alluvial lands and then we have hill lands, of course, which are not included and they are red clay, but this character of land would apply to all the land along the Gulf coast.

Senator Raxsocel. Taking this section as a whole, is it not a fair type of the sugar-cane lands throughout Louisiana?

Senator Broussand. As I said before, I have known this land for years. my father-in-law having owned it, and he made erops on the land which now forms this farm. These 500 acres were taken out of the Iope farm, and the State has given it over to the Cnited states Government free of charre. 'This is the best paying farm the State has and these alre just 500 acres talien off the western portion of that plantation; there was no selection made but just a line drawn and that many acres grven over to the Government. However, the Statc is cultivating lands much farther back than this farm land, lands that have been reclaimed since the eonvinets were there. When there is nothing else to do they aro out in the woods and clear this land; it is then put under cultivation nnd it is productive.

Mr. Berdasis. Does this land extend to the sea of the Gulf? 


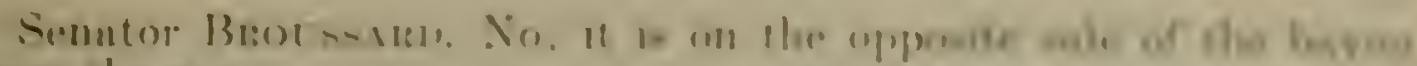
from thesese.

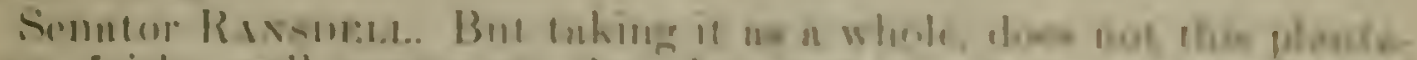

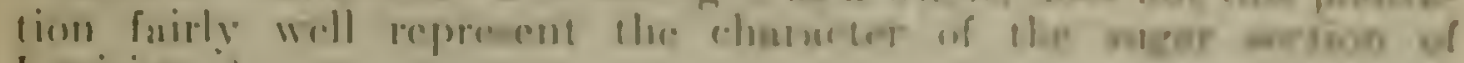
L.11)isismu!

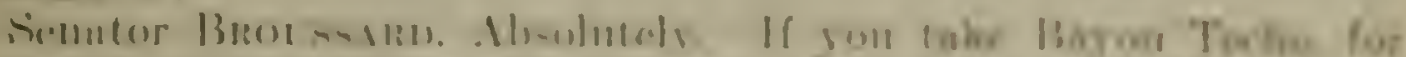

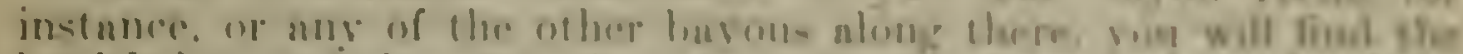

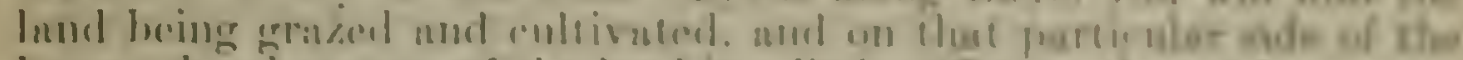

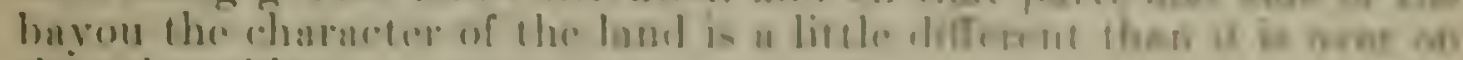
the ullere -iels.

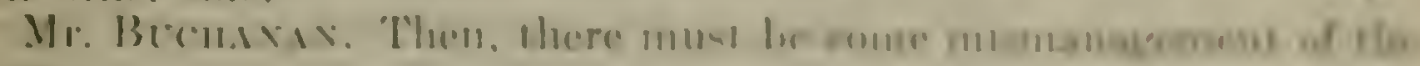
fallm.

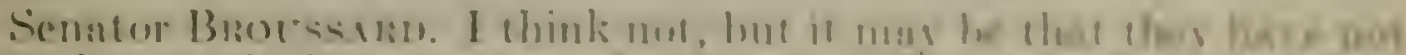

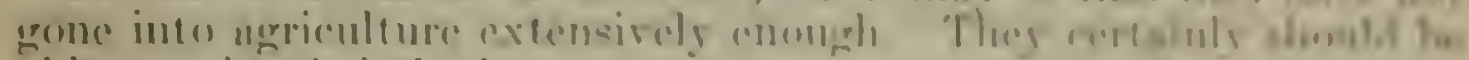
nble to risise their ferest.

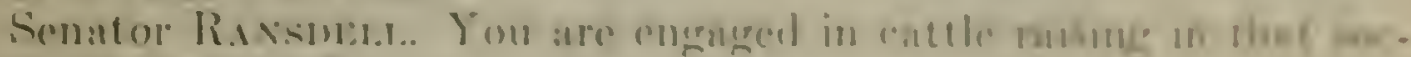
tion, ure you not?

Sonafor Brotssulin. I have imustoret farme.

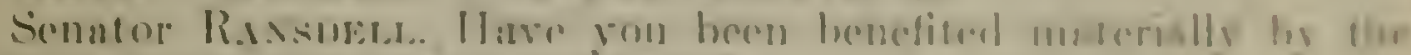
experinents anricil on at this farm?

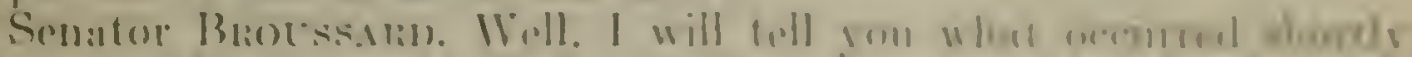

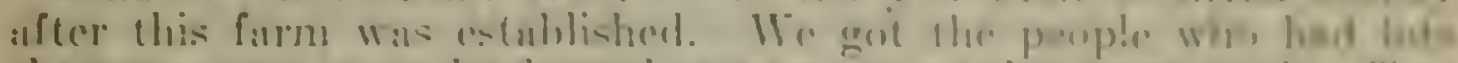

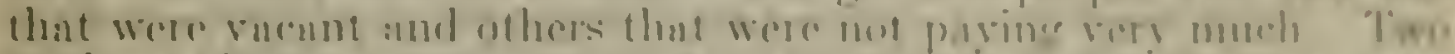

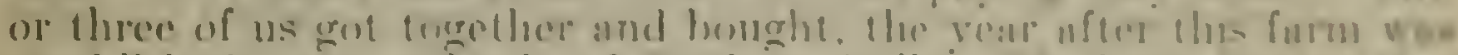

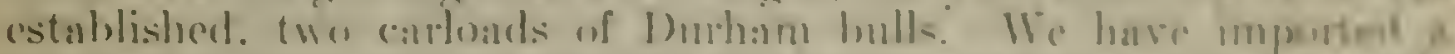

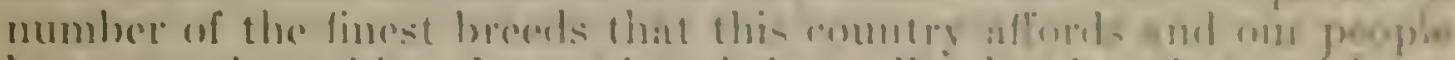

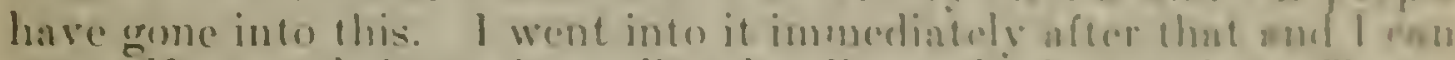

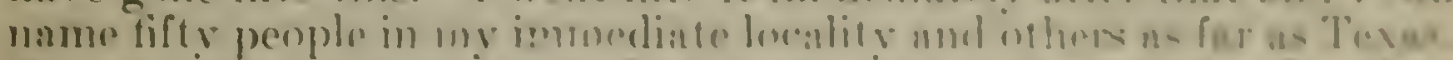

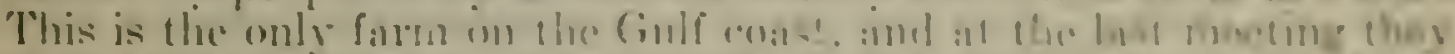

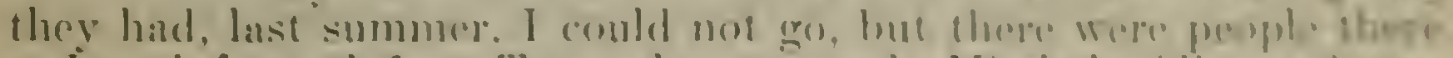

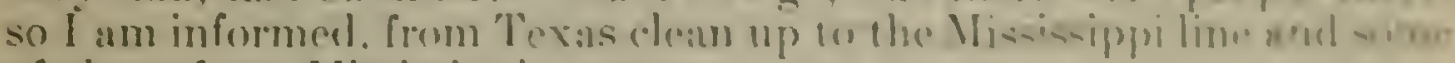
of them from Mlississippi.

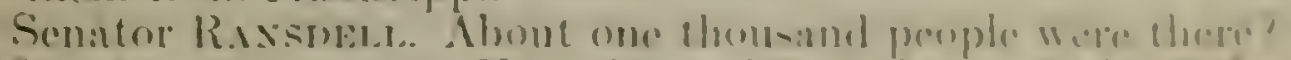

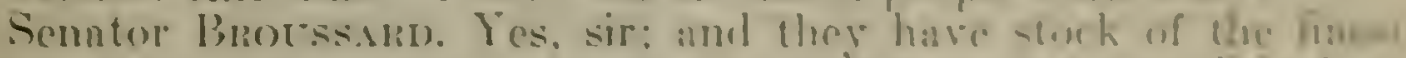

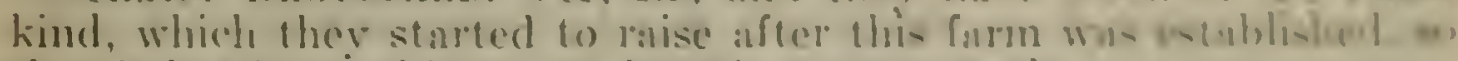
that it has berri of immense henedit io our prouples.

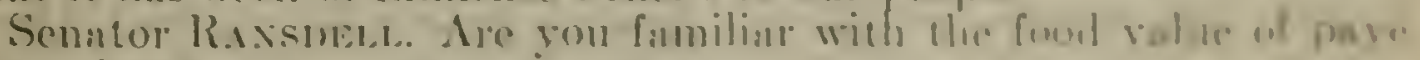
Finne hay?

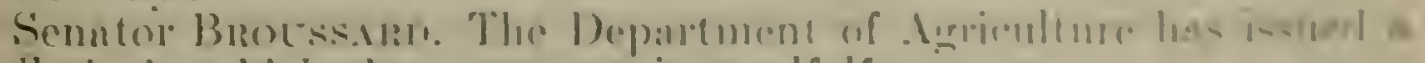
bullotin in which they compane it 10 alfulfas.

Senator Raxsseli.: How does that grow?

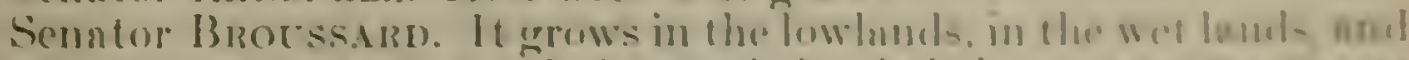

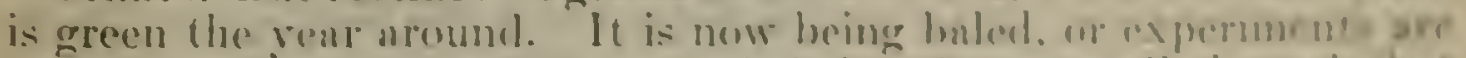

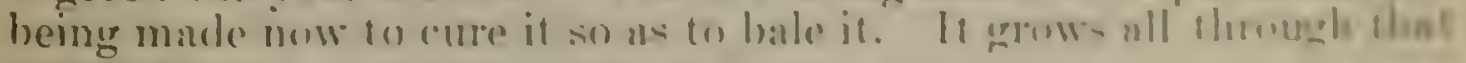
country.

Mr. Wasox. Thut in mutive or wild grase?

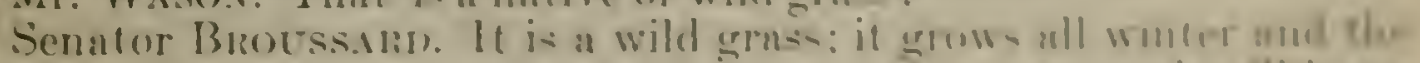
streck will remain in those lands all winter. Iy aros-lenk will lrew

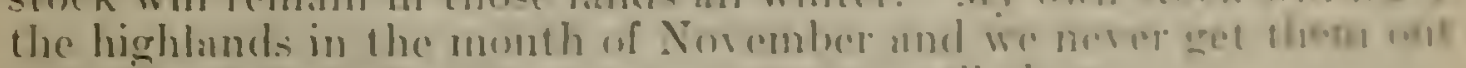
until the lst of Marche mulesen we want en soll them.

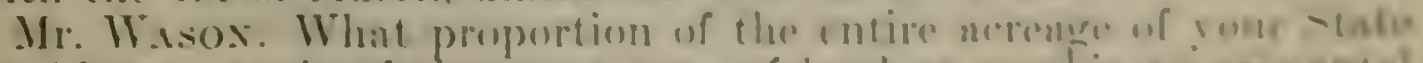

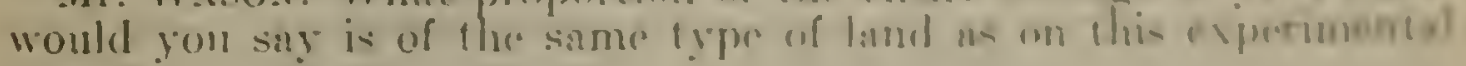
r rm! 
Senator Brocssalid. I will answer that by first eliminating the hill lands, which will not compare at all in fertility or production, and are altogether of a clifferent character; but all of our alluvial landsI mean by that soutl of the Red River, and on the east side of the Mississippi, south of Yazoo City, there are some places where there are allurial lands, but all of the lands on our side of the river, south of the Red River, are lands of this type; they are lowlands: there is not much elevation there, hut they are very fertile. 'The lands fronting on the streams are sundy because of later deposits from the Red Rirer, but the black lands are always lands of the charneter described. Nost people prefer the black limds muder certain weather conditions. When you have extreme drought your crop is fine on these lands, but if you have tro much lain it is hard to work them; that is the difficulty, but they are more productive and year after year will arerage more than your sandy lands.

I11: Wasox. For my benefit, and perhaps for the benefit of the other members of the committee, will you state the percentage of alluvial lands--and I group the alluvial lands and sandy lands trigether-and hill lands as compared to your entire acreage?

Senator Brotssand. When I said one-third or one-fourth awhile agro I did not mean that is the total area of black lands as compared to sindy lands; but the people usually work the front lands as they are more casily drained. If you want the proportion of black lands in the alluvial section as compared to the sandy lands I should say that over hall" is black, but as to cultivation I should say there is onethird of it in cultiration. All of the fields in the rear are black lands.

Mr. Bucunsax. But taking roul State as a whole and counting the allurial lands and the blick lands that constitute the section where this farm is located as one unit, how would that compare with your State as a whole-one-fourth, one-fifth or one-eighth?

Senalor Broussari). I suppose one-fourth or one-fifth.

Somator R.x.sones. I am pretty familiar with that because I huve sperialized on flood comtrol. We have in Lonisima around 14.000 staline miles of hands which are subjeret to overdow from the floods of the Mississippi River and all of that laun is the kind of land which Sonator liroussard hats described. Now, we have a considerable area in and along streans-we have a great many streams in the Stateand much of that is of the same general charater. The whole State is between 46,000 and 47,000$)$ sefuile miles, but there are some 14,000 scfume miles of the sume general character which the Semntor has described. I am fimiliar with the whole State.

Genator Brocssint). 'This black land extends as far as the drkansas lime along the river, whilo the hill lands are in the northwestern part "of the Sinte and are pine lands. That character of farm hands extomds alongr the Gulf const, and this furm is not to be comsidered morely for onr immerliate locality. Wo have always viewed it as unc for rexperimental and demonstration work for all of the people along the culf roast. 'Tlhis is the only one in that area. . Whout onethirel of the state is of thant chaneneter of hand.

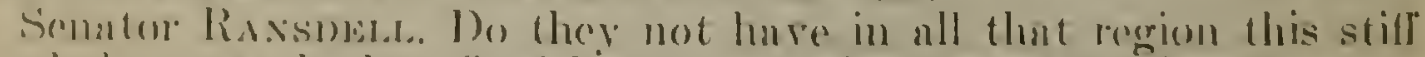
land that muy be benefited hi the experiments on the farm?

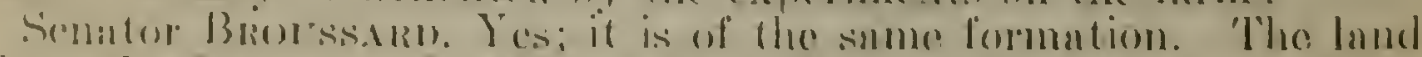

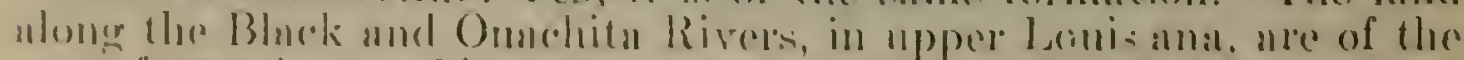
sume formation as this. Florere is a mumber of longous and rivers up 


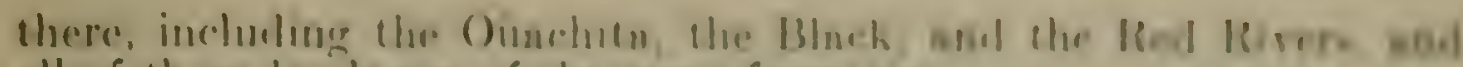

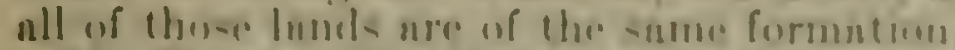

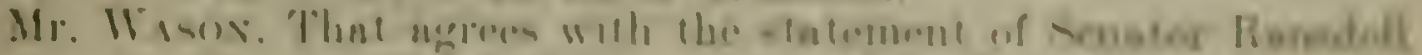

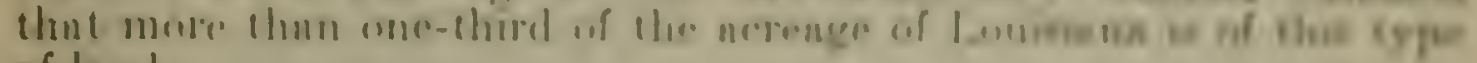
of lind.

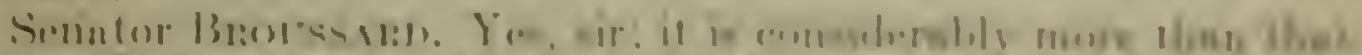

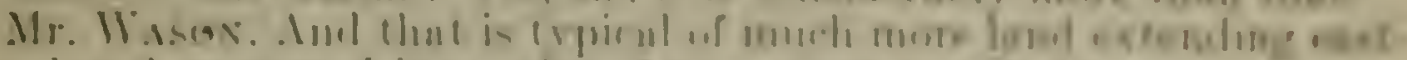

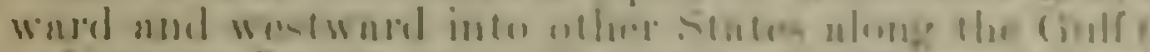

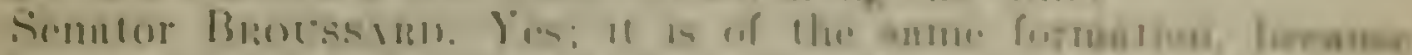

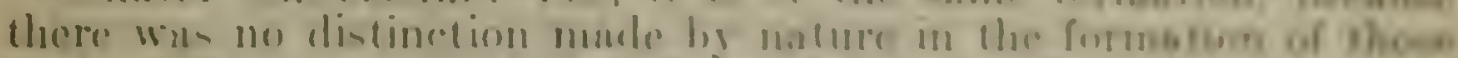

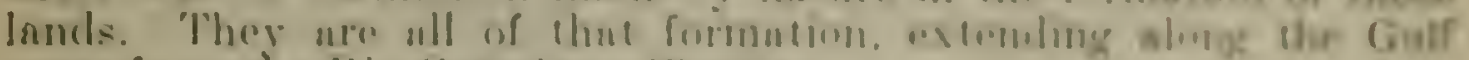
const from the Rin Ginnde lo liberis!n.

\section{STATEMENT OF HON. JOSEPI E. RAISDELL, A UNITED STATES SENATOR FROM LOUISIAIA.}

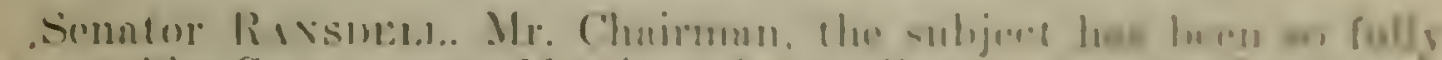

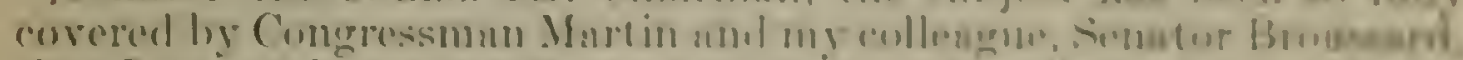

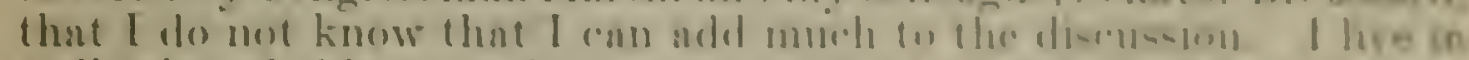

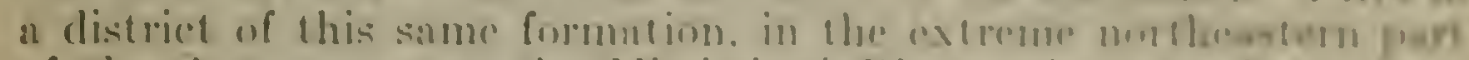
of the Sentre, next to the Missin-ippi Riser. Where we late some

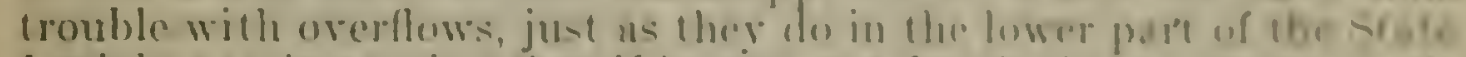

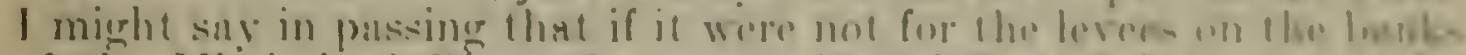

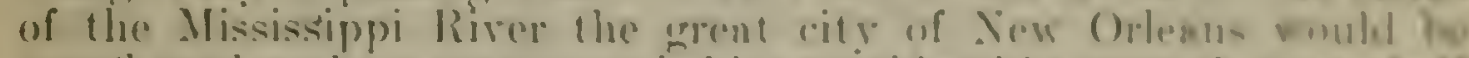

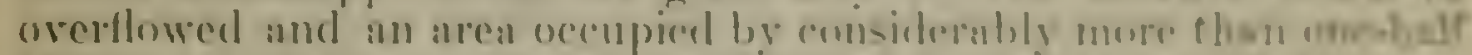

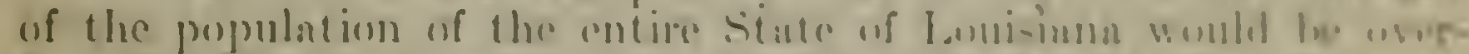
flowed. Therefore, when I spenk of the territors -uhject to orerflow, you must hear in mind that that includes 11 gerent deul now in

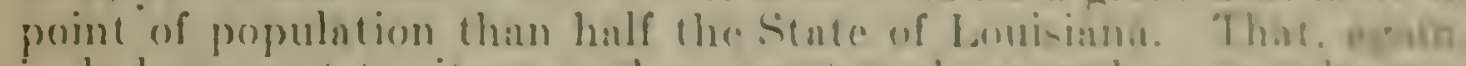
includes a vist territory. und we want to de condelume to tahe or

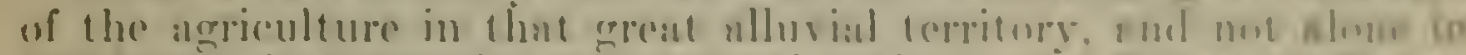
our state. but covering the coistal plain in lhe states of the Mississippi, Ahhuma, und Floridu.

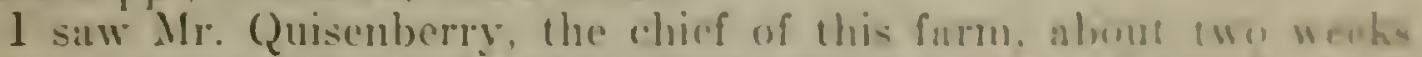

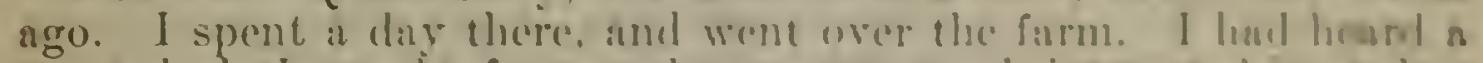
great deal ubout the farm and was vory much intereforl on $\|_{1}$ hut I lad never seen it before. I asked him ahous the comdicions il m. and I found thut the experiments being made inere wore opplicable

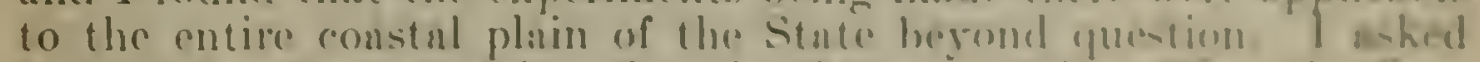
him if what he was doing there in the way of henefiemg the fir stock industry, purticularly relnuing to intele. mules, und hops

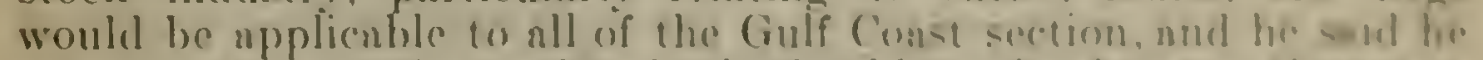
suw no renson in the world why it should not bu. Lecenter thest is th

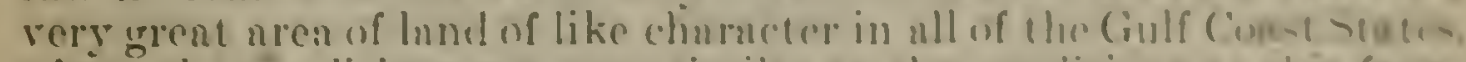
where the conditions are very similar to the conditions ne this form

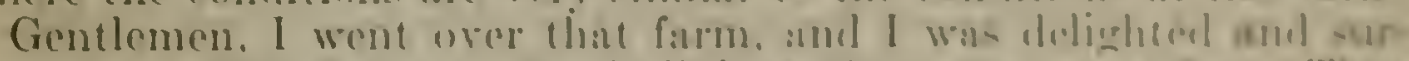
prised nt what I saw. The huildines there nre rert fine They

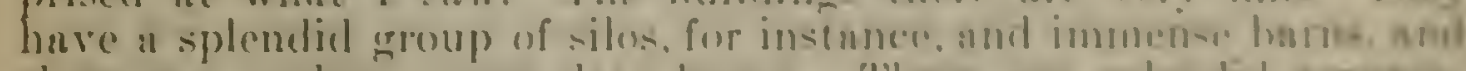

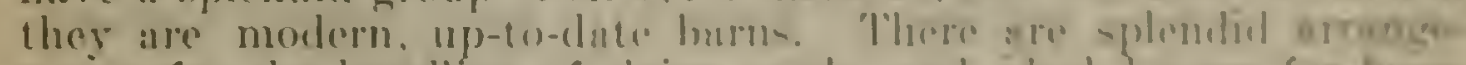

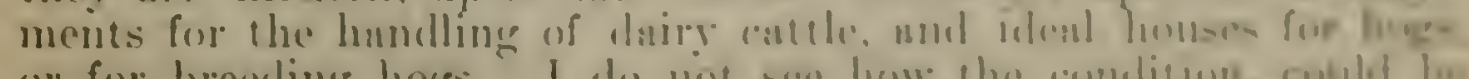

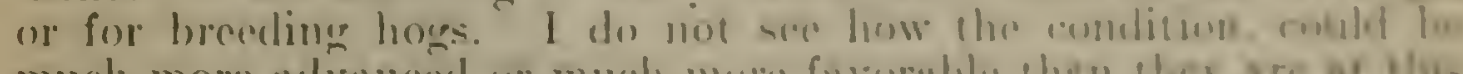

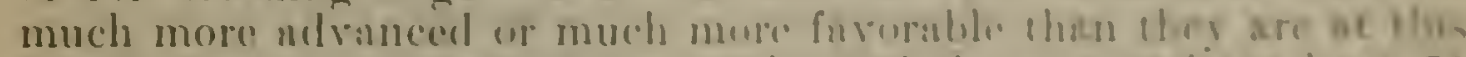

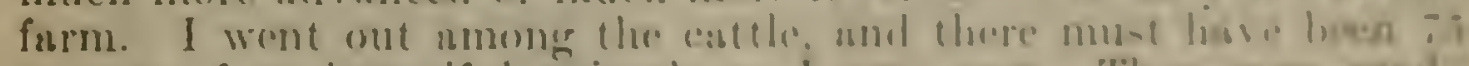

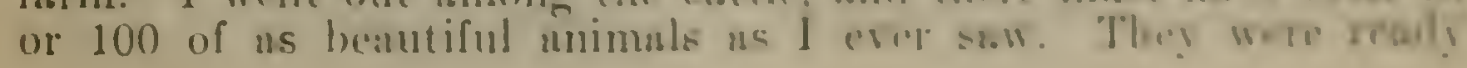


then for the market, and Mr. Quisenberry told me that they had not had one pound of feed exeept what they got on the natural pasture. I went out in the pasture, and out on the black lands in the rear, that so much has been said about. I found there a beautiful growth of Bermudn grass. Some of you know what Bermuda grass is. In a portion of it there was a wonderful growth of white clover. It was fine, and certainly the cattle had thrived upon it. They had gotten very fat. and were in splendid condition on the natire pasture.

You will bear in mind, gentlemen, that the trouble on these lowlands does not occur for usually more than 60 days in the spring of any year. They had some trouble last spring, which you heard about. from the great orerflow in the Mississippi River." A large area of land in the State was orerflowed. There was a break of the levee in Coneordia Parish, and there were two breaks below New Orleans. We had a great deal of destruction there. The high water backed up on some parts of this farm and did some damage, but it was only temporary damage. The grass continued to grow. Water does not hurt Bermuda grass, and I have seen the most beautiful crop of Bermuda grown on land that had been overflowed for 60 days and sometimes for 90 days. As a matter of fact, the grass is benefited by that orerflow, and you must not be bothered about that. You must bear this thought in mind, that this farm was put there originally to help the people of the sugar section on the Gulf to combat this condition and to help them make a crop of some kind in addition to cane on the lands subject to overflow. When a sugar plantation is orerflowed and the seed is destroyed, it costs a good deal to reseed it. You do not put sugar cane seed in the ground at an expense of one or two dollars per acre, as can be done in the ease of most other crops, and some of them for less than that, but it costs a very large sum. I can not tell you how much.

Mr. Bechasan. You must get the cane and phant it.

Senator Ranspell. Yes, sir; you must get the cane itself and put it in the ground, and that is quite an expensive proposition. Furthermore, the people with statesmanlike vision, when in 1914 they were threatened with the absolute destruction of the sugar industry in Louisiana. realized that something else must be produced. 'That applies not only to Louisiana but to a portion of Texas, and it is something of an inclustry now in Florida. They felt that it was necessary to do something in that section to build up a live-stock inclustry. They lolt that any genuine agriculture must be based upon live stock anylow. It was then we asked Congress to show us how to raise cattle in Louisiana in the sugar-cane section, so that if the sugnr planters were put out of that business they could do something else that would be profitable. 'They were also extremely anxious 10 lunve some kind of industry carried on on those heary hatek lands which are on the rear of every plantation practically in that comntry. I have them on my place, and ereryody has them. certuin portions of this area woukd be very line for "ane, other portons for corn, or, perhups, for cotton. In muny sections the lands were fine lor rier.

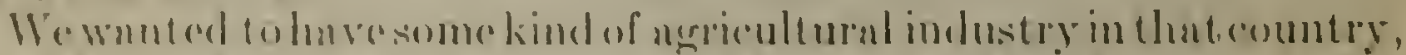
in mddition to cance, cotton, or riere, and we did not know how to gret

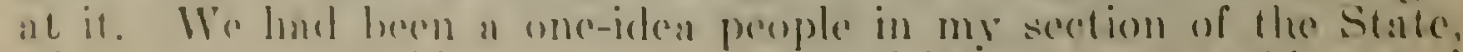

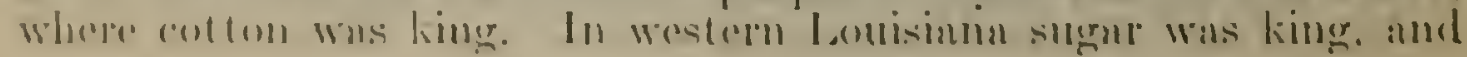




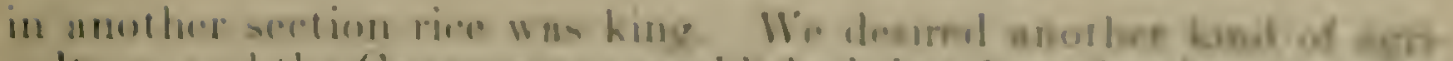

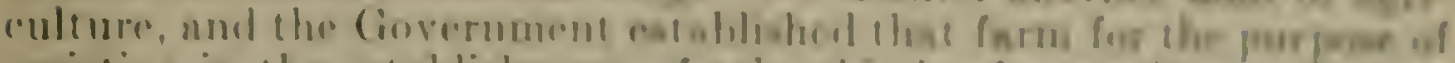

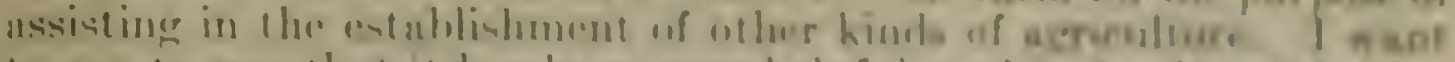

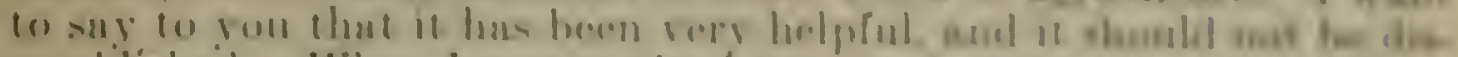

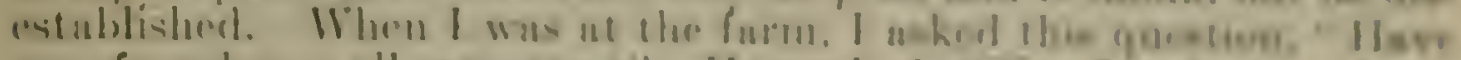

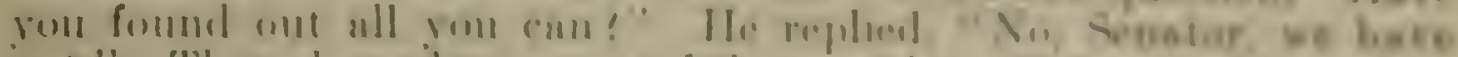

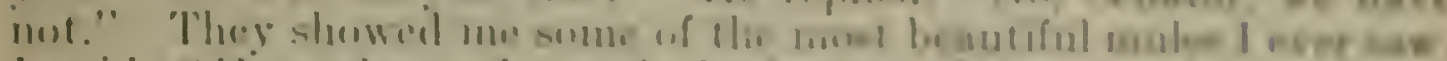

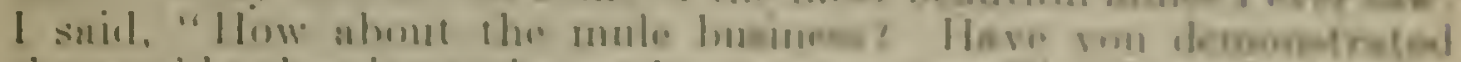

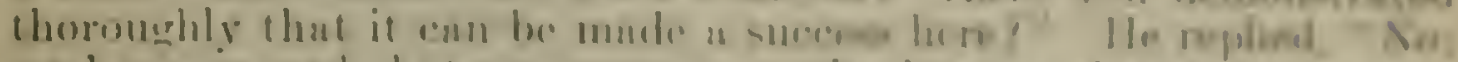

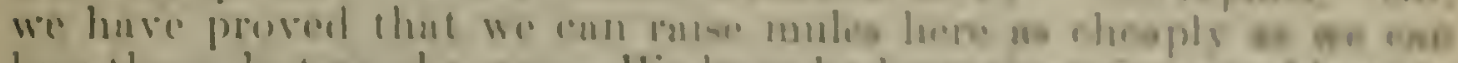

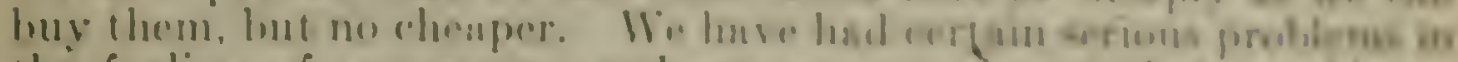

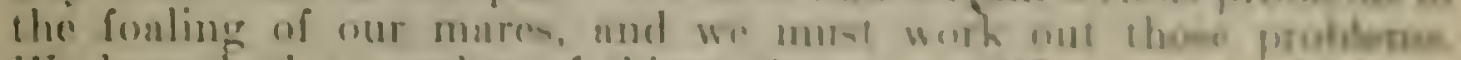

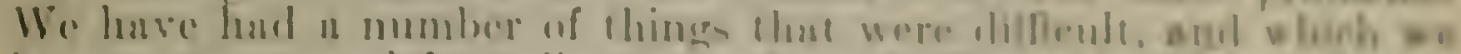

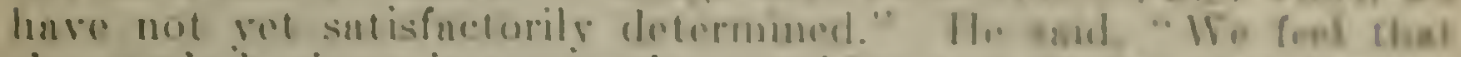

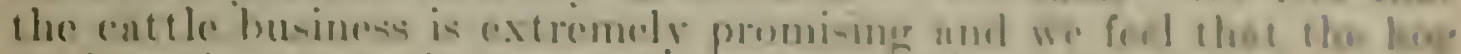

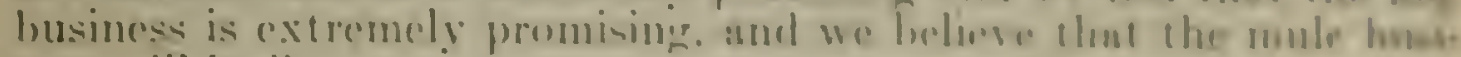
ness will lue."

Gentlemen, if you should be anrrying on a farm in one of the

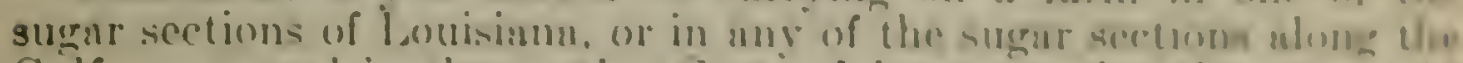

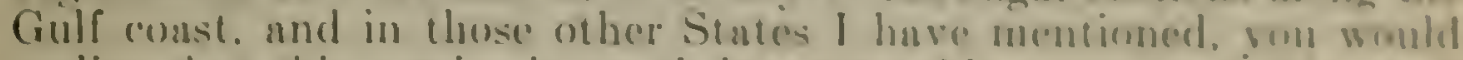
realize that this service is worth incomparubly mere thon the -mall

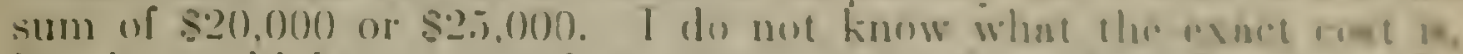
but it wenld be most unfortunate to stop thuse esperimente while they are right in the midst of things. It would be mont unformonte to give up this rery extensive plant that has bern whahh hed there

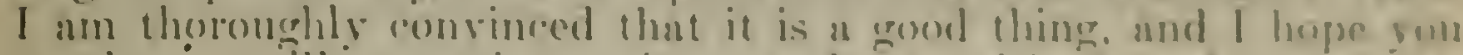
gentlemen will enry it ons in alecordnnee with the mishen of the Secretary of Aerriculture, of Dector Mohler, the Chief of the Buresu of Animal Industry, and of Doetor 'Tnylor, the ('hief of the Burenu of Phant Industry I have seen all of them. and they upprome it and want it done; but, of course. they had to roncure in the antion of the Budget Burestl.

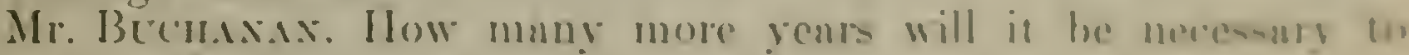
(amry it on?

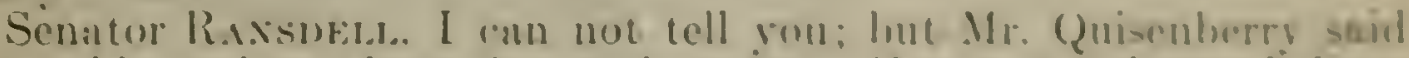

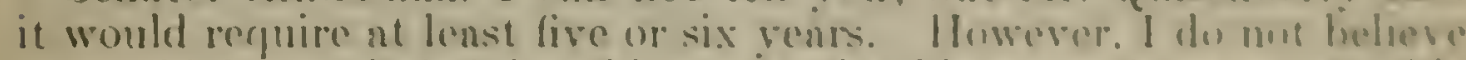

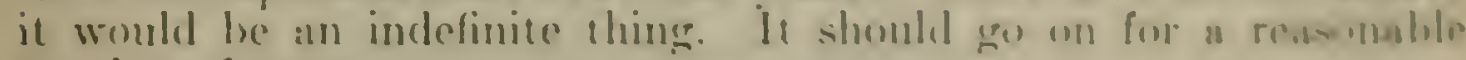
number of yeirs.s.

Mr. Wasos. I do not know moreh ahout rome country, and the is probably a forlish question on ast: The nerosity for miule problur tion there is for farm power!

Semntor R.ixistrito. Yes.

Mr. Wisox. Is there ang substitute for mulen there:

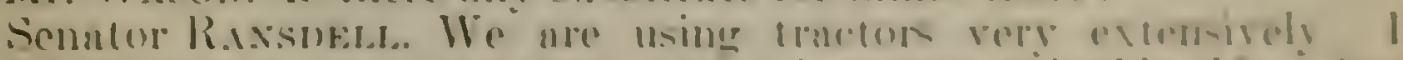

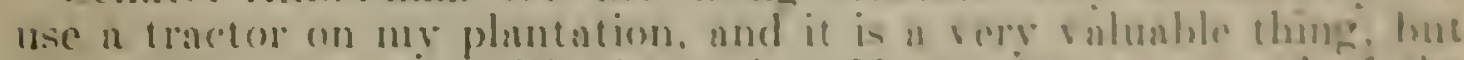

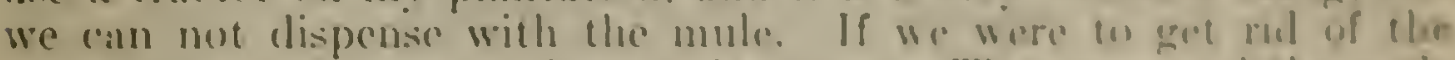
mule, we womld have to give up the newro. The megre and the mule

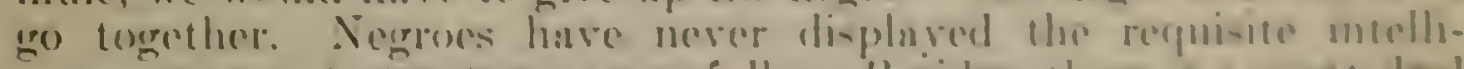

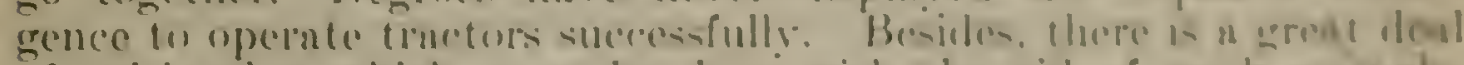
of cultivating which must he deme with the nid of work ammel.

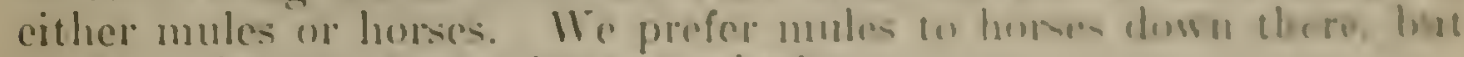
wo ne using traters quite extensisoly.

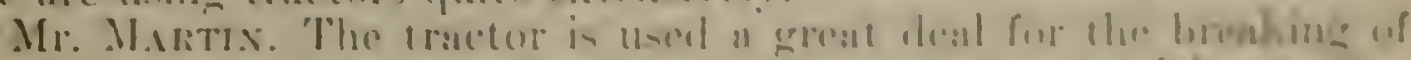

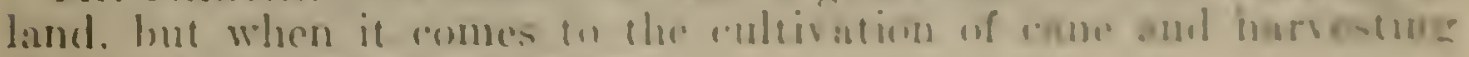
the same, you must use mules. 


\section{Mr. Axuensox. Is this station operated in cooperation with the} State!

Senator Raxsiel. I do not understand that it is.

Mr. Martix. There was a committee of three appointed. I do not know who the meinbers of the rommittee are, but I think that Doctor 'Taylor is a member, and Doctor Dodson. who is in charge of the state experiment farm, is on that committee. Doctor Dodson does some work for that station, and gets out bulletins.

Mr. Axonersox. The State does not contribute anything toward the maintenance of the station?

Mr. Martix. It only contributes the land. I want to state that I have a telecram from Doctor Dodson here, that came this morning. I wanted a statement of the work done by that farm, and he telegraphed me on the 29th that he was mailing a statement regarding live stock. When that statement comes in, I would like to submit it for insertion in this record.

Mr. Anderson. That may be done.

Senator Raxsueld. We thank you very much for this hearing.

Mr. Avoersox. We are much obliged to you for your statements.

(Doctor Dorlson's statement is attached hereto.)

Batox Rouge, La., Torcmber is, 19?2.

Mr. II. P. MARTIN, M. C.,

W'ashington, D). C.

Deali Mr. MArTix: I have just received your letter of the 24th stating that the Budget committee had rerommended the discontimuance of the lberia live-stock firm and had recommended an appropriation of only $\$ 5,000$ for helping to dispose of the equipment.

I think it would be a serious mistake to stop this work at the present stage of its development and I hope that the Appropriations Committee may favor a continuation of the work now in progress until such a period as the most important projects now under investigation may be rompleted.

Louiciana dunated 500 acres of land to the Federal Government for this work. The experiment station rented 500 acres additional and turned it over to the Iberia livestock farm for three years. Since that time the rental has been donated by the state penitentiary board.

When the experiments were begun the soil was very much depleted from the continued harvesting of cane and rice, but it was representatire of the lype of land that will be clevoted to live stock or agricultural muposes other than the prochetion of sugar cane and cotton, as we develope new enterprises to supplenent these two chief industrics.

There have been a great many difliculties to be overeome; for instance, in getting good pastures, in completely crarlicating cattle ticks, and in other wars that represent fionrering work along the lines projected when the station was established.

The major projects mulertaken there lave been along the line of growing and feed-

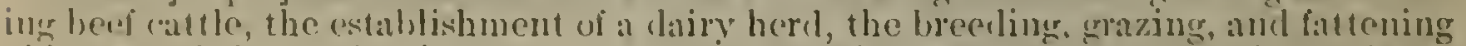
of hogs, and the production of mules. ('ompled with each of the lom major projects, of colluse, has heren the problem of producine crops most suitable to the animals to which they would be fed. Any one of these projerts wil] require the results of several

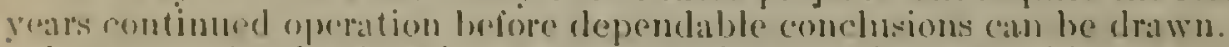

lase grat, for the first time, we were able 10 market a considerable mumber of heef

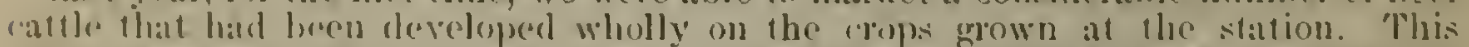

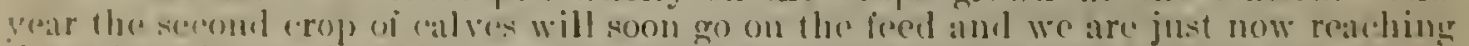

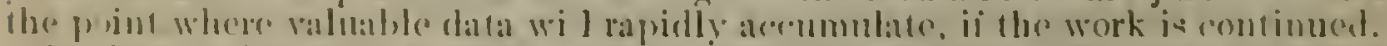

In the gromsing of mule colss we huve eneountered many diflienlties that were not.

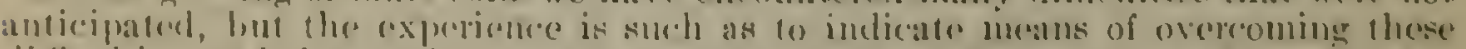

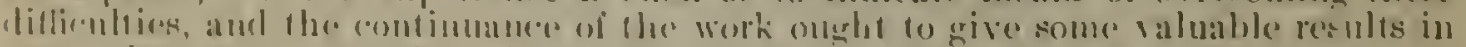

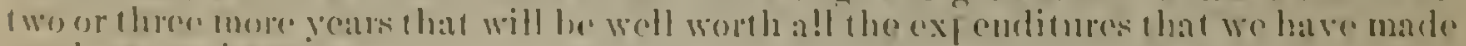
on the expmerimentia.

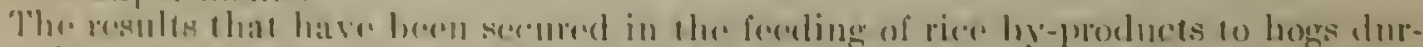

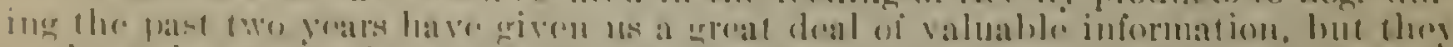

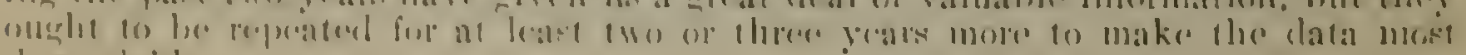

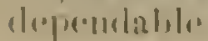




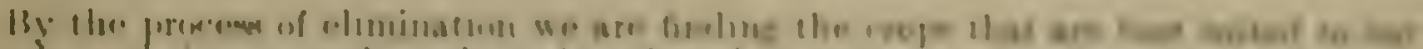

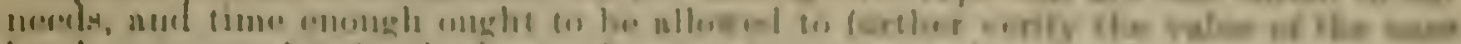

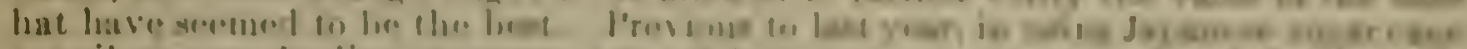

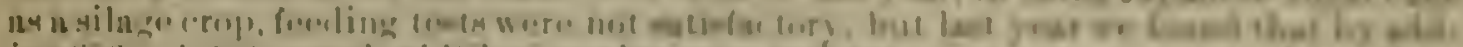

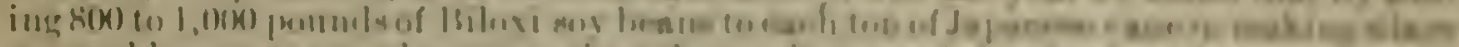

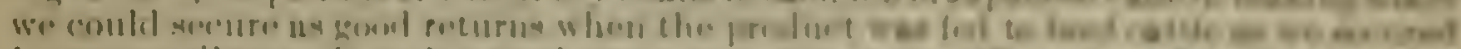

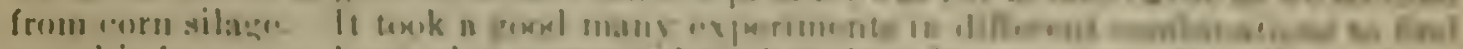

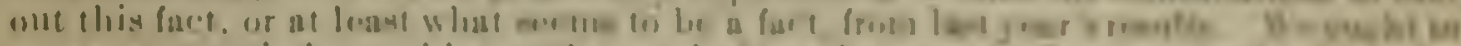

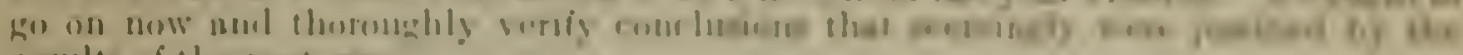

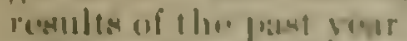

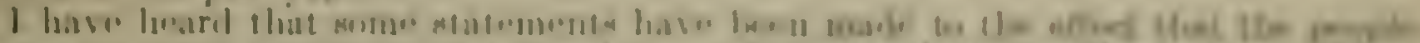

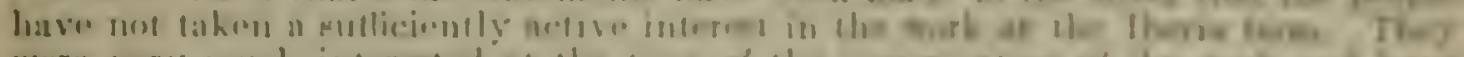

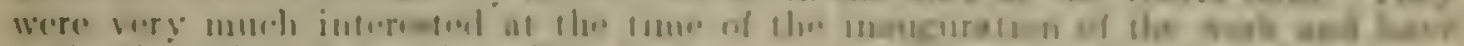

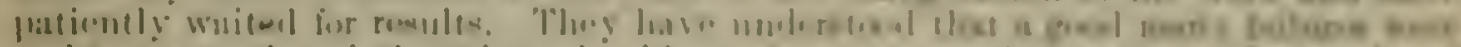

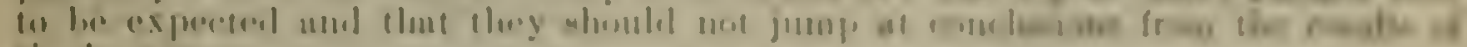

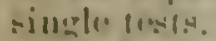

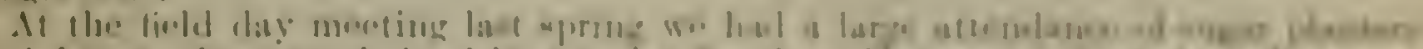

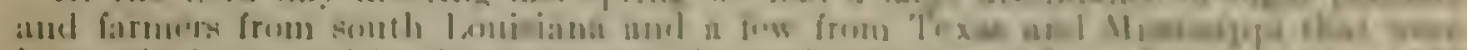

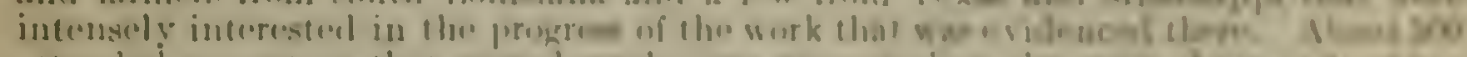

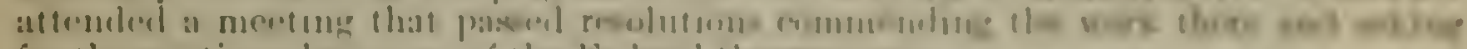

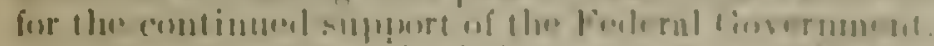

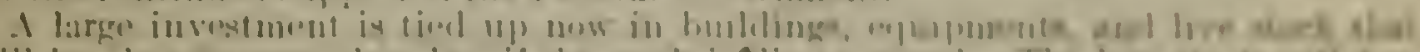

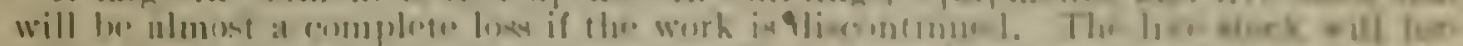

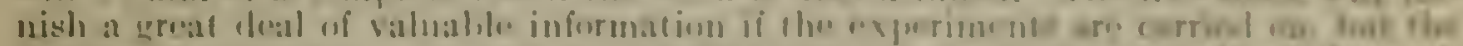

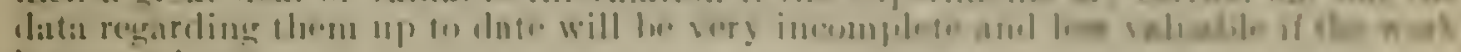
is steppleal unsw.

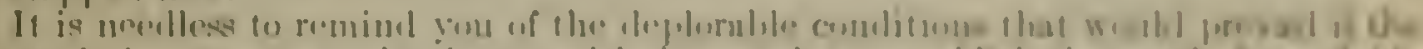

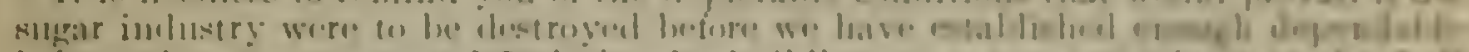

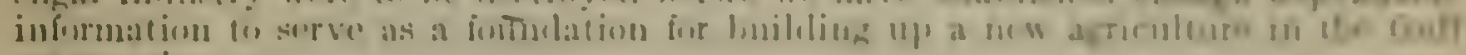
const region.

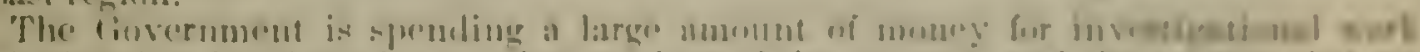

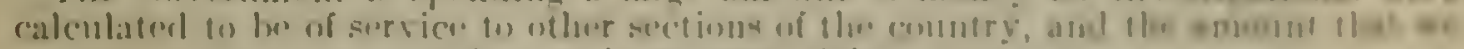

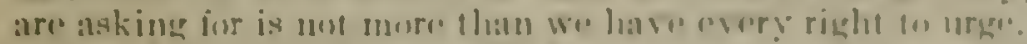

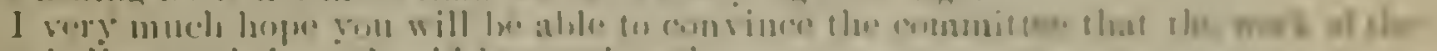

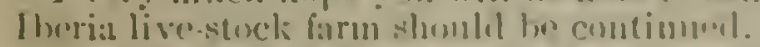

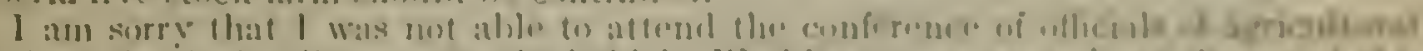

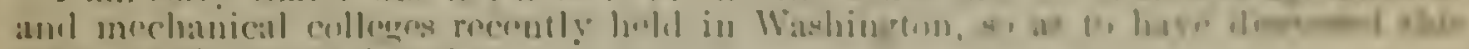
matter with youl at that time.

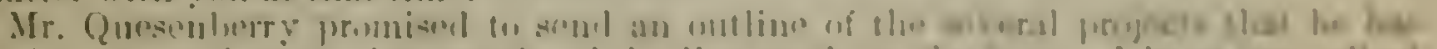

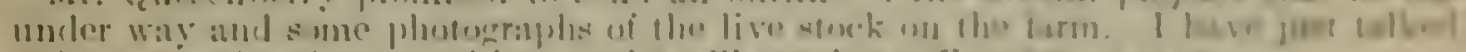

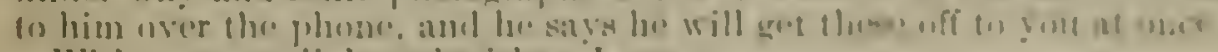

With most corilial gousl wishess. I an. Viry iruly yiurs. 
Accounts and disbursements, division of ....................... 334

A gricultural Econonics, Bureau of.............................. 380

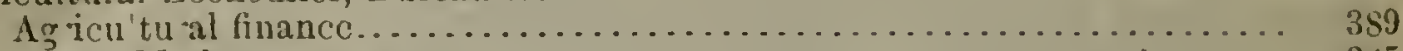

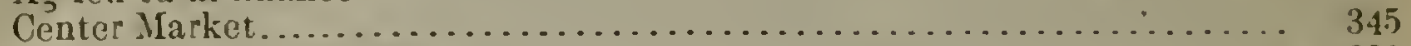

Consj i lation of bureaus. . . . . . . . . 351

Cutton future 3 act, enforcement of . . . . . . . . . . . .

Crop and live-stock estimates.............................. 411

Cosperation with Statez.............................. 412

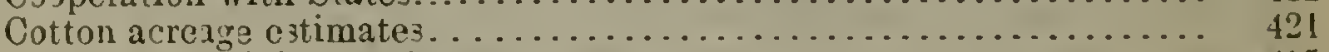

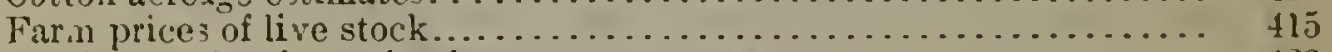

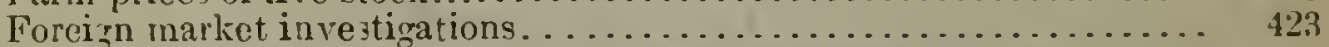

farm manazement and practice, for improved methods of ............. 355

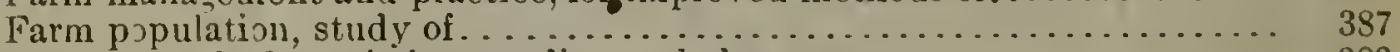

Federal Trade Commi sion, studies made by ..................... 353

General administrative expenses............................ 355

Geweral character.................................... 350

Grain standards act, for enforcement of ......................... 444

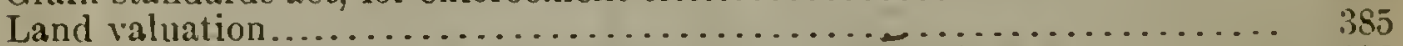

Marketing and distributing of farm products, investigations of......... 396

Cotton haridling and marketing...................... 400

Egors, standardization of................................ 403

Fruits and vegetables, marketing of ........................ 399

Grain investigations.................................. 406

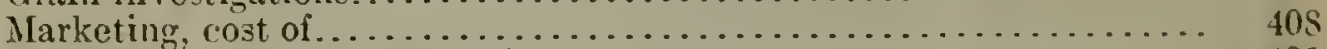

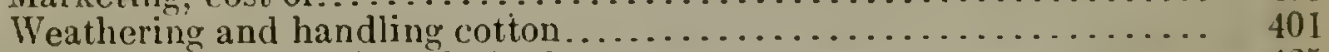

Market inspection of perishable foods ..................... 425

Fruits and vegetables, inspection work in................... 428

Hay-inspection service................................ 425

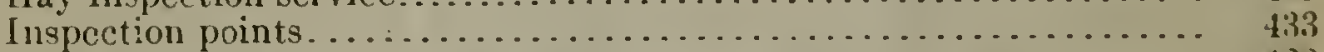

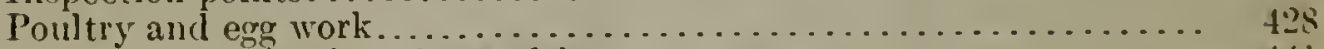

Radio rommunication, demand for............................ 441

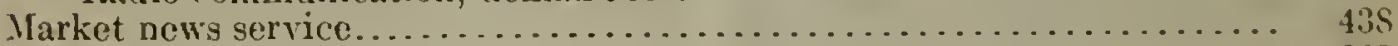

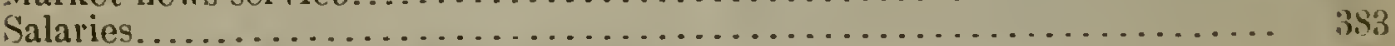

Standard container act, enforcement of ..................... 452

Terminal handling of fruits, vegetables, and other perishables.......... 410

Tractors on farms, use of ................................... 391

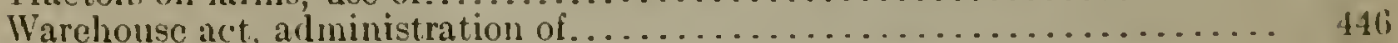

Wool work, for completion of............................... 453

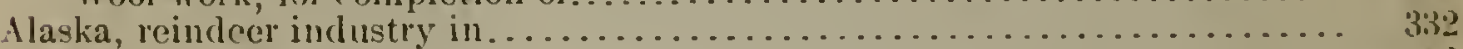

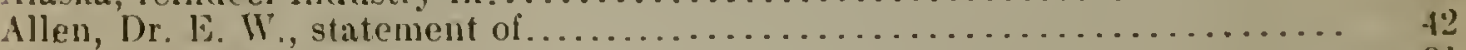

Animal Industry, Burean of ...............

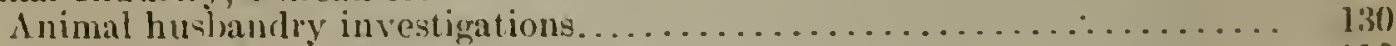

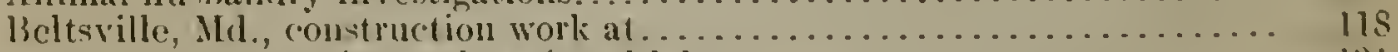

Clark County experimental station, ldaho.........................

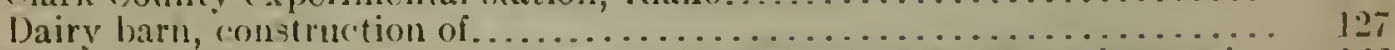

Dairy industry, necessaly expenses for investigations and experiments in: l20

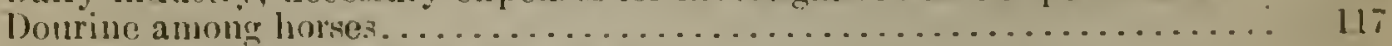

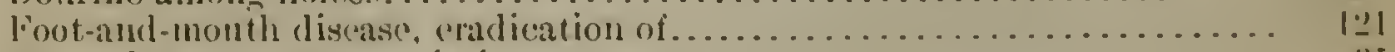

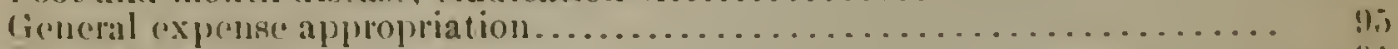

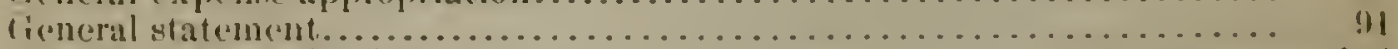

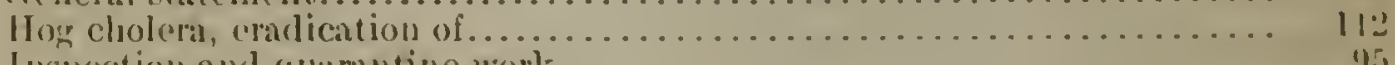

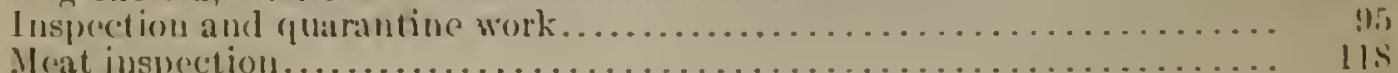

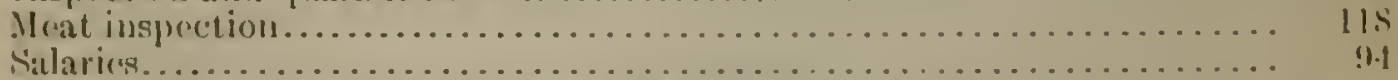

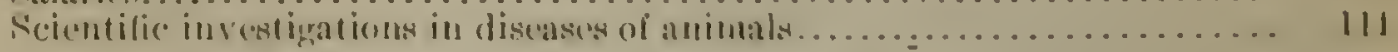




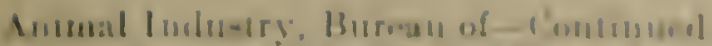

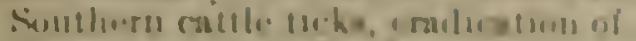

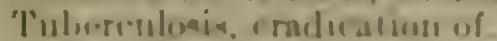

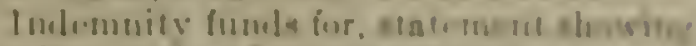

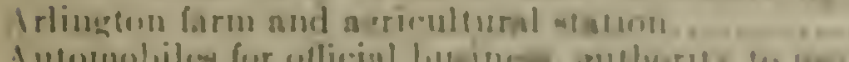

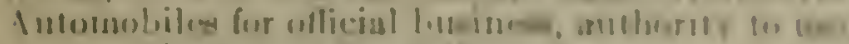

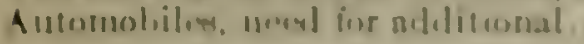

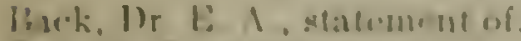

Rall, lo

Barhorrs rallimation.

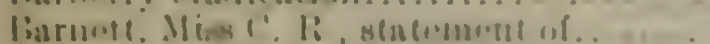

lioles illo. Mld, farm ..........

Binloyingl Sursury, Bureats of.

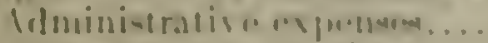

Biological invintiznliona.

|Birds and animals finul halifisof.

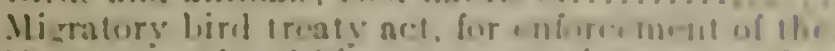

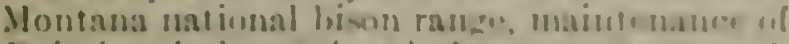

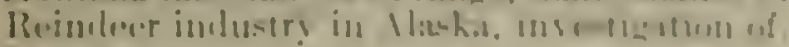

Salarios.

Sillys llill Nallonal lark gabue preserso

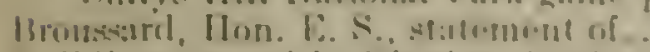

linililinge renterl in Distriet of (islumblia.

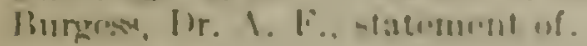

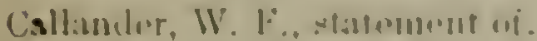

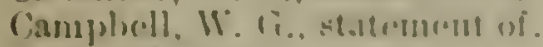

Center Market....

ihemistry, liureall uf

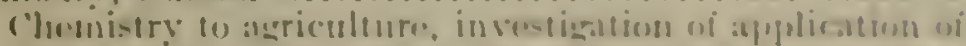

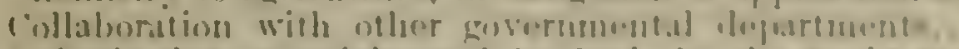

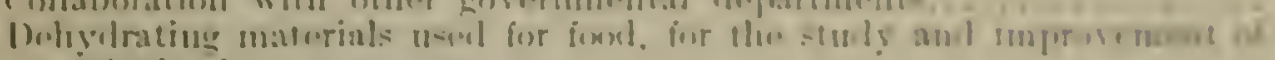
michorla of ......

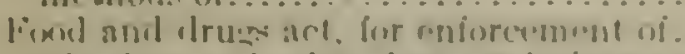

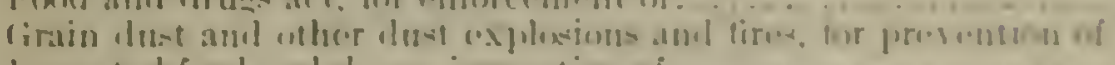

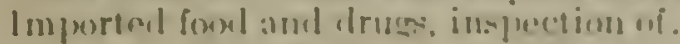

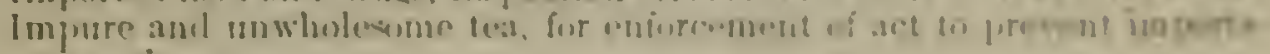
thon wi.

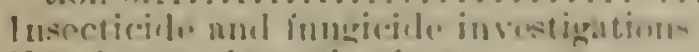

lisu:H Hores invertigations.

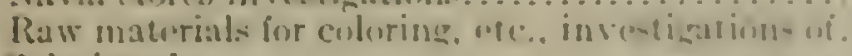

Sillaries of...

Sirups and sugar, inverigation of methet and manulactur at

Whol-acouring waste anvestigations........

Christie, fi. I., stattoment ni.

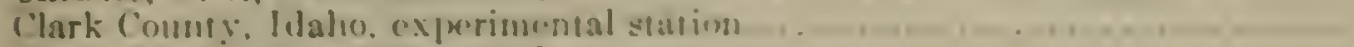

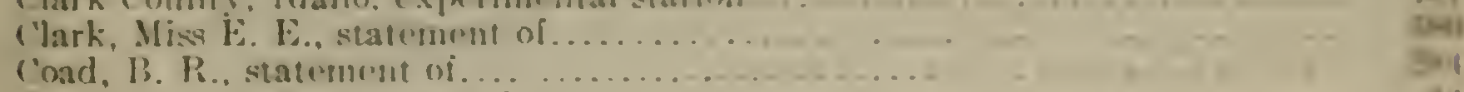

('obls, fohis L... kitatement ui.

Conteresional seet! ...........

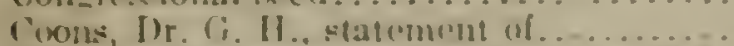

Comperative agricultural melension worh

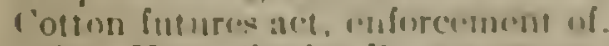

('risp. IIon. (harles li . statement uf....

frecheron. If II . statomest of

()

Dalle scalle, endication of

Divinions, resuranization of

 
Employees, additional scienitic and technical.

Page.

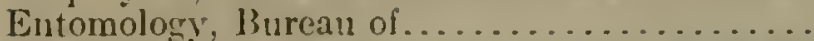

Administrative and miscellancous ('xpenses.

Bee culture, for investigations and lemonetrations in . . . . . . . . . . . . .

Cereal and forage insects investigations and for the control and destruction of grasshoppers.

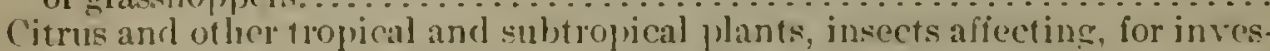
tigations of.

Deciduous fruit insects investigations

European corn borer, prevention of spread of

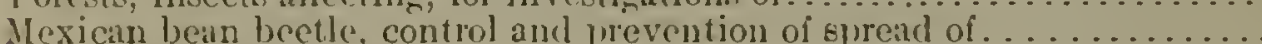

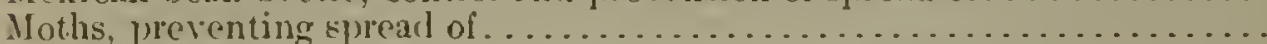

Southern field clops, insects affecting, for investigitions of . . . . . . . . .

Truck crols, insects affecting, etc., for investigations of ..............

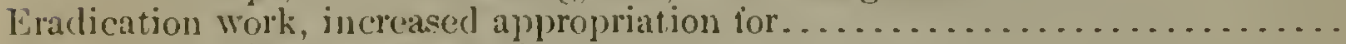

Pstabrook, L. Ml., statemeit of..

Lst imates for 1924 and applopriations for 1923, statement showing classification. European corn borer, preventing spread of . . . . . . . . . . . . . . . . . Evans, Dr. W. N., statement of .

Finhibts al fairs.

Pixperiment stations, ollice of.

Agricultural college extension work, etc.

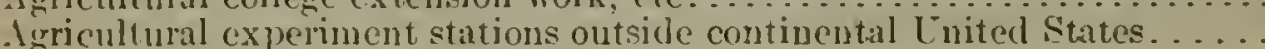

- Maska experiment station...........................

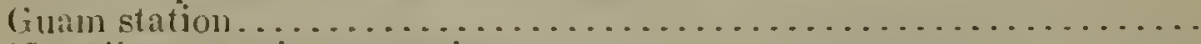

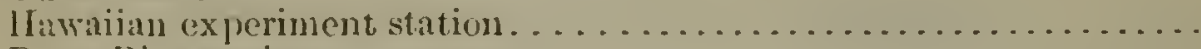

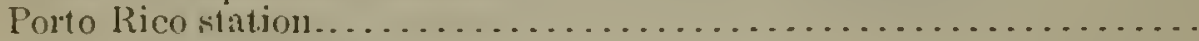

Virgin Islands station.

Duties oi.

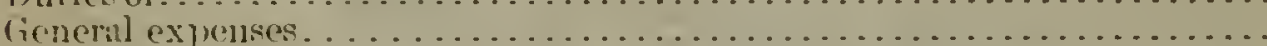

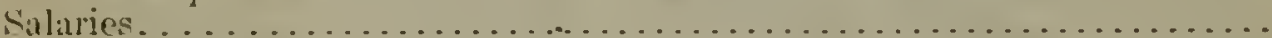

lixtelsion service.

Igents, number of.

Igricultural exhibits, International livestock lixposition . . . . . . . . .

lericultural extension work in ('alifornia.

Illotments irom all sources, statement showing......................

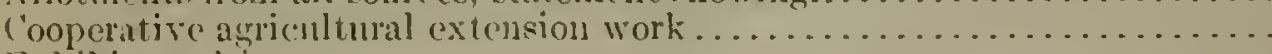

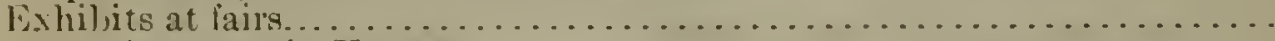

Fxtension work in Kansas.

l'armers' cooperative (lemonst antion work. . . . . . . . . . . . . . . . . . .

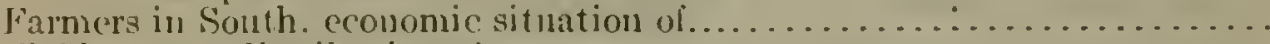

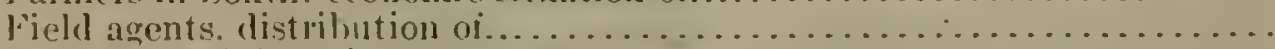

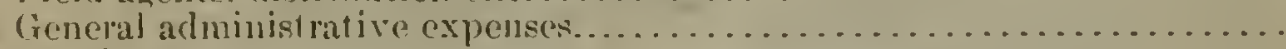

Salaries.

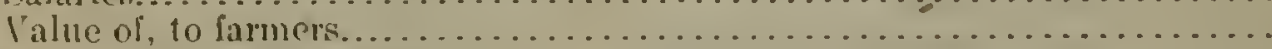

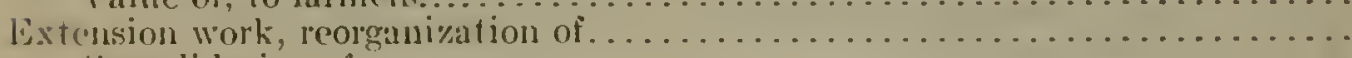

rossolidation of.

203

3111

$\geq 85$

306

$? 96$

$: 312$

302

258

29.3

296

519

507

7

306

42

67

42

14

14

lineral IIorticultural lioard.

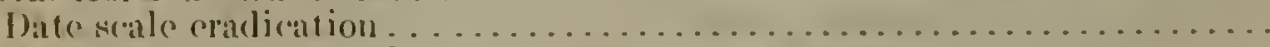

Ilexican loorder control.

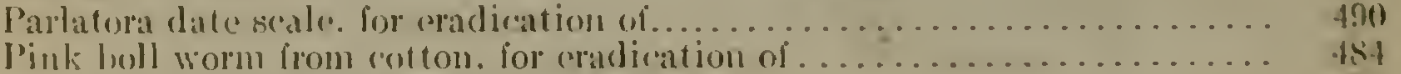

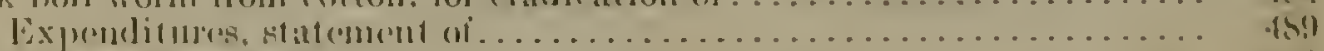

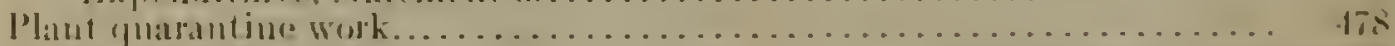

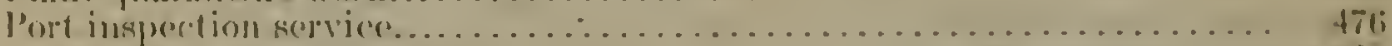

Potalo wart, "xtomination of . . . .

Sil linicis...

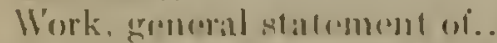


Formet sioritio.

Appropriation muler an of Ware ha les

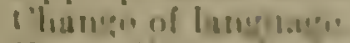

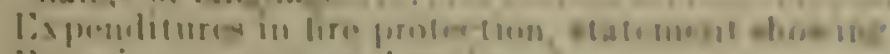

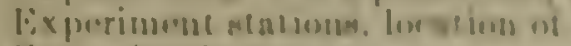

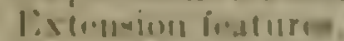

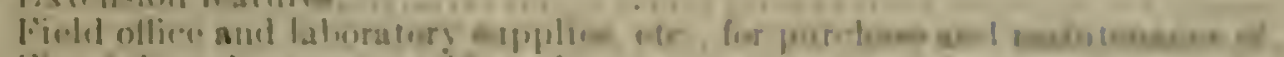

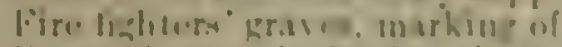

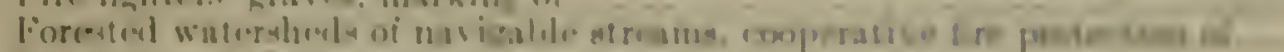

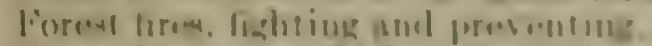

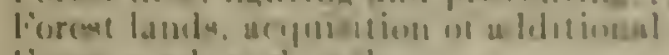

liorest romils surel inule

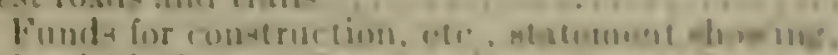

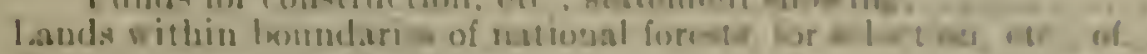

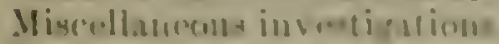

Vationsl ioremets. atea oi

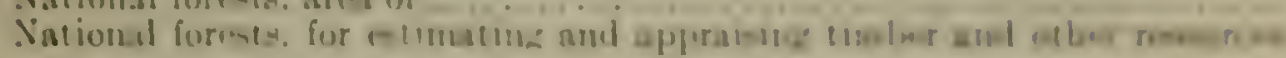

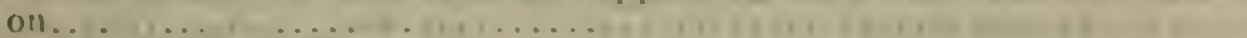

()lympir . Sulonal lorei

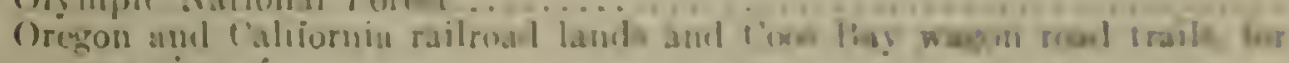
protere(ion of.

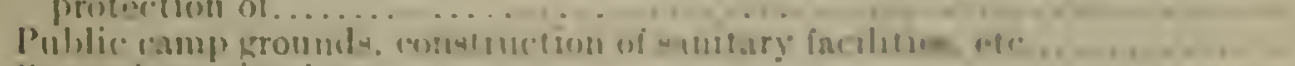

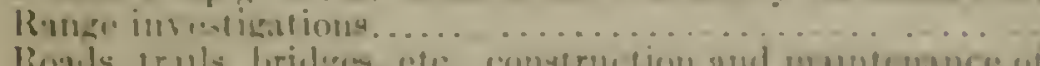

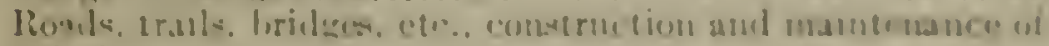

S.laries.

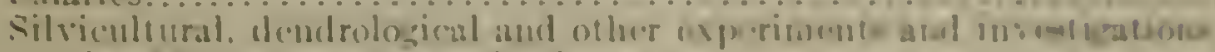

Timber-hilliug inseret insestigntions.

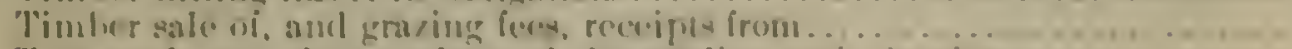

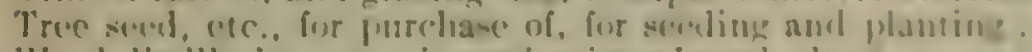

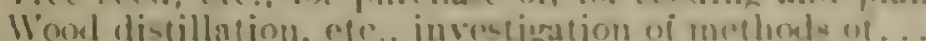

Fuller, Harri-un, statcmentil of

. $1.11 .$.

(i

(iraf, Dr. John E., statemrnt of .

Groin futures act, for enforcement of .

Cirsin etandards act, eninrcenent of

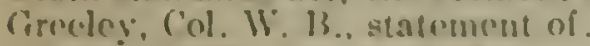

Giscene. D. .I. statement of.

liregr. iv $R$, statement ni.

111

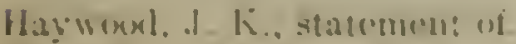

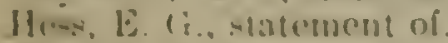

ITnm Économics. Bi:re:un of

licorganisation, plan of ...

Silaries.

llork, errieral stato:me on

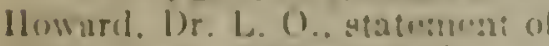

Hlunt. I. II . Flatroment of.

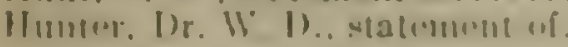


I.

Lantworthy, C. F., statement of

larson, l)r. ('. WV., statement of

Genemal statement of work.

Salaries

live-stock productions:

l'ane-sugar districts.......

337

IVostem irrigated districts.

\section{II.}

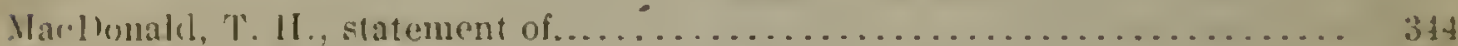

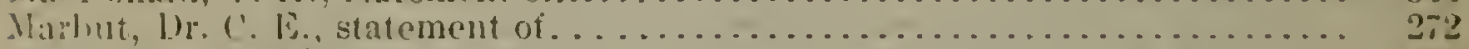

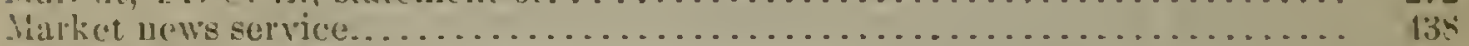

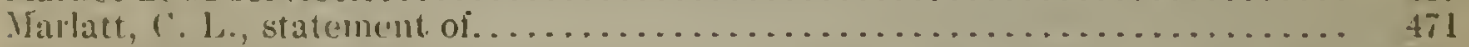

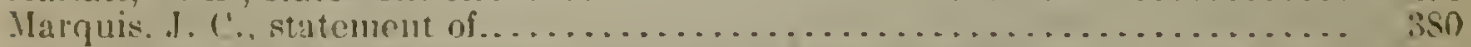

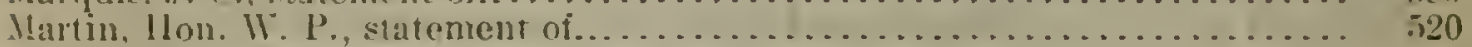

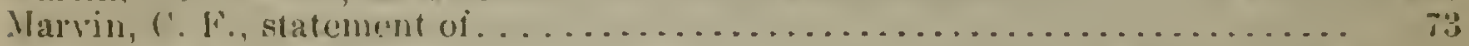

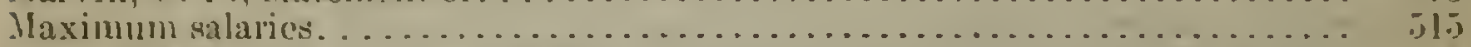

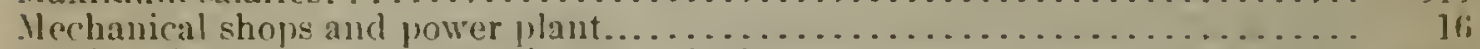

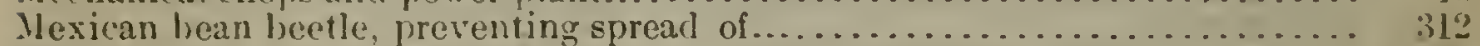

Migratory bird act, enforcement of .............................. 330

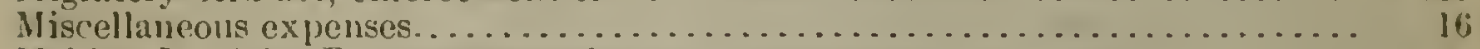

Wohler, Jr. John R., statement of . . . . . . .

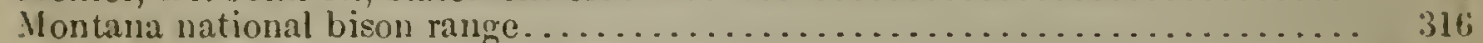

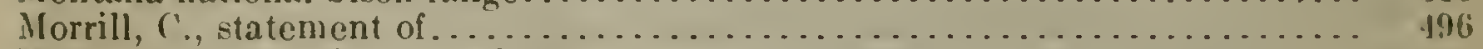

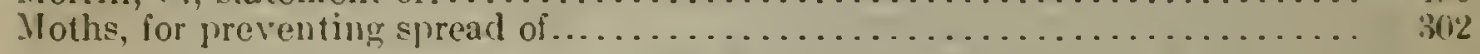

$\mathrm{N}$.

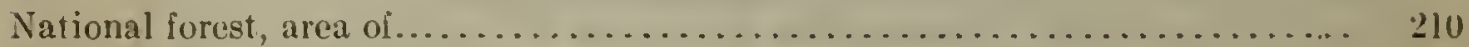

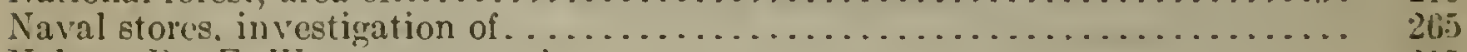

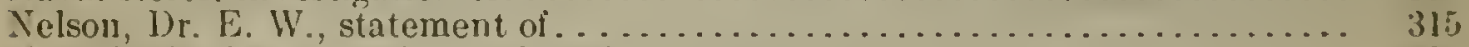

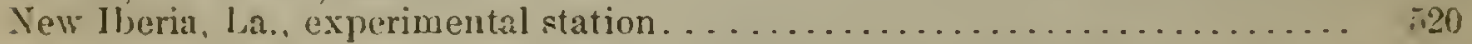

(1).

Olympir: National linest. . . . . . . . . . . . . . . . . . . . . .

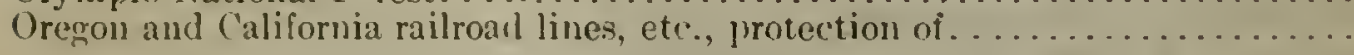

\section{$P$.}

Packers and stockyards act, enforcement of

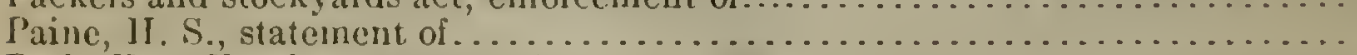

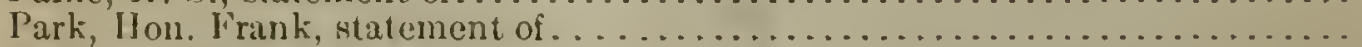

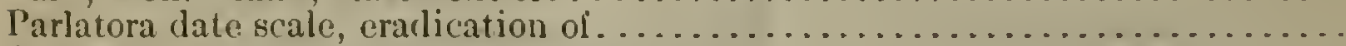

Passenger-carrying vehicles.

'Transferred from War Department, use of . . . . . . . . . . . . . . . . . .

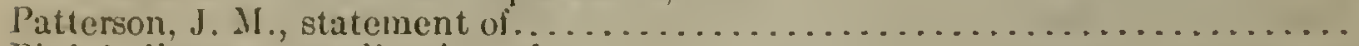

Pink boll worm, eractication of .

Plant Industry, Burean of. .

Alkali-resistant aud droughit-resistant rops, breeding and plysiological

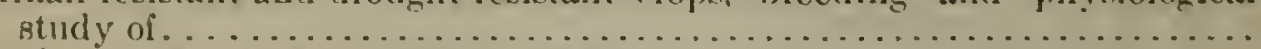

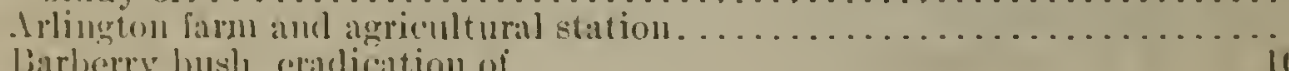

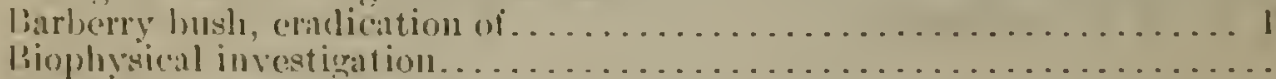

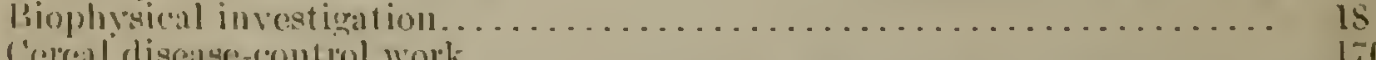

lereals, for investipational work in the impromement of ............. is!n-1si

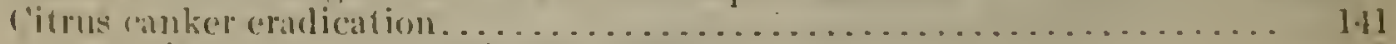

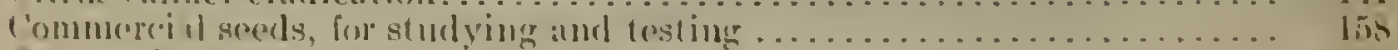

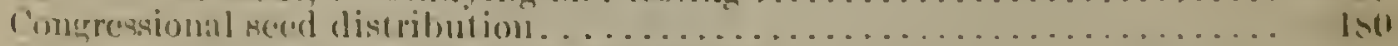

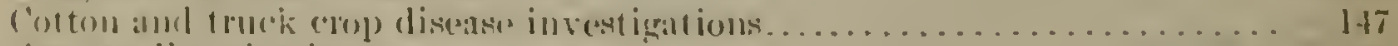

('rep) arclimatimation. . . . . . . . .

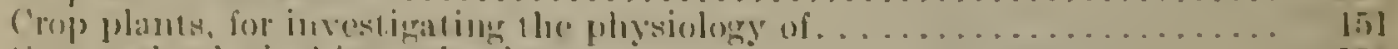

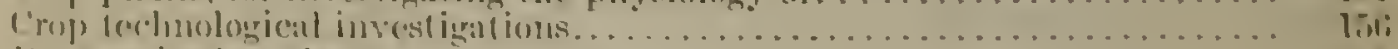

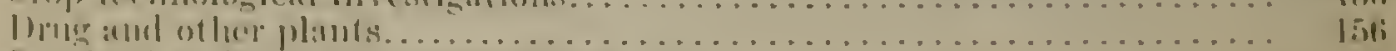

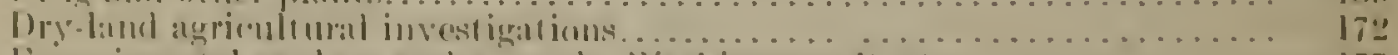

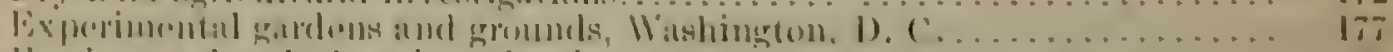

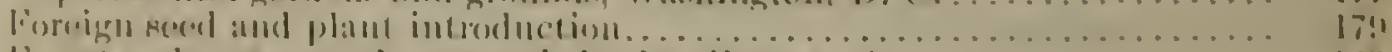

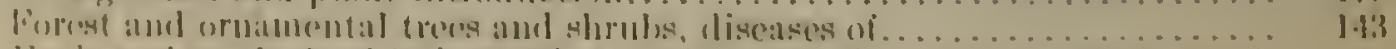

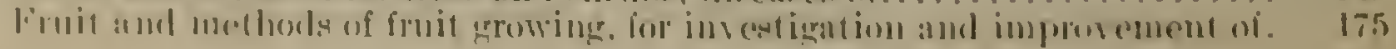




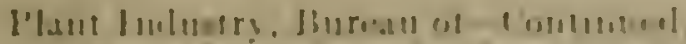

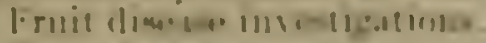

locheral mtaters 10118 .

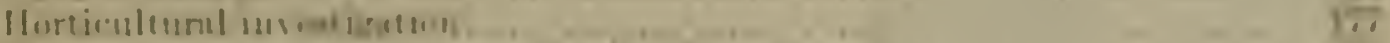

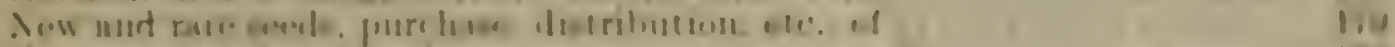

Xirmery aloch mor literlitase

Vut cilturre

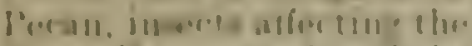

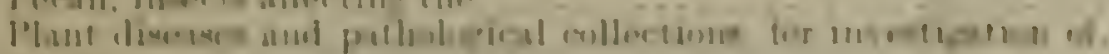

Sillurien

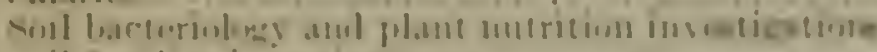

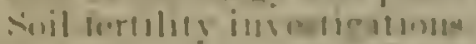

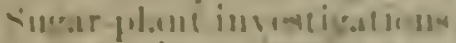

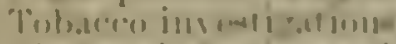

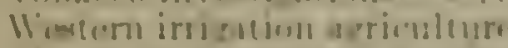

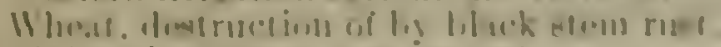

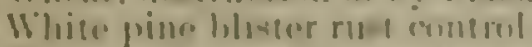

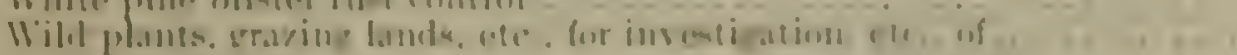

Printiate oud bindim:

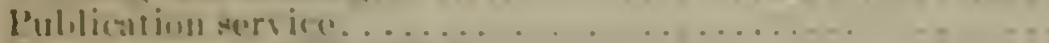

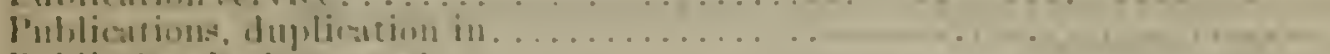

Puldice limala, Burean of. .

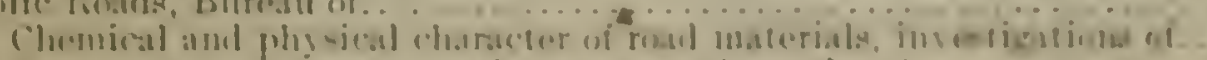

lixperiments! highwas. mintenanee and repairs of

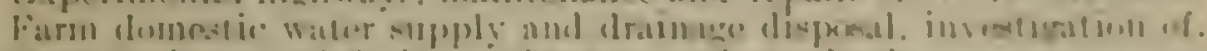

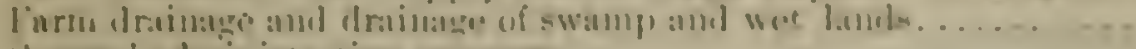

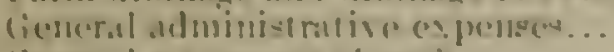

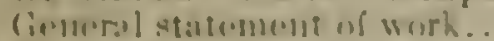

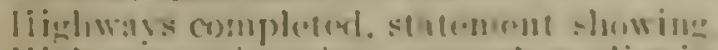

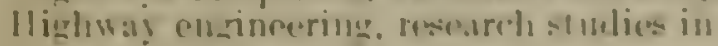

Jalls revolatione trallir.

Ifaterials used in rosal comatruction,

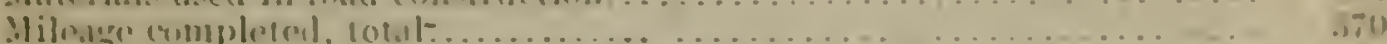

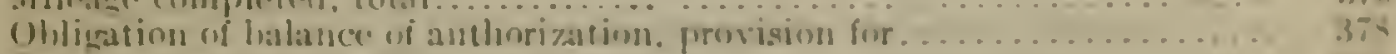

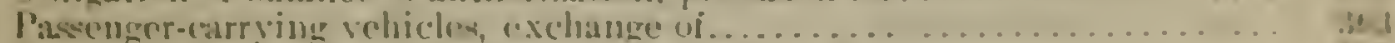

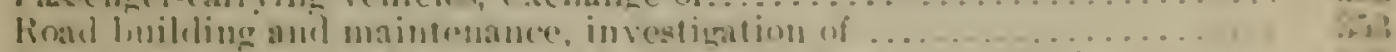

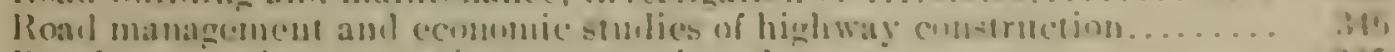

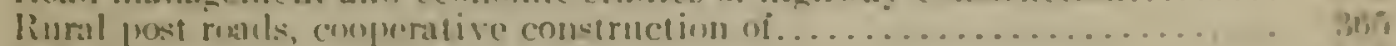

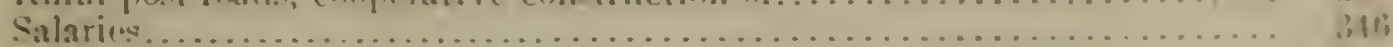

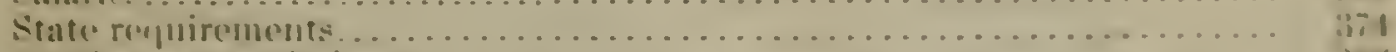

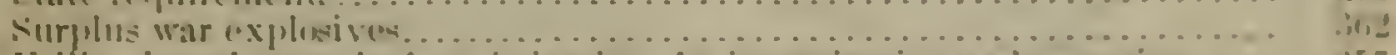

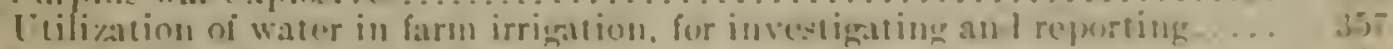

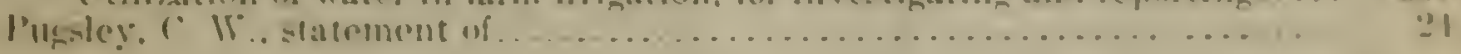

(1).

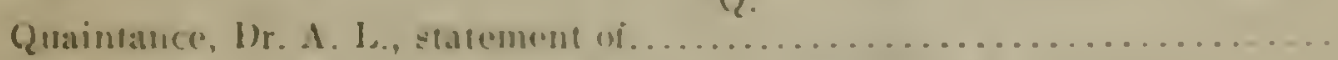

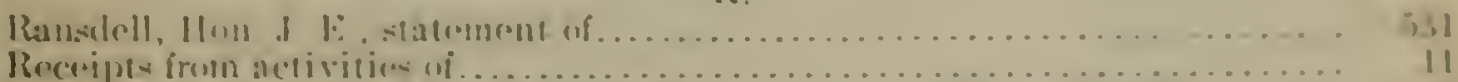

Reclamition project. dentm

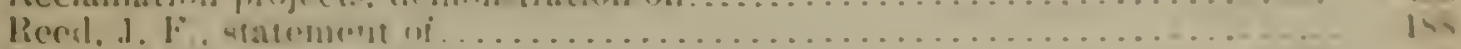

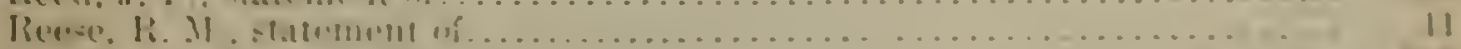

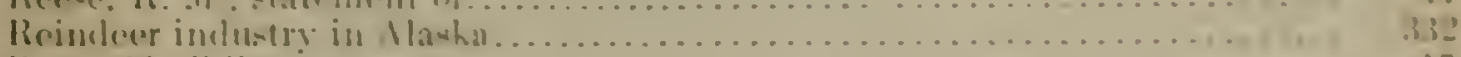

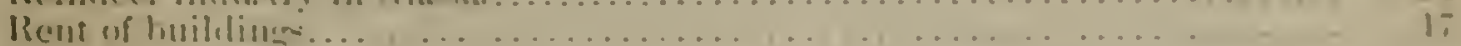

$s$

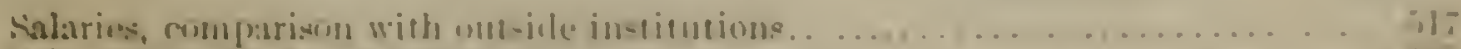

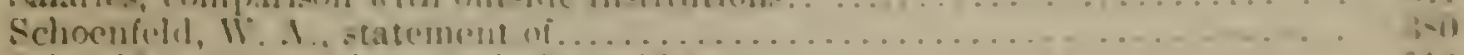

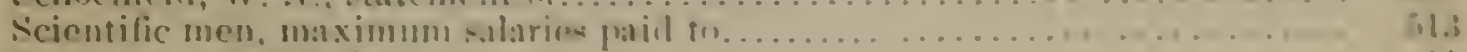

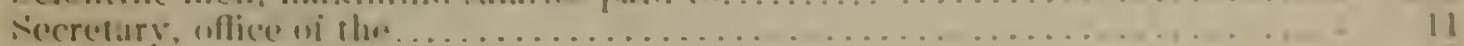

Administation a

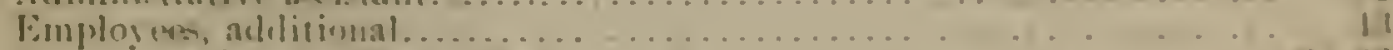

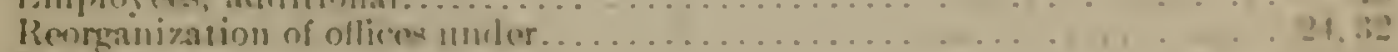

Salaric..........................

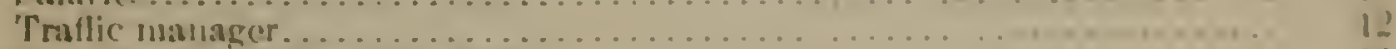

Transfers from other divisiona..................... Is

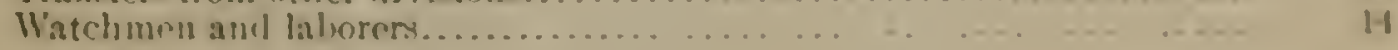


seed grain loans, collection of . ...

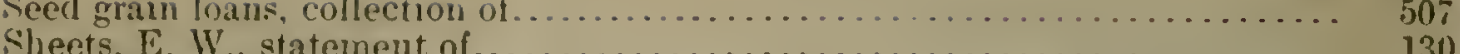

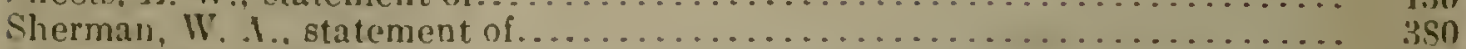

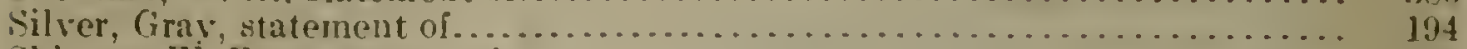

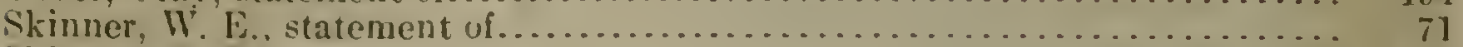

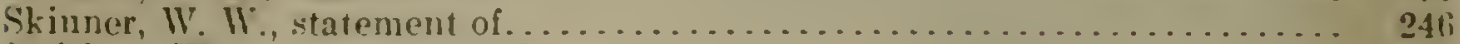

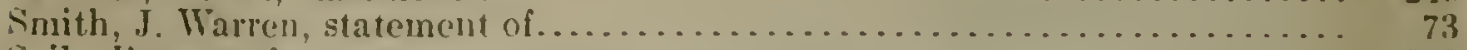

Soils. linreat of..................................... 272

Agricultural lands, for cxamination of soils to aid classification of....... 2S

Fertilizer resonres, for investigation of ..................... 277

Physical inrestigations of important properties of................ 277

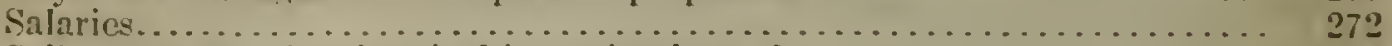

Soil types, etc. for chemical investigations of $\ldots \ldots \ldots \ldots \ldots \ldots \ldots \ldots \ldots \ldots \ldots . .275$

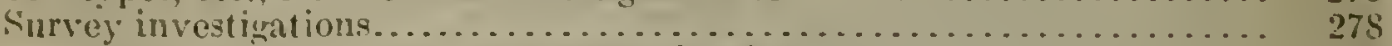

Funds expended, 1922 , statement showing.................. 27 !)

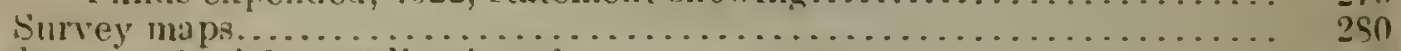

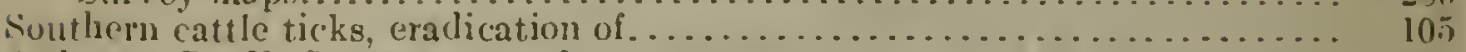

Stakman, Dr. E. C., statement of............................ 197

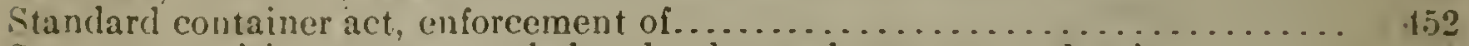

Statutory positions recommended to be dropped, statement showing......... I0

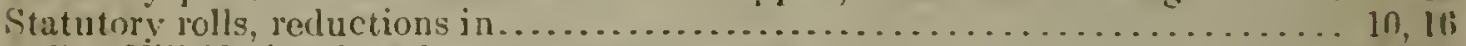

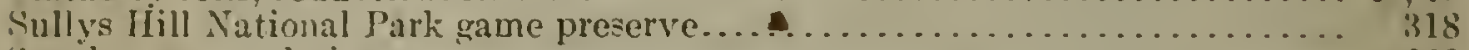

Surplıs war explosives..................................... 362

T.

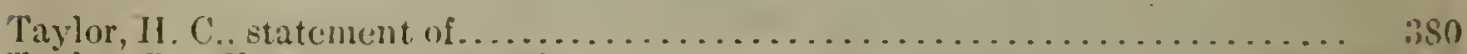

'Taylor, Dr. Vi. A., statement of ....................... 134, 184, 490

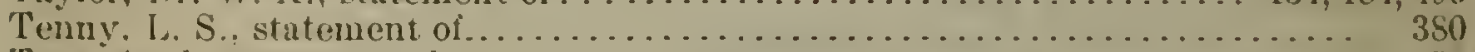

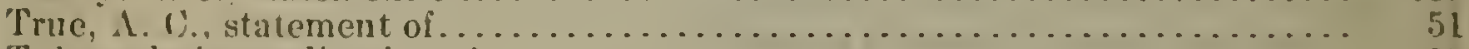

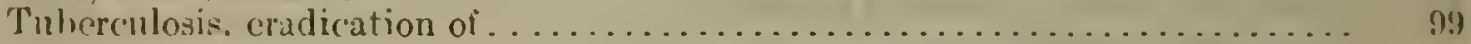

T.

$V$ ault ior inflammable materials, completion of . . . . . . . . . . . . . . 17

Veitch. I)r. S. P... statement of . . . . . . . . . . . . . . . . . . . . . .

IV.

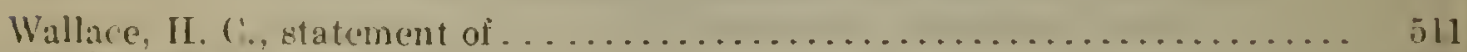

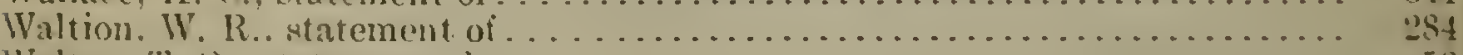

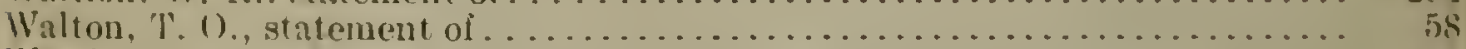

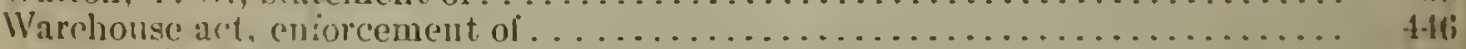

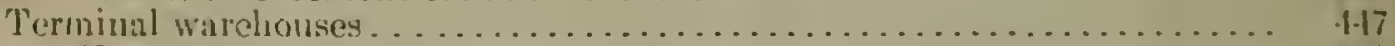

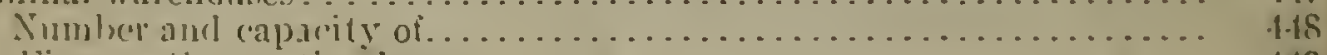

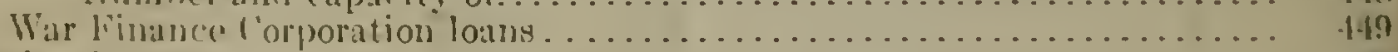

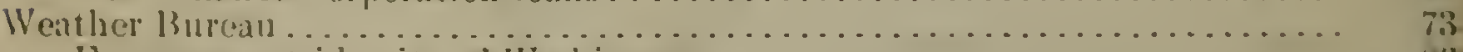

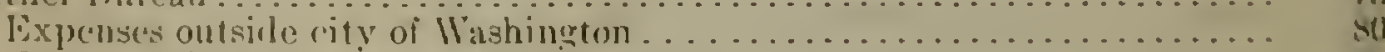

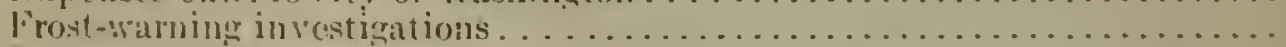

General axpenses.

Cicmoral statement

Increased persouncil neal

l'hotorraphic illustrations.

Sialarios.

stations for olo

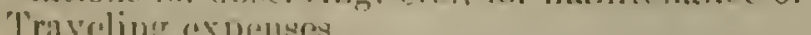

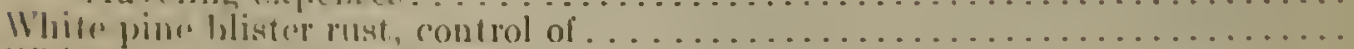

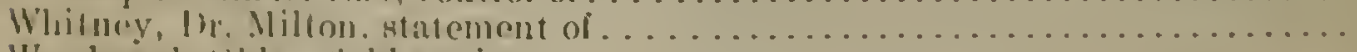

Woorwatrl, t)kla., licld station.

W'oolwork. for (oompletion of.

liork of diprortument

Yohe. II. S. Htatemorut of 


NON-CIRCULATING BOOK 
